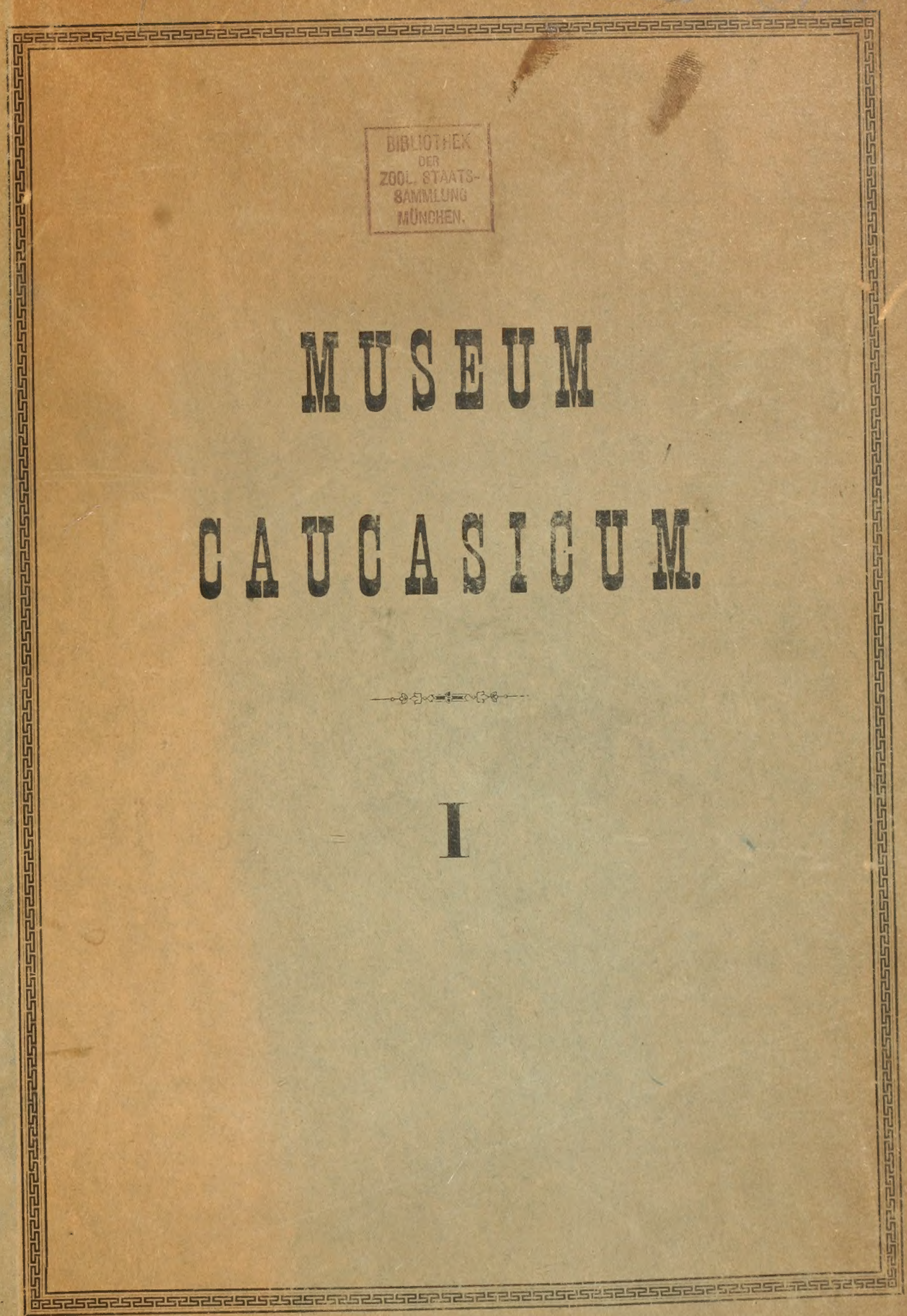




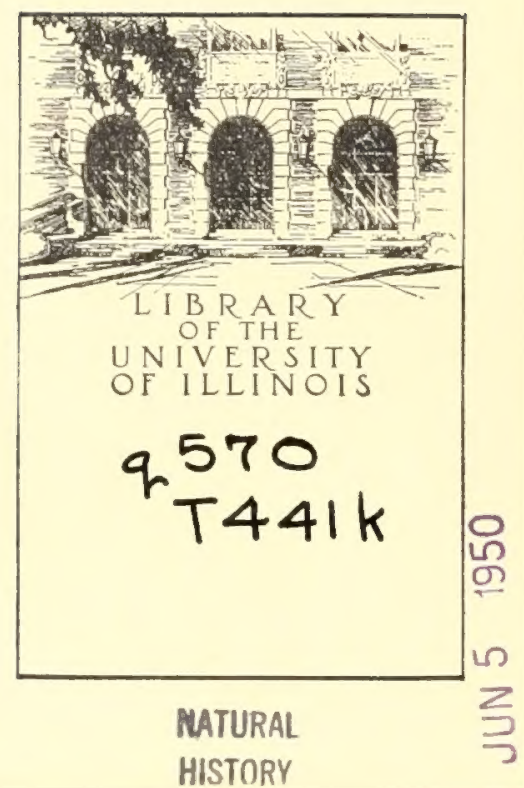


Digitized by the Internet Archive in 2011 with funding from

University of Illinois Urbana-Champaign

http://www.archive.org/details/diesammlungendes00tbil 


\section{MOJJERIII}

\section{КАВКАЗСКАГО МУЗЕЯ}

обработанныя совмБстно съ учеными спеціалистами

и

И 3 д а Н Н В Я

\section{др. Г. П. Радде}

Директоромъ, Кавказскаго музея и Публичной библіотеки вь Тифлись, Почетнымъ иленом-корреспондентомъ Королевскато Географнчсскаго общества въ Јондоны, Почетным членом Географическихъ общесть въ. Берлинь, Дрездень, Будапешт, Амстердамғ; и т. д. Членомъ-корреспондентомъ Ими. Академіы Наукъ и Ими. Геогр. обшества иъ С.-Петербург ь.

\section{ТОMЂ I. 300 I O I I I. C O С ТА В Н Ћ Ђ Др. Г. И. Радде.}

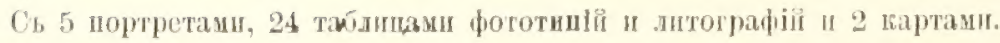




\section{DIE SAMMLUNGEN}

D E S

\section{KAUKASISCHEN MUSEUMS}

IM Vereine mit SPECIAL-GeLEHRTEN BEARBEITET, $\mathrm{und}$

HERAUSGEGEBEN

v 0 n

\section{Dr. Gustar Radde}

Director des Kauk. Museums und der offentl. Bibliothek in Tiflis, Ehrenmitglied (korr.) der Kgl. Geographischen Gesellschaft in London,

Ehrenmitglied der Geographischen Gesellschaften von Berlin, Dresden, Budapest, Amsterdam, ect., ect.

Korrespondirendes Mitglied der Kais. Akademie der Wissenschaften

und der Kais. Geographischen Gesellschaft in St.-Petersburg.

\section{BAND I. \\ 20 O I O G I E \\ VON \\ Dr. Gustav Radde.}

mit 5 Portraits, 24 Tafeln Phototypen und Lithographien und 2 Karten

TエFエエS.

Typographie der Kanzelei des Landeschefs.

1899. 
Напечатано по распорлженію Директора Кавказскаго музея и Тирлиской Публичной Њибліотеки.

Gedruckt auf Verfügung des Directors vom Kaukasischen Museum und der offentlichen Bibliothek in Tiflis. 


\title{
ЕГО ИМПЕРАТОРСКОМУ ВЫСОЧЕСТВУ
}

\author{
ВЕЛИКОМУ ГНЯЗЮ
}

\section{МИХАИЛУ НИКОЛАЕВИЧУ}

HAMbCTHUKY KaBKA3CKOMY

1863-1882

ВСЕПРЕДАННЬЙІШЕ

посвящаеть

Авторъ. 


\section{ВАШЕ ИМПЕРАТОРСКОЕ ВЫСОЧЕСТВО!}

Неизгладимыми письменами начертаны на скрижаляхь исторіи Ваши дыянія на Кавказь. Покореніемъ черкесскихъ племенъ закончена 2 г мая г 864 года выковая Кавказская война; съ 6 ноября і 877 года Русское знамя развьвается на твердыняхь Карса. Труды Ваши на поприщ⿱ гражданскаго развитія и преуспьянія края ознаменованы освобожденіемъ крестьянь оть крђпостной зависимости, введеніемь новаго судоустройства и многими другими важными преобразованіями.

Среди заб̆оть по управленію об̆ширнаго края Ваше Императорское Высочество не оставляли безъ должнаго вниманія и поощенія также и научныхъ зидачь. Составленный мною, по почину барона А. П. Николаи, планъ біологогеографичсскаго пзсльдованія Кавказскихъ странъ удостоился 14 февраля I 864 года Вашего одобренія. Посль окончанія путешествія моего по долинамъ Колхиды, возникла мысль объ основаніи Кавказскаго Музея. Ваше Императорское Высочество соизволили утвердить это предположеніе 2 іюня I 865 года, а 2 января І 867 года удостоили новое учрежденіе Вашимь первымъ посыщеніемъ.

$\mathrm{Cъ}_{\text {ъ }}$ тхъ порь прошло болье тридцати льть. Скромное собраніе предметовь естествознанія и народовьдьнія разрослось вь обширное учрежденіе, поддерживаюшее дыятельныя сношенія сь представителями науки отечественными и иностранными.

Отчеть о времени управленія моего Кавказскимъ музеемъ со дня его основанія содержится въ шести томахь систематическаго описанія его научныхъ богатствъ.

Повергая трудъ этоть къ стопамъ Вашимъ, почтительнђйше прошу милостиво принять его, какъ слабое выраженіе моей безграничной благодарности Вашему Императорскому Высочеству за постоянное и неизмынное Ваше ко мны благоволеніе и поощреніе трудовъ моихъ по научному изсльдованію Кавказскаго края.

\section{Вашего Императорскаго Высочества}

всепреданндйшій и всепокорньйшій слуга

Дира Г. Н. Радде. 


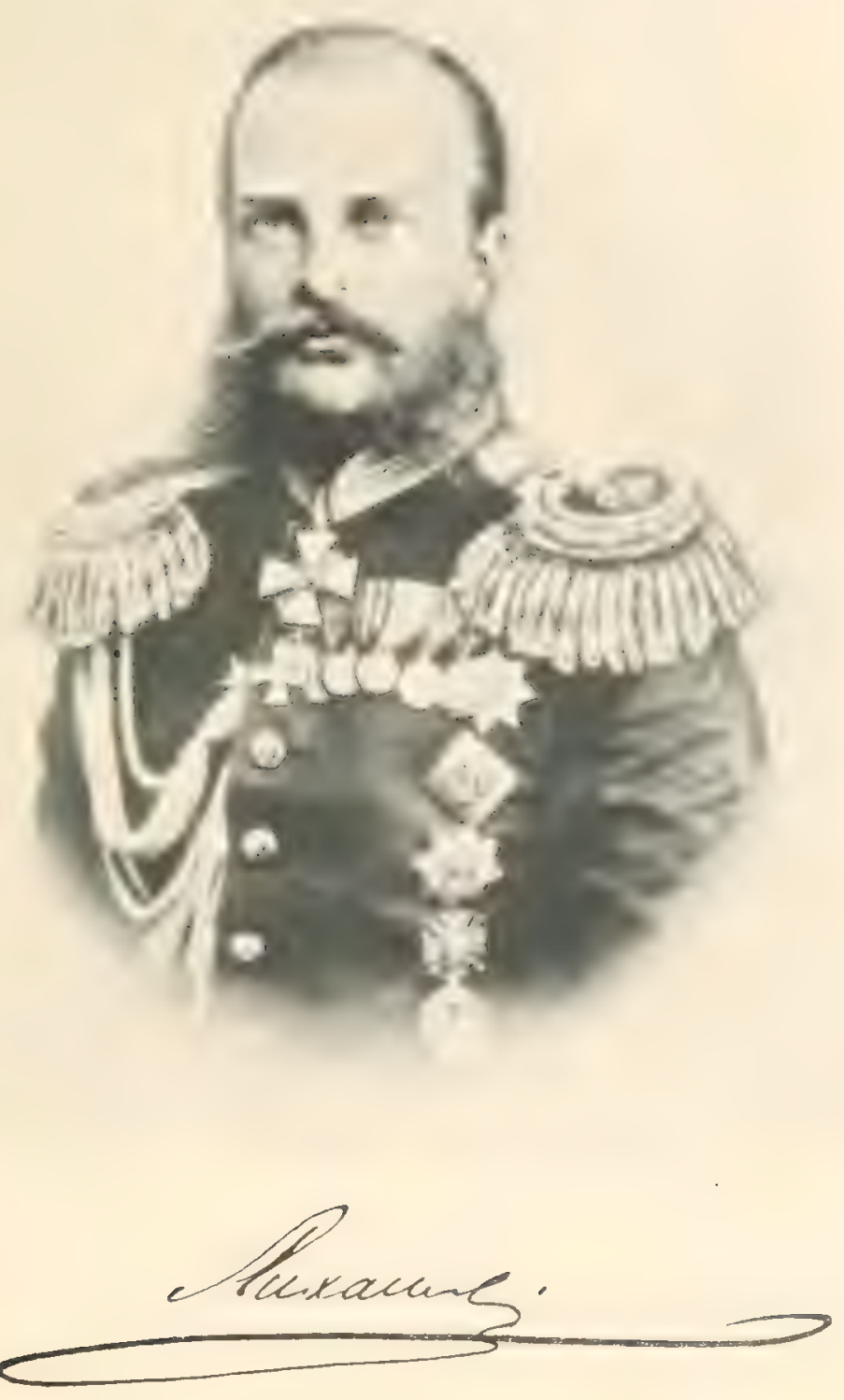





\title{
SEINER KAISERLICHEN HOHEIT
}

\author{
D E M \\ GROSSFÜRSTEN

\section{MICHAIL NIKOLAJEWITSCH} \\ STATTHALTER des kaUkASUS \\ 1863-1882
}

IN EHRFURCHT UND DANKBARKEIT

gewidmet

vom Verfasser. 


\section{EURE KAISERLICHE HOHEIT!}

\section{Erhabener Grossfürst und Herr!}

Mit eherner Iapidurschrift sind dic Kriegs-und-Sicgesthaten, welche Ew. Kaisl. Hoheit wahend Ihrer Regierungszeit der Kaukasuslïnder vollbrachten, für alle Zeiten im Buche der Geschichte verzeichnet.

Am $2 I^{-t}$ Mai I 864 war das Gebiet der Adige-der nordwestliche Kaukasusendrëltig untervorten; am $6^{-1}$ November $187-7$ wehete an Stelle des Halbmondes dic russische Standarte auf der Citadelle von Kars.

Auf dem friedlichen Boden der inneren Entwickelung des Landes stehen als daucrnde Marksteine Ihrer crleuchteten Verwaltung dic Befreiung der Baucrn, die neuen Gerichtsinstitutionen und eine Reihe anderer administrativer Reformen da.

Auch der Wissenschatt greruheten Ew. Kaisl. Hoheit cincn würdigen Platz anzuwisen. Das ren mir, nach den Intensionen des Barons Nicolai, entworfene Programm

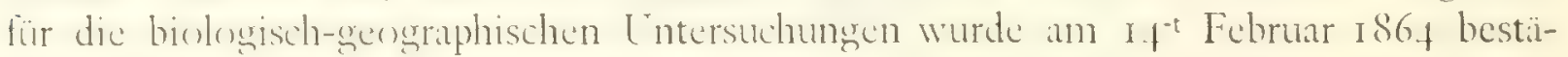
tigt. Nach Vollendung meiner ersten Reise in die kolchischen Längenhochthäler traten die Pline zur Gründung des Kaukasischen Muscums hervor. Am 2-t Juni i 865 worden sie bestittigt und am $2^{-t}$ Januar I 86 , würdigten. Ew. Kaisl. Hoheit das junge Museum eines ersten Besuches.

Seit jenen Tagen sind 32 Jahre verflossen.

Aus den kleinen Anfängen hat sich cin grosses Institut entwickelt, welches auf den wissenschaftlichen Gebieten mit dem In-und-Auslande in regstem Verkehr steht.

Was ich im Verlaufe dieser langen Zeit gearbeitet habe enthalten die sechs Bände über die Sammlungen des Kaukasischen Museums.

Eurer Kaiserlichen Hoheit lege ich sic zu Füssen mit dem innigen Wunsche, dass dic Donkbarkit in mir Ew. Kaisl. Hoheit gecgenüber meiner Begeisterung und Pllichttreme im Dienste der Wissenschaft ebenbeirtis sic und seitens Ew. Kaisl. Hoheit ein anerkennender Blick auf mein Werk falle.

unterthänigst

Ew. Kaisl. Hoheit

getreuester Diener

Dir. A. Raile. 



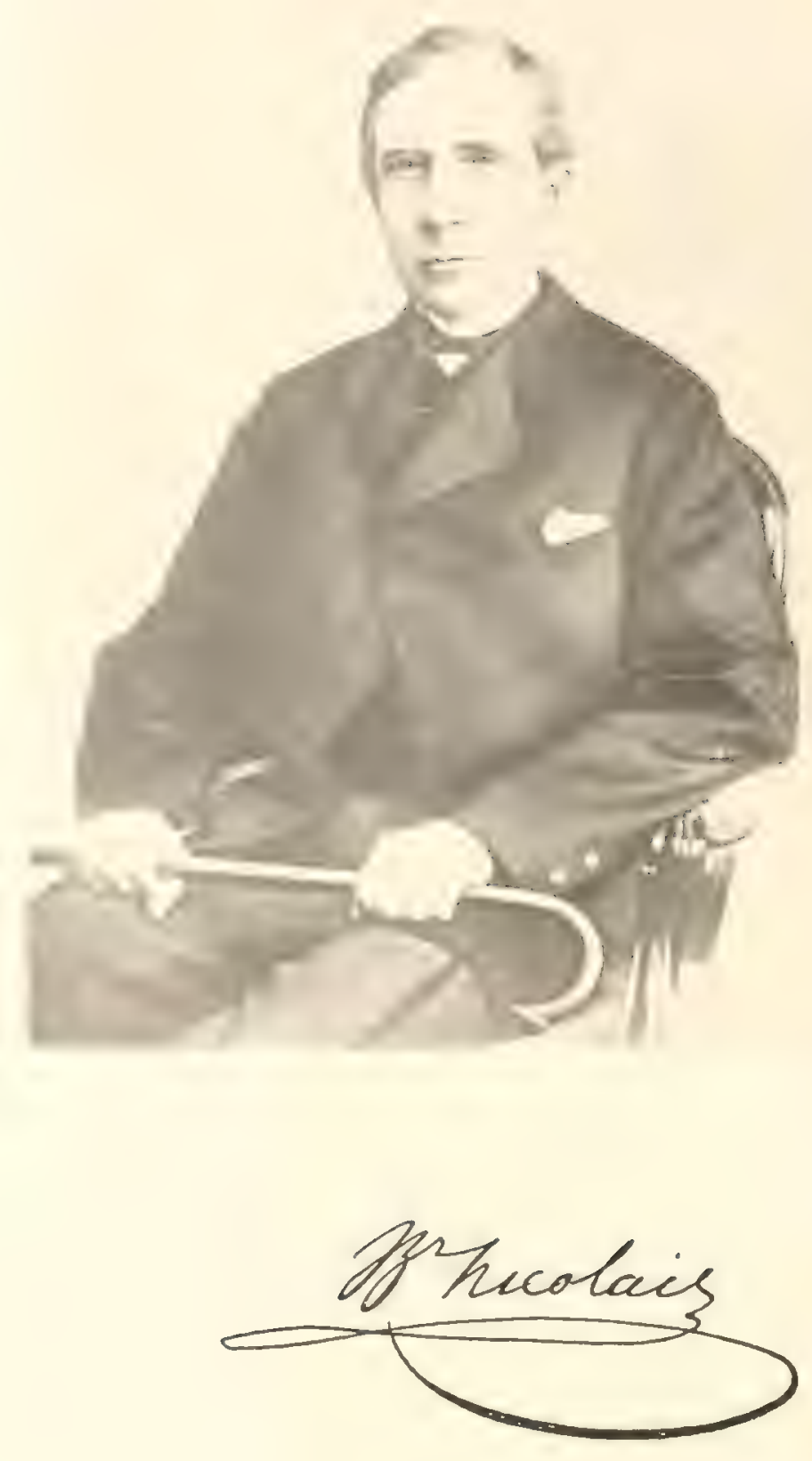




\section{Herr Baron!}

Als Sie vor sechsunddreissig Jahren mein breites Program für die biologisch-geographischen Untersuchungen der Kaukasuslïnder entgegennahmen und mir für die Ausführung desselben volles Vertrauen schenliten, war damit auch die Idee zur Gründung eines Museums gegeben, welches die erworbenen Schätze jedweder Art dieses herrlichen Landes in sich aufnehmen und sie in übersichtlicher Anordnung dem Besucher vor die Augen führen sollte.

Mein Werk konnte nur gedeihen unter dem mächtigen Schutze Sr. Kaisl. Hoheit des Grossfürsten Statthalters und dem erlcuchteten Interesse, welches Sic der Wissenschaft und meinem Streben stets entgegenbrachten. Deshalb gestatten Sic mir, Herr Baron, Ihnen an dieser Stelle zu dankien in dem befriedigenden Gefühle, dass ich Ihren Erwartungen, soweit es die gebotenen Mittel und ïussere Verhältnisse gestatteten, entsprach und freudig meine Pflichten so lange Jahre hindurch der Wissenschaft, dem Staate und Ihnen, Herr Baron, gegenüber erfüllte.

Ir. G. Rastele.

Sr. Hohen Excellenz

Herrn Baron A. P. Nikolai.

Tiflis in Mai 1899. 



\title{
„КОЛЛЕКЦИ КАВКАЗСКАГО МУЗЕЯ“.
}

\author{
MPOIPAMMA.
}

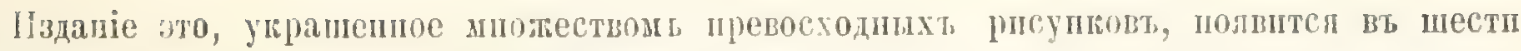
томахт, какдиі вь подичеств 500 әкземллровт.

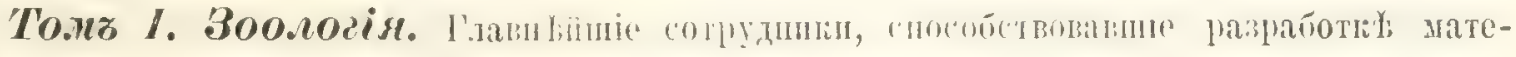

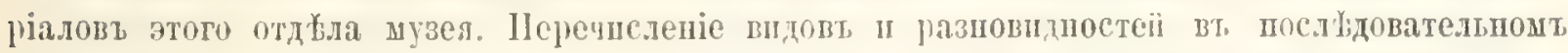

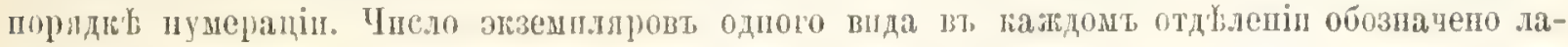

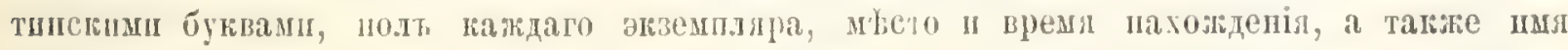

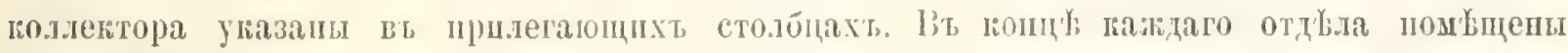

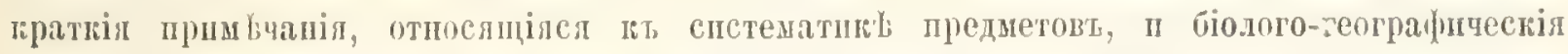

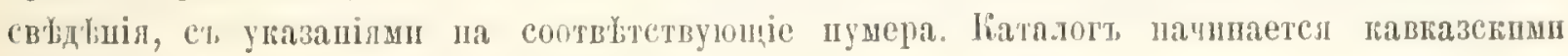
позвоночными й допчаегея низшими животпыми Чернаго моря.

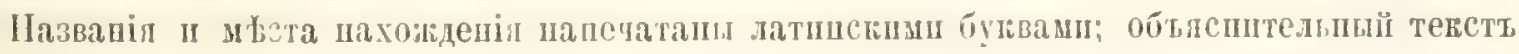

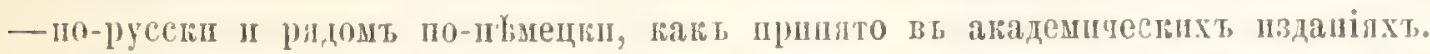

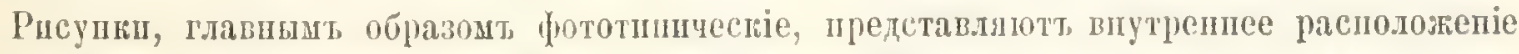

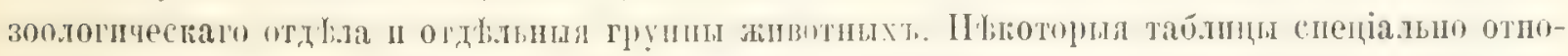

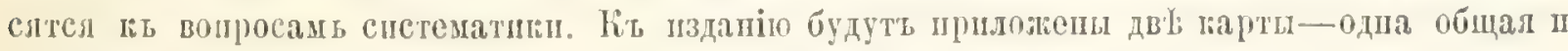

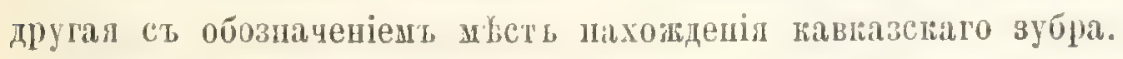

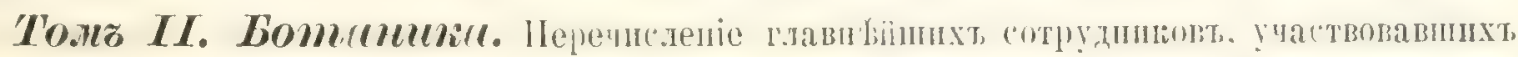

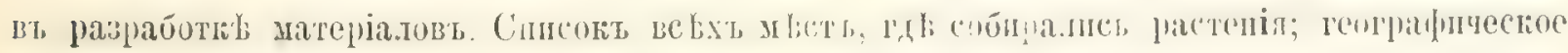

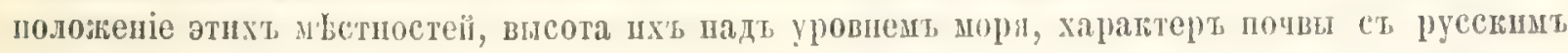
Iп и иециия обълспительным тегстомъ.

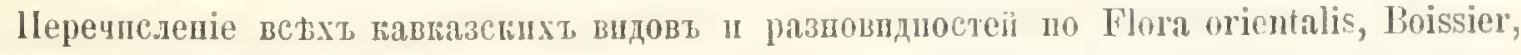

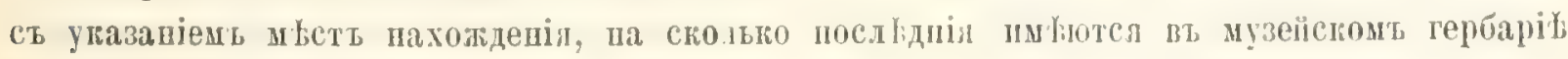
(около 3500 видовь).

Cписокт кавказскихт тайнобрачныхь и места пхт пахотдепіл.

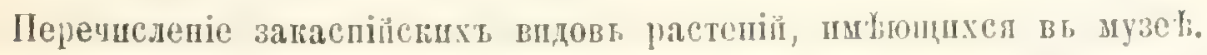

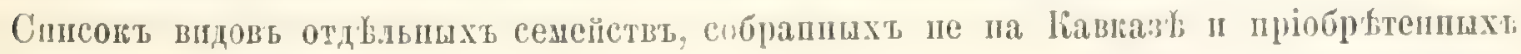
пакт матеріаль длл сравненіл.

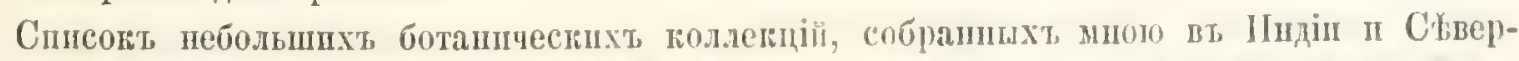

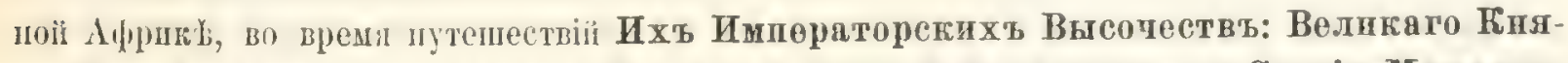
яя Насльдника Цесарөвича и Великихъ Князөй Алөксандря п Сергія Миханловичей.

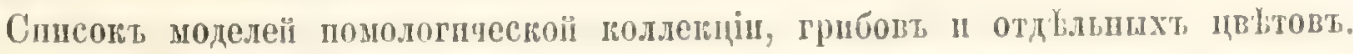

ІІпшки хвойныхт и особепно интереспье экземплири растеній. 
Составь дентродогтеской поляетцін.

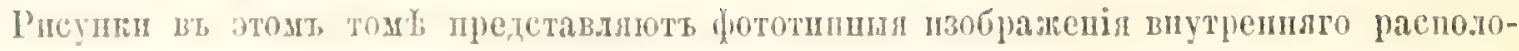
menia ботанческаго отыней.

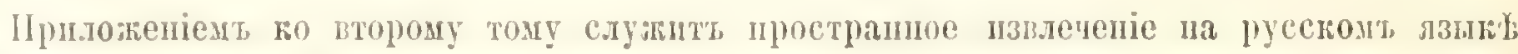

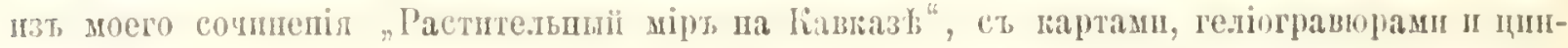

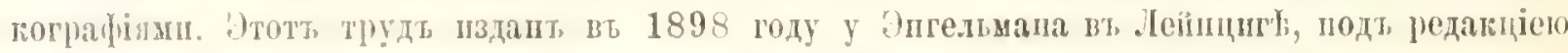

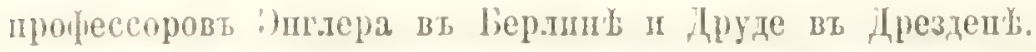

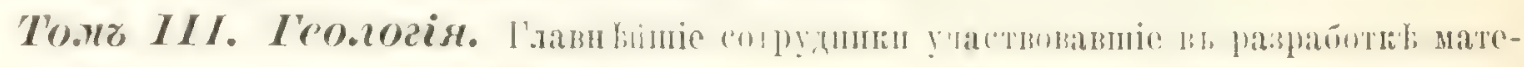

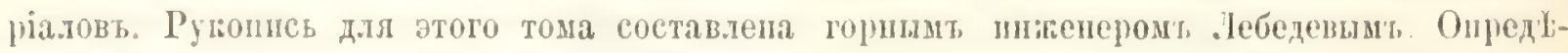

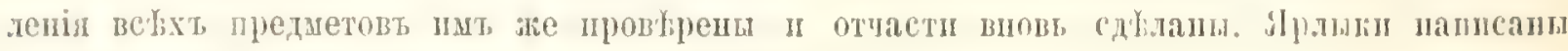

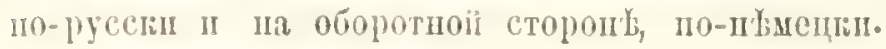

Каталог' содерлить:

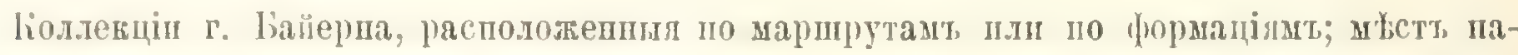

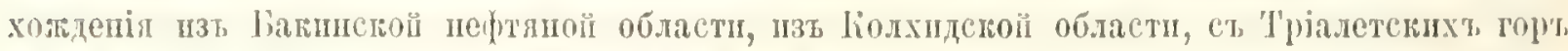

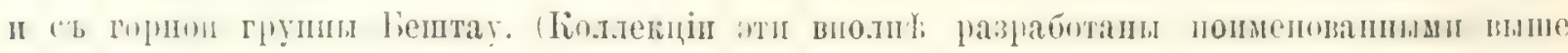

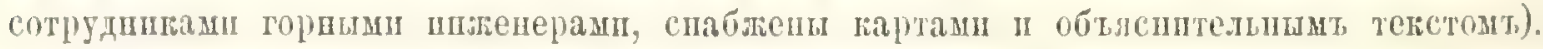

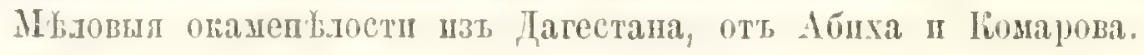

Металлургческіе образци, образц миераловт и строптлынхт матеріаловт, пзт, различихт, мустпостей Кавказа.

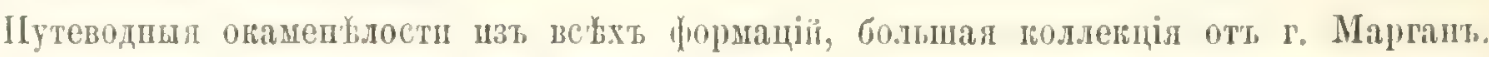

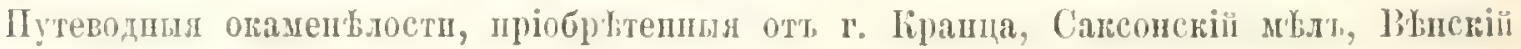
третпчшй бассейпт.

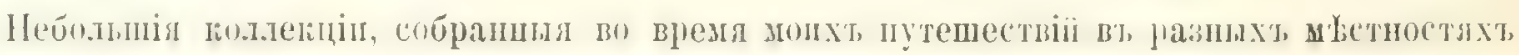
Kaвтаза. Арарать, Алагезг, Аралст, восточпй берегь Уернаго морл и проч.

Модели, отдъ.лыне особенио иптересшые образци, гарты.

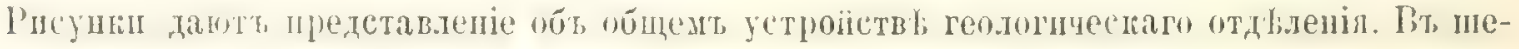

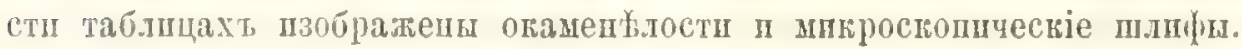

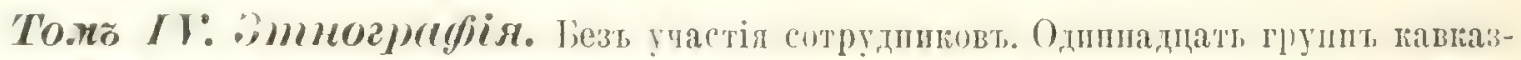

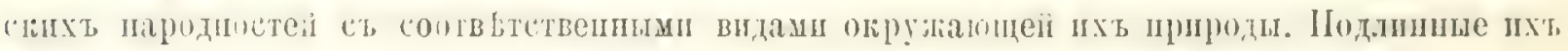

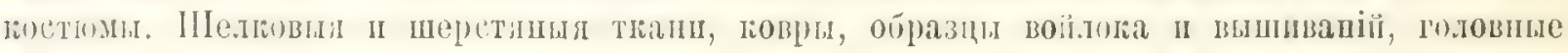
уборы ш обувь. Сосуды пзт дерева, металл, глин и шитера, восточиые новые изразци (майолики).

Opузіе, арматуры, огнестрбльпе п холодное оружіе.

Модели этллшқ п поселепій, полевыхт, орудій п домапней утвари, повозовь и лодокт.

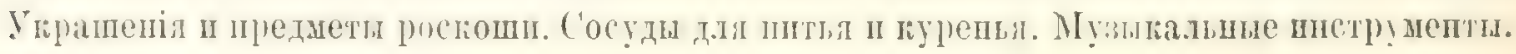

Миніаторныя нодели народностей Россіиской ІІперіи.

Фотографи: пародие тпш; групш, строенія, поселенія и виды мхстностей.

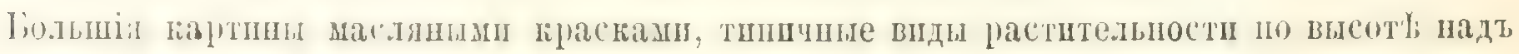

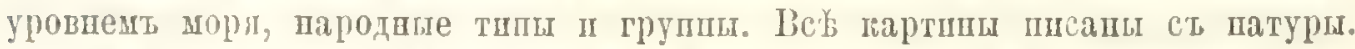

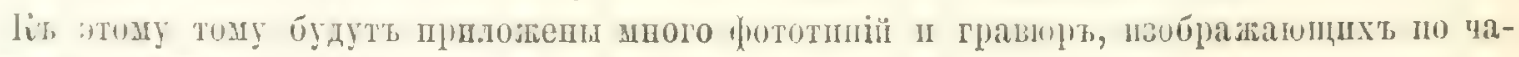

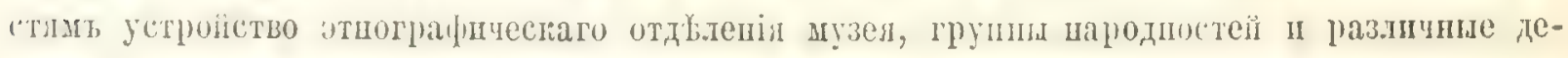

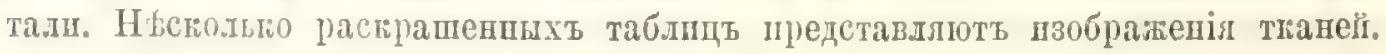

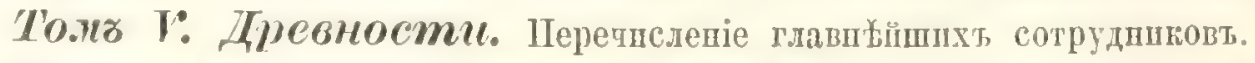

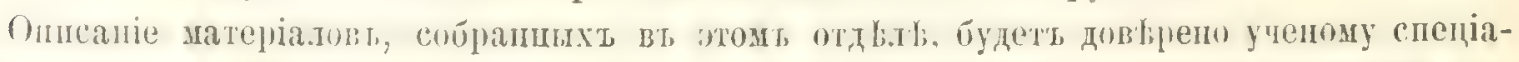

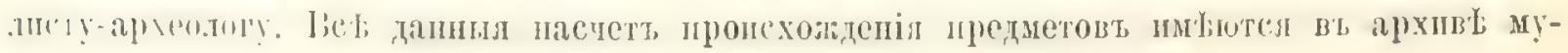




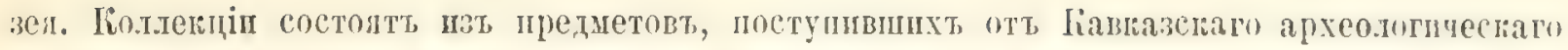

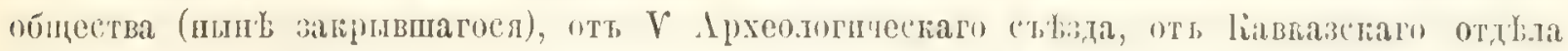

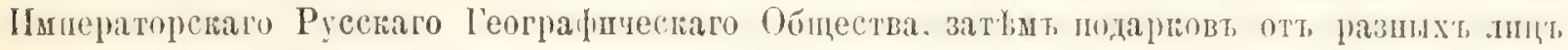
и из пріобрятепій, сдылапихт во время мопхт путешествї.

Древпостп музея располовени по четыремъ главным рьным системам.

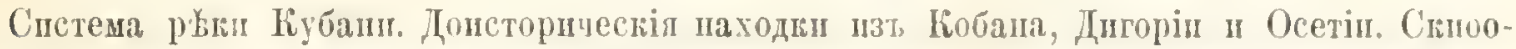

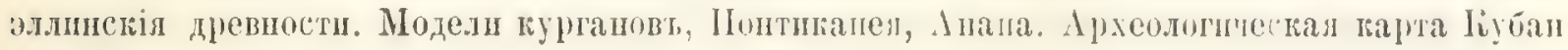
ской областг.

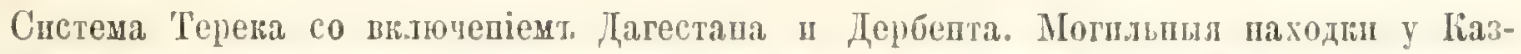

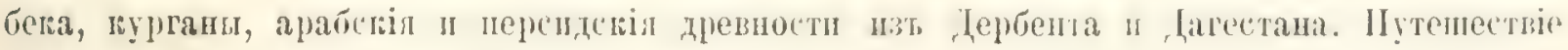
Олеарія. Шзт, ЗЗакаспійскаго грая.

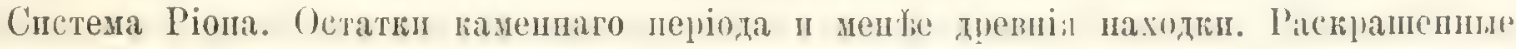
рисунгп мозань (mosaïque cloisonné) изт, I'елатскаго собора.

Система Куры и Аракса. Могльныл паходи изт Сантара и Редниа, изт, өрпвапсъой области и пзт Карабага.

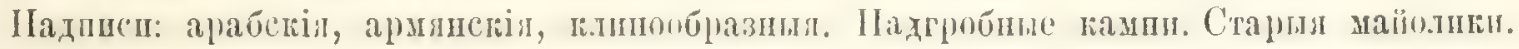

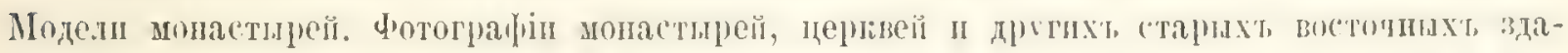

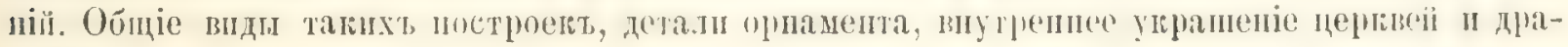
гопьности.

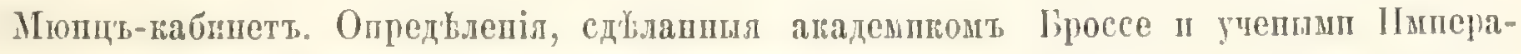
торскаго Әрмитажа. Спнсокт подаренних монеть.

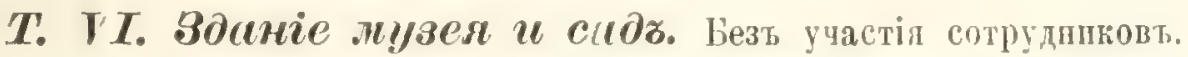

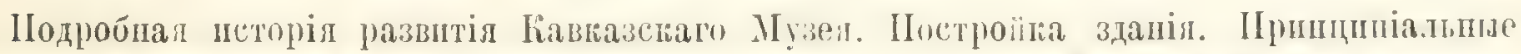

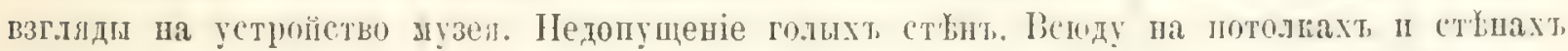

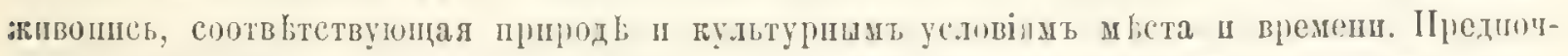

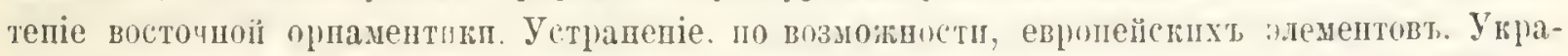

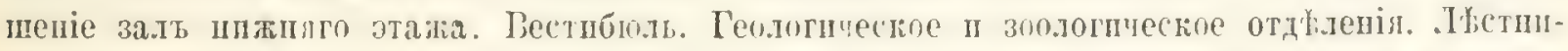

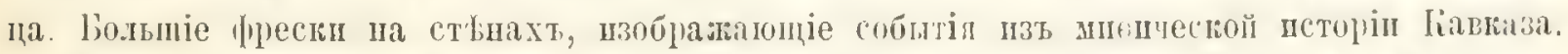

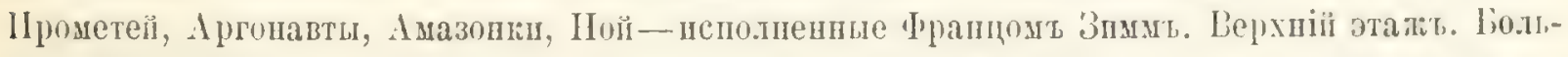

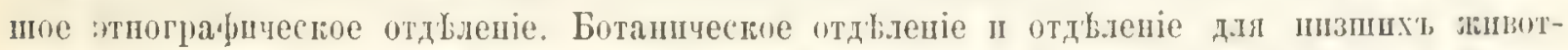

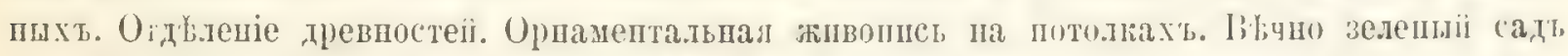

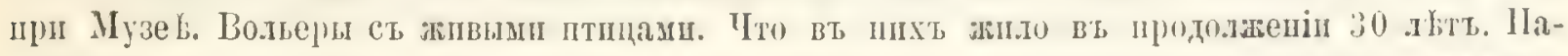

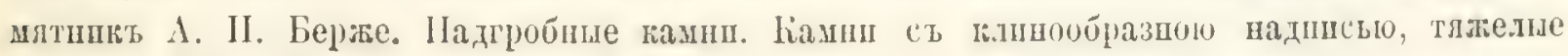
каменные орнаменть.

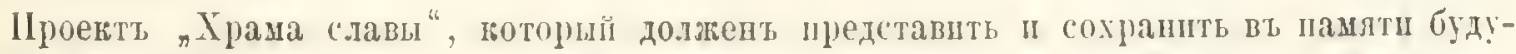

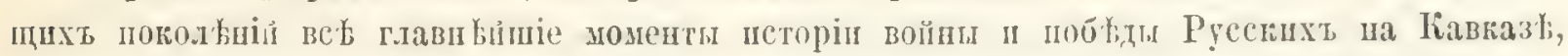

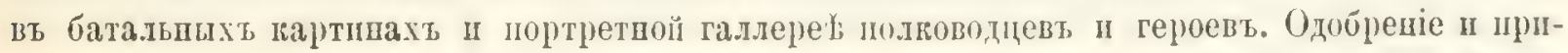

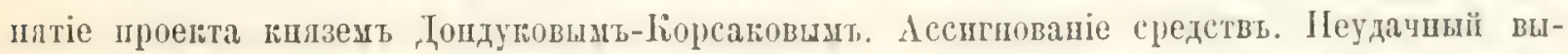

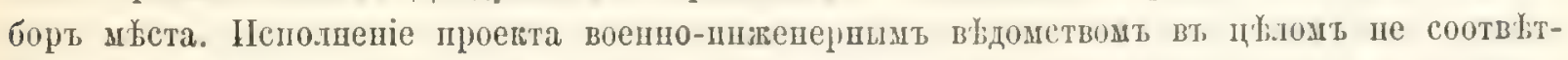

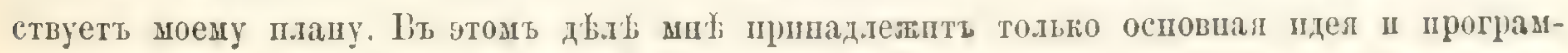

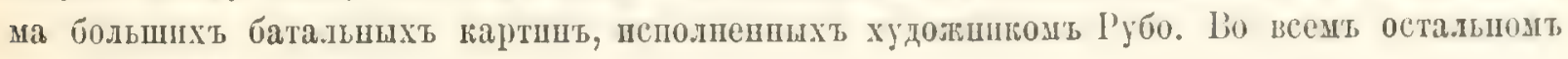
л не принималь участіл.

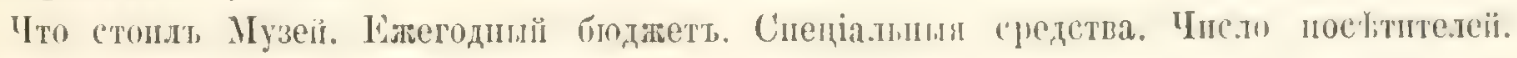
ІІолный списогъ ве'ххт сотрудниовт. 


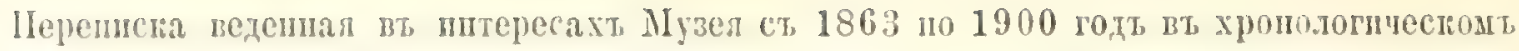

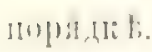

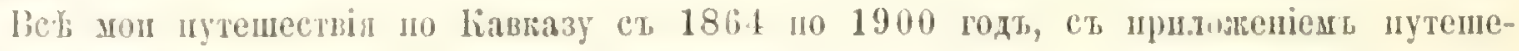
ствіï совершеншкт миол сь 1852 по 1863 годт.

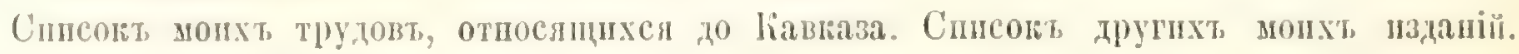
lipartiú oчepro sоeй жизи.

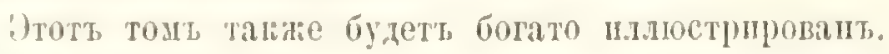

Заключеніе. Іредиолояенія насчетъ будуцисти Кавтазскаго Музея.

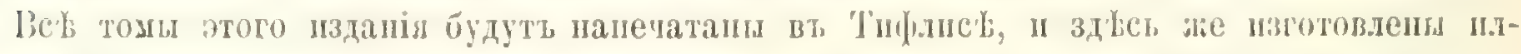

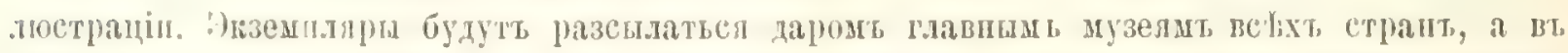

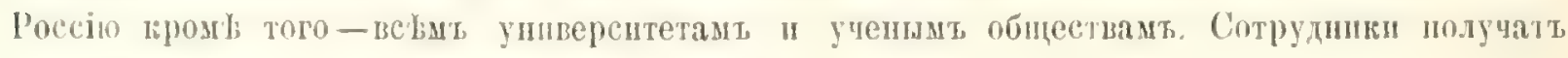

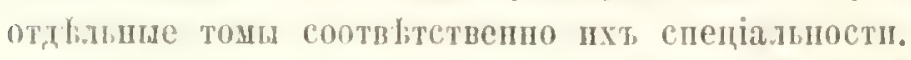

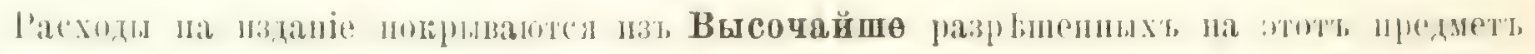
вредствт.

Нечатаніс тощовт, I ІІ ІІІ пачнетея вт, полор); настолщаго года.

¿иректорт, Д-рт, I'. Padde.

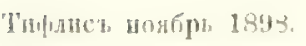

5 сентибра настоцаго р.да Ето Императорское Высочество Великій Княвь

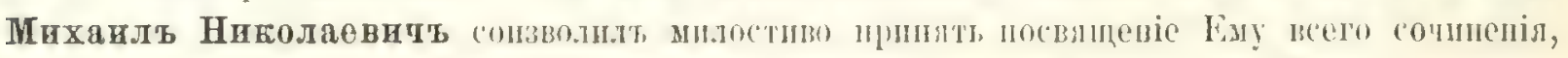

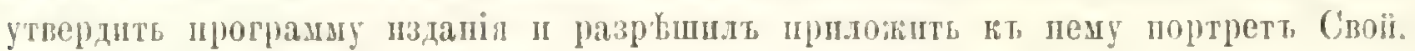

'Такае сонзволили припль посвященіе отдыловъ:

Его Императорскоө Высочөство Великій Киязь Насльдникъ Цөсаревичъ Георгій Алөксандровнуь-отділ рыбт.

Его Императорское Высочество Великій Князь Николай Михапловпчь-отдыль чешуецилыхт.

Его Императорское Высочество Великій Князь Сөргій Михаиловичь-статл o liавказсконт зубрт.

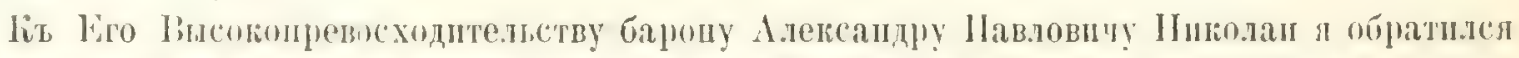

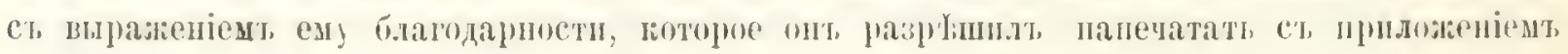
кі изданію своего портрета. 


\section{„DIE SAMMLUNGEN DES RAUKASISCHEN MUSEUMS“.}

\section{PROGRAMM.}

Das reich illustrirte-Werk erscheint in sechs Bänden und in einer Autlage von 500 Exemplaren. Es enthält:

Bd. I. Zoologie. Nennung der vornehmlichsten Mitarbeiter.

Aufzählung aller Arten und Varietäten, sowie aller Exemplare unter fortlaufender Nummer der Species, welche in jeder Abtheilung mit Ji: beginnt. Die Zahl der vorhandenen lixemplare wird mittelst liuchstaben des Tateinischen Mphahetes markirt. In den sich anschliessenden linhriken werden Geschlecht, Fumbrt, Iatum und Yamen des Sammlers bei jedem Exemplare notirt. Am Ende jeder Abtheilumg folgen mit Angabe der entspredenden Nummern kurz gehal-

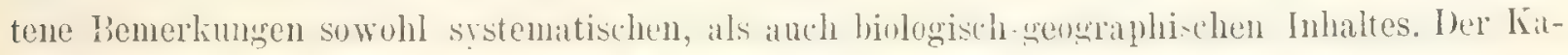
talog begimnt mit den kankasischen Wirbelthieren und endet mit den niederen Thieren des Schwarzen Meeres.

Namen und Fundorte werden lateinisch, Text I'ussisch und daneben deutsch (wie bei manchen der akademischen Publicationen) gedruckt.

Die Illustrationen, meistens Phototypen, stellen sowohl allgemeine Ansichten des Arrangements der" zoologischen Abtheilung, als anch Gruppenbilder dar. Einige Tafeln sind speciell der Systematikjgewidmet. Eine Uebersichtskarte und eine andere, die Standorte des Anerochsen im Kaukasus zur Anschaung bringende, sind in Aussicht genommen.

Bd. II. Botanik. Nennung der vornehmlichsten Mitarbeiter.

Verzeichniss aller Sammelplätze, russisch und deutsch mit Angabe der Ortslage, IIolıe über d m 'Meere: und Charakteristik des Borlens.

Aufzïhlung aller kaukasischen Arten und Varietäten mit $\Lambda$ ngabe der Fundorte, sowcit solche im Herbarium des Musenms vorhanden sind nach der I'lora orientalis von Boissier (reichlich 3000 Species).

Verzeichniss der kaukasischen Cryptogamen mit Angabe der Fundorte.

Aufzählung: der vorhandenen transkaspischen Pflanzenarten.

Verzeichniss der Arten einzelner Familien, welche nicht im Kauliasus gesammelt und als vergleichuares Material beschafft wurden.

Verzeichniss der kleineren botanischensusbeuten von den Reisen nach Indien und NordIfrilia mit Ihren Kaisl. Hoheiten dem Grossfürsten Thronfolger nud den Grossfürsten Alexander und'Sergei Michailowitsch.

Verzeichnis: von den Modellen der pomologischen Sammlung, von Pilzen und cinzelnen Blüthen.

Verzeichniss der Coniferen Zapfen und einzelner interessanten Pflanzenexemplare. 
Verzeichnisi der dendrologischen Sammlung.

Die zu diesem liande gehörenden Jlhustrationen veransehaulichen in Phototypen die Arrangements in der botanischen Abtheilung.

Als Anhang wird diesem Bande ein umfangreicher Auszug aus meinem Werke nde Pflanzenwelt der Kaukasusländer" mit allen Karten, Ifelio-mo-Zhinkogravüren nur in mssischer Slrache beigefügt. Dieses Werk erscheint Fude 1898 unter der Redalition der I'rofessoren Engler (Berlin) und Drude (Dresden) bei W. Engelmann in Leipzig in deutscher Sprache.

BN. IIT. Geolorgie. Nennung der vornehnlichsten Mitarbeiter.

Herr Bergingenieur Lebedew hat das Manuscript dieses Bandes hergestellt. Die Bestimmungen aller Objecte wurden von ihm revidiert, resp. gemacht Die Signaturen sind russisch und auf der Rückseite dentsch. Die Kataloge enthalten:

Die Sammlungen von F. Bayern nach Marschronten oder nach Formationen von gewissen Localitäten.

Das Naphtagebiet ron Bakil

Das colchische Gebiet / volistandig bearbeitet mit Karten und Test versehen

Aus dem Trialeth

Die Gruppe des Besehtin

Dagestanische Kreide Verstemerungen ron Abich und Komarow. Kaukasus.

Metallurgische Belegstücke, Mineralien, Baumaterial von verschiedenen I,ocalitïten im

Leitfossilien aus allen Formationen, grosse Sammlung von Herrn Morgan.

Leitfossilien gekauft von Krantz.

Sächsische Kreide.

Wiener' Becken (tertiair).

Kleinere Sammlungen von verschiedenen Iocalititen, welche während neiner Reisen besucht wurden. Ararat, Mlagös, Araxes, Ostufer des L'ontus ect

Modelle, Schaustücke, Karten.

Die Illustrationen repräsentiren das Arrangement. Scchs Tafeln geben Abbildungen von Versteinerungen und Schliffen.

bil. I V. Ethmogrophie. Ohne Mitarbeiter.

'Zwölf kankasische Völkergruppen, zum Theil in gemalter landschaftlicher Umgebung. Original Kostüme.

Stoffe in Seide und Wolle. Gewebe, Teppiche, Filze, Stickereien. Kopf-unt-Fussbedeckung.

Gefässe in Holz, Metall, Thon, Schiefer, orientalische moderne Majoliká.

Waffen, Irmaturen, Feuerwafien, kalte Waffen.

Iodelle von Gebüuden, Ansiedelungen, Acker-und-Hausgeräthen, Wagen, Böten.

Schmuck-und Luxus-Objecte. Trink-und Ranch-Gefisse. Musikalische Instrumente

Miniatur Modelle der Völkerschaften des Russischen Reiches.

Photographien: Völkertypen, Gruppen, Bauten, Insiedelu:gen, Landschaften.

Grosse Bilder in Oel, typische Vegetationsansichten nach den Meereshöhen, Vülkertypen, Gruppen. Alles mach der Natur gemalt.

Dieser Band wird durch eine grosse Anzahl von Phototypen und Graviren illustrirt. Die ersteren stellen Ansichten des Arrangements und die Vökergruppen dar, die letzteren ethnographische Details. Für die Gewebe sind etliche Tafeln in Farbentruck bestimmt. 
Bd. V. Alterthümer. Nennung der vornehmlichsten Mitarbeiter.

Die Bearbeitung dieser Abtheilung wird einem Special Gelehrten anvertraut. Alle Documente uber die Ierkunft der Objecte liegen im Archir des Museums vor. Die Collectionen bestehen aus den Beitrïgen der ehemaligen hauk. archaeologischen Gesedschaft, vom 5 t. archaeologischen Congress, von der kauk. Abtheilung der Kaisl. Geographischen (ievellschaft, von verschiedenen Sehenliungen und aus den dequisitionen, welche ich während meiner lieisen machte

Die Alterthümer sind nach den vier Flusssystemen aufgestellt:

Kubrn System. Siytho-hellenische Alterthumer, Kurgan Nodelle, Panticapaemm, Anapa. Karte mit Verzeichniss der Fundstellen.

Terel: System. Mit Einschluss vom Dagestan und Derbent. Vorhistorische Funde von Koban, aus Digorien, Ossetien. Gräberfunde rom Kasbek, Kurgane, Arabisches und alt Persisches von Derbent, aus dem Dagestan. Reise von Olearius. Aus Transkaspien.

Rion System. Reste aus der Steinzeit, jüngere Funde. Zeichnungen in Farben von Mosaik cloisonné aus der Kathedrale von Gelati.

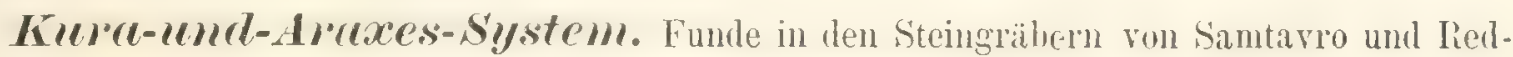
kin. Aus dem eriwanschen Gebiete. Von Karabagh.

Inschriften, arabische, armenische, Kuilschrift. Grab-teine. Mte Majolika. Modelle von Klüstern. Photographien von Kibustern, Kirchen und profanen orientalischen alten Prachtgebäuden. Gesamutansichten solcher lauten, Ornament Details, innerer Kirchen-chnuck unl Kostbarkeiten.

Mrïn:aboinet. Bestimmungen ron Frosset. Bestimmungen ron den Gelehrten der Kaisl. Ermitage. Verzeichniss geschenkter Mủnzen.

Bd. TI. Gebïude Wnd Gurten Mes Museums. Ohne Mitarbeiter.

Ausfuhrliche Entwickelungsgeschichte des Museums. Die latuten. I'rinzipielle Anschauungren. Keine kahlen Wände. Ueherall den Natur-und-Kultur-Verhältnissen entsprechende Wandund-Deckenmalerei. Bevorzugung der orientalischen Ormamentik. Nöglichste Vermeidung europäischer Elemente. Ausschmükung der liäume in der unteren Etage. Das Vestibul. Die geologische und die zoolorgische Abtheilung Das Treppenhaus. Grosse Wandfresken a tempera die kaukasischen Mythen anlangend: P'rometheus, die Argonauten, Amazonen, Noah, von Franz. Simm gemalt. Die ohere Etage. Das grosse Ethnographikum. Die Abtheilung für Botanik. Die Abtheilung für niedere Thiere. Die Altheilung für Alterthümer. Ornamentale Deckenmalerei.

Der immergrüne Garten bei dem Museum. Die Volieren mit lebenden Vügeln. Was darin im Verlaufe von 30 Jahren gelebt hat. Bergés Monument. Grabsteine. Keilinschrift, schwere steinerne Ornamente.

Mein Project einer Ruhmeshalle, welche die Kriege und Siege der Russen im Kaukasus in ihren wichtigsten Momenten durch dine lieihe von Schlachtenbililern und durch tine I'ortraitgallerie der Fetherrn und Ilelden dem Iesthaner vorführen und der Zukunft in lible erhalten soll. Annahme desselben durch den f'ürsten Dondukow-korsaliow. liewilligte Hitel. Verfehlte Wahl des I'latzes. Dir Auführung durh die Ingenienre des Militairressorts. An der ganzen Sache gehört mir nur dic Grundidee, der Plan und der Auftrag für

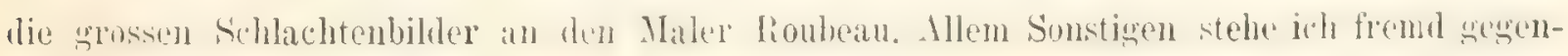
iiber. Das Ganze entspriclit nicht dem, was ich wollte.

Was das Kaukasische Museum geliosten hat. Sein jährliches Budget. Seine Special Mit- 
tol. Zahl der Besucher. Vollstindiges Verzeichniss aller Mitarieiter. Die Correspondenzen im Interesse des Museums meiner Reisen und wissenschaftlichen Beziehungen von 1863-1900 chronolorisch nach Jahren geordnet.

Alle meine kaukasischen leiserouten von 1864-1900 mit Anhang uber die lieisen von $1852-1863$.

Verzeichniss aller meiner die Kaukasusländer angehenden Editionen. Anhang sonstiger Werke, die ich schrieb. Kurzer Abriss meines Lebenslaufes.

Auch dieser land ist reichlich illustrirt.

Schlass. Wie wird sich die 'Zukunft für das Kaukasische Museum gestalten?

Die Herstellung des Werkes in Druck und Illustration wurde in Tillis besorgt. Wis wird mucntgreldich an die bellentendsten Museen aller Länder, in liussland auch an die Univer-

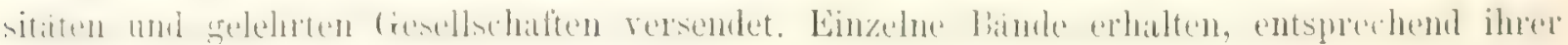
Specialitit, die Mitarbeiter.

Die Unkosten werden aus den Allerhöchst bewilligten Extra-Iü̈lfsmittelı des Museums bestritten.

Der Druck von Dil. I und Bil. III begrinnt im Novemker dieses Jahres.

Direktor, D1: G. Radde.

Tillis im Novb. 1898.

In ; Sentember 1. .T. erenheten Sr. Kaisl. Hoheit der Grossfürst Michail Nikolajewitsch die Widnung des gangen Werkes huldvollst cutgeren zu nehuen, das l'rogramm zu bestatigen und zu gestatten sein Portrait dem Werke hinzuzufügen.

Ebenzo geruheten die Widmung folgender Abschnitte entrgegen zu nehmen:

Sr. Kaisl. Hoheit der Grossfürst Thronfolger Georg Alexandrowitseh, die Fische.

Sr. Kaisl. Hoheit der Grossfürst Nicolai Michailowitsch, die Lepillupterie.

Sr. Kaisl. Hohoit der Grossfürst Sergei Michailowitsch, den Artikel ühre den kaukasischen Wisent.

An Sr. hohen Excellenz den Baron A. P. Nikolai wendete ich mich bei Gelegenheit der Publikation dieses Werkes mit einigen Dankesworten, welche zu drucken und sein Portrait hinzuzufügen, gestattet wurde. 


\section{OTЂ ABTOPA.}

டіто въ пастоящее время хочеть райотать вт области оншательной зоодогіи или бота-

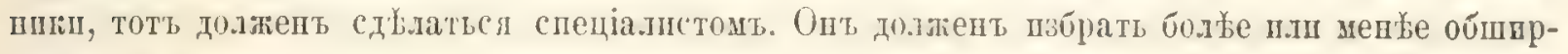

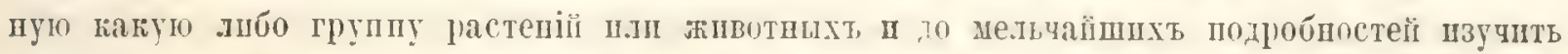

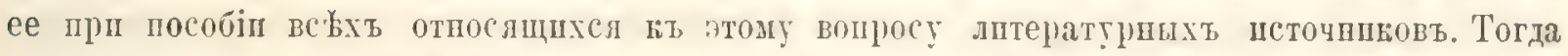

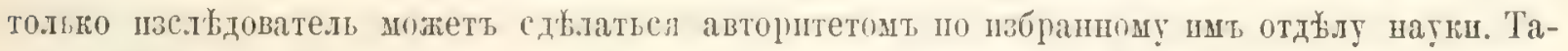

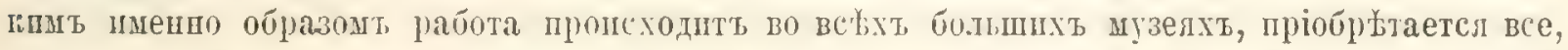

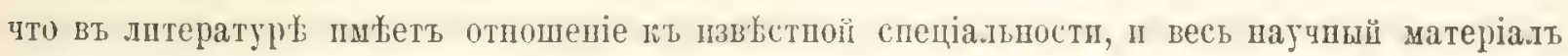
распредъляетсл д.ля пзученія мезду спеціалпстамп. Одинъ пзъ нихъ, напр., занимается пе

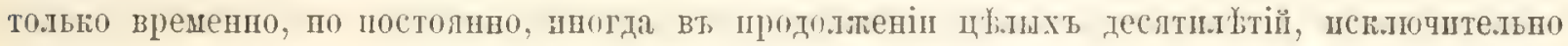

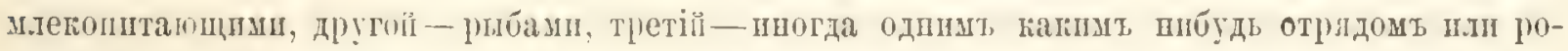

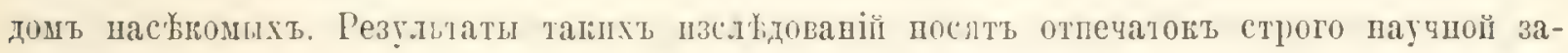

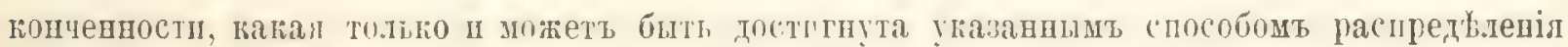
работ'т.

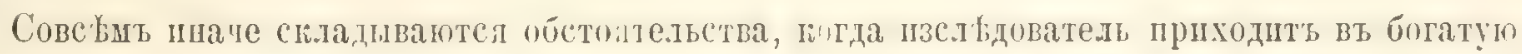

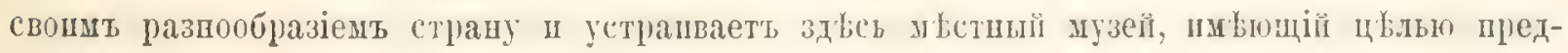

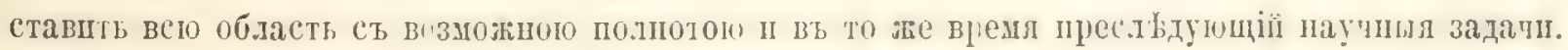

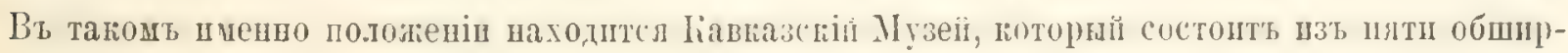

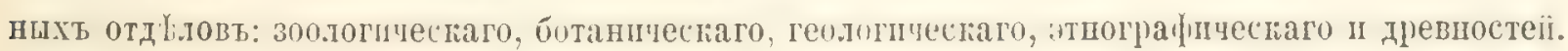

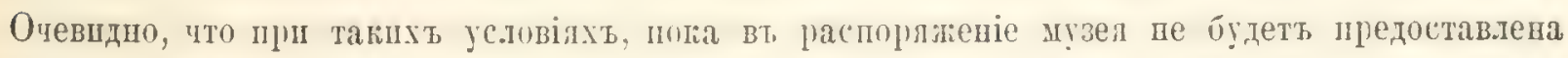

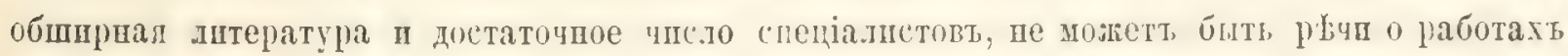

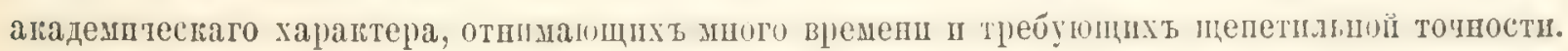

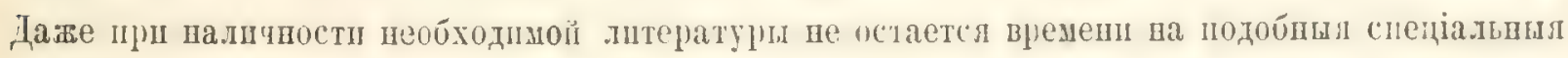

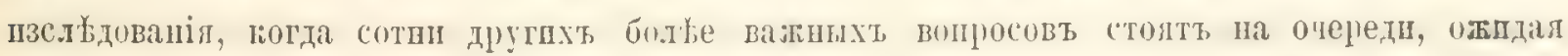

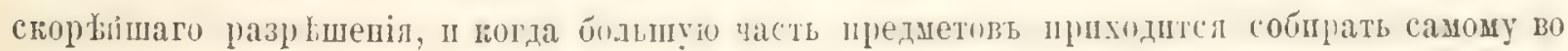

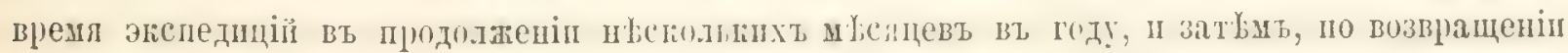

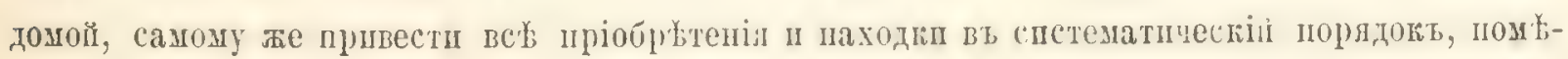

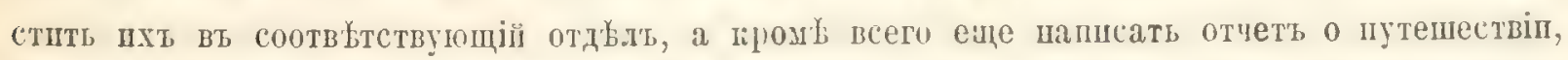

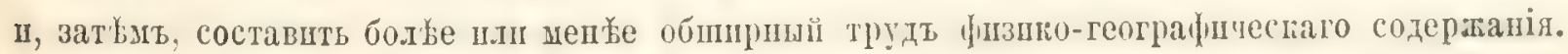

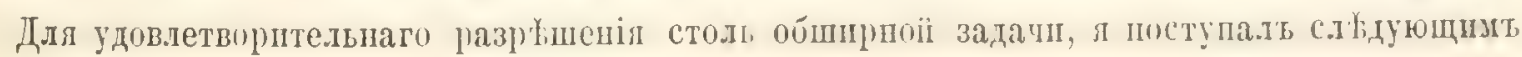
образощт:

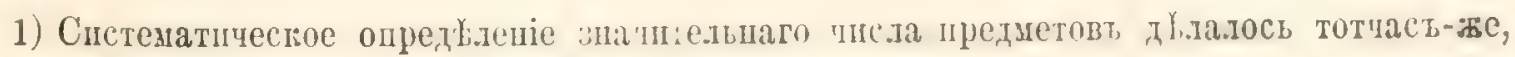
если не требовалось особыхт научно-литературпвх пособіи. 


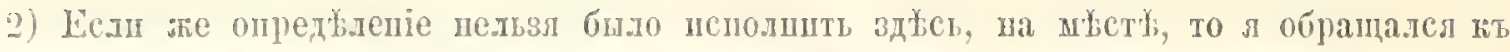

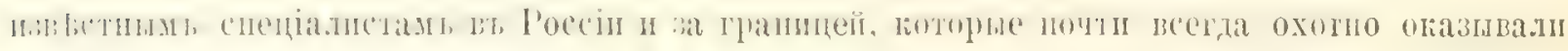

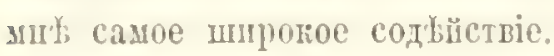

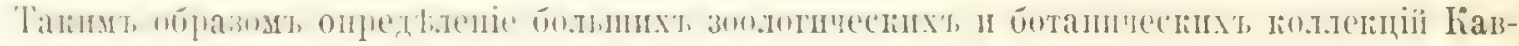

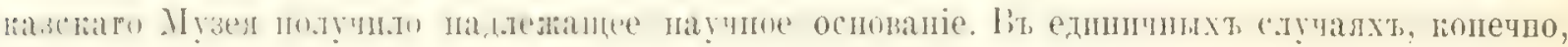

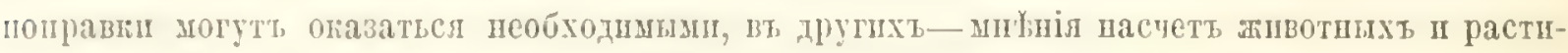

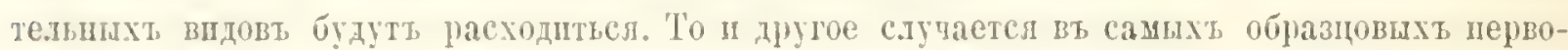

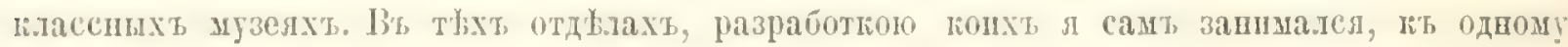

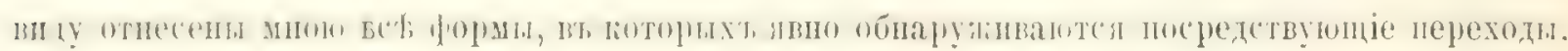

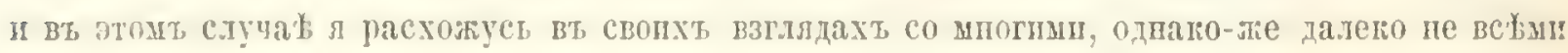

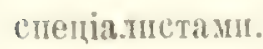

Да-рг I'. Радде. 


\section{VOM AUTOR}

Wer heutezutage systematische Arbeiten auf dem Gelicte der beschreibenden Zoologie oder Botanik machen will, muss Specialist werden, d. h. er muss sich eine Gruppe, nemen wir sie Ordnung, Familie, ein Genus von 'Thieren oder Pflanzen wählen und diese mit Hülf" erschöpfender Literatur bis in die kleinsten Inetails studiren. Geschieht das, so wird die betreftende Persünlichleit eine Autorität für solches Specialfach. In allen grossen Museen wird in dieser Art gearbeitet. Man schafit an Literatur Alles an, was irgend wie Bezug auf das Special-Studium hat und so kam demn das mehr mo meln heranwachsende Naterial im Verlaufe der Jahre bewaltigt werden. Der Fine beschiftigt sich \%. I. nicht nur zeitweise, sondern beständig, oft während mehrerer Decennien nur mit Säugern, der Antere mit Fischen. mit irgend einer Insecten Ordnung, nlex sogar anch nur rornehmlich mit cinem Genus wihrend seines ganzen Lebens. - Die Ergebnisse solcher Lntersuchungen, in Druck gelegt, tragen den Stempel streng akademischer Abhandhungen, wie solche nur auf dem erwähnten Wege erstrebt werden können.

Ganz anders liegen die Verhältnisse da, wo man in ein entferntes, in jeder Hinsicht überreiches Land kommt und ein Museum gründen soll, welches dem liesucher dieses Gebiets seine Reichthümer in möglichster Vollständigheit vor die Augen führen und den wissenschaflichen Inforderungen auch genïgen soll. Das ist auch hei dem kaukasischen Musemm der Fall. Schon der eine Umstand, dass dasselbe fün grosse Abtheilungen, nämlich eine zoologische, botanische, geologische, ethnographische und eine für Alterthümer in sich fasst, wird es Jedermam lial stellen, dass, so lange nicht für eine Anzahl von Specialisten und hreiter Literatur gesorgt ist, von den zeitraubenden, peinlich durchgefühnten Irbeiten aliademischen Charaliters nicht die Rede sein kann. Selbst, wenn man die nöthige Literatul hätte, wo kümnte man die genügende Zeit hernehmen. um z. B. genaue /ahn-mu-Schädel-Untersuchungen zu machen, wem Hunderte anderer Fragen von oft grösserer Wichtigkeit vorliegen, die ihrer Erledigung harren und wenn man, zum grössten Theile wenigstens, die Museums Objecte auf monatelangen lieisen selbst beschaffen, dann ordnen und aufstellen muss und überdies noch Reiseberichte und grrössere Werke allgemeinen physico-gengraphischen Inhaltes jublicirt. Bei solcher Gesammtaufigabe muss man, um den Anforderungen nachzukommen sich folgenderweise einrichten:

1. Ein grosser Theil der Objecte kinn sofort, auch ohne vollständige literarischn Hilfsmittel, richtig bestimmt und damit erledigt werden.

2. Ein geringerer Theil bedarf genauer Prüfung. Wo sulche hier an Ort und Stelle 
nicht müglich war, habe ich mich an bekannte spectiblisten des In-und-Iuslandes gewendet und ist mir ihre Hnlfe fast immer im weitesten Umfange zu Theil geworden.

Auf diese Weice erhielten die liestimmungen iter egrossen zoologischen und botanischen Sammlungen des libuliasischen Museums die unerlit-sliche wissenschaftliche hasi- In einzelnen Fällen werden Berichtigungen maturlich stattfinden können, in anderen mügen die Meinungen uber Art, Varietit, Form anseinander sehen. Bejdes wird auch in den mustergiltigen Museen ersten lianges der labll sein. Iuf den Gebieten, welche idh selbst pttegte, rereinige ich artlich das, was durch vermittehule Uchereänge entsehieden zusimmengehört und stehe dadurch mit vielen Specialisten, aber lieinesweges mit allen, in Widerspruch.

Dr. G. Radde 


\section{СОКРАЦЦЕH'ค.}

Его Императорское Высочество Великій Князь Насдьдникъ Десарөвичъ Георгій Алөксандрович'

Seine Kaiserliche Hoheit, Grossfürst Thronfolger Caesarewitsch George Alexandrowitsch

Его Императорское Высочество Великій Князь Михапль Ниволаевичъ

Seine Kaiserliche Hoheit, Grossfürst Michail Ni. kolajewitsch

Ел Императорское Высочество Велиғая Княгиня Одьга Өводоровна

Ihre Kaiserliche Hoheit, Grossfürstin Olga Feo. dorowna

Его Императорское Высочество Великій Князь Николай Михацловичь

Seine Kaiserliche Hoheit, Grossfürst Nikolai Michailowitsch

Его Императорское Высочество Великій Князь Миханль Михапловичъ

Seine Kaiserliche Hoheit, Grossfürst Michail Michailowitsch

Его Императорское Высочество Великій Князь Георгій Михавловичь

Seine Kaiserliche Hoheit, Grossfürst George Michailowitsch

Его Императорское Высочество Великій Князь Александръ Михаиловичъ

Seine Kaiserliche Hoheit, Grossfürst Alexander Michailowitsch

Его Императорское Высотество Великій Князь Сергій Миханловичъ

Seine Kaiserliche Hoheit, Grossfürst Sergei Michailowitsch

Iмпе аторсгал Аъадемія наутт

Kaiserliche Akademie der Wissen chaften

Графь Берленпь

Берлипскій Музей
Graf Berlepsch

Berliner Museum

\section{ABKÜRZUNGEN.}

E. II. Вис. Насл. Цес.

S. Kaisl. Hoh. Grf. Thronf.

E. II. Buс, В. К. Мих, Ник.

S. Kaisl. Hoh. Grf. Mich. Nik.

E. II. Вuс. B. K. О. Өеол.

Ihre Kaisl Hoh. Grfn O. Feod.

E. II. Bнс, В. К. Ник, Mих.

S. Kais!. Hoh. Grf. Nik. Mich.

Е. ПТ. Вис. В, К. Мих, Мик.

S. Kaisl. Hoh. Grf. Mich. Mich.

Е. ІІ. Выс. В. К. Г'еор. Мих.

S. Kaisl. Hoh. Grf. Geor. Mich.

Е. II. Вис, B. К. Алек. Мих.

S. Kaisl Hoh. Grf. Alex. Mich.

E. II. Bruc, B. K. Cep. Mux.

S. Kaisl. Hoh. Grf. Serg. Mich.

Akad.

Grf. B.

Berl. M. 


\begin{tabular}{|c|c|c|}
\hline Қ.лазіуст старніи & blasius senior & 131. snr. \\
\hline lïттерт & Büttger & Bttg. \\
\hline Ipeccepts & Dresser & Drs. \\
\hline ゆ.ıёpนre & Förike & Flrk. \\
\hline I'омейерт, Евтеніи & Homeyer, Eugen & $110 \mathrm{~m}$. \\
\hline ¿ІевнIт & Jasewitsch & Jas. \\
\hline Калиповесій & Kalinowski & Kal. \\
\hline Кёпนr & König & K. \\
\hline Іоренцт & Lorenz & I. \\
\hline Menec $\tau_{2}$ & Mewes & M. \\
\hline Р’аде & Radde & R \\
\hline Радде и Ва.тьтер'т & Radde und Walter & li. W. \\
\hline Радде п hёнпт, & Radde und Königg & li. K. \\
\hline Зарудиый & Sarudny & Sard. \\
\hline Сатупинт & Satunin & Sat. \\
\hline IIЕельовнивов & Schelkownikow & Schlk. \\
\hline III.дютерт & Schlüter & Schilt. \\
\hline 'Зеземан т & Sesemann & Ses. \\
\hline Т'анкие & 'T'ankré & 'T. \\
\hline Baльтерт, & Walter & W. \\
\hline
\end{tabular}

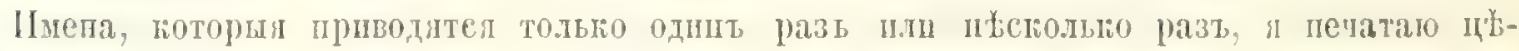
ликомг.

Namen, die nur cinmal oder wenige Male angeführt werden, drucke ich vollständig. Дальше согращеніл по рубрикан обозначають сльдующее:

Ferner bedeutet in den Rubriken:

o-caseñ -Männchen

Q-cama- Weibchen

G. - поставлениое чуче.л0-gestopft und aufgestellt

B. - набитал шгура-Balg

F.-пенабитал шкура-Fell

Cr.- черепъ-Schådel

K. - голова-Kopf

Sc.-Cre.леть-Skelet

H. - pora-Horn oder Geweih

Transkp-3апаспіiская область-T'ranskaspien

Unt. Kura-minina liypa-Untere Kura

Mit. Kura-cредпял Kура-Mittlere Kura

'Turk.-Tyргестап-Turkestan

gkft. - Isyn.reno-geksuft

gesch.—подарено-geschenkt 


\title{
VERTEBRATA.
}

\section{позвоночныя.}

\author{
WIRBELTHIERE.
}




\section{MAMMALIA.}

\section{МЛЕК ОПИТ АЮЩІЯ.}

\section{SÄUGETHIERE.}

IIIкапъ_42, $43,53,53{ }^{1}$ )_Schrank.

Iі отвршто постав.тено - und frei aufgestellt. 


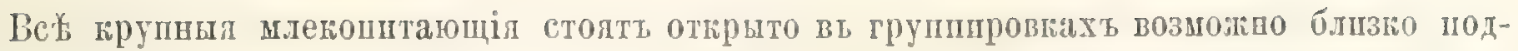
ходицихь ћъ ихъ естествениоу состоянію. ІІкапт 42 содержпть летучшх мышей гры-

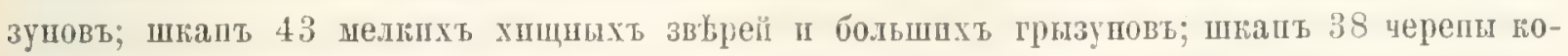

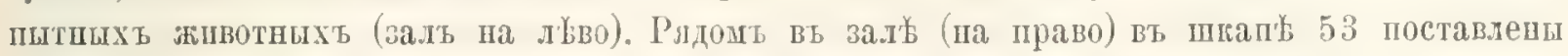
семейства кошачьиь пा собачыхь, и въ шапахь 53 I II 53 II ихъ черепь.

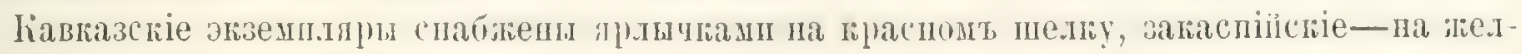
томт, остальнце-на синемъ.

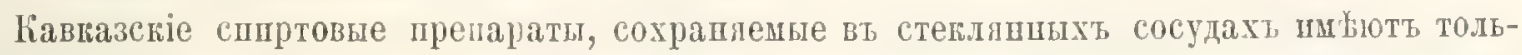

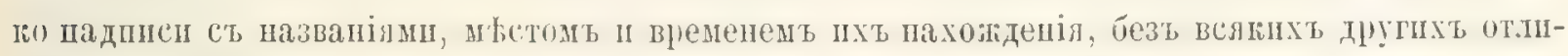

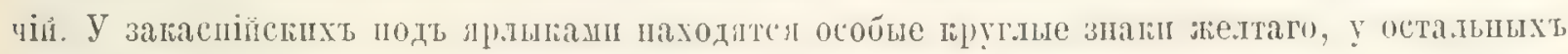

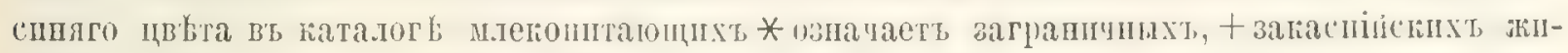

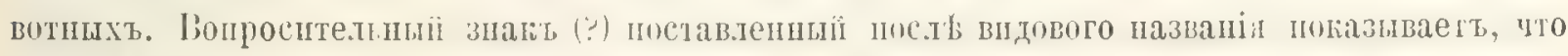

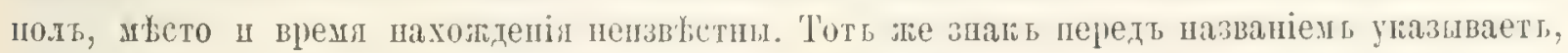
что опредъ.леніе соотвьтствующаго впда сомнительное.

До 1886 года л опреджлил всъхт илекопитающих; въ 1887 году юоллекдія была

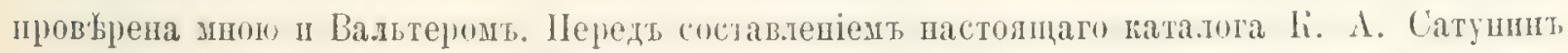

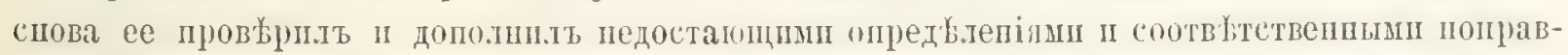

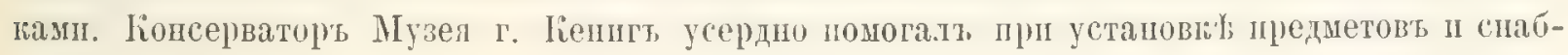
жепіп шхъ надписями.

Alle grossen Sïngethiere wurden frei aufgestellt und möglichst maturlich gruppirt. Schrank 42 enthält die Fledermäuse und Nager. Schrank 43 kleinere Raubthiere und grosse Nager Schrank 38 Schärdel der IIufthieve (Saal links) Daneben im Saale (rechts) Schrank 53 Feliden und Caniden und in den Schränken 53 I und 53 II deren Schädel.

Die kaukasischen Exemplare tragen die Signatur an rother seide, die transkaspischen an gelber, die anderweitig erworbenen an blauer.

Die Gefisse in welchen die Exemplare in Spiritus aufbewahrt werden, haben für die Kankasier ausser der Signatur mit Bestimmung, Datum und Fundort lein Abzeichen. Die aus 'Transkaspien stammenden Objecte weisen unter der Signatur cin gelbes, lireisformiges Abzeichen, die anderweitig erworbenen ein solches in blaver Finbe auf. Im Katalog der Siusger bedeutet ein * Ausland ein + Transkaspien. Ein Fragezeichen (:) nachgestellt soll sagen, dass (ieschlecht, Fundort und Datum nicht bekannt sind oder vorgestellt, dass die Lestimmung der betreffenden Art zweifelhaft ist.

lis 1886 habe ich die gesammelten Süuger bestimmt. 1887 wurle die Sammlung von mir und Walter wiederum revidirt. Zur Herstellung dieses Kataloges hat Herr Satuniu sie nochmals durchgeschen und die noch fehlenden Bestimmmgen ergianzt, resp. berichtigt. Herx Conservator Künig hat hei dem Signiren und Aufstellen der Säugetliere rifrigst geholfen. 


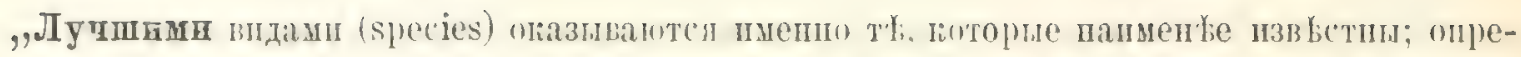

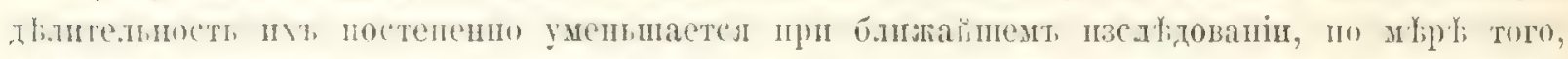

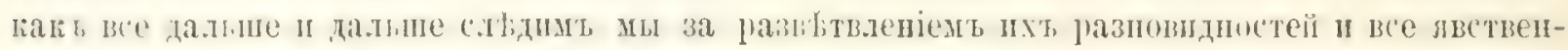

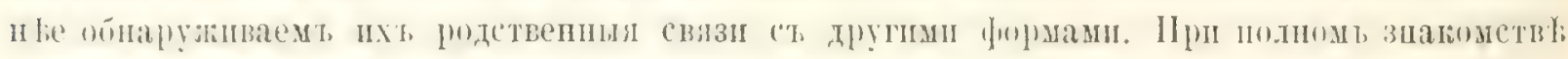

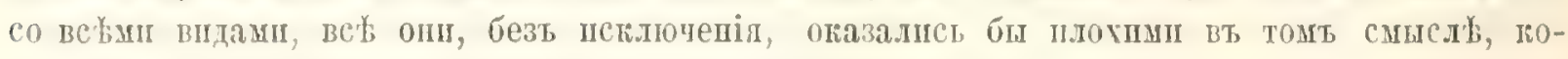
торнй дағоть әтому слову любптели раздробленности видовъ.

Эрнсть Геккөль (Generelle Morpholngie, II. 360).

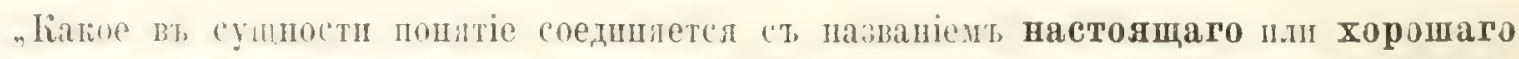

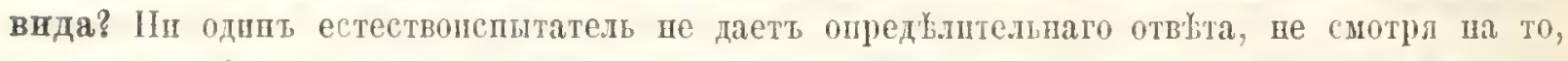

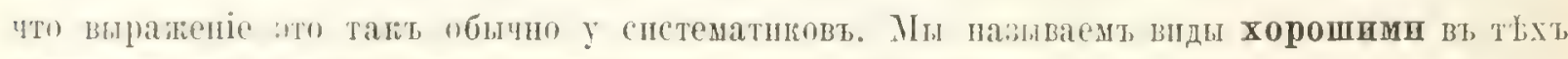

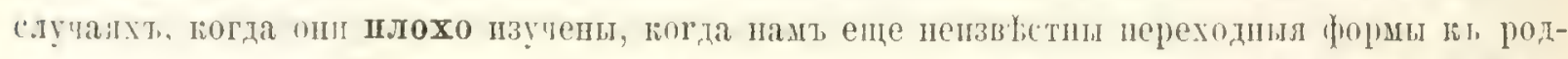

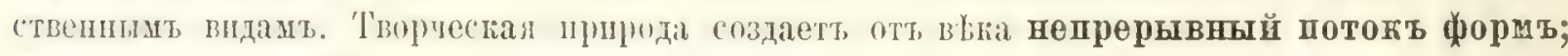

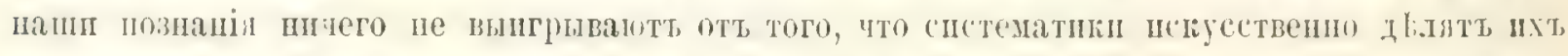

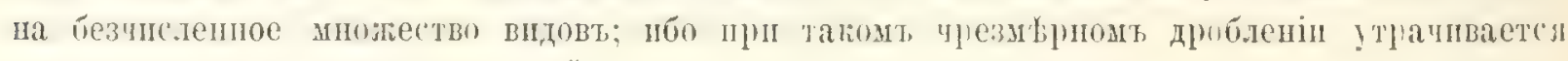
созпапіе пхт, естествепної связи".

Эрнсть Геккель (Natürliche Schöpfungsgeschichte).

"Die am wenigsten bekannten Species sind die "besten"; sie werden um so schlechter, je besser wir sie kemen lernen, je weiter wir die Divergenz ihres Varietäten büschels verfolgen und je deutlicher wir ihren Zusammenhang mit verwandten Formen nachweisen künnen. Schlechte Arten im Sinne der Species Fabrikanten würden alle Species ohne Ausnahme sein, wenn wir sie vollständig kennen würden".

Ernst Haeckel (Generelle Morphologie II. J. 360).

"Was eigentlich eine echte oder gate Art jst, diese Frage vermag kin Naturforscher zu beantworten, obgleich jeder Systematiker täglich diesen Ausdruck gebraucht. Wir nennen die Arten dam gat wenn wir sie schlecht liennen, wemm uns die Uebergangsformen zu verwandten Arten unbekannt sind. Die schaffende Natur bewegt sich ewig in cinem ununterbrochenen Flusse der Formen, ihre Erkenntniss gewinnt dadurch nicht, dass die beschreibenden Systematiker sie in unzählige Arten lïmstlich spalten; die Erkenntniss des natürlichen Zusammenhanges geht durch diese übertriebene Zersplitterung verloren".

Ernst Haeckel (Natürliche Schöpfungsgeschichte). 
Taf. I.

Caproc cancasica

$\hat{\jmath}$

jur.

$q$

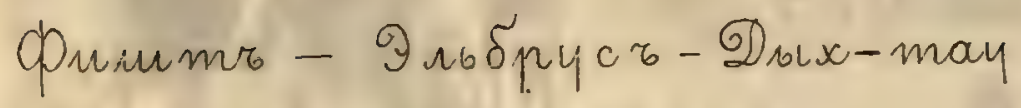

Fischt - Elbuns - Dïchtan.

+ Capra ibex of Mbrinapia

Schureiz. 
I. FoT

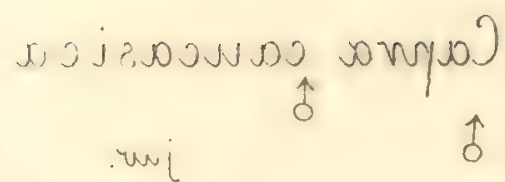

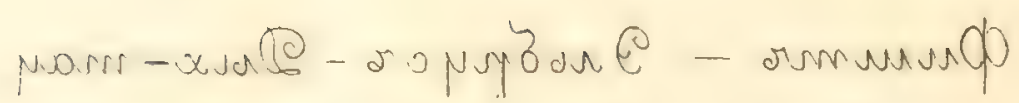

$$
\begin{aligned}
& \text { sutshaj@-smeth - tracit } \\
& \hat{j} \text { xadi nonspoj t }
\end{aligned}
$$

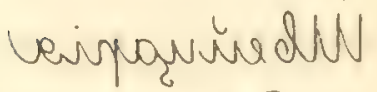

$$
\begin{aligned}
& \text { sivensto? }
\end{aligned}
$$




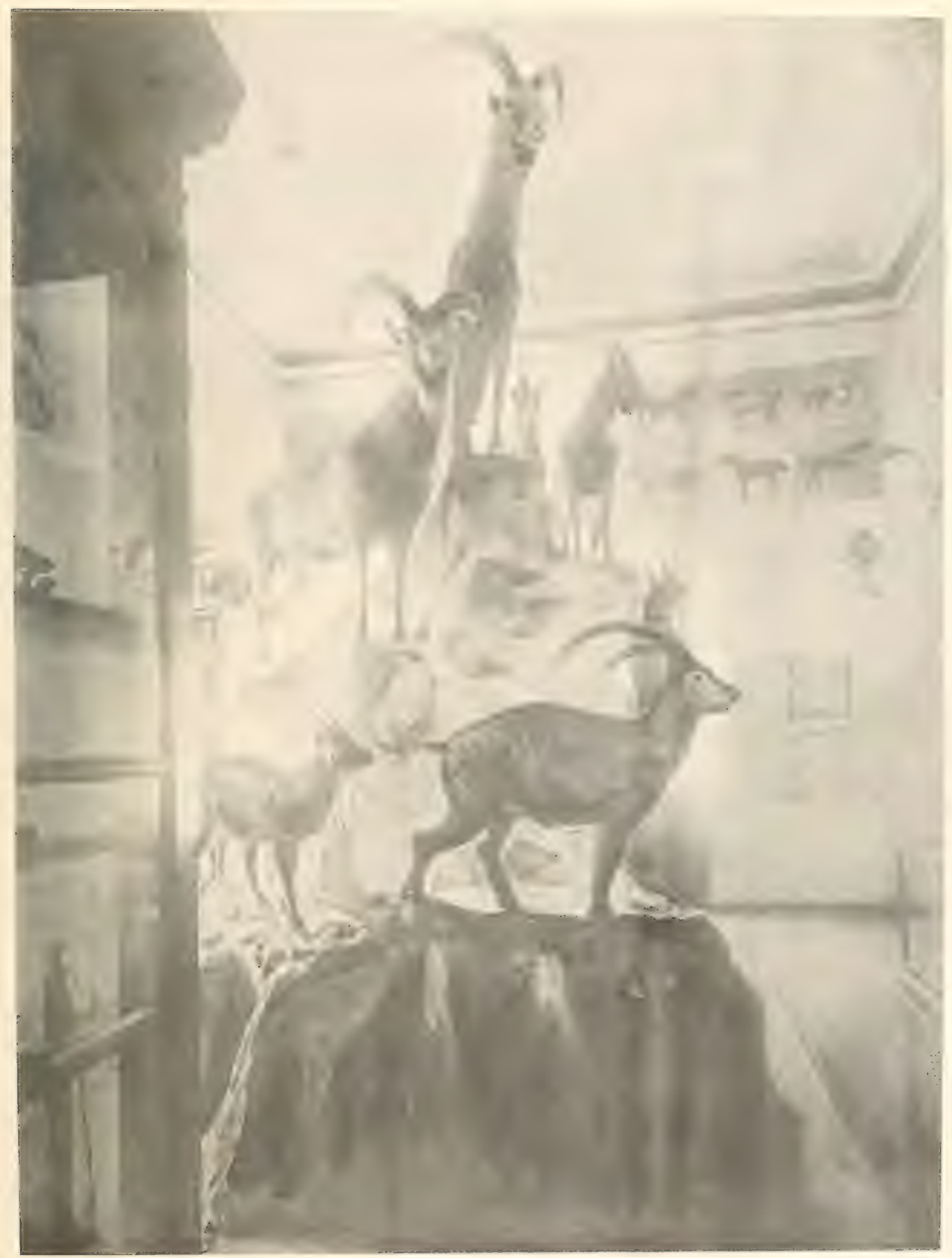





\section{A M M A L I A \\ COTPУ ДНИКИ-MIT ARBEITER.}

Prof. Blasius (W.). Braunschweig

Prof. Nelıring. Berlin.

Dr. Radde. Tillis.

K. Satunin. Tiflis.

Dr. Walter.Tiflis. Jena.

Опредъленіе.
Ревизіл видовь.

Bestimmungen.

Revision der Arten.

Eug. Buchner. Petersburg.

i'h. Sclater. London.

C. Greve. Moskau.

Литературиц указанія.

Literatur Nachweise.

Составт колдеціи млекоптащшх до 1 лнваря 1899.

Gesammtbestand der Sammlung von Säugethieren bis 1 Jan. 1899.

\begin{tabular}{|c|c|c|c|c|c|}
\hline Ord: & Chiroptera & 22 & Arten & 305 & Expl. \\
\hline$"$ & Insectivora & 13 & " & 89 & $\pi$ \\
\hline 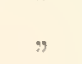 & Carnivora & 31 & $"$ & 461 & $\pi$ \\
\hline r & Rodentia & $6 \overrightarrow{7}$ & $\pi$ & 511 & $"$ \\
\hline . & Ungulata & 25 & $"$ & 190 & $"$ \\
\hline 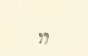 & Cetacea & 3 & 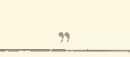 & i; & . \\
\hline & & & & 1562 & \\
\hline
\end{tabular}




\title{
C H I R O P T E R A
}

\author{
FAM. VESPERTILIONIDAE
}

Пкапь-42-Schrank.

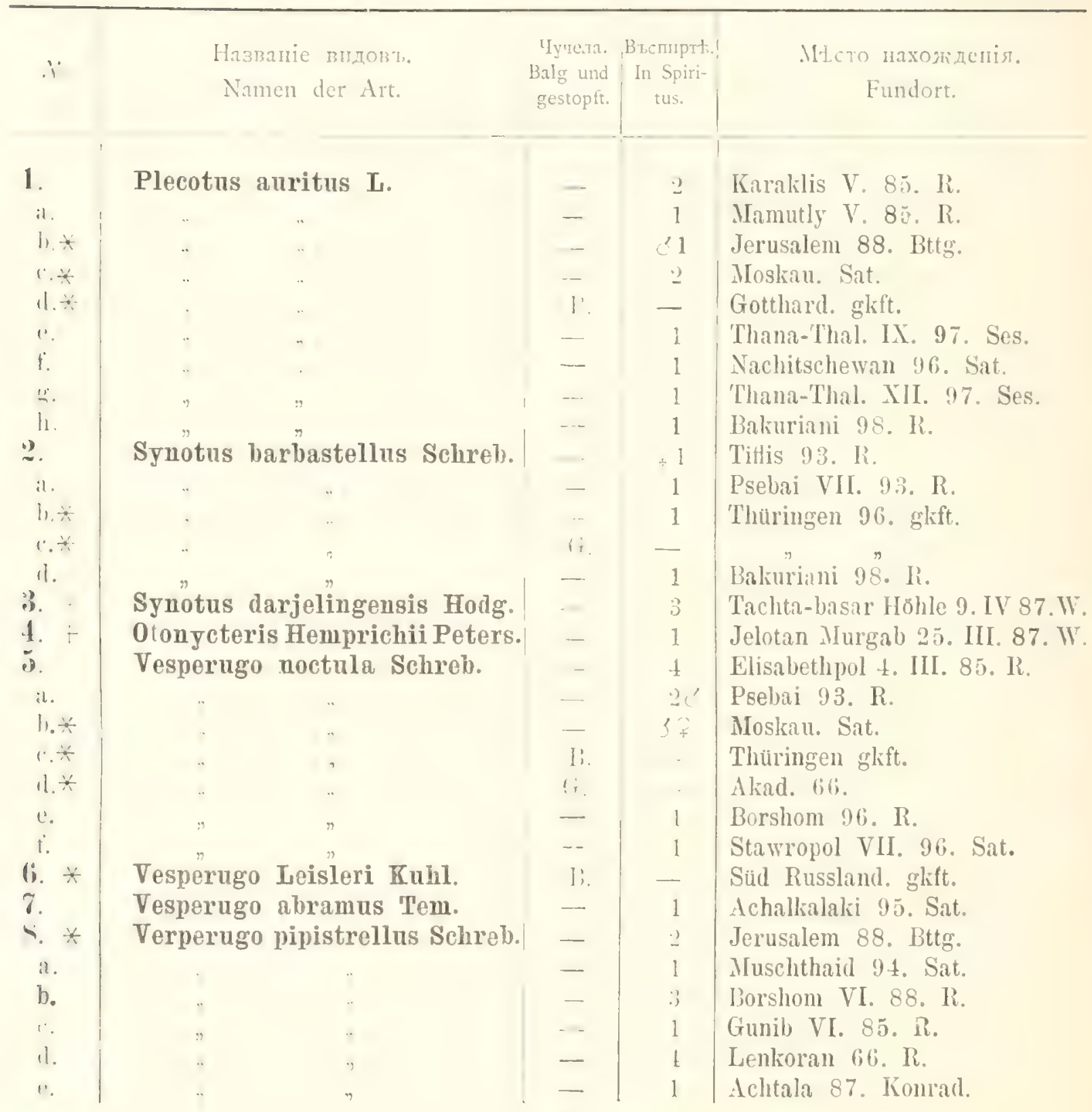




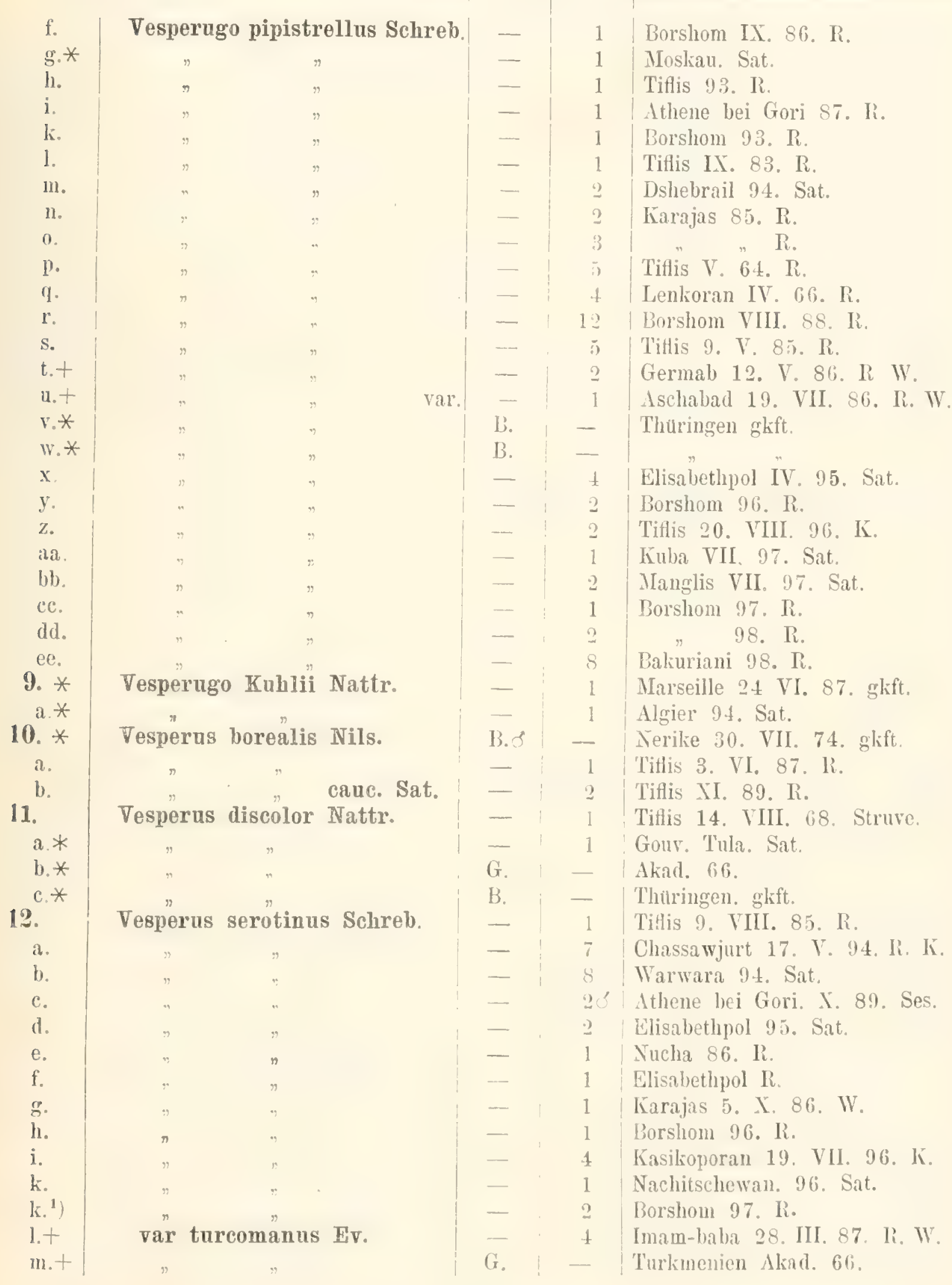




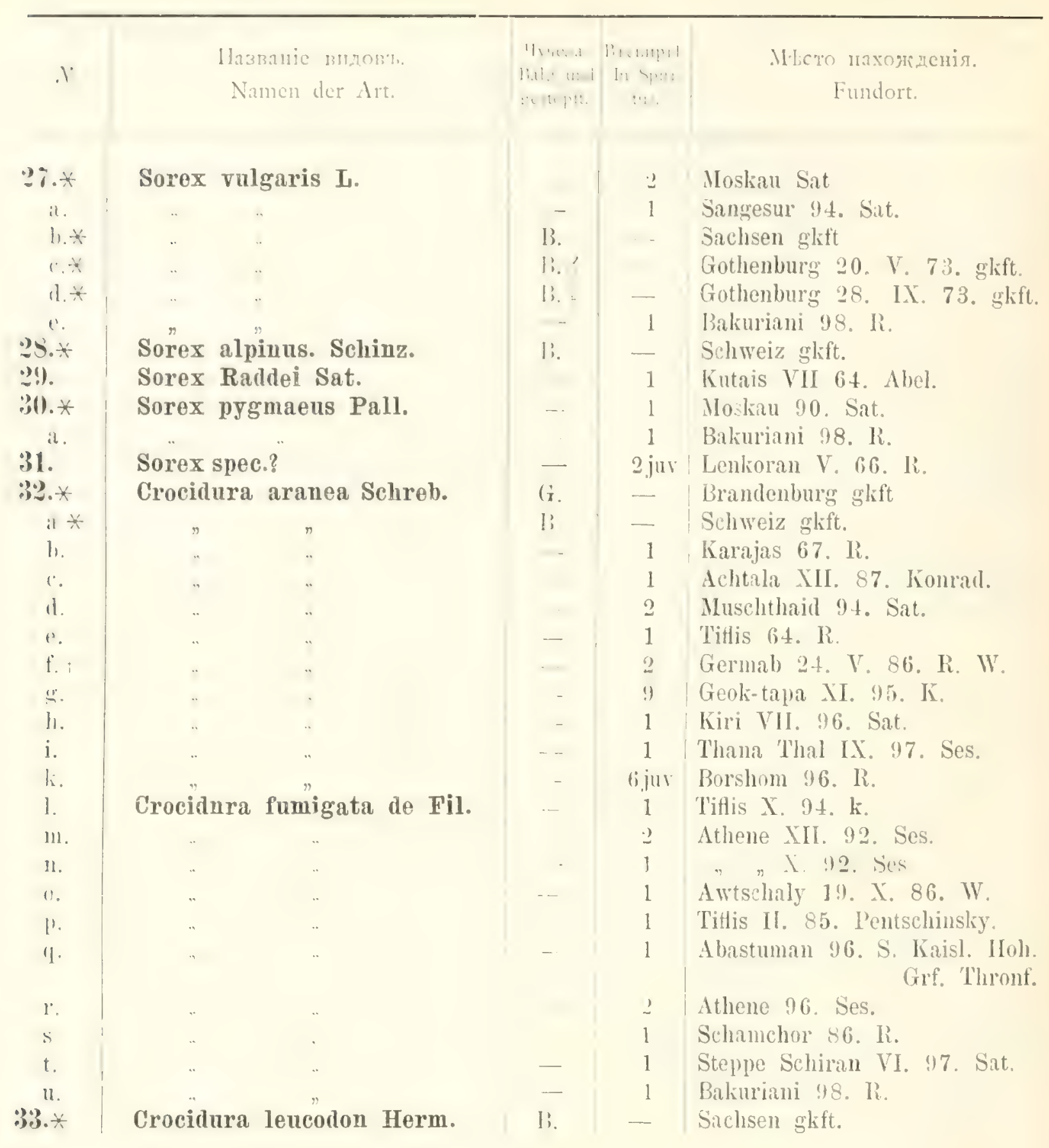

\section{FAM. TALPIDAE}

34.* Talpa europaea I.

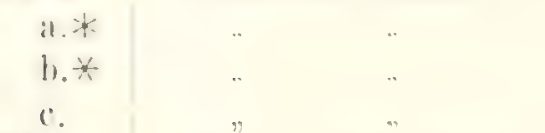

:ij.

Talpa caeca Savi.

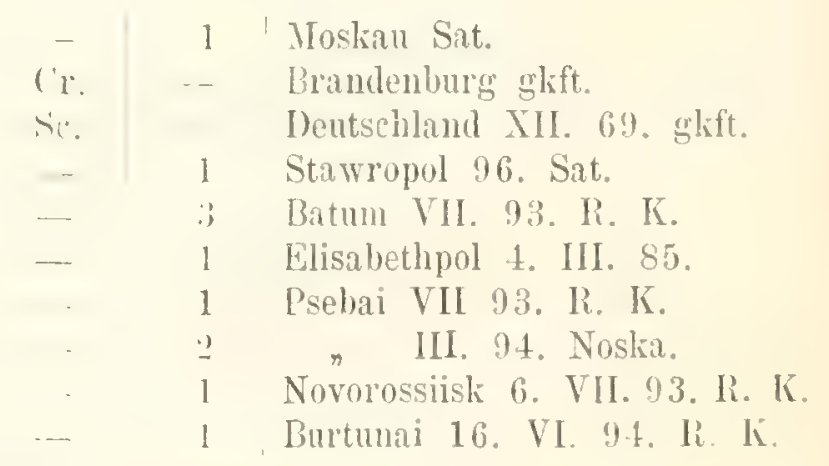




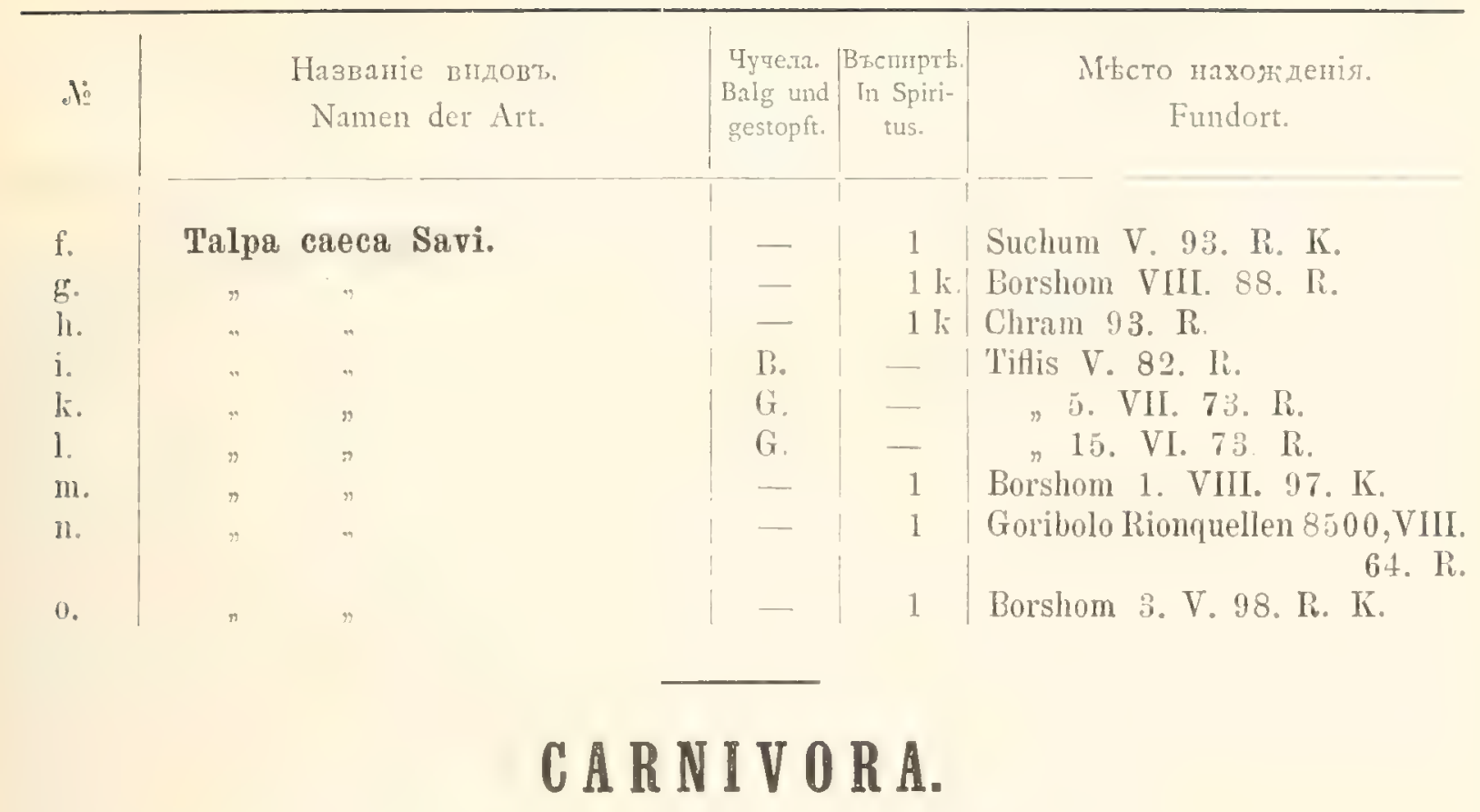

$F A M . F E I I D A E$

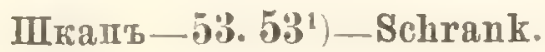

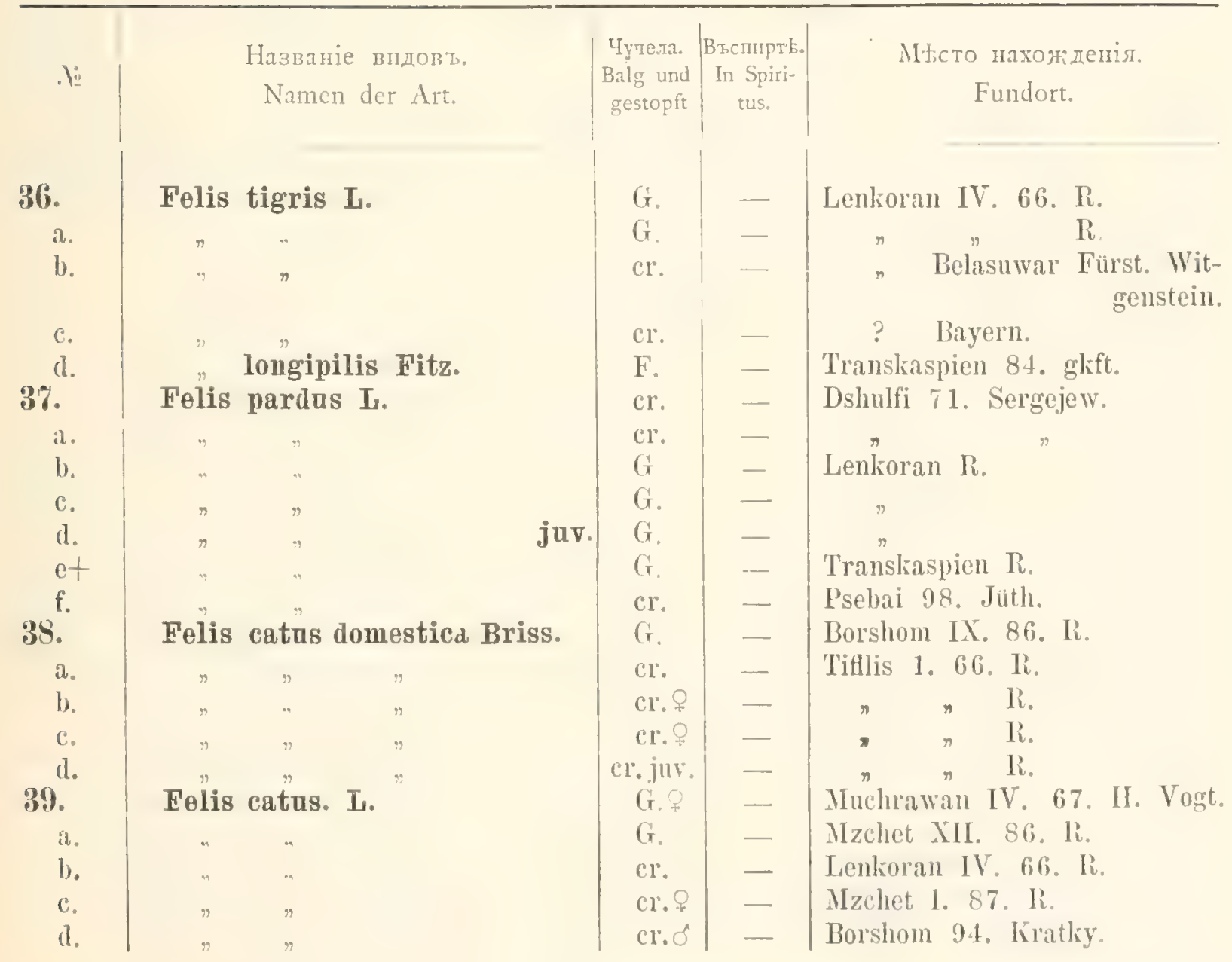




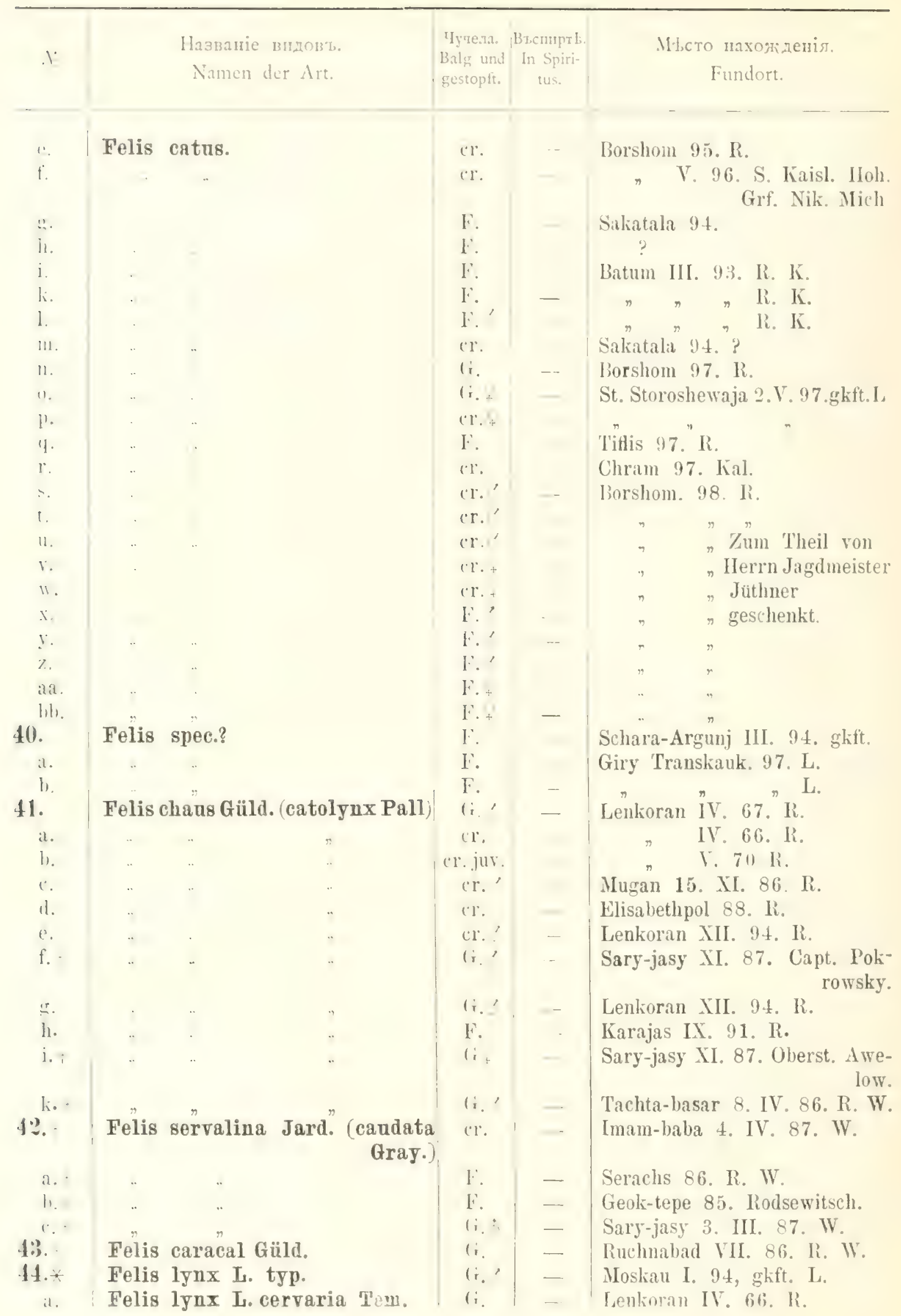




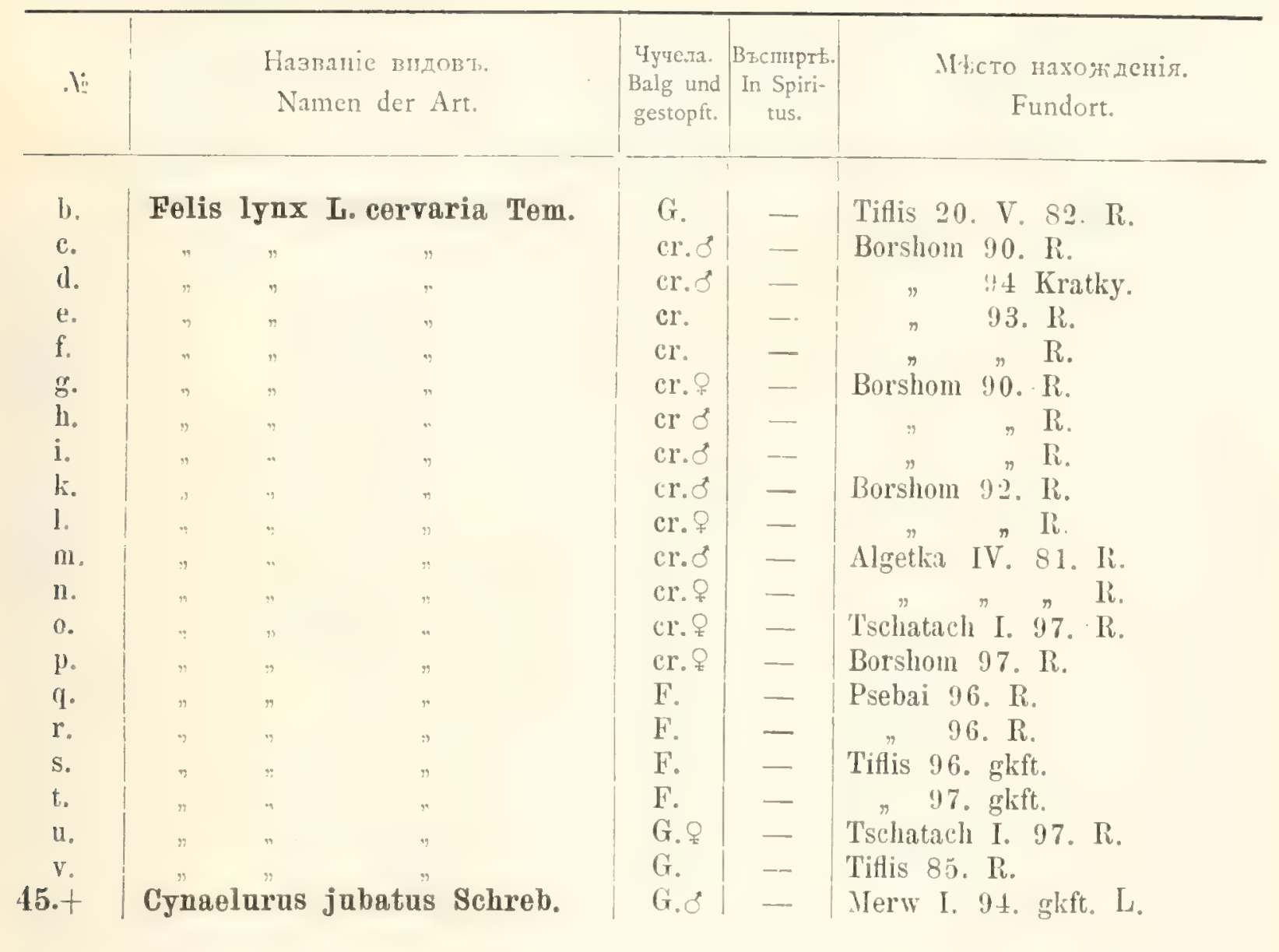

$$
\begin{aligned}
& \text { F A M H Y A N I D E. } \\
& \text { IIкапъ_5\%. } 53^{2} \text { ). _-Schrank. }
\end{aligned}
$$
46. Hyaena striata Zimm.
a.
c.
d.
e.
\begin{tabular}{c|c|cc} 
G. & - & Tiffis 69. & $R$ \\
G. & - & . & R.
\end{tabular}
G. - Zarsk. Kolodes XII. 68. Prinz
Albert von Altenburg.

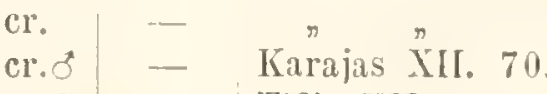
cr.f - T Tiflis XII, 70 .

\section{FAM CANIDAE.}
\begin{tabular}{c|c} 
47. Canis lupas L. \\
a.
\end{tabular}

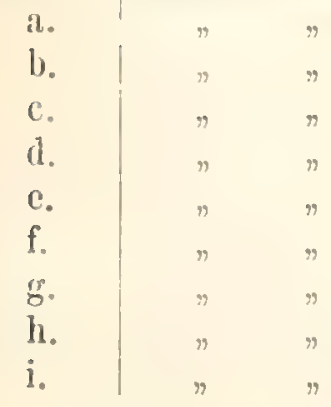

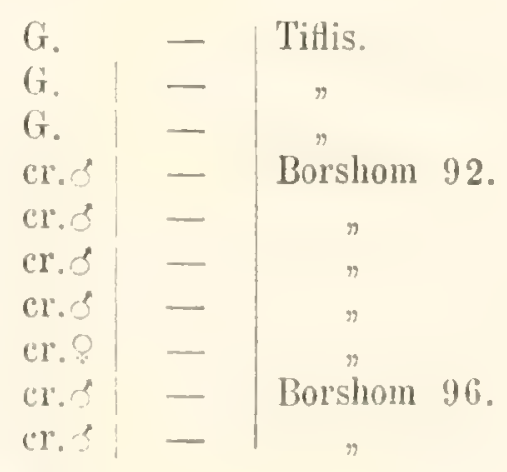




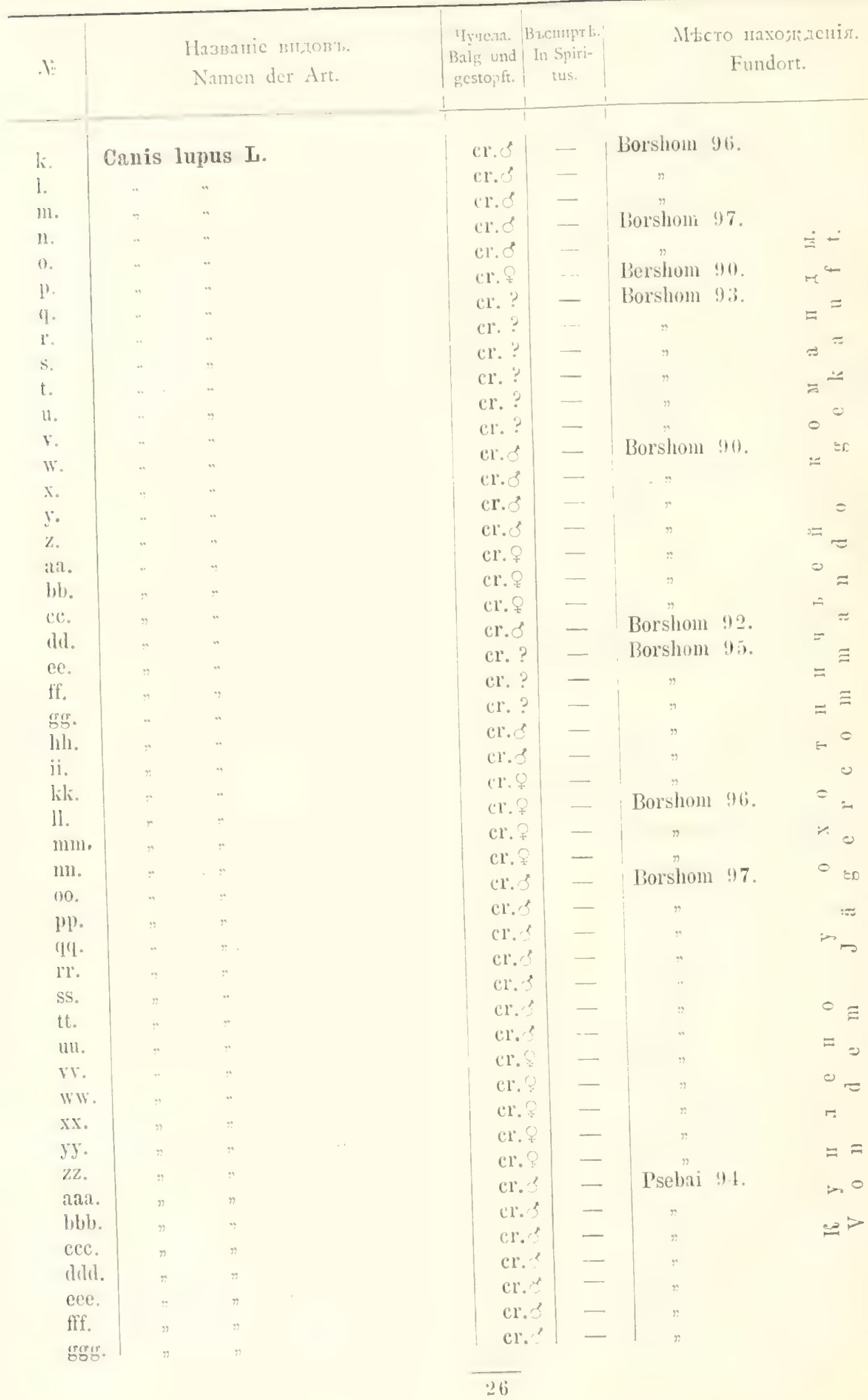



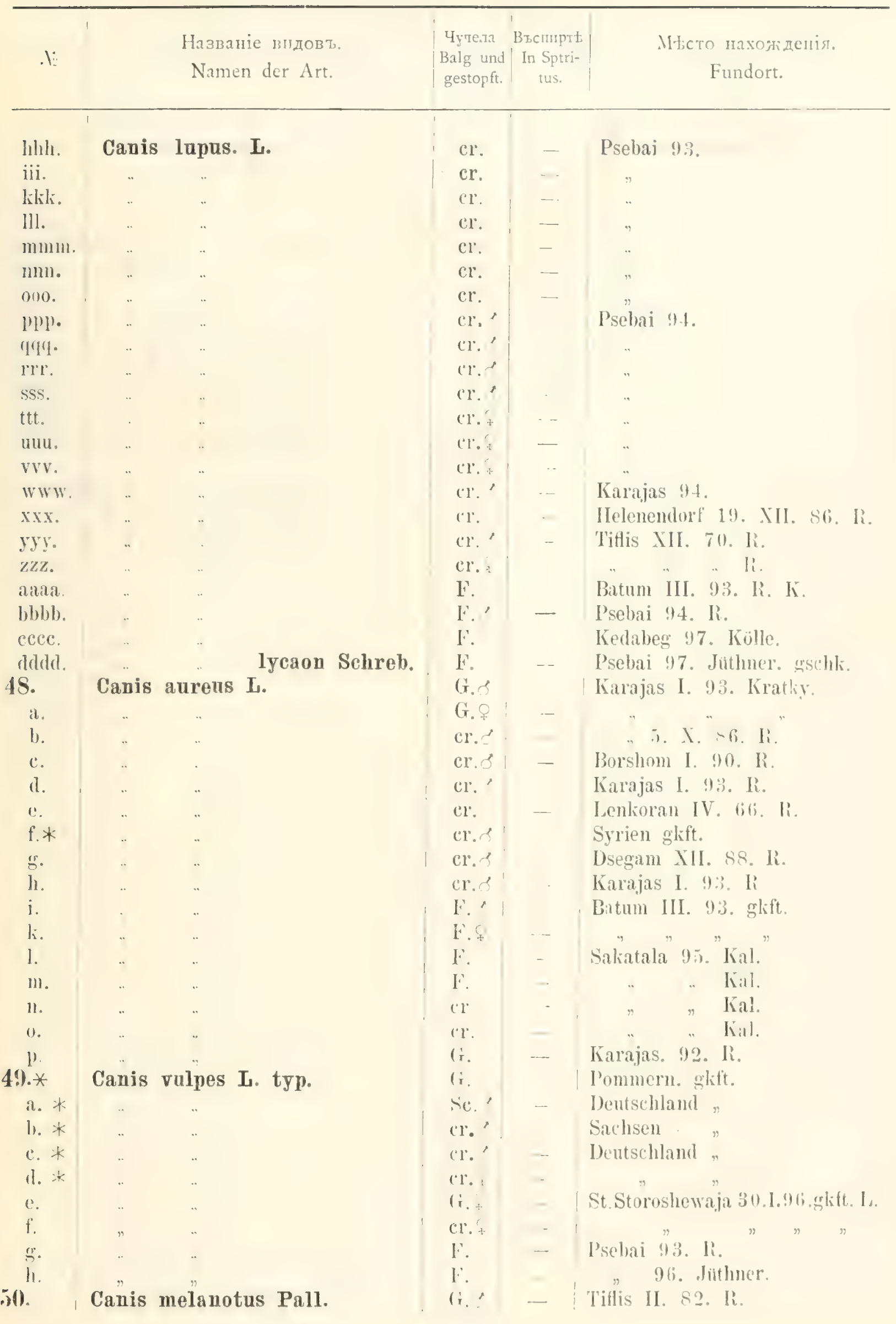
Названіс вИдов".

Namen der Art.

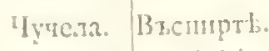

Balg und In Spiri-

gestopft. tus.
Mнто наяоя денія

Fundort.

\section{a. Canis melanotus Pall.

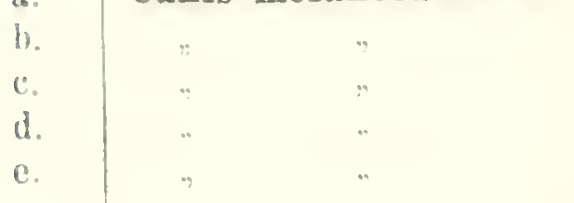

f.

g.

h.

i.

li.

1.

m.

11.

0 .

p.

I.

r.

s.

t.

u.

$\mathrm{r}$.

w.

$\mathrm{x}$.

$y$.

$\mathrm{z}$.

aa.

bb.

ce.

dd.

ee.

ff.

gg.

hh.

ii.

$\mathrm{kk}$.

Il.

$\mathrm{mm}$

nn.

00.

pp.

)ฺุ.

Ir.

SS.

tt.

uu.

Vy.

Ww.

$$
\begin{aligned}
& \text { G.8 - Titlis IV. 67. R. } \\
& \text { G. } 8 \text {. - } ~=1.88 . \mathrm{K} \text {. } \\
& \text { G.juv. - } \quad \text { - R. } \\
& \text { G. - } \quad \text { R. }
\end{aligned}
$$

G. - Gudaur X. (38. I. Kaisl. Hoh.

Grfn. O. Feod.

\begin{tabular}{l|l|l} 
G. & - & Kasbek 5. XII. 93. Ii.
\end{tabular}

F. - Psebai 93. Noska.

F. - Mlety IV.94. R. K.

F. - Jewdokimowsk VII. 94. R. K.

F. - Wladikawkas 5. V. 9.t. R. I.

F. - , "

F. - Borshom II. 93. Kratky.

cr.8 - Schamchor XI. 88. R,

cr. - Untere Kura III. 66. R.

cr. - Psebai 93.

cr.

cr. -

\begin{tabular}{l|l|l}
$\mathrm{cr}$. & - &
\end{tabular}

cr. - $\quad$ "

cr. -

\begin{tabular}{l|l|l}
$\mathrm{cr}$. & - &
\end{tabular}

cr. -

cr. -

cr. -

cr.

Borshom 90.

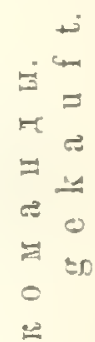

$\div=$

$=$

c $=$

$\approx \approx$

$=\Xi$

$=\Xi$

$=0$

$\because 0$

$0:$

\%

0 to

:

$\therefore=$

$c \equiv$

$=2$

$0=$

$=$

$=$

$\cdots=$

$\therefore$ 


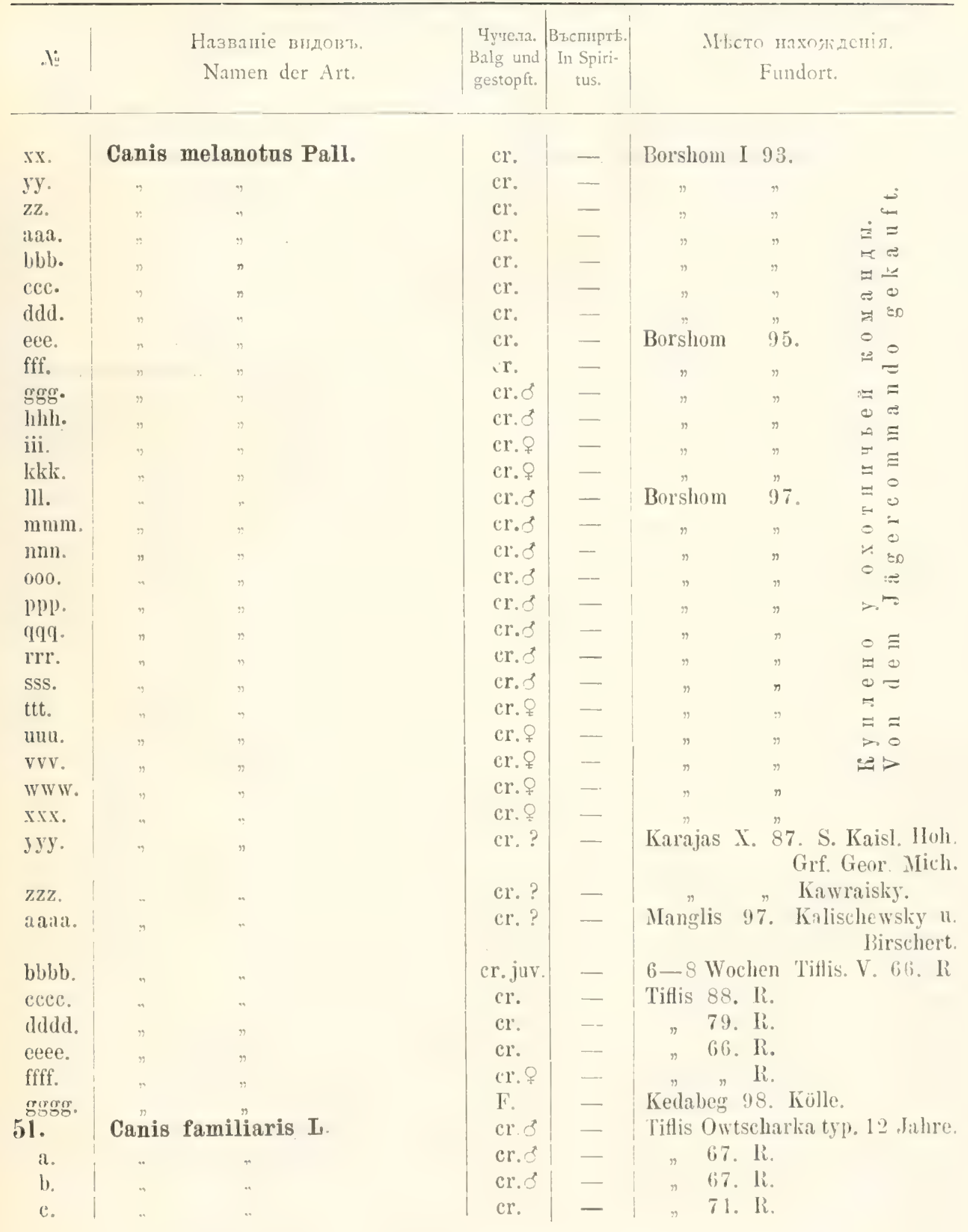

FAM URSIDAE

IIIкапъ-5 $3^{1}$ ). - Schrank.

Назвапіе видовт,

Namen der Art.
Balg und In Spiri-

tus.
Fundort.

52. 


\begin{tabular}{|c|c|c|c|c|}
\hline i: & $\begin{array}{l}\text { Hazmanie Buzon's. } \\
\text { Namen der Art. }\end{array}$ & $\begin{array}{l}\text { Iyvera. } \\
\text { Balg und } \\
\text { gestopft. }\end{array}$ & $\left|\begin{array}{c}\text { Br.cmupti. } \\
\text { In Spiri- } \\
\text { qus. }\end{array}\right|$ & $\begin{array}{c}\text { Mticto naxomzeniss. } \\
\text { Fundort. }\end{array}$ \\
\hline & $\begin{array}{l}\text { Hmp. et Ehrb. et isabell } \\
\text { nus Adams. }\end{array}$ & & & \\
\hline a. & " & G. & - & XI.72. 'Mitlis R. \\
\hline b. & .. & $\mathrm{G}$. & - & ? 7., , , \\
\hline c. & . & G.juv. & - & VI. 83 \\
\hline d. & .. & G.juv. & - & $" \quad . \quad . \quad$. \\
\hline c. & . & G.juv. & - & $" \quad " \quad n$ \\
\hline f. & r & G. & - & Psebai 91. \\
\hline s. & . & $\mathrm{cr}$. & - & MzchetKalischewskyu, Birschert. \\
\hline h. & .. & $\mathrm{cr}^{\circ}$ & $\ldots$ & Tiflis 72. \\
\hline i. & . & er.s & $\cdots$ & $\begin{array}{r}\text { Tschatach I. 66. S. Kaisl. Moh. } \\
\text { Grf. Mich. Nik. }\end{array}$ \\
\hline li & . & $\mathrm{cr}$. & -- & Borshom VIII. 64. \\
\hline l. & . & cr.s & $-\cdots$ & Psebai XII. 93. R. \\
\hline 111. & .. & ('r. ' & - & .. $\quad . \quad \ldots$ Ii. \\
\hline 11. & . & $\mathrm{er} .3$ & - & $=\quad, \quad R$. \\
\hline 0. & . & $\mathrm{cr}^{\circ}$. & - & $\Rightarrow \quad, \quad R$. \\
\hline 1). & $\cdots$ & $\mathrm{cl}^{2} . \mathrm{f}$ & - & n $n \quad R$. \\
\hline १. & $\cdots$ & i cr.s & - & Umpir 93. R. \\
\hline 1. & .. & $\mathrm{cl} . \mathrm{s}$ & - & Psebai 93. Ii. \\
\hline$\therefore$ & . & er.s & $\ldots$ & "XII. 93. R. \\
\hline t. & .. & $\mathrm{cr}$. & $\ldots$ & $", \quad \mathrm{R}$. \\
\hline 11. & & $\mathrm{cr} .8$ & - & Manglis L。 96. \\
\hline$\checkmark$ & & $\mathrm{cr}^{\circ} 8$ & - & Psevai 9. \\
\hline w. & .. & cr. \& & - & $\eta \quad "$ \\
\hline$x$ & . & cr. & - & $" n$ \\
\hline y. &. & $\mathrm{cr} \cdot \mathrm{c}$ & - & Borshom 94. \\
\hline$z$. & .. & $\mathrm{cr} \cdot 3$ & - & $n \quad n$ \\
\hline na. & .. & $\mathrm{cr} \&$ & - & Borshom 95. \\
\hline b). & .. & cr. \& & - & $\theta \equiv$ \\
\hline cc. & . & $\mathrm{Cl}^{\circ}$ & & $\overline{0}$ \\
\hline dd. &. & cr. Đjuv. & & ". \\
\hline ee. & , & er.juv. & - & Titlis. \\
\hline ff. &. & cr. $5 \mathrm{M}$. & - & $"$ \\
\hline $\operatorname{sg} g$. & .. & $\mathrm{cr}^{2}$ 1 Jahr & - & 67. Dr. Kioch. \\
\hline hh. & .. & $\mathrm{cl}^{\circ}$ & - & Alexandropol. \\
\hline ii. & & er. & - & Sakataly 95. \\
\hline kik. & . & cr.\& & - & Borshom 96. \\
\hline 11. & . & F.? & - & Psebai 94. \\
\hline IIm. & . & F.? & - & $"$ \\
\hline n11. & $n$ & F.? & 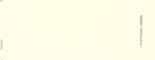 & $"$ \\
\hline 00. & . & F!? & - & $n$ \\
\hline 11!。 & .. & K.? & - & $"$ \\
\hline 14. & & $\mathrm{~F}:$ & - & $"$ \\
\hline ir. & & I : ? & - & Wladikawkas 91. \\
\hline$\therefore$ & & cr:? & & Borshom 98. \\
\hline 11. & & (r)' & & " \\
\hline 111. & & $\cdots I^{\prime}$ & & , \\
\hline
\end{tabular}




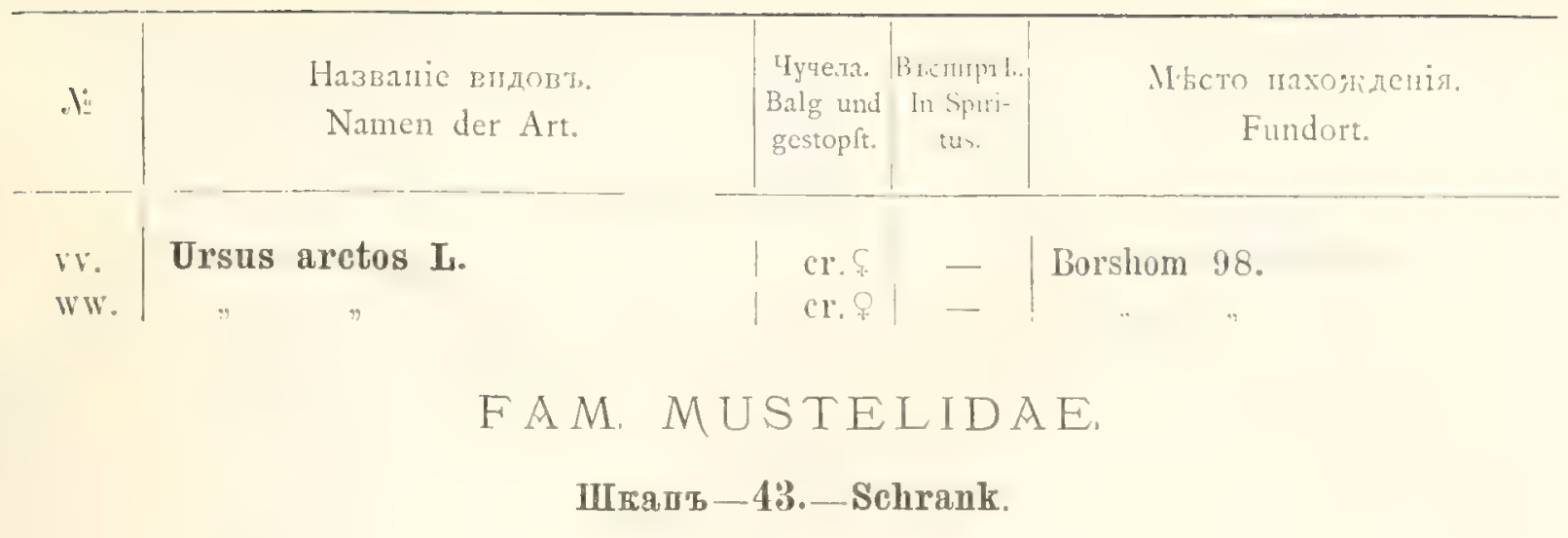

\section{Lutra vulgaris Erxl.}

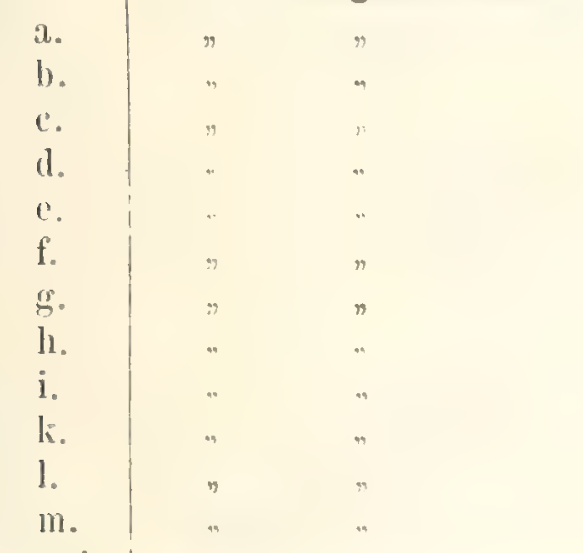

54

Meles taxus Schreb. 付p.

a.

b.

c.

d.

e.

f.

g.

h.

i.

k.*

1.

m. Mèles taxus canescens.

55. Mustela martes I.
G.\& - Tiflis 12. IX.91. R.

G.8 - Borshom I. 93. Juthner.

G.J - Titlis 12. IX, 91, R.

G.juv. - . V. Sis. IR.

cr.

(c).

cr. - Borshom I. 93. R.

cr. $\delta$ -

cr.8 - Psebai 94. R

cr.s -

cr.o - | Borshom I. 90. R.

cr. 우 - " li.

cr. ㄴ - Psebai 94. R.

cr. Brandenburg gkft.

G. ‥ Borshom IX 84. First Schachowskoi.

Tiflis?

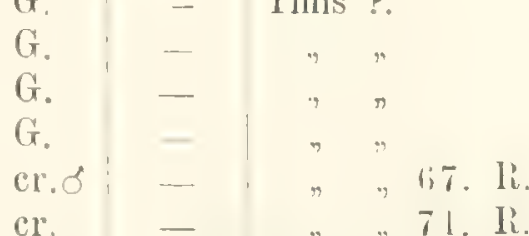

Borshom I. 90. R.

Borshom " 95.2.

Sachsen glift.

Borshom 96.

Borshom 97.

(1.) - Lenkoran 12.94. R.

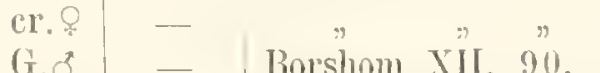

$\begin{array}{lll}\text { G. } & \text { B } \\ \text { G.8 } & - & \text { Borshom XII. 90. } \\ \text { Sc. } & - & \end{array}$

Sc. - $\quad$ I. 89 . Kratly.

cr.s -

cr. - " " $" 93 \mathrm{k}$

cr. - Psebai 93. I.

cl. -

cr. $\quad$ tr.

\begin{tabular}{l|l|l} 
cr.3 & - & Borshom ? R. \\
\hdashline$r$. & - & Sachsen glift.
\end{tabular} 


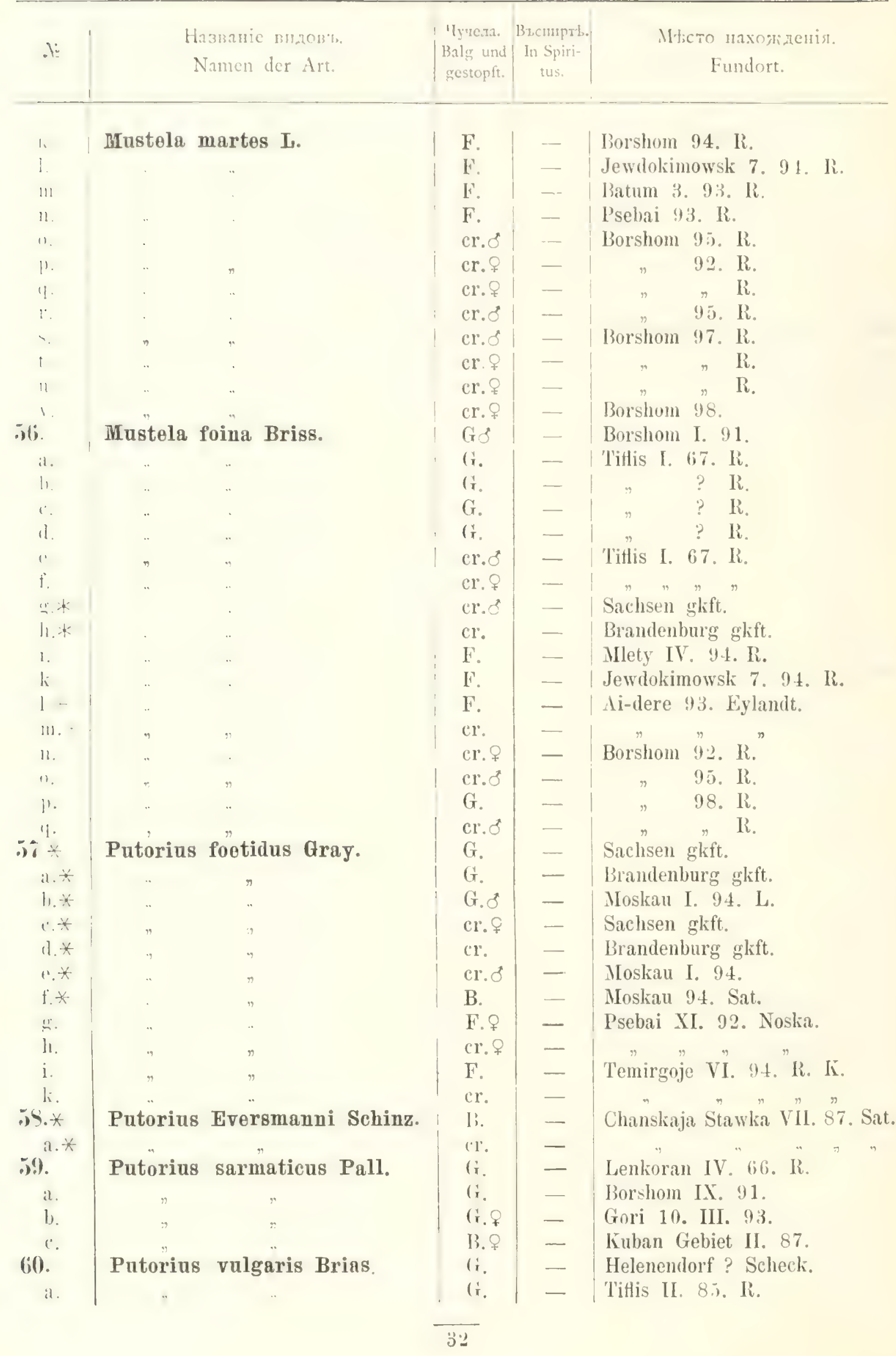




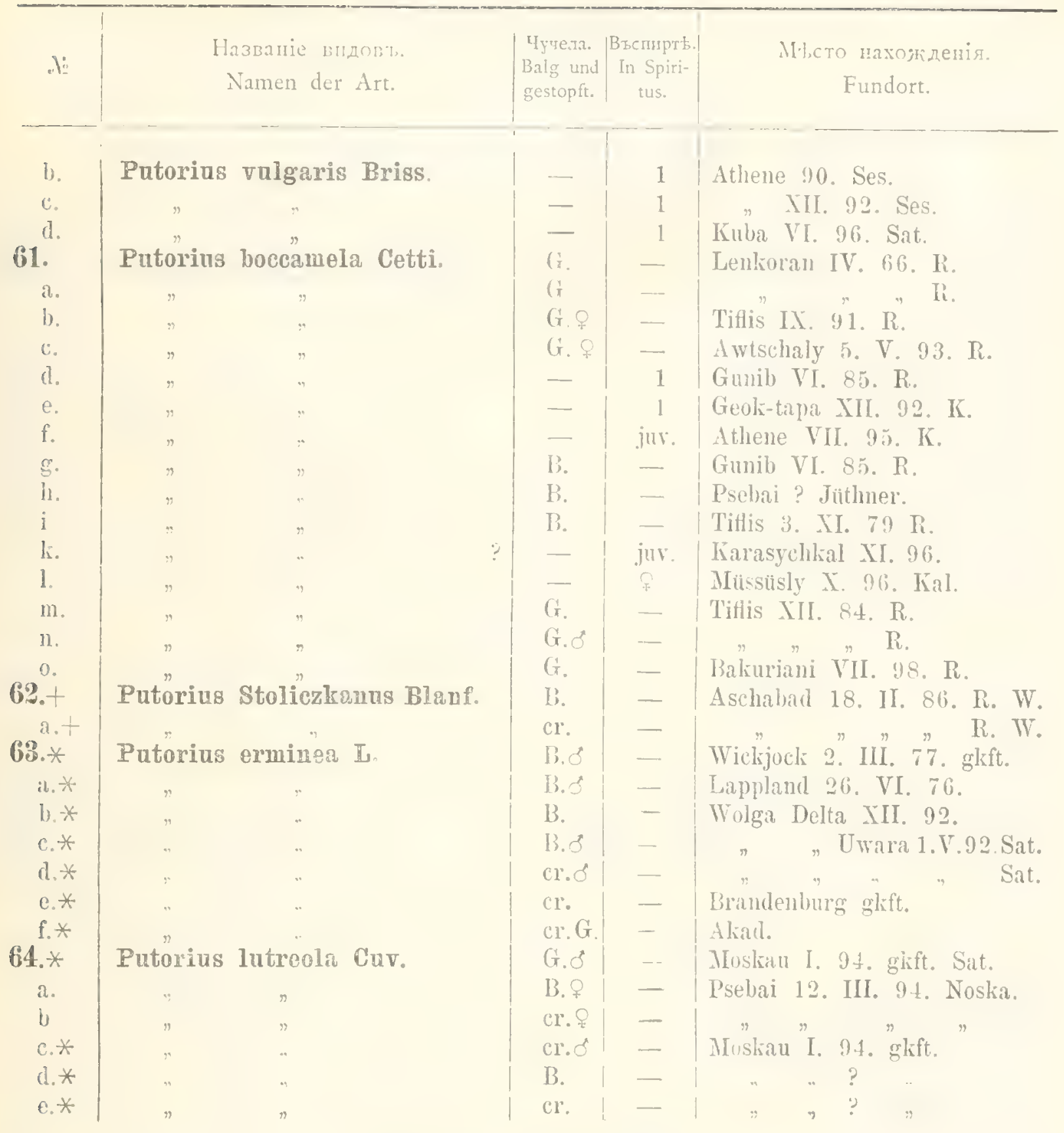

\section{FAM. PHOCIDAE}

65.* Phoca vitulina L.

66.

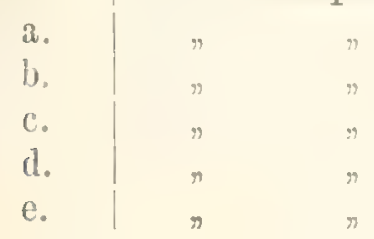

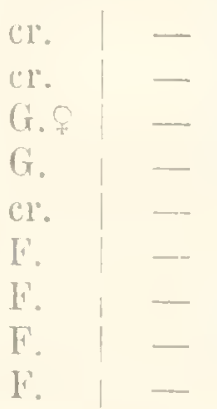

| Nordsec giff

Ostsee

Nordsec

Lenlioran IV. 67. R.

V. 67. R.

Petrowsk VI. 94. Sat.

Kaspisches Meer. Sat.

Sat.

Sat. 


\section{R O D E N TIA}

\section{FAM. SCIURIDA E}

IIIкапь-4\%. 4\%.-Schrank.

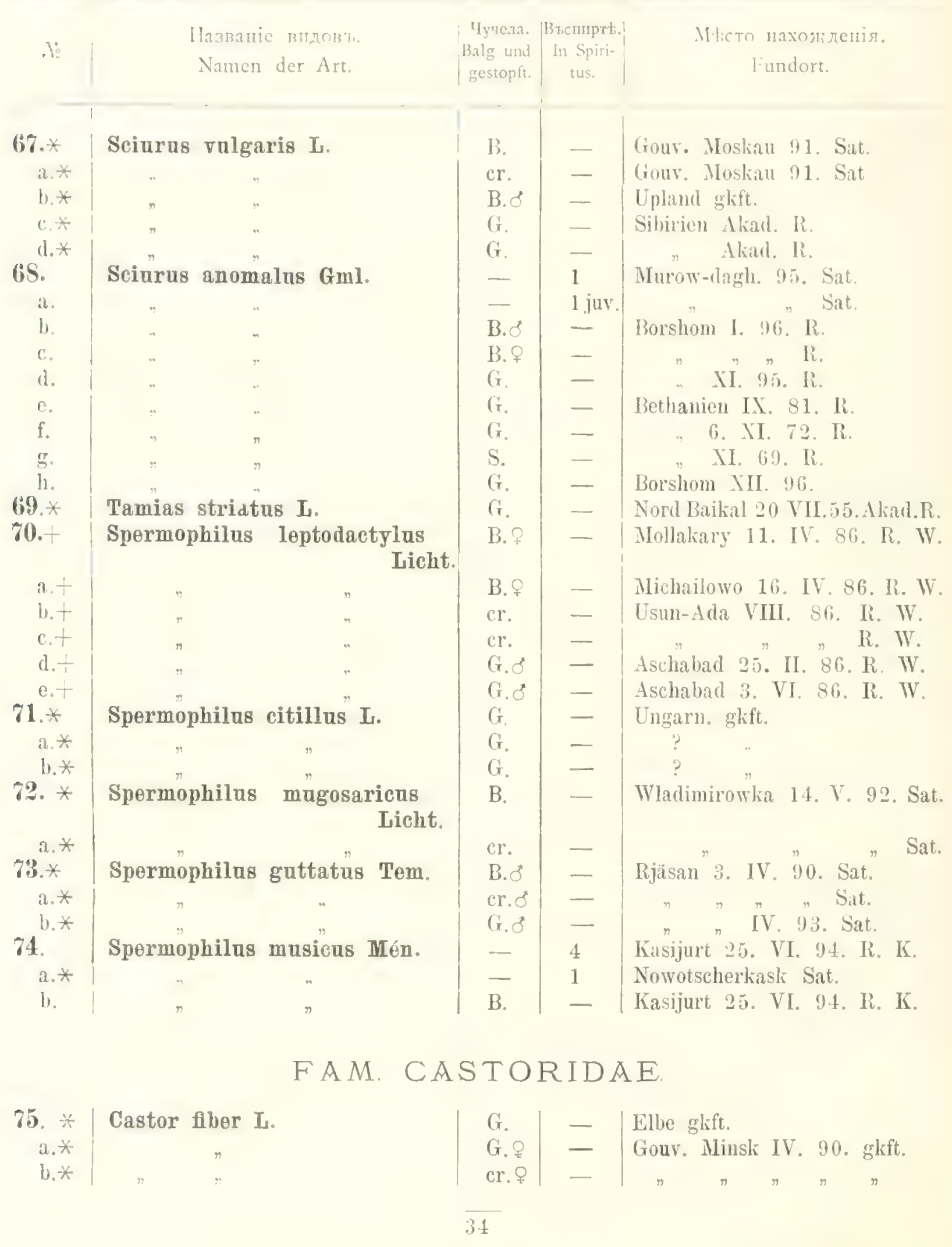




\begin{tabular}{|c|c|c|c|c|}
\hline . & $\begin{array}{l}\text { Названіе видовъ. } \\
\text { Namen der Art. }\end{array}$ & $\begin{array}{l}\text { Чучела. } \\
\text { Вalg und } \\
\text { gestopft. }\end{array}$ & $\left|\begin{array}{c}\text { Въспирть. } \\
\text { In Spiri- } \\
\text { tus. }\end{array}\right|$ & $\begin{array}{c}\text { MHсто нахожденія. } \\
\text { Fundort. }\end{array}$ \\
\hline $\begin{array}{l}\text { d. } \\
\text { e. } \\
\text { f. } \\
\text { g. } \\
\text { h. } \\
\text { i. } \\
\text { k. } \\
\text { l. } \\
\text { m. } \\
78 . \\
79 . * \\
90 . *\end{array}$ & $\begin{array}{c}\text { Myoxus glis L. } \\
", \\
"\end{array}$ & $\begin{array}{l}- \\
- \\
\text { Cr. } \\
\text { G. } \\
\text { G. } \\
- \\
- \\
- \\
- \\
- \\
\text { Cr. } \\
\text { G. } \\
\text { B. } \\
\text { B. } \\
\text { B. } \\
\text { B. } \\
- \\
\text { G. } \\
\text { G. } \\
\text { G. } \\
\text { B. }\end{array}$ & $\begin{array}{l}1 \\
\text { 30 } \\
- \\
- \\
-1 \\
1 \\
1 \\
1 \\
1 \\
- \\
- \\
- \\
- \\
-1 \\
- \\
-\end{array}$ & 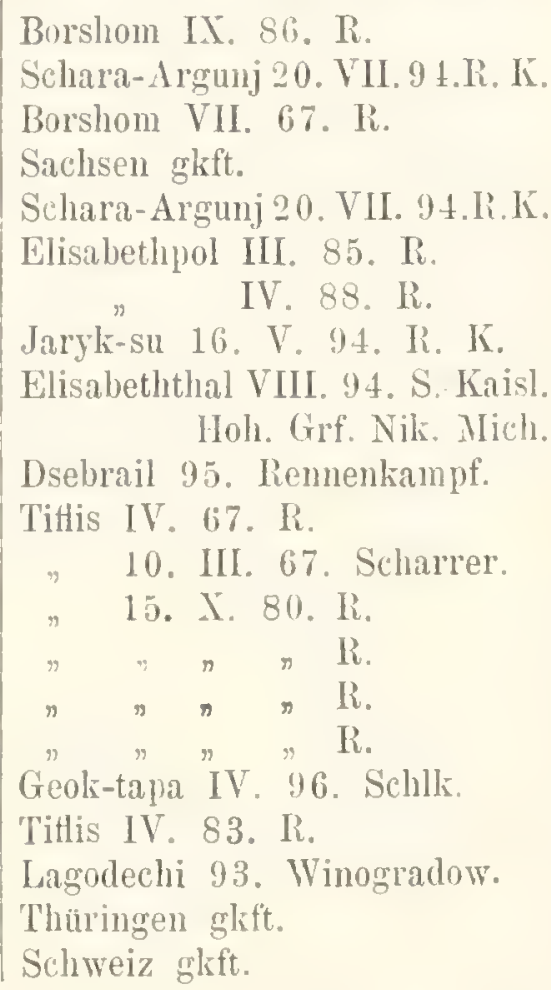 \\
\hline
\end{tabular}

\section{F A M. MUR I A E.}

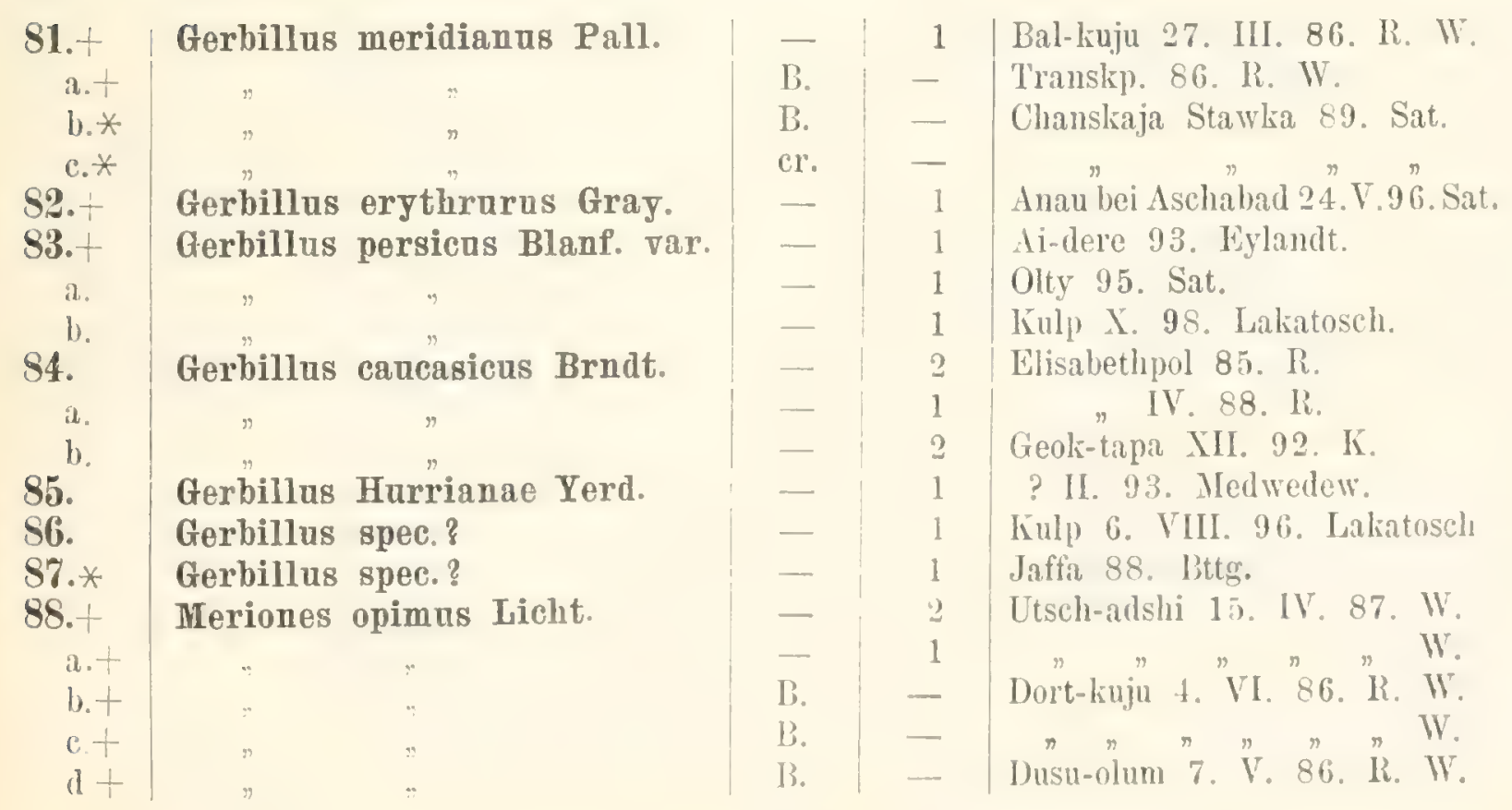




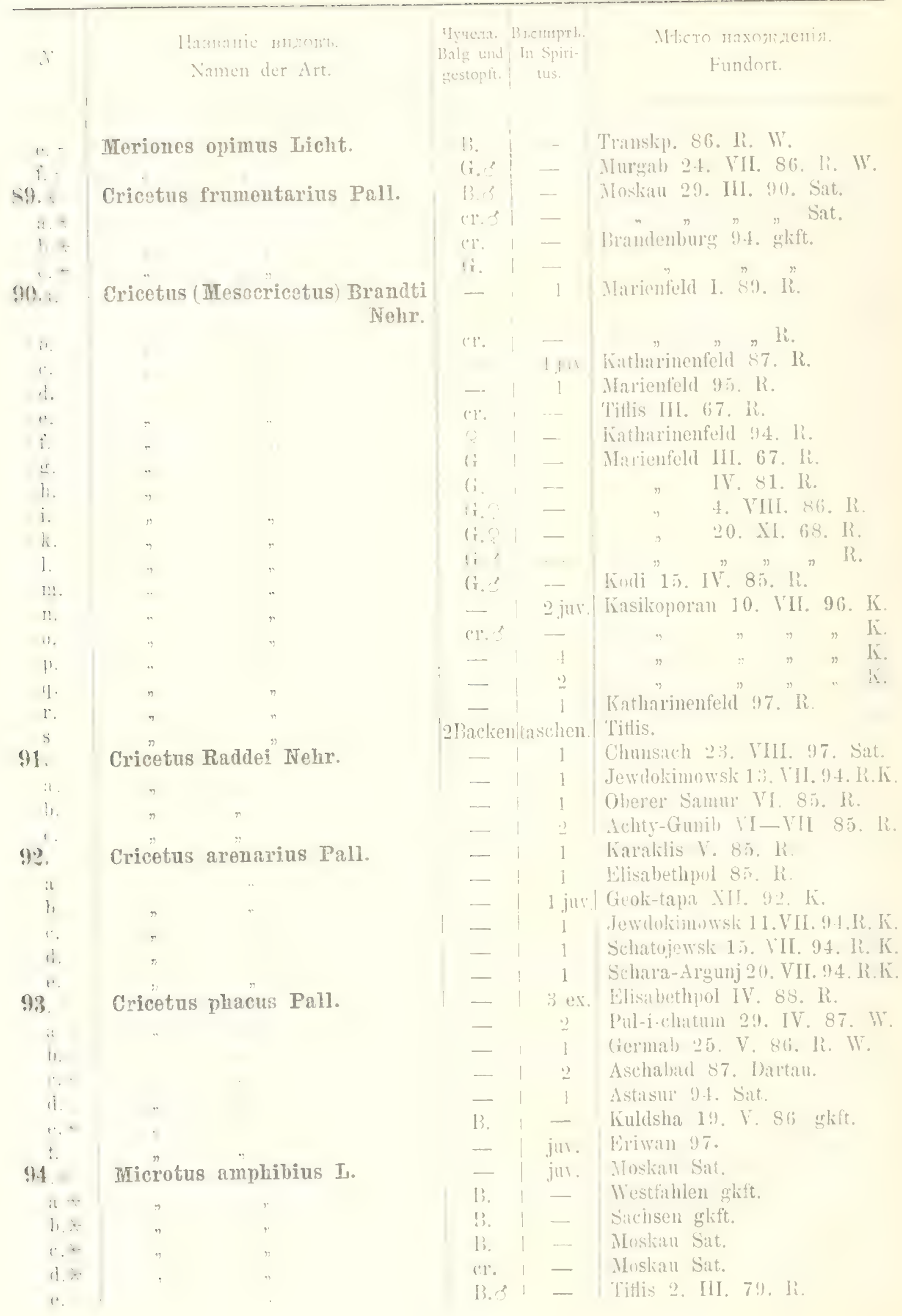




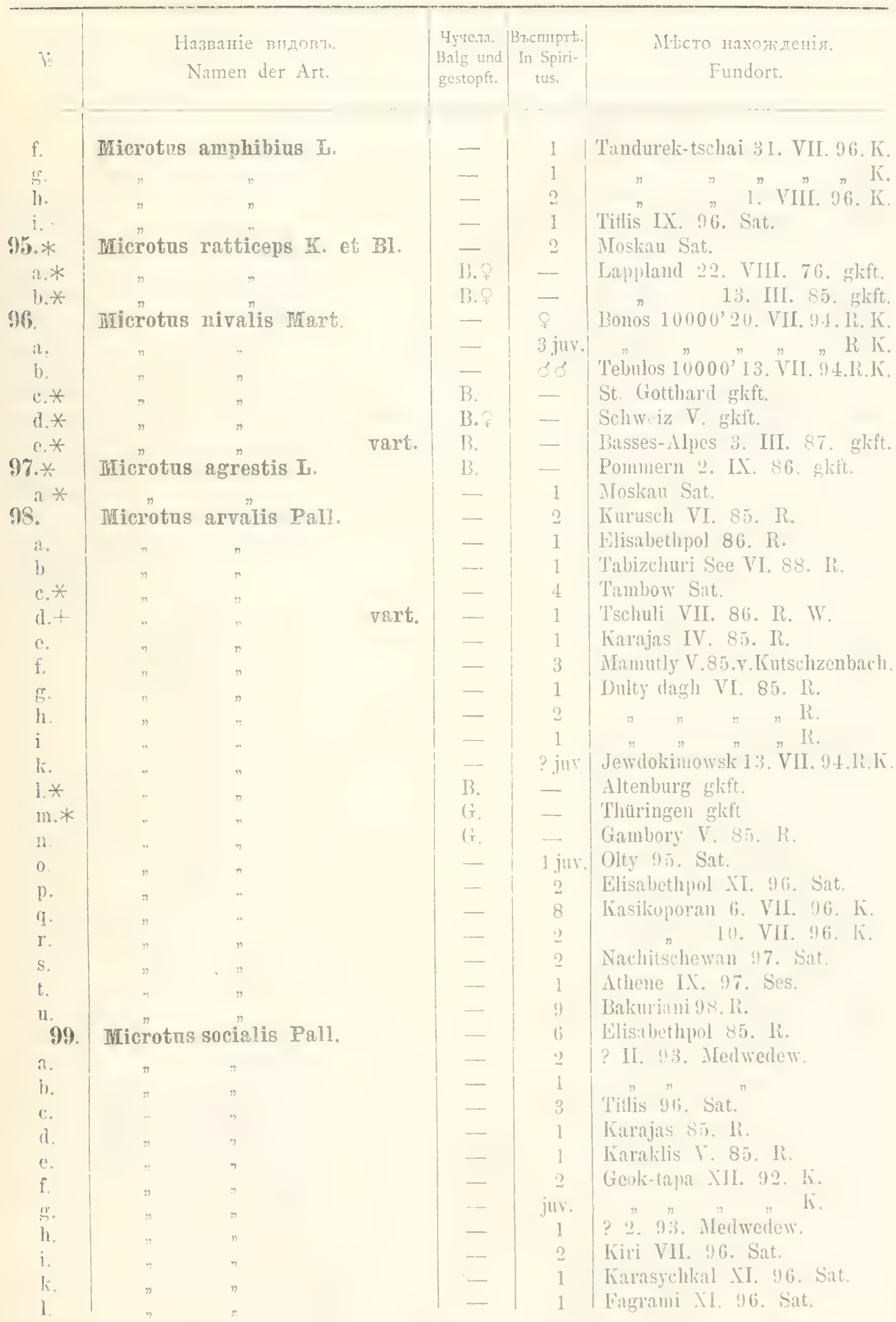




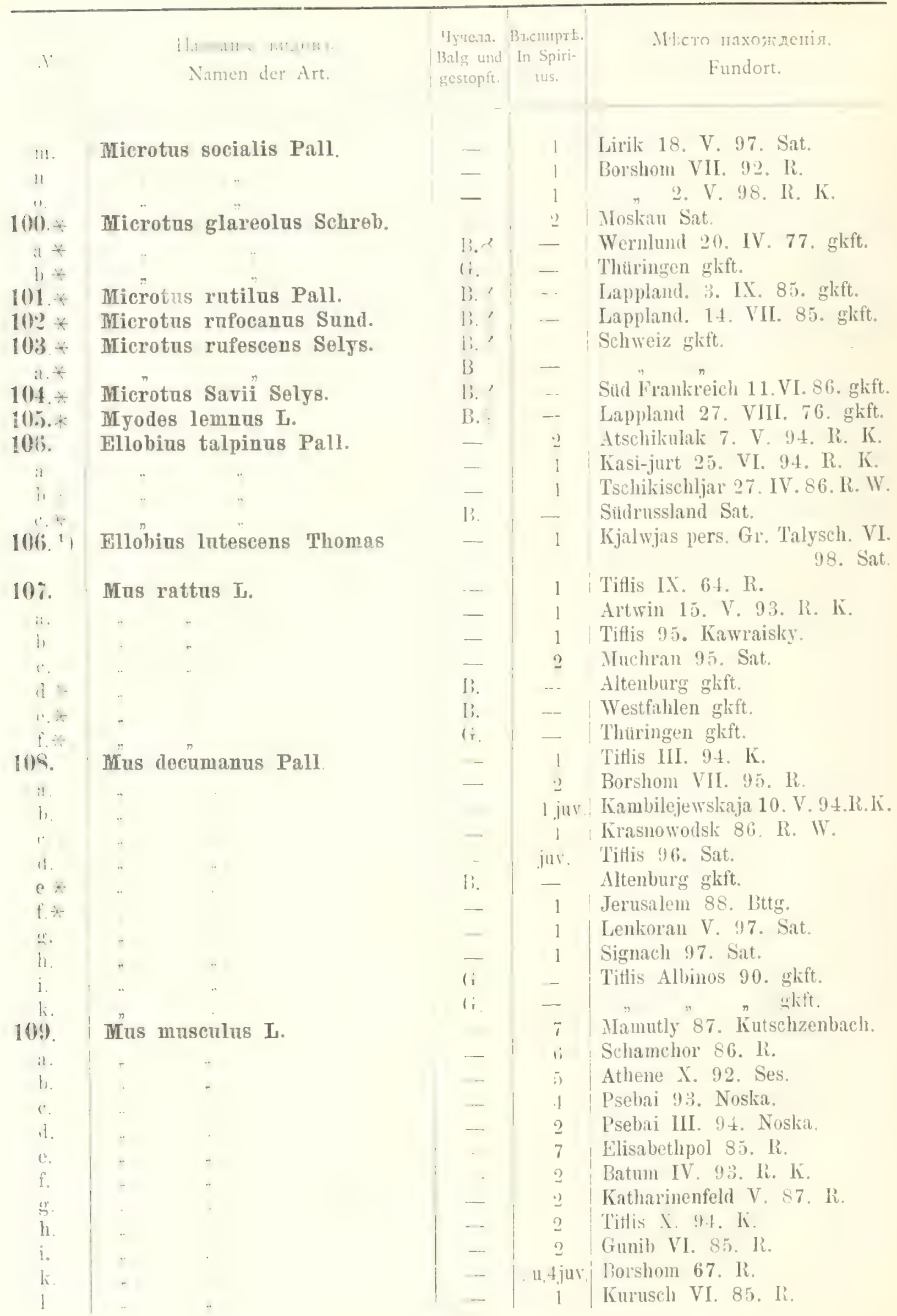




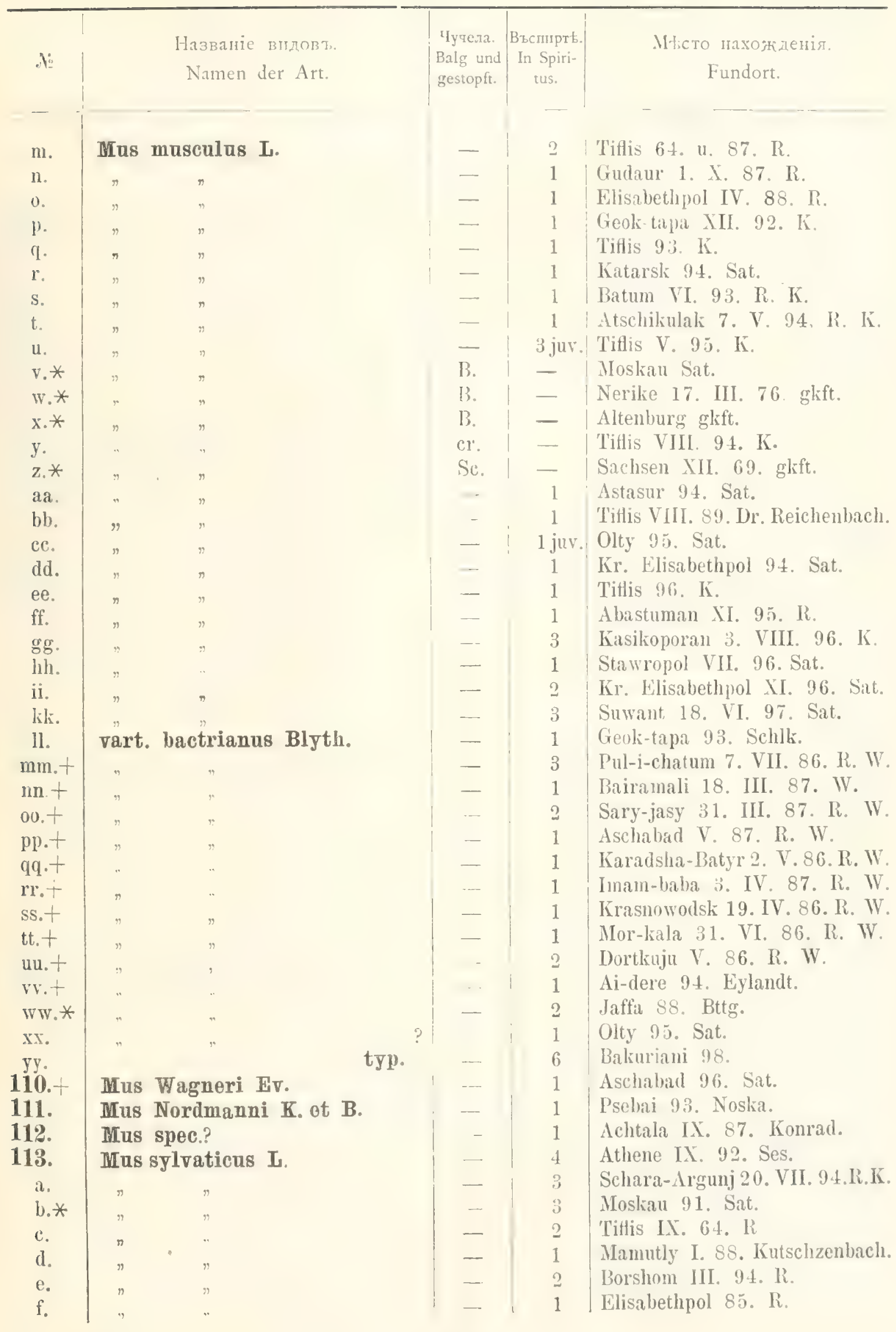




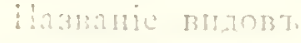

Samen der Are
Mticto naxojizenis.

Fundort.
MIus sylvaticus I.

vart, arianus Blanf.

1. A. Iras agrarius Pall.

‥

1)

$1 \cdot-$

$11, \ldots$

$116 \%$

$117 .-$

il.

114. - Nesokia Boettgeri Walt.

IIns minutus.

IIus spec?

Nosokia Hardwiclni Gray.

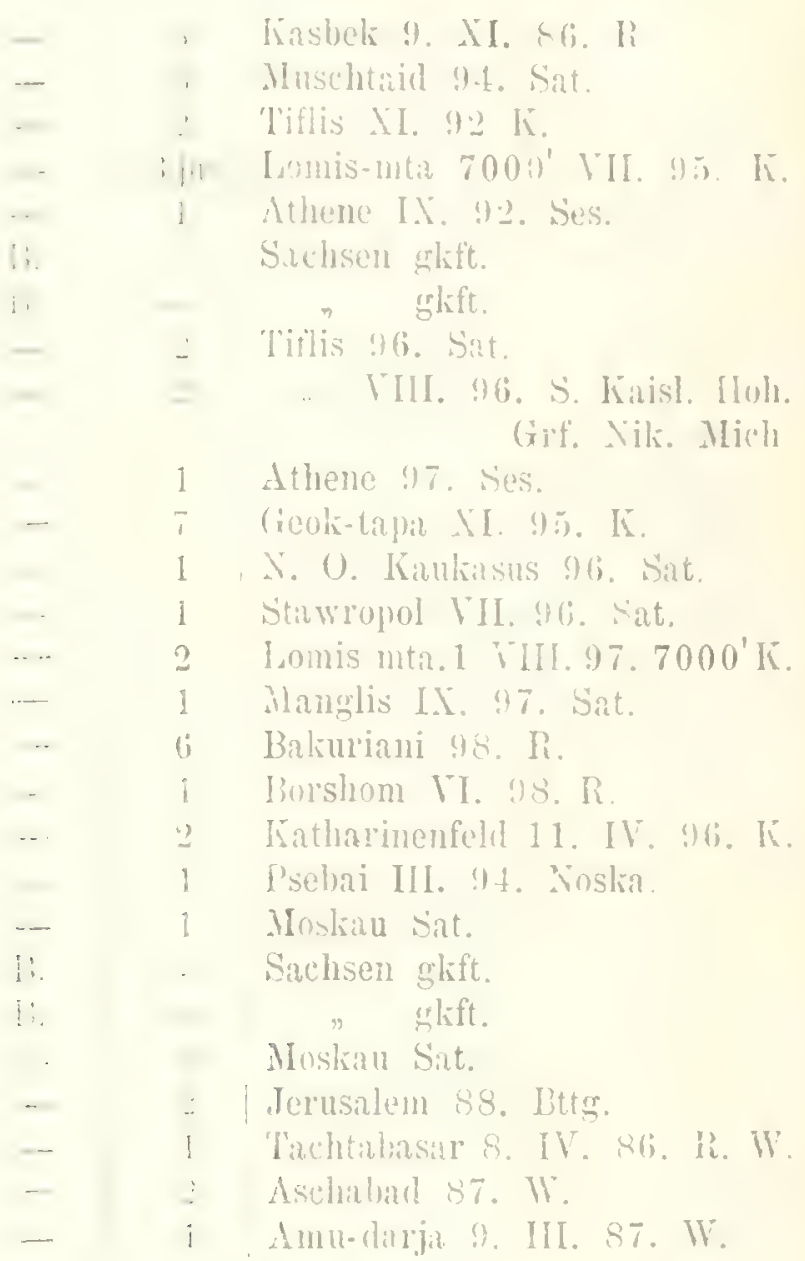

\section{FAM. SPALACIDAE}

11\%: Spalax Threnbergi Nohr.

il. II, 1 ,

.1.

b.

111

\section{Spalax Shrentergi Nehr.}

Spalax Nohringi Sat.

Spalax giganteus Nohr.

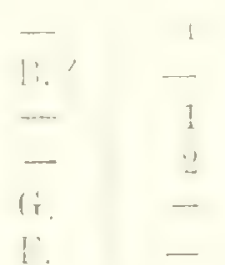

Jerusalem \&8. Di. Btto.

Djesir As. min. 20. XI. 77. glkft. Kasikoporan 5. FiL. 96. K.

14. VII. 95. K.

Tschir-jurt IX. (1. R. K.

\section{FAM. DIPODIDAE}
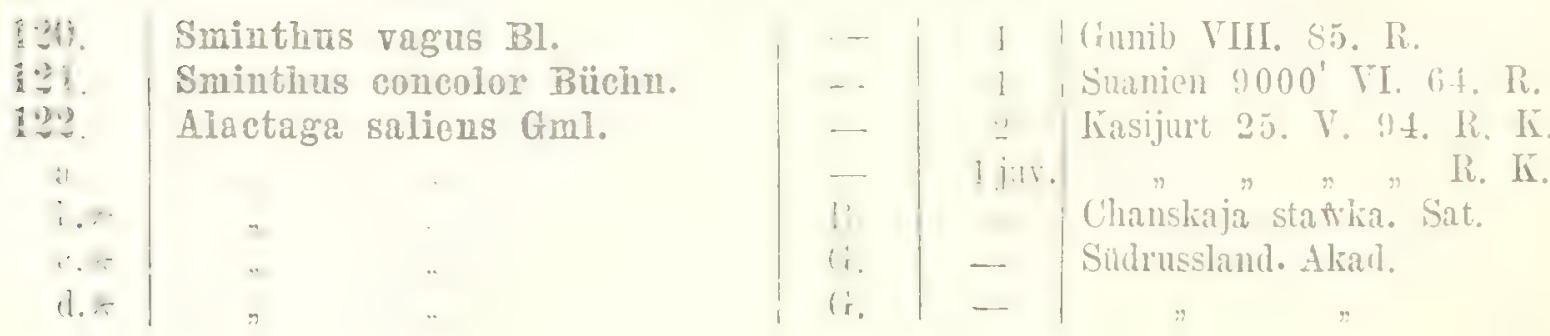


\begin{tabular}{|c|c|c|c|c|}
\hline. & $\begin{array}{l}\text { Названіе видовт. } \\
\text { Namen der Art. }\end{array}$ & $\begin{array}{l}\text { Чучела. } \\
\text { Balg und } \\
\text { gestopft. }\end{array}$ & $\begin{array}{c}\text { Brcmuprt. } \\
\text { In Spiri- } \\
\text { tus. }\end{array}$ & $\begin{array}{c}\text { Mticto maxожденія. } \\
\text { Fundort. }\end{array}$ \\
\hline
\end{tabular}

\begin{tabular}{|c|c|c|c|c|c|}
\hline $\begin{array}{r}123 . \\
a . \\
\text { b. } \\
124 . \\
\text { a. } \\
\text { b. } \\
125 .+\end{array}$ & $\begin{array}{l}\text { Alactaga } \\
\text { Alactaga } \\
\text { Alactaga }\end{array}$ & $\begin{array}{l}\text { Williamsi Thoms. } \\
\text { " } \\
\text { elater Lichst. } \\
\text { " } \\
\text { indica Gray. }\end{array}$ & $\begin{array}{l}- \\
- \\
- \\
\bar{G} \\
-\end{array}$ & $\begin{array}{l}1 \\
1 \\
2 \\
2 \\
2 \\
-2 \\
2\end{array}$ & $\begin{array}{l}\text { Kuba VII. 97. Sat. } \\
\text { Kulp X. 98. Lakatosch. } \\
\text { Kasijurt 25. V. 94. R. K. } \\
\text { Mugan 95. Sat. } \\
\text { Udshari XI. 87. R. } \\
\text { Karybent 19. III. 86. juv. V. } \\
\text { 86. R. W. }\end{array}$ \\
\hline
\end{tabular}

FAM, HYSTRICIDAE,

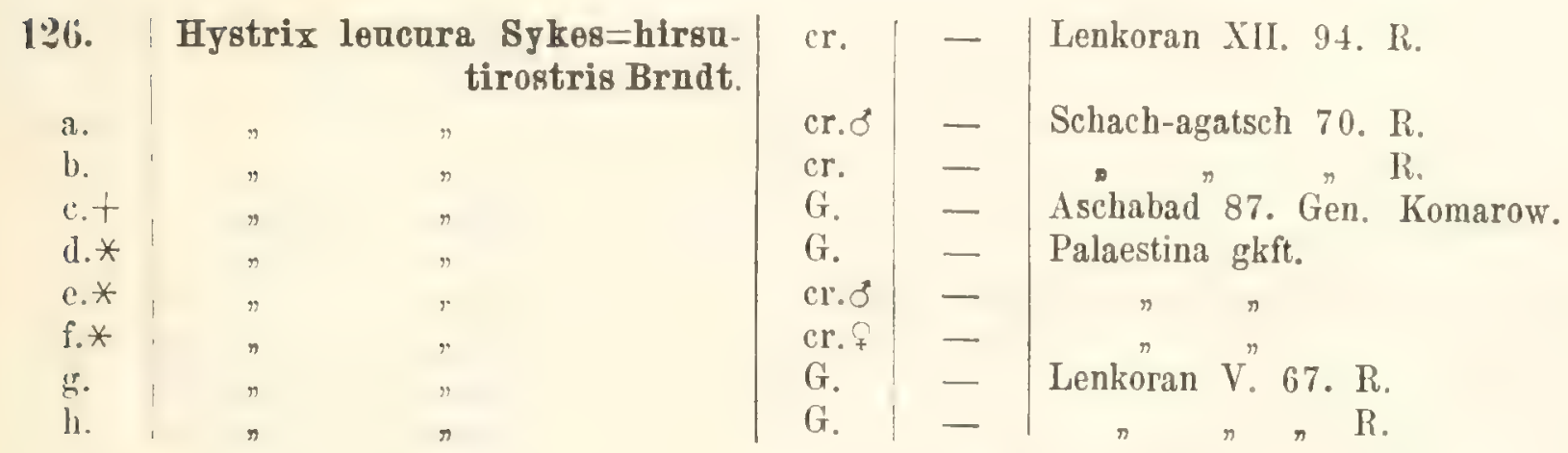

\section{FAM. CAVIIDAE.}

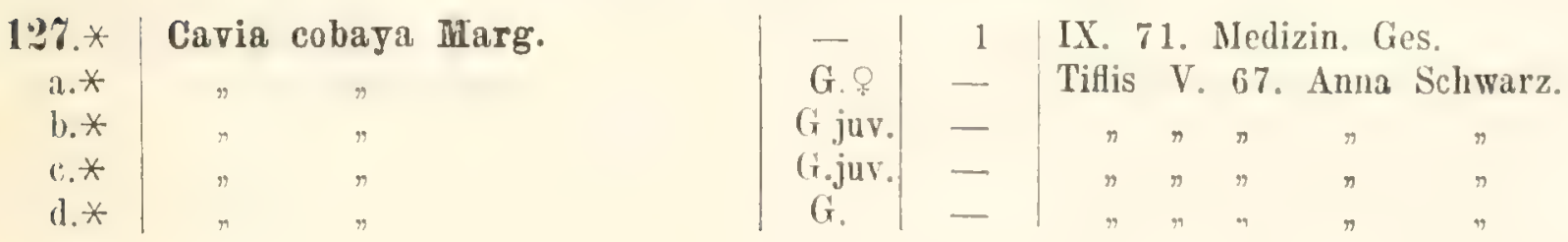

\section{FAM. LAGOMYIDAE.}

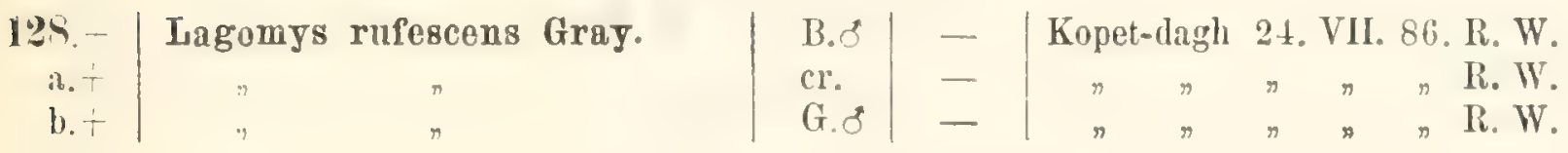

\section{FAM LEPORIDAE.}

\begin{tabular}{c|c|c|} 
129. & Lepus europaens Pall=timidus L. \\
a. & $"$ & $"$ \\
b* & $"$ & $"$ \\
c. & $"$ & $"$ \\
d. & $"$ & $"$ \\
e. & $"$ & $"$ \\
f. & $"$ & $n$ \\
g. & $"$ & $"$
\end{tabular}

\begin{tabular}{l|l|l} 
G. & - & Kumbaschinsk 10. III. 80. R. \\
I.. & - & Tiflis 25. III. 82. R. \\
(x. & - & Moskau I. 94. gkft. I. \\
G. & - & Tiflis Herbst. 85. R. \\
(:.juv. & - & Tiflis IV. 85. R. \\
- & 3 juv. & Atachly 93. gkft. \\
- & 1 juv. & Saljan 95. Sat. \\
- & 1 juv. & A resch 9S. Schlk.
\end{tabular}




\begin{tabular}{|c|c|c|c|c|c|}
\hline $1:$ & & $\begin{array}{l}\text { Названіс видовт. } \\
\text { Namen der Art. }\end{array}$ & $\left|\begin{array}{c}\text { tyuena. } \\
\text { Balg und } \\
\text { gestopft. }\end{array}\right|$ & $\begin{array}{c}\text { Bzспирты. } \\
\text { In Spirj- } \\
\text { tus. }\end{array} \mid$ & $\begin{array}{c}\text { Niсто nахожденія. } \\
\text { Fundort. }\end{array}$ \\
\hline h. & \multicolumn{2}{|c|}{ Lepus europaens Pall.=timidusL.| } & $(\mathrm{r} .8)$ & - & L'sebai III. 94. Noska. \\
\hline i. $*$ & . & -. & cr.요 & - & Sachsen gkft \\
\hline li. $\star$ & $\ldots$ & - & $\mathrm{cr}^{\circ} \mathrm{O}$ & - & $n \quad$, \\
\hline 1. & . & . & (cr. & - & Schamchor XI. 88. R. \\
\hline 111. & $"$ & " & cr.juv. & - & $" \quad \Rightarrow \quad n \quad \mathrm{li}$. \\
\hline$n$. & - & " & cr. 7 & - & Tiflis $\mathbf{X} .94 . \mathrm{K}$. \\
\hline 0. & $\cdots$ & n & $\mathrm{cr} . f$ & 一 & $" \quad \Rightarrow 95 . \mathrm{K}$. \\
\hline 1) & ? & " & $\operatorname{cr.8}$ & - & $"$ I. $96 . \mathrm{K}$. \\
\hline 1. & . & . & er.juv & -- & $n$ X.96. K. \\
\hline$\therefore$ & & .. & $\mathrm{cr}^{2} .8$ & - & Schanchor XI. 88. R. \\
\hline$\therefore$ & . & . & $\operatorname{cr} \varangle \mathbf{j}$ & - & $n \quad " \quad n \quad \mathbf{R}$. \\
\hline t. $*$ &. & ; & $\mathrm{cr}^{3}$ & - & Moskiu 1.94. gkft. I. \\
\hline 11. & $\Rightarrow$ & . & G. & - & 'Tiflis $8 \overline{0} . \mathrm{R}$. \\
\hline$r$. & . & . & G. & - & $" n R$. \\
\hline w. & - &. & G. & - & $n \quad n \quad \mathrm{R}$. \\
\hline $\mathrm{x}$. & , & . & $\mathrm{l}$ & - & Kedabeg 98. Kölle. \\
\hline y. & , & $"$ & B. 8 & $-\cdots$ & Bakuriani VII. 98. R. \\
\hline$\%$ & $i \quad n$ & $\pi=$ & $\mathrm{cr} .8$ & - & $n \quad$ n $\quad$ R. \\
\hline $130 * *$ & $\mathrm{I}^{3} \mathrm{pus} \mathrm{t}$ & imidus $L_{.}=$variabilis Pall. & $\mathrm{G} .8$ & - & Moskau 1\%. I. 94. gkft. \\
\hline a. $*$ & 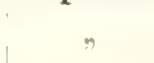 & $n$ & G. 8 & - & Wladimir VII. 94. gkft. \\
\hline b. $*$ & $\eta$ & $"$ & cr. 8 & - & Moskau 15. I. 94. gkft. \\
\hline c. $*$ & $n$ & $"$ & $\mathrm{cr} .8$ & - & Wladimir VII. 94. ghft. \\
\hline $1: 31$ & Lepus I & Lehmanni Sev._tolai Pall. & Ii.' & -- & Ljutfabat 2s. III. 86. R. W. \\
\hline a. + & , & v. Lehmanni. Büch. & B. & - & Duschak 16. III. 86. R. W. \\
\hline b. + t & $"$ & $n$ & B.juv. & - & $=18$. III. 86. R. W. \\
\hline et & $"$ & $n$ & 6.8 & - & 20. III. 86. R. W. \\
\hline $1: 3 \cdot 3$ & Lepus & cuniculus L. & G. & - & Brandenburg gkft. \\
\hline a.* $*$ & $r$ & " & cr. & - & $\pi$ \\
\hline b. $*$ & " & $\Rightarrow$ & G. & 一 & Tillis. \\
\hline
\end{tabular}

\section{U N G U L A T A.}

FAM. SUIDAE

Шгапь-38. 43.-8chrank.

\begin{tabular}{|c|c|c|c|c|}
\hline . & $\begin{array}{l}\text { Hазваніс видовт. } \\
\text { Namen der Art. }\end{array}$ & $\begin{array}{l}\text { Чyчc.ia. } \\
\text { Balg und } \\
\text { gestopft. }\end{array}$ & $\begin{array}{c}\text { Bzcmuprt. } \\
\text { In Spiri- } \\
\text { tus. }\end{array}$ & $\begin{array}{c}\text { Mtсто nахождденія. } \\
\text { Fundort. }\end{array}$ \\
\hline $\begin{array}{l}\text { 1:3:3. } \\
\text { i.. } \\
\text { b. }\end{array}$ & $\begin{array}{c}\text { Sus scrofa L. } \\
" \quad " \\
"\end{array}$ & $\begin{array}{l}\text { G. } \\
\text { G. } \\
\text { G.juv. }\end{array}$ & $\begin{array}{l}- \\
-\end{array}$ & $\begin{array}{l}\text { Karajas } 70 . \text { S. Kaisl. Hoh. Grf. } \\
\text { Mich. Nik. } \\
\text { Lenkoran 67. R. } \\
\text { Karajas 5. V. 82. R. }\end{array}$ \\
\hline
\end{tabular}




\begin{tabular}{|c|c|c|c|c|}
\hline. & $\begin{array}{l}\text { Названіе вндовт. } \\
\text { Namen der Art. }\end{array}$ & $\begin{array}{l}\text { Чучела. } \\
\text { Вalg und } \\
\text { gestopft. }\end{array}$ & $\left|\begin{array}{c}\text { Bъспирть. } \\
\text { In Sptri- } \\
\text { tus. }\end{array}\right|$ & $\begin{array}{c}\text { Mむсто нахозденія. } \\
\text { Fundort. }\end{array}$ \\
\hline r. $\bar{\dagger}$ & Sus scrofa L. & B. $j$ j. & - & Tedshen 20. III. 86. Ii. W. \\
\hline d. & $n$ & cr. $f$ & 一 & Lenkoran III. 66. R. \\
\hline e. & " & cr.juv. & - & $\Rightarrow \quad$ IV. 66. R. \\
\hline f. & $"$ & cr. 3 & - & Tiflis 78. R. \\
\hline$\dddot{2}$ & $"$ & cr.s & - & Borshom 92. R. \\
\hline h. & $"$ & cr. \& & - & Psebai 94. Noskíl. \\
\hline i. & , & $\mathrm{cr} \cdot \mathrm{q}$ & 一 & $n 94 . \quad r$ \\
\hline k. & $"$ & cr.오 & - & $\Rightarrow \quad 94 . \quad \%$ \\
\hline 1. & , & $\mathrm{cr} .8$ & - & $\begin{array}{r}\text { Karajas 97. S. Kaisl. Hoh. (irf. } \\
\text { Nik. Mich. }\end{array}$ \\
\hline m. & " & cr. & - & $\gg 96 . \mathrm{R}$. \\
\hline H. & .. & cr. & - & Lenkoran $\mathrm{R}$. \\
\hline 0. & "domestica & cr. $\delta^{\prime}$ & - & Tiflis 98. R. \\
\hline 11. & , & cr. & - & $" n \quad l i$. \\
\hline ' & " & $\mathrm{cr} .{ }^{\circ}$ & - & Mingrelien 98. I'rinz Murat. \\
\hline$r$. &. & cr. 운 & - & $n$ \\
\hline
\end{tabular}

FAM CAMELIDAE.

\begin{tabular}{|c|c|c|c|c|}
\hline $1: 31$. & Camelus dromedarius $\mathbf{L}$. & cr. $0^{*}$ & - & Mugan 24. XI. 85. I. \\
\hline it. & " & cr. + & - & r li. \\
\hline b. & $"$ & cr.? & 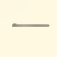 & ". \\
\hline 1:3.\%. & Camelus bactrianns L. & cr. & - & 'Tiflis 67. Oberkiefer'. \\
\hline .6. & 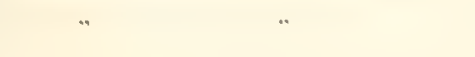 & $\mathrm{cr}$. & - & $"$ \\
\hline & $"$ & G. & 一 & $\eta$ \\
\hline
\end{tabular}

FAM CERVIDAE.

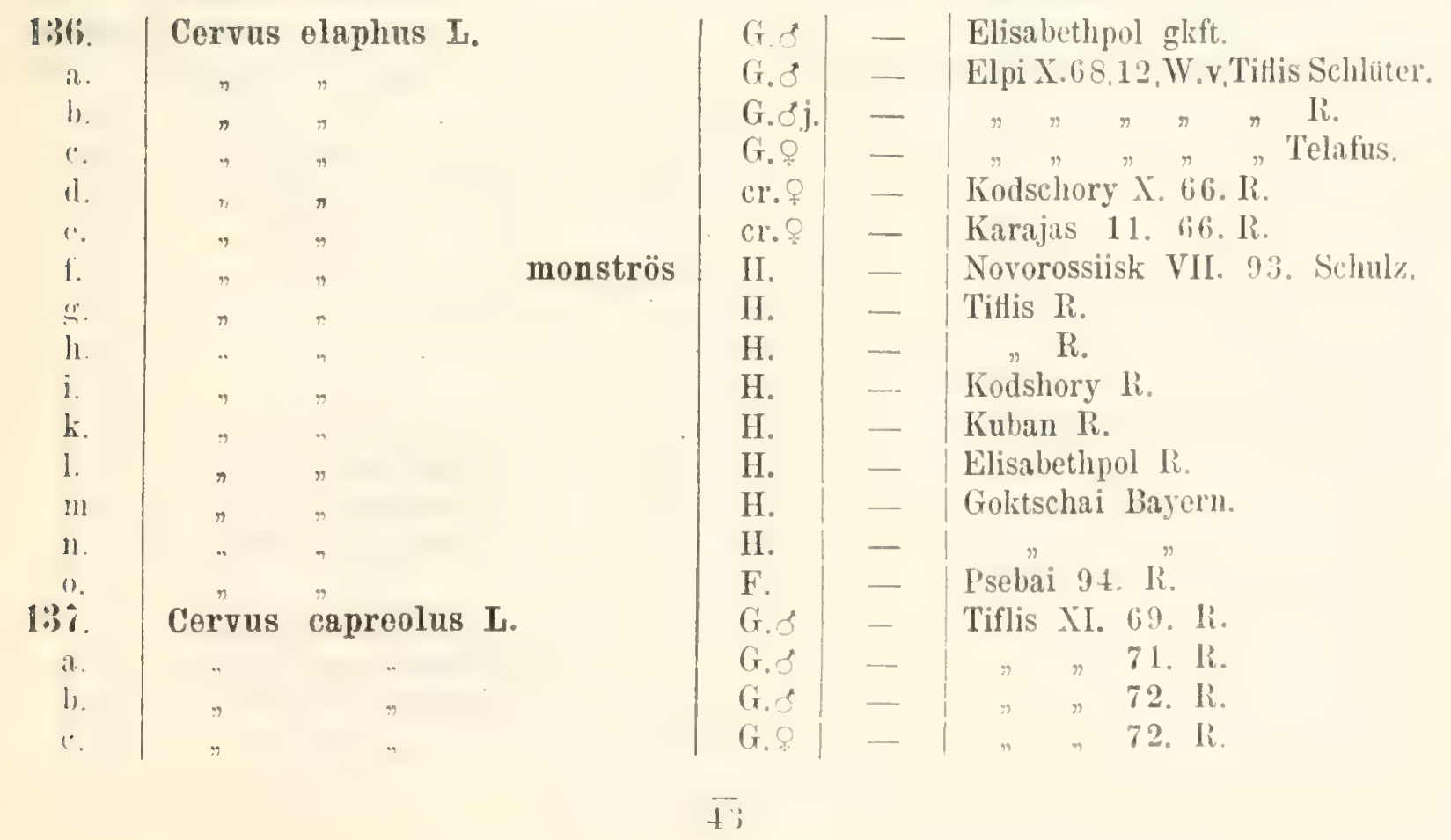




\begin{tabular}{|c|c|c|c|c|c|}
\hline$\therefore$ & & $\begin{array}{l}\text { Hazmanie видов'. } \\
\text { Namen der Art. }\end{array}$ & $\begin{array}{l}\text { पуचела. } \\
\text { Balg und } \\
\text { gestopft. }\end{array}$ & $\begin{array}{c}\text { Bzemuprt. } \\
\text { In Spiri- } \\
\text { zus. }\end{array} \mid$ & $\begin{array}{c}\text { Mtсто naxogrденiя. } \\
\text { Fundort. }\end{array}$ \\
\hline 11. & Cervus & capreolus L. & (i.juw.) & - & Tiflis XI. 72. \\
\hline$\because$ & & . & cr. 8 & - & "XII. 66. \\
\hline f & & & er.f & 一 & $\begin{array}{r}\text { Synobad. Kr. Elisabethpol } 28 . \\
\text { XII. } 86 .\end{array}$ \\
\hline 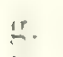 & & . & cr. $\delta$ & - & $n \quad " n \quad n=n$ \\
\hline h. & .. & .. & $\mathrm{cr}^{2} 3$ & - & $\begin{array}{r}\text { Derbent 5. XII. 78. A. W. Ko- } \\
\text { marow. }\end{array}$ \\
\hline i. & .. & 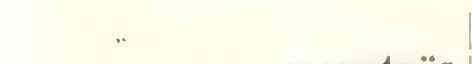 & H. & - & Novorossiisk Schulz VII. 93. \\
\hline$k$. &. & monströs. & Fuss & $\longrightarrow$ & Synobad IX. 87. \\
\hline 1. & .. & . & $\operatorname{cr} .8$ & $\cdots$ & $\begin{array}{r}\text { Delishan 97. Kalischewsky u. } \\
\text { Birechert. }\end{array}$ \\
\hline III. & $"$ & $"$ & H. & - & Tiflis. \\
\hline n. & , & $"$ & $\mathrm{H}$. & 一 & $\begin{array}{r}\text { Tiflis-Bjely-klutsch Gen. Mura- } \\
\text { wjew. }\end{array}$ \\
\hline 0. & . & .. & $\mathrm{H}$. & - & $n$ \\
\hline 1 . & . & . & H. & - & $\eta$ \\
\hline I!. & * & m & H. & - & $"$ \\
\hline$r$. & . & " & $\mathrm{H}$. & - & 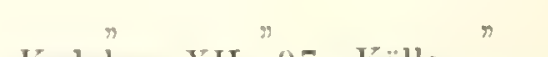 \\
\hline s. & " & $n$ & cr. 8 & - & Kedabeg XII. 97. Külle. \\
\hline t. & Cervus & $\begin{array}{r}\text { capreolus L. pygargus } \\
\text { Pall. }\end{array}$ & II. & - & Maikop VII. 93. Gen. Hunnius. \\
\hline u. & n & - & $\mathrm{H}$. & - & Kuban VII. 93. Schulz. \\
\hline$r$. & $"$ & $"$ & H. & - & $\begin{array}{r}\text { Kisljar 23. V } 9 \text { t. Satrapes- } \\
\text { nikow. }\end{array}$ \\
\hline
\end{tabular}

FAM. BOVIDAE,

135. Saiga tatarica L.

139. Gazella subgutturosa Güld.

is.

b.

('.

d.

i.

f.

f.

140. Capolla rupicapra L.

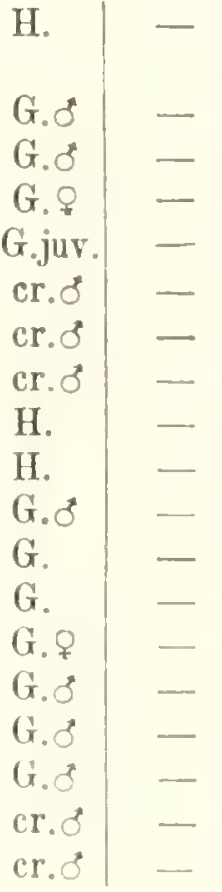

Transkaspien 5. XII. 78, A. W. Komarow.

Karajas XI. 67. R "XII. 69. R.

$\rightarrow 72 . \mathrm{R}$

Tiflis V.8 1. R.

" $66 . \mathrm{R}$

Karajas. R.

n R.

$\rightarrow \mathrm{R}$.

Abastuman 68. $\mathrm{R}$.

Bjely-klutsch 72. R.

Borshom XI. 92, R.

Psebai 94. Noska.

9. 4 .

$\rightarrow 94$.

Schweiz. gkft.

Borshom 69. R. 72. R. 


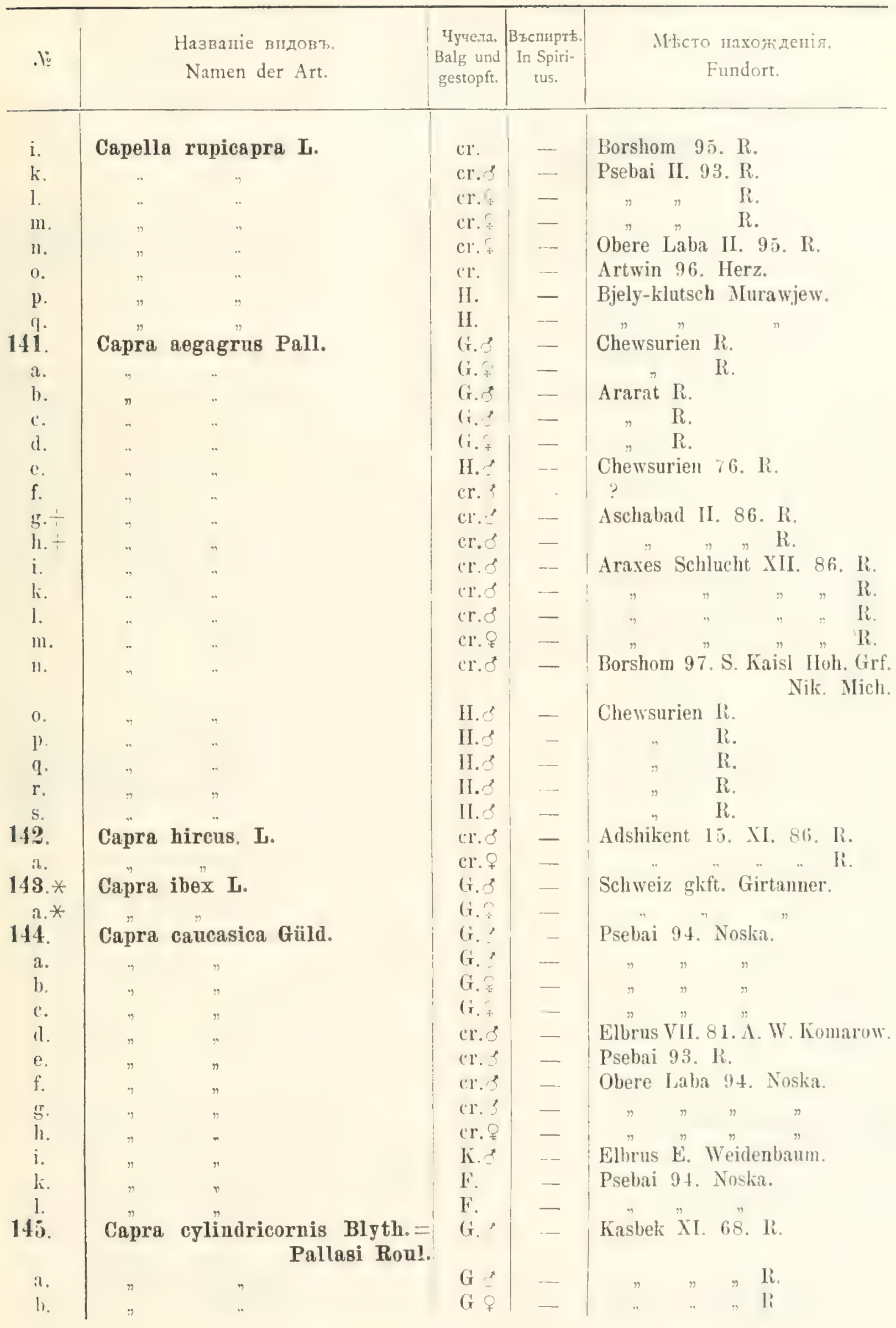




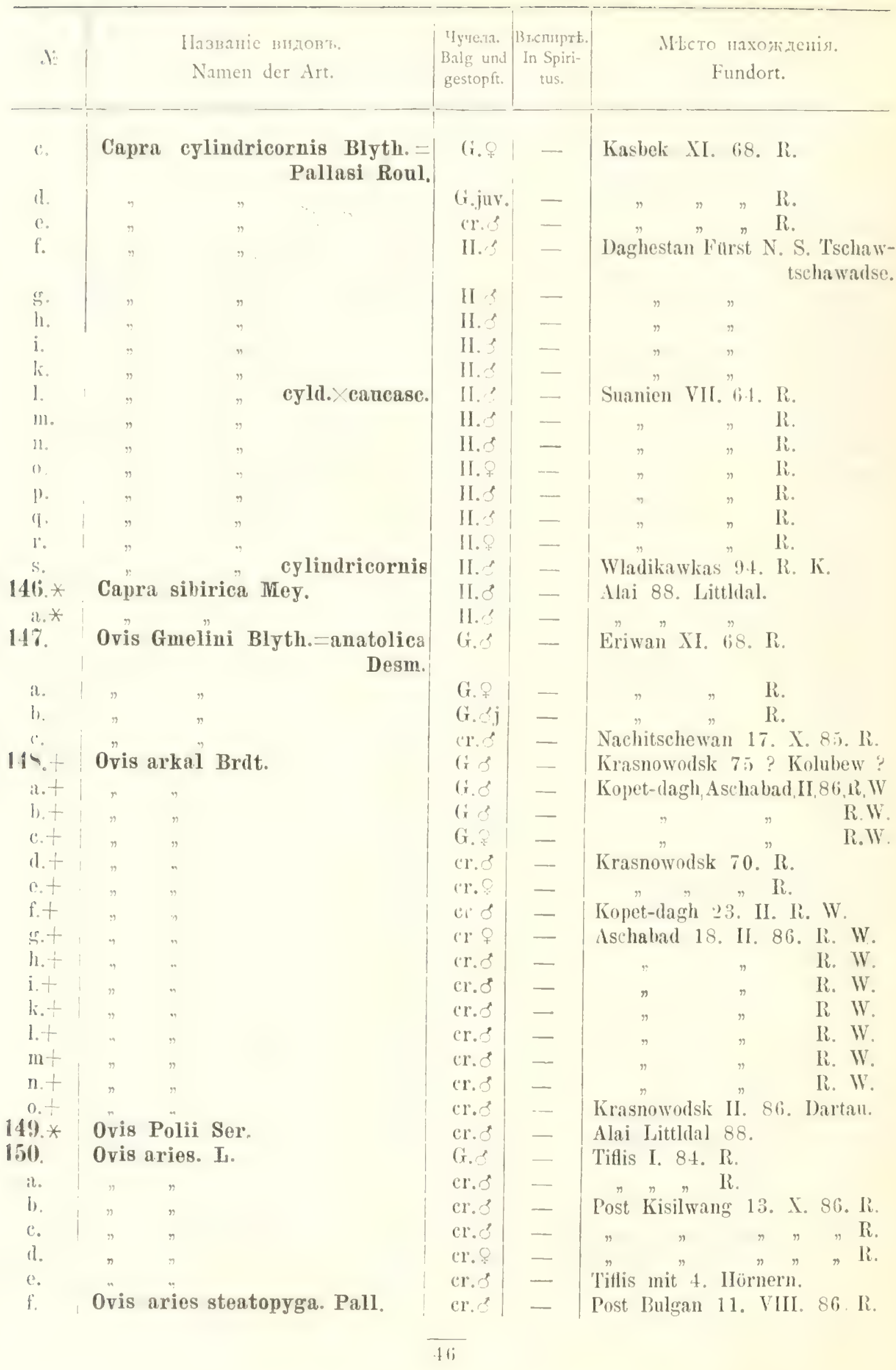




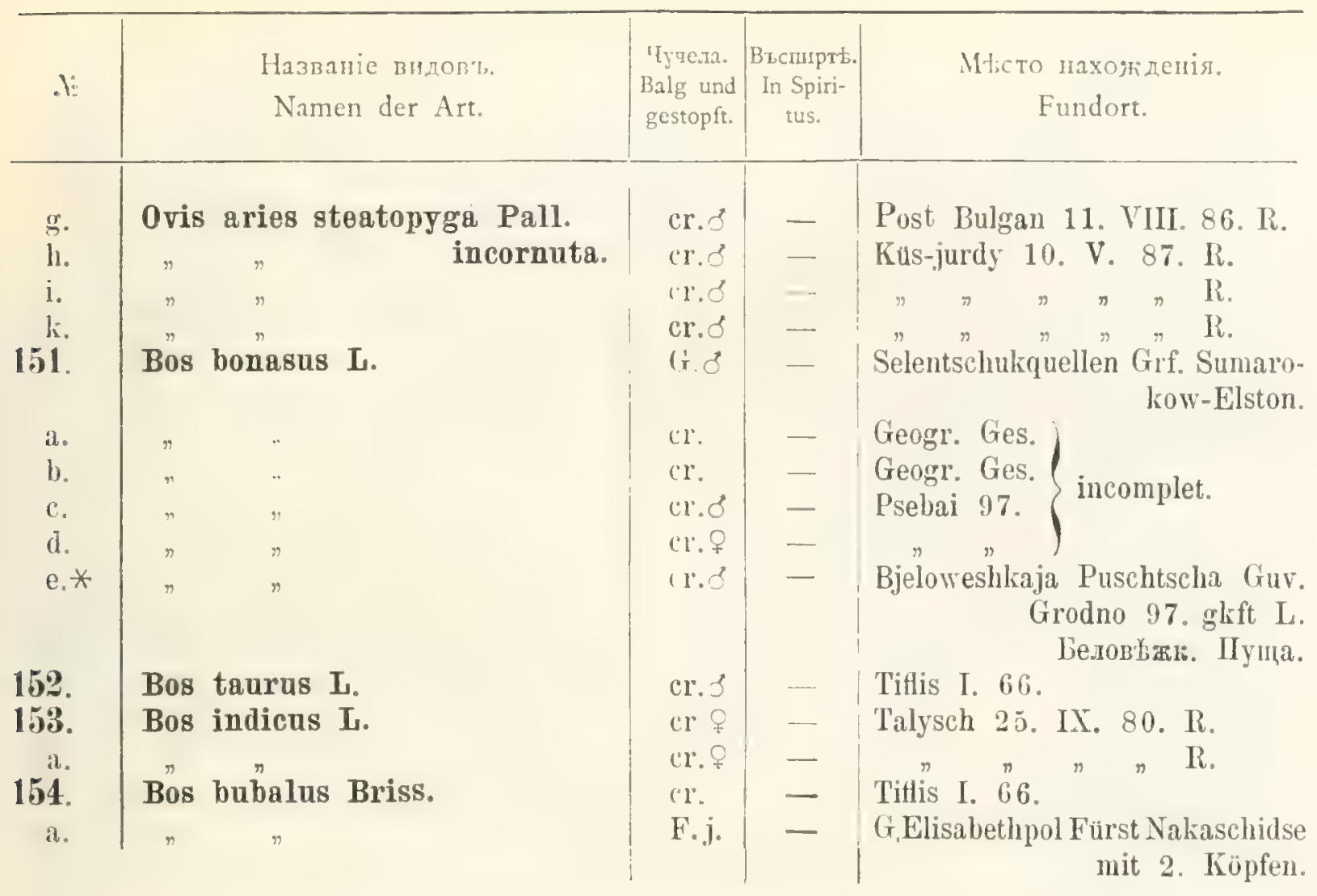

\title{
FAM. EQUIDAE.
}

155. Equus caballus L.

156. Equus asinus $L$.

157. + Equus hemionus Pall.

\begin{tabular}{l|l|l} 
cr. & - & Tiflis I. 66. R. \\
cr. & - & Helenendorf 25. III. 87. R. \\
r. & - & Tiflis I. 66. R. \\
(1. & - & Aschabad V.86.A.W. Komarow.
\end{tabular}

\section{E T A C E A.}

\author{
FAM. BALAENIDAE
}

Шॉкапъ-43.-Schrank.

\begin{tabular}{|c|c|c|c|c|}
\hline . & $\begin{array}{l}\text { Названіе видовт. } \\
\text { Namen der Art. }\end{array}$ & $\begin{array}{l}\text { Чyुчeza. } \\
\text { Balg und } \\
\text { gestopft }\end{array}$ & $\mid \begin{array}{c}\text { Bzcmiprt. } \\
\text { In Spiri- } \\
\text { tus. }\end{array}$ & $\begin{array}{c}\text { Mtсто нахождденія. } \\
\text { Fundort. }\end{array}$ \\
\hline 158. & Balaenoptera rostrata Fab. & Sie. & - & $\begin{array}{l}\text { Ihatum V. sll. (ien. K. W. Kóo- } \\
\text { marow. }\end{array}$ \\
\hline
\end{tabular}




\begin{tabular}{|c|c|c|c|c|}
\hline. & $\begin{array}{l}\text { Назваnie вндог\%. } \\
\text { Namen der Art. }\end{array}$ & $\begin{array}{l}\text { 'y're.sa. } \\
\text { Balg und } \\
\text { gestopft. }\end{array}$ & $\mid \begin{array}{c}\text { Bвепирть. } \\
\text { In Spiri- } \\
\text { tus. }\end{array}$ & $\begin{array}{c}\text { Mticro naxождcuis. } \\
\text { Fundort. }\end{array}$ \\
\hline $\begin{array}{l}15 ! \\
\text { ib. } \\
\text { b. } \\
160 . * \\
\text { a. * }\end{array}$ & $\begin{array}{l}\text { Delphinns delphis } \mathrm{L} \text {. } \\
\text { Phocaens communis. Cuv. }\end{array}$ & $\begin{array}{l}\text { Sc. } 8 \\
\text { cr. } \\
\text { cr.juv. } \\
\text { G. } 8 \\
\text { cr. } 8\end{array}$ & $\begin{array}{l}- \\
- \\
-\end{array}$ & 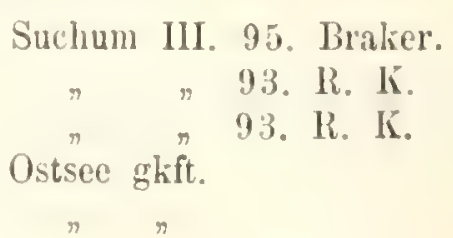 \\
\hline
\end{tabular}




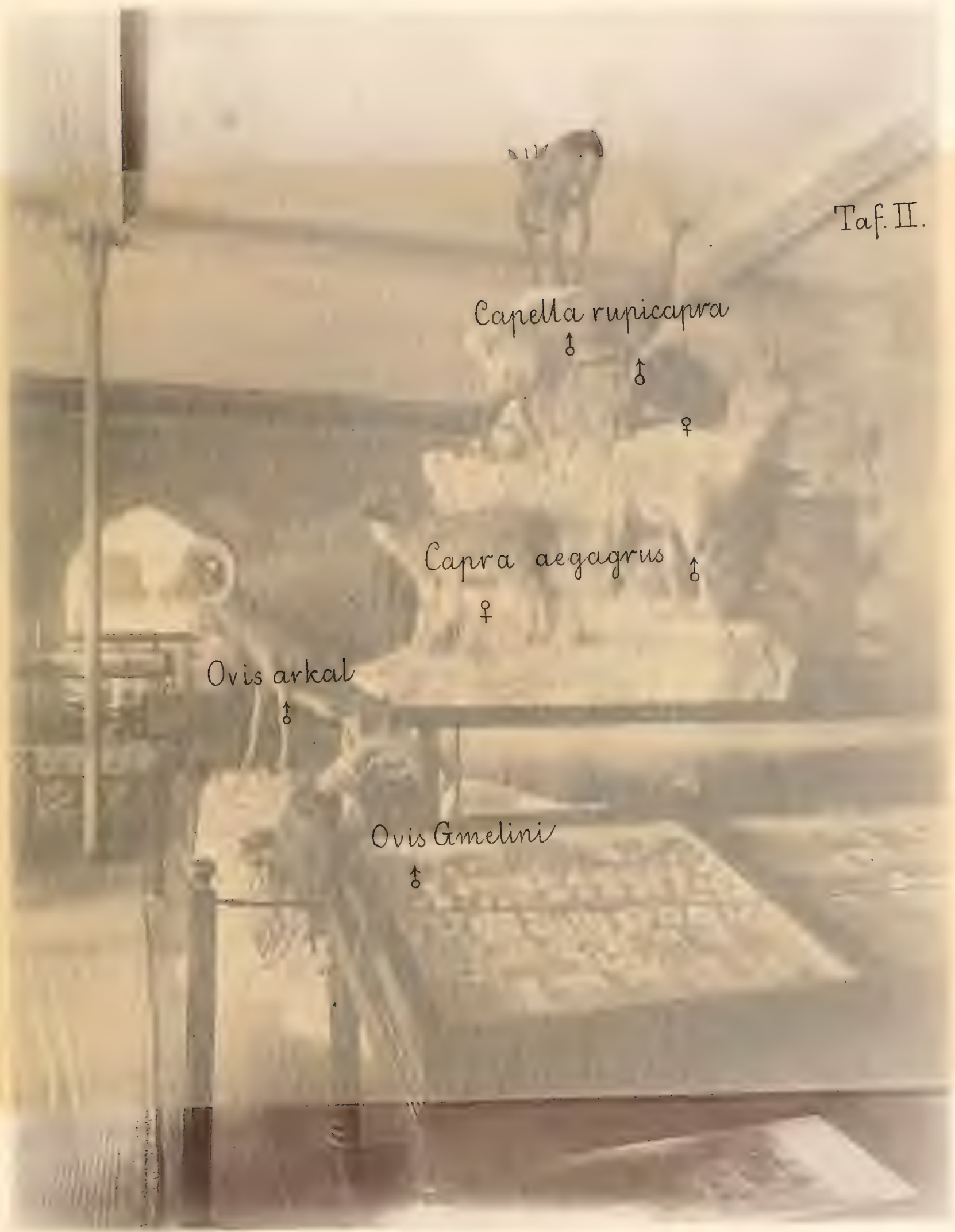


II $7_{0} \mathrm{~T}$

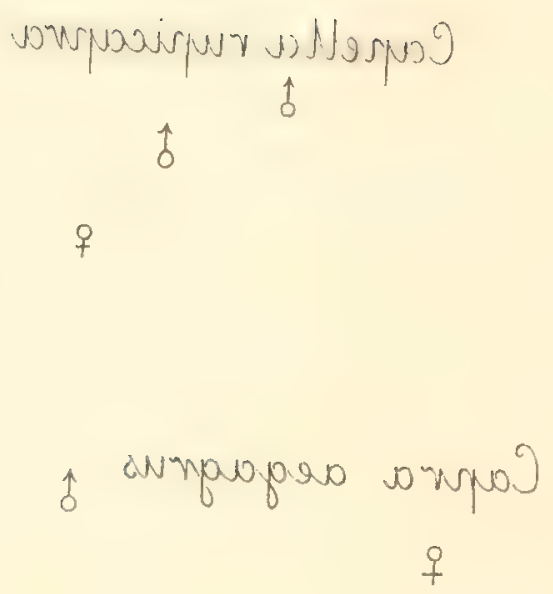

Jaodno ejvo

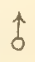

vimilome civo 


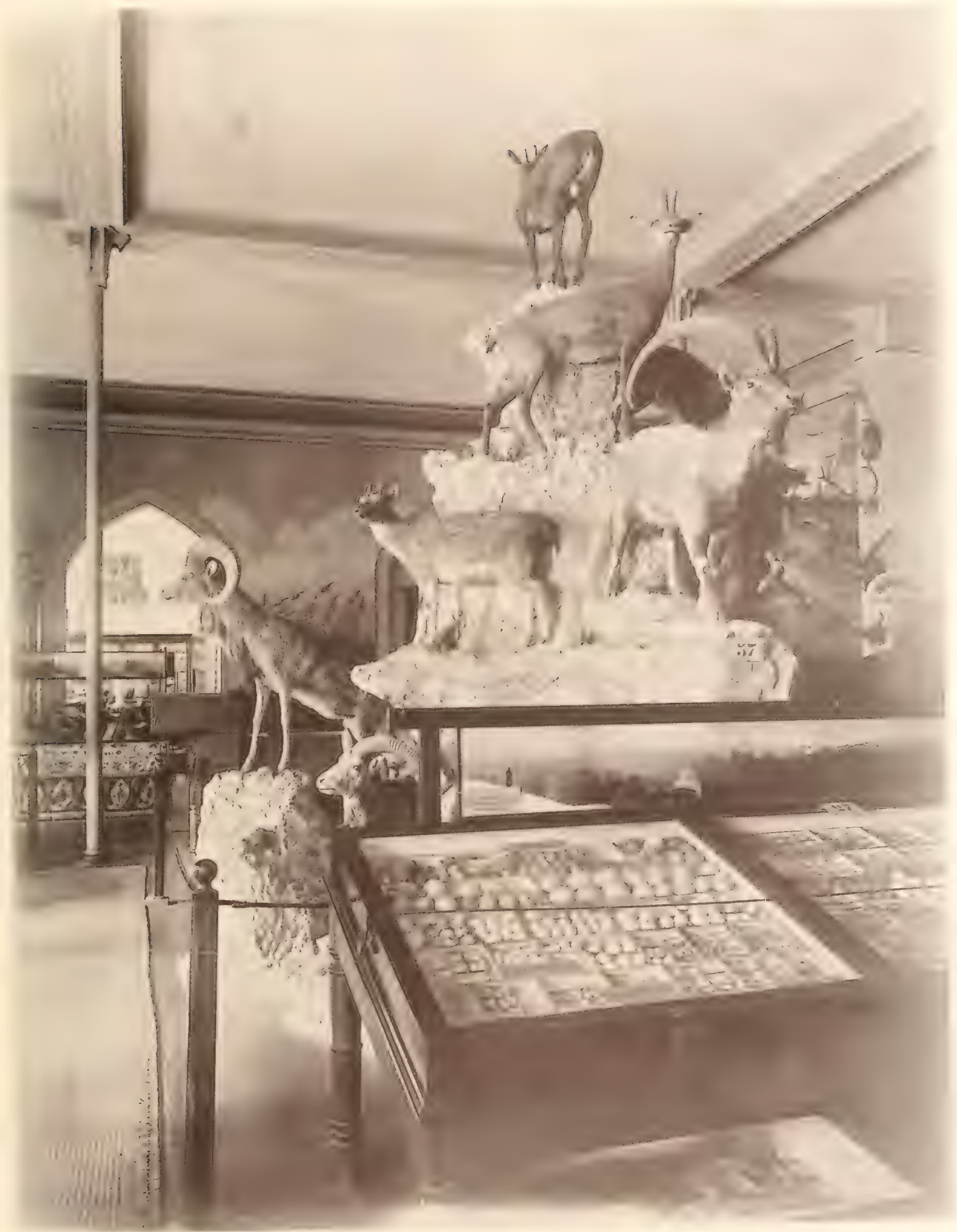





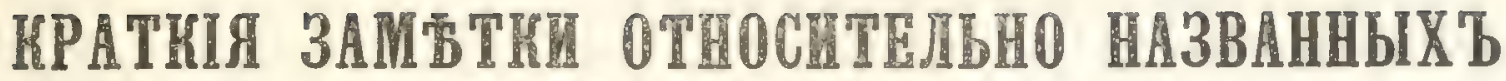

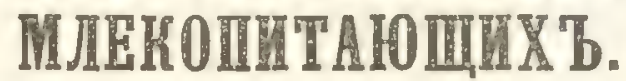

\author{
Нодшсь Сат. обозначаеть К. А. Сатуниь. \\ Р. $\quad$ I. II. Радде. \\ CHIROPIERA.
}

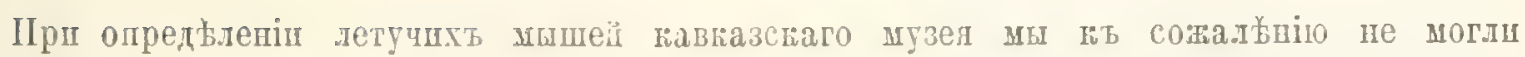
пользоватьсл капитальнм сочнепіем по әтому отрлду: Dobson, Catalogue of the Chiroptera i: the collection of the British Museum. Lond. 1876, что значптельно затрудня-

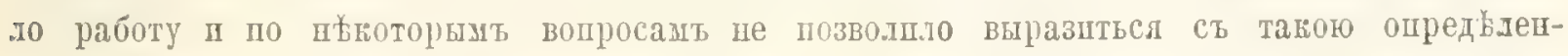

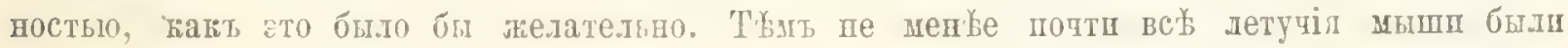

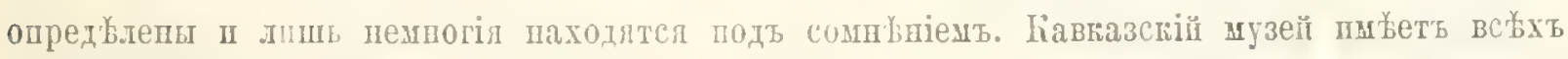

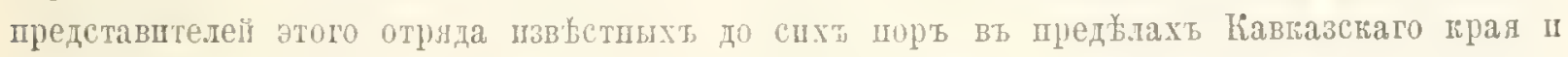

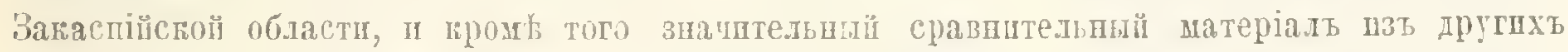

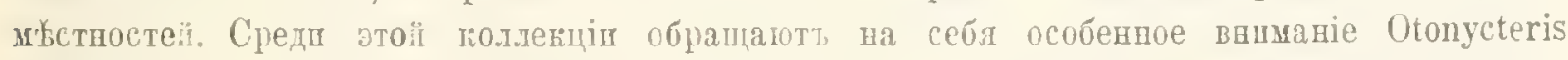
Hemprichii, Synotus darjelingensis In Rhinolophus euryale, пасюольюо пащь пзвъстно, един-

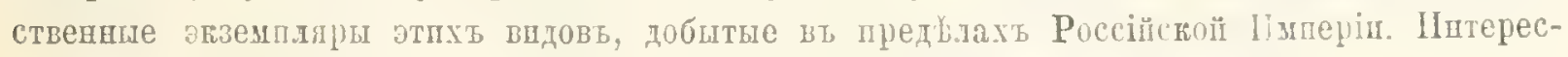

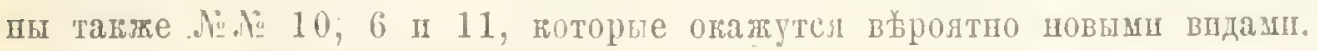

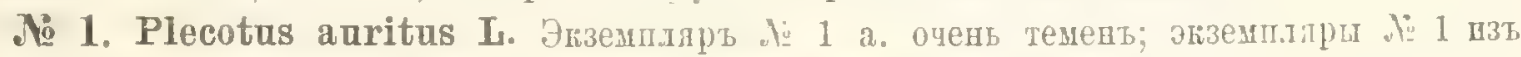

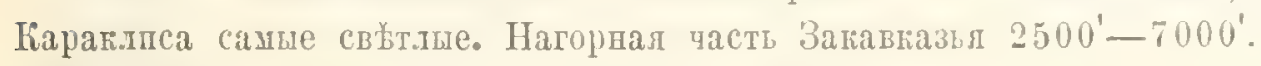

Cat.

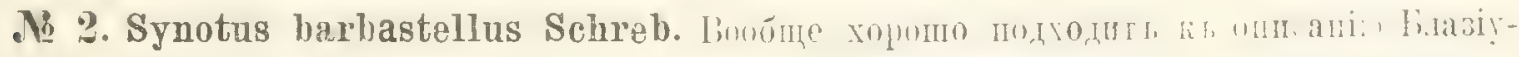
ca (Die Säugethiere Deutschlands. $1857 .$, p. 43 fl.), но отнопеніе 3-льг па.лца пь б-ому

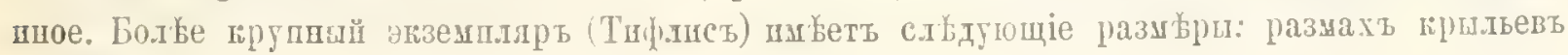
$-210^{\mathrm{mm}}$.

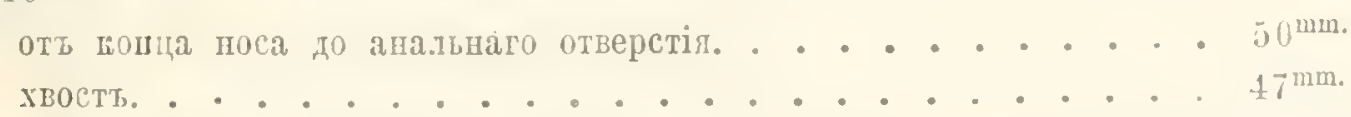

Сат.

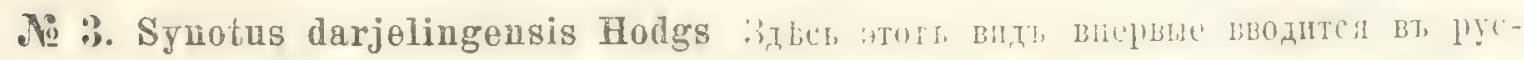

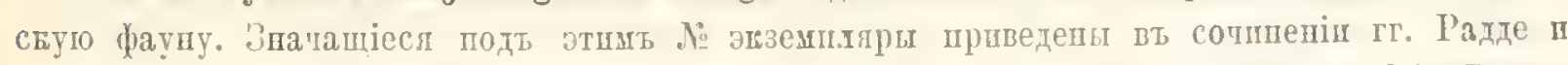
Вальтера о Закаспійски м.тепоптаппих (Dr. G. Radde und Dr. A. Walter. Die Säuge-

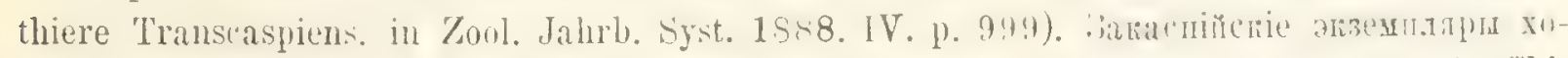
рошо подходлтб подт оцисаніе Тобсоша въ его сочиепіп „Nonograph. of the Asiatic Chiroptera", 1876. p. 86 .

Cat.

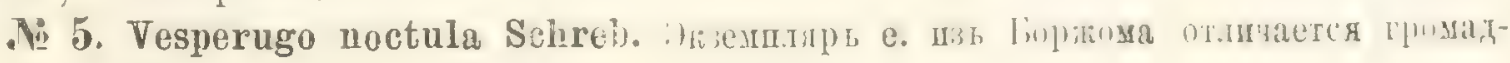
иым ростомт: 


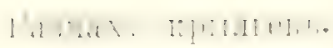

; 111$)^{2: 1111}$

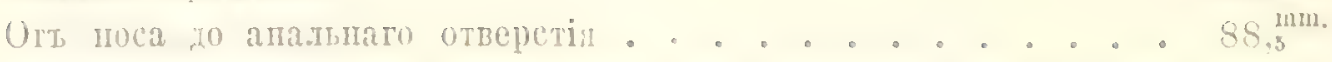

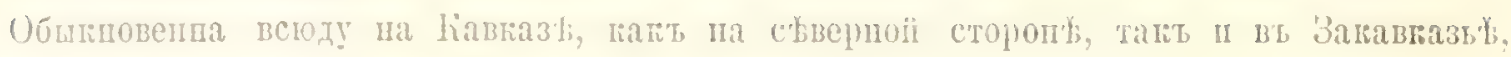

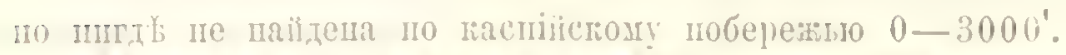

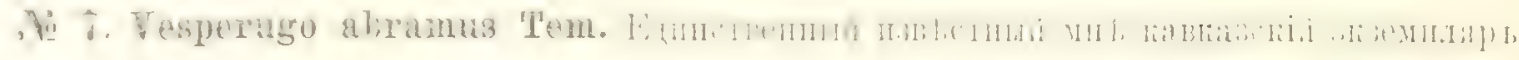

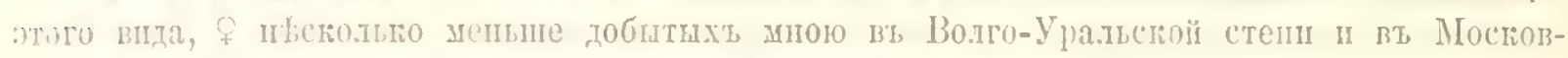

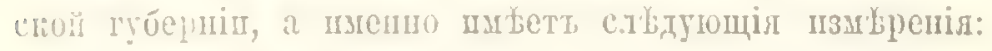

паздахт три.тевъ. - . . . . . . . . . . . . . . $215^{\mathrm{mm} .}$

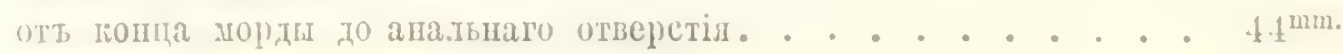

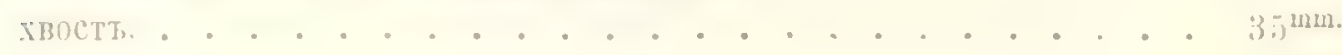

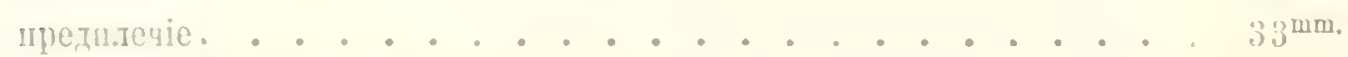

CaT.

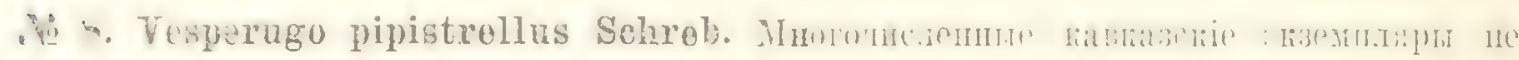

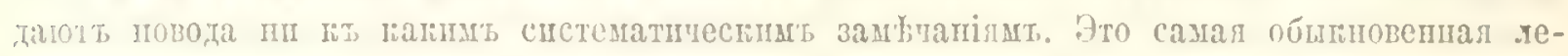

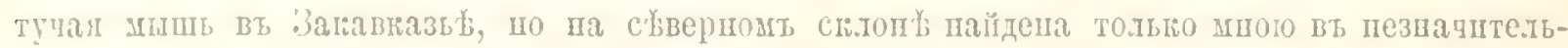

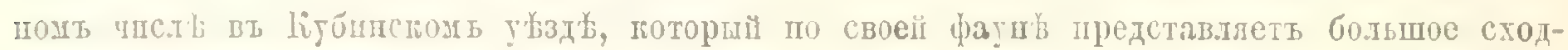
ство сь Ӟанавтазьемт $0-5000$.

Cat.

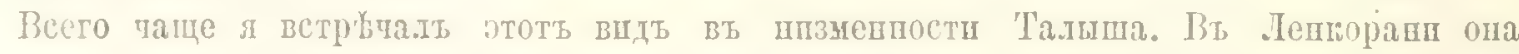

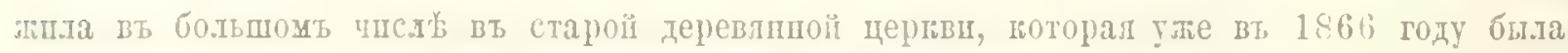
по.турава.твппсь, а вь 1880 представляла одич развалини.

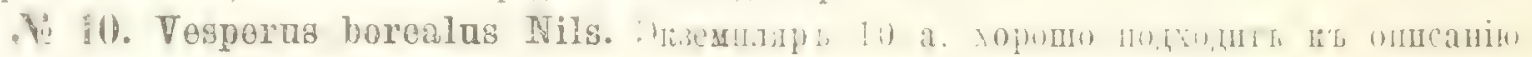
bizaivea (1. c. 1). 70. V. Nilssoni).

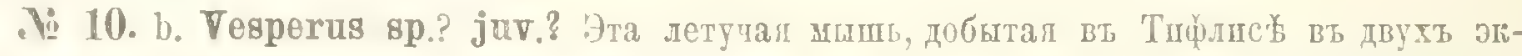

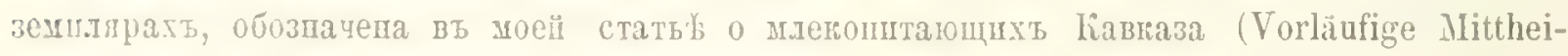
lungen über die Săugethiere der hiakasusländer. Zool. Jahrb. Syst. IX. p. 284.) rañ V.

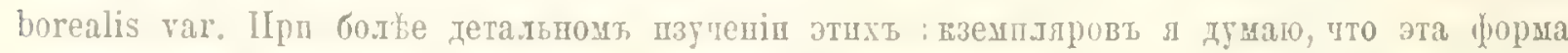

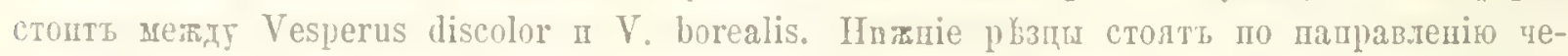

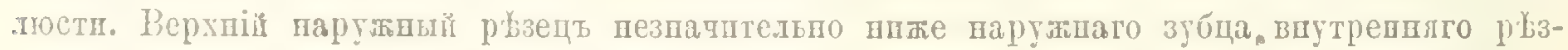

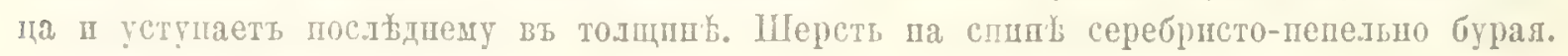

Cat.

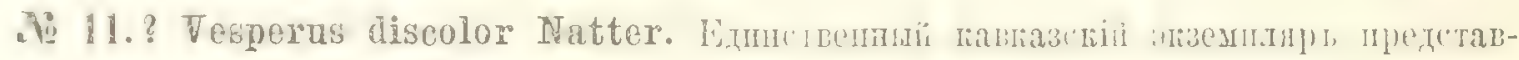
.летт много особенностеї вь огра"

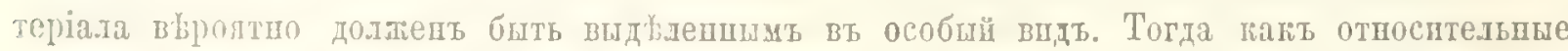

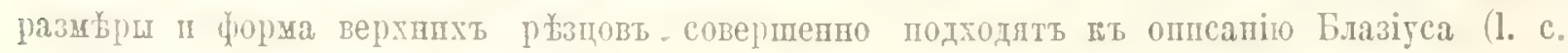

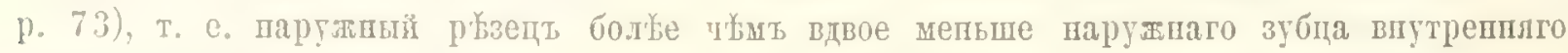

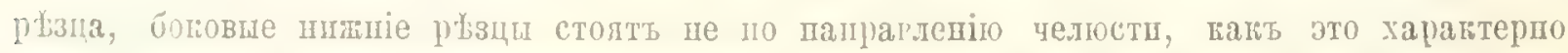

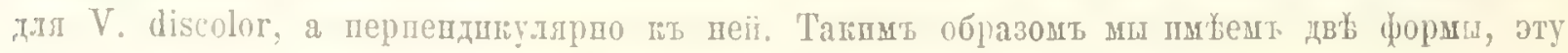

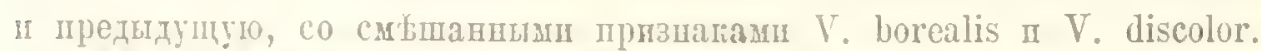

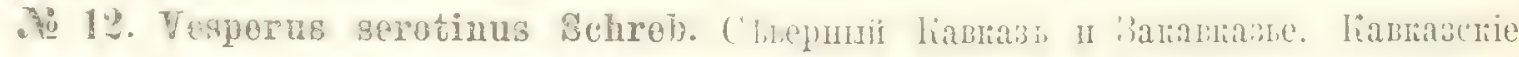

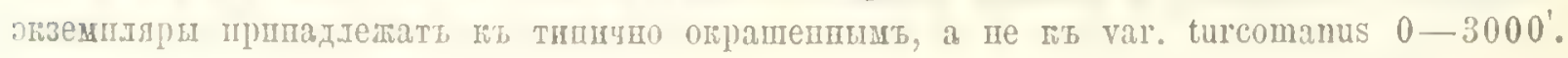
Сат.

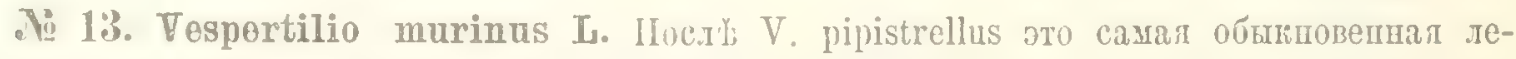

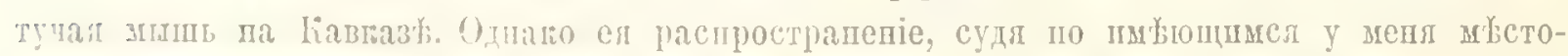

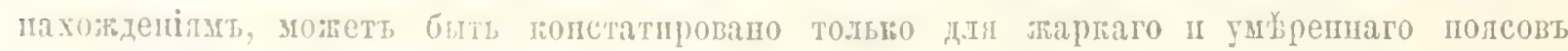

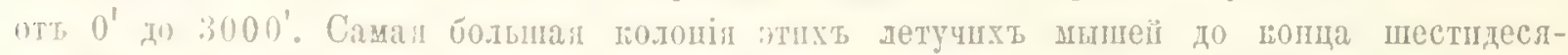

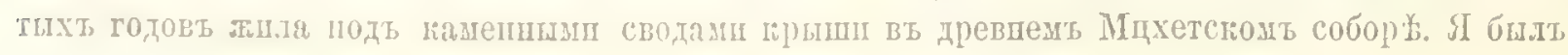


приглашепь туда духовенствомь, чтобн подать совьть, ғашит образомь выгнать оттуда

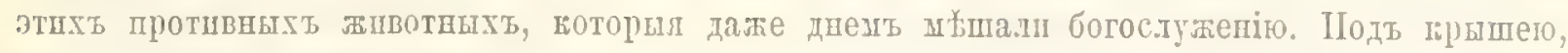
поторал была выведена изь большихъ тесаныхь ґаменныхь плть, была удуплиая жа-

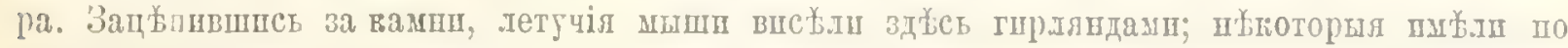

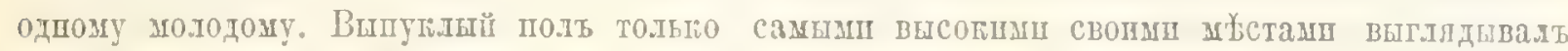

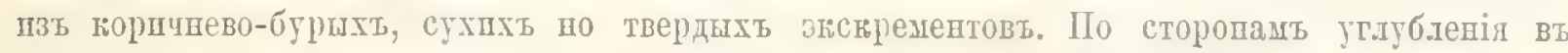
1'-2' были тапь наполшены әтшмь гуано, что можно было въ пемь завязнуть. Мы сами

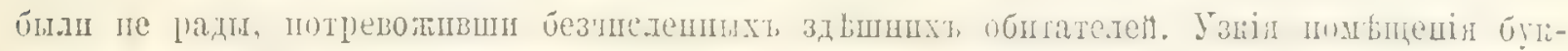
ва.льно наполнлись порхаюими летүимп мышам, оть нихь невозмодно было защп-

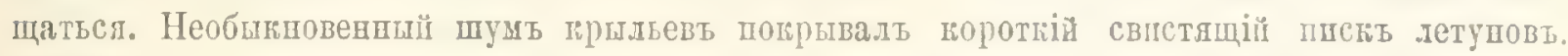

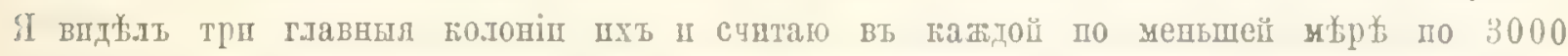

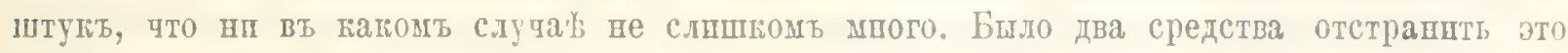

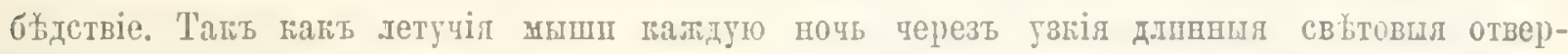

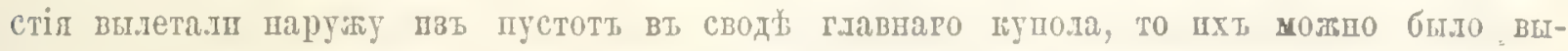

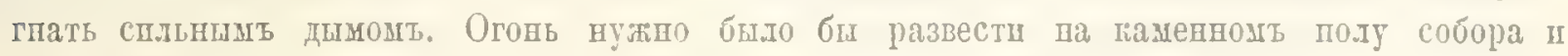
лучшимт матеріаломь для полученія дыма быль бы сухой навозъ. Шосль 2-3 разь 24 часоваго выгурпванія врядь ли хоть одна летуяая щышь осталась бы подь прыпею. Тогда слуховыя окна нужно бнло бы закрыть шроволочноло сбтғою. На әто предложеніе духо-

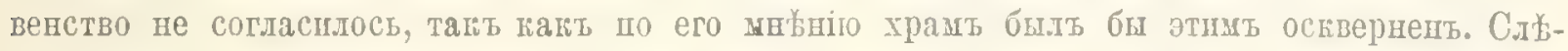

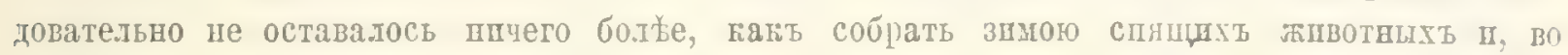
всяюонь случағ, закрыть слуховыя огна

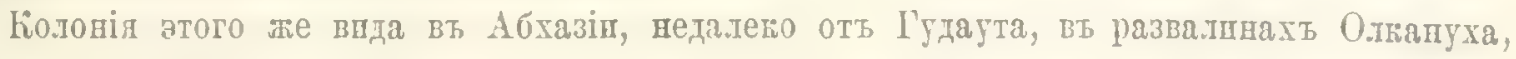
поторуг Е. Г. Кёншгь посьтиль 2-то іюнл 1893 года, состояла только изь нұспольихт соть экзеиплировт.

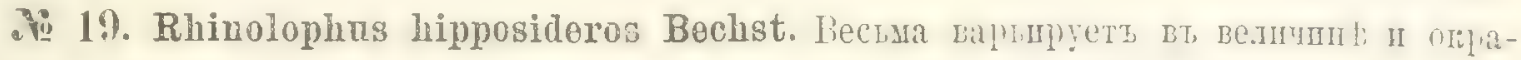

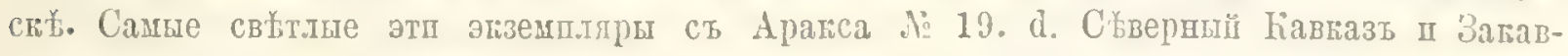

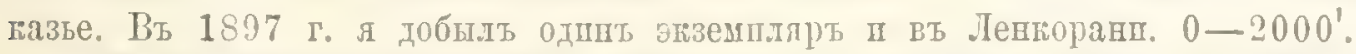

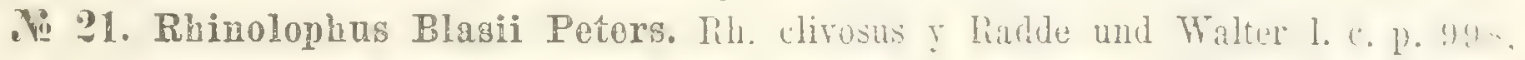

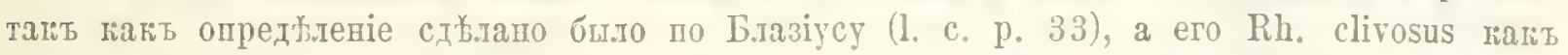
пзвестно, есть Rh. Blasii Peters, a не Rh. clivosus Cretschmer. Весьша веролтпо, что ту-

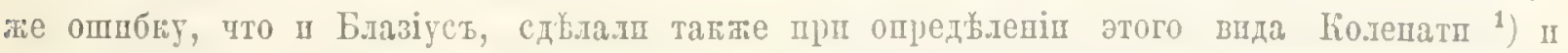

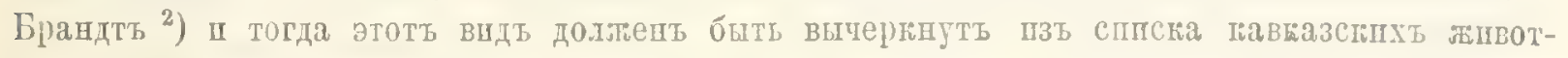

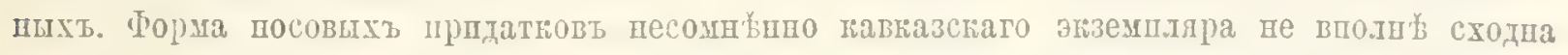
съ нарпсованиого у Блазіуса, по по полозенію перваго ложпо коренного зуб́а верхней чепюсти онь несощньнно относштсл ґь этону вшду, а не clivosus Cret.

\section{ํㅡ 22. Rhinolophus earyale Blasius.}

Cars.

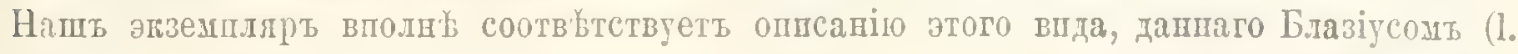
c. p. 35$)$.

Cat,

\section{INSECTIVORA.}

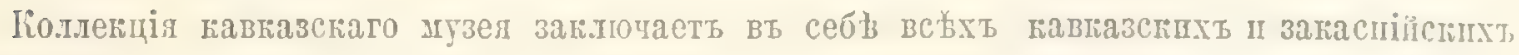

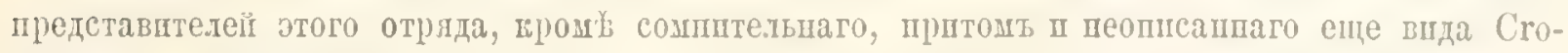
cidura longicaudata Dobs.

1) Kolenati. Monographie der europäischen Chiropteren. Brünn. 1860,

2) I. F. Brandt, Die Mandflügler des europ. u. asiat. Russlands etc. 1851. 


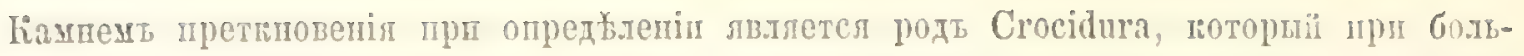

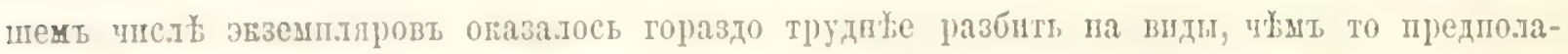
га.тось, пота эъзезитяровт, бнто мало.

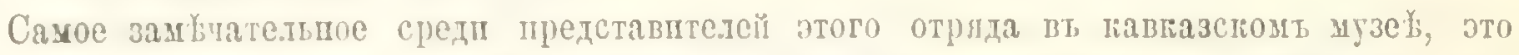

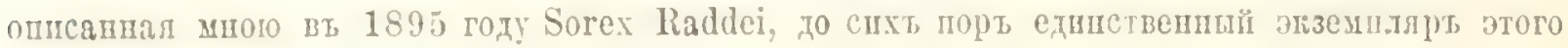
mитереспаго вида.

Caт.

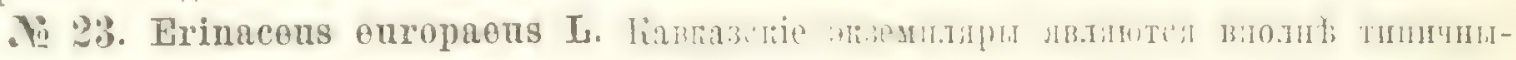

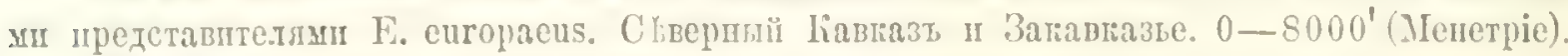

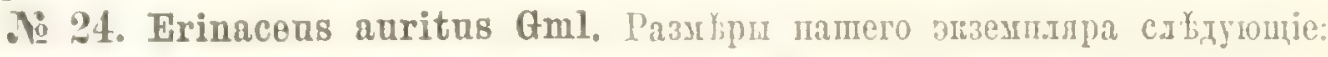

оть ковда поса до оспованія хвоста (спиз). . $170 \mathrm{~mm}$

дыппа хвоста. . . . . . . . . . $21^{\mathrm{mm}}$

висота уха отт темени. ........ $31^{\mathrm{mm}}$

самыл длипныя пглы . . . . . . . . . $17^{\mathrm{mm}}$

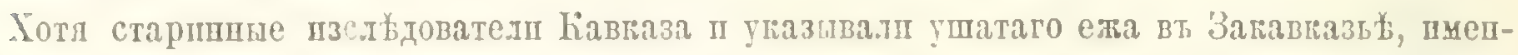

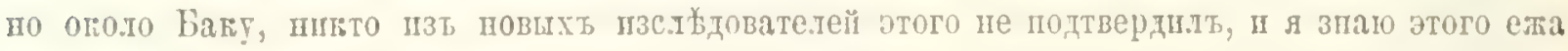

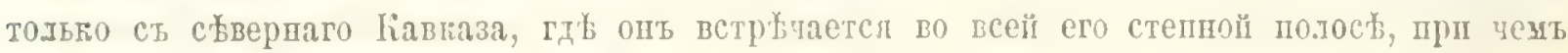
въ восточиой ея части гораздо чаче.

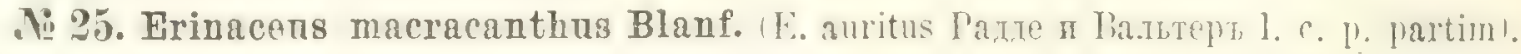

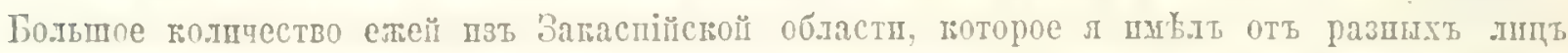

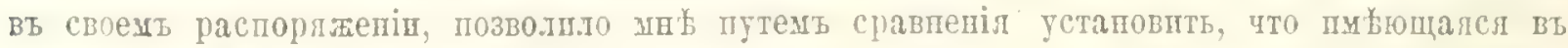

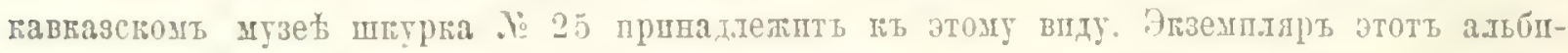
нось, если тольво можно такь пазеать это лвленіе $\mathbf{E}$. macracanthus, болье половинш

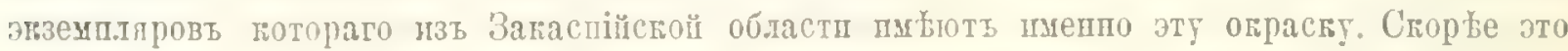

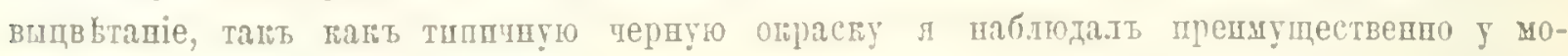
Іодахь.

Cat.

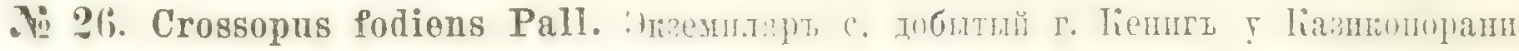

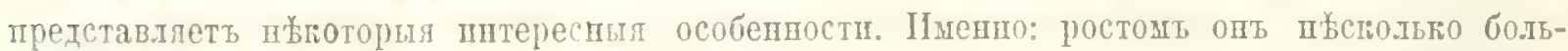

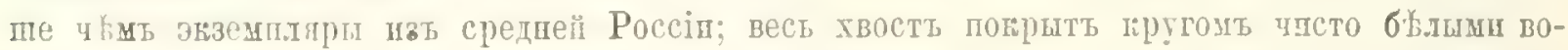

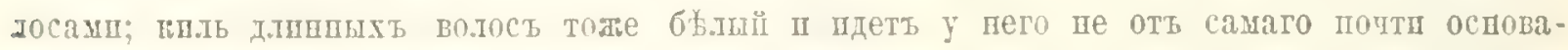

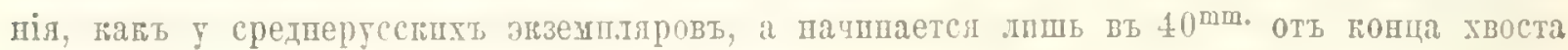

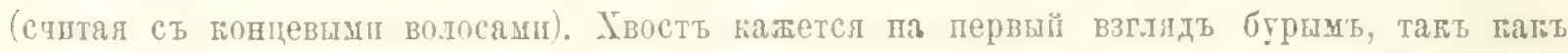

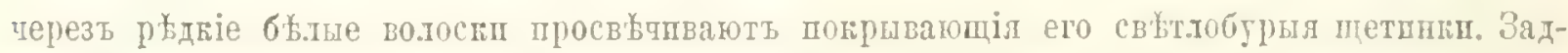

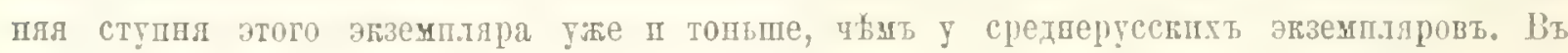

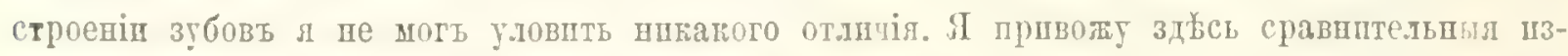

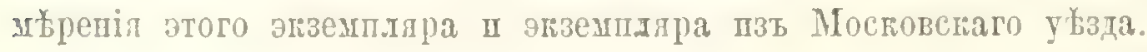

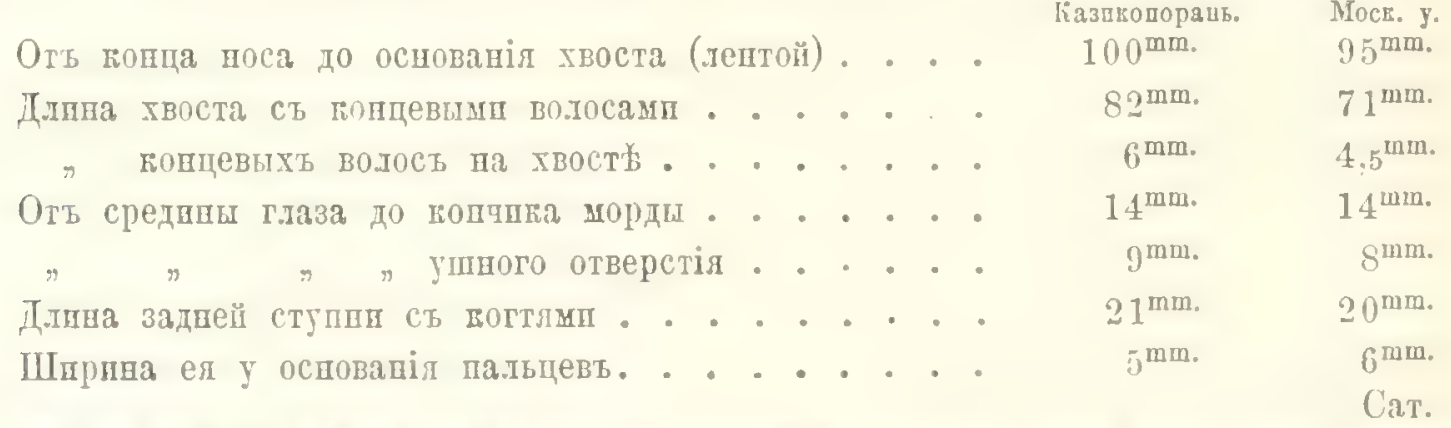

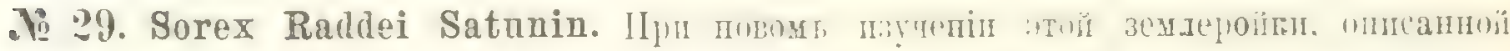

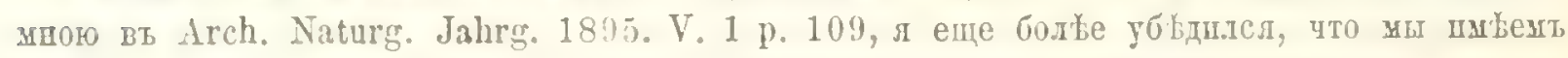

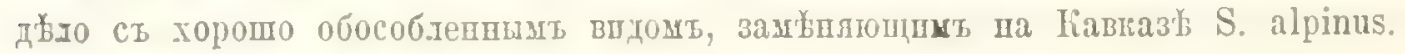




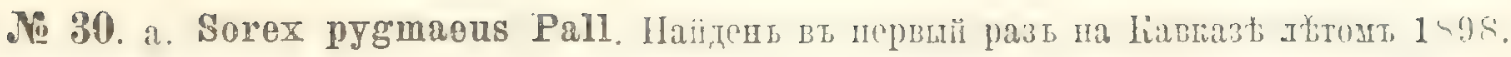
вь Бавуріанахь $\left(5000^{\prime}\right)$.

Ni. 32. Crocidura russulus Herm. $=$ Cr. araneus auctorum. il pacmaram бolt-

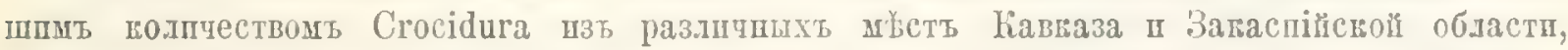

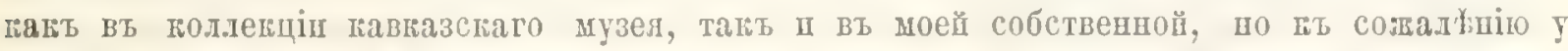

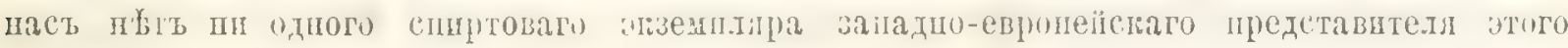

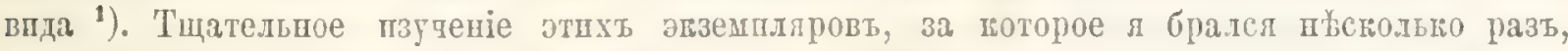

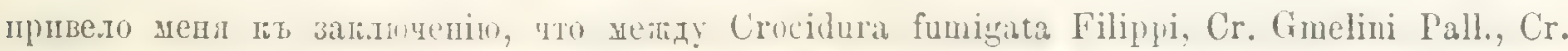

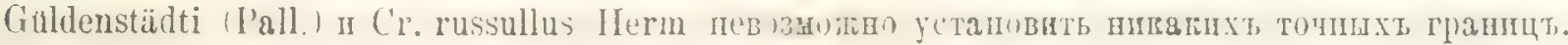

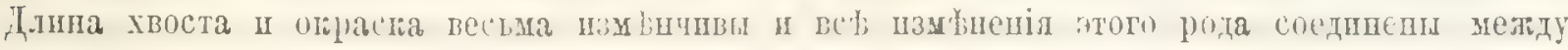

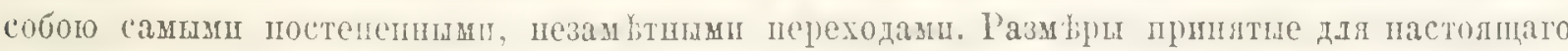
ғаталога не позволяють мн входить вь детальное разсяотрыніе п потому л отлага это

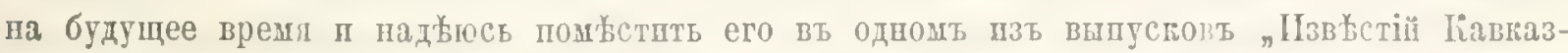
скаго Мувея". Здысь же замиу еце тольго, что п строеніе зубовь не позволяеть установпть нпгакпхъ различій.

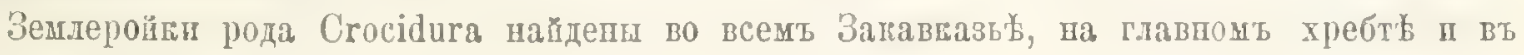
Дагестан $0-4000^{\prime}$.

Cat.

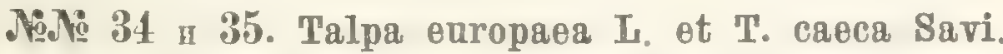

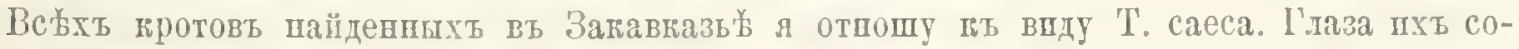
вершенно заврыты кожей. Средиіе верхніе р'хзды почти вдвее пире бововыхъ, но другіе

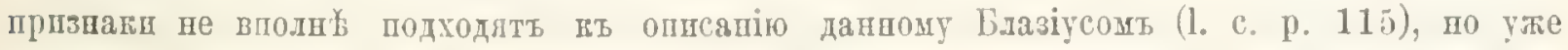
Добсопь указаль па пхъ несостоятельность (Dobson. A Monograph of the Insectivora. Pt.

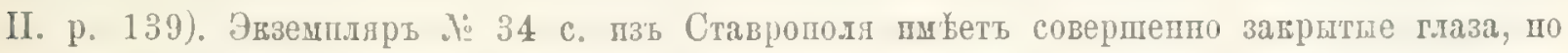

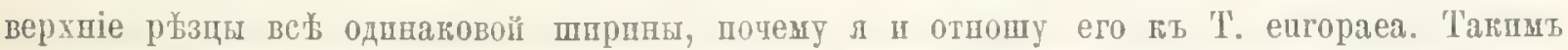

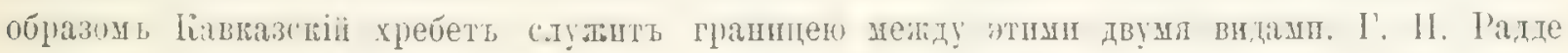
напедт Т. саеса у источниговъ Ріова (Горпболо) вт 8500' падъ ур. цоря.

\section{A R N I V O R A.}

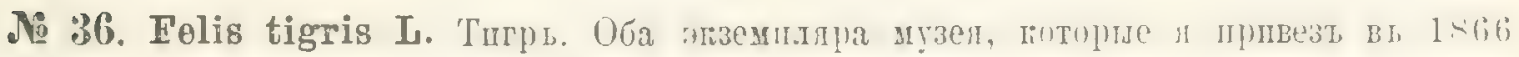

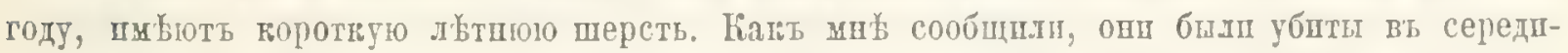

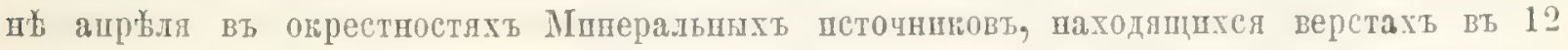

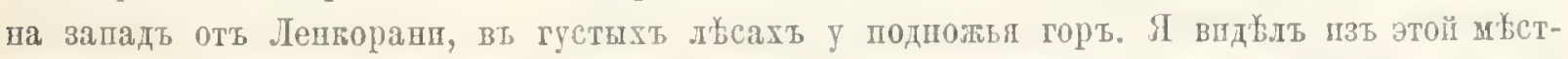
дости тольго тигровь съ б'дою грудью, не особенно больпаго роста. Въ то время тшгръ вовсе не быль рыдқостью въ этомь сыверо-западном углу Альурсстой спстем, по дер-

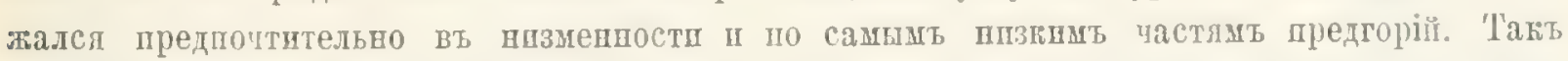

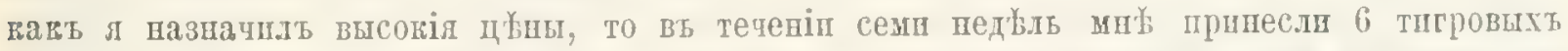

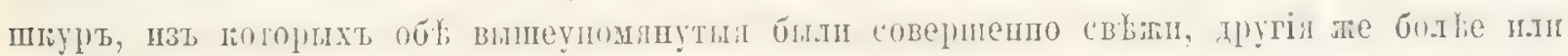

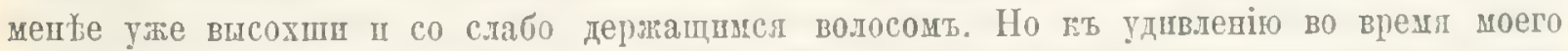

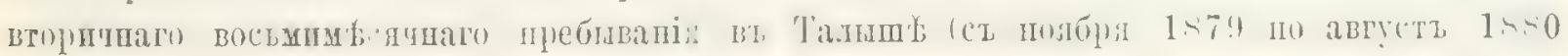

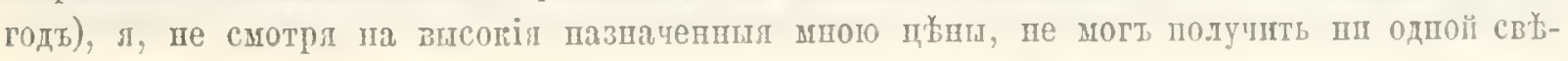

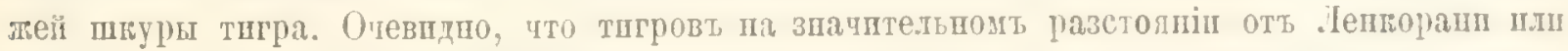

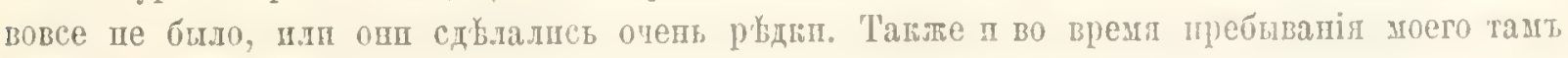

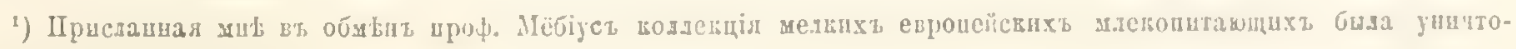

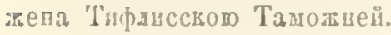




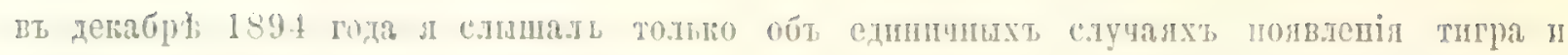

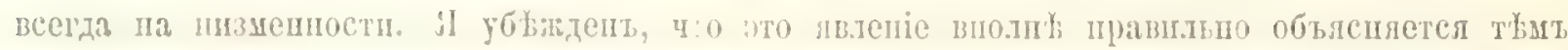

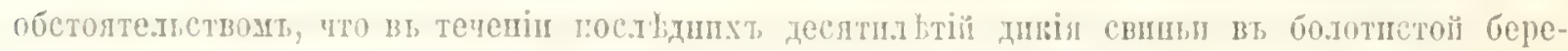

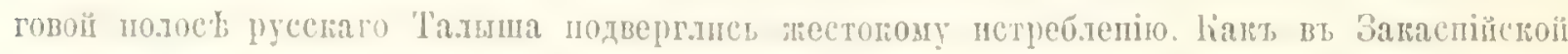

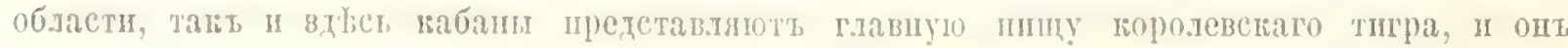

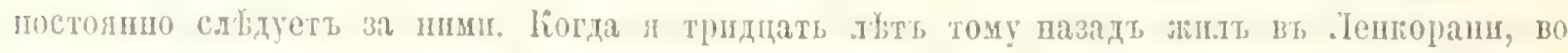

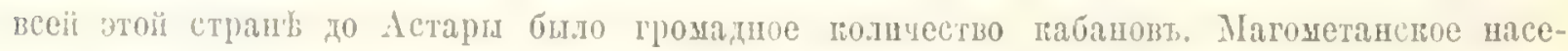

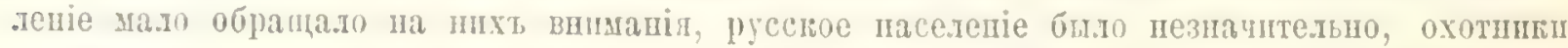

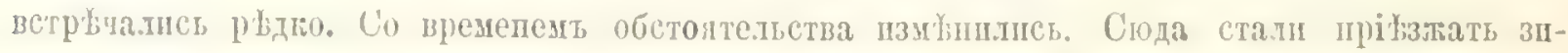

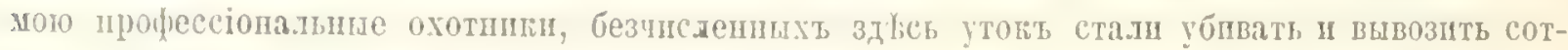

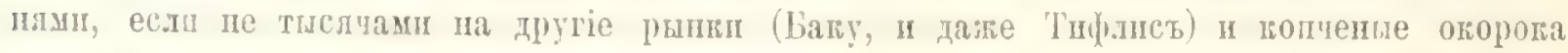

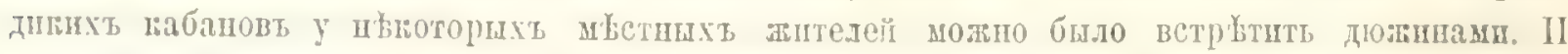

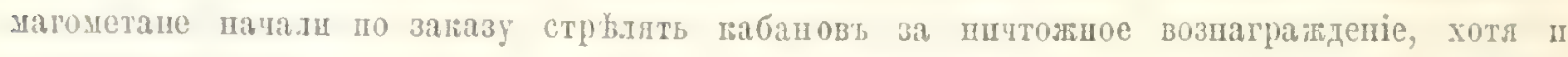

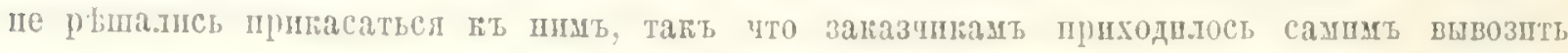

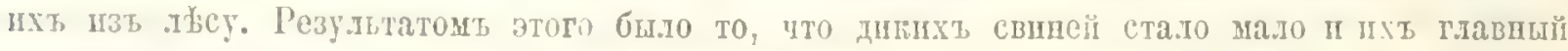

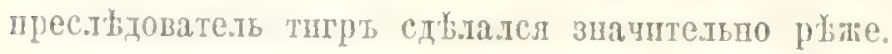

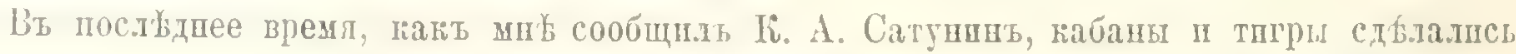

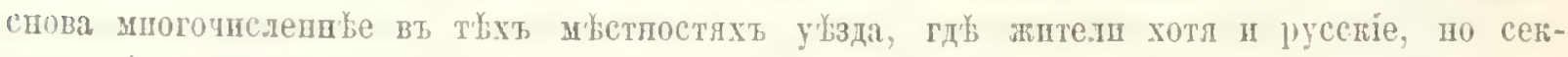

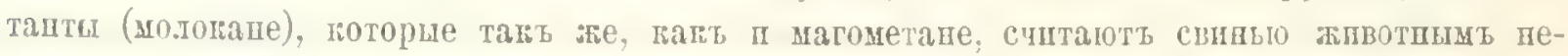

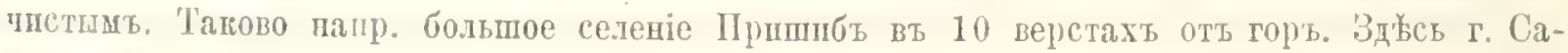

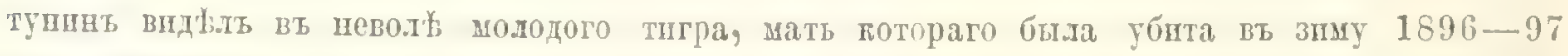
года. Вознояно, что пока тигрь получаеть вь данной мъстостп достаточно пшщ, овь

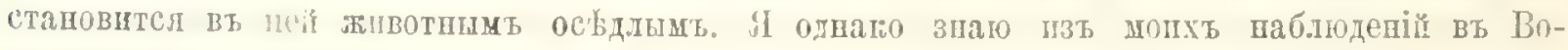

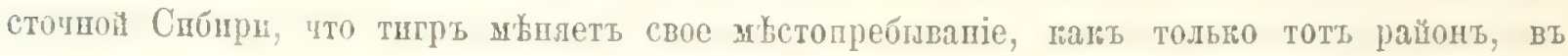

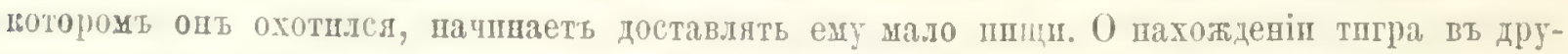

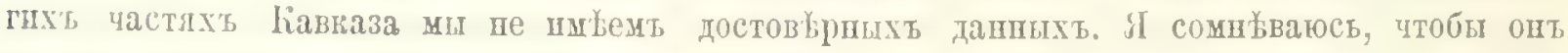

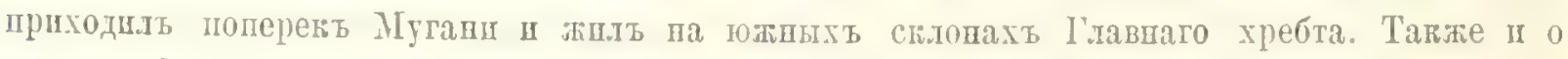

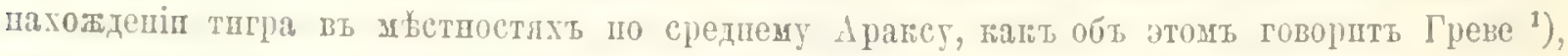

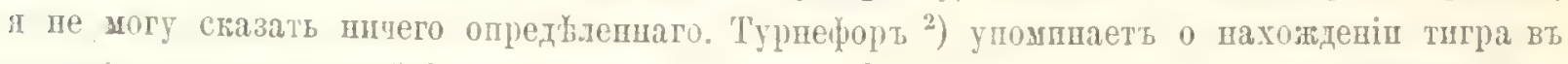
пачаль прошлаго стольтія у Арарата. Чпхачевъ ${ }^{3}$ ) говорпть о немь въ своем сочненіп.

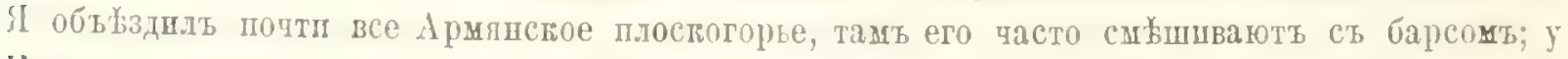

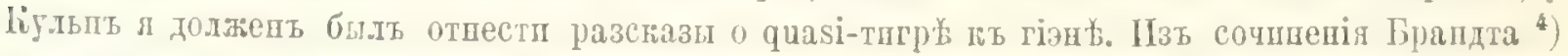
вндно что объ большія ношц, тигрь и барсь, вз прежнія времена јыли распространены гораздо дальв п्, C.-3.

[ильдештедть и Шардепь соошають о пршсуствіп тшгја вь Минреліп, даяе вт

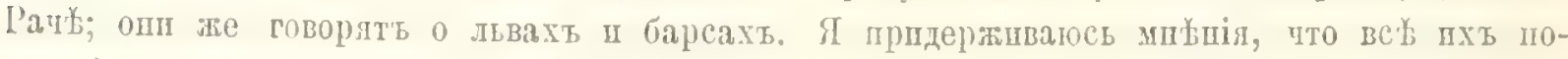

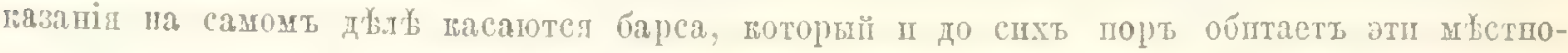

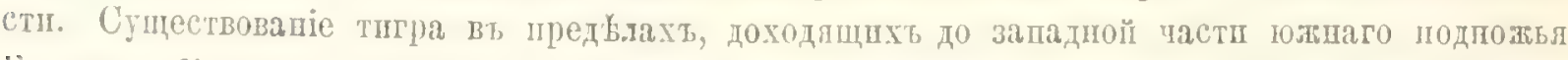

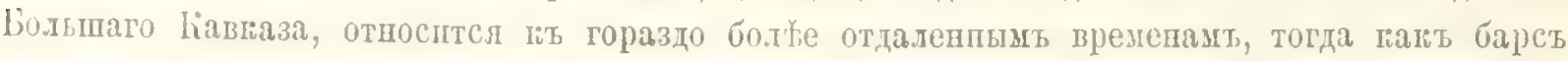

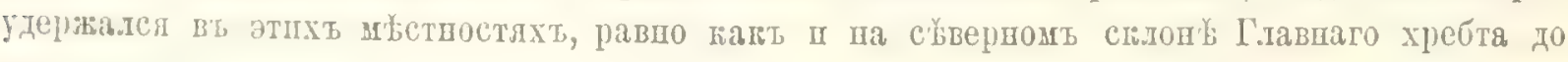
настолщаго времеш.

') Carl Greve. Uebersicht der geogrą̧hischen Tertheilung jetzt lebender Feliden in Zool. Jahrb. Bu. VI. p. 63.

2) Relation d'un voyage du Levant ect. par M. Pitton de "lournefort Vol. III. pag. 216.

3) Asie mineur. Vol. II pag. 612-613. Сам авторь его пе видаль.

`) Untersuchungen über die Verbreitung des Tigers ect. Mémoires de l'Acad. Imp. des sciences de St.-Itb. T. rIII. 1859 , pag. $175 \mathrm{sgt}$. 


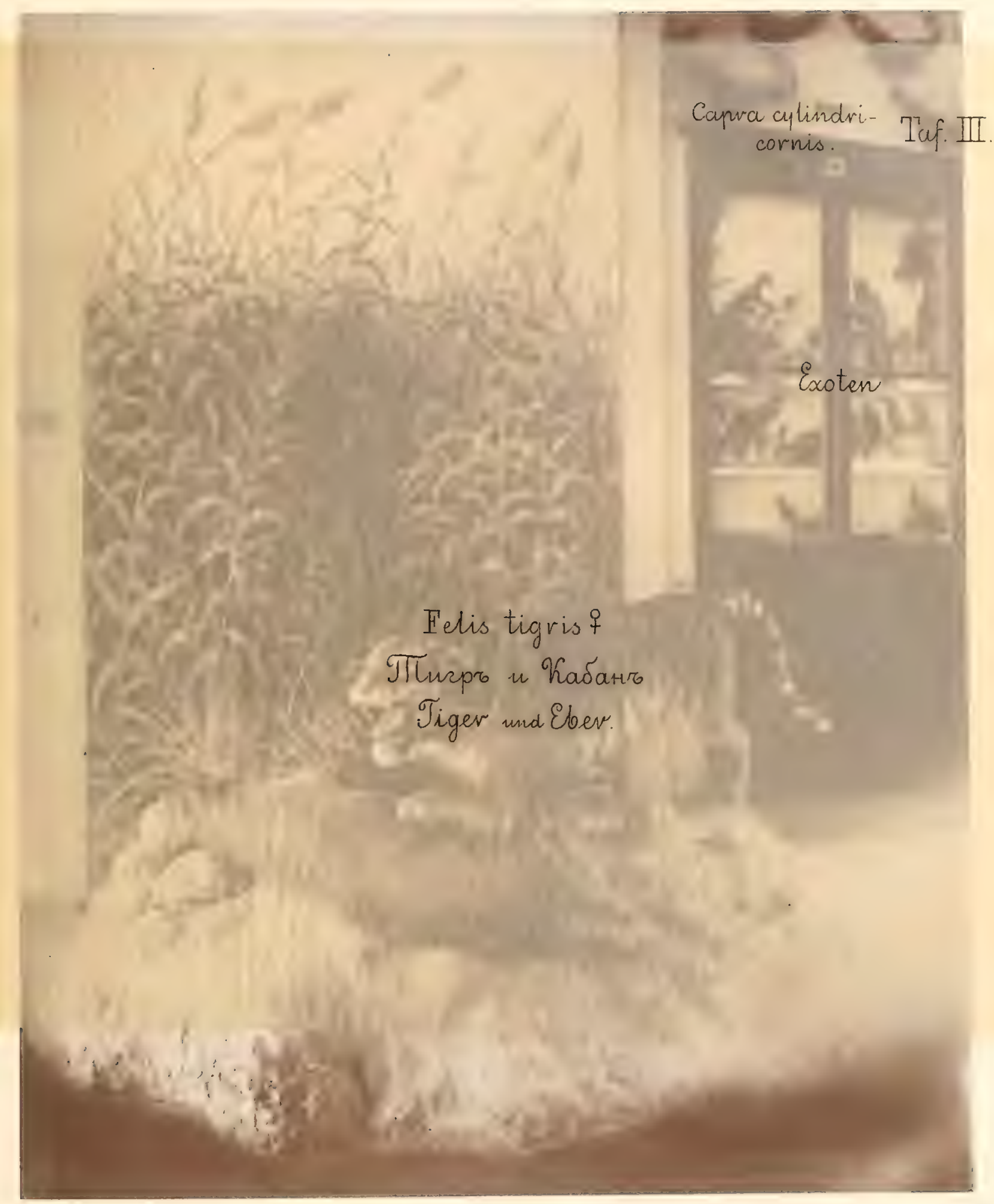




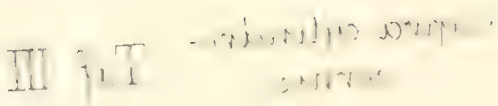

- $\cos 5 \pi$

$$
\begin{aligned}
& \text { f } 210,015 \text { c. } 51.54
\end{aligned}
$$

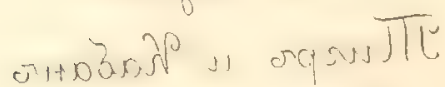

$$
\begin{aligned}
& \text { wade asias wapji? }
\end{aligned}
$$




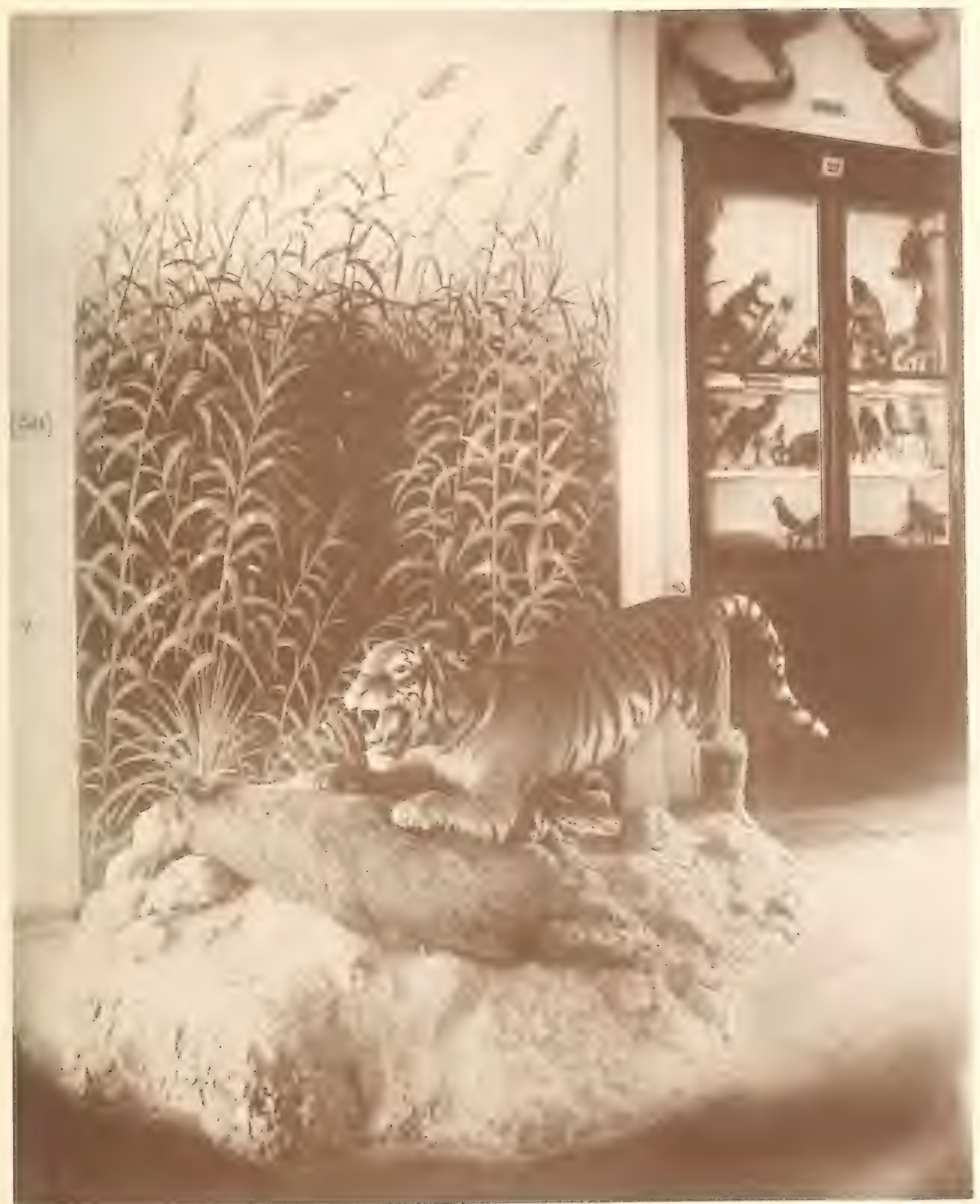



С́ того времени область распространенія титры сшльо совратилась по паправленію

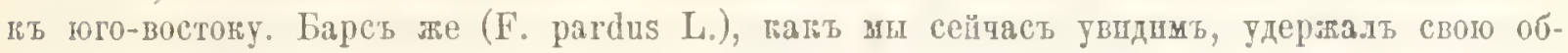

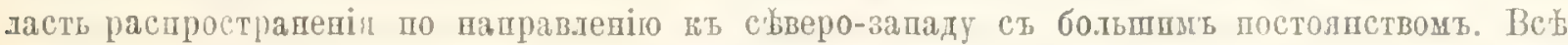

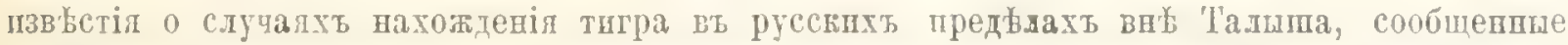

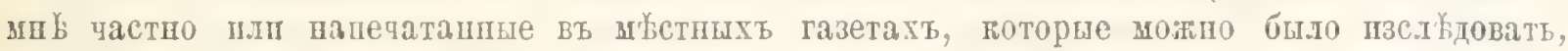

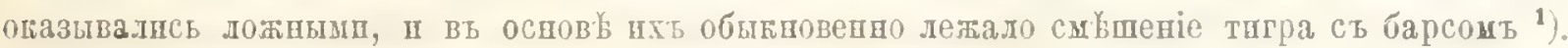

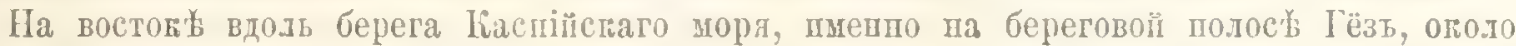

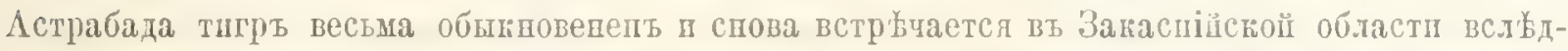
ствіе обшлія кабановь и каџшшевыхь зарослей вдоль большихь ytюь. Въ 1886 году мш

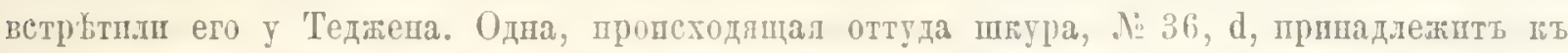

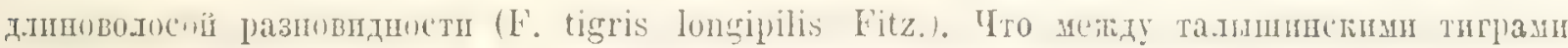
встрьчаютя ш очень крупнте экемляры доказываеть черепь подареншы гавгазстому

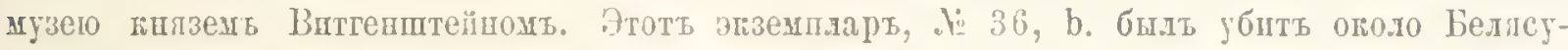
вара, сльдовательно на граю Мугани, вблизп сбверной подопвы Талыпипских гор'ь.

Нашбольшая основная длина черепа оть задняг прая затылчнаго олверстія до переднлто крал верхнеї уелюсти . . . . . . . . . 36,5 ст.

Наполошая пшрина сеуловыхь дугъ . . . . . 27 ст.

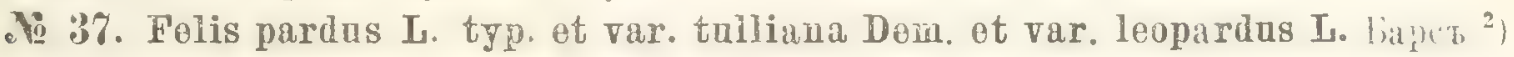

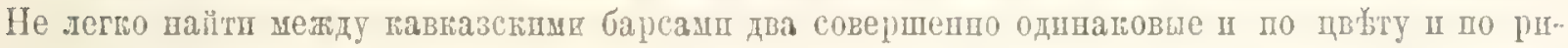

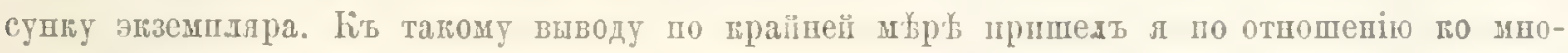

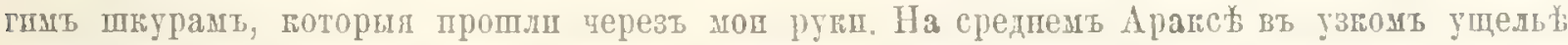

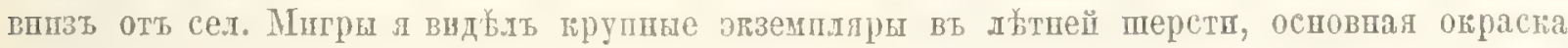

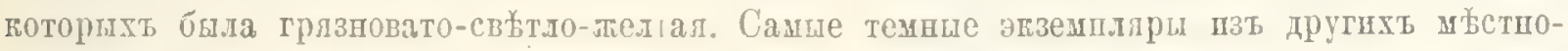

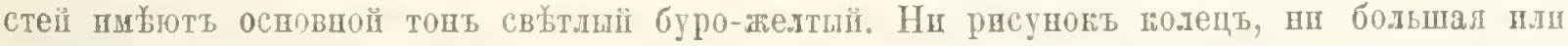
меньпал сомпутость составляющпх пхъ дугооразшыхь пятепъ, ни форма плтень пе представляють ничего шостоянаго. У болье молодыхъ животныхь центральци пятна въ иоль-

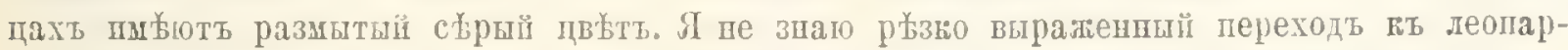
лу съ Кавказа, но знаю его пзъ Заґаспійской области. У г. половпига Вестмана въ Асха-

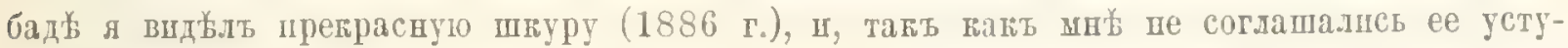
пить, срнсоваль ее. Осповної тонъ быль сверху довольпо теменъ, на бокахь становиля

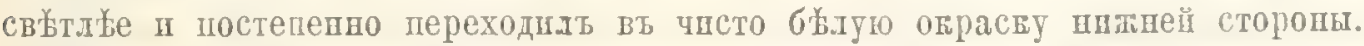

Барсь, хотя и пе осбдло, а почуя, и пе вь болышомь числ盖, живеть по всему Кав-

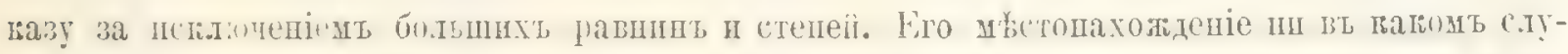
ча

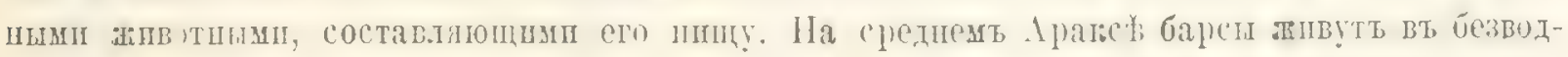

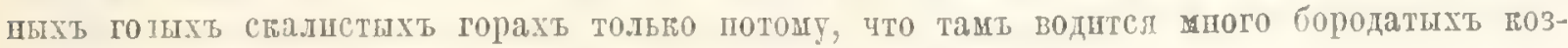

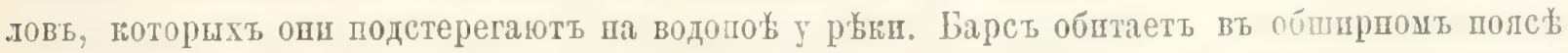

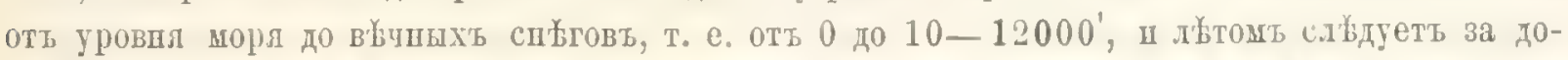

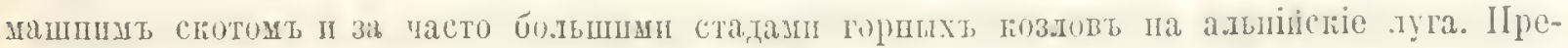

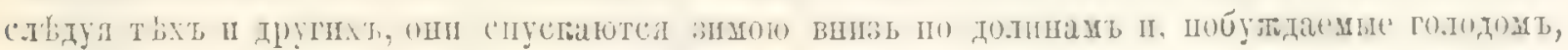

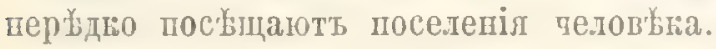

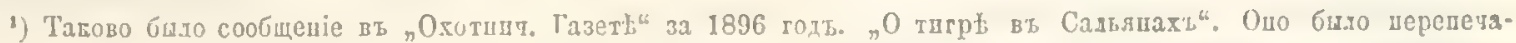

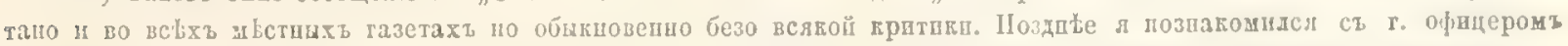

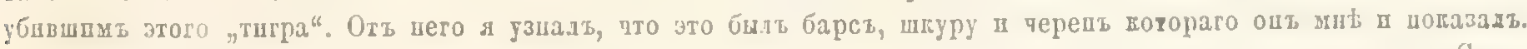
Cat.

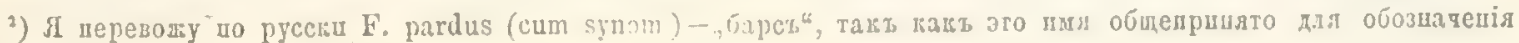
этого жввотиаго на Кавказђ. Car. 


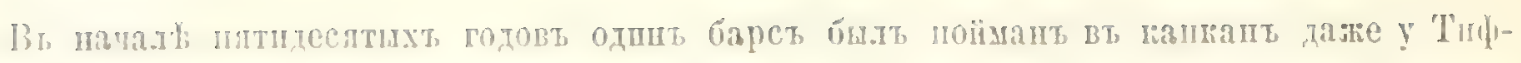

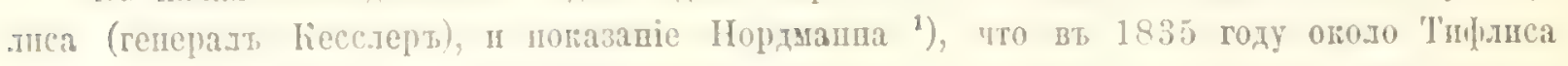

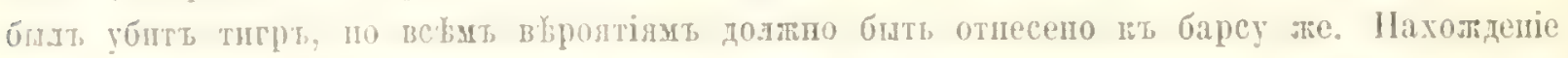

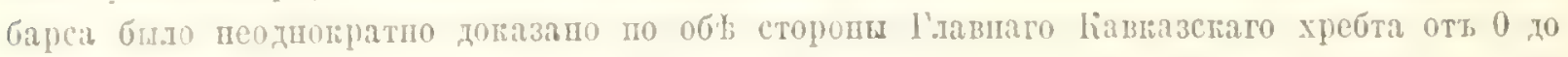

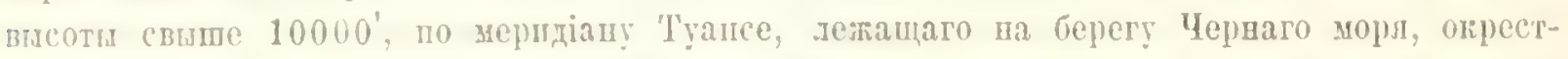

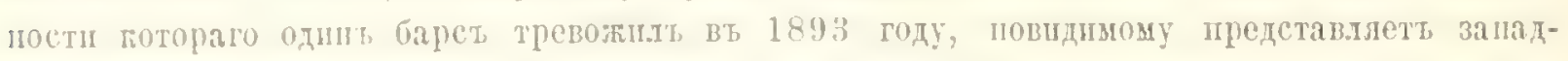

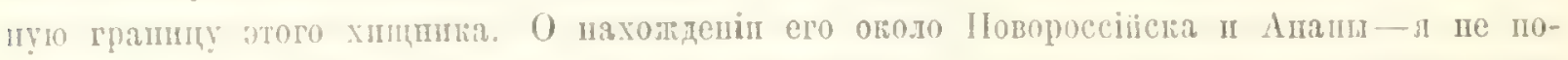

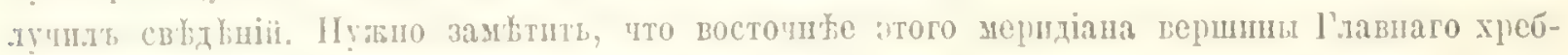

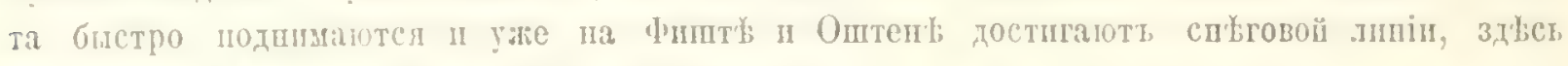

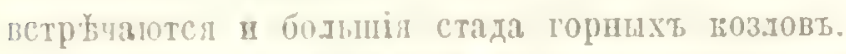

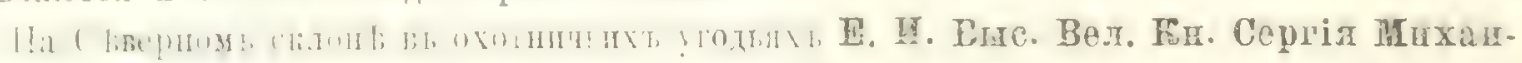

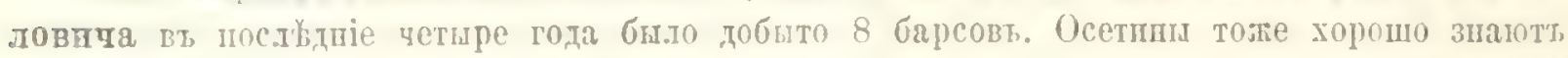

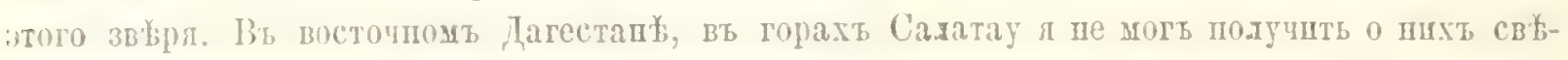
тыній, но тамт и туры были үәде. Напротпвт догазано, что въ зиму 1881 - 82 года ого-

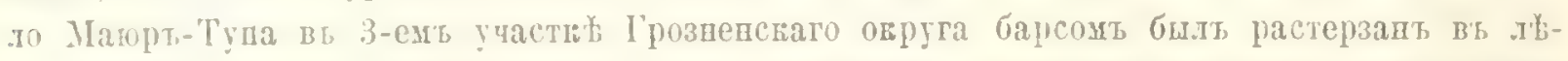

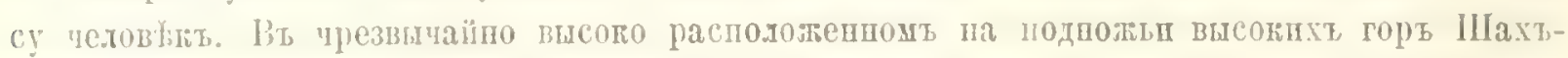

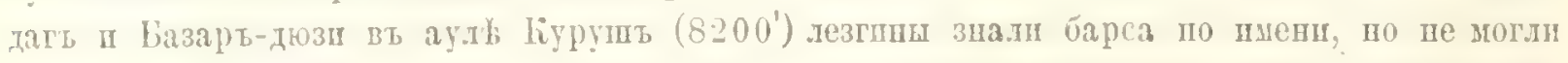

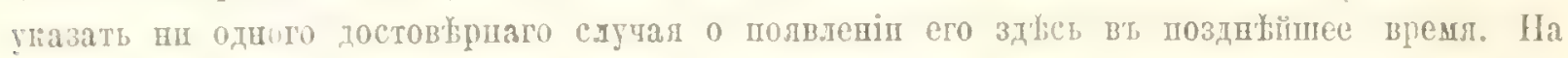

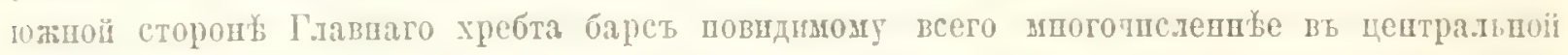

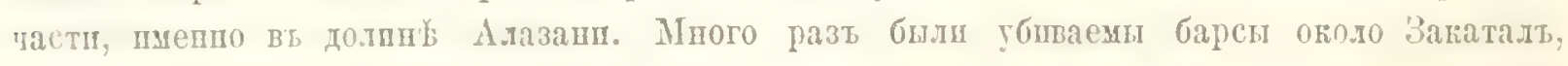
-Іатодехт, Нухи и въ Бумстомь ущели.

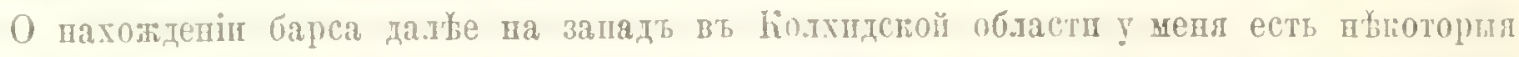

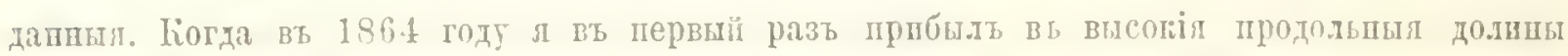

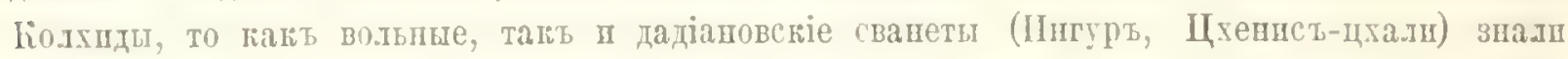

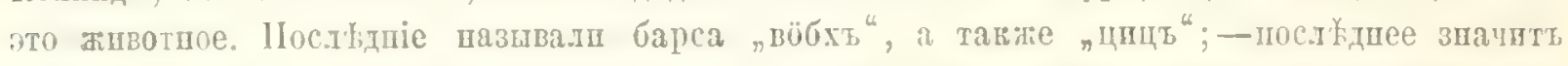

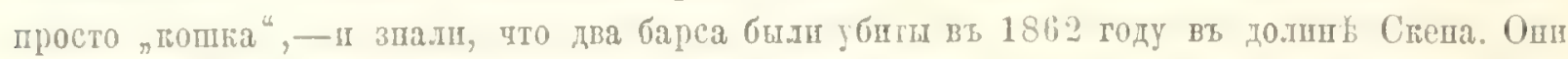

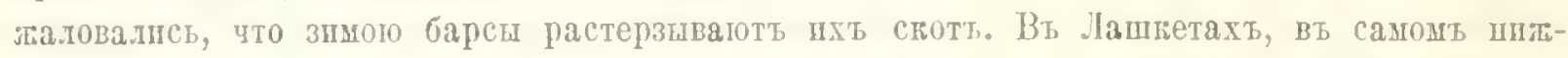

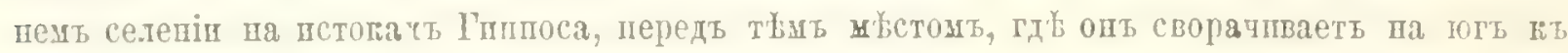

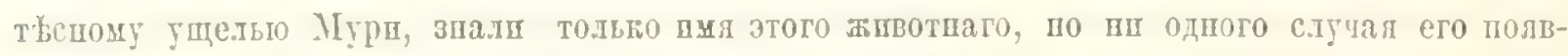

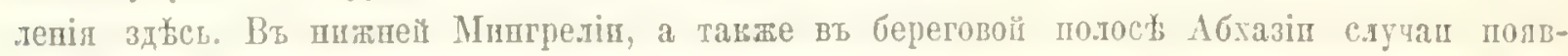

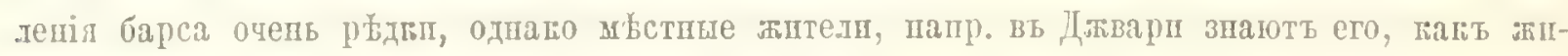
вотное держащеесл на високихъ горахъ. Въ 1861 году одипт барсь быль убить у Бзцба.

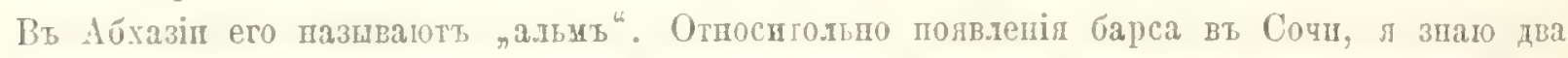
случая; вь 1875 году барст папаль ша рвбочаго, спавпаго на открытомь воздухш, тилело порапиль сму затилогт и хотьль унест; рабочій этоть был спасень и лечиля въ

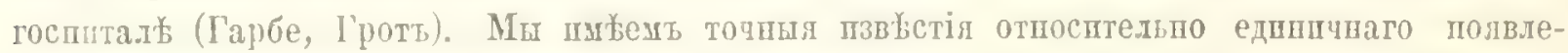

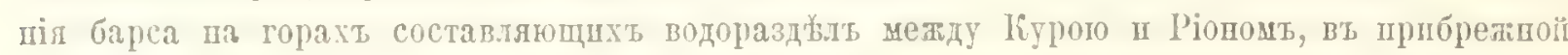

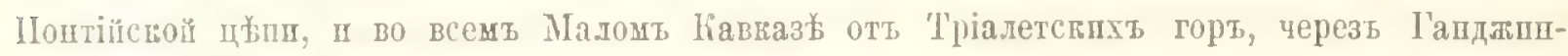

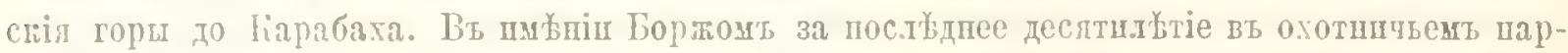

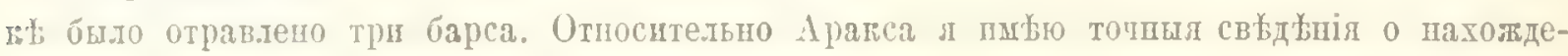

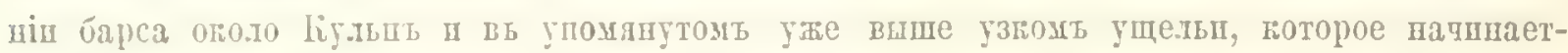
сл у Ордубата ш тлнетсл вдоль самаго обршвистаго ск.лона liарабахсдшхь горь. Но всего

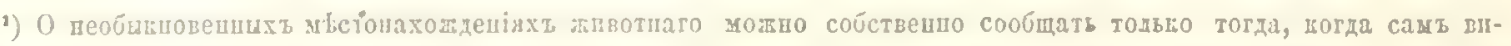

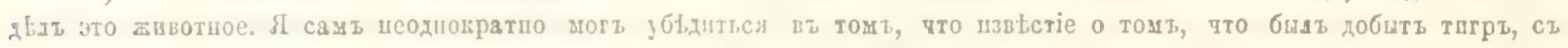

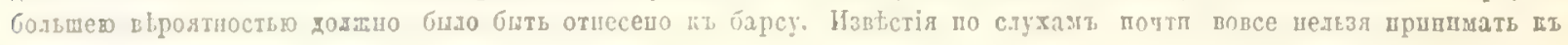
cBtsinio.

P. 


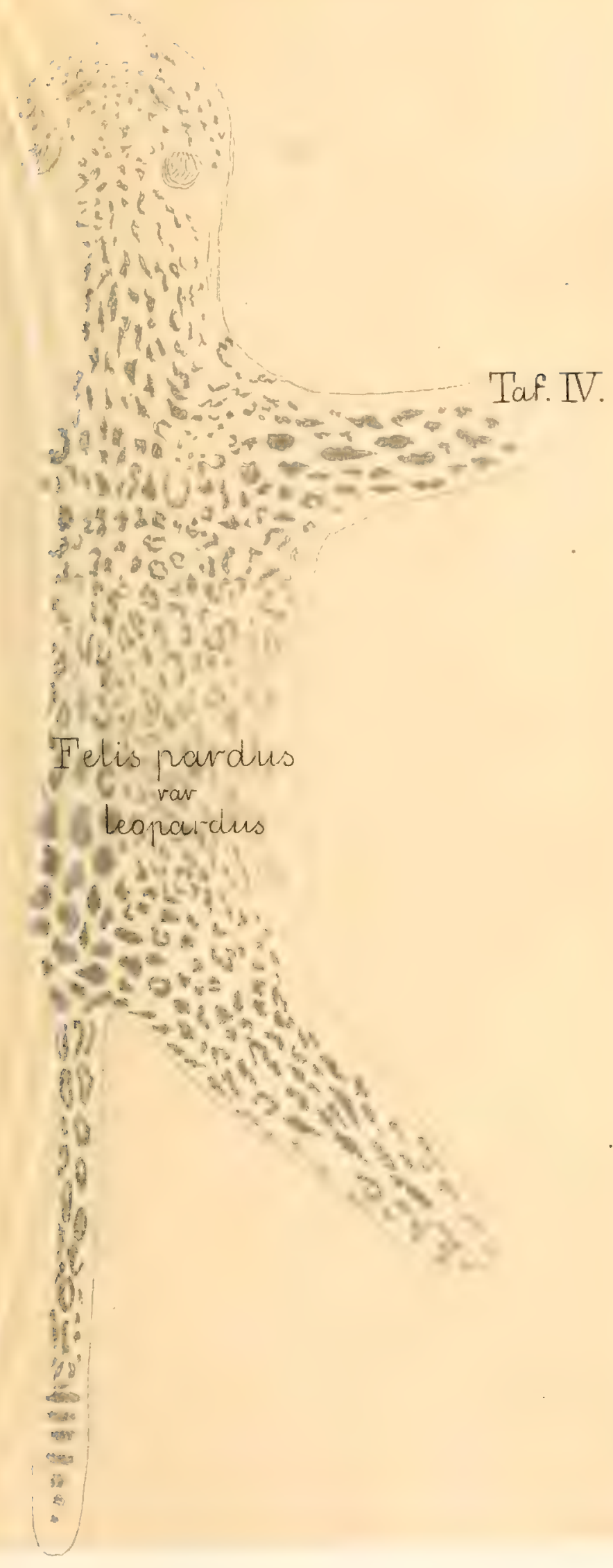

алшшћ. Когда въ 1866 году, во вре-

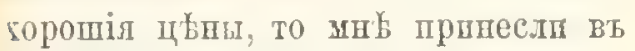
:орченцихъ пгурь. P. моря до границе льсовт. Находя$\therefore$ не представляють никайх значи-

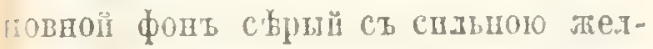
чистаго сьраго цвтта; это крупншй mета 69 ст., и длину хвоста съ кон-

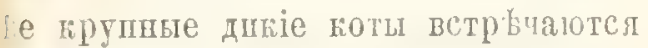
лисло пхь шкурь, представлявпнх т дъ вь лавғахь Батума, и изъ кото-

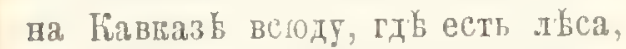

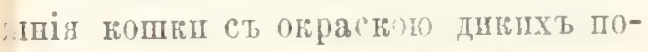
гє⿻ разлиной окраски обыцновенны

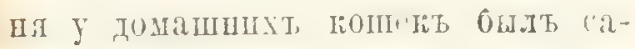
P.

.оляно-черпаго цвъта, шногда сь рвзгопнства. Во многіх мыстахь охотптея не тольњо на Каввазь но и въ

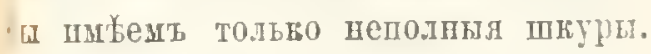
:лтых' волось.

во въ пизменностяхъ восточнаго Кагбепно въ заросляхт кампша II ежеон' Главпаго хребта, но чаще всег) зрагь вайдевь, а танже фазановь и , распространепіе сь достов вриостьо

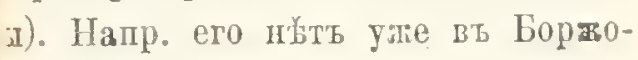

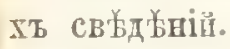

3000'? Типичную сьверную рись Л "в мххоыхт лавнахь многія сотні цвогда силио пспещрена. Основной ганого до желтовато-съраго (Дагезаль параллельо средней линіи сштНа льтнеи шерстп плтнпстость видюбороть у молодихь она выражепа

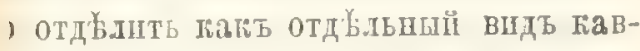

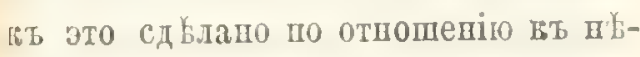
с.туча'⿱⺊口灬 таґой тацъ вазываемыї видт 4 трнзани не во всьхъ случаяхь буЗъ Дагестанє спрашпвали за такую I.

acal Güld. II Cynaelurus jubatus

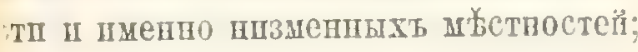
P.

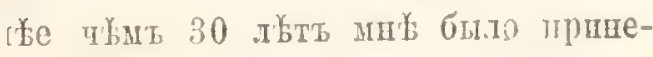


II I I I

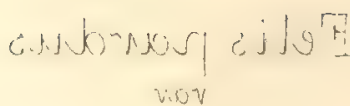

3. 3h. and 09 
$\therefore=4$

$\therefore$

$\therefore \therefore$

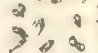

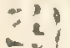

$: 1$

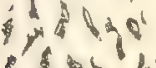

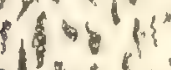

$90<1$

$3 k^{1} a^{2}+2$

2.

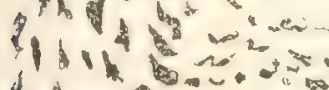

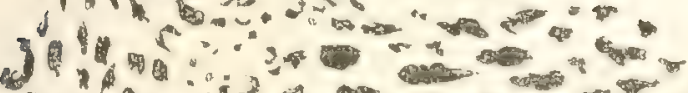

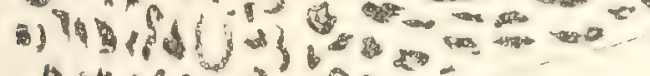

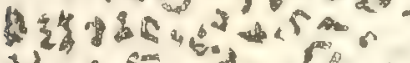

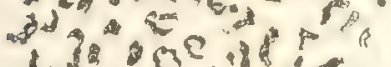

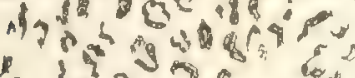

r 135

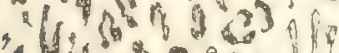

1) 7 ,

iि

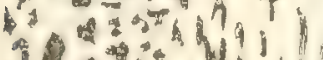

of 100

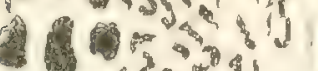

- $18 c^{2} 1$

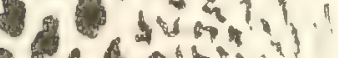

3. $3<<+1$

4102313

- - |ง "a

- $45-2$ - $2 x^{2}{ }^{2}$

(i)

(ii)

20

3

6

6

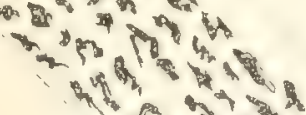

on 20

क स ?
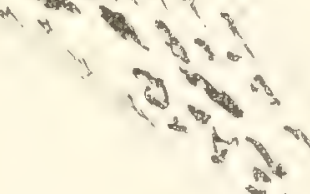

(1).

Ie?

$16 \circ$

if

(rese

सश्ना

is

E 


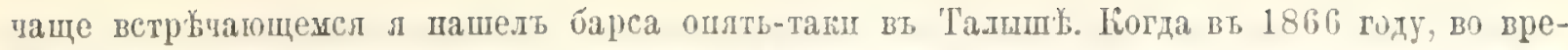

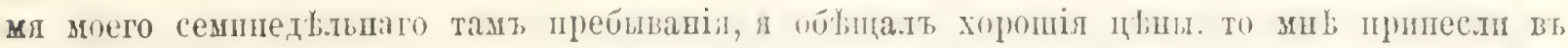

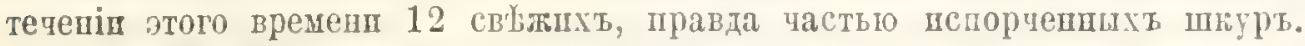
P.

№ 39. Felis catus $\mathrm{L}$. Дигій коть. Отъ уровпл жоря до гранци а всовт. Находя-

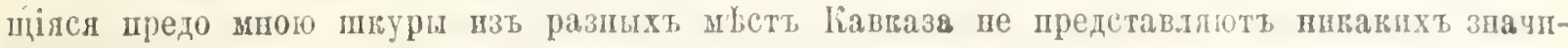

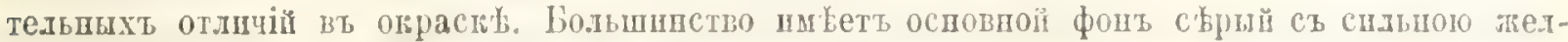

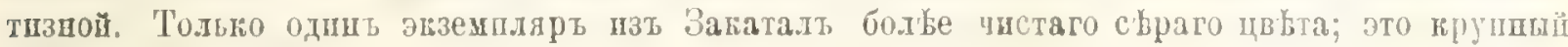

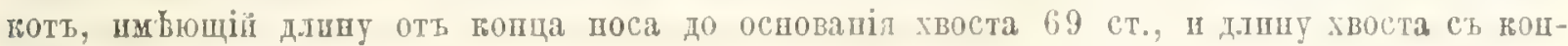

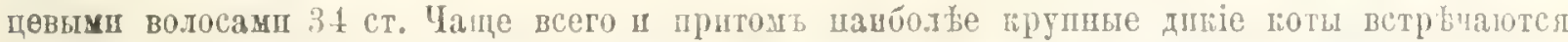

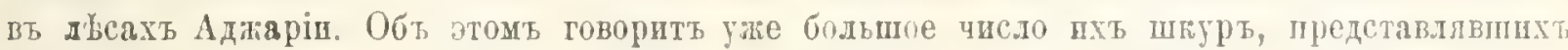

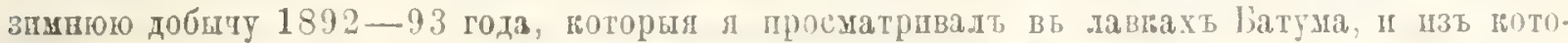

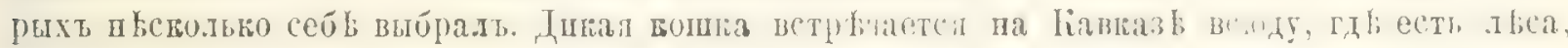

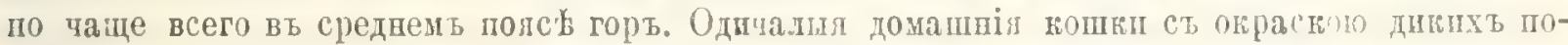

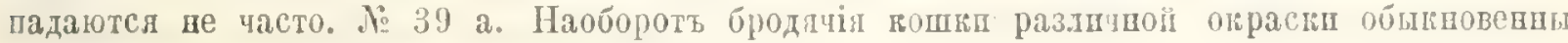
въ долинахт, въ охотничьхь райошахъ.

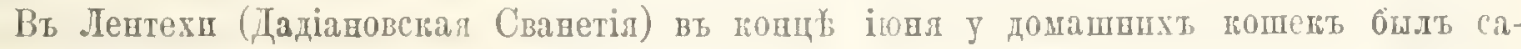
мй разгарь мюбовной порш.

№ 40. Felis sp. Величиною съ дитуго копюу, смоляно-черпаго цвыта, пногда ст раз-

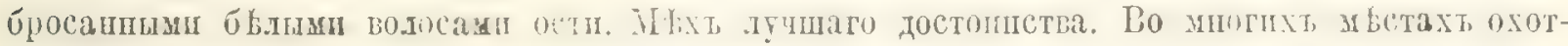

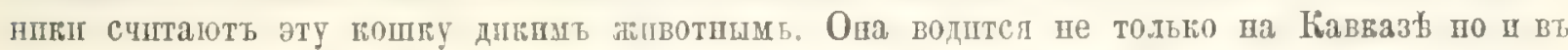

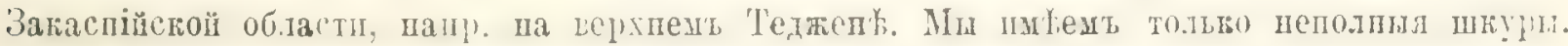

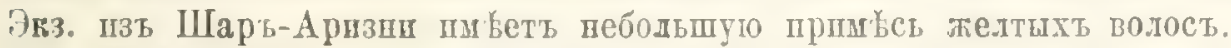

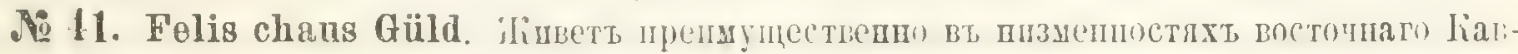

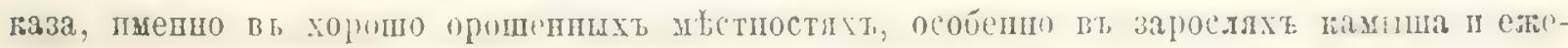

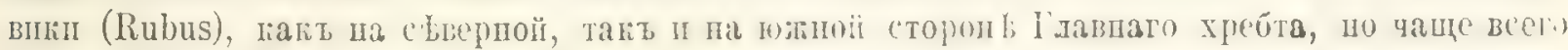

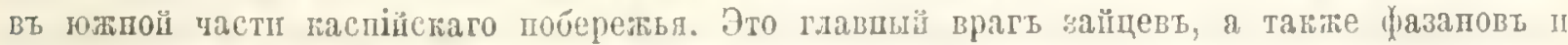

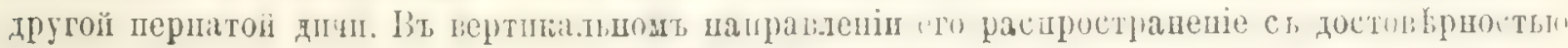

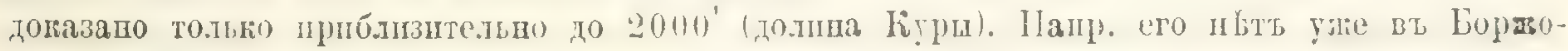

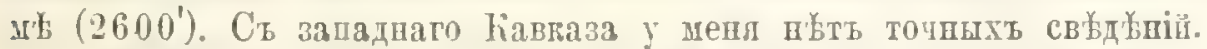

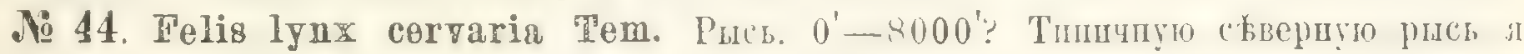

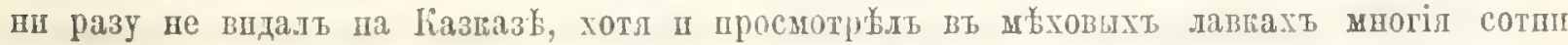

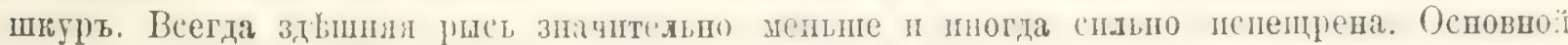

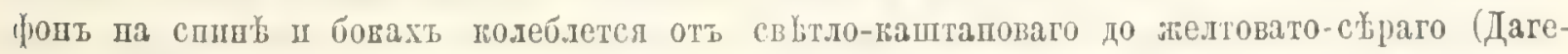

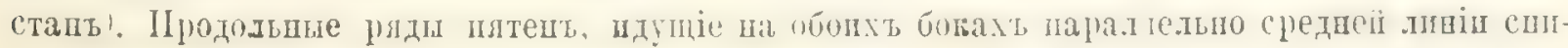

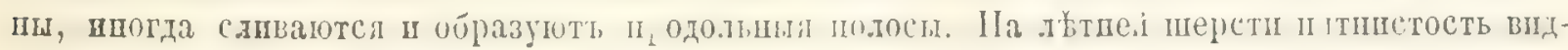

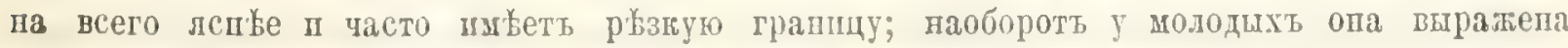

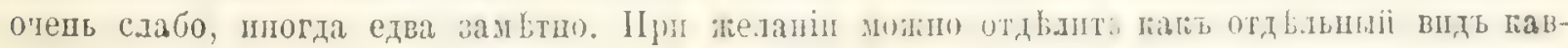

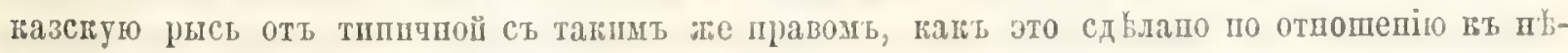

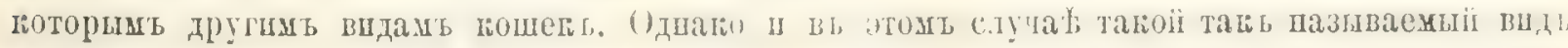

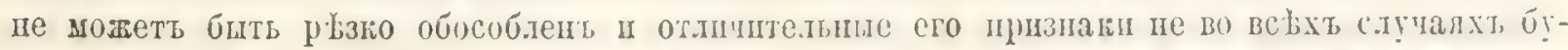

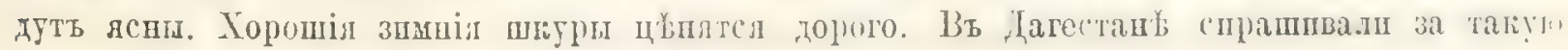

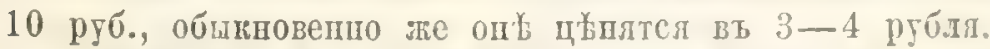

№. 42, 4:, 45. Folis caudata Cray, F. caracal Güld. n Cynaelurus jubatus

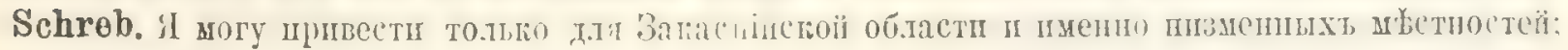
на Кавказџ опи пиногда пе били паидени.

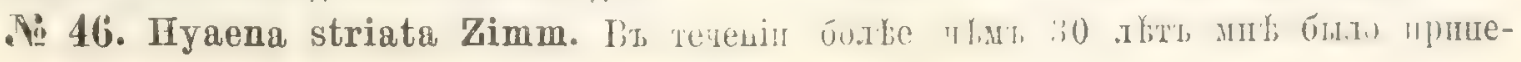




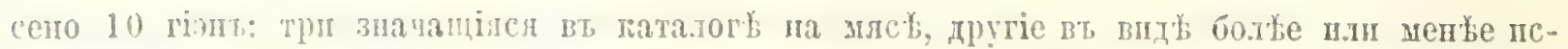

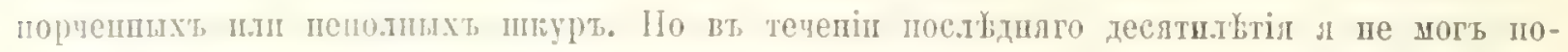

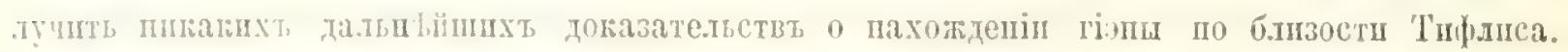

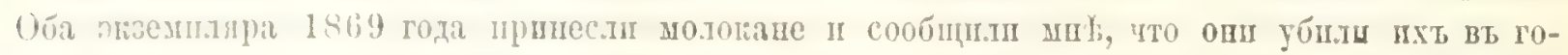

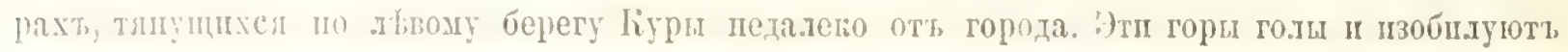

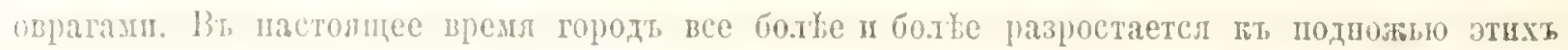

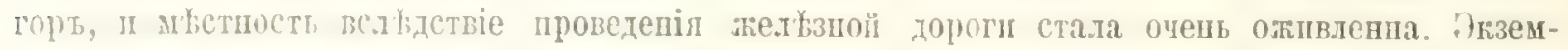

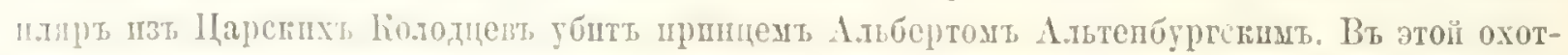

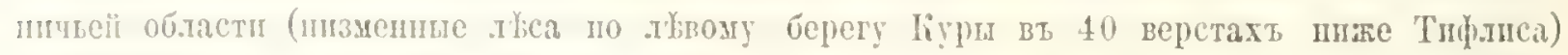

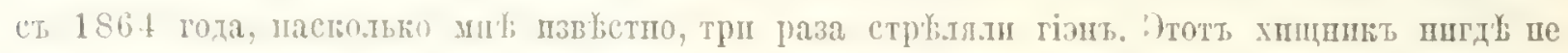

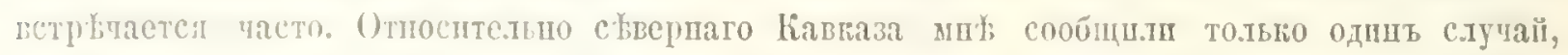

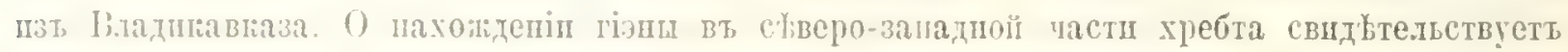

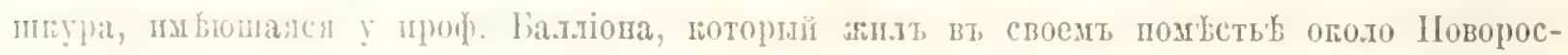

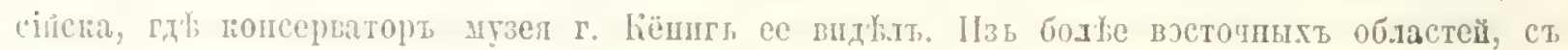

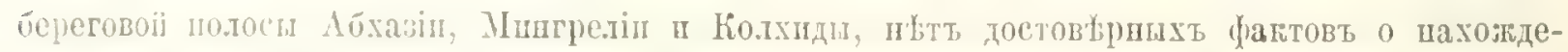

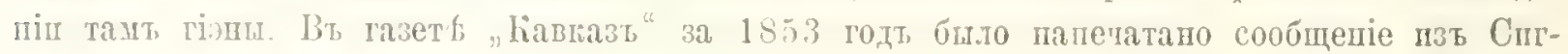

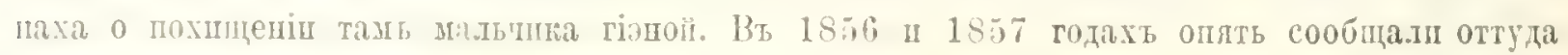

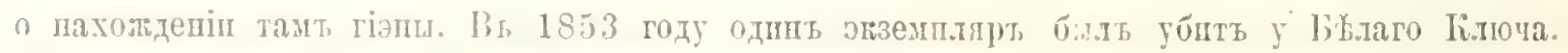

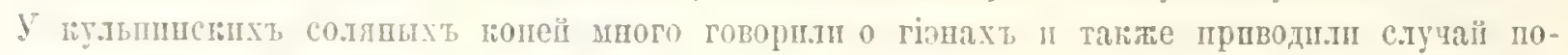
хпщенія одшого маличина

P'.

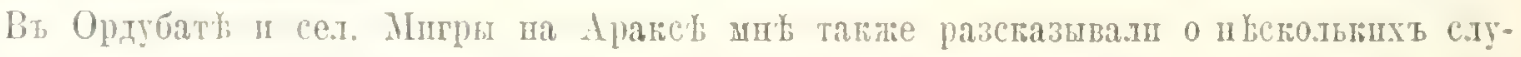

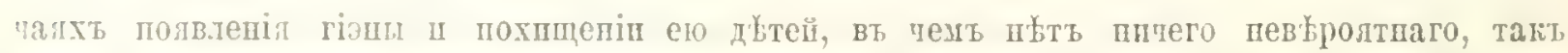

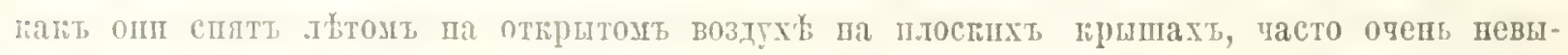

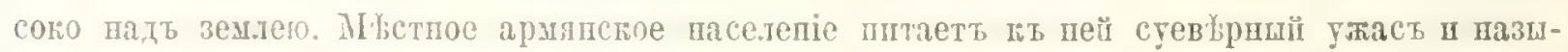

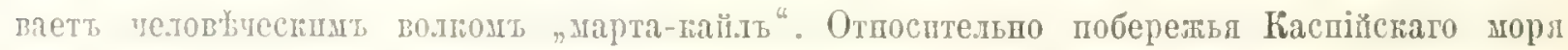

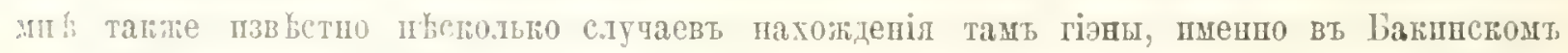

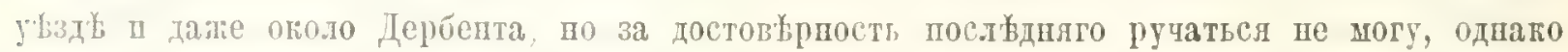

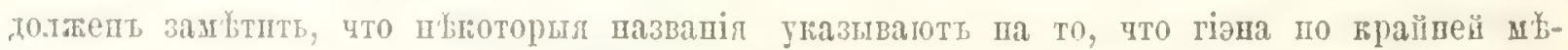

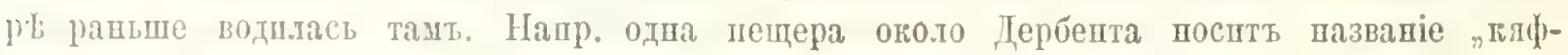

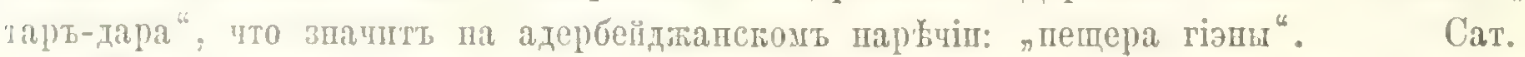

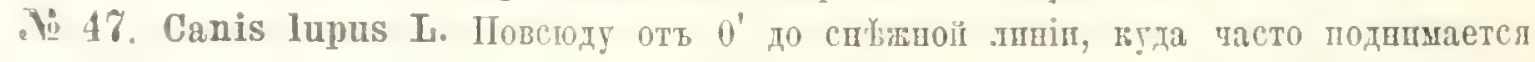

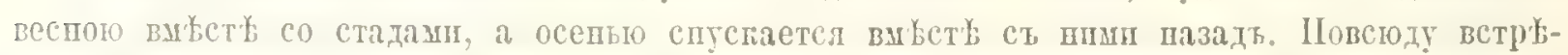
чаетсл часто и приосить вредт. Вь рачиской области выше Оши жители отрицали суце-

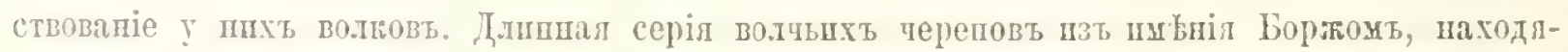

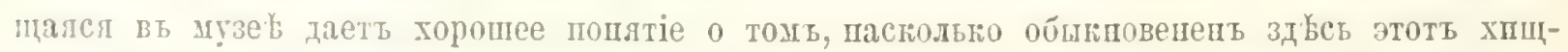

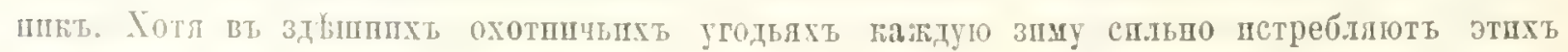

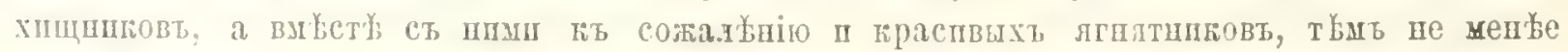

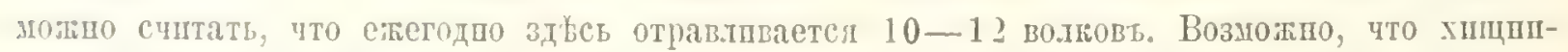

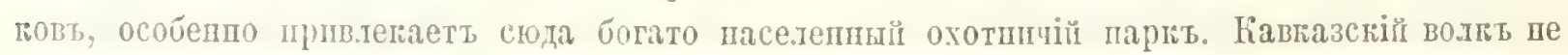

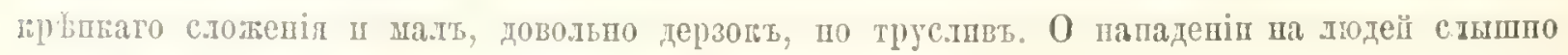

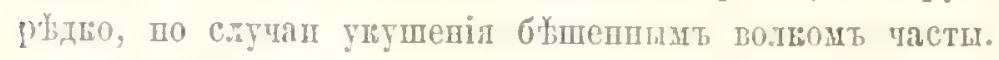

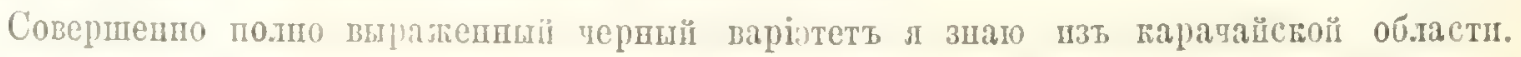

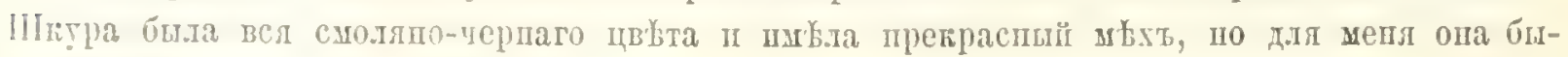
.а черезт-чррт дорога (100 руб.).

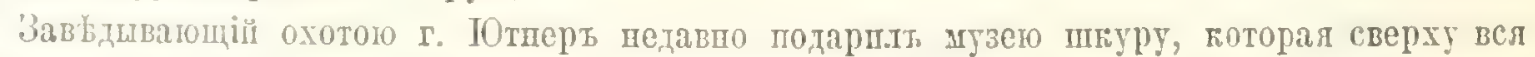

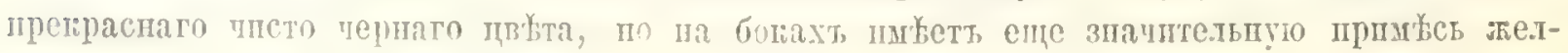




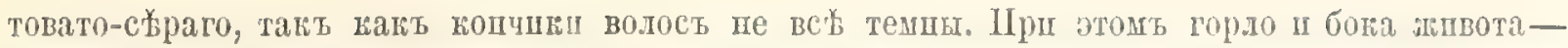

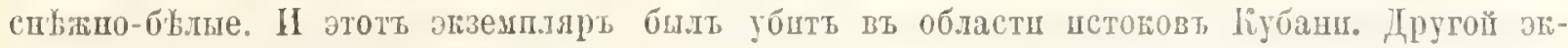

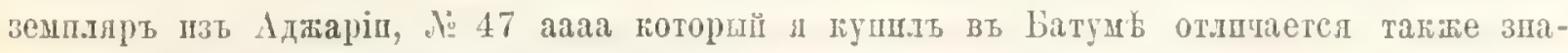
чптельною чернотою на бокахь.

P.

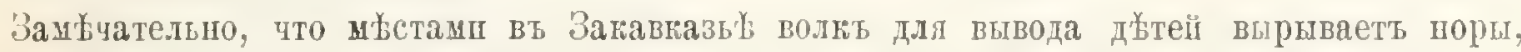
подобно пакалу п лисђ. „І наблюдаль это блпвъ Сальян'ь вт 1897 году. Подобное же лв-

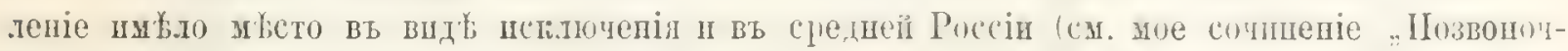

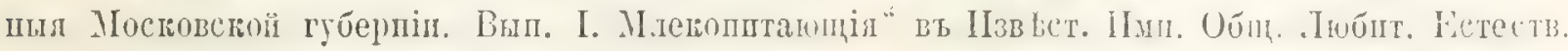
'T. LXXXVI, вып. I, 1895 ).

Car.

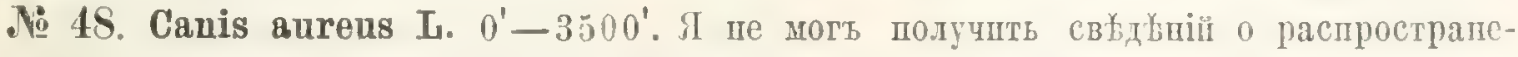

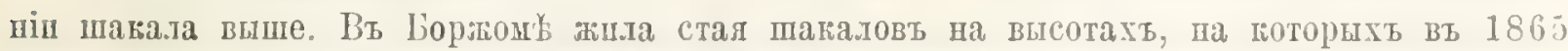

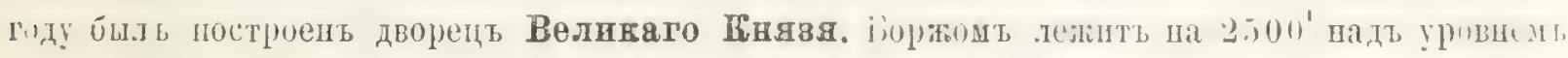
моря, а эти высоты возвышаютсл шадъ нимь на 500-600 футовъ. Каздый вечерь сль-

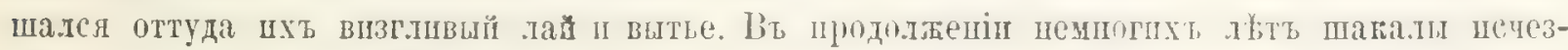

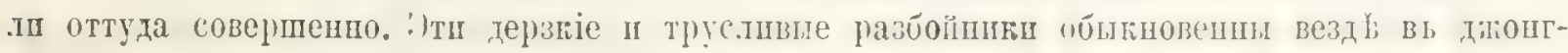
лахъ на пизменностяхь, пменно вь Закавказь' оть одного моря до другого въ восточной

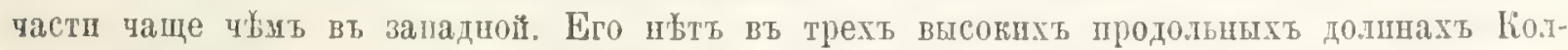

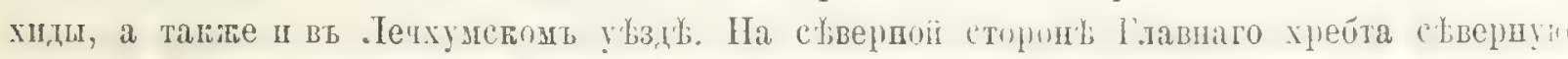

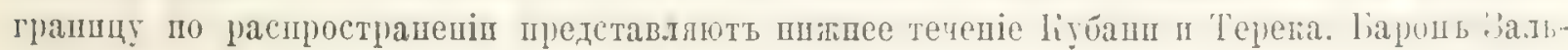

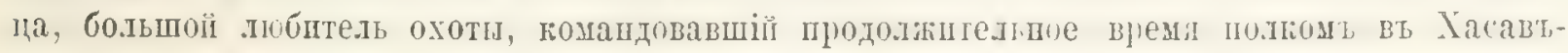

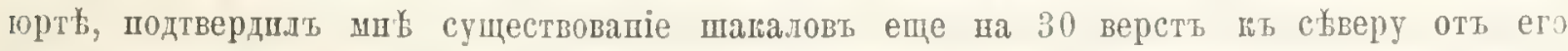

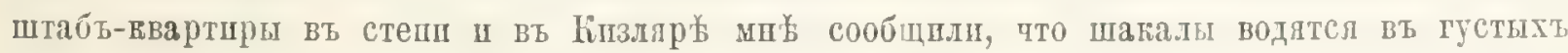
памышахъ дельты Терека. 48, $1 . \mathrm{m}$. изъ Закаталь отдичется крупныз ростомь п пыш-

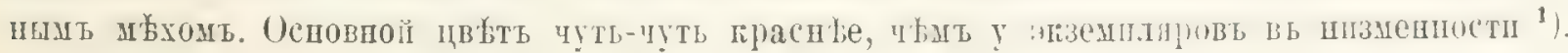

Въ 1893 году я нашель п раскопаль много шакальшъ норь въ густьхь заросляхъ

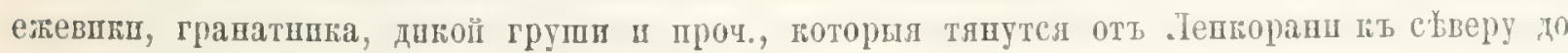

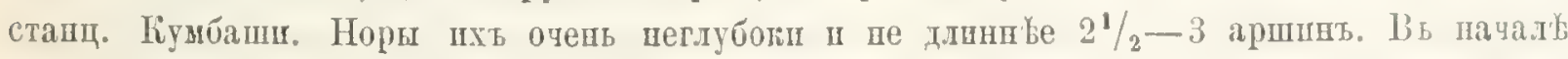
мая вь ншхъ было оть 4 до 5 мододыхъ шапалять, въ возрасть отъ 1 до 2 шедыль Что касается его распространенія по побережью Каспійскаго уоря, то л ве напель его въ

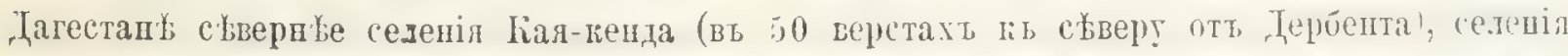

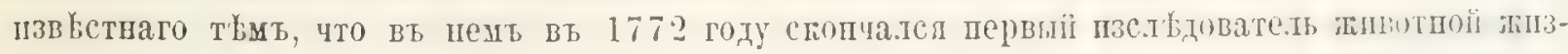

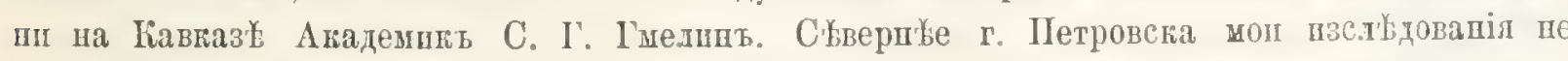
простпралпсь, погему я и не знаю водитсл ли опь въ настолщее время вь дельть Терека.

Caт.

. 49. Canis vulpes typ. In . 50. Canis melanotus Pall. Labrascian imena

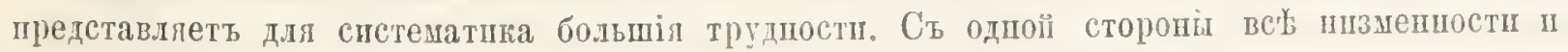
предторья до высоты $5000^{\prime}$ обштаеть одинъ видъ лисшцы, который шиюгда де достигаеть

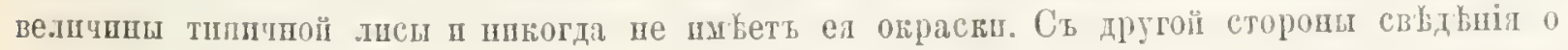

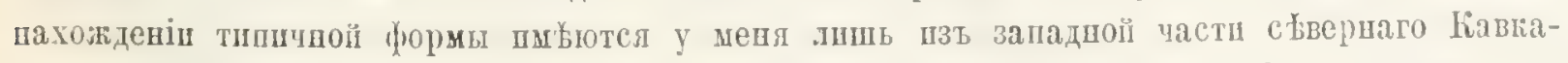

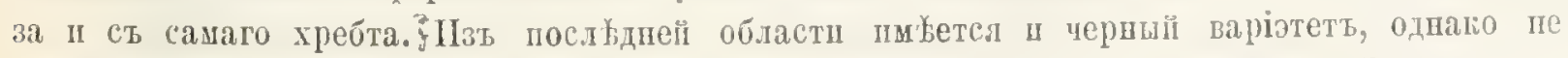

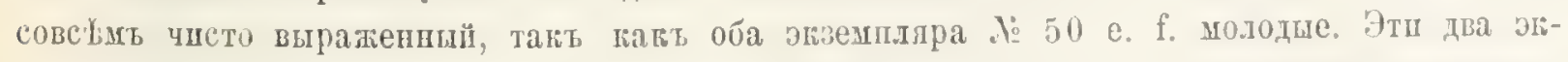

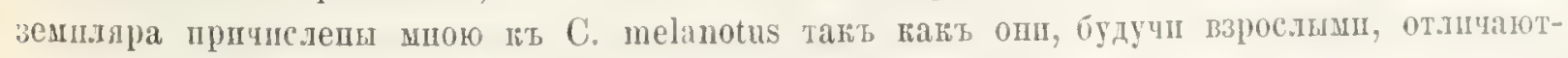

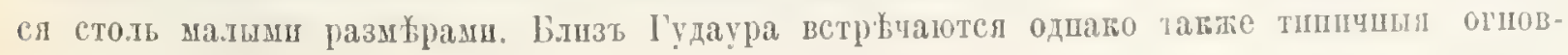

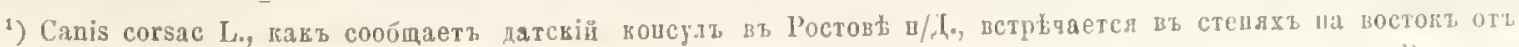

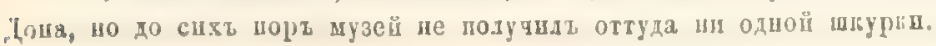




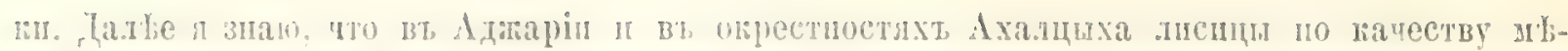

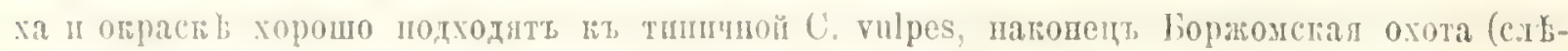

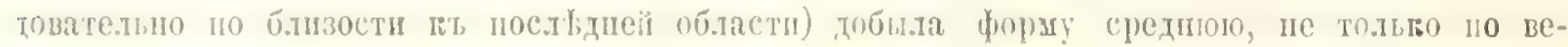

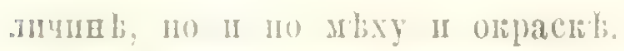

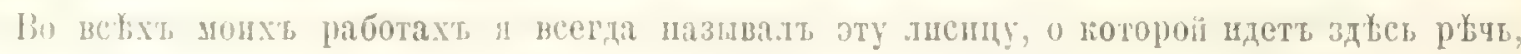

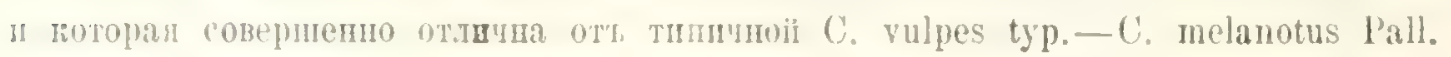

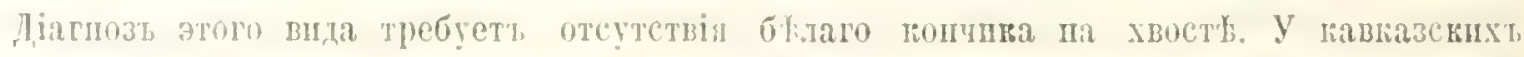

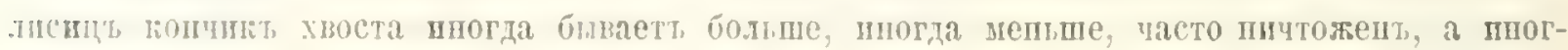

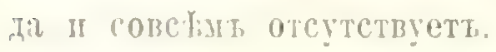

IГатлась пnners: (Zoogr. Rosso-Asiat, vol I. pag. 45). "Cauda plerumque in adlatis pellibus deest, apice nigricans". Стуаетея, что шри сиимани шиури особенио қогда охот-

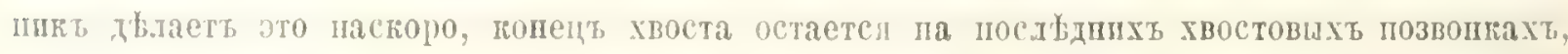

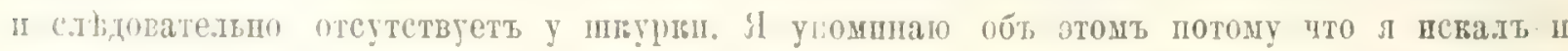

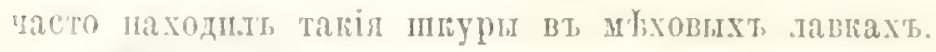

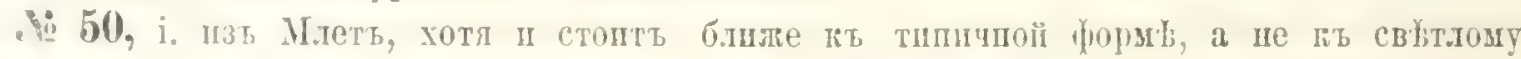

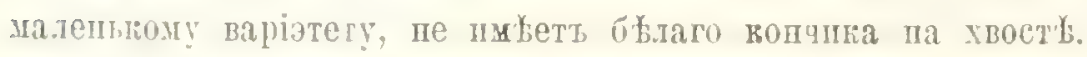

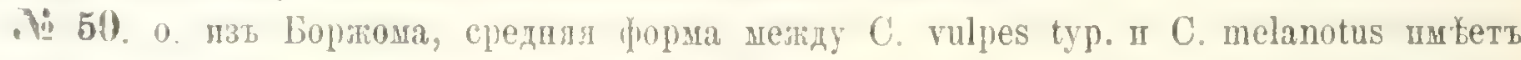

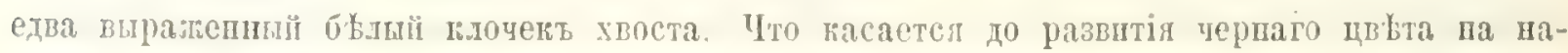

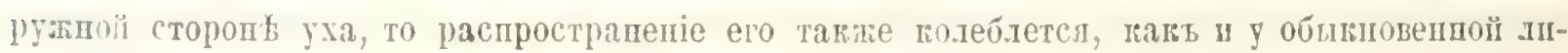

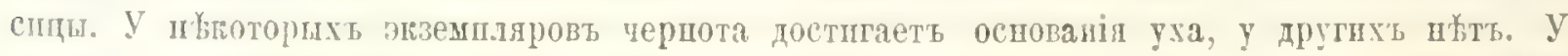
ппурољт изт западной части сłвернаго lавказа оно типино.

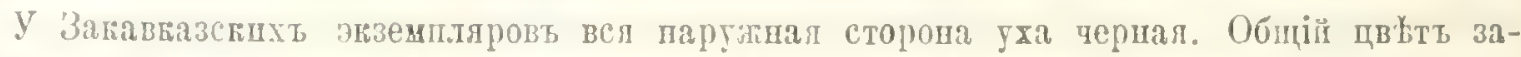

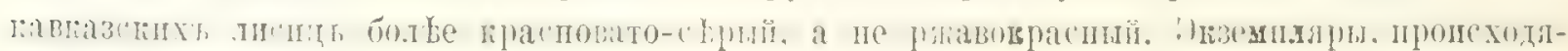

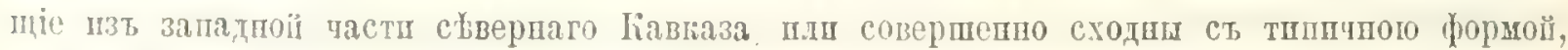

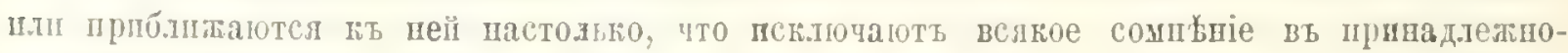

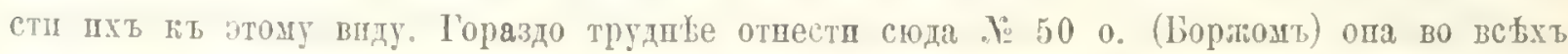

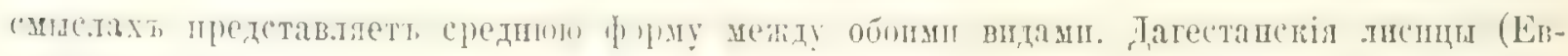

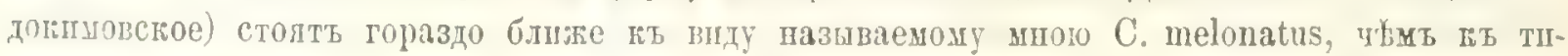

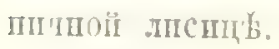

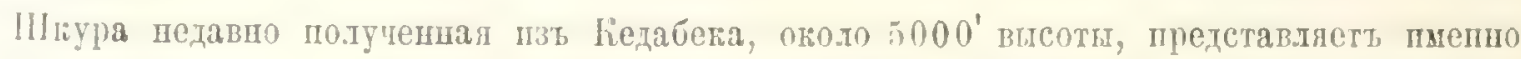
то, тто л называю С. melanotus; весь мбхь до самой морды пе представ.ляеть и слғда ржаво грасиоці окраски.

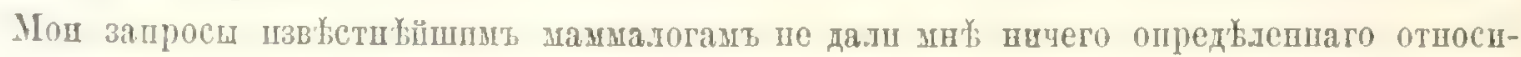

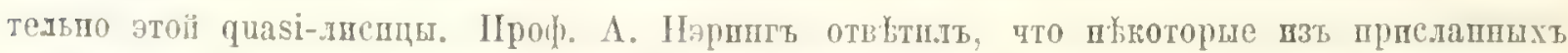
ему череповь безт затрудшенія могутт быть отнесены по свопм относительнымь размюрамт

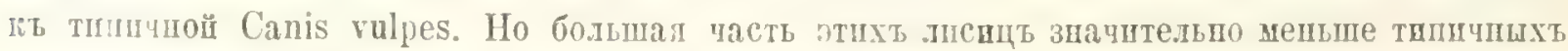

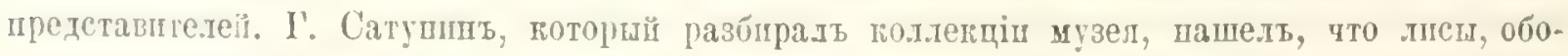

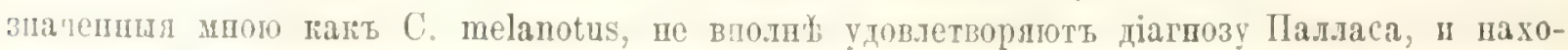

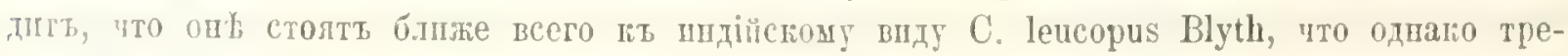

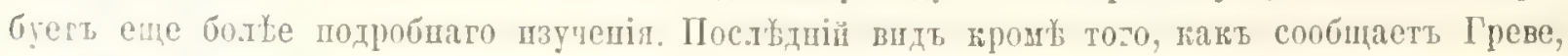

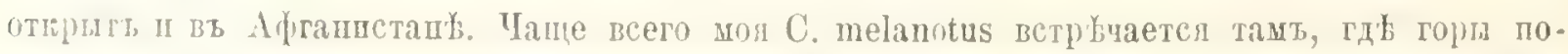

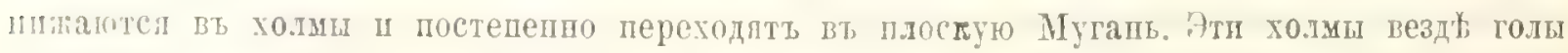

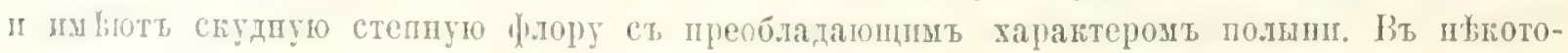

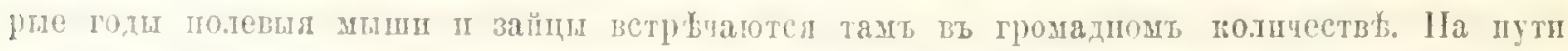

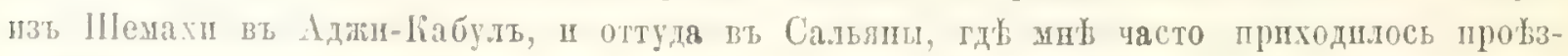

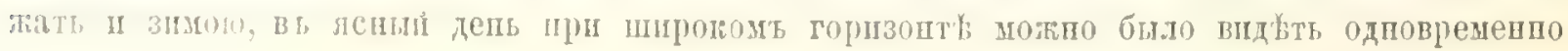




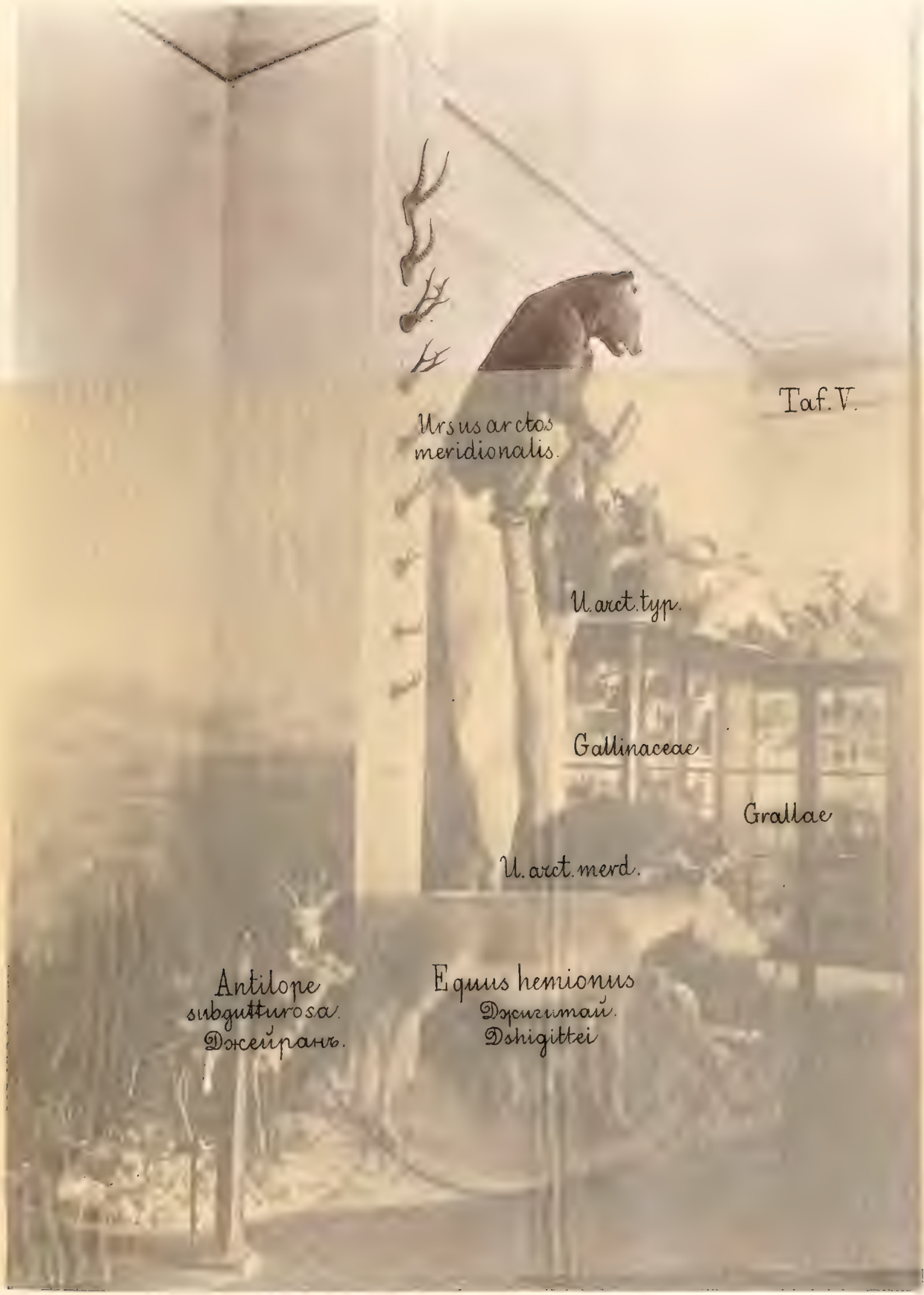




\section{.7 .705}

sats No cos zNN

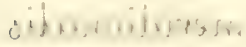

sput taro N

$.3092003 \mathrm{NON}^{2}$

unl(nat)

bromb bois, II

$$
\begin{aligned}
& \text { entratangl and } \\
& \text { isosen zagres } \\
& \text { istlip)..t.? (? }
\end{aligned}
$$










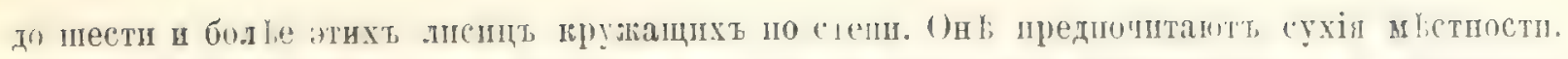

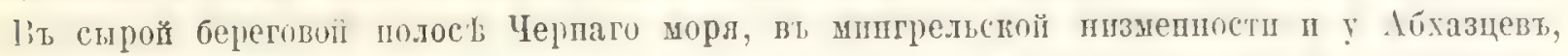

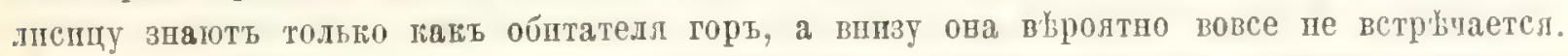

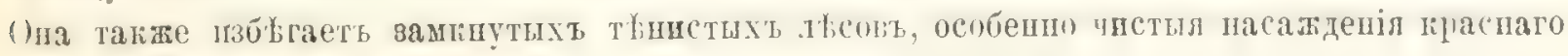
бука.

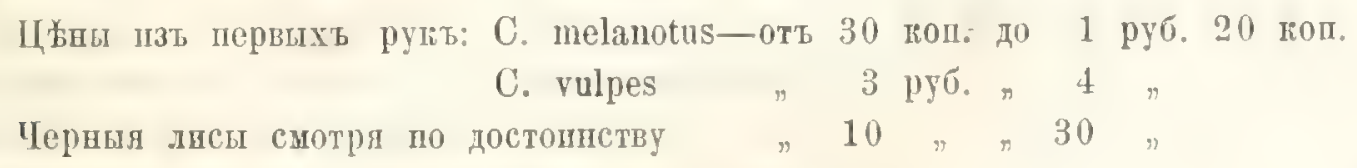

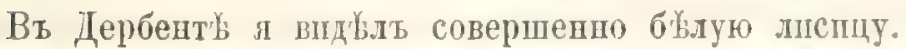

Ni 52. Ursus arctos typ. et meridionalis Midd. (incl. syriacus Hempr. et Ehrenb.

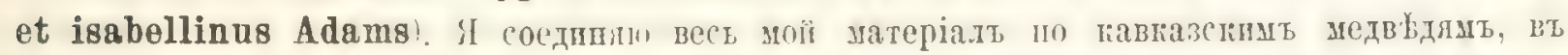
одиньь видь (Греве отдыляеть U. syriacus оть arctos) п говорго тольно объ U. arctos typ.

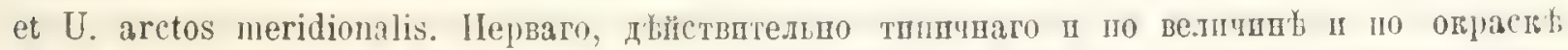

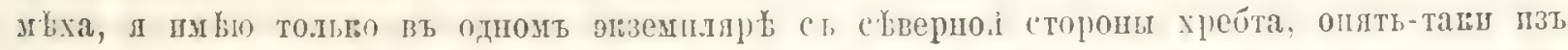

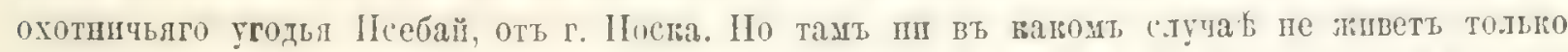

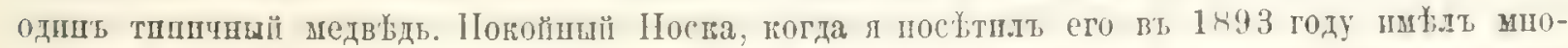

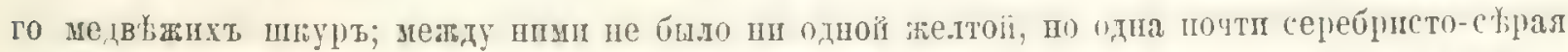

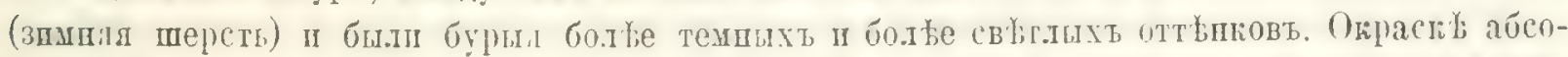

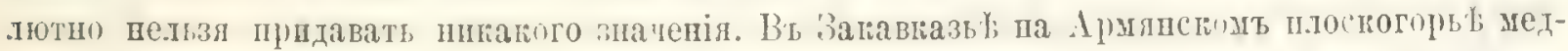

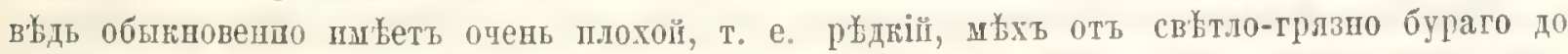

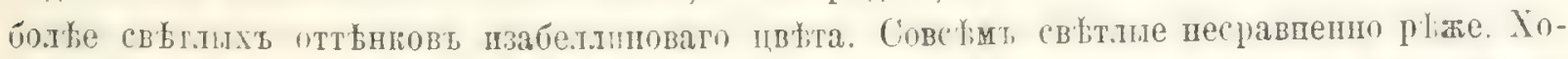

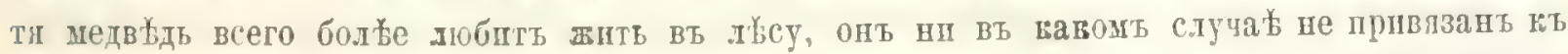

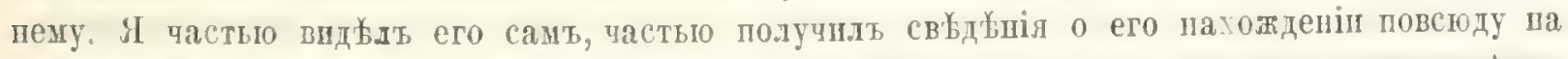

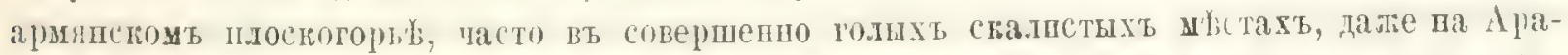

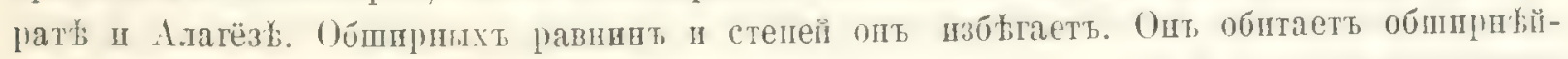
шій пояст, оть $0^{\prime}$ до 12000', а льтомь подншмется п еще выше, такъ кағъ тогда онь охотно

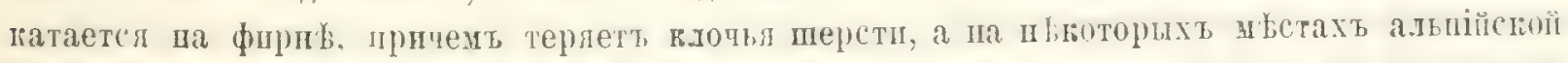

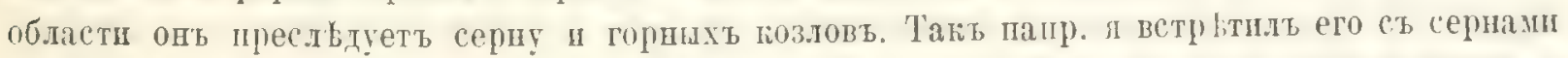

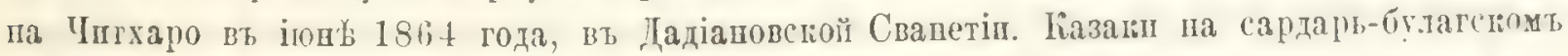

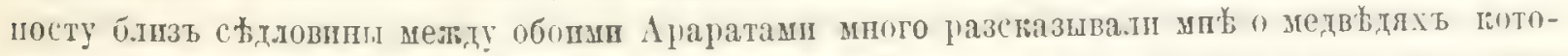

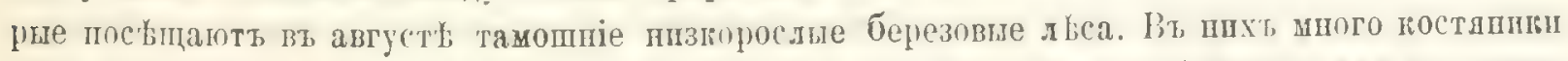

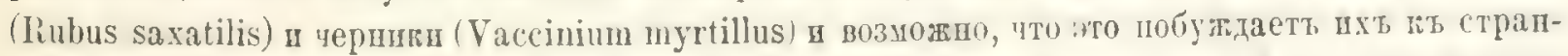

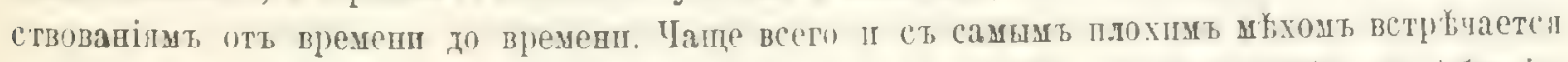

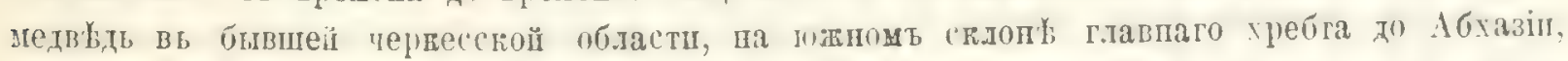

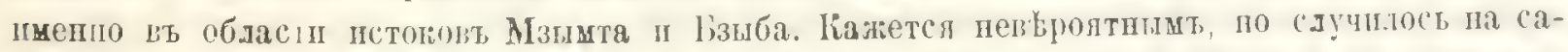

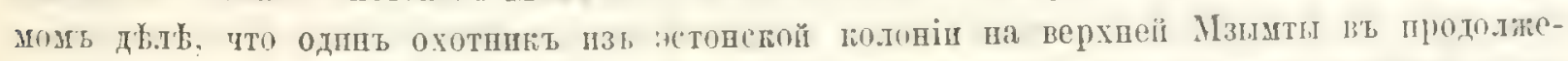

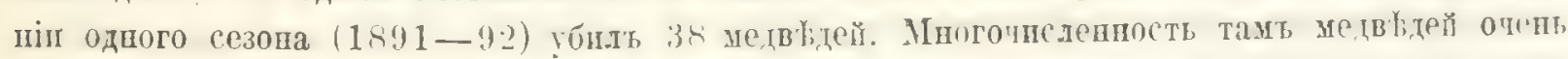

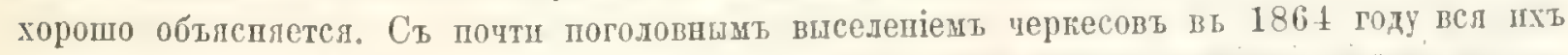

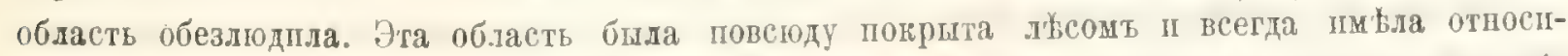

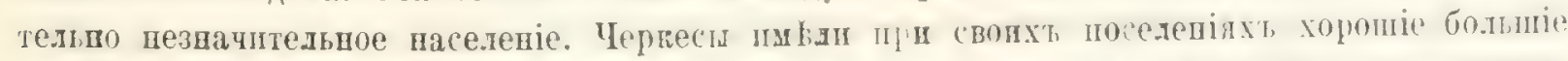

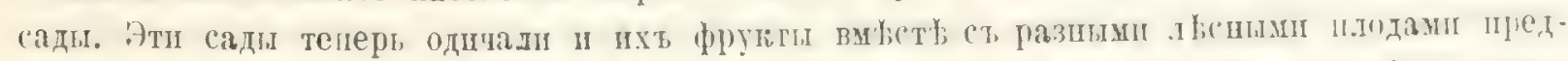

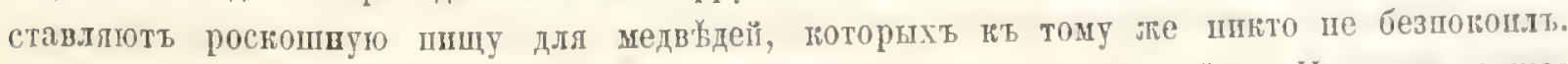
Отсюда и сильное увелпчепіе ихъ въ течепіп послудних $20-30$ льть. II въ настоящее

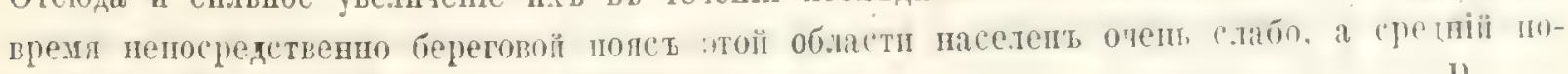
лсъ горъ почти вовсе не наседепъ. 


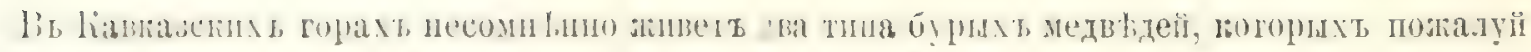

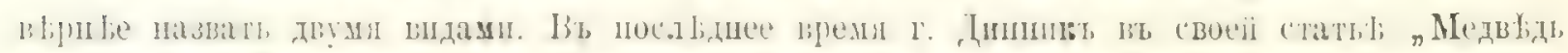

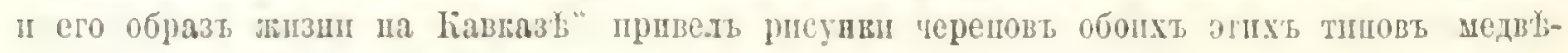

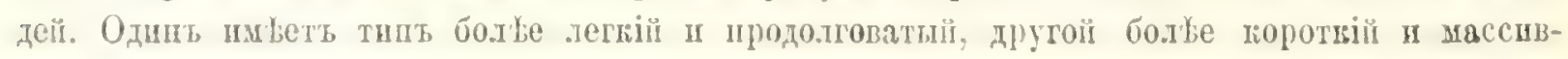

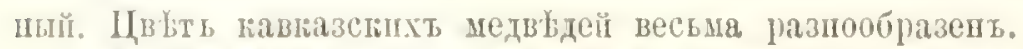

Car.

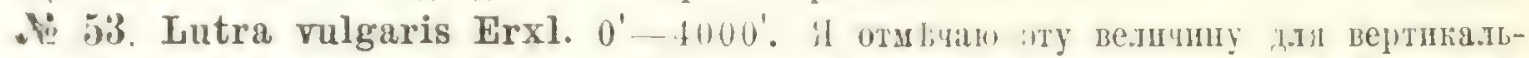

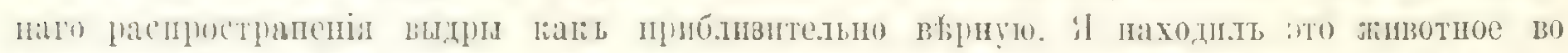

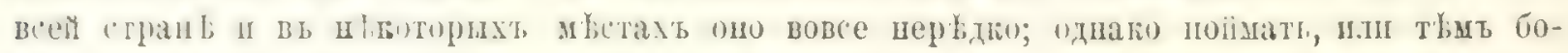

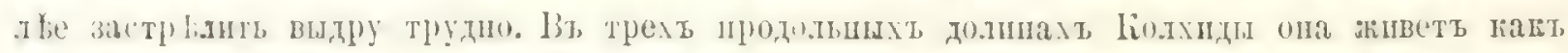

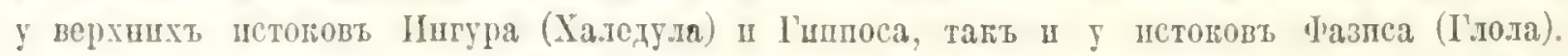

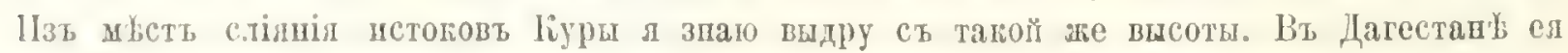
нуть у подиожья Салатау, жители Бутурна отрицал ея пристствіе здъсь.

P.

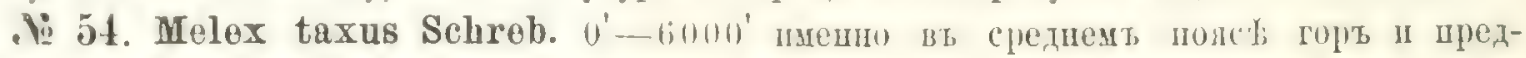

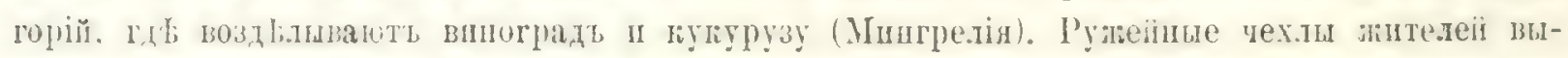

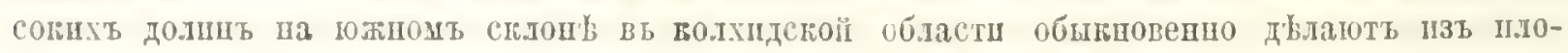

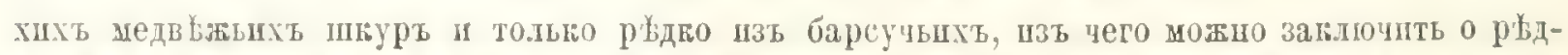

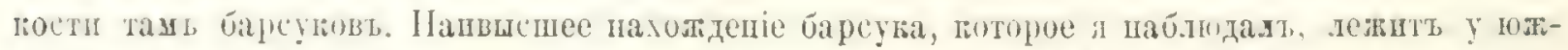

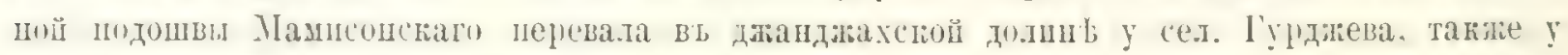

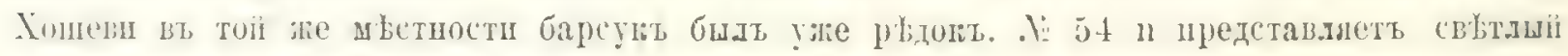
варіэтеть саnescens изъ низнениости Талшша.

P.

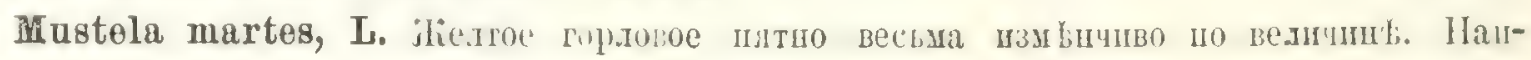

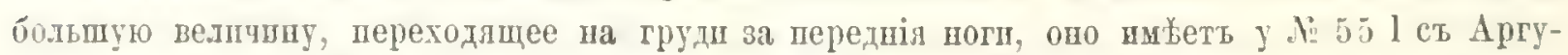

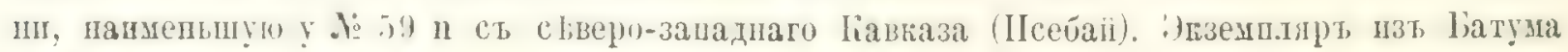
.

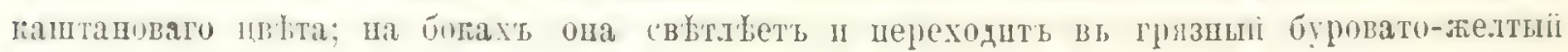

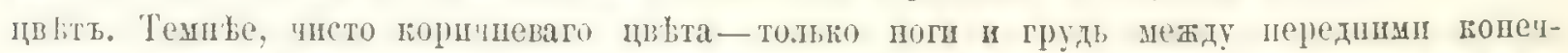

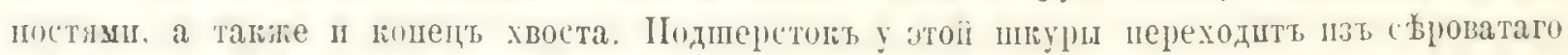

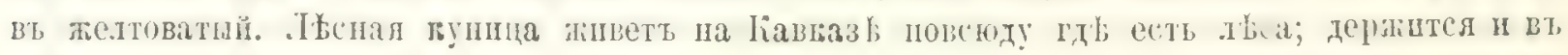

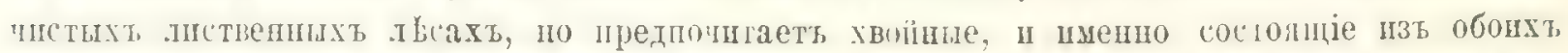

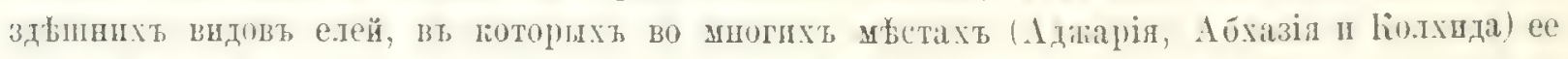

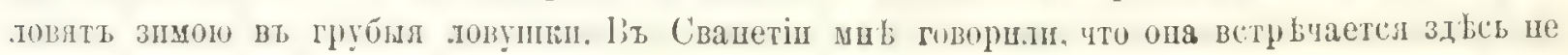

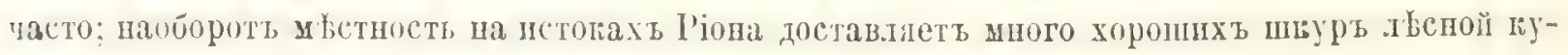

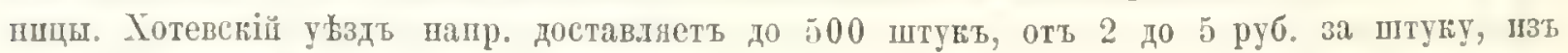

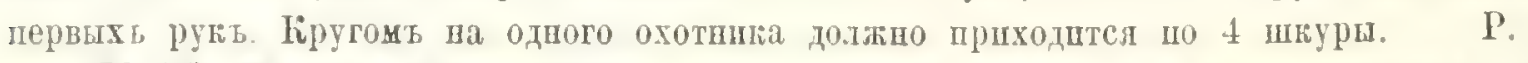

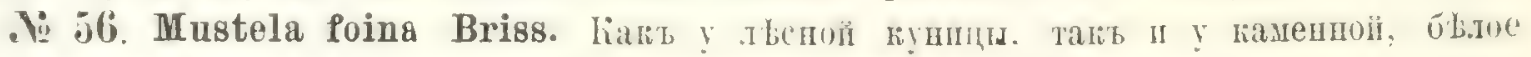

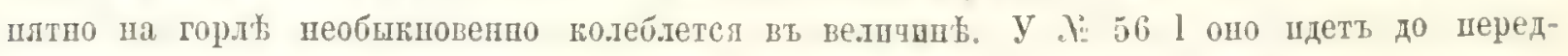

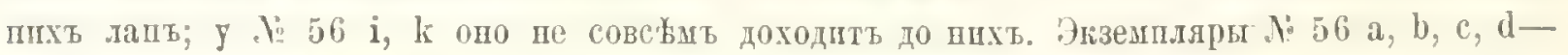

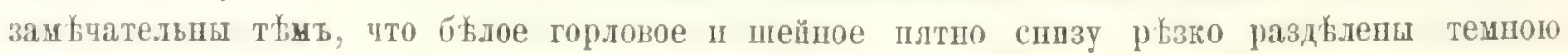
продольною по.тосою.

1 .

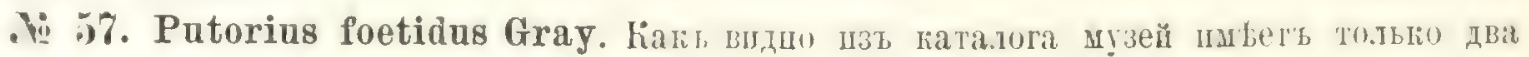

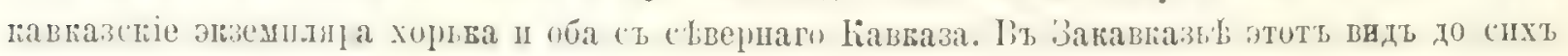

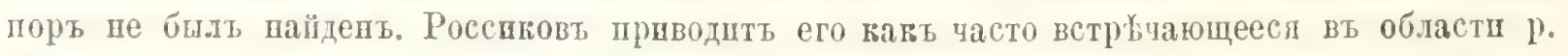

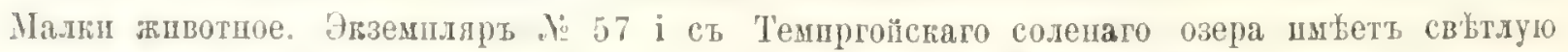

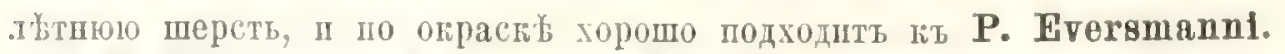

I?.

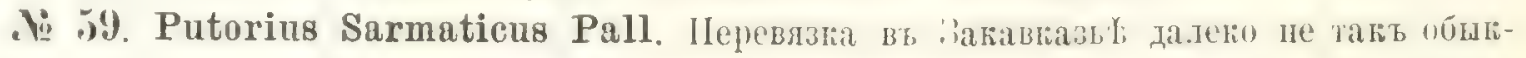

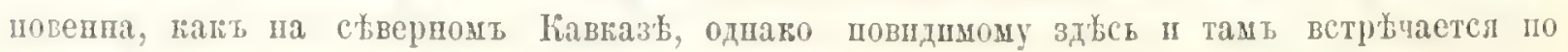




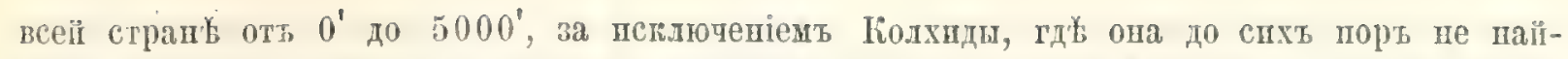

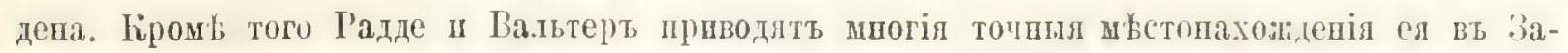
ґаспійсвой области (1. с. отд. оттиск. стр. 31).

Со временемь опублиованіл моей статьи о кавказскпхъ мленоптающихъ (въ Zool.

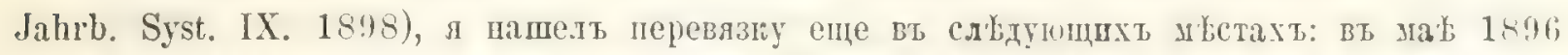

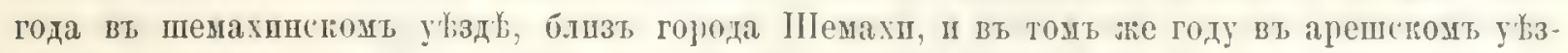

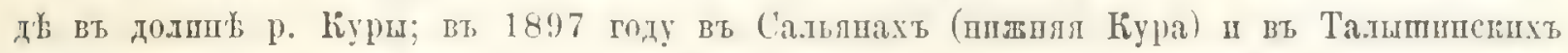

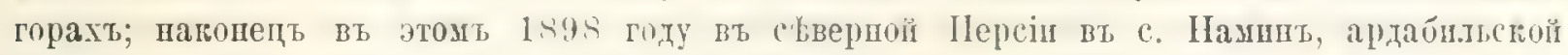

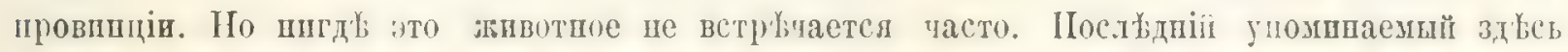

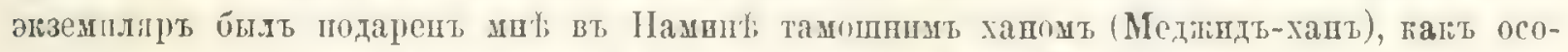

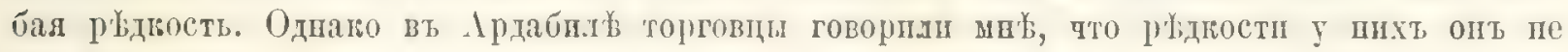
представляеть.

Cat.

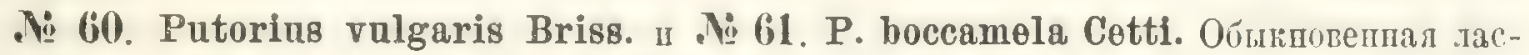

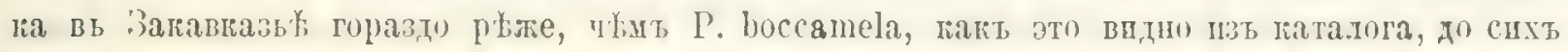

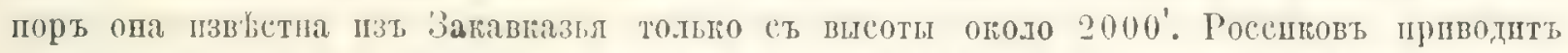

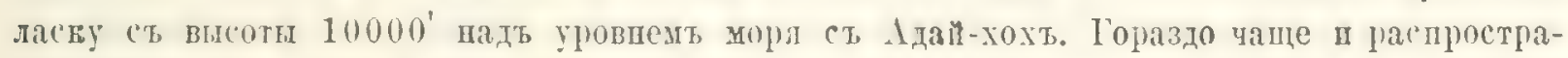

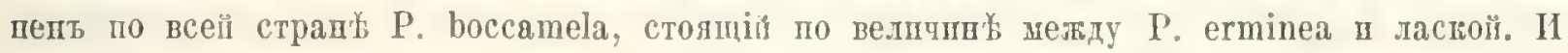

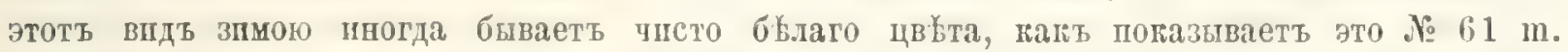

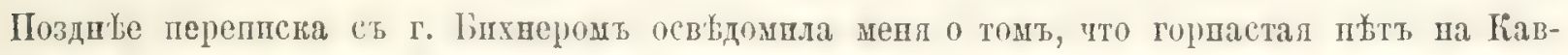

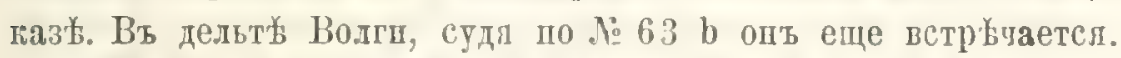

P.

Vi 6\%. Patorius Stoliczkanus Blanf. Mи (Г. п В.) дали въ статьж „Die Sïugethiere

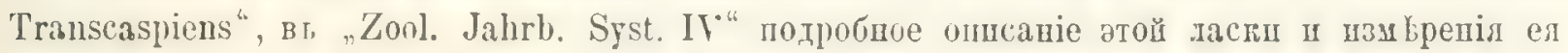
перепа.

P.

Ni 64. Patorius lutreola (Cuv.). il получн.т только одинт әкземпярт норгіл ст

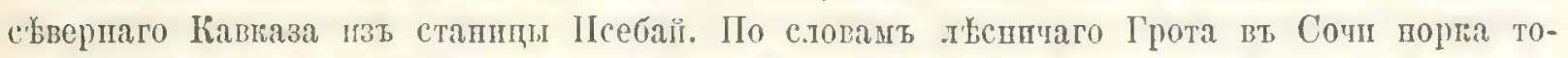

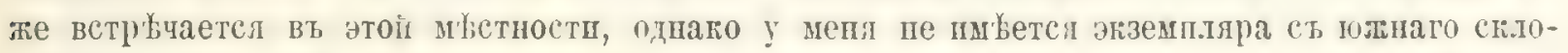
на главнаго хребта.

P.

\section{R O D E N T I A.}

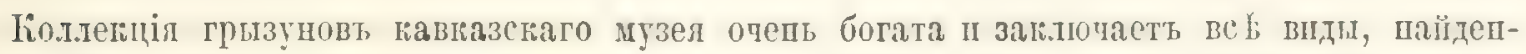

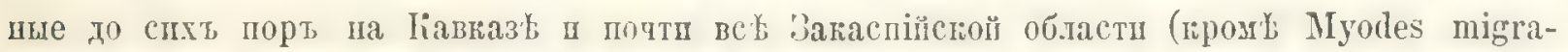

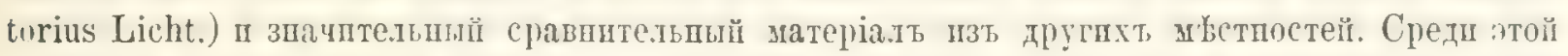
юоллекціп обращають на себп вниманіе: серія экзезпллровт Sciurus anomalus по поторой

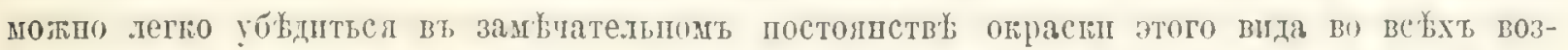
растахъ и во велгое времл года. Затжыт: Муохи pictus 13lanf., Gerbillus erythrurus Gray, G. persicus Blanf., G. Hurrianae Jerd., Cricetus Raddei Nelıring, Microtus nivalis petrophilus (Wagner), Nesolia Boettgeri Walt., Sminthus concolor Buchner, Alactaga Williamsi Tho-

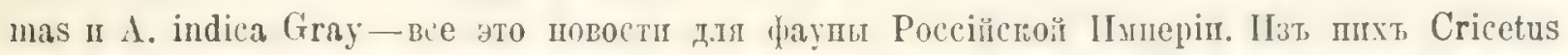
Raddei In Nesokia Boettgeri впды совеншешп новые для паукп, а Sminthus concolor и 1. Williamsi первостепеппия рәидтости.

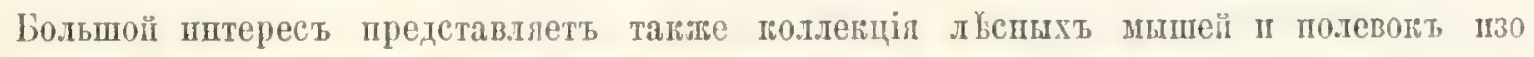
всъхъ частей Кавказа; надъ шим прпдетсл однако еще много поработать.

Car.

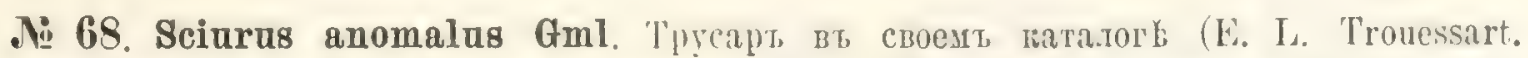
Catalogus Mammalium tam viventium, (fuam fossilium. Nova cditio (prima completa) p. 191. 


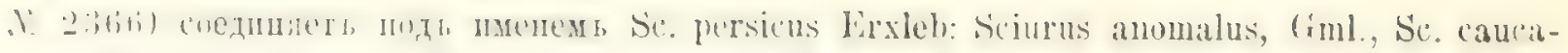
sicus lall., Se Syriacu- Lhrenh., Se. russitus Wagner, Se. historicus (iray u Se, fulvus lilanf.

llazıac (P. S. Pallas. Zoographia Rosso-Asiatica I, p. 186) самь roвopнтт, что его

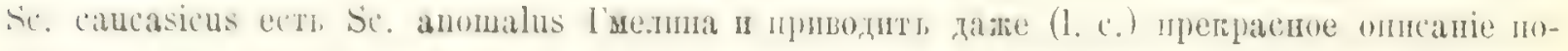

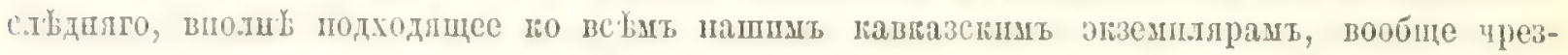

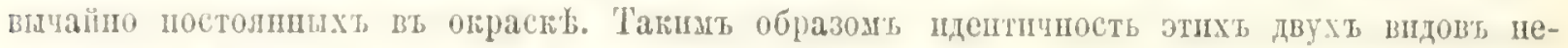
сомнына, а право пріорнтета за пменемт Sc. anomalus GmI.

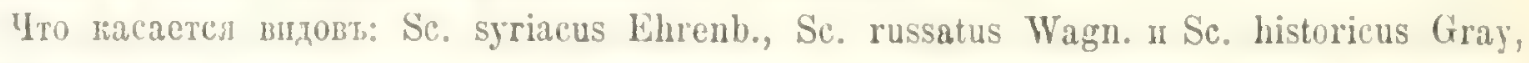
го не видавши ихт и ше пия подъ рунащ даже хорошаго описанія этихъ видовь, л не могу

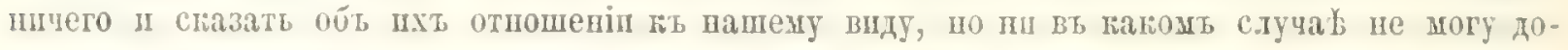
пустить ндентичости Sc. Anomalus ст Sc. fulvus Blanf. У насъ есть молодыл и старти,

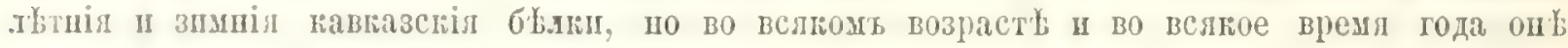

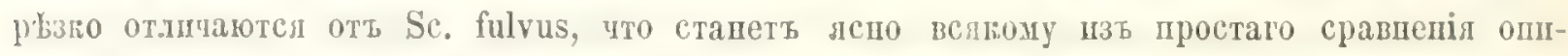
саній I'мелша (v. s.) и Блэнорда (W. Blanford. Easteru Persia vol. II. p. 49, 'J'. IV).

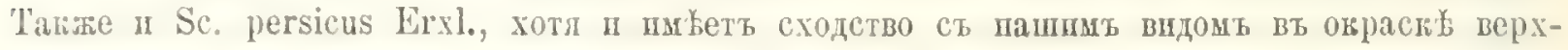
пей части тыла, по существенио отлиаетел оть пего, по описано Гмелина Младшаго (ци-

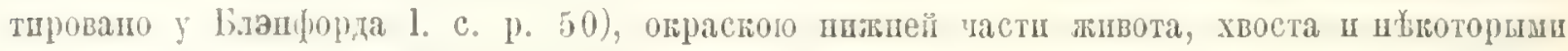

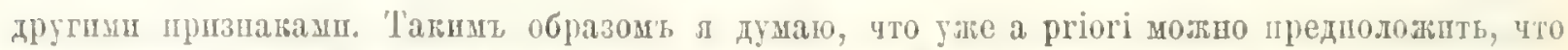

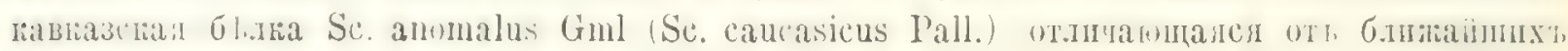

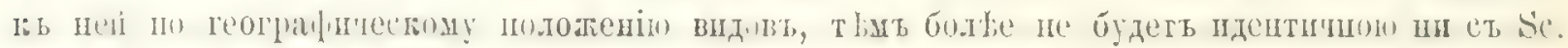

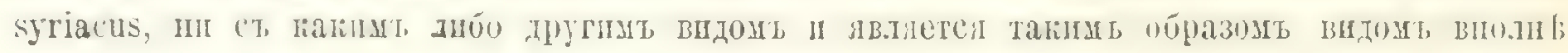
самостоятельнит.

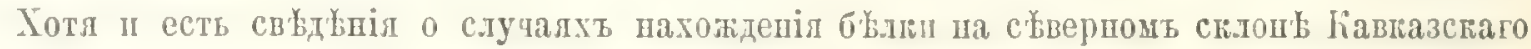

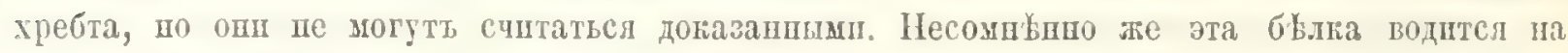

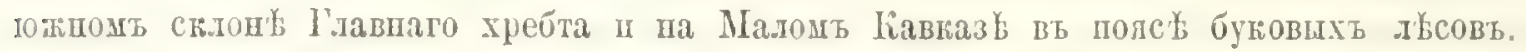

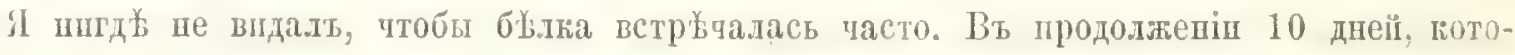
рые въ 1864 году л употребиль на то, чтобы шройти черезт недоступное ущелье Пнгура

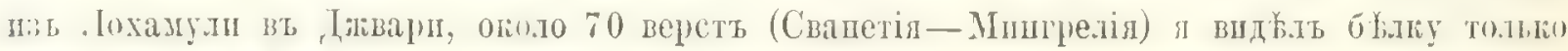

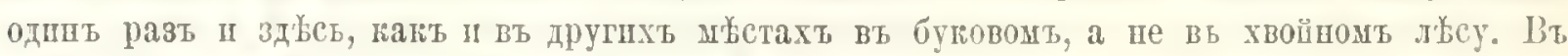

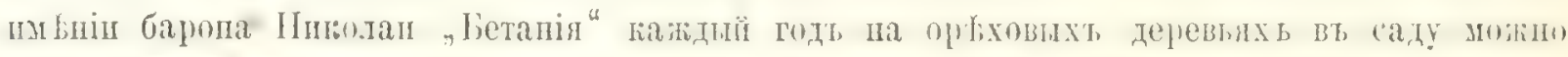

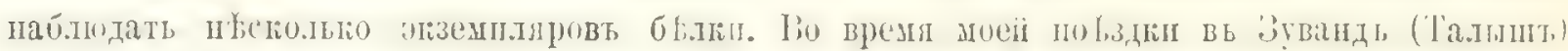

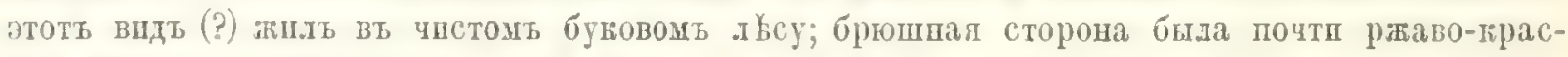

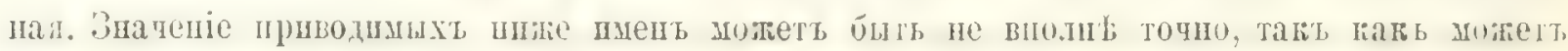

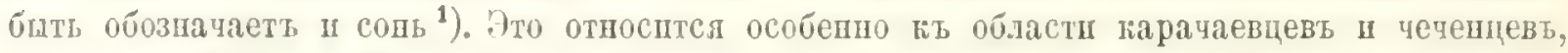

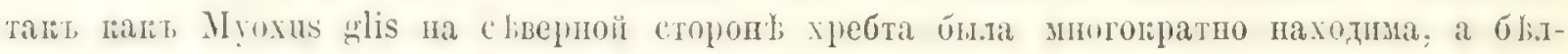
ка сь полною достовырдостьо не доказана.

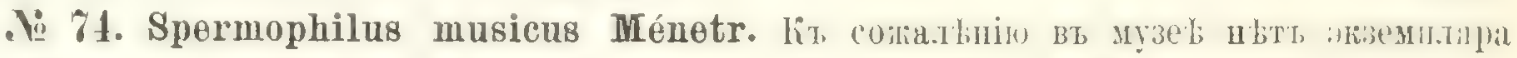

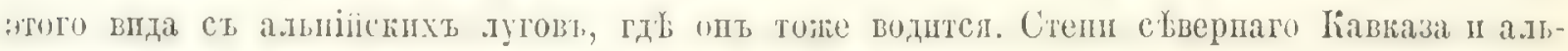
пійскіе луга Главпаго хребта $0-10000$ '.

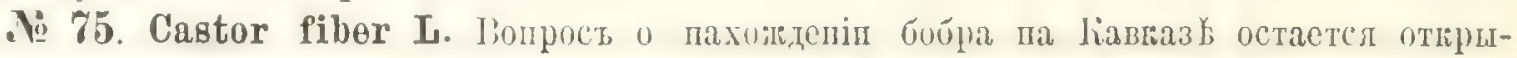

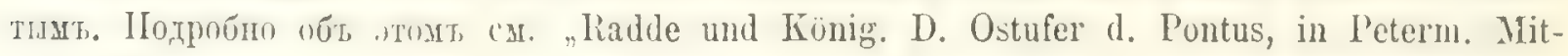
theil. Ergänzungh. 112 p. $116^{\text {" If }}$ "Satunin 1. c. p. $297^{\text {". }}$

$$
\begin{aligned}
& \text { 1) У Сванетов , dad.-Tратпве } \\
& \text { - Абхазцевъ - Абхпдха }
\end{aligned}
$$

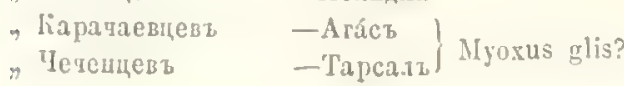




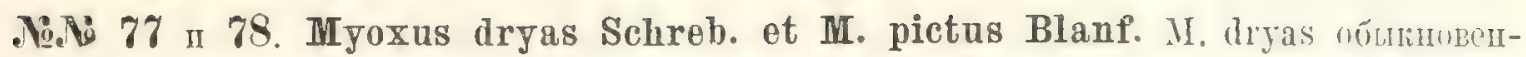

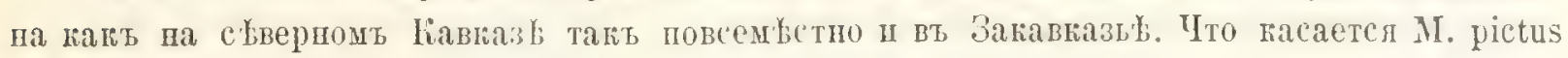
Blanf., то хотя щногіе современные спстематик, напр. Трјссарь (1. с. р. 454), Рёвенст (C. L. Roevens. Die Myoxidae oder Schlaefer. Leiden 1890.) и дl\%. сqштають се синин-

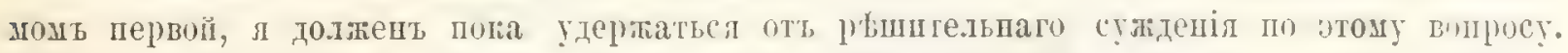

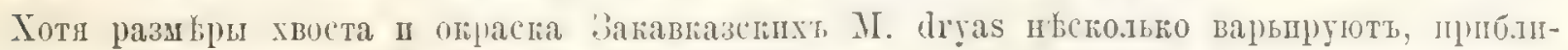

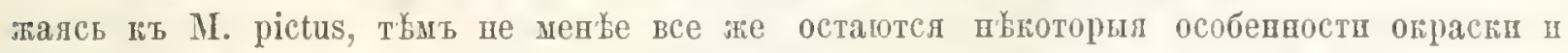

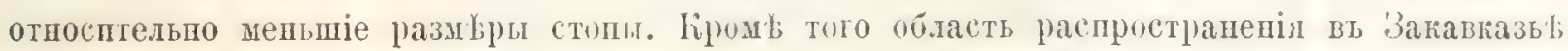
M. pictus обособлена оть об́.ласт распрострапеніл М. dryas, и л знано первую тольто шзт, с'ьверо-востонної части Закавказья со склоновь главнаго хребта.

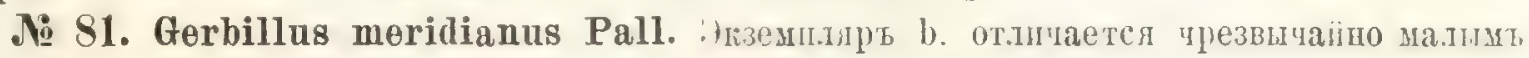
ростомт.

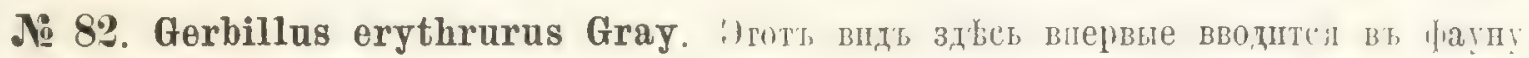

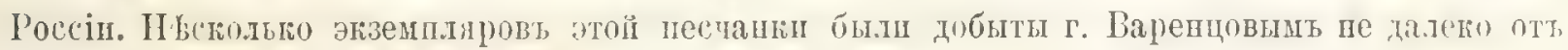
Аехабада.

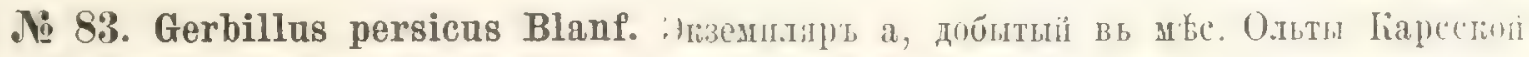
области, шриведен вь моей стать' о мекоптающих Кавтаза (1. с. p. 300) подъ . 61

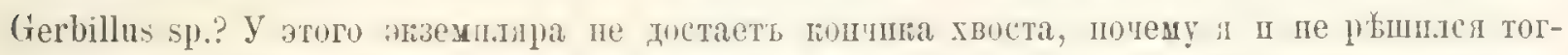
да его опред

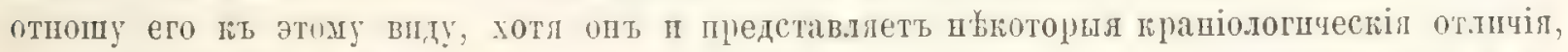

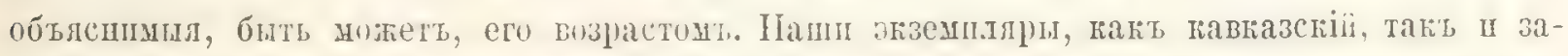

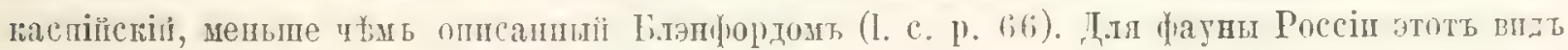
приводитслі виервые.

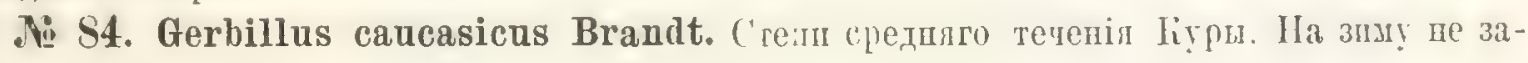
сыпаеть.

№ 85- 86. Gerbillus Hurrianae Jerdon. Ст большиь сомнвніем отпошу я сюда

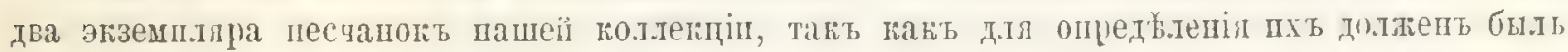

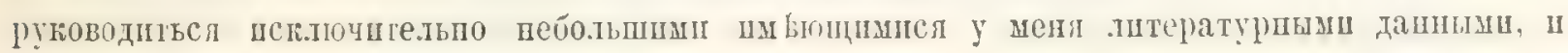
не имбъль никаюого сравнительнаго матеріала.

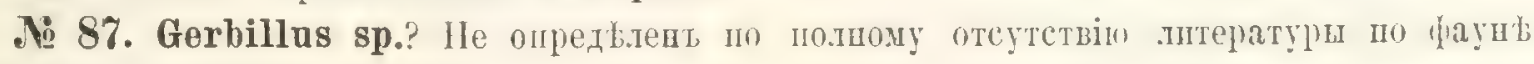
этой нъстиости.

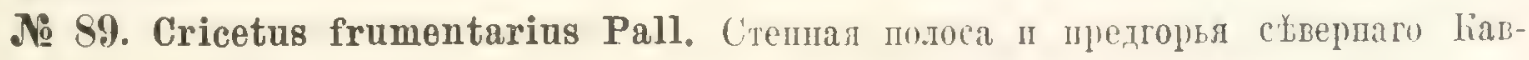
каза.

N2 90 -91. Cricetus (Mesocricetus) Brandti Nehring u Cr, Raddei Nelring.

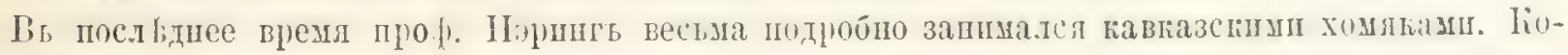

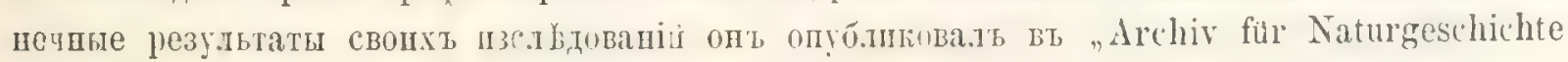
1898, тошь I, стр. $373-392$ (съ таблпеко).

Переходя къ предмету этой работы, л должень, основывалсь па неї, сказать о хомлґахъ ґавказскато музея сльдующее.

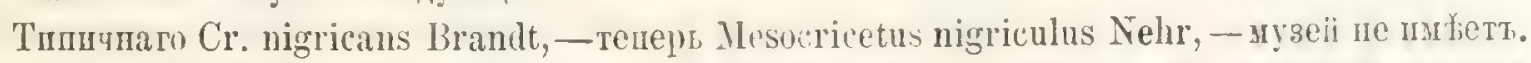

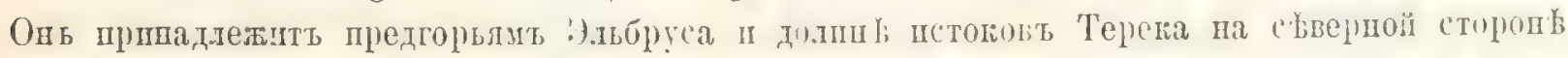

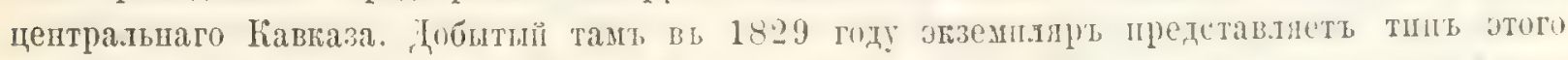

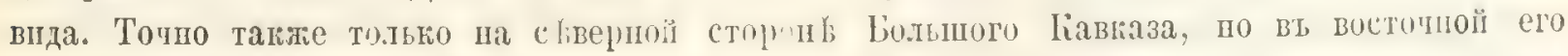

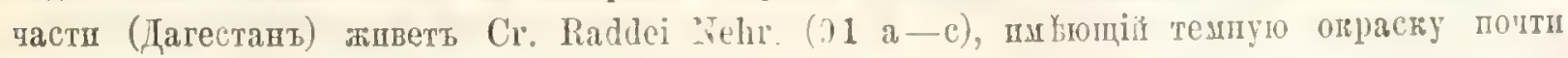

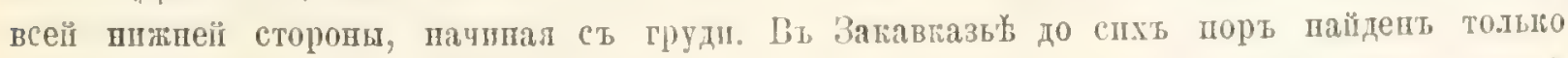

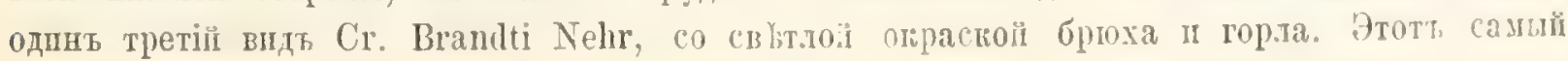




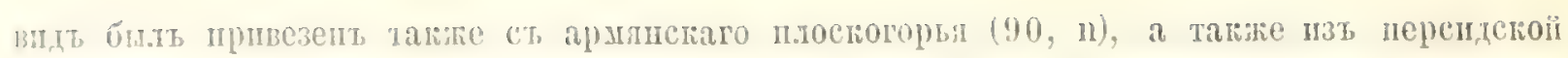

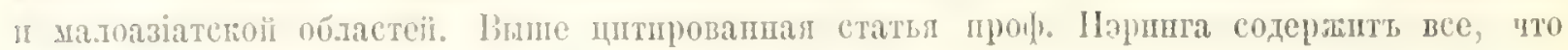

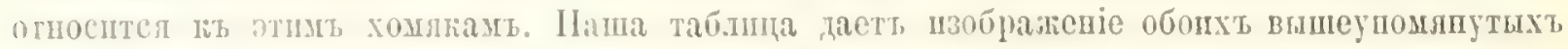
Bแдовт, ИЕ ихт череповт.

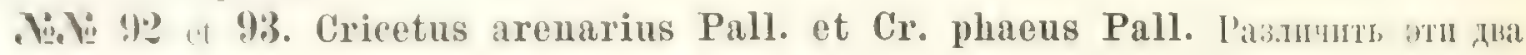

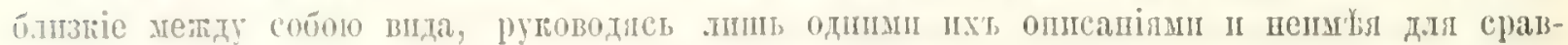

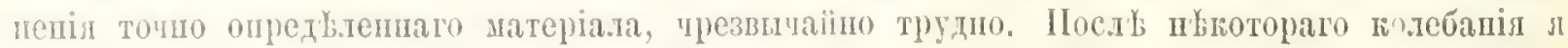

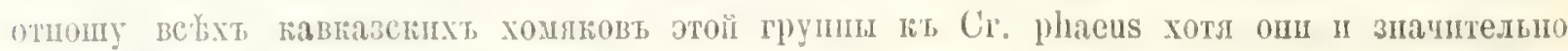

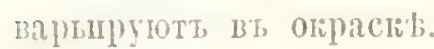

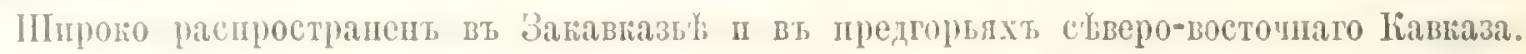
$0-1000^{\prime}$.

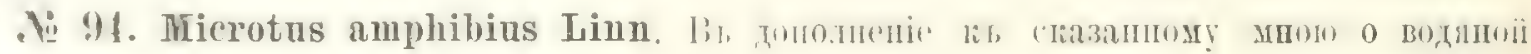

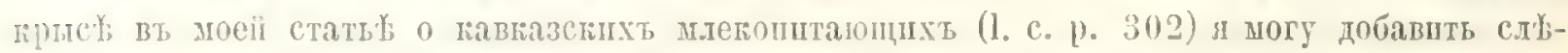

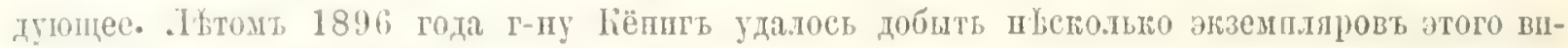

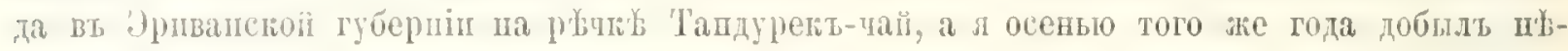

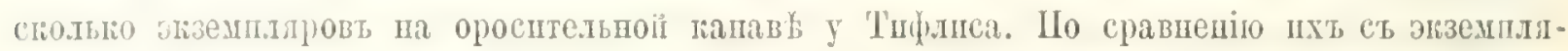

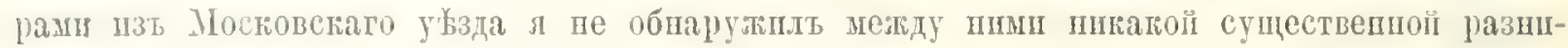
й, ши по наружному вшду, ши вь строеніи зубовь.

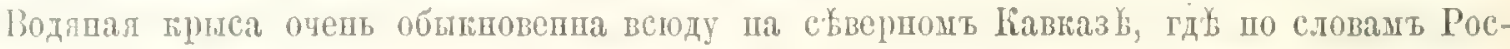

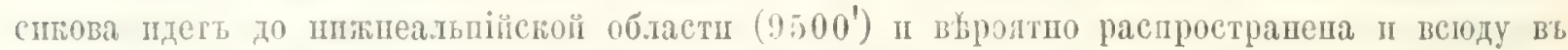

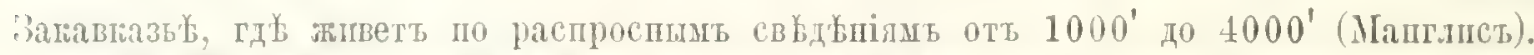

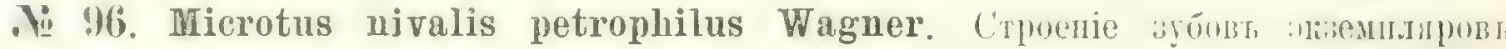
$\because Y$ ! ! зубовт, приведепной вь сочиеніп Блазіуса (1. с. р. 360). Даже эюземплрь .: 96 взрослал

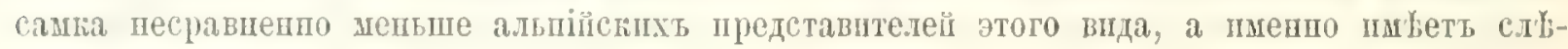

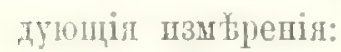

Оть цонцика носа до оспованія хвоста (спну). . . . . . . $107^{\mathrm{mm}}$

Хвостћ сь ғонцевыми волосамт. . . . . . . . . . . 56,5m.

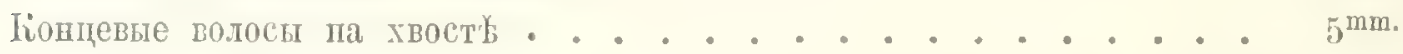

Длпга задпей ступп съ погтлм . . . . . . . . . . 19,5

Остальпые экземпляры молодые, но уже сь пастольго развптыми зубами, что возмояно топпое опредынтепіс.

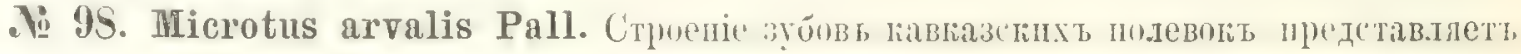
стольио ґолебапій, что оппсаніе ихт составит предметь особой статьи. Это относптся и

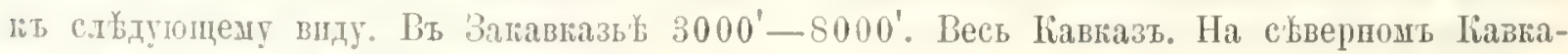

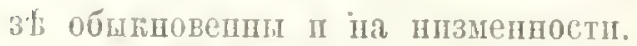

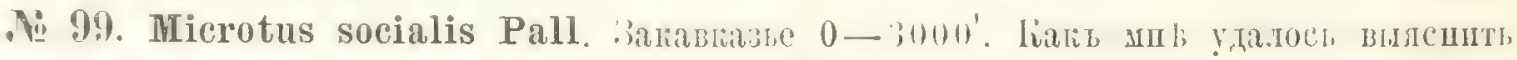

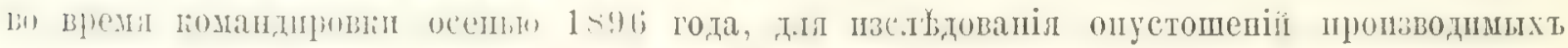

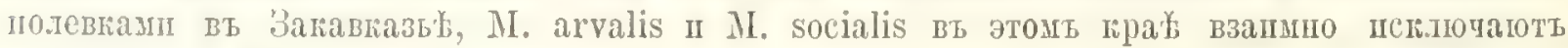

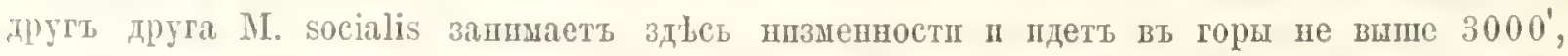

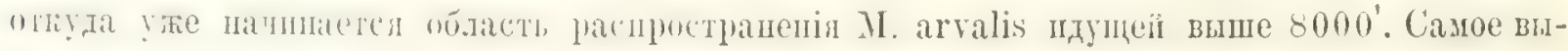

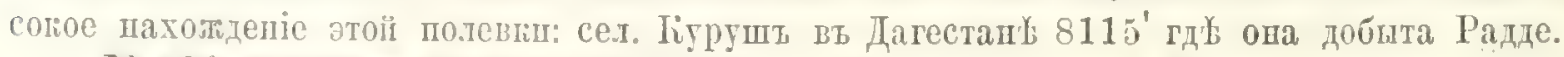

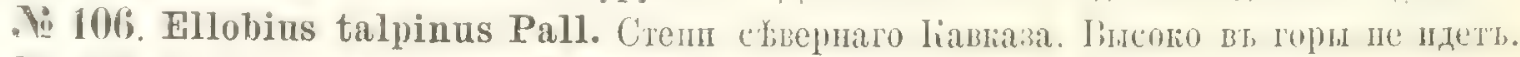

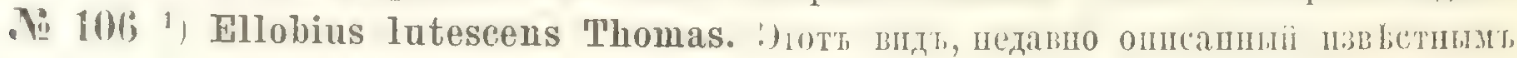

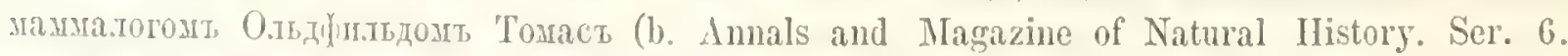

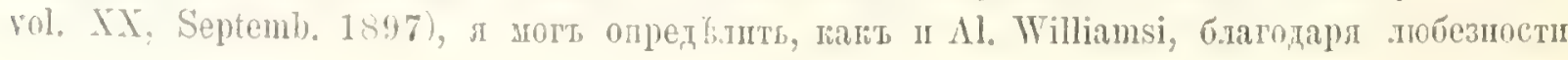


Taf.VI.

Cricetus Brandti a a.
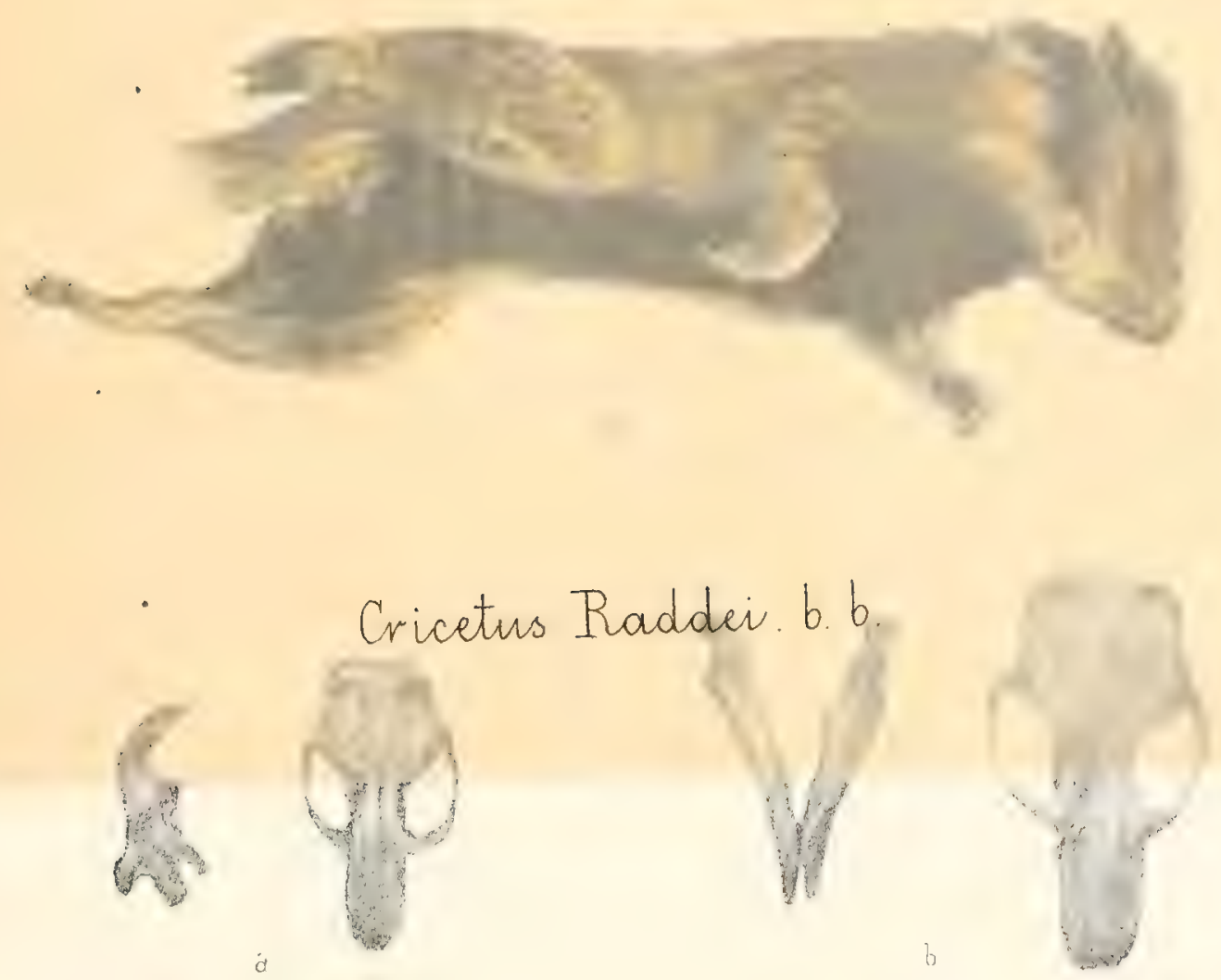
IV. $70 \mathrm{~T}$

. w w itbsurer zutorir's

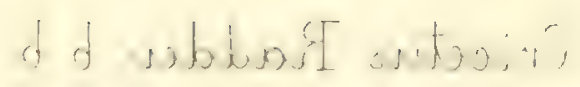




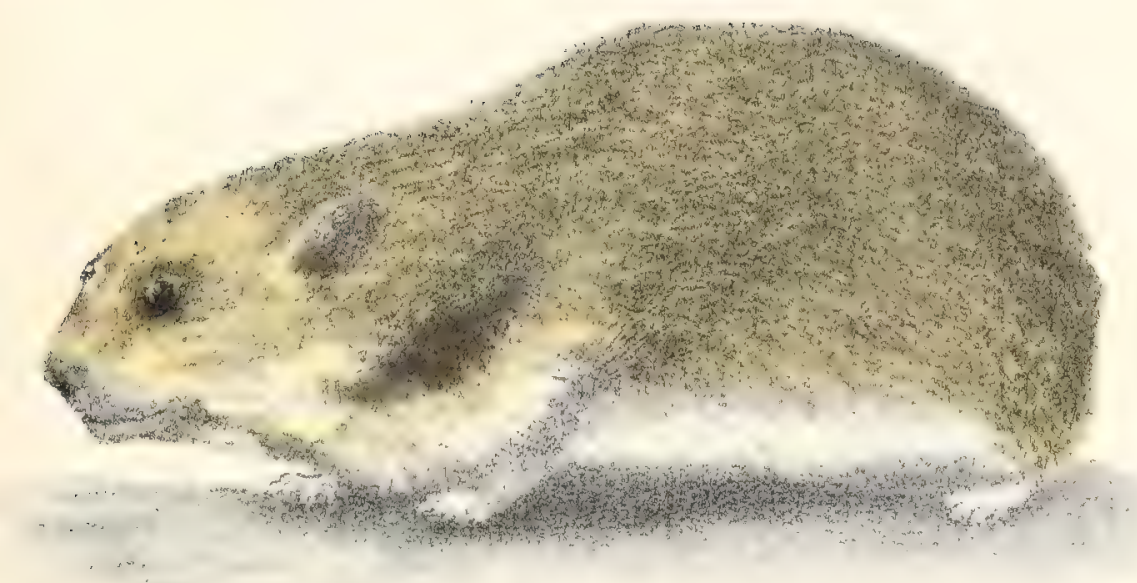

a
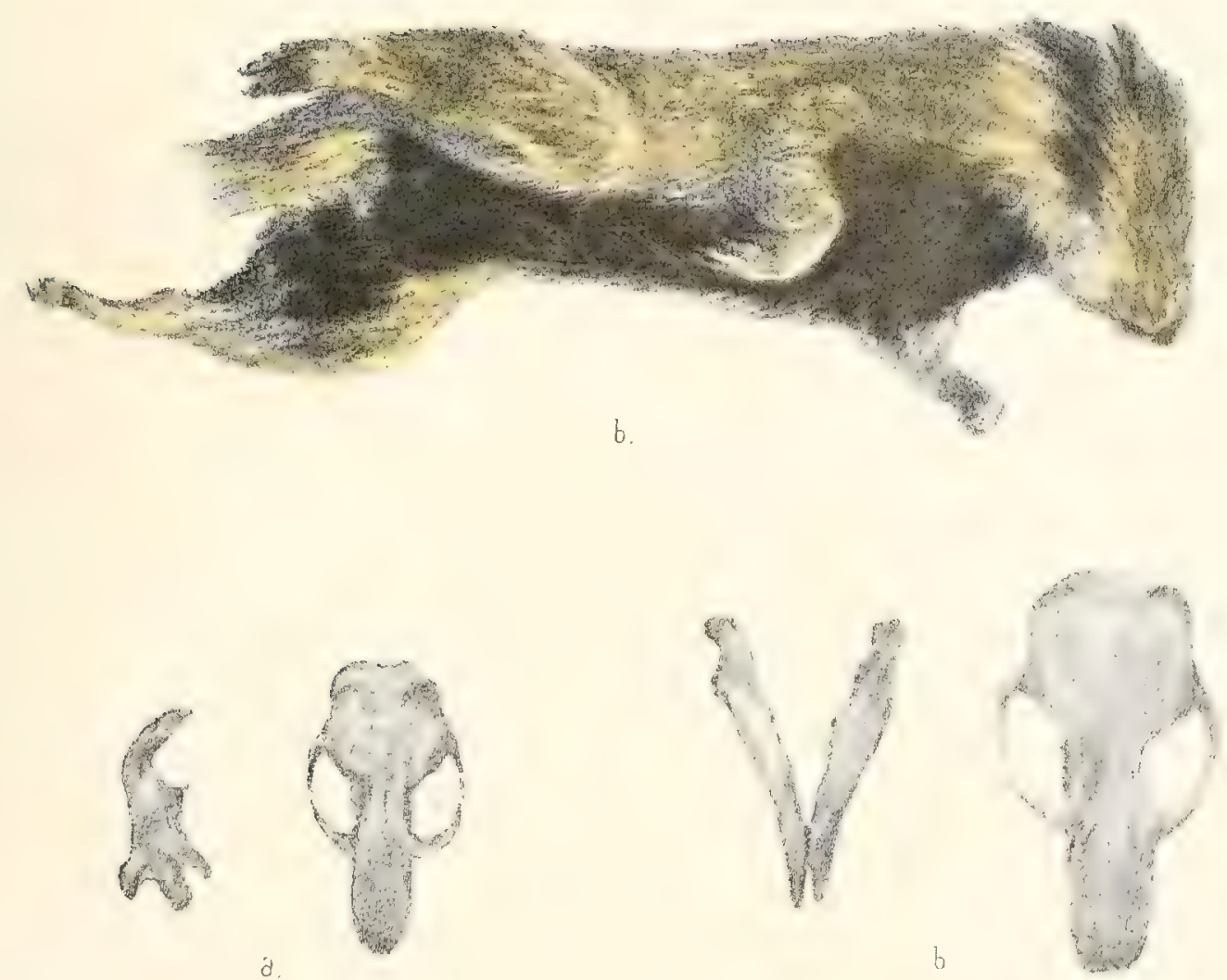



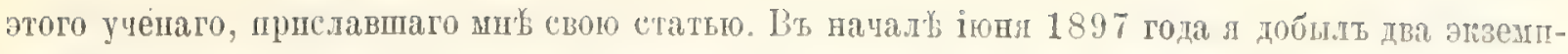
лира этого иштереснаго грызуна благодаря усердгой помопи оипцера погранпчпої стра-

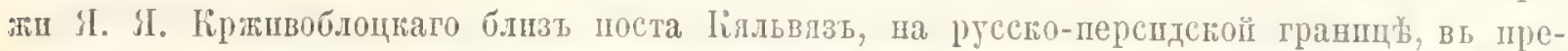

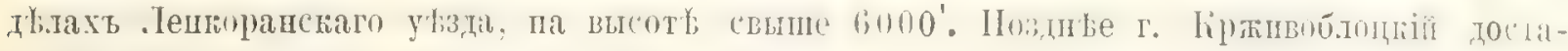

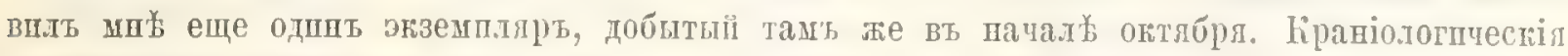

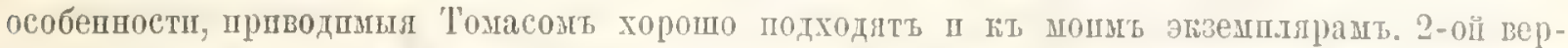

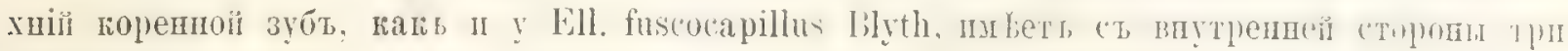
явственныхъ зубца, а не 2, какъ у Ell. talpinus Pall.; также п посовая часть терепа у этого вида значительно длинне, чьщь у посльдняг. Что касаетсл персти, то огтябрскій

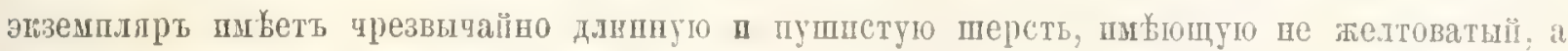
б ұловато-пепельный палент.

Cat.

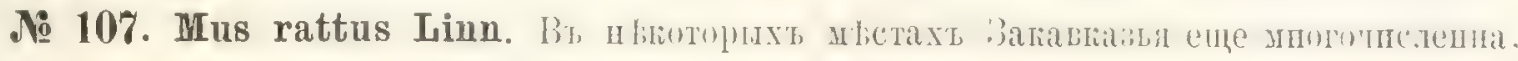

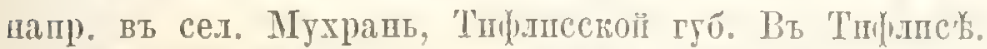

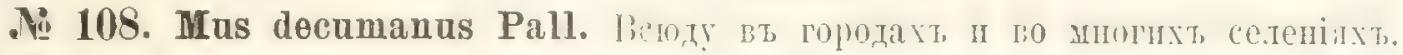

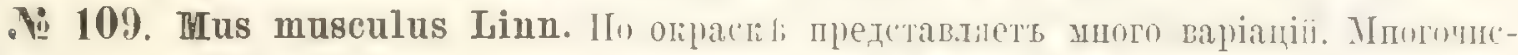

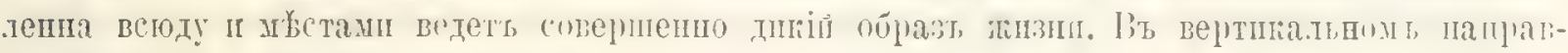

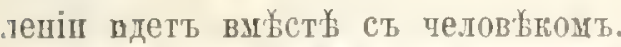

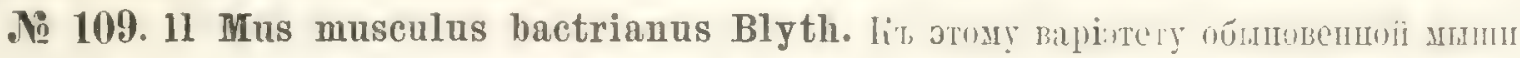

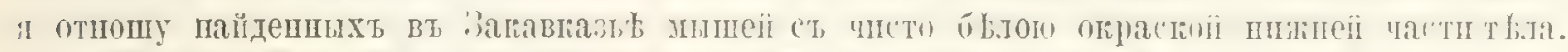

ํ. 110. Mus Wagneri Eversmann=M. bactrianus R. W. 1. c. 1. 11.

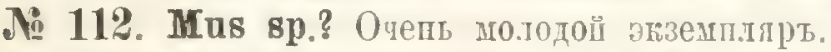

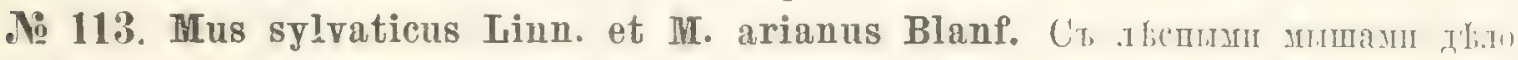

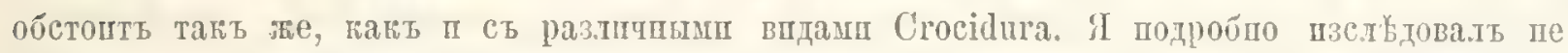

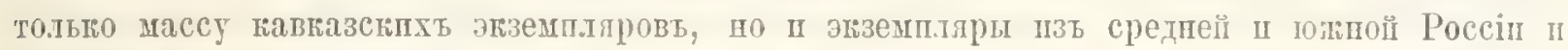

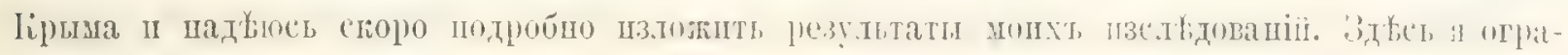
пичусь схтдующим замтчапілм:

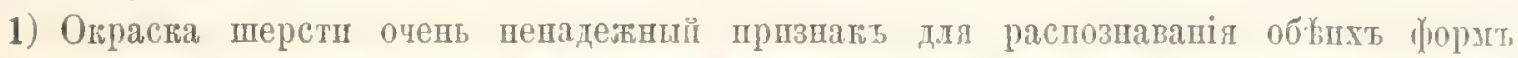

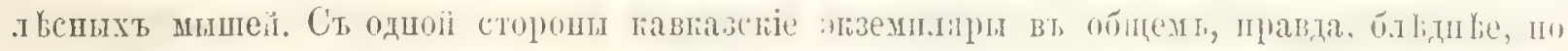

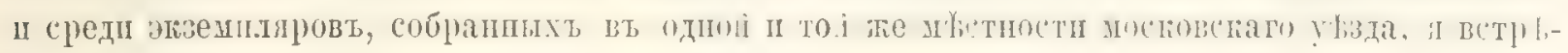
чаль пі ярко и бльдно ограпепные әгземлярш.

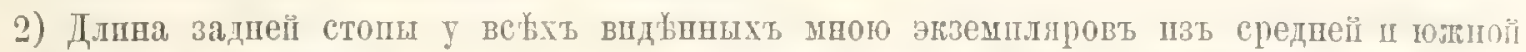

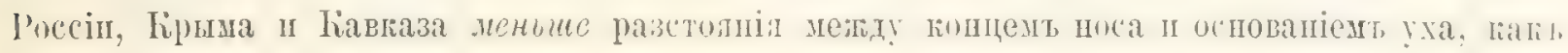
y Mus arianus.

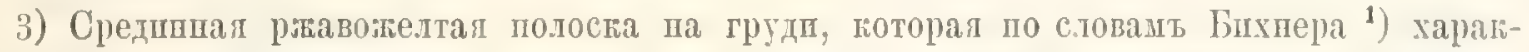
терна для M. sylvaticus и отеутетвуеть у М. arianus, у ве'ххъ видънншхъ мною әкземпллровъ хорошо выралена.

№ 114. Mus agrarius Pall. Западпия часть сłвернаго Кавказа.

Ni 119. Spalax Ehrenbergi Nehr.

i․ $119^{1}$ I $119^{2}$. Spalax Nehringi Satunin Ir Sp. gigantens Nehring.

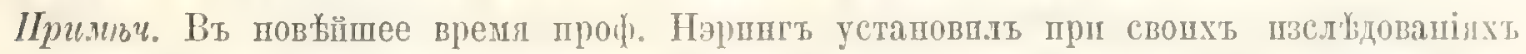

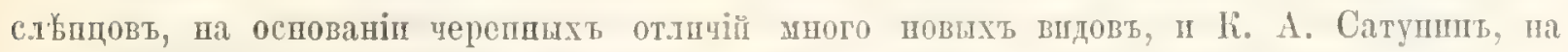
основаніи пзученія вашего матеріала, описаль одного Spalax и пазваль сго вт честь этого ученаго. II не могь уже два пашихт вшда, этоть и $\mathrm{Sp}$. giganteus Nehr. поставить подт.

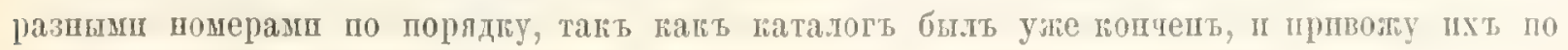
этощу подъ 으 119 ${ }^{1}$ ) п $119^{2}$ ).

1) E. Buchner. Wissenschaftl. Result. Przewalskys Reise. Mammalia, p. 90. 


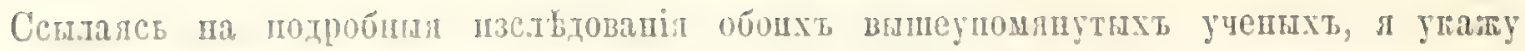

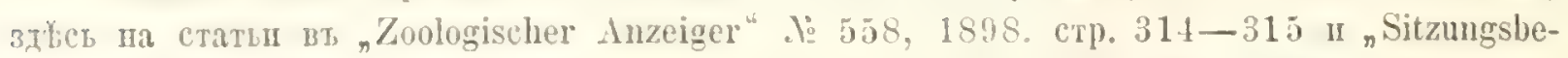
richte der Gesellschaft naturforschender Freunde zu Berlin" 1897, do 10 프 do 1, 1898 годъ.

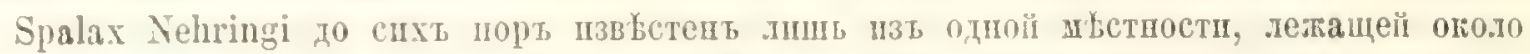

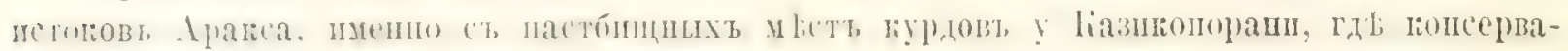

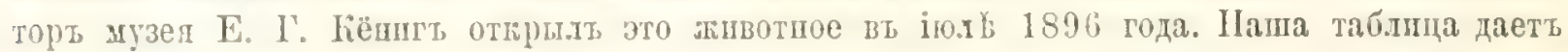
пзображеніе этого поваго вида п черена пести других видовь слыновт.

P.

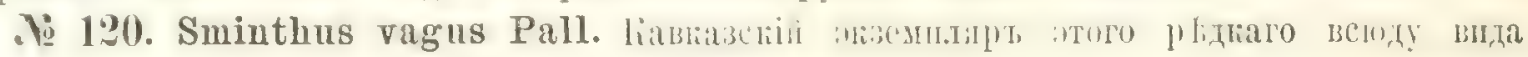

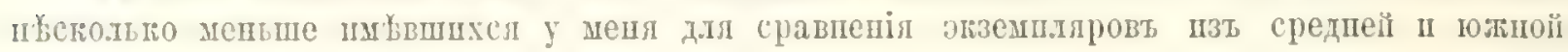
Poccir.

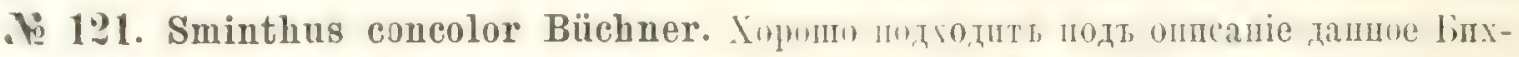

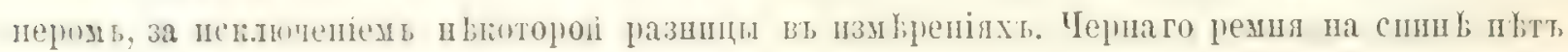

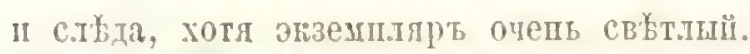

.12 12:. Alactaga alactaga 0liv.=A. saliens Satunin 1. c. p. :307. ()йлипвенеп вь степях сжвернаго Кіаваза.

Vi 123. Alactaga Williamsi Thomas. (Am. und Mag Nat. Hist. Ser. (i. Vol. XX.

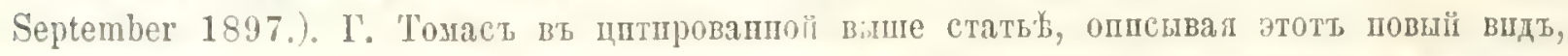

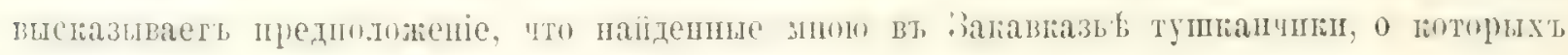

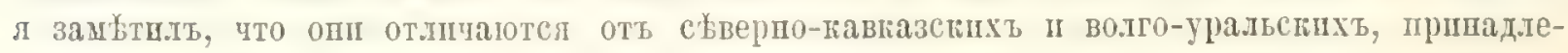
жать иь этому повому впду. Получпвь, благодарл пюбезности Г. Томаса әту статью, л

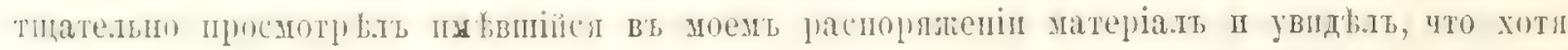

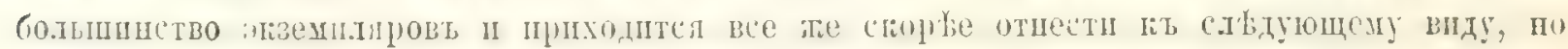

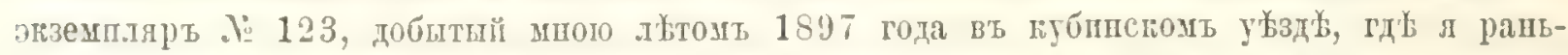

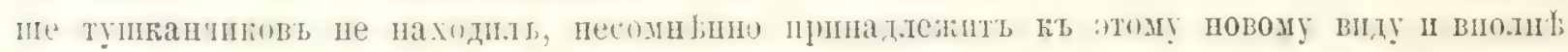

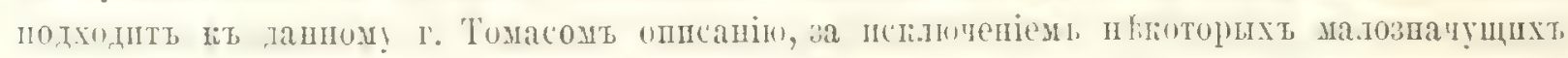

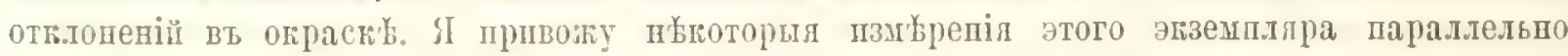

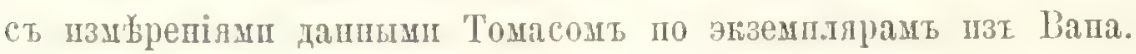

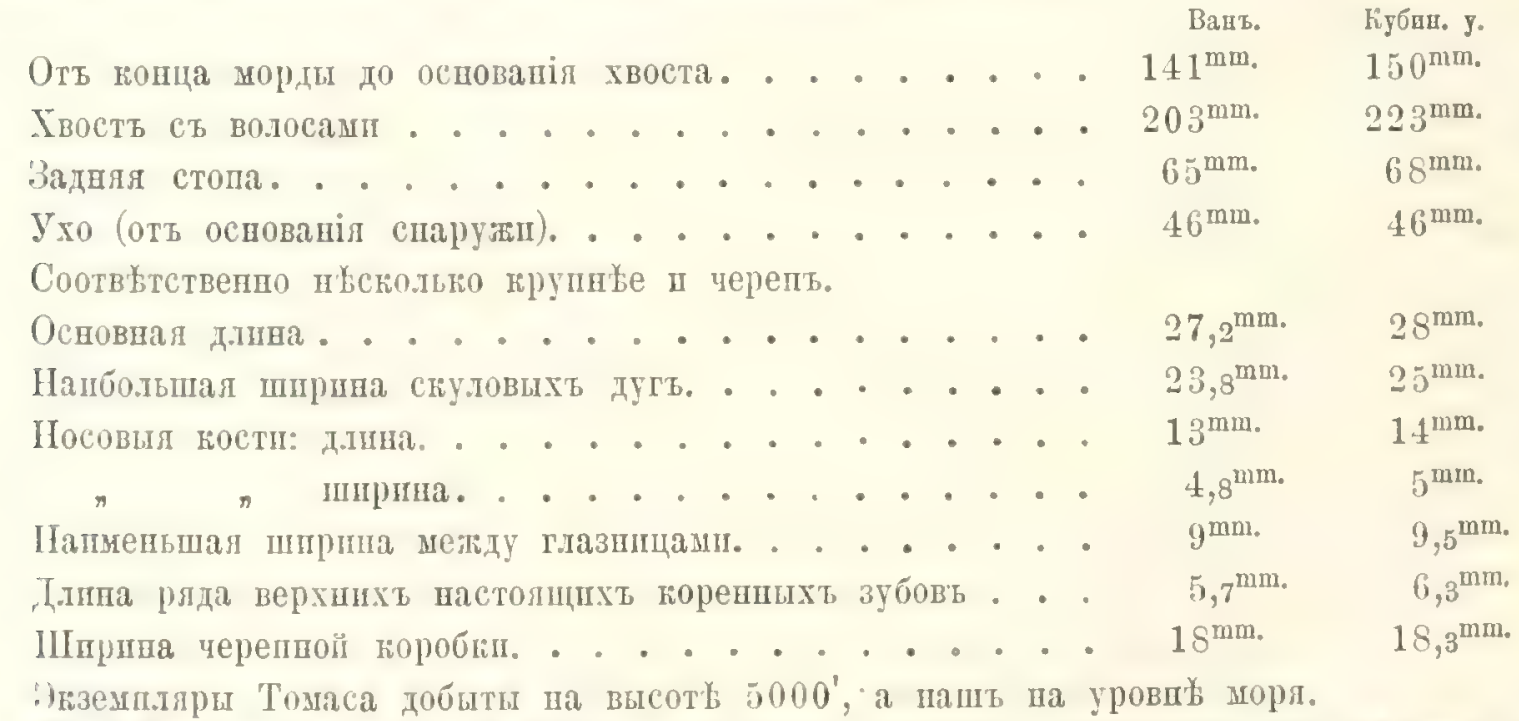

1?4. Alactaga elater Licht.=Alactaga acontion auctoram nec Pallas. Iir

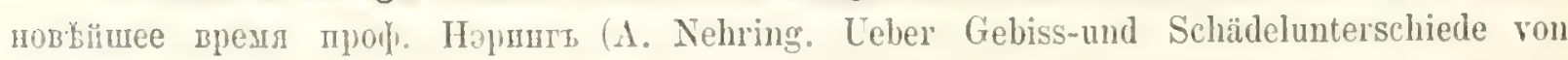
Alactaga elater Licht. und A. acontion Pall. in: Sitz. Lericht Gesellsch. Naturf. Berl. 16

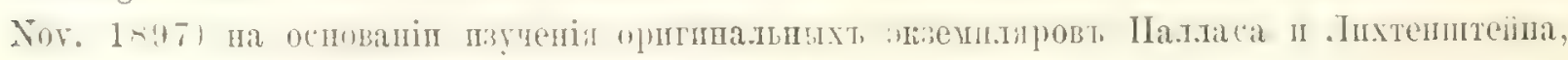

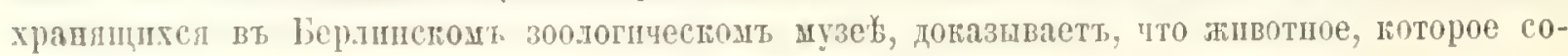




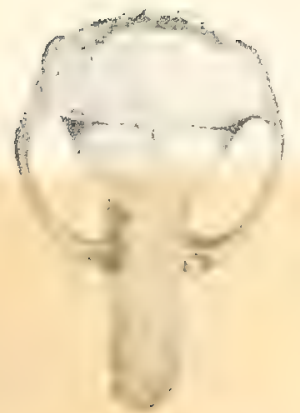

Sp. hurgisorum

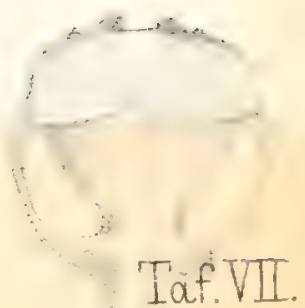

Sp Ehrenbergi

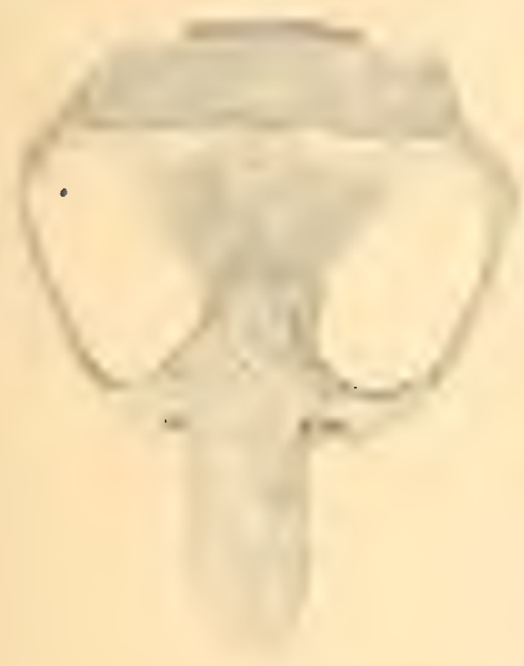

Sp.grganteus.

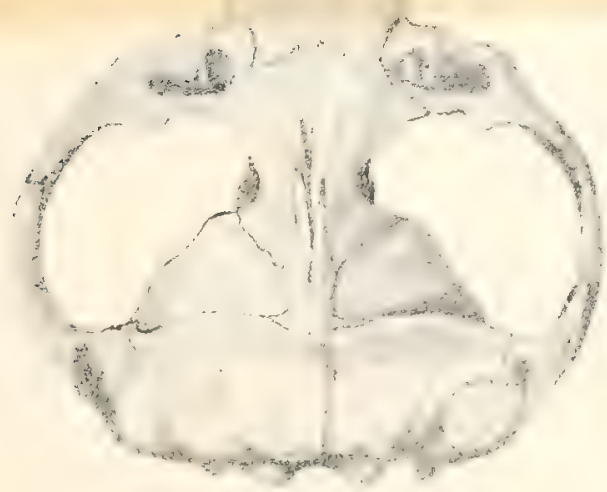

Sp.giganteus Nehr.

\section{Spalax Nehringi}

Sp. microphthalmus

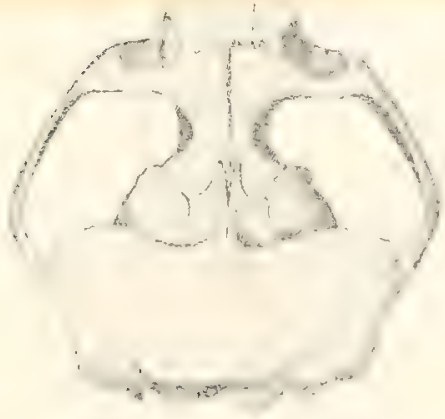

Sp.microphthatenus Giild.
Sptyphtus

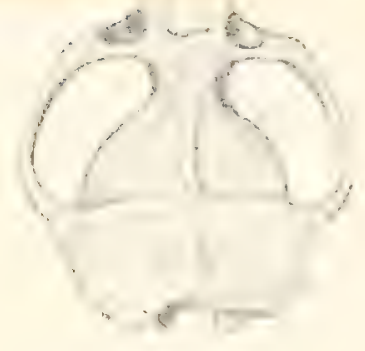

Sptuphius Pall. 
grogemente mis

jasnindo W xalosie

outhrypu vi

anmbandingaraion si?

zustmapip.y? 


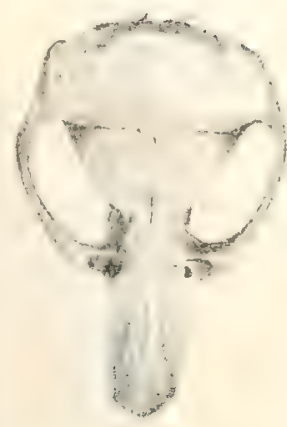

Sp kirgisorum Nehr.

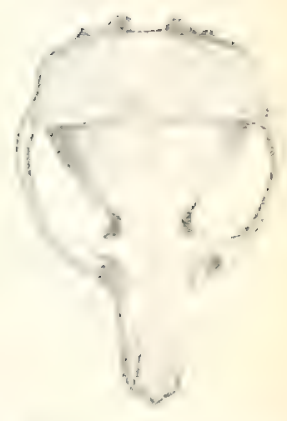

Sp Ehrenberge Wehr

Spatax Nehring! Süt
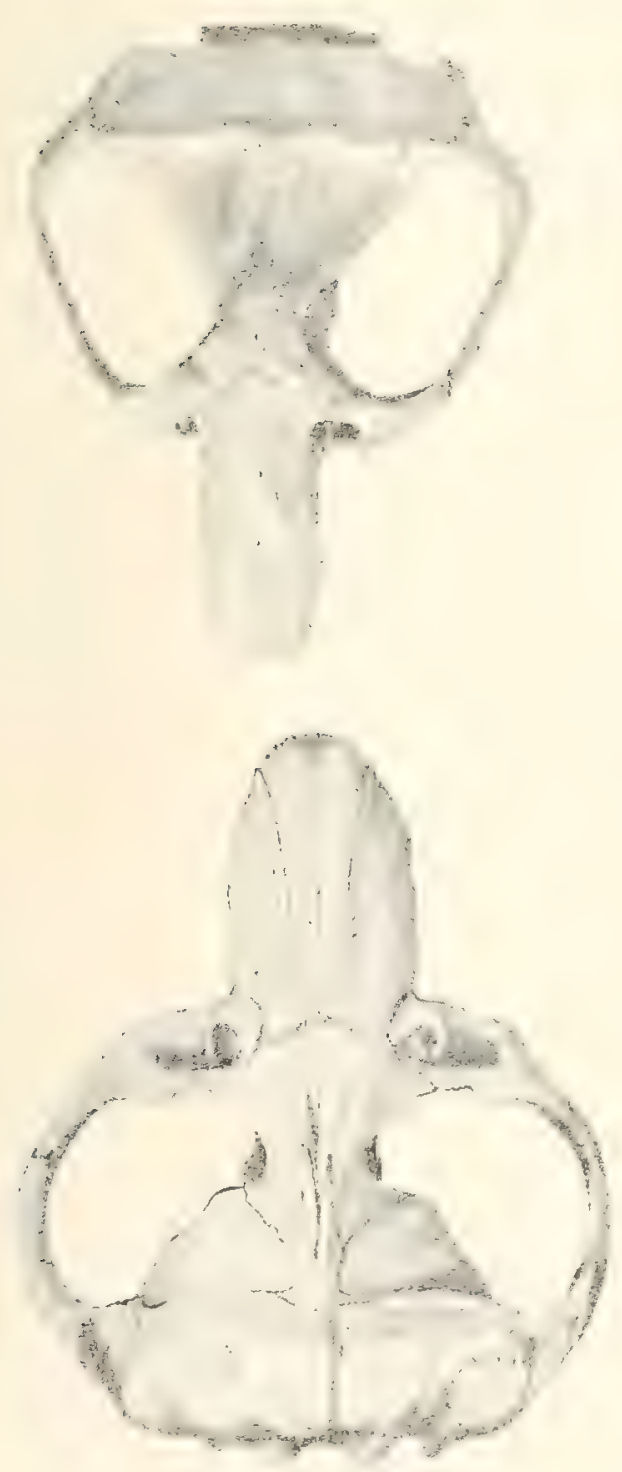

Sp.giganteus Nehr.
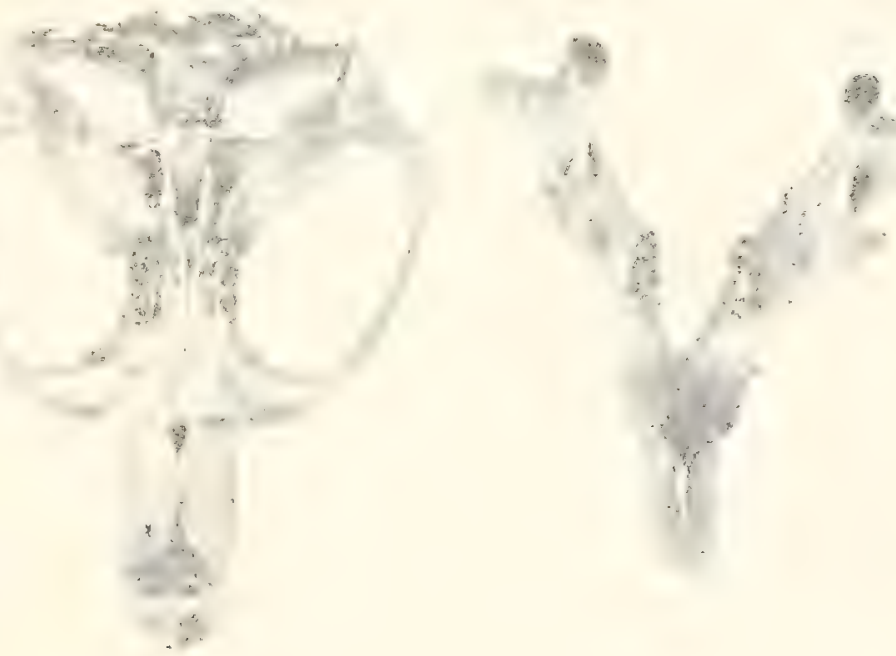

Sp Nehringi iot

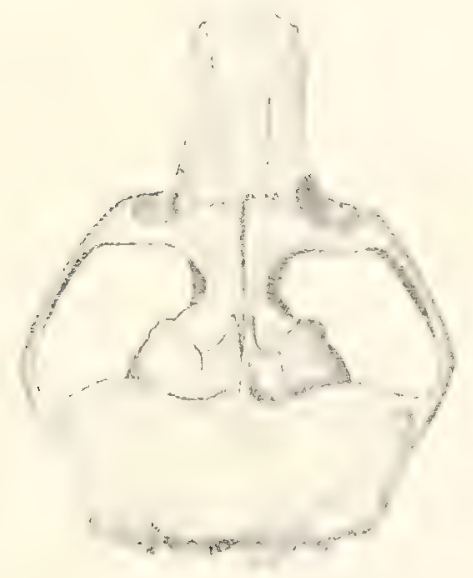

Sp.microphthatrue Giild

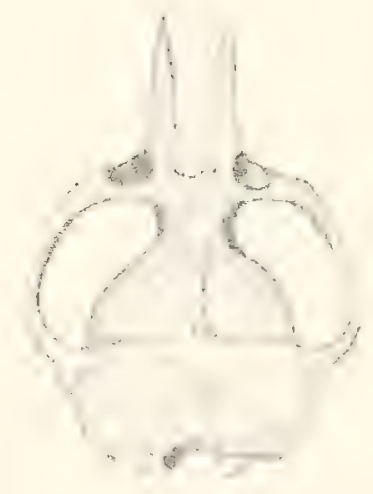

Sp.typhlus Pall 

времеппше автори называнды Alactaga acontion Pall. есть A. elater Licht, a A. acontion

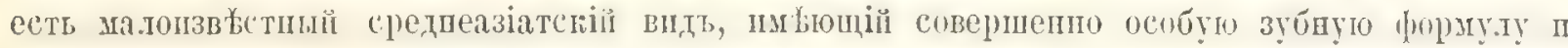
друге строепіе черепа, такь что его приходится даже выдылть въ особый родтtagulus.

Хотя это совершеншо не согласуетсл ст тою об.тастью распространен, которую при-

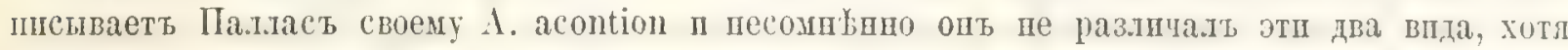

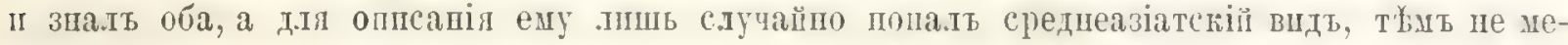
нъе приходитея призать, что описаппый Палдасом подт пменем Dipus jaculus var. pygmaea впдъ есть дыйствите.льо пе тоть Alactaga acontion, потораго пцпзнавали авторш со-

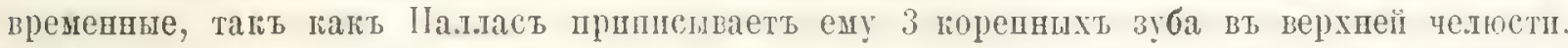

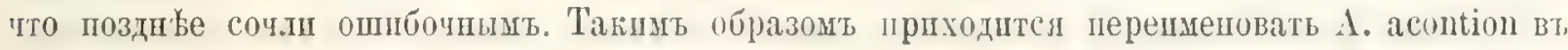
1. elater.

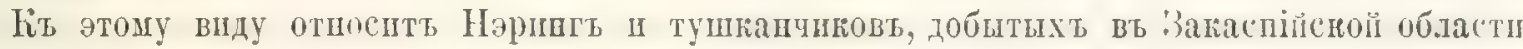
близь Красноводска, но я знаю оттуда лишь А. indica Gray.

Сат.

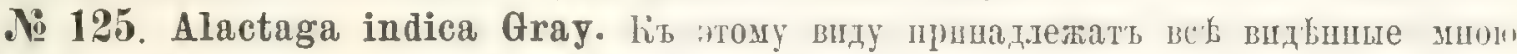

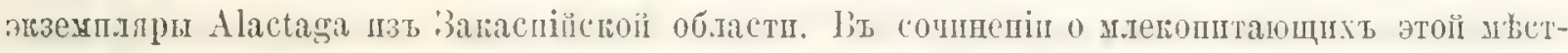

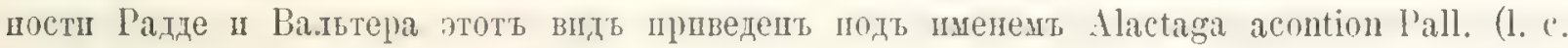
p. 57).

Vi 126. Hystrix leucura Sykes $=$ H. hirsutirostris Brandt. Lian на Liaвказ;

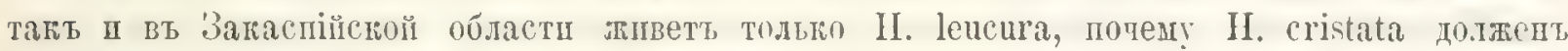

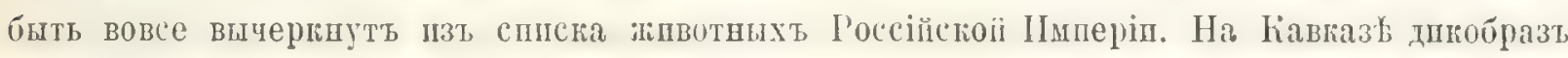

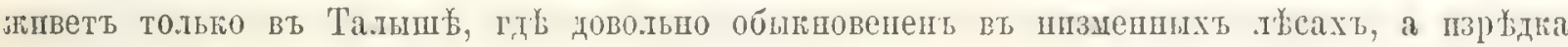
попадается п въ степи, напр. у сел. Іришибъ.

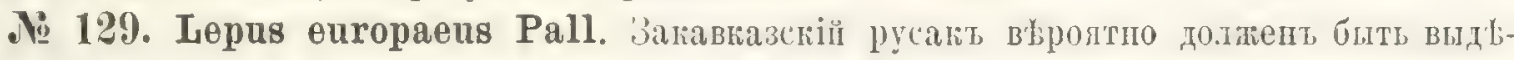

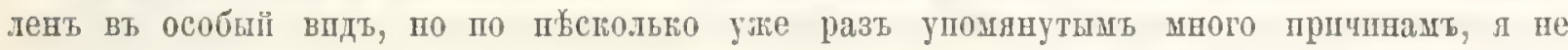
могу этого сджлать вь настоящее время.

No 131. Lepas tolai Pall. (=Lepus Lehmanni Paдze ni Bantepa 1. c. p. 62). Bit

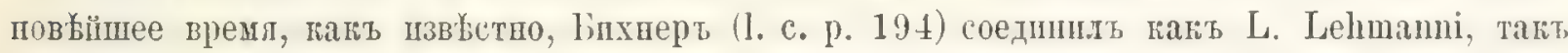
I нйкоторше другіе впды среднеазіатскшъ зайцевъ съ L, tolai Pall.

Сат.

\section{U N G U L A T A}

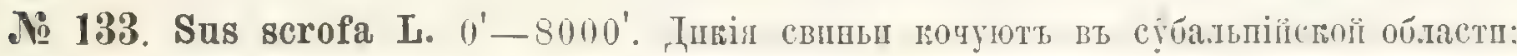

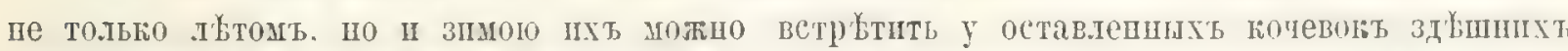

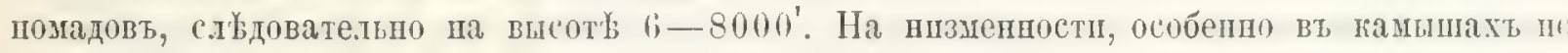

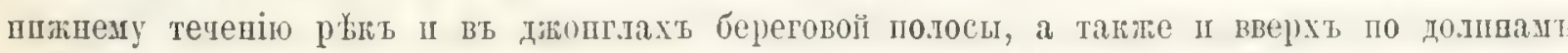

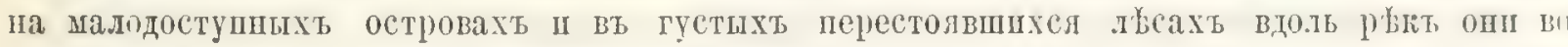

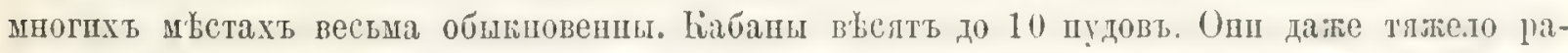

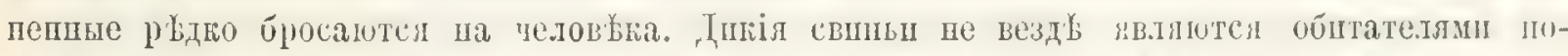

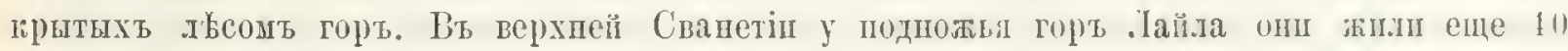

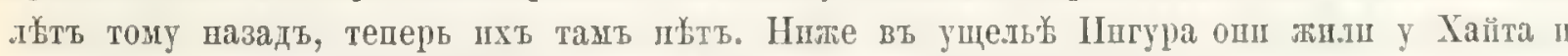

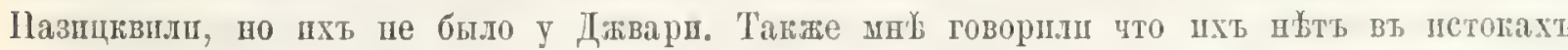

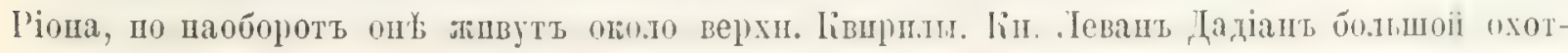

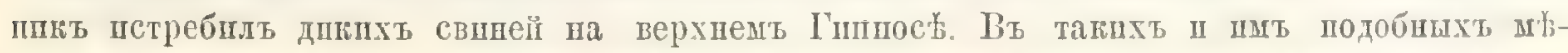

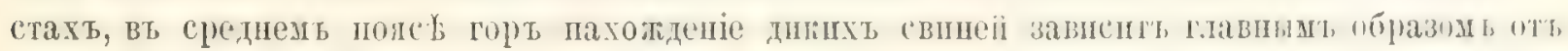

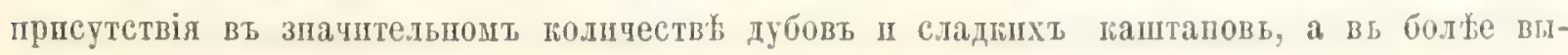




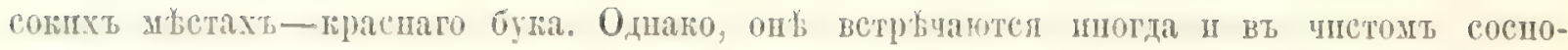

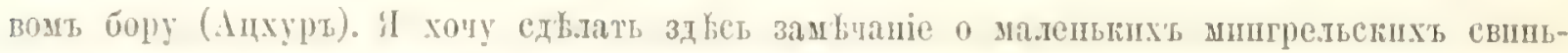

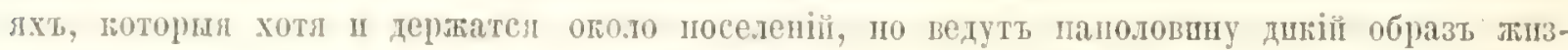

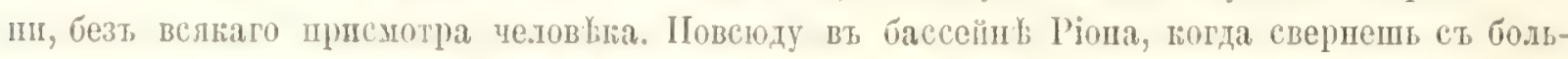

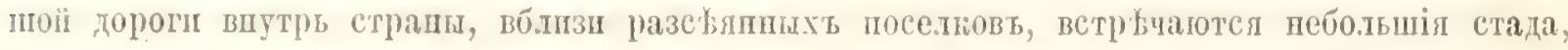

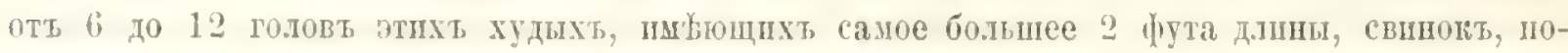

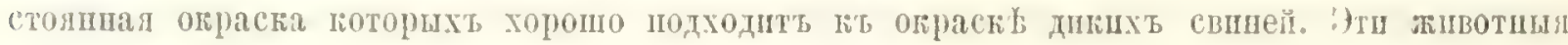

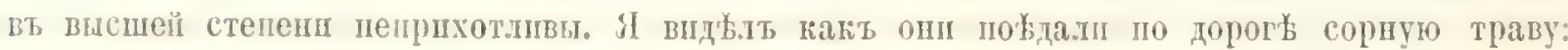

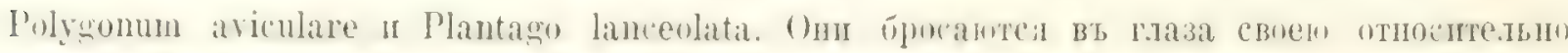

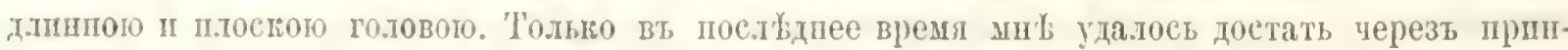

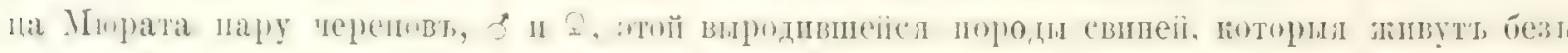
ухода, предоставленшя самп себж, пмы тольо па шеж треугольнит шзт палогъ, чтобы

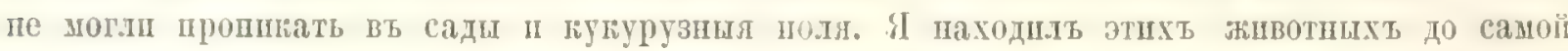

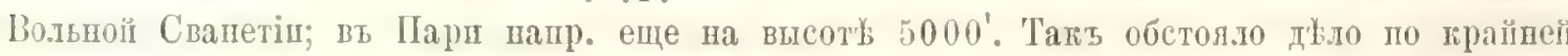

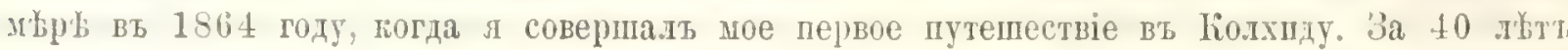

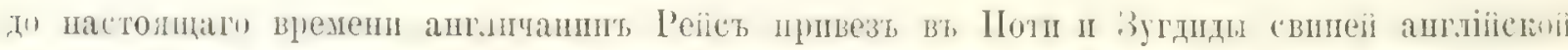
породы, а въ 1865 году г. Анановт ввсзъ въ Варзихе тоже таких же. Въ шастояцее вре-

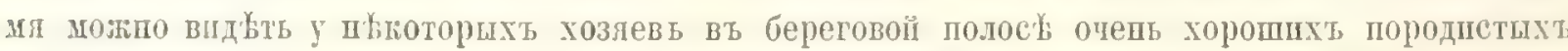
свиней, а ублюди въ неотдленныхъ местахъ, встрбчаютел почтп повсюду, Р.

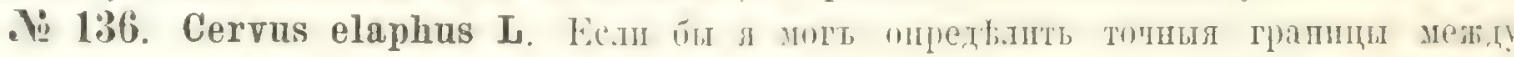

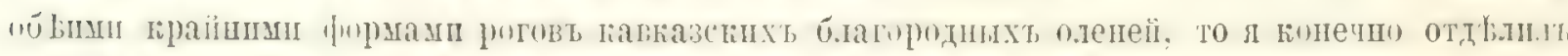

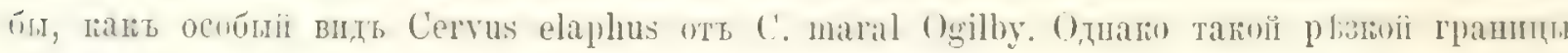

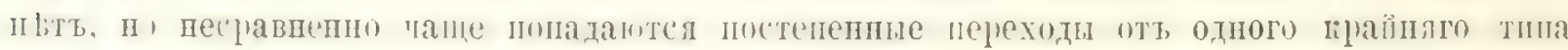

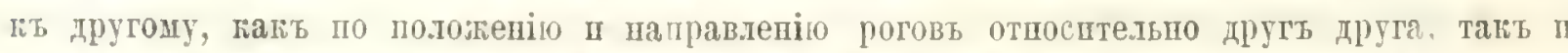

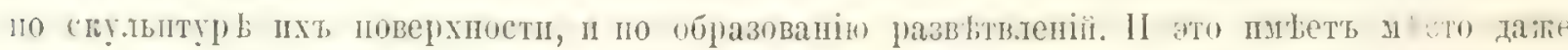

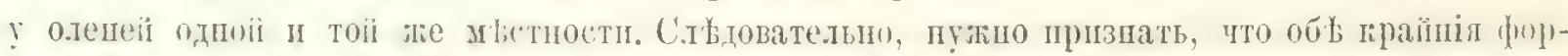

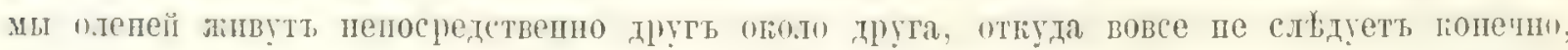

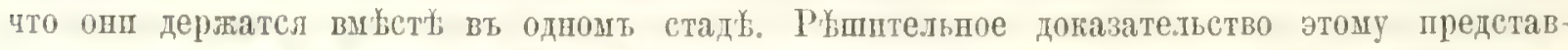

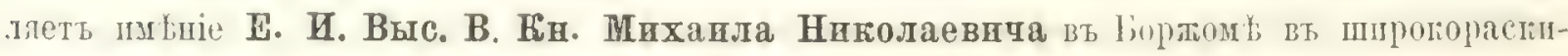
пувптея пепрерывных льсахъ ғотораго уғе сь 1867 года ведется правплнал охота па

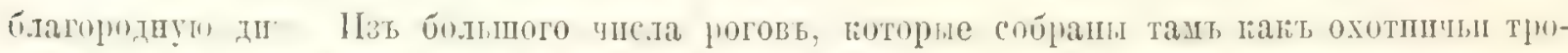

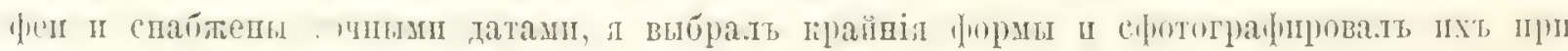
помоци г. Мольденгауера.

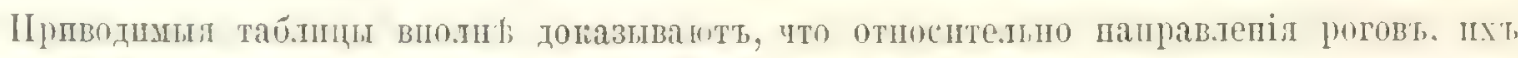

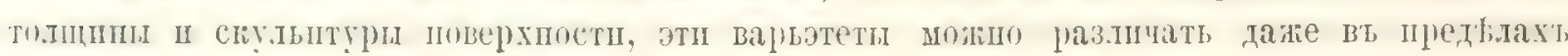
одпой п той же стоянки.

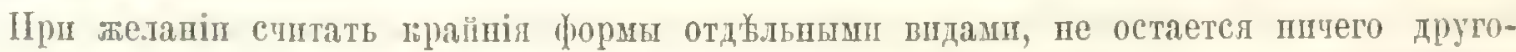

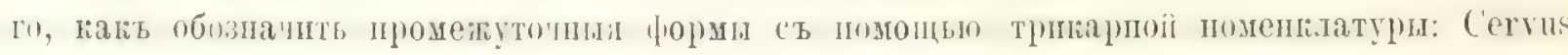

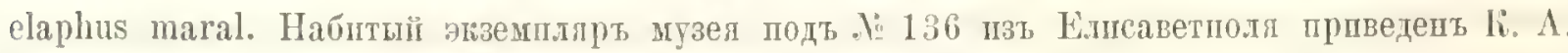

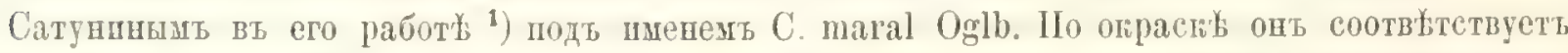

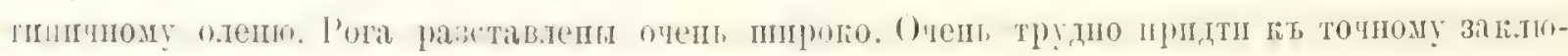

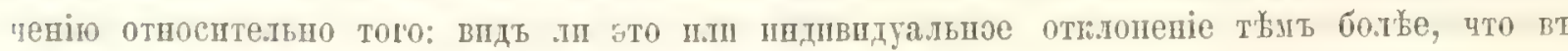

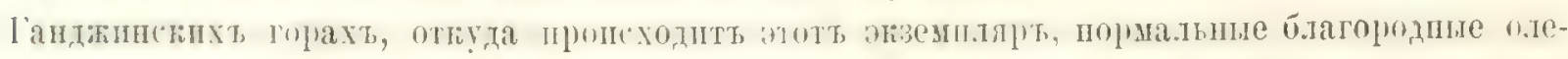

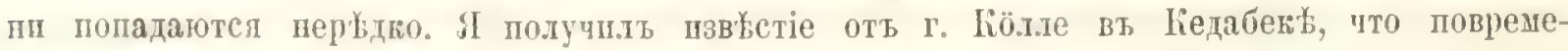

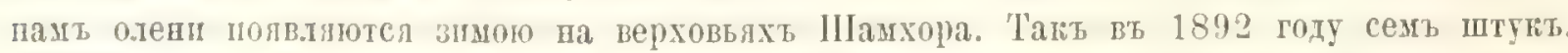

1) Vorlaufige Nittheilungen uber die Sảugethierfauna der haukasusländer, in Zool. Jabrb. Syst., IX cтр. 309. 


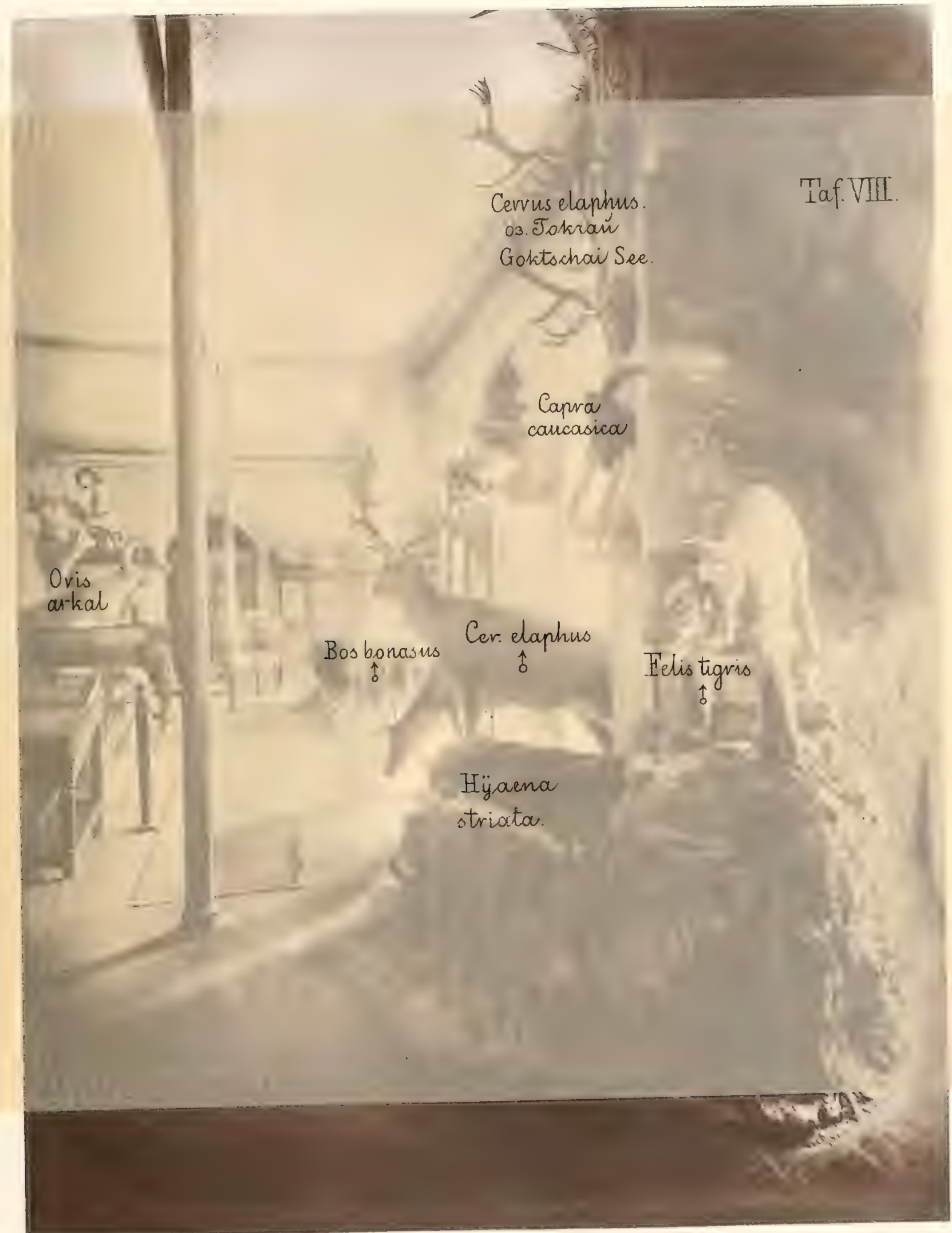


IIIV7.70T

$$
\text { cuntupale zasvor }
$$

$3 x-4,-3=$

202 intant i :

onpal
wiscostris

aivo

Jo iो:

$$
\text { vamajH }
$$




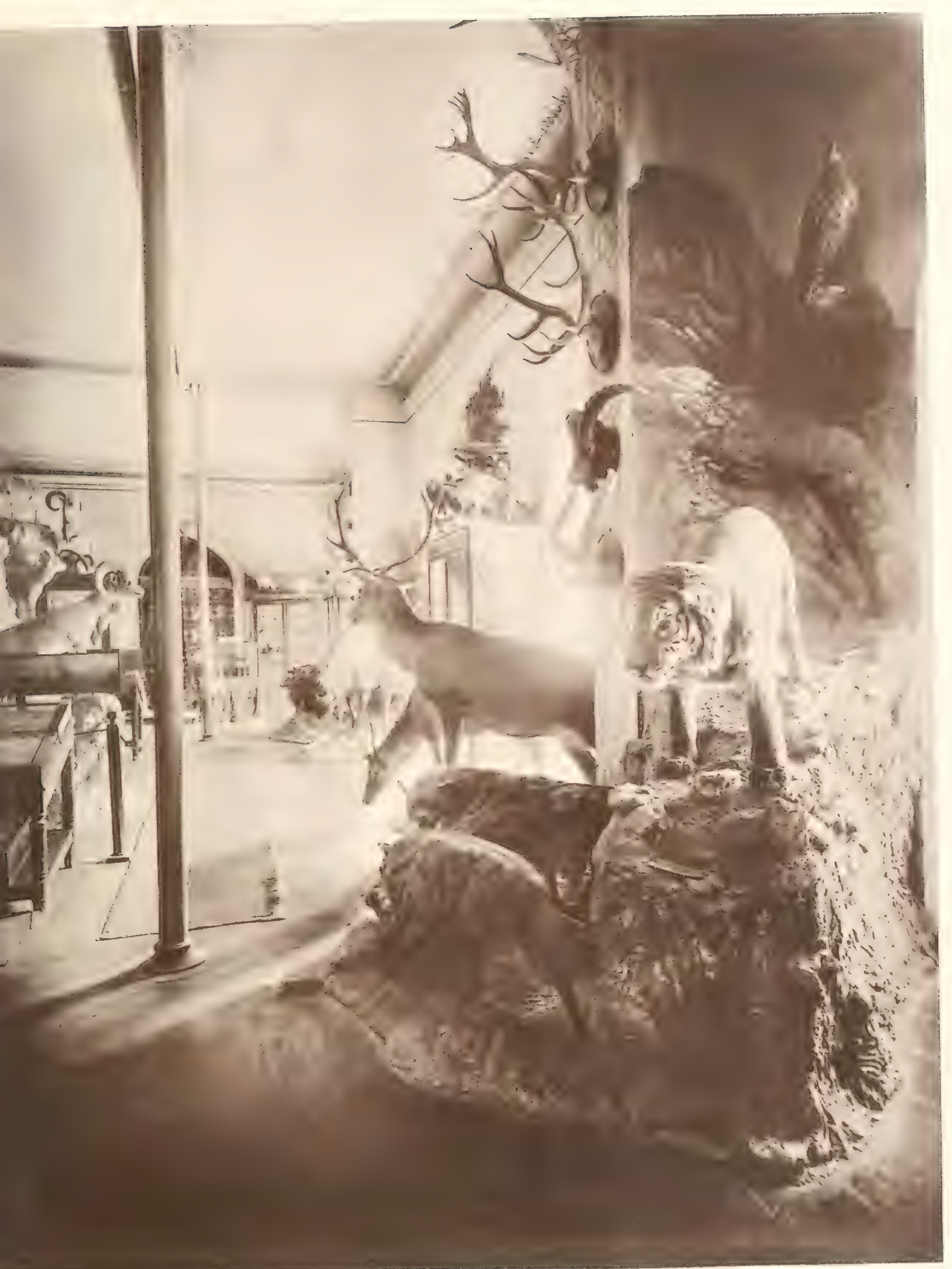





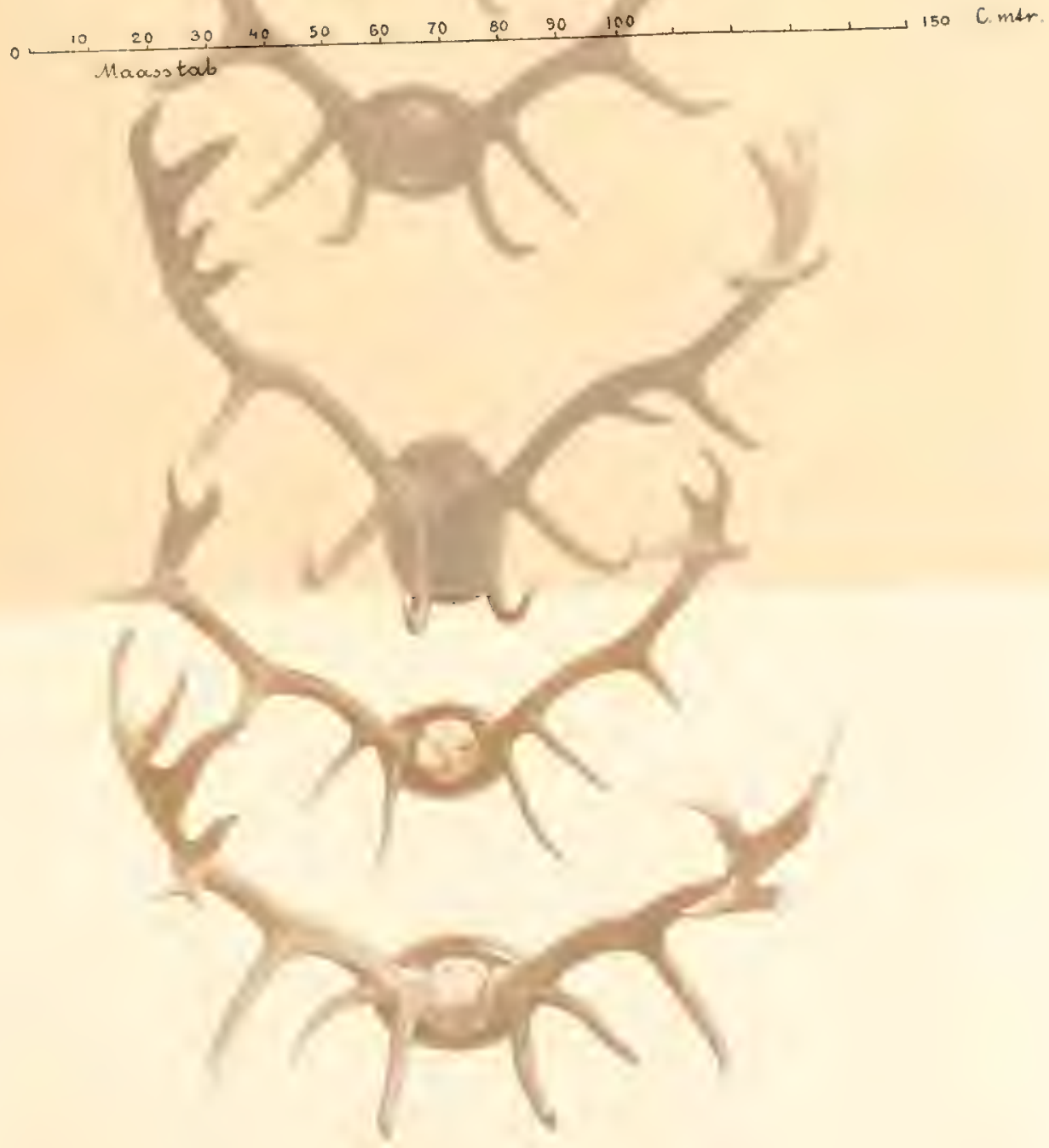


XI $\operatorname{~in~}$

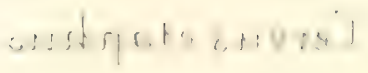

$$
\begin{aligned}
& \text { orr.averioct } \\
& \text { srrascuade }
\end{aligned}
$$

andm opl 


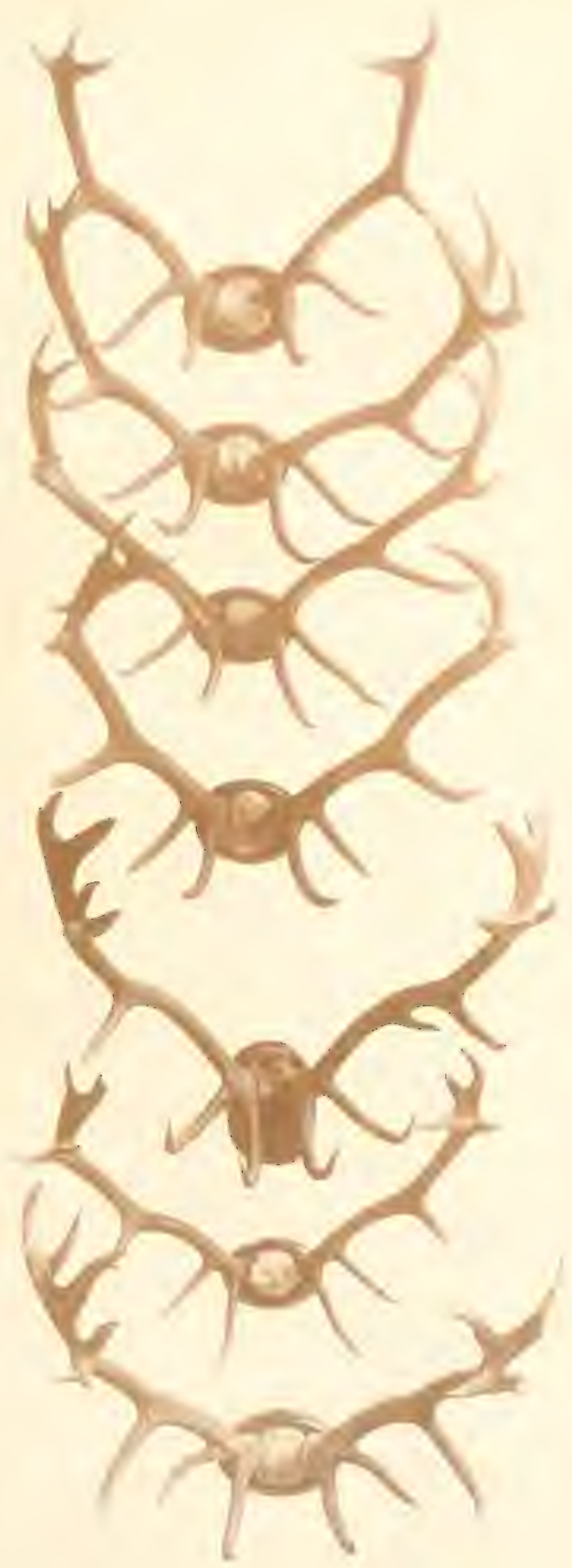





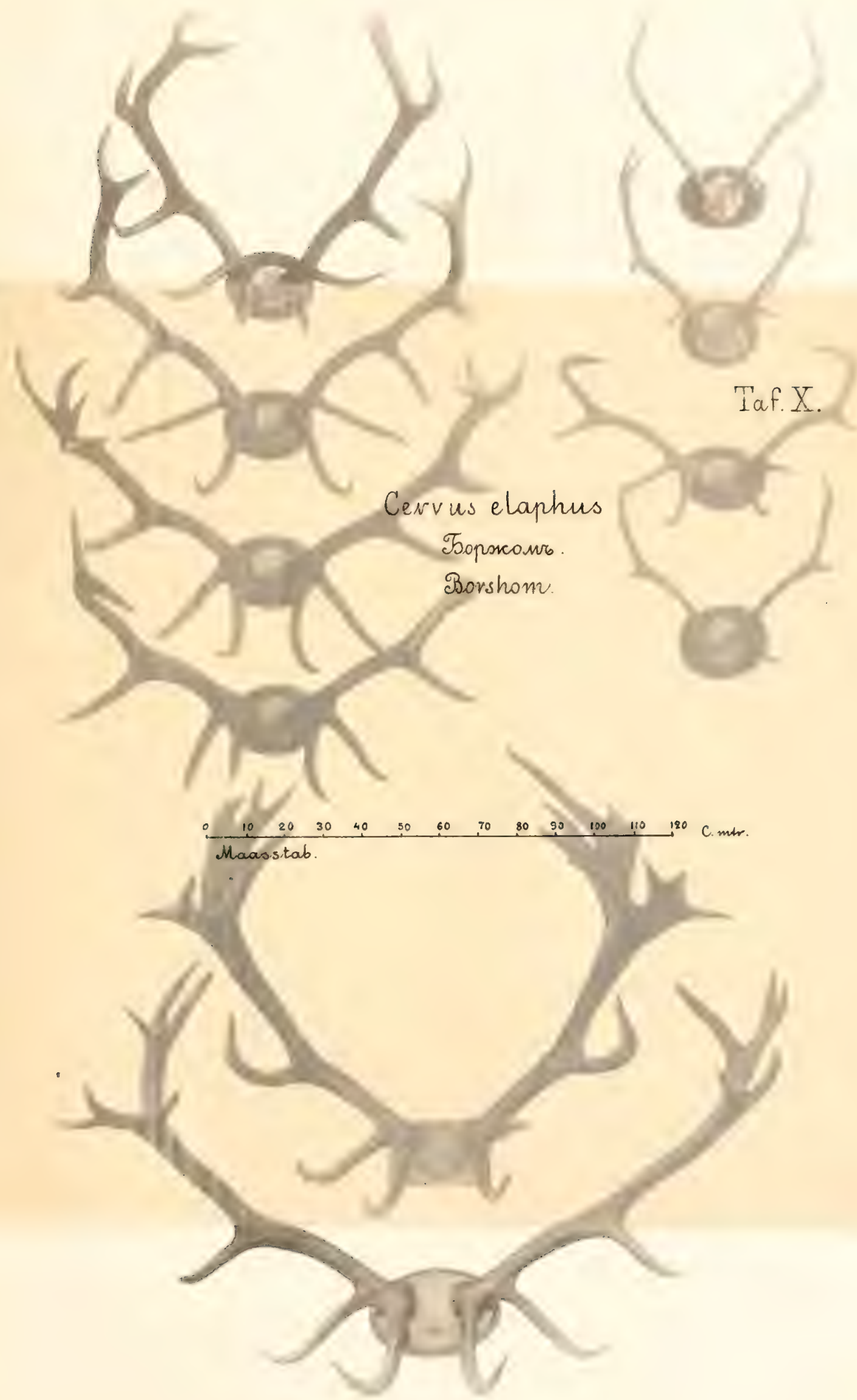


X.7.0 T

$$
\begin{aligned}
& \text { owstipalg envag } \\
& \text { anouract } \\
& \text { urranizrado }
\end{aligned}
$$

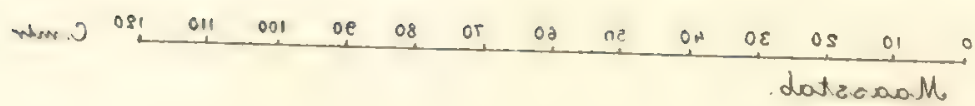




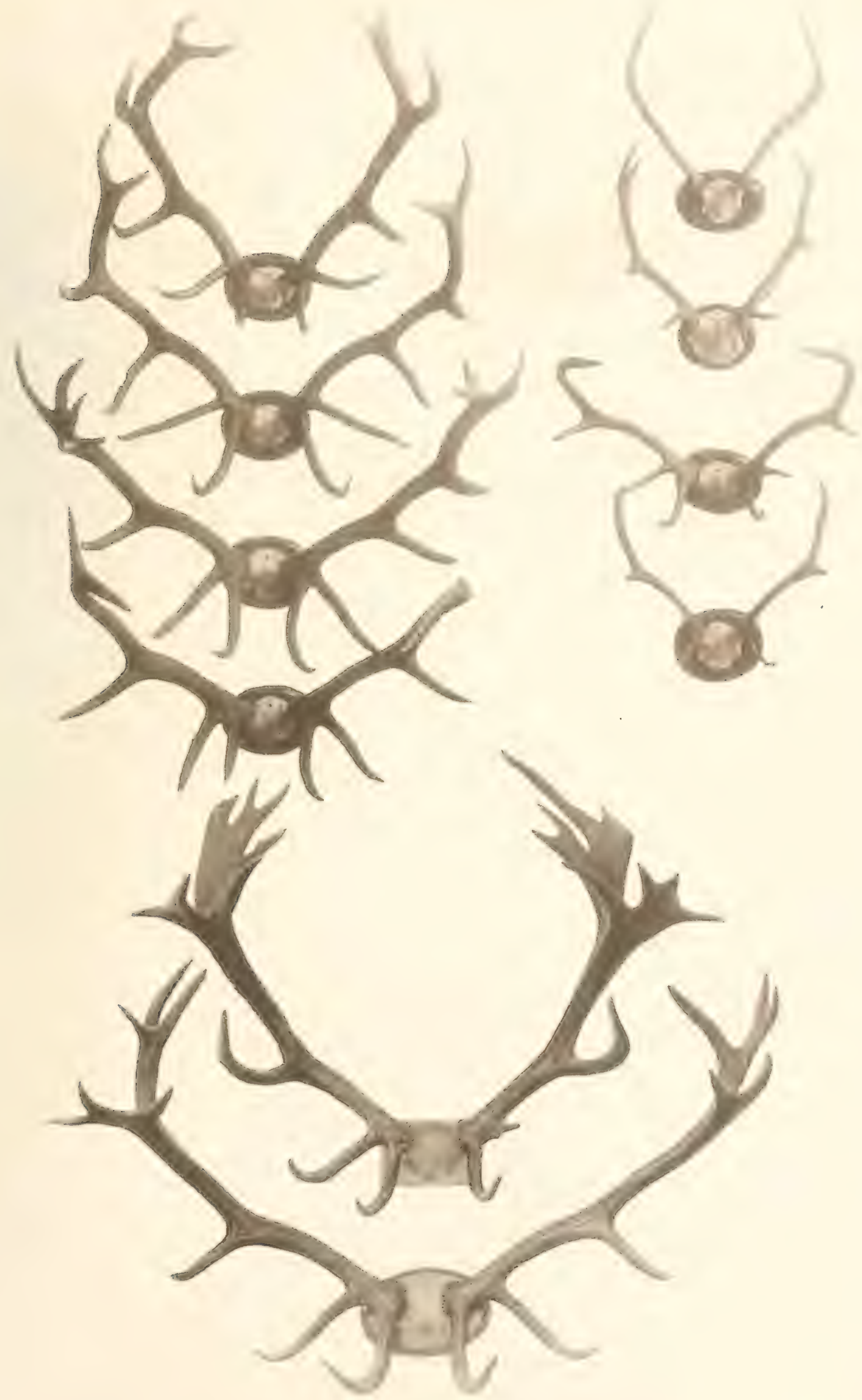





$$
\text { Taf.XI }
$$

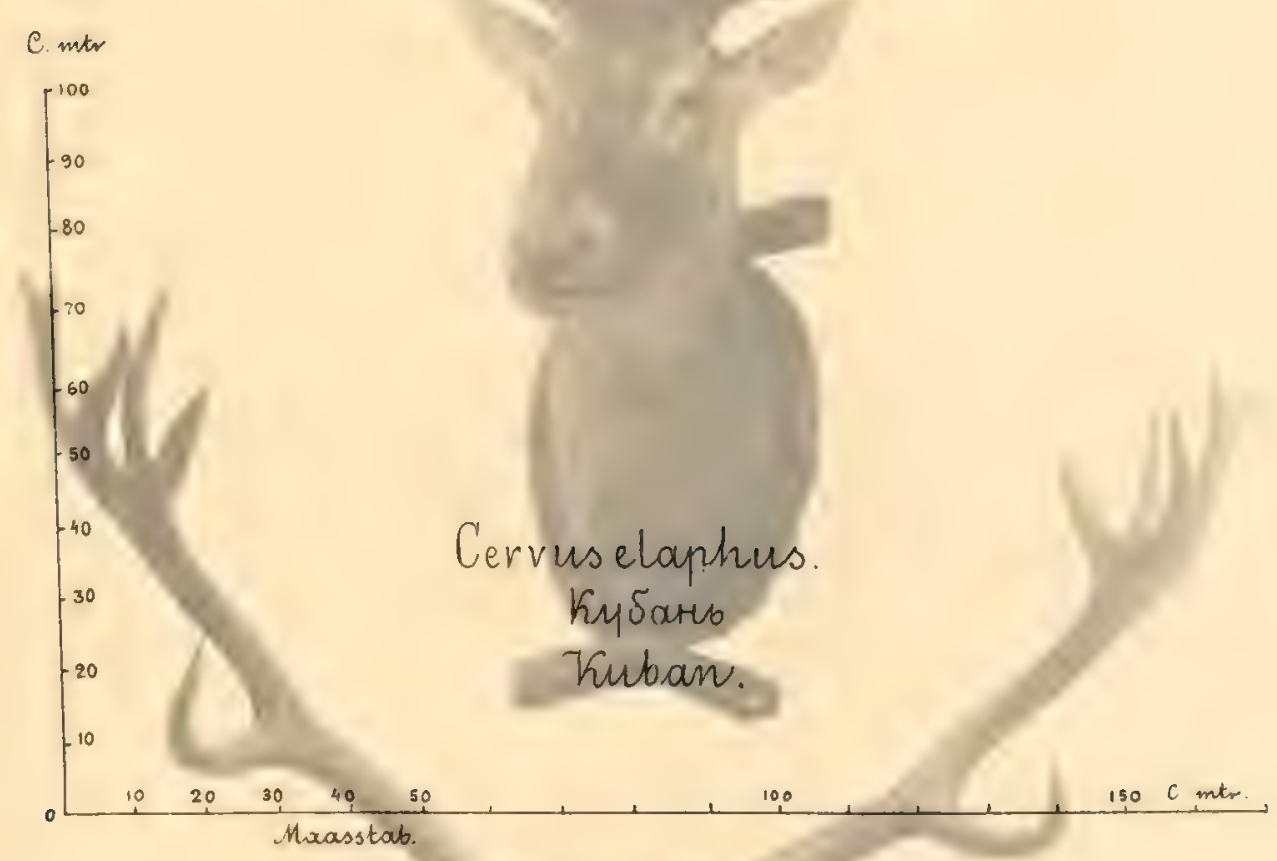


IX $700 \mathrm{~T}$

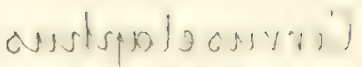
अभOCे Mîे

srodjich

Fine

001

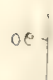

09

$c^{-1}$ 


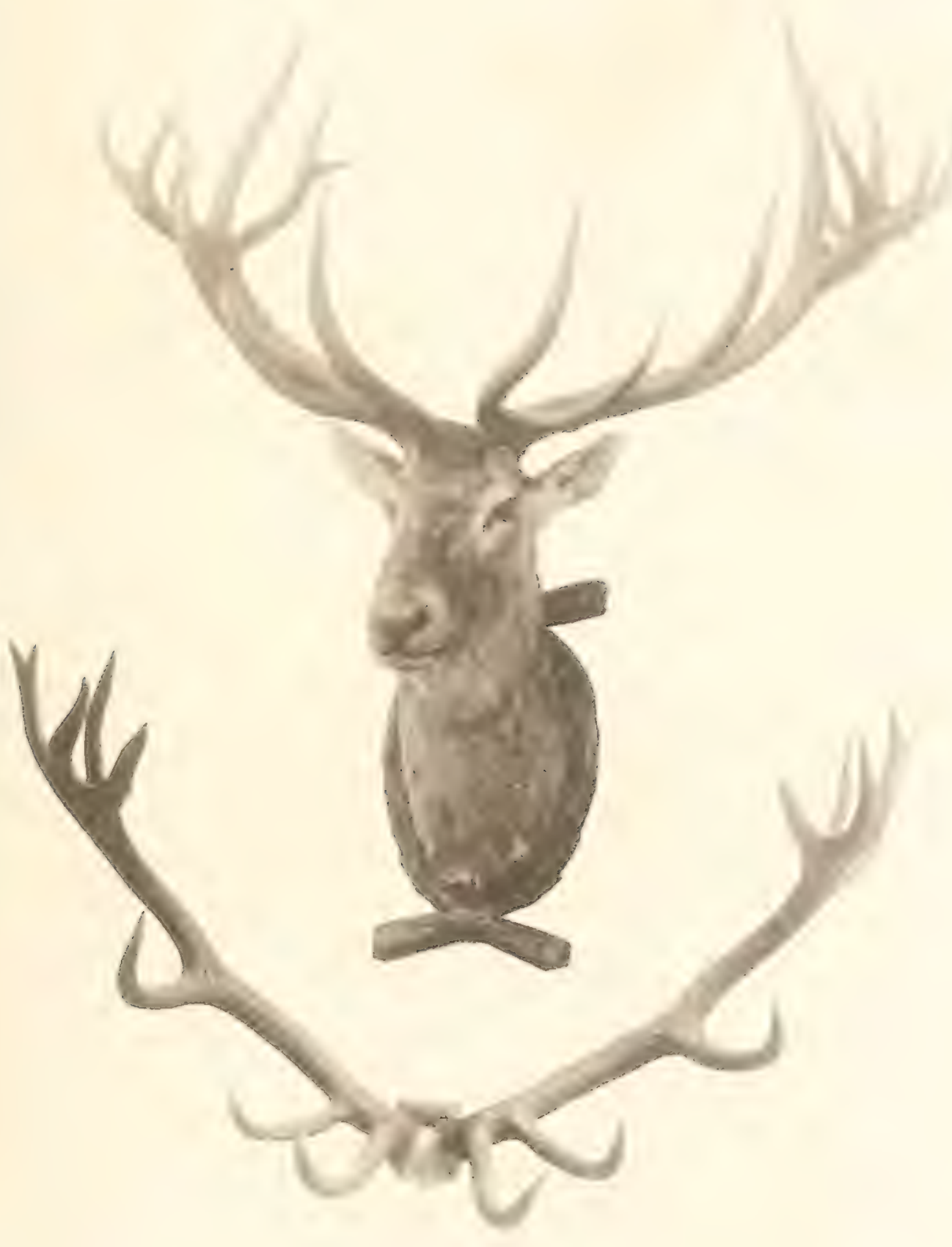

$\checkmark$ 



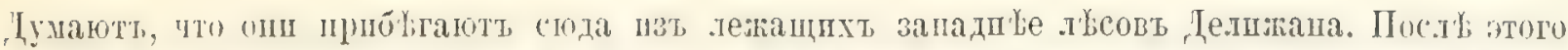

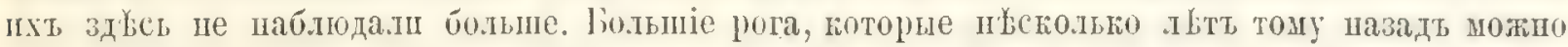
было выдыть вт домь калапендскаго льснпаго, пропсходпли не пзъ әтой области, а изь Јагпча (шемахпнск. уъзда), отвуда пкъ принесли сюда мьдник.

Охотник отличагть тинчнаго олепл оть такь называеяаго плопатника", который

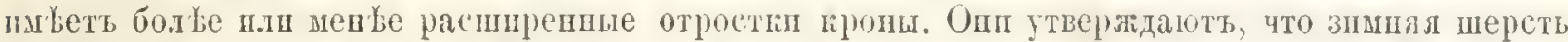

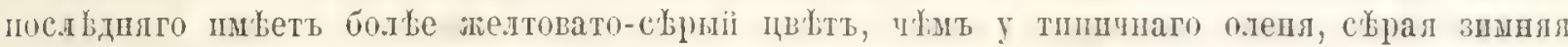

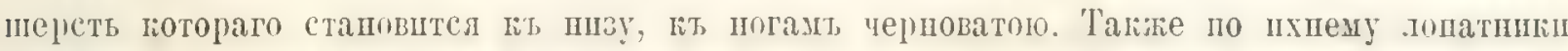

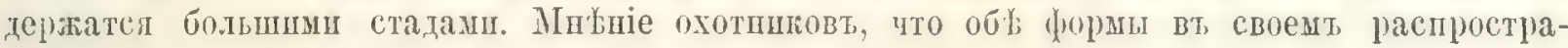
пеніп взапмн другь друга искючають, пе можеть быть прпнято.

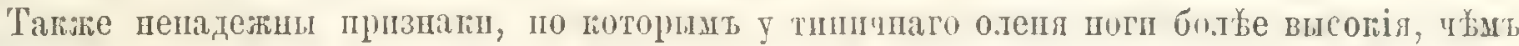

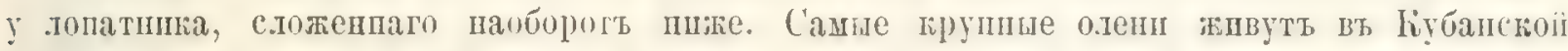

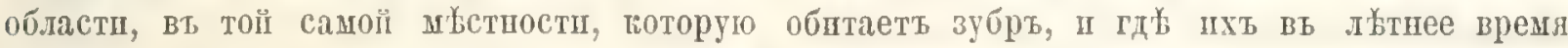

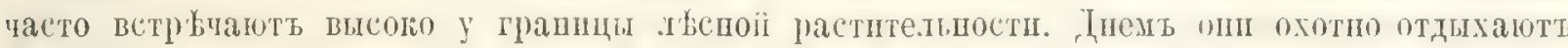

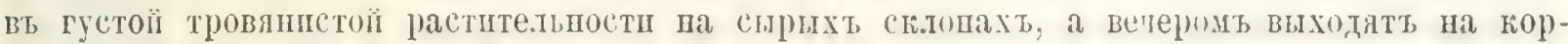

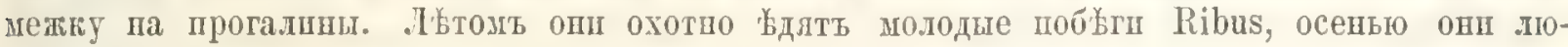

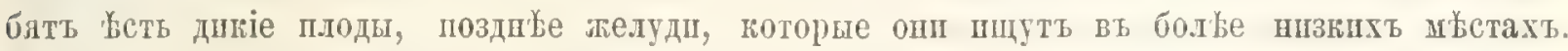
Олени съ 20-22 концачи обыноовены въ әтой богатой охотничей области. IІослғдніе

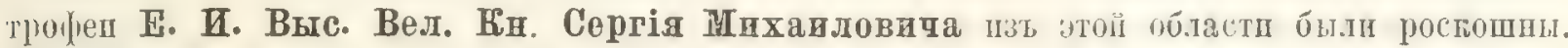

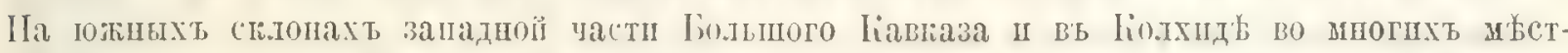

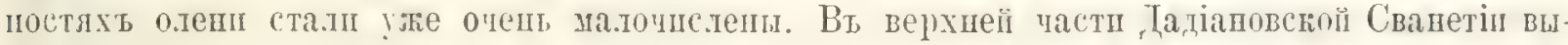
пе Лептехи въ 1864 году пхт не было вовсе: шхь совершенно пстребшли въ сифжныя зи-

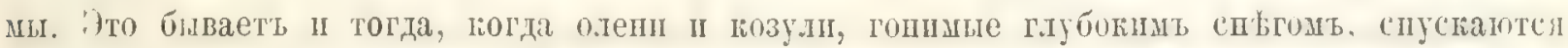

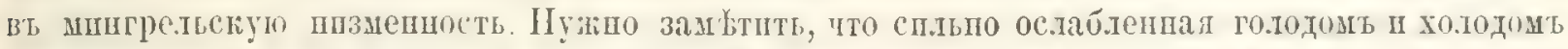

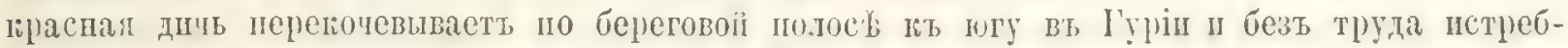

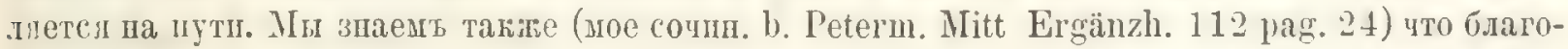

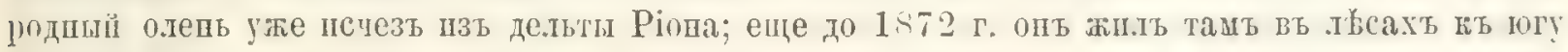

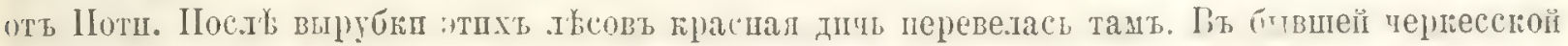

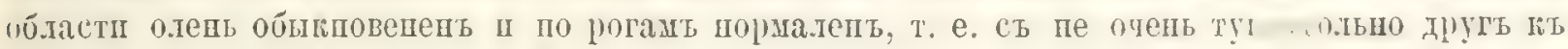

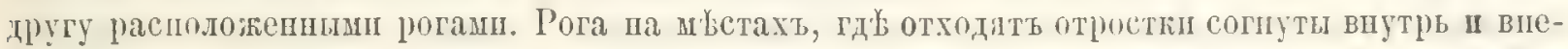
редъ; лобцые отростип д.тнны п часто согнуты почли полугругуъ. У одвого абхазскаго

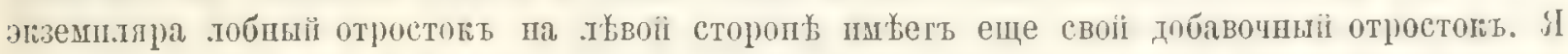

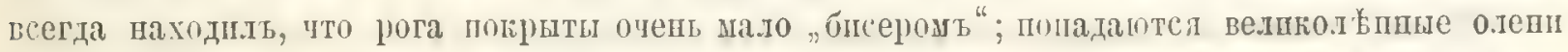

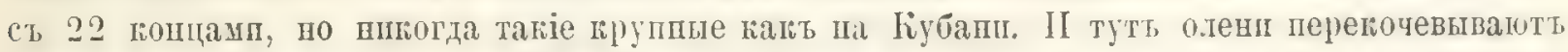

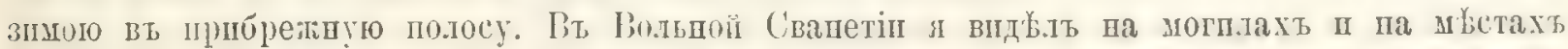

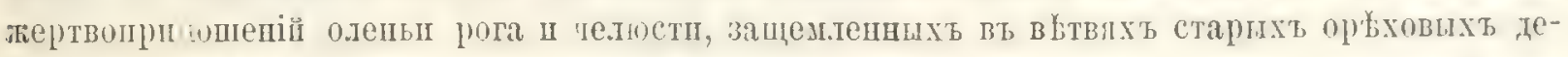

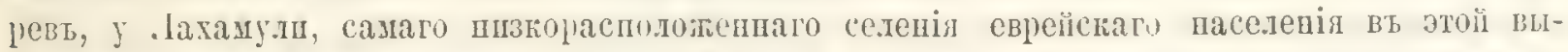

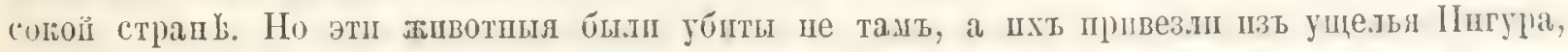
лежацаго шиғе па разстояніп одного дня путп. Въ пшінеї тиетп әтого ущельл, готорое

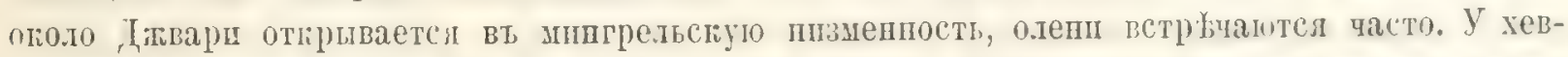

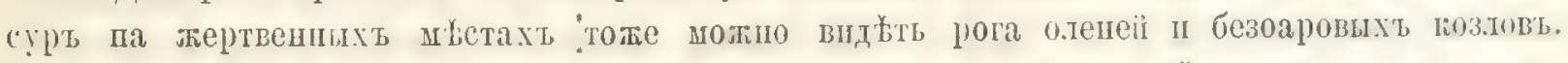

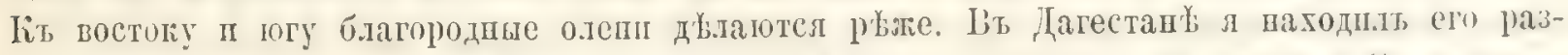

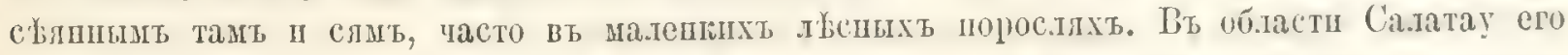

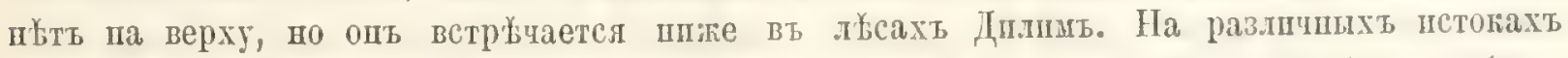

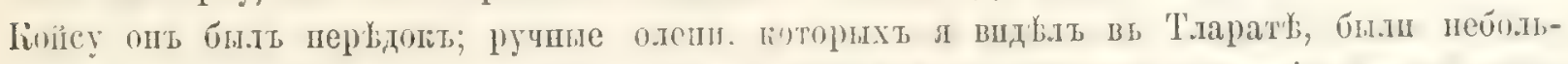

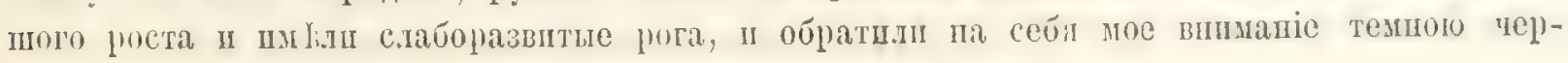




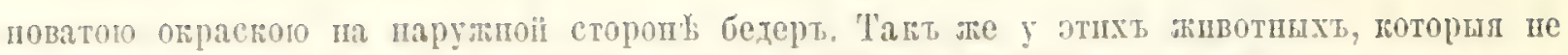

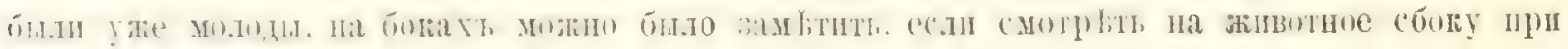

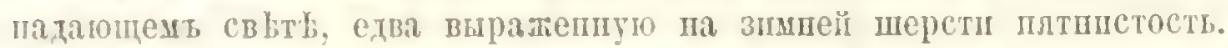

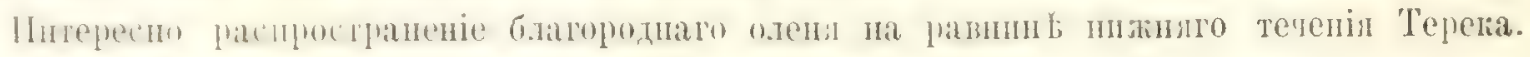

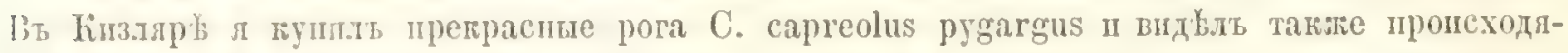

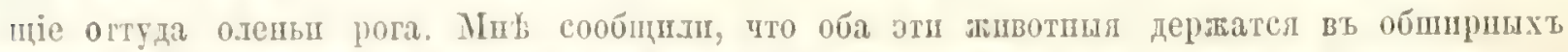

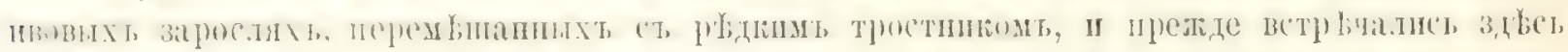

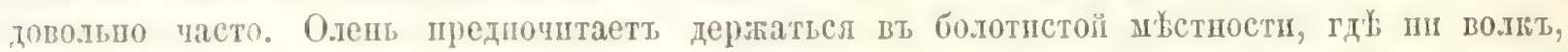

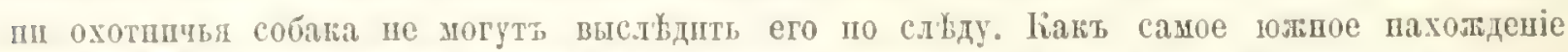

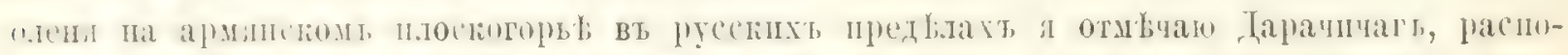

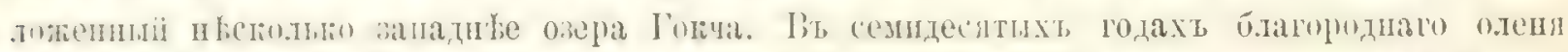

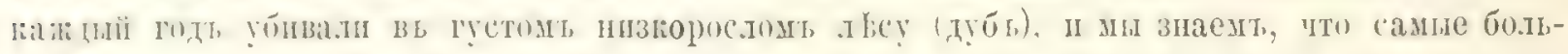

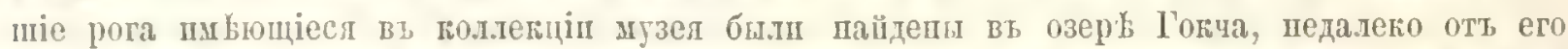

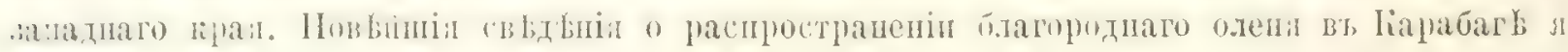

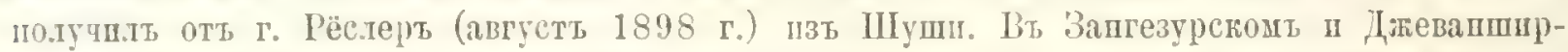

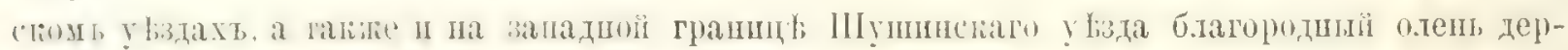

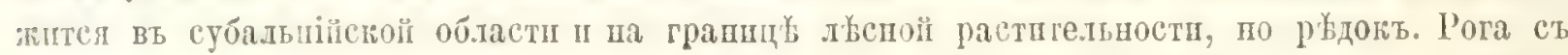

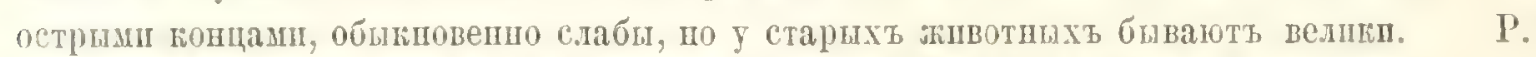

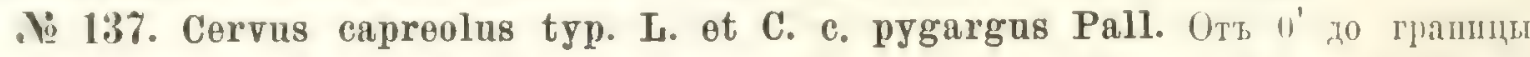

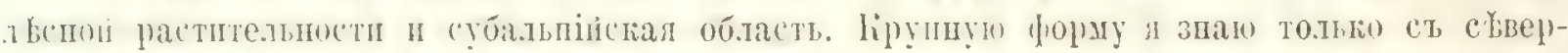

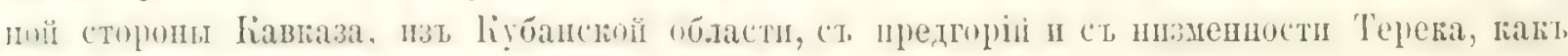
уате би.ло сказано об́ этощь выше.

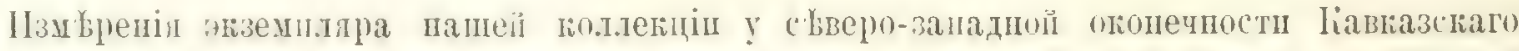

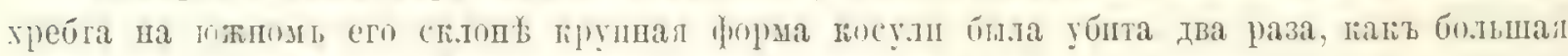

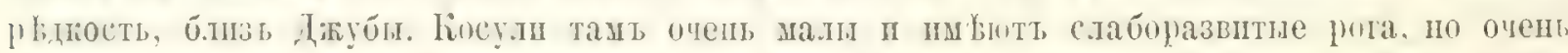

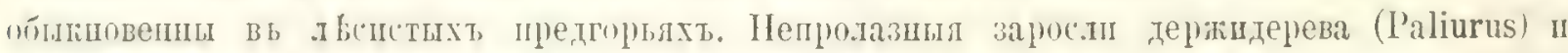

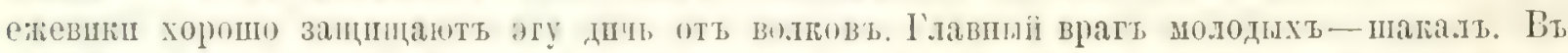

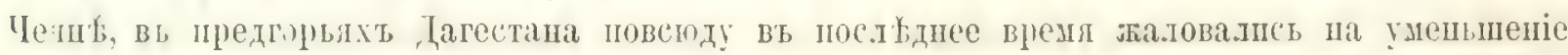
посули. Тащт, гды ирежде броди.ли стада въ 10-15 головь, теперь қосулш мьстам со-

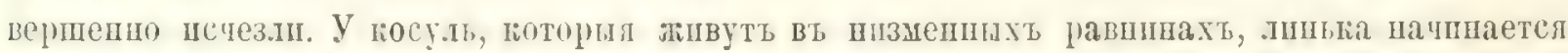

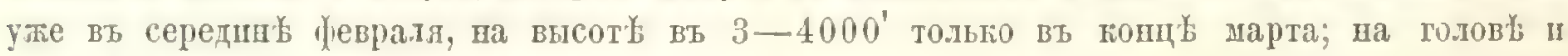

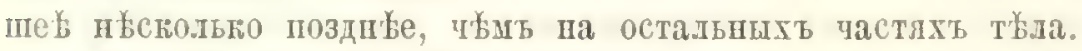

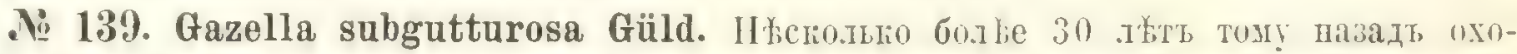

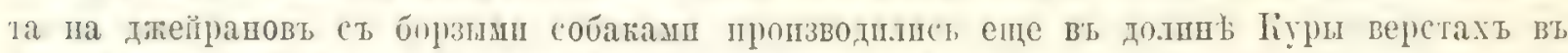

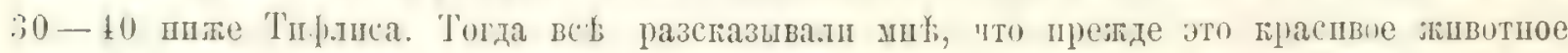

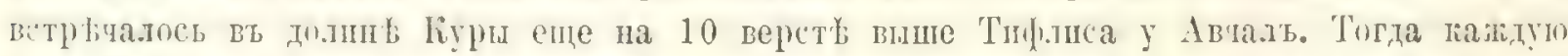

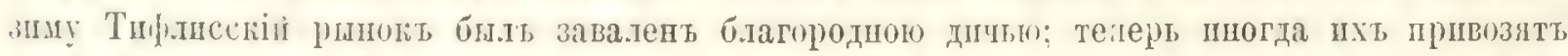

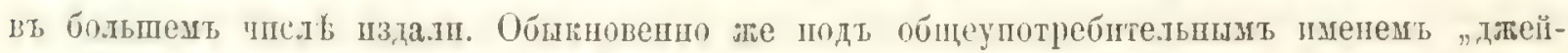

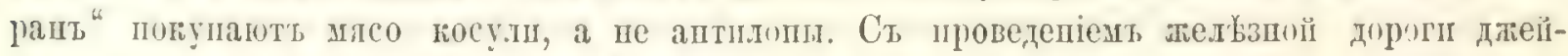

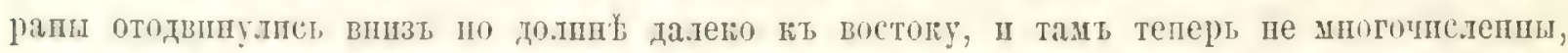

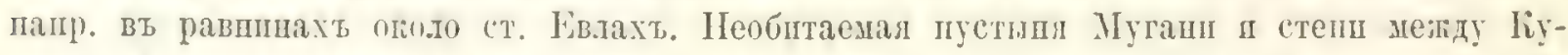

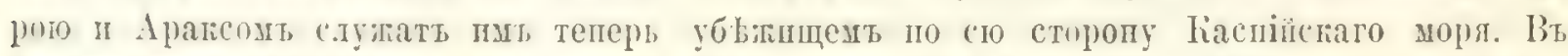

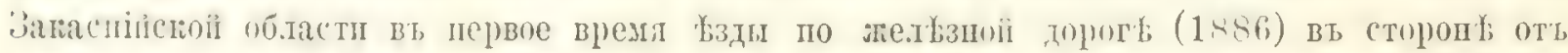

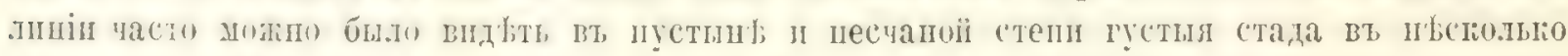

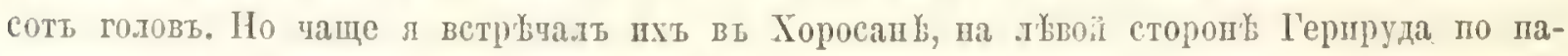

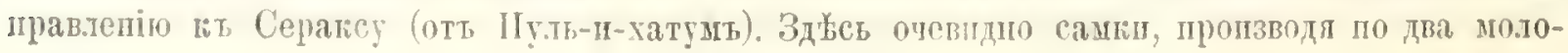


пумй Іт приолитеніп наубетгли передъ нами. Вт ги.топу п сд'валь ел шзпя мбшкообразныл углубоппсапіе п рнсупокь, а

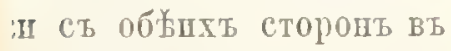
ообразиыя углбиенія коo небольиой железь, пошми и сальны па ошупт, готорня совершенио завепіи окружащих частей วиму, напбольпая же шии незначительном успли $3^{\prime \prime \prime}$ шпрпны. Напболпшал мотрыть на пхъ верхпююо пп копцентрически лежа-

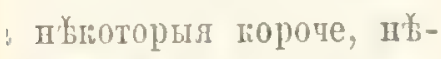
іокимг п морщинистьми. Iу тоторыми рыпко раз:твіе того, что облечепи , конды декабрл видълеI HIxь образуютел стоп3б жирово иасе' попаслабо держатся па виут:ніе шметъ грлзчо-сьро,iaчmuli и отда.тенно шаченныя на щяс', приво-

$$
\begin{aligned}
& \text { до ионца } \\
& \text {-. . 12" } \\
& \text { •. • • } 10^{\prime \prime} \quad \text { • } \\
& \text {. . . } 7^{\prime \prime} .1 " \\
& \text {. . } 133^{11} 1^{1 / 2, "} \\
& \text {. . } 18 \\
& \text {.. . . 2 } 2^{\prime \prime} 1 / 2^{\prime \prime \prime} \\
& \text {. . - } 10^{11 "} \\
& \text {. . . - 5 } \\
& \text {. . - } 10^{111} \\
& \text { уга... } 2^{\prime \prime} 7^{\prime \prime \prime} \\
& \text {. . } 2^{\prime \prime} 11^{\prime \prime \prime}
\end{aligned}
$$

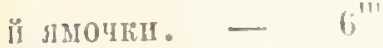

$$
\begin{aligned}
& \text { 1... . } 1^{\prime \prime} 2^{\prime \prime \prime} \\
& \text {. . . : }
\end{aligned}
$$



пуме пю прнбляеніп наубжгал передъ памп. Въ плопу п сджлаль ея пгIя мвпкообразныя углубоппеапіе п рнсунок $\mathrm{s}$, a :II съ обұнхъ сторонъ въ ообразныя углјбденія ґоо небольпой желез в, қожщи II сальны на ошцуг, ґоторыя совершенно завеніп оцружащихь частей วйту, папоольшая же ппи незначптельнощ успліп 3"' ширшп. Напбо.льпая мотревть на пхъ верхното II ґонцентрпчесп лежа: нивоторыя гороче, п歺іогіми иі морщшнетым. қу ґоторыми рьдюо раз:твіе того, что облечепи - гонды декабря выджлет нпхь образуютел стопЗъ жировой масес попаслабо держатсл па внут:піе пмћеть грлзно-сьро, 'ченныя на мяс', прив-

$$
\begin{aligned}
& \text { I0 romца } \\
& \text {. . } 42^{\prime \prime} \\
& \text {. . . 4" }
\end{aligned}
$$

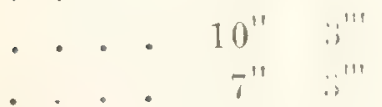

$$
\begin{aligned}
& \text {. . } 13^{\prime \prime} 1 \frac{1}{2}{ }^{\prime \prime} \\
& \text {. . . } 14^{\prime \prime} 3^{\prime \prime \prime} \\
& \text {. . } 18 \\
& \text {. . . } 2^{\prime \prime} 4^{1 / 2} \\
& \text {. . . - } 10^{1 " 1} \\
& \text { •. • - - } \\
& \text {. . - }-10^{\prime \prime \prime} \\
& \text { yra. . 2 } 2^{\prime \prime} 7^{\prime \prime \prime} \\
& \text {, . . 2 } 2^{\prime \prime} 11^{\prime \prime \prime} \\
& \text { Iี ЛМОчкI. - } 6 \text { " } \\
& \text { เa. - . } 1^{\prime \prime} \quad 2^{\prime \prime \prime}
\end{aligned}
$$





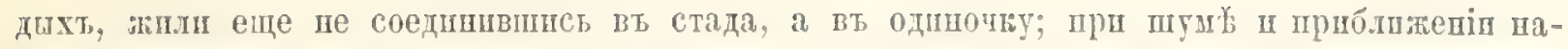

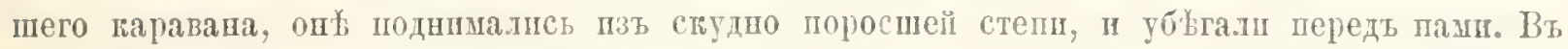

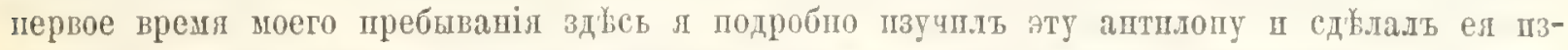

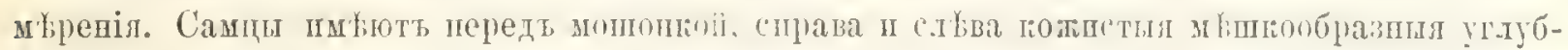

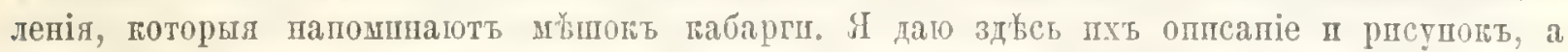

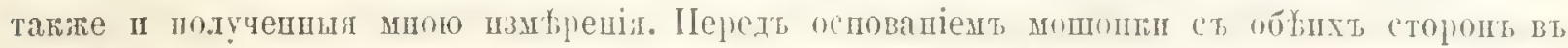

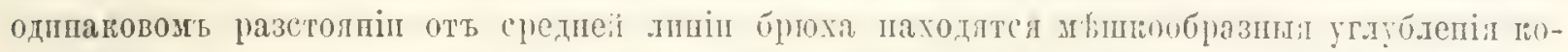

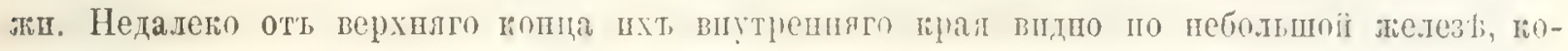

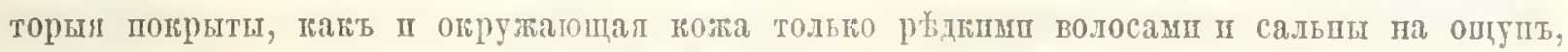

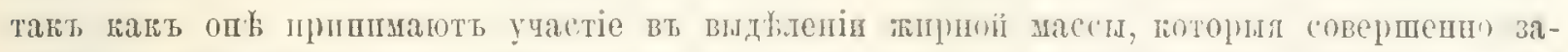

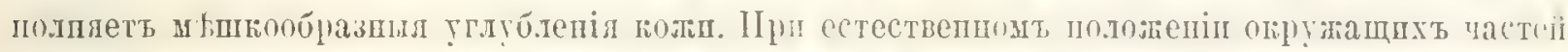

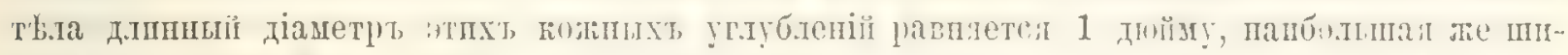

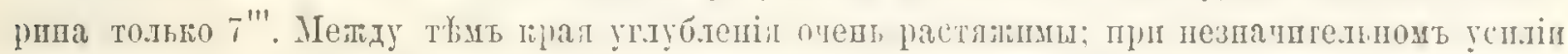

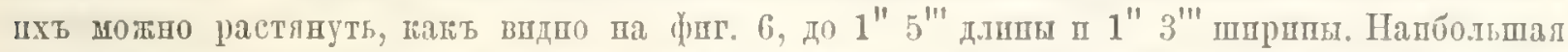

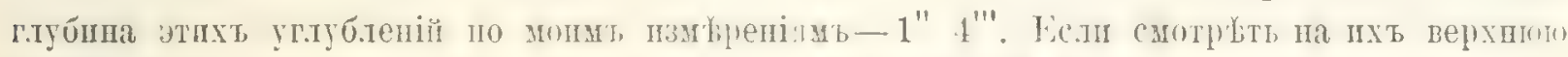

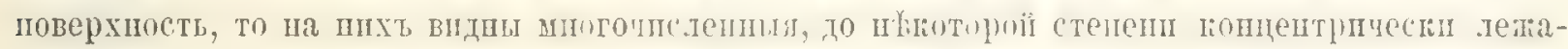

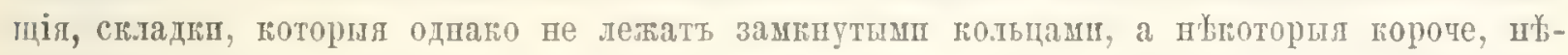

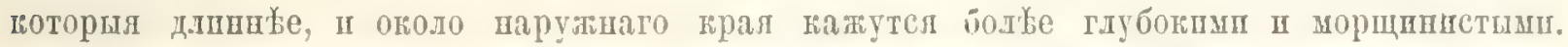

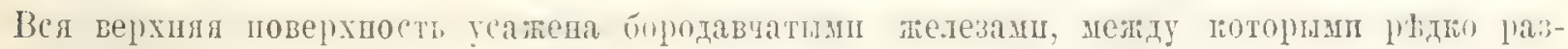

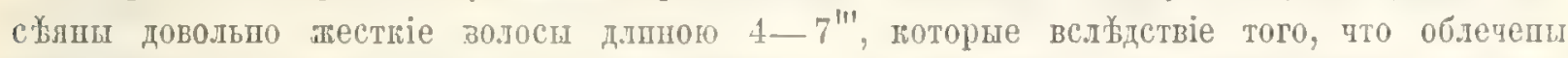

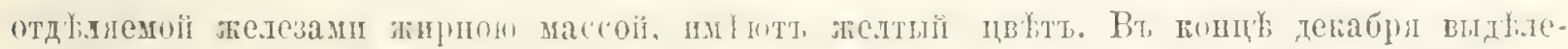

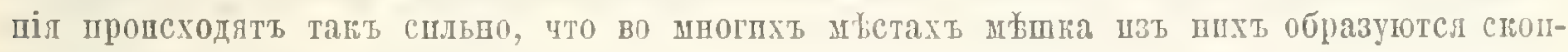

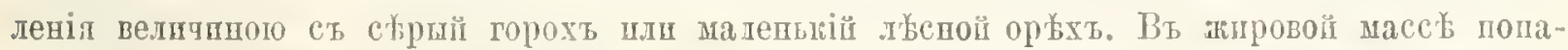
даются кањъ кусочюг эпшдерпса, тањъ п волосы; посльдніе очень слабо держатсл на внут-

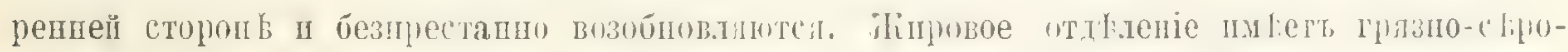

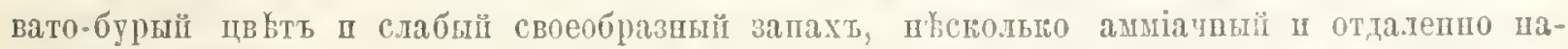

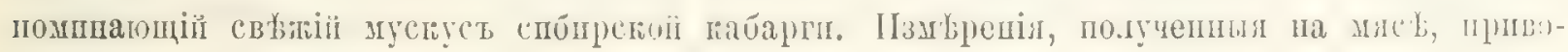
дятся вь слъдующей таблпщ:

\section{Старий самецъ.}

Общап длина въ естественночь положепіт. Отъ попца носа до понца туловппа (прямо)

Длина хвоста оть основапіл до конца безъ волосъ.

Чнсло полець на рогу

18 Длина отверстіл рта.

Длшший діаметүь воздрей 。

Напбольшая высота пхъ у наружнаго крал .

Разстолніе верхнихь угловт слезныхь лмочењ лруг оть друга.

\begin{tabular}{cc}
$2^{\prime \prime}$ & $7^{\prime \prime \prime}$ \\
$2^{\prime \prime}$ & $11^{\prime \prime \prime}$ \\
\hline & $6^{\prime \prime \prime}$ \\
$3^{\prime \prime}$ & $2^{\prime \prime \prime}$
\end{tabular}
нижнпх ъ впутренняго уг.ла глаза от терхпяго угла слезиой лмочиц.

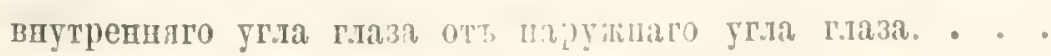
между внутренпми углами сблпхь глазь 


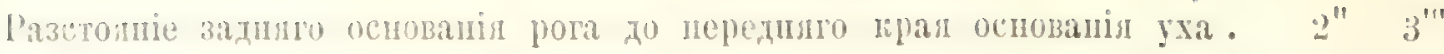

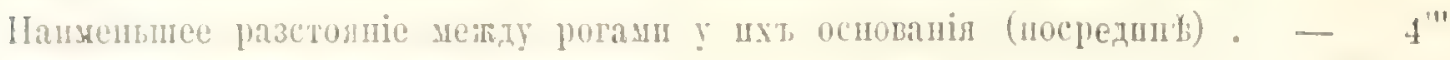

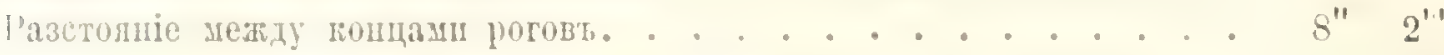

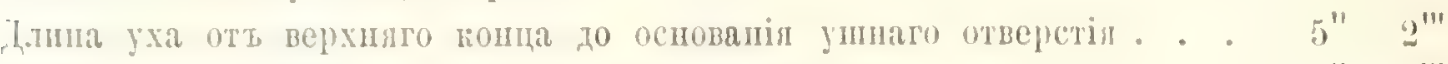

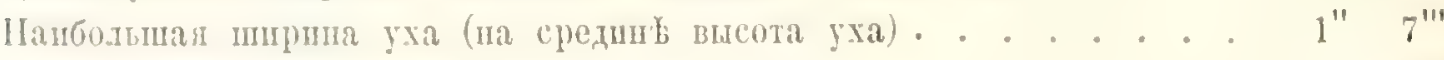

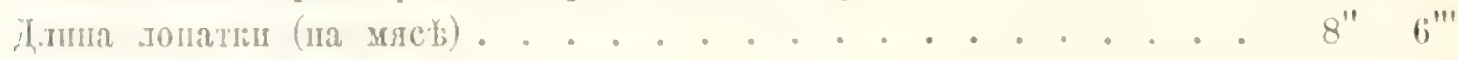

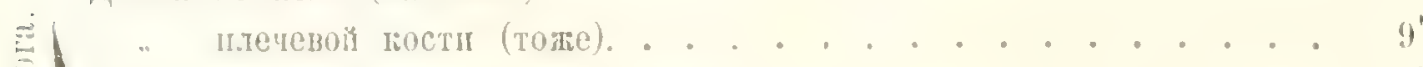

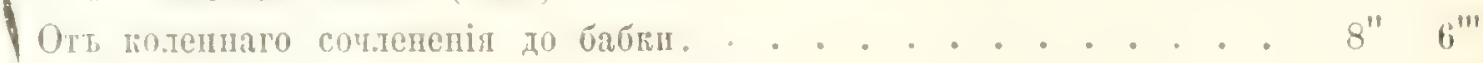

耳.тин бабінг . . . . . . . . . . . . . . . 2 $2^{\prime \prime} 8^{\prime \prime \prime}$

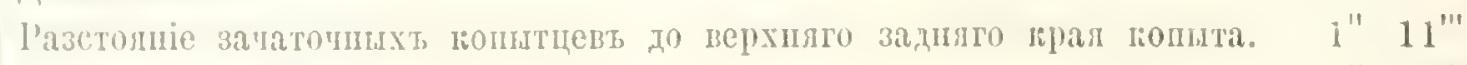

liscota ronuta crepezir . . . . . . . . . . . . . . . . 1" $1^{\prime \prime} 5^{\prime \prime \prime}$

сзали. . . . . . . . . . - - $8^{\prime \prime \prime}$

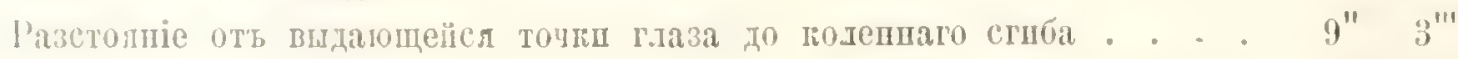

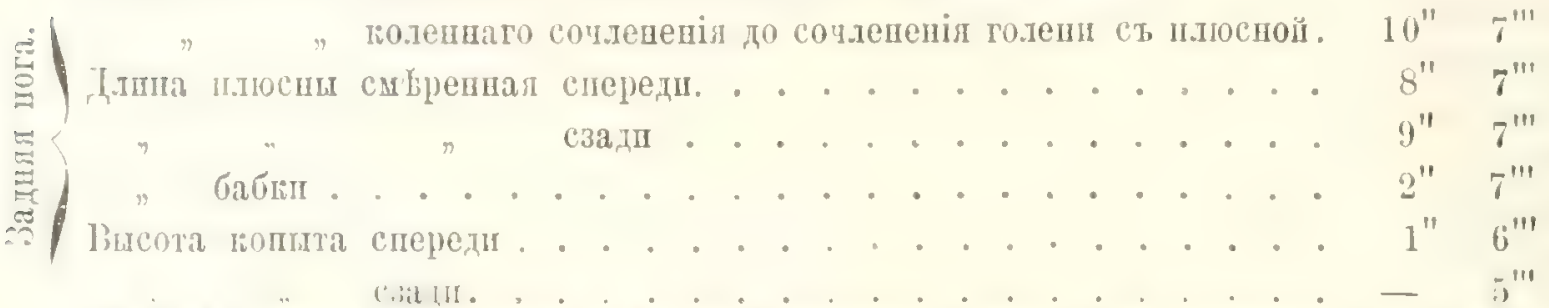

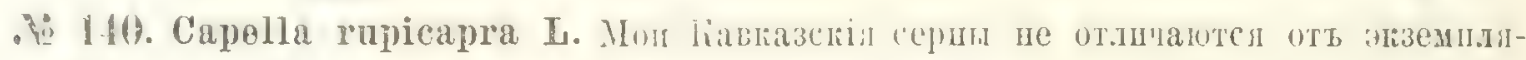

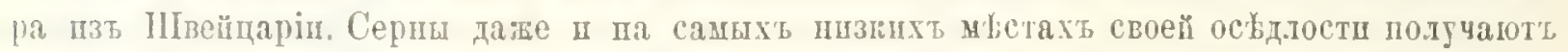

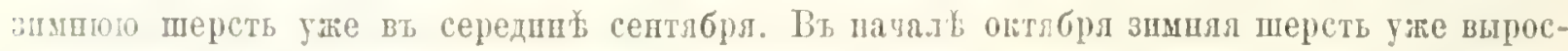

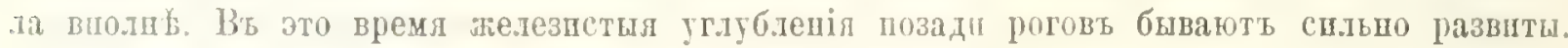

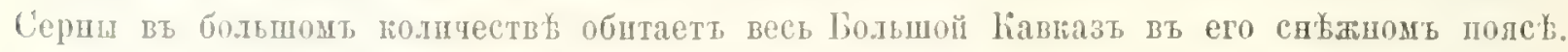

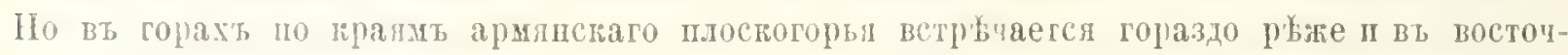

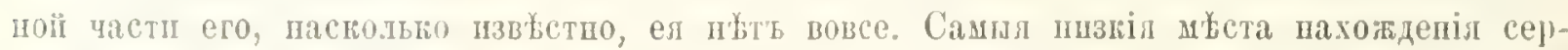

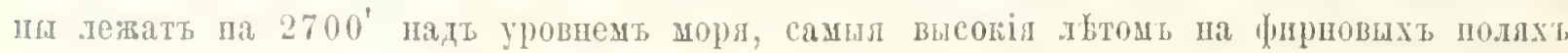

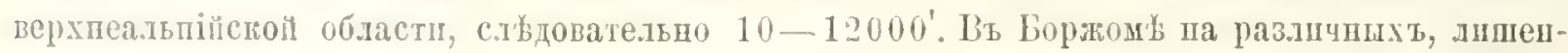
пшь льса мьстахь, держались до понца пестдеслтхь годовт маленькіл стада сернь, но

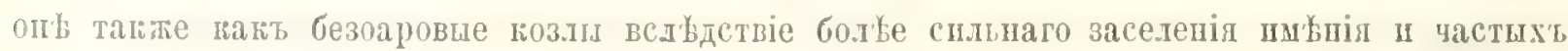
охоть скоро отвочевали оттуда. Стада въ високогорной области бывають иногда очень ве-

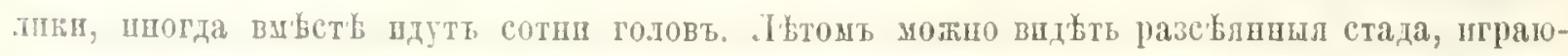

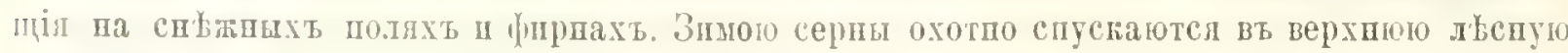

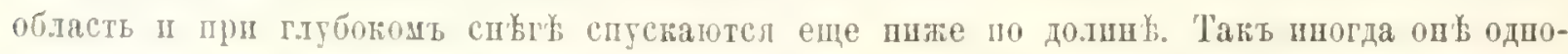
врезенп сь госудей появлются болынии стадами на южних прутизиахт горь Накаре-

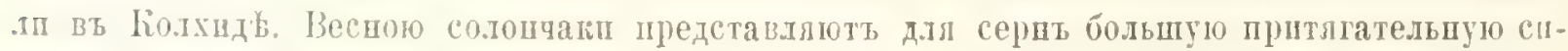

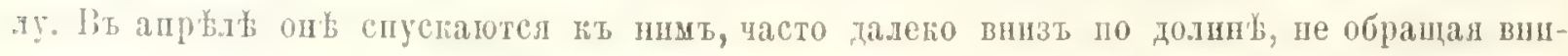

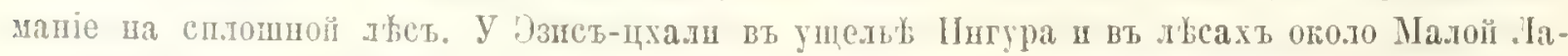

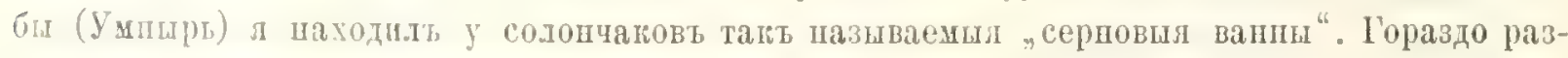

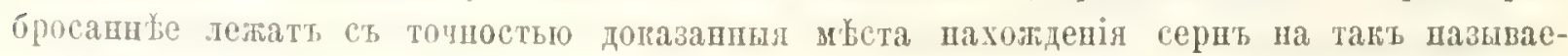

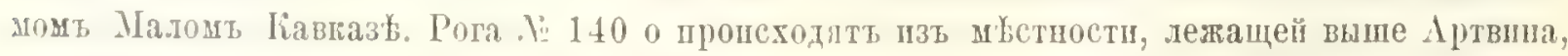

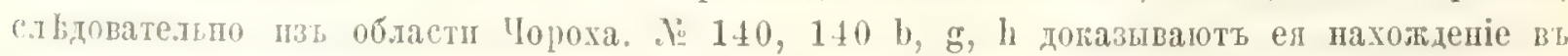

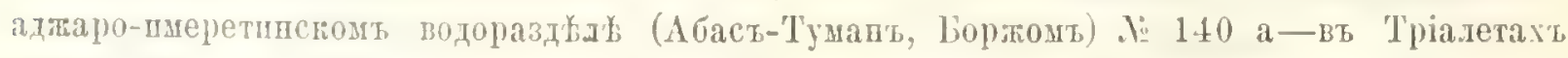

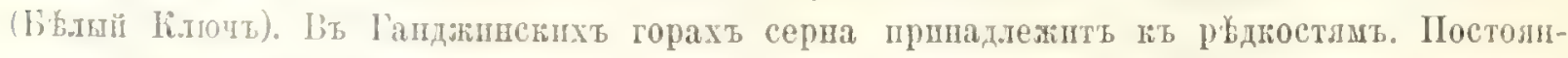

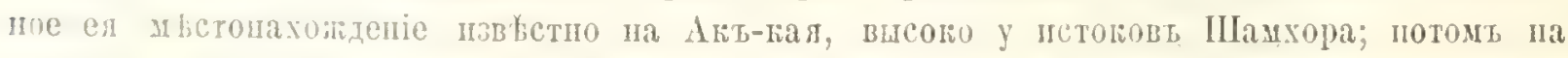

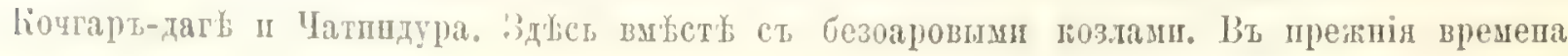




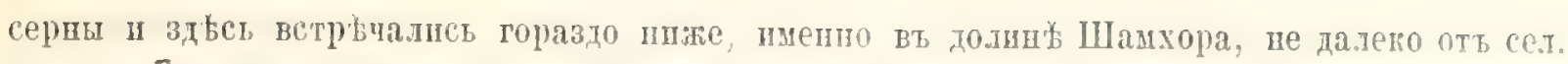

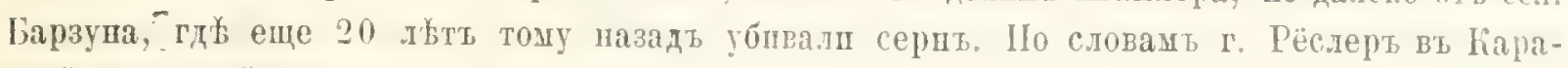

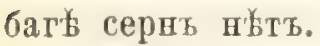

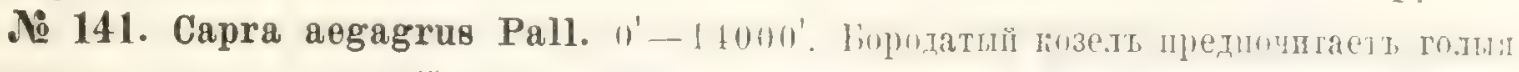

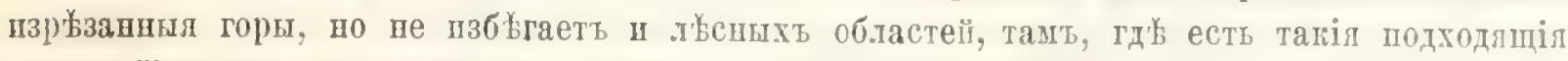
мест. Таєь около Боржома въ 1866 году было убито девлть штуг у рушит Петро-цшхә.

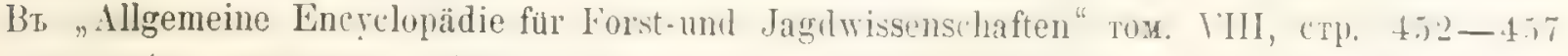

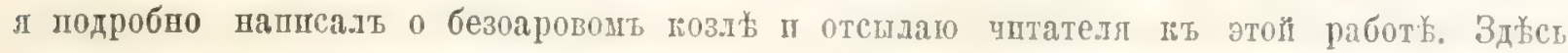

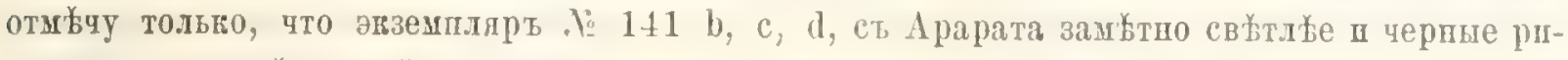

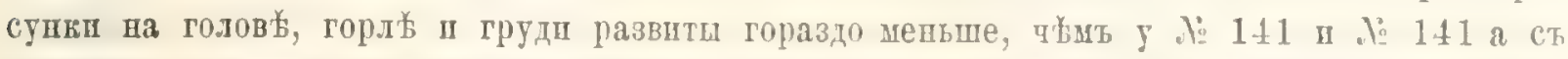

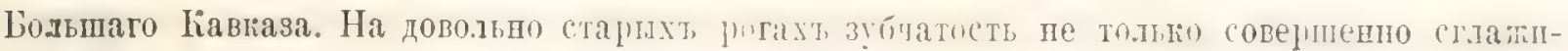

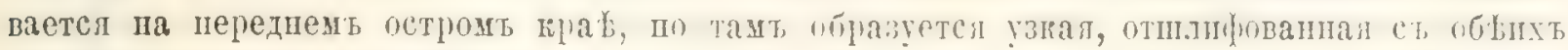
сторонъ, плоскость. Њольшему или мепьшему разстоянію роговъ другь оть друга нельзя

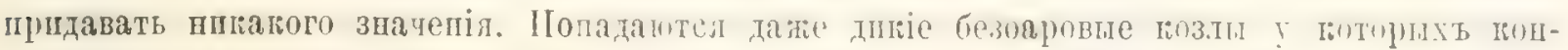

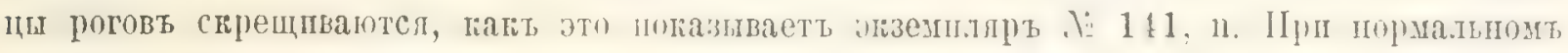
строеніп начбольшал шириа мелду обопп рогам голеблется отъ 35 до 55 ст. Въ цитированвомъ вите сочпненіи д сообщиль и о помьсяхь сь домашнею позою и ст туромт (C. cylindricornis).

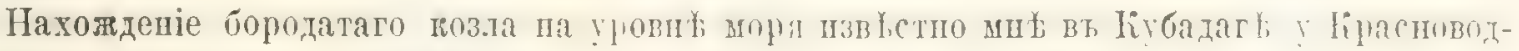

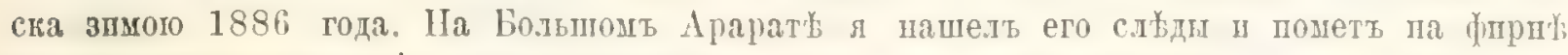

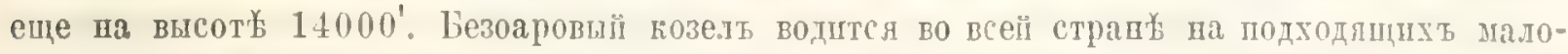

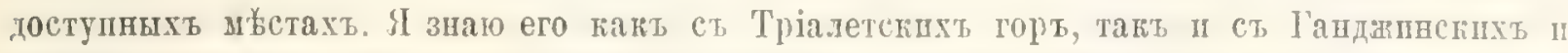

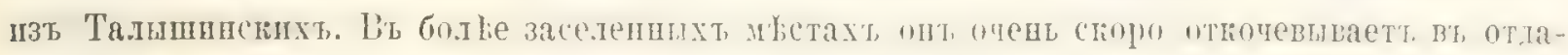
ленныя обнажениыя горпыл пустыни.

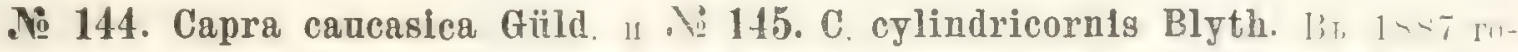

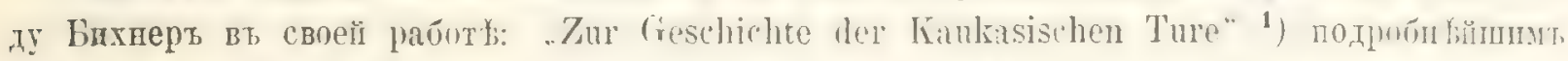

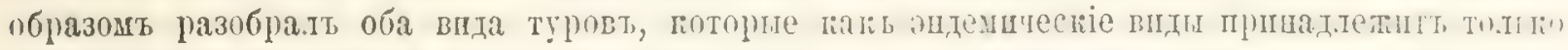

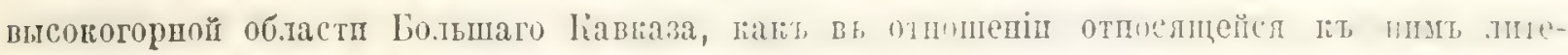

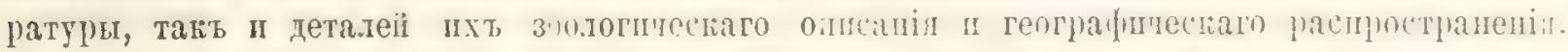

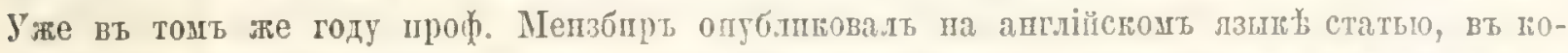

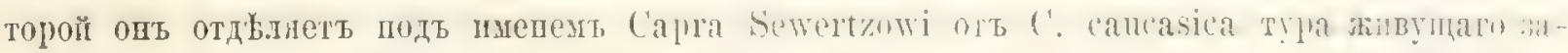

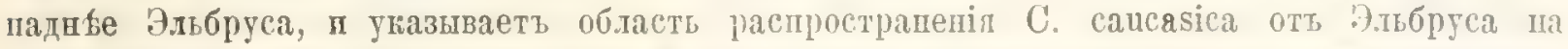

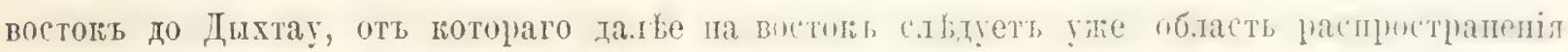

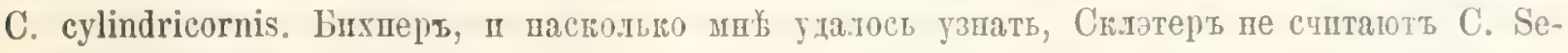

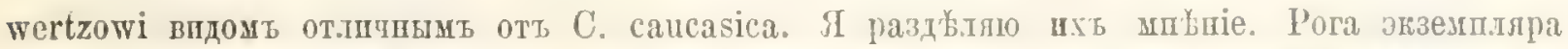

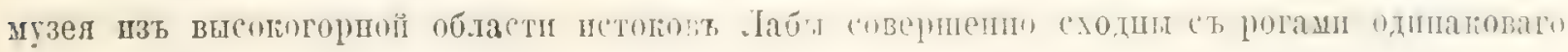

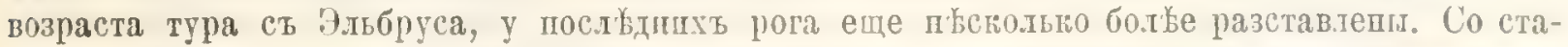

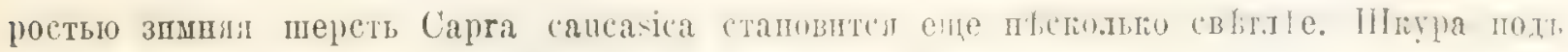

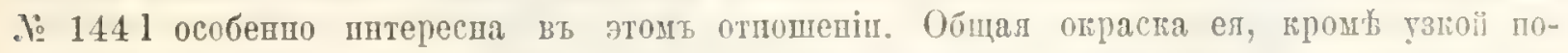

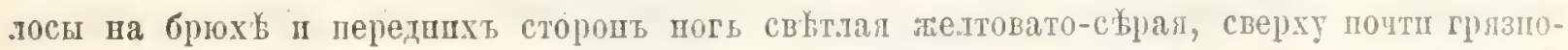

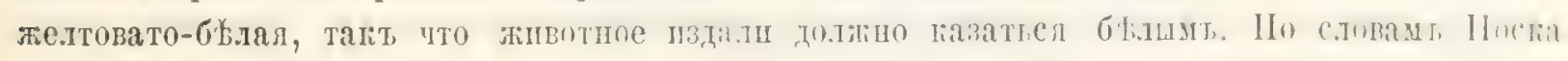

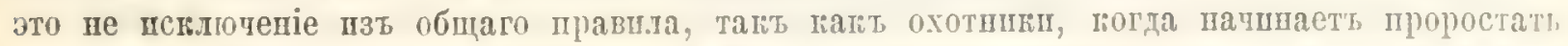

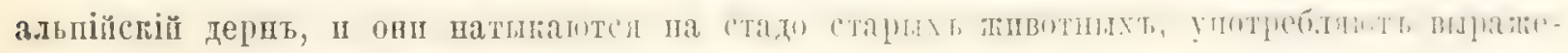

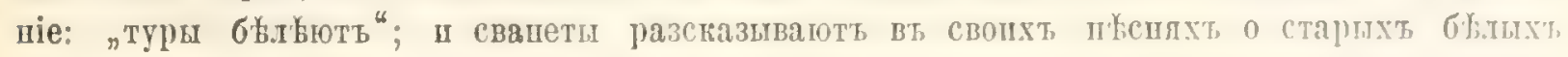

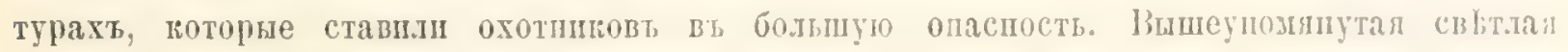

') Mémoires de l'Acad. Imp. de sc. St, $-\mathrm{l}$ tb. 'T, XXXV . 8. 


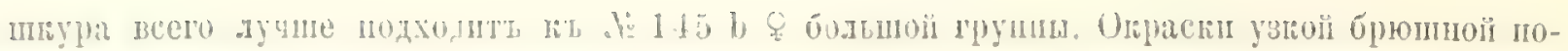

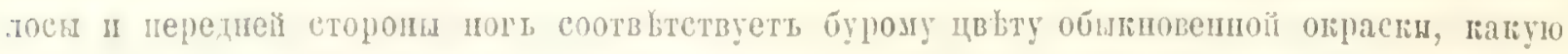

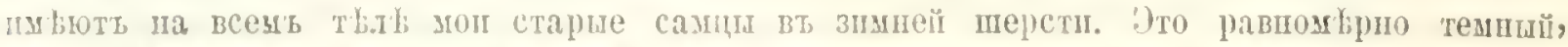

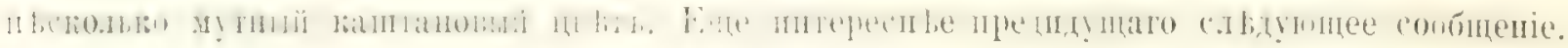

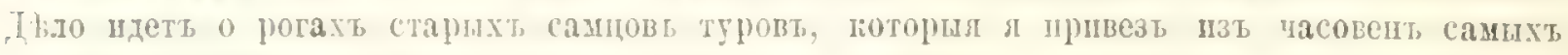

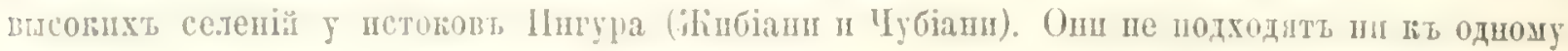

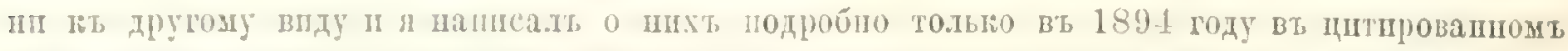

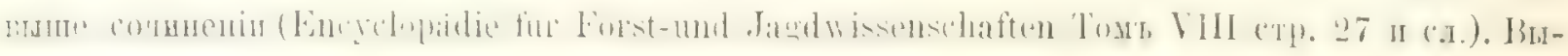

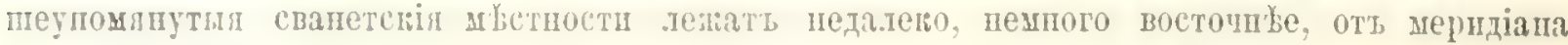

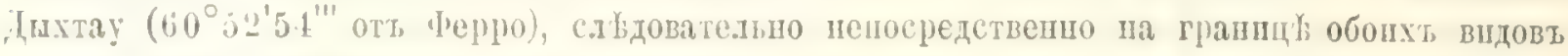

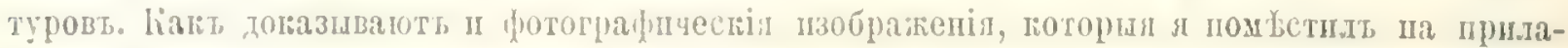

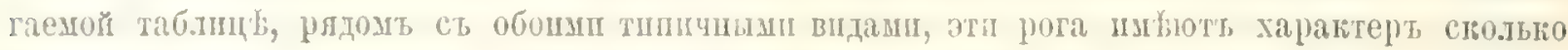
Capra caucasica, стольо жie Ir Capra cylindricornis, пменно оть иостыдиго вида спульту-

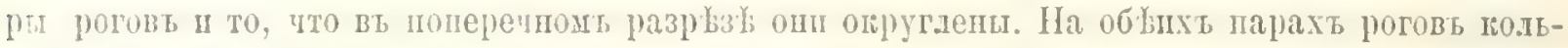

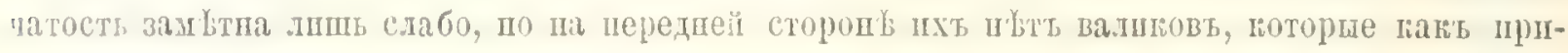

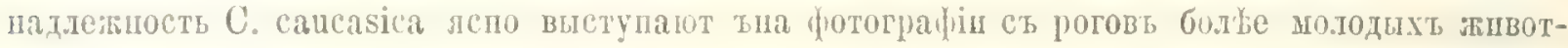

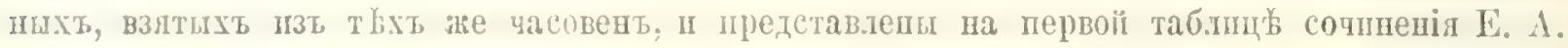

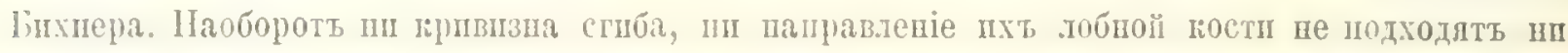

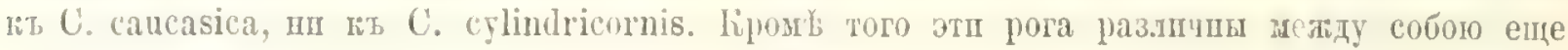

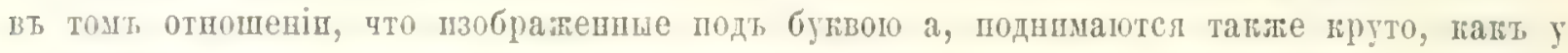

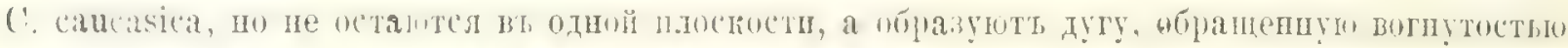

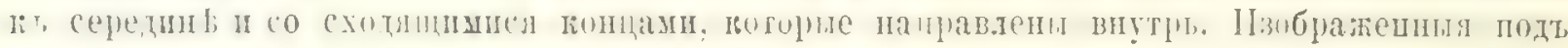

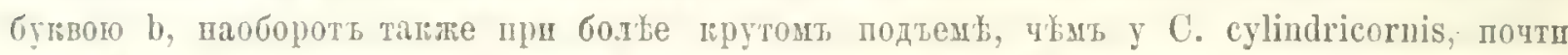

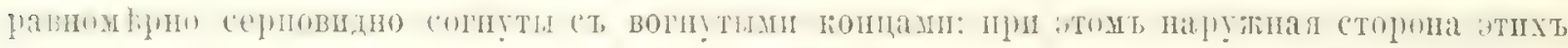
роговт почти гладкал. грая находпщшт другь на друга пластиноц выступатоть очепь

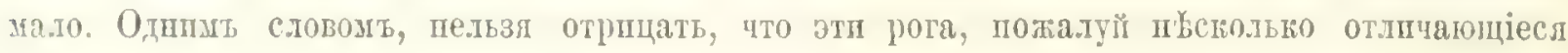

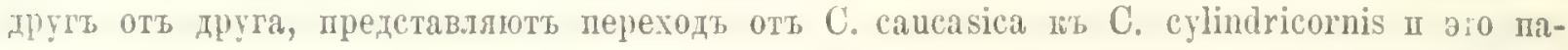

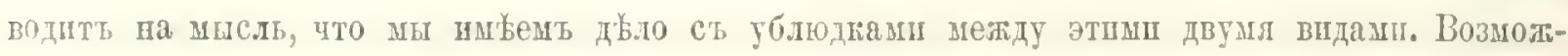
постп того, что әто дыйствтельно такъ, нцчто непротиворбчпть, такъ кать б.ликіе впды

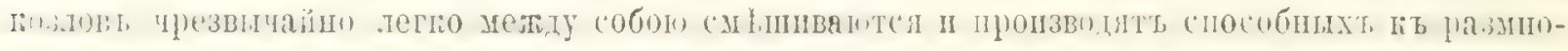

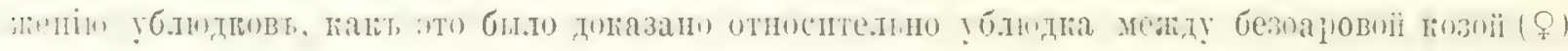

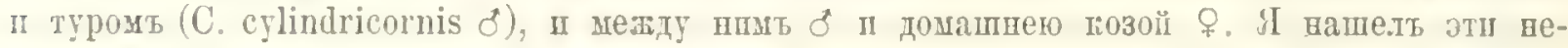
норыальные рога пменно тамь, гды сходится гранцпа распространеніл әтихь видовь. Вос-

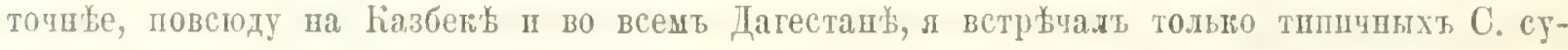

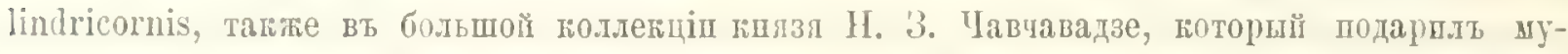
зело преграсшуко серіо . liaвказстаго хреб́та, оба вшда туровъ бродять большим стадами, особенно ліобять сои́ш-

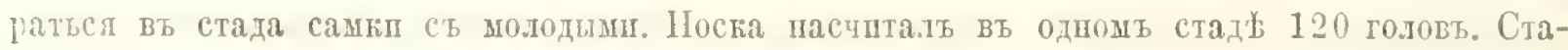

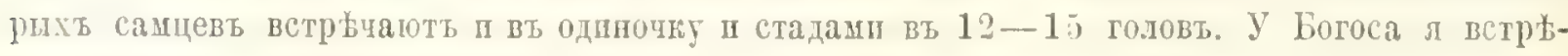

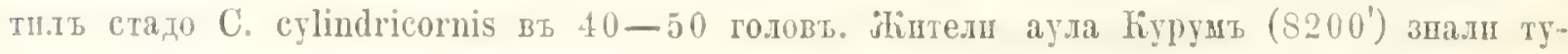
ровь сь лежапей вб.пип на главномт хребть вершины Базарь-дюза ш Шахь-дага. Прп

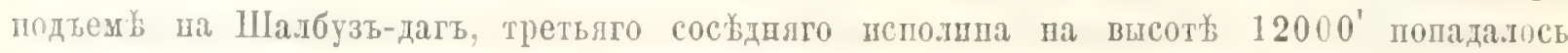
онень миого Megalaperdix caucasicus, но л пе нашель никакого сльда туровъ ${ }^{1}$ ).

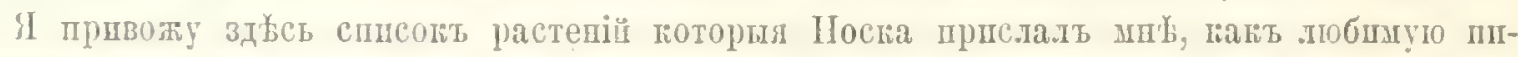

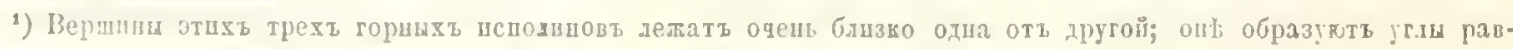

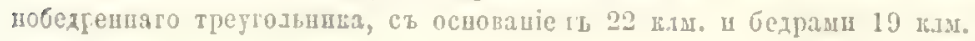




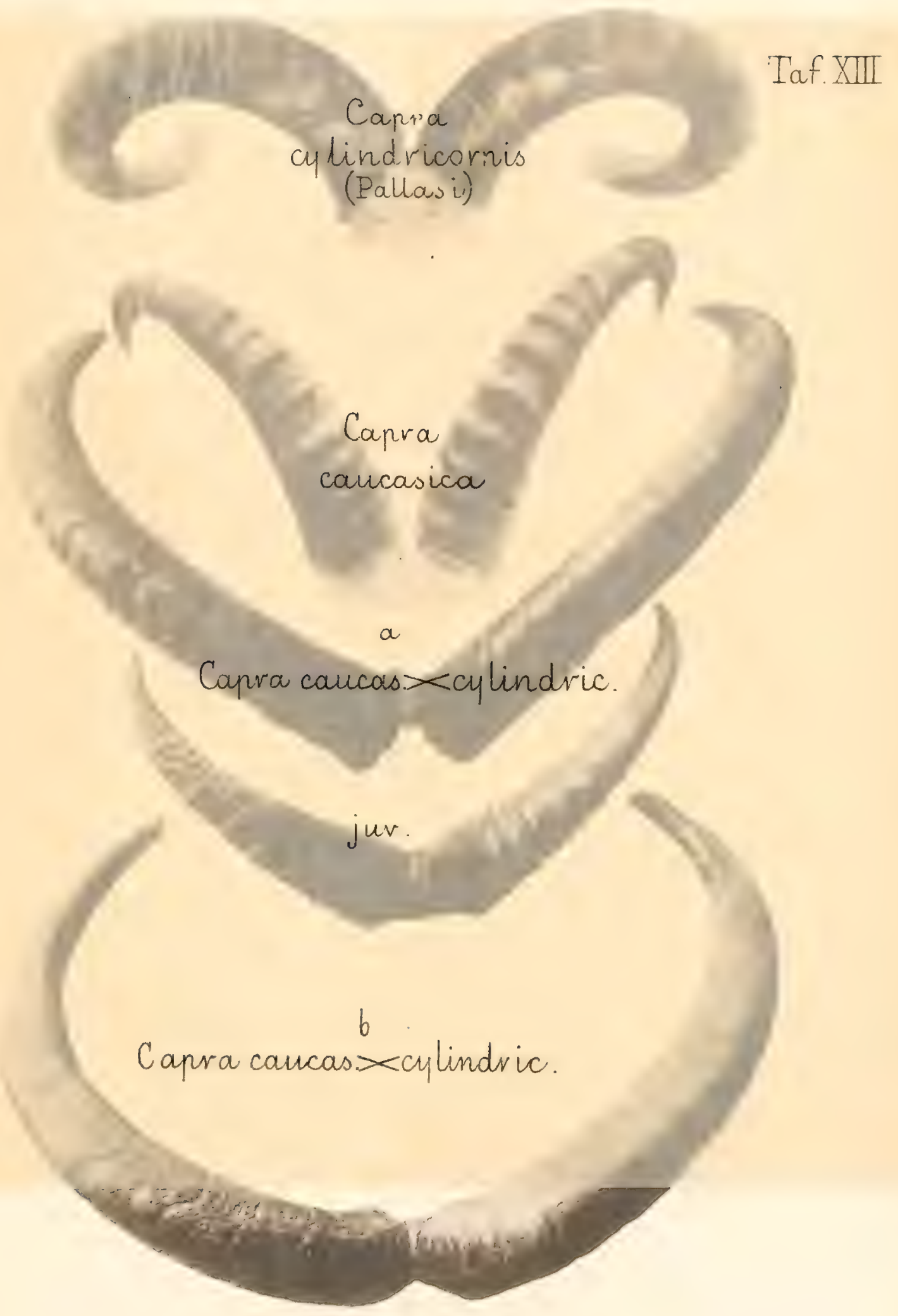


IIIX $7{ }^{\circ} \mathrm{T}$

$$
\begin{aligned}
& \text { jocisos }
\end{aligned}
$$

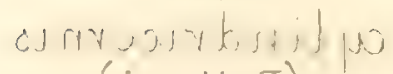

$$
\begin{aligned}
& \text { (icoJjo 9) }
\end{aligned}
$$

$$
\text { D.s. no }
$$$$
\text { waicanos: }
$$

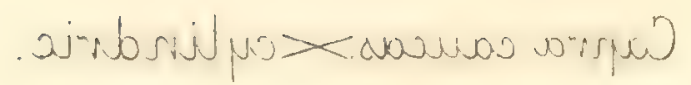

$$
v N L
$$

d

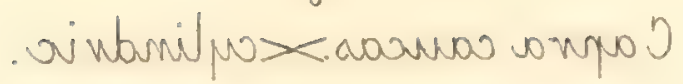




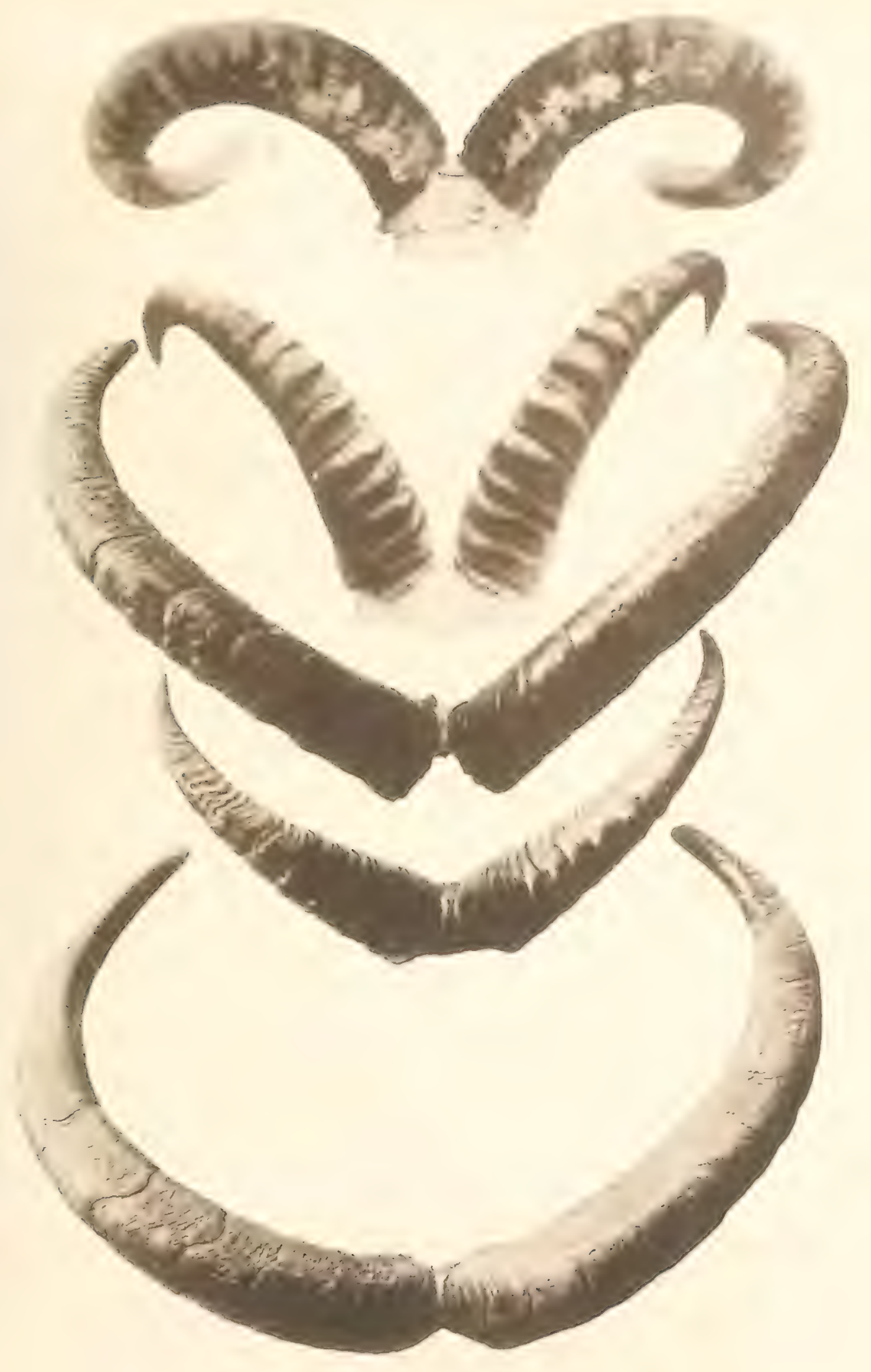





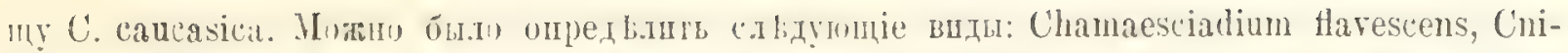
¿lium sp., Pimpinella sp. (heino.ru.), Valeriana alpestris, Gentiana pyrenaica, (r. rerna, Androsace albana, Viola grandiflora, Primula clatior, Campanula tridentata, Veronica gentianoiles, Anemone nareissiflora, (\%) Saxifraga exarata, Saxf. Hagellaris, Draba scabra, Dr. tridentata, I)r. siliguosa, Dr. imbricata, Alchenilla vulgaris, Alch. sericea, I'olygonum bistorta, I'araxacum Sterenii, Senecio pyrnglossus, Eritrichum naum, Pedicularis caucasica Ped. crassirostris, Anthemis sp., Alsine inbricata, Hedysarum caucasicum, Luzula spicata, Cares leporina, Festuca sp. ${ }^{1}$ ).

$\mathrm{P}$.

Вь 1896 году л отправился изъ сел. Курушь, въ сопровожденіи трехь тамошнихъ охот-

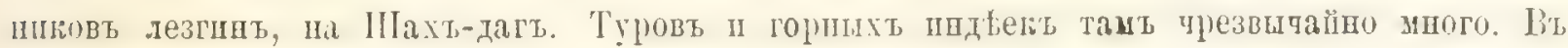

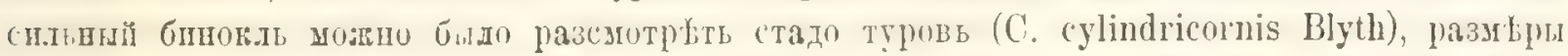

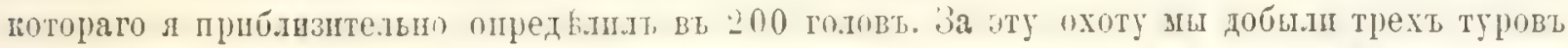

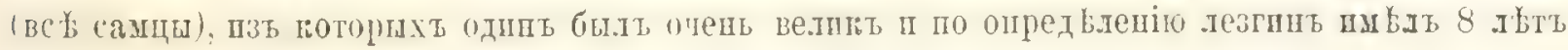
оть роду. Эти рога былп отосланы мною проф. Т. Ноаюу въ Брауншвейгъ. Сат.

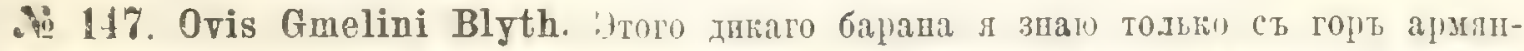

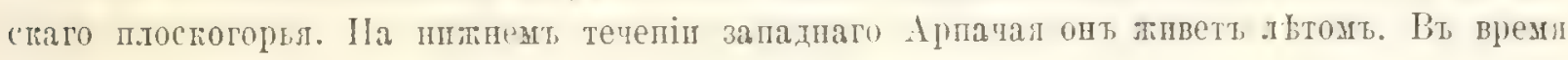
суровыхъ зимъ въ долин Арагсса этп барапы спускатотся впшзъ; въ это время они бы-

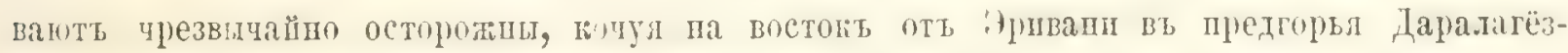
скаго уъзда, между Нахичеванью и Ордјбатомь. Зимою 1871 г. я прпвез оттуда экзем-

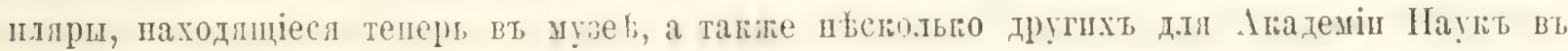
С.-Петербургљ.

$\mathrm{P}$.

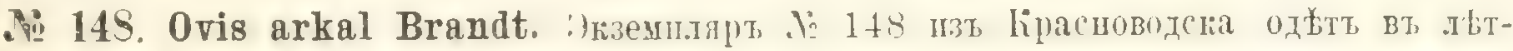

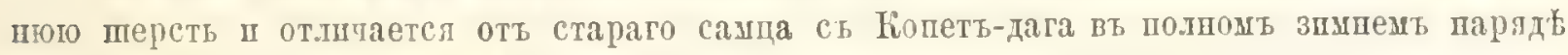

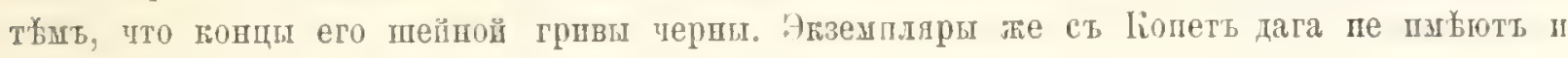
сльда чернаго, а одноцветны, почти чнсто былаго цвъта

I'.

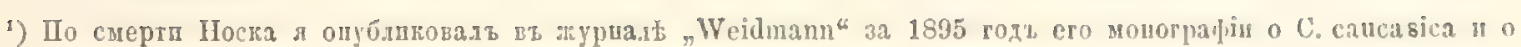
Capglla rupicapra; тамт читатель шайдет болишія подробности по этому предмету.

I. 


\title{
ЕГО НМПЕРАТОРСКОМУ ВЫСОЧЕСТВУ
}

\author{
ВЕЛИКОМУ КНЯЗЕ
}

\section{СЕРГІЮ МИХАИЛОВИЧУ}

IIOCBFITI AETCY

Вт. знакъ благодарности и преданности

Авторомъ. 


\section{ВАШЕ ИМПЕРАТОРСКОЕ ВЫСОЧЕСТВО!}

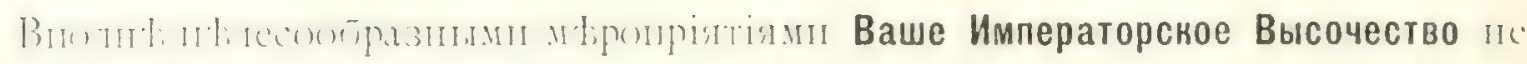
только установил современиую область распространсиія зуо̆ра, этого вымириоцаго псполина Кавказа, опредыливт, па сколько возможно, число иыны

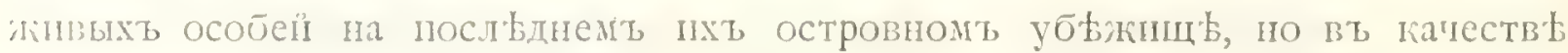

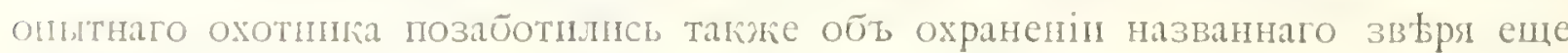

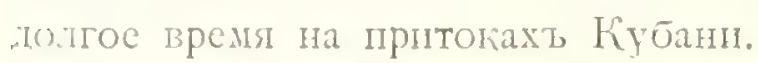

Хотя моп замьтки по этому поводу, соотвьтствснно цьли пастояцаго труда, весьма кратки и суцественнынт образомт касаются только гсографи-

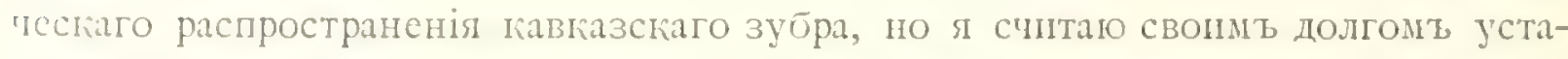
попнт упомячтый факть передъ всьиь утенымъ міронь и оть его пмени

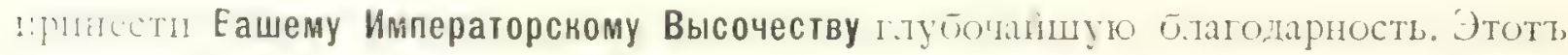

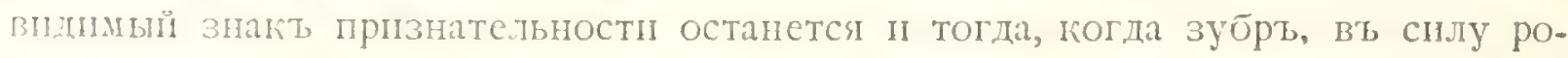

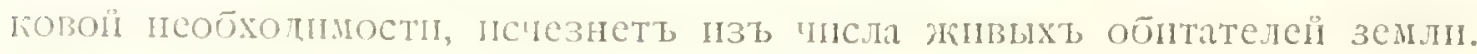

\section{Вашего Императорснаго Высочества}

всепреданныишіи слуга

Див Г. II. Ридае. 


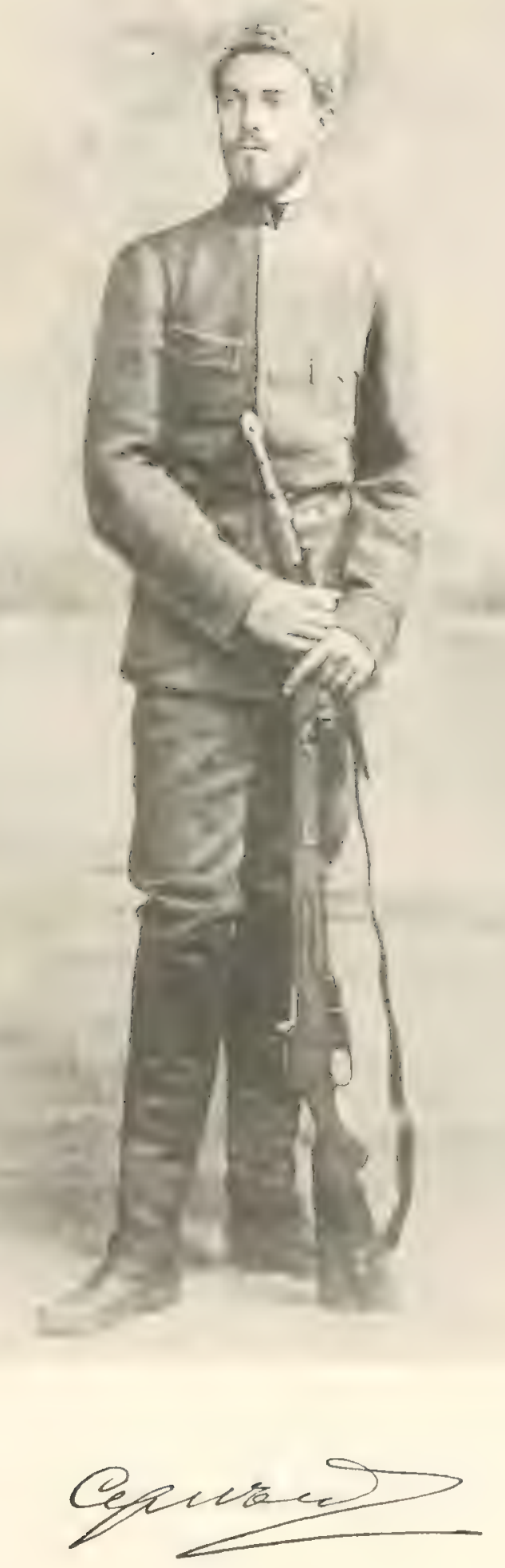





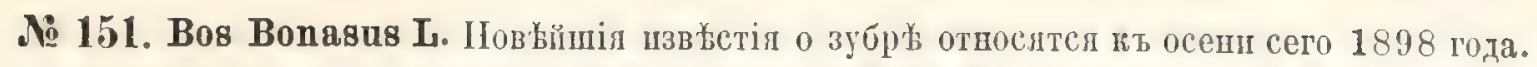

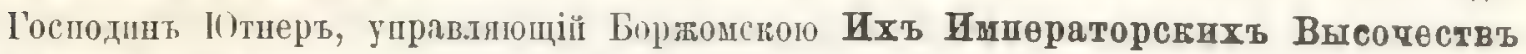

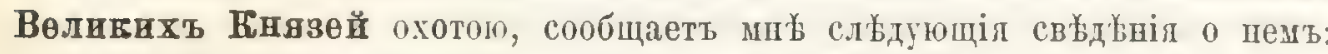

До 189.5 года вь охотничнхь угодьяхь Ero Нвператорскағо Высодества Веднкаго Князя Сергія Миханловича на líúaп пользовались пишь не столь отдаленими

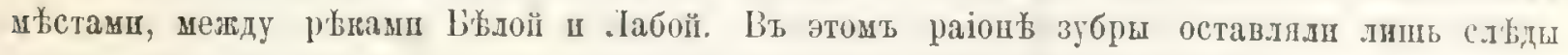
своего аммнго пребыванія, отступая во время охотпичьей порш въ болье отдалешше .тьса,

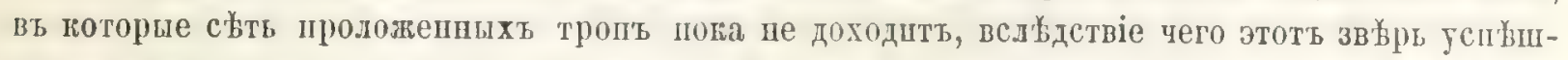

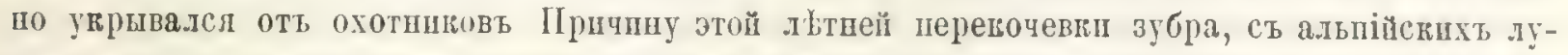

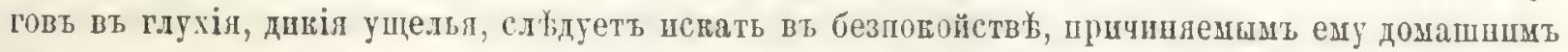

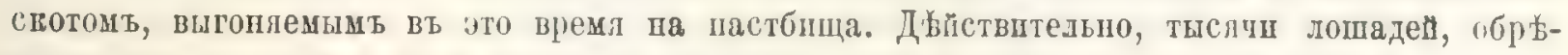

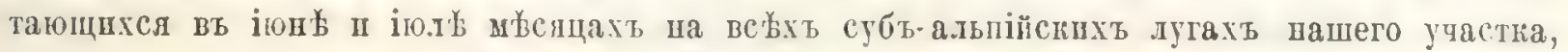
должны запугать дикаго зв'ьря ш заставить его уврыться въ льсныхь трущобахь ущелій.

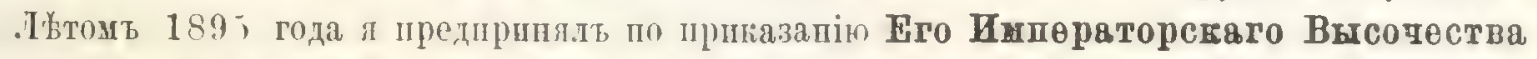

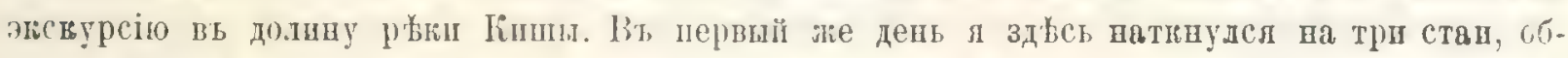

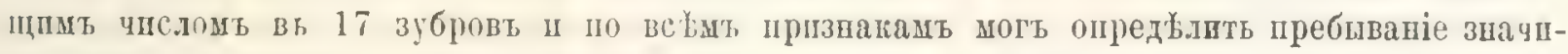

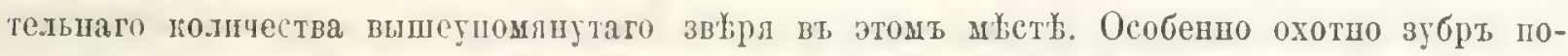

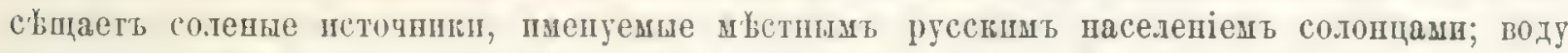
однапо онь не пьеть, по облизлваеть омываемье ею камни. З наблюдаль за 4-мл әпзеплярамп, которые запималпсь әтим часамп. Солонцы соеднены тропамп, протоптанным

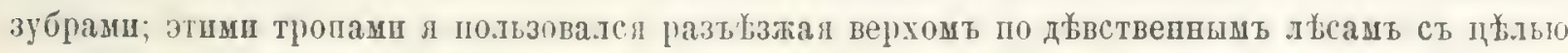
опредълить колпчество дичи.

Веспой, до полвленія домапняго скота, т. е. въ мањ и началь іюпя, зубры встрб-

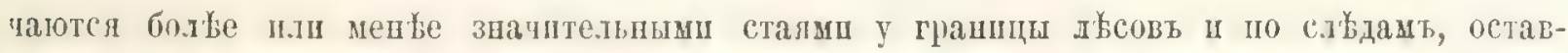

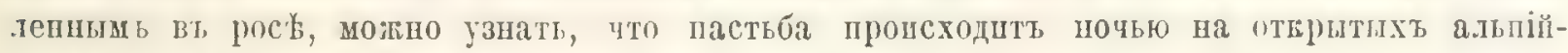
скихъ лугахъ; всльды затьшт, животныя переходять юь солонцамь. IІисутствіе зубра вь

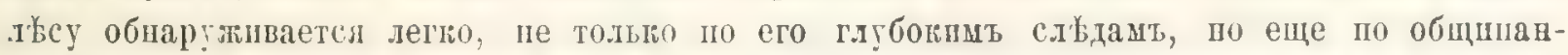

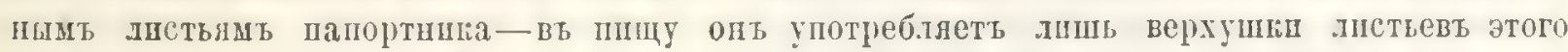

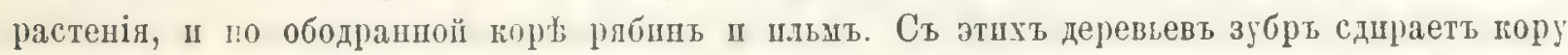
круглый годъ, но особепно усердстуетъ весной, когда растенія вь соку, шрп чем кора срывается имь длинымп полосами съ пизу вверхь. Сдираніе коры съ других древесинъ породъ, жромњ упомянутыхъ, не замғчается.

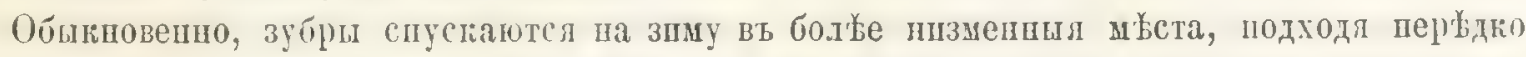

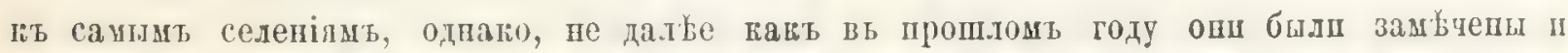
высопо вь горахт, между рынами Мальеной п Абагой, гды благодаря глубовому сштгу

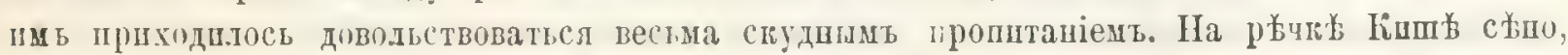
разложенное вь голодную пору вь видт опита, зубрц не тронули, за то опи съ жадностью пабросились на прпготовленную для нихъ соль.

Во время лра вт августћ, каждый самець обзаводится 2-6 самиам. Борьбы между бугаями вь это время не замњалось, такте пе было слышио рева. ПІлодовитость зубровю

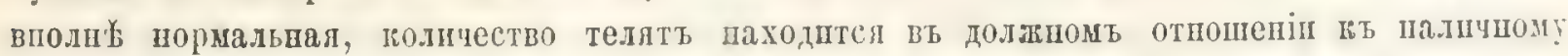
числу самокь, дающихъ прпшлдъ съ 3-го шли 4-го года.

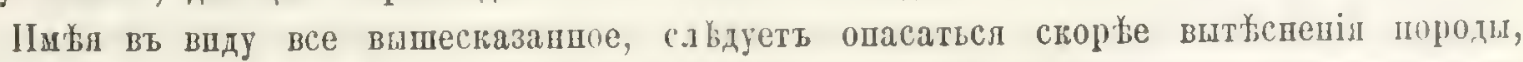

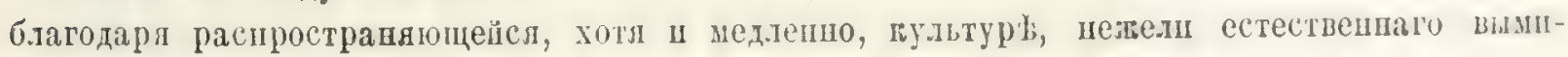

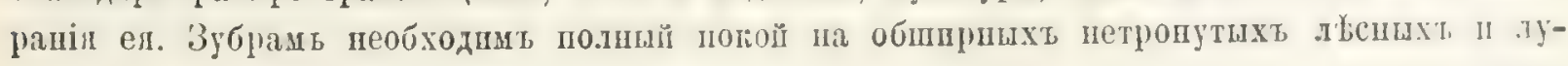
говихь участкахт, близость человьга они не перепосятъ. 


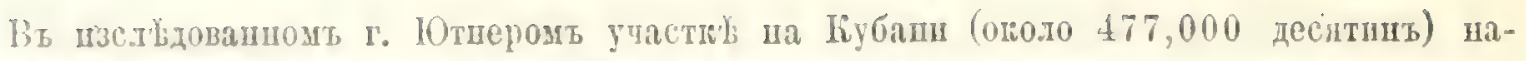

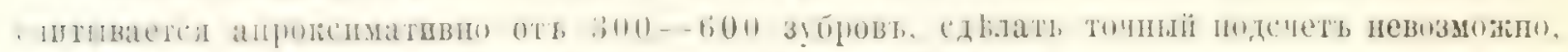

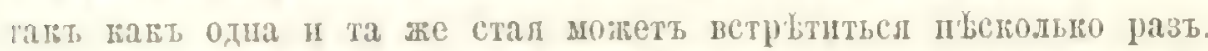

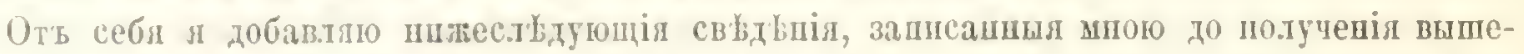
ириведениаго иисьм r. l0тнера:

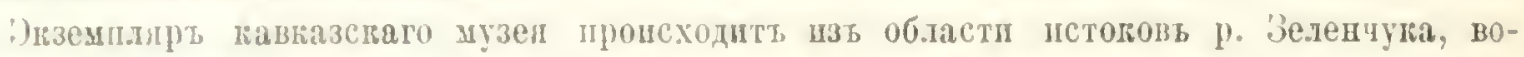

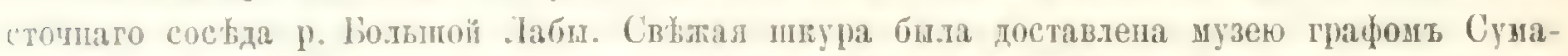

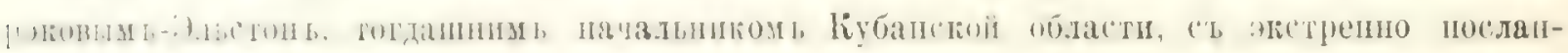

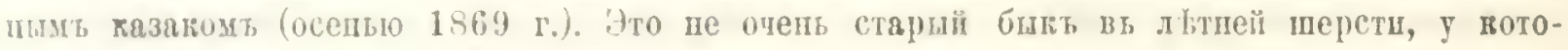

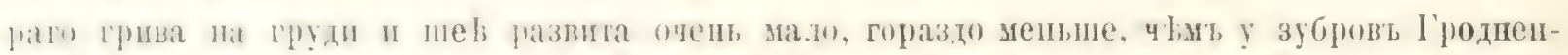

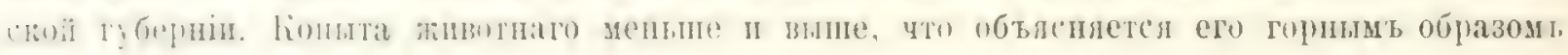

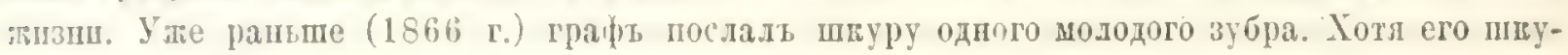
ра была всл цыла, ио волосы во многих мвстахт был уже испорчены. Iосль получеиія хоропаго эвземляра л уле могь устранит плохои. До 1892 года это быль едивст-

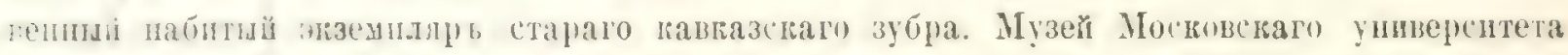

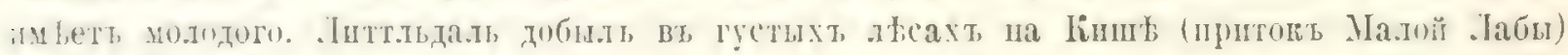

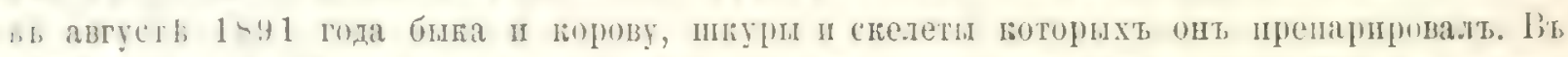

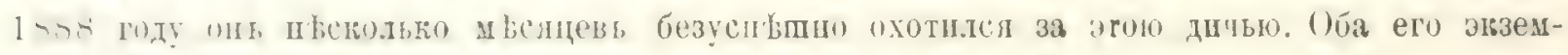

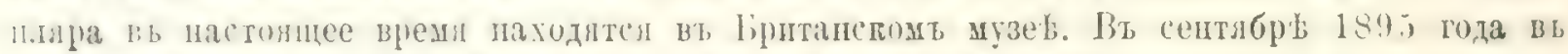

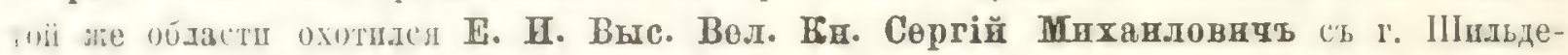

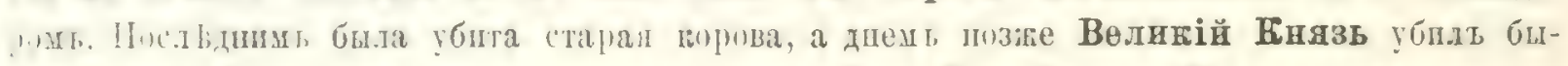

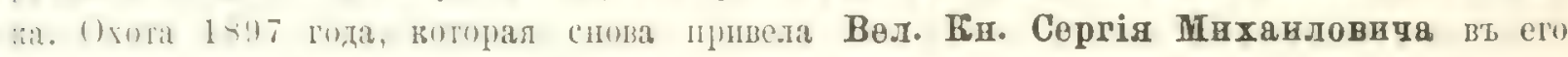

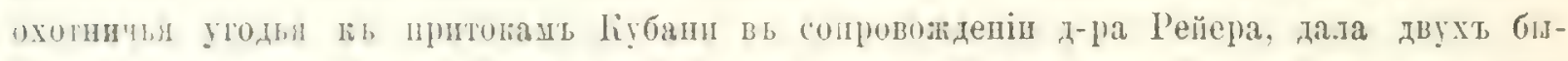

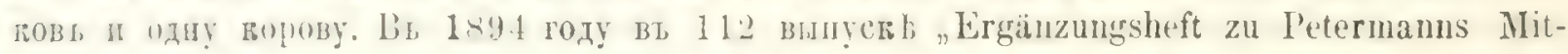

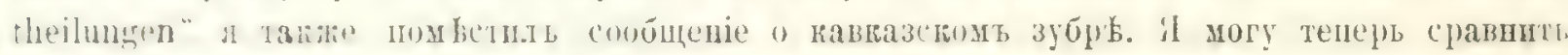
шхь съ новымп данпыи и вахожу, что все тогда сказаннее подтверғдаетсл. Также и дю-

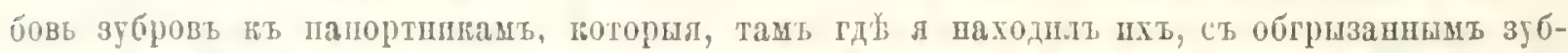

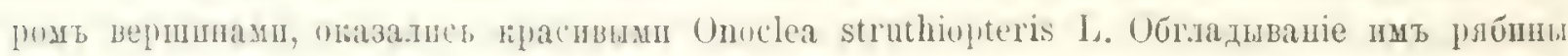

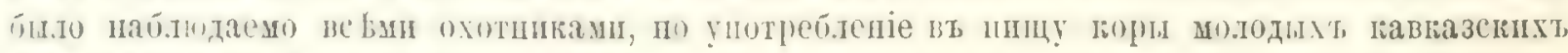

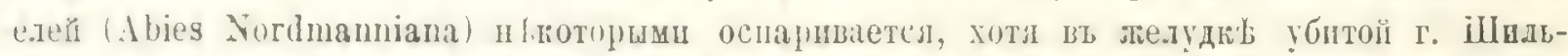

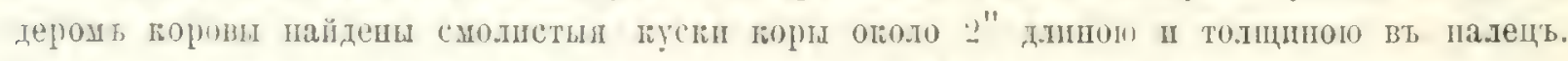

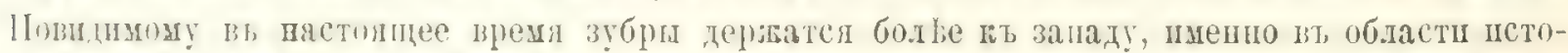

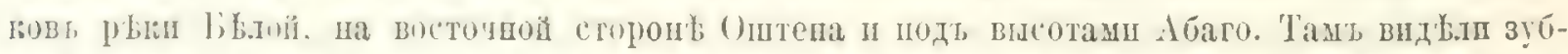

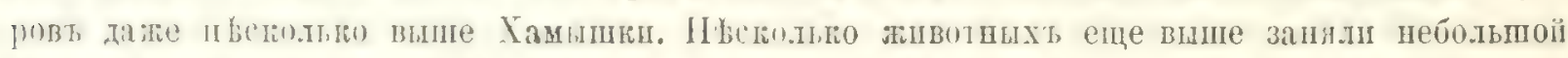

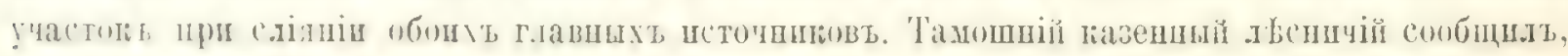
что они попали туда недавно, посль того гағт были потревожены въ 1897 году па Уруш-

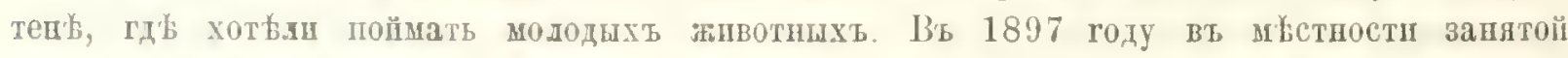

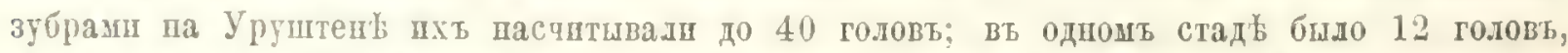
вь другығ-

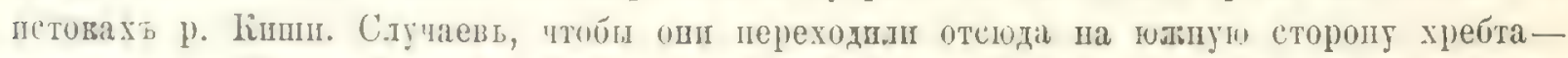

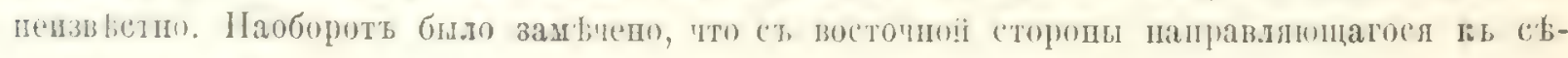
веру отрога Абаго, вт верховьяхь увкой долина Теге, зубры зпмою спускаются иь Дахе,

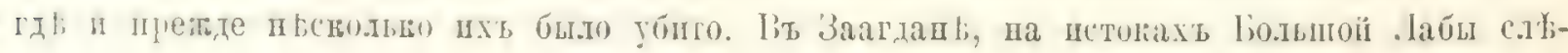

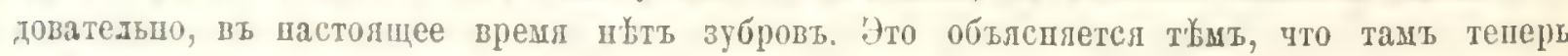

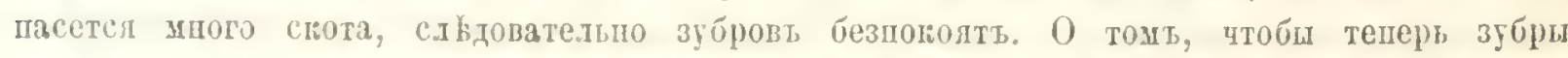

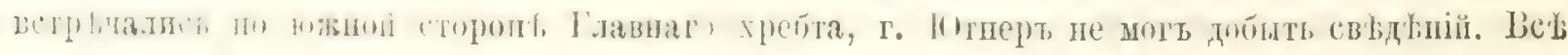




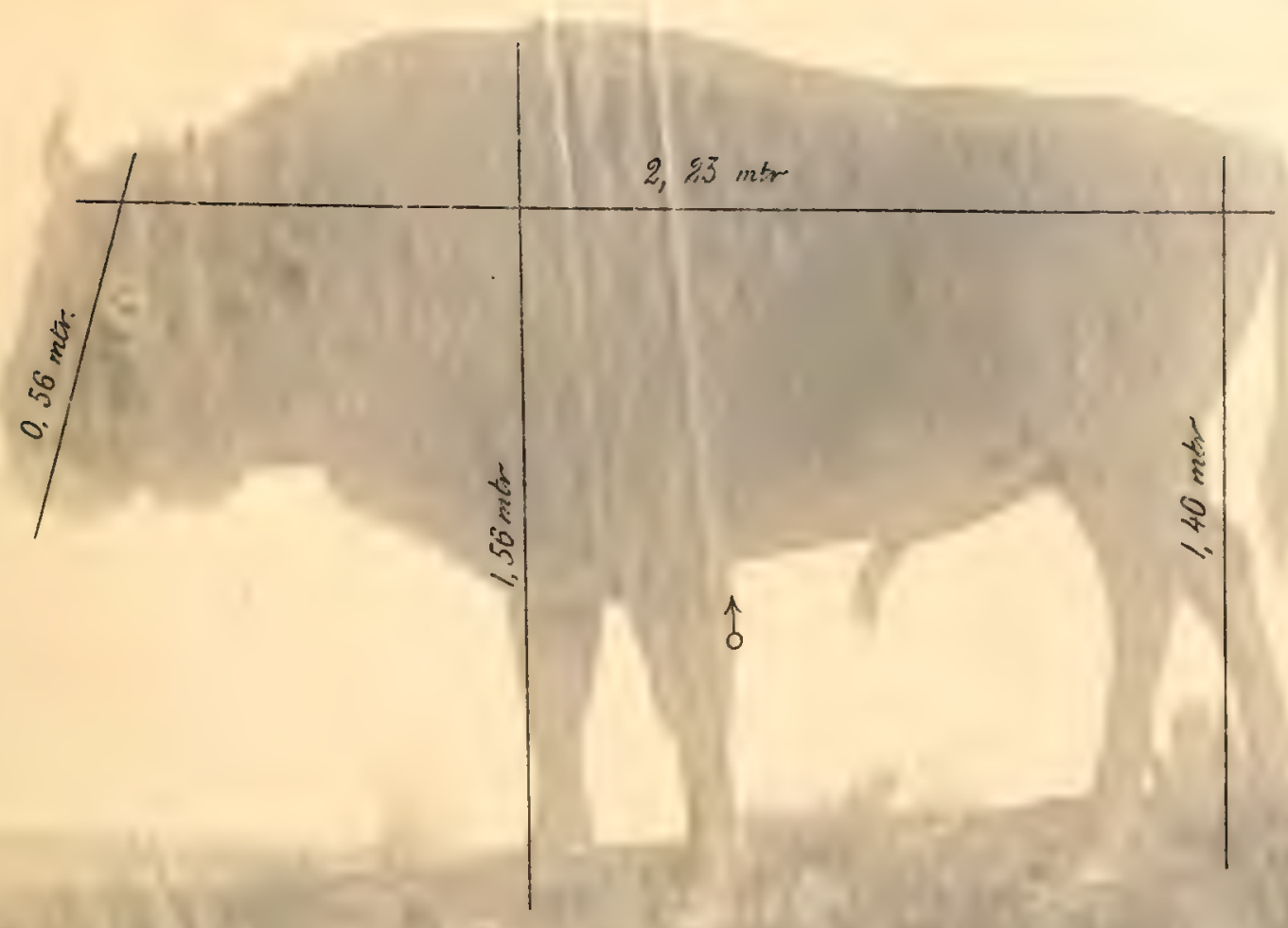

Bos bonasus. Зибрб

Wisent.

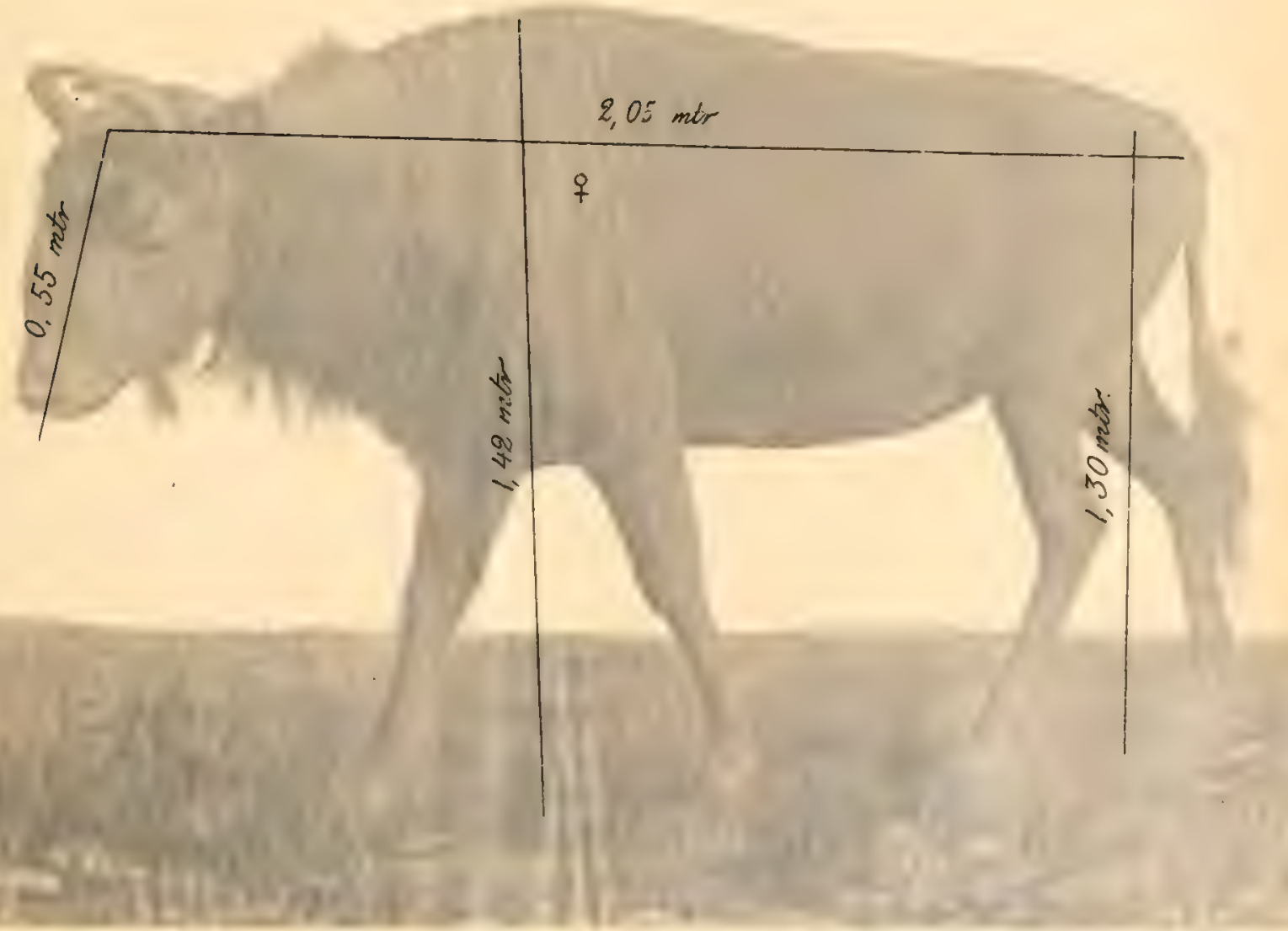


VIX Ból $^{1}$

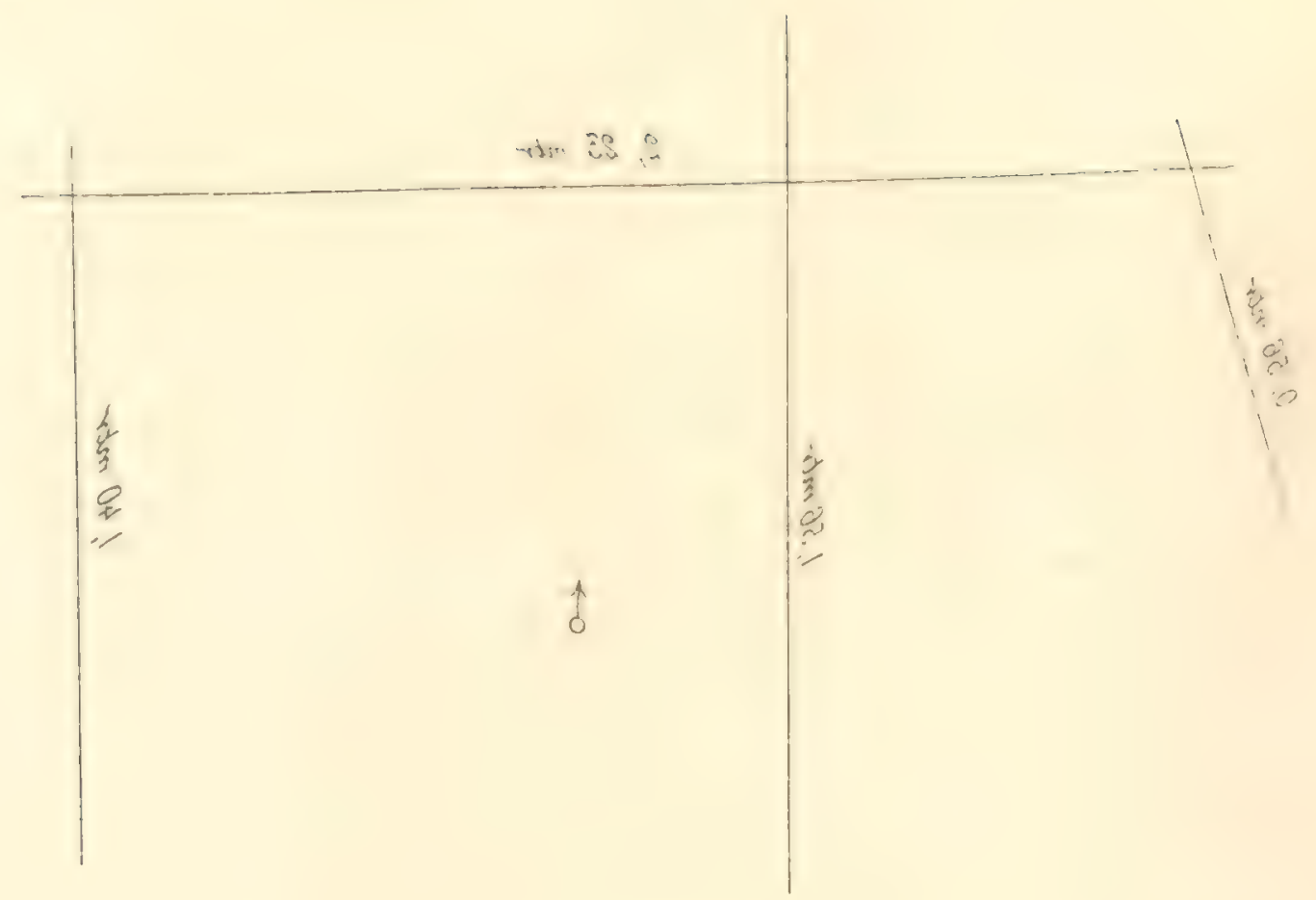

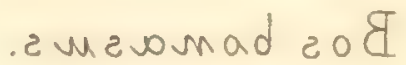

aqons

draciW

tim $20 ?$

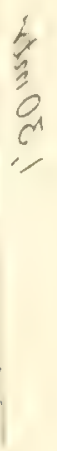






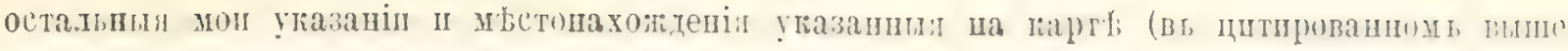

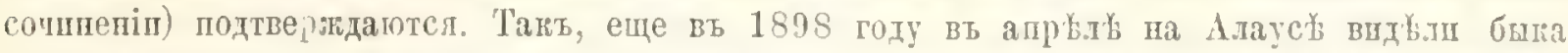

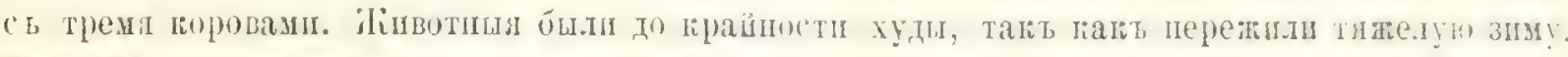

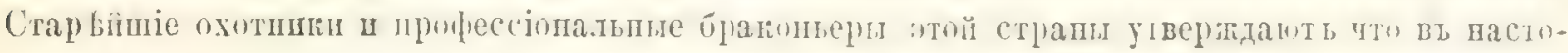

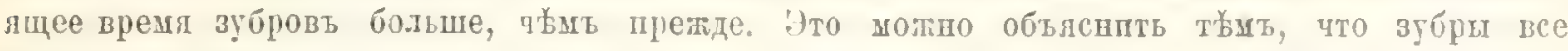

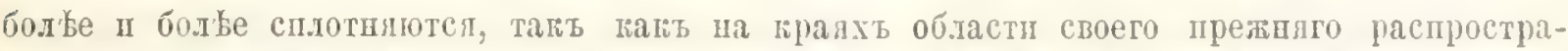

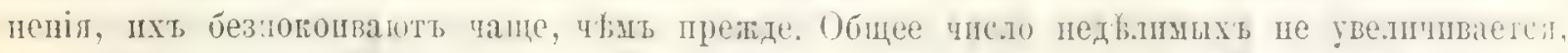

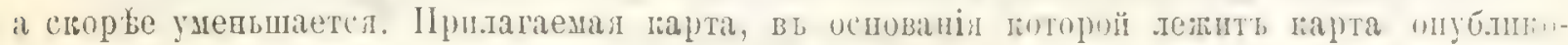

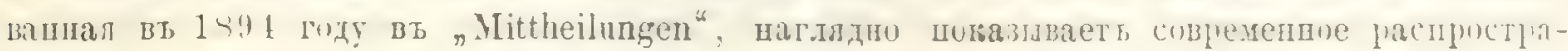
nеніе зубра.

\section{E T A C E A.}

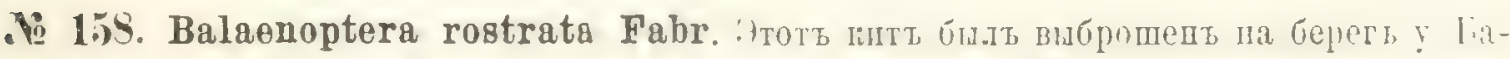
тума вт Mán 1880 T.

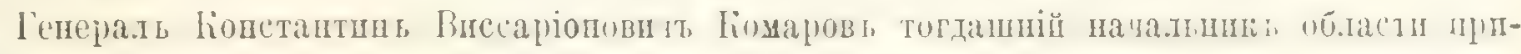

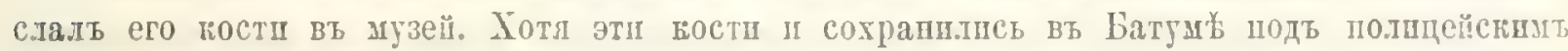

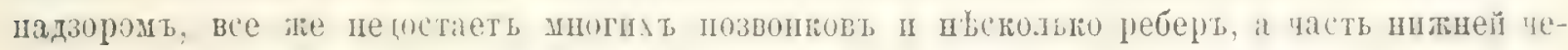

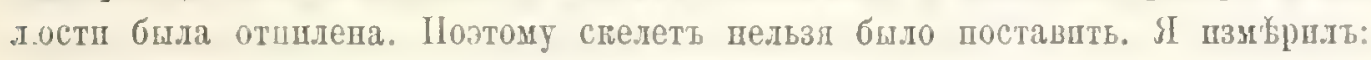

Длина черепа отъ for. осрt. до гопца носа . . . . . . . . . 2 mtr.

Напбольшая ппрна между глазнымп впадппамп . . . . . . . . 1,2 mtr.

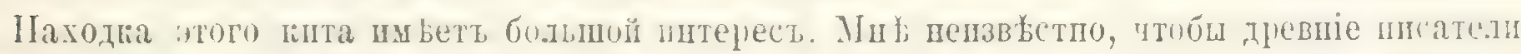

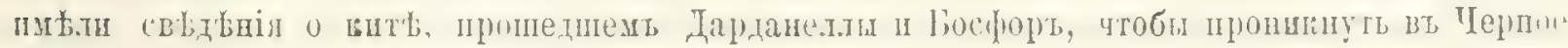
море. Вь новййі же времена это безуловно единственный случай. 
Hitze und in la an Sinuren hingen die fledermase am frostein, oft mit einem Jungen. ber sewolbte sinbulen schaute nur an seinen bochsten Stellen aus den zimmetbraunen. trockenen aber harten Lxcrementen hervor. Seitwärts waren die Tiefen $1-2^{\prime}$ hoch mit

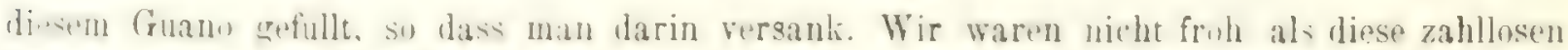

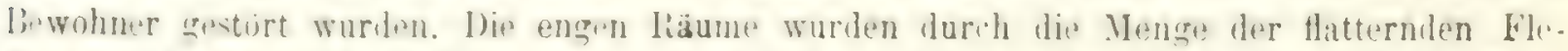
dermäuse buchathlich endult, man konnte sich ihwer nicht erwehren. Das muledentende ligug-

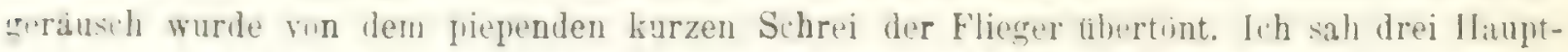

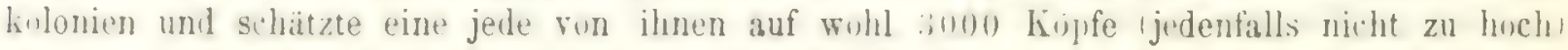
Fis crab zwei Mittel diese Plage zu beseitigen. Da die Fledermäuse aus den Irachräunen in die Haupthuppel und zu den langen schmalen Lichtuffnungen an den Wänden derselben allnachelich in's Freie gelangten, so konnte man sie durch starken kauch wohl vertreiben. Fis hatte derselbe auf dem steinfusiboden der Kathedrale erzeugt werden mussen und das wirksamste Material dazu wäre getrockneter Mist gewesen. In 2 his :3 mal vier und zwanzig stunden bestindiger Raucherung wäre wohl kaum eine Fledermaus in den Riumen geblieben. Iann hätte man die Lichtüfnungen durch enge Drahtgeflechte schliessen mü-ien. Iuf diesen Vurschlag gingen die (reistlichen nicht ein, weil nach ihrer Meinunı die hirehe dadurch entheiligt werde Es blieb als, nichts anderes ubrig zu thun als im Winter die schlafenden Thire alsammeln zu la-sen unter allen Bedingungen aber die Lichtrinfälle zu verschliessen.

Die Kolonie dieser Art in Abchasien, welche H. Koenig unweit von Gudant am $2^{-t}$ Juni 1893 besuchte zählte nur nach wenigen IIunderten von Exemplaren.

R.

li 19. Rhinolophas hipposideros Bechst. Variirt sehr in Grusse und Firbung. An hellsten sind die Exemplare ro:n Araxes . 19 d. In Cis-und Transhaukasien. In Jahre 1897 fing ich ein Evemplar in Lenkoran $0^{\prime}-2000^{\prime}$.

.. 21. Rhinolophas Blasii Peters. Rh. clivosus Cretsch. hei Radde und Walter 11. c. p. 998) diese Bestimmung wurle nach Blasius (1. c. p. 33) gemacht, aber, wie bekannt, so ist dessen Rh. clivosus gleich Rh. Ilasii Peters und nicht Rh. clivosus Cretschmer. E: ist sehr müglich dass denselben Fehler wie Blasins bei der bestimmung dieser Art auch Kinlenati ${ }^{1}$ ) und brandt ${ }^{2}$ ) machten und dann muss letztere Art aus dem Verzeichniss der kaukasischen 'Thiere gestrichen werden. Die Form der Nasenanhingsel ist hei dem unzweifelhaft kaukasischen Exemplare nicht völig identisch mit der Zeihnung von Bla-ius, jedoch ist es nach der Lage des ersten falchen Backenzahnes unbedingt auf diese Art zu beziehen und nicht auf clivosus Cretsch.

.2. 2. Rhinolophas earyale Blasias. Unser Hxemplar entspricht vollständig der Beschreibung von Blasius (1. c. p. 35).

Sat.

\section{INSECTIVORA.}

Die sammlung de Kaukasischen Museum: schliesst alle Arten dieser Ordnug sowohl des Kaukasusländer als auch Transkaspiens in sich. mit Ausschluss der zweifelhaften und nicht heschriebenen ('rocidura longicaudata IDobs. Dieses Genus bietet bei den Bestimmungen der Arten grosse Schwierigkeiten and zwar sind bei grosser Anzahl ron Exemplaren diese now bedeutender als bei geringer. In der Sammlung durfte Sorex Iaddei, welche ich im Jahre 1495 beschrieb, das bearhtenswertheste Stück sein, es ist bisjetzt das einzigre Exemplar dieser Species, welches bekannt wurde.

Sat.

3) Kolenati. Monographie der europäischen Chiropteren. Brüan. 1860.

$\left.{ }^{2}\right)$ I. F. Brandt. Die Handflügler des europ. u. asiat. Russlands etc. 1851. 
Ni 23. Erinacens europaens L. (Aanz identisch mit dem europäischen Igel. $0-4000^{\prime}$ Ménétries) $\mathrm{Y}$ - und S. Seite des Gebirges.

1i 24. Erinaceus auritus Gmel. Die Masse an utiserem Exemplare sind folgende:

Nasenspitze bis Schwanzbasis . . . . ... $170^{\mathrm{mm}}$

Schwanzlänge. . . . . . . . . . . $21^{\mathrm{mm}}$

Ohrenhöhe vom Scheitel. .......... $31^{\mathrm{mm}}$

Grösste Länge der Stacheln. . . . . . . . 17 $17^{\mathrm{mm}}$

Obwohl die fraheren Forscher diese Art aus den Umgegenden von Iaku aufuhren, so haben das die jüngeren bisjetzt nicht bestätigt. Mir ist der Ohrenigel nur von der Nordscite des Kaukasus bekannt, wo er im gesammten steppengebiete, im üstlichen hiutiger als im westlichen vorkommt.

Ni. 25. Erinaceus macracanthus Blanf. Eine grosse Anzahl ron transcaspischen Igceln welche ich von verschiedenen Personen erhiclt und untersuchte gestattete mir die Haut sub .t: 25 im Kauk. Museum als zu dieser Art gehörend zu erkennen. Ls ist ein Albino, wenn man das noch so nennen darf, obwohl mehr als die Hälfte meiner transkaspischen Igel dieser Art ebenfalls diese helle Färbung besitzt. Ich glanbe, dass die helle Farbe nur durch Verbleichen entstand, da junge Thiere stets dunkel waren.

№ 26. c. Crossopas fodiens Pa1l. Von Koenig bei Kasikoporan gefunden, weist einige interessante Eigenthümlichkeiten auf. Dieses Exemplitr ist etwas grösser als die von Mittelrussland, der Schwanz ist rundherum mit einzelnen weissem Haar besetzt. Dur Kiel der langen Haare ist ebenfalls weiss und geht nicht von lieginn der Basis wie bei den russichen Exemplaren, sondern fängt erst $40^{\mathrm{mm}}$. vom Ende des Schwanzes an, gerechnet von den Spitzen der Fndhaare. Auf den ersten Blick erscheint der Schwanz braun, da durch die wenigen weissen Iaare die hellbraune Schu,penbeleckang der Haut durchschimmert. Die hinteren Sohlen sind an diesem Exemplare schmäler und düner als bei den mittelrussischen. Im Zahnbau kann ich keine Unterschiede tinden. Ich lasse die Masse dieses Exemplares folgen und setze ihnen die eines im Moskauer Kreise erstandenen zur Seite.

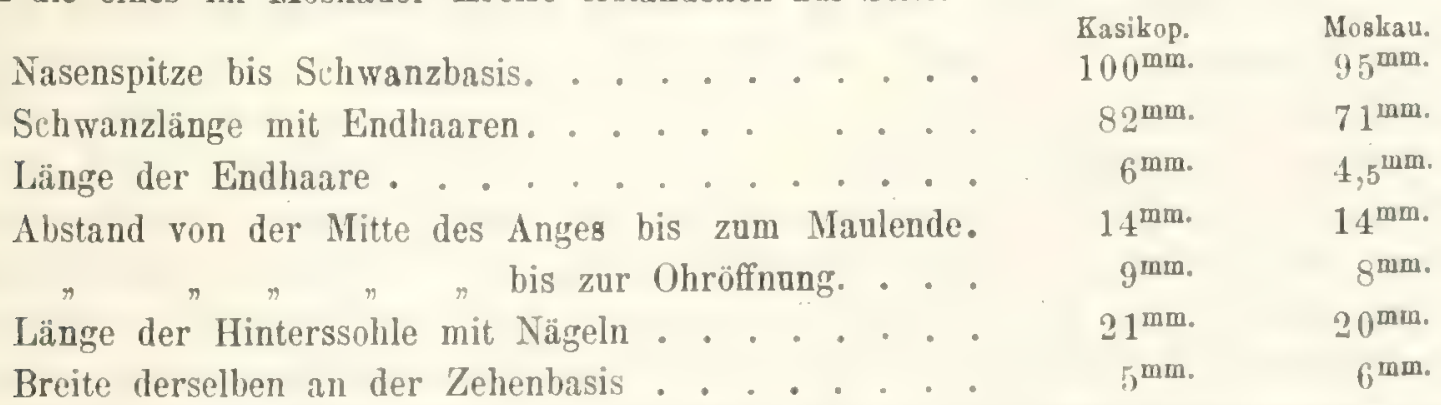

Ni 29. Sorex Raddei 8at. Bei neuerdings abermali ausgefuhrter Untersuchung dieser Spitzmaus, welche ich 1895. im Archiv Naturg. V. 1 pag. 109 beschrieb, bin ich noch mehr davon uberzeugt worden, dass wir es hier mit gut gesonderter Species zu thun haben, welche im Kaukasus S. alpinus rertritt.

Sat.

Nie 30 a. Sorex pygmaous Pall. Wurde im Sommer 1898 zum ersten Male für den Kaukasus von Bakuriani (5000') nachgewiesen.

R.

.12 3: Crocidura ressulus IIerw=C. araneus auct. Snwohl aus den Sammlungen des Kauk. Huseums wie auch aus den meinigen liegt mir eine grosse Anzahl von biomplaren dieser Art aus dem gatmzen tehiete und auch aus Transkaspien vor, ahe: ‘ fohlt mir leider ein spiritusexemplar aus Westeurnpa ${ }^{1}$ ). Jio genaue Intersuchung dine suite,

1) Eine Sendung von Spiritus Exemplaren kleiner europäischer Sänger, welche Profo Mühius mir sendete wurde rom Zollamt in 'Jiflis vernichtet. 


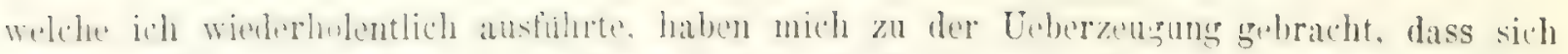

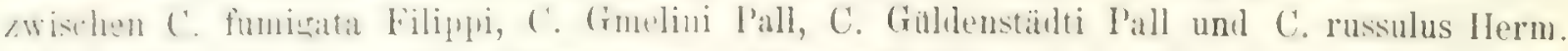
sthhhaltigen Giremen nicht ziehen bissen. Schwanzlingen und Colnrit schwanken ausserorWentlich und dabei sind alle Varianten durch ganz allmahliche lebergiage untereinander berhumden. Der I'mfang der Mitheilumen in diesem kataluge gestittet mir nicht in die

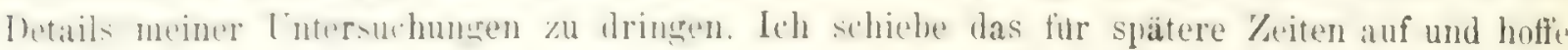
es in cinem der. Hefte der "Nittheilungen aus dem Kauk. Museum" zu thun. Hier nur noch

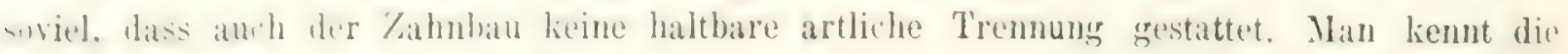
Cociduren im Kaukasus bisjetat von $0-4000^{\prime}$ Meereshöhe.

N 34-3.). Talpa europaea L. and T. caeca Savi. Ille Maulwurfe welche bisjetyt in Tran-kitukasitn gefunden wurden gethoren zu T. caeta. I)ie Iugen sind volkommen durch die Ilaut verdertht. Ine mittleren wheren Sehneidezähne sind fast doppelt so brejt als dit seitlichen lie sumstimen Cinterscheidunesmerhmales stimmen nicht ganz zu der beschreibung ron Blasius (1. c. pag. 115) doch hat schon Dobson auf ihre Unhaltbarkeit hingewiescn (Dobson, A Monograph of the Insectivora Pt. II. pag. 139). Das Exemplar 34 c von Stawlupol hat zwar auch granz verdeclite Augen, aber die Schmedezähne sind alle von gleicher Ireite, deshalb stelle ich es zu 'T'. europaea. Der Kaukasus wird also zum Scheider fur beide Arten. Radle fand 'T. caeca noch in $8500^{\prime}$ an den Quellen des Rion (Goribolo).

Sat.

\section{A R N I V O R A.}

Dig. :36. Felis tigris. Die beiden Exenplare des Museums, welche ich 1866 von Lenkiran mithrahte, tragen kurzes Sommerhaar: sie wurden Mitte April dort erlegt, wie man mir sagte, in der Ňähe der Mineralquellen, d. h. circa 12 Klm. landeinwärts von Lenkoran auf dem gut hewaldeten Gehirgsfusse. Ich sah aus dieser Gegend nur weissbrastige Tiger von nicht sehr starkem Wuchse. Damals war der Tiger garnicht selten in jenem $\mathrm{N}$. W. Finde des Alburssystems, lebte aber rornehmlich im Tieflande und in den äussersten VerHachungen des Gebirges. Im Verlaufe von 7 Wuchen brachte man mir, da ich huhe Prämien arboten latte, sechs Tigerfelle, fon denen die beiden oben erwähnten ganz frisch, die and.ren schon mehr oder weniger aufgetrocknet und im Haare theilweise verdorben waren. lirstaunt war ich während meines achtmonatlichen Aufenthaltes im Gebiete von Talysch (Norb). 1. () bis August 1 isol keine frischen Tigerfelle, trotz guter Preise, gestellt zu bekommen. (nfinbar war das Thier i!n weiteren Umkreiso von Lenkoran entweder garnicht rorhanden, oher doch sehr selten. Auch $1: 9 \mathrm{t}$ im December hörte man nur von vereinzelten Fảllen in denen ein Tigrer sich fezeigt hatte und zwar immer nur im Tieflande. Ich bin uberzeugt, dass sich diese Lrscheinung richtig erklart, wenn man bedenkt, dass das Wildschwein in der sumptigen Kiustenzone von russ. Talysch in den letzten Decennien sehl stark beschossen wird. Dieses liefert nämlich dem lionierstiger hier, wie auch in Transkasplien die Hauptnahrung und er geht dem $\$$ lıwarzwilde nach. Ils ich vor dreissig Jilhen zum ersten Male in Lenkoran lebte arab es noch starke Saubestimle auf ler ganzen Strecle bis Astara. Die mohamedanische lievilkerung kummerte sich un diese wenig, die russische lievölkerung war gering, Jäger nur vereinzelt. Hit der Zeit veränderte sich das. Es kamen Jäger von l'rofession im Winter durthin, zu Humderten, wenn nicht zu Taukmden wurden die mogrzihlten Wildenten dort für

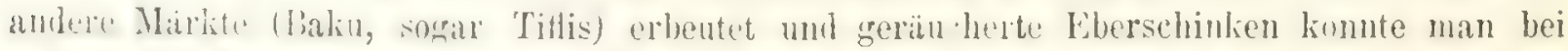
manchen liewhinern dutzendweise sehen. In. Vohamedaner schossen auf I?estellung für cin 
Geringes die Beute, aber rührten sie nicht an, man musste sie selbst holen. Die Folge war, dass das Wildschwein viel seltener und damit auch sein Hauptverfolger, der Tiger rarer wurde. In jungster Zeit nun sollen wieder, wie Herr Satunin mir mitheilt, Wildschweine und Tiger in einer Gegend häufiger geworden sein, wo die Bewohner zwar Russen, aber Sektirer sind, die ebenfalls, wie die Mohamedaner, das Schwein fur unein haltun. Ls ist das das grosse Dorf Prischib, schon in der Ebene $60 \mathrm{Klm}$. vom åussersten Nordfusse des Gebirges gelegen. Hier sah S. einen jungen Tiger in der Gefangenschaft, dessen Iluter im Winter 1896-1897 geschossen war. Mag sein, dass solange der Tiger gut genäht wird, er an der betreltenden Localitat senshaft beiht Lus meinen ostsibirischen Erfahrungen weis; $\mathrm{i} \cdot \mathrm{h}$ aher, dass er seinen Iufenthaltsplatz doch wechselt, sobald ein gewisses Revier rum ihm bejagt und die Nahrung darauf spärlicher wurde.

Verburgte Nachrichten uber anderweitiges Vorkommen des Tigers in den liaukasuslindern liegen gegenwartig nicht ror. Dass der 'Tiger quer durh die Mugan zun inhahlange des Cirossen Kaukasus gewandert und in letzteren gelebt habe, bezweitle ich. Auch über sein Vorkommen in der Gegenwart am mittleren Araxes, wie Grevé ${ }^{1}$ ) angiebt, habs ich nichts Sicheres ermitteln lionnen. Tournefort ${ }^{2}$ ) crwähnt sein Vorkommen zu Infang des virigen Jahrhunderts bei Lrzerum. 'Tshichatsehef ${ }^{3}$ ) spricht von ihm. Ich bereiste fast ganz Hocharmenien, man verwechselt ihn da oft mit dem Panther, ja bei Kulp musste ich die Erzählungen vom quasi Tiger auf die Hyaene deuten. Wir wissen ron Brandt ${ }^{4}$ ) dass im Alterthume die beiden urossen Katzen, Tiger und Panther gegen X. W. weiter verbreitet waren als in der Gegenwart. Güldenstädt und Chardin führen den Tiger noch aus Mingrelien an, sogar aus der Ratscha, sprechen auch von Löwen und Panthern. Ich halte dafur, dass sich alle ihre Angaben in der That nur auf den Panther beziehen, der auch jetzt noch in jenen Gebiet n leht. Das Vorkommen des Tigers bis zum westlichen südusse des Grossen

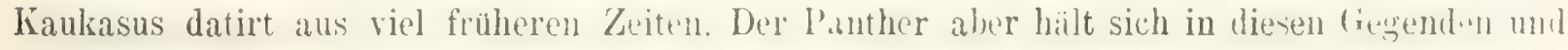
auch an der Nordseite der Hauptkette bis in die Gegenwart.

Seit jener Zeit wurde dem 'Tiger sein Verbreitungsgebiet sehr weit gegen S. O. zuruck geschnitten. Der Panther behauptete dighgen sein Revier gegen $\mathrm{N}$. W. Wie wir gleich sehen werden, viel standhafter. In allen Fällen, welche nur privatim oder in den Localblättern das Vorkommen des Tighrs ausserhali) von Talysch auf russischem Boden medeten und di.

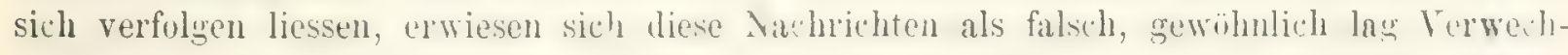
selung mit dem Panther vor. Ostwärts, entlang der Südküste des Kaspi, namentlich im

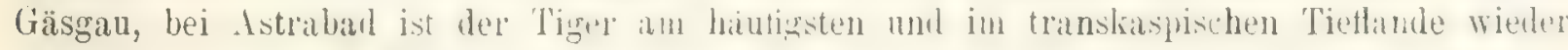
vornehmlich auf das Wildshwein, somit auf die dichten Rohrhestionde cntlang den wriveren Flüssen angewiesen. Schon am Tedshen trafen wir ihn 1886 an Ein von dort stammentes Fell, 36 d gehört der langhaarigen Form ( $\mathrm{F}$. tigris longipilis Fitz) an.

Dass es unter den talyscher 'Tigern auch starkwüchsige Exemplare griebt, erkennt man am Schädel, den Fürst Witgenstein dem Museum schenkte. Dieses Exemplar, lí 36 b, wurde

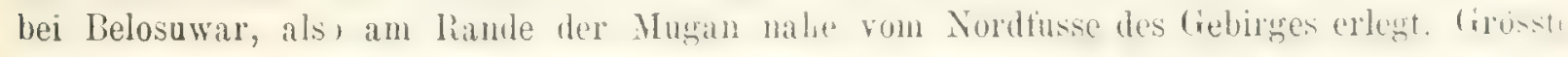

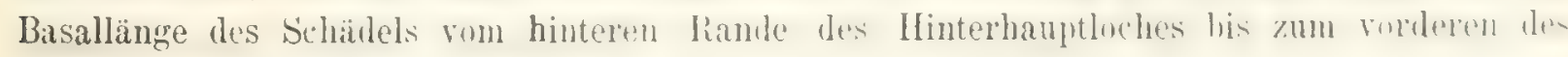
Oberkiefers. 36,5 Ctm. Grösste Breite in den Jochbögen $27 \mathrm{Ctm}$.

Ni 37. Felis pardus I. typ. et vart. tullianus Dem. ot vart. leopardus L Li wirl

8) Carl Grevé. Uebersicht der geographischen Vertheilung jetzt lebender Feliden, in Zool. Jahrb. 131. 1\%. 1. 63.

$\left.{ }^{2}\right)$ Relation d'un voyage du Levant ect. par M. Pitton de Tournefort Vol. 1II. pag. 216.

$\left.{ }^{3}\right)$ Asie mineure. Vol. II. pag. 612-613. Der Autor sah aber das 'Thier nicht.

-) Untersuchungen über die Verbreitung des Tigers ect. Mémoires de l'Acad. Imp. des sciences de St.-l'th. T. VIII. 1859, pag. 175 sgt. 


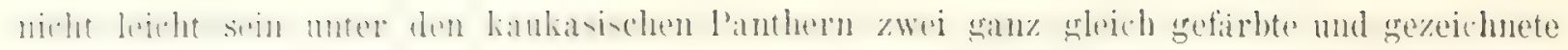
Exemplare zu finden. So lautet wenigstens mein Urtheil nach den vielen Fellen, die mir lurch die Hände gingen. Am mittleren Araxes in der Lingschlucht abwärts von Migri sah ich sehr starke Exemplare im Sommerhar, deren Grundfarbe kaum etwas in Gelbhamois getrublt war. Dic dunkelsten von anderen Localitäten weisen ein lichtes Brïunlichgelb als Cirundton auf. Weder die Zeichnung der Ringe, ihr mehr oder weniger intimer Schluss der

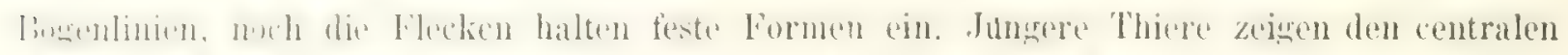

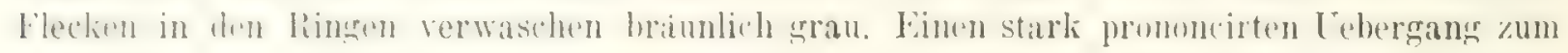
Leoparden kenne ich aus dem Kaukasus nicht, wohl aber aus Transkaspien. Bei Herrn Oberst Westmann in Aschabad sah ich das herrliche Fell (1886) und zeichnete es, da es nicht fortgegeben wurde ab. Die Grundfarbe war obenher recht dunkel, an den Flanken wurde sie heller und ging allmählich in das reine Veiss der Banchseite uber.

l'anther leben, wenn anch nicht beständig und in grosser Kahl, so doch ab und zu vinubergehend fitst uherall im Kaukisus mit Ausichluss der ausgedelmten Elenen und steppen. Ihr Vurkmmen hängt lieinesweges ron den Wiildern vielmehr nur vom Nahrungsteichthum an grisicen Thiern ab. Im mittleren Araxes leben sie im wasserlosen, nackten, zerklüften Fohengelirge nur deshalb, weil dort die bezar Ziegen sehr haufig sind, denen sie am Flusse bei der Tränke auflauern. Sie bewuhnen die breite Zone ron 0 bis zum ewigen Schnce, also im Mitrel 10-12001 und gehen sowohl im Sommer auf die alpinen Weiden den Hausthieren, als ath ten oft wrosen Rudeln des Steinwildes nach. Mit diesen, wie mit jenen wechseln sie im Winter thalabwärts und besuchen, vom Hunger getrieben, nicht selten die Ansiedelungen der Menschen. Anfangs der fünziger Jahre wurde sogar bei Tiflis ein Panther im T'llereisen gefangen (Cieneral Kessler) und Nordmanns Mittheilung ${ }^{1}$ ), dass 1s.3.j Tiger bei 'Tillis geschossen wurden, wird wohl der Berichtigung auf Panther bedürfen.

Zu beiden Seiten des Grossen Kaukasus ist der Panther von 0 bis reichlich $10000^{\prime}$ viclfach nachgewiesen, aber. der Meridian vom Tuapse am NO. Ufer des Schwarzen Meeres, wo ein P'anther 1893 die Umgegend beunruhigte, scheint ihm gegenwärtig die Westgrenze seines Vorkommens zu zichen. Für Noworossisk und Anapa habe ich ihn nicht erliundet. Es muss bemerkt werden, dass östlich von diesem Meridiane die Kammhöhen des Grossen Kankasus rasch wachsen und schon im Fischt und Oschten die Schneelinie erreich"ll, hier auch die reichen Steinwildstände hrinnen. In der Nordseite hat das Jagdyebiet Sr. Ks!. Hoheit des Grossfürsten Sergei Michailowitsch in den letzten vier Jahren acht I'anther greliefert. Die Osseten liennen ihn. Oestlicher, im Dagestan, konnte ich ihn fiur die Vorkette des Salatau nicht erkundigen, dort soll aber anch der Tur fehlen. Dagegen steht es fest, dass im Winter 1881-1882. bei Majur-tup, im $3^{\text {ten }}$ Kreise des Bezirkes ron Grosny ein Mann im Walde vom Panther zerrissen wurde. Die Lesginer im höchstgelegenen Durfe Ímrusch $\left(8200^{\prime}\right)$ zu Füs.en des hohen Schah-dagh und Basar-düsu kannten den I'anther dem Xamen nach, konnten aber lieinen Fall aus jüngster Zeit melden, welcher das Vorkommen bestïtigt hätte:

An der Sudseite der Hauptkette scheint er im Centraltheile, so im unteren Alasan Cowifte, an häutigsten vorzukommen. Mehrfach wurden Panther bei Lagodechi, Sakatali, Nucha und in der Bumschluht erlegt. Westwärts liegen für das colchische Gebict mir ctliche Fälle über das Vorkommen zur Hand. Als ich 1864 zum ersten Male in die Iän-

3) Man müsite eigentlich nur dann auffallende Fundorte melden, wean man die in Rele stehenden Thiere selbst sals. Ich habe mich zu oft davon überzeugen können, dass die besprochene Beute sich nicht auf den Tiger, sondern mit Sicherheit auf den Panther bezog. Auf die Xachrichten von Hörensagen kann man fast nie etwas geben. 
genhochthäler von Colchis kam, kannten sowohl die freien-als anch die-dadianschen Suanen (Ingur, 'Tskenis-tskali) das Thier. Die letzteren namnten den Panther "Wóch " und auch nur mit der Bezeichnung von Katze: "Ziz", wussten, dass $1862 \mathrm{im}$ Scenathale zwei erlegt wurden, klagten darüber, dass er im Winter ihr Vieh würge. In Laschketi, dem tiefstgelegenen Dorfe am Quelliufe des Hiplos bevor er Hach s. in die Engsehlucht nach Mu. i biegt, kannte man nur den Namen des Thieres, aher lieinen Fall uber sein Vorkommen. Im unteren Mingrelien und auch in der Küstenzone ron thchasien sind die Fille des Vurkommens wohl nur sehr selten, doch liannten lie Iewohner $\%$. B. ron Ishwari das Thiel als im Hochgebirge lebend. An Psyb wurde 1861 ein Panther erlegt. In Abchasien nannte man ihn Alm. Von Sotschi liegen mir zwei Fälle vor, 1876 wurde Nachts ein im Freien schlafender Arbeiter von einem Panther alerfallen, die liestic verwundete inn schwer im (renik und wollte ihn fortschleppen, er wurde gerettet und im Hospital geheilt (Garbe, Grot).

Auch für das Rion- Kura Scheidegebirge, für das pontische Küustengebirge, wie für den gesammten Antikaukasus, vom Trialet-über das Gandsha Gebirge nach Karabagh hin liegen sichere Nachrichten iiber das vereinzelte Vorkommen des Panthers vor. Auf der Domäne Borshom wurden im letzten I)ecennium drei I'anther im Wildpark vergiftet. Für das Iraxesthal kenne ich sichere Fälle von Kulp und aus der oben schon erwithnten Engschlucht, dic: bei Ordubad begimnt und sich lart an der steilen sülfront des Liarahagh Gebirges hinzicht.

Am häutigsten aber traf ich den I'anther wieder in Talyseh an. Bei guten s:hussprämien wurden mir in Lenkoran 1866 während meines siebenwöchigen Aufenthaltes 12 frische freilich zum 'Theil verdorbene Pant'lerfelle gebracht.

R.

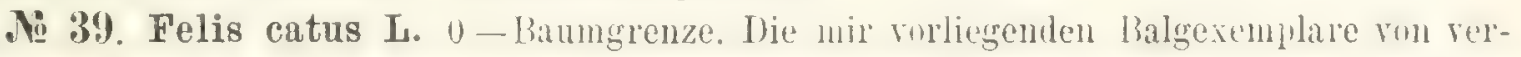
schiedenen Orten de's Kaukasus weisen keine wesentlichen Lnterschiede in C'nlurit auf. Die meisten haben eine stark in's Gelbliche zichende, grane Grundfarhe. Nur ein Excmplar aus Sakatali ist reiner grau, es ist cin starker Kater, seine grösste Länge von der Nasenspitze bis Schwanzwurzel Leträgt 69 Ctm.; die Schwanzlänge mit Haarspitze 34 Ctm.

Am häufigsten und stärksten muss die Wildkatze in den Wialdern Adshariens sein. Ditfur s srachen die bedeutenden Fell Vorräthe in den Buden Batums, die ich als die Winter ausbente von 1892-93 dort musterte und meine Auswahl traf.

Die Wildkatze ist da, wo Wald vorhanden, im Kankasus überall zu finden, in Mittelgebirgs am häufigsten. Verwilderte Inauskatzen in Colorit dew Wildkatze sind nicht hainfig (o 39 a) dagegen Feldkatzen in verschiedener Färbung gemein, namentlich auf den Jagdrevieren in den Ehenen. In Lentechi (dad. Suanien) waren die Iauskatzen Lnde duni in voller Brunst.

M: Felis sp. Von der Grösse der wilden Katze, pechschwarz, bisweilen mit weissen Stichelhaaren. Pelzwerk erster Güte. An vielen Orten sprechen die Jäger von diesem als von einem, wilden" Thier. Lebt nicht allein im Kaukasus, sondern auch in Transkaspien, z. B. am oberen Tedshen. Wir haben nur unvollständige Felle. Das Exemplar vom ScharaArgunj zeichnet sich durch fleckenartig vertheilte gelbliche Stichelung aus.

$\mathrm{R}$.

No 41. Felis chaus Güld. Lebt rornehmlich in den ostlichen Tieflindern und zwar in de'n gut bewässerten, zumal, wenn cie von Rohr- und Rubus-dshongel bestanden sind. Sowohl an dre Nord-als namentich an der Sudseite des Grossen Kaukasus und am häutigsten in der sullichen Kaspis he.. Lferzone. Haupteind der Iasen, Hasanen und des Federwildes im Mllgemeinen. Mit

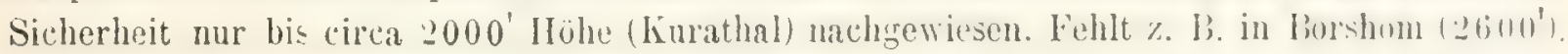
Aus dem westlichen Kaukasus liegen mir lieine garantirten Nachrichten vor.

R.

12 41. Felis Iynx cervaria Tem. 0 - 8000 ? In typischen, nordischen luhs habe ich 


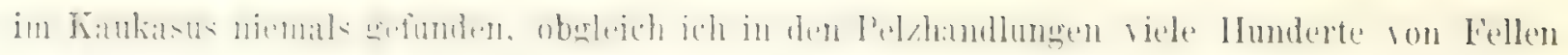
sah. Stets sind hicr die Exemplare bedeutend kleiner und oft sehr stark gefleckt. In der Cipundfarbe auf der Ruckenseite und den Flanken schwanlit der Ton von hell Kastanienhraun his Crabuedblich (I)agestant. Die Flechereihen beiderseits entlang der Mittellinie des

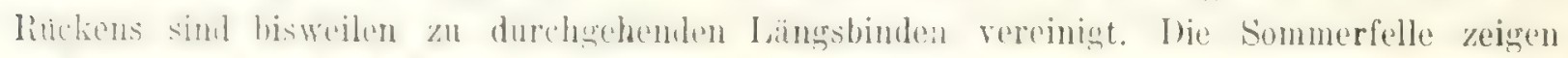

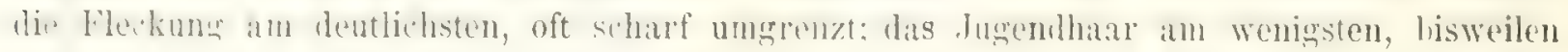
kaum angedeutet. Wenn man will, so kann man den kaukasischen Luchs mit demselben Recht rom typischen artlich trennen, wie das bei anderen Katzearten geschah. Scharf

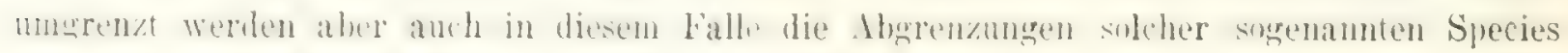
sich nicht ziehen und durch die Erfahrung bestätigen lassen.

Der Luchs ist im ganzen gebirgigen Kaukasus Gebiet verbreitet und unabhängig vom Walde. Lil bewohnt auch kahles Felsengebirge, \%. 13. unmittelbar bei Titlis. Im bewaldeten Mittelgebirge ist er am häufigsten. Schöne Winterfelle preisen hoch. Im Dagestan forderte man dafur bis zu 10 libl. gewöhnlich zahlt man 3-1 lábl.

R.

Ii 4:, 43. 45. F. servalina Jerd, F. caracal und Cynaelurus jubata Schreb. liann ich nur fur Transkaspien und zwar nur ans tieferen Gebieten aufführen, sie wurden im Kaukasus niemals gefunden.

Ii 4ti. Hyaena striata Zimm. Im Verlate lon mohlih dreissig Jahren sind mir 10) Iyänen gevracht worden, die drei im Kataloge genamten im Fleisch, die anderen in meistens verdorbenen oder unvollständigen Fellen. Im Verlaufe aber der letzten zehn Jahre hahe ich keinen weiteren Beleg fur die Lxistenz der Iyäne in der Nähe von Tiflis ermittehn kümen. Die beiden Kxemplare von 1869 brachten Molokaner und sagten mir; dass sie dieselben in den rom linken Kuraufer zuricktretenden Höhnzügen, unweit von der Stadt,

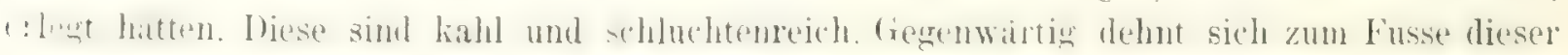
IHöhen die Stadt mehr und mehr aus und wird die Gegend durch die Eisenbahn stark beunruhigt. Das Exemplar bei Zarskije Kolodzy wurde vom Prinzen Albert von Sachsen-Alten-

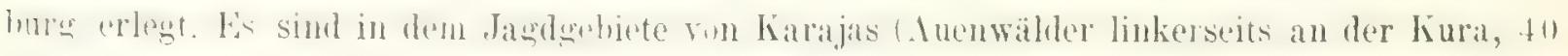
Klın. unterhalb von Tiflis) seit 1861 , soviel ich weiss, dreimal Hyänen ges hossen worden. Nirgend ist dieses Raubthier häufig. Von der Nordseite des Grossen Kaukasus hat man mir nur einen Fall von Wladikawkas mitgetheilt. Einen Beleg über das Vorkommen am N. W. Ende des Gebirges lieferte ein Fell des Prof. Ballion, welcher in der Nähe von Nowurossiisk auf seinem Gute lebte, wo Konservator Koenig es salı. Von östlicleren Gegenden aus dem Küstengebiete, von Abchasien, Mingrelien und Colchis liegen keine garantirten Facta

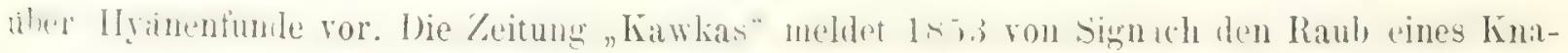
ben durch eine Hyäne, 1856 und 57 wird von dorther das Vorkommen wiederum erwähnt. 1853 erlegte man 1 Expl. bei Bjely-Klutsch. Im Araxesthal spra:h man bei den Salzwerken von himp viel yon Hyänen, auch der Fall eines Kinderraubes wurde erwähnt. R.

In Ordubad und in Migri am Iraxes erzihlte man mir ebenfalls von einzelnen Fïllen dev Vorkommens der Iyane und dem Kinderraube derselhen. Ietzteres ist sehr möglich, da man im Sommer in Freien auf den flachen Dïchern der nicht hohen IJäuser schläft. Die lowate armenische Bevolkerung fürchtet sis ühertrieben und nemt sie den Menschen-Wolf (marta-kail). Auch von der Westküste des Kaspi sind mir Fälle uber das Vorkommen der Ifyäne bekannt, nicht nur aus dem Kreise Baku sondern sogar von Derbent. Für die letztere Angabe will ich keine Verantwortung ibernehmen aber bemerken, dass einige Ortsbenennungen wenigstens auf das ehemalige Vorkommen der. Hyäne hinweisen So wird z. B. eine Höhle bei Derbent "Kojaftar-dara", d. h. Hyänen Höhle genannt. 
№ 47. Canis lupus L. (xanzes Gebiet ()-Schneelinie, oft den Heerden im Fruhjahr nuchwandernd und im Ierbst mit ilnen zuruckhehrend. Ueberall häufig und listig Iin Ratseha Gau oberhalb von Oni verneinten die Bewohner das Vorhandensein der Wülfe. Die lange Reihe der Wolfsschädel des Museums von der Domäne Borshom giebt genügende Auflikirung aber die Gemeinheit des Raubthieres. Obwohl hier im Jagdgebiete schon seit Jahren allwinterlich dem Raubzeug und leider auch den schönen Lïmmergeiern stark zu Leibe gegannen wird, so kann man doch im Durchschnitte auf 10-12 vergiftete Wölfe im Jalure rechmen. Magr sein, dass das Raubwild durch den reich besetzten, grossen Thierpark besonders angelockt wird.

Der Wolf ist im Kaukasus nicht stark und grross gebaut, wohl dreist aber doch furchtsam. Von Angriffen auf Menschen hört man selten, häufiger vom Bisse toller Wölfe.

Die schwarze Varietät (C. lycaon) kenne ich in vollkommenster Ausbildung aus dem Karatschai Gebiete, in der That war das ganze Fell pechschwarz und sehr schon in Haar, für mich aber zu theuer (100 Rbl.). Ilerr Jagdleiter Juthner schenkte nenerdings ein Fell dem Museum, welches obenher überall schom recht rein schwary ist, an den Flanken aber disch noch viel Gelbgran aufweist, weil nicht alle spitzen der Haare dunkel wurden. I)abei aber Kehle und die Batheite schneeweiss. Auch dieses Exemplar wurle im (buellgebiete des Kuban erlegt. Ein anderes aus Adsharien $.^{4}+7$ aa welches ich in Matum kaufte, zeichnet sich ebenfalls durch viel Schwarz, namentlich an den Flanken, aus.

$\mathrm{R}$.

Ni 4S. Canis aureus L. $0-3.000^{\prime}$. Ich habe bedentendere Hohen fur das Vorkommen des Schakals nicht ermittelt. In Borshom hestand ein Rulel Schakale die Hohen, an deren Fuss 181;.; das Palais des Grossfürsten gebaut wurde. Borshom lingt 2.jo(0' abber de:n Mecre, jene Höhen äberragen es um 5061-600'. Allabendich hörte man von dorther ihr winselndes und betlendes Henlen. Im Verlaufe von wenigen Jahren verschwanden dort die Schaliale vollständig. Gemein ist dieser freche und feige Räuber überall in den Dshongehn der 'Tiefländer, namentlich in Transkaukasien bis zu den Ufern beider Mtere, östlich häuti. ger als westlich. Den drei Längenhochthälern von Kolchis fehlt er, ebenco im Letschgumgau. Am Nordfusse der Hauptkette weisen die Unterläufe des Kuban und Terek ihm die Grenzen seiner Verbreitung an. Baron Salza, ein eifriger Järger, welcher lange Zeit in Chassaw-jurt commandirte, bestatigte mir das Vorkommen des Schakals noch 30 Kilm. noudlich von seinem Posten in der Steppe und in Kisljar theilte man mir mit, 'dass es Schakale in den dichten Geröhren des Terekdelta gäbe. li. 4 1. m. von Sakatali zeichnen sich durch starken Wuchs und appiges Haar aus. Der Grundton der Färbung ist kaun etwas rothlicher, als bei den Exemplaren des Tieflandes ${ }^{1}$ ).

Vi 49. Canis vulpes L. typ. und No. C. melanotus Pall. Der Kaukasische Fuchs macht dem Systematiker Schwierigkeiten. Fincrseits werden das ganze transkaukasische Tiufland und die Vorberge bis zu 5000' von einer Fuchart bewohnt, die niemals die Grösse und auch niemals das Colorit des typischen Fuches erreicht, andererseits liegen mir Belexpstüclie für den letzteren nur ron dem westlichen Nordfusse des Ciebirges und aus der Kam.uzone vor. Ius letzterer auch die schwarze Varietät in nicht ganz ansqubildeter Reinheit, weil die beiden Exemplare noch jung sind, di jo e, f. Ich habe diese beiden Exemplare, da sie obgleich ausgewachsen so geringe Grösce haben zu C. melanotus gezugen. Is kommen aber bei Gudaur auch trpische Brandfuchse (ornobsin) vor. Ferner lienne ich, was die Fäbung und Pelzgüte anbelangt Bälge aus den (iebirgen Adshariens und von den Umgengenden Achalzichs, die den typischen C. rulpes gut entsprechen und endlich lieferte die Jagd in Burshom

8) Anmerk. Canis corsac L. soll, wie der dänische Consul in Rostow mittheilt östlich vom Ion in den Steppen vorkommen, doch erhielt bis 'dato' von dort her das Musèm' kein 'Fell. 
(also nahe den letateren Gebieten) Mischformen, nicht nur in der Grosse, sondern auch im Haar und seiner loibung. In allen meinen frheiten habe ich den in liede stehenden, ron C. rulpes typ. entschieden versehiedenen Fuchs immer ('. melanotus l'all, genannt. Die Diagnueve verlangt fur diesen zwar das fehlen der weisven Schwanzspitze, welche bei den Kankasiern bald wrosser, bald lileiner vorhanden, oft sehr reduzirt ist und bisweilen granz fehit. Pallas schreibt Zoogr. russ. asiat. Fol. I pag. 4\%: . cauda ferumque in adlatis pellibus deest, apice nigritans". Lis kommt vor, dass bei dem Abbalgen, namentlich, wenn es Jager eilig verrichten, die Schwanzspitze an den Endwirbeln haften bleibt und dann dem Ialgr natürlich fehlt. Ich wrwähne liss, weil ich gerade nach solchen Bälgen in den Kaufliden suchte und sie mehrfach fand. I: 50 i von Mlleti hat, obwohl dem typischen Fuchs nüher, als der hellen lileinen Varietat, keine weisse Schwanzspitze. .l. 50 0, Borshom, ein Mittelding zwischen ('. rulpes typicus und C. melanotus, hat die weisse Schwanzspitze kaum angedeute. Was die Auslehnung des Schwarz auf der äusseren Ohrseite anbelangt, so ist sie ebenso scliwaliend, wie bei dem gewöhnlichen Fuchs, bei manchen Exemplaren erreicht sie die Basis, bei anderen nicht. Typisch ist sie bei den an der westlichen Nordseite erstandenen lialgen. Die Transkaulasier haben das Sihwarz auf der ganzen äusseren Ohrseite. Das gesammte Colorit der Transkaukasier zieht namentlich obenher mehr in ein Rothgrau als in's Fuchsroth. Die von der westlichen $\%$ rdseite erstandenen Exemplare schliessen sich entweder total an den typischen (: vulpes, der nähern sich ihm doch so sehr, dass jeder Zweifel an der Art gehuben ist. Viel weniger ist das der Fall bei .50 o (Borshom), welches Fell in jeder Hinsicht die Mittelstufe zwischen beiden Formen einhält. Die Dagestaner (Jewdolimowsk) stehen dem von mir als C. melanotus benannten viel näher als dem typischen Fuchs. Ein neuerdings aus circa 5000' Iöhe von liedabeg erhaltenes Fell ist genau das, was ich C. melanutus nenne, his auf die Schnauze hat dieser Balg keine Spur der fuchsruthen Firbung am gesammten Pelz. Meine Anfragen hei den bekantesten Mammalugen gaben mir lieine Gewissheit uber die-en qua:i Fuchs. Prof. Nehring fand, dass aus dem ih!n zugesendeten Schädelmaterial sich in einzelnen Fälen ohne Schwierigkeit der Anchluss in den Grusienverhälnissen zum typischen C. vulpes ergiebt. Die überwiegende Zahl dieser Füchse ist aber bedeutend kleiner als der typische Repräsentant.

Herr Satunin, welcher die Vorräthe des Museums musterte, findet, dass die von mir als C. melanotus bezeichneten, nicht genugsan der Diagnose von I'allas entsprechen und hält sie an nithsten zu dem indischen. C. leucopus lilyth. stehend, was indessen noch näherer Intersuhung bedarf. Der letatere ist abrigens, wie (rreve mittheilt, fur Afganistan ermittelt.

Am häutigsten war mein C. melanotus im östlichen Transkaukasien da, wo das Gebirge sich in Hügeln allmählich in die Mugan verflacht. Diese sind überall kahl und ernihren eine nicht uppige Steplenthora mit vorwaltendem Wermuthcharakter. Jahrweise sind dort Feldmäuse und Hasen erstaunlich gemein. A uf der Wegstrecke von Schemacha nach AdshiKabul und von dort nach Salian, die ich mehrmals auch im Winter passirte, konnte man hei weitem Ilorizont gleichzeitig am hellen Tage sechs und mehr dieser liüchse kreisen seben. Sie bevorzugen troclene (iebiete. In der nassen Ufer\%one des Schwarzen Meeres, in mingrelischen Tietlande und bei den Abchasen kent man den Fuchs als Bewohner des Gebirges, unten sull er fehlen. Auch meidet er die vollschattigen, geschlossenen Hochwälder, besonders die reinen Bestände der Rothbuche.

Preise aus erster Hand für C. melanotus: 30 Kop. bis 1 Rbl. 20 Kop.

$$
\text { C. vulpes } 3-4 \text { Rbl. }
$$

$" n \quad$ C. viwarzfuchse je nach der Gute 10-30 Rbl.


. 52. Ursus arctos typ. et meridionalis Midd. (incl. syriacus Hemp. et Ehrb. et isabellinus Adams). Ich ziehe mein kaukasisthes Material an Bären artich alles zusammen (Grevé scheidet syriacus von arctos) und spreche nur von U. arctos typ. und U. arctos meridionalis. Den ersteren, in frösse und Firbung des Pelzes wirklich typisch, besitze ich nur in einem Exemplar von der Nordseite des Kaukasus, wiederum aus dem Jagdgebiete von Psebai durch Itern Noska beschafte. Keinesweges aber lebt dort nur der typische Bär. Der verstorbene Noska hatte, als ich ihn 1893 besuchte, viele bärendecken, darunter zwar keine gelben, doch aber eine fast silbergraug (Winterhaar) und braune in dunkleren und helleren Nuancen. Auf die Färbung kann man absolut nichts geben. In Transkaukasien und Hocharmenien trägt der Bär gewöhnlich ein schlehtes, d. h. dünnes Haarkleid von mehr oder weniger schmutzig brauner, lichter Farbe bis in die helleren Nuancen von Semmelgelb. Die ganz hellen sind die bei weitem selteneren.

Der Bär ist zwar am liebsten Waldthier, keinesweges aher ausschliesslich an den Wald gebunden. Ich habe ihn uberall in Itocharmenien, oft in durchaus nackten Felsengegenden theils gesehen, theils erkundet, sogar am Ararat und auf dem Alagös. Die breiten Ebenen und Steplen meidet er. Er bewohnt die breiteste Zone von $0-12000^{\prime}$ und im Sommer darüber hinaus, da er sich dann gerne auf dem Firn wïlzt, lahei Haarflocken verliert und an manchen Plätzen in das hochalpine Sommergebiet der Ciemse und des Steinwildes tritt. So traf ich ihn z. 13. am Tschitcharo im dadianschen Suanien mit der Gemse im Juni $186 t$ an. Die Kosaken an Sardar-bular I'osten, nahe der Einsattelung zwischen beiden Araraten erzählten nir viel ron liären, welche das dort vorhandene, niedergedruckte l'irkengehöl\% im August besuchen. Da griebt es recht viel Rubus saxatilis und auch Vaccinium myrtillus und das mag sie whl zur zeitweisen Passage reranlassen. Am häutigsten, aber auch am schlechtesten in Haar ist der Cär in dem ehemaligen 'Tscherkessen Gebiete an den Quellläufen der Msymta und des Psyb. Es klingt unwahrscheinlich, ist aber doch wahr, dass ein Jäger der esthnischen Kolnnie an der oheren Isymta in cinem Jahre 38 Bären erlegte (1891-92). Man kann sich die dortige Häufigkeit des Lären ganz gut erkären. Mit der fast vollständigen Auswanderung aller T'scherkessen im Jahre 18;it wurde ihr ganzes (xebiet entvölkert. Dasselbe war überall waldhedeckt und die Zahl der Bewohner verhältnissmässig immer nur gering. Die Tscherkessen hatten bei ihren Ansiedelungen recht gute und grosse Gärten. Diese verwilderten nun, ihre Früchte sammt sonstigem Wildobst gaben den IBären reichliche Nahrung und Niemand beumruhiggte sie. Daher die starke Vermehrung im Verlaufe der nächsten $\supseteq 0$ - $; 0$ Jahre. Auch jetzt ist nur die unmittelbare Küstenzone diese's Gebietes spärlich bevölkert, das Mittelgebirge so gut wie leer.

$\mathrm{R}$.

Es leben im Kaukasus zweifellos zwei Typen vom braunen Bären, die man wohl rich. tiger als zwei Arten benennen durfte. In jüngster Zeit hat Dinnik in seiner Arbeit „der Biir und s:ine Lebensweise in Kaukasus" Abbildungen der Schädel dieser bei 'en Typen gegeben. Der eine ist schlanker und leichter, der andere gedrungener und massiver gebaut. Die Färbung ist cehr variabel.

Sat.

№ 53. Lutra vulgaris Erxl, $0^{\prime}-: 000^{\prime}$. Tch notire diese Höhe fur die vertilale Verbreitung der Fischotter als cinch ammïhernd richtigen Nittelwerth. Ich fand das Thion' im ganzen Gebiete und an manchen Stelien garnicht selten, wohl aber sch:. r zu fangen und noch schwerer zu erlegen. In den drei Längenhochthälern ron Kolchis lebt es sowohl an den Oberlaufen des Ingur (Cheledula) und Hipps, als auch an denen des Phasis (Ginla). Von den Quellzuflussen der Kura lienne ich is als sfleichen Höhen. Im Darestan fulte es am Fusse des Salatau, die Bewohner von Buturnai verneinten sein Vorkommen.

R. 


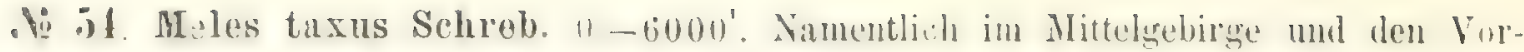
bergen mit Wein-und-Alaisbau (Mingrelien). In den Hochthälern an der Sudseite im col-

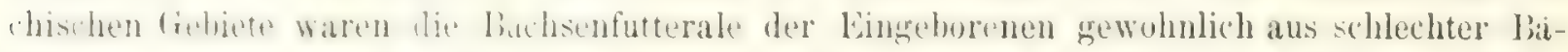
renhaut, nur selten aus Dachsfell gemacht, was auf die Seltenheit des Dachses daselbst

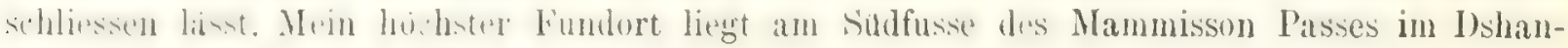
dshach 'Thale bei dem Dorfe Gurschewi auch bei Chotewi in derselben Gegend war der

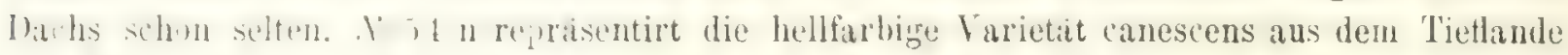
ron Talysch.

IR.

. 5i. Mustela martes. L. Ias gelle Kehlfeld ist in der Grusse seln wechselnt.

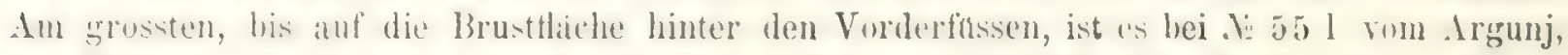

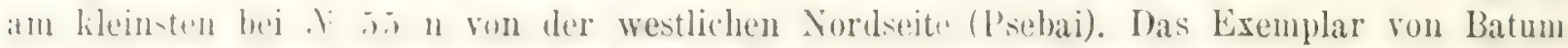
I is m weist durch die gesamme hirperfarbe im Colorit auf die Parallele zum Zobel hin. lin liches, gelbliches Kastanienbraun dedit die sanze filckenbeite und hellt sich seitwairts auf den Flanken in schmutziges Bräunlichgelb auf. Dunkler, reiner braun sind nur die F'usce und die lirustlitehe zwischen den vorderen, sowie die Schwanzspitze. Das Wollhar an diesen Balge ist sehr hell und zieht von grau in's Gelbliche. Der Edelmarder lebt im Kaukasus uberall wo Walder sind, fehlt dem reinen Jauhwalde nicht, bevorzugt aber die Coniferenhestambe und zwar die heiden Tamen, in denen cr ron den liergvolkern in Winter an vielen ()rten (Adsharien, Abchasien, Colchis) mit plumpen Schlagfallen gefangen wird. In Suanien gab man mir ihn als nicht häutig an, dagegen liefern die Gebiete der Rionquellen ziemlich viel u.d gutes Pelzwerk vom Edelmarder. Der Chotewi'sche Kreis z. B. an 500 Felle von 2-5 Rbl. das Stück aus erster IIa:d, im Durchschnitte sollen da 4 Felle auf einen Jäger kommen.

$\mathrm{R}$.

.․ 5(). Mustela foina Briss. Wie bei dem Ldelmarder so schwankt auch bei dem Steinmarder die Verbreitung der weissen Farbe auf liehle und IIalsseiten ungemein. Bei .561 aus Transkaspien geht sie bis an die Vorderfusse. Bei № $56 \mathrm{i}, \mathrm{k}$ erreicht sie die Vorderfusse nicht ganz. Die Exemplare von Tillis aus, das durch ein dunkles, abwïrts gerichtetes Iängenband das weisse Kehl-und-Halsfeld scharf getheilt wird.

R.

. 1i 57. Putorius foetidns Gray. Wie aus dem Verzeichnisse zu ersehen ist, besitzt das Museum nur zwei kauk. Exemplare vom Iltis und zwar beide von der Nordseite. Ius Transkaukasien wurde die Art bisjetzt nicht nachgewiesen. Riossikow führt den Iltis als ziemlich häufig im Gebiete der Malka an. Das Exemplar ło 58 i rom Temirgoje Salzsee trägt dünnes und recht helles Sommerhaar, es schliesst sich im Colorit gut an P. Eversmanni an.

Ii.

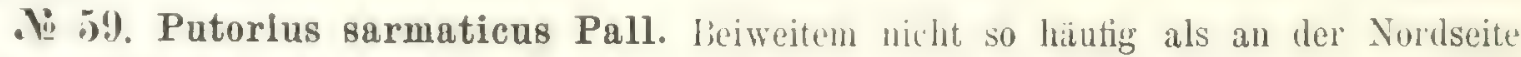
int ler Tigeriltis in 'Transhaukasien. es scheint jedoch, dass er mit Ausschluss von Liolchis (bisjetzt ron dort nicht nachgewicen) in den Höhen von $0-5000^{\prime}$ im ganzen Gebiete hier und da vorkommt und uberdies haben R. und W. auch mehrfach sichere Fundorte fur Transkaspien genannt (1. c. seprt. p. 31).

$\mathrm{R}$.

Seit der Publication meiner Arheit über die kaukasischen Säugethiere (in \%ool. Jahrb.

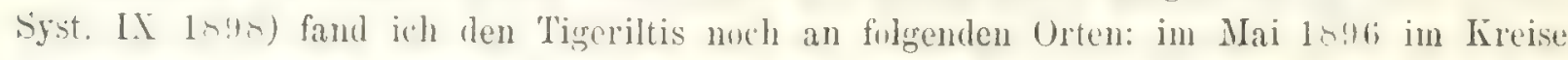
Schemacha, unweit der Stadt und in demselben Jahre im Kreise Aresch in der Kura Ebene; im Jahre 1597 in Saljan (untere Kura) und in den Talyscher Bergen; endlich im Jahre

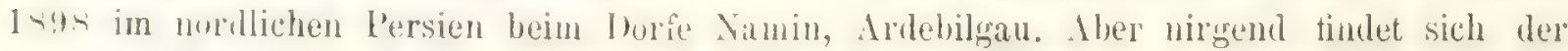
Tigeriltis häufg. Das letzte hier erwähnte Thier wude mir in Namin vom Medshid-chan 
als besondere Seltenheit geschenlit. Jedoch sagten mir die Händler dass or bei ihnen keine Seltenheit sei.

Sat.

№ 60. Putorius vulgaris Briss. und . (i1. P. boccamola Cetti. I)as gewöhnlich. Wiesel ist in Transkaukasien ungleich seltener als P. boccamela, wic ans dem Verzeichnisn. hervorgeht. Bisjetzt kennt man es in 'Transkauliasien nur bis zu Ilohen von cirea 2000'. Rossikow fuhrt das Wiesel aus 10000' Meereshöhe rom Adai-chm an. Viel häutiger und uber das ganze Gebiet verbreitet ist P. boccamela, in der (rrösse zwischen I'. erminf und dem Wiesel stehend. Auch diese Art wird im Winter bisweilen weiss $1.161 \mathrm{~m}$ ). Wahrschtinlich

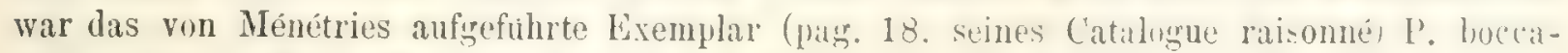
mela gewesen. Heine Mitheilung aber das Vorkommen de; Hermelins in Talysh muss an $\mathrm{f}^{\circ}$ Pat. boccamela berichtigt werden. Spätere correspondenz mit Herrn Iächner gab) mir die: Gewissheit, das; das Hermelin in den Kaukasuslindern fehlt. In Wolgadelta kimme es nach 으 $63 \mathrm{~b}$ noch vor.

R.

Nọ 62. Patorius Stoliczkanus Blanf. Von diesem seltenen Wiesel haben wir (I. W. im dem Pande I über die Trinskasp. Exped. die ausfühliche lieschreibung, welche I'r.fessor W. Blasius nach unserem Exemplare machte, publicirt. Vergleiche auch: Znol. Jahrbücher Bd. IV.

R.

No 64. Patorius lutreola Cuv. Nur ron der Nordseite aus der Staniza l'sehai erhielt ich ein Exemplar. Laut Angaben des Forsters Grot in Sotschi soll der Nörz durt auch rolkommen, ein Belegstuck liegt mir aber von der S. Seite der Hauptkette nicht vor.

R.

\section{R O DEN T I A.}

Die Sammlung von Nagethieren des Kaukasischen Museums ist sehr reichhaltig, sie enthalt sämmtliche Arten, welche bis jotzt in den Kaukasuslindern cefumlen wurden, beimalıe alle aus 'Tran-kaspien (ausser Hyodes migratorius Licht.) und (in bedentendes Tergleichsinittrrial aus anderen Gegenden. In dieser Sammlung lenkt eine suite von siciurus anmmalus die Aufmerksamkeit auf sich, nach welcher man leicht die bemerkenswerthe Bentändigkeit der Firbung dieser Irt in allen Altersstufen und zu allen Jahreszeitem erhemen kann. Feme'l sind Myoxus pictus Blanf., Gerbillus erythrurus Gray, G. persicus Blanf., G. Hurrianae Jerd., Cricetus Raddei Nehr., Mierntus nivalis petrophilus Wagner, Nesulia Tuttereri R. et W., Sminthus concolor Büchn. Alactaga Williamsi Thumas und A. indica tiray sowic Spalax giganteus Nehr. und Sp. Nehringi Sat. in der sammlung-alle diese sind Neuheiten für die Fauna des russischen Reiches. Von diesen sind Cricetus Raddei, Cr. lirandti und Nesokia Boettgeri sıwie die beiden Spalax Arten uberhaupt neu fur die Wissensch.ıft uml Sminthus concolor und $A$. Williamsi Seltenheiten ersten Ranges.

Von grossem Interesse sind auch die Sa:mmlungen ler Wald-und Feldmáse aus allen Theilen des Kaukasus, allein man wird sich mit innen in Kukunft noch viol beschiftigen müssen.

Sat.

№ 6S. Sciurus anomalus Gmel. Troussart vereinigt in seinem liatalog (E. L. T'rontensart. Catalogrus Mammalium tam viventium, quam fossilium. Nova colitio (prima completal' fl.

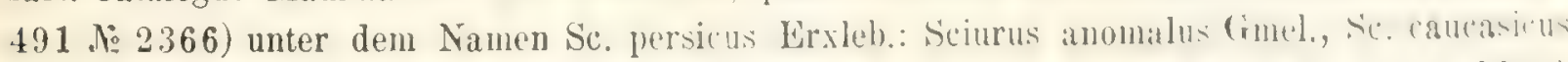
Pall., Sc. syriacus Ehrenb., Sc. russatus Wagner, Se. historicus liray und Si. fulvus lilint.

Pallas (P. S. Pallas Zoographia Rosso-Asiatica I p. 186) sagt selbst, dass sein Se.

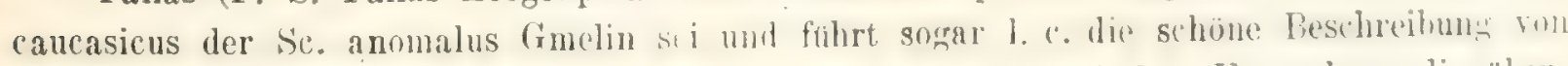
letzterem an, welche vollständig auf unsere sïmmtichen kaukasischen Lxemplare, die uber- 
haupt in der Firbung ïusserst beständig sind, passt; so lommt die Priorität dem Se. anomalus Gmel. zu.

Was die Arten: Sc. Syriacus Fhrenb., Se. russatus Wagn. und Se. historicus Gray anbetrifft, so kann ich, weil sie mir in natura unbekannt sind und ich keine guten Beschreibungen davon zur IIand labe, nichts uber ihre Beziehungen zu unserer Art sagen, doch darf ich unter lieiner Bedingung die Identität von Sc. anomalus mit Se. fulvus Blanf. zu-

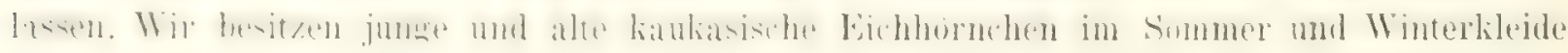
sie unterscheiden sich in jeder Altersstufe und zu jeder Jahreszeit siharf von Sc. fulvus, was Jedem bei der Vergleichung der Tieschreibuugen von Gmelin (v. s.) und Blanford (W. Blanford. Eastern Persia rol. II 1. 49, T. IV) deutlich wird, Ebenso verhält es sich mit Sc. persicus Erxl., obgleich dieses Fichhörnchen Ännlichleit mit unserer Art in der Fürbung des oberen 'Theiles des Körpers hat, s) unterscheidet es sich doch, nach der Beschreibung ron Gmelin jun. (citirt bei Blanford 1. c. p. 50) durch die Färbung des unteren Theiles les IBuches, Schwanzes und einiger anderen Merkmale, sicher von ihm. Auf liese Weise, meine ich, kann man schon a priori voraussetzen, dass das kaukasische Fichhörnchen Sc. anomalus (imel. welches sich von den nach der geographischen Verbreitung nitchsten Arten unterscheidet, auch weder mit Sc. syriacus, noch mit irgend einer anderen Art identisch sein wird, sondern cine röllig selbstständige Art darstellt.

Obgleich Nachrichten ron Fällen uber das Vorkommen des Fichhörnchens auf der Nordseite des whesien Kaukasus borhanden sind, su kimmen sie doch nicht als erwiesen betrathtet

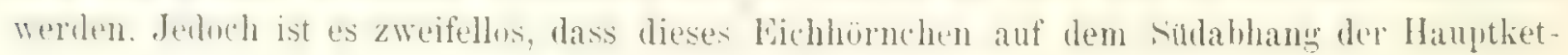
te und im kileinen Kaukasus in der Zone der Buchenwälder lebt.

Sat.

Ich habe das Eichhörnchen nirgends häufig angetroffen. Im Verlaufe von zehn Tagen, welche ich 1864 brauchte, um in der ungangbaren Ingur Schlucht von Lachamuli nach Dshwari rime 70 Klm. (suanien- Mingrelien) zu gelangen, sah ich es nur eimmal und zwar hier wie lherall andersw im louchenwah, nicht im Nadelholz. Auf dem Gute . Betanien" les Barons Nikulai unweit von Tiflis wird es alljährlich im Gillten auf den Wallnussbäumen in wenigen Exemplaren resehen. Während der Wandrung zum Suantgan (Tallysch) Whte diese Irt (?) ebenfalls im reinen Buchenwalde, die liauchseite war fast furhstoth. Die [heutung der nachfo] genden Samen ist nicht ganz sicher, sie hann anch dem siehencchläfer welten. Nanentlich silt das fur das Gebiet der Karatsehaizen unl l'schetschenzen, da von

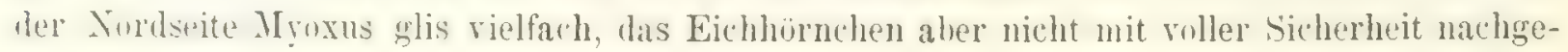
wiesen wurde. Die erkundigten Namen lauten:

Suanien, dad.-Tritine

Abchasien - Abshidsha

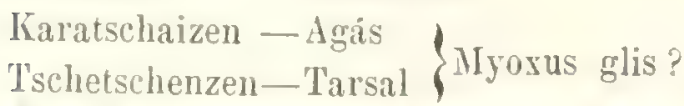

R.

.ị it. Spermophilus musicus Mén. Leider befindet sich im Museum léin Exẹnplar dieser Art aus der alpinen Zone wo sie auch vorkommt. Koenig beobachtete sie in grosrer Anzalil am Küliürtikol 100100'. Steppen des Nordkaukasus und Alpenwiesen der norrwestlichen Hauptkette $0-10000^{\prime}$.

li 75. Castor fiber I. Die Frage über das Vorkommen des Bibers im Kaukasus blcibt 11 ch eine ofiene. Näheres darüber siehe: G. Radde und E. Koenig. Das Ostufer des l'ontus, in Peterm. Mittheil. Ergänzh. 112 p. 116 und "Satunin 1. c. p. 297 “.

Vie 87 - 75. Myoxus dryas Schreb. und M. pictus Blanf. M. drras ist sownll im nurilichen kiankasus als auch iberall in Transhaukasien gewöhnlich. Was den M. pictus 
Blanf. anbelangt, so muss ich mich, trotz dem viele neneste Systematiker z. B. Troussart (1. c. p. 454), Roevens (C. L. Roevers. Die Myoxidae oder Schläfer. Leiden 1890) 11. a. diese Art mit der crsteren rereinigen, vorläutigs eines entscheidenden Cirtheils enthalten. Wenn auch die Länge des Schwanzes und die Firbung dec transkaukasischen M. dryas ein wenig variirt und er sich dem M. pictus nähert, so bleiben doch cinige Eigenthümlichkeiten in der Fảrbung und verhältnissmässign kleinere Masse der suhlen als unterscheidende fiemzeichen. Ausserdem ist das Verbreitungsgebiet von M. pictus von dem des M. dryas verschieden, ich keme die erstere Irt nur aus dem nordistlichen Theil Transkankasiens ron den Abhängen der Hauptkette.

Sat.

V. S1. Aerbillus meridianus Pall. Das Lxemplar \&1. b. zeichnet sich dureh aussergewöhnlich kleinen Wuchs aus.

. 8\%. Gerbillus erythrurus Gray. I)iese Art wird hier zum ersten Male in die russische Fauma cingefürt. Es wurden einige Evemplare von Herm Warentzow unweit Aschabad erbentet.

№ S3. Gerbillus persicus Blanf. Das Exemplar 83 a, welches in Olty im (iebiete von Kars erbeutet wurde, ist in meiner Abhandlung aber die Säugethiere des Kaukasus (1. c. p. 300) aufgefuhrt unter 61 Gerbillus spec? Bei diesem Fixemplar fehlt das Ende des Schwanzes, daher wurde es damals nicht bestimmt. Jetzt stelle ich es nach Vergleich mit transkaspischen Exemplaren zu dieser Art, obgleich es einige craniolugisehe Interschiede aufweist, welche wohl durch das Alter zu erklïren sind. Unsere Fxemplare sind alle kleiner als das von Blanford (l. c. p. 66) beschriebene. Far die Fauna des russischen Reichs wird diese Art hier zum ersten Male aufgefuthrt.

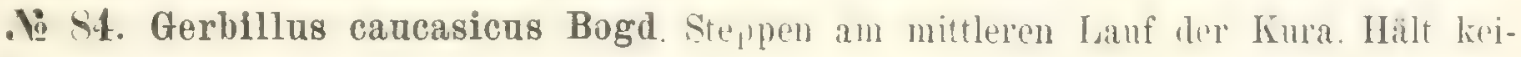
nen Winterschlaf.

Ni \$4-8.). Gerbillus Hurrianae Jerdon. Mit grossem Zweifel beziche ich zwei Evemplare unserer Sammlung auf diese Irt, la iph zu ihrer liestimmung mich nur geringer Literatur bedienen konnte und kein Vergleichsmaterial besass.

Xi S7. Gerbillus spec.? Jaffa. Wenen rolligem Literaturmangel aber lie Fama dieser Gegend unbestimint geblieben.

Sat.

Nì 89. Cricetus frumentarius Pall. In der Steppenzone und den Vorbergen des nörlli:hen Kiaukasus.

№ 90 und . 91. Cricetus (Mesocricetus) Brandti Nehr und Cr. Raddei Nehr. Prof. Nehring hat ich in letzter Zeit sehr eingehend mit den hauk. Hamstern beshäftigt. Ias Endresultat seincr Lntersuchungen reroffentlichte er im Archir fur Naturgeschichte 1898. Bd. I. jag. 373-392 nebst 'Tafel. Indem ich die Vorläufer zu dieser Arbeit übergehe muss ich, anf die letztere fussend, Folgemles uber die Hamster des liauk. IIusemms sigen. Den typis hen Cr. nigricans Brdt, jetzt Mesocricetus nigriculus Nehr. besitzt das Museum nicht. Er gehört den Vorbergen des Elhrus, den Quellthälern des Terek an der Nordseite des centralen Kaukasus an. Das von Lenetries 1 s 29 rom dort heschaffe Evemplar ist der Typus dafur. Libenfulls nur an der Nordseite des Crossen Kaukasus, aher im ostlichen Theile (I)at-

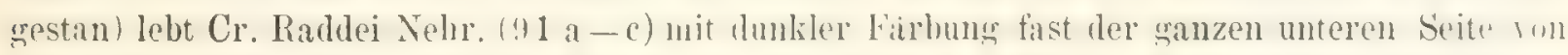

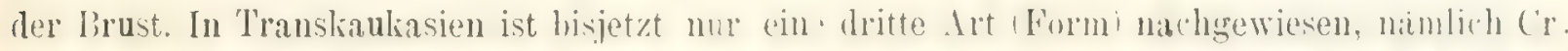

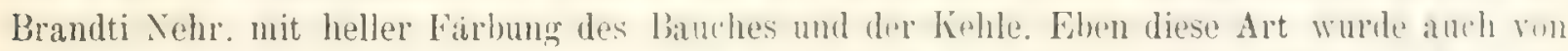
IIocharmenien (90 n) gebracht, ehenso aus persischem und klcinasiatischem Gebiete. Ibe when citirte Abhandlung Nehrings enthält Mlles was sich anf diese IIamster bezieht. Tinsere Taf lel giebt die Abbildungen der oben genannten zwei Hamster Arten und ihrer Schädel. R. 
(li !) - !: Cricetus arenarius Pall. und Cr. phaeus Pall. l)ie Unterschedunt dieser zwei rerwandten Arten ist äusserst schwer, wem man sie nur nach ihren Beschrei-

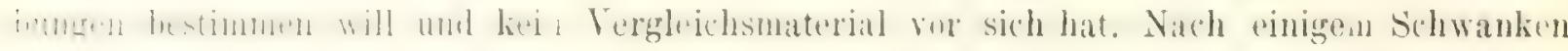
ziche ich simmtliche kaukasischen IIamster dieser Gruppe zu Cr. phaeus, obgleich sie bedentend in der Färbung variiren.

In Transkaukasien und den Vorbergen des nordöstlichen Kaukasus weit verbreitet. $0-1000^{\prime}$. Sat.

3. 94. Microtus amphibius L. Zu dem von mir aber die Wasserratte in meiner Arbeit uber die latukasischen Säugethiere (1. c. p. 302) Gesagten, kann ich hier noch Fol-

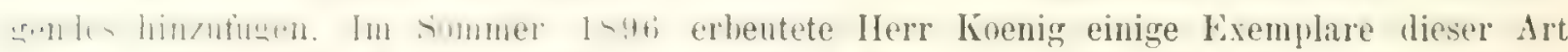

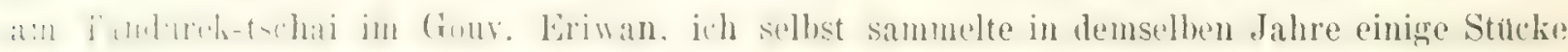

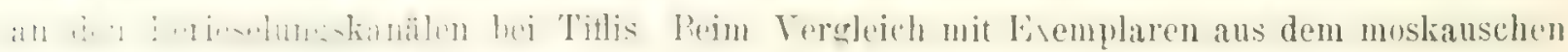
lireise lionnte ich keine Unterschiede, weder im äusseren lian, noch in der Bildung der Yähne? finden.

bis Wasserratte ist in nördlichen Kaukasus überall häufig, wo sie sich nach Rossikow his in lir subaline Kone 9.100') verbreitet. Wahrscheinlich kommt sie auch wherall in Translatrasion vor und zwar in den Höhen von 1000-4000'. (Manglis).

Sat,

. 9: Microtus nivalis petrophilus Wagner. Der Zahnbau von . I: 96-9) । stimmt gnt mit der Beschreibung von Iypudaeus petroplilus Wagner uberein und mit dem Diagramm der Zähne welches bei Blasius (1.c. p. 360) abgebildet ist. Selbst das Exemplar 1: 96, cin erwachsenes Weibchen, ist bedentend kleiner als die Repräsentanten dieser Art aus den Hpen, es hat nämlich folgende Masse:

Von der Schnauzenspitze bis zur Sehwanzbasis (von unten) . . . . 107 $\mathrm{mm}$.

Der Schwanz mit den Haaren an Ende . . . . . . . . . $56,5^{\mathrm{mmm}}$.

Die Endhare am Schwanze . . . . . . . . . . . . 5 mm.

Länge des Ilinterfusses mit Nägeln. . . . . . . . . . 19,5 $\mathrm{mm}$.

Die ubrigen Exemplare sind noch jung, aber mit schon so weit entwickelten Zähnen, dass man sie genau bestimmen kann.

Sat.

. 94. Microtus arvalis Pall. Der lau der Zühne der kaukasischen Feldmäuse un.

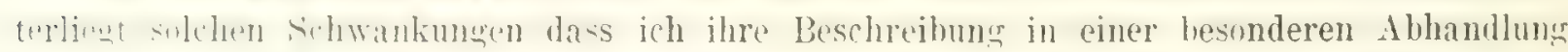
publiciren werde, ein Gleiches soll auch über den Zahnbau von M. socialis geschehen. Im

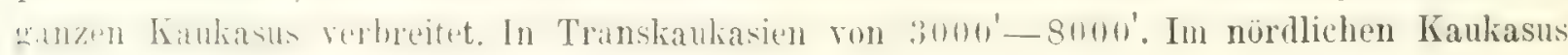
ist M. arralis auch in der Ebene gemein.

. 9.). Microtns socialis Pall. In Transkankasien von 0-;000'. Während meiner Reise im Herlst 1896, welche zur Untersuchung der Verheerungen durch Feldmäuse in

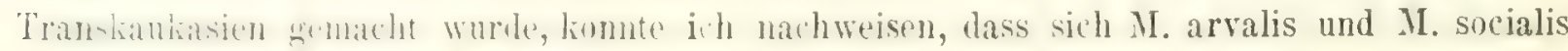

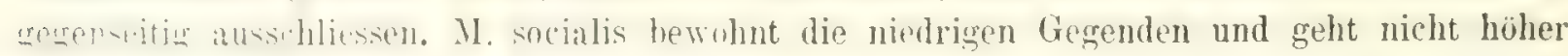
als $3000^{\prime}$, dann beginnt die Verbreitung von M. arvalis, welche bis uber $8000^{\prime}$ vorkommt. Der höhste Fundort dieser Art ist Kurusch in Dagestan $8115^{\prime}$ wo sie von Radde erbeutet wurde.

- io 106. Ellobius talpinus Pall. Stepnen des nordlichen Kaukasus. Geht nicht hoch ins G birge.

. li 106; 1), Ellohius lutescens Thomas. I)iese unlingst ron Thomas beschriebene Art (Amals and IIagazine of Natural history Ser. 6. Vol. XX Septb. 1897) konnte ich cbenso wie 1l. Williamsi bestimmen, nachdem mir der Gelehrte seine Arbeit darüber zuchlinhte. Dank dep laibulte des Herrn J. J. Krjiwoblozky, oftiziers der Grenzwache des 
Postens Kjalwjas konnte ich zwei E emplare erbeuten. Der genannte I'nsten liegt an der persisch-talysuher Grenze in 6000' Meereshöhe. Ein drittes Exemplar Anfangs (actober ebenda gefangen, sendete der Offizier mir später zu. Die von Thomson erwähnten craniologisehen Eigenthumlichkeiten bestätigen sich gut an meinen Exemplaren. Der ate obere Iackenzahn hat wie bei Ell. fuscocapillus Blyth an der inneren Seite drei deutliche Zahnungen und nicht deren zwei wie bei Ell. talpinus, auch die Schnanze ist bedeutend länger als bei dem Letztgenannten. Die Behaarung ist bei diesem October Exemplar aussesordentlich lang und dicht mit nicht gelblichem, sondern mit weisslich aschgrauem Anfluge.

Sat.

o. 107. Mus rattus. L. An einigen Stellen Transkauliasiens noch zahlreich, z. B im Dorfe Muchran, Gouv. Tiflis.

No 105. Mus decumanus Pall. Ueberall in den Stidten und in den meisten Iörfern. Sat.

In Tiflis liegen beide Rattenarten noch im Kample, doch ist II. rattus nicht so gemein als die Wanderratte.

R.

Ni 109. Mus musculus $L$. Sie variirt sehr in der Färbung. Ueherall zahlreich und fuhrt stellenweise eine vollstïndig wilde Isebensweise. In verticaler Verbreitung geht sie mit dem Menschen zusammen.

№ 10!). 11. Mus muscalus bactrianus Blyth. Zu dieser Varietät der gewölnnlichen Ilausmaus rechne ich die in Transkaukasien gefunlenen Mäuse (.) 109 ll.) mit rein weisser Färbung der Unterseite des Körpers.

Ni 110. Mas Wagneri Eversm.=Mus bactrianus R. W. 1. c. p 1113:3 (sept. 41).

ํ. 112. Mus spec? Ein sehr junges Exemplar.

. 113. Mus sylvaticus $\mathbf{L}$. unı $\mathbf{M}$, arianus Blanf. Nit de Waldmänsen verhält es sich ebenso wie mit den verschiedenen Arten der Spitzmäuse. Ich habe nicht nur eine Menge kaukasischer Exemplare eingehend untersucht, sondern auch sulche aus dem mittleren und sildichen Russland und der Krim und hoffe in kurzer Zeit die Resultate meiner Untersuchungen ausfuhrlich zu veröffentlichen. Hier beschränke ich mich auf folgende liemerkungen:

1) Die Färbung der Haare ist ein sehr unzuverlässiges Merkmal für die Unterscheidung. Einerseits sind im allgemeinen die kaukasischen Exemplare heller, loch fand ich unter den von mir an ein und demseiben Platze im moskauschen Kreise gesammelten Fvemplaren grell und blassgefärbte Thiere.

2) Die Länge der Sohle des Hinterfusses ist bei den von mir untersuchten Exemplaren aus dem mittleren und suddlichen Russland, der lirim und dem Kaukasus geringer als die Entfernung von der Schmanzenspitze bis zur liasis des Ohres, wie bei M. arianus.

3) Der mittlere rostgelbe Streifen auf der Brust, welcher nach Buchntr ${ }^{1}$ ) charakteristisch für MI. sylvaticus ist und bei M. arianus fehlt, ist bei allen von mir gesehenen Exemplaren gut ausgeprägt.

1: 114. Mus agrarius Pall. Bis jetzt nur aus dem westlichen Theile des nördichen Kaukasus nachgewiesen.

. $119^{1}$ ) und $119^{2}$ ). Spalax Nehringi Sat. und Sp. giganteus Nehr. In letzter zeit hat Prof. Nehring, in Folge seiner Untersuchungen der Schäleldifferenzen bei S alax viele neue Irten aufgestellt und K. A. Satunin hat nach Prifung unseres Materiales einen Spalax beschrieben, welchen er zu Ghren diess Gelehrten benannte. Ks war mir nicht mehr möglich diese beiden Arten mit laufenden Nummern zu versehen da der Katalng hereits

† k. Buchner. Wrissenschaftl. Result. Przewalsky's Reise. Mammalia, p. 90. 
abgeschlossen war und führe ich sie darum sub t: $11^{1}$ ) und $119^{2}$ ) an. In Bezurg auf diese

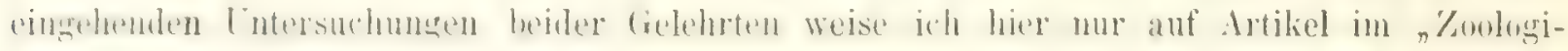
schen Anzeiger" . turforschender Freunde zu Berlin" 1897, lo 10 und . 1, 1898.

Sp. Nehringi ist bisjetzt nur von einer Localität aus dem Quelllande des Araxes be-

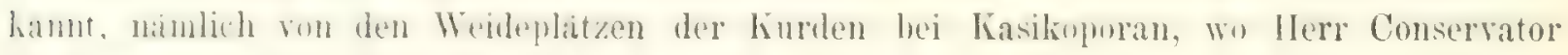
13. Koenig im Juli 1896 das 'Thier entdeckte.

Unsere Tafel griebt die Abbildung dieser neuen Art und die Schädel von sechs anderen Blindmollen.

Ir.

. 120. Sminthus vagus Pall. Ias kaukasische Exemplar dieser uberall seltenen Int ist ein wenig liteiner als die mir zum Vergleich zur Verfugung stohemlen Statcke aus

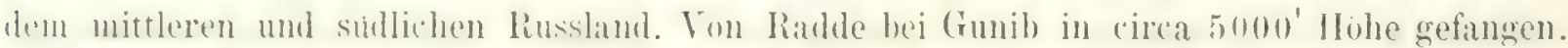

Vì1. Sminthas concolor Büchnor. Stimmt gut mit der von Bithner gegebenen

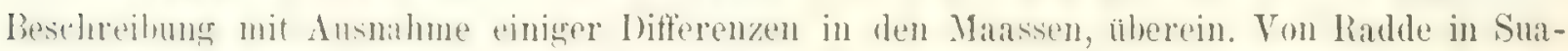
nien in $9000^{\prime}$ gefangen.

12.2. Alactaga alactaga 0liv. = A. saliens Sat. 1. c. 1. 307 . (iewönlich in den Steppen des nördlichen Kaukiasus.

Vi 13:3. Alactaga Williamsi Thomas. (.Mn. a Mar. Nat. Hist, Fer. (i. Vul, XX. September 1 95 ). Thomas sprach in der ohen citirten Ahhandlung die Vermuthung aus, dass die von mir in Transkaukasien gefundenen Alactaga, welche wie ich bemerkte, sich

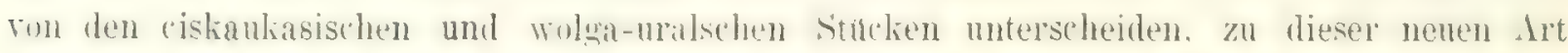

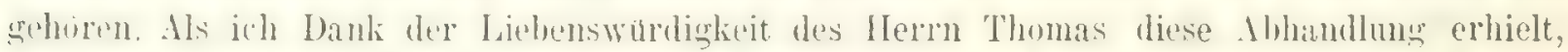
untersuchte ich sormtaltig das mir zur Verfugung stehende Material und fand dass, ohgleich

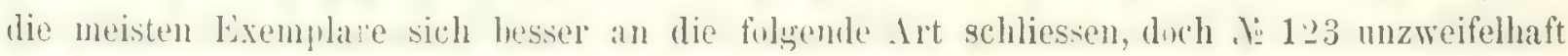
zu dieser neuen Art sehort und mit Iusnahme einger unbedentenden Abweichungen in der Firbung rollkwmmen mit der von Thomas gemebenen beschreibung ubereinstimmt. Das Thier wurde im Kreise Kuha, wo ich frühe: keine Sandhasen gesehen, erbentet. Ich führe hier einige Jeusungen dieses Exemplares sowie die von Thomas nach Fxemplaren ans Wan gegebenen Maasse auf:

Von der Schnauzenspitze bis zur Schwanzbasis.

$\begin{array}{rr}\text { Wan. } & \text { Kuba. } \\ 141^{\mathrm{mm} .} & 150^{\mathrm{mm} .} \\ 203^{\mathrm{mm} .} & 223^{\mathrm{mm} .} \\ 65^{\mathrm{mm} .} & 68^{\mathrm{mm} .} \\ 46^{\mathrm{mm}} & 46^{\mathrm{mm} .}\end{array}$

Schwanzlänge mit den Haaren

$23^{\mathrm{mm}}$

liasillinge

$27,2^{\text {mm }}$

$25^{\mathrm{mm}}$.

Grösste Breite der Jochbögen.

$23,8^{\mathrm{mm}}$

$14^{\mathrm{mm}}$.

Breite.

$13^{\mathrm{mm}}$

$4,8^{\mathrm{mm}}$.

$5^{\mathrm{rnm} \text {. }}$

Geringster Abstand des inneren Augenhöhlenrandes

$9^{\mathrm{mm}}$

$9,5^{\mathrm{rum}}$

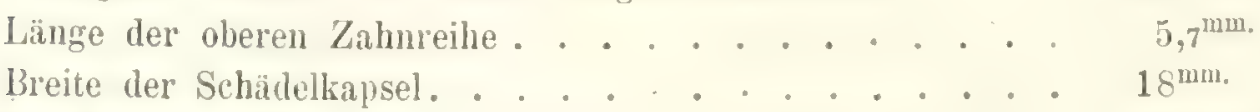

$6,3^{\mathrm{mm} \text {, }}$

$18,3^{\mathrm{mm}}$

Die Exemplare von Thomas wurden in einer. Iöhe von $5000^{\prime}$, unseres im Niveau des Meeres gefunden.

Sat.

. 124. Alactaga elater Licht.=A. acontion aut, nec Pall. In neuester Zeit hat P'rof. Nehring (1. Nehring. Ueber Gehiss- und Schädelunterschiede von Alactaga elater Licht. 
und A. acontion Pall. in: Sitz. Bericht. Gesellsch. Naturf, Berlin 16 Nov. 1897) auf Grundlage der Untersuchungen der Origin lexemplare von Pallas und Lichtenstein, welche sich im lierliner zologischen Museum befinden, bewiesen, da-s das Thier, welches gegenwärig die Zoologen als Alactaga acontion Pall. bestimmen nicht diese Art, sondern $\Lambda$. elater Licht. ist. Dagegen ist 1. acontion Pall. eine wenigh bekante centrala:iatische Specie, welche eine ganz besondere Zahnformel mud anderen liau des Schädels besitzt, s' dass man sie surar in ein besonderes Genus - Alactagulus abtrennen muss.

Obgleich das garnicht mit dem Verbreitungsgebiet, welches Pallas seinem $\Lambda$. acontion bilegt äbereinstimmt und er whe Zweifel beide Irten nicht unterschied, obwoll er die hetreftenden Exemplare kannte, so erhielt er zur lieschreibung znfillig nur die centralasiatische Art. Daher muss man zugeben, dass die von Pallas als Dipus jaculus var. pygmaea beschriebene Form in der 'That nicht mit Alactaga acontion der jüngeren Autoren identisch ist, um so mehr als Pallas ihr drei Backenzähne im Oberkiefer zuschreibt, was später für einen Schreibfehler gehalten wurde. Auf diese Weise ist $\Lambda$. acontion in $\Lambda$, elater umzunennen.

Zu dieser Art zieht Nehring auch die in 'T'ranskaspien in der Nähe von Krasnowodsli crbeuteten Sandhasen, mir ist von dort nur A. indica Gray bekannt

Sat.

ํㅜ 125. Alactaga indica Gray. Zu dieser Art gehöen alle ron mir ge ehenen Exemplare von Alactaga aus Transkaspien. In der Arbeit uber die Sibrethiere aus diesem Gebiete von Radde und Walter (1. c. p. 1049 Sept. 57) ist diese Art unter dem Namen von Alactaga acontion Pall. aufgefuhrt.

126. Hystrix leucura Sykes $=$ H. hirsutirostris Brandt. Sowohl im Kialiasus, wie auch in Transkaspien lebt l.ur H. leucurd, daher ist H. cristata ganz aus dem Verzeichuiss der Situgethiere des russischen Reiches zu streichen. Im Kaukasus findet man dis Stachelschwein nur in Thasch, wo es in den niedriger gelegenen Gebieten auch in den IVialdern recht gewöhnlich ist, seltener wird es auch in der Steppe angetroffen z. B. beim Dorfe Prischib.

ํo 129. Lepus enropaeus Pall. Her transkaukasische Hase wird wahrscheinlich als besondere Art abgetrennt werden müssen, aber aus den von mir schon mehrfach angefühten Gründen ist es jetzt unmöglich dieses zu thun.

.o 131. Lepus tolai Pall. (=L. Lehmanni Radde und Walter l. c. p. 1051 Sejt. 62). Wie bekannt vereinigt Buchner (l. c. p. 194) in letzter Zeit den L. Lehmanni wie auch einige andere Arten der centralasiatischen Hasen mit L. tolai Pall.

Sat.

\section{UNGUL \ TA.}

Ni 133. Sus scrofa L 0 - $80000^{\prime}$. Das Wildschwein soll nicht nur in Sommer his in die subalpine Zone wandern, man will es auch im Winter, namentlich an den verlasse. nen Lagerplätzen der Nomaden, also in IJöhen von 6-s000' angetroffen laben. In den Tieflindern ist es, besonders in den Rohrbestïnden entlang den unteren Stromlïufen und in den Dshongeh der Uferzonen, sowie thalaufwïrts auf entlegenen Inseln und verrotteten Wallbeständen entlang den Flüssen an vielen Orten sehr gemein. Die Keiler werden bis 10 I'ur schwer. Sie greifen, auch wenn lirank gexchossen, selten an. Nicht uherall ist das Wildshwein der Bewolner des bewaldeten Gebirges. Im oberen Suanien soll es noch vor 40 Jahren am Fusse des Laila Gebirges gelebt haben, jetzt fehlt es da. Mbwith in der Ingursehucht lebte es am Chaiseh und Nazisquil, fehlte aher hei I)shwari. So anch wurde mir das Vorlommen an den quellen des Rion verneint, dagegen fur dio obcre Kwirila bestitignt. First Lae- 
Wan Dadian vernichtete als gewaltiger Nimrod die liestimle des Wildshweines am oberen

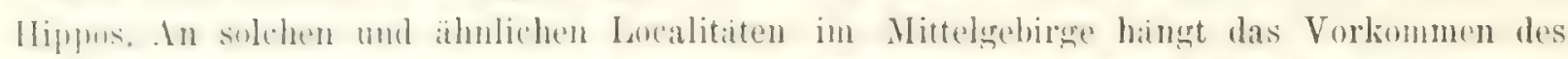
Wildschweines wesentlich fon der llaufigleit der Eithe und süssen hastanie, in höheren Lagen ron der Rothbuche ah. Ther andh im reinen Kiefermwalde triftt man es bisweilen an (Azkur).

Ich will hier eine liemerkung uber das kleine mingrelische schwein machen, welches sich zwar zu den Ansiedelungen der Menschen hält, aber doch halb wild lebt und nicht hesomders geptlegt wird. Ueherall findet man im Rimbassin, wenn man abwärts von den Enosen strassen in's Innere des landes liommt in der Nihe dep zerstrent liegenden Ansiedelungen kleine Trupps ron $6-12$ Köpten dieses clenden, hochstens zwei Fuss langen shweinchens bon constanter Farbe, die dem Colorit des Wildshweins recht sut entspricht.

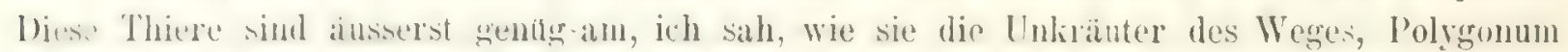
ariculare und Plantagn lanceulata abweideten. Sie fallen durch ihren verhailtnissmässict langen mot tlachen liopf auf. Erst neuerdings gelang es mir durch den I'rinzen Murat ein Paar Sichidel if und ₹ run dieser verkommenen, kleinen Schweinesorte zu erhalten, die ohne I'flege sich selbst üherlassen bleb und durch ein um den Hals gelegrtes, aus Stäben gemachtes Dreieck daran velhindert wird in die Girten uul Maisfelder zu dringen. Ich fand diese Thiere bis in das freie Suanien hinein; in Pari z. B. noch in 5000'. So verhielt sich die Sache wenigstens als ich 1861 meine erste Reise in Kolchis machte. Vor nummehr 10 Jahren hatte der Gnglander Reiss die ersten fast nackthäutigen shwaine englischer Race nath Poti und Sugdidi gehracht und 1865. führte Ananow dergledchen in Warziche ein. Gegenwiirtigr kann man in der Küstenzone bei einzelnen Wirthe.1 sehr schöne Racenthiere schen, Mischlinge an den nicht entlegenen Orten fast überall.

R.

Mi 136. Cervus elaphus L. Könnte ich sicher scheidende Grinzen ziehen zwischen den beiden extremen Geweihformen der kankasischen Edelhirsche, so würde ich naturlich C. elaphus von (: maral Ogilby artlich trennen. Solche scheidende Grenzen sind aber nicht vorhanden, vielnehr finden sich vermittelnde Uebergänge von einem Extrem bis zum anderen, sowohl in der Auslage der Geweihe, als auch in der Textur an der Basis und in d.r lironenbildung und zwar hat das statt auf ein und demselben Terrain. Man muss also zugeben, dass beide extreme Furmen unmittelbar beieinander leben, womit aber noch nicht gresagt ist, dass sie auch in demselben Rudel strhen. I) Domine Sr. Kaisl. Hoheit des Grossfürsten Michail Nikolajewitsch, Borshom, in deren weithin zusammenhängenden Wildern stit 1 n67 die Ilochwildjagd regelrecht ausgeibt wird, liefert dafür die schlagendsten beweise. Ich habe aus der grossen Anzahl von Geweihen, die dort als Jagritrophizen mit Erenauen Angahen der Schusslaten aufhewahrt werden, die extremen Formen grupuirt und war Her. Moldenhater so liebenswarlig sie photographisch aufzunehmen. Die beigegebenen Tafeln beweisen zur (ienüge, dass in Ijezug auf Auslage, stirlie und Textur die Variationen selbst aus einem Stande auseinander zu halten sind.

Will man die extremen Formen artlich auseinander halten, so bleibt nichts anderes zu thun übrig, als den vermittelnden die trinäre bezcichnung C. elaphus-maral beizulegen. Dat aufgestellte Hxemplar des Museums .1: 136 rom Elisabethpol ist ron Satunin in seiner Arheit ${ }^{1}$ ) als C. maral Oglb. benannt worden. In der Färbung entspricht es durchaus dem typischen IIirsch, die Auslage der Geweihe ist recht flach. Es hält schwer zu cinem festen, endgiltigen Crtheil uber Art oder individuelle Varietät zu kommen, um so mehr, als anch im Gandsha Gebirge, dem jenes Exemplar entstammt, normale Edelhirsche nicht selten sind.

\footnotetext{
1) Vorlaufige Mitheilungẹn über die Sâugethierfauna der Kaukasusländer, in Zool. Jahrhücher, Id. IX, pag. 309.
} 


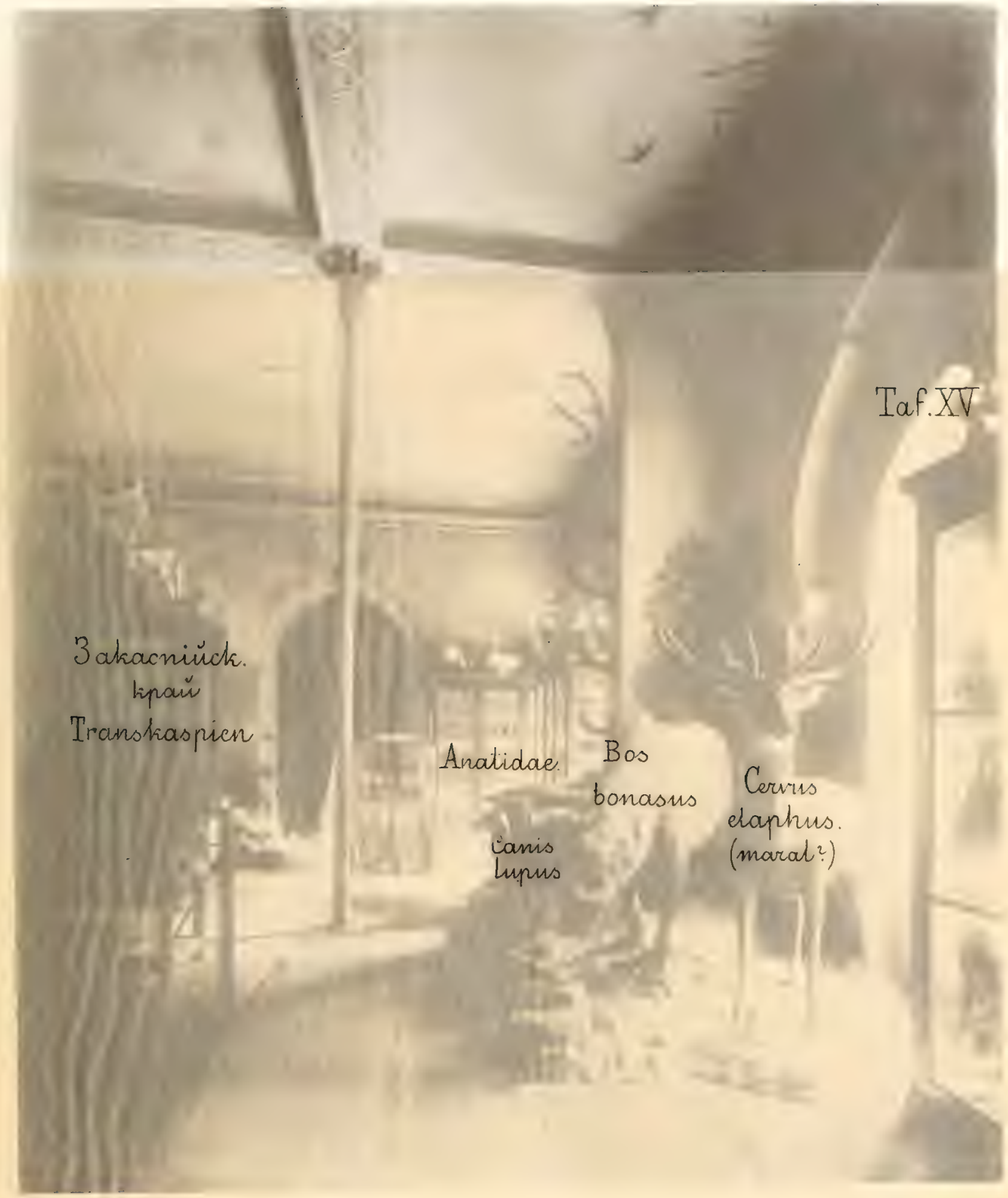


77961

Husisactole wirnpit varigenasichnt?

chensas ancosiog cosest spalo

(forasht)

CNRAS ansun 


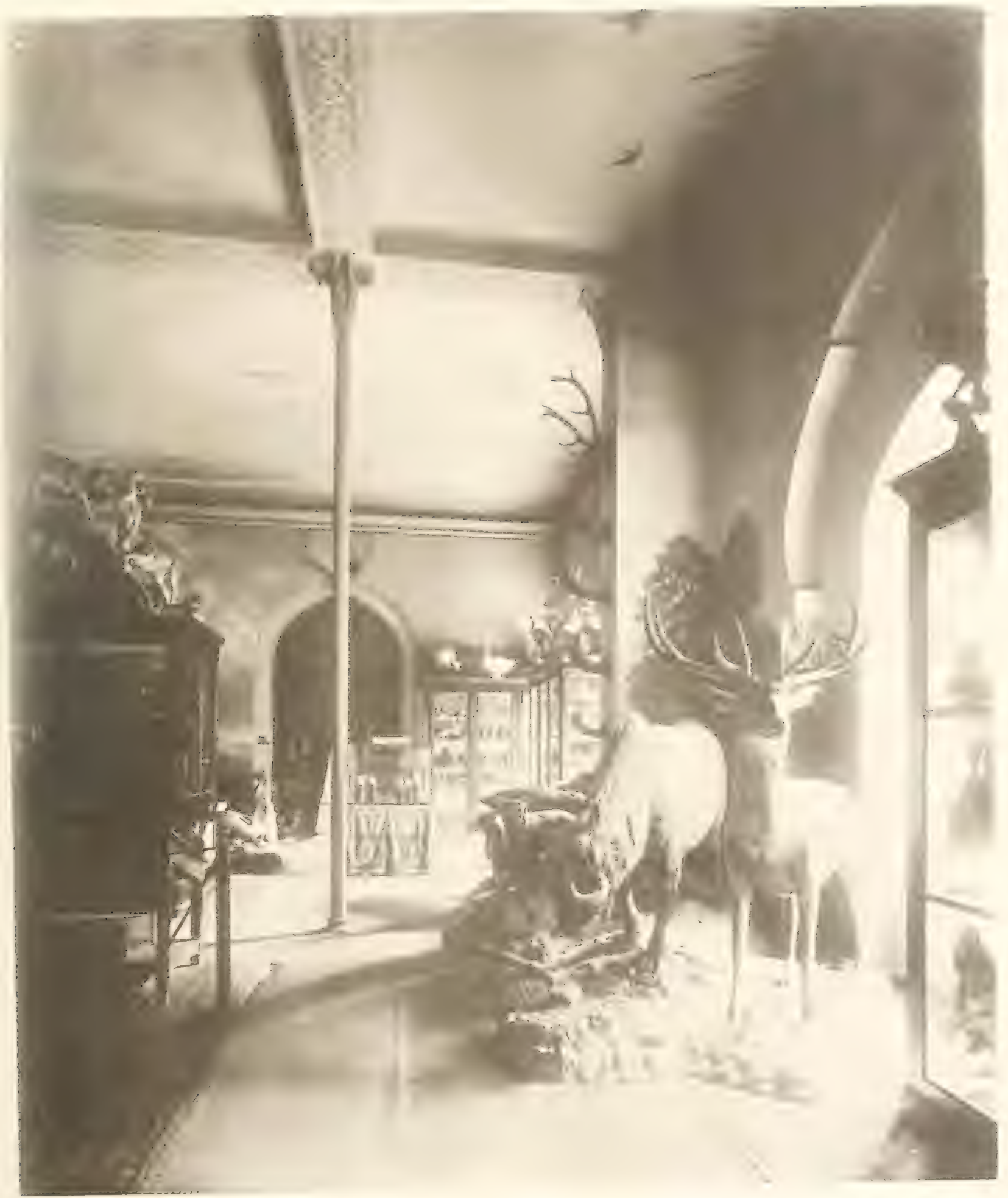





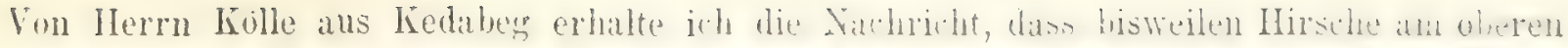

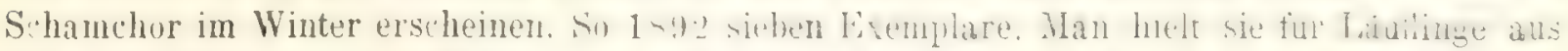
den westlicher gelegenen Wäldern von Delishan, slater wurden keine inehr beoharhtut. Die starken Geweihe welche in der Forstei von Kalakent vor Jahren zu sehen waren, stammten nicht aus diesem Gebiete sondern won Laisch (schemacha) ron wo sie lie liupferefunicde

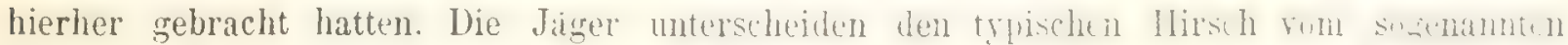

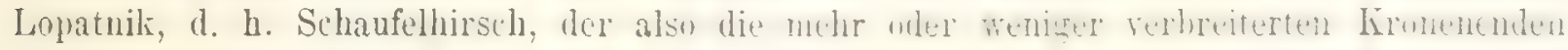

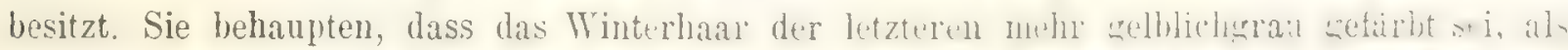

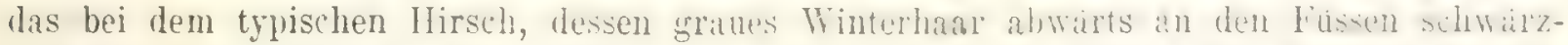
lich wirl. Auch soll der Schaufelhirseh in grosseren Rudehn stehen. Die Meinung her Jit-

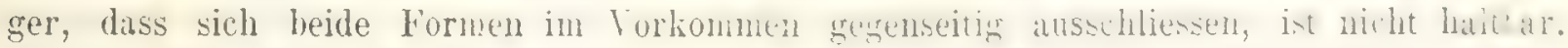

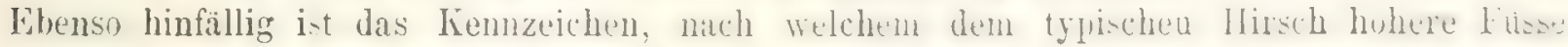
zukommen sollen, der Schaufelhirsch dagegen niedriger gebaut sein soll.

Die stärksten Hirsche leben im Kuban Gebiete in denselben Revieren die der Auer besteht, wo man sie zur Sommerzeit hoch oben an der Baumgrenze häufig antrifft. Am Tage ruhen sie gerne in der 6-8' hohen, dichten Krautvegetation an feuchten Gehängen und treten Abends zur Aesung auf die Lichtungen. Sie nehmen im Sommer gerne die jungen Triebe von Ribes alpinum an, im Herbst ist innen das Wildobst, später die Eichelmast lieb, die sie in tieferen Lagen aufsuchen. 20-22 Ender sind in diesen reichen Jagrevieren gewönlich. Die letzte liente Sr. Kaisl. Hoheit des Grf. Sergei nichailumitsch lin ru von dorther wahre Prachtstucke.

In dem westlichen Theile der Sudseite des Grossen Kaukasus und in Kolchis sind die Hirsche an vielen Stellen schon sehr decimirt. Im oberen Theile des dadianischen Suaniens, von Lentechi aufwïrts fehlten sie $186 t$ gänzlich, man hatte sie in schneereichen Wintern alle niedergemacht. Das geschieht auch, wenn sie und die Rehe sich, vom tiefen suchnee

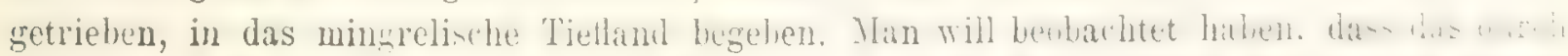

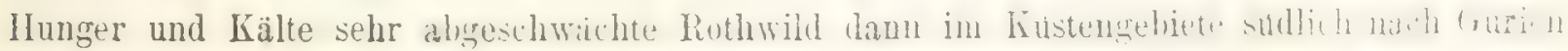

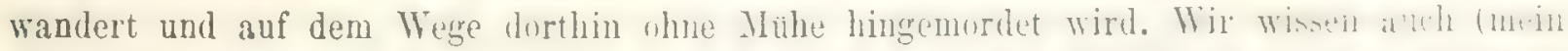

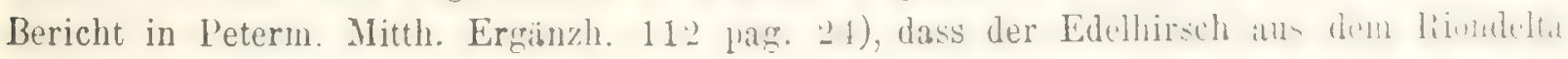
verschwunden ist, er bestand da noch bis 1872 die Wälder südlich von Poti. Mit del

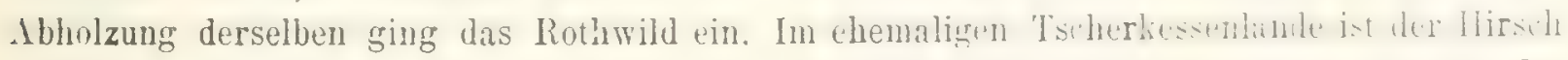
häufig und im Geweih normal, d. h. mit nicht sehr stark stumpfwinkliger Auslage des

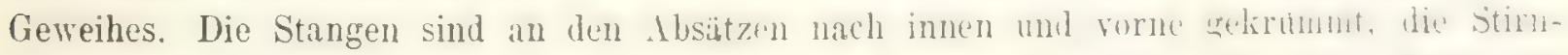

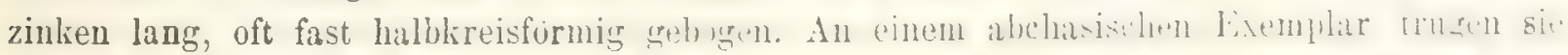

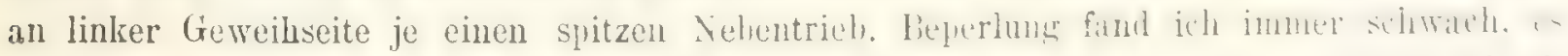
giebt stattliche 22 Ender, aber nie so starke wie am Kuban. Auch hier tritt der Hirsch zum Winter in die Uferzone. In freien Suanien sah ich Hirschgereihe und Kinnbacken

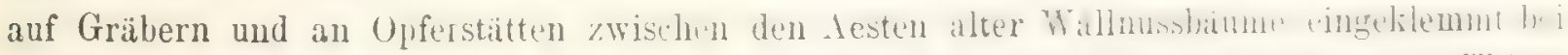

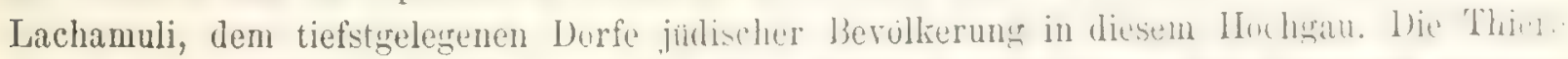

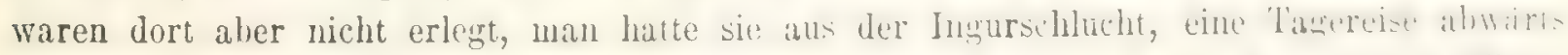

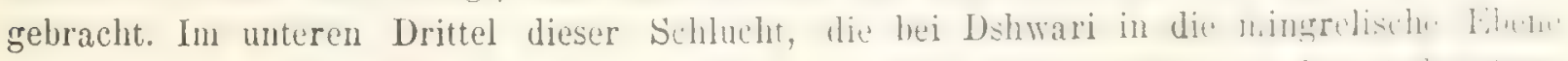

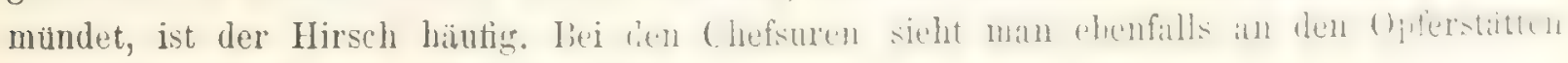
manches Hirschgeweih und Bezoargehürn.

Gegen Osten und Süden wird der ECHihirsch seltener. Im Dagestan fand ich ihn in

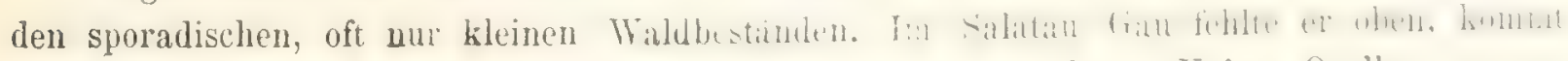
aber tiefer in den Wäldern von Dilim vor. An curn rerschiedenen Koissu Quellen Wal cl" 
nicht selten, die zalmen Hirsche, welche ich in Thata sah, trugen bei geringerer Körnerorosse schwaches Geweih und tielen mir durch die dunkle, schwäraliche Färbungr auf den dussenseiten der Schenliel auf. Auch an diesen 'Thieren, die nicht mehr jung waren, machten sich die kaum angedeuteten Fleckungen im strammen Sommerhar bemerkbar, man sieht sie bei a ullallendem Lichte, wenn man shrigge ron der Seite anf das Thier schaut. Interessant ist das Torkommen des Edelhirsches in den Ebenen am unteren 'Terek. In Kisljar erstand ich ein sehr schönes Geweih von C. (apr. p)gargus und sah auch Hirschgeweihe, wdehe ron dort stammten. Man theilte mir mit, dass beide in den ausgedehnten Bestinden der strachweiden, die mit schwachem Rohr untermischt sind, bestindig lebten und fruher recht häufig gewesen wären. Der Hirsch soll sogar mit Vorliebe in Sumpfgebiete gehen, weil in ihnen weder Wolf noch Jagdhund die Spur fassen kam. Das südlichste Vorkommen in Hocharmenien anf russischem Gebiete markire ich mit Daratschitschach, wenig westlich rom Croktschai see. In den siebenziger Jahren wurde da der Lidelhirsch im dürftigen Buschwalde (Liche) alljahrlich erlegt und wir wissen ja, dass das grösste Geweih der Museums Sammlung dem Goktschai See, nahe von dessen westlichen Rande, entnommen wurde.

Die neuesten Nachrichten über das Vorkommen des Ldelhirsches in Íarabagh erhalte ich durch Herrn Rösler (Aug. 98) von Schuscha. Im Sangesur-und im Dsewanschir Kreise sovie an der westlichen Grenze des Schuscha Kreises besteht der Edehirsch die subalpinen Gebiete und Baungrenze, ist aber nur selten und das Geweih spitz nicht schaufelig und bei alten Thieren auch stark

R.

- 1:3i. Cervus capreolus L. typ nud C. (- pygargus Pall. o-liammarenze unl subalpin. Ich kenne die starkwächsige Form nur von der Nordseite des Kaukasus im Kubungebiete aus den Vorbergen und aus dem Tietlande des 'T'erek, wie oben schon gesagt wurde. Der zur Erklärung der Tafeln beigegebene Maasstab genügt um ein richtiges Urtheil uber Stitke und Spreitzung (Auslage) der Geweihe sich zu bilden.

Am nordwestlichen Fude des Kaukasus hat man an der Südseite des Gebirges die starke Rehform noch bei Dshuba zweimal als grosse Seltenheit erlegt. Das Reh ist dort durchwer schwach im Korper und in der Krone, aber in den bewaldeten Vorbergen recht häufig. Die Paliurus-Makis und die Irombeerdshongeh schützen das Wild gut ror dem Wolf. Hauptfeind der Jungen ist der Schakal. In der 'Tschetschna und in den Vorbergen des Dagestan kilagte man uberall uher die Abnahme des Rehes in jüngster Zeit. Wo früher 10-15 Lopf starke Rudel gringen, fehlten die Rehe oft schon ganz (Salatau). Bei den Rehen, welche in den Ebenen der Tiefländer uberwintern begimnt der Harwechsel schon Mitte Februar. In Hohen von 3-4000' erst Ende Mürz, an Kopf und Hals etwas später als am Körper.

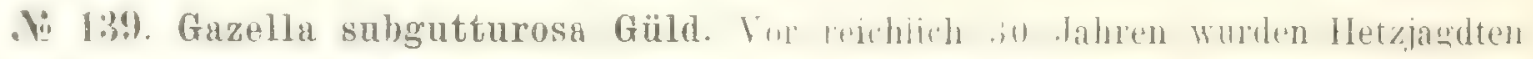
auf Antilopen mit Windhunden noch im Kurathale, 30-10 Kim. abwärts ron Tiflis abge. halten. Damals erzählten mir alte Lente, dass ehedem das zierliche 'Thier im. Kurathale aufwäts noch $10 \mathrm{Klm}$. von Tiflis bei Awtschala vorgekommen sei. Damals war allwinterlich der Markt ron 'Titis mit dem edlen Wildpret besetzt, jetzt kommt es bisweilen von weither in grösserer Zahl, gewönlich kauft man unter dem üblichen Namen "Dshairan" das Reh, aber nicht die Antilope. Sie hat sich mit der Eisenbahn weit thalabwärts gegen Osten verzogen und ist auch da nicht mehr hiutig, so 2. B. in den Ebenen von Jewlach. Die unbewohnte Einode der Mugan, die Steppen zwischen Araxes und Kura sind ihre jetzigen ZuHuchtsorte in Ciskaspien. In Transkaspien konnte man in der ersten Zeit der Eisenbahnfahrten (1886) seitwärts ron der Tinie oft noch geschlossene Rudel von Hunderten von Köp- 


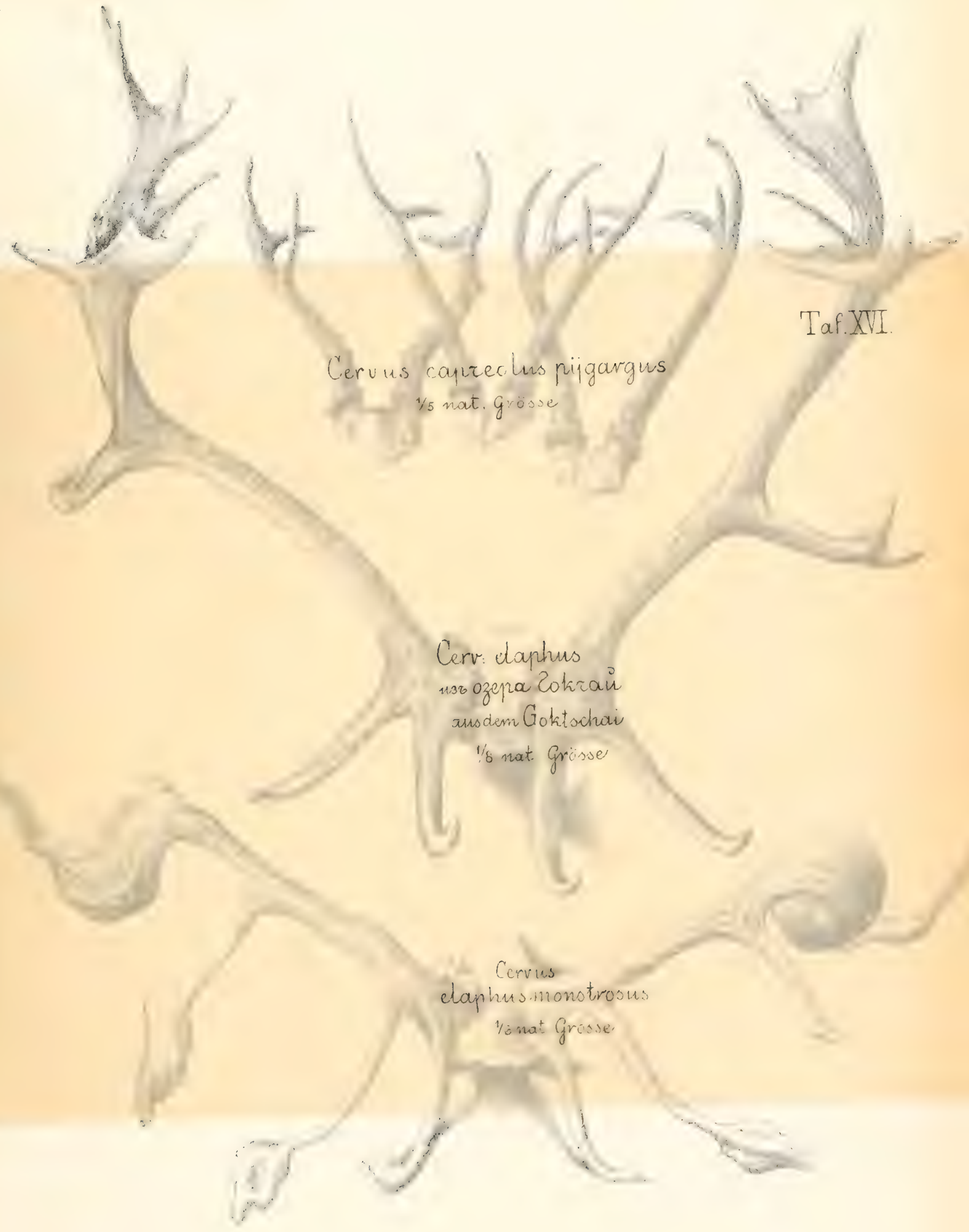


IVX:F

$$
\begin{aligned}
& \text { zwproping asjogsnas zan uro } \\
& \text { weaörp. tan } 2 l^{\prime}
\end{aligned}
$$

$$
\begin{aligned}
& \text { contaction ais }
\end{aligned}
$$

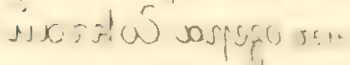

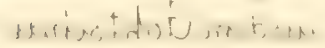

$$
\begin{aligned}
& \because \because+\ldots+i^{\prime}
\end{aligned}
$$

[av ver?

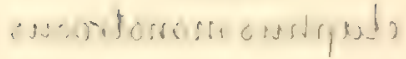

scoörp $\tan$ al 


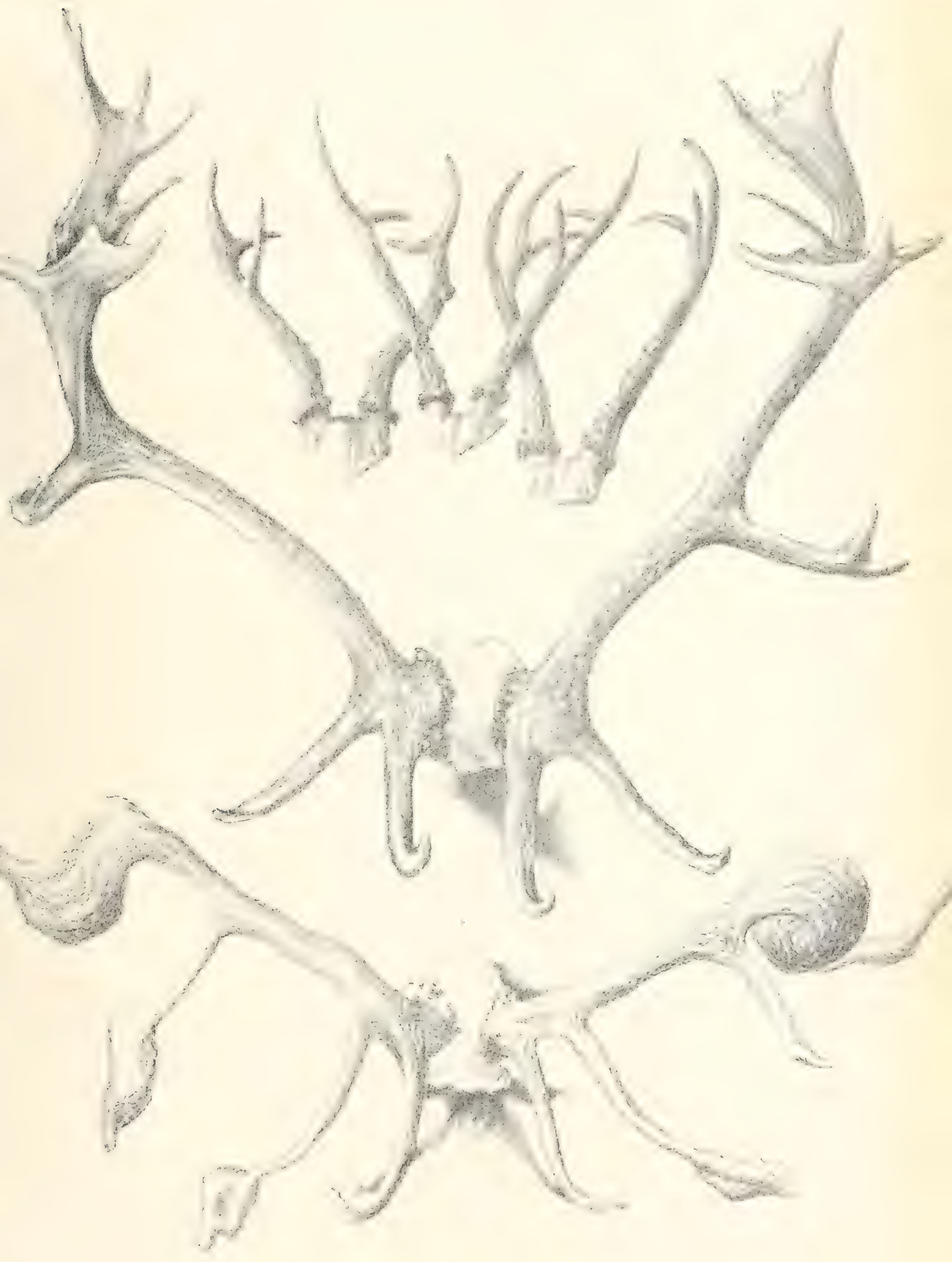



fen in der Wüste und Sandsteppe sehen. Am häufigsten traf ich sie in Chorassan auf linker Seite des Herirud in der Richtung auf Serachs (von Pul-i-chatum). Hier hatten die Weibchen offenbar je 1-2 Junge gesetzt, sie lebten noch nicht geschart, sondern vereinzelt, aber auf Schritt und 'Tritt erhoben sie sich von der dürftig bewachsenen Steppe und flohen vor unserer Karawane.

Ich habe vor Jahren diese Antilope genauer untersucht und ausgemessen. Die Böcke besitzen ror den Hoden links und rechts je eine IIautrinstilpung, welche an die linutel des Inschusthieres erinnert. Ich gebe die leschreibung und Zeichnum, su wie die ermittenten Maasse hier.

Seitwärts und vor der Basis des Hodensackes befinden sich in gleicher Entfernung von

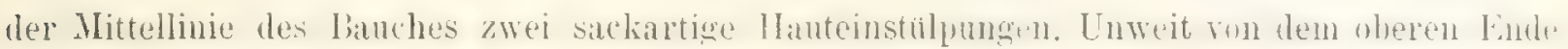
ihres Jnnemrandes sieht man je eine verkümmerte Drüse, welche wie die umgebende Haut nur spärlich behatrt sind und sich schmierig anfihlen, da sie Antheil an der Ausschwitzung ciner fettigen Masse nehmen, welche die sachartigen Vertiefuncen ganz iberzieht. Bei natürlicher Jage der umgehenden lörpertheile ist der Inungendurchnesser dieser Hanteinstilpungen 1 Zoll lang, der grösste Querdurchmesser jedoch nur $7^{\prime \prime \prime}$. Indessen sind die Ränder sehr dehnbar, mit geringer Mühe kanm man sie wie fig, b. zeigt auf $1^{\prime \prime} 5^{-1 "}$ Länge und 1" $3^{\prime \prime \prime}$ Breite bringen. Die grösste Tiefe dieser Einstülpungen messe ich zu $1^{\prime \prime} 4^{\prime \prime \prime}$. Betrachtet man die Obertlächt derselben, so sieht man anf ihr viele einigermaassen concentrisch gestellte Falten, die aber nicht in geschlossenen Ringen stehen, sondern bald kürzer, bald lünger sind und namentlich dem Aussenrande zu tiefer und wulstiger erscheinen. Die ganze Oberfäche ist mit warzenförmigen Drüsen besetzt zwischen welchen $4-7$ "' lange, ziemlich straffe Haare sparsam stehen, welche in Folge der sie einhüllenden, von den Drüsen abgesonderten Fettschmiere gelb sind. Die Ausscheidungen sind um diese Zeit (Ende Decb.) so stark, dass sich davon Anhäufungen in Grösse einer grauen Lruse oder kleinen Hasehuss

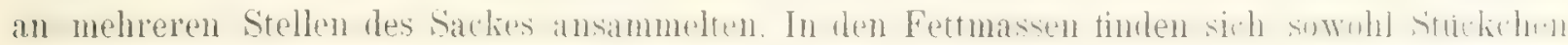
der Kidermis, als auch Haare, die letzteren sitzen nur lose anf der Innenseite und emenern

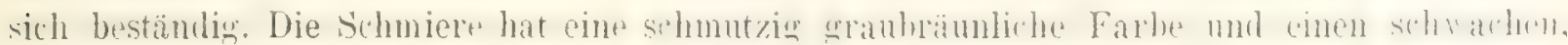
eigenthümlichen Geruch, der etwas amoniakalisch ist und entfernt an den frischen Moschus Iles sibirischen Moschusthieres erinnert.

Die ermittelten Maasse ergeben nachstehende Tabelle (im Fleisch gemessen).

Alter Bock.

Total in natürlicher Haltung. Nasenspitze bis Körperende (gerade) . . 42'

Länge des Schwanzes von der Wurzel bis zum Ende ohne Haare

des Kopfes von der Spitze bis zur Basis der Hörner . . . ." i"

der Hörner von der Spitze zur Basis gerade gemessen. . . . $13^{\prime \prime} 11^{1 / 2}$

der Biegung entlang an der äusseren liäche. . 1 1." :"

Zahl der Windungen des Hornes . . . . . . . . . . . . 1

Mundspaltenlänge . . . . . . . . . . . . . . . . 2 $2^{11} 4^{1 / 2}{ }^{1 \prime \prime}$

Längendurchmesser der Nasenlöcher . . . . . . . . - $10^{\prime \prime \prime}$

Grösster Höhendurchmesser derselben am Aussenrande. . . . . . - 5 ("'

Länge der Thränengrube. . . . . . . . . . . - $10^{\prime \prime \prime}$

Abstand der oberen Winkel der Thränengrube voneinander . . . . $2^{\text {" }} 7^{\prime \prime \prime}$

unteren

des inneren Augenwinkels vom oberen Thränengrubenwinkel . _ 6 " 
Abstand des inneren Augenwinkels vom äusseren Augenwinkel. . . . 1" ." "' del. "Angenwinkel von einander . . . . . . g"

der hinteren Hornbasis rom vorderen liande der Ohbasis. . 2" $3^{\prime \prime}$

Kalanster Abstand der lasis der Hörner roneinander (Mitte) . . . - 4 "

Abstand der Hornspitzen roneinander . . . . . . . . . . . 8 " $8^{\prime \prime} 2^{\prime \prime \prime}$

Grösster Abstand der inneren Hornnänder (liegt im obersten Viertel) . \& 8 " 6 "

Liinge des Ohres ron der Spitze zur Basis der Ohrspalte . . . . . 5 " $5^{\prime \prime} \quad 2^{\text {"' }}$

(iröste Mreite des Ohres (in der Mitte der Ohrenhǒhe) . . . . . 1 1" $7^{\prime \prime \prime}$

Isinge des Schulterblattes (in Fleische). . . . . . . . . . 8 $8^{\prime \prime} 6^{\prime \prime}$

- Obermmes (dito) . . . . . . . . . 9"

Von der Kniebenge bis zur Fusswurzel . . . . . . . . . . $8^{\prime \prime} 6^{\prime \prime \prime}$

Iänge der Fusswurzel . . . . . . . . . . . . . 2" $2^{\prime \prime \prime}$

Alstand der Afterklauen ron dem oberen, hinteren Rande des IIufes. 1" $11^{\prime \prime \prime}$

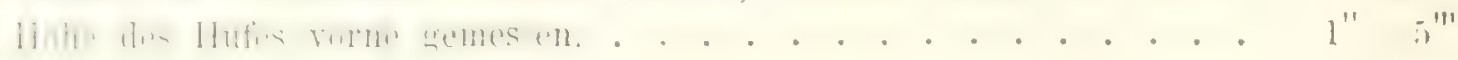

linten . . . . . . . - - $8^{\prime \prime \prime}$

Entfernung der vortretenden Spitze des 13eckens von der Kiniebeuge . $9^{\prime \prime} 3^{\prime \prime \prime}$

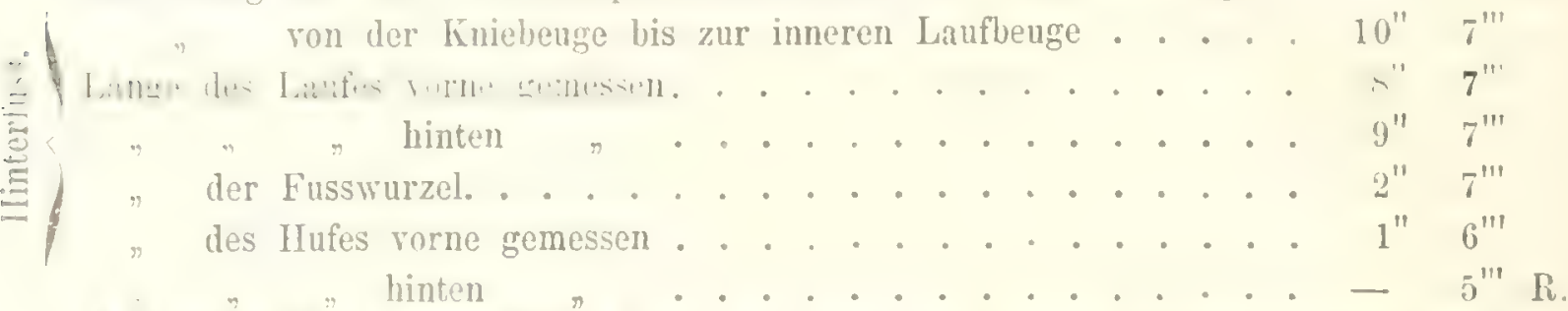

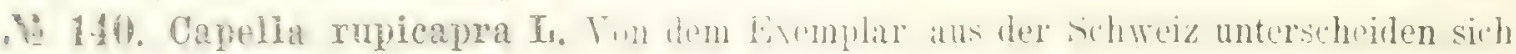
meine kauk. Gemsen nicht. Das Winterhaar legen die Gemsen auch an den tiefsten Standorten schon Mitte September an. Anfang; October ist die Behaarung ausgewachsen. Um diese Zeit sind die drüsigen Einstullungen hinter den IIöneru sehr entwickelt. Die Gemse bawhnt in grösster Menge den gesammten Grossen Kaukasus in seiner schneeführenden Fimmzone wird aber im Randgebirge Hocharmeniens viel seltener und fehlt dem östlichen Theile dessclben soriel bisjetat bekinnt ganz. Die tiefstgelegenen Fundorte liegen $2700^{\prime}$ über „lem Neere, lic hürhten in Sommer auf den Firnfeldern der hochalpinen Zone, also 1012000'. Ijei Lorshnm lebten an verschiedenen waldenthlosten Steilungen bis Ende der sechsziger Jahre lileine wull, dic aher gleich den Bezoarziegen sehr bald nach der stärlieren [Besiednun der D.mäne und den häufigeren Jagdten verschwanden. Die Rudel in Hougehire siml oft sehr stark, es sullen inanchmal an hundert Köpfe beisammeu gehen. Man sicht dir zersirengten Rudel in simmer auf den Schnefeldern und Firndecken spielen. Zum Minter troten die Gensen werne in die obere Waldzone und wandern bei tiefem Solnee awh wh the thalwärts. Su crscheinen sie manchmal in Kolchis auf den Südschroffungen des

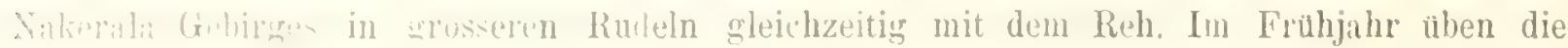
Salzlek no me arose Anzlehungskraft auf die Cemsen aus. Sie steigen im April zu ihnen

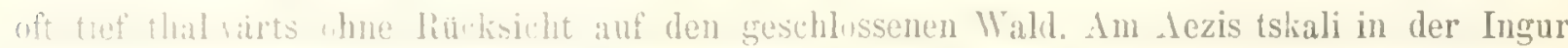
Whuth und in den Wialdern an der kleinen Isaba (Umpir) fand ich bei den Salzlecken s'grnante Gemswanmen. Tial vereinzelter liegen die mit sicherheit nachgewiesenen Fundorte in sugenanuten Kínen Kaukasus. Das Gehörn io 110. o stammt von oberhalb Artwin, also aus dem 'Tschoroch Gebiete. I: 140. 140 b, g, h gelten der Adsharo-imeretishen Scheide (Abastuman, IBorshom) li 140. a dem 'Trialeth (Bjely-klutsch). Im Gandsha Gebirge gehört die Gromse zu den Seltenheiten. Standurte sind von Ach-kaja hoch oben an 
den Quellen des Scham hor bekannt. ferner vom Kotshgar-dagh und vom Tschatindura. Hier mit der Bezoarziege. In früherer Zeit standen die Gemsen auch hier viel tiefer, so namentlich im Thale des Schamchor unweit vom Dorfe Barsuna, wo vor zwanzig Jahren noch Gemsen erlegt wurden. Fur Karabagh verneint Herr Rösler das Vorkommen der Gemse. R.

№ 141. Capra aegagras Pall. $0-14000^{\prime}$. Bevorzugt nacktes und zerrissenes Gebirge, fehlt aber den Waldgebieten da nicht, wo, wenn auch nur an einzelnen Stellen, sich solche zerkluftete Plätze finden. So auch bei Borshom, wo 1866 neun Stück bei den Ruinen Petroziche erlegt wurden.

Ich habe in der "Allgemeinen Encyklopädie für Forst-und-Jagdwissenschaften" Iid. VIII. pag. 452-157 ausfuhrlich uber die Bezoarziege berichtet und weise den Leser auf diese Arbeit hin. Hier nur soviel, dass 141 b, c, d vom Ararat bedeutend heller sind und die schwarzen Zeichnungen am Kopf, Hals und Brust viel weniger entwickelt zeigen, als ㄴ. 141 und $﹎{0} 141$ a aus dem Grossen Kaukasus. An recht alten Gehörnen schleifen sich die Zahnungen auf der vorderen scharfen Schneide nicht nur ganz ab, sondern es bildet sich da eine: schmale, jederseits abgerundete Fläche. Auf die grössere oder geringere Spreitzung der Gehörne darf man kein Gewicht legen. Es giebt sogar wilde Bezoarziegen an deren Gehörn die Spitzen sich kreuzen, wie das Exemplar l: 141 n zeigt. Bei normalem Bau schwankt die grösste Breite zwischen beiden Hörnern von 35 bis 55 ctm. In dem citirten Aufsatze habe ich auch uber die Bastarde mit der Hausziege und dem Tur (C. cylindricornis) Mittheilungen gemacht.

Der Standort $1 \pm 1$ o ist mir vom Kubadagh bei Krasnowodsk (Transkaspien) rom Winter 18,86 bekannt. Auf dem Grossen Ararat fand ich noch in 14000' auf dem Firn Spuren und Losung. Die Bezoarziege gehört dem ganzen Gebiete an passenden entlegenen Plïtzen an. Sowohl aus dem Trialeth, als auch aus dem Gandsha Gebirge und oben von Talysch kenne ist sie. In bewohnteren Gebieten zieht sie sich sehr bald in die entlegenen, liahlen Gebirgseinöden zurïck

R.

\section{N.144. Capra caucasica Güld. und ํ. 145. Capra cylindricornis Blyth.}

1987 hat E. Büchner in seiner Abhandlung „Zur Geschichte iler Kaukasischen Ture" ") die beiden 'Steinbockarten, welche als endemische Species nur dem Hochgebirge des Grossen Kaukasus angehören, erschöpfend behandelt, ebensowohl in Bezug auf die sie betreffende Literatur, als auch im Datail ihrer zoologischen Beschreibung und grographischen Verbreitung. Schon in demselben Jahre veröffentlichte Prof. Mensbier in englischer Sprache einen Artikel, in welchem er den Steinbock westlich vom Llbrus artlich als C. Severtzowi von C. caucasica trennt, dem letzteren die Zone vom Elbrus östlich bis zum Dychtau anweist und dann weiter üstlich im Anschlusse C. cylindricornis folgen lässt. 13uchner und soviel ich erfuhr anch Sclater halten C. Severtzowi artlich nicht verschieden von C. caucasica. Ich theile die Ansicht beider. Die Gehörne der Exemplare des Museums aus len Hochgebirgen an den Labaquellen stimme: zu dem des gleichalten Thieres rom Librus vollkommen, das letztere düfte in Auslage noch etwas melr gespreizt sein.

Mit zunehmendem Alter wird das Winterhaar bei Capra caucasica heller. Die Declie sub . 1 : 144 ist von besonderem Interesse in dieser Hinsicht. Die Gesammtfarbe derselben ist bis auf einen schmalen Streifen in der Mitte der Pauc'ifliche und die Vorderseiten der Läufe, hell gelbli hgrau, ohenher fast schmutzicr gelblichıceiss, so dass das thicer in der Ferne geschen weiss erscheint. Es soll das nach Noska keine Ausnahme von der Recrel sein, da die Jäger im Frühjahr, wenn der alpine liasen sprie st und sic dann auf Rudel

1) Mémoire de l'Acad. Imp. de sc. St.-Ptb. T. XXXV jẹ. 8. 
alter Thiere stossen, den Ausdruck gebranchen: 'T'uri beljeet, $d . h$. die 'lure hellen weiss ant und die Suanen in ihren Gesängen von alten weissen Turen erzihlen, welche den Jäger in

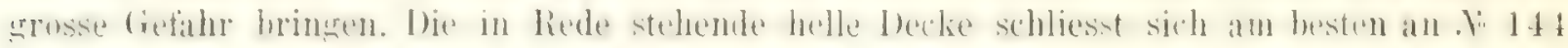
b of der grossen Gruppe an Die Farbe der schmalen Bauchzone und der Vorderseiten der Lïufe entspricht dem Braun des gewöhnlichen. Colorites, wie es meine alten \& am ganzen

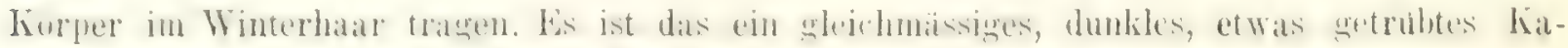
stanienbraun.

Von grösserem Interesse als das Vorstehende halte ich die nun folgende Mitheilung.

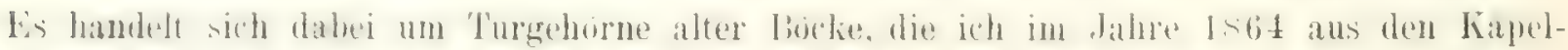

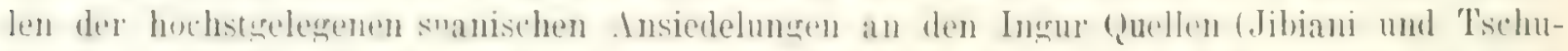

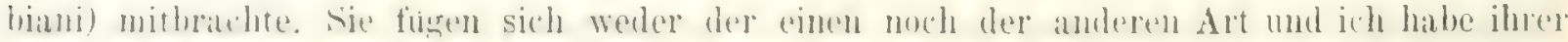

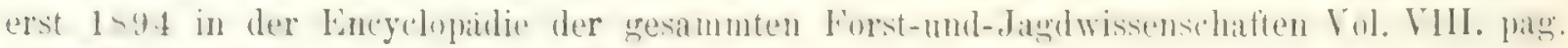

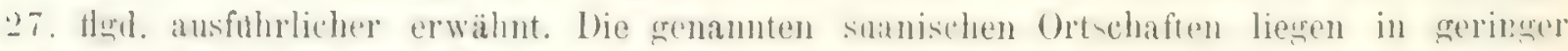

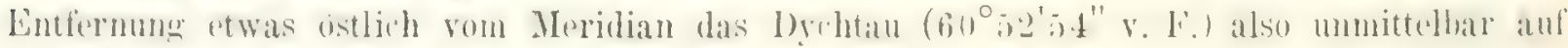
der Grenzscheide beider Steinbockspecies. Wie nun auch die photorgaphischen Abbihumen, welche ich auf beistehender Tafel neben denen der typischen beiden Arten setze darthun, so haben diese Gehörne ebensowohl Charaktere von Capra caucasica, als auch von C. cylindritornis. Von letzterer nimlich die Sliulptur der Schale und den perundeten cherdurchschnitt. Man sieht an den beiden Gehörnen nur Ueberwallungen, nicht aber auf der Vor"derseite Linten, wie solche als der C. Caturasica zukmmmend hei den Gehornen jungerer Thiere. die denselben kapellen entnommen wurden auf unserer Photographe sehr dentlich pron:n-

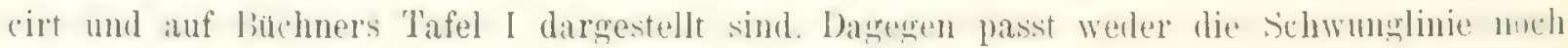
der Anstieg vom Stirnbein zu C. cylindricornis und ebenso wenig zu C. caucasica. Ueberdie's sind beide Gehorne auch in dieser Hinsicht verschieden das sub a abgebildete crheht sich ebenso steil wie bei C. cancasica bleibt aber nicht in einer Fläche, schwingt in der Mitte concav im Bogen zur Spitze, die nach innen gekehrt ist, aus. Das unter b abgebillete ist dagesen ebenfalls bei stäkerem dnstiene als ihn C. cylindriornic hesitat, fast re-

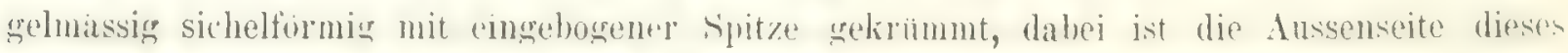
Hornes fast glatt, die dherlagernden Lamellenrinder sind nur sehr schwach pronnn'irt. Man kann mit einem Worte diesen beiden, immerhin ron einander ctwas abweichenden (rehurme'n den vermittelnden Leberang von C. caucasica zu C. Crlindricornis nicht absprechen mil wird dadurch auf die Idee geführt, dass man es mit Bastarden von beiden zu thun hat. ber Wahrsheinlichkeit, dass das whklich der Fall sei, steht insofern nichts entregen, at: die verwandten Ziegenarten sich geschlechtlich ungemein leicht verhinden und fruchtbare Ilendlinge erzeugen, wie das zwischen bezoar f und Tur (cylindrc.) \& und zwischen diesem \& und der Hausziege $\&$ nachgewiesen wurde. Gerade nur hier, an der Stelle, wo sich die Verbreitungsgremzen beider Steinbockarten berühren, habe ich solche ahnorme Gehorne sefunden. Weberall ustlicher, auch am Kasbek und im tresammten 1)agestan sah ich immer nur typischen C. cylindricornis, so auch in der grossen Sammlung des Fürsten. N. S. Tschawtschawadze, welcher dem Museum die schöne Suite . $145 \mathrm{f}$-k. schenkte.

In den entlegenen Hochrevieren der Mpen des Grossen Kaukasus gehen beide Steinwildarten in starken Rudeln. Namentlich ist das der Fall bei dem Mutterwild. Nuska zathlte in einem Stande 120 Köpfe. Alte Böcke. trifft man vereinzelt und in Banden bis 12-15 Individuen an. Am Bogos fand ich C. cylindricornis mit $40-50$ Köpfen bei einander. Die

') Die Gipfel dieser drei Bergriesen liegen sehr nahe beieinander, sic bilden die Ecken eines gleicbschenkligen Dreieckes von $22 \mathrm{k} l \mathrm{~m}$. Basal-und $13 \mathrm{Klm}$. Schenkellänge. 
Bewohner von Kurusch kannten den Tur vom nahen in der Hauptkette gelegenen Basardusi und auch rom Sihah-dagh. Bei der Besteigung des $13700^{\prime}$ hohen Schalhus ${ }^{1}$ ), dem $3^{-t}$ der Nachbarriesen war Megaloperdix caucasica sehr häufig, vom Tur fand ich aber keine spur. Ich gebe hier noch das Verzeichmiss derjenigen Pflanzen, welche Noska mir als Lieblingsfutter ron C. caucasica einsendete. Es liessen sich folgende bestimmen:

Chamaesciadium flavesceus, Cnidium sp. Pimpinella sp. (defect) Valeriana alpestris, Gentiana pyrenaica, G. verna, Androsace albana, Viola grandiflora, Primula elatior, Campanula tridentata, Veronica gentiannides, Anemone narcisiftora, (?) Saxifraga exarati, Saxf. Hagellaris, Draba scabra, Dr. tridentata, Dr. siliquosa, Dr. imbricata, Alchemilla vulgaris, Alch. sericea, Polygonmm bistorta, T'araxacum stevenii, Senecin pyruglossus Fritrichium nanum, Pedicularis caucasica, I'ed. crassirostris, Anthemis sp. Alsine imbricata, Iledysarum caucasicum, Luzula spicata, Carex leporina, Festuca sp. ${ }^{1}$ ).

$\mathrm{R}$.

. 147. Ovis Gmelini Blyth. Ich lienne dieses Wildschaf nur von den Crebirgen Ilocharmeniens. Am Unterlaufe des westlichen Arpatschai lebt es im Sommer. In harten Wintern wandert es in bedeutender Zahl im Araxesthale abwärts, ist dann sehr fluchtig und schwärmt östlich von Eriwan in den Vorbergen des Daralagös Ganes zwischen Nachitschewan und Ordubad umher. Von dort holte ich die Exemplare des Museums und einige anch für die Akademie der Wissenschaften in Ptb. im Winter 1871.

R.

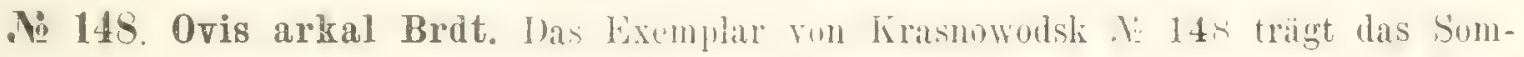
merhaar und unterscheidet sich dadurch von den alten Böcken aus dem Kopet-dagh, im vollen Winterhare, dass die Spitzen der Ialsmähne schwarz sind. Oie Kopet-dagher habon davon keine Spur, sie sind einfarbig fast rein weiss.

R.

2) Nach dem Tode Noskas veröffentlichte ich im nWvidnann" 1895. seine beiden Monographien über C. cancasica und Capella rupicapra, dort findet der Ieser Specielleres. 



\title{
SEINER KAISERLICHEN HOHEIT
}

\author{
$D E M$ \\ GROSSFÜRSTEN \\ SERGEI MICHAILOWITSCH
}

in Dankbarkeit und Treuc

der Autor. 


\section{EURE KAISERLICHE HOHEIT!}

Durch aweckentsprechende Maasmahmen haben Eure Kaiserliche Hoheit nicht allein das jetrige Verbreitungsgebiet cines aussterbenden Riesenthieres im Kaukasus-des II isents-festgestellt und soweit es möglich war, die Anzahl der noch lebenden Individuen auf dieser letzten insulären Zufluchtstïtte crmittelt, sondern auch als gewiegter IVaidmann dafür gesorgt, dass der Auer noch möglichst lange in Jhrem Jagdgebiete an cinigen der Quellenzuläufen des Kuban erhalten bleibe.

Wenngleich meine Notizen darüber, entsprechend dem Zwecke dieses Werkes nur apostrophisch gehalten sind und wesentlich den geographischen Standpunkt betreffen, so) halte ich es doch für meine Pflicht der wissenschaftlichen Welt an dieser Stelle dieses Factum zu constatiren und Eurer Kaiserlichen Hoheit in ihrem Namen dafür yu danlien. Dieses sichtbare Zeichen des Dankes wird crhalten bleiben auch dann, wenn der Auer seinem unabwendbaren Schicksal verfiel und seine Existen\% als lebender Coloss aufhörte.

Ich bin

Eurer Kaiserlichen Hoheit

treu ergebener Diener

Dir. G. Brolde. 
. 151. Bos bonasus $\mathbf{L}$. Die nenesten Vilchrichten diber den Stand ded Anerochsen datiren rom Ilerbst dieses Jahres (1\&98). Her' Juthner, welcher die Jatgdten Sr. Kaisl. Froheit des Grossfürsten Sergei Michailowitsch verwaltet, macht mir dartilut folgend. Mittheilungen.

Bis zum Jahre 149; hatte man im Jaglyebicte Sr. Kaisl. Hoheit des Grossfürsten Sergei Michailowitsch nur die zwischen den Flüssen Ijelaja und Laba inn liblan Gebict. nïher gelegenen Distrikte im Ange. Die Anerochsen hinterliessen da zwar sjuren von ihren Winterstande, zur Zeit der Jagdten aber zogen sie sich in die cntleneneren Wialder zurith. wohin sich das Netz der Jagdwege noch nicht erstreckte. Deshalb blieb dieses Urwild von den Jägern verschont.

Die Ursache, weshalb sich das Auerwild im Sommer von den alpinen Wiesen in die entlegenen und wilden Schluchten zurtickzieht, ist in der Beunruhigung zu suchen, welche das Weidevieh veranlasst. Tausende von Pferden bewegen sich während ded drei Sommermonate, Juni bis Iugust, auf allen oberhalb der Baumgrenze gelegenen Wienen dieses Jaghgebietes und verdrängen natürlich das scheue Auerwild in die Lrwäler der Thalschluchten.

Im Sommer 1895 unternahm ich auf Befehl Sr. Kaisl. Hoheit eine Excursion in das wilde Thal der Kischa. Schon am ersten Tage traf ich dort in drei Rudeln 17 Stück Inerwild an und durfe nach den beobachteten Anzejchen auf einen starlien stam sichliessen.

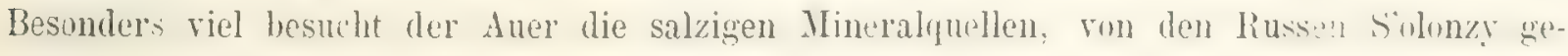
nannt, wo er aber das Wasser nicht schlürft, sondern die davon bespülten Steine belecht. Stundenlang heobachtete ich vier Aner bei diesen Genusse. Won einer soldhen Leclie fulnen stark ausgetretene Wechsel zu einer anderen, so diss ich solche benutzte, um reitend weiter in die Urwälder zu dringen und mich uber den Wildstand zu orientiren.

Im Fruhjahr vor dem Eintreffen des Weideviehes, also im Mai und Infang Juni trifit man den Auerochsen in kleineren oder grösseren Rudeln an der Baungrenze und aus den Thaufähten kann man schliessen, dass das Will während der Nacht auf den offenen alpinen Wiesen weidete, von wo es dann nach den oben erwähnten Salzlecken wechselt. Im Walde selbst verrathon die Auerochsen ihren Aufenthalt sehr bald, ausser den tief eingetretenen Spuren bemerlit man den Verbiss des Farrenkrautes von welchem sie aber nur die äussersten Spitzen abäsen und ferner das Schälen der linde an den Stimmen der Vugelbeeren (Sorbus aucuparia) und Clmen (Llmus campestris). Das schälen der Rinde findet währem des ganzen Jahres statt, besonders aber im Frühjahr bei Eintritt des Saftes. Dann wird die Rinde de: Clme in langen strähnen von unten mach oben abgeschält. An anderen Hol\%arten wurden Schälungen nicht bemerkt.

Im Winter wechseln die Anerochsen tief thalabwärts und werden sogar offers in unnittelharer Nähe der Ortschaftun gesehen. Duch trifft man sie auch in Winter im Hochgebirge an, si) noch im rorigen Jahre, zwische: den beiden Baichen lialtschepa und Aharu, wo sie im tiefen Schnee ein karges Dasein fristeten. Das als Nothfutter fur den Winter am Kischa Fiusschen hingelegte Heu blieb unberührt, wohl aber nahmen die Anerochsen die künstlichen Salzlecken gierig an.

Die Brunstzeit fällt in den Monat August, der Stier behauptet dann ein Rudel ron 2 bis d Stück Mutterwild. Ein Kampf zwischen den stieren wurde nicht hemerlit, ehrnst anch kein Lautgeben. Der Zuwachs ist ein ganz normaler, die Zahl der Kälber entspricht der Zahl der Kühe, welche vom dritten und vierten Jahre an setzen. L's wäre daher auch cin natüliches Aus terben der Anerochsen im Kaukasus weniger zu befurchten als ibr lnter-

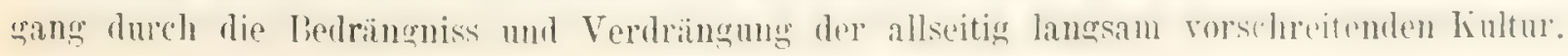


Der Auerochs bedarf an seiner Entwickelung und Erhaltung unbedingt der grössten Ruhe

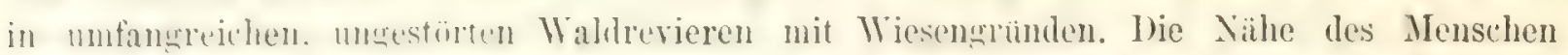
verträgt er absolut nicht.

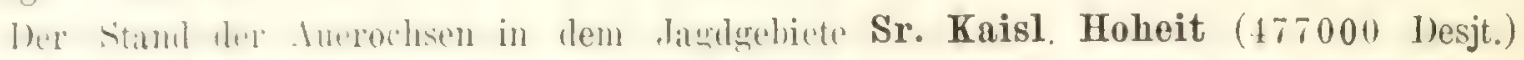

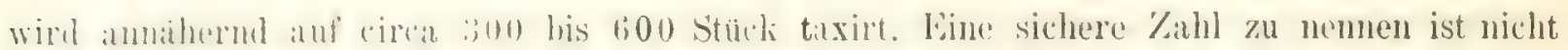
thmli h, weil eine wirhlicht Zaihlung unmönlich und es leicht rorkommen kam, dass schon eimmal geschene 'l'rupps doppelt gezähit werden.

Heran sehliese ich cinige Nitheilumgen wehehe ich ror Empfang dieser letaten Nachlichten fütr diesen Artiliel niederschrieb.

Das lixemular des Vusemus stammt aus dem Guellgebiete des Selentschuk dem östichen Nachlarthise der (irosen Laba. I)ie frische Haut wude durch einen Kosaken per Estra-

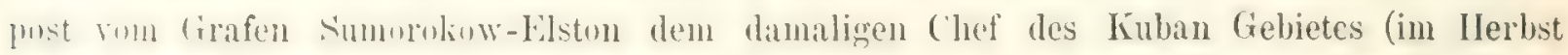
1869) dem Musenm zugrestellt. Es ist ein nicht sehr alter Stier im Sommerhar an wel('hern der Hals-und-Brusthehang sehr wenig ausgehildet ist, viel schwacher als an den Wischten im Grudnoshen (innernement. Die Hufe des Thieres sind kleiner und höher, was mit den stand in (iahiren zn erliären ist. Shon fraher (1866) hatte der Graf das Fell

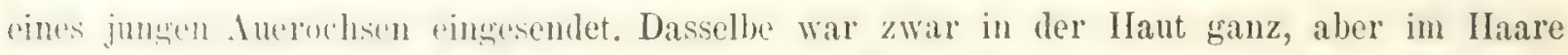
an virlen titen defert. Xiuh Empfang des guten Stuckes konnte ich das schlechte Exemplar hesciticn. lis 14!) z wal dies das cinzige anfgestelle Exemplar eines alten kaukasischen Wisents. Muskan besitzt ein junges. Littldal beschathte aus den Wildnissen an der Kischa (kl. Laba) im August 1891 of und $f$ in Haut und Slielet, nachdem er schon 1888 dort monatelang vereblich auf dies Wild grejagt hatte. Seine beiden Exemplare betinden sich jetzt in liritish Museum. In demselben Gebiete jarte Anfangs September 1895 So. Kalsl. Hoheit der Grossfürst Sergei Michailowitsch und II. v. Schilder. Von letzterem wurde cime alte Kuh erlent, tages darauf schoss der Grossfürst einen Stier. Die Jagd von 1897, welche den Grossfürsten Sergei Michailowitsch wiederum in sein Revier zu den Kuban-Quellen in Begleitung des Dr. Regher fuhrte, ergab 2 o und 1 \%. Ich habe 1894 in d+m $112^{-t}$ Ergänzungsheft zu I'tetermanns Mitth. jag. 110 flgd. auch Nachrichten uber den katkasichen Auer gugeben. Ich konnte dieselben nun mit neueren Beiträgen vergleichen und fi de dis damals Gesagte Illes bestïtigt. So auch die Vorliebe des Wisents fur Farrenkraut, welches da, wo ich es in den Spitzen vom Auer verfressen fand, die stattliche -mulea Struthinteris Is. War Das Schälen der Eheresche ist ron allen Jägern beobachtet worden, aber die Annahme von junger Rinde der Nordmamstanne wird von einigen bezweifelt. wwohl man in dem Magen der schilderschen Kuh harzige Rindenstücke von 2" Lainge bu löngudicke fand. Ls scheint, dass die Auerochsen gegenwärtig mehr westlich, d. h. Mabmentlin im Guellgehiete der Ljelaja, an der Ostseite des Oschten und unter den Abaw" Hohen stehen. Man will dort Wisente sogar bis wenig oberhalb von Chamyschki gesehen haten. Etliche Thiere nehmen auch hoher noch, am Zusammenflusse der beiden Ilauptquellen ein kleines Terrain ein. Der dortige Reriermugsfurster theilte mit, dass sie nenerdings da eingetroffen waren, wahrscheinlich, weil man sie 1897 am Uruschten, wo man junge Thiurw cinfangen wollte, gestort hatte. In Jahre $1 \wedge 97$ schätzte man den Stand am Uruschten auf, " Kople, in einem Rulel ningen 12 in einem anderen 6 Wisente. Der Iauptstand soll aber jetat unter dem Mhan an den Quellen der Kischa liegen und sind ron diesem Platze keine Wanderungen werm $s$. uher das Hauptgebirge bekannt. Dagegen wude beobachtet, dass von der Ustseite der nich N. gerichteten Verzweigung des Abago, von den Höhen des engen Tschene Thales die Wisente im Winter weit abwirts steigen, also in der Richtung 


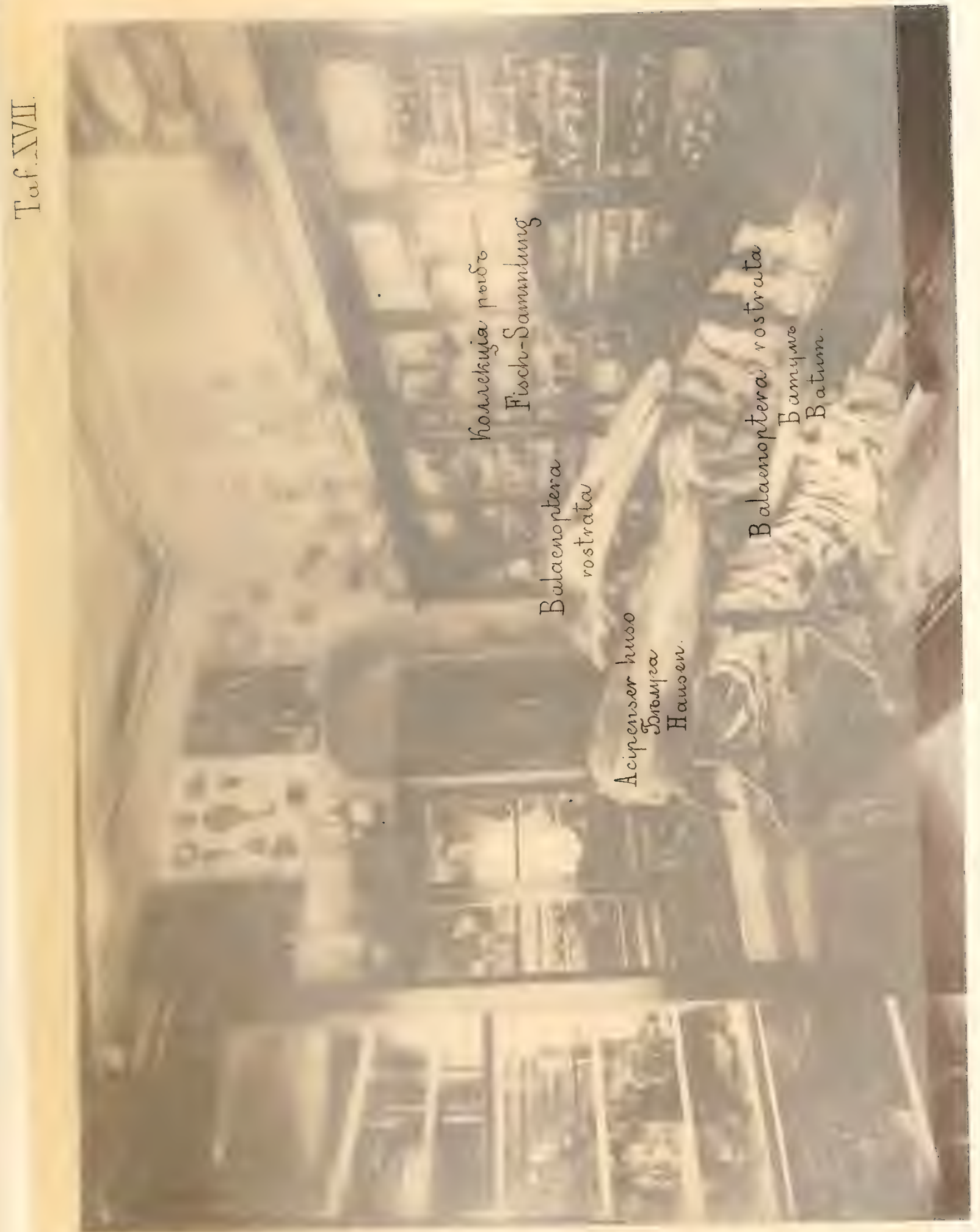




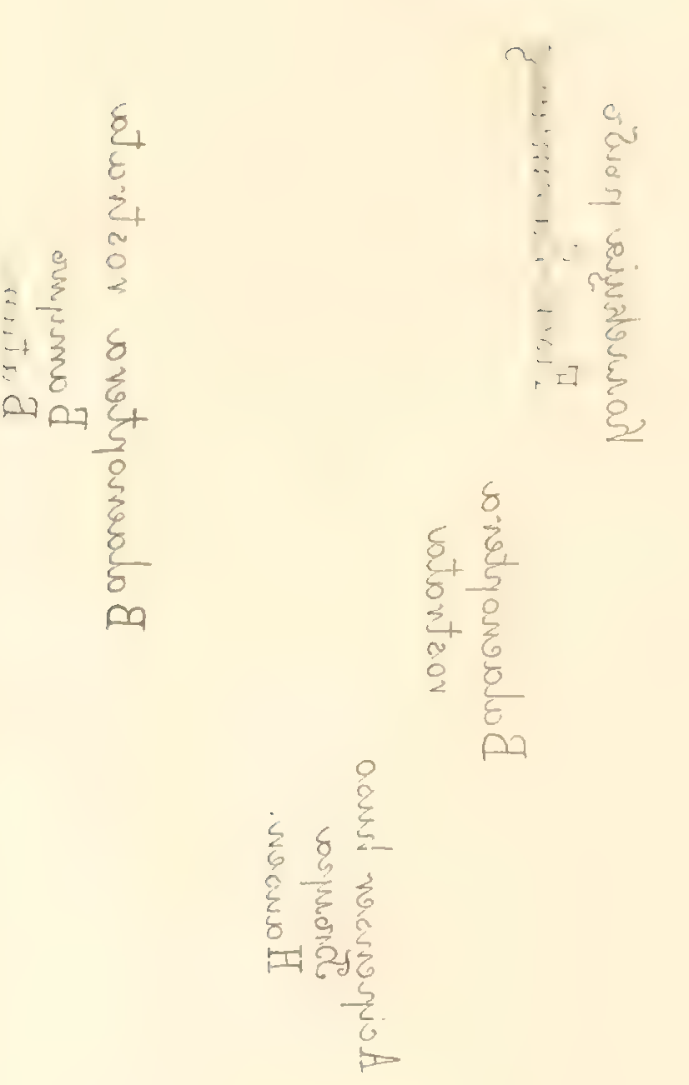



zur Dache hin, wo auch frihher schon welche erlegt wurden. Am Saagdan, also am (turlllaufe der Gr. Laba sollen ebenfalls gegenwärtig keine Anerochsen leben. Man erkiil't sich das dadurch, dass dort jetzt viel Vieh gelıt, mithin die Wisente beunruhigt werden. Von d('x" Südseite der Hauptkette erkundete Herr Jüthner den Wisent nicht. Alle meine sonstigen Anıraben und in der Karte (in jenem citirten Artikel) verzeichneten Standorte bestätigen sich. su hat man noch $1898 \mathrm{im}$ April 1 o und 3 \& zusammen am Alaus gesehen. Die Thiere waren äusserst mager, sie hatten einen schweren Winter durchgemacht. Die ältesten Jäger und professionellen Wilddiebe in diesem Gebiete behaupten, dass es gegenwärtig mehr Wisente gäbe, als fruher. Es lässt sich das so erliären, dass die vorhandenen meln und mehr zulsammenrücken; da sie an den Rändern ihres ehemaligen Verbreitungstrebietes hïufiger leun. ruhigt werden, als früher. Die Gesammtzahl der Individuen nimmt nicht zu, vielmehr al. Die beigefugte Karte, welcher lie bereits $189+$ in den n. Mithleilungen" publicirten zu Grunde liegt, veranschaulicht den gegenwärtigen Stand der Wisente.

R.

\section{E T A C E A.}

소 158. Balaenoptera rostrata Fabr. Dieser Wal strandete im Iai 1sso bei liatum. General Konstantin Wissarionowitsch Komarow, der damalige Chef des Gaues, sendete die Knochen an das Museum. Obwohl diese unter polizeilicher Aufsicht in Batum bewahrt wuden, fehlten doch viele Wirbel und einige Rippen, vom Unterkiefer war ein Stücli abgesägt. Es konnte deshalb das Skelet nicht aufgestellt werden.

Ich messe: Schädellänge vom Hinterhaupte obenher bis zur Spitze reichlich. 2 mtr.

Grösste Breite unter der Augenhöhle gerade. . . . . . . 1,20 $\mathrm{mtr}$.

Der Fund dieses Wales ist von grossem Interesse. Es i:t mir nicht bekannt, ob dic alten S:hriftsteller Nachricht geben über cinen Wal der die Dardanellen und den linspo. rus passiren müsste um in den I'ontus zu gelangen. Aus nenerer Zeit ist dieses wohl der erste Fall. 


\section{Поясненіе карты.}

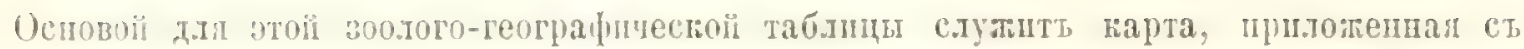

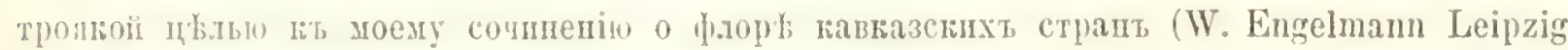
1899). Не смотрл па малыі маснтабт, она предетавляеть довольно лснуо нартну топо-

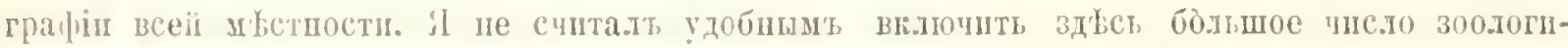

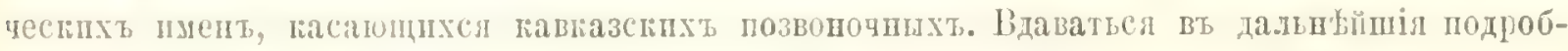

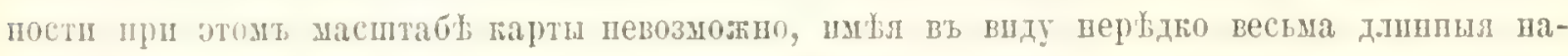

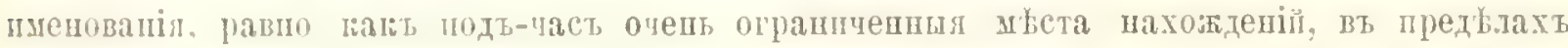

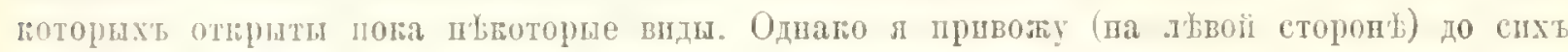

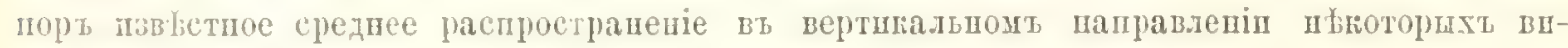

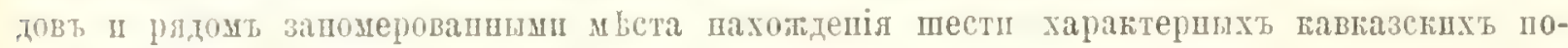

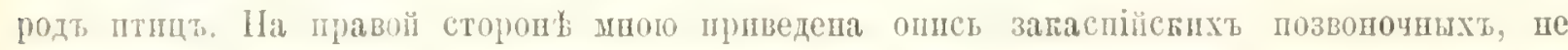

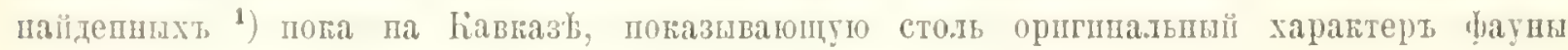

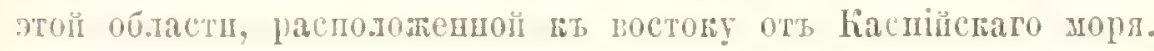

P.

\section{Erklärung der Karte.}

Ich lege für dieses zoologisch-geographische Blatt die Karte zu Grunde, welche meinem Werke uber die Vegetation der Kaukasusländer (W. Engelmann, Leipzig 1899) in dreifither Verwendung bejgereben wurde. Trutz des geringen Maasstabes gielit sie uber das Ledief des gesummten Gebietes ein recht klares libld. In diese's mehr zonlogische Namen, soweit sie dir kaukasischen Wirbelthiere anbelangen, einzutragen. hielt ich nicht für gut. liei den oft langen, Namen und den ebenso oft nur ganz beschrinkten Fundurten, für welehe manche Sifecies bisjotzt rmittelt wurden, ist es für diesen Maasstab der Karte unmüglich mehr Details zu geben. Iagecen fuhre i h (linkerseits) für einige Arten die bisjetzt ermit. telten Mittelwerthe in der Vertikalverbreitung und daneben unter Nummern die Fundorte fur sechs charahteristische kaukasische Vogelarten an. Rechterseits dagegen gebe ich ein Verzedoniss sulcher transhaspischer Wirbelthere, welche hisjetat im Kaukasus nuth icht nathewitsen ${ }^{2}$ ) wurden und welche zugleich den so originellen faunisti-chen Charakter jener östich vom Kaspi gelegenen Gebiete erkennen lässt.

R.

1) :3a uckinueuierz Hystris II Gazella. ${ }^{2}$ ) Mit Ansnahme von Ilystrix unb Gazella. 


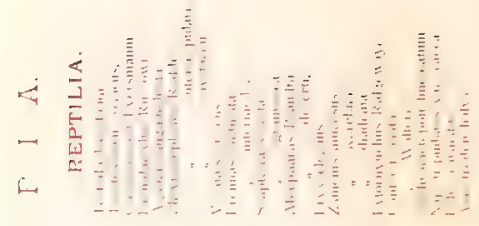

U

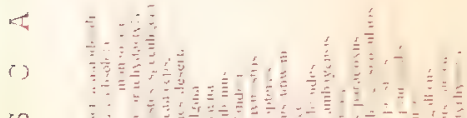

(1)

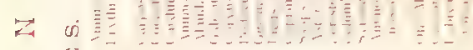

$\begin{aligned} & 0 \\ &<<\end{aligned}$

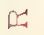

E - 年

-

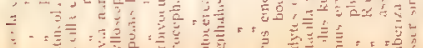

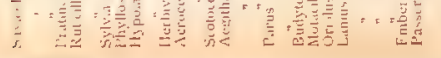

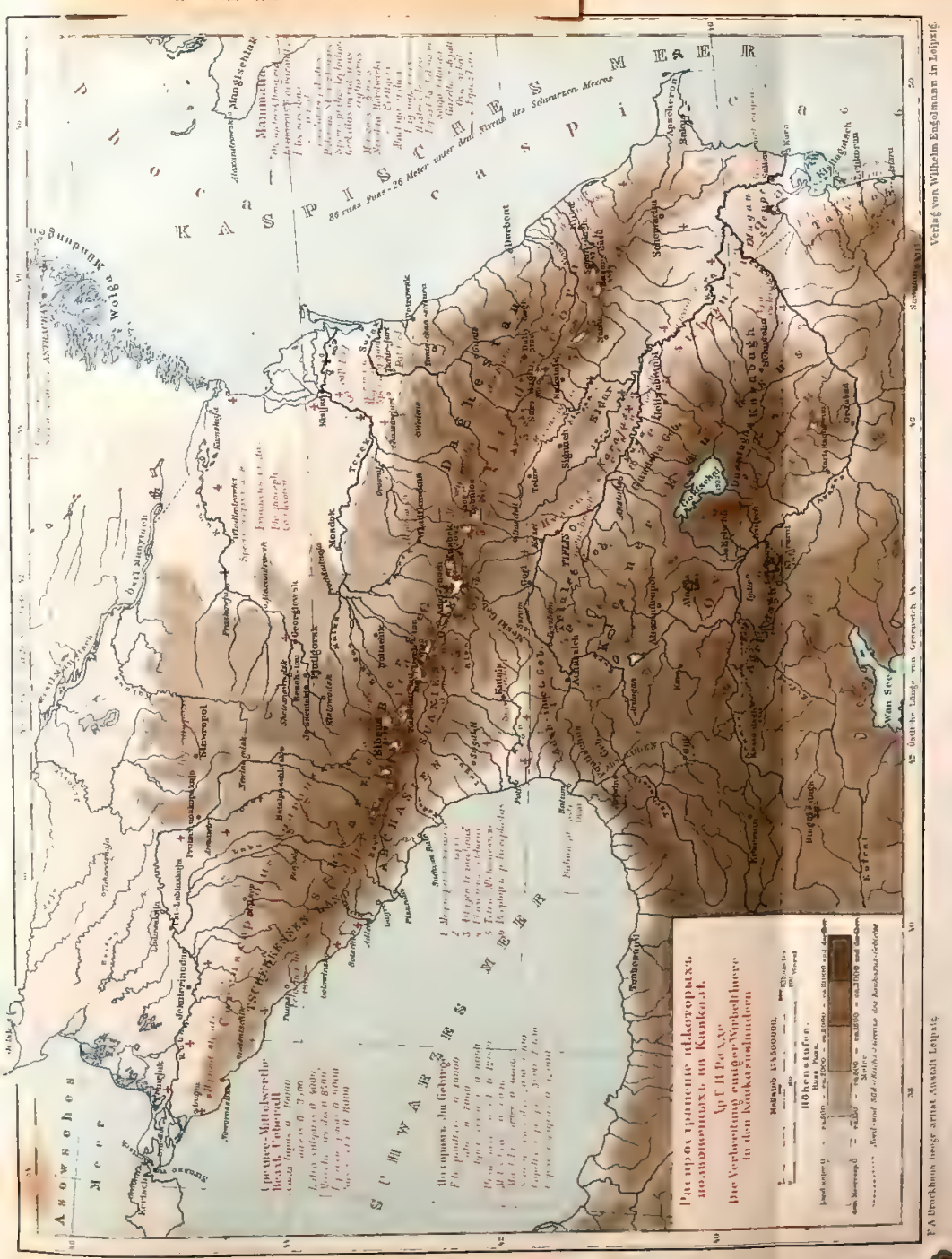




\title{
A V E S.
}

\author{
II TIII Ы.
}

\author{
V Ö G E L.
}

IIкашъ-16, 17, 18, 19, 20, 21, 22, 2:, 24.--Schrank 
- In the present day the tendeney amongst ornitholugists is towards a subdivision of species to an extent that was never thought of twenty years ago; and though I personally am far more dispused to "lump" than to split", I find myself compelled, to some extent, to march the times".

\section{H. Dresser.}

(A history of the birds of Europe. Suppl. Part. IV. Aug. 1895. pag. 174).

Затьм. сравивал Picus major п P. leucopterus, Lanius excubitor II L. leucopterus

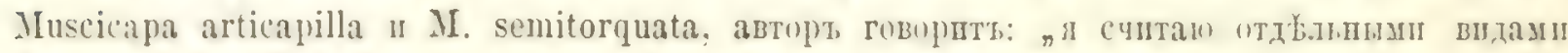

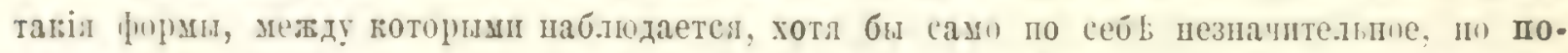

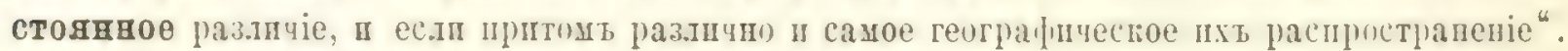

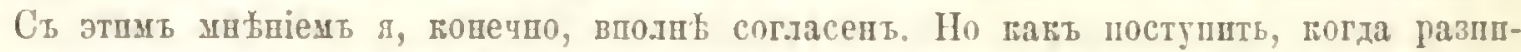

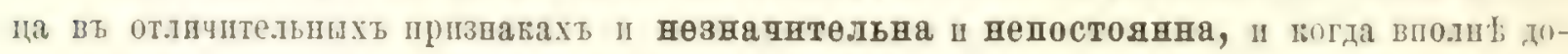

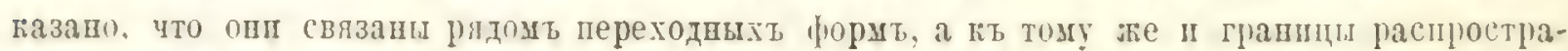

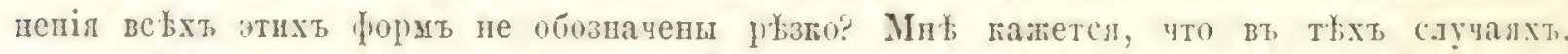

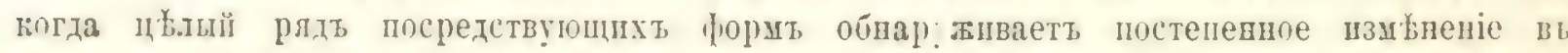

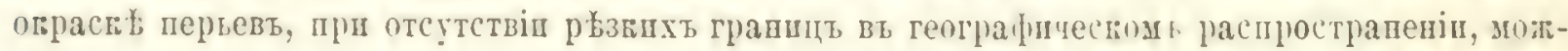

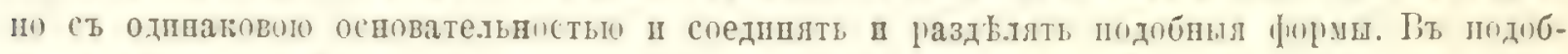

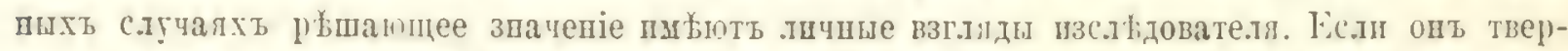

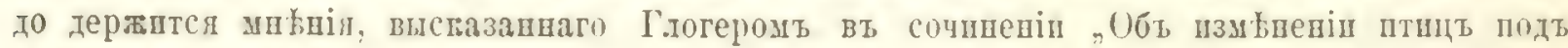
вліянемь клиата ", то для него мпогіе варіанти въ царствъ пернатнхт буд!ть только фор-

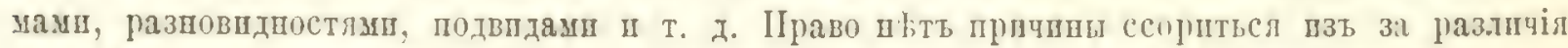

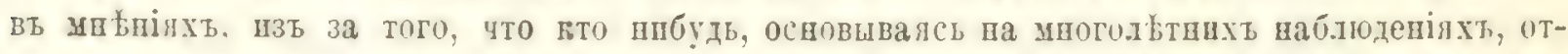

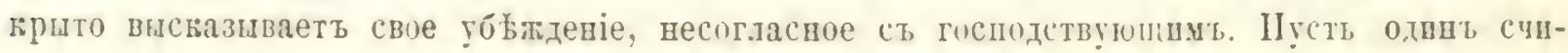

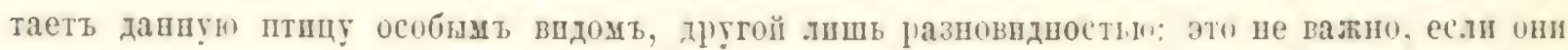
приводять основанія свопхъ мнъній.

„Есть средство устранить частыя пререканія о виды (species): для этого надо ввести

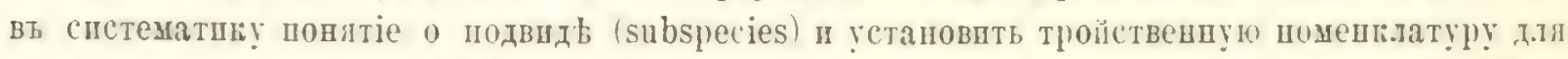

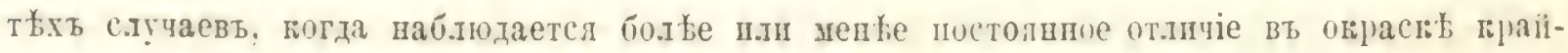
нихъ формз".

\section{0. Клөйншмидтъ.}

(Ueber das Variiren des Garrulus glandarius, in ,Ornitholog. Jahrbuch"6 1893. p. 201).

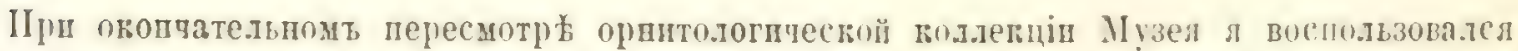

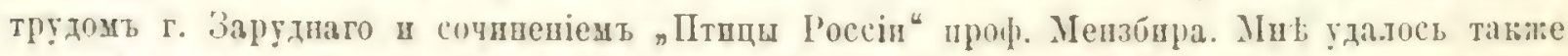

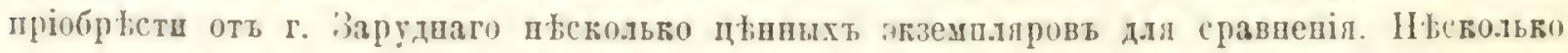

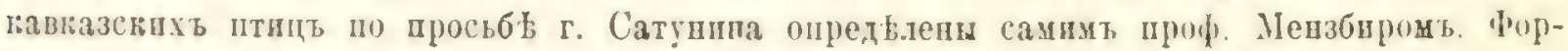




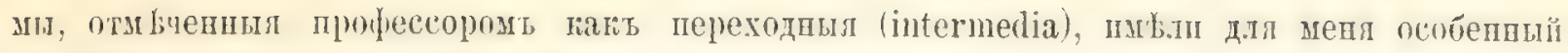

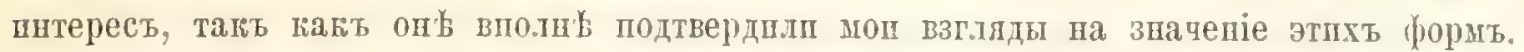

Іосльдвательность при перечпсленіи впдовъ та же, что у Заруднаго въ его „Орнш-

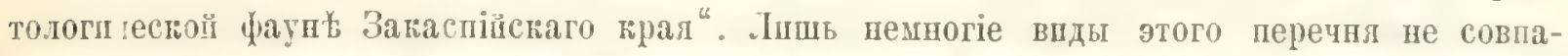

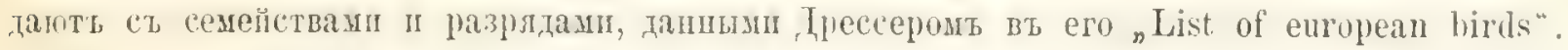

Всғ Кавказскіл птиц снабжены лрлыками па грасномь пелку.

$\begin{array}{llllll}\text { Закаспійскія } & & & & & \\ & \text { заграничныя } & & & & \end{array}$

"In the present day the tendency amongst ornithologists is towards a subdivision of species to an extent that was never thought of twenty years ago; and though I personally am far more disposed to "lump" than to "split", I find myself compelled, to some extent, to march the times".

\section{H. Dresser.}

(A history of the birds of Europe. Suppl. Part. IV.Aug. 1895. pag. 174).

Der Autor bespricht dann Picus major und P. leucopterus, Lanius excubitor und L. lencopterus, su wie Muscicapa atricapilla und M. semitorquata und sagt: "ich halte es fur nöthig in ?n Fällen die Formen artich zu tremnen, wo, wenn auch nur geringe Differenzen beständig sind und die geographische Verbreitung verschieden ist".

Damit bin ich natülich ganz einverstanden. Was aber thun, wenn die geringen Differenzen nicht beständig sind, vielmehr nachweislich durch Uebergïnge vermittelt werden und wenn die Grenzen des Vorkommens der Formen ebenfalls keine scharfen sind?

Es wird wohl ebenso gerechtfertigt sein, da, wo sich aus längeren Suiten die Uubergänge in der Färbung des Gefieders ergeben und die scharfe Sonderung in geographischer Hinsicht nicht vorliegt, zu vereinigen, als nach Belieben zu tremen. Das hängt von der persünlichen Auschauung des Autors ah. Wer die Grundideen Gloger’s über "das Abändern der Vögel durch Einfluss des Klimas" sich als unumstüsslich wahre angeeignet hat, mol von ihnen geleitet die Varianten im Reiche der Vügel beurtheilt, wird in vielen Füllen nur von Formen, Varietäten, Subspecies etc. sprechen. Es liegt wahrlich kein Grund dafür vor, sich deshalb zu zürnen, wenn in diesen Falle, wie in so vielen anderen, Meinungsverschiedenheiten stathaben und wenn man, gegenüher der herschenden Richtung, den Muth hat seine ehrich erwurbene, auf langjährige lienbachtung hegründete Ueberzeugung anszusprechen. Ob der Eine den betrefienden Vogel als eine Art, der Andere ilm nur als eine Varietät betrachtet, ist unwesentlich, wem beide sich nur verstehen und wissen, was sie meinell.

"Dem vielen Streiten um Art oder Nicht-Art geht man leicht aus dem Wege, in dem man den Begrift der subsuecies in die s. stematik cinfuhrt und die firbungsextreme, subald sie einigermaassen ständige Varietäten darstellen, trinär benennt".

\section{Kleinschmidt.}

(Ueber das Variiren des Garrulus glandarius, in ,Ornitholog. Jahrbuch." 1893, pag. 201), 
Von Sarudny's Werk und ron Prof. Mensbiers "Vögel Russlands" habe ich bei der

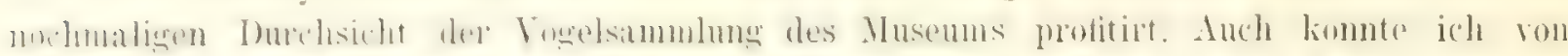

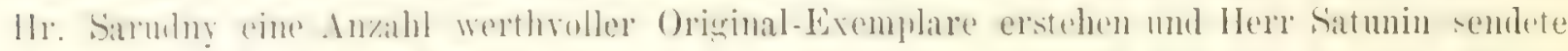

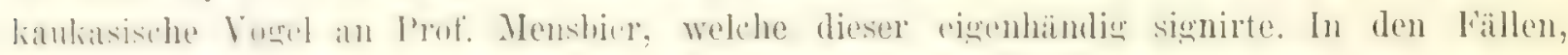
wo er rermittelnde Formen als solche (intermedia) bezeichnete, latte das für mich einen besonderen Werth, da es meine Ansichten bestïtigte.

Die Reihenfolge bei Aufzihlung der Arten schliesst sich an das Verzeichniss, welches

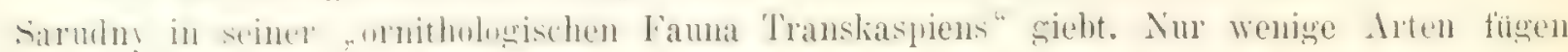

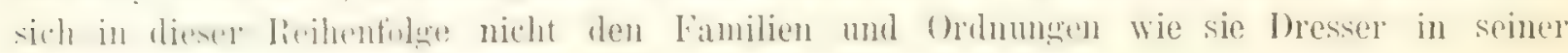
"List of curopean birds" giebt.

Alle Kaukasier tragen die Signatur an rother Seide.

"Transkaspier " " " gelber "

"Ansländer " " " " blauer " 


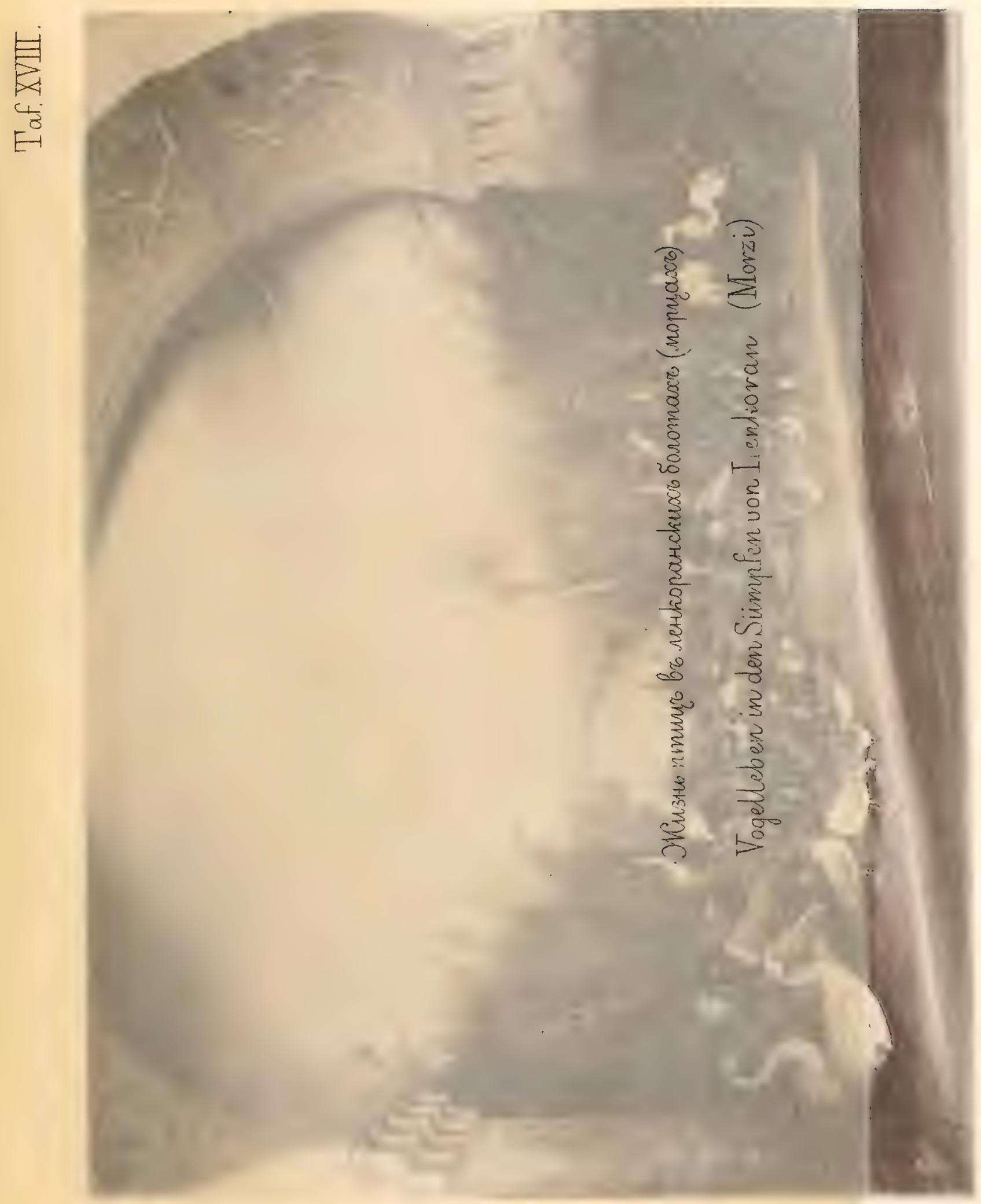




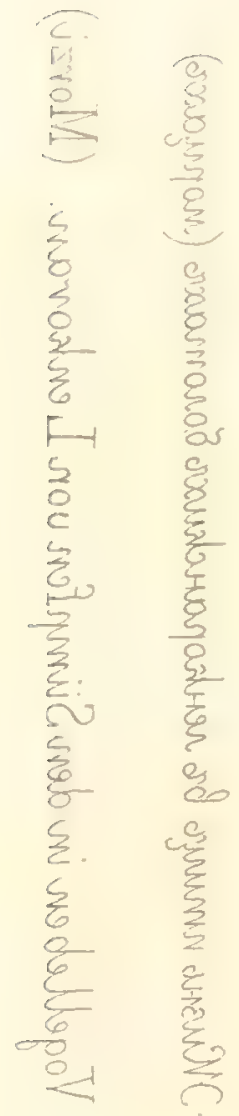




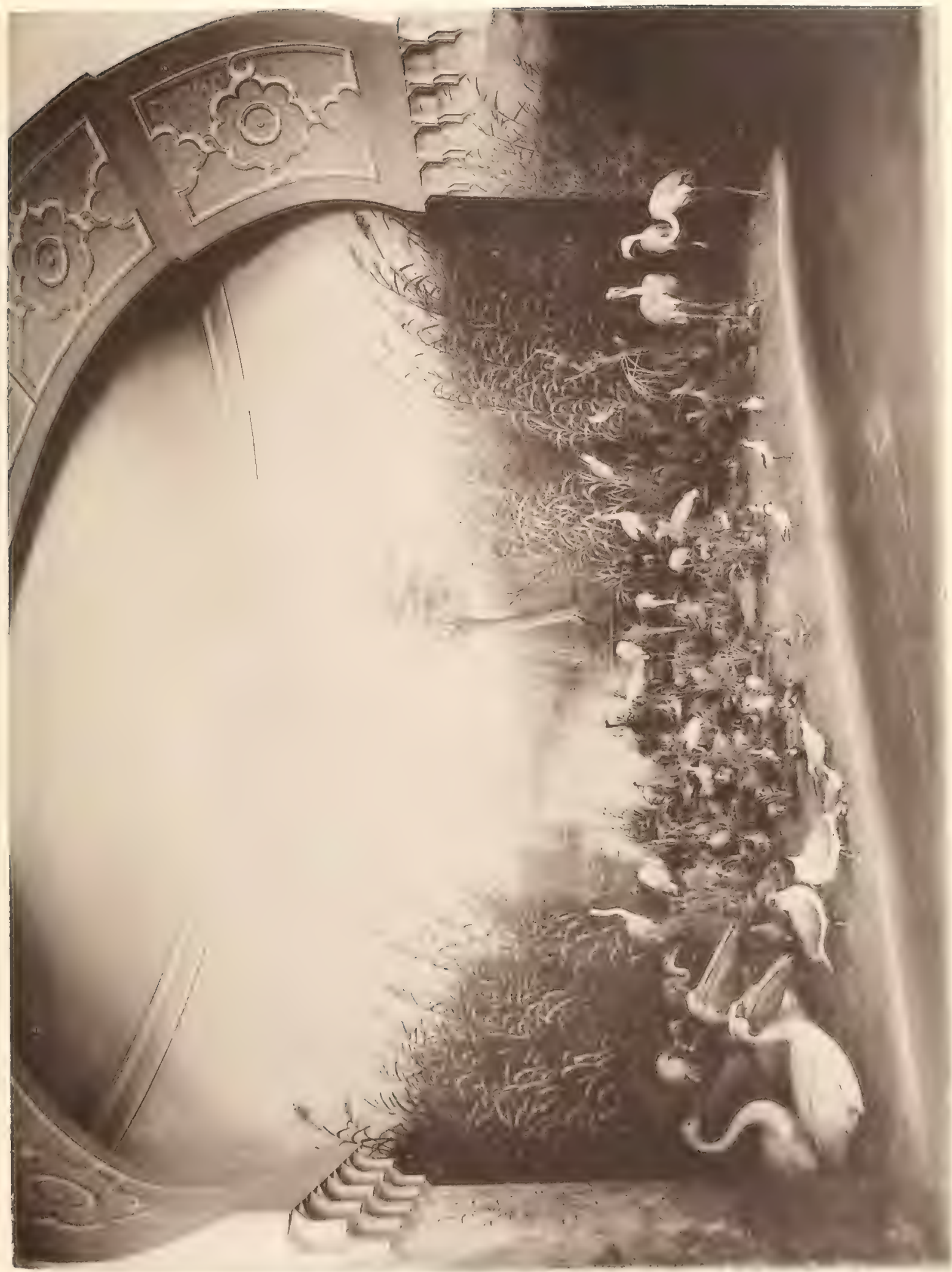





\section{A V E S. \\ COTРУДНИКИ-MITARBEITER.}

Prof. J. Cabanis, Berlin.

Prof. Rudolph Blasius. Braunschweig.

H. Dresser. London.

E. r. Homeyer. Stolp.

Th. Lorenz. Moskau.

Dr. G. Radde. 'Titlis.

Prof. Ant, Reichenow. Berlin.

Victor Ritter v. Tschusi zu Schmidhoffen. IIallein.

Dr. A. Walter. Tillis, Jena.

Составъ водлегцін птиц до 1 января 1899.

Gesammtbestand der Sammlung von Vögeln bis 1 Januar 1899.

\begin{tabular}{lrrrr} 
& Vögel & Nester & Eier & Div. Sc. cr. \\
Passeres & 2715 & 254 & 940 & 34 \\
Picariae & 187 & 2 & 119 & 5 \\
Raptores & 360 & - & 178 & 29 \\
Steganopodes & 18 & - & 17 & - \\
Lamellirostres & 143 & 1 & 73 & 7 \\
Herodiones & 77 & 1 & 90 & 3 \\
Columbae & 33 & 1 & 31 & 3 \\
Pterocletes & 27 & - & 7 & - \\
Gallinae & 146 & - & 92 & 14 \\
Alectorides & 60 & - & 59 & 4 \\
Limicolae & 304 & - & 62 & 4 \\
Longipennes & 111 & - & 44 & 2 \\
Pygopodes & 25 & - & 26 & 2 \\
\multicolumn{1}{c}{ 508 Arten } & 4206 Vogel & 259 Nester & 1738 Eier & 107.
\end{tabular}

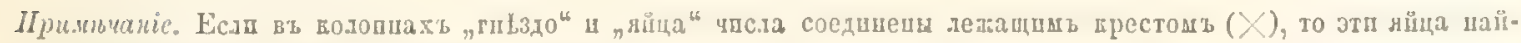

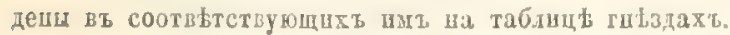

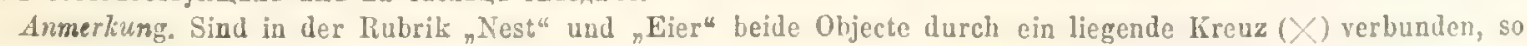
wurden die Eier in diesem Neste gefunden. 


\section{PASSERES}

\section{FAM. T U R D I D E}

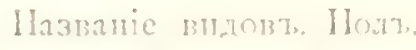

Namen und Geschlecht.

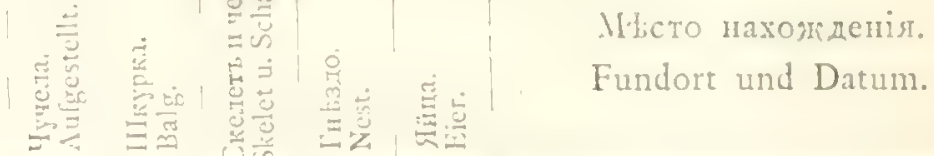

1. Turdus viscivorns $\mathrm{L}$.

\section{Turdus musicas L.}

$\therefore$ | Turdus iliacus I.

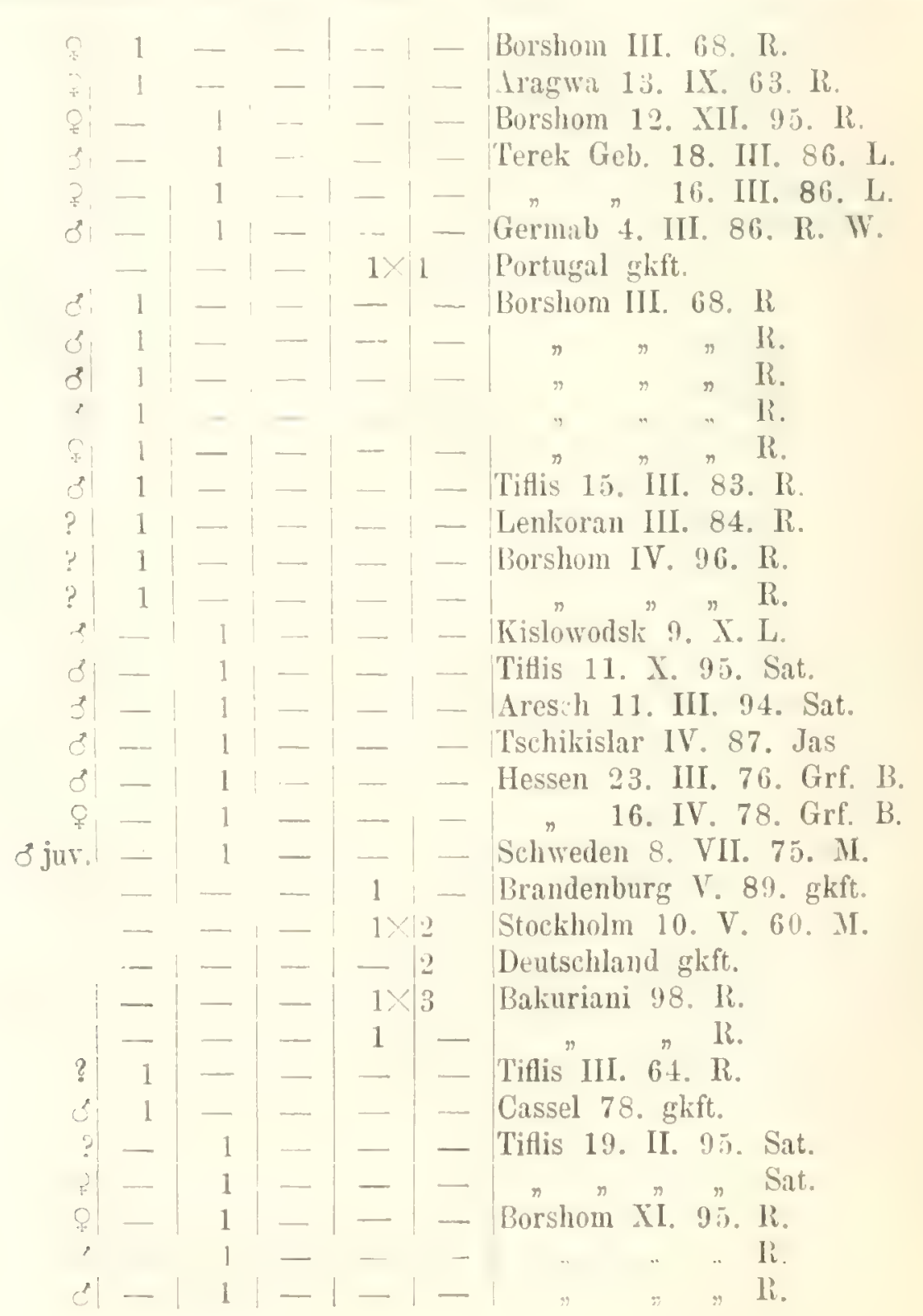




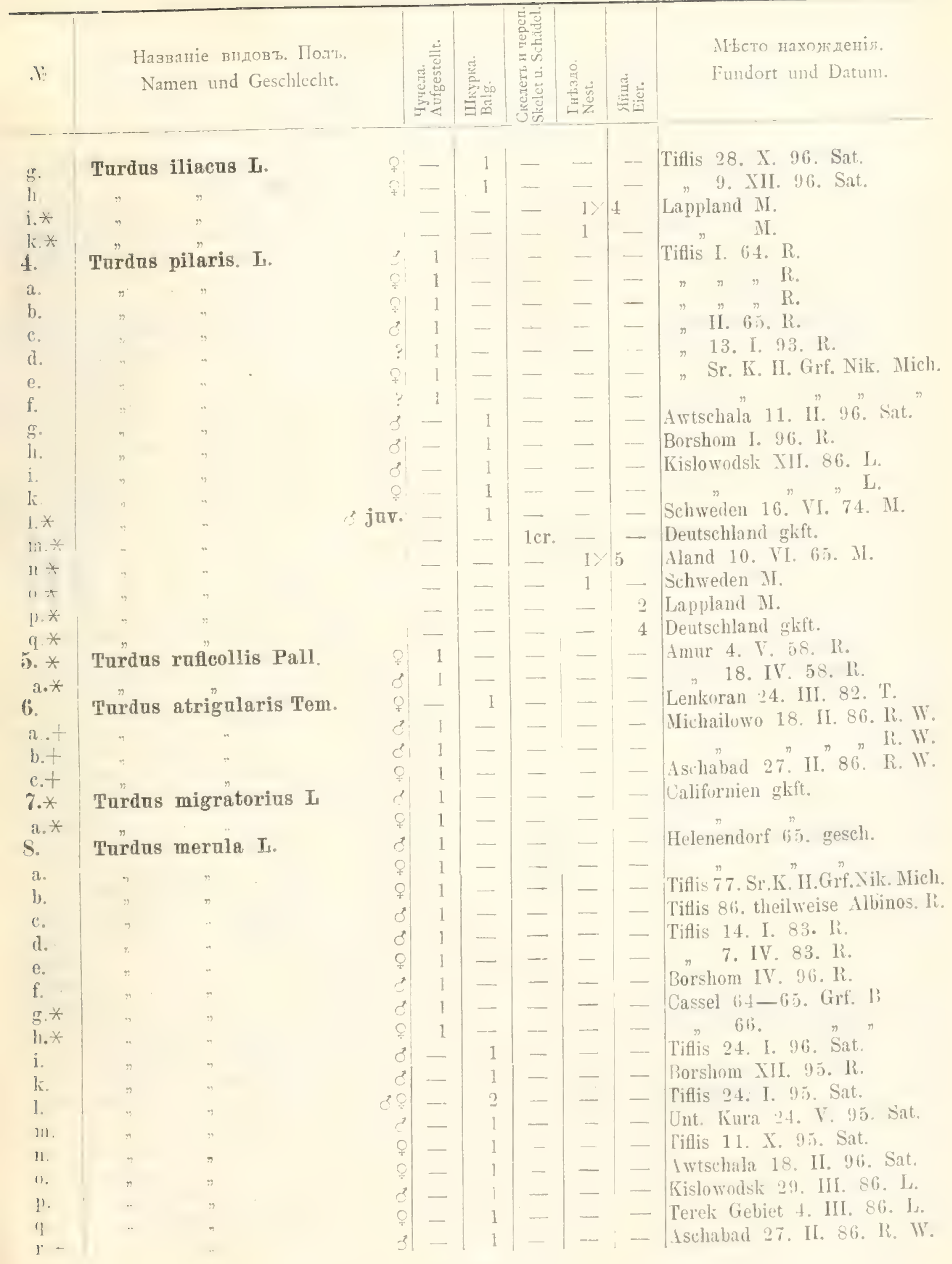




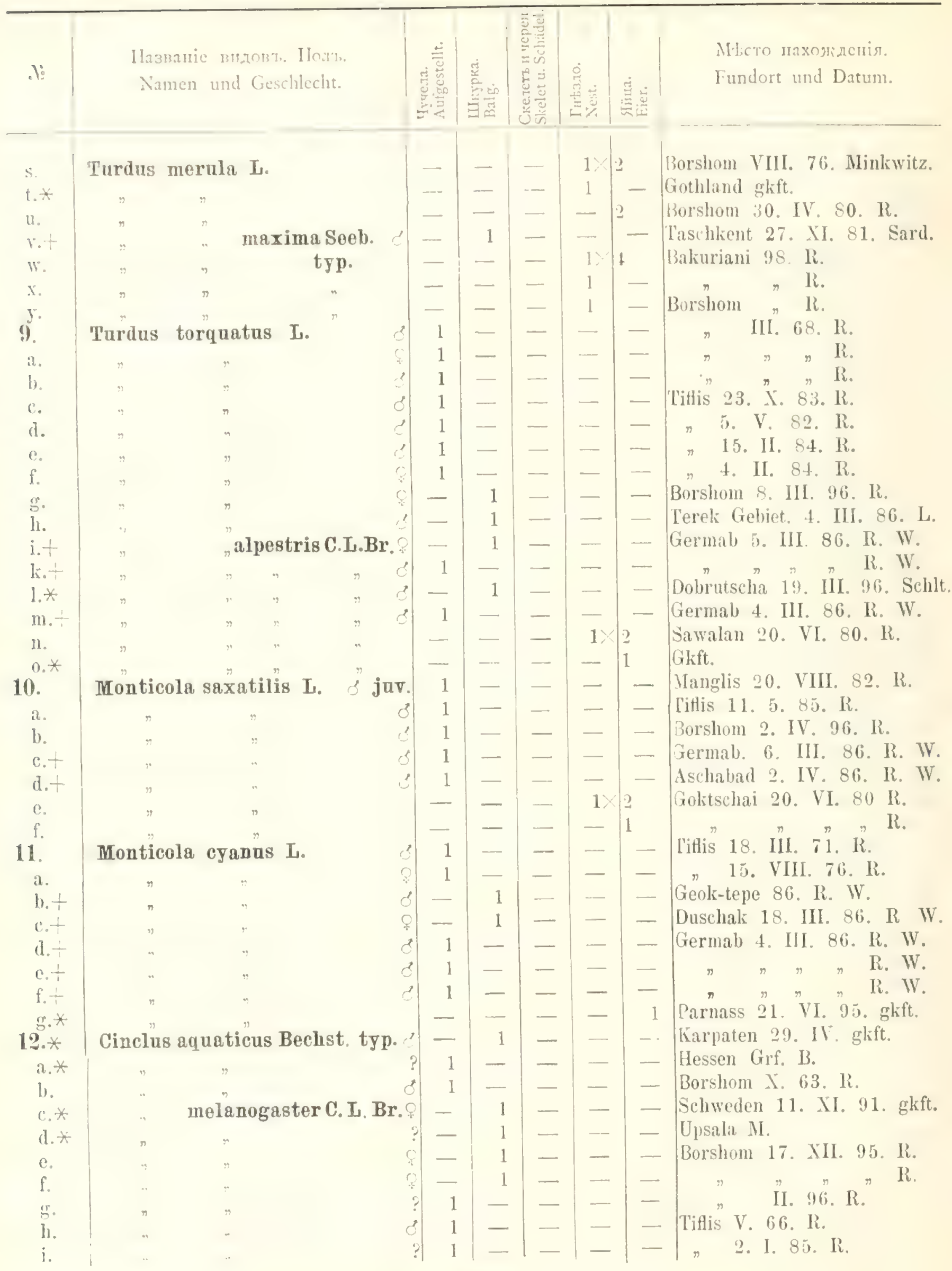




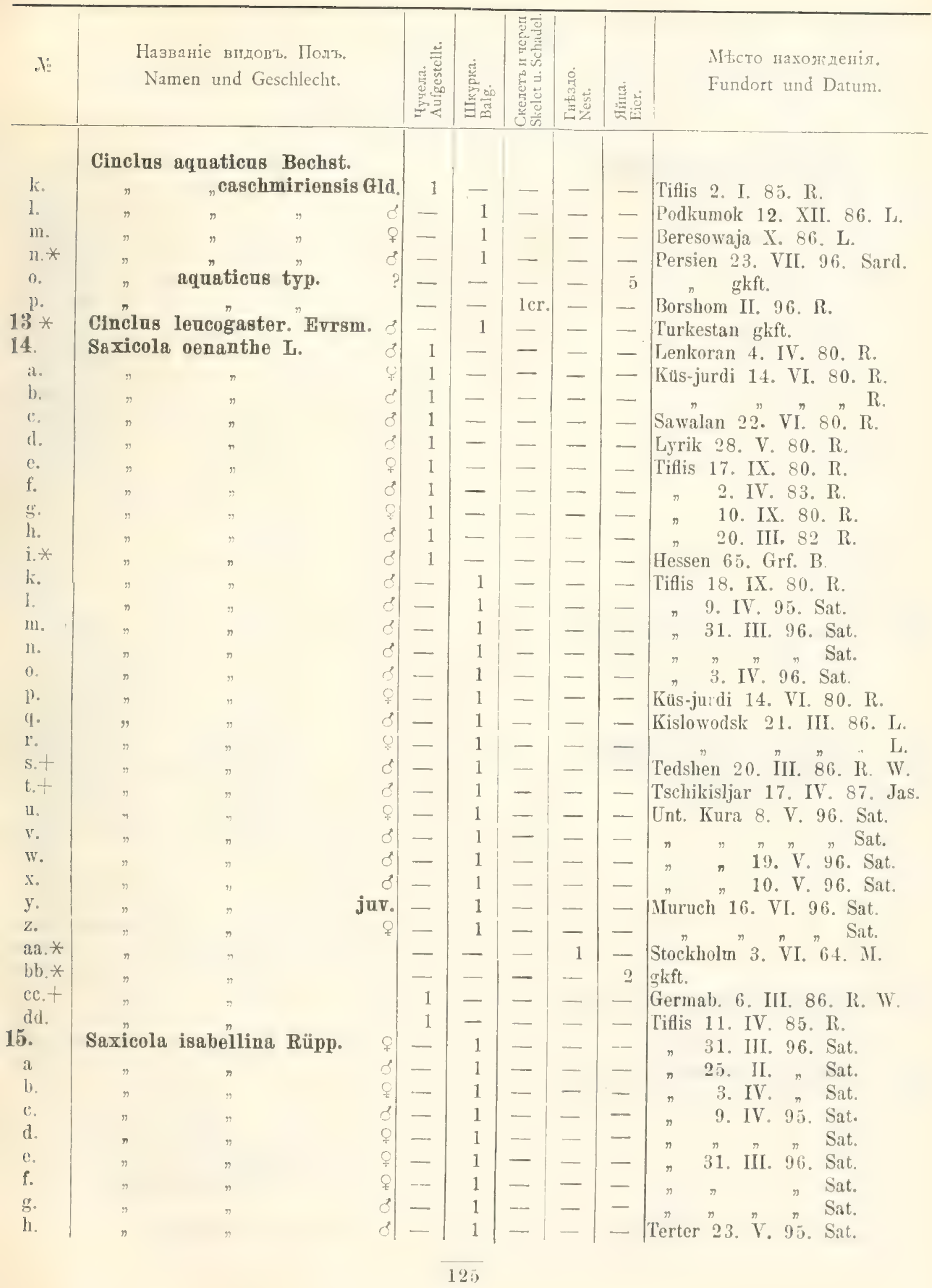




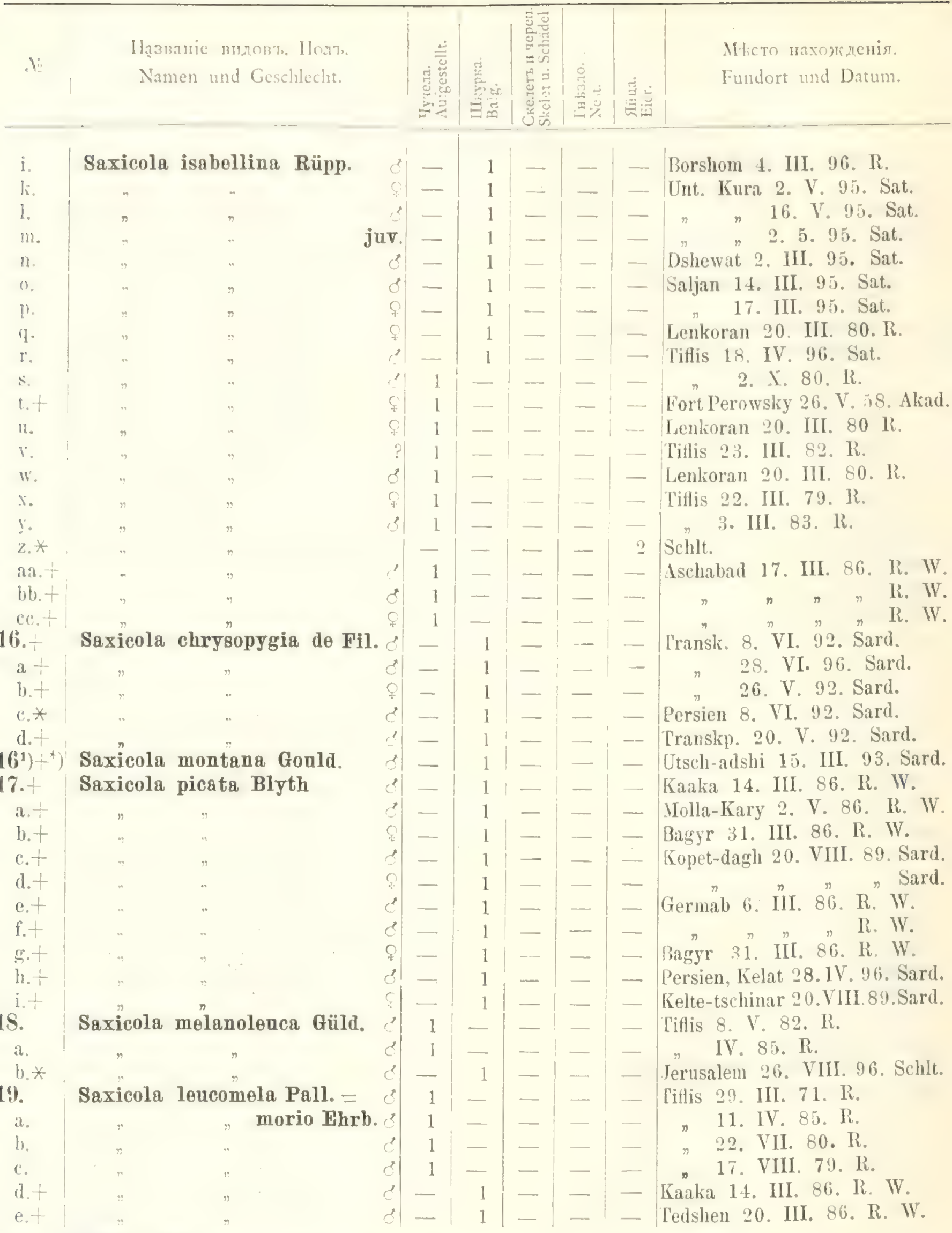

") Später, aach Abschluss des Katalnges erhalten, deshalb unter 16 ${ }^{2}$ ) als selbständige Art eingeschaltet. 


\begin{tabular}{|c|c|c|c|c|c|c|c|c|}
\hline dio & \multicolumn{2}{|l|}{$\begin{array}{l}\text { Названіе видов'ь. Поль. } \\
\text { Namen und Geschlecht. }\end{array}$} & 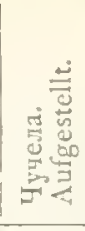 & 焉 & 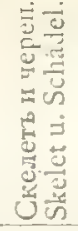 & 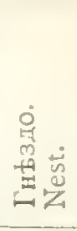 & 竞峦 & $\begin{array}{l}\text { Mьсто нахожденія. } \\
\text { Fundort und Datum. }\end{array}$ \\
\hline f. + & \multicolumn{2}{|l|}{ Saxicola leucomela Pall. } & - & 1 & - & - & - & \multirow{15}{*}{$\begin{array}{l}\text { Krasnowodsk 19. IV. 86. R. W. } \\
\text { Djebel 3. VI. 96. Flrk. } \\
\text { Baba-durmas 28. IV. 92. Sard. } \\
\text { Transk. 15. V. 92. Sard. } \\
\text { Tiflis 9. IV. 95. Sat. } \\
\text { 11. VIII. 96. Sat. } \\
\text { Marasly 2. V. 96. Sat. } \\
\text { Titlis 9. IV. 95. Sat. } \\
\text { Donau 25. VI. 75. Hom. } \\
\text { ? 20. IV. 77. Hom. } \\
\text { Dobrutscha 28. VI. 75. } \\
\text { Pul-i-chatum 3. VII. } 86 . \text { R. W. } \\
\text { Kaaka 14. III. 86. R. W. } \\
\text { Tiflis 7. V. 82. R. }\end{array}$} \\
\hline g.t & $"$ & 8 & - & 1 & - & - & 一 & \\
\hline h. $t$ & $"$ & 8 & - & 1 & - & - & - & \\
\hline i. + & " & 8 & - & 1 & - & - & - & \\
\hline k. & $"$ & 3 & - & 1 & - & - & - & \\
\hline 1. & n & $\delta$ & - & 1 & 一 & - & - & \\
\hline $\mathrm{m}$. & $"$ & $\delta$ & 一 & 1 & 一 & - & - & \\
\hline n. & $"$ & 8 & - & 1 & - & - & 一 & \\
\hline $0 . *$ &. & $\delta$ & 1 & - & - & - & - & \\
\hline p.* & , & $\delta$ & 1 & - & - & $一$ & - & \\
\hline$q . *$ & $\pi$ & o & 1 & 一 & - & - & - & \\
\hline$r . *$ & $"$ & Q & 1 & - & - & - & - & \\
\hline s.t & 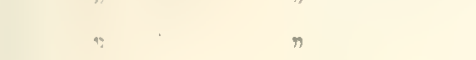 & juv. & - & 1 & - & - & - & \\
\hline t. $t$ & $"$ & q & - & 1 & - & $\cdots$ & 一 & \\
\hline 11. & $\eta$ & ? & - & 1 & - & - & - & \\
\hline v. & " & d & - & 1 & - & - & - & " 25. IV. 95 . Sat. \\
\hline w. & , & 8 & - & 1 & 一 & 一 & - & 27. VIII. 95. Sat. \\
\hline$x$. & " & 운 & - & 1 & 一 & 一 & - & 12. V. $82 . \mathrm{R}$ \\
\hline $\mathrm{y}$ & $"$ & 운 & - & 1 & - & - & - & Unt. Kura 22. IV. 95. Sat. \\
\hline$z .+$ &. & C & 一 & 1 & - & - & - & Kopet-dagh 20. VIII. 89. Sard. \\
\hline aa. + & . & $\%$ & - & 1 & - & - & - & Duschak 18. III. 86. R. W. \\
\hline bb. + & " & 8 & - & 1 & - & - & - & Transkp. 21. IV. 86. R. W. \\
\hline$c c$. & $n$ & $q$ & 1 & - & 一 & - & - & Tiflis V. $85 . \mathrm{R}$. \\
\hline dd. & $"$ & & 一 & 一 & - & $1 \times$ & 6 & $\Rightarrow \quad 10 . \mathrm{V} .82 . \mathrm{R}$. \\
\hline ee. $*$ & $"$ & & - & 一 & - & - & 1 & Schlt. gkft. \\
\hline $\mathrm{ff} . *$ & & & - & - & - & - & 2 & Altai.gkft. \\
\hline 20. & Saxicola deserti Rüpp. & ¿ & 1 & 一 & - & - & - & Baku ? 67. R. \\
\hline a. + & $n \quad "$ & & - & 1 & - & - & - & Nolla-Kary 30. IV. 86. R. W. \\
\hline b. + &. & & 一 & 1 & - & - & - & Baba-durma 13. III. 86. R. W. \\
\hline c. & 4 & 3 juv. & - & 1 & - & - & -- & Titlis 28. VIII. 94. Sat. \\
\hline d.* & , & C & 1 & - & - & 一 & - & Smyrna 16. VIII. 76. Schlt. \\
\hline e.t & . & d & 1 & - & - & - & - & Perewalnaja 10. IV. 86. R. W. \\
\hline $\mathrm{f}, \frac{1}{\mathrm{t}}$ & & c & 1 & - & - & - & - & $\pi \mathrm{R} . \mathrm{W}$. \\
\hline 21. & $\begin{array}{r}\text { Saxicola Finschii Heagl. } \\
\text { thraea H. et }\end{array}$ & $\begin{array}{l}\text { S. ery } \\
\text { Ehrb. }\end{array}$ & 1 & - & & - & - & Baku 2. II, 80. R. \\
\hline a. & " & c & 1 & - & - & - & - & Aksu 9. XI. 79. R. \\
\hline b & .. & d & - & 1 & - & - & - & Schemacha 1. V. 96. Sat. \\
\hline c. & , & 운 & - & 1 & - & - & - & Aksu 9. XI. 79. R. \\
\hline d. $t$ & , & 8 & - & 1 & - & 一 & - & Dsebel 3. V. 96. Flrk. \\
\hline e.t & " & 8 & - & 1 & - & - & - & Kuba-dagh 6. II. 86. R. W. \\
\hline f. + & 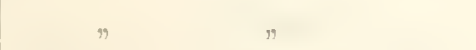 & $\delta$ & - & 1 & - & - & - & โmam-Guljar 24. III. 96. Sard. \\
\hline$g \cdot t$ & & q & - & 1 & - & - - & -- & Transkp. 20. IV. 92. Sard. \\
\hline $22 * *$ & Saxicola leucura Gml. & 8 & 1 & - & - & - & - & Sianien 22. I. 76. Schlt. \\
\hline a. $*$ & $n \quad$, & & - & - & - & - & 2 & $\pi \pi$ Schlt. \\
\hline $23 . *$ & Saxicola aurita Temm. & $e^{2}$ & 1 & 一 & - & - & - & $2 \mathrm{~V} .7 \%$. Schlt. \\
\hline a.* & r & 8 & 1 & - & - & - & - & VI. 66. Schrader. \\
\hline b. $*$ & $\pi$ & & 1. 一 & - & - & 一 & 2 & Parnass Schlt. \\
\hline
\end{tabular}




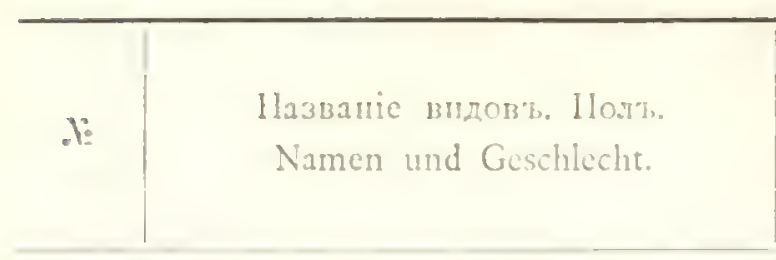

\section{Pratincola rubetra L.}

a.

b.

c.

d.

e. 长

f. +

s.

li.

i.

k.

l.

III.

11.

0.

1) $x$

q. *

r.*

$\mathrm{s}$.

25.

a.

b. *

c. $*$

(1)*

d. *

e. *

f. *

n.

il.

i. +

k.t

$1 .+$

m. +

n. +

$0 .+$

1.. +

(I.

r.

s.

t.

II.

$\left.u^{1}\right)$

r.

w.

$\mathrm{x}$.

y.
Pratincola rubicola L. typ.

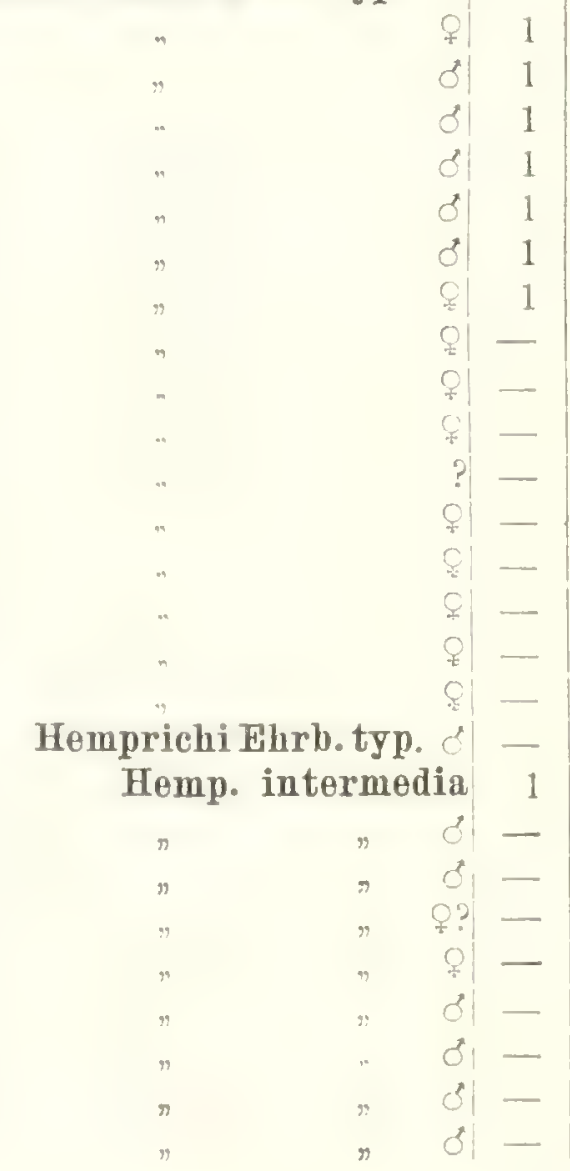

juv.
Мtето пахоя денія.

Fundort und Datum.

\&| - $11 \mid=$

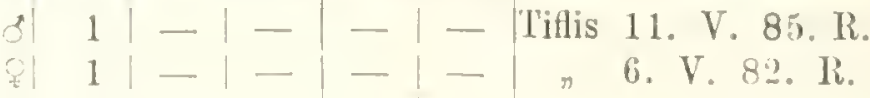

f $1|-|-|-|-7$ 23. VIII. 80. R.

이 $1|-|-|-|-\mid$ Lenkoran 1. IV.66. R.

o $|1|-|-|-|-|$ Kobi 6. V. 80. R.

8| $1|-|-|-|-$ Hessen 21. IV. 70. Grf. B.

8|-| $1|-|-|-|$ Krasnowodsk 20. IV. 86. R. W.

- Elisabethpol. 18. IV. 95. Sat.

- Tillis 27. VIII. 95. Sat.

- Kislowodsk 16. V. 86. L.

\begin{tabular}{l|l|l|l|l|l|l|}
8 & - & 1 & - & - & - & Bermamut 12. V. 86. L. \\
3 & - & 1 & - & - & - & Titlis 11. VIII. 96. Sat.
\end{tabular}

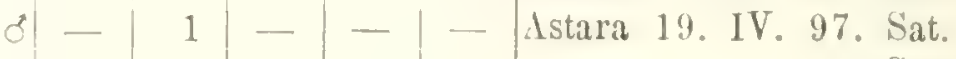

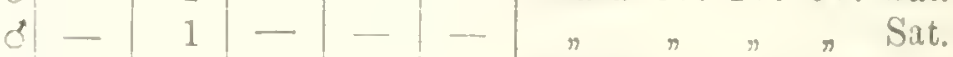

Orenburg 18. V. 87. Sard.

Brandenburg gkft.

$1 \times 3$

$-13$

$-12$

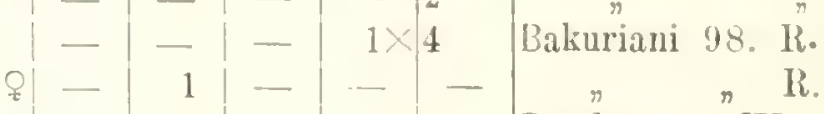

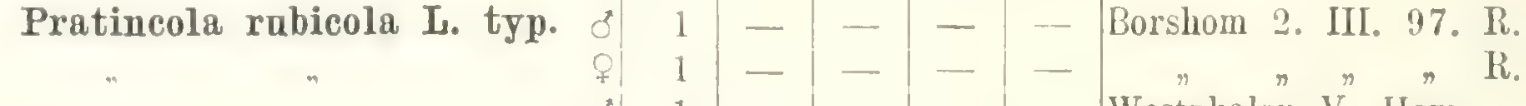

Westphalen V. Hom.

$\therefore$ Hom.

Deutschland 6. IV. 52. Hom.

Galizien

Hom.

Hessen 10. VI. 67. Grf. B.

Grf. B.

- Titlis 11. IV. 96. Sat.

- Lenkoran 13. III. 80. R.

- Repetek 10 V. 92. Sard.

- Kodsha-kala 10. V. 86. R. W.

- $" \gg$, Ii. W.

- Dusuolum 6. V. 86. R. W.

- Duschal 18. III. 86. R. W.

Repetek 19. V. 92. Sard.

Aschabad 13. II. 86. R. W.

Kumbaschinsk 11. IV, 96. Flrk.

- Schemacha 24. III. 66. R.

- $\quad 28$. IV. 96. Sat.

- Borshom IV. 92. R.

- Titlis 30. III. 97. Sat.

- $" \#$ 96. Sat.

- Schemacha 8. V. 96. Sat.

- Borshom 22. III. 96. R.

- $" 20$. III. 96. R. 


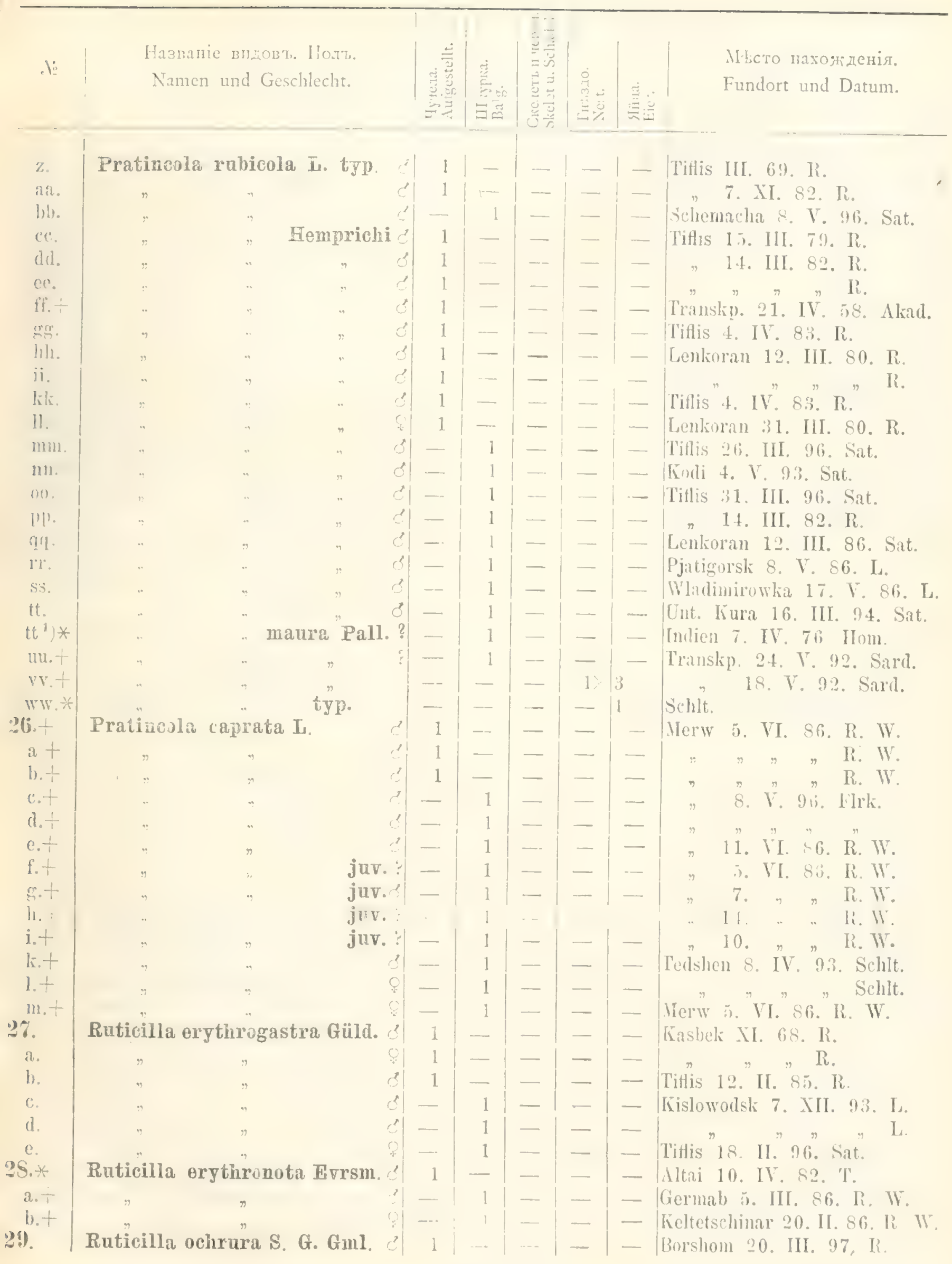




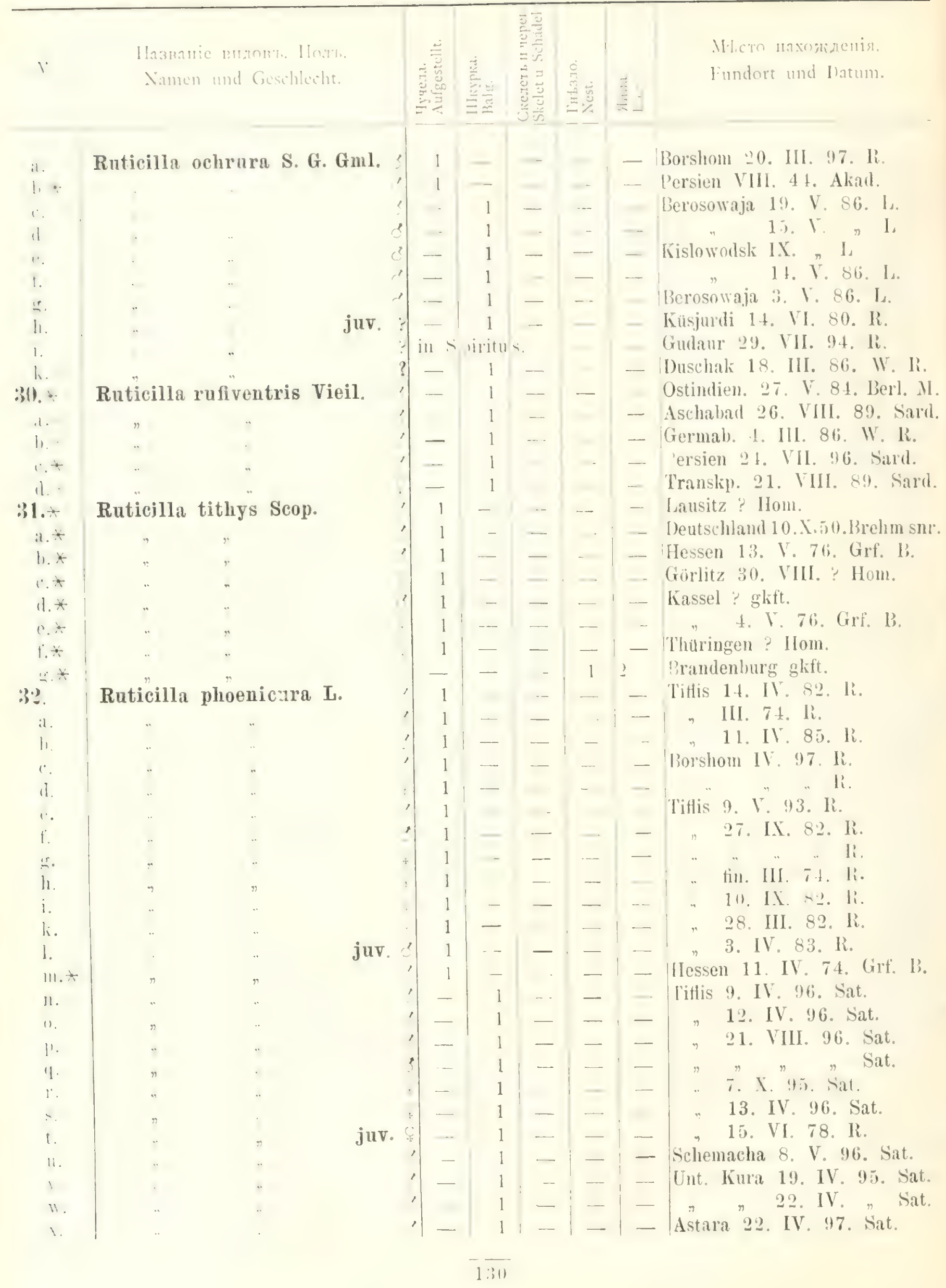




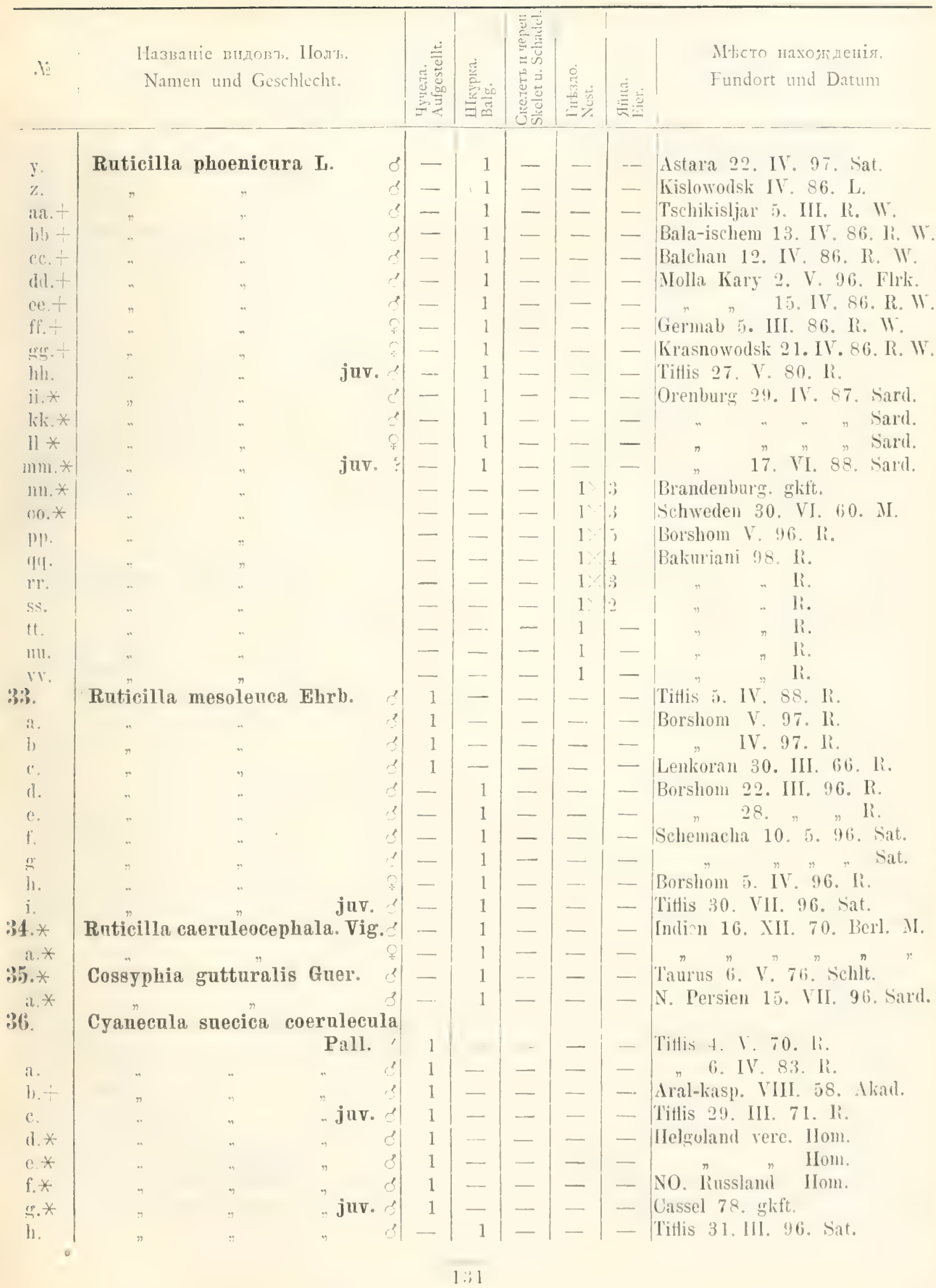




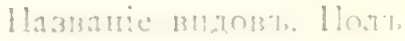

Namen mut Geschlecht.
MHetro maxngizenis.

lindort und Datum.
Cyanecula suecica coeruleata

ian. * $3 \%$

a.

i.

1.

$$
\text { Pall. }
$$

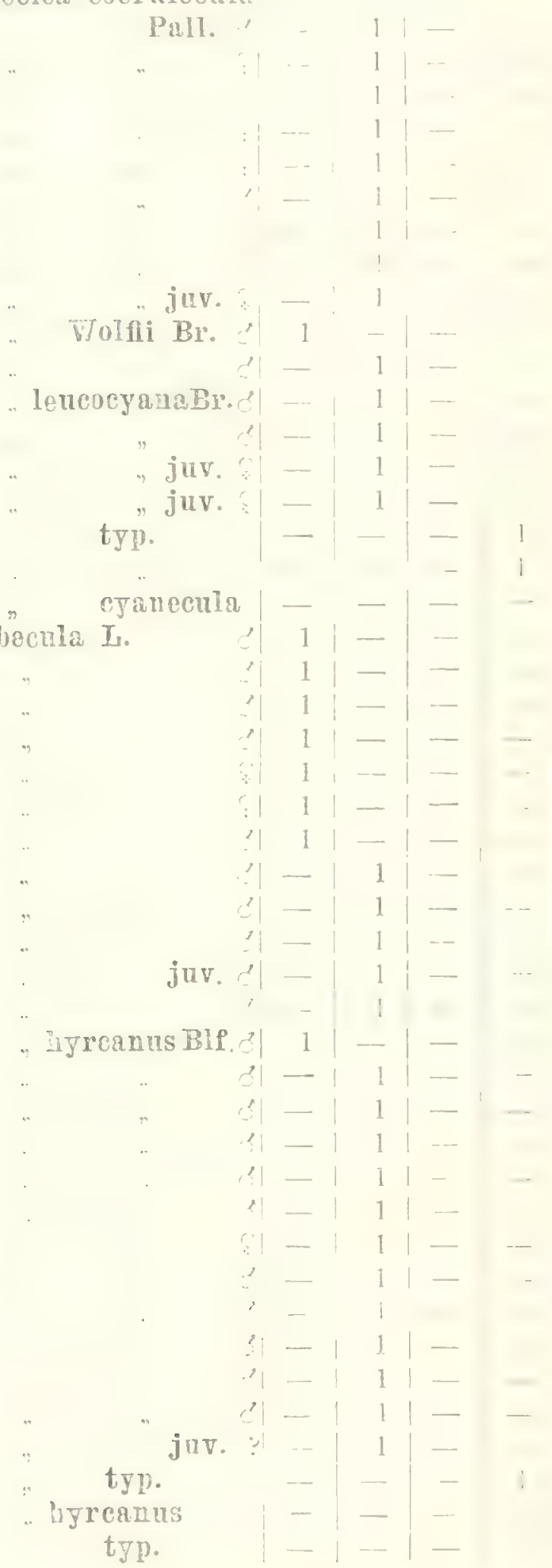

liflis 31. III. 9). Sat.

". . "Sat.

3. IV. 96 . Sat.

- Batum \&. IV. 9:?. R. K.

limmlasehinsk -0. IV. 80. IR. liag! :31. 11!. 86. R. II.

R. $\mathrm{IV}^{\mathrm{T}}$

Ischabal 1. IV. 86. R. W. Lapplanel ez: VI. 77. M. arsel 7s. glift.

l'iflis 22. III. 82. R.

Nizza 92. Sichlt.

Polt, (xuy, 27, VI. 95. Sart. 10. VI. 91. Sard.

7. VII. 90. Sard.

Lapuland 6.1. M.

sthweden 64. II

Hamover 4. VI. 6t. Schlt.

Titlis 3. III. 83. R. 17. I. 83. IR.

Borshom 5. HI. 97. R.

$" \quad n \quad n \quad " \quad \mathrm{R}$.

Inclitu? " " T'。 "10. XI. 78. 'I'.

Borshom I. 96. Ii.

Tittis 1. !). K.

Berosowaja 3. XI. 86. L.

IIanglis 5. I 1.97 . Sat

'skow 8. IX, 9.1. Sirrd.

Borshom III. 67. R.

-

Geok-tene (Lenk.) 4. III. 96. Sat.

Sat.

Sat.

Sat.

Sat.

Lenknran 31. I. 80. Li.

Lyrik 1 '. VI. 97 Sat.

- Tittis 9. Xi. 95. Sat

$$
\text { 23. X. 95. Sat. }
$$

21. 111. 97. Sat.

Unt. Kura 1:. IX. 96. Sat.

isrik 18. V1. 97. Sat.

Shweden 19. I. 62. ML.

Ifonkmin 24. V. 94. Sat. lghift. 
Llazванie видов\%, Hoлt. Namen und Geschlecht.

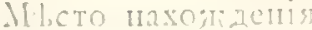

Fundort und Datum. b. Erythacus rabecula L.

ec.

ill. 39.

it.

b.

c. $*$

l.

e

t.

w..

It $*$

i $*$

k. $t$

$1 . \div$

in.

II.

$0 . *$ $39 . *$

10

;

a. $\%$

b. $*$

c. $*$

0.

a.

b.

c.

d.

c

f.

i

i.

1.

111

11

(1)

(1)

'1

r.

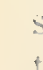

in.

$\{1$

it

b $*$

\section{Daulias philomela Bechst.}

Danlias Inscinia $\mathbf{L}$.

Daulias Hafizi Severz.

Sylvia nisoria Bechst.
Bialkưiani 9S. LR.

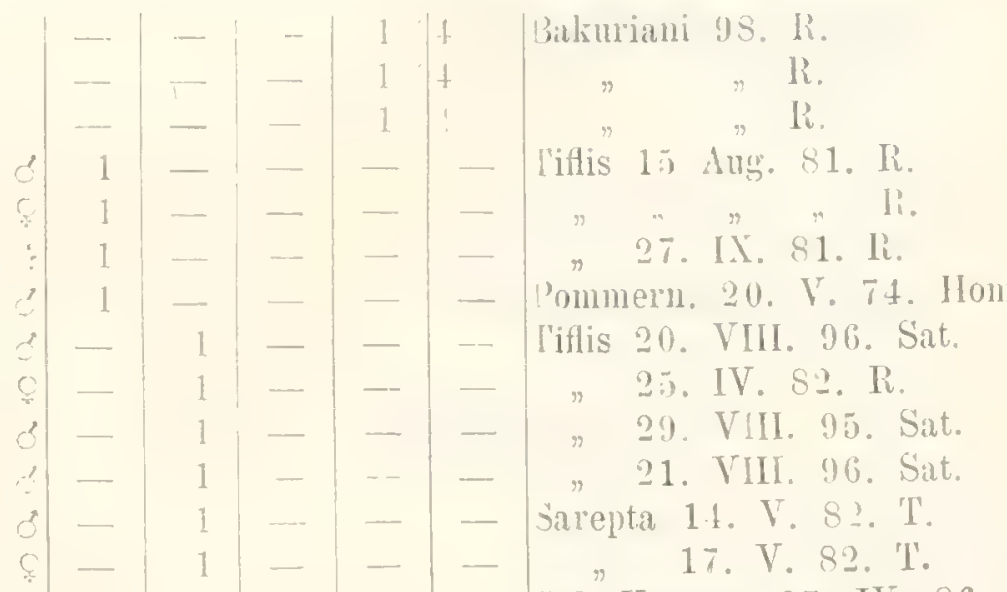

Bel. Kurgan. 27. IV. 86. IR.

Гschikisljar 13. IV. 86. Jas.

Borshom 29. III. 97. li.

shift.

rkft.

Nizza III. 79. Schlt.

"97. Schlt.

Brandenburg Schlt.

shift.

Titlis 13. V. 81. I.

-_ Lenkoran 30. V. 97. Sat.

- Astara 22. IV. 97. Sat.

-

- " " " " " " " Sitt.

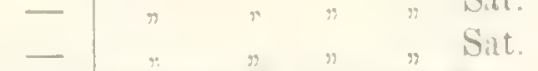

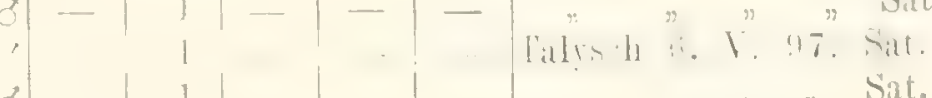

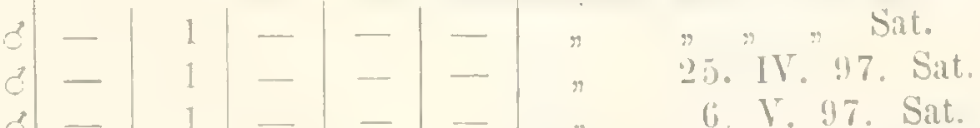

$$
\text { 6. V. 97. Sat. }
$$

$"$ " Sat.

Talysch :30. Y. 97. Sat.

$$
\text { Sat. }
$$

Kuba 26. T. 96. Sat.

10. VI. 9). Sat.

Silhemacha 10. V. 96. Sat.

Ischabad 2. IV. S6. R. II.

- Tedshen 13. V. \&6. R. W.

- Ischabad 24. V. 86. R. W.

I.enlioran V. 8\%. IR.

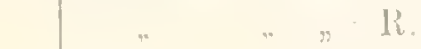

- Tiflis 2\%. I. 8.. I.

- $"$ i. V. 83. li.

- Pommeru. vere? Hom. 


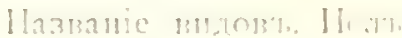

Nanen und Geschleche.

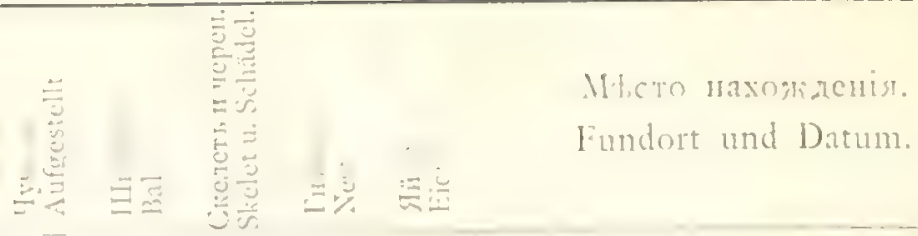

Sylvia nisoria Bechst.

Sylvia orphea Tem. typ.

ad. Jerdoni Blyth. typ.

1:? Sylvia hortensis Gm1.

il $\quad \therefore$ $11 \div$ $\because \div$ 1).

Sylvia cinerea Bechst. typ.

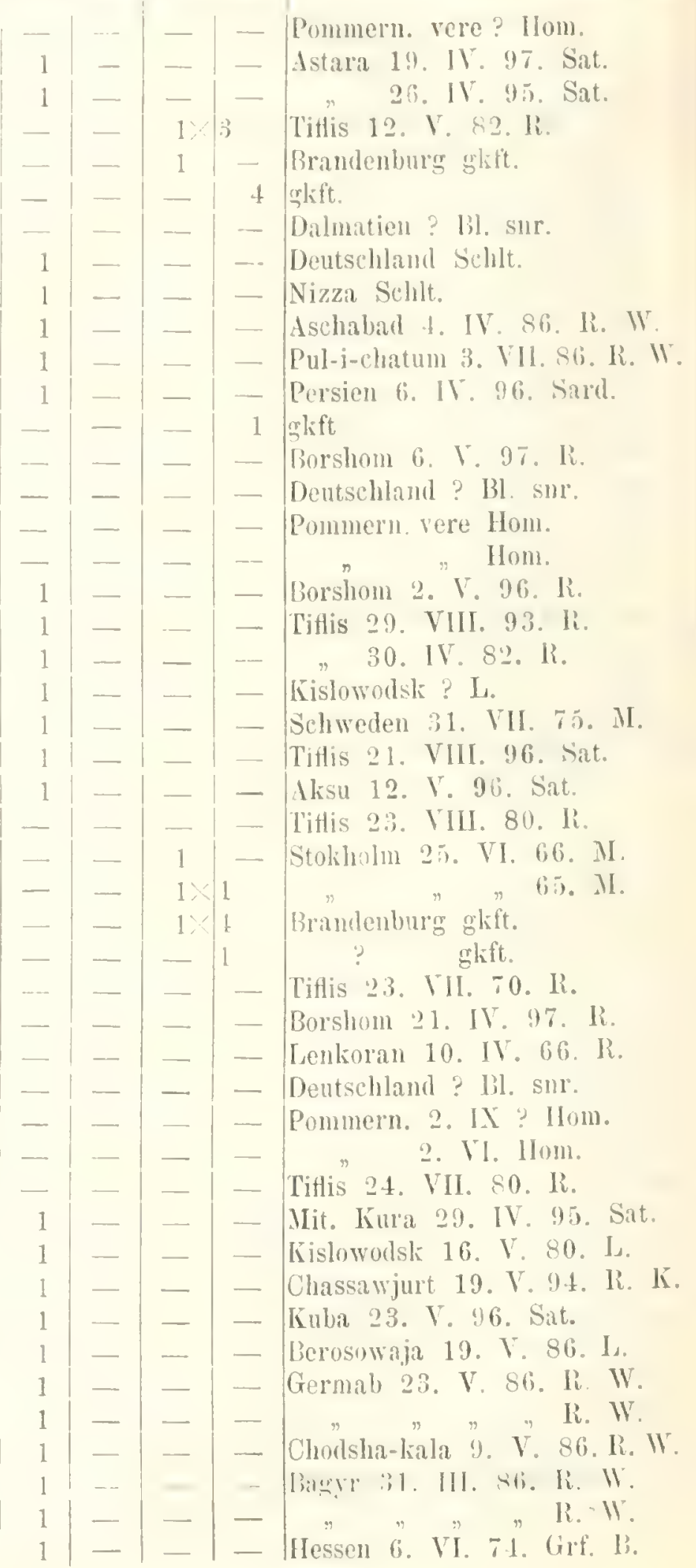


Названіе видовт. Llоть.

Namen und Geschlecht.
Sylvia cinerea Bechst. typ.

1.' ")

$r^{2}{ }^{2}$

$\mathrm{r}^{3}$ )

$r^{4}{ }^{4}$

$\mathrm{s}$.

t.

11.

i.

w.

$x$.

y.t

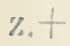

an +

ub.*

ec. +

dil.t

ee.

ifi.

45.

$$
0
$$

a.

b.

$(1$

c

f

s.

h.

i.t

k.t

$1 . *$

m

II

(1)

1)

q. +

r.t

s.t

t. +

u.

$46 . *$

$47^{2}$

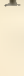

fuscipilea Serv.

typ.

fuscipilea

typ.

Sylvia mystacea Méntr.

Sylvia provincialis Gml.

Sylvia curruea L.

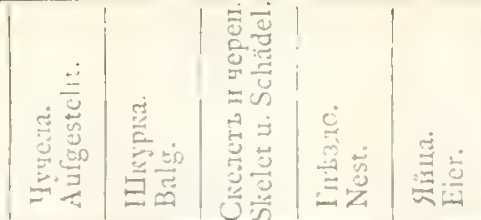

Mticto naxo;rдеnist.

Fundort und Datum. 


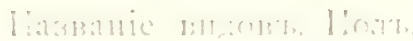

Damien und Gesilulecht.
Mrecton naxnmichis.

Fundort und Datum.
1. $x^{-}$Sylvia curruea $L$.

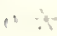

i.

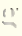

II.

i.

li.

1.

III .

11 .

(1).

1).

11 i

li. $t$

s. $\frac{1}{1}$

t. $x$

$11 . \div$

$1 \div$.

11. $\frac{1}{1}$

X. $\frac{1}{1}$

I. *

\%. $\frac{1}{1}$

เ2. - +

lil).

(c).

45.

il.

i).

(

(')-

it

15. *

1.

i.

k

111.

11.

0 .

1).

(1)

i. $t$

$5 \times$

i.

11. $x$ affinis Blyth.

$$
\text { min }
$$$$
\text { typ. }
$$

althea

minuscula

Sglvia atricapilla L. 


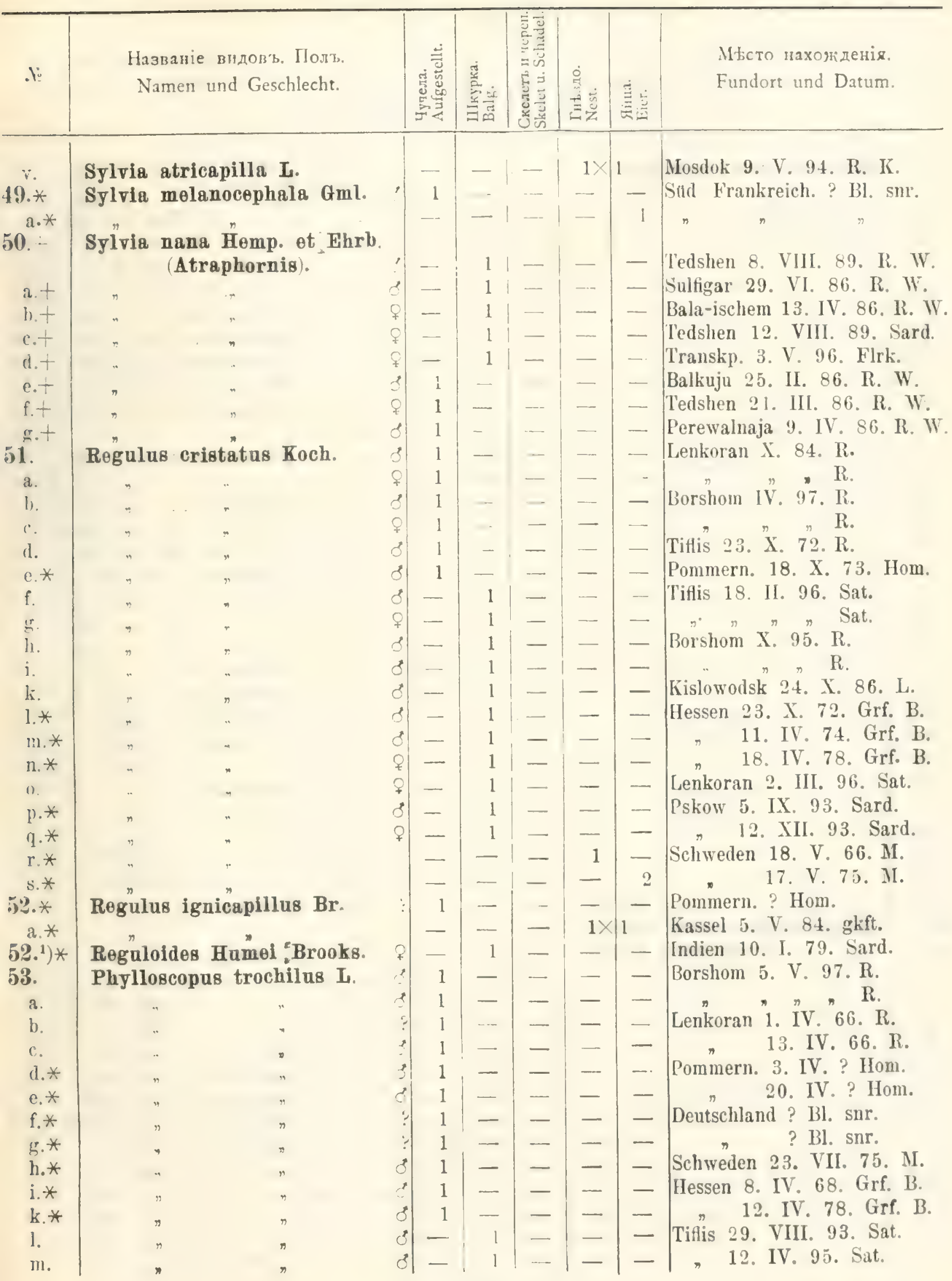




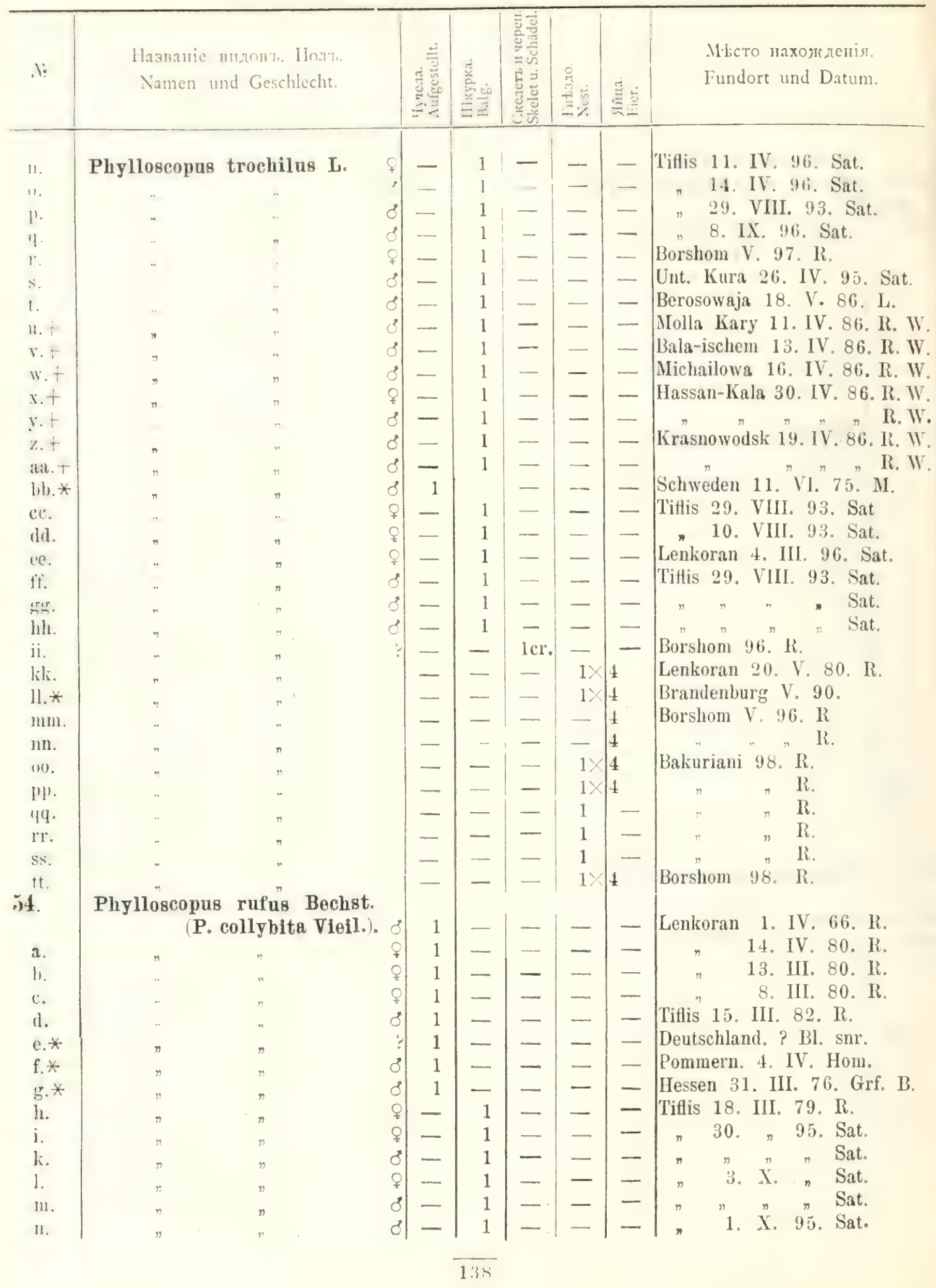




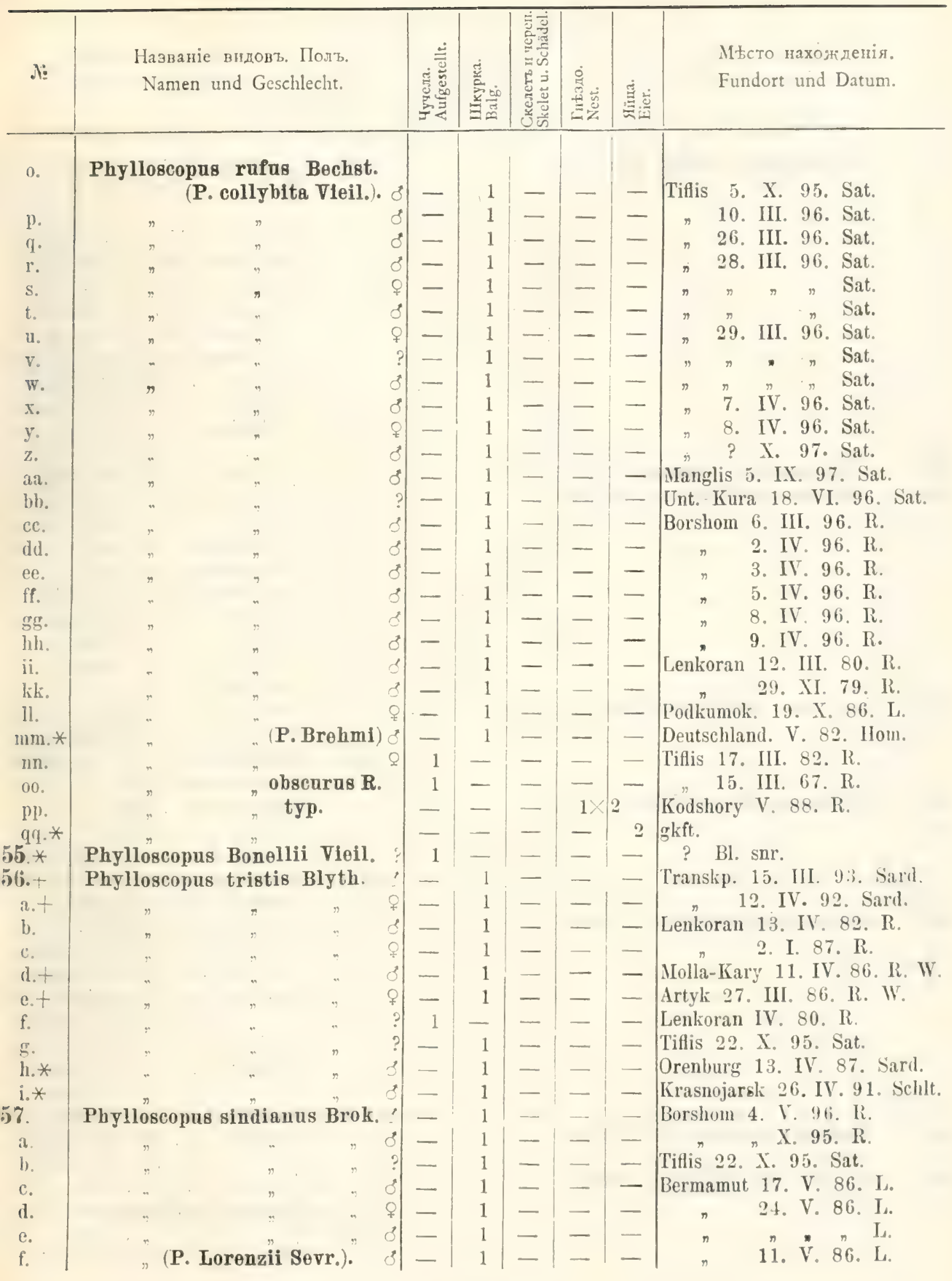




\begin{tabular}{|c|c|c|c|c|c|c|c|}
\hline$\therefore$ & $\begin{array}{l}\text { Названіе видовт. IІплт. } \\
\text { Namen und Geschlecht. }\end{array}$ & 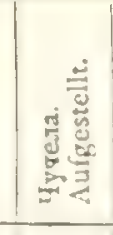 & 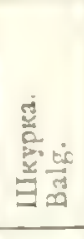 & 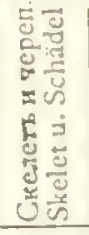 & 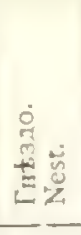 & 至总 & $\begin{array}{l}\text { Mfсто нахожденія. } \\
\text { Fundort und Datum. }\end{array}$ \\
\hline ist. & Phylloscopus nitidus Blyth. of & 1 & - & $\cdots$ & - & - & Borshom 5. VI. 97. R. \\
\hline a. & 2 & - & 1 & - & 一 & - & \% 5. V. 97. R. \\
\hline b. & * & - & 1 & - & - & $\cdots$ & $\Rightarrow n \quad R$. \\
\hline c. & n & - & 1 & - & - & - & 'Tiflis 29. IV. 80. R. \\
\hline d. & $"$ & - & 1 & - & - & - & Schemacha 20. V. 96. R. \\
\hline e. & , & ? - & 1 & - & - & 一 & Kuba 15. VI. 96. Sat. \\
\hline f. & , & - & 1 & - & - & - & Lenkoran 5. V. 96. Sat. \\
\hline g. & $n$ & - & 1 & - & - & - & Kislowodsk 28. V. 86. L. \\
\hline h & ? & -- & 1 & - & - & - & Bermamut 23. V. 86. L. \\
\hline i. + & " & - & 1 & - & - & - & Transkp. 13. VII. 92. Sard. \\
\hline $\mathrm{k} \cdot \div$ & , & - & 1 & - & - & - & T'schikisljar 2. V. 87. Jas. \\
\hline 1. & $"$ & $?-$ & 1 & - & - & 一 & Bakuriani 98. R. \\
\hline$=0^{11}$ & & - & - & - & :; & - & $n \quad n \quad \mathrm{R}$ \\
\hline $99 . \div$ & $\begin{array}{l}\text { Phylloscopus viridanus Blyth. } \\
\text { Phylloscopus sibilatrix Bechst. }\end{array}$ & - - & 1 & - & - & - & Transkp. 22. IV. 92. Sard. \\
\hline $60 . *$ & loscopus sibilatrix Bechst. & - & 1 & - & 一 & -- & Schweden 19. VI. 7.5. M. \\
\hline a. $*$ & , & 1 & - & - & - & - & Hessen 8. VI. 74. Grf. B. \\
\hline b. $*$ & . & 1 & 一 & - & 一 & $\cdots$ & itschland? I3l. snr. \\
\hline c. $*$ & 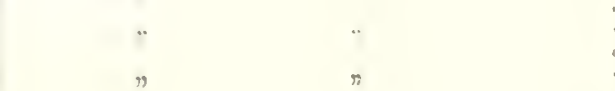 & 1 & - & - & - & - & Brandenburg. 94. gkft. \\
\hline d. & $\pi$ & 1 & - & - & - & -- & Deutschland 6. V. 59. Hom. \\
\hline$\because$ & . & 1 & 一 & - & & 一 & Pommern. 26. IV.? Hom. \\
\hline f. $*$ & - & - . & 1 & - & - & - & Pskow 2. Y. 93. Sard. \\
\hline$\stackrel{i n}{h_{0}} * *$ & $n$ & $3-$ & 1 & - & & - & $n n " n$ Sard. \\
\hline $61 * *$ & Hypolais polyglotta Vieil. & - & - & $\cdots$ & 1. & 1 & Brandenburg gkft. \\
\hline $\begin{array}{r}61 . * \\
a . *\end{array}$ & Hypolais polyglotta Vieil. & 1 & - & - & - & - & Nizza IX. 75. Schlt. \\
\hline $\begin{array}{l}\text { a. } * \\
\text { b. } *\end{array}$ & $\begin{array}{ll}* & - \\
& \end{array}$ & 1 & $\cdots$ & - & - & $\cdot$ & Valentia 29. VI. 56. Brehm snr. \\
\hline $\begin{array}{l}\text { b. } * \\
\text { c.* }\end{array}$ & & - & 1 & & - & - & Deutsehland 21. V. 82. Schlt. \\
\hline $6 \% * *$ & Hypolais icterina Vieil. & & - & -- & $1:$ & 1 & Brandenburg gkft. \\
\hline $\begin{array}{l}62 . * \\
\text { a.* }\end{array}$ & Hypolais icterina Vieil. & 1 & - & -- & - & - & Deutschland.? gkft. \\
\hline $\begin{array}{l}\text { a. } * \\
\text { b. }\end{array}$ & $\begin{array}{ll}n & n \\
& n\end{array}$ & 81 & - & - & & - & sen. 64. Grf. B. \\
\hline b. & , & $8 \mid-$ & 1 & - & - & 一 & Istara 20. IV. 97. Sat. \\
\hline $\begin{array}{l}* * \\
d *\end{array}$ & $\ddot{n}$, & - & - & - & 1 & - & Schweden 2. VII. 67. M. \\
\hline 63. & Hypolais (1duna)caligata Lichst & - & - & - & 1 & ; & Währen 27. V. 85. gkft. \\
\hline 63. & Hypolais (lduna)ealigata Lichst & - & 1 & & -- & - & Lenkoran 7. IV, 82. T. \\
\hline $\begin{array}{l}\text { a. } * \\
\text { b. }-\end{array}$ & $\ddot{*}$ & + & 1 & - & - & - & Kirgisensteppe VI. 74. Hom. \\
\hline $\begin{array}{l}\text { b. }-- \\
(1,--\end{array}$ & . & q - - & 1 & & - & - & Tedshen 10. VIII. 83. Sard. \\
\hline$\because-$ & 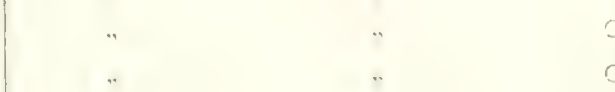 & s - & 1 & - & - & - & Transkp. 5. V. 92. Sard. \\
\hline 11. - & 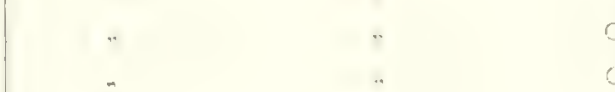 & C - & 1 & - & - & -- & $\Rightarrow \quad 21$. VII. 89. Sard. \\
\hline$\because$ & - & $3 \mid-$ & 1 & - & -- & $-\cdot$ & Salian 20. IV. 97. Sat. \\
\hline f. & . & s- - & 1 & - & -- & - & Lenkoran 29. V 97. Sat. \\
\hline$\because$ & 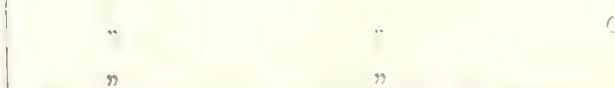 & 8 & 1 & - & - & - & 6. V. 97. Sat. \\
\hline h. $*$ & Hypolais languida" H. et Thrb. & - & 一 & - & 1 & 1 & Orenburg 3. VI. 80. Sard. \\
\hline 64. -- & Hypolais langaida H. et Ehrb. & $\mathfrak{f}-$ & 1 & - & - & - & Transkp. 28. IV. 96. Sard. \\
\hline $\mathrm{at},-$ & Hypolais pallida Hemp. et Ehrb. & 2 & 1 & - & -- & - & $" 27$. IV. 96. Sard. \\
\hline a. & Hypolais pallida Hemp. et Ehrb. & 3 - & 1 & - & - & - & Terter 2. VI. 95. Sat. \\
\hline i. & $\begin{array}{ll}- & - \\
\cdots & +\end{array}$ & - & 1 & 一 & - & $\cdots$ & Salian 14. VI. 97. Sat. \\
\hline$\therefore$ & r. & $\cdots$ & 1 & - & - & - & Sat. \\
\hline$\therefore$ & & $\prime-$ & 1 & - & - & -- & Schemacha 12. V. 96. Sat. \\
\hline
\end{tabular}




\begin{tabular}{|c|c|c|c|c|c|c|c|c|c|}
\hline$\therefore$ & $\begin{array}{l}\text { Названiе } \\
\text { Namen u }\end{array}$ & $\begin{array}{l}\text { видовъ. IІоль. } \\
\text { and Geschlecht. }\end{array}$ & & 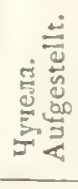 & 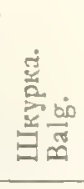 & 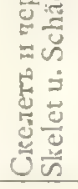 & 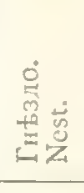 & 递总 & $\begin{array}{l}\text { Mtсто паложденія. } \\
\text { Fundort und Datum. }\end{array}$ \\
\hline d. & Hypolais pallic & da Hemp. et Ehrb. & & - & 1 & - & - & $\cdots$ & Kuba ״. VI. gt. Sat. \\
\hline e. & " & & 8 & - & 1 & - & - & - & " 3. VI. 96. Sat. \\
\hline f. & $"$ & & q & - & 1 & 一 & - & - & ᄁ 10. VI. 96. Sat. \\
\hline g. & $n$ & & 3 & - & 1 & - & - & - & $\Rightarrow \quad n \pi$ Sat. \\
\hline h. * & $"$ & & 8 & - & 1 & - & 一 & 一 & Klein Asien 18. IV. 76 . Schlt. \\
\hline i. & . & & & - & - & - & 1 & - & Salian 14. VI. 97. Sat. \\
\hline$k$. * & 》 & & & - & - & - & 一 & 2 & Spanien 14. V. 94. gkft. \\
\hline 1. * & $n$ & & & - & - & - & - & 1 & $g \mathrm{gft}$. \\
\hline $66 .+$ & Hypolais ram & na Sykes. & 8 & - & 1 & - & - & - & Michailowo 16. IV. 86. R. W. \\
\hline a. $t$ & $n$ & & 8 & - & 1 & 一 & - & - & $n \quad$ 18. IV.86.R. W. \\
\hline b.t & $"$ & & 8 & - & 1 & - & - & - & Molla Kary 11. IV. 86. R. W. \\
\hline$c^{---}$ & . & & 8 & - & 1 & - & - & - & $\pi \quad$ $\quad 15 . \mathrm{IV} .86 . \mathrm{R}, \mathrm{W}$ \\
\hline $11 . t$ & n & & 8 & - & 1 & - & - & - & $n \quad n \quad n \quad n \quad \pi R, W$. \\
\hline e. - & r & & 0 & - & 1 & - & - & - & Bala-ischem 14. IV. 86. R. W. \\
\hline f. - & $"$ & & b) & $\longrightarrow$ & 1 & - & - & - & Dusu-olum 6. V. 86. R. W. \\
\hline s. $t$ & " & & o & - & 1 & - & - & - & Jelotani 16. VI. 86, R. W. \\
\hline l.. - & * & & d) & 一 & 1 & - & - & - & Dort-Kuju 2. VI. 86. R. W. \\
\hline i. + & .. & & 5 & - & 1 & - & - & - & $n \quad n \quad " \quad n \quad \mathrm{R} \cdot \mathrm{W}$. \\
\hline li.t & , & & d & - & 1 & - & - & - & Merw 15. VI. 86. R. W. \\
\hline 1. $\div$ & $"$ & & s & - & 1 & 一 & - & - & $"$ 10. VI. 86. R. W. \\
\hline $111+$ & . & & c) & - & 1 & - & 一 & - & $" \quad$ 5. VI. 86. R. W. \\
\hline II. $T$ & , & & c & - & 1 & - & - & - & $n \quad n \quad n \quad n \quad$ R. W. \\
\hline $11 \div$ & .. & & 8 & - & 1 & - & - & - & Sultigar 29. VI. 86. R. II. \\
\hline $11 .+$ & . & & 8 & - & 1 & - & - & - & Buchara 3. VII. 89. Sard. \\
\hline $1 .-$ & . & & \& & - & 1 & - & - & - & 4. VII. 89. Sard. \\
\hline r. $T$ & . & rama pallida & d & - & 1 & - & - & - & Merw 23. III. 89. Sard. \\
\hline s. + & . & & \& & - & 1 & - & - & - & Buchara 15. VI. 89. Sard \\
\hline 1. - & $n$ & rama & & - & - & - & $1>$ & 3 & Chodsha-Kala 10.V.86.R. W. \\
\hline $11 . \div$ & » & & & - & - & - & $1 \times$ & 2 & $m \quad n, \quad n \quad, \quad \mathrm{R}, \mathrm{W}$. \\
\hline r. - & " & & & - & - & - & 1) & 2 & Merw 10. V. 86. Sard. \\
\hline$w+$ & $n$ & & & - & - & - & 1) & 2 & Karybent 5. V. 86. Sard. \\
\hline$x \cdot t$ & & rama-pallida & & - & - & - & 1) & 3 & Herw 9. V. 86. Sard. \\
\hline $6 \%$ - & Herbivocula & neglecta Hume & $\because$ & - & 1 & - & & - & Koplet dagh 27. VII. 86. R. II. \\
\hline a. $\uparrow$ & " & $n$ & ? & - & 1 & - & 一 & - & $"$ 24. VII. 86. R. W. \\
\hline$b_{1}+$ & $"$, & & q & - & 1 & - & - & - & $" \quad$ $" 22$. VIII. 89. Sard. \\
\hline 6 (6.) & Acrocephalus & turdoides Mey. & $d$ & 1 & - & - & - & - & Tittis 11. Y. 82. R. \\
\hline a. & $"$ & $"$ & 8 & 1 & - & - & - & - & " 1 t. V. S2.R. \\
\hline b. & $"$ & " & $\delta$ & 1 & - & - & $\longrightarrow$ & - & n $\quad 6 . \mathrm{V} .82 . \mathrm{R}$ \\
\hline$\because$ & $"$ &. & $\delta$ & 1 & - & - & - & - & Deutschland? Bl. snr. \\
\hline d. 1 & . & \% & ? & - & 1 & - & - & 一 & Transkp. 30. VII, 92. Sard. \\
\hline$\because$ & . & , & & 一 & 1 & - & - & - & Lenkoran 31. V. 97. Sat. \\
\hline ti. + & " & $"$ & & - & - & - & $1 \times$ & 4 & Keltetschinar $87 . \mathrm{K}$. \\
\hline$\because * *$ & , & $"$ & & - & 一 & - & 12 & 3 & Brandenburg gkft. \\
\hline $\begin{array}{l}\text { h. * } \\
69 . *\end{array}$ & Acrocephalu & stentoreus Hemp & & - & - & - & - & 6 & ghlift. \\
\hline$a *$ & 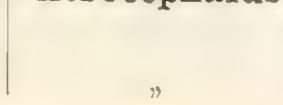 & et Ehrb. & 7 & $\begin{array}{l}1 \\
1\end{array}$ & - & - & - & - & \begin{tabular}{|cc} 
Damiette 23. & XII. 86. $\mathrm{T}$. \\
& $16 . \mathrm{X}, 81 . \mathrm{T}$.
\end{tabular} \\
\hline
\end{tabular}




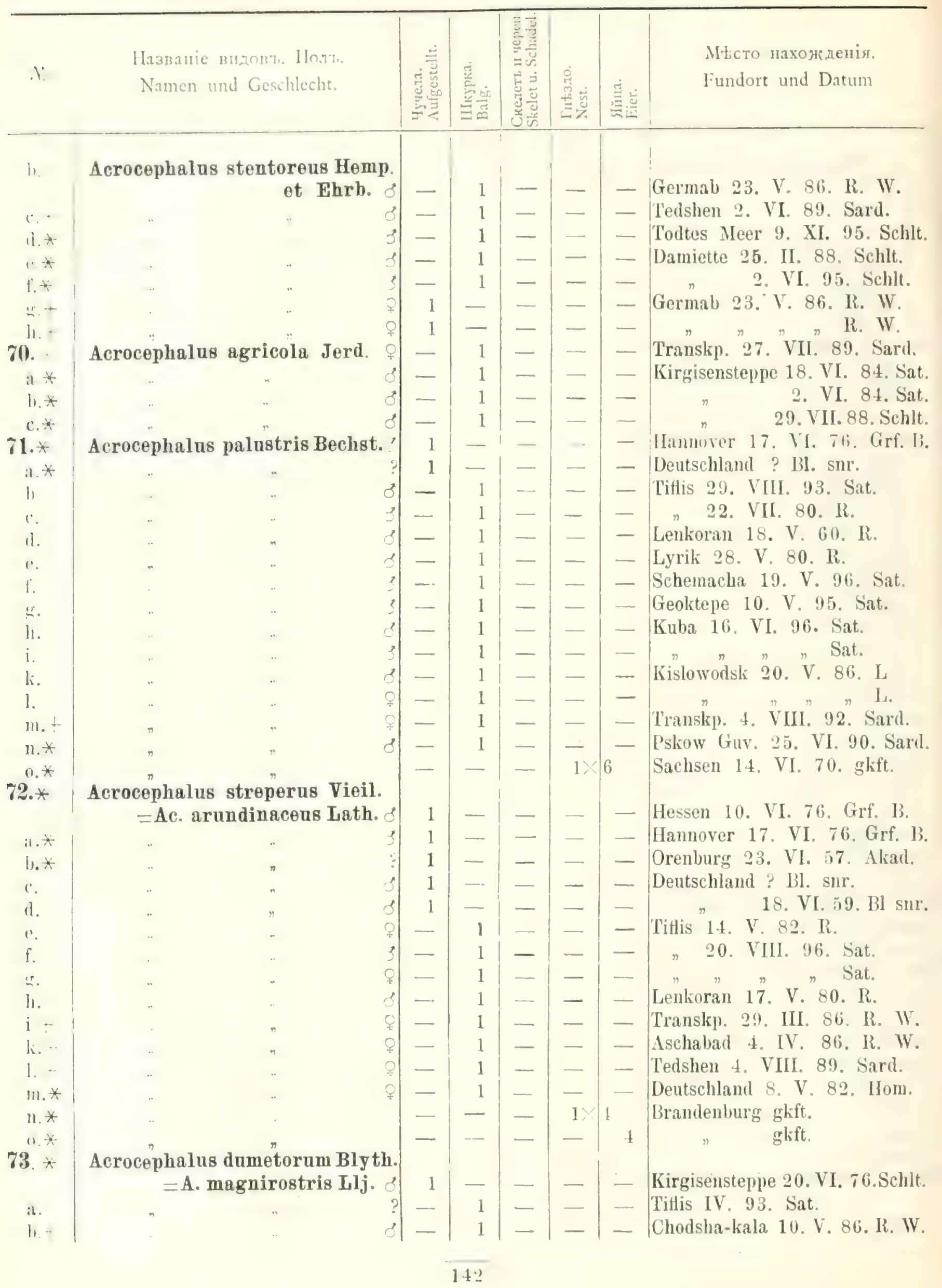




\begin{tabular}{|c|c|c|c|c|c|c|c|}
\hline i & $\begin{array}{l}\text { Названіе видовъ. Полт. } \\
\text { Namen und Geschlecht. }\end{array}$ & 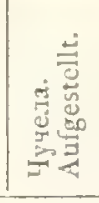 & 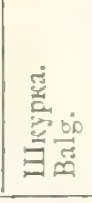 & 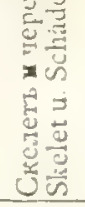 & 焦 & 咅递 & $\begin{array}{l}\text { Mето пахонденія. } \\
\text { Fundort und Datum. }\end{array}$ \\
\hline$\therefore$ & $\begin{array}{r}\text { Acrocephalus dumetor } \\
=\text { A. magnirost }\end{array}$ & - & 1 & - & 一 & - & |'Transk|). \\
\hline d. $*$ & $r$ & - & 1 & 一 & - & - & Krasnojarsk 31. V.92. Schlt \\
\hline (1) $*$ & " " " & & 1 & - & - & - & Orenburg 15. V. 87. Sard. \\
\hline 14. & $\begin{array}{l}\text { cephalus phragmitis Bechst. } \\
=\text { A. schoenobaenus L. }\end{array}$ & 1 & - & 一 & 一 & - & Tiflis 25. IV. 81. R. \\
\hline$a$. & " & 1 & - & - & - & 一 & $" \quad " \quad \Rightarrow \quad R$. \\
\hline h. & ." & 1 & 一 & 一 & - & 一 & $\because \quad \mathrm{R}$. \\
\hline il & " & 1 & - & - & - & - & Lenkoran 20. V. 80. R. \\
\hline 11. & “ & 1 & 一 & 一 & 一 & - & $" n \quad m$ li. \\
\hline$\because$ & " & 1 & 一 & - & 一 & 一 & 16. V. 80. Ii. \\
\hline i. & . & I & - & - & - & - & 6. V. 80. R. \\
\hline ir. & . & 1 & - & - & 一 & - & 17. V. 80. K. \\
\hline $\begin{array}{l}\text { il. } \\
\text { i. }\end{array}$ & $n$ & 1 & - & - & - & - & 18. V. 80. R. \\
\hline i. & , & 1 & 一 & 一 & 一 & - & Titlis 25. IV. 81. R. \\
\hline $\begin{array}{l}\text { k. } * \\
\text { l. } *\end{array}$ & $n$ & 1 & - & - & 一 & - & Deutschland 1. VI. 75. Hom. \\
\hline $\begin{array}{l}1 . * \\
111.7\end{array}$ &. & 1 & - & 一 & - & - & Pommern. VI. 75. Hom. \\
\hline 111. & . & 1 & 一 & - & - & - & Deutschland? Bl. snr. \\
\hline n. & \% & - & 1 & 一 & 一 & - & Lenkoran 19. IV. 97. Sat. \\
\hline 1). $*$ & $"$ & - & 1 & - & 一 & 一 & Deutschland 6. V. 82. Hom. \\
\hline $1, *$ &. & - & 1 & - & 一 & - & Serbien 24. IV. 94. Schlt. \\
\hline $\begin{array}{l}\text { if. } * \\
\text { r. }\end{array}$ & .. & - & 一 & - & & 3 & Brandenburg gkft. \\
\hline 5 & & - & 一 & - & 一 & 3 & $m \quad$ gkft. \\
\hline 5. . & Acrocephalus aquaticus Tem. & 1 & - & - & - & - & Pommern. 2. VII. 7t. IIom. \\
\hline a. * $*$ & " & 1 & - & - & - & - & VI. VII. 74. H \\
\hline b. &. & 1 & - & 一 & - & - & 27. VII. 73. Hom. \\
\hline$\because$ &. & - & 1 & - & - & - & Nizza 95. Schlt. \\
\hline 1 . & . & - & 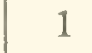 & - & - & 一 & Frankieich ? ? \\
\hline$\therefore$ & (cariceti) & - & 1 & - & - & - & Pommern. 27. VII. 74. Hom. \\
\hline$f \cdot *$ & & - & - & 一 & - & 1 & Brandenburg 3. VI. 94. gkft. \\
\hline 66. & Locustella fluviatilis Wolf. & 1 & - & - & - & 一 & Tiflis 27. IV. 82. R. \\
\hline a. 7 & . & 1 & 一 & 一 & - & - & Deutschland.? Bl. snr. \\
\hline b. & $*$ & 1 & - & - & - & 一 & Sarepta 29. V. 82. T. \\
\hline${ }^{\circ}$ & $:$ & - & 1 & - & - & 一 & Tiflis 19. VIII. 82. R. \\
\hline 11. $*$ & " & - & 1 & - & - & 一 & Orenburg 25. V. 90. Sard. \\
\hline c.* & & - & - & 一 & - & 1 & gkft \\
\hline & $\begin{array}{l}\text { Locustella locustella Lath. } \\
\text { straminea Sevr. }\end{array}$ & 1 & - & - & - & 一 & Orenburg 29. VI. 57. Akad. \\
\hline a. & $n$ & 一. & 1 & - & 一 & 一 & Bermamut 23. V. 86. L. \\
\hline l. & $n$ & - & 1 & 一 & - & - & Podkumok $n \pi n$ L \\
\hline$c \rightarrow$ & typica & 1 & 一 & 一 & - & 一 & Pommern. 23. V. 74. Hom. \\
\hline d. & $n$ & 1 & 一 & 一 & - & 一 & . 76. $\mathrm{T}$. \\
\hline e. & , & ? - & 1 & - & - & 一 & 95. Schlt. \\
\hline$f *$ & . & 一 & - & - & 1 & - & Darmstadt 26. V. 92. gkft. \\
\hline g.* $*$ & & 一 & - & - & 一 & 2 & ind gkft. \\
\hline $\begin{array}{l}\text { 78. } * \\
a .+\end{array}$ & Locustella luscinioides Savi. & 1 & - & - & - & 一 & $\begin{array}{l}\text { Holland ? BI. snr. } \\
\text { Artyk 29. III. 86. R. }\end{array}$ \\
\hline a. $t$ & $n \quad \pi$ & $\because-$ & 1 & - & 一 & 1 - & ( \\
\hline
\end{tabular}




\begin{tabular}{|c|c|c|c|c|c|c|c|c|c|}
\hline .1 & $\begin{array}{l}\text { Hazваи } \\
\text { Namen }\end{array}$ & $\begin{array}{l}\text { ie mนnom\%. IJosz. } \\
\text { und Geschlecht. }\end{array}$ & & 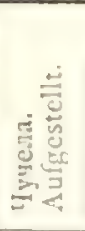 & 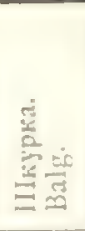 & 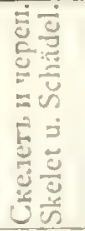 & 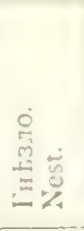 & 总离 & $\begin{array}{l}\text { Nlсто нахонденія. } \\
\text { Fundort und Datum. }\end{array}$ \\
\hline h. & Locustella & Inscinioides Savi. & & - & 1 & - & - & - & Drtyk 29. III. 86. R. W. \\
\hline$\therefore$ & $n$ & $\pi$ & & - & 1 & - & - & - & Poltw. Guv. 16. VI. 90. Sard. \\
\hline i!). & Lusciniola & molanopogon Tem. & & 1 & - & - & - & - & 'litlis 28. XI. 81. R. \\
\hline a. & & . & & - & 1 & - & - & - & Kumbaschinsk 17. II. 87. R. \\
\hline 1. & & & 3 & - & 1 & - & - & - & . 21. III. 87. R. \\
\hline ‘. & . & " & 8 & -- & 1 & - & - & - & 7. III. 87. R. \\
\hline 11. - & . & .. & ' & -- & 1 & - & - & - & Artyk 27. III. 86. R. W. \\
\hline ‥ & & . & c & & 1 & & - & - & $n, \quad, \quad R, W$. \\
\hline$i \cdot$ & & & 8 & - & 1 & - & - & & $n \quad-\quad$ R. W. \\
\hline$-(1)$ & Cettia cott & i Marm. & 3 & 1 & - & - & - & - & Lenkoran 21. XI. 79. R. \\
\hline a. : & $n$ & & 2 & 1 & 一 & - & - & - & Spanien 6. X. 76. Schlt. \\
\hline 1, & $"$ & & $f$ & - & 1 & - & - & 一 & Lenkoran 1. II. 87. R. \\
\hline$\therefore$ &. & & $f$ & - & 1 & - & 一 & - & Transkp. 5. III. 86. R. W. \\
\hline 11. & .. & & $q$ & - & 1 & -. & 一 & - & $" \quad 20$. II. 86. R. W. \\
\hline $11+$ & 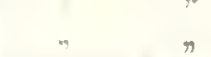 & & $?$ & - & 1 & - & - & - & ? 20. XII. 82. Hom. \\
\hline$-1 . \pi$ & Cisticola & ursitans Frank. & ? & 1 & - & 一 & - & - & Algier ? IIom. \\
\hline$a+$ & & . & $?$ & 1 & - & - & - & - & ? Bl. snr. \\
\hline $11 . \cdot$ & & .. & & - & $=$ & - & -- & 3 & Spanien 30. IV. gkft. \\
\hline $5 \%$ & Aëdon fam & iliaris Méntr. & 2 & & & & & & T. 0 Afrika $2 \mathrm{BL}$ snr \\
\hline il & , & $\begin{array}{l}\text { galactoues iom. } \\
\text { typ. }\end{array}$ & 8 & $\frac{1}{-}$ & 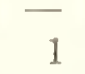 & - & - & - & Thiflis V. 80. R \\
\hline b) & & . & c & - & 1 & - & -- & - & Unt. Kura 16. V. 95. Sat. \\
\hline$\therefore$ & .. & & 8 & - & 1 & - & - & - & Geok-tepe 16. V. 94. Sat. \\
\hline 11. - & . &. & ? & - & 1 & - & - & - & Bairam-ali 9. V. 96. Flrk. \\
\hline$\therefore-$ & . & . & 3 & - & 1 & - & - & $\ldots$ & Transkp. 28. V. 96. Flrk. \\
\hline 1. & & . & 8 & - & 1 & - & - & - & Salian 16. VI. 97. Sat. \\
\hline$\because 2$ & .. &. & $d$ & - & 1 & - & - & - & $n \quad n \quad n$ Sat. \\
\hline h. & .. & .. & s) & - & 1 & - & - & - & $" n$ "Sat. \\
\hline i. & . & . & 8 & - & 1 & - & - & - & Kuba 27. VI. 97. Sat. \\
\hline kis & .. & .. & $?$ & - & 1 & - & - & - & $" \quad \pi \quad$ Sat. \\
\hline 1. & . & - & 8 & - & 1 & - & - & - & $\Rightarrow$ Sat. \\
\hline 111. & & , & $\varnothing$ & 1 & - & - & $\ldots$ & - & Mugan 30. III. 66. R. \\
\hline 11. : & . & .. & 8 & 1 & - & - & - & $\ldots$ & Aschabad 13. V. 86. R. W. \\
\hline 11.- & . & .. & d) & 1 & - & - & - & $\ldots$ & n $\quad 16 . \mathrm{V} .86 . \mathrm{R} . \mathrm{W}$. \\
\hline p. $T$ & .. & .. & 3 & 1 & - & - & - & - & $\leadsto \quad, \quad \mathrm{R} . \mathrm{W}$. \\
\hline 1. + & & . & 8 & 1 & - & - & - & - & Murgab 4. VII. 86. R. IV. \\
\hline$r$ & & & & - & - & - & - & 1 & Lenkoran V. 84. R. \\
\hline S:. : & Scotocerca & inquieta Cretz. & $\geq$ & - & 1 & 一 & - & - & Balchan 13. IV. 86. R. W. \\
\hline a. - & .. & .. & $\mathcal{Z}$ & - & 1 & - & - & - & Transkp. 29. IV. 92. Sard. \\
\hline b. - & n & . & $c$ & - & 1 & - & - & - & Buchara 29. VI. 89. Sard. \\
\hline c. $-T^{-}$ &. & त & & - & 1 & - & - & 一 & Transkp. 6. V. 96. Flrk. \\
\hline d. + & $r$ & .. & & 1 & - & - & - & - & Krasnowodsk 6. II. 86 R. W. \\
\hline e. $t$ & $"$ & $"$ & & 1 & - & - & - & - & " $\quad 9$. II. $86 . \mathrm{R} . \mathrm{W}$. \\
\hline f. $T$ & $n$ & . & & 1 & - & - & - & - & Bal-kuju 25. II. 86. R. W. \\
\hline s. - - & . & - & & 1 & - & - & - & - & Balchan 12. IV. 86. R. W. \\
\hline 11. : & \% & $"$ & & - & - & - & - & 6 & Dsibell 3. V. 96. Sard. \\
\hline
\end{tabular}


FAM. TROGLODYTIDAE.

\begin{tabular}{|c|c|c|c|c|c|c|c|}
\hline I: & $\begin{array}{l}\text { Названіс видовт. Ilолт. } \\
\text { Namen und Geschlecht. }\end{array}$ & 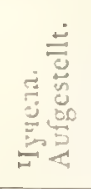 & 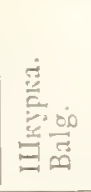 & 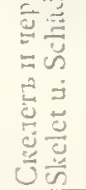 & 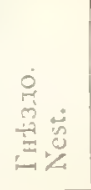 & 导这 & $\begin{array}{l}\text { Micto нахояденія. } \\
\text { Fundort und Datum. }\end{array}$ \\
\hline
\end{tabular}

S1. Troglodytes parvulus Koch.

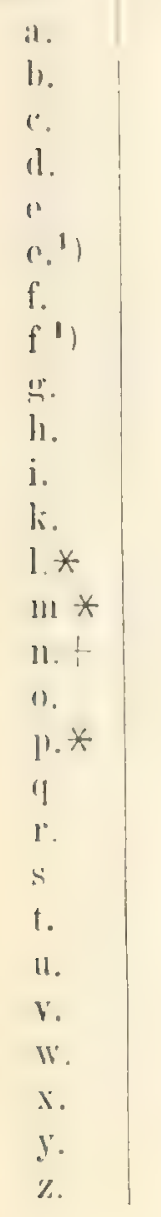

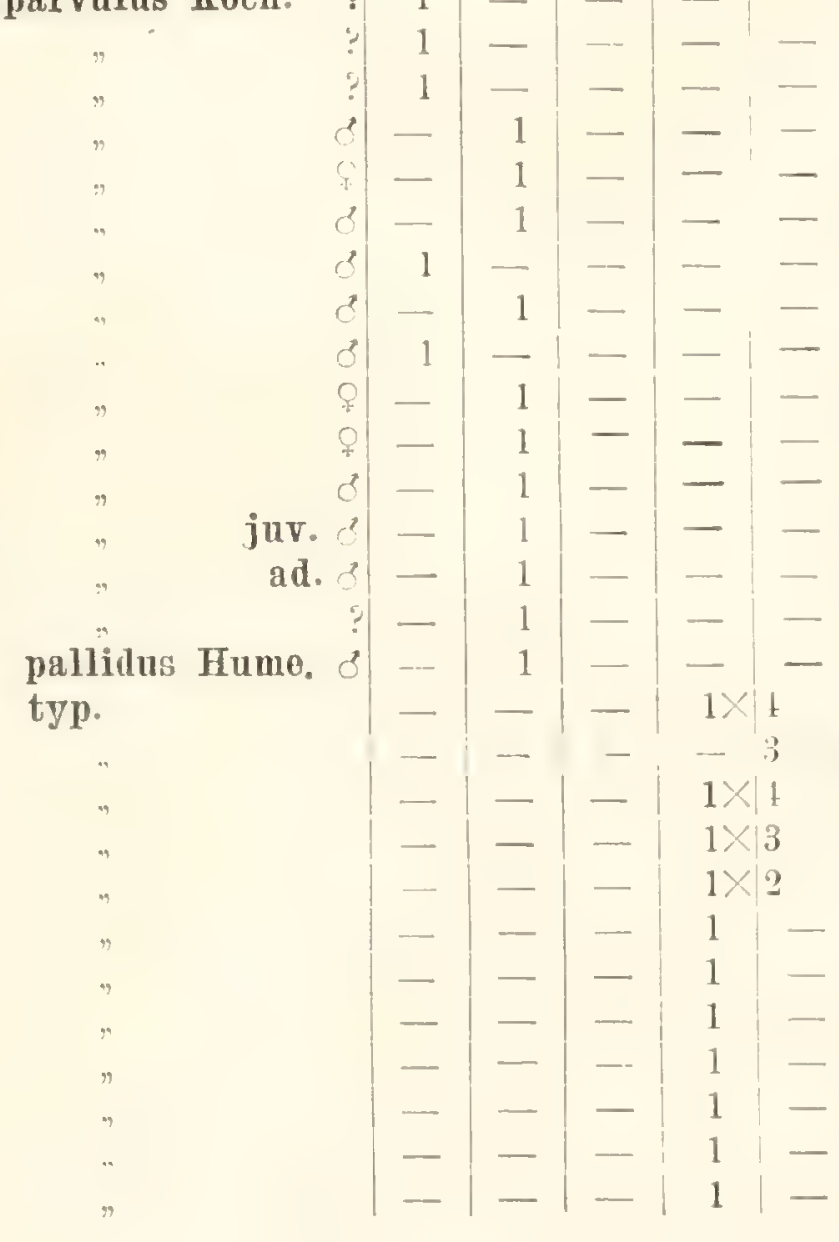

Borshom III. 97. R.

$" \quad \Rightarrow \quad \mathrm{R}$.

II. $96 . \mathrm{li}$.

X. 95. Ri.

Tiflis 27. X, 93. Sat.

20. II. 68. 12.

14. I. 96. Sat.

7. III. 83. IR.

11. II. 9R. Sat.

Salian 14. III. 95. Sat.

Geok-tepe 13. XI. 95. Sat.

30. V. 97. ?

Hessen. 30. III. 78. Grf. B.

Pskow 8. IV. 95. Sard.

Transki. 20. VIII. 89. Sard.

Borshom 96. li.

Dents hland glift.

Bakmiani V. 98. R.

Ii.

R.

li.

R.

R.

R.

R.

R.

R.

FAM. ACCENTORIDAE
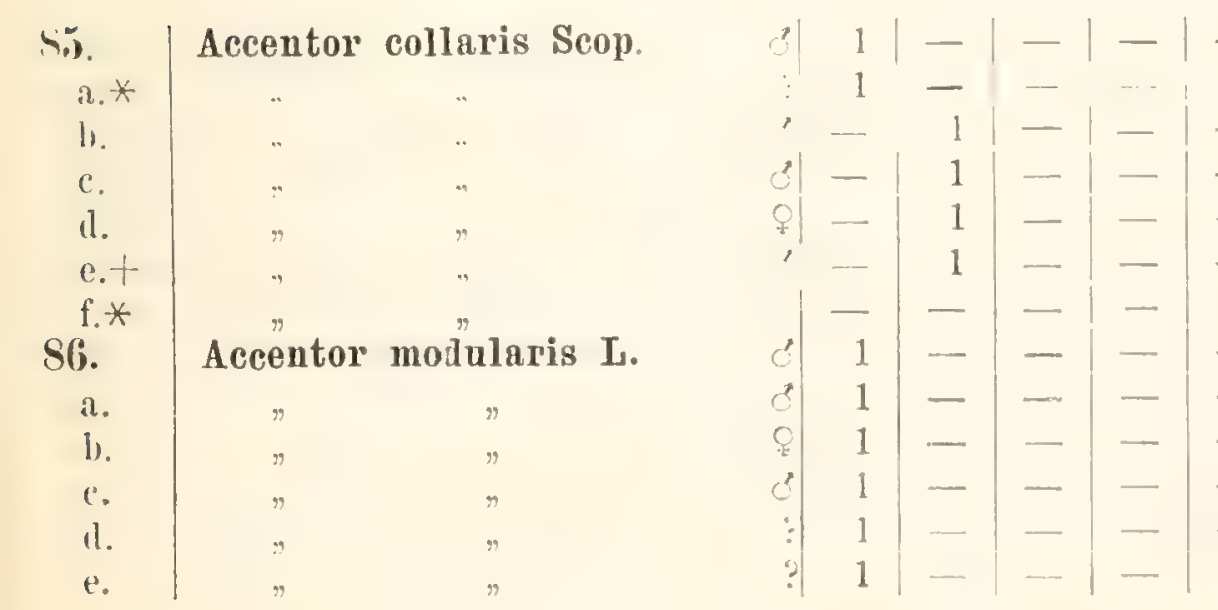

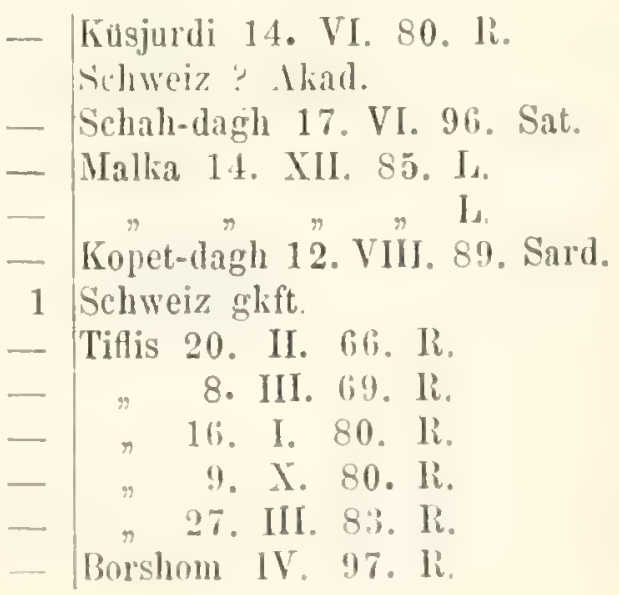




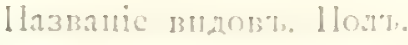
Namen und Geschlecht.
NHсто пахоядспія.

Fundort und Datum.
Accentor modularis I.

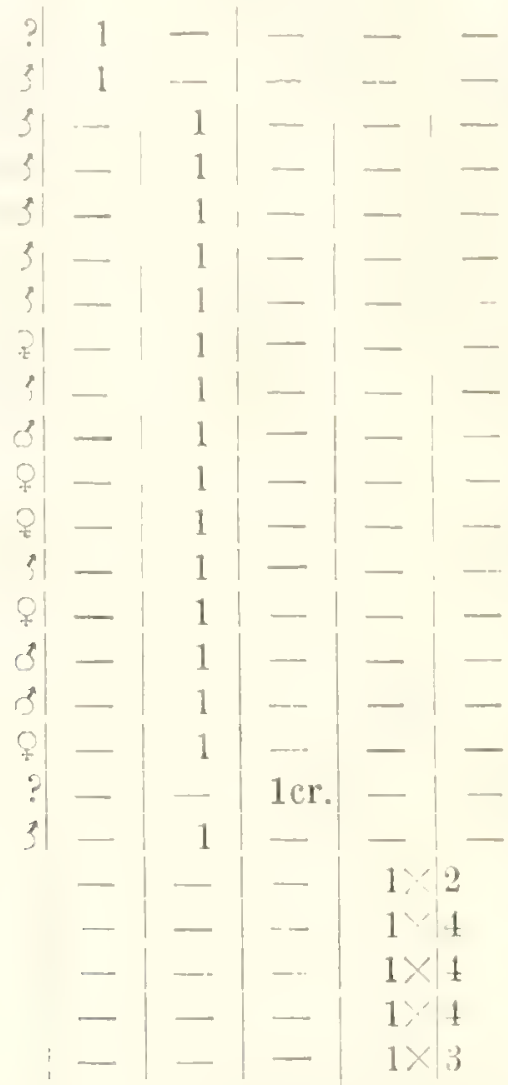

- Borshom IV.97. R.

IJesen 4. 76. Grf. 1?.

l'itlis 4. XI. 95. Sat.

" "Sat.

23. X.95. Sat.

19 I. 96. Sat.

11. II. 96. Sat.

18. II. 96. Sat.

I. 97. Sat.

Sat.

Dshewat 23. IV. 95. Sat.

Geol-tepe 3. III. 95, Sat.

Kobi 6. Y. so. R.

Borshom XI. 95. R.

I. 96. R.

Kislowodsk IX. 85. L.

Hessen 25. IV. 75. Grf. 13.

Borshom I. 96. R.

Pskow 19. IV. 92. Sard.

Brandenburg 25. IV. 89. gkft.

Bakuriani VI. 98. R.

\section{- - 1 \\ - Ussuri ? Hom.}

Accentor montanellus Pall.

Accentor fulvescens Sevr. $=$ ocularis $\mathbf{R}$.

- dlatau ? 13l. jumr.

- Exp. l'ewzow? Sard.

- Küsjurdi VI. 80. R.

_- Indien? Rey.

\section{FAM. PANURTDAE.}

90

il

(.

1. .

e.
Panurus biarmicus I.

FAM. PARIDAE.
91. i.

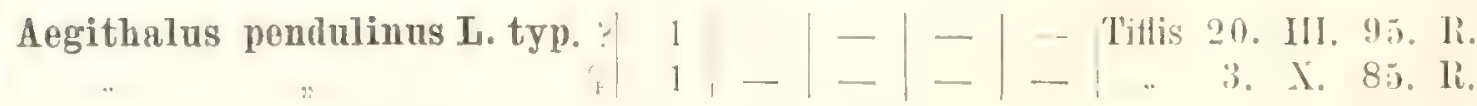




\begin{tabular}{|c|c|c|c|c|c|c|c|c|c|}
\hline i: & \multicolumn{3}{|c|}{$\begin{array}{l}\text { Haзваніс втдовт. IЈолт. } \\
\text { Namen und Geschlecht. }\end{array}$} & 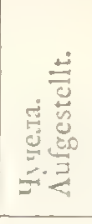 & 递 & 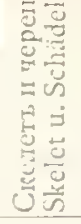 & 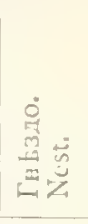 & 送结 & $\begin{array}{l}\text { MHсто ппхояддснія. } \\
\text { Fundort und Datum. }\end{array}$ \\
\hline b. & \multicolumn{3}{|c|}{ Aegithalus pendulinns L typ. } & - & 1 & - & 一 & - & Sari 3. III. 86. IR. \\
\hline c. & \multirow{2}{*}{\multicolumn{3}{|c|}{$"$ altaicus }} & - & 1 & - & -- & - & $n, ", \quad \mathrm{R}$. \\
\hline d. & & & & - & 1 & $\longrightarrow$ & - & - & Lenkoran 28. IV. 90. R. \\
\hline e. $*$ & \multicolumn{3}{|c|}{$\Rightarrow \quad$ typ. } & $\longrightarrow$ & 1 & - & - & 一 & Nizza 76. Schlt. \\
\hline f. $*$ & \multicolumn{3}{|c|}{$" \quad n$} & - & 1 & - & - & - & $n \quad " \quad n$ \\
\hline$g .+$ & \multicolumn{3}{|c|}{$" \quad n$} & 一 & - & - & 5 & - & Transkp. 82. Petruschewitsch. \\
\hline h. $=+$ & \multirow{2}{*}{\multicolumn{3}{|c|}{$"$}} & 一 & - & - & 1 & - & II. 78. Jakuwlew. \\
\hline $00^{i} *$ & & & & - & - & - & - & 1 & ggkft. \\
\hline $92 . *$ & \multirow{2}{*}{\multicolumn{3}{|c|}{ Aegithalus castaneus Sevr. }} & 一 & 1 & - & - & 一 & Wolga ? Hom. \\
\hline a.* $*$ & & & & - & 1 & - & 一 & 一 & Orenburg 26. IV. 88. Sard. \\
\hline b. * & \multicolumn{3}{|c|}{$"$} & - & 1 & - & - & - & $" \quad " \quad " \quad$ Sard. \\
\hline$c . *$ & \multicolumn{3}{|l|}{$"$} & - & 1 & - & - & - & Südrussland 7. IV.? Schlt. \\
\hline d. * & \multirow{2}{*}{\multicolumn{3}{|c|}{$"$}} & - & 1 & - & - & - & "25. III. ? Schlt. \\
\hline e.* & & & & - & - & - & - & 2 & Astrachan 30. V. 95. gkft. \\
\hline $93 .+$ & \multicolumn{3}{|c|}{ Aegithalus rutilans Sevr. } & - & 1 & - & - & - & Merw 3. III. 87. W. \\
\hline a. + & \multirow{2}{*}{\multicolumn{3}{|c|}{ Aegithalus Stoliczkae Hume d }} & - & 1 & - & - & - & Tedslien $=0$. III. 94. Sard. \\
\hline $\left.93 .{ }^{1}\right)+$ & & & & - & 1 & - & - & -- & Merw X. 95. Sard. \\
\hline $\left.93 .^{2}\right)-$ & \multicolumn{3}{|c|}{ Aegithalus atricapillus Sevr. } & - & 1 & - & & - & Tedstern :12-93. Winter. Sart. \\
\hline $94 . *$ & \multirow{2}{*}{\multicolumn{3}{|c|}{$\begin{array}{cc}\text { Acredula caudata I. } & \text { ad. } \\
\| & \text { ad. }\end{array}$}} & 1 & - & - & - & - & Pommern ? Hom. \\
\hline$a *$ & & & & -- & 1 & -1 & - & - & Hessen 17. IV. 78. Grf. B. \\
\hline b. $*$ & “ & $"$ & 81 & - & 1 & -1 & 一 & - & Pskow う. XI. 95. Sard. \\
\hline$c . *$ & $"$ & $"$ & d) & - & 1 & - & - & - & Mähren 9. XI. 96. Schlt. \\
\hline d. * & " & " & o! & 一 & 1 & - & - & 一 & Amur 17. XI. 81. Schlt. \\
\hline e.* & " &. & q & -- & 1 & - & - & 一 & $" \quad " \quad " \quad$ Sclilt. \\
\hline f. $*$ & $"$ & " & $8 !$ & - & 1 & 一 & - & - & Ungarn 16. II. 94. Schlt. \\
\hline g. * & , & , & juv. $\sigma^{2}$ & - & 1 & - & - & - & ? 18.VI. 76. Schlt. \\
\hline h. $*$ & " & " & & - & - & - & $1>$ & 1 & Stockholm 27. VI. 60. MI. \\
\hline i. $*$ & $n=3$ & & & - & - & 一 & 1 & - & Brandenburg gkft. \\
\hline 5. & Acredula ter & phronota $G$ & ünth. $b$ & 一 & 1 & - & 一 & - & Lenkoran 5. III. 80. R. \\
\hline a. & $"$ & $"$ & juv. & 一 & 1 & 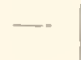 & - & - & Butasar 20. IV. 97. Sat. \\
\hline b. & " & $"$ & ad. $b$ & - & 1 & - & - & - & $\eta \quad " \quad \pi$ Sat. \\
\hline c. & $"$ & " & juv.? & 一 & 1 & 一 & - & - & " " Sat. \\
\hline d. & - & $"$ & है। & 一 & 1 & - & 一 & - & Lenkoran IV. 97. Sat. \\
\hline c. & . & $m$ & 8 & 一 & 1 & - & - & -- & $"$ sat. \\
\hline f. * & - & " & d) & - & 1 & - & - & - & | l'aurus 23. XII. 81. Danford. \\
\hline$g \cdot t$ & $"$ &. & o) & - & 1 & - & - & - & Astrabad 18. XI. 86. Sard. \\
\hline h.* & " & $"$ & & - & 1 & - & - & - & Taurus 28. III. 76. Drs. \\
\hline $96 . *$ & Acredula irb & byi Sharp. & typ.? & - & 1 & - & - & - & Gibraltar 2. V. 70. Drs. \\
\hline a. $*$ & $"$ & & & - & 1 & - & 一 & - & loskana ? Iom. \\
\hline b. $*$ & " & & $\operatorname{adl} .{ }^{2}$ & --- & 1 & - & - & - & Italien ? Schl. \\
\hline b. $\left.{ }^{3}\right) *$ & ros & sea Blyth. & & - & 1 & 一 & - & - & Farnham 27. XII. 75. Drs. \\
\hline c. & . caucasi & ica Lorz int & ermed.d! & - & 1 & - & - & - & Borshom XI. 95. R. \\
\hline d. & $" \quad r$ & . & d) & - & 1 & - & - & - & $" \quad \mathrm{R}$. \\
\hline e. & " caucas & sica typ. & & 1 & - & - & - & 一 & III. 96. R. \\
\hline f. & , & $"$ & 이 & 1 & - & - & - & - & $\Rightarrow \quad n$ R. \\
\hline s. & $"$ & $"$ & ठ) & - & 1 & - & - & - & I. 84. R. \\
\hline h. & $n$ & & 8 & -- & 1 & - & - & - & XI. 96. Sat. \\
\hline
\end{tabular}




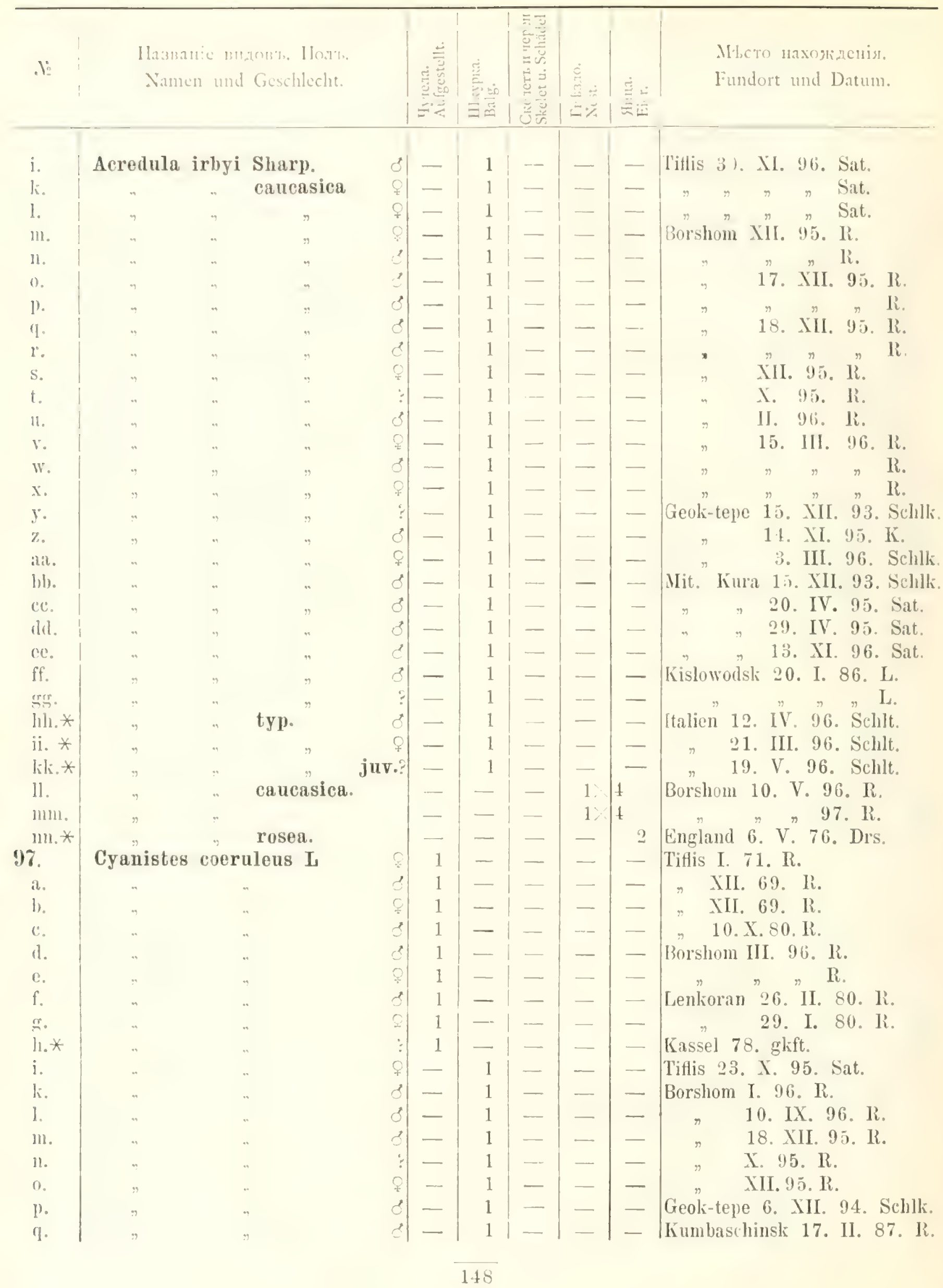




\begin{tabular}{|c|c|c|c|c|c|c|c|c|c|}
\hline. in & & $\begin{array}{l}\text { званіе видовт. Полэ. } \\
\text { amen "und Geschlecht. }\end{array}$ & & 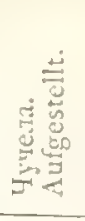 & 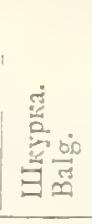 & 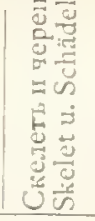 & 品 & 题递 & $\begin{array}{l}\text { MНсто nахокденіs. } \\
\text { Fundort und Datum. }\end{array}$ \\
\hline $\mathrm{r}$. & Cyanist & tes coeruleus L. & \& & - & 1 & - & $\ldots$ & 一 & Kumbaschinsk 21. II. 96 . Flrk. \\
\hline s. & " & $"$ & b & - & 1 & - & - & - & $\begin{array}{cccc}n & \end{array}$ \\
\hline t. & $"$ & $"$ & $q$ & 一 & 1 & - & - & - & Salian" 14. III." 95. Sat. \\
\hline u. & $"$ & $r$ & juv.? & 一 & 1 & - & - & - & Unt. Kura 25. V. 95. Sat. \\
\hline v. & $"$ & $"$ & 8 & - & 1 & - & - & - & " $\quad 10$. V. 96. Sat. \\
\hline w. & $"$ & $n$ & 8 & - & 1 & - & - & - & N. Kauk. 11. XI. 86. L. \\
\hline x. & $"$ & $"$ & Q & - & 1 & - & 一 & - & Podkumok 19. X. 86. L. \\
\hline$y \cdot *$ & $"$ & $"$ & d) & - & 1 & 一 & 一 & - & Kassel 21. III. 69. Grf. B. \\
\hline$z . *$ & , & $"$ & 8 & - & 1 & - & - & - & Kassel ? gkft. \\
\hline aa. * & $"$ & $"$ & $d$ & - & 1 & - & - & - & Kuldsha III. Schlt. \\
\hline bb. * & $"$ & $"$ & $q$ & - & 1 & 一 & - & - & $" \quad$ I. Schlt. \\
\hline ec. & $"$ & $"$ & $?$ & - & - & $1 \mathrm{cr}$. & - & - & Borshom I. $96 . R$. \\
\hline$d d . *$ & C. & 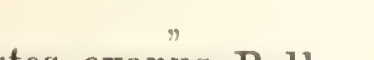 & & 一 & - & - & - & 3 & Deutschland gkft. \\
\hline $\left.977^{1}\right) *$ & Cyanist & stes cyanus Pall. & $\because$ & - & 1 & - & - & - & Orenburg 27. X. 88. Sard. \\
\hline 98. & Poecile & e palustris L. & f & 1 & - & 一 & - & - & Tiflis 9. IV. 82. R. \\
\hline a. & $"$ & $"$ & 8 & 1 & - & - & - & - & $n \quad " \quad n \quad \mathrm{R}$. \\
\hline b. & $"$ & $"$ & $c \mid$ & 1 & - & - & - & - & Borsliom III. 96. R. \\
\hline c. & $"$ & $"$ & $s \mid$ & 1 & - & - & - & -- & $n \quad n \quad \mathrm{R}$. \\
\hline d. $*$ & $"$ & $"$ & $d$ & 1 & - & 一 & - & - & Kassel 78. glkft. \\
\hline e. & $"$ & $"$ & $\delta$ & - & 1 & - & - & - & Borshom I. 96. R. \\
\hline f. & $"$ & $"$ & 8 & - & 1 & - & - & - & , XII. 95.R. \\
\hline g. & $"$ & $"$ & s) & - & 1 & - & - & - & $\Rightarrow \quad$ X. $95 . \mathrm{R}$. \\
\hline h. & " & $"$ & $\because$ & - & 1 & 一 & - & - & $n \quad n \quad \mathrm{R}$. \\
\hline i. & $n$ & $"$ & d) & - & 1 & - & - & - & I. $96 . \mathrm{R}$. \\
\hline $\mathrm{k} . *$ & $"$ & $n$ & $?$ & - & 1 & - & - & $\ldots$ & Hessen 5. I. 78. Grf. 13. \\
\hline 1. * & $"$ & $n$ & ad. & - & 1 & - & - & - & $" \quad$ 1. IV 78. Grf. I3. \\
\hline $111 * *$ & $"$ & $\eta$ & $G$ & - & 1 & - & - & - & Stockholm 22. I. 76. M. \\
\hline $0 . *$ & $"$ & kamtschatkensis B & 3upt. & 一 & 1 & -- & - & - & Baikal ? Hom (Dubowsky). \\
\hline $1 . *$ & $"$ & baicalensis & 8 & - & 1 & $\ldots$ & - & - & Ural 5. XII. 86. Sald. \\
\hline q. * & $"$ & borealis & d) & - & 1 & - & - & - & l'skow 28. XI. 92. Sart. \\
\hline r. $*$ & $"$ & „ typ. & 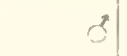 & - & 1 & 一 & - & - & $" \quad " \quad$ Sard. \\
\hline s.* & $"$ & & & - & - & 一 & 1 & 3 & Schweden 20. V. 65. MI. \\
\hline $99 . *$ & Poecile & - lugubris Natt. & . & - & 1 & 一 & - & - & Taurus V. 76. Schlt. \\
\hline $\begin{array}{r}2 . * \\
100 *\end{array}$ & Poecile & e cincta Bodd. & juv.? & 一 & 1 & - & - & - & Klein Asien 1. VIII. 76. Schlt. \\
\hline$a *$ & $n$ & $=$ sibiric & $\begin{array}{l}0 \\
0 \\
q\end{array}$ & - & $\begin{array}{l}1 \\
1\end{array}$ & - & - & - & 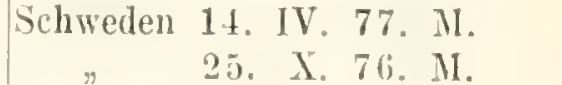 \\
\hline b. * & $n$ & $n$ & 3 & - & 1 & - & - & - & Lappland 9. XI. 81. T. \\
\hline c. $*$ & $"$ & $"$ & d) & - & 1 & - & - & - & ? $19 . \mathrm{V} . ? \mathrm{Hom}$ \\
\hline d. $*$ & $"$ & $"$ & $c$ & - & 1 & - & - & - & V. 81. Hom. \\
\hline e. $*$ & m & $"$ & & - & - & - & 1 Х & 2 & Lappland $\mathrm{M}$. \\
\hline 101. & Parus 1 & major $\mathbf{L}$. & d) & 1 & - & - & - & - & Tiflis XII. 66. R. \\
\hline a. & $"$ & " & d) & 1 & - & - & - & - & Schamchor 5. XI. 79. R. \\
\hline b. & $"$ & $"$ & of & 1 & - & - & - & - & Lenkoran 30. III, 66. R. \\
\hline c. & $"$ & $"$ & d) & 1 & - & - & - & - & ${ }_{n} \quad 28$. I. $80 . \mathrm{R}$. \\
\hline d. & $\eta$ & $n$ & 8 & 1 & - & - & - & - & Borshom III. 96. R. \\
\hline c. & $"$ & $"$ & q) & 1 & - & - & - & - & $\Rightarrow \quad \Rightarrow \quad R$. \\
\hline
\end{tabular}




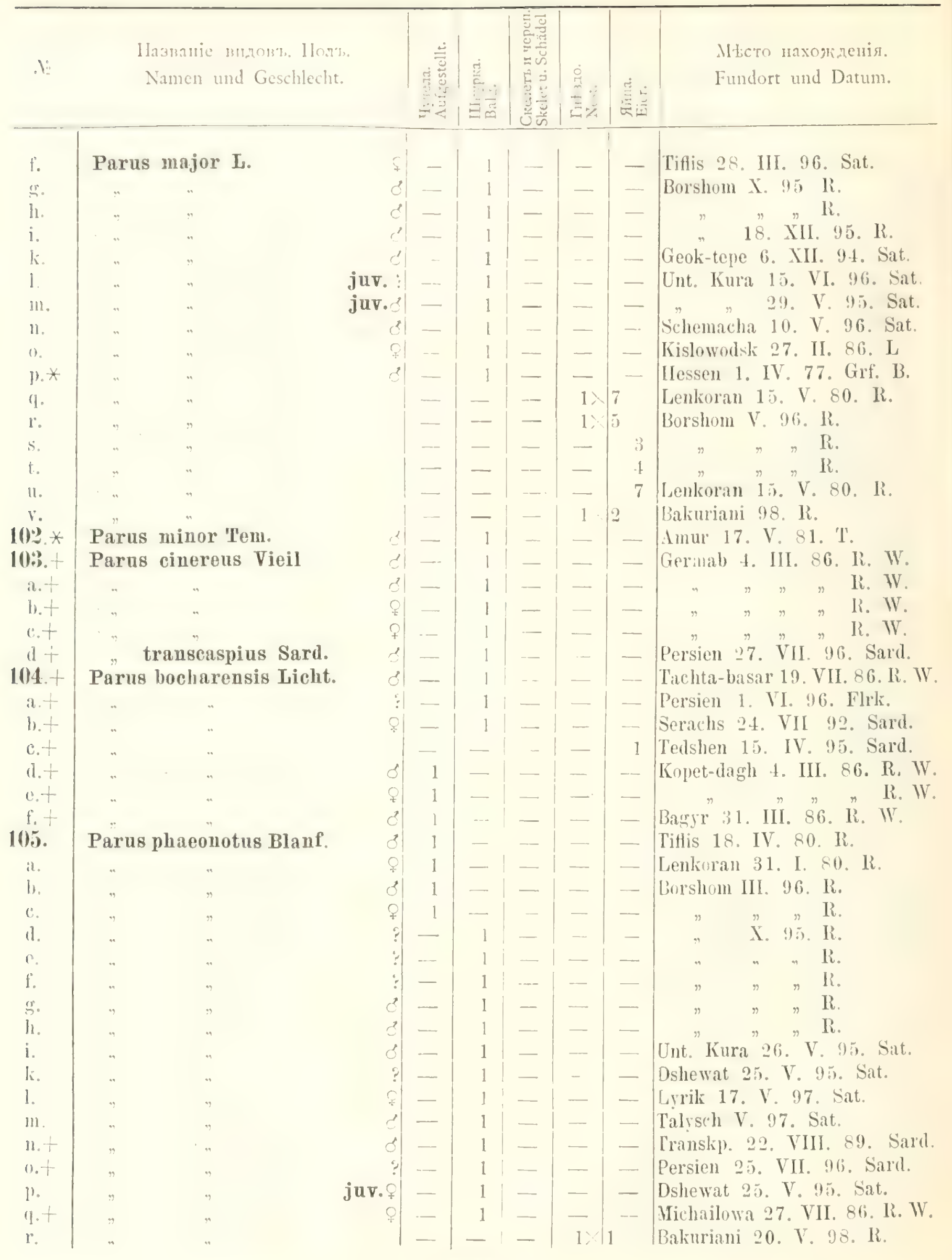




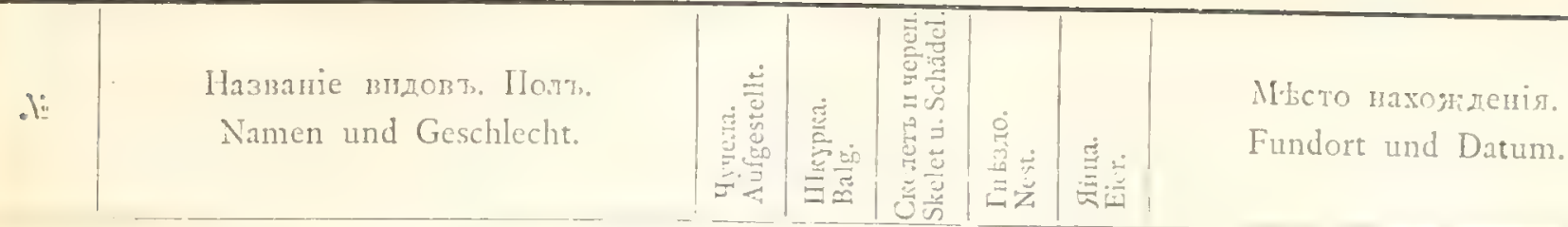

s. Parus phaeonotus Blanf.

106. * Parus ater I.

a. $*$

b. $*$

c. $*$

d. $*$

e. *

107.* Lophophanes cristatus

a. $*$

b. $*$

c.*

1. $*$

e.*

f. $*$

$\mathrm{s} . *$ ad. $--|-| 1 \mid-$ Bakuriani 20. V.98. R.

- - - Ilessen 25. III. 78. Grf. B.

14 IV 74. Grf. B.

- Pskow G. 8. II.94. Sart.

- Orenburg 87-88. W. Sard.

1 skft.

- Anliam 8. XII. 74. IIom.

- Schweden 23. III 75. M.

- Hessen 3. IY. 78. Grf. B.

- Pskow G. 27. III. 94. Sard.

- $\quad 30$. XII. 94. Sard.

Schweden 30. IV. 68. M. 4. V. 67. M.

1 Brandenburg gkft.

\section{FAMSITTIDAE.}

\section{Sitta caesia Wolf.}

a.*

b.

c.

d.

e.

f. $*$

w*

I. $*$

i. *

k.

1.

in.

n.

0 .

$\mathrm{u}$

$\mathrm{v}$

W.

$x$. *

y.*

z

aa.

$\mathrm{bb}$

$c c * *$

\section{amurensis}

typica.

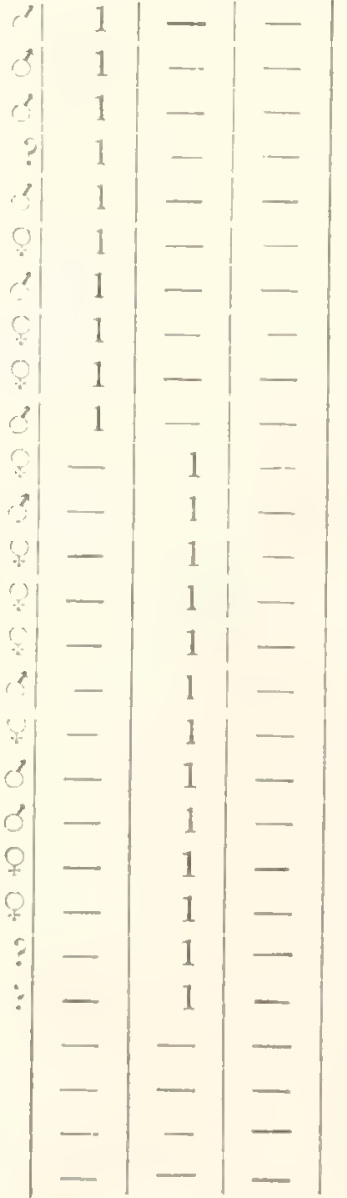

-
-
-
-
-
-
-
-
-
-
-
-
-
-
-
-
-
-
1
$1 \times$
-
- Tiflis 1\%. X.79.R.

- Hessen 30. III. 76. Grf. B.

- Lenkoran 2. Ir. 80. R.

- Borshom IV. 97. R.

- $\quad " \quad$ " R.

- $\quad " \quad " \quad$ R.

- Pommern 11. IV. 75. Hom.

- $"$ " $"$. II

- Iruar II. 81. T.

- $\quad \#, \mathrm{~T}$.

riflis 2". II. 95. Sat.

Borshom 12. III. 96. R.

21. III. 96, R.

-- Kodi 4. V. 93. Sat.

- Schamchor 5. XI. 79. IR.

- Lenkoran 30. V. 97. Sat. 30. V. 80. R.

- Astara 22. IV. 97. Sat.

- Unt. Kura 28. IV. 95. Sat.

- " $" 28$. IV. 95. Sat.

- Iaikop 15. IV. 86. I.

- Kassel ? glift.

Cenkoran 7. V. 80.R.

10. V. 80. R.

11. V. $80, R$. 


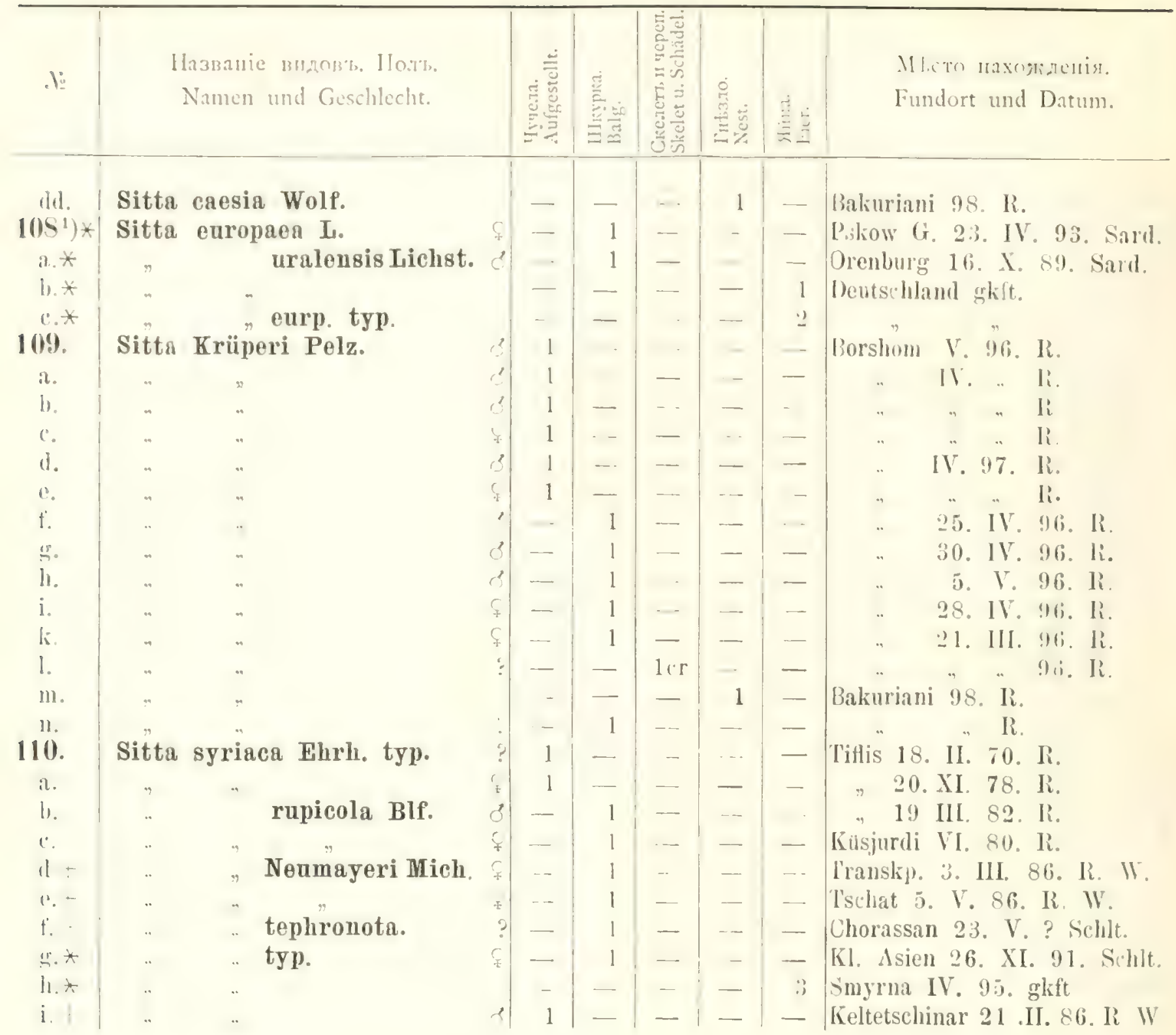

\section{FAM, MOTACILLIDAE}

111. Budytes flavus L. typ.

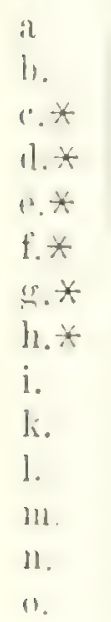

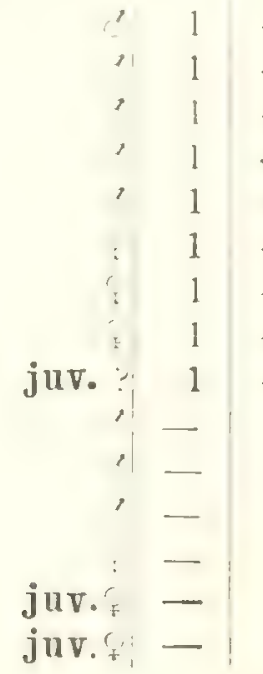$$
-
$$

Названіе вแдпв'

Namen und Geschlecht.

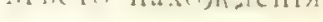




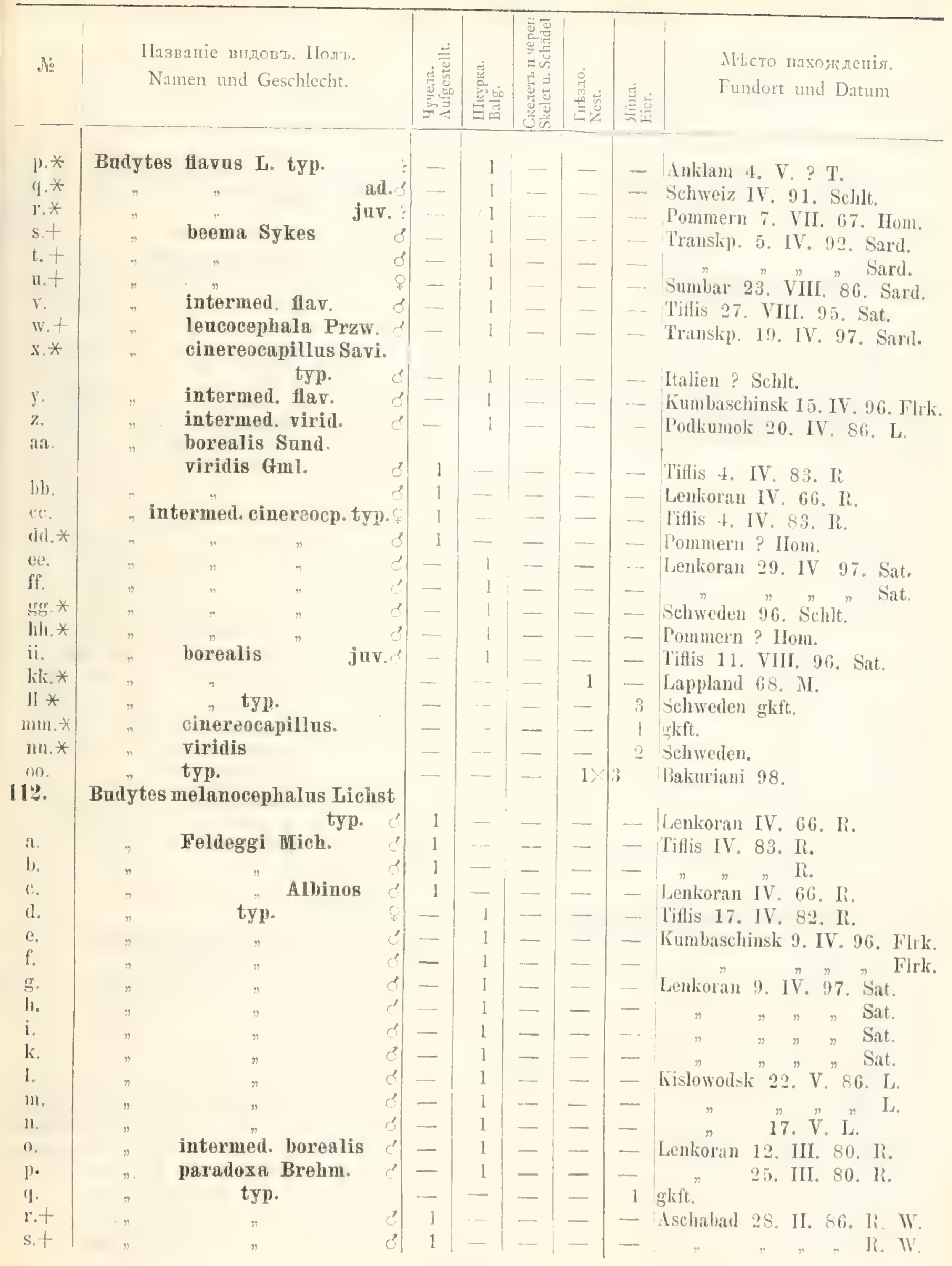


Hazmanic emgnot, Ilont.

Nimen und Geschlecht.
Мнто пахояденія.
11:. Budytes campostris Pall.

il.

1.

a.

111.

i).

h. + .

1 $\therefore$

11. $x$

11.). $*$

111 .

\section{it.}

in

1

1).

$i$

1

(1)

(1)

Budytes citreoloides Hodgs. Motacilla boarula L.

Budytes citreolus Pall. Hotacilla boarmia

117

Motacilla alba L. dukhunensis Sykes.

$\therefore$

11.

(.

f.

11.

i. $*$

h

III.

11.

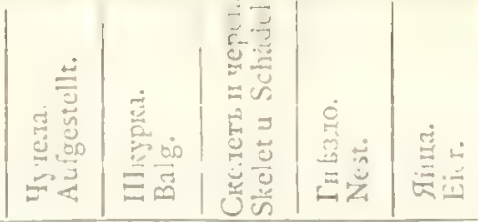

泣

\section{Fundort und Datum.}




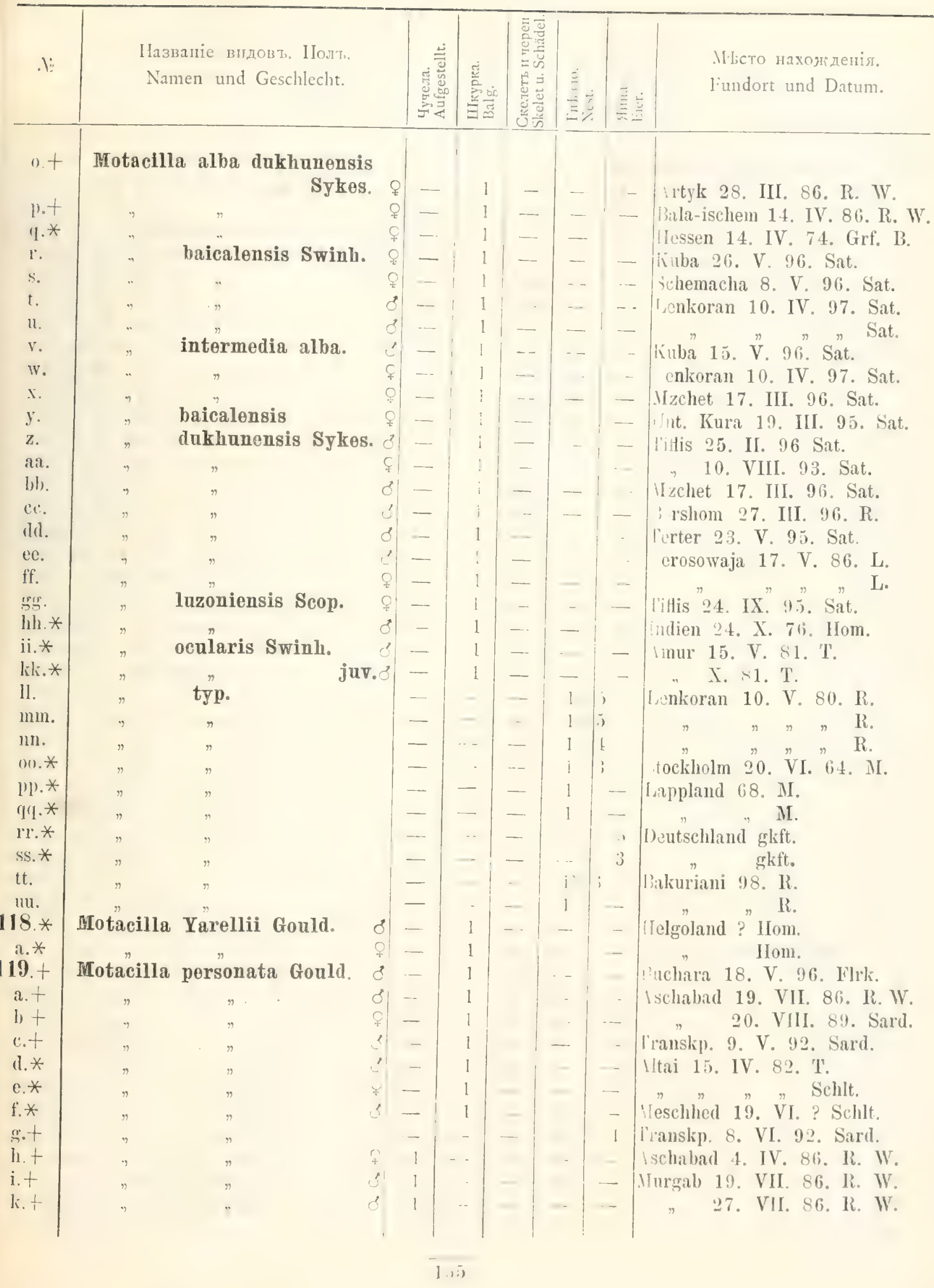




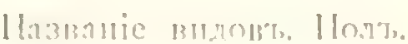

Samen und Geschlecht.

1?). Anthus arboreus Bechst. $=A$. trivialis I.

il.

1. :

( $)$

1 .

1?.

i.

4i.

h.

i.

li.

1.

i1].

11.

(1).

11.

1.

l.

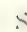

†.

11.

V.

w. $*$

צ.

1.)

a. $*$

l) $*$

('.

1) $*$

(1. .

I.

10.

il.

1 .

(')

il.

1 .

f.

s.

11. $*$

i. *

li. $*$

$1 . *$

נ11. $\mathrm{A}$
Anthus cervinus Pall.

Anthus pratensis L.

\section{s.}

Mlero maxomzenist.
Fundort und Datum.

Mleto maxomacnist.
Fundort und Datum.

Borshom IV. 97. R.

" " $" R$.

Kassel 78. ghft.

Tittis 23. III. 7\%. R.

$n$ 12. II. 80. R.

30. III.' 82. R.

7. IV. 82, R.

27. VIII. 95. Sat.

Borshom 28 III. 96. R,

13. IV. 96. R.

2. IV. 96. IR.

Lyrik 28, V. 80, R.

Berosowaja 9. V. 86. L.

Podkumok 23. V. 86. Id.

Ischabad 4. IV. 86, R. IV.

Molla-Kary 11. IV. 86. R. W. Hessen 22. IV. 76. Grf. I3.

Tiflis 8. X. 95. Sat. "12. IV. 95. Sat.

Murow-dagh 28. V. 95. Sitt.

Kuba 15. VI. 96. Sat.

Schweden 64. M.

gkft.

Bakuriani 98. IR.

" $\quad$ R.

Tiflis 28. IV. 73. R.

- ? 28. IV. $82.110 \mathrm{~m}$.

Schweden 21. VII. M.

Tiflis 28. IV. 82. R.

Orenburg 29. VIII. 87. Sard.

Sard.

17. IX. 94. Sard.

Schweden M.

Tifllis IV. 82, R.

Salian 14. III. 95. Sat.

Unt. Kura 24. III. 95. Sat.

Sat.

Lenkoran 9. II. 80 l.

Lyrik 28, V.80. R.

I'schikisljar 25. III. 86. R. W.

Ialmö 17. X. 75. Schlt.

Orenburg 20. IX, 88. Sarl.

Pskow 22. IV. 93. Sard.

Deutschland gkft.

Schweden 24. V. 64. M.

23. VI. 66. M. 


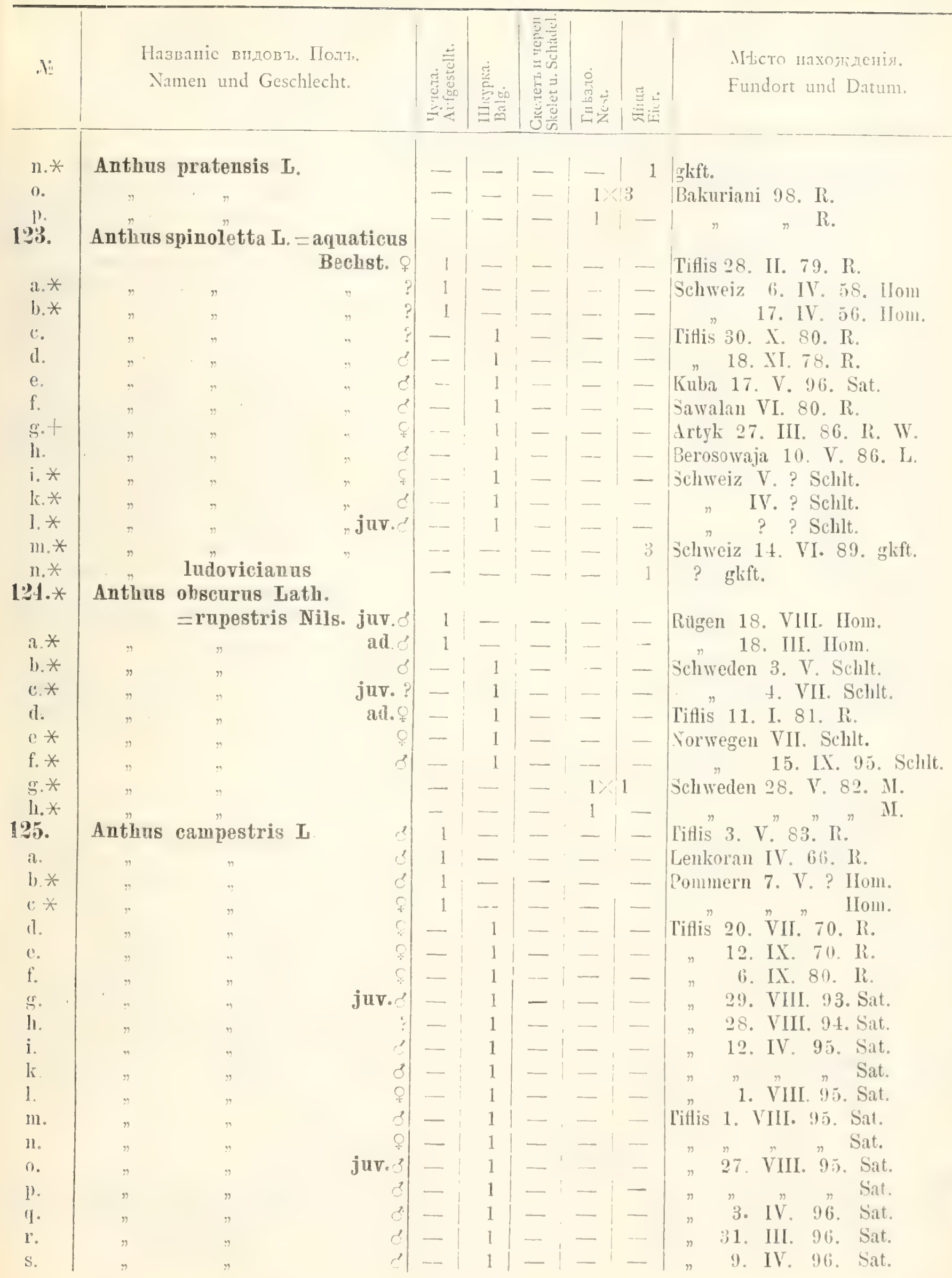




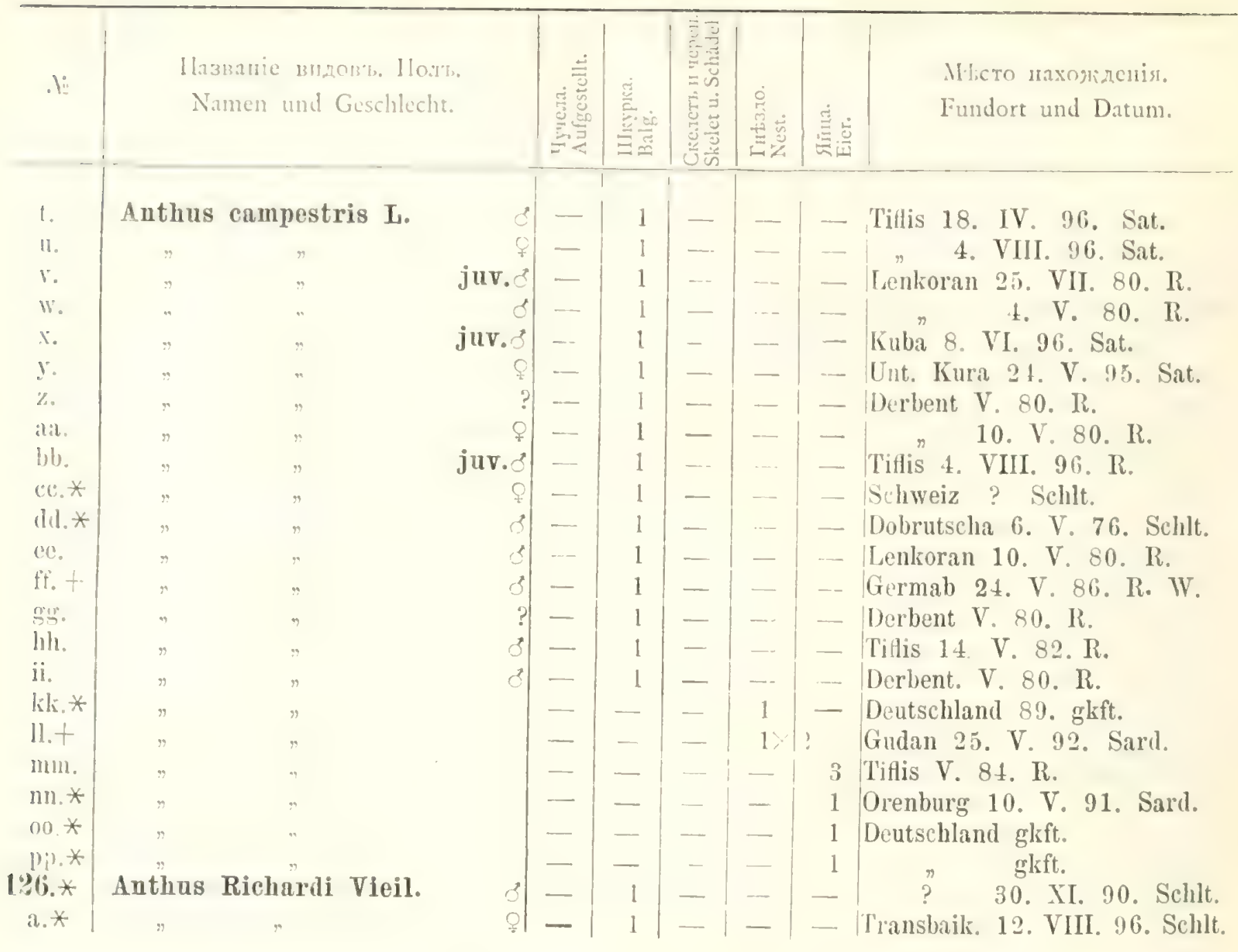

\section{FAM. ORIOLIDAE}

127. Oriolus galbula L.

il.

b.

c.

d.

e. *

f.

s.

11. $t$

i. $*$

1:8. Oriolus kundoo Sykes.

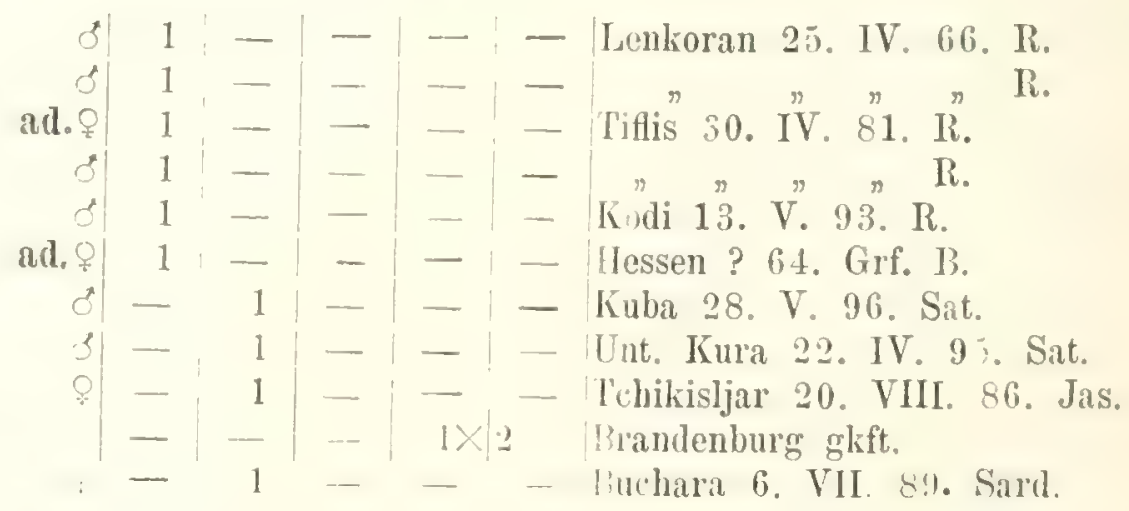

FAM UPUPIDAE

129. Upupa epops I.

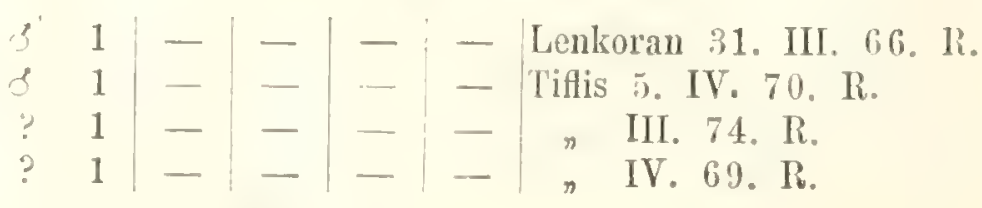

i) 


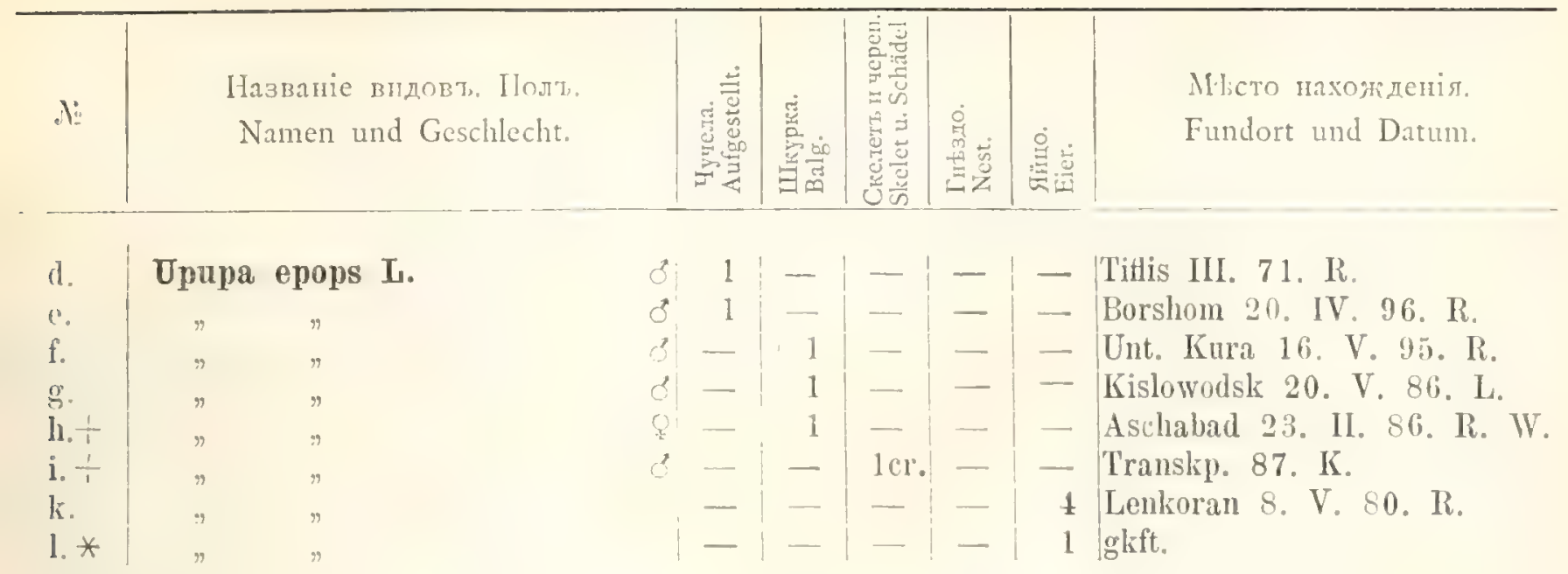

FAM. CERTHIIDAE.

130). Tichodroma muraria L.
a.
b.
c.
1.
e.

31. Certho familiaris $\mathrm{L}$. typ.

a.

b.

c

d.

e.

f. *

g.* $*$

h.

i.

$\left.i_{.}{ }^{1}\right)$

$\left.\mathrm{i}^{3}\right) *$

i. $\left.{ }^{3}\right) *$

l. $*$

1. *

m.*

n.

0

p.

q

r.

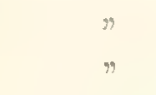

$$
\begin{aligned}
& " \\
& " \\
& " \\
& " \\
& " \\
& " \\
& "
\end{aligned}
$$

brachydactyla Natt. typ.

\section{FAM. LANIIDAE}

132. Lanius collario Is.

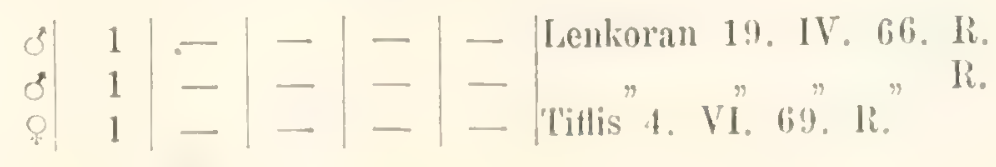

b

, 


\section{Lanius collurio I}

$$
1
$$$$
\text { i. }
$$$$
\text { 1. }{ }^{1}
$$

1.

ilil

liil.

11.

H...

re.

ff.

ㄴ...

lih.

ii.

ki. *

11.

I1111.

IIII.

(i).

1)!

$13: i$.

Lanius rufus Briss.

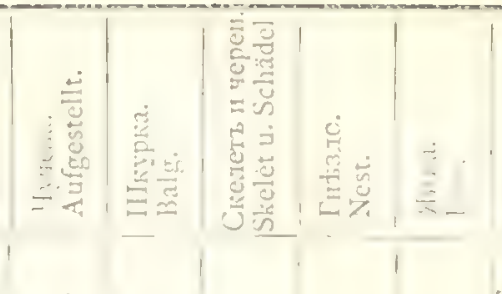

Tiflis 15, IV. 82. R.

Borshom 14. IV. 97. Li.

li.

Tankoran "20. "T. 80 . Ii. . VI. . li. ryrik 28, V. -0, R.

Derbent VI. 80. R. 4. V. $80, R$

Ilessen 74. Grf. 13.

- Viflis 16. VII. 95. Sat.

- $\quad$ L. V. 95. Sat.

24. VI. $80 . R$.

. 24. VIII. 95. Sat.

$" \quad "$ Sat.

- Lenkoran 19. V. 97. Sat.

- Schemaclia 2. V. 96. Sat.

4. V. 96. Sat.

10. V. 96. Sat.

Sat.

- Unt. Kura 18. IV. 95. Sat.

$"$ " " " Sat.

Astrachanka 5. V. 96. Sat.

Sat

Tschilisljar 28. IV. 87. Jas.

Berosowaja 9. V. 86. I.

Kislowodsk 22. V. 86. L.

juv.

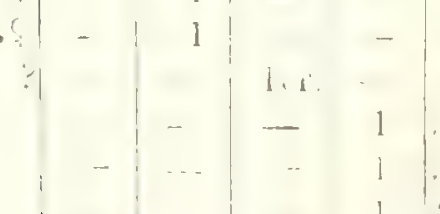

- $"$ " $"$ L. Schweden 21. VIII. 75. Schlt. Geok-tepe IV. 96. K.

Lenkoran 16. IV. 80. R.

2. V. 80. I.

Tiflis 25. IV. 76. R.

Lenkoran $\mathrm{T} .80 . \mathrm{R}$.

Brandenburg. glift.

gikf.

Titlis V. 91. R.

$t " n 92 . \mathrm{R}$.

3 Lenkoran IV. 80. Ri.

3

$$
\text { 24. IV. } 80 . R .
$$

- Tiflis 6. VI. 85. R.

Görlitz 12. V.? IIom. .. .. . $110 \mathrm{~m}$.

juv. nid.

-. Deutschland 20. V.69. BI. sir". Tiflis V. 70. R.

Elisabethpol 3. 1. 95. Sat.

Lenkoran V. 84. R. 


\begin{tabular}{|c|c|c|c|c|c|c|c|c|}
\hline$\stackrel{i}{*}$ & $\begin{array}{l}\text { Hazks } \\
\text { Nan }\end{array}$ & $\begin{array}{l}\text { званіс гтдов. Jолт. } \\
\text { men und Geschlecht. }\end{array}$ & 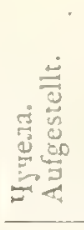 & 密品 & 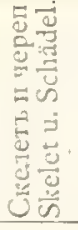 & 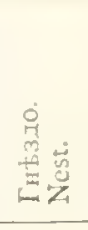 & 总递 & $\begin{array}{l}\text { Mьсто нахояденія. } \\
\text { Fundort und Datum. }\end{array}$ \\
\hline $\begin{array}{l}\text { i. } \\
i . *\end{array}$ & Lanius $r$ & rafus Briss. & - & 1 & - & - & - & $\begin{array}{l}\text { Geok-tepe V. 94. Sat. } \\
\text { Ungarn. }\end{array}$ \\
\hline $134 * *$ & Lanius $n$ & nubicas Lichst. & 1 & - & - & - & - & K1. $A$ sien 3. V. 81. 'I'. \\
\hline$a *$ & $"$ & 윔 & 1 & - & - & & - & $n \quad " \quad \Rightarrow \quad n \quad n \quad \mathrm{~T}$. \\
\hline b. $*$ & & juv. 8 & 1 & - & - & - & - & Smyrna 2. IX. 72. Hom. \\
\hline 135. $*$ & Lanius & erythrouotus Vig. & 1 & - & - & - & - & Fort Perowsky 7. V. 58. Akad. \\
\hline 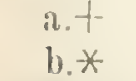 & $"$ & " & - & 1 & - & -- & - & 'Tschardshui 5. VI. 83. Sard. \\
\hline $36 *$ & Lanins & phoenicurioides Sevrz. & $\ldots$ & 1 & - & - & - & |'Turkestan Schlt. \\
\hline a. * & Damiss if & typ. & - & 1 & - & - & - & Altai 19. V. 85. Schlt. \\
\hline $\begin{array}{l}a . * \\
b+\end{array}$ & $"$ & $s$ & 一 & 1 & - & - & - & Turkestan? Schlt. \\
\hline $\begin{array}{l}\text { bt } \\
\text { c. } t\end{array}$ & $"$ & 8 & 1 & 一 & - & - & - & Duschak 18. III. 86. R. W. \\
\hline $\begin{array}{c}\text { c.t } \\
137.2+\end{array}$ & $"$ & TT & 1 & & -- & - & - & $" \quad " \quad n, \quad \mathrm{R} . \mathrm{W}$ \\
\hline $\begin{array}{l}\text { 137.at i } \\
\text { b.t }\end{array}$ & " & Karelini Bogd. & - & 1 & - & - & -- & Kopet-dagh 21. VIII 89. Sard. \\
\hline e & $"$ & 3 & - & 1 & - & - & $\ldots$ & $\begin{array}{l}\text { Duschak 16. III. 86. R. W. } \\
\text { Aschabad } 19 . \text { II } 86, \mathrm{R} \text {. W. }\end{array}$ \\
\hline d t & $"$ & Romanovi Bogd. & - & 1 & - & - & - & \\
\hline e.t & $"$ & 운 & - & 1 & - & - & - & $" \quad " \quad "$ Sard. \\
\hline $\mathrm{f}+$ & $=$ & 3 & -- & 1 & - & - & - & Germab 25. V. 86. R. W. \\
\hline$g \cdot t$ & r & जी & 一 & 1 & - & - & - & $" \quad " \quad " \quad$ R. W. \\
\hline h.t & $\Rightarrow$ & isabellina H. et Ehr. & & 1 & & -- & 一 & T'edshen 20. III. 86. R. W. \\
\hline i. + & 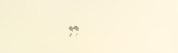 & ". & $\cdots$ & 1 & - & - & - & $n \quad n \quad$ R. W. \\
\hline k.t & . & Romanovi Bogd. & - & - & 一 & 1 . & j & Gulylü-dagh 31. V. 92. Sard. \\
\hline 1. + & & isabellina Bogd. & $\cdots$ & -- & - & $-\cdots$ & 1 & Transkp. 6. VI. 92. Sard. \\
\hline 138.t & Lanius I & Raddei Dress. & - & 1 & - & - & $\cdots$ & Kukulau 24. V. 86. R. W. \\
\hline 139. & Lanius I & minor Gml. & 1 & - & -- & - & - & Lenkoran 21. IV. 66. R. \\
\hline a & $"$ & $s$ & 1 & - & $\cdots$ & - & - & $n \pi n \pi$ R. \\
\hline b. & " & 3 & 1 & -- & -- & - & -- & Tiflis 27. IV. 81. R. \\
\hline c. & $"$ & c. & 1 & - & - & - & 一 & "27. V. 82. R. \\
\hline d. & $\because$ & 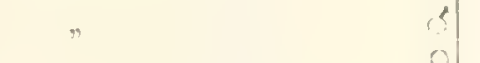 & 1 & - & - & - & - & Derbent VI. 80. R. \\
\hline c。 & $"$ & ? & 1 & - & - & - & 一 & $n \quad m \quad l l$ \\
\hline f. & $"$ & ? & 1 & 一 & - & - & - & Borshum 7. V.97. R. \\
\hline$g$ & $n$ & 8 & 一 & 1 & & 一 & -- & Elisabethpol 3. V. 95 . Sat. \\
\hline h. & $"$ & 8 & - & 1 & - & - & 一 & Genk-tepe 16. V. 94. Sat. \\
\hline i. & $"$ & ? & - & 1 & - & - & - & Schemacha 8. V. 96. Sat. \\
\hline k. & $"$ & 3 & - & 1 & & - & - & Unt. Kura 27. IV. 95. Sat. \\
\hline 1. & $"$ & @ & - & 1 & - & - & - & Astara 22. IV. 97. Sat. \\
\hline $\mathrm{m}$ & $"$ & ‡ & - & 1 & - & - & - & Stawropol 9. V. 88. I. \\
\hline n.t & $"$ & 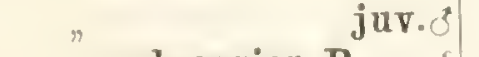 & - & 1 & - & 一 & - & Boharden 20. VIII. 86. R. W. \\
\hline 0. & $"$ & $"$ obscurior R. & 1 & - & - & 一 & - & riflis $25 . \mathrm{IV} .69 . \mathrm{R}$. \\
\hline $1 . *$ & $n$ & typ. & - & 1 & - & - & - & Orenburg 9. V. 93. Sard. \\
\hline (1) & 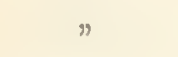 & $"$ & - & - & - & 1) & 6 & l'iflis 20. IV. 65. R. \\
\hline$r^{2}$ & r & $n$ & - & - & 一 & 1) & $t$ & n 10. V. 67. 1R. \\
\hline S. & $"$ & $n$ & - & & - & 1) & 6 & Schura 16. VI. 94. R. K. \\
\hline t. $t$ & $"$ & $"$ & - & & & $1 \times$ & $t$ & [rauskp. 26. V. 92. Sard. \\
\hline v. + & $"$ & $"$ & - & - & - & $1 x$ & 3 & $\begin{array}{l}\text { "2. V. 92. Sard. } \\
" \quad 3 . \text { VI. 92. Sird. }\end{array}$ \\
\hline
\end{tabular}




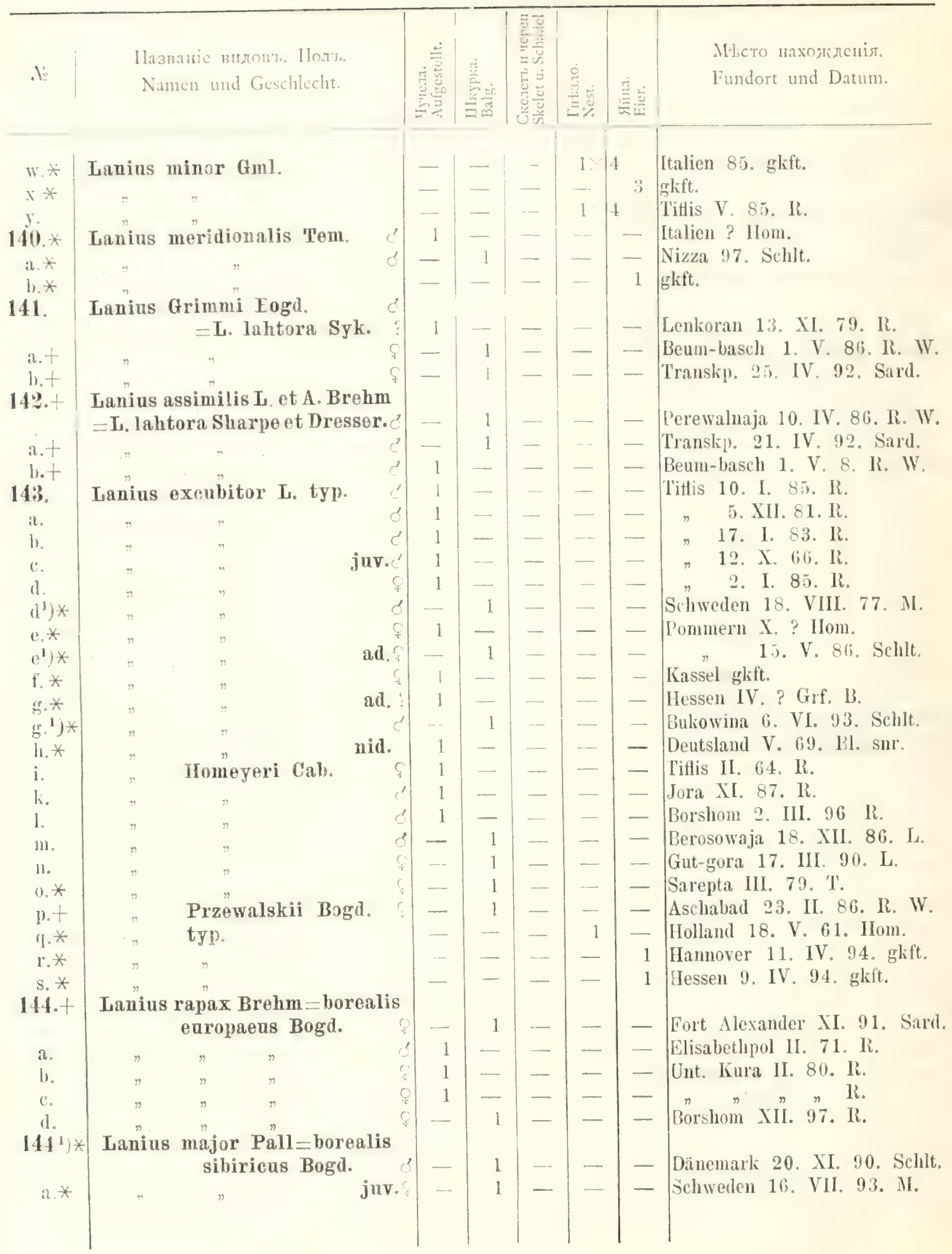




\begin{tabular}{|c|c|c|c|c|c|c|c|}
\hline . & $\begin{array}{l}\text { Ilaзваніс впдовт. IЈолт. } \\
\text { Namen und Geschlecht. }\end{array}$ & 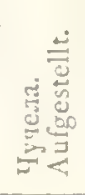 & 密 & 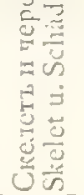 & 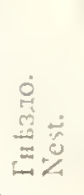 & 恶脑 & $\begin{array}{l}\text { Mћсто пахожденія. } \\
\text { Fundort und Datum. }\end{array}$ \\
\hline
\end{tabular}

145. Bombycilla garrula I.

a.

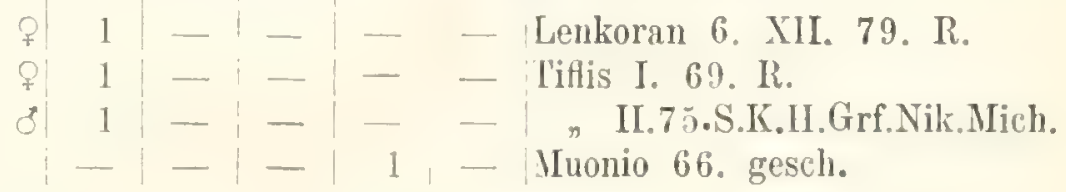

FAM. MUSCICAPIDAE.

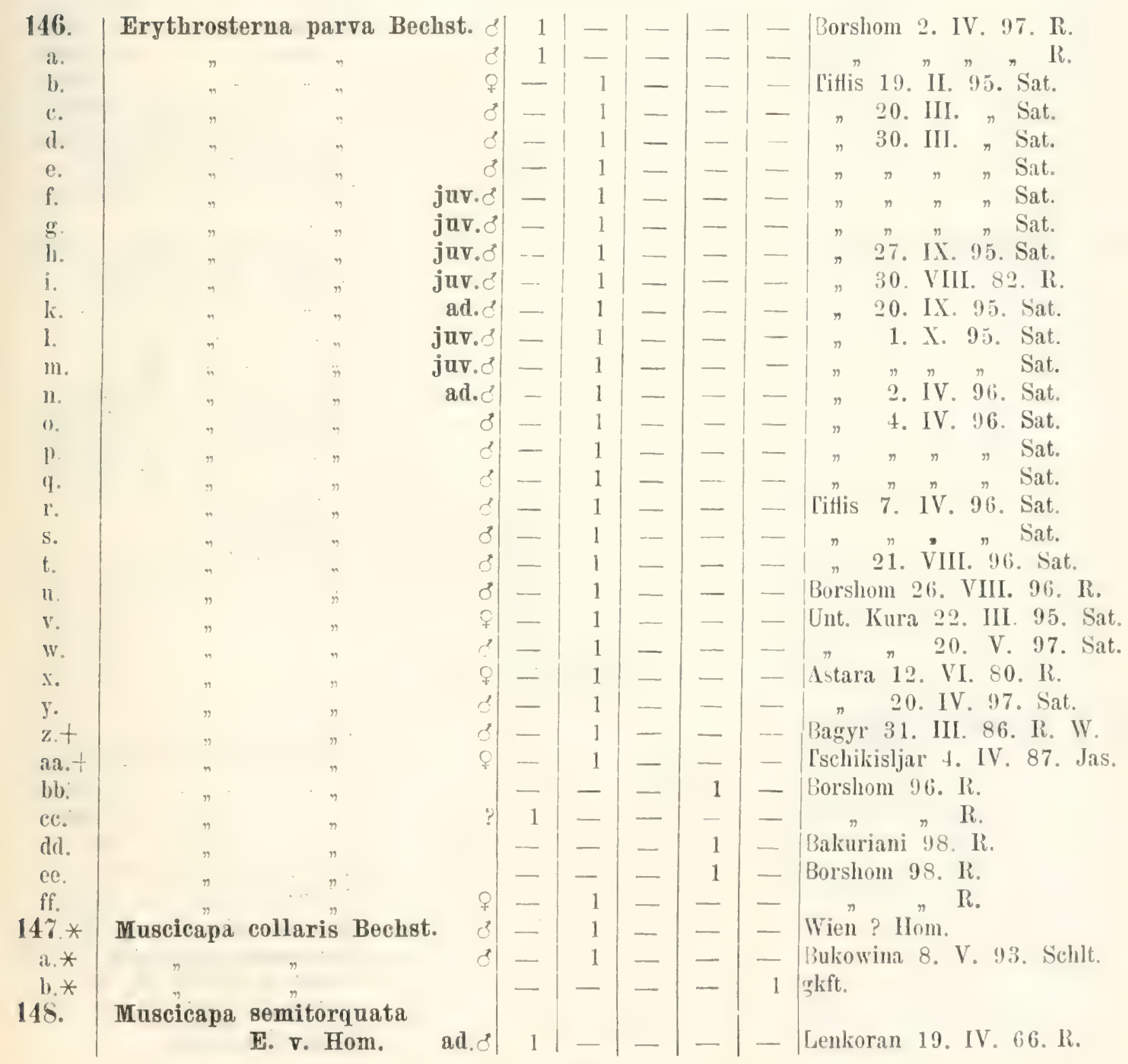




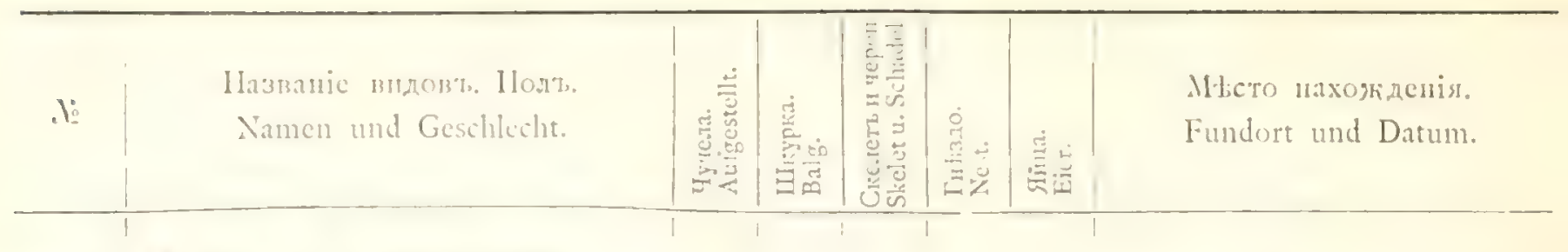

a. Muscicapa semitorquata

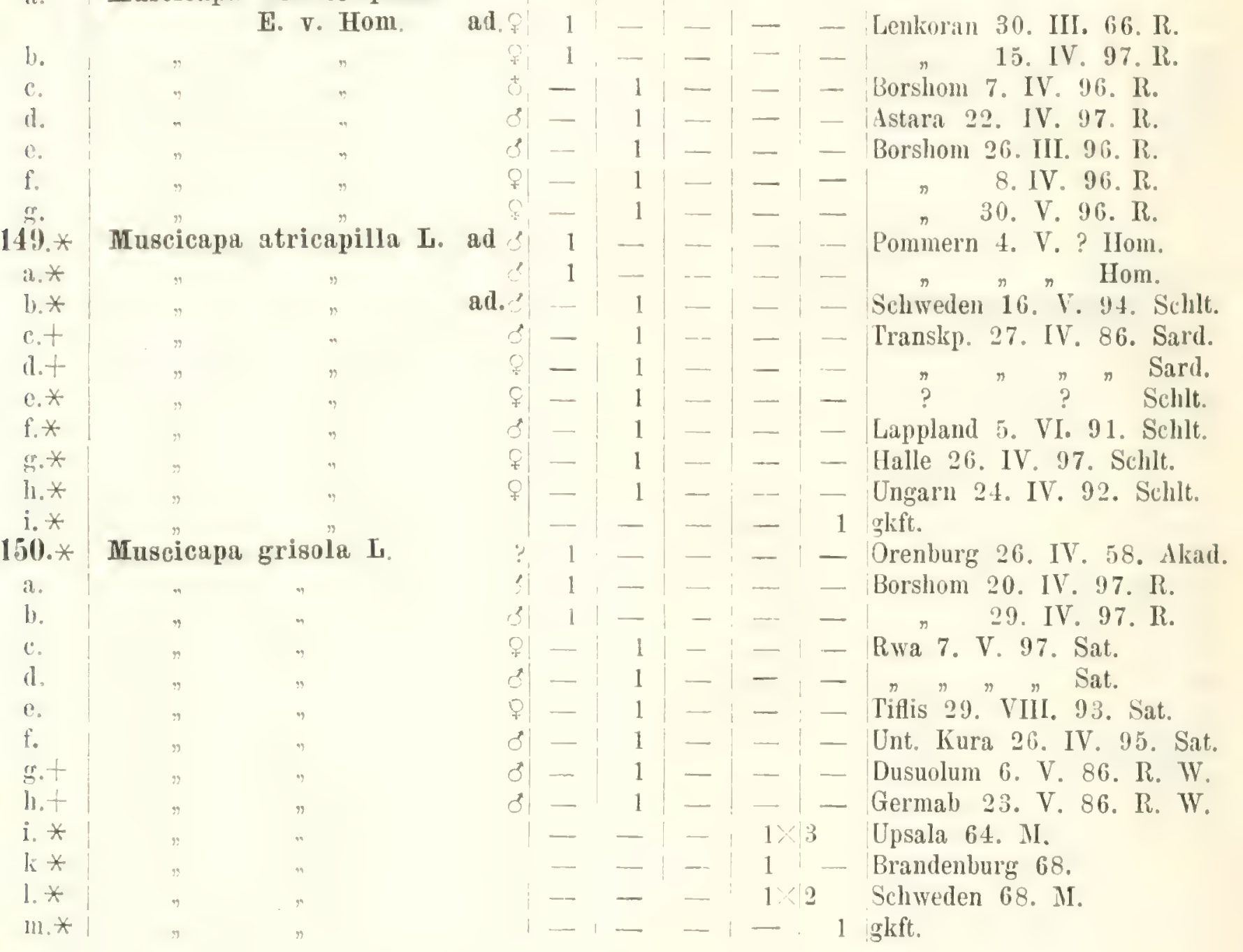

\section{FAM. HIRUNDINIDAE}

15) H. Hirundo rustica L.
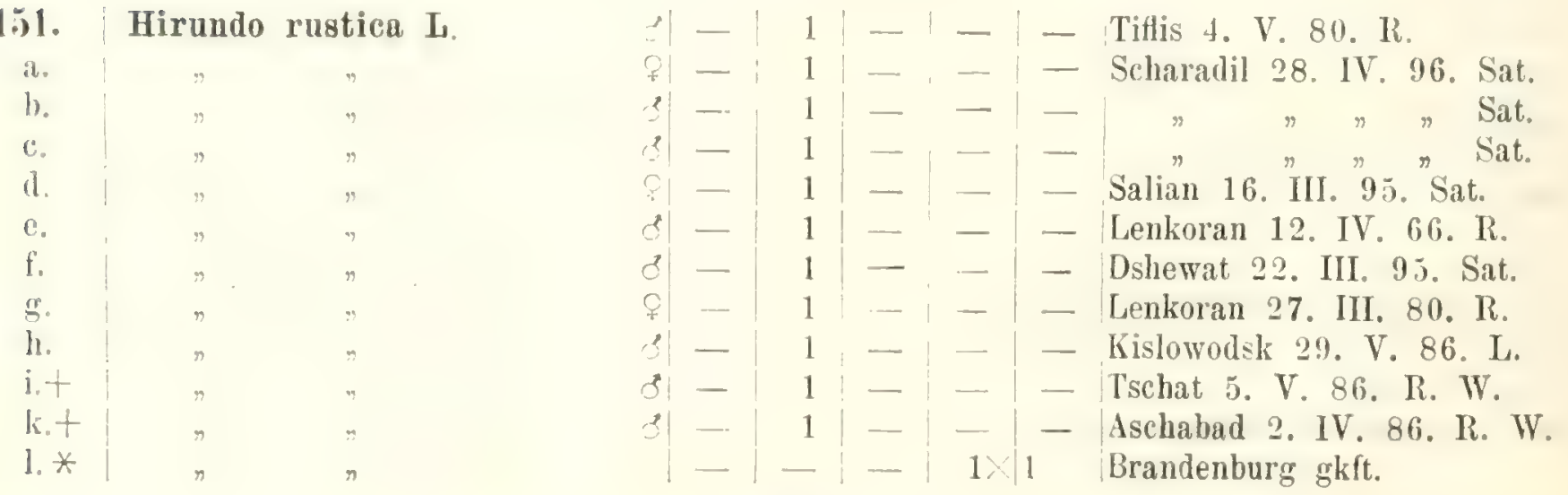


\begin{tabular}{|c|c|c|c|c|c|c|c|c|}
\hline. & $\begin{array}{l}\text { Названіе видов'ь. لоль. } \\
\text { Namen und Geschlecht. }\end{array}$ & & 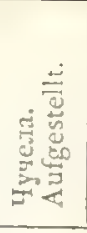 & 窇。 & 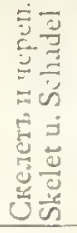 & 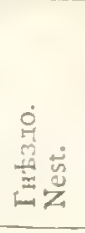 & 䖯富 & $\begin{array}{l}\text { Mtсто пахюденія. } \\
\text { Fundort und Datum. }\end{array}$ \\
\hline$m+$ & Hirundo rustica I. & & - & - & - & - & 1 & Keltetschinar 87. K. \\
\hline $152 .+$ & Hirundo alpestris Pall. & 8. & - & 1 & - & - & - & T'schat 5. V. 86. R. W. \\
\hline$a+$ & - & 3 & - & 1 & - & $-\infty$ & - & Transkp. 29. IV. 92. Sard. \\
\hline b. $t$ & $"$ & क & - & 1 & - & - & - & "3. V. 92. Sard. \\
\hline$c . *$ & & & - & - & - & - & 1 & Olymp. VI. 75. gkft. \\
\hline 153. & Hirundo rupestris Scop. & d & - & 1 & - & - & - & Tiflis $12 . \mathrm{V} .82 . \mathrm{R}$. \\
\hline a. & $"$ & o) & - & 1 & - & - & - & Kislowodsk $17 . \mathrm{V} .86 . \mathrm{I}$. \\
\hline b. & $"$ & ㅇ & - & 1 & - & - & - & Berosowaja $20 . \mathrm{V} .86 . \mathrm{L}$ \\
\hline c. + & " & d) & - & 1 & - & - & - & Kopet-dagh 19. VII. $86, \mathrm{R}, \mathrm{W}$. \\
\hline$d .+$ & $"$ & ? & - & 1 & - & - & - & Transkp. 3. V. 96. Flrk. \\
\hline c. $*$ & $"$ & 8 & - & 1 & - & - & - & Nizza? glift. \\
\hline f. $\frac{1}{1}$ & 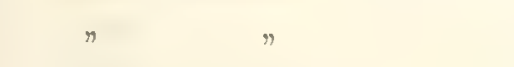 & & - & - & - & - & 1 & Goudan 10. V. 94. Sard. \\
\hline$R^{*} *$ & & & -- & - & - & - & 1 & $g \mathrm{kft}$ \\
\hline 154. & Chelidon urbica $\mathbf{I}$. & d) & - & 1 & - & - & - & Janglis 1. VIII. $80 . \mathrm{R}$. \\
\hline a. & $"$ & $?$ & - & 1 & - & - & - & Marasly 2. V. 96. Sat. \\
\hline b. & " & c। & - & 1 & - & & - & Kislowodsk 14. V. $86 . \mathrm{L}$. \\
\hline $\begin{array}{l}\text { c. } \\
\text { il. }\end{array}$ & $"$ & \% & - & 1 & - & - & - & $n n \pi n \mathrm{~L}$. \\
\hline 155. & Cotyle riparia $L$. & 3) & - & 1 & - & - & $\begin{array}{r}1 \\
-\end{array}$ & Tiflis 11. VIII. 96. Sat. \\
\hline a. & " & $\delta$ & - & 1 & - & - & - & Unt. Kura 25. V. 82. R. \\
\hline b. & " & क) & - & 1 & - & - & - & Lenkoran 19. IV. 66. R. \\
\hline$\therefore$ & $"$ & $d$ & 一 & 1 & - & - & - & 3. V. $80 . \mathrm{R}$. \\
\hline d. & $"$ & $?$ & - & 1 & - & - & -- & 2. IV. $80 . \mathrm{R}$. \\
\hline e.t & . & 아 & - & 1 & - & - & - & Molla-Kary 11. IV. 86. R. W. \\
\hline f. $t$ & " & 8) & - & 1 & - & - & - & Krasnowodsk 21. IV. 86. R. W. \\
\hline$n$ & $"$ & & - & & - & - & 7 & \\
\hline
\end{tabular}

FAM. FRINGILLIDAE.

156.* Plectrophanes lapponicus L. \& 1 : $1-|-|-|-|$ Helgoland 79. Ilom.
a. *
b. $*$
(c* $*$
d $*$
e. $*$
1.57
i.
1. * *
( $* *$
d. *
e. *
f. *
158
a
Emberiza miliaria" L.

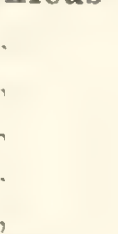
Plectrophanes nivalis $\mathrm{L}$.

*
- Lappland 7. V. 97. Schlt.
- Alaska 21. VI. 96. Sehlt.
- Orenburg 26. II. 88. Sard.
- Grönland 62. M.
- Finnmarken 65. M.
- Kislowodsk 2. III. 88. L.
- $\pi n \pi$ L.
- Pommern II ? Hom.
- $\rightarrow$ Hom.
- Schweden 11. V. 77. M.
- Pskow G. 5. III. 95. Sard.
1 gkft.
- Lenkoran 1. III. 80. R.
- Tiflis 4. IV. 67. IR.
- Hessen VII 70. Grf. B.
- Lenkoran 2. IV. 80. R. 


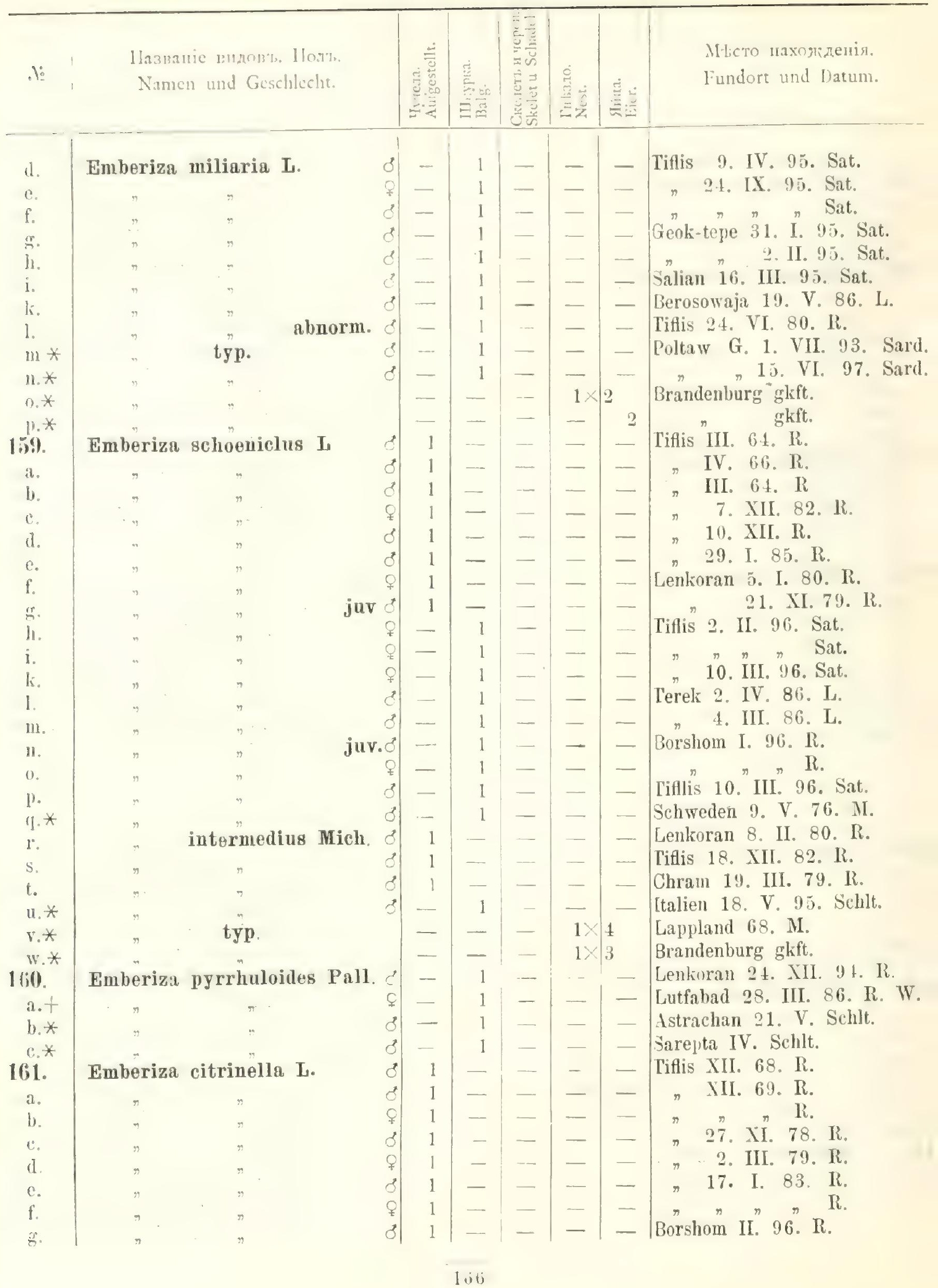




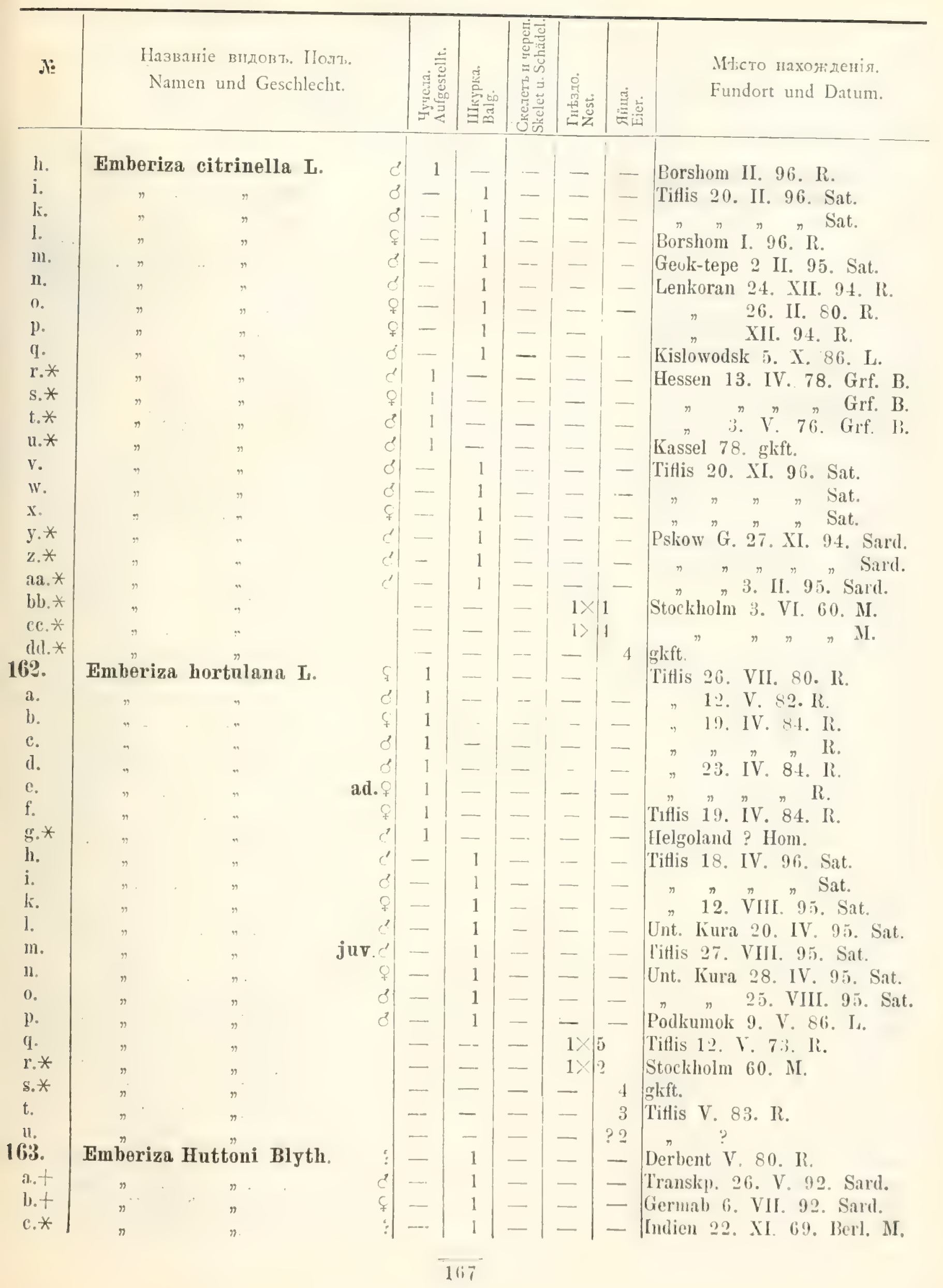




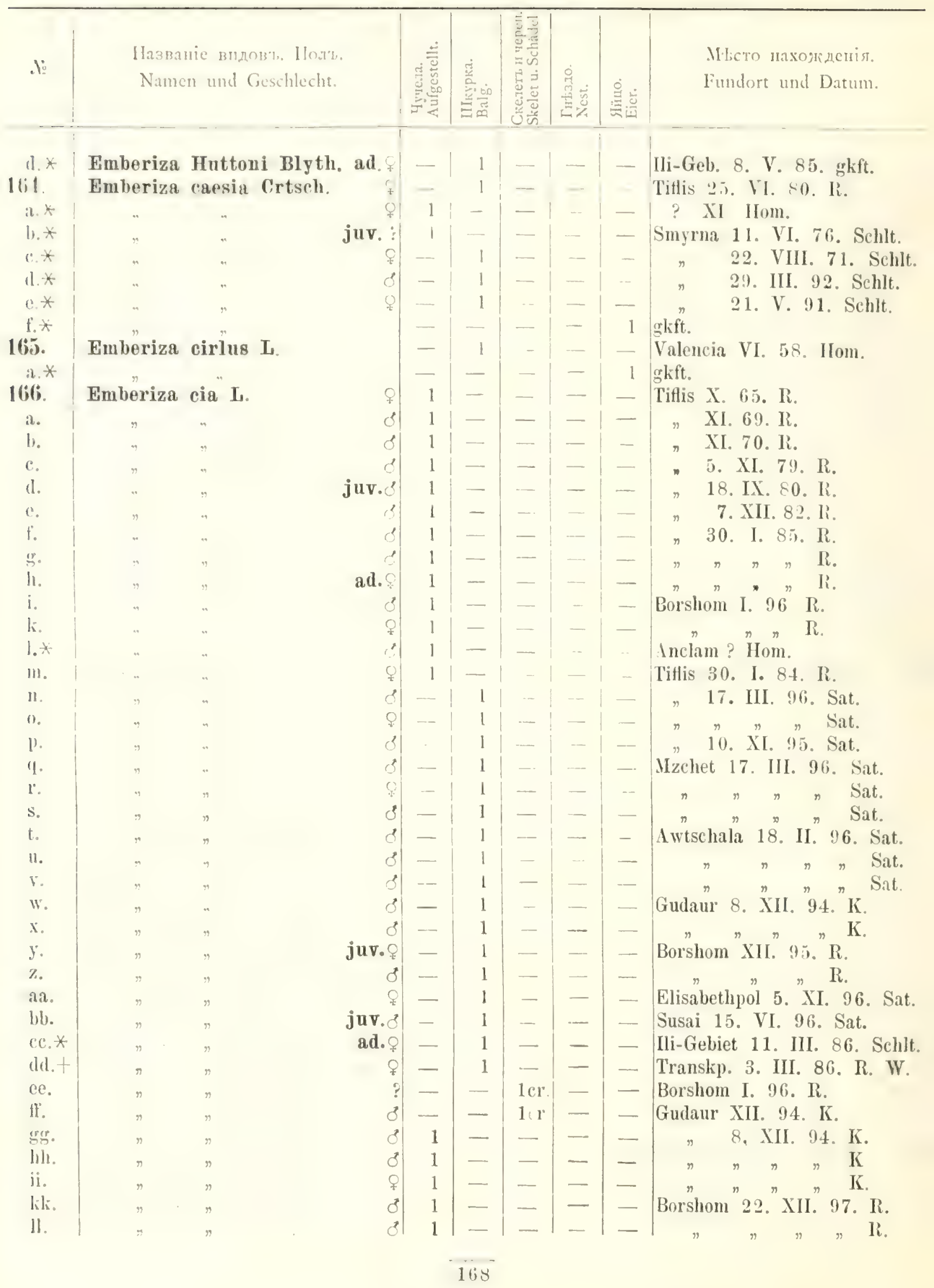




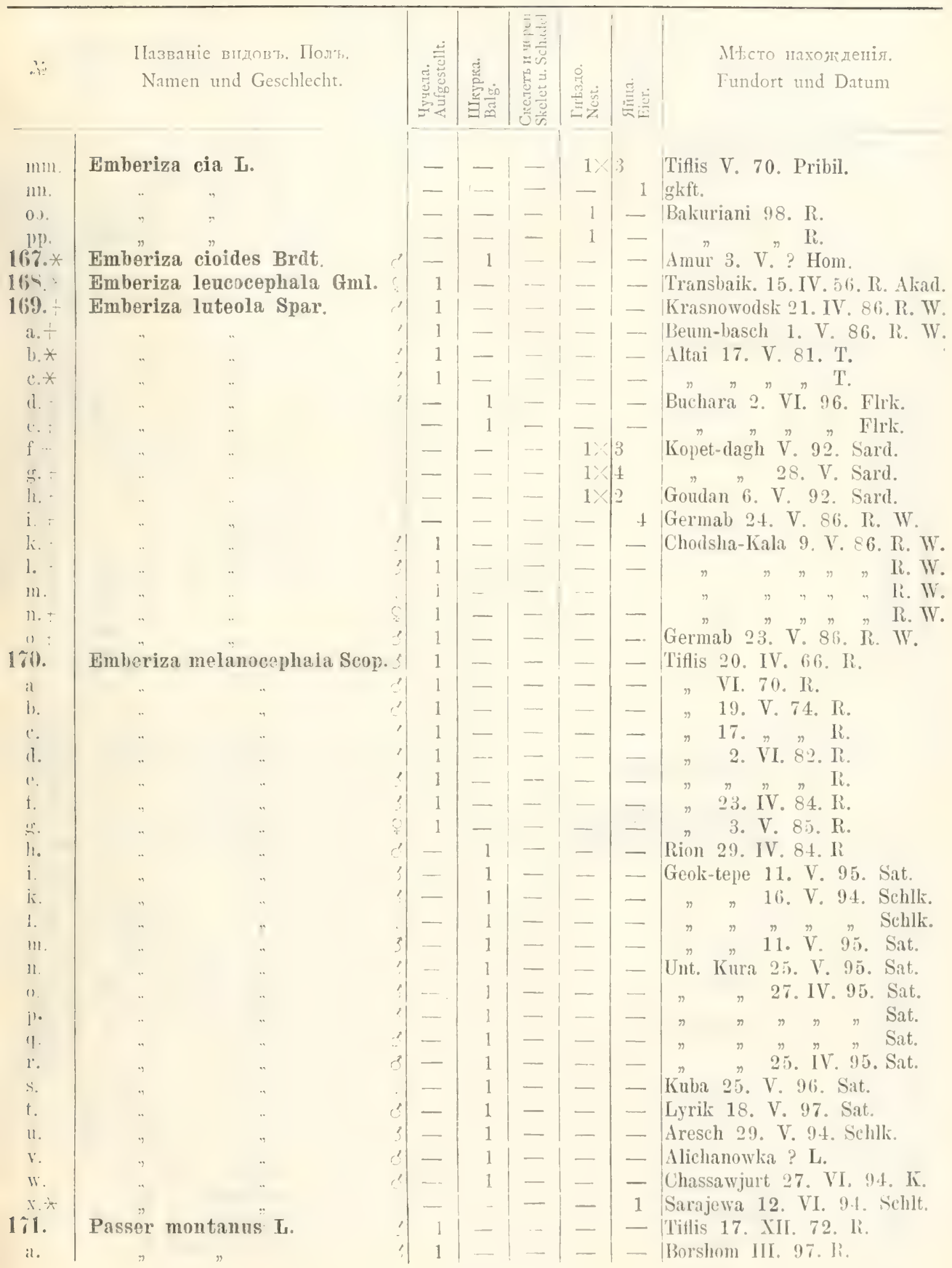




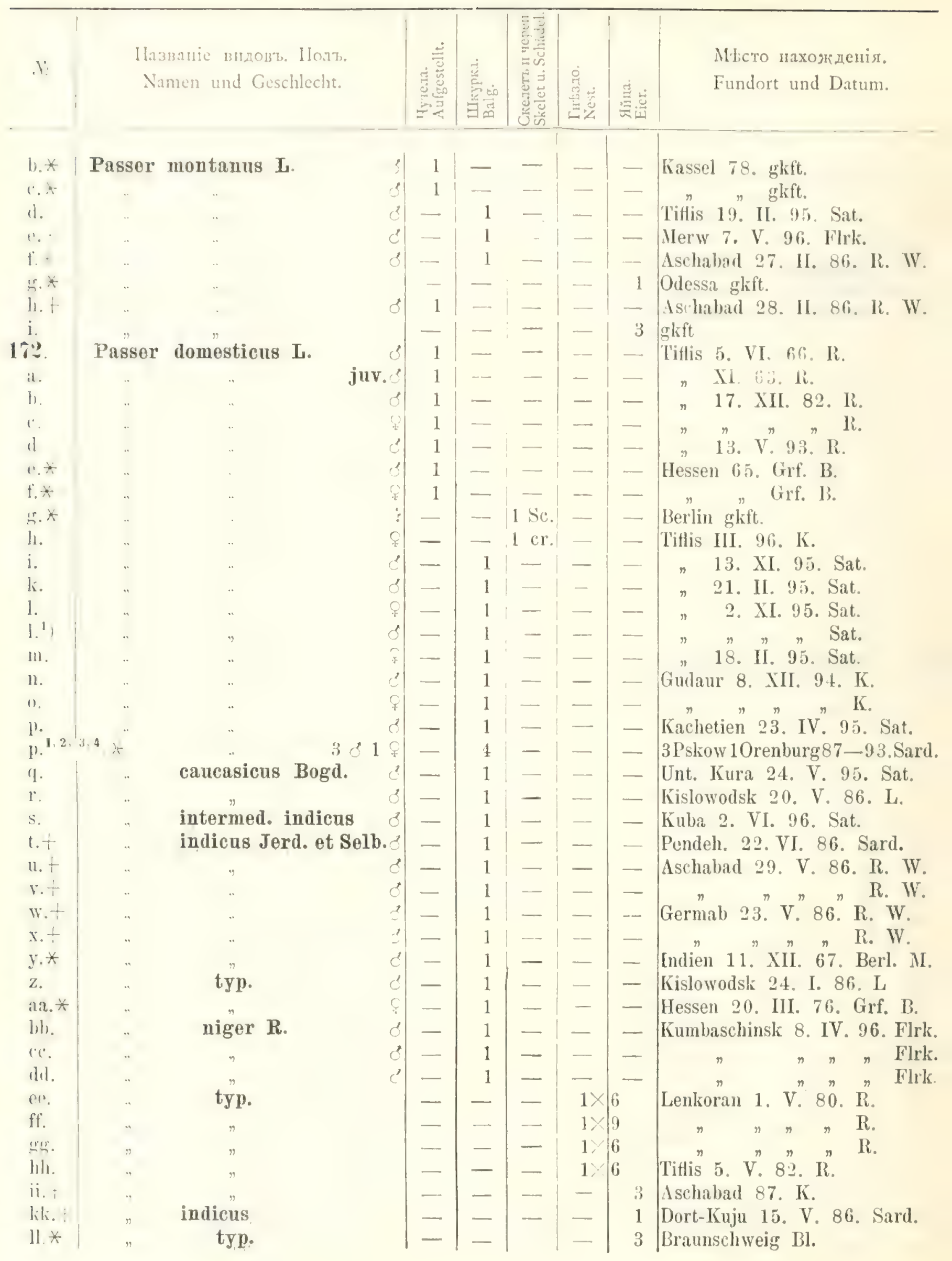




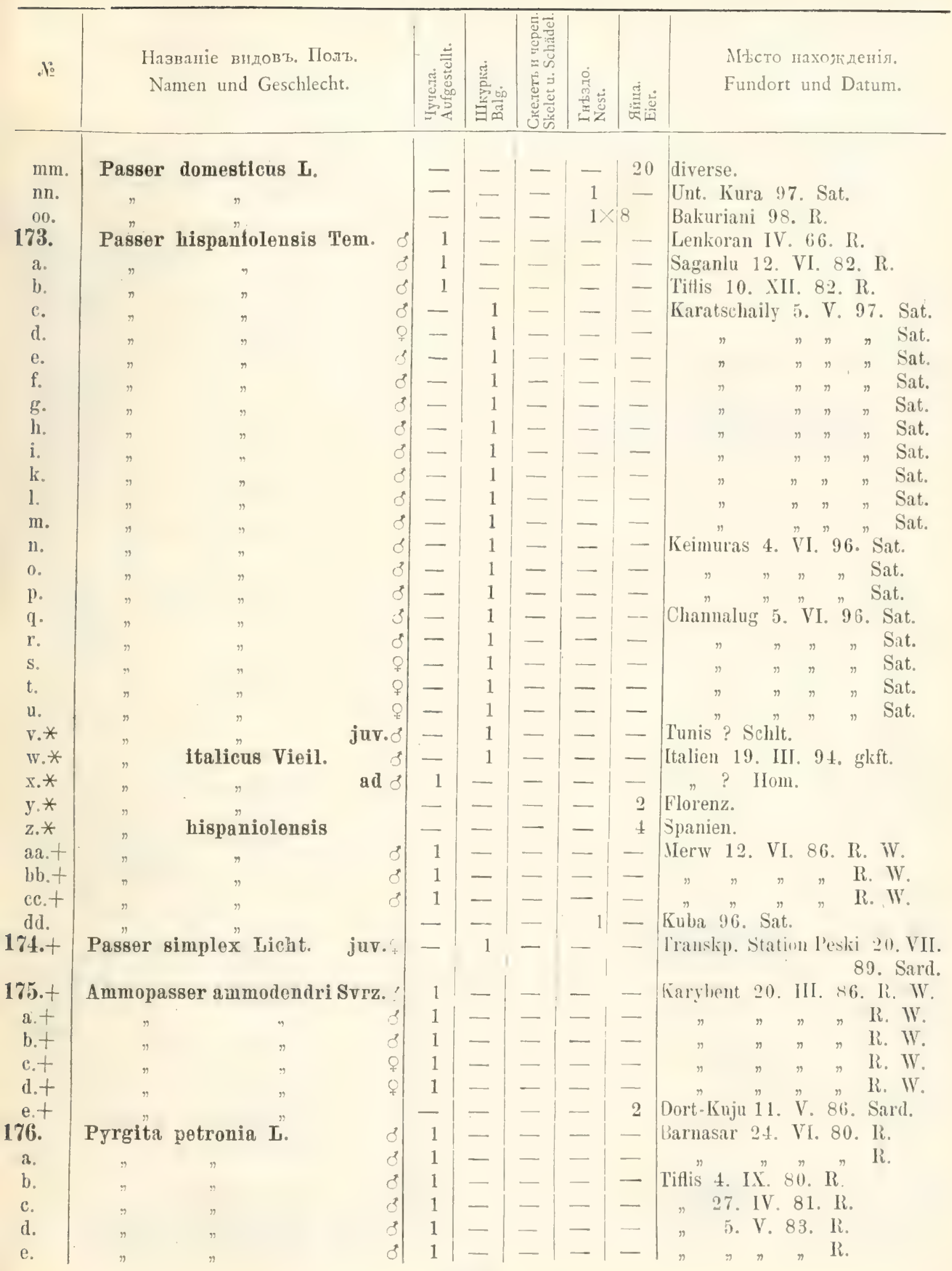




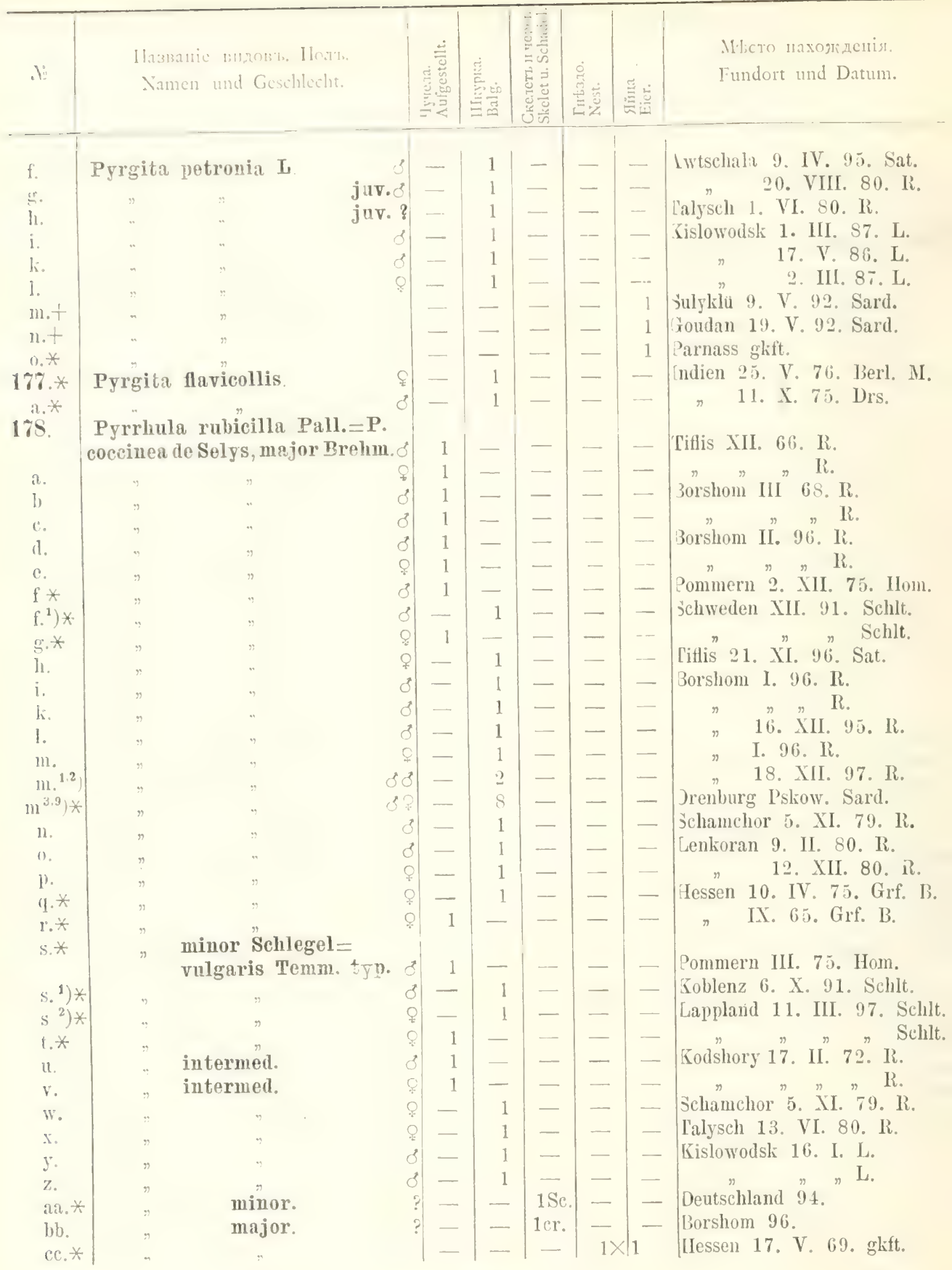




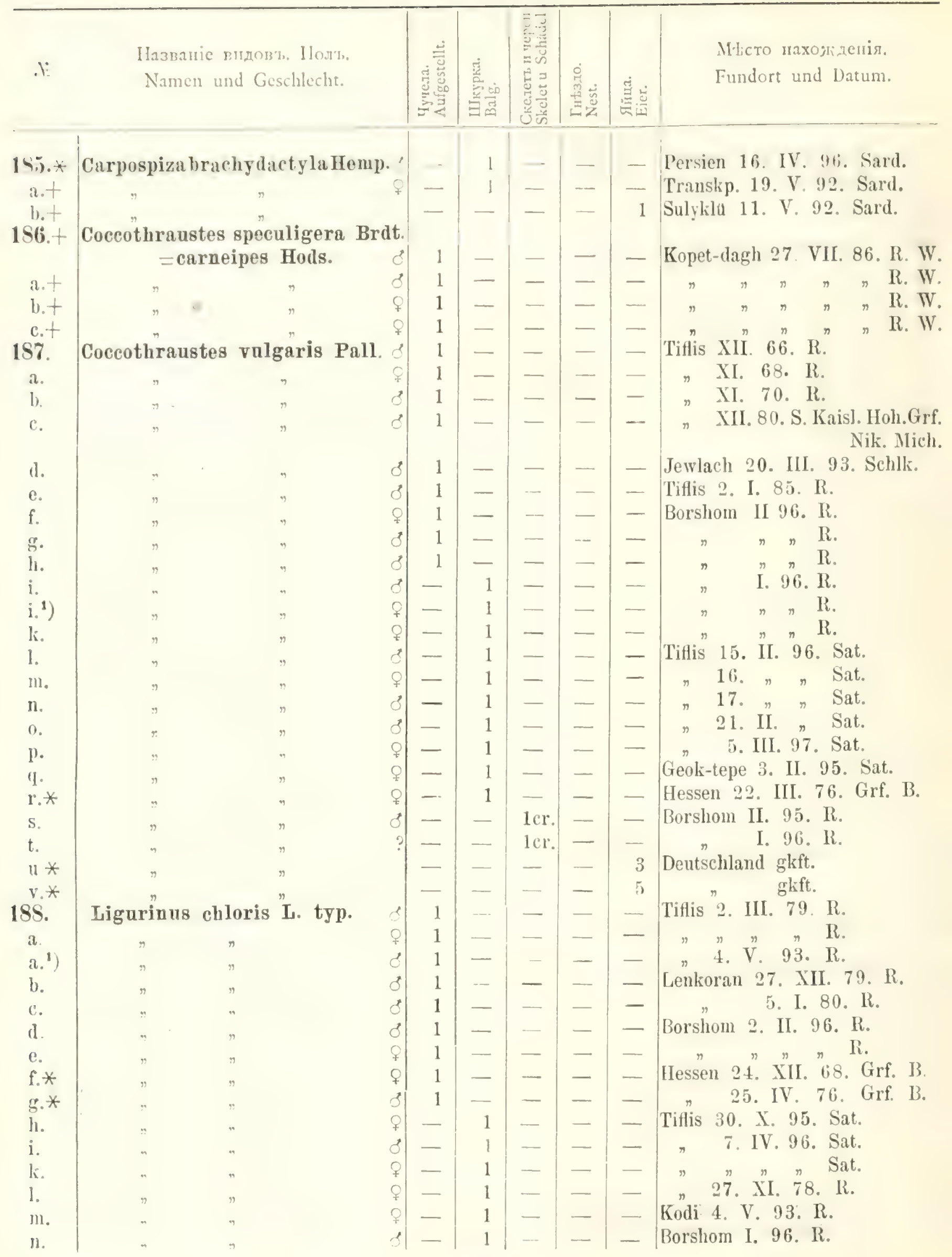




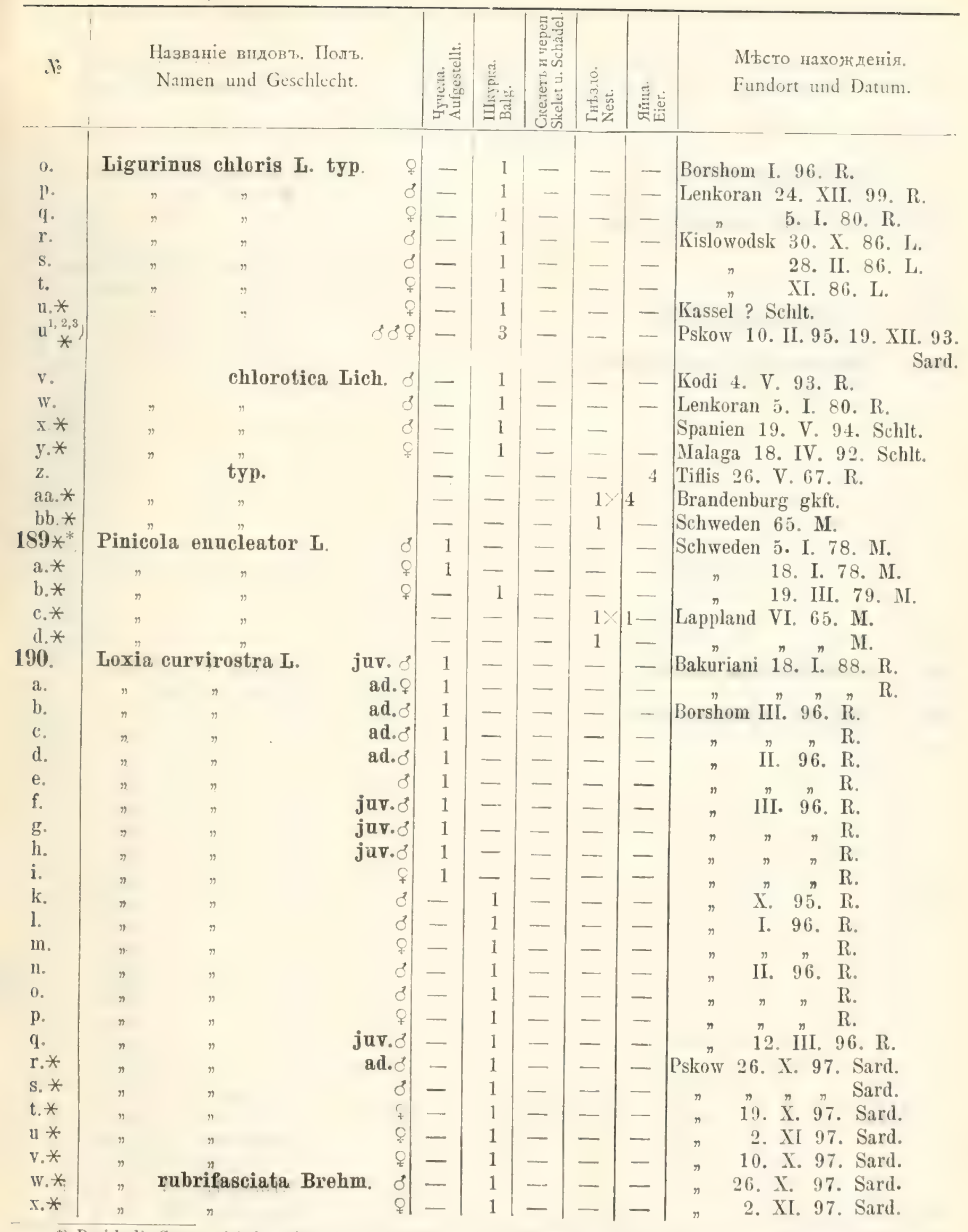

nicht alles ${ }^{*}$ ich die Genera Pinicola und Loxia bei Ilerstellung dieses Kataloges nicht richtig placirte, nämlich bei Pyrrhula und nicht alles wieder umändern wollte, so schalte ich sic hies cin unl fuhre dan mit Fringilla fort. 


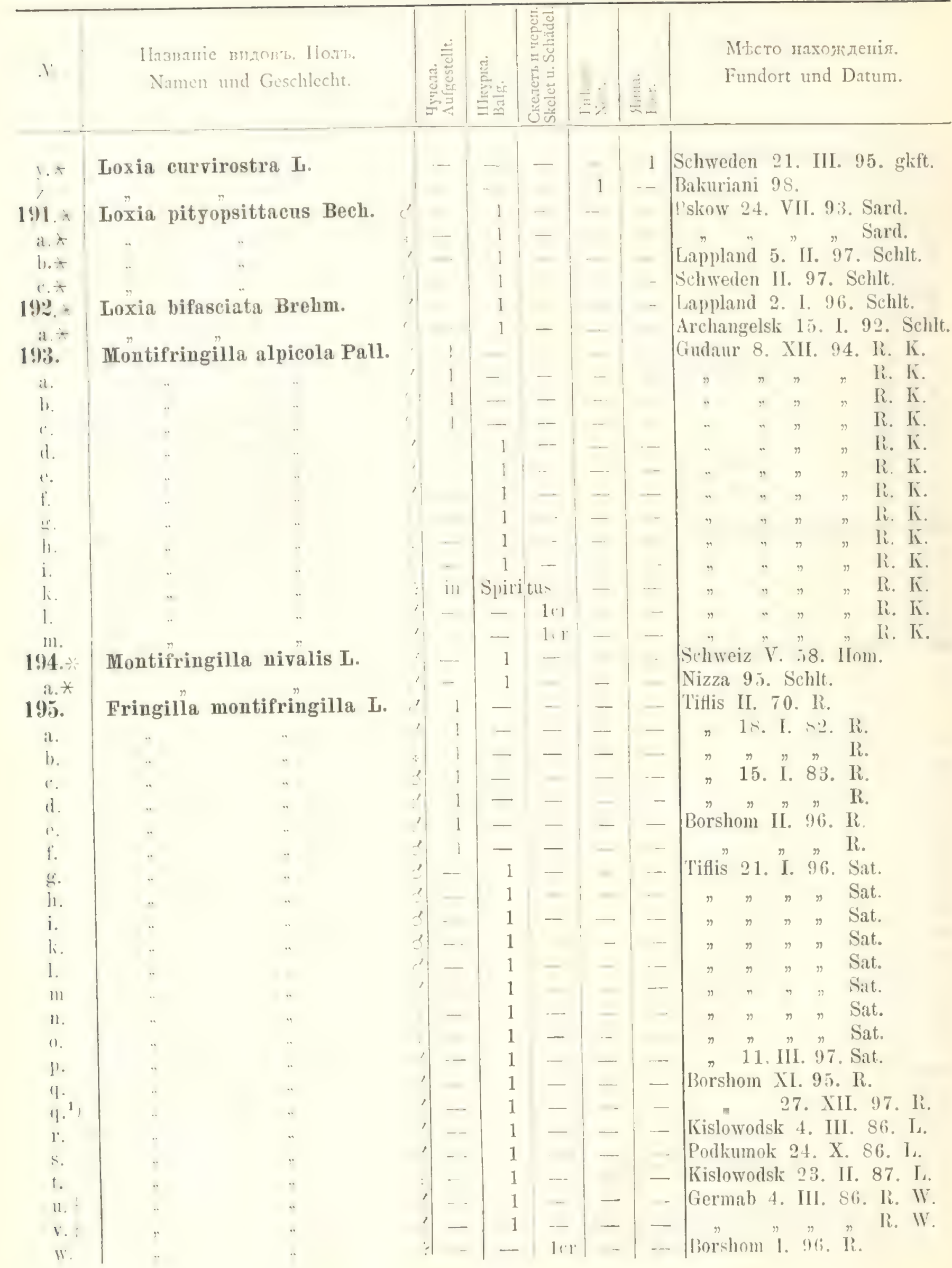



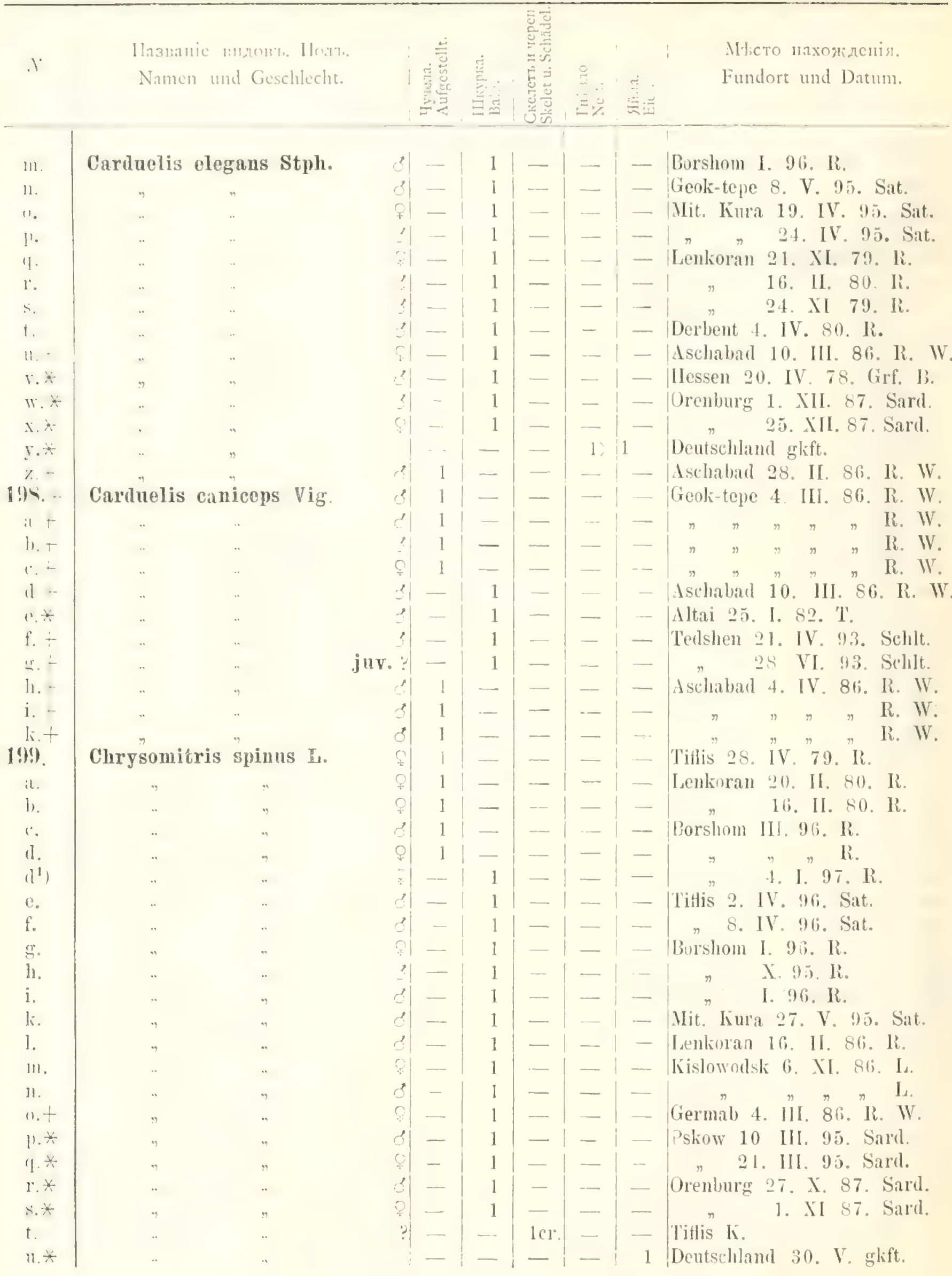

II). Carduelis caniceps Vig.

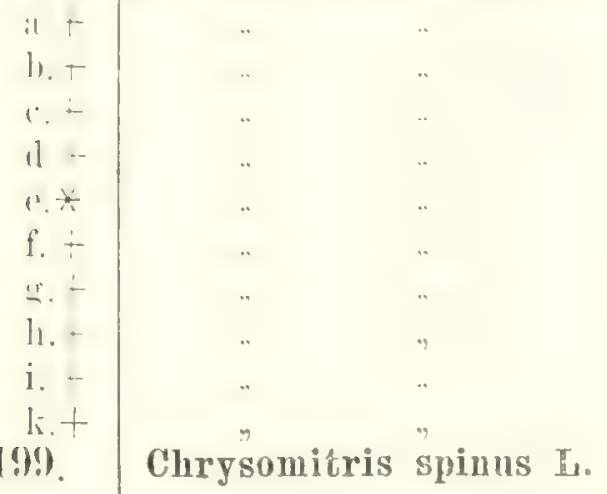




\begin{tabular}{|c|c|c|c|c|c|c|c|}
\hline di & $\begin{array}{l}\text { Названіе видовт. 1Толт. } \\
\text { Namen und Geschlecht. }\end{array}$ & 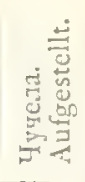 & 密焉 & 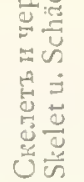 & 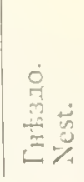 & 恶 & $\begin{array}{l}\text { Mltc'то нхояденія. } \\
\text { Fundort und Datum. }\end{array}$ \\
\hline
\end{tabular}

?o0. Linota cannabina L.

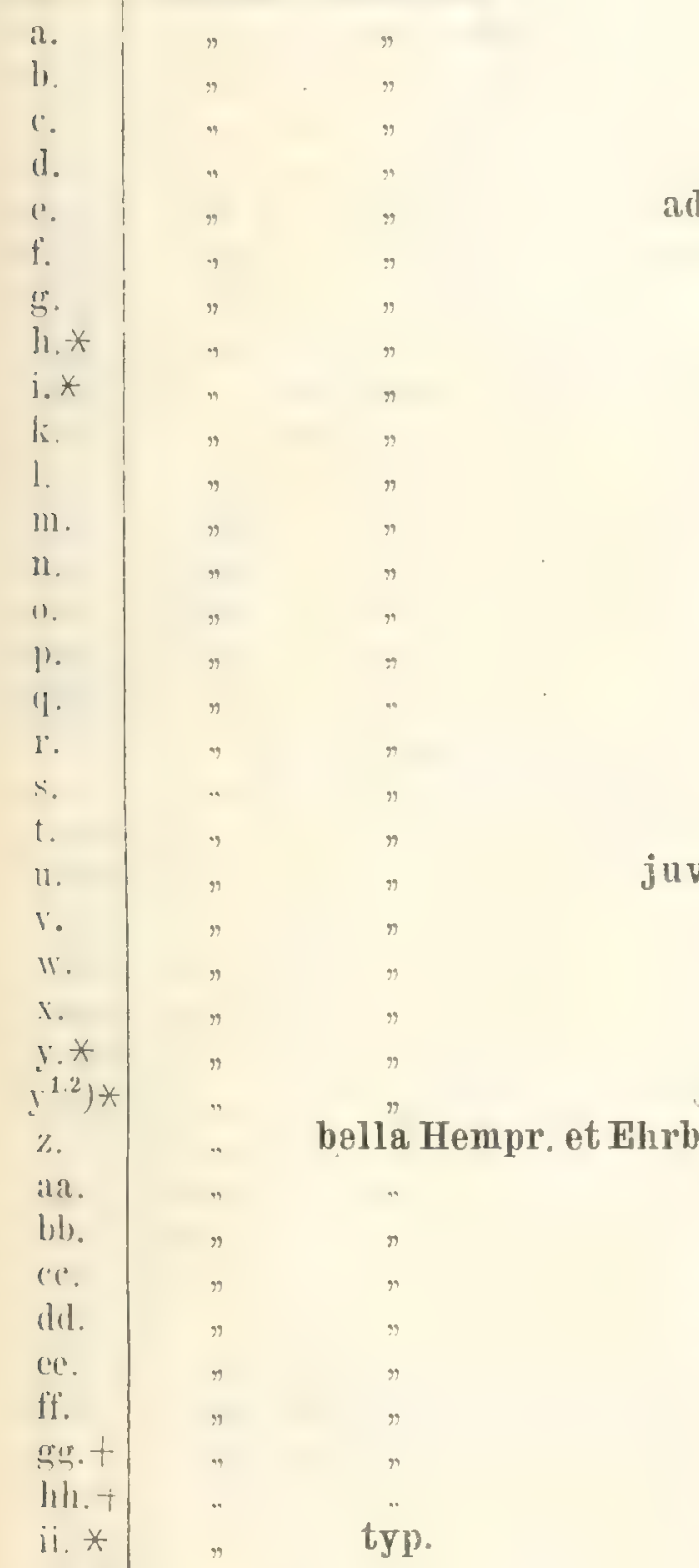

Linota flavirostris I

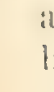

at

l) $11 .+$

Tiflis IX.73。 R.

Lenkoran 7. XII. 79. R. ㄱ. XII. 7!) I

Tiflis $16 \quad \mathrm{X} .7 \%$. R.

Lenkoran 5 I. 80, R. 28. III. $80, \mathrm{R}$

- Tiflis 19. I. 83. R.

Kassel "78, "rkfit. li.

Pommern Hom.

Tifflis 9. IV. 95. Sat.

$$
\text { } 723 . X I .95 . \text { Sat. }
$$

" $"$ "Sat.

"26. XI. 95. Sat.

"21. I. 96. Sat.

"23. XI. 95. Sat.

"11. II. 96. Sat.

$" 11.11 .96$. Sat.

Borshom I. 96. R.

Lenkoran 8. IJ. 80. R.

- Kus-jurdi 15. VI. E0. R.

-- Polkumok 28, V. 86. L.

Berosowaja 15. Xil. 85. L.

Kislowodsk 24. XI. 86. L.

-- Hessen 28. III 76. Grf. B.

- Pskow G 8. IV. 95. Sard.

\begin{tabular}{l|l|l|l|l|ll}
- & 1 & - & & - & Tiflis 3. IV. 96. Sat. \\
\hline & 1
\end{tabular}

- 21. I. 96. Sat.

- Marasly 2, V.93. Sat.

" Sat.

Kuba 16. VI. 96. Sat.

- Dshina 23. V. 86. L.

Kanterlik? Sard.

$$
\text { ? Sard. }
$$

Stuckholm 24. V. 65. M.

29. VI. 67. MI.

1 Deutschland gkft.

- Pommern Hom.

- Anklam 10. XII. 79. 'T'.

- Upsala 29. III. 88. Schitt.

-- Schweden 20. XI. 90. Schlt.

- Tiflis I. 85. R.

- Podliumoli 13. I. 86. Is.

- $n " n \pi L_{1}$.

- Terek Gebt." 30." XiI. 85. I.

-- Fort Perowsk 15. XI 57. Akial. 


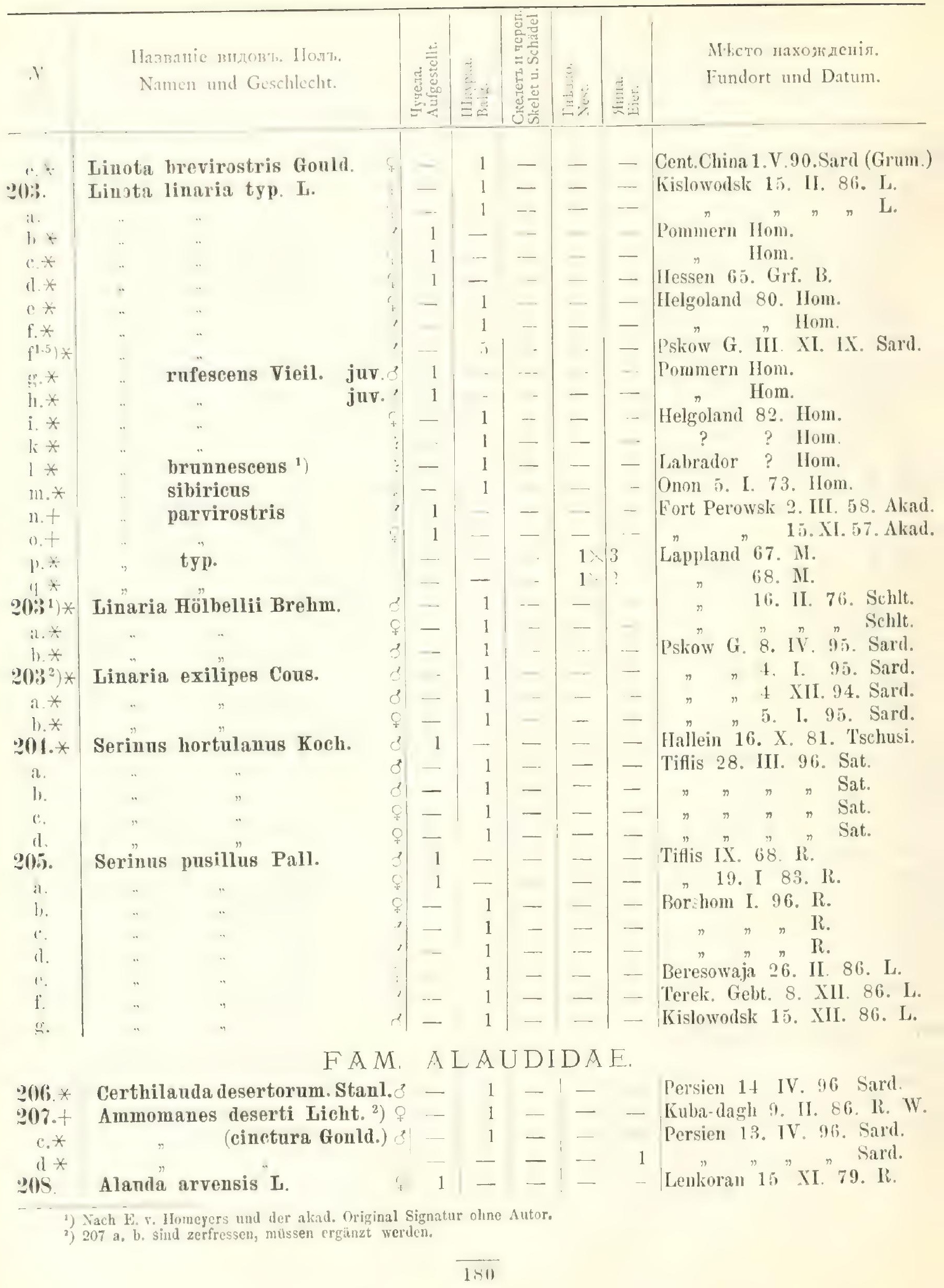




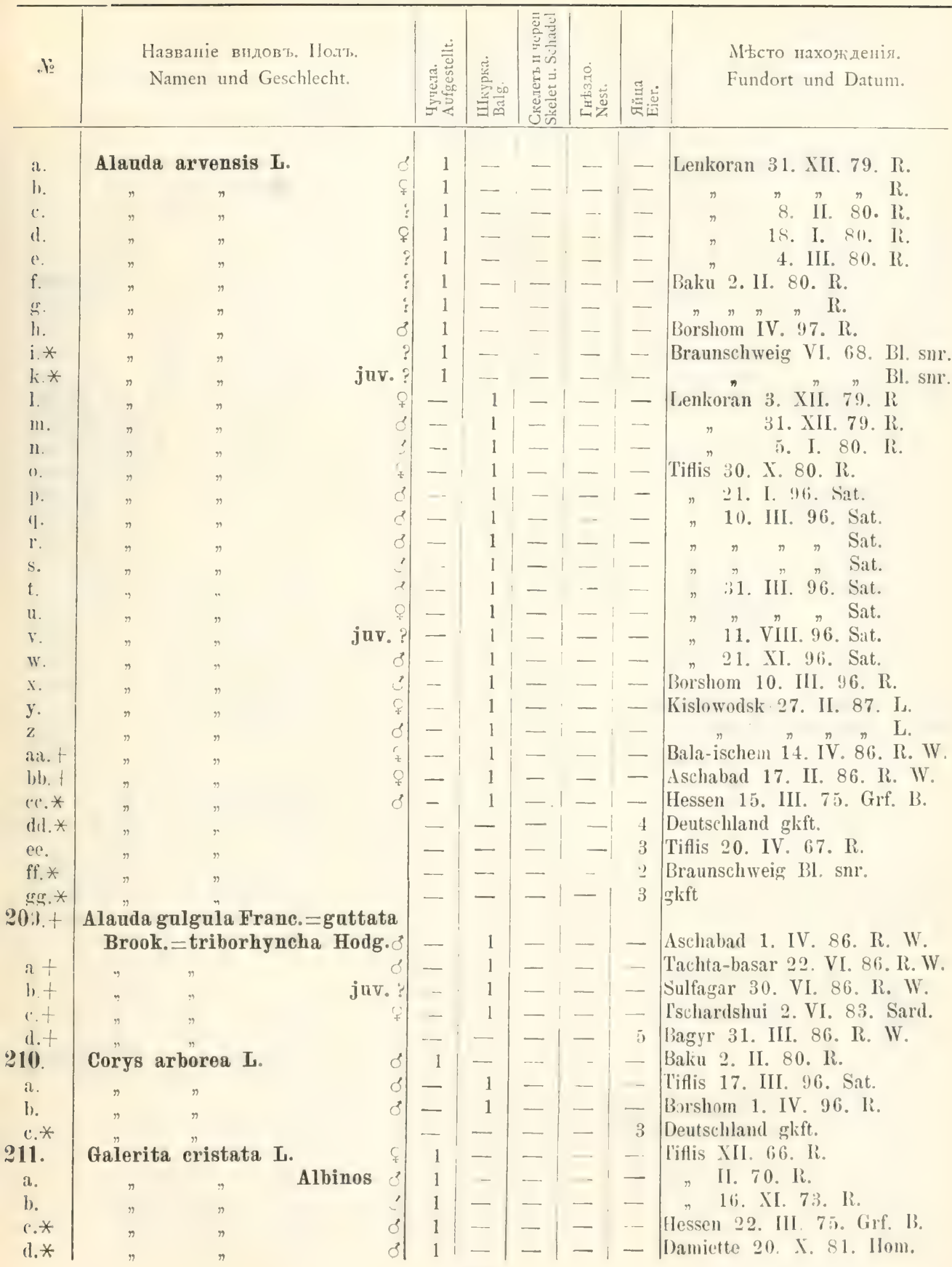




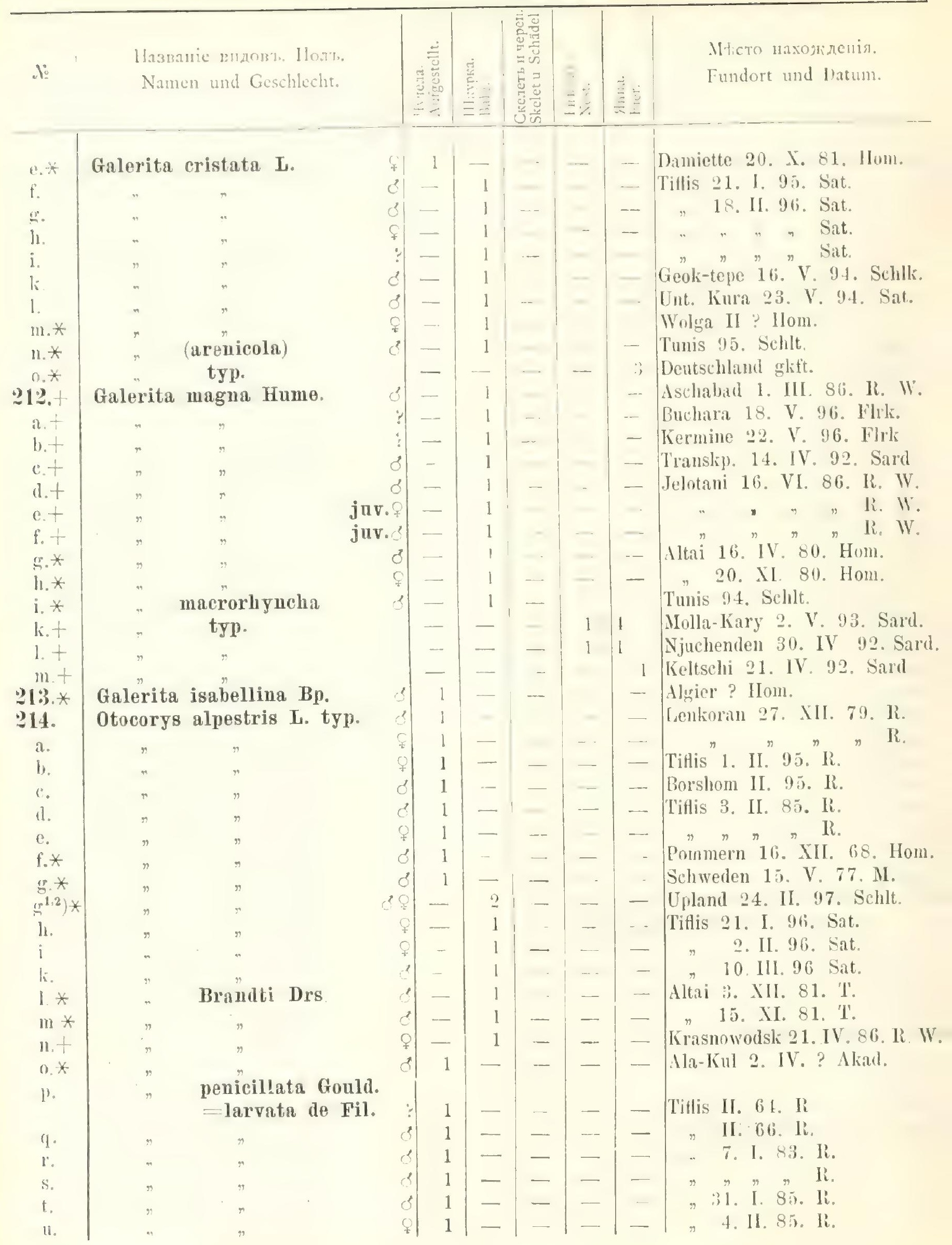




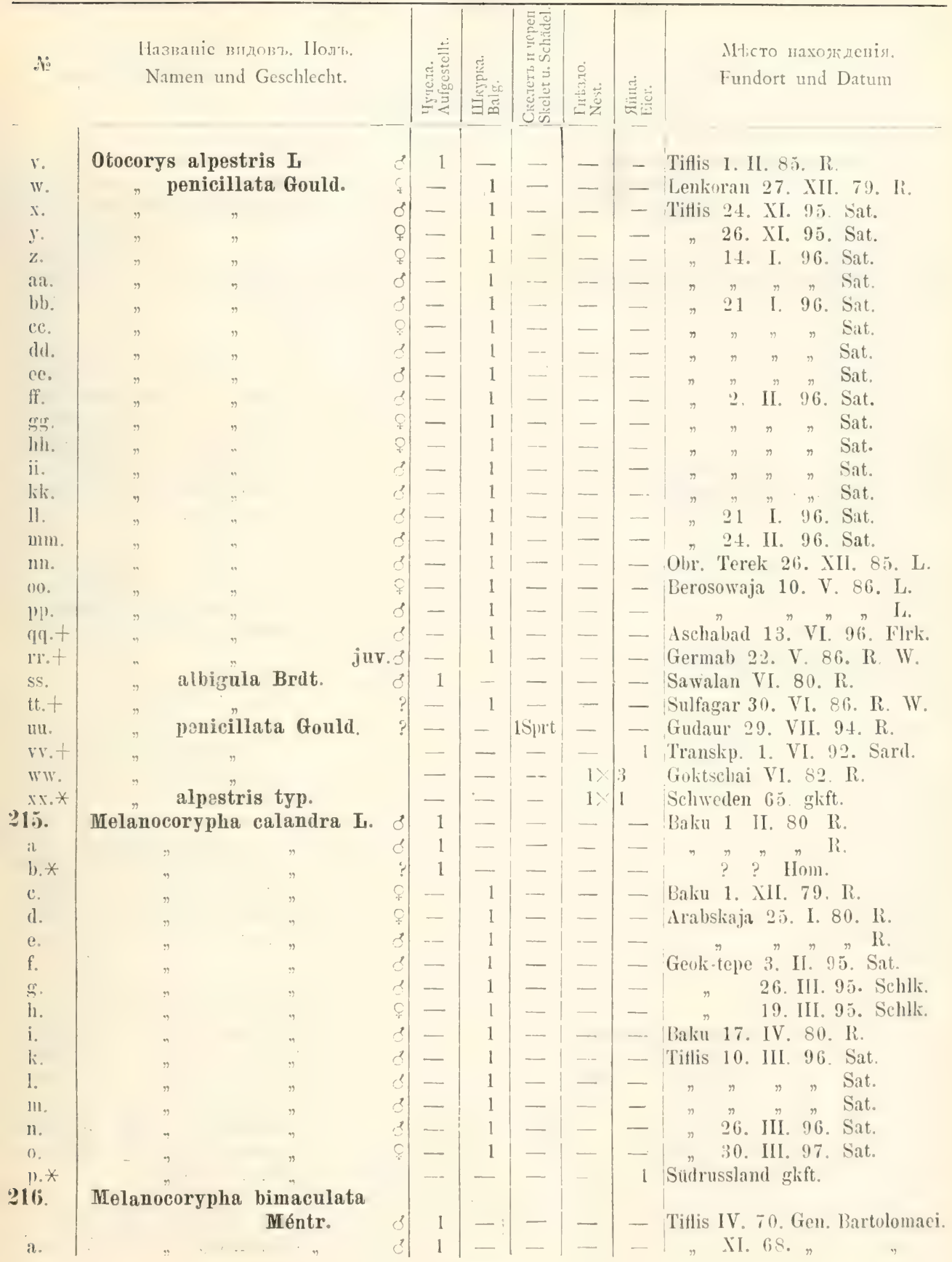









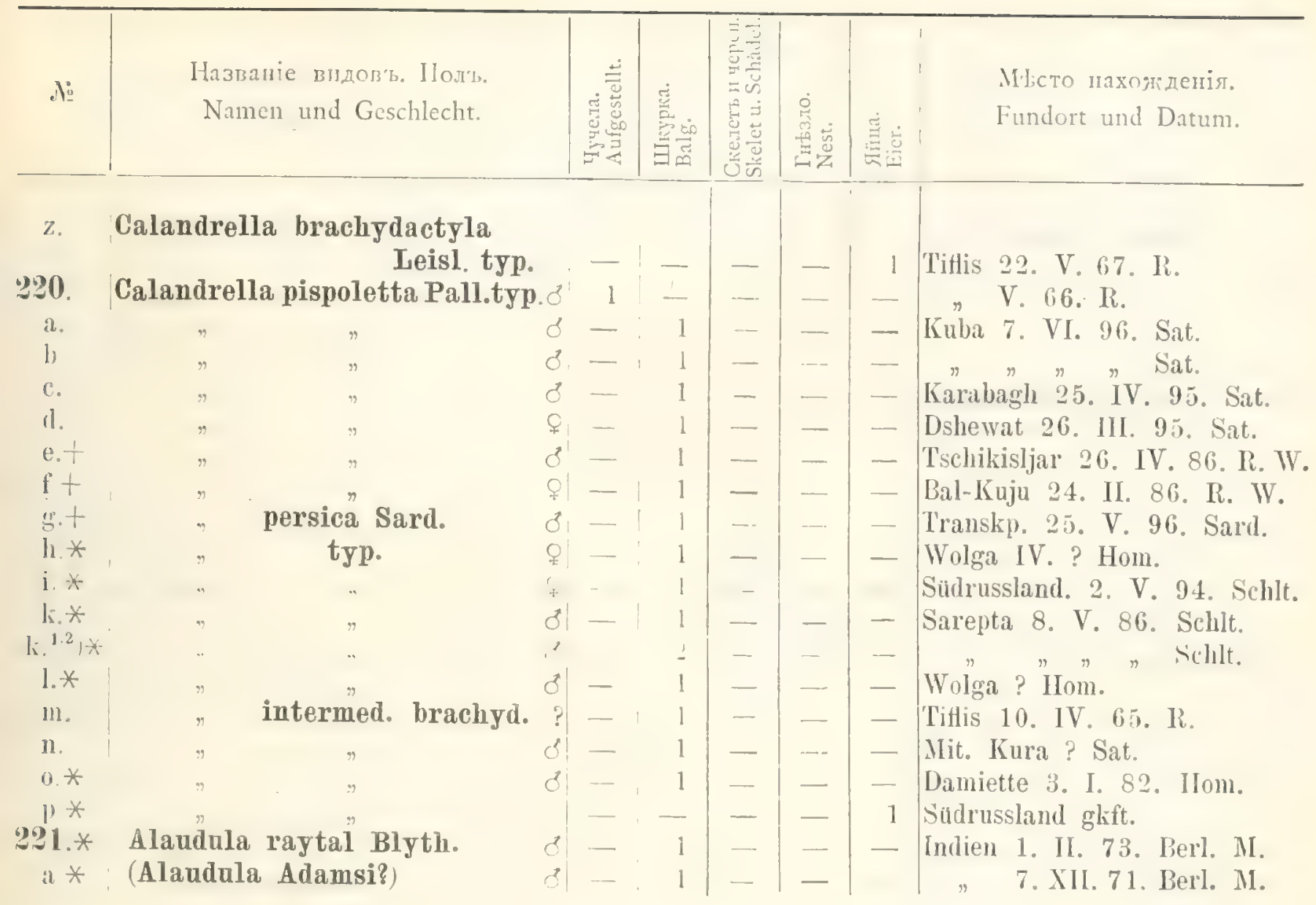

FAM. STURNIDAE.

2.2. | Pastor roseus I

(1)

f.

g

h.

i.

k

1

11

1).

1

l。

$\mathrm{s}$

t

11.

v.

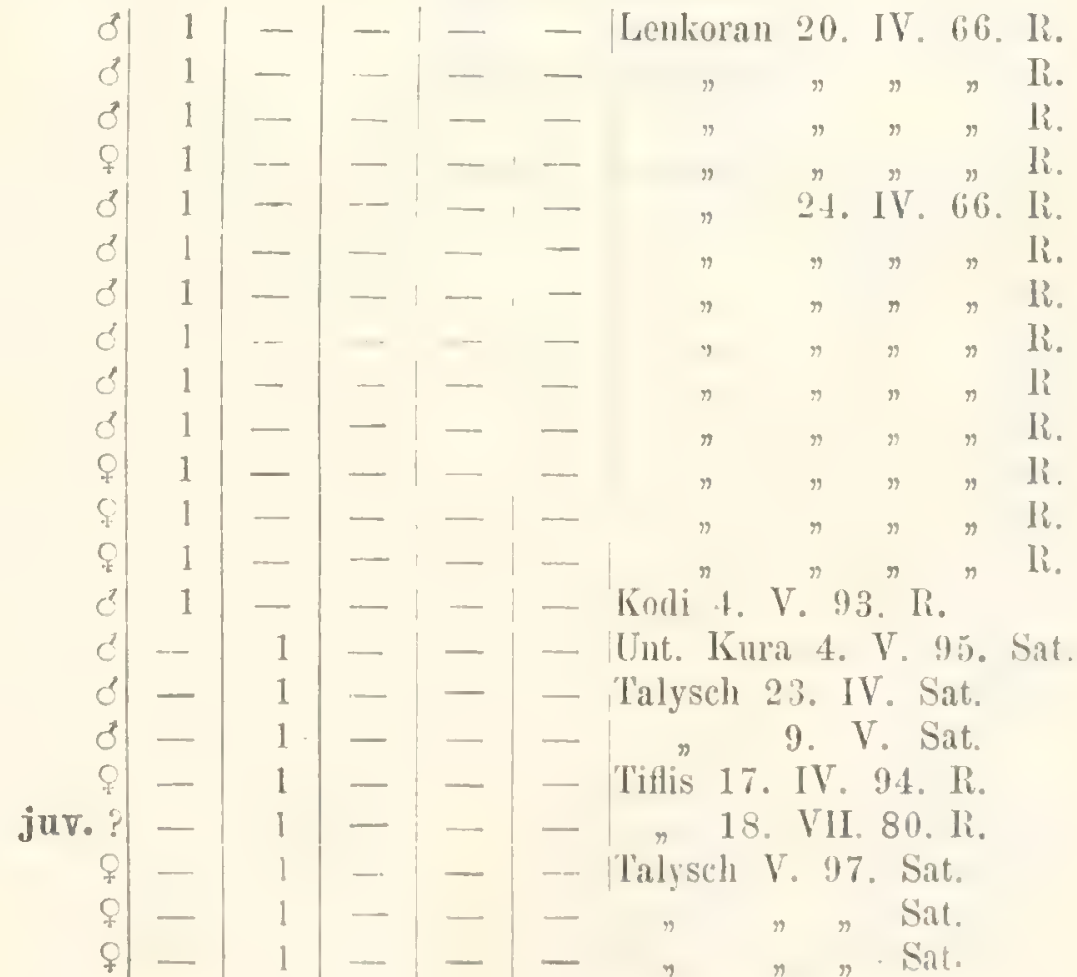




\begin{tabular}{|c|c|c|c|c|c|c|c|c|c|}
\hline $.1:$ & $\begin{array}{l}\text { Hazma } \\
\text { Nam }\end{array}$ & 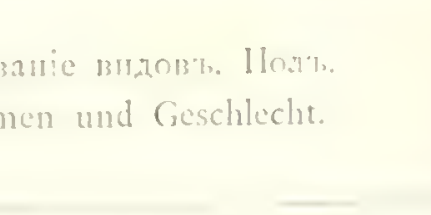 & & 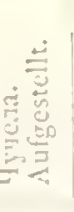 & 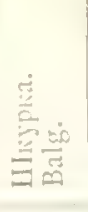 & 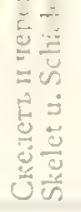 & 空 & 䓌密 & $\begin{array}{l}\text { MАсто пахоядеиія. } \\
\text { Fundort und Datum. }\end{array}$ \\
\hline w. & Pastor r & rosens L. & : & - & 1 & - & -- & - & Talysch V. 97. Sat. \\
\hline$x$ & .. & $n$ & $\varsubsetneqq$ & - & 1 & - & - & - & \\
\hline$y$ & $n$ & . & Q & $\ldots$ & 1 & - & - & - & 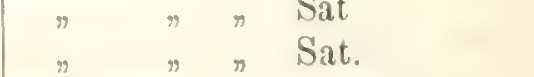 \\
\hline$z$ & , & juv. c & & - & 1 & - & - & - & [nsel Sari" V. 97. Sat. \\
\hline nia. & :- & & & - & - & - & - & 2 & $\begin{array}{l}\text { Insel Sari } .97 . \text { Sat. } \\
\text { Tiflis } 25 . \mathrm{V} .65 . \mathrm{R} \text {. }\end{array}$ \\
\hline 223. & Sturnus & vulgaris L. typ. & q & - & 1 & - & - & - & $\begin{array}{ll}\pi \\
\pi\end{array}$ \\
\hline a. & " & n & ? & - & 1 & - & - & - & n 5. X.95.R. \\
\hline b. & " & $=$ & & 一 & 1 & 一 & -- & -- & " 12. II. 96. R. \\
\hline$\because$ & &. & & - & 1 & - & 一 & - & Geok-tepe 15. III. 94, Sclilk \\
\hline d. & & " & $\dot{\varphi}$ & - & 1 & - & 一 & - & Lenkoran 28. II. 80. R \\
\hline c. & $\because$ & " & क & - & 1 & - & $\ldots$ & - & » 30. III. 80. R. \\
\hline f. & " & . 5 & & - & 1 & - & - & - & 23. XII. 94. R. \\
\hline s. & , & juv. & & - & 1 & - & - & 一 & 29. V. 97. Sat. \\
\hline 11. & . & " & 3 & - & 1 & 一 & - & - & Berosowaja 4. III. 86. L. \\
\hline i.t & $"$ & , & 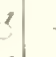 & - & 1 & - & - & - & Aschabad 18. II. 86. R. W. \\
\hline li.* & $"$ &. & () & - & 1 & - & - & - & Pskow G. 16. III. 95. Sard. \\
\hline 1. * & $n$ &. & 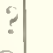 & - & 1 & - & - & - & Kassel glift. \\
\hline$m$ m * & $\because$ & $\because$ & & - & 1 & - & - & - & " 5. IV. 75. Grf. B. \\
\hline $11 . *$ & $"$ & $"$ & ? & - & - & $1 \mathrm{Sc}$ & - & -- & Brandenburg gkft. \\
\hline $0 . *$ & $\because$ & & & - & 一 & $一$ & - & 2 & Schweden 24. III. 69. MI. \\
\hline j. $*$ & r & $n$ & & - & - & - & - & 1 & Deutschland gkft. \\
\hline q. & $"$ & 9l & & - & - & - & - & 9 & Tithis IV. 76. IR. \\
\hline$\left.\left(a^{1}\right)^{2}\right)$ & $r$ & Menzbieri Sharp. & & - & 1 & - & - & - & Tiflis 10. III. 96. Sat. \\
\hline$\left.h^{3}\right)$ & $"$ & 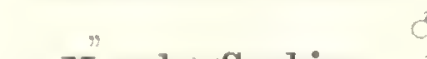 & & - & 1 & - & - & - & ? 3. IV. 95. Sard. \\
\hline$c^{1} *$ & " & Meuzb. Sophiae. & & - & 1 & - & - & - & Omsk 6. VII. 87. Sard. \\
\hline$\left.a^{2}\right) *$ & $n$ & Sophiae. & & - & 1 & - & - & - & Psliow G. 29. III. 93. Sard. \\
\hline$\left.a^{3}\right)$ & $\Rightarrow$ & purpurascens Gould. & & - & 1 & - & - & - & Haikop 25. V. 86. L. \\
\hline$b^{3}+$ & $=$ & $"$ & & - & 1 & - & - & - & Kunine 22. V.96. Flrk. \\
\hline$\left.a^{4}\right)$ & . & Poltorazkii Finsch. & 3 & 1 & - & - & - & - & Tiflis 16. I. 69. R. \\
\hline $\left.11^{4}\right)$ & $"$ & " & $f$ & 1 & - & - & - & - & $" n \quad n \quad n \quad R$ \\
\hline$\left(c^{4}\right)$ & $=$ & , & & 1 & - & - & 一 & - & $\eta \quad 0$. III. 83. R. \\
\hline$\left(1^{4}\right)$ & $"$ &. & & 1 & - & - & - & - & $n \quad n \quad n$ R. \\
\hline$\left.e^{4}\right)$ & " & .. & & 1 & - & - & - & - & $\pi \Rightarrow \pi \quad \pi$. \\
\hline$\left.f^{4}\right)$ & - & " & 3 & 1 & - & - & - & - & ॠ 5. V. 83. R. \\
\hline$\left(y^{7}\right)$ & " & .. & s) & 1 & - & - & - & - & $"$ 18. V. 83. R. \\
\hline 11.4 & " & . & 8 & 1 & - & - & - & - & $"$ II. 95. R. \\
\hline$\left.i^{*}\right)$ & $"$ & $c$ & d) & 1 & - & - & - & - & $n \quad n \quad \mathrm{R}$. \\
\hline$\left.k^{4}\right)$ & " & " & d) & 1 & - & - & 一 & $一$ & $\Rightarrow \quad \mathrm{l}$. \\
\hline $\left.1^{4}\right)$ & . & $"$ & q & 1 & - & - & - & - & $n \quad \Rightarrow \quad \mathrm{R}$. \\
\hline $\left.11^{4}\right)$ & n & . & of & 1 & - & - & - & 一 & $n \quad n \quad \mathrm{R}$. \\
\hline $\left.11^{4}\right)$ & $"$ & d & 8 & 1 & - & - & - & - & $n \quad " \quad \mathrm{R}$. \\
\hline$\left(0^{4}\right)$ &. & * & 8 & 1 & 一 & - & - & - & $" \quad \mathrm{li}$. \\
\hline$\left.v^{4}\right)$ & " & $"$ & d & 1 & 一 & - & - & - & $n \pi \quad \mathrm{R}$. \\
\hline$\left(1^{4}\right)$ & 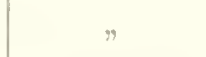 & o & b) & - & 1 & - & - & - & ${ }$ IX. 91. IR. \\
\hline$\left.r^{4}\right)$ & $\Rightarrow$ & $d$ & ol. & - & 1 & - & - & - & $n n \quad n$ R. \\
\hline
\end{tabular}

*) Da unsere Stanren Suite sehr gross ist, so beginne ich hei Fiwähnung der Formen wieder mil a. 


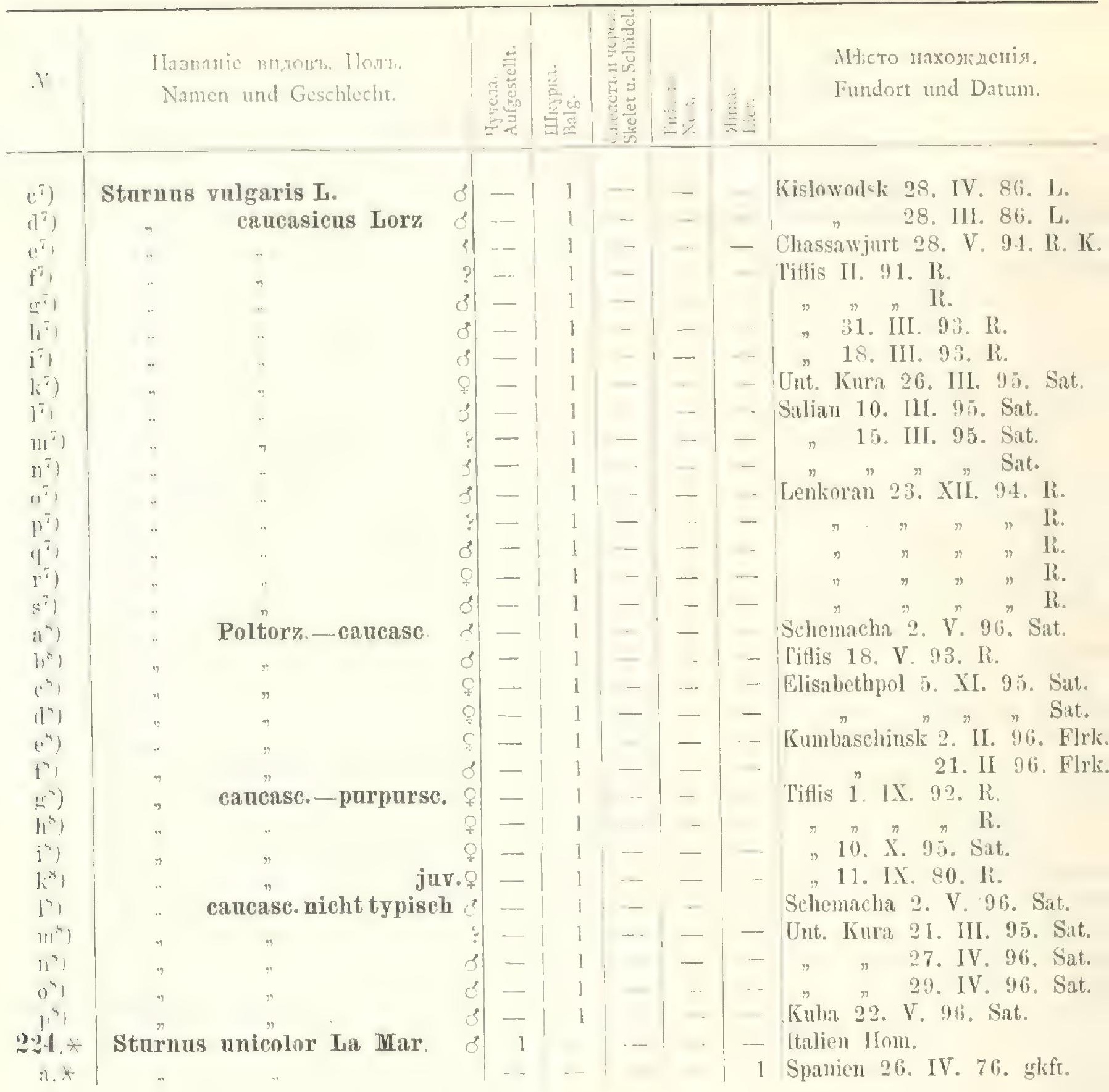

FAM. COR VIDAE.

2.). Corvus monedula L

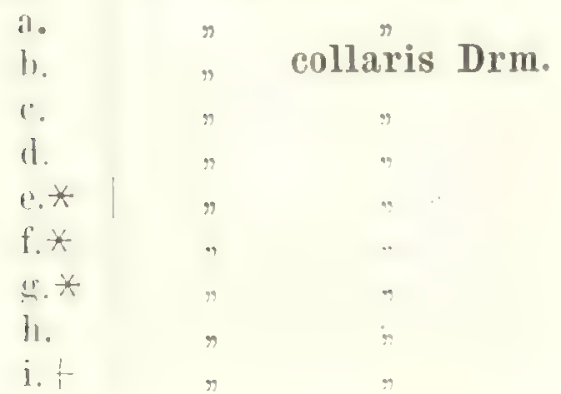

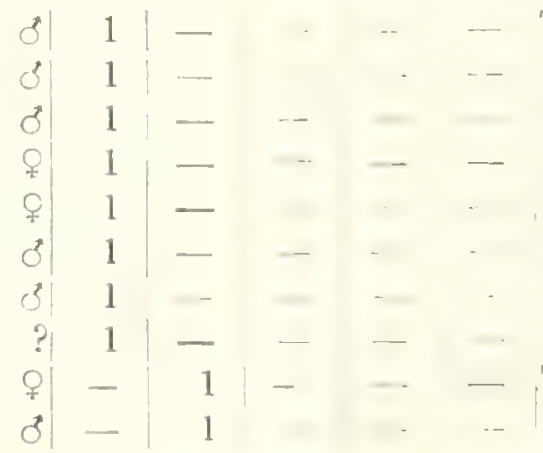

Tiflis I. 70, R.

, 15. I. 74. R. 2!) IX. 7!. IR.

4. V. «1. li.

13. I. 93. R.

Hessen 78. gkft. 64. Grf. B. 64. Grf. B. Tiftis 18. V. 93. R. Aschabad 23. II. 86. R. W. 


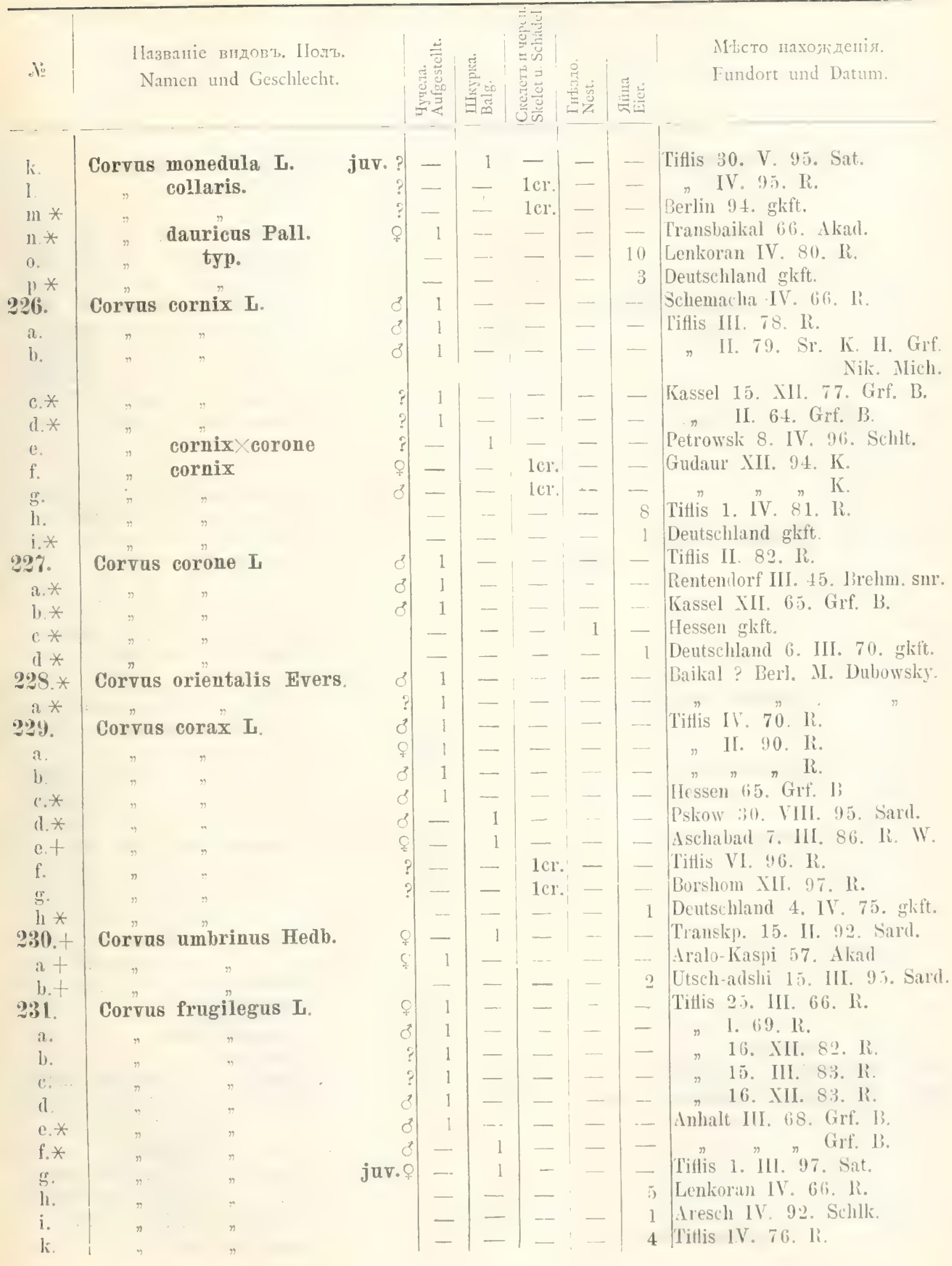


?:2. Fregilas graculus L.

il.

1.

1.

11.

1'.

i. :

ㅍ․ $;$

l1. $\rightarrow$

i.

li

283.

it

1)

234. Pica caudata L. typ

i! ,

i).

19

11

(x)

t

$\because *$

ll.

i.

k.

1

III.

11. $*$

11.

I).

11.

1

$\therefore$

1.

II

V.*

W. $*$

9.8.

$2316 *$

i. *

1) $*$

c. $*$

1. $*$

$0 *$

1.5 japonica Schl. et Bp. typ.

\section{leucoptera Gld.}

leaconota Brehm. typ.

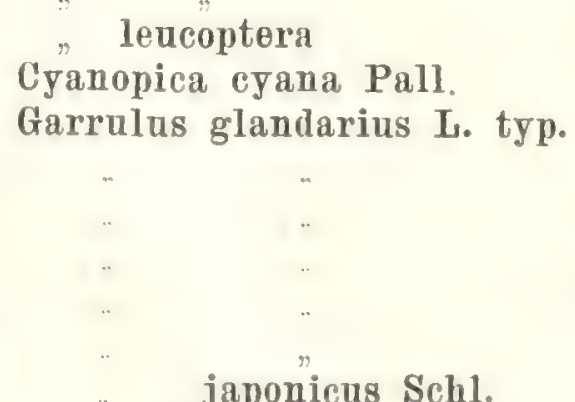

japonicus Sch1.

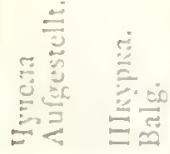

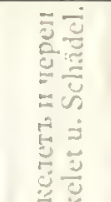

$=\cdots$

Pyrrhocorax alpinus Briss.

juv.

himalayana Gould. typ. 
Ilaзваніс вгдова. IIก.77. Namen und Geschlecht.

Podoces Panderi Fisch. 410 Polloces Pleskei Sari.
Micно пахоялденія.

Fundort und Datum.

\section{P I C I. \\ FAM. PICIDAE.}

11. Gecinus viridis $\mathrm{T}$.

i.

b.

1.

(l.

$\because$

t.

ㅍ.

l.

i.

li.

I. :

II. :

$11 . ;$

11.

1. $x$

-1\%. Gecinus flavirostris Sard. =G. Gorii Harg.

a. i

?1:3.* Gecinus canus Gml.

il. $*$

$11 . *$

244. Picus major I typ.

i.

l).

$\because$

d.

$\because$

f.

世.

II.

i.

li.

1 .

111.

$11 *$

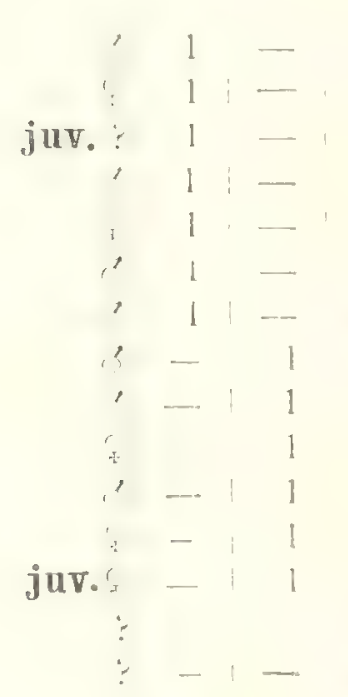

1 Utsch-arlshi 20, IV. 92. Sari.

1 Persien V. 98. Sard. 


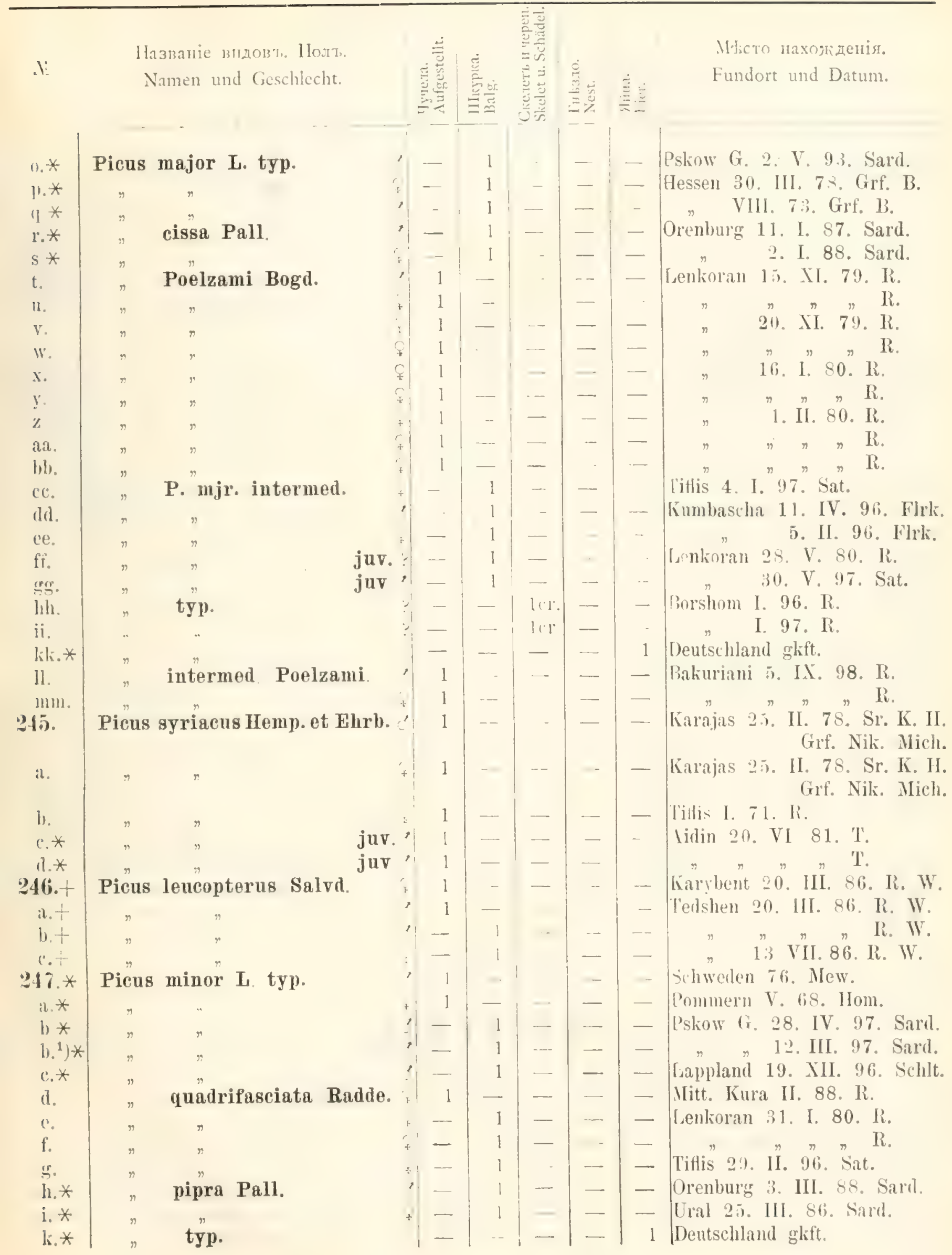




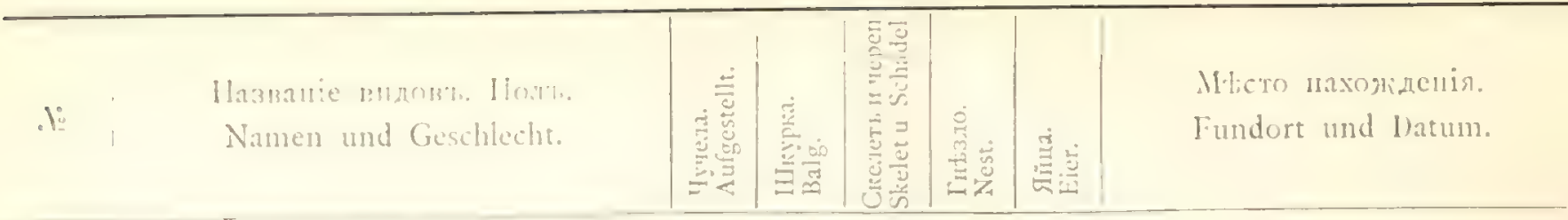

245. Picus medius L. typ.

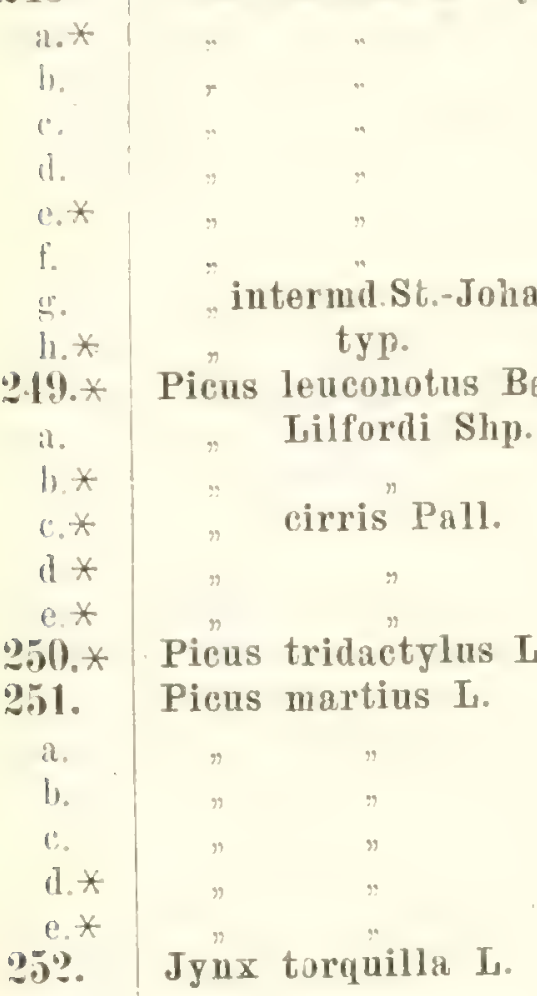

a.
b.
i.
e*
f.
g.
h.
i
k.

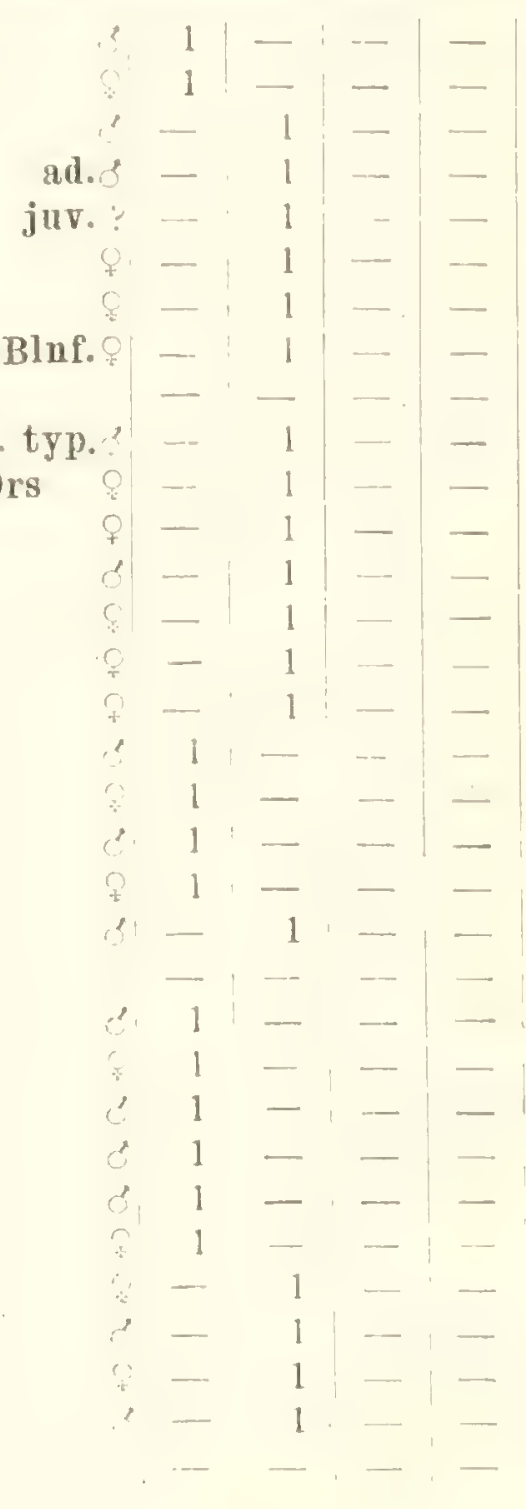

- Tillis 6. I. 71. R.

- IJessen 30. XII. 75. Grf. B.

- T'iflis 15. II. 95. Sat.

- Unt. Kura 30. IV. 95. Sat.

- 'Tiflis 21. II. 95. Sat.

- Poltaw G. 17. VIII. 90. Sard. Kislowodsk 17. IX.85. Id.

- Tiflis 29. VIII. 82.R.

1 Deutschland grkft.

- Bukowina 16. VIII. 97. Schlt.

- Borsh m 19. III. 96. R.

- Parnass 25. VIII. 96. Schlt.

- Orenburg 2. I. 87. Sard.

- Ural 21. XII. 86. Sard.

- Amur 18. II. 82. Schlt.

- Schweden 21. XII. 77. M.

Lenkoran 4. IV. 66. IR
III. SO. IR.

- $\quad$ 17. XI. 79. R.

- Borshom 8. XII. 96. K

- Amur 20. III. 58. Akad. R.

2Schwedn 1. V. 94. glift.

- Tiflis 10. V. 81. R

9. IX. 82. li.

28. VIII. 82. R.

Borshom IV. 97. IR.

R.

- Hessen 10" Vi. 76. Grf. 13.

- Tiflis 7. IV.9., Sat

- $\quad 20.1 Y .95$. Sat.

- Borshom 12. IV. 9!. R.

Kislowodsk 7. V. T.

3 Deutschland glift.

\title{
C O C C Y GES.
}

\author{
F A M. C U C U L IDAE。
}

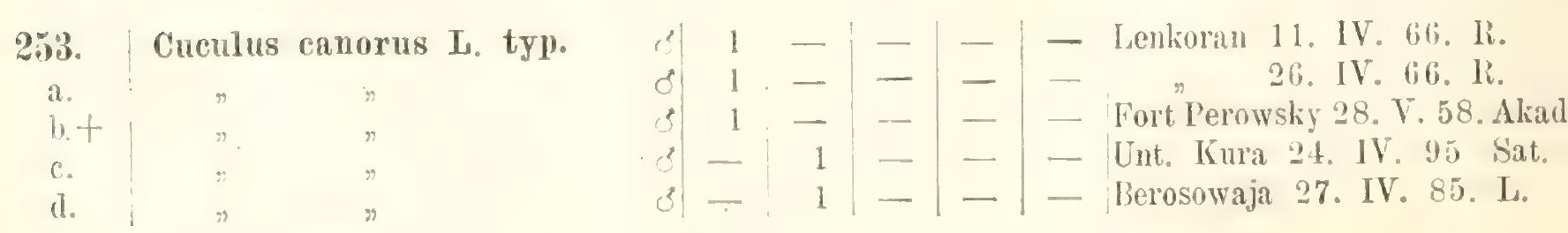




\begin{tabular}{|c|c|c|c|c|c|c|c|}
\hline. & $\begin{array}{l}\text { Названіс вндовд. ІІоль. } \\
\text { Namen und Geschlecht. }\end{array}$ & 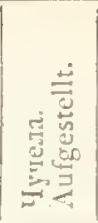 & 意总 & 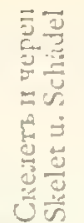 & 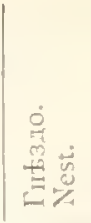 & 递莹 & $\begin{array}{l}\text { Mtcro naxожденія. } \\
\text { Fundort und Datum. }\end{array}$ \\
\hline
\end{tabular}

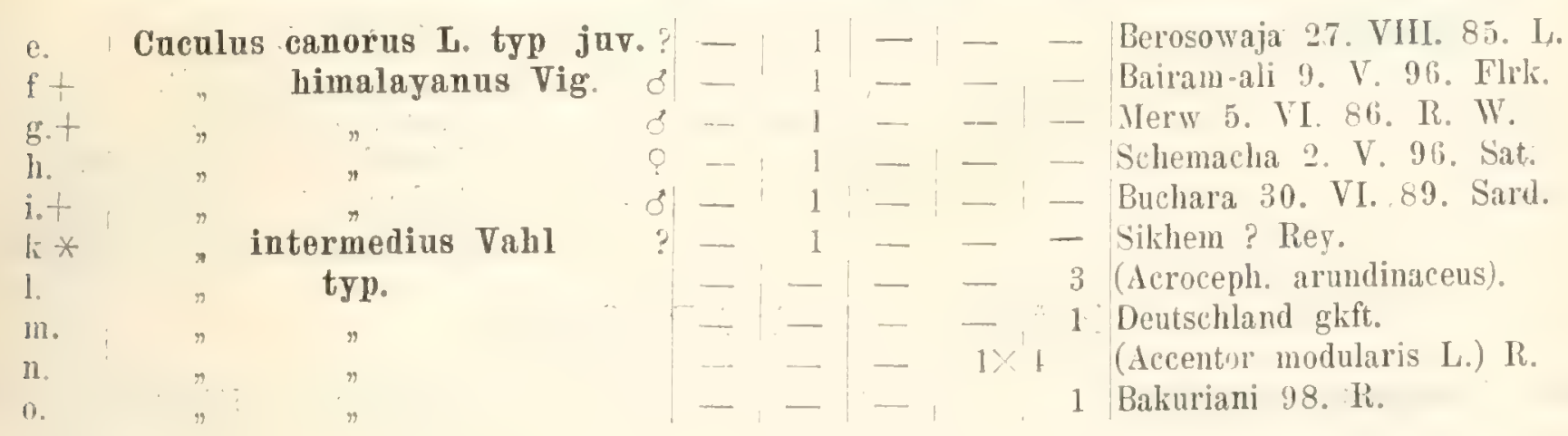

FAM. A LCEDINIDAE

A.7.*. Alcedo ispida L. typ.

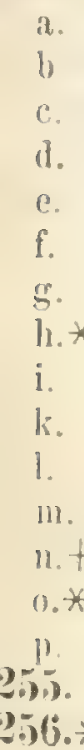

a. *

\section{bengalensis $\mathrm{Gml}$.}

typ

Halcyon smyrnensis L.

Ceryle rudis $\mathbf{L}$.

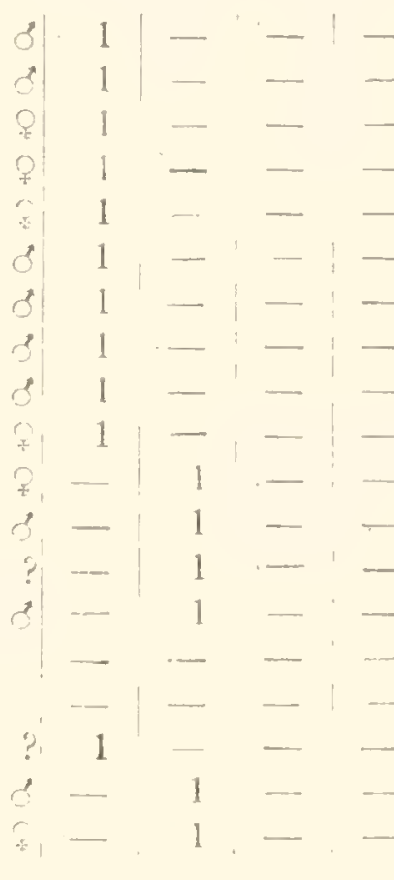

- Hessen X. 79. glitit.

Titlis 1\%. IX. 7 i. R.

Lenkoran 20. IV. 66. R.

IV. $66, \mathrm{li}$.

2. XII, 79. li.

18. XII. 7\%. R.

- Iiflis 19. VII. 80. R.

7. IX. 82. R.

Indien 73. Schlt.

Borshom III. 97. R.

อ. III. 96. R.

- Lenkoran 24 XII. 94. R.

- Kumbascha 28. II. 96. Flrk.

- Merw 9. VI. 86. I. W'.

6 Deutschland 28. VI. 63. glift.

3 Titlis 10, V. 8\%. R.

- Lenkoran VI. 84. K.

Damiette 10. V. 95. Schlt.

Schlt.

\section{FAM. CORACIIDAE.}

Coracias garrula $\mathbf{L}$.

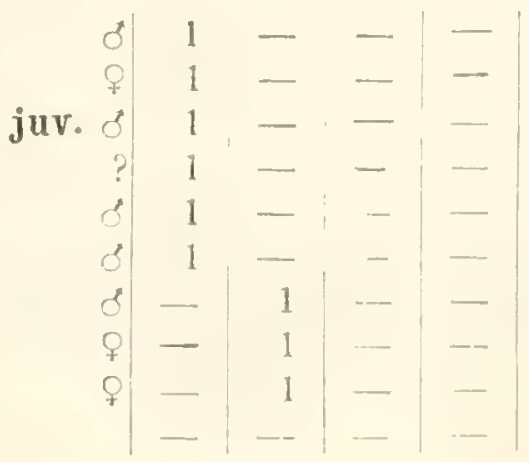

- Lenkoran IV. 66. R.

- I $"$ r

- Titlis 3. IX 7: R.

- Lenkoran כ. VI. 80. R.

?. VI. 80, R.

16. IV. $80 . \mathrm{R}$.

- Geok-tapa 10. V. 94. K.

- Kuba 24. V.96. Sat.

-- Kislowodsk 26. V. 86. I。

2 Tiflis 12 . V. 82. R. 


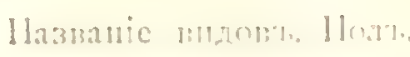

Namen und Geschlecht.

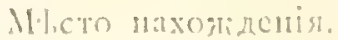
Fundort und Datum.

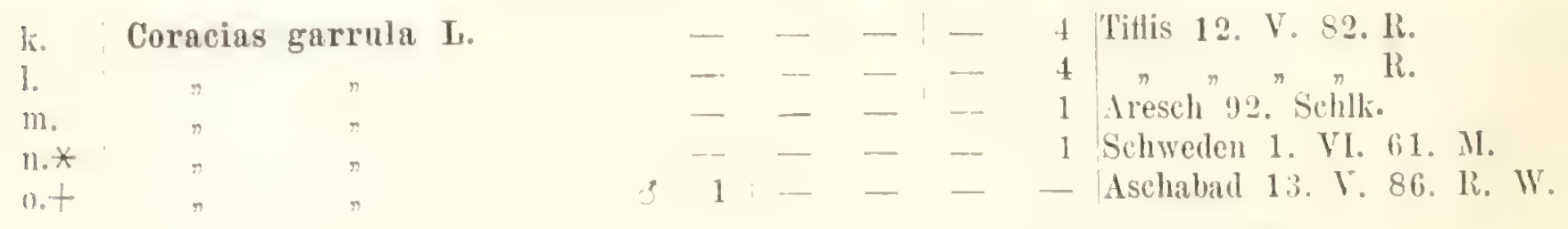

FAM. MEROPIDAE.

258. Merops apiaster L.

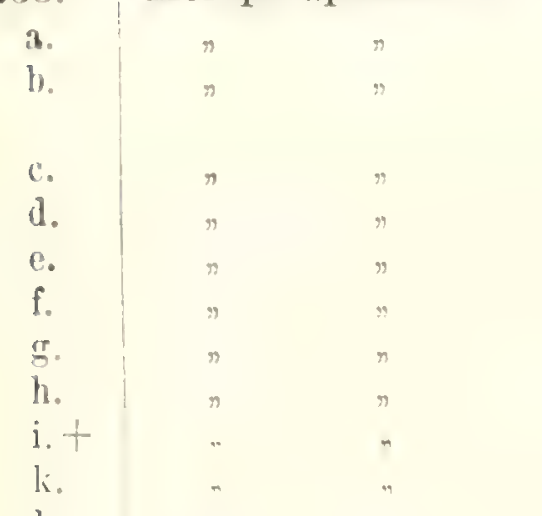

l.

259. Merops persicus Pall.

a.

b.

c.

d.t

e.

f.

g.

h.

i.

k.

l.

m.

n.

0.

p.t

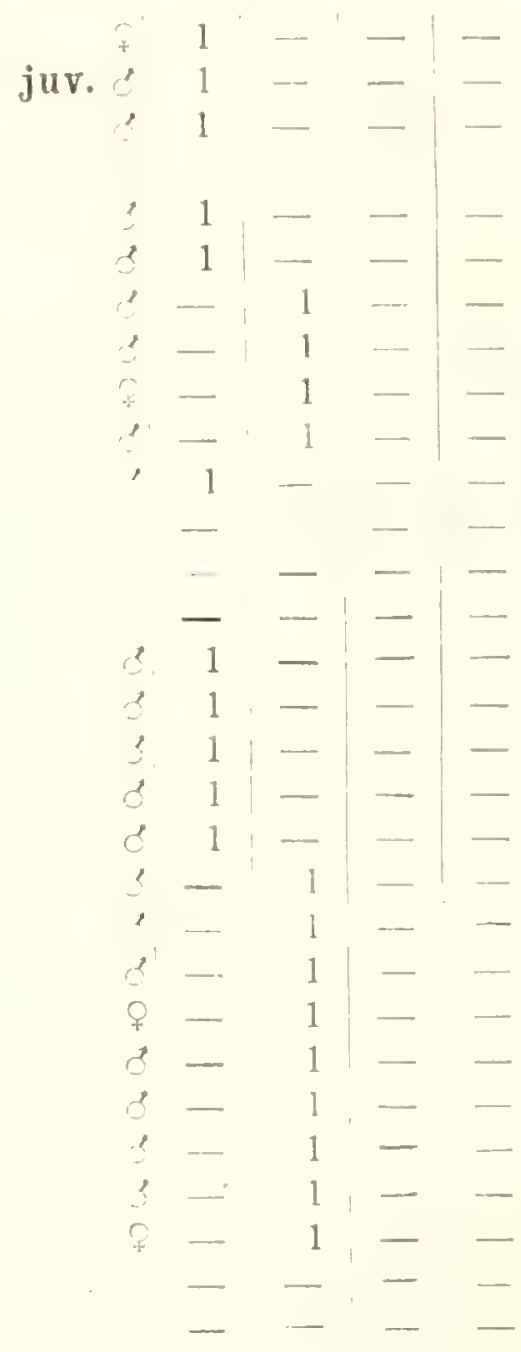

- Lenkoran 19. IV. 66. R.

- Tíllis 8. VI. 73. R.

- $\rightarrow$ 78. Sr. K. II. Grf. Mich.

Kodi 13. V. 93. R.

- $\quad n \rightarrow n$ R.

- $" r . \quad$ R.

- Unt. Kura 27. IV. 95. Sat.

- Lenkoran 18. IV. 97. Sat.

- Kislowodsk 24. VII. 86. L.

- Beum-basch 1. V. 86. R. W.

31 Lenkoran 16. V. 80, R.

2 Aresch 92. Schlk.

5) Transkp. V. 96. Flrk.

- Lenkoran 18. IV. 66. R.

2. V. 66, ll.

VI. 84. R.

n, R.

- Aschabad 8. IV. 86. R. W.

Lenkoran 12. V. 80, R.

" $"$ R.

- $\quad$ - 30. IV. 96. Flrk.

- Kumbascha"7. VI. 97. Sat.

- Kat.

- $\quad$ n

19) Lenkoran 1. VI. 80, R.

Transkp. V. 96. Flrk. 


\section{MACROCHIRES.}

FAM. CYPSELIDAE.

\begin{tabular}{|c|c|c|c|c|c|c|c|}
\hline 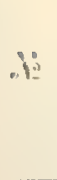 & 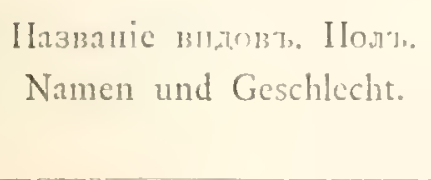 & 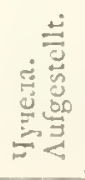 & 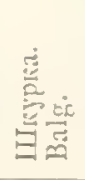 & 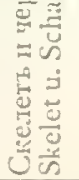 & 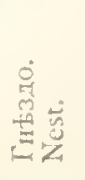 & 惫藻 & $\begin{array}{l}\text { Mrсто нахонденія. } \\
\text { Fundort und Datum. }\end{array}$ \\
\hline
\end{tabular}

960. Cypselus melba L.

$a * *$
b.*
c.*
$2(i 1$.
$a *$
b.*
c.*
it
c.t
f.
g t
$h . *$
$i . *$

$\theta 62$.

$a *$

b. *

*

typ.
Cypselus afflnis Gray.

Cypselus apus $\mathbf{L}$. typ.

pallidus Shel. unicolor Jard.

FAM. CAPRIMULGIDAE.
263

ฉ.

b

c.

d.

e.

s. +

h.

i. $\frac{1}{+}$

$k+$

$1 .+$

in.

$n$

$0 *$

$10 .+$

261.

$2(0.9 .+$

a. + f $1-\ldots-$ Tiflis 8. IX, R.

3) - $1,1-1-$ Griechenland 30. VII.98. Schlt.

\$ - $1-1-1-$ Palaestina 18. V. 95. Schlt.

1 gkft.

- Tiflis 20 VII. 74. R.

- Halle 29. V. 97. Schit.

- Spanien 29. V. 96. Schlt.

- Madeira 16. VII. 94. Schlt.

- Krasnowolsk 19. IV.86. R. W.

- Aschabad 4. IV. 86. R WV.

- R. IV.

- Tschikisljar" 19. IV. 87. Jas.

Brandenburg gkft.

3 Stockholm 28. VI. 64. M.

- Pul-i-chatum 5. VII. 86. R. W.

- N. Persien 9. VI. 96. Sard.

- Indien Rey.

\section{Caprimulgus europaeus L. typ.}

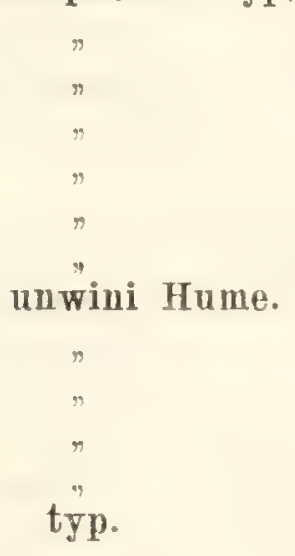

unwini.

Caprimulgus inornatus Heugl.
$1-$

\begin{tabular}{l|l}
- & - \\
- & - \\
- & - \\
- & - \\
- & - \\
- & - \\
- & - \\
- & - \\
- & - \\
- & - \\
10 & - \\
- & - \\
- & -
\end{tabular}
Tiftis 17. IX. 71. R. ᄁ 15. VIII. 81. R.

4. IX 81. R.

$\pi, \pi, \mathrm{R}$.

Kuba 7. VI. 96. Sat.

Unt. Kura 29. IV. 95. Sat.

Tiflis 19. VIII. 80, R

- Tachta-basar 22. VI. 86. R. W.

- Sary-jasy 18. VI. 86. R. W.

- Germab 24. V. 86. R. iV.

- Merw 25. VII. 89. Sard.

23. VII. 89. Sard.

Kasikoporan VII. 96. K.

2 Lenkoran 12. V. S0, R.

1 Deutschland gkft.

1 Tedshen 18. V. 93. Sard.

- Tiflis 23. VII. 80. R.

- Atrek 2. V. 86. R. W.

- Transkj. 2. V. 86. R. W. 


\section{ACCIPITRES.}

\section{FAM BUBONIDAE}

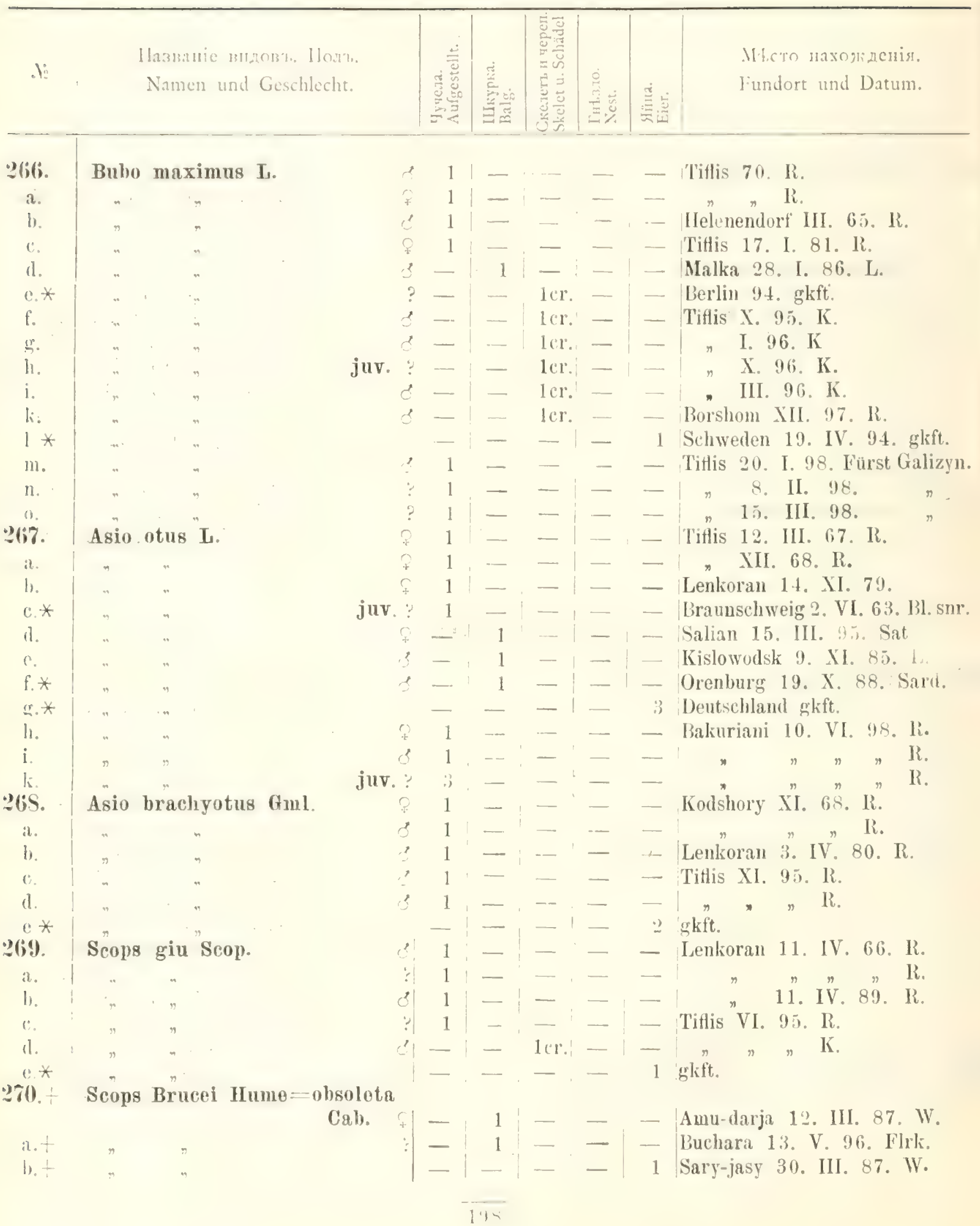




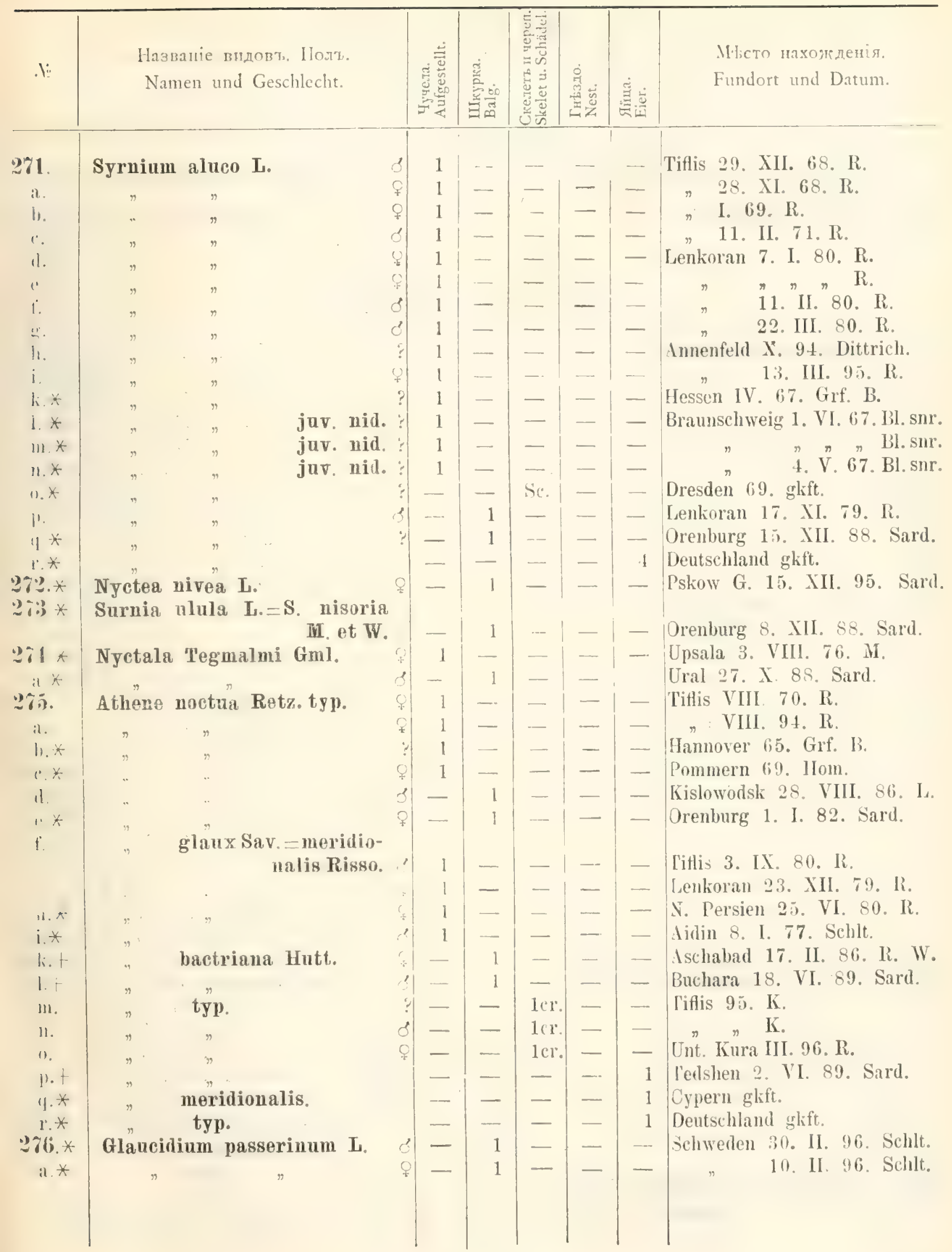




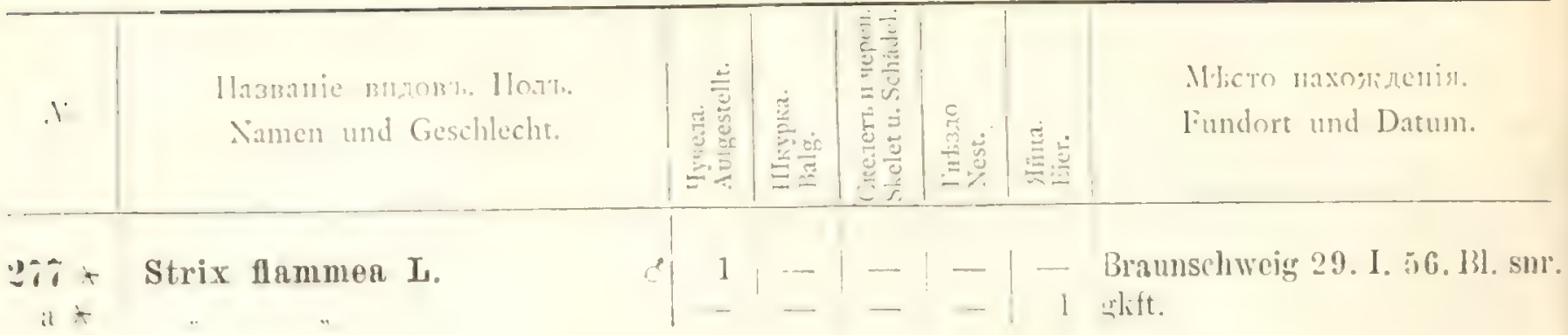

\section{FAM. FALCONIDAE}

?is. Circus aernginosus L. ad.
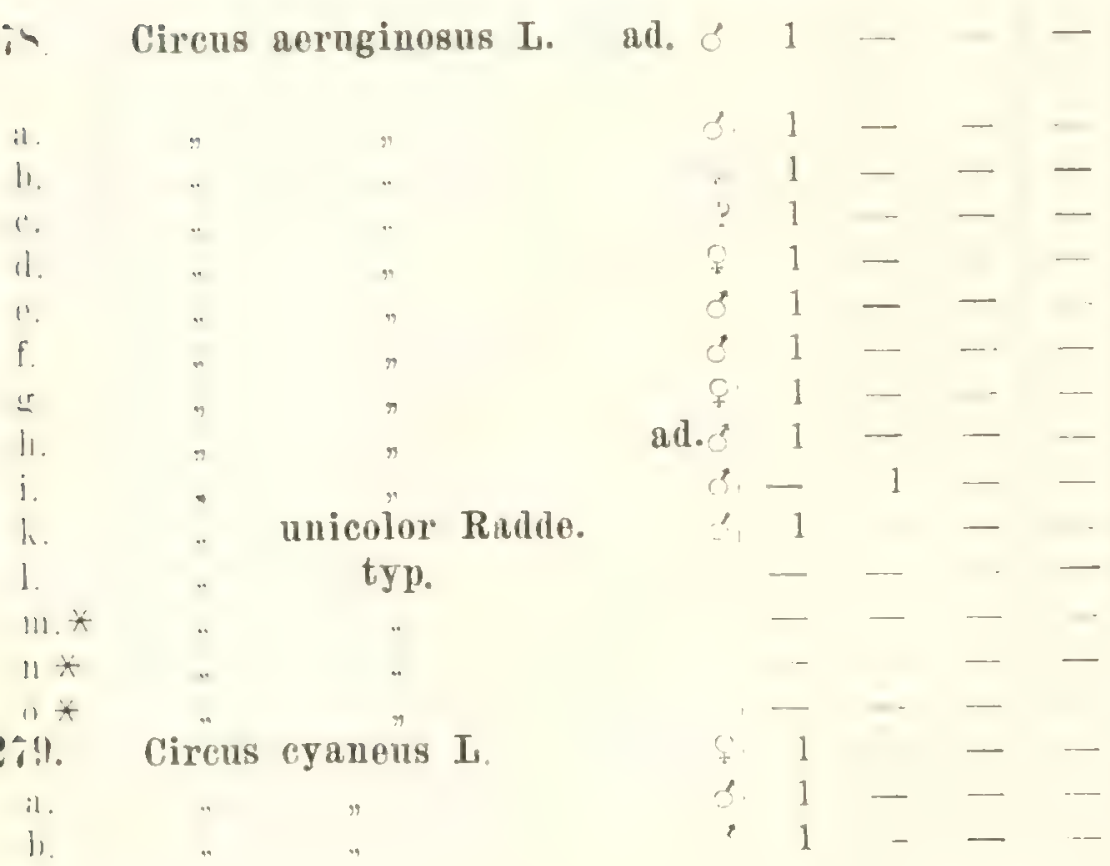

Tiffis 2. IV. 76. Sr. K. H. Grf. Nik. Nich.

- Lenkoran 14. XI. 79. R.

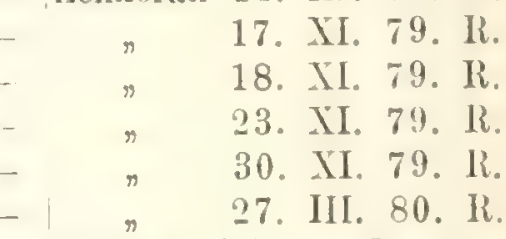

- Tiflis 9. IV. 82, R.

n $\gg \pi \mathrm{l}$.

- Borshom 30. III. 96. R.

- Tuenkoran 17. III. 80. R.

$+\pi$ 12. IV. $80 . \mathrm{h}$.

1 Ungarn 11. V. 94. gkit.

26. VI. 94. glift.

1 Deutschland ghlft.

Tiflis III. 68, R.

27!. Circus eyaneus L.

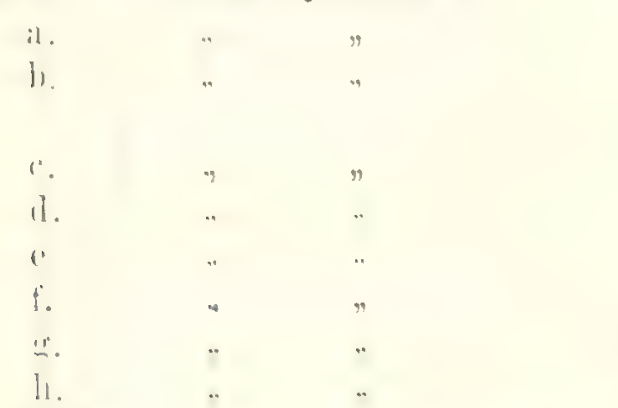

$\Rightarrow \quad \mathrm{I} .76 . \mathrm{R}$.

ᄁ IV. 76. Sr. K. II. Grf.

Nik. Mich.

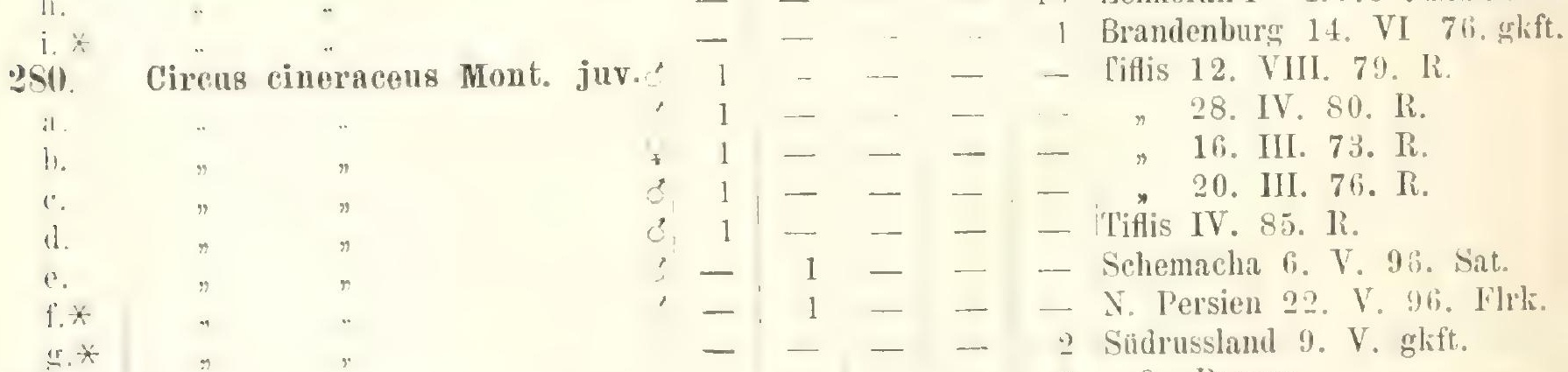

l. $\quad-\ldots-\ldots$ ? Bayern.

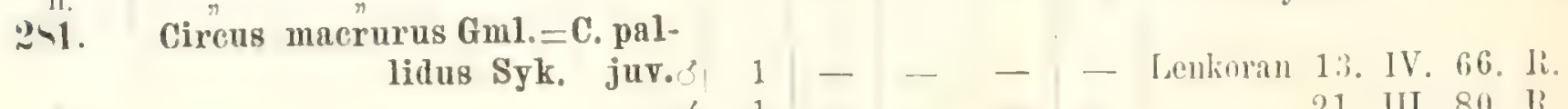

a. 


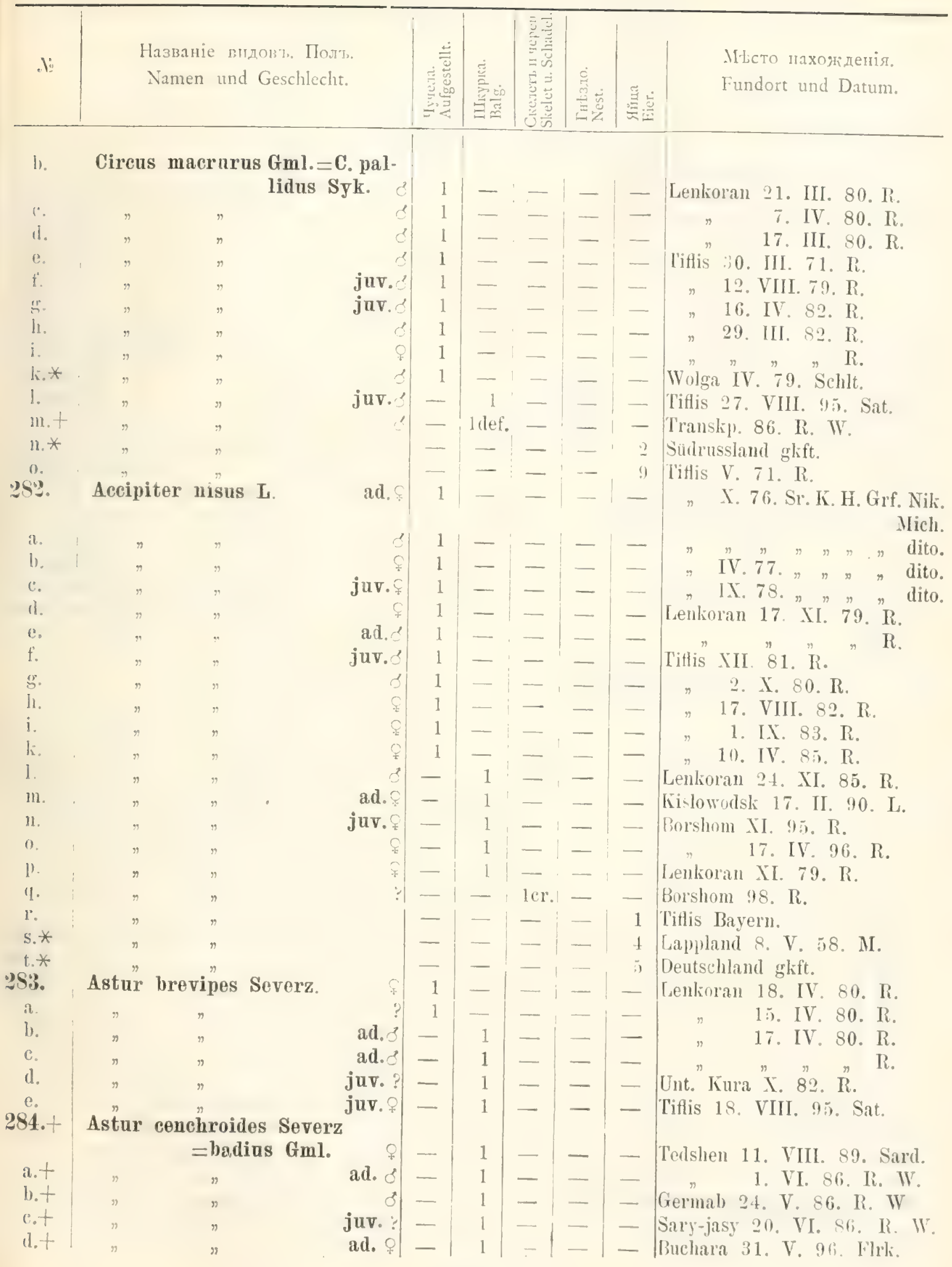


Ilazmanic muon:t. Inols.

Namen und Cissthlecht.

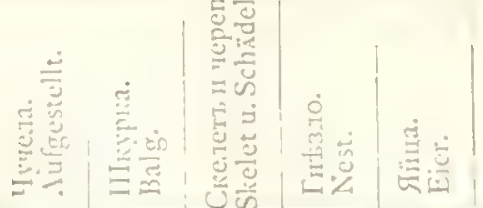

Ilkeто пахояденія.

Fundort und Datum.

\section{r.t Astur conchroides Soverz \\ = badins Gml.}

\section{5,5}

i.

1.

e.

il.

c.

f. $*$

fr. *

l. $*$

i.

k. *

1.*

111.

286.

i. $*$

b. $*$

c. $*$

d.*

c. $*$

f。 $*$

$28 \%$

al.

b.

c.

1.t$$
\text { f. }
$$

n.

h.

i.

k.

1. *

in. *

11. *

0 .

1 .

1.

I.

$$
\text { s. }
$$

t. $*$

u. $*$

$r$.

258.

¿.
Astur palumbarius L. juv. ad. juv. ad.

Erythropus vespertinus $L$.

\section{Tinnunculus alaudarius Briss.}

ad.

nid.

juid. 


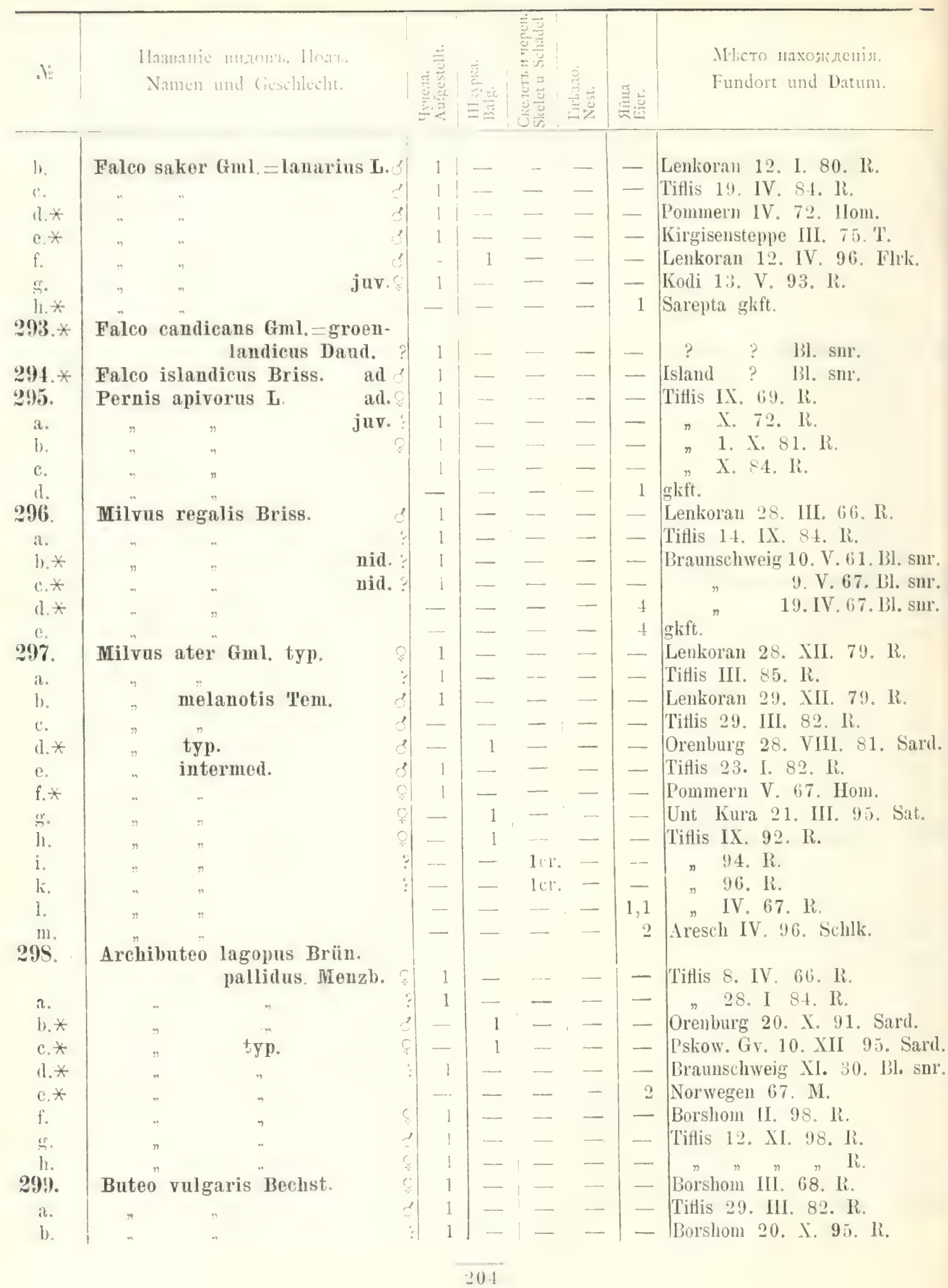




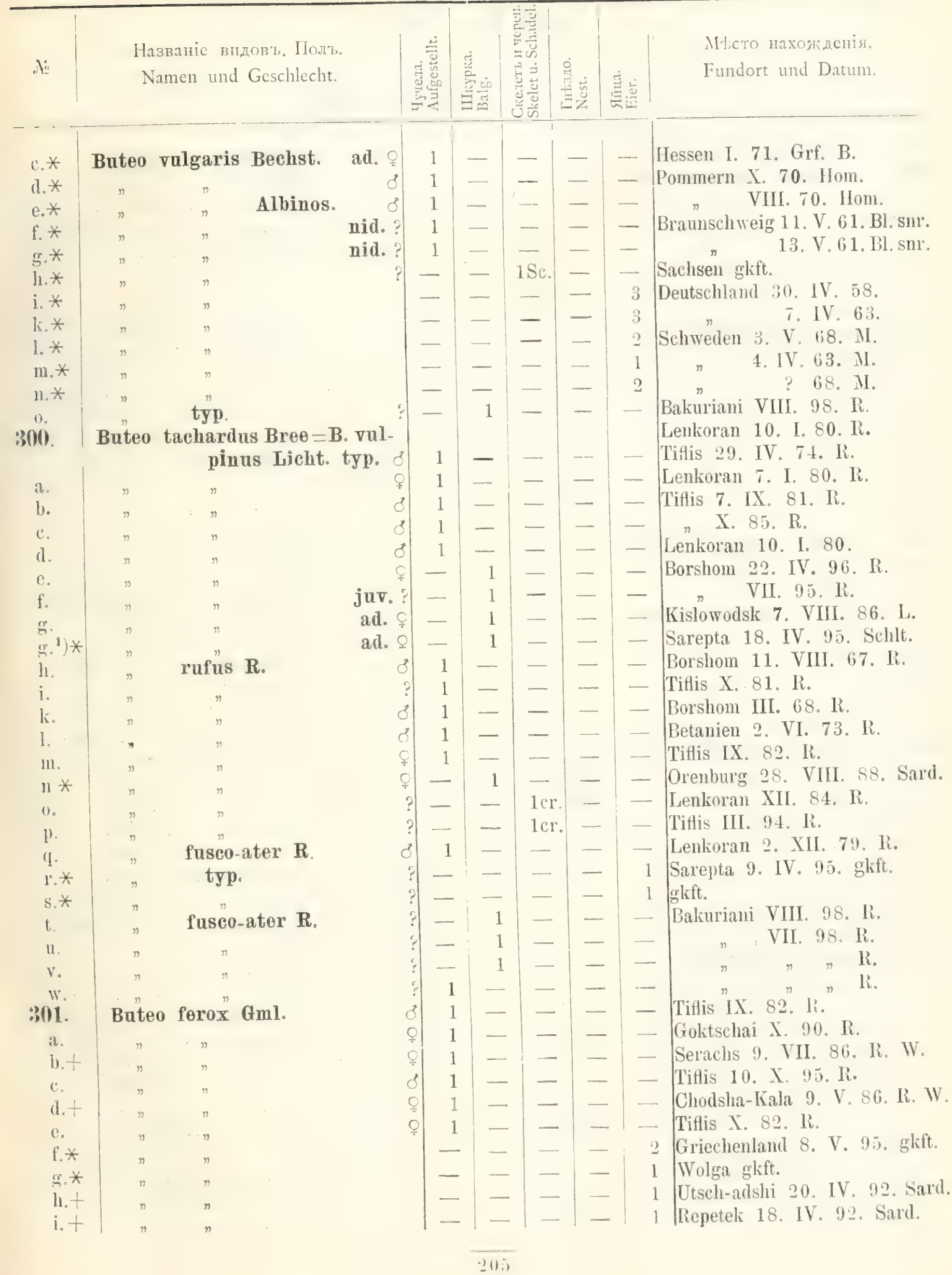


Haзваніе myor\%. Iloim.

Namen und Geschlecht.

\section{$30 \%$}

a.

b. $*$

c.

d.

c.

30\%. Paüdion haliaëtos $\mathrm{L}$.

a.

b.

c.,

d.

c.

is.

301.

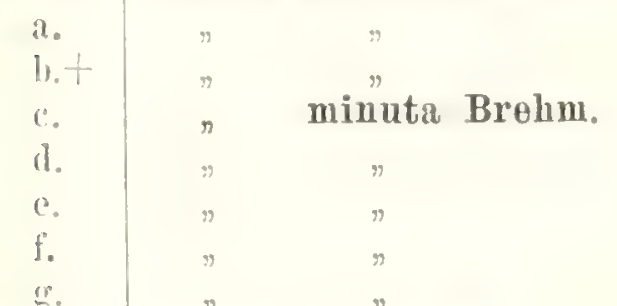

305 .$$
\text { (1) }
$$$$
\text { (1) }
$$$$
\text { (1) }
$$

306. Aquila clanga Pall.

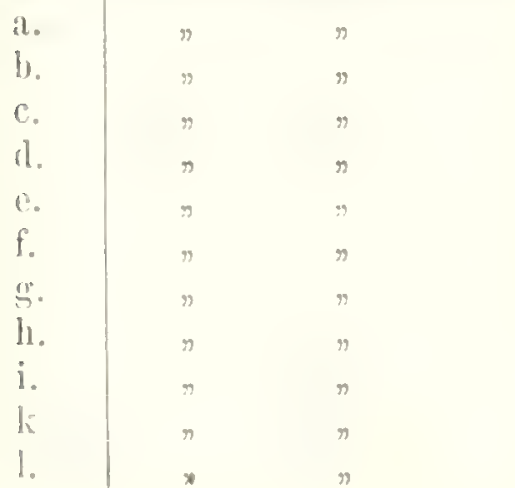

Buteo ferox Gml.

Circaëtos gallicus Gml. typ.

Aquila naevia Meyer. juv.

$$
\text { ad. }
$$

ad.

juv.

juv.
Micто нахондсиія.

Fundort und Datum.
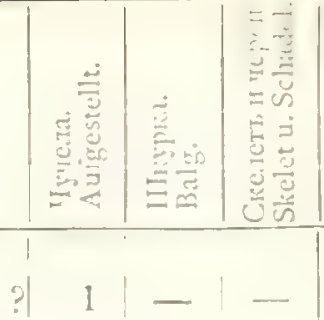

1

- 1 - $-\mid$ Kakuriani 15. VIII. R.

ㄴ 1 - - - Chram 2. IX.92. R.

. - $-1-1-$ Pskow 27. IV. 97. Sard.

? $1-1-$ Titlis IX. 85. R.

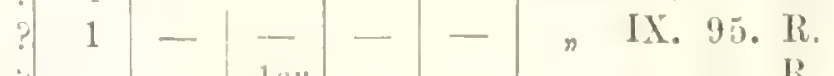

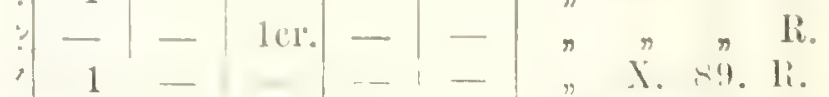

8 1 - $1-1-|-|$ Lenkoran IV. 66. R.

8 1 - - - 1 26. III. 80. R.

$\div \quad 1--$

$-$ n $\rightarrow$ R. 15. II. 92 . R. 20. IV. 84. R. Lenkoran IV. 66. R. 3 " " R.

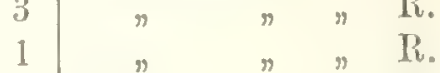

$1 \% n$ R.

- Tiflis 19. VIII. 80. R. IV. 85. R.

- Translip. 24. VII. 92. Sard. - Tiflis 6. IX. 81. R.

- $\quad 28 . \mathrm{IX} .82 . \mathrm{R}$.

- Lenkoran 21. IX. 84. R. Tiflis 25. I. 85. R.

- Borshom 18. IV. 96. IR.

1 Karyent 5. V. 92. Sard.

- Bakuriani IX. 98. R.

- $"$ " $"$ R.

- Ungarn X.77. Schlt.

- ? Hom.

- Braunschweig Bl. snl.

- Pskow 14. V. 95. Sard.

1 Pommern 9. V. 60. Hom.

Tiflis X. 98. R.

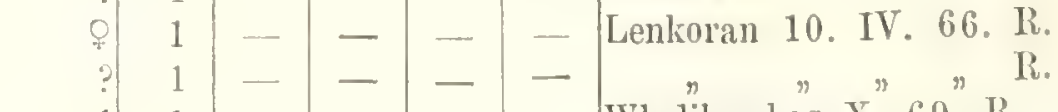

Wladikawkas X. 69" R.

- Lenkoran 16. XI. 79. R.

- 24. XI. 79. R.

- $\quad$ 9. XII. 79. R.

$R$.

7. X"II. 79. IR.

24. I. 80 . R.

$n n$ R.

II. $92 . \mathrm{R}$. 


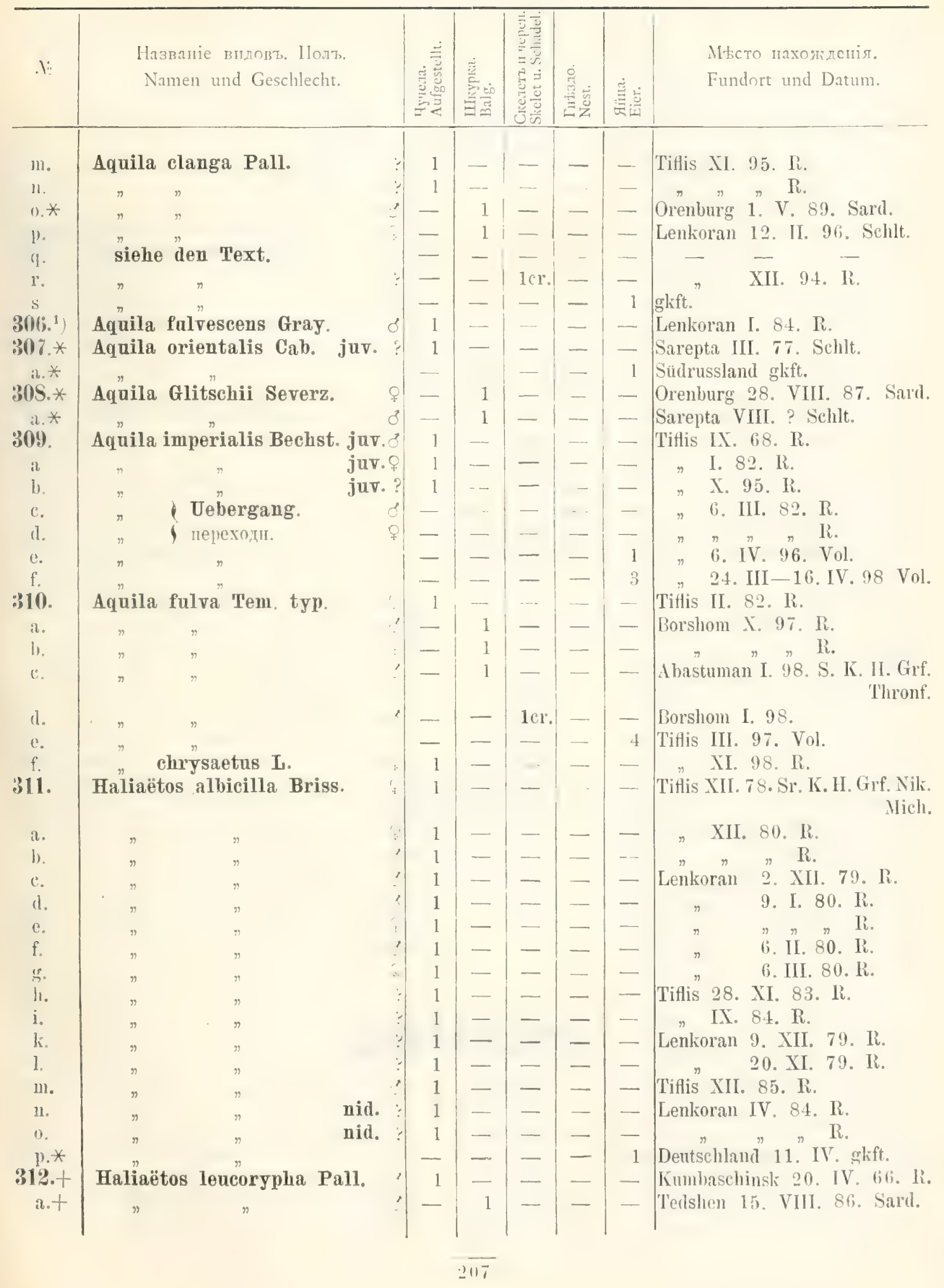




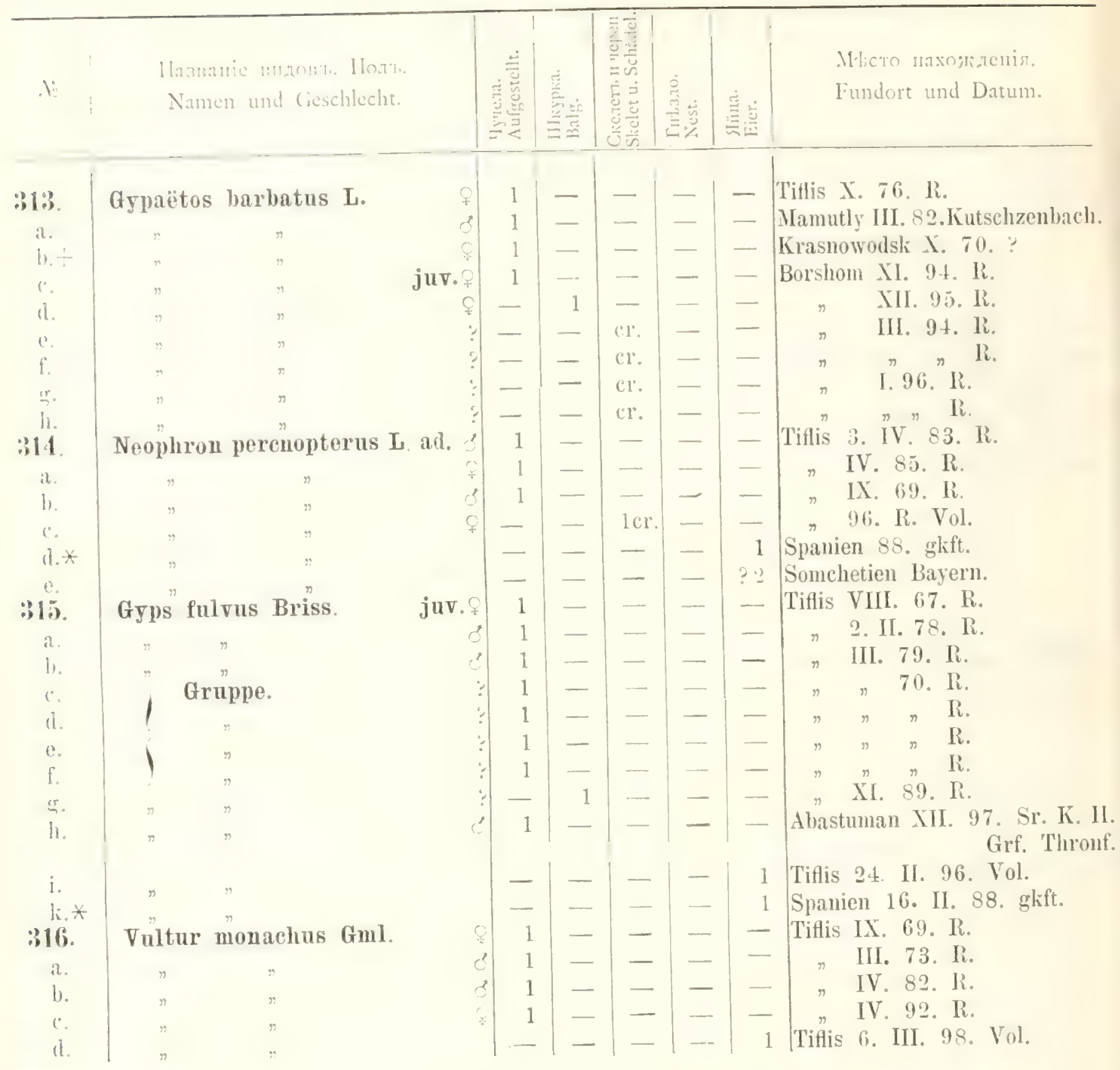

\section{STEGANOPODES.}

FAM. PELECANIDAE

31\%. Pelecants erispus Bruch. \& $1|-|-|-|-\mid$ Lenkoran 3. XII. 79. R.

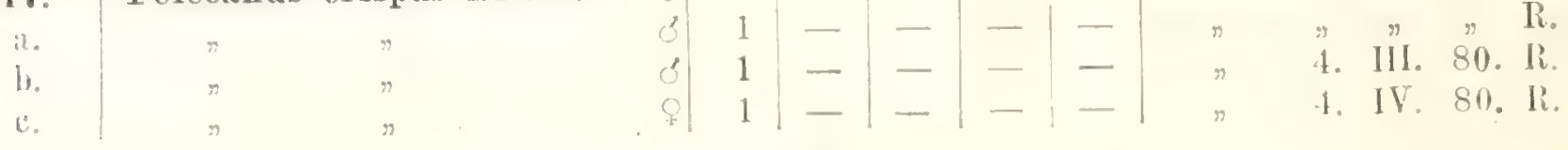




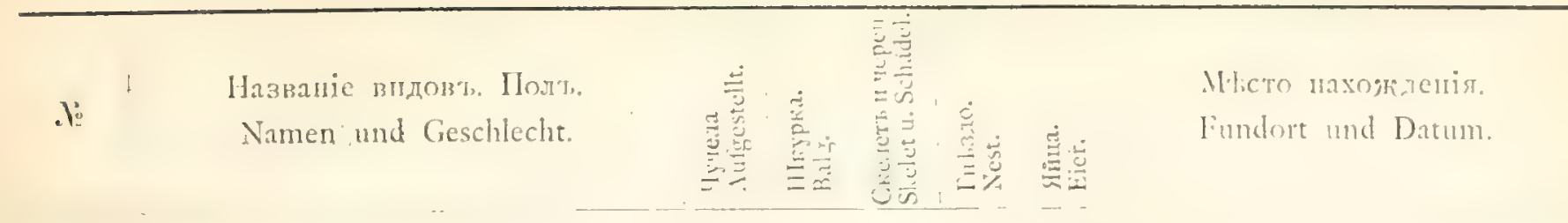

1. Pelecanus crispus Bruch.

c.

f.

:318. Pelecanus onocrotalus L.

a.

b.

319. Pelecanus minor Rüpp.

a.

b.

320. Phalacrocorax" carbo L.

a.

b.

c.

d.

3:1. * Phalacrocorax graculus L.

a. $*$

:

a.

b.

$t^{2}$.

11

ad.

Lenkoran IV. 66. R.

dkuscha 15. V. 80. R.

gkift.

'Titlis II. 68. IR

Lonkoran 20. III. 80, R. gkft.

Lenkoran 21. III. 80. Ii. 12. II 80 , Ii. 14. III. 80. IR.

1 Akuscha 11. III. 80. Ii.

- Lenkoran 1. IV. 67. IR.

- Tithis 7. ILI 71. I.

15. X. $73, \mathrm{R}$.

Borshom 13. II. 96. Sr. K. H.

Grf. Nik. Nich.

ghift.

Norwegen 11 om.

2 gkft.

Lenkol'an 1. IV. 66. IR.

Tittis I. 71. R.

Lenkoran 18. XI. 7!。 R.

IV. $80, R$.

\title{
A N S E R E S.
}

\author{
$F A M A N A T T D A E$
}

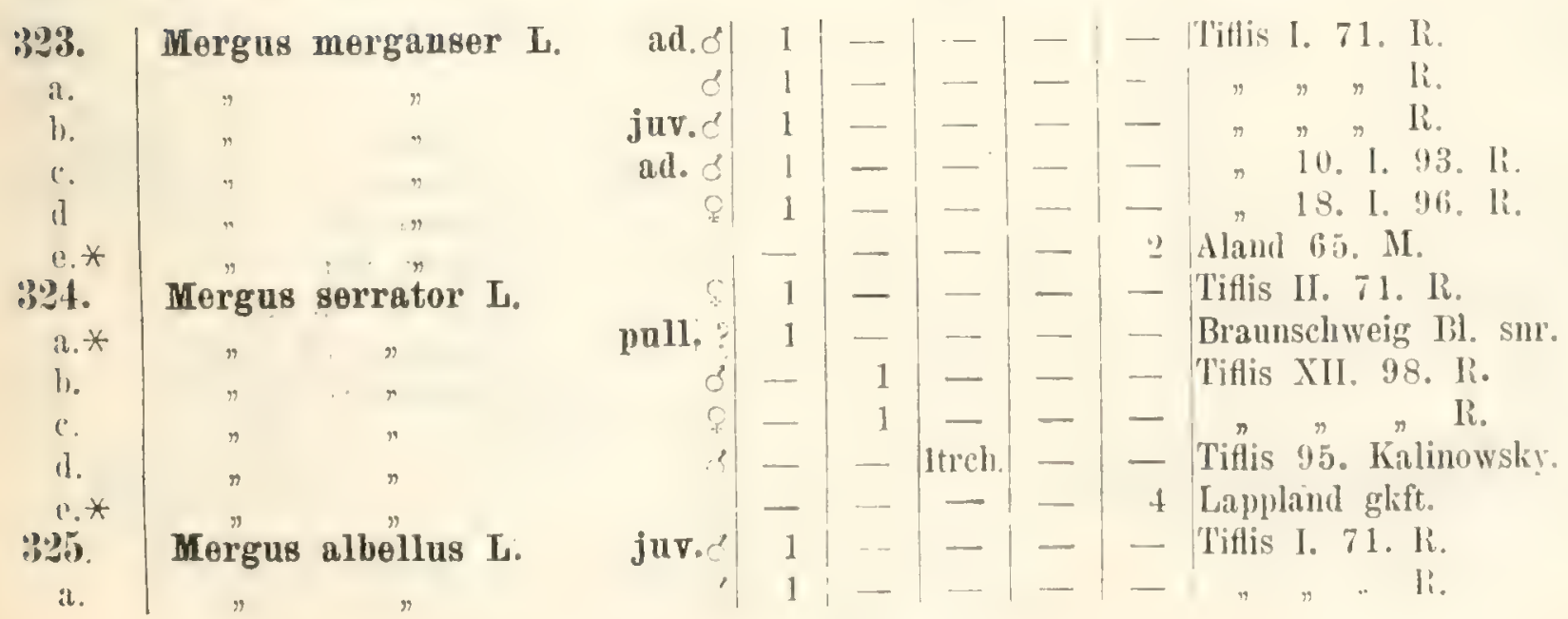




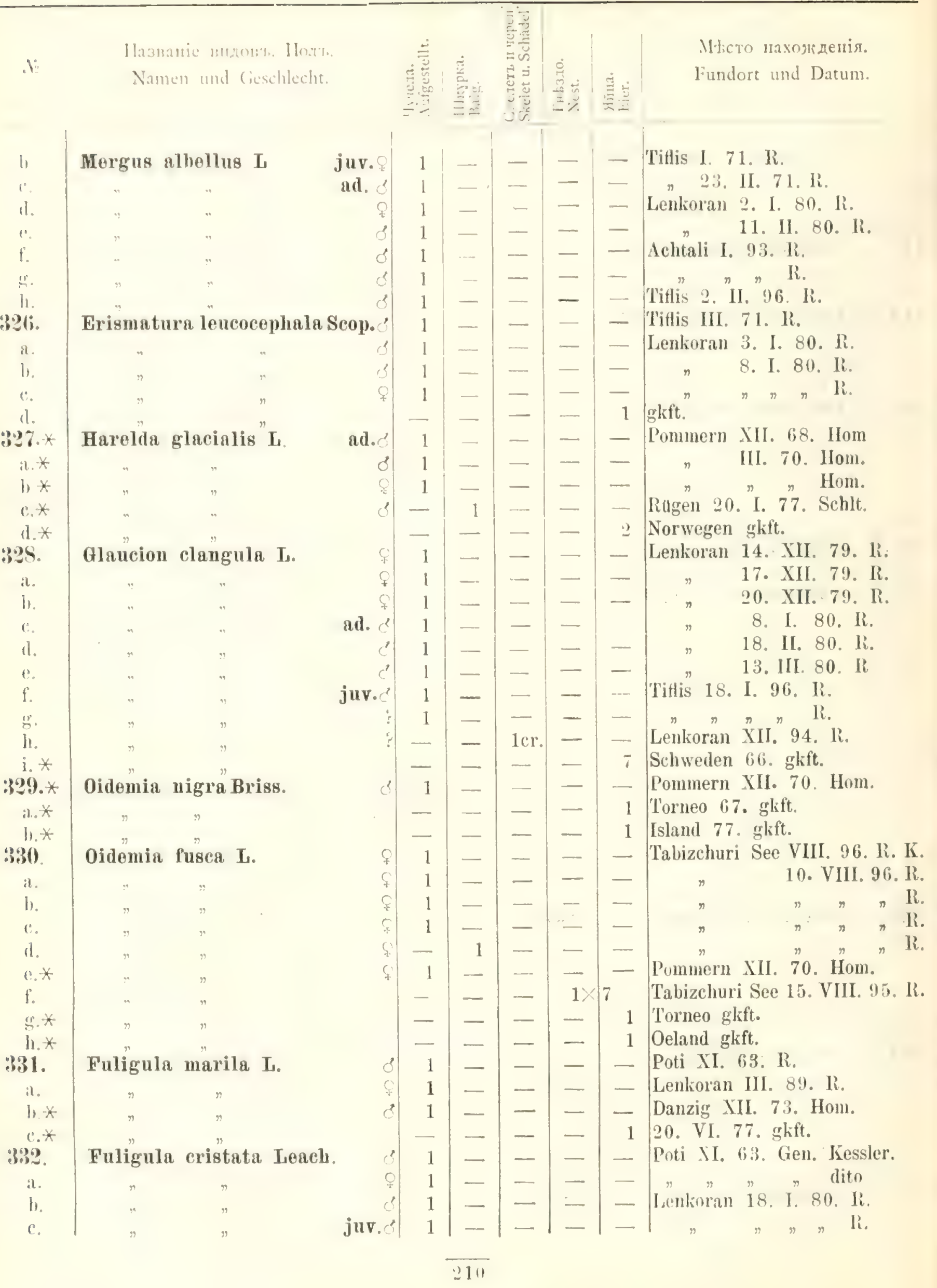




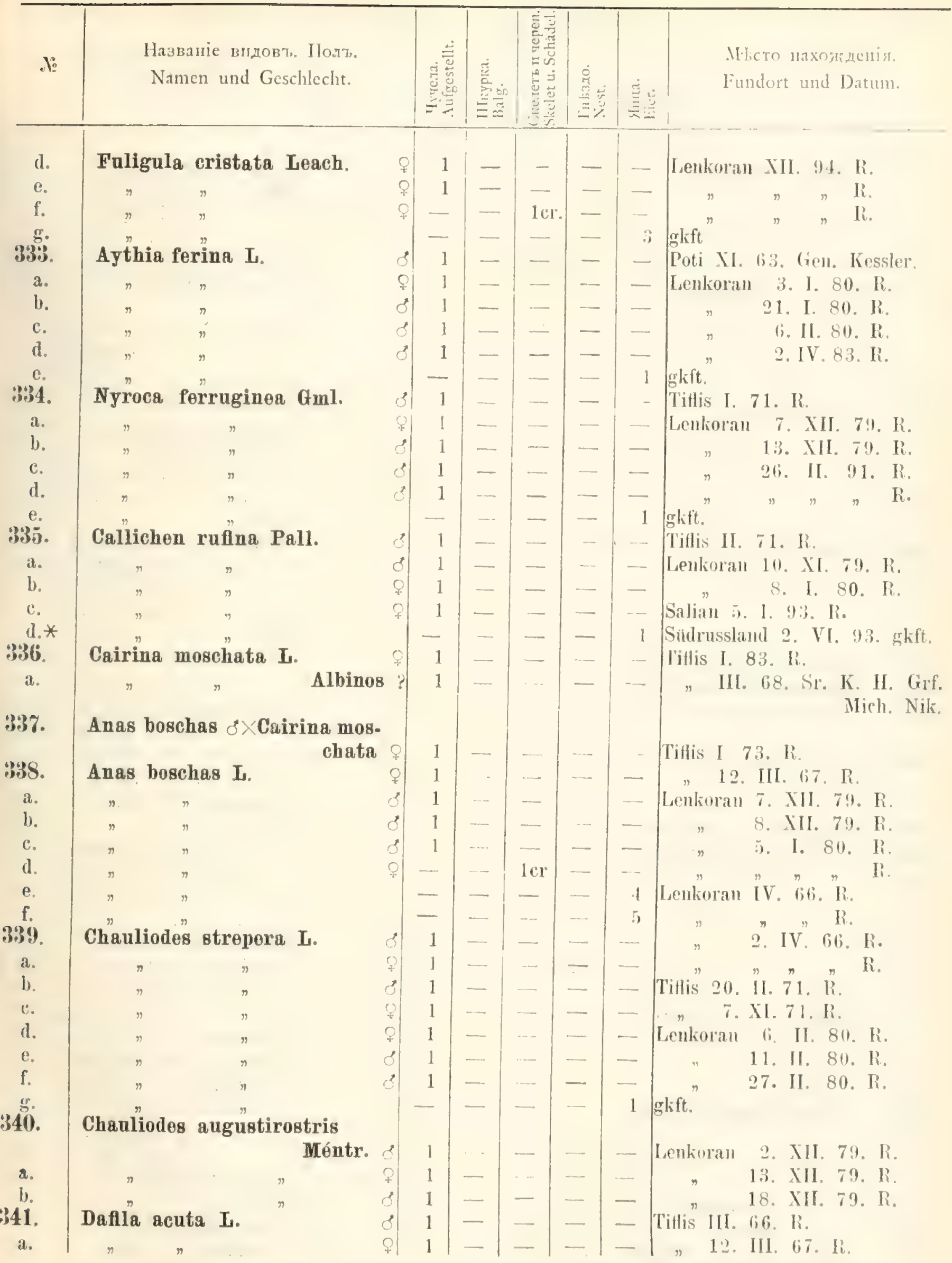




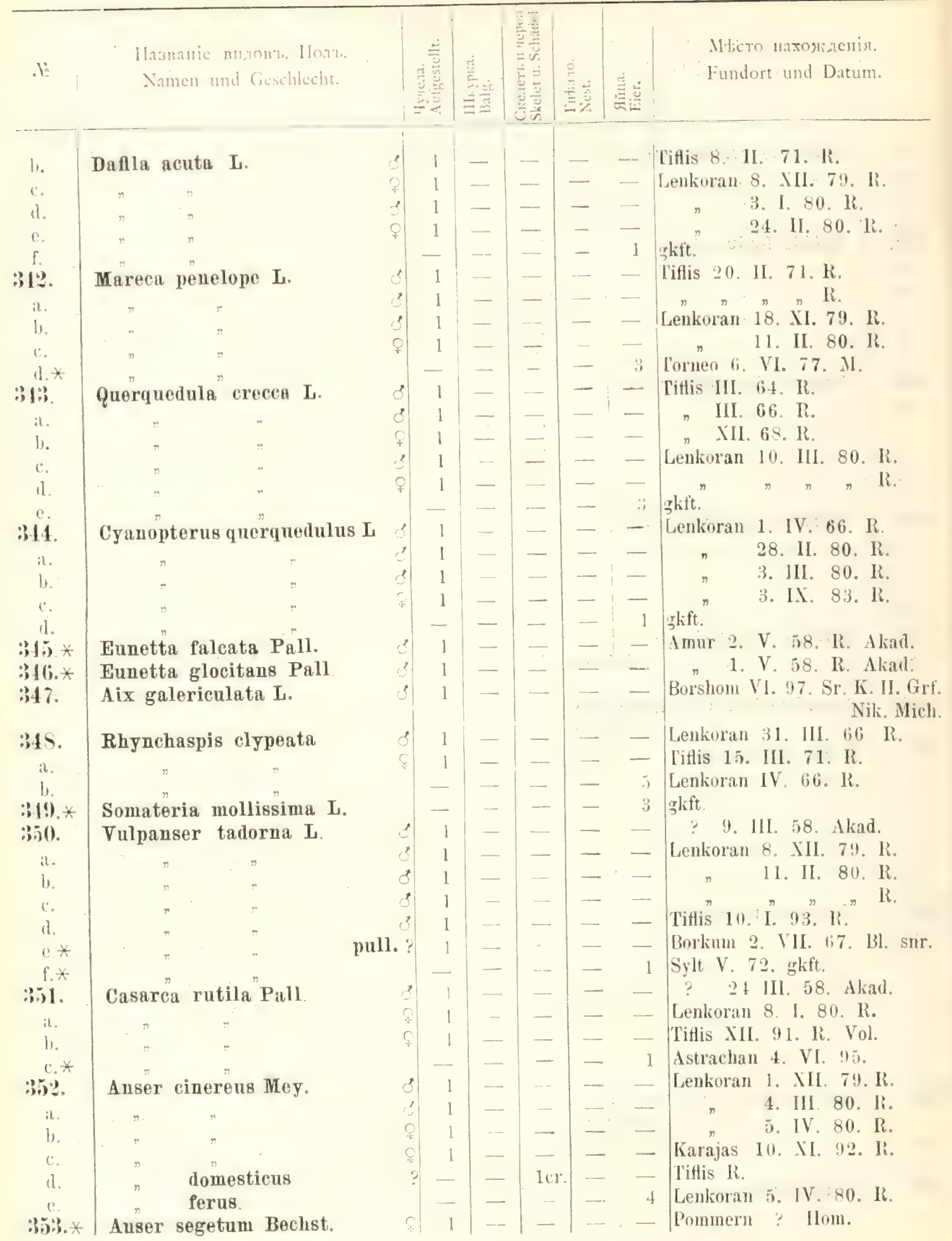




\begin{tabular}{|c|c|c|c|c|c|c|c|}
\hline. & $\begin{array}{l}\text { Haзвансі ендов'. l Іол", } \\
\text { Namen und Geschlecht. }\end{array}$ & 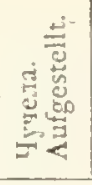 & 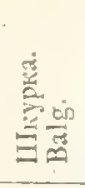 & 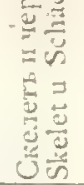 & 要 & 总 & $\begin{array}{l}\text { Mtcro пахояденis. } \\
\text { Fundort und latum. }\end{array}$ \\
\hline
\end{tabular}

354. Anser albifrons Penn. $=$ erythropus $\mathbf{I}$.

a.

औ. Anser minutus Naum. =erythropus Pall.
a.
b.
c.
l.

156. Bernicla rufficollis Pall.

a.

b.

c.

d.

357. Cygnus olor. "Gml.

a

d. *

e.

:35. Cygnus musicus Bechst.

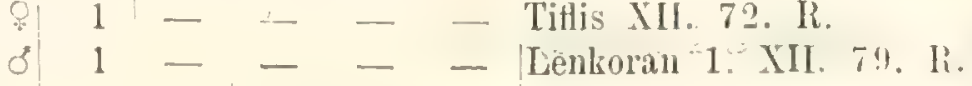

? - - Icr. _ - Tittis III. 96. li.

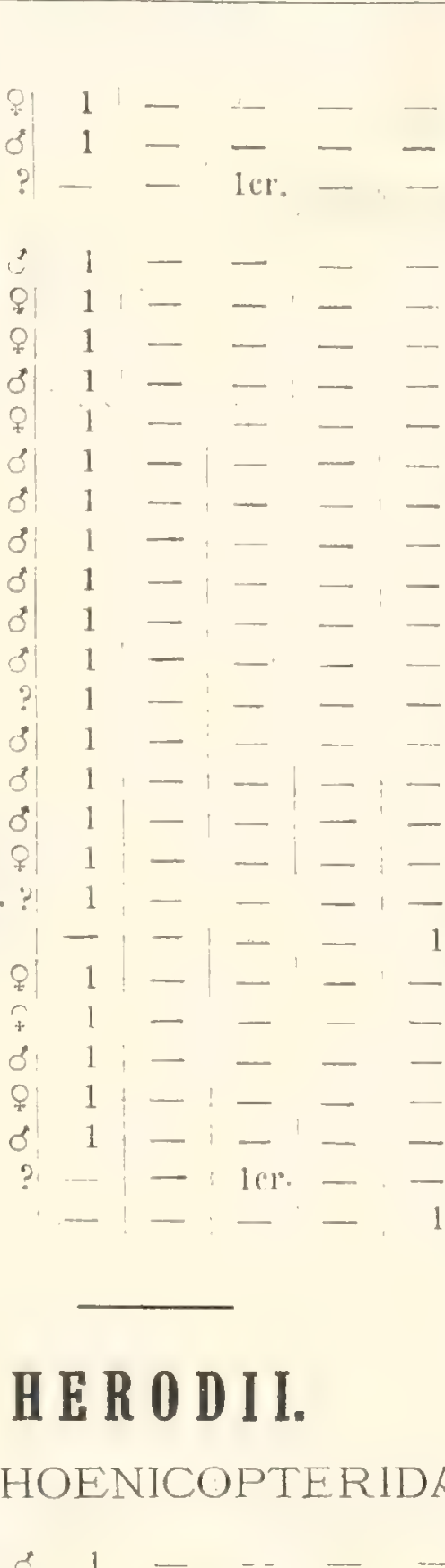

FAM. PHOENICOPTERIDAE.

8.) P. Phoenicopterus rosens Pall.

il
h.
i".
di.
e.
id.

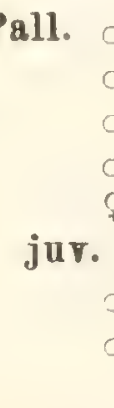
Lenkoran 22 IX. 79. R.

$\pi \sim n$ li.

9. XII. 79, R.

$n \rightarrow \mathrm{R}$.

22. I. 80. R.

8. II. 80. R.

21. II. 80 . R.

28. II. 80. R.

$n \pi, \mathrm{R}$.

10. III. 80 . R.

11. III. 80. Ii.

Lenkoran 18. II. 80. R.

21. II. so. R.

26. II. 80 . R.

27. II. $80 . R$.

Braunschweig Bl. snr.

gkft.

- Lenkoran 22. II. 80. R. 26. II. 80 . R.

b.

d.

e.

f.*

$\because$. : R

27. II. $80 . \mathrm{R}$.

liftis XII. 70. R.

1 Island 9. VI. 95. gkft. 


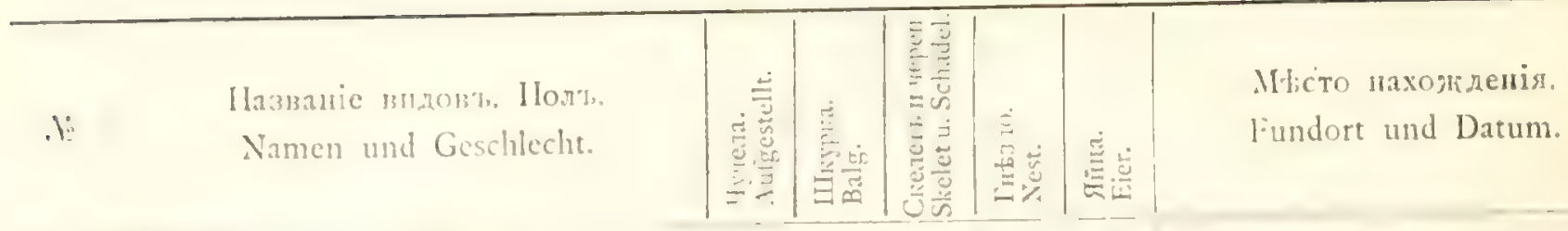

:360. Platalea leucorodia L.

it.
b.
c.
i.

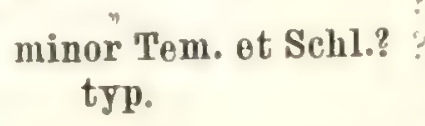

FAM. I B I D A E.

\section{:31. Plegadis falcinellus $\mathrm{L}$.}

$i$.
$i$.
$i$.
$i$.
$\therefore$.

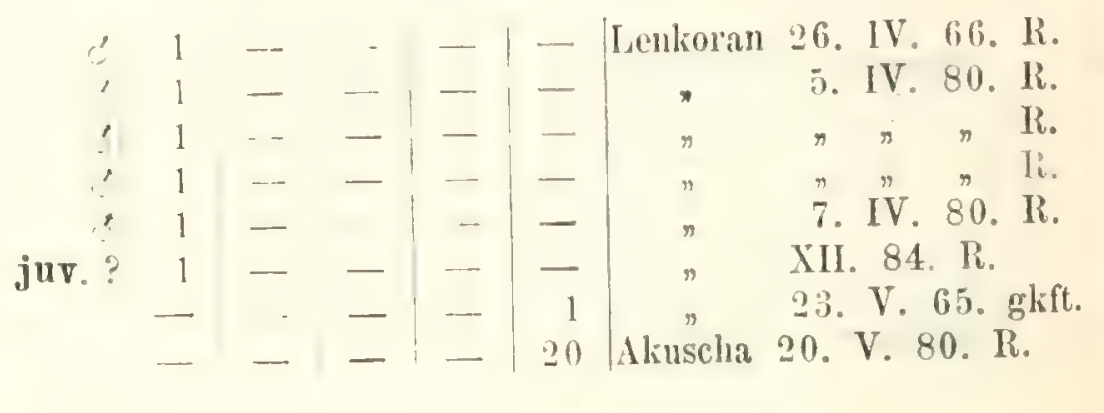

:36:. Ciconia nigra L. 1.

36:3. Ciconia alba Briss.

:iit. Ardea cinerea L.

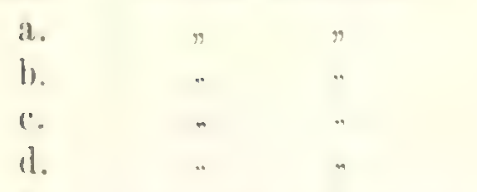

36.). Ardea purpurea L.

\section{FAM CICONIJDAÉ.}

- Tiflis VIII. 69. $k$.

- Baku IX. 85. R.

- Tschikisljar III. 86. Jad.

9 Akuscha 15. V. 80. R. 1 gkft.

$$
\begin{aligned}
& \text { ¿ } 1 \text { _ _ _ _ Lenkoran IV. 66. R. }
\end{aligned}
$$

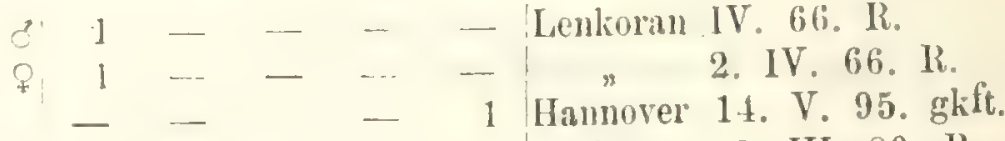

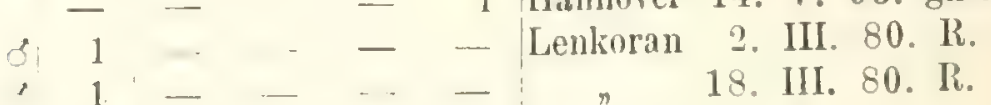

$$
\begin{aligned}
& 1 \text { - } 1 \text { - - Tiflis IV. 85. R. } \\
& \text { 8. } 1 \text { - - - Unt. Kura 12. IV. 94. R. } \\
& \text { c. " ? " - }
\end{aligned}
$$

\section{F A M. AR DEIDAE.}




\begin{tabular}{|c|c|c|c|c|c|c|c|}
\hline . Ii & $\begin{array}{l}\text { Названie вндовт. Нолт. } \\
\text { Namen und Geschlecht. }\end{array}$ & 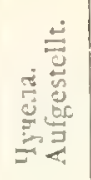 & 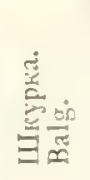 & 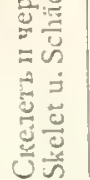 & 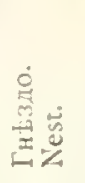 & 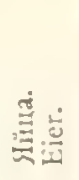 & $\begin{array}{l}\text { Mtсто нахояденіл. } \\
\text { Fundort und Datum. }\end{array}$ \\
\hline
\end{tabular}

366. Herodias alba $\mathrm{L}$.

a

a.
b.
c.
d.
e.
f.
$\mathrm{g}$.
$\mathrm{h}$
$\mathrm{i}$.
$\mathrm{k}$
$\mathrm{l}$

367.

a.

b.

c.

d.

e.

368

$$
\begin{aligned}
& a \\
& b \\
& \text { d }
\end{aligned}
$$

369

i.

370. Botaurus stellaris $\mathrm{L}$.

$3 \% 1$.

.

Egretta garzetta L.

Bubalcus ibis Hassq.

Ardeola comata Pall.

a.

b.

c.

d.

e.

f.

*..* $*$

Botaurus minutas $\mathrm{L}$. $=$ russata Keys et Bl.

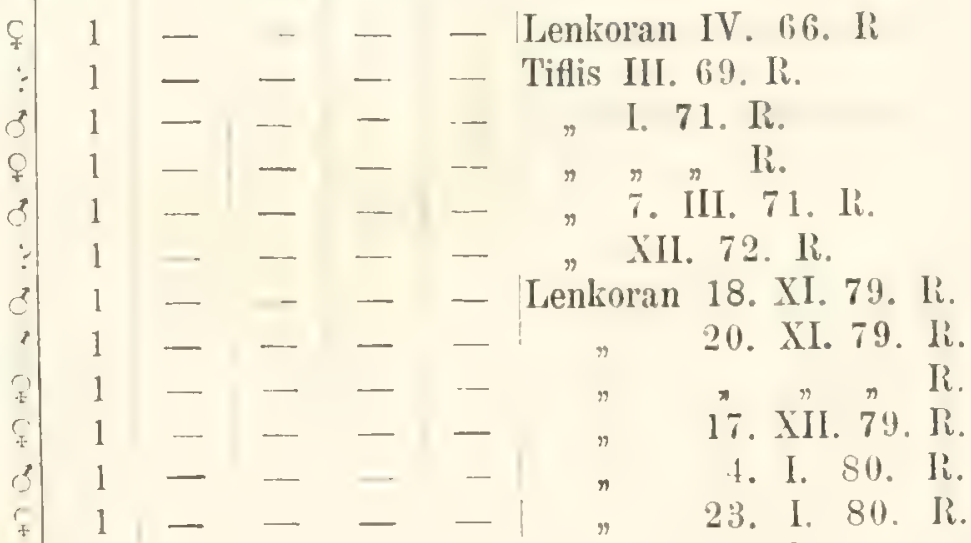

1 18. V. 70. gkft

- Lenkoran 1. IV. 66. R. 28. XII. 89. R. 2. I. 80 . li.

- Baku 14. X.82. R.

- Unt. Kura 5. IV. 94. R.

13 Akuscha 15. V. 80. R.

1 gkft.

Lenkoran 22. XI. 79. R.

- Unt. Kura 17. VII. 79. R.

-,$n$ n $\mathrm{R}$

- Lenkoran 16. IV. 82. T.

- Unt. Kura 27. VI. 93. Schllk.

4 Aresch 28, IV. 95. Schll.

- Lenkoran 19. IV. 66. R.

21. IV. $66 . \mathrm{IR}$.

Tiflis 12. VIII. 79. R.

8 " 8 " 15 " V

1 glift.

- Tiflis X. 64. Sr. K. II. Grf. Mich.

- Lenkoran 30. XI. 79. R.

31. XI. 79. R.

2. XII. 79. R.

6. XII. 79, R.

8. XII. 79. R.

Nik.

Tiflis IX. 83. R.

1 Sutdrussland gkft.

- Lenkoran 21. IV. 66. R.

17. IV. $80 . R$.

23. IV. 80. li.

24. XII. 84. R.

li. 

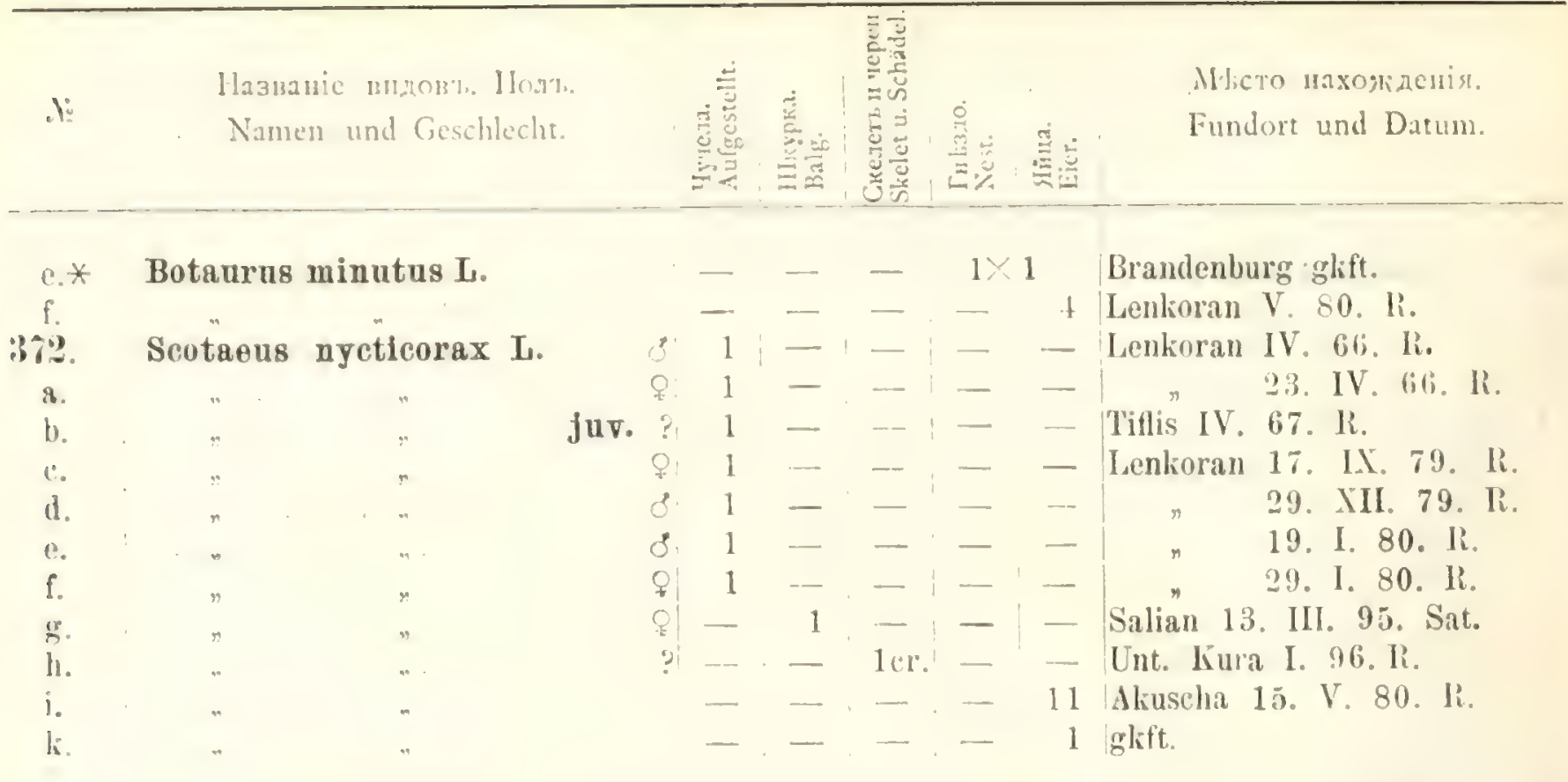

\title{
COLUMBAE.
}

\author{
FAM, COLUMBIDAE.
}

:17:?. L Peristera cambayensis Gml.

:if. Turtur auritus $\mathrm{L}$.

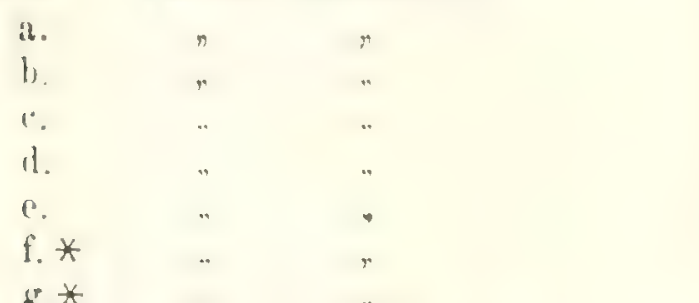

:37\%. * Turtur ferrago Evrs.

:376. Turtur risorius $\mathrm{L}$.

il.

1.

$: \because \%$ Columba palumbus $\mathrm{L}$.

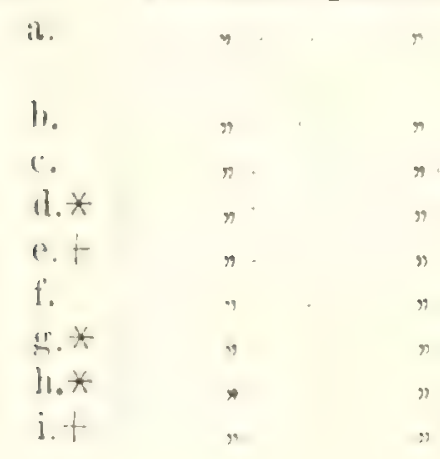

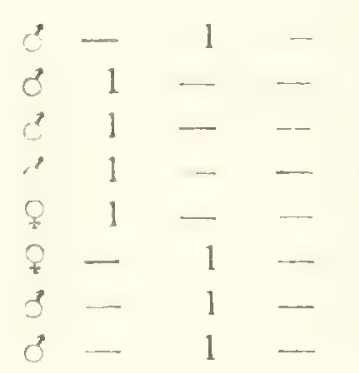

- - Tschardshui 8. III. 87. W.

- Lenkoran IV. 66. R.

- 28 . IV. 66 . R.

- Tiflis 2. VI. 81. R.

- Unt. Kura 14. V. 95. Sat,

- Podkumok 28. V. 85. L.

- Hessen 4. VI. 76. Grf. B.

2 Ungarn 6.VI. 95. gkft.

- Baikal? 76. gkft.

- Tiftis 95. R. Vol.

- 7 " $" 95-97 . ~ V o l$.

- Tiflis 25. XI. 68. Ii.

- IX.76. Sr. K. H. Grf. Nik.

- Aresch III. 94. R.

Mich.

14. III. 94. R.

- Hessen IV. 64. Grf. B.

- Tschuli 27. V. 86. R. W.

- Unt. Kura 2. V. 96. Sat.

1 Schlesien 28. IV. 94. ghft.

1 Halle 4. V. 95 gkft.

- Tschuli 27. V. 86. K. W. 


\begin{tabular}{|c|c|c|c|c|c|c|c|}
\hline li & $\begin{array}{l}\text { Названіе вгдов'ь. Иолт. } \\
\text { Namen und Geschlecht. }\end{array}$ & 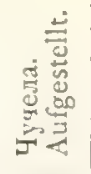 & 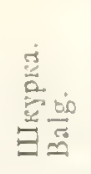 & 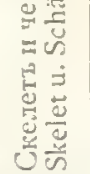 & 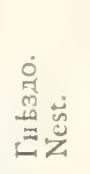 & 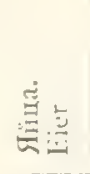 & $\begin{array}{l}\text { Mьсто нахождсиія. } \\
\text { Fundort und Datum. }\end{array}$ \\
\hline
\end{tabular}

:37. Columba livia Briss.

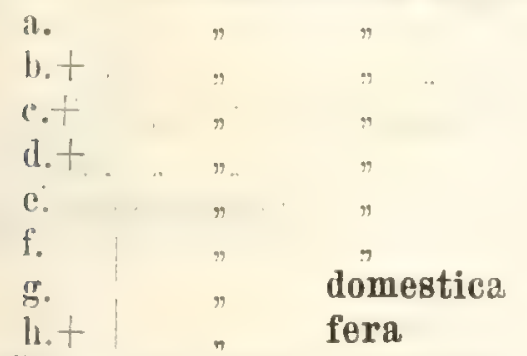

399.* Columba rapestris Pall.

:30. - Columba fusca Pall.

381. Columba oenas Gml.

a.

b.

c.

d.

e.t

f. *

g.*

\section{intermedia Sarud.}

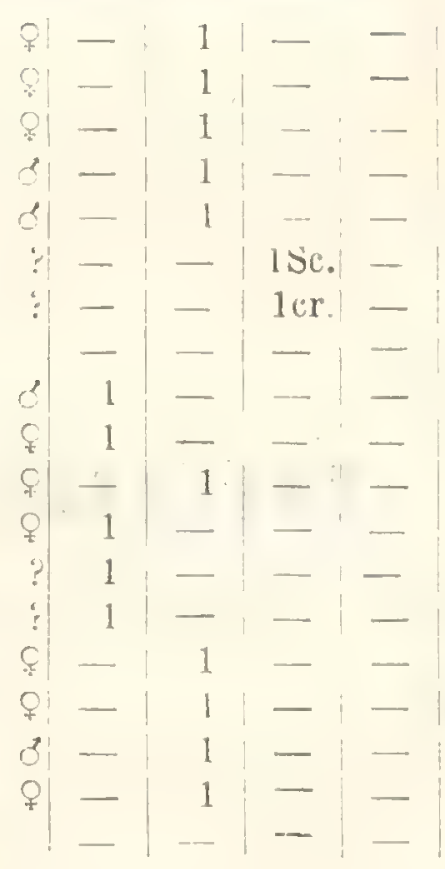

- N. Kauk. 9. II. 86. I.

- Malka 21. II. 86. L.

Germab 5. III. 86. R. W.

R. iV.

n $"$ " R. W.

Deutschland gkft.

Gudaur XII. 94. K.

j Tiflis III. 96. Vol.

Geok-tepe 6. III. 86. R. W.

- Bailial 22. III. 70. gkft.

- Chodsha-Kala 9. V. 86. R. W.

- Lenkoran 11. IV. 66. R.

Tiflis IX. 66. R.

I. 71. R.

Kuba 29. V. 96. Sat.

- Tiflis 4. V. 95. Sat.

- Duschak 18. III. 86. R. W.

N. Persien 11. V. 96. Sard.

4 Schweden 17-28. IV. 65. M.

\section{FAM PTEROCLIDAE,}

\section{2.+' Syrrhaptes parrdoxus Pall.}

\section{Pterocles arenarius Pall.}
a.
b.
c.
i.
e.
f.
g.t
h. +
i. +
k.t
1. +
m.t
n.t

:84. Pterocles alchata I.

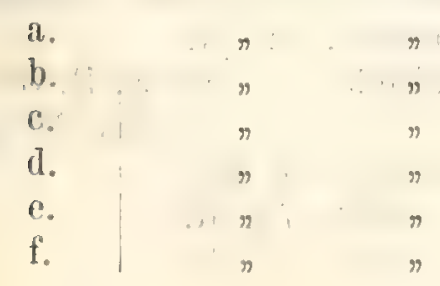

Krasnowodsk IV. 71. Br.v. Mey-

endorf.

Schamchor 8. V. 85. R.

Elisabethpol 8. I. 86. R.

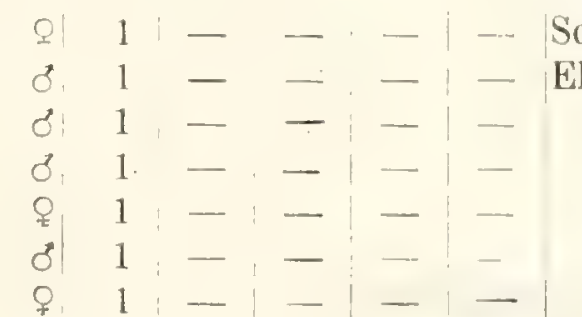

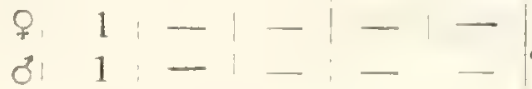

Transkp. 20, II. 86, R. W.

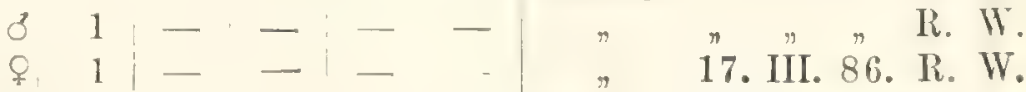

3 3 1 - - - Emba 13. IX. 57. Akad.

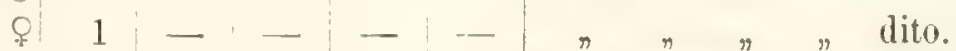

\& - 1 - -1 - Tachta-basar 22. VI. 86. R. W

8 - 1 - 1 - -1 Kuschk 27. VI. 86. R. W.

6 Tiflis 1. VI. 95-6. VI. 97. Vol。

- Lenkoran 1. IV. 66. R.

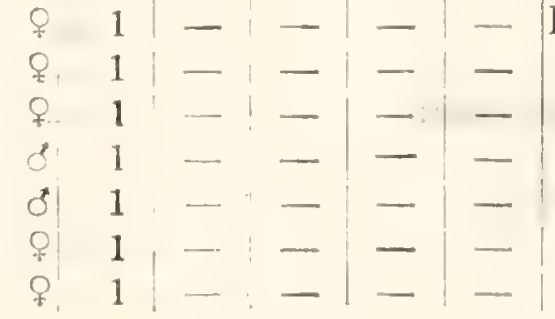




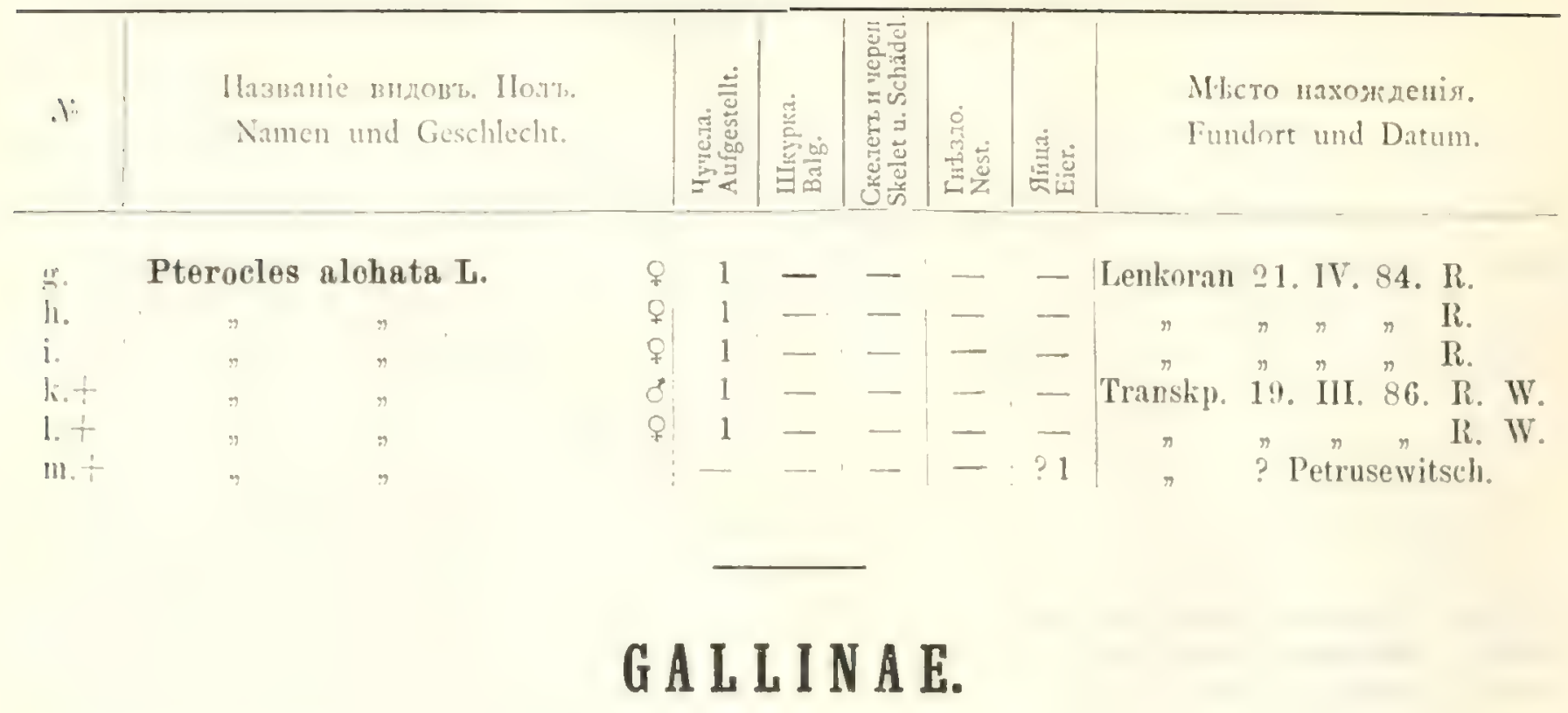

F A M. PHASIANIDAE.

36.). Coturnix communis Bnut.

$\therefore \quad 1--1$ - Helenendurf IV. 65. Schenk.

a. " of 1 " - - - Tlitlis VII. 66. R.

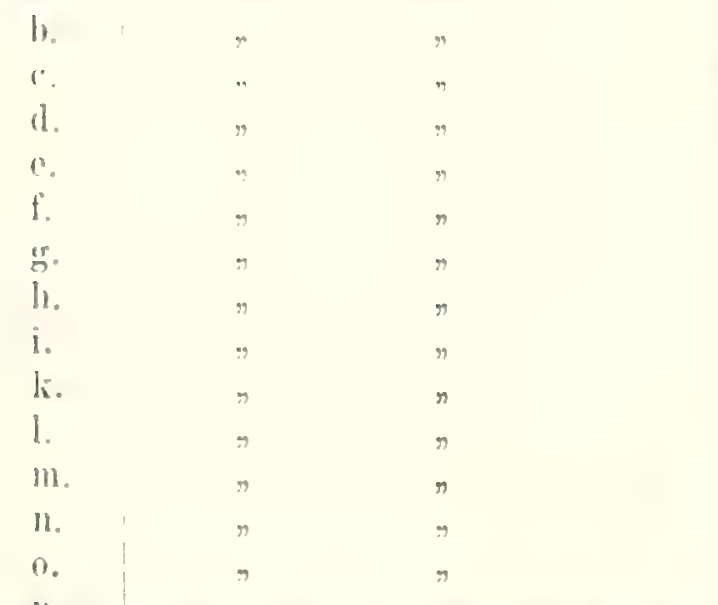

346 Megaloperdix "aucasica Pall.

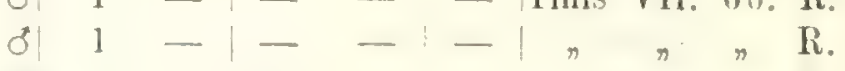

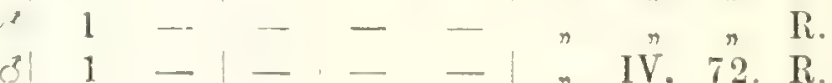

- - -1 - T. $72 . \mathrm{R}$

$1 \quad 1-1-\cdots-1 \%$ -

8| $1-1--1-1$ \% VIII. 74. R.

o 1 - $1-1-1-1-1$ n

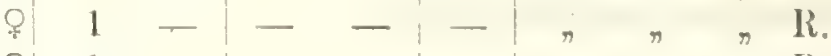

\$ $1-1-1-1-\mid$ n $\quad 1-\infty \quad n$

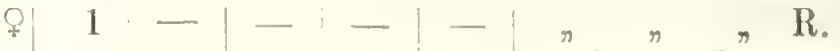

8 1 - - - Borshom IV.97.R.

8 - 1 - - - Stawropol 1. V. 88. L.

o - 1 - 1 - - - Podkumok 28. V. L.

- Unt. Kura 25. V. 95. Sat.

28 Tiflis V. 67-97.

- Wladikawkas I. 64. Kieser.

- Kasbek II. 82. R.

i.

l.

d.

e.

f. I n

‥

h. $n$

i. Megaloperdix caspia Gml. 385. Starna cinerea Briss.

i.

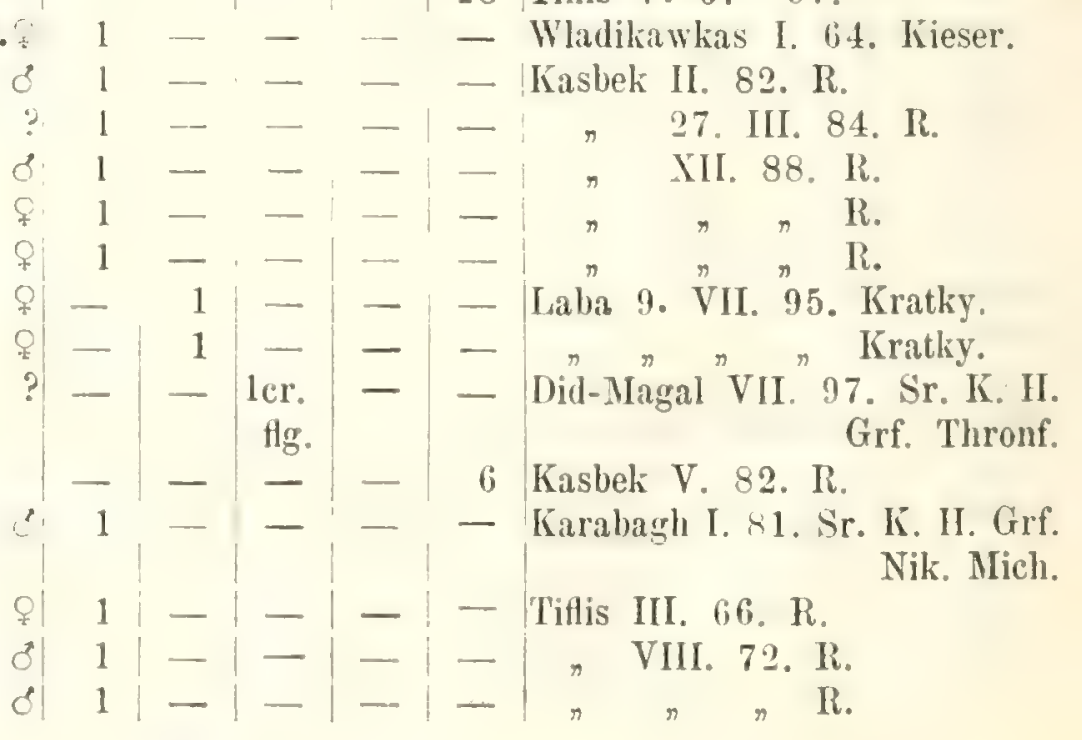




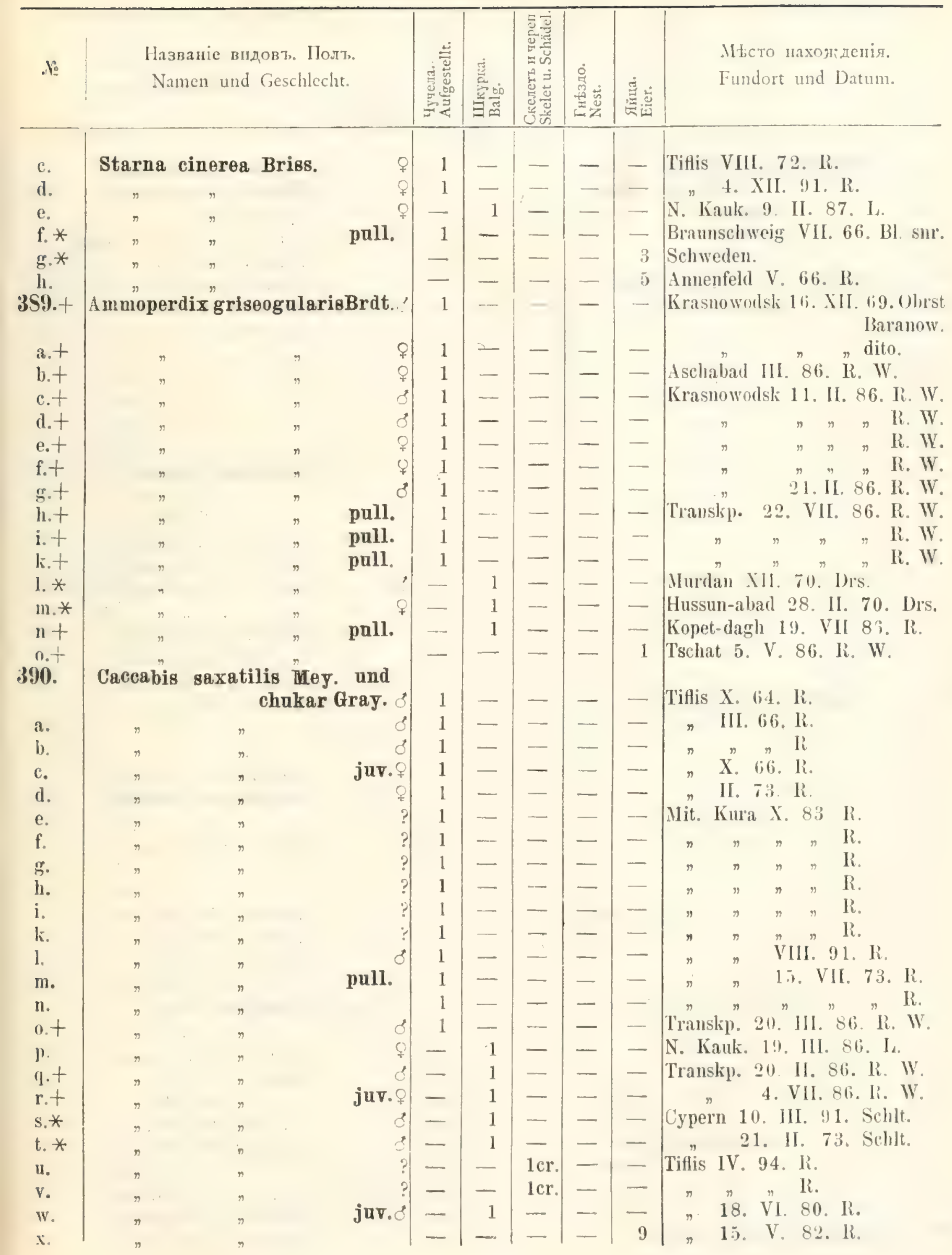




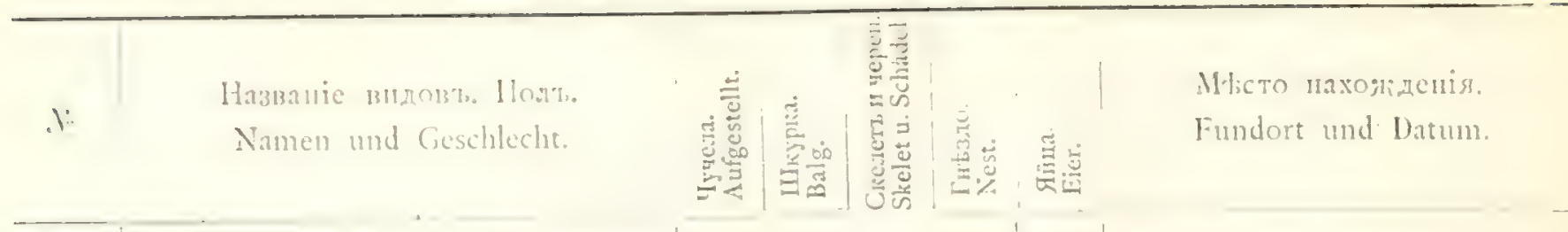

y. Caccabis saxatilis Mey und

\begin{tabular}{c|cc}
$z, *$ & & chukar. \\
aa.* & $\eta$ & graeca. \\
bb. & typ.
\end{tabular}

391. Attagen francolinas Briss

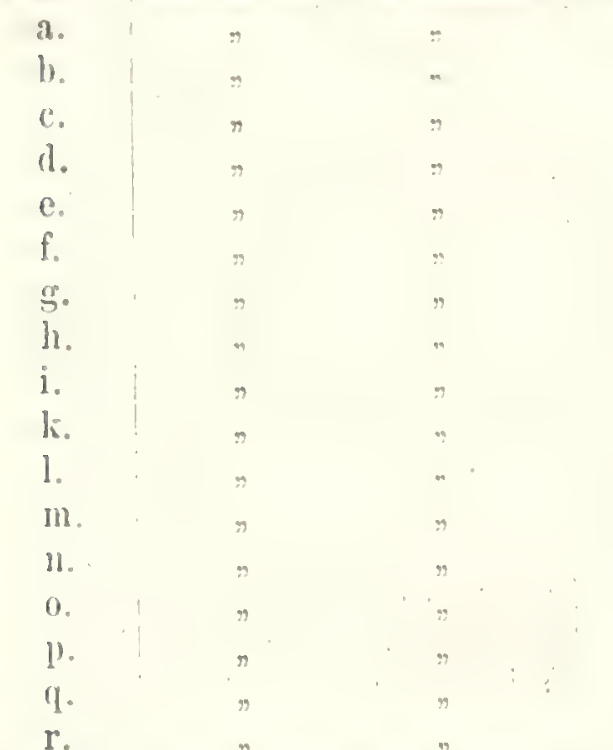

3!). Phasianus colchicus L.

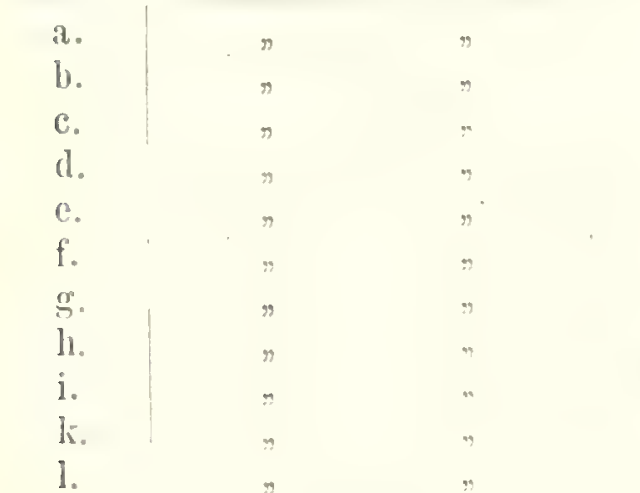

m.

n.

i).

q.

1 .

$\mathrm{S}$.

t.

u.

v.

$39 \%$. septentrionalis. Lor.

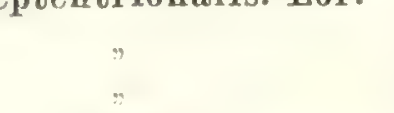

tgp.

$$
\begin{gathered}
\text { pull. } \\
\text { talyschensis Lor. } \\
\text { " pall. }
\end{gathered}
$$

typ.
Phasianus persicus Sevr.

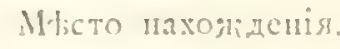

Fundort und Datum. 


\begin{tabular}{|c|c|c|c|c|c|c|c|c|}
\hline . & $\begin{array}{l}\text { Названіе видов'ь. Пол'т. } \\
\text { Namen und Geschlecht. }\end{array}$ & & 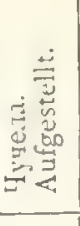 & 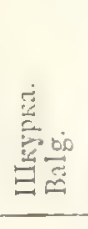 & 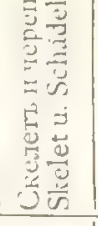 & 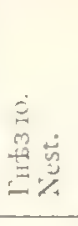 & 焉 & $\begin{array}{l}\text { Mfсто нахожденія. } \\
\text { Fundort und Datum. }\end{array}$ \\
\hline a.t & Phasianus persicus Sevr. & 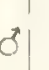 & - & 1 & - & - & - & Atrek 1. III. 87. L. \\
\hline & Phasianus principalis Sclt. & 3 & 1 & - & - & - & $\div$ & $\begin{array}{r}\text { Murgab II. 88. Pokrowsky Vol. } \\
\text { gesch. }\end{array}$ \\
\hline a. + & " & s! & 1 & - & - & - & - & Nerw 2. II. 88. L. \\
\hline b. & $n$ & 8 & 1 & - & - & - & - & Transkp. 17. III. 86. R. W. \\
\hline c.t & $n$ & 8 & 1 & - & - & - & 一 & $" \quad \Rightarrow \quad n \quad " \quad R \cdot W$. \\
\hline d. + & ... & q & 1 & - & - & - & - & n R. W. \\
\hline e.t & $"$ & q & 1 & - & - & - & - & $" \quad " \quad$ R. W. \\
\hline f. + & Albinos. & \& & 1 & - & - & - & - & 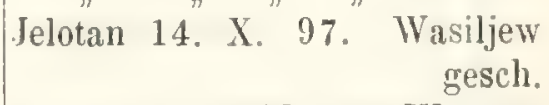 \\
\hline g.t & pull. & & - & $=$ & Sprt. & - & - & Karybent 14. V. 87. W. \\
\hline h. + & , & & - & - & - & - & $: ;$ & Transkp. Petrusewitsch. \\
\hline i.t & " $\quad "$ & & 一 & - & $\ldots$ & - & 1 & Tedshen 25. IV. 94. Sard. \\
\hline $395 . *$ & Phasianus mongolicus Brdt. & 3 & 1 & $\ldots$ & - & - & - & Turkt. I. 82. 'T'. \\
\hline $\begin{array}{l}\text { a. } * \\
b . *\end{array}$ & 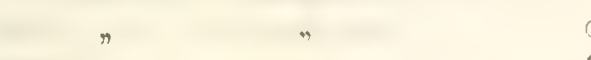 & & 1 & - & - & - & - & Sy1-darja I. 88. L. \\
\hline $\begin{array}{l}b . * \\
996 . *\end{array}$ & 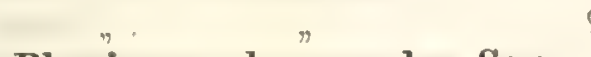 & 요 & 1 & 一 & - & - & 一 & $" \quad n \quad n \quad$ L. \\
\hline $\begin{array}{l}\text { 396. } * \\
\text { a.* }\end{array}$ & Phasianus chrysomelas Sevr. & & 1 & - & - & - & - & Anu-darja XII. 86. L. \\
\hline $\begin{array}{l}\text { a.* } \\
97 . *\end{array}$ & & & 1 & - & - & - & -- & $n \quad " \quad n$ \\
\hline $\begin{array}{l}97 . * \\
\text { a.* } *\end{array}$ & Phasianus torquatus Tem. & 3 & 1 & - & - & - & - & Amur X. 87. L. \\
\hline 998 & Pavo cristatus "L. alb. & & 1 & - & - & - & - & " $"$ L. \\
\hline$: 39 ! \%$ & & 8 & 1 & - & - & - & - & Tiflis X T0.Sr.K. H.Grf.N.N.snr. \\
\hline a. & $\begin{array}{l}\text { Gallus domssticus vart. } \\
\text { ", abn. }\end{array}$ & & 1 & - & sprt. & - & 一 & $\begin{array}{l}\text { "67. Gen. Chodslio. } \\
\text { X. 6t. gesch. }\end{array}$ \\
\hline b. & $"$ & ? & - & - & $1 \mathrm{cr}$. & - & - & $" \quad " \quad$ gesch. \\
\hline c. & noll ohn & & - & 一 & - & $=$ & 8 & Tiflis. \\
\hline d. & pull. abn. & & - & - & Sptr. & - & - & $\begin{array}{l}\text { Chowne 17. VII. 98. Fürst. } \\
\text { Ishawachow. }\end{array}$ \\
\hline 100. & Numida meleagris $L_{\text {. domest. }}$ & $\delta^{3}$ & 1 & - & - & - & - & Lenkoran 84. R. \\
\hline a & $"$ & $?$ & 1 & - & 一 & 一 & 一 & Tıflis 92. R. \\
\hline b. & $\therefore \quad \eta$ & 8 & 一 & 一 & $1 \mathrm{cr}$ & 一 & - & Tiflis 95. Vol. \\
\hline c. & $"$ & & - & - & - & - & 1 & " Vol. \\
\hline
\end{tabular}

\section{FAM. TETRAONIDAE}

411. Tetrao Mlokosiewiczi Tacz.

a
b
is
d
f
i.
i =acatoptricus Radde.

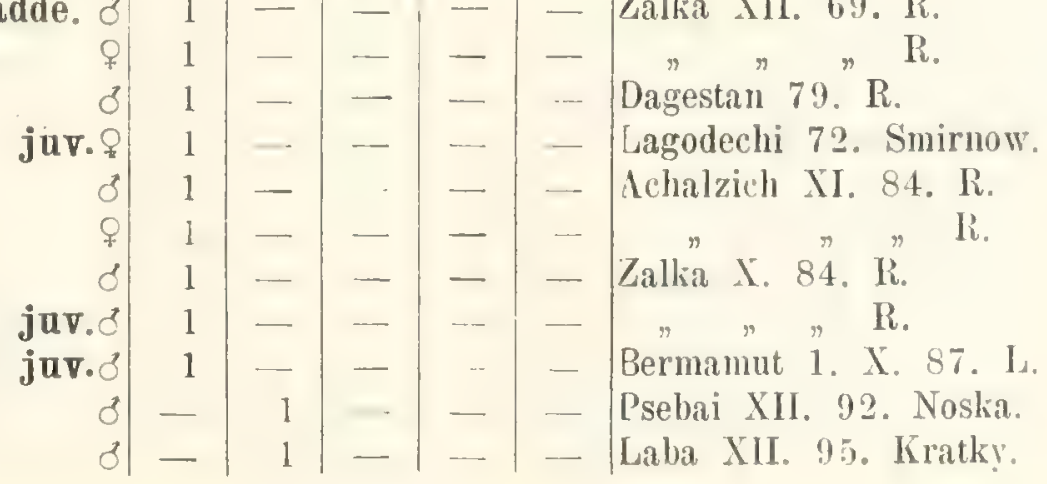




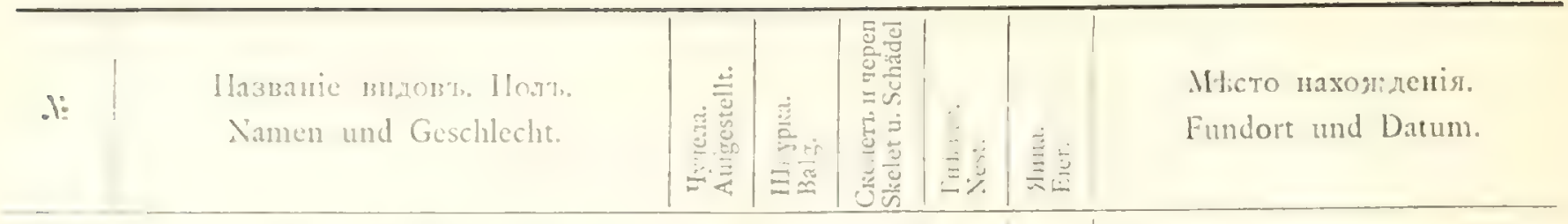

l. 'letrao Mlokosiewiczi Tacz. =acatoptricus Radde.

III.

4(1).*.* Tetrao tetrix $\mathrm{L}_{\mathrm{L}}^{\mathrm{n}}$
a $*$
b. *
(. * *
1. $*$
vart.
tetr. $\times$ urogall.

e*

103.*

a. $*$

b. *

c. $*$

404.* Lagopus albus Gml.

a.*

10\%. *

a. $*$

b. *
Tetra urogallus L.

Bonasa canescens Spar.

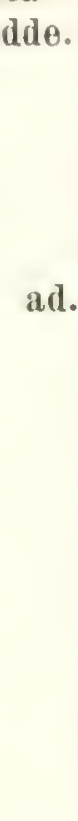

ad.
\& 1 - 1 - - Laba XII. 95. Kratky.

\& - 1 1 1 - - Gudaur XII. 94. R.

8 1 - _ - Transbaik.6. XII. 56. Akad. R.

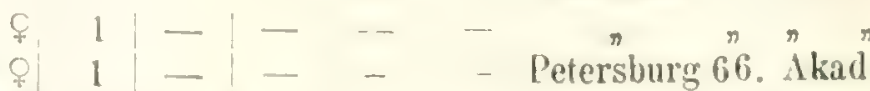

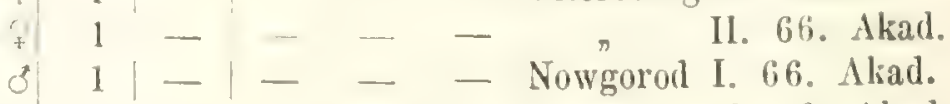

- PetersburgII. 66. Akad.

- " " " Akad.

- $\pi$ n $n$ Akad

1 Lappland $\mathrm{M}$

Akad.

- Petersburg XI. 67. Akad.

Akad.

10. I. 47. Akad.

Akad.

Archangel II. 66. Akad.

\title{
GRALLAE ET LIMICOLAE.
}

\author{
FAM. OTIDAE
}

406. Otis tarda L.

$$
\begin{aligned}
& \text { a. } \\
& \text { c. } \\
& \text { d. } \\
& \text { c. } \\
& \text { f. } \\
& \text { s. } \\
& \text { h. * }
\end{aligned}
$$

$$
\begin{aligned}
& \text { a. } \\
& \text { b. } \\
& \text { c. } \\
& \text { d. } \\
& \text { e. } \\
& \text { f. }
\end{aligned}
$$$$
\text { : } *
$$

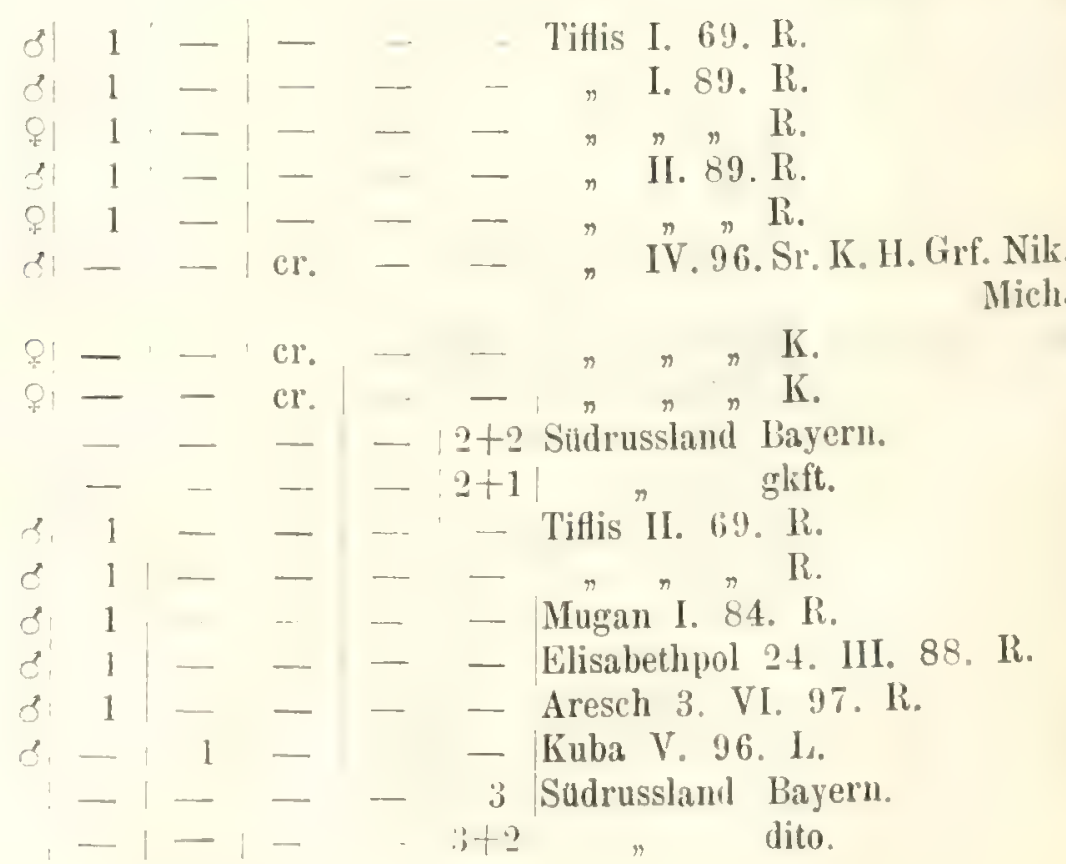




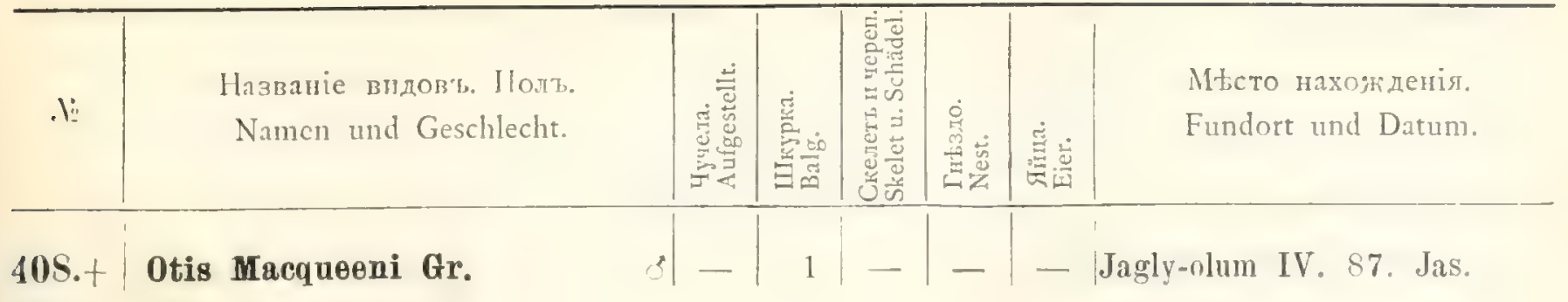

$$
\text { FAM GRUTD A E. }
$$

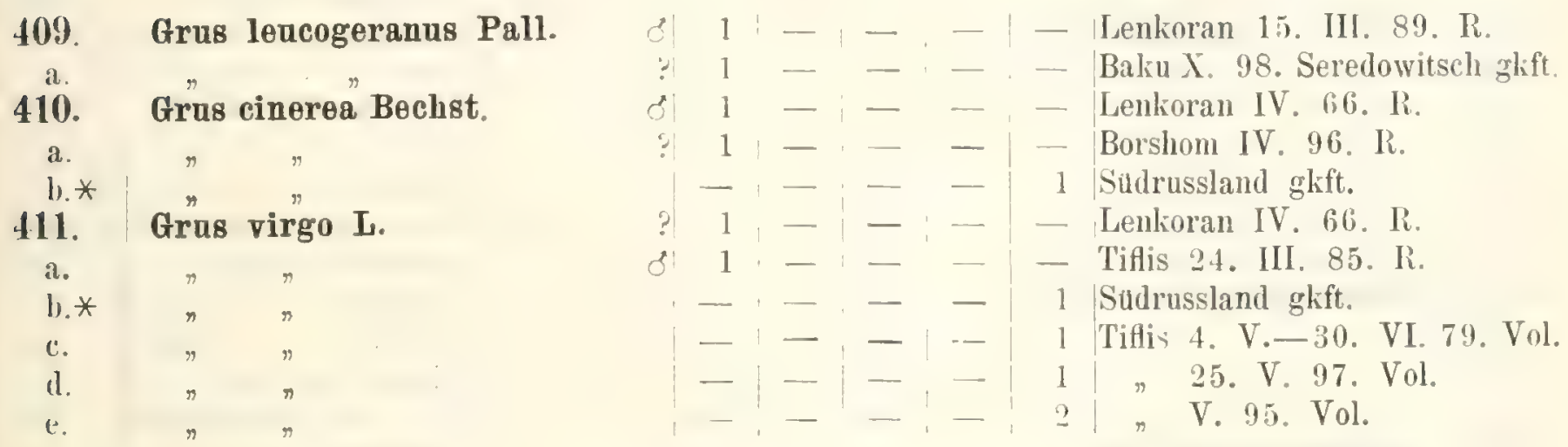

$$
\text { F A M. RA L L I A E. }
$$

\begin{tabular}{|c|c|c|c|c|c|c|c|c|}
\hline 412. & Fulica atra & $\mathbf{L}$. & 1 & - & - & - & - & |Lenkoran IV. 66. R. \\
\hline a. & $\eta$ & 8 & 1 & - & - & - & - & 26. XI. 79. Ii. \\
\hline b. & $\eta$ & 안 & 1 & - & - & - & - & R. \\
\hline c. & \# & $?$ & - & - & $1 \mathrm{cr}$ & 一 & - & XII. 94. R. \\
\hline$d . *$ & n & pull. & 1 & 一 & - & - & - & Braunschweig 68. Bl. snr. \\
\hline e. & $\pi$ & & 一 & - & - & - & 17 & Lenkoran IV. 66. 7. V. 80. R. \\
\hline$f *$ & $n$ & & - & 一 & - & - & 2 & Schweden 12. V. 64. MI. \\
\hline 13. & Gallinula c & hloropus. L. & 1 & - & - & - & - & Lenkoran IV, $66 . \mathrm{R}$. \\
\hline a. & $\eta$ & 0 & 1 & - & - & - & - & Tillis 21. III. 78. R. \\
\hline b. & $n$ & 우 & 1 & - & - & - & - & Lenkoran 16. XI. 79. R. \\
\hline c. & n & $\pi$ & 1 & - & - & - & - & $n \pi$ \\
\hline d. & $"$ & o & 1 & - & - & 一 & - & Tiflis 21. IV. 82, R. \\
\hline e. & $"$ & pall. & 1 & - & 一 & - & - & 8. M. 78. R. \\
\hline f. * & Pornh & n & - & - & - & - & 3 & glift. \\
\hline & Forpingro & jollocepnarus LaLl. & 1 & - & - & - & - & 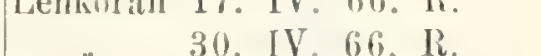 \\
\hline b. & $n$ & 8 & 1 & - & - & - & - & 2. XII. 79, R. \\
\hline c. & " & 8 & 1 & - & - & - & - & $" \mathrm{r}$. \\
\hline d. & $"$ & ? & 1 & - & 一 & - & - & li. \\
\hline e. & $n$ & q & 1 & - & - & 一 & - & $r \quad "$ \\
\hline f. & n & 8 & 1 & - & - & - & 一 & $n n$ \\
\hline$g$. & , & $\delta$ & 1 & - & - & - & 一 & Karasu XII. 90. R. \\
\hline h. & & & - & - & - & - & 2 & Lenkoran IV. 66. R. \\
\hline 115.* & Porphyrio & hyacinthinus Tem. $\delta$ & 1 & 一 & - & - & 一 & Sicilien ? Hom. \\
\hline 416. & Crex prate & nsis Bechst. & 1 & - & - & - & 一 & Titlis IV. 67. R. \\
\hline & $\eta$ & ? & 1 & - & - & - & - & $\Rightarrow 69 . \mathrm{R}$. \\
\hline fi. & $\pi$ & o & 1 & - & 一 & - & - & V. il. I \\
\hline
\end{tabular}




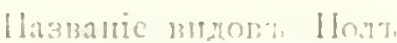

Nimen und Geschlecht.
Micto maxom ienis.

Fundort und Datum.
Crex pratensis Bechst.

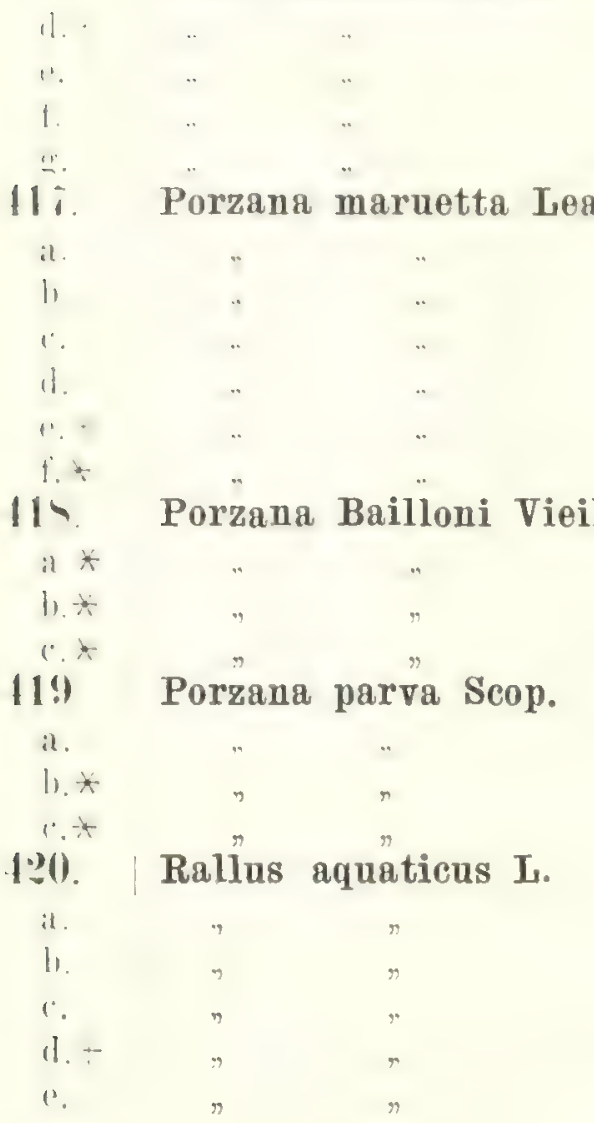

\section{What}

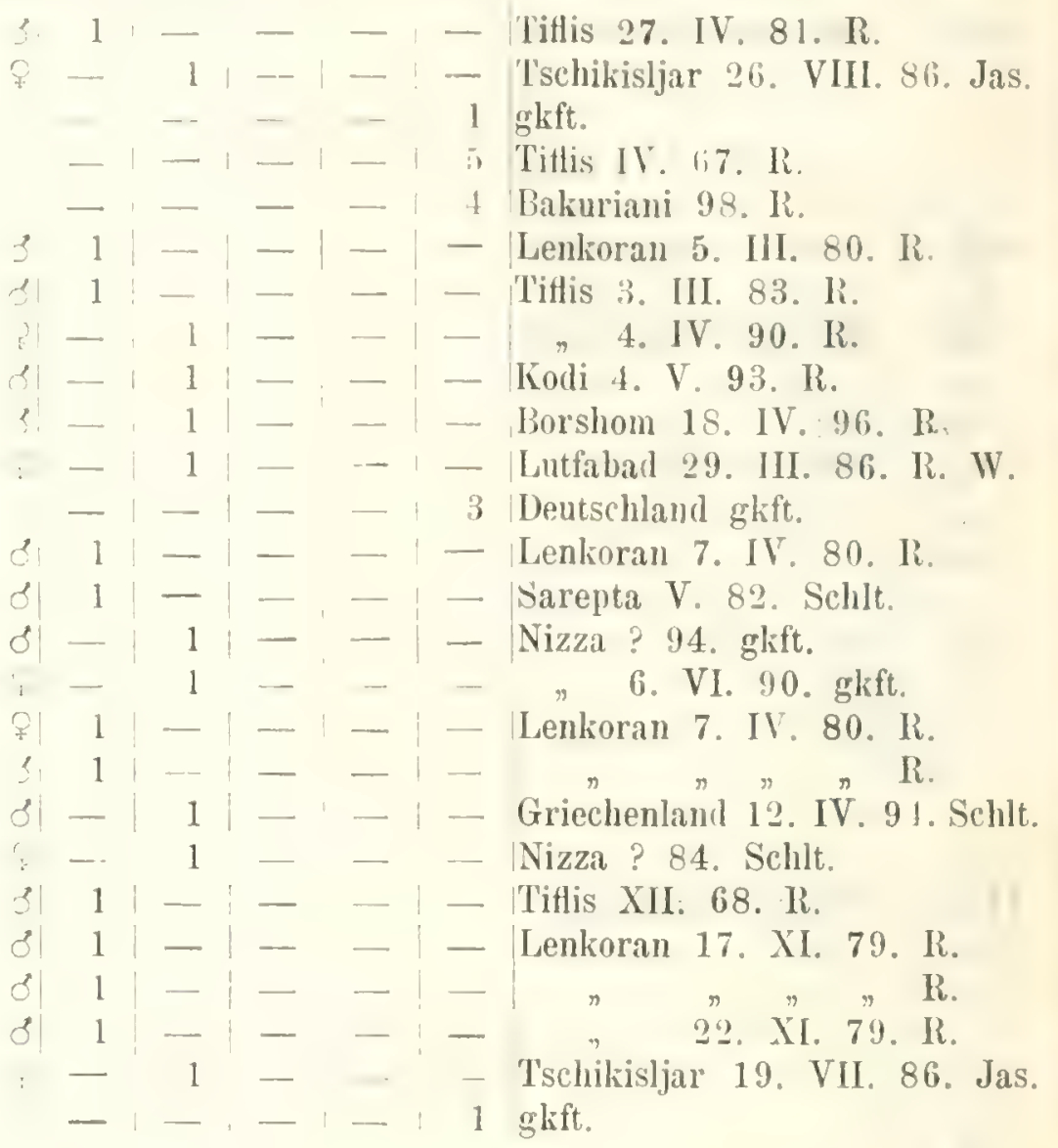

FAM. GLAREOLIDAE

421.* Glareola pratincola L。

il.

b)

(1)

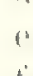

1:.”. Glareola melanoptera Nord.

$$
\begin{aligned}
& \text { ₹| } 1|-|-|-|-\mid \text { ? 58. Akad. } \\
& \therefore 1 \text { - - - Lenkoran 4. IV. 80. R. } \\
& \text { : }-1:-1-\text { Kuba 6. VI. 96. Sat. } \\
& \text { 8. 1 - - - Serachs 9. VII. 86. R. }
\end{aligned}
$$

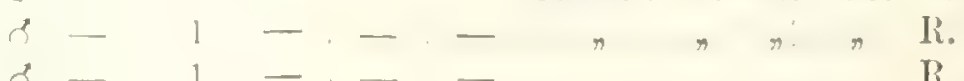

$$
\begin{aligned}
& 8 \text { - 1. - - Tschikisljar 11. 1V. 87. Jas. } \\
& 2 \text { Oesterreich glkft. } \\
& \begin{array}{l}
1 \text { - } \\
1 \\
1
\end{array}
\end{aligned}
$$

\section{FAM. CHARADRIDAE}

12:?. Cursorius gallieus Gml. 


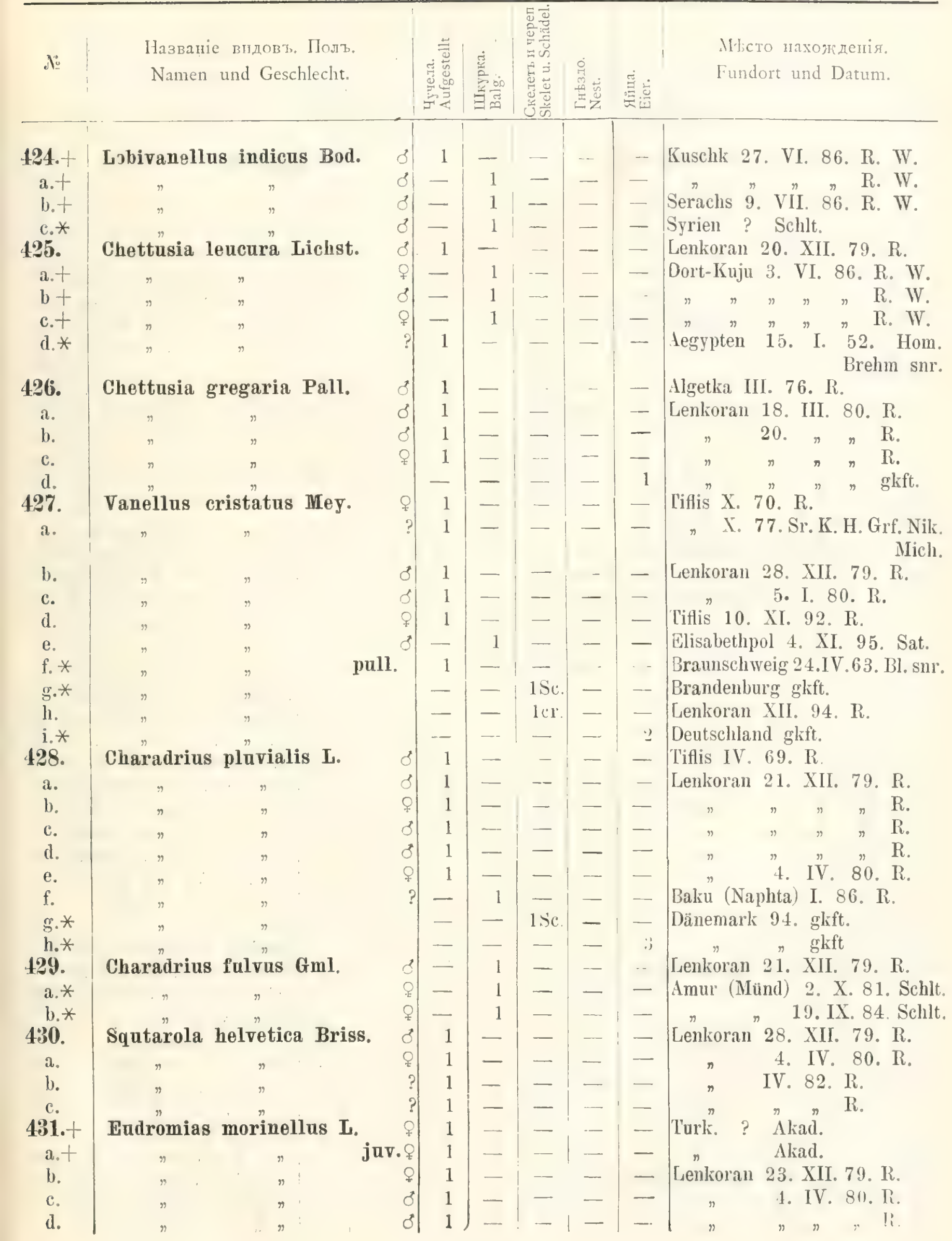




\begin{tabular}{|c|c|c|c|c|c|c|c|c|c|}
\hline$\ell^{\circ}$ & $\begin{array}{l}\text { Hazmat } \\
\text { Name }\end{array}$ & $\begin{array}{l}\text { Iіс пндовт. Ilолт. } \\
\text { n und Geschlecht. }\end{array}$ & & 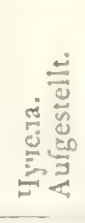 & 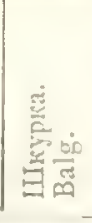 & 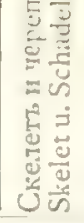 & 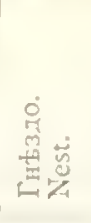 & 愛产 & $\begin{array}{l}\text { Mtсто иаходенія. } \\
\text { Fundort und Datum. }\end{array}$ \\
\hline e & Eudromias & morinellus $\mathbf{I}$. & ? & 1 & - & - & - & - & Genkoran 4. IV. 80. R. \\
\hline f. & $"$ & $"$ & 是 & 1 & - & - & - & - & $n \quad n \quad n \quad n$ R. \\
\hline w. & $"$ & $"$ & 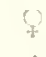 & 1 & -- & - & - & - & $n " n R$. \\
\hline h. & , & $"$ & : & 1 & 一 & - & - & - & I. $84 . \mathrm{R}$. \\
\hline i. $*$ & $"$ & $"$ & $s$ & 1 & - & - & - & - & Pommern VIII. Hom. \\
\hline$k . *$ & $"$ & $"$ & 8 & 1 & 一 & 一 & - & - & ITelgoland XI. 80. Hom. \\
\hline 1. & $"$ & $"$ & $s$ & - & 1 & - & - & - & Unt. Kura 29. III. 94. Sat. \\
\hline 432. & Eudromias & asiaticus Pall. & 8 & 1 & - & - & - & - & Lenkoran 7. IV. 66. R. \\
\hline a. & $n$ & $r$ & g & 1 & 一 & - & - & - & . 4. IV. 80. R. \\
\hline b. & $n$ & $"$ & c & 1 & - & - & - & - & $n \quad n \quad n \quad \mathrm{R}$. \\
\hline c. & $"$ & $"$ & $d$ & 1 & - & - & - & - & $n \mathrm{R}$. \\
\hline l. & " & $"$ & d & 1 & - & - & - & - & $n \quad n \quad \mathrm{R}$ \\
\hline e. & $"$ & $"$ & s & 1 & - & - & - & - & $n n \quad n \quad \mathrm{R}$. \\
\hline f. & $"$ & $"$ & 우 & 1 & 一 & - & - & 一 & $\Rightarrow \quad \eta \quad \mathrm{R}$. \\
\hline g. & $"$ & " & 웅 & 1 & 一 & 一 & - & - & $\eta \quad \pi \mathrm{R}$. \\
\hline h. & $"$ & $"$ & Q & 1 & - & - & - & 一 & $n \quad n R$. \\
\hline i. & " & & 8 & 1 & - & - & - & - & $"$ II. 84. R. \\
\hline 433. & Eudromias & Geoffroyi Wagl & q & 1 & - & - & 一 & - & 13. III, $80 . R$. \\
\hline a. & " & 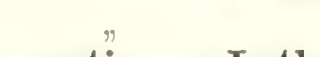 & q & - & 1 & - & - & 一 & 29. V. 97. Sat. \\
\hline 134. & Eudromias & cantianus Lath & 우 & 1 & - & - & 一 & - & 10. III. 80. R. \\
\hline a. & $"$ & $"$ & q & 1 & - & 一 & - & - & 13. $\pi \Rightarrow R$. \\
\hline b. & $"$ & $"$ & 우 & 1 & - & - & - & - & $" \quad \Rightarrow \quad$ R. \\
\hline c. & $"$ & , & ? & 1 & - & - & 一. & - & III. 84. R. \\
\hline 1. $*$ & $"$ & $"$ & q & 1 & 一 & - & - & - & Rugen 20. VI. 68. Hom. \\
\hline e.t & $"$ & $"$ & q & - & 1 & 一 & - & - & Molla-Kary 11. IV. 86. R. W. \\
\hline f. $t$ & $"$ & $"$ & o & - & 1 & 一 & - & - & $n \quad n \quad n \quad n \quad \mathrm{R} . \mathrm{W}$. \\
\hline g.t & $"$ & $"$ & s & - & 1 & - & - & - & Michailowa 16 . IV. 86, R. WV. \\
\hline h. + & $"$ & $r$ & : & - & 1 & - & - & - & Buchara 31. V. 96. Flrk. \\
\hline i. + & $"$ & $"$ & ? & - & 1 & - & - & - & " $\quad " \quad$ Flrk. \\
\hline k. * & $"$ & , & 8 & - & 1 & - & $\ldots$ & 一 & 6. I. 82. Hom. \\
\hline $1 . *$ & $"$ & $\eta$ & q & - & 1 & - & - & - & ? $" \pi$, Hom. \\
\hline $\mathrm{m}$. & $"$ & $n$ & o & - & 1 & - & - & - & Kaspi 6. VI. 96. Sat. \\
\hline n. & $"$ & $"$ & 인 & - & 1 & - & - & - & $n \quad " \quad "$ Sat. \\
\hline $0 . *$ & $"$ & $\eta$ & & - & - & - & - & 1 & gkft. \\
\hline p. + & & & s & 1 & - & - & - & - & Duschak 16. III. 86, R. W. \\
\hline $435 *$ & Aegialites & hiaticula I. & 8 & 1 & - & - & - & - & Schweden $20 . \mathrm{V} .76 . \mathrm{M}$ \\
\hline a. $*$ & $\eta$ & $"$ & V. ? & 1 & - & - & - & - & Helgoland 19. VIII. 76. Schlt. \\
\hline b. $*$ & $"$ & $\eta$ & c & 1 & - & - & - & 一 & Ruggen V. Hom. \\
\hline c. $*$ & $n$ & $"$ & $\delta$ & 1 & - & - & - & - & $\Rightarrow \quad ;$ Hom. \\
\hline d. & 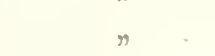 & $"$ & \& & - & 1 & - & - & - & Tiflis 3. IX, 95. Sat. \\
\hline e. & $"$ & $"$ & 운 & - & 1 & - & - & 一 & $" n \quad n$ Sat. \\
\hline f. & " & $\eta$ & & - & - & - & 一 & 4 & IV. 67. R. \\
\hline$g$. & $"$ & " & & 一 & - & - & - & 2 & gkft. \\
\hline $11 . *$ & & & 8 & 1 & - & - & - & - & $\pi$ 6. IV. $86 . \mathrm{R} . \mathrm{W}$. \\
\hline 136. & Aegialites & curonicus Bes. & 8 & 1 & - & - & 一 & - & n $15 . \mathrm{V} .73 . \mathrm{R}$ \\
\hline a. & " & 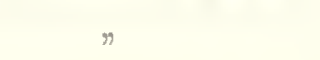 & q & 1 & - & - & - & - & Lenkoran 28. II. 80. R. \\
\hline b. & $"$ & $n$ & 8 & 1 & - & - & - & 一 & 14. III. 80. R. \\
\hline
\end{tabular}




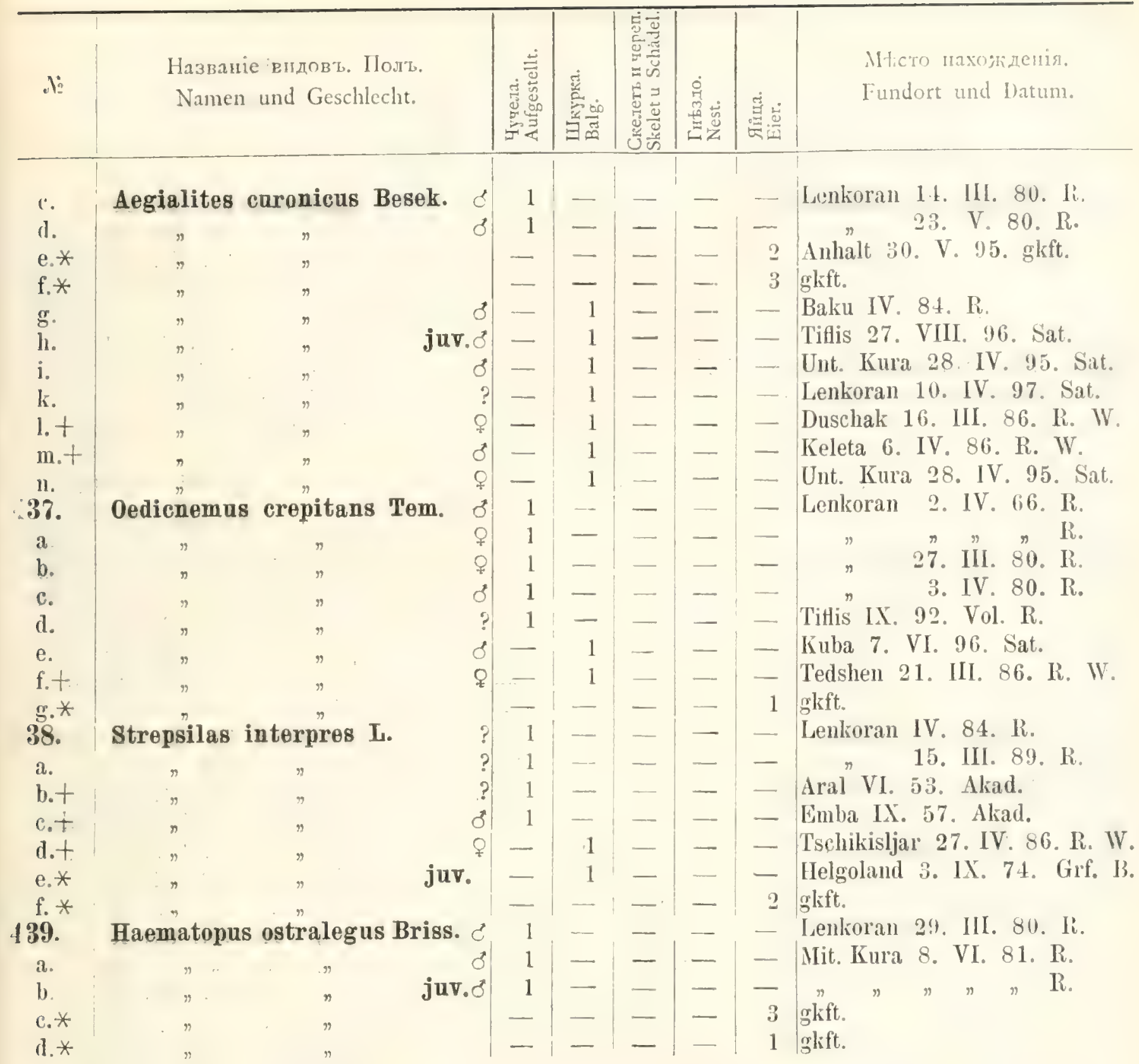

\section{FAM. SCOLOPACIDAE.}

\begin{tabular}{|c|c|c|c|c|c|c|c|c|c|}
\hline 10. & Hypsibates hi & himantopus $\mathrm{L}$. & 31 & 1 & - & - & - & $\cdots$ & Lenkoran 2. IV. 66. R. \\
\hline $\mathrm{a}$ & $\pi$ & , & o & 1 & - & - & 一 & - & Tiflis 2. IV. 66. R. \\
\hline b. & $"$ & 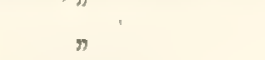 & 7 & 1. & 一 & - & - & - & ^ 16. IV. 68. R. \\
\hline c. & ; & $"$ & 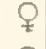 & - & 1 & - & - & - & Unt, Kura 9. V. 95. Schlk. \\
\hline d. $\dot{T}$ & $\pi$ & $n$ & $q$ & 一 & 1 & - & - & - & Molla-Kary 11. IV. 86. R. W. \\
\hline e.t & » & $m$ & 8 & - & 1 & - & - & - & Tschikisljar 22. IV. 87. Jas. \\
\hline f. * & & $n$ & & - & - & - & - & 1 & ghift. \\
\hline 1. & Recurvirostra & a a vocetta $\mathbf{L}$. & o & 1 & - & - & 一 & - & Lenkoran 28. XI. 79. R. \\
\hline & 》 & $n$ & ó & 1 & - & - & - & - & 1. II. $80 . \mathrm{R}$. \\
\hline b & $=$ & , & 0 & 1 & - & - & - & - & 26. II. 80. R. \\
\hline & 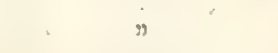 & $n$ & ? & 1 & 一 & - & - & 一 & Emba 14. IX. 57. Akad. \\
\hline & & & & - & - & - & - & 1 & gskft. \\
\hline
\end{tabular}




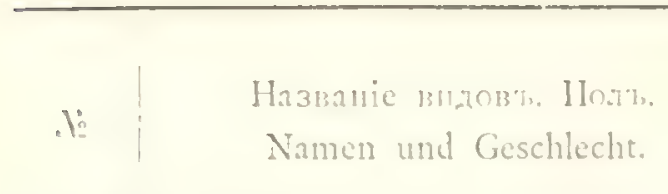

\section{Ihit}

112. Numenius phaeopus L.

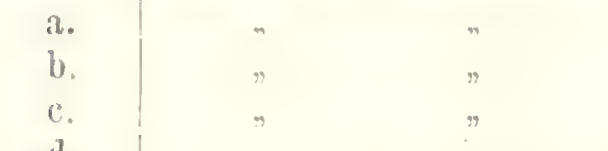

113.* Numenius tenuirostris Vieil. 14. Numenius arquata $L$.

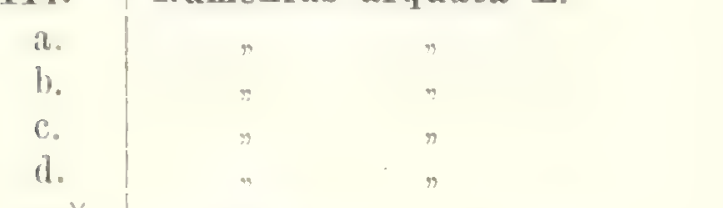

145. Limosa melanura Leisl.

\begin{tabular}{c|c} 
¿.* & Limosa rufa "Briss. \\
a.* & To" \\
47. & Torekia cinerea Güld.
\end{tabular}

148. Actitis hypolencos L.

\begin{tabular}{l|l|l}
\hline a. & $"$ & $"$ \\
b. & $"$ & $"$ \\
c. & $"$ & $"$ \\
d. & $"$ & $"$ \\
e. & $"$ & $"$ \\
f. & $"$ & $"$ \\
g. & $"$ & $"$ \\
l. & $"$ & $"$ \\
i. & $n$ & $"$ \\
k. & $"$ & $"$
\end{tabular}

419. Totanus fuscus L.

450. Totanus glottis L.

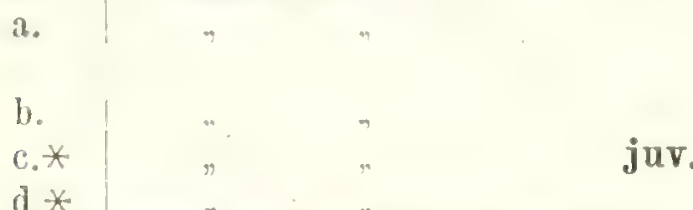

451. Totanns stagnatilis Bechst.

\section{1}

Miсто иаховд депіs. Fundort und Datum. 


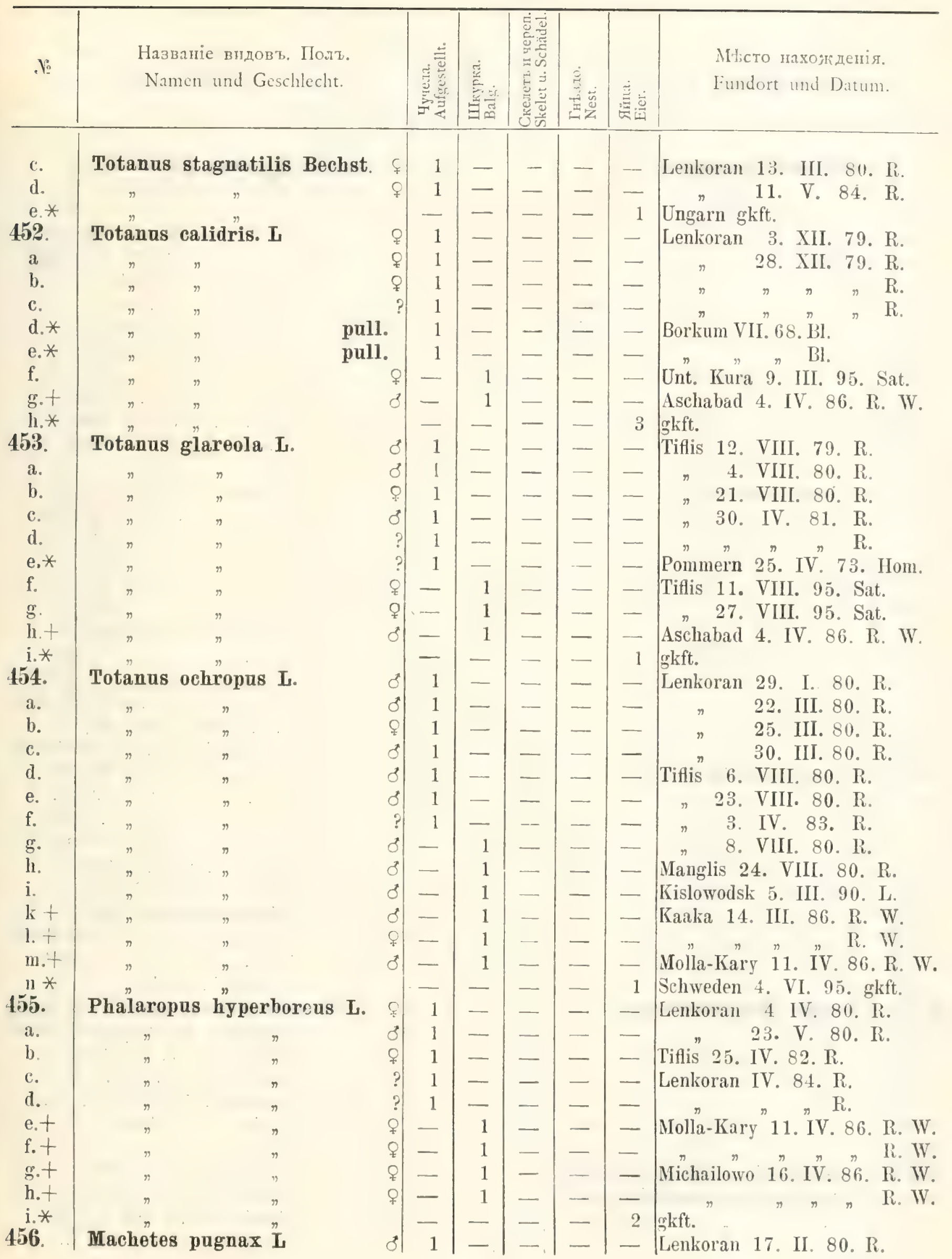




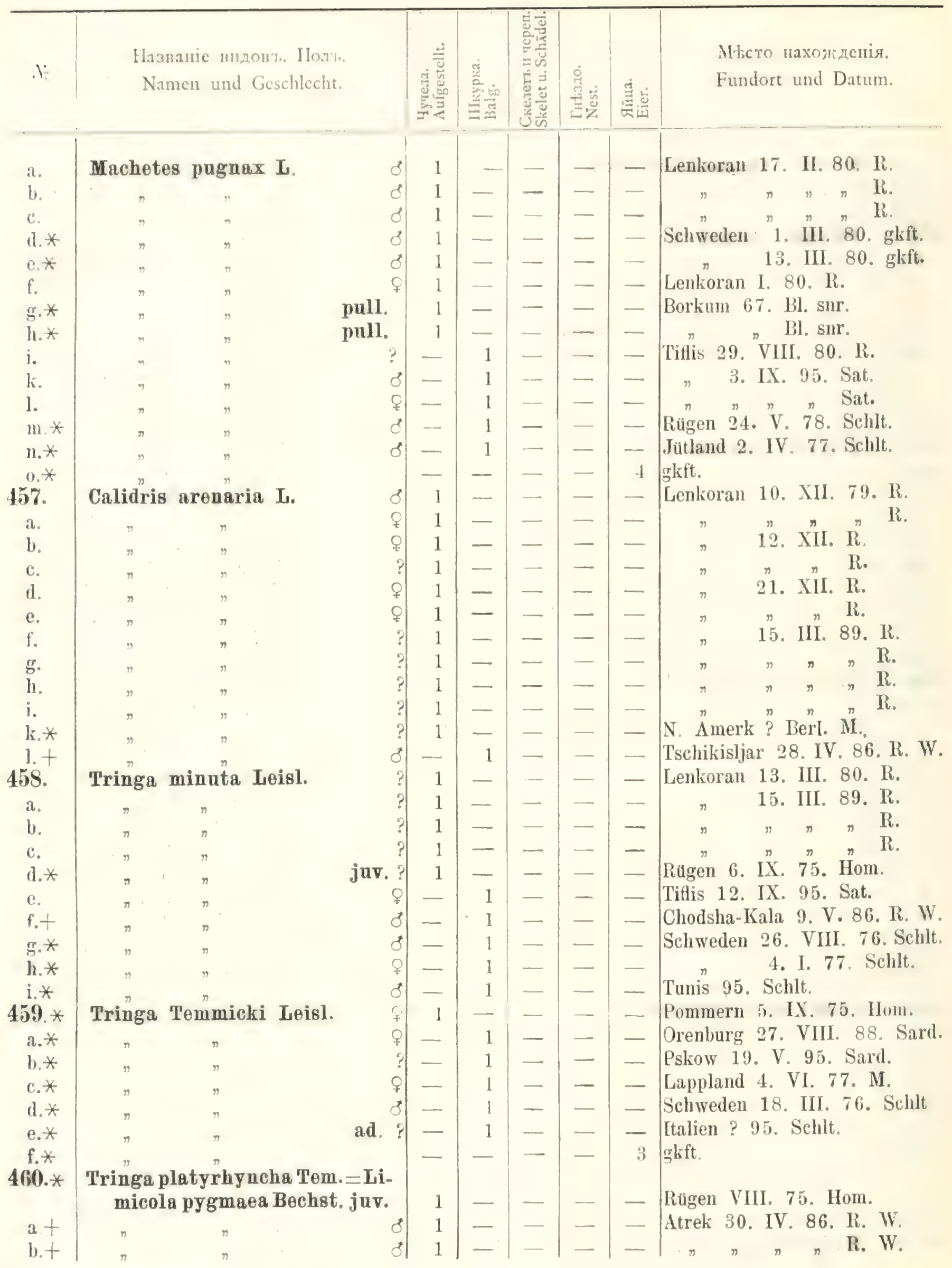




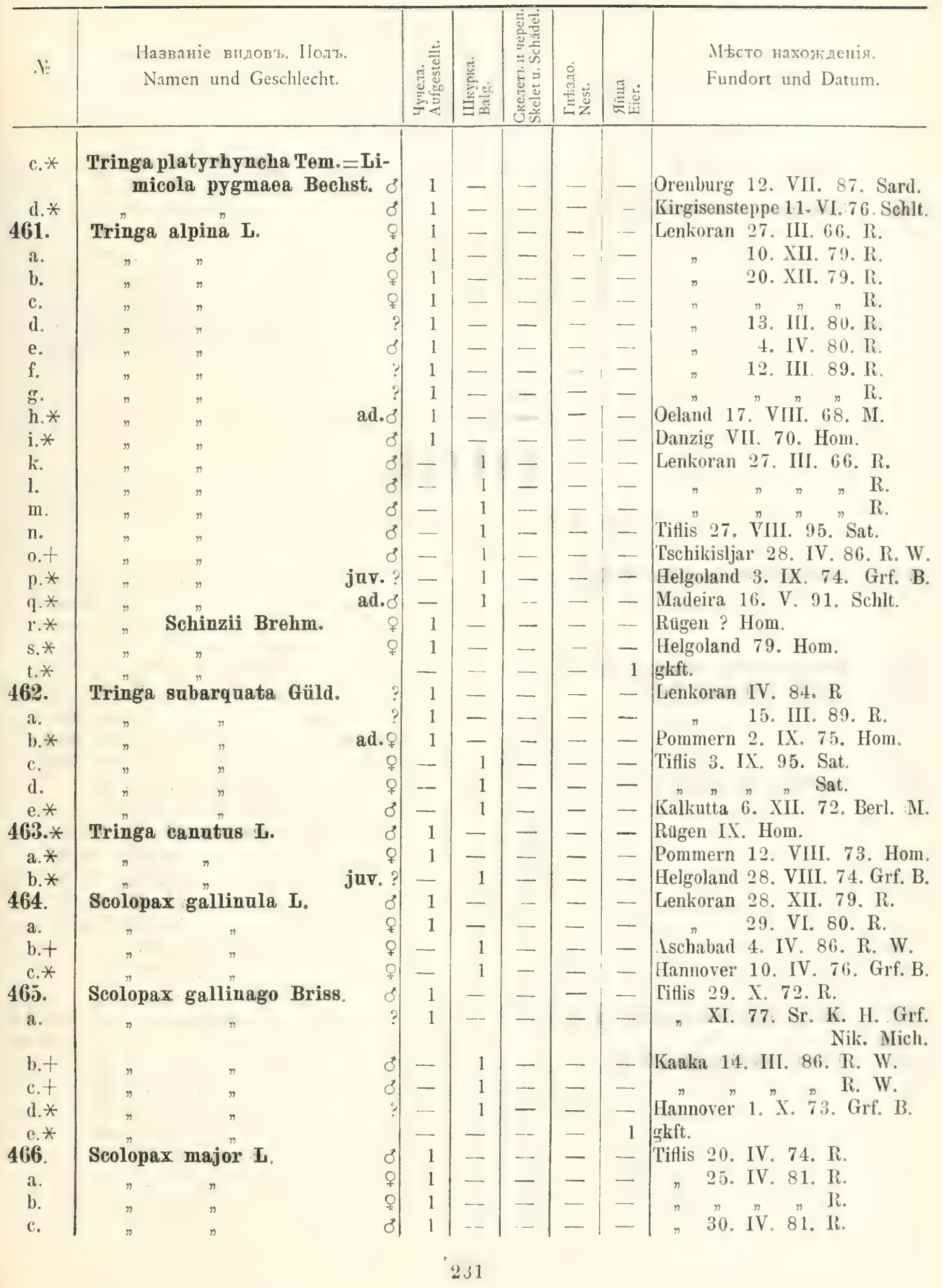




\begin{tabular}{|c|c|c|c|c|c|c|c|}
\hline I: & 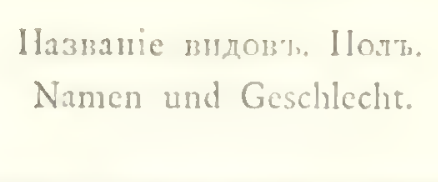 & 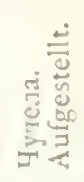 & 童的 & 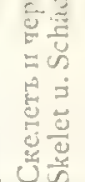 & 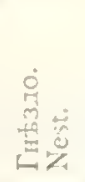 & 鄫亮 & $\begin{array}{l}\text { Mtсто нахонденія. } \\
\text { Fundort und Datum. }\end{array}$ \\
\hline
\end{tabular}

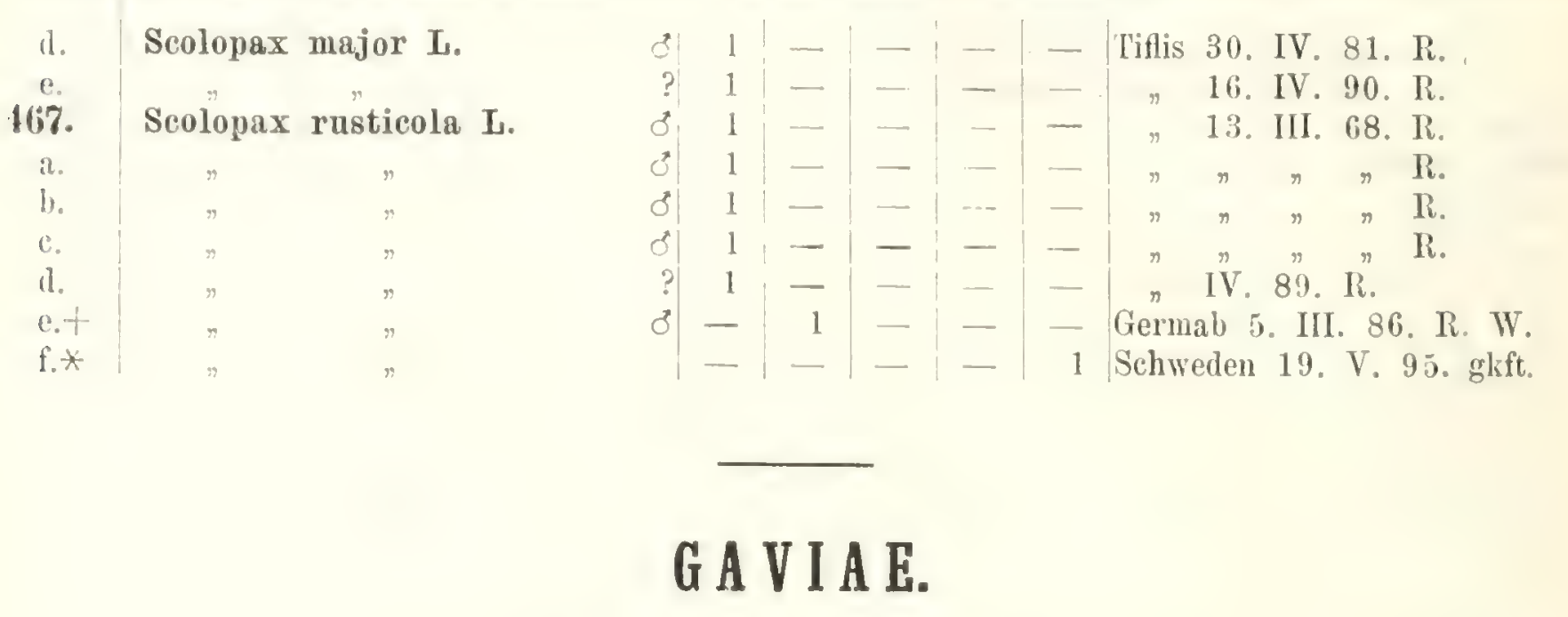

\section{$F A M \quad L A R I D A E$}

465.* Stercorarius crepidatus Gml.
a.*
b。 $*$
c. $*$
470. Larus minutns Pall.

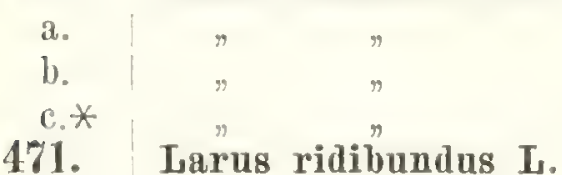

469.* Stercorarius catarrhactes. L.
a.
b.
c.
d.
f.
f.
h.

47*.* Larus melanocephalus Natt.

4

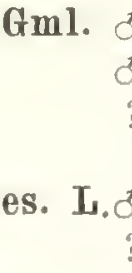

$$
\text { juv. }
$$

juv.

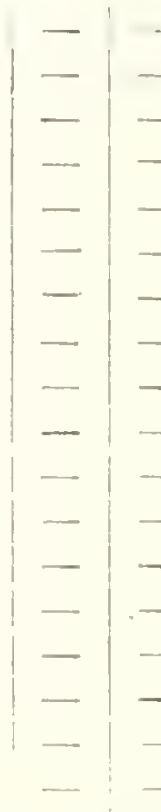

\begin{tabular}{l|l}
- & - \\
- & - \\
- & \\
- & - \\
- & - \\
- & - \\
- & - \\
- & - \\
- & - \\
- & - \\
- & - \\
- & - \\
- & -
\end{tabular}

- Grönland VIII. :38. Hom.

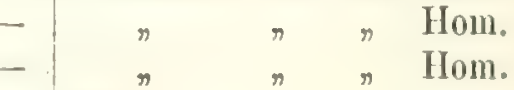

$$
\begin{aligned}
& 1 \text { gkft. } \\
& \text { Island? Hom. } \\
& \text { - Lenkoran 10. IV. 96. Flrk. } \\
& \text { - ? 10. I. 96. Schlt. } \\
& \text { - ? 11. XI. 96. Schlt. } \\
& \text { - Sarepta 21. V. 97. Schlt. } \\
& \text { Lenkoran IV. 66. R. } \\
& \text { 'Tiflis 7. III. 73. R. } \\
& \text { Lenkoran 29. XI. 79. R. } \\
& \text { 3. XII. 79. R. } \\
& \text { 17. XII. 79. R. } \\
& \text { 26. II. 80. R. } \\
& \text { 10. III. } 80 . R
\end{aligned}
$$

Tiflis 15. I. 96, R.

$1 \mathrm{gkft}$

9. II. $96, R$.

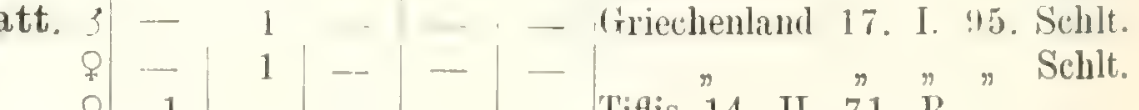

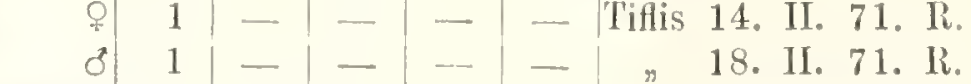

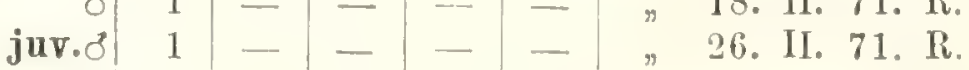

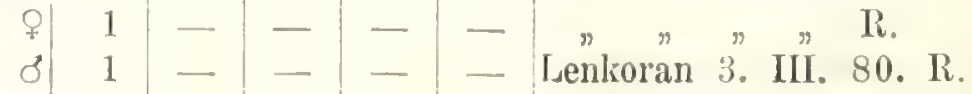

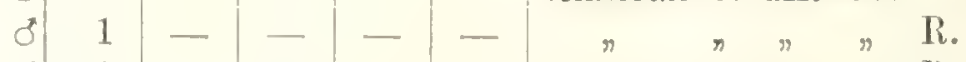

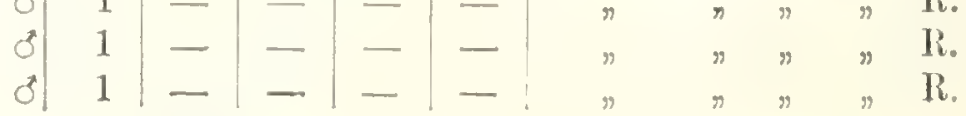




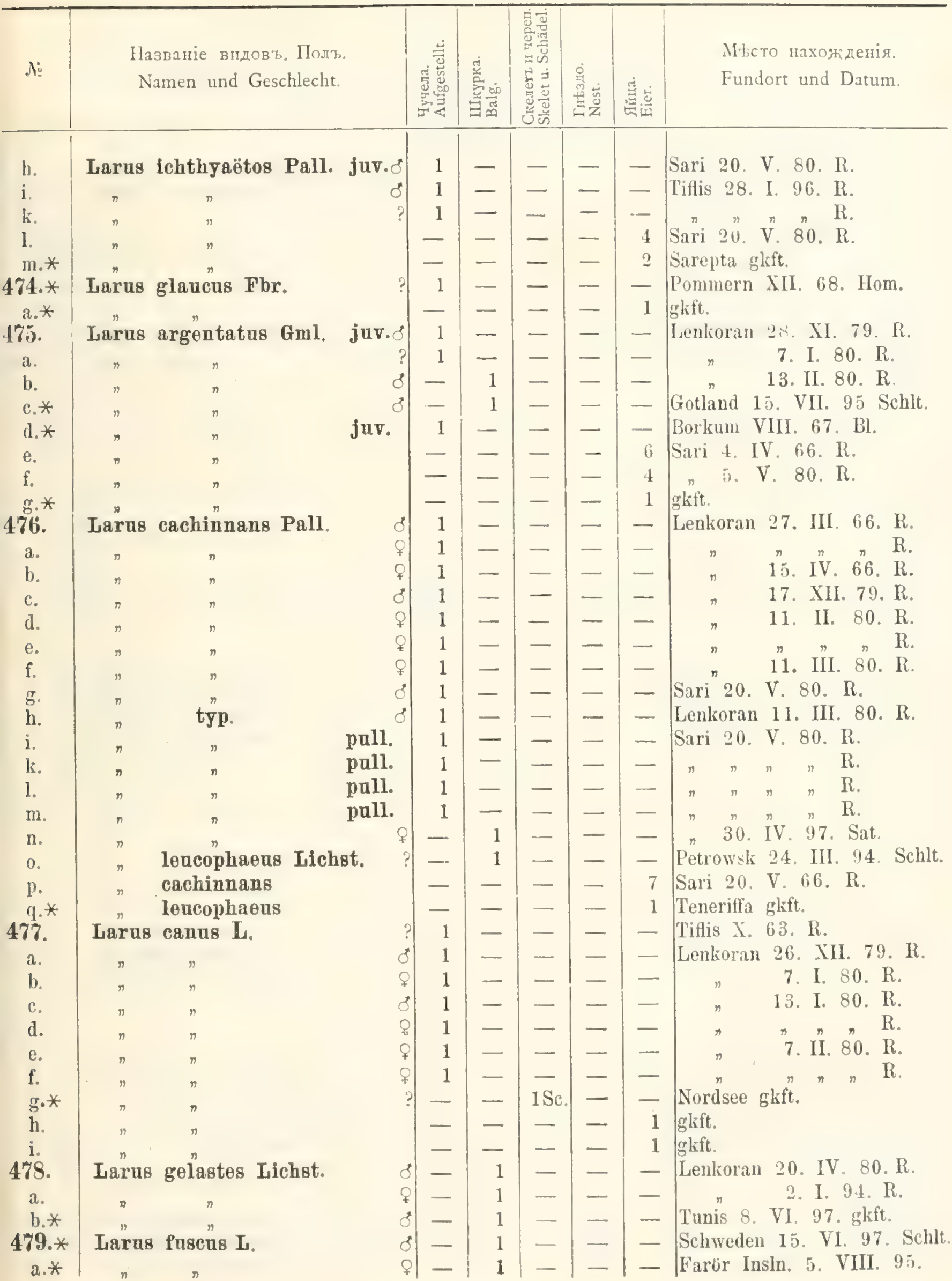




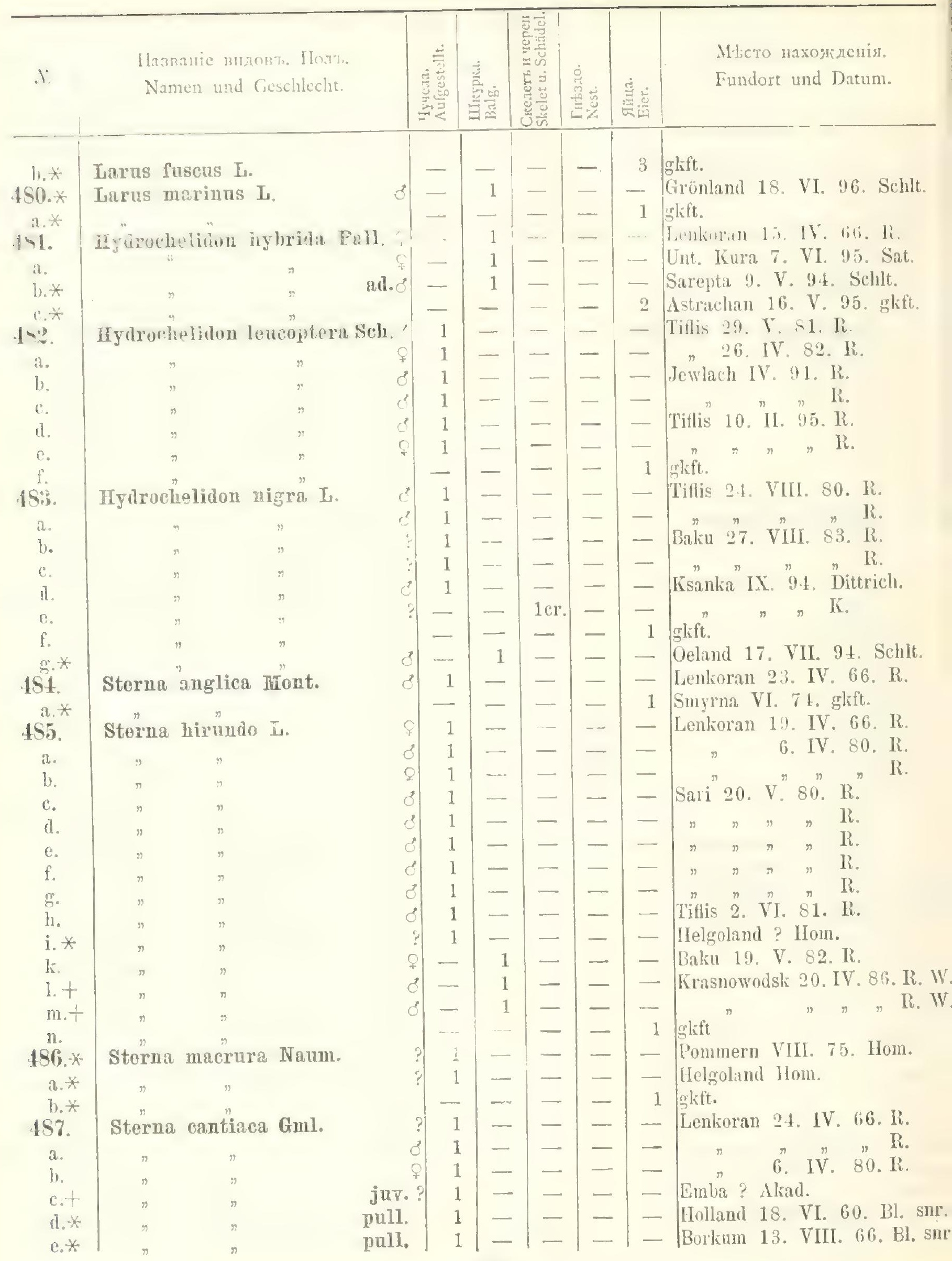




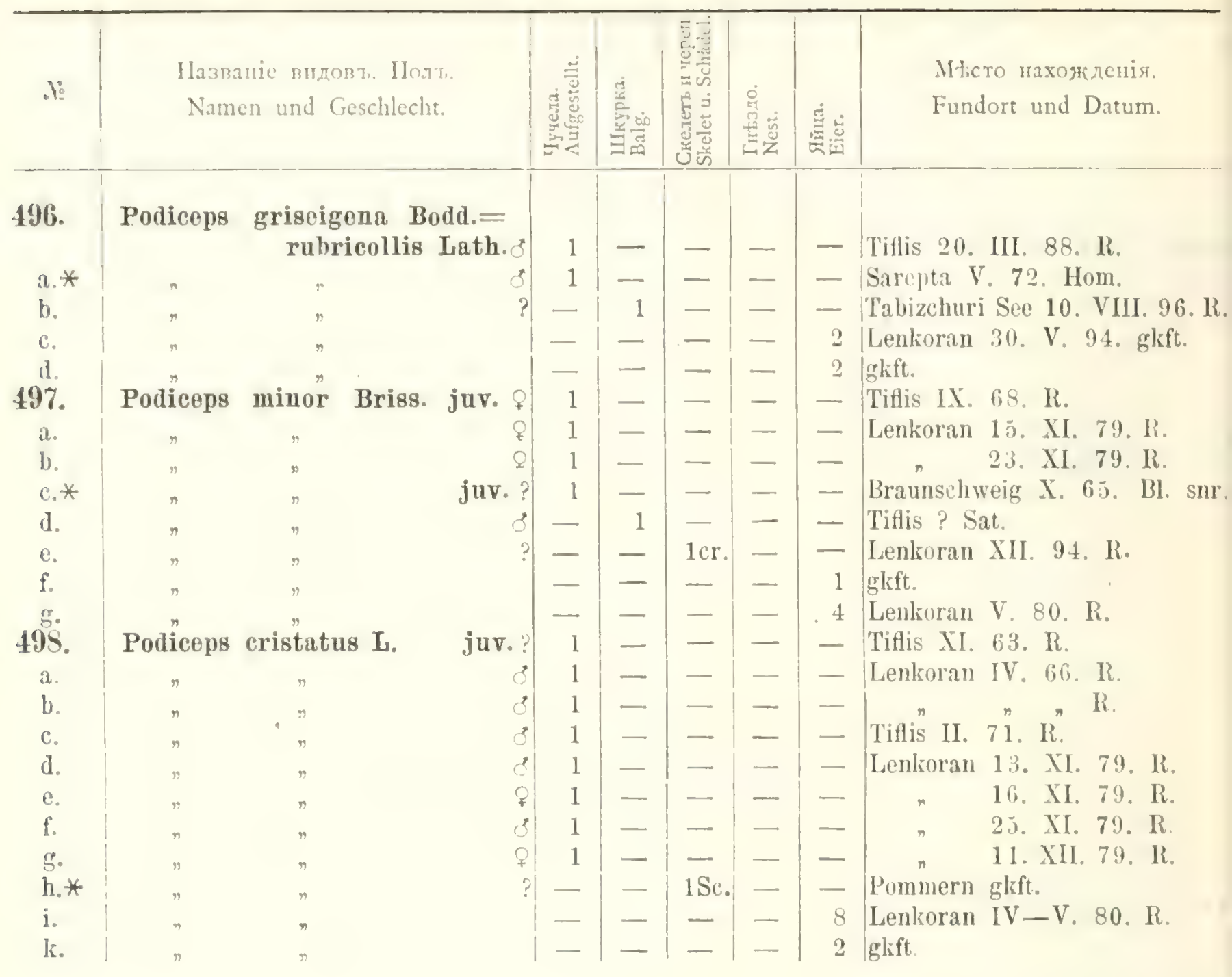




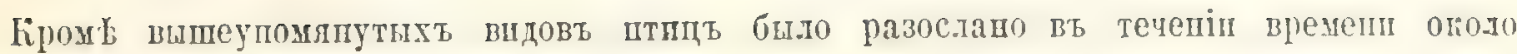

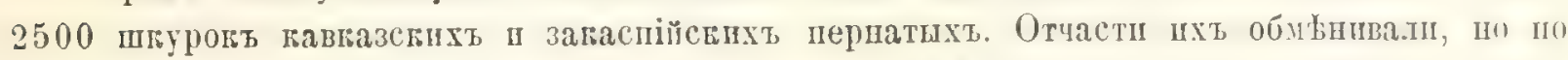

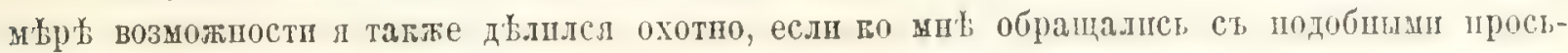

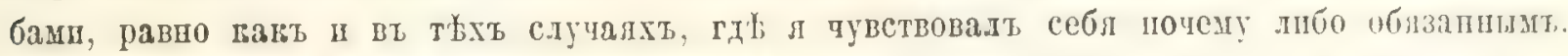

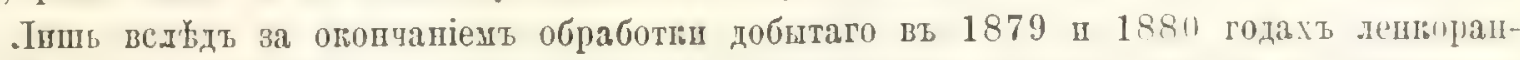

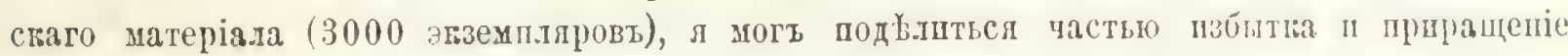
голлевцій въ посльдующіе годы позволило мпь прододжать это дыло.

Ausser den im Vorstehenden aufgeführten Vogelarten sind im Verlaufe der Zeit circa 2500 kaukasische und transkaspische Vogelbälge versendet worden. Zum Theil geschah das im Tauschverkehr, aber auch in den Fällen, wo man sich an mich wendete, oder wo ich mich anderweitig verpflichtet fuhlte, habe ich gerne mitgetheilt, soweit das müglich war.

Erst nachdem das Material der grossen Ernte, welche ich $1 \times 79$ und 1880 in Lenkoran machte (3000 Balg Exempl.) bearbeitet war, konnte ich beginnen rom Ueberflusse zu vertheilen und der Zuwachs der Sammlung in den folgenden Jahren gestattete mir damit fortzufahren.

\section{Получилн-Es erhielten:}

Sr.Kaisl.Hoht. Grossf. Nicolai Michailowitsch in St.-Petrb. 1000 Expl. kauk 1883. Sr. Kaisl und Kngl. Hoht. Kronprinz Rudolph in Wiell. 100 .

Eugen v. Homeyer und Tankré, in Stolp und Anklam . . 200

Graf Berlepsch in Kassel. . . . . . . . . 60 ,

Naturforschende Gesellschaft in Danzig . . . . . 100 ,

Professor R. Blasius in Braunschweig . . . . . . . 150

Zool. Museum der Kaisl. Akad. d. Wissft. St.-Petersburg.

Professor A. Bogdanow in Moskau . . . . . . . .

Professor Hartig in München . . . . . . . . . .

Professor Gigliogli in Florenz ............

30

Eugen v. Homeyer in Stolp... . . . . . . . 25

Professor R. Blasius in Braunschweig. . . . . . . 40

Dombrowsky in Wien.............. . 28

O. Reiser in Sarajewo. . . . . . . . . . .

Graf St. v. Washington ............ . 1

Dresser in London . . . . . . . . . . . 60

Senkenberg Museum in Frankfurt a/Main ....... 11

Smithsonian Institution in Washington. . . . . . . 67

Professor Dubois in Brussel. . . . . . . . . 18

Dresser in London .............. . . 27

\begin{tabular}{|c|c|c|c|}
\hline (1) & $"$ & $\pi$ & $n$ \\
\hline 80 & " & $n$ & $\pi$ \\
\hline 67 & $n$ & $\pi$ & $n$ \\
\hline 25 & $"$ & transkp. & 1887. \\
\hline 25 & $\pi$ & » & 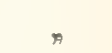 \\
\hline 40 & $n$ & $n$ & 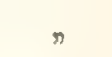 \\
\hline 28 & п & * & $n$ \\
\hline 9 & $n$ & $n$ & 1888. \\
\hline 1 & $n$ & $n$ & $\pi$ \\
\hline 60 & ه & kauk. u. trskp. & $n$ \\
\hline & $"$ & $\pi$ & $\pi$ \\
\hline & $n$ & $n$ & $n$ \\
\hline 18 & $n$ & $\pi$ & * \\
\hline 27 & $n$ & $n$ & 1889 \\
\hline
\end{tabular}


'Tschusi ron Schmidhoffen in IIallein ......... 26 Exl. liauk. u. trskp. 1889. Chantre in Lyon . . . . . . . . . . . . . 52 \%

1). Valentin in Frankfurt a/Miain........ . . 48 n

Mr. Wood-Mason in Calcutta (6 Säuger) . . . . . 64 " 64 " 1891.

Dr. Sander in St-Petersburg (auch Eier und Conchylien). 14 n liank. 1894. Professor Milne Edward in Paris (Säuger). - . . . 40 " $\quad 1898$. Summa. . 2458 Exl.

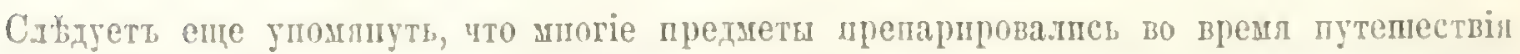

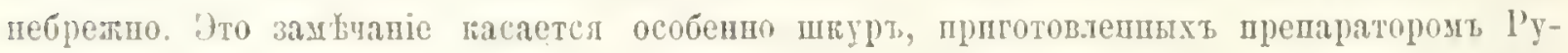

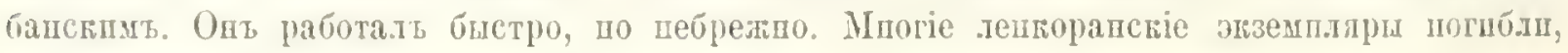

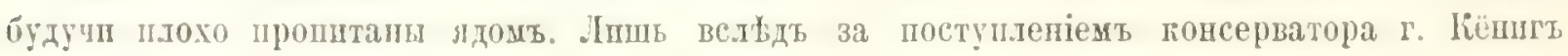
па слуғбу въ жузей (въ 1892 г.) удалось ододъть постененио вредныхъ Anthrenus.

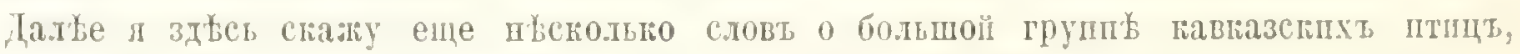

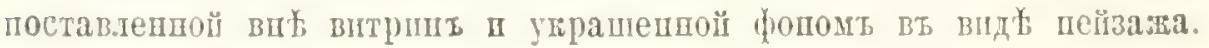

\section{Большая группа водяныхъ птицъ въ ленноранснихъ низменностяхъ (стр. 120).}

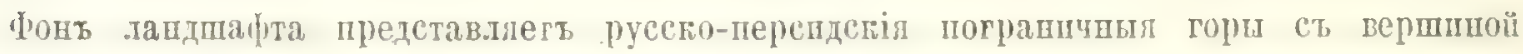

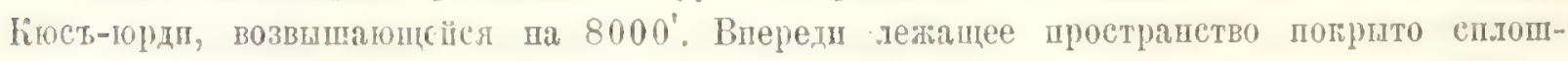

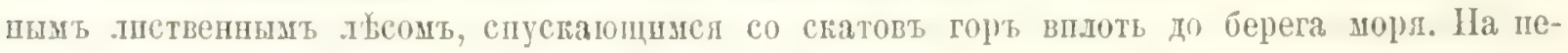

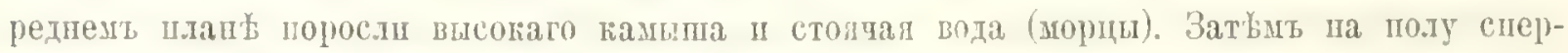
ва болотистыя места ст. пресиоводным формами, а виереди морской берегъ ст содеповодициг формами.

Noch muss erwähnt werden, dass Manches während der Reisen nachlässig präparirt wurde. Tamentlich war das mit den Baigen, welche der Präparant Ruhansky machte, der Fall. Er arbeitete rasch aber nachlibsig. Von den Lenkoranern gingen viele in Fulge schlechter

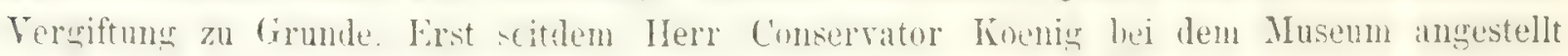
wurde (1892) sind nach und nach die lästigen Anthrenus ganz bewältigt worden.

Ferner will ich hier noch von der grossen Gruppe kaukasischer Vögel sprechen, welche mit landschaftlichem Hintergrunde frei aufgestellt wurde.

\section{Die grosse Gruppe von Wasservögeln in den Niederungen von Lenkoran (pagr. 120).}

Den landschaftlichen Hintergrund bildet das russisch-persische Grengachirge mit dem

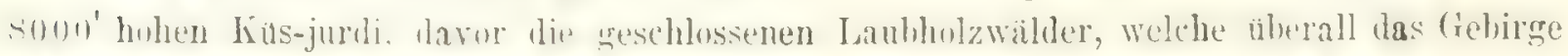

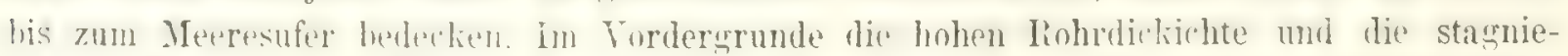
renden Wassertachen (Moni), dann auf dem Fusshuden zuerst sumpfterain mit den Süswasserformen, davor Meerestrand mit den Salzwasserformen. 


\section{Группированы сльдующіе виды:}

\section{Folgende Arten wurden gruppirt:}

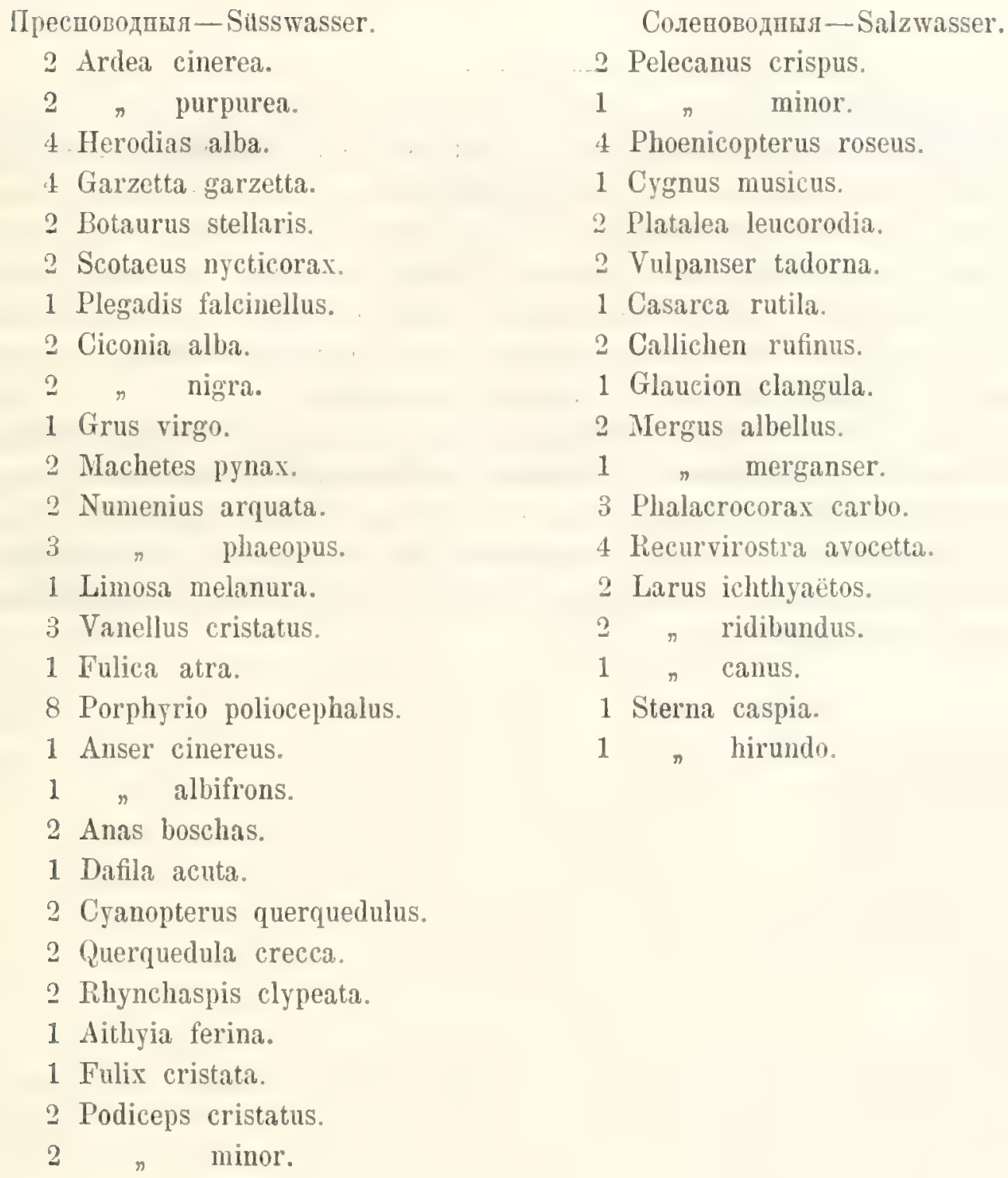

O прочпхъ группахъ一фазанахъ пा другпхь курпныхъ породахъ, равно какъ о тропическиъ птпцах, я сообщу въ VI топь при подробнощт описаніи установеп зоодогшчесгано отдвла.

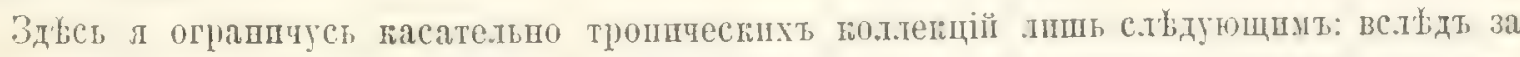

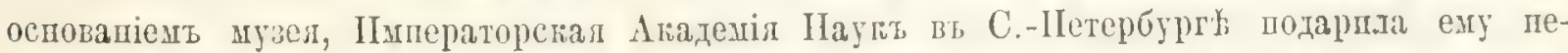

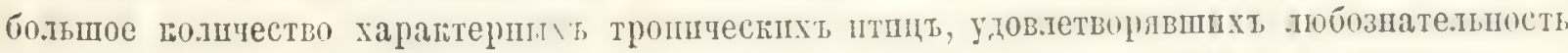
особенно туземцевь, справлявшхся часто о райспшть птпахь, толибрп п попугаяхь.

Наконець Ихъ Ищператорскіө Высопөствя Великіө Княвья Александръ и

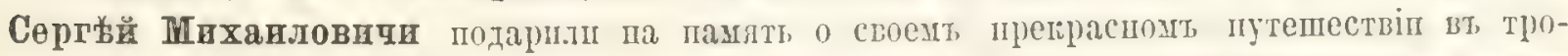

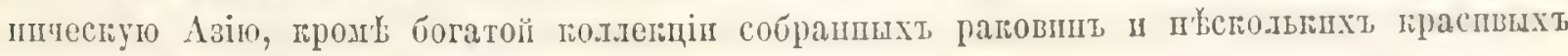
диевших бабопепь епе 140 тучель. 


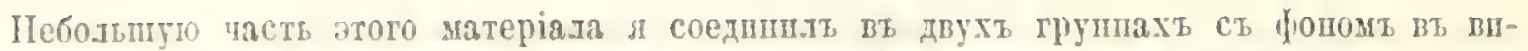

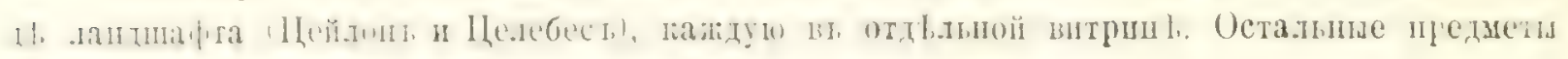

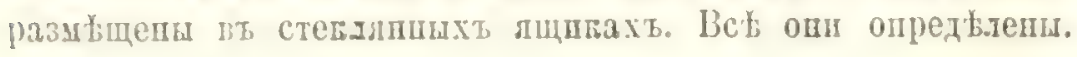

T"eber sunstige (iruppirungen-Phasanen, Waldhühner, abdere Gallinaceen-und dic Exoten herichte ich im VI liande bei der detaillirten lieschreibung des Arrangements in der zooJugichen ththeilung. Hier, heschränke ich mich in liezug auf die Exoten nur auf FolgenAt's: Gledih nah der Grundung des II shaften in st.-Petershurg demselben eine kleine Anzahl tropiseher, charakteristischer Vü[n] $(10 \mathrm{Fxpl}$.). welche das Interesse namentlich der Eingeborenen befriedigte, da diese sich oft nach Paradies Vügeln, Kolibris und Papageien erkundigten.

Zum Indenken endlich an die herrliche lieise in die asiatischen Tropen schenkten Ihre Kaisl. Hohoiten die Grossfürsten Alexander und Sergei Michailowitsch ausser ciner roichen Sammlung erbeuteter Conchỵlien und etlicher Prachttagfalter auch 140 Togelbälge. Ich habe aus einer klein'n Zahl dieses Materiales zwei Gruppen mit landschaftlicher Umnrebum (Ceylon und Celebes) in zwei grossen Vitrinen arrangirt. Das Uebrige betindet sich in Schaukasten. Alles ist bestimmt. 


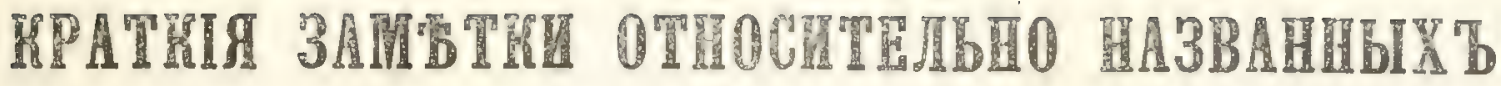 ITWLI'B.
}

\author{
P A S S E R E S.
}

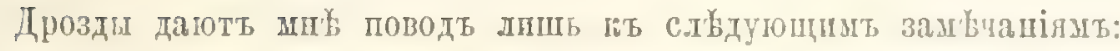

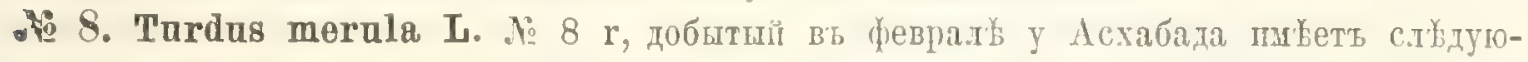

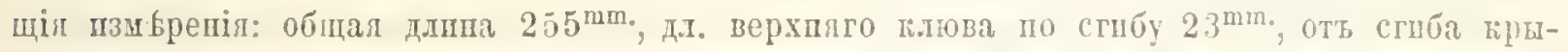

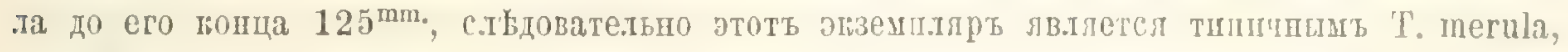

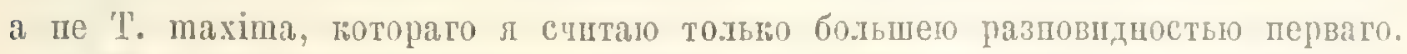

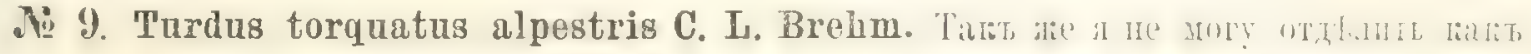

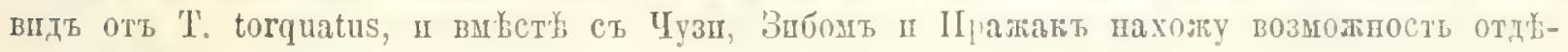
лпгь его толью пользусь трширной поменкатурой.

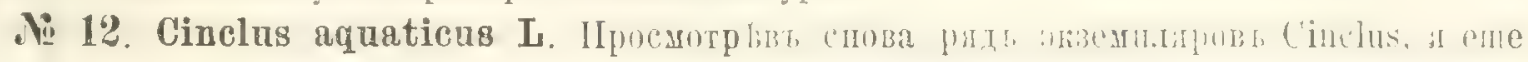

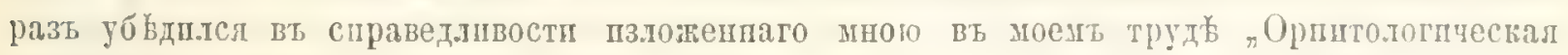

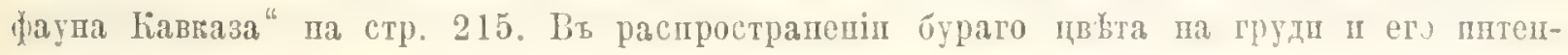

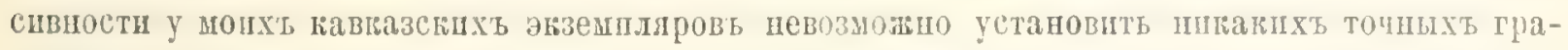

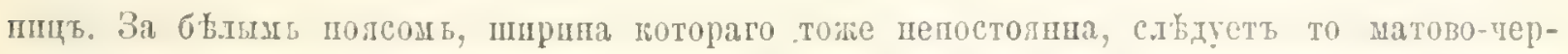
нциі цвъть C. melanogaster, то бльдиал буроватая окраска C. caschmiriensis. Равицыв об-

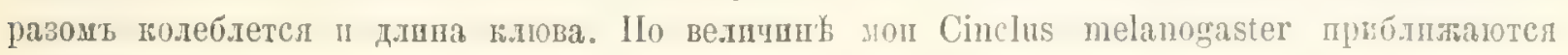
кт пведсниз.

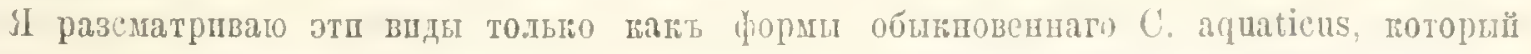

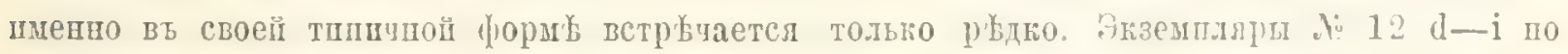

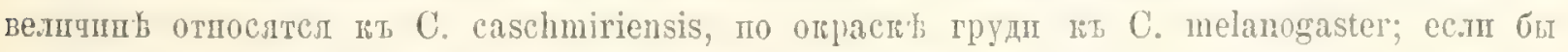

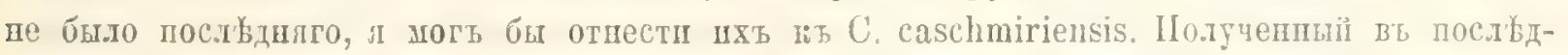

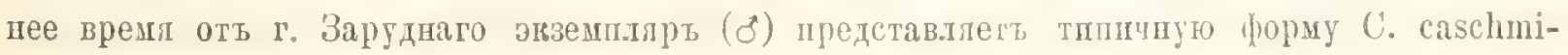
riensis. Дрессерт (Supl. Part. 1 Jan. 95) отдылеть қавказипхь птицв вт видовомт от-

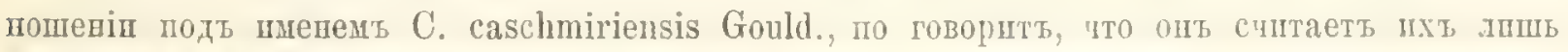

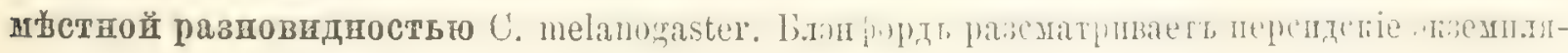
ры лшшь какь C. aqt. vart, caschmiriensis.

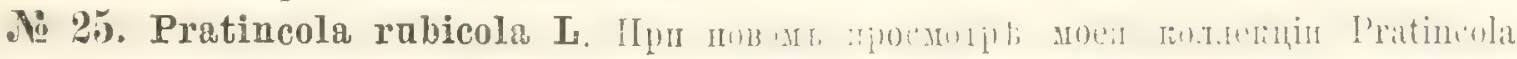

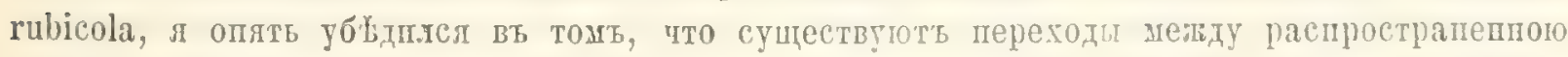

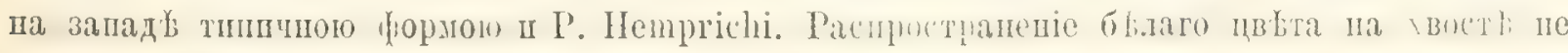

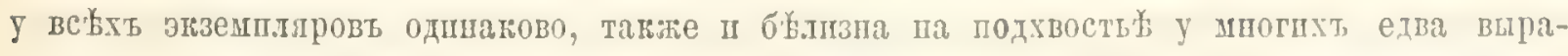

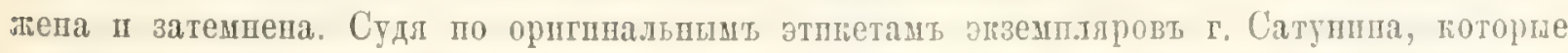

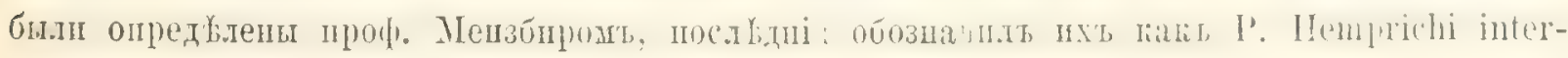

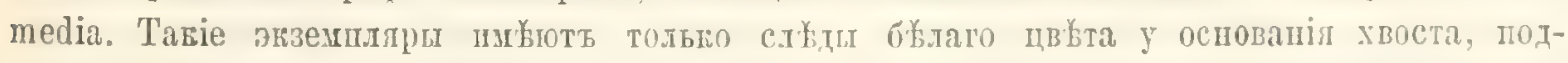

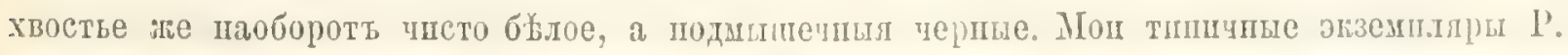

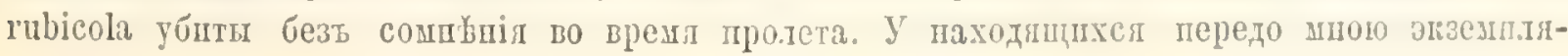




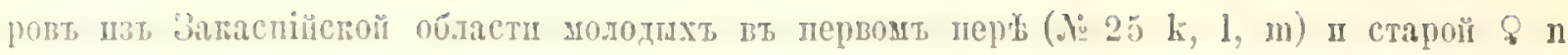

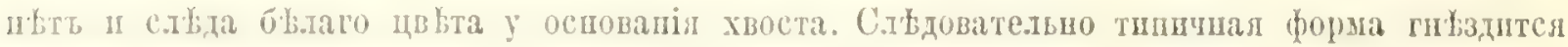
Bт этої страны Hнода.

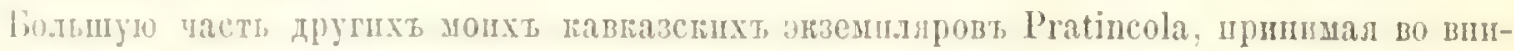

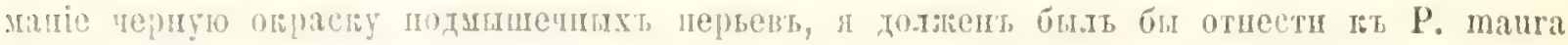

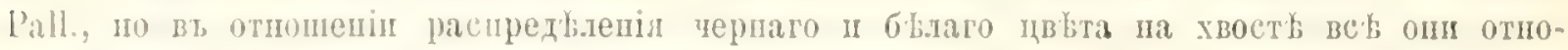

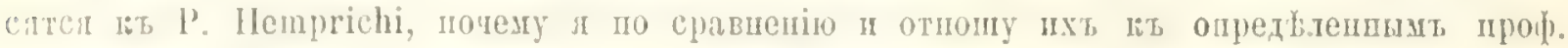

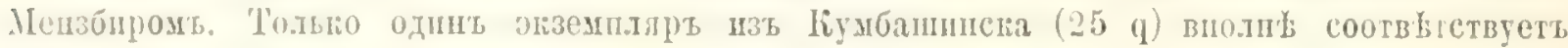
nuncanio P. Hemprichi.

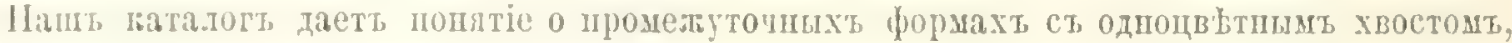

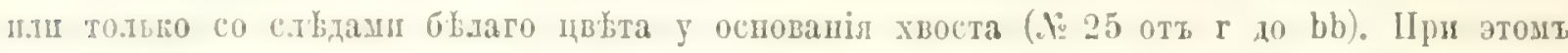

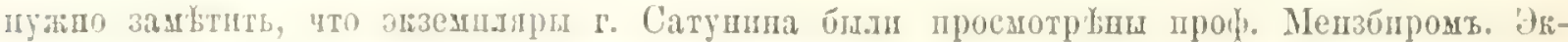

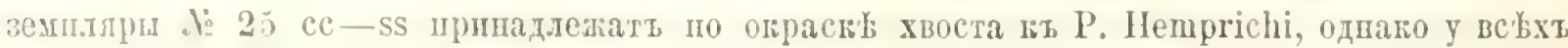

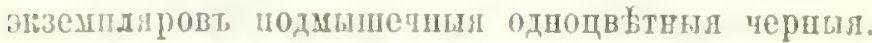

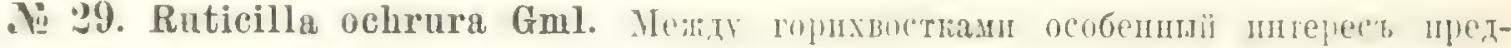

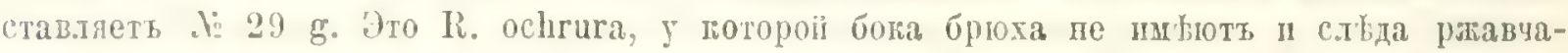

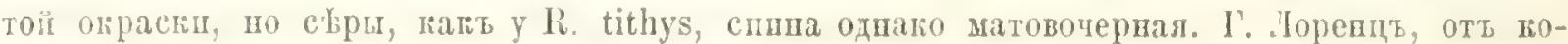

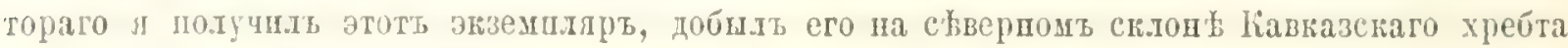

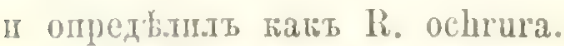

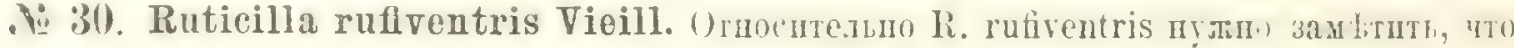

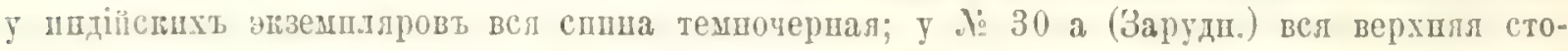

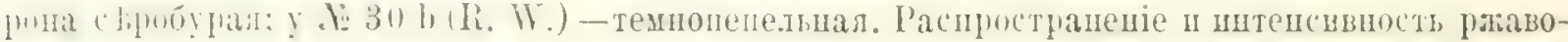

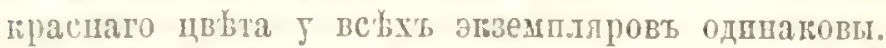

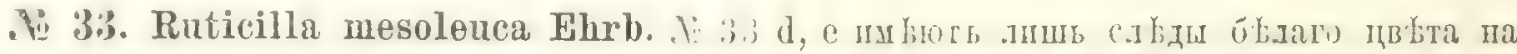

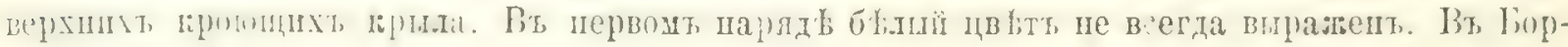

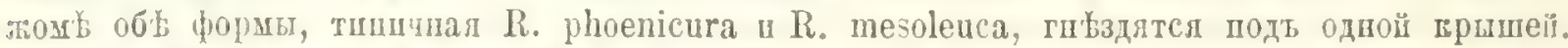

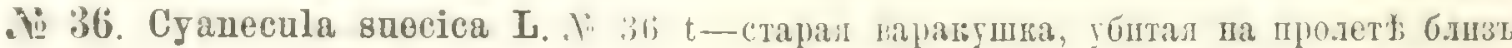

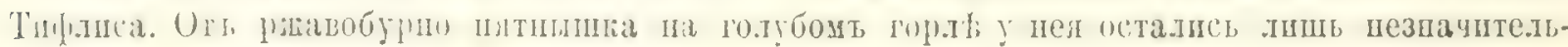

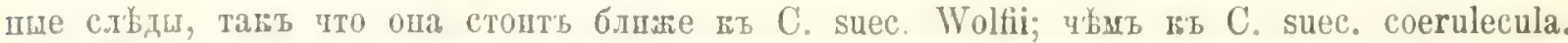

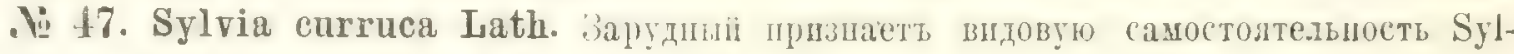
via minuscula Hume (стр. 90) и S. althea Hume, по говорить что сущестують переходш къ S. curruca aftinis (стр. 95), поторце оцъ объясняетъ гибрндам. Такае онъ говорнтъ (стр. 99) о гийридахт между S. althea n S. c. affinis. Oтпотенія длпны больших моховыхт полеблетсл у обыих форм. Iроф. Мензирт въ стать' о S. curruca (стр. 960) го-

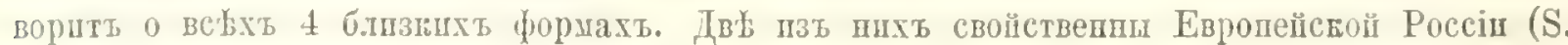

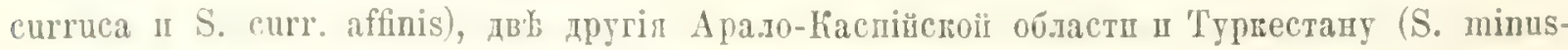

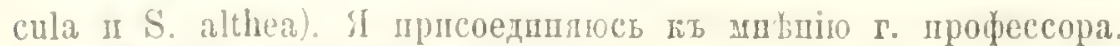

.

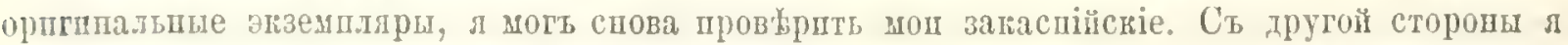

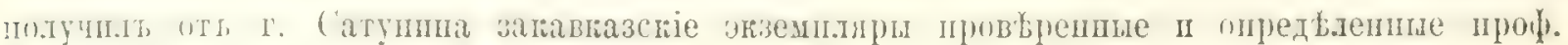

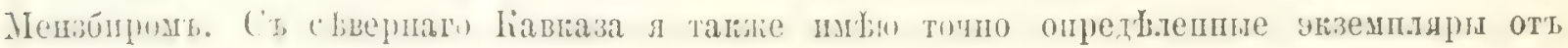

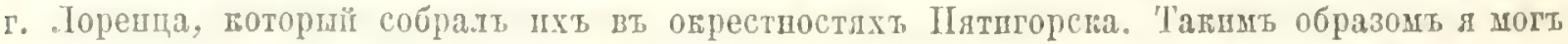

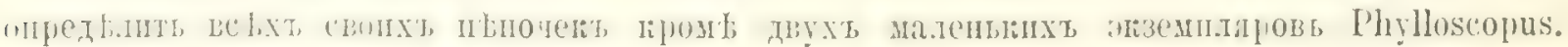

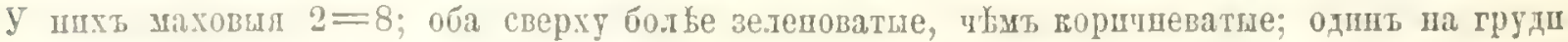

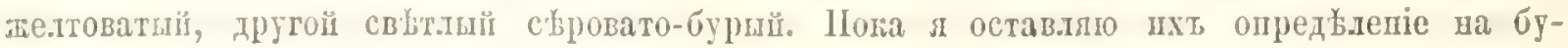
дуцее время, ие включая ихъ в’ь каталогь. 


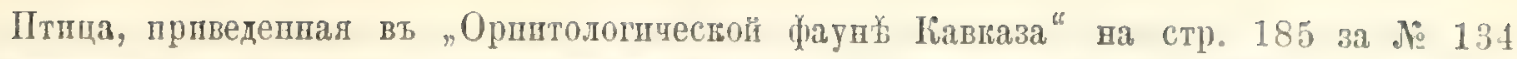

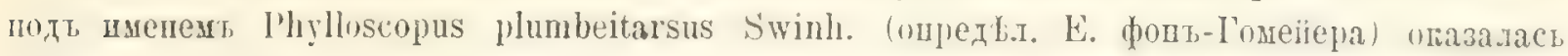

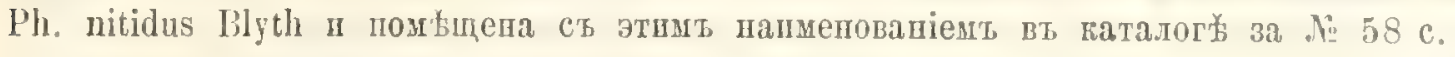

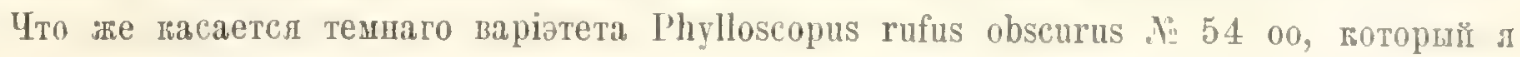

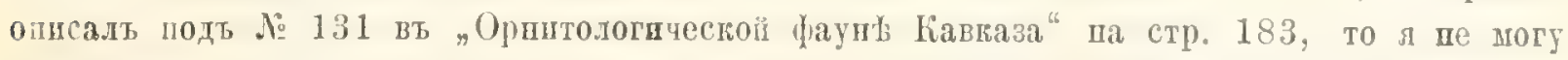

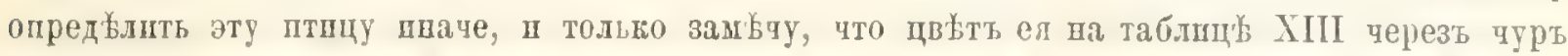

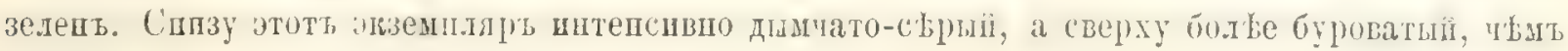
веленоватий.

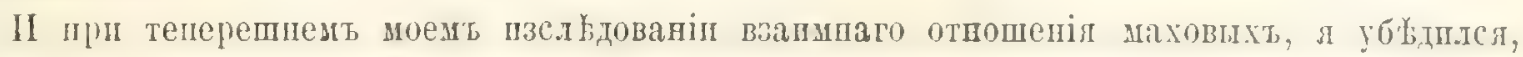

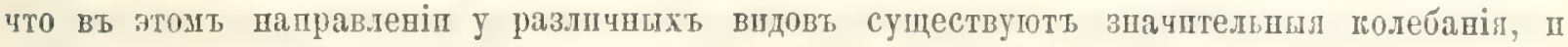

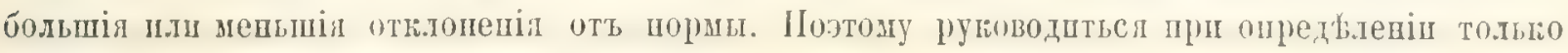
әтими признатами-невозможно.

№ 7\%. Locustolla straminea Sev. Разсматриваетсл Мешзбпрог на стр. қ68 лить

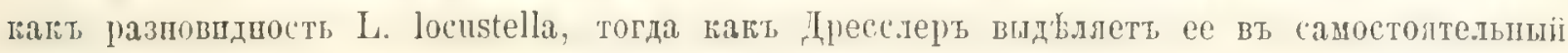
видт, (Supl. Part. II).

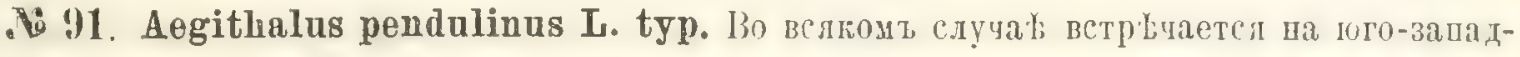

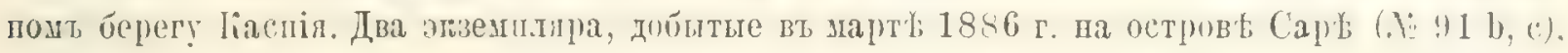

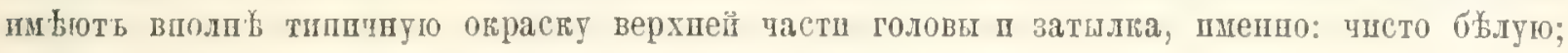
у

Настопщихъ Aeg. castaneus Sewerz, я пмюю тольго изъ Закаспійсгой области.

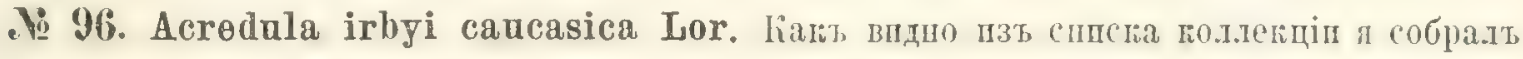

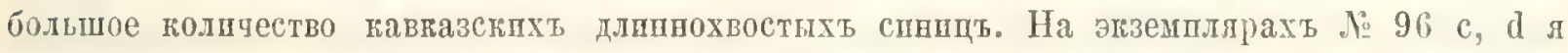

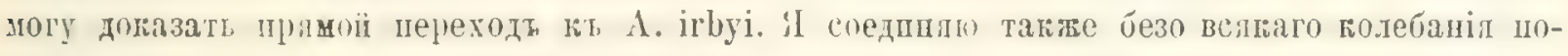
лучепный мною оть г. Дрессера экземлярт А. rosea съ A. irbyi. Моп глаза не находять

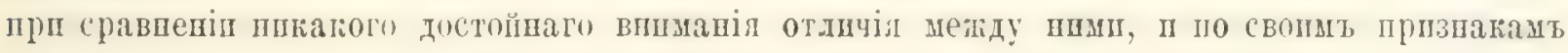

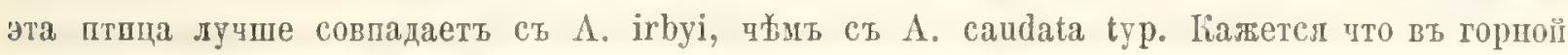

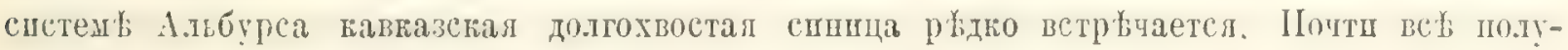
ченпыл оттуда отвосятся къ меньшей толстопосой A. tephronota.

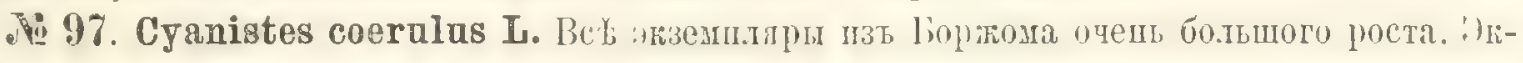

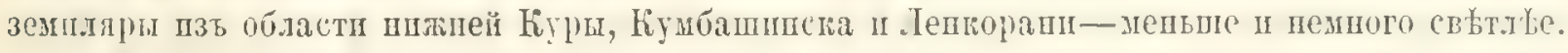

№ 101. Parus major $\mathbf{L}$. Экземдляы пзъ Боржома настолщіе великаны.

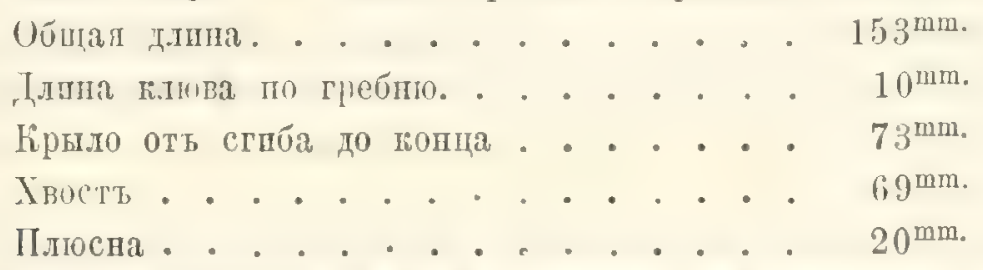

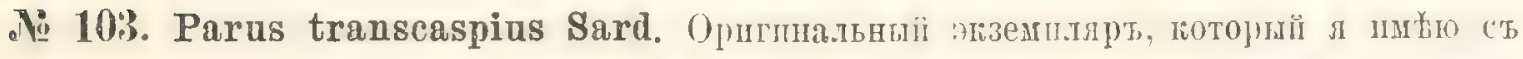

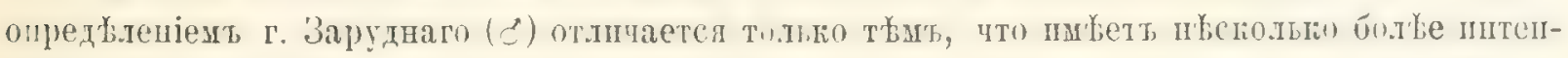

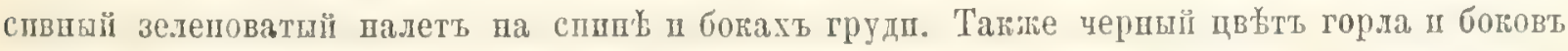

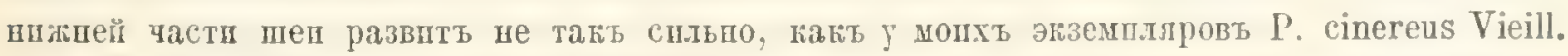

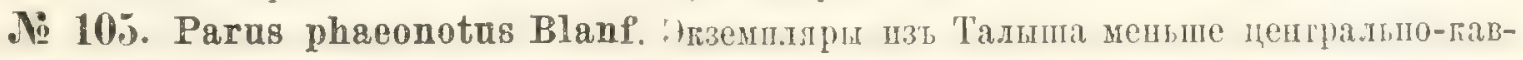

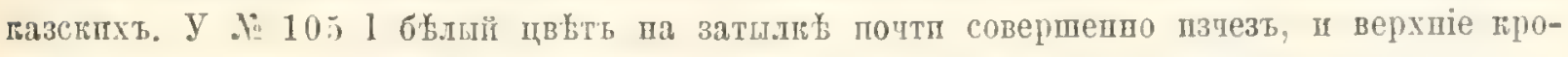

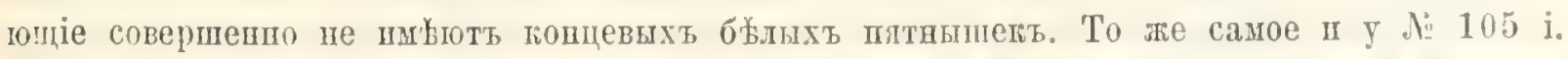

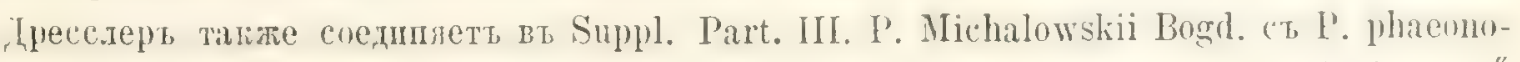

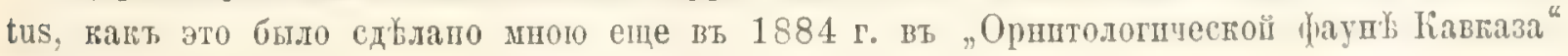
на стр. 108. 


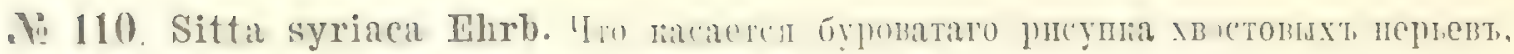

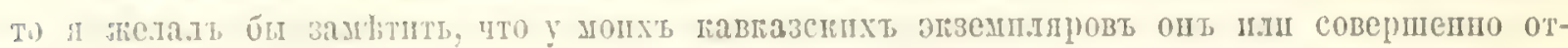

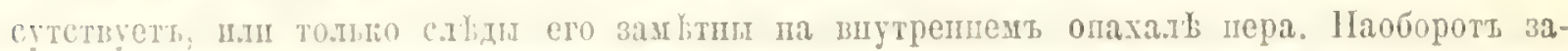

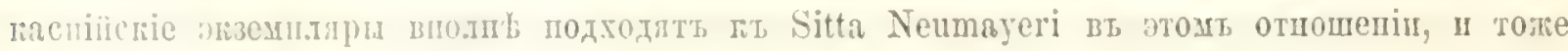

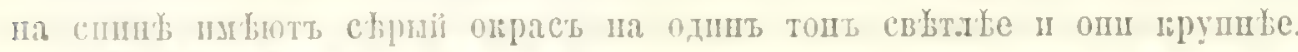

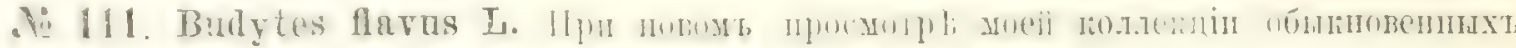

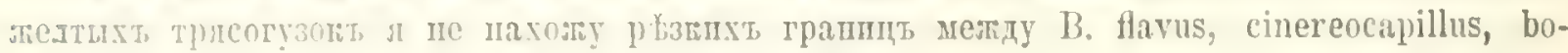

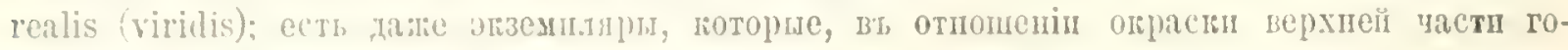

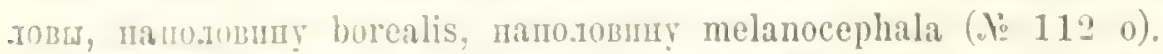

lí 11\%. Budytes melanocephalus Licht. Hot. Xanthphrys Sharpe, munanian no

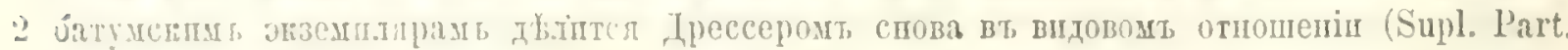

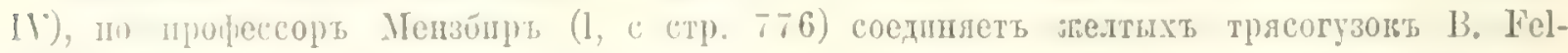

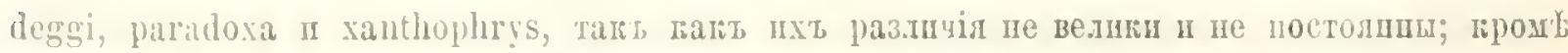

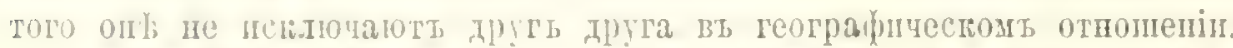

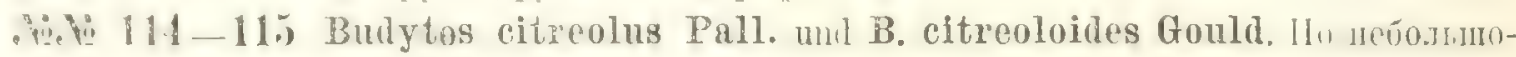

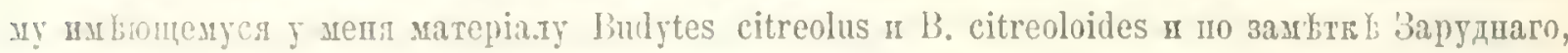

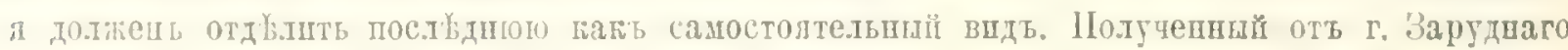

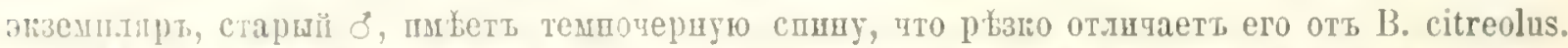

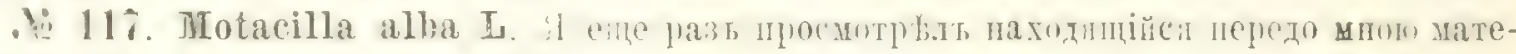

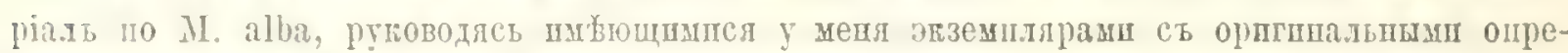
дылпіям гг. Мензира, Заруднаго и .Іоренца, и еще разъ убфдися, что пи для распро-

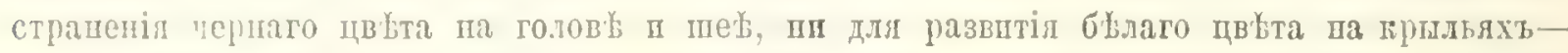

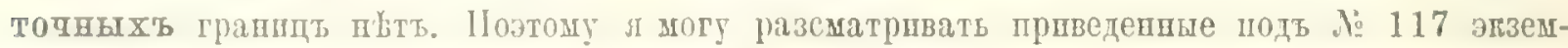

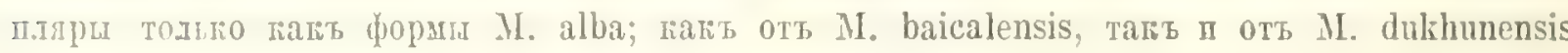

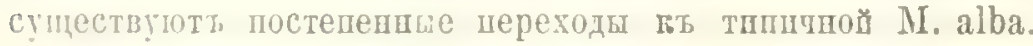

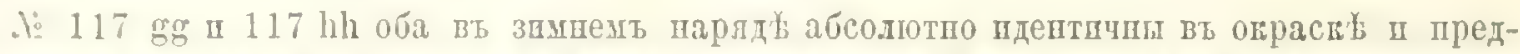

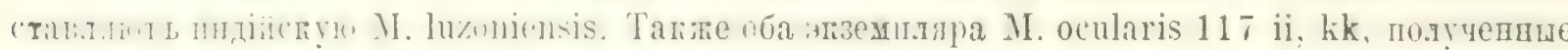

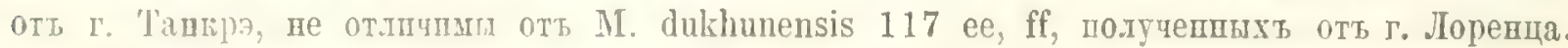

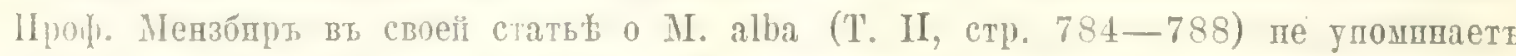
o MI. dukhunensis; онъ говоритт толью о M. baicalensis, которая тояе отличаеся боль-

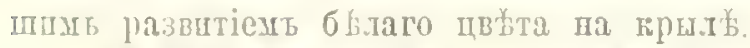

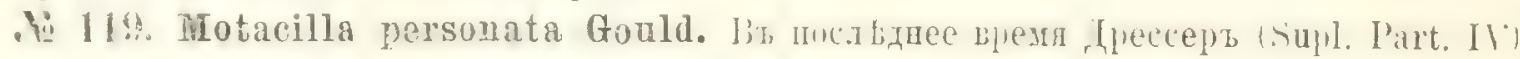

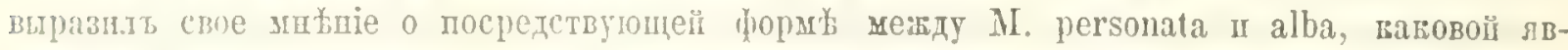
ллетсл М. personata persica Blnf. Онь занучаеть вь әтомь случан: the variations inter se of this form are great".

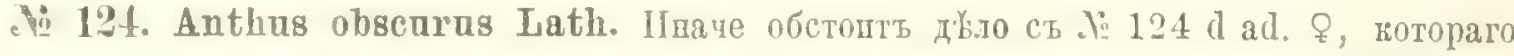

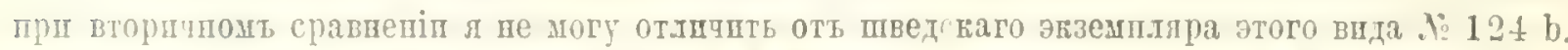

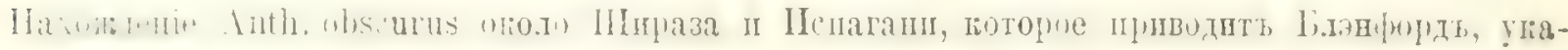

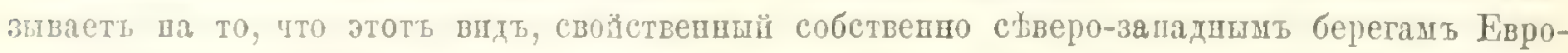

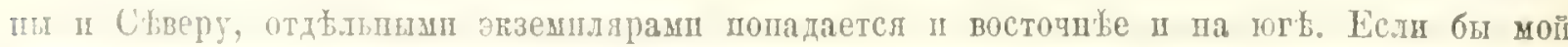

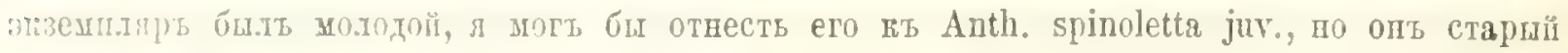
u xopono ovinчreтел.

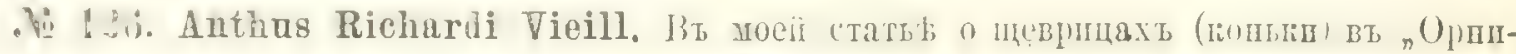

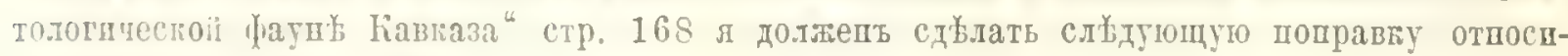
resıno Anthus Richardi:

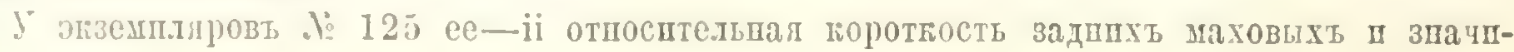




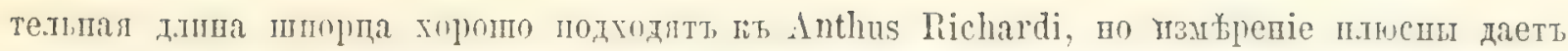

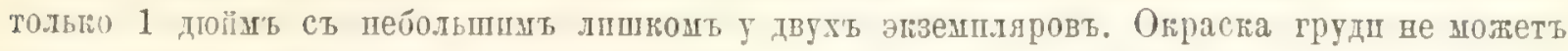

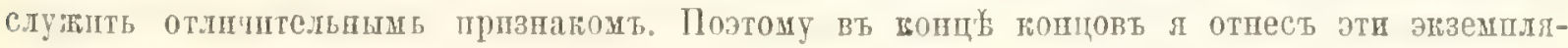
p

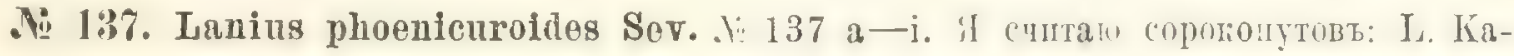
relini Bogd., L. Romanovi Bogd. II L. isabellinus Hempr. et Ehrenb., paзсматрпваемшхт

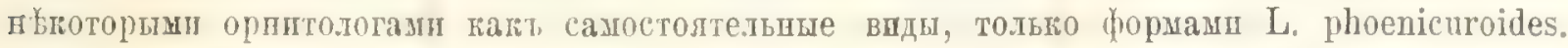
O какомь нибудь постолнств' окраски п величнны зеркальца на крылы нечего п гово-

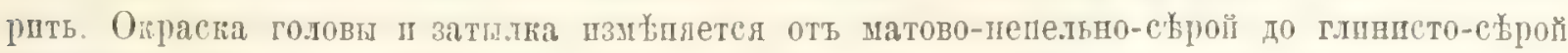

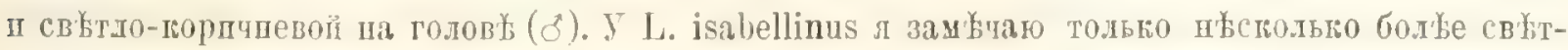

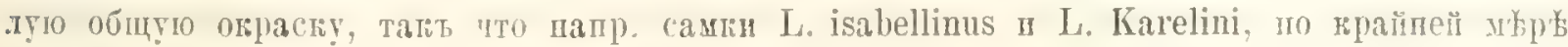
у монхт эпземпляровт, 一 не разлиним.

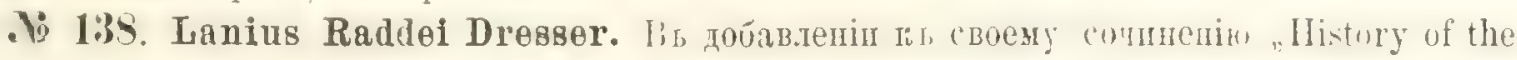
Birds of Europe" Part. IV, Автусть 1895 г. стр. 171 и 172. Дрессерь пзатаеть основаніл, по которшм онт прпшель й убызденіо въ самостоятельвости әтого вида. Самостолтель-

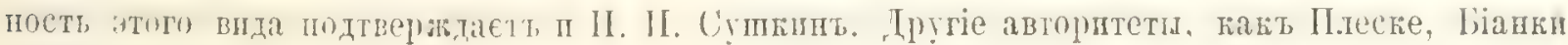

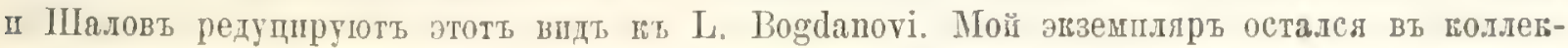

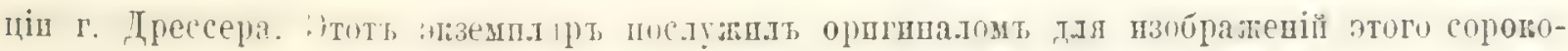

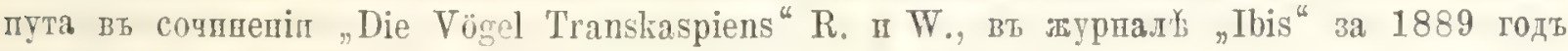
и вь дополненіи вь сочпненію Ірессера о птцахт Европы.

Niv 141 If 142. Lanius Grimml Bogd. If L, assimilis L. et A. Brehm. II хотл II приволу вь вастоящемь паталог', по прпвьру г. Заруднаго, Lanius Grimmi п L. assimi-

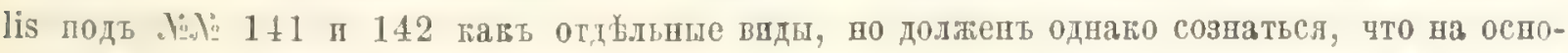

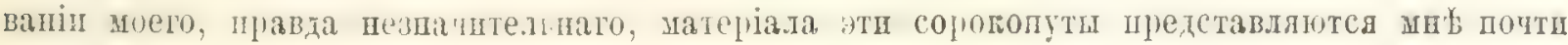
пдетпчнми. Нолученный оть г. Заруднаго экземпляь L. Grimmi не отлпчается оть L. assimilis даже и по величнш.

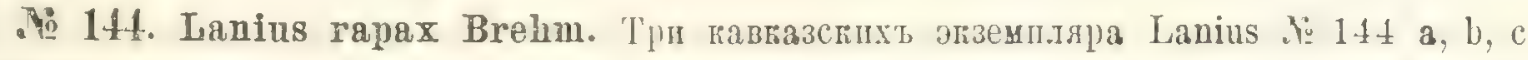

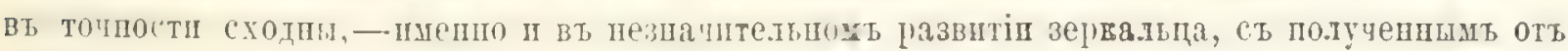
г. Заруднаго әпзепляромъ L. borealis empaeus Bogd.=L. rapax, почему я п отнопу ихъ къ этому виду.

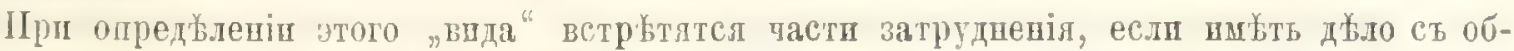

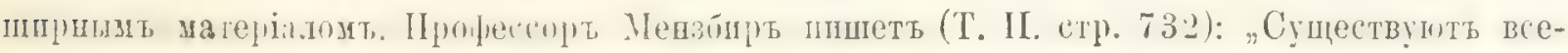
возмопные переходи оть сьвернаго сорокопута ғъ обыюновенному сьрому п по крайней

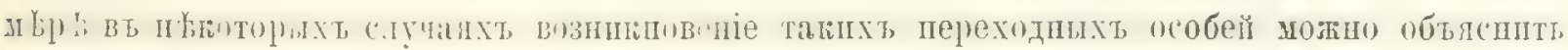

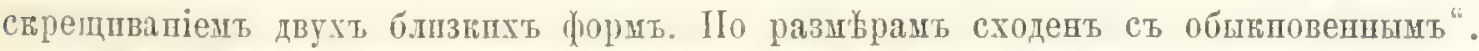

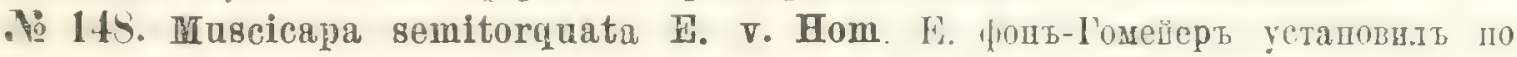

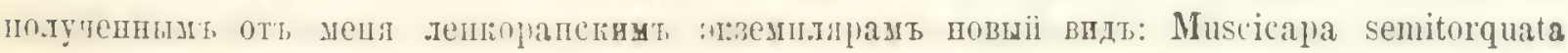

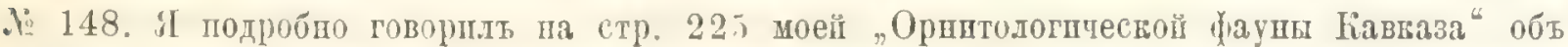

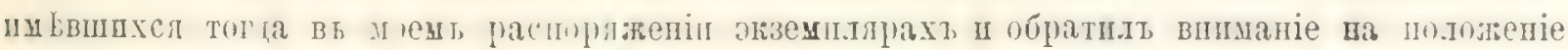
әтого вида межлу М. atricapilla n M. collaris. Шоэтому л замбчу здъсь тодьго, что зача-

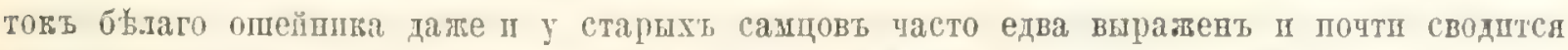

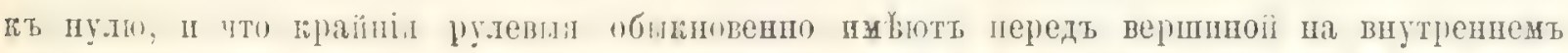

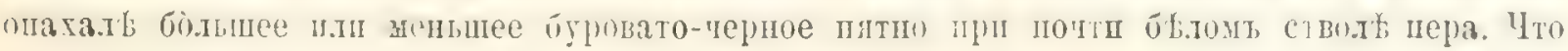
эта птпца зимуеть ша зиномь берегу Каспікскаго морл, какь обт этомь говорить проф).

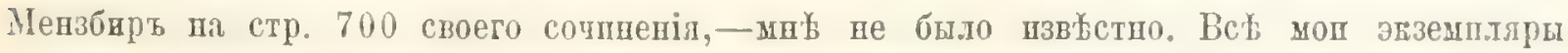
оттуда добыты на пролет в со средшны марта до средины апрх.я. 


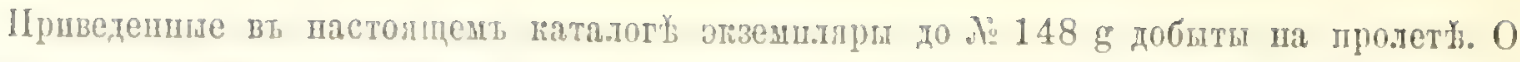

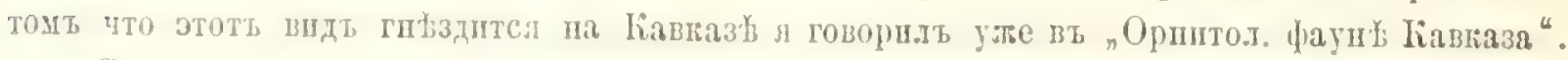

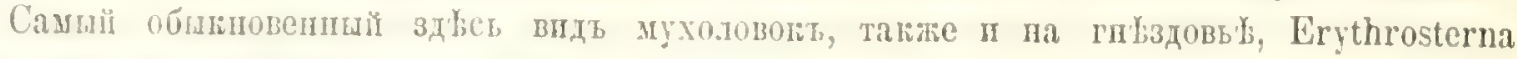

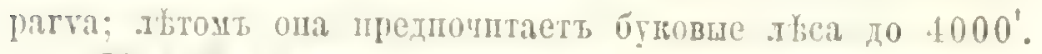

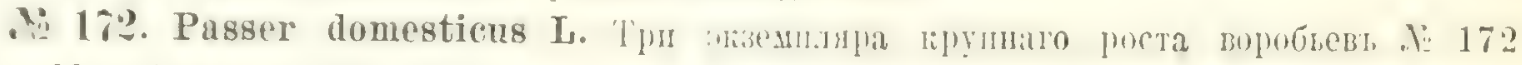

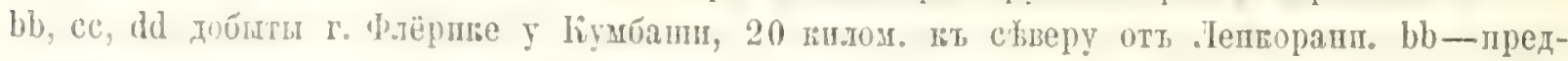

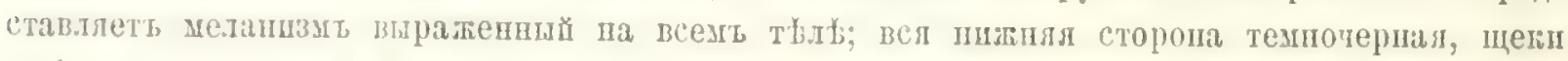

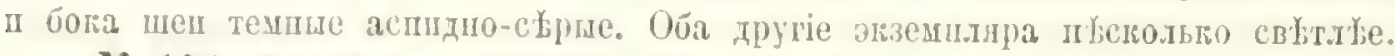

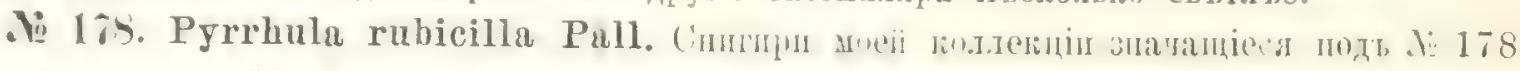

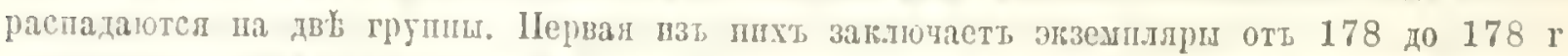

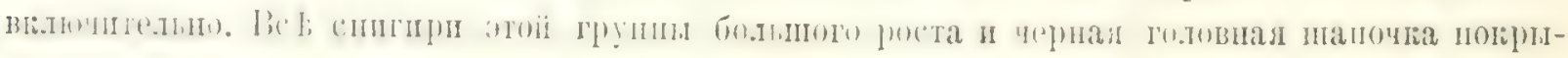
ваеть у нить и затилок.

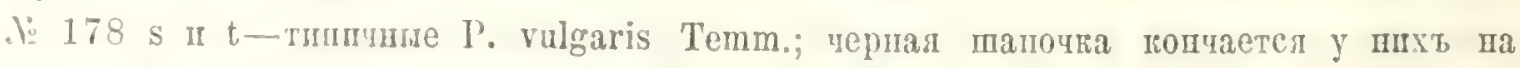

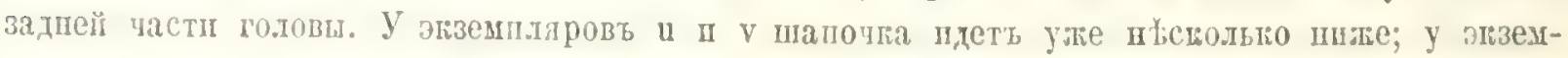

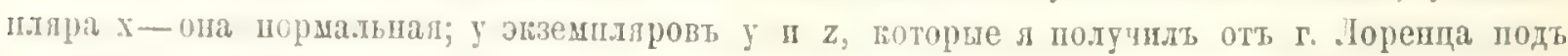

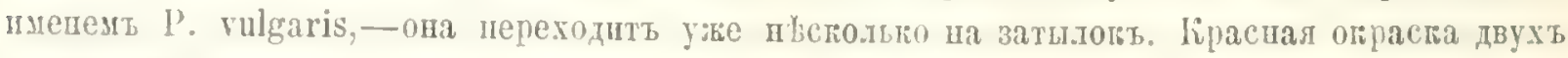

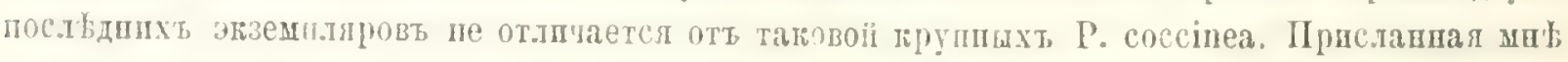

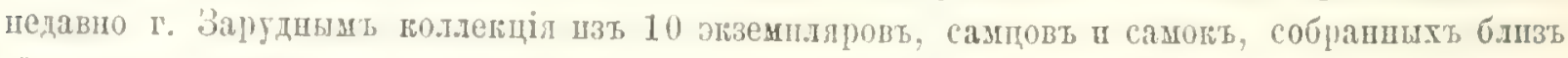

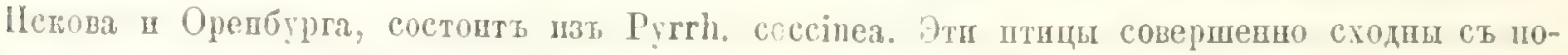

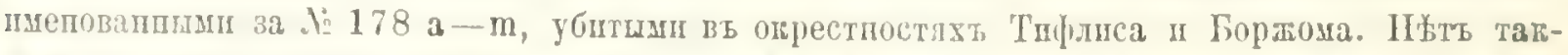

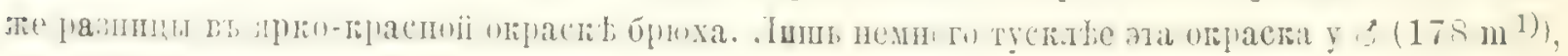

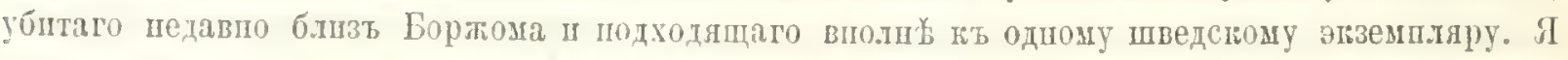

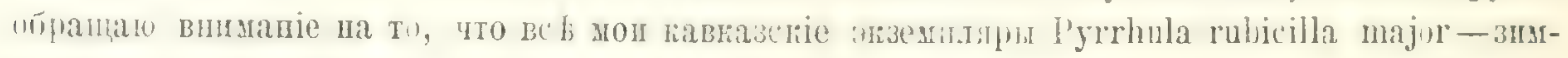

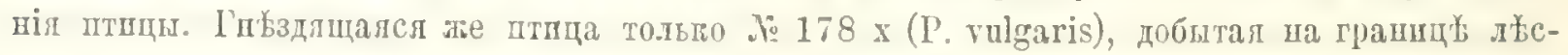
ной растительнсти вь Талып危.

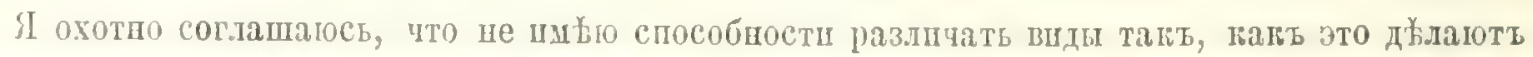

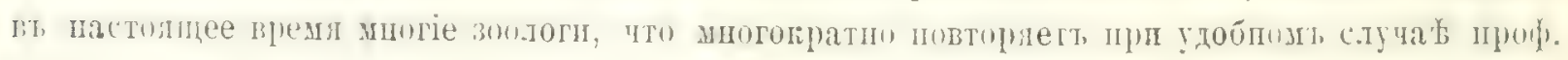

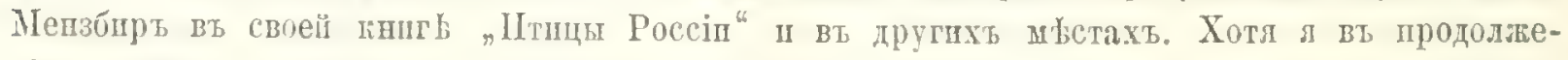

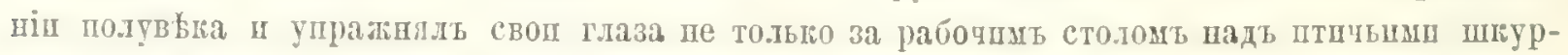

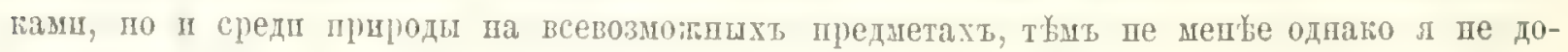

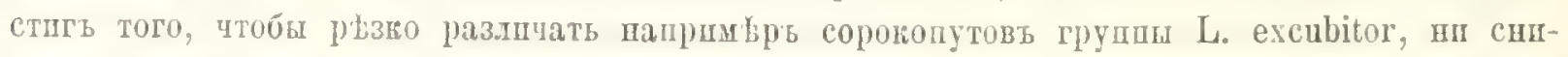

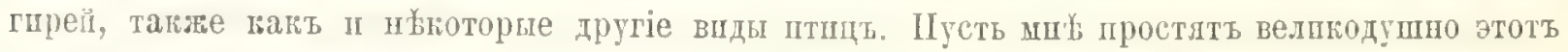
дедостатокь въ понпманіи!

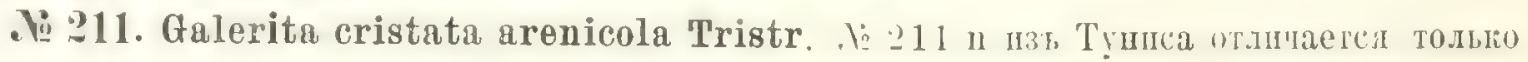

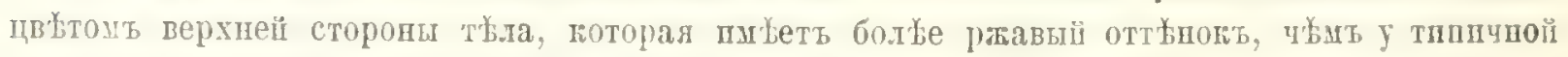
птцци, п едва отлпчаесл оть таковой G. magna п macrorhyncha. Moй әкземплив G. ma-

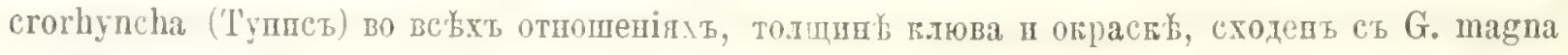

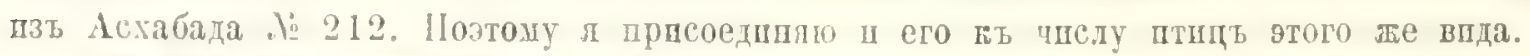

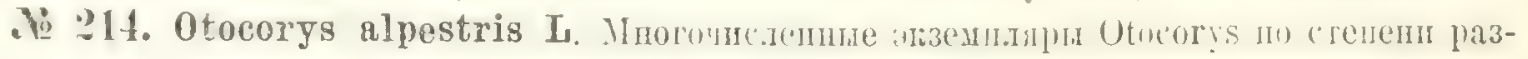
витія черного пвыта па голов бокахъ шеп п груди раздылютсл па 4 группы. Здысь за-

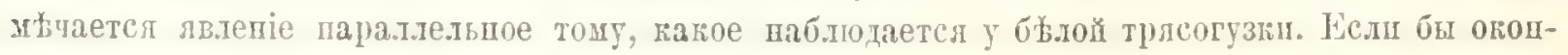

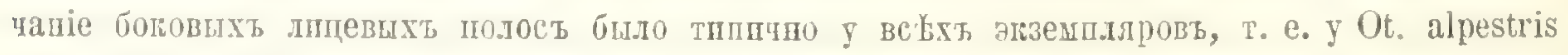

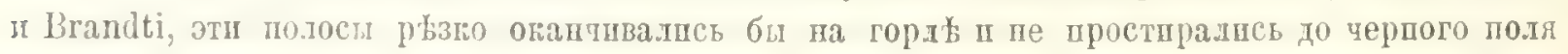
на груди, наобороть у Ot. penicillata, larvata п albigula опи были бш пепосредственио свя-

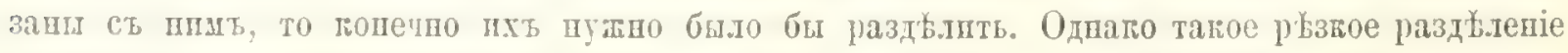

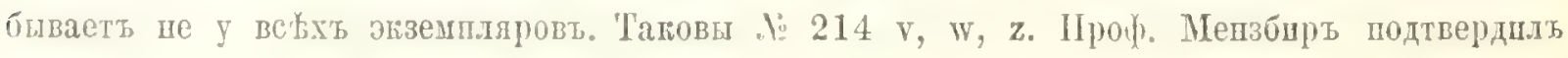


огредхеніе эгземляра z

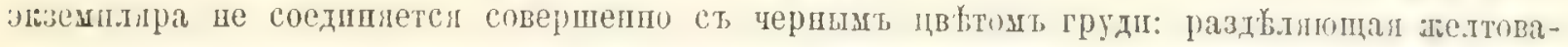

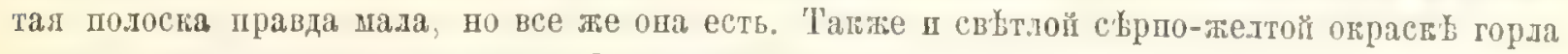

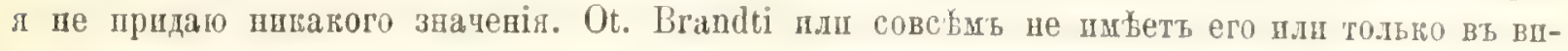

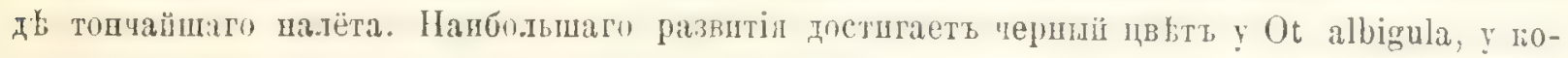

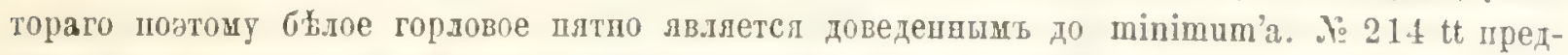

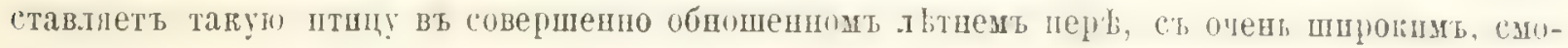

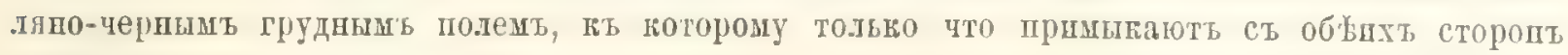
боковыхь шейныя полосш. SI могу утверждать, что Otoc. penicillata пзъ высовогоршой об-

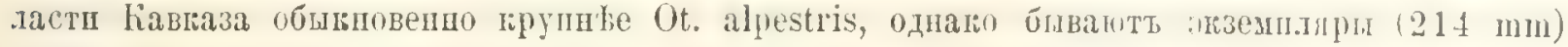

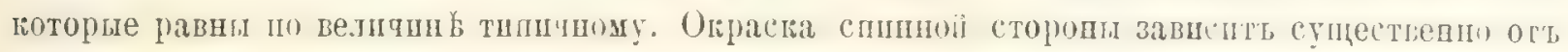
возраста птццы. Экземллрн типинаго Ot. alpestris я считаю за птпць, готорпя пршлета-

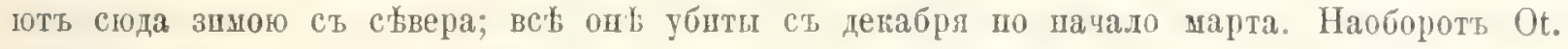
penicillata зимою, по крайней жръ по большей части, спускаются вншз сь горт; а весног

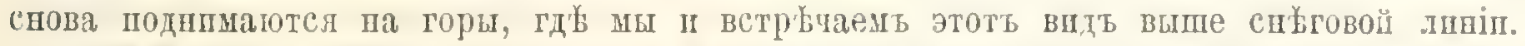

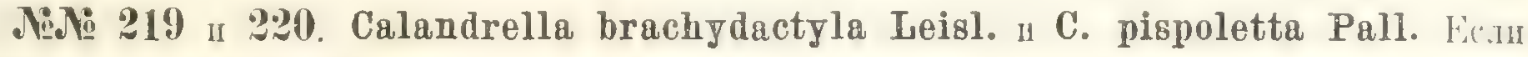

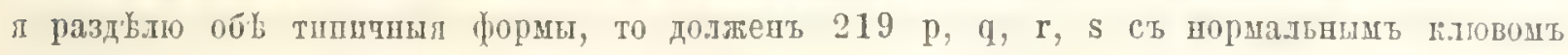
C. brachfdactyla п задним маховымп C. pispoletta, in .li 219 t ст норжальними (для С.

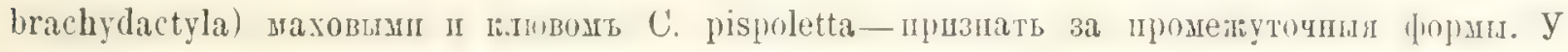
әкзепляровъ $220 \mathrm{~m}, \mathrm{n}$, о задніл маховил порнальпы для С. pispoletta, тилювъ-С. brachydactyla.

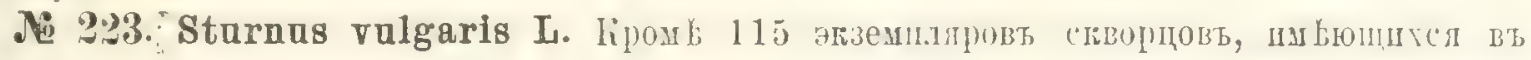
голлеціп въ теченіп временп бцло препаршровано еще большее число ихъ, поторцхь л

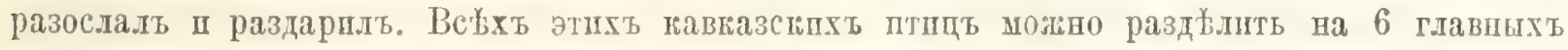

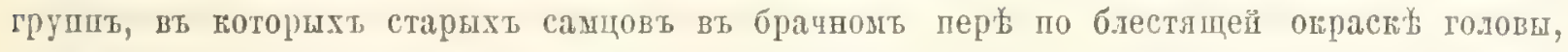

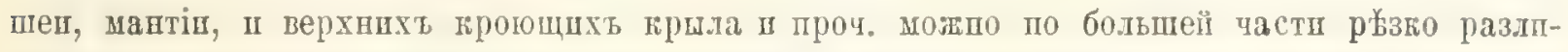

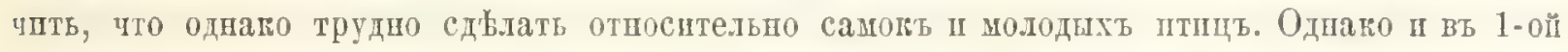

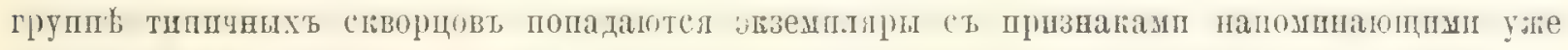

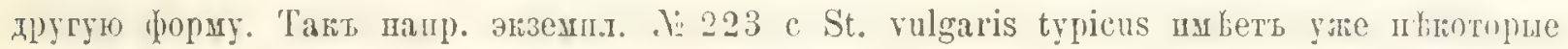
признаки St. Poltorazkii; толе самое у ํㅡㄹ 223 е.

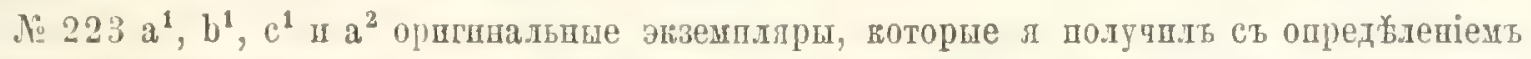

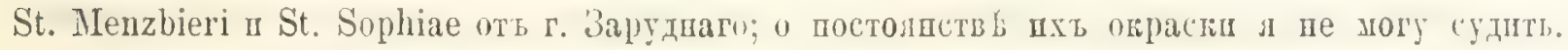

ㅇ․ $223 \mathrm{a}^{3} \cdot \mathrm{b}^{3}$. представдлоть типчныхт St. purpurascens Gould.; въ восьмой труппњ

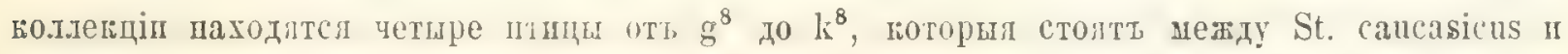

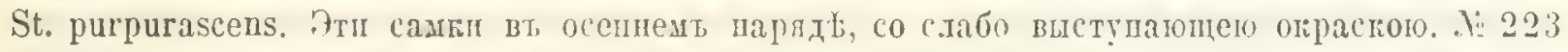

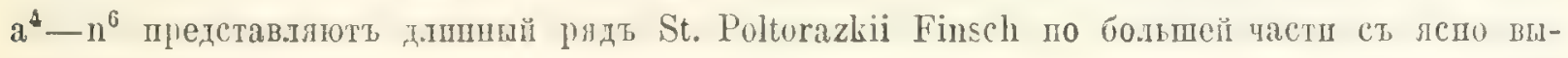
ражениого ограстою.

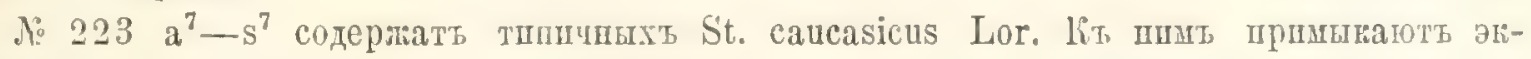
земплри d: 223 оть $a^{8}$ до $p^{8}$-переходпые отт St. Poltorazkii к'́ St. caucasicus, oть St.

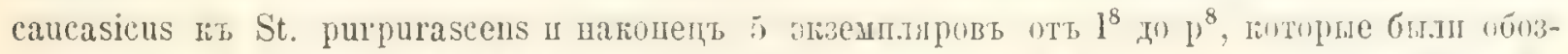

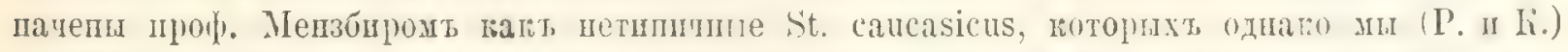

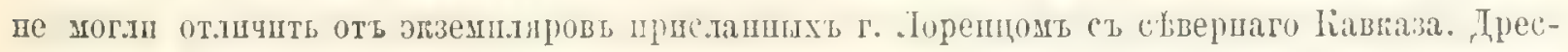

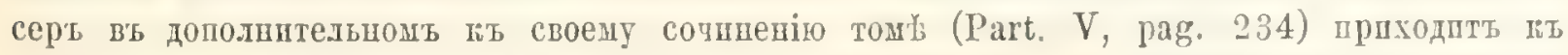

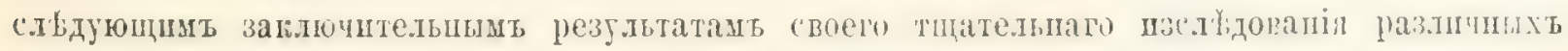
формт скворцовт: Sturnus unicolor-должепт быть отлиепт гіат особый вщдт.

Другіе же сьворды могуть быть раздысяы на двъ группы: па тактх, готорые имы- 


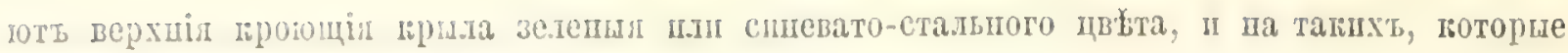

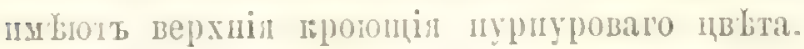

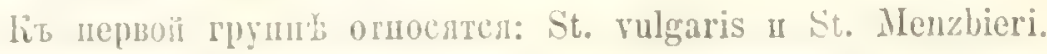

Kit, вropoii: St. purpurascens, St. porphyronotus, St. l'oltorazkii un St. caucasicus. Orno-

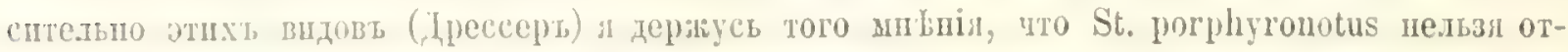

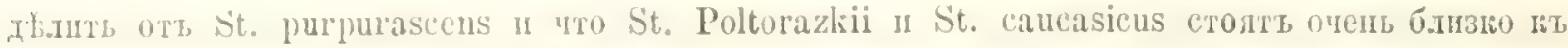

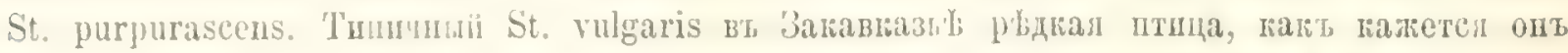

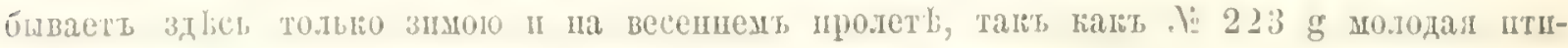

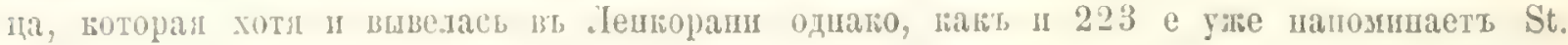

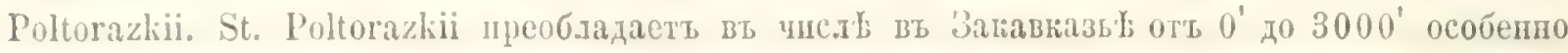

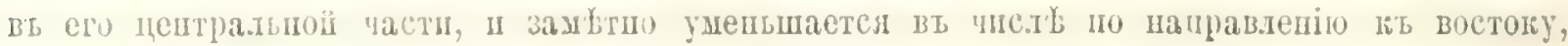

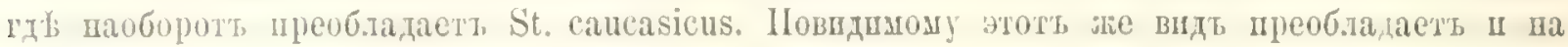

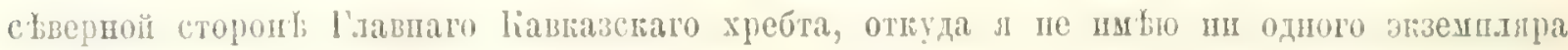
St. Poltorazkii.

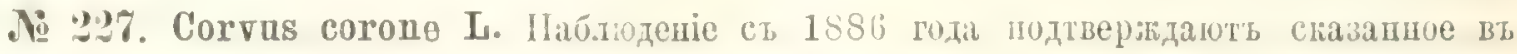

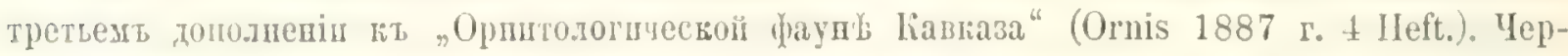

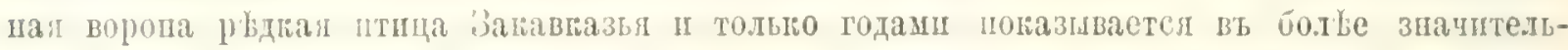

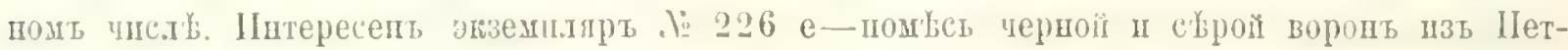

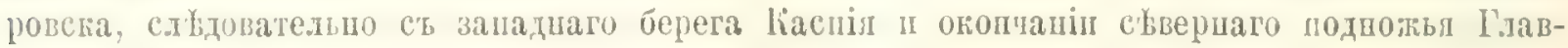
паго хребта.

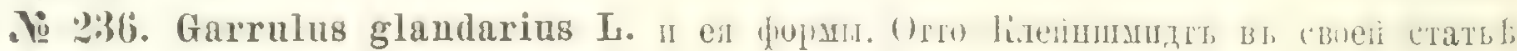
- вapisniax y Garnulus glandarius (Ornith. Jahrb. Jahrg. IV IIft. 5, Pag. 167-210). Y6b-

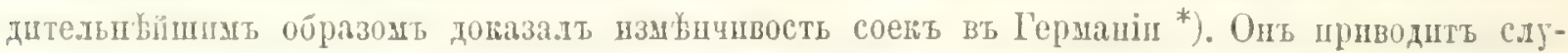

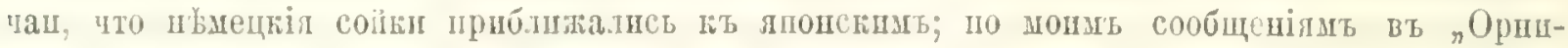

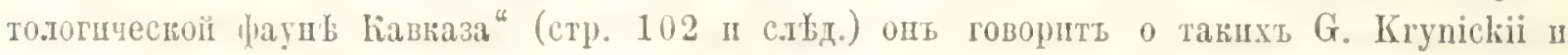

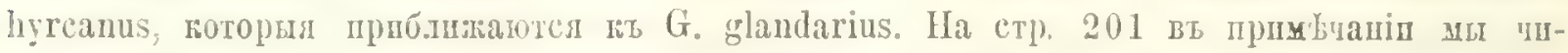

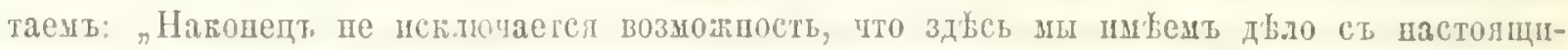

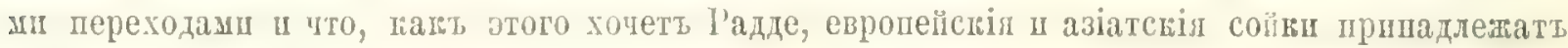
цьь одному виду". Однако авторь пршзпаеть видовуг самостоятельость G. Brandti пи стр.

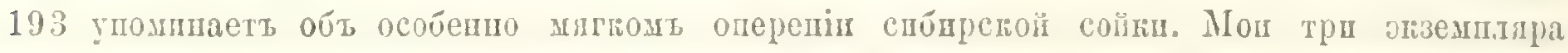

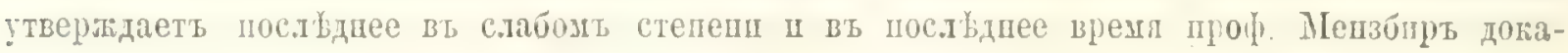

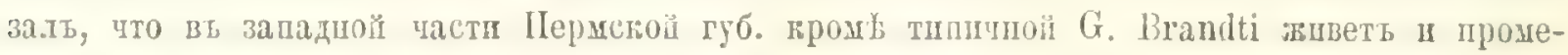
жуточнал форма, шереходпал й G. glandarius. Эта dopна (G. Severtzowi) встрьчаетсл и

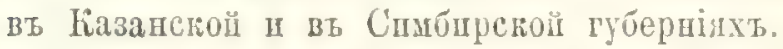

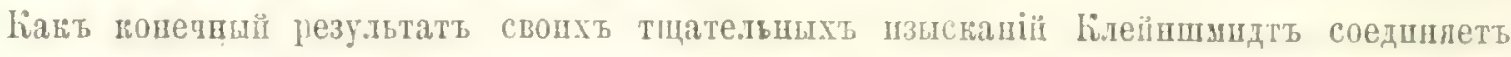

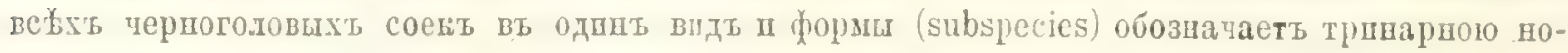
มенилатуроï:

Garrulus melanocephalus hyrcanus Blanf.

$\begin{array}{lll}" & n & \text { Krynickii Kalen. } \\ " & " & \text { albifrons=albicapillus Geoffr. } \\ " & n & \text { cervicalis Rïpp. var. taeniura. }\end{array}$

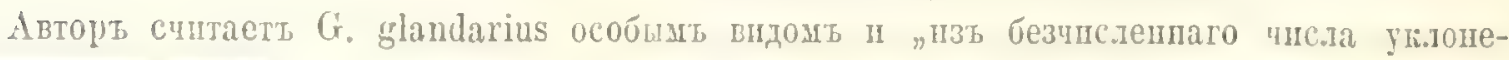

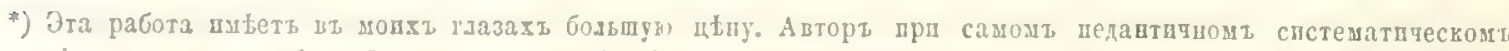

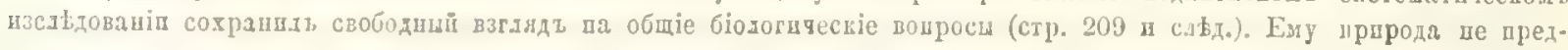

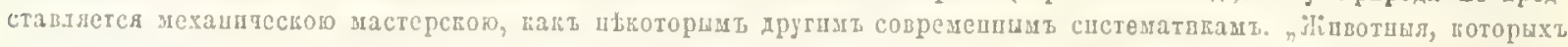

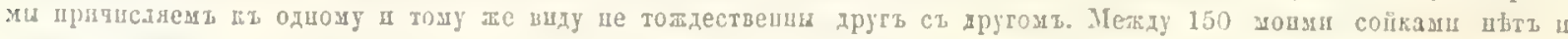

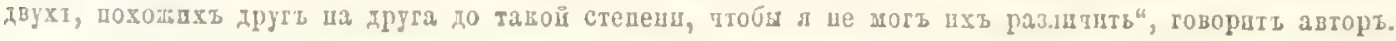




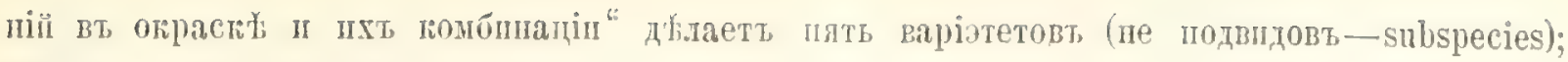
пмени):

Garrulus glandarius varietas rufina.

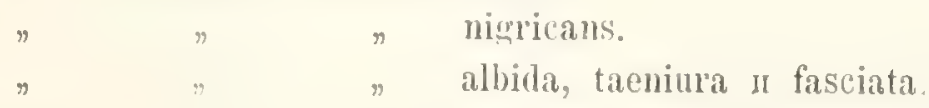

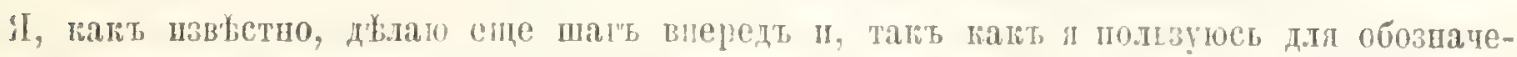

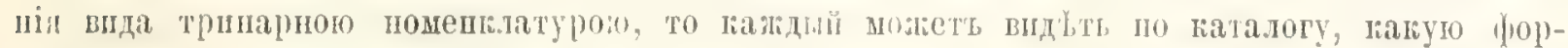

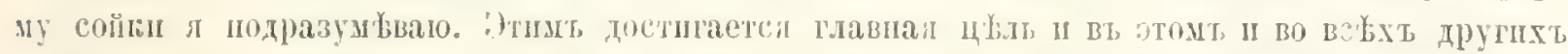

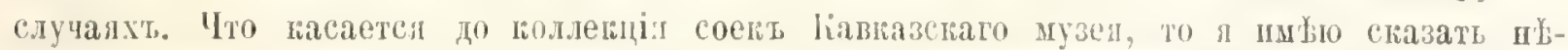
скольо словт тольо о двухт, сойнахт, поторпхт Ш.лерпе поставплт вт, 1896 году. Это

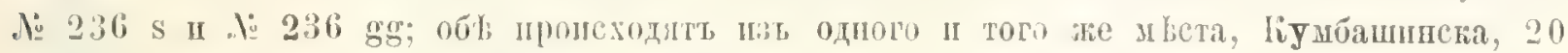

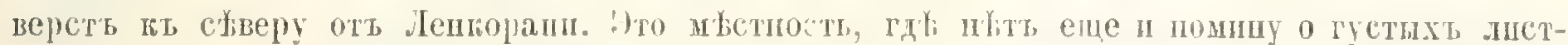

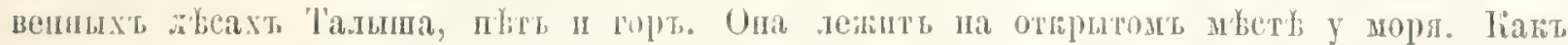

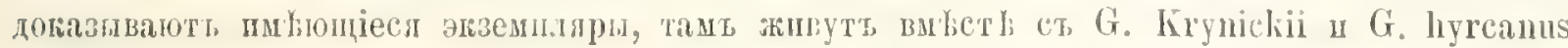

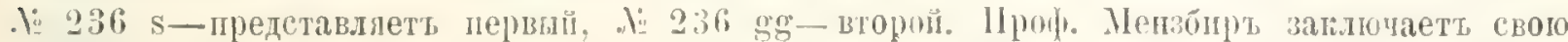

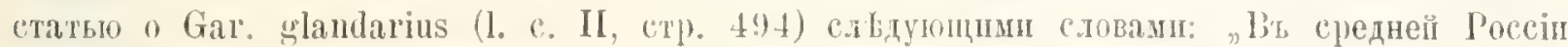

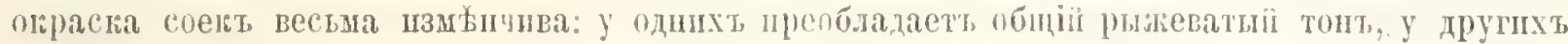

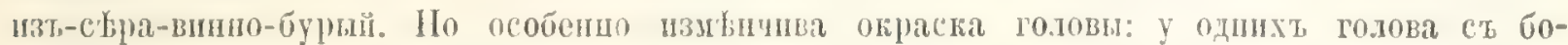

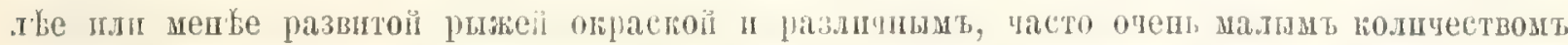

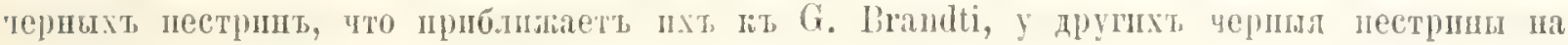

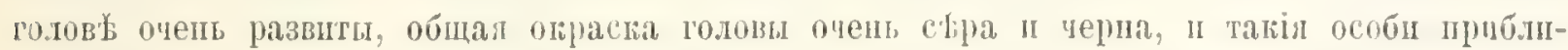

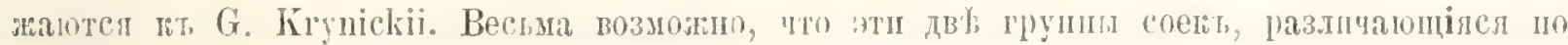

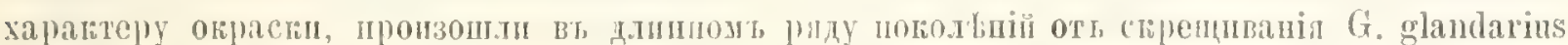

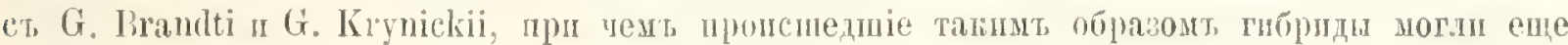

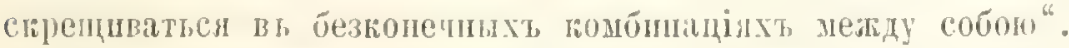

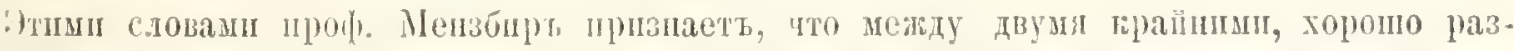

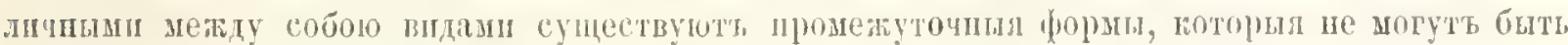

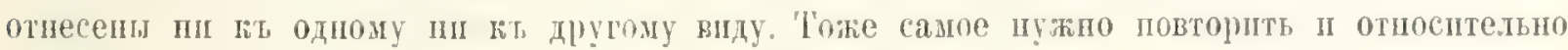

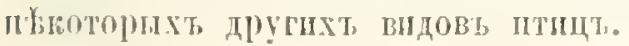

\section{P I C I.}

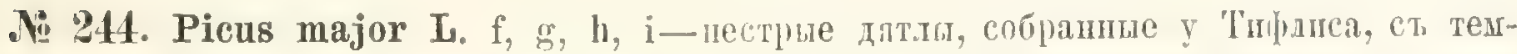

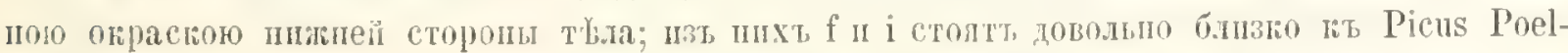

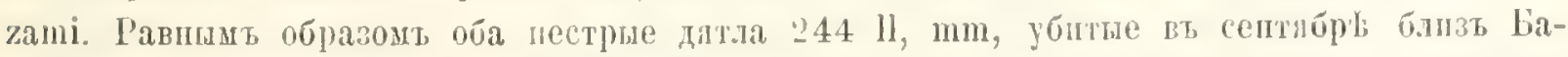

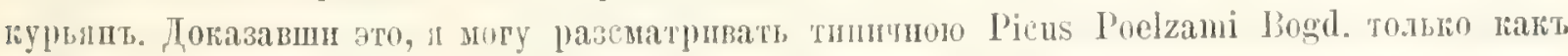

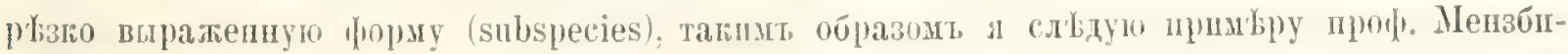

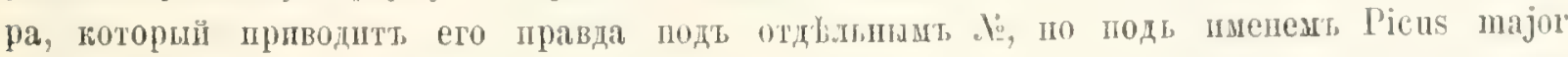

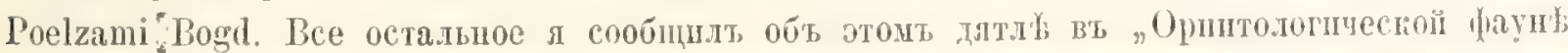

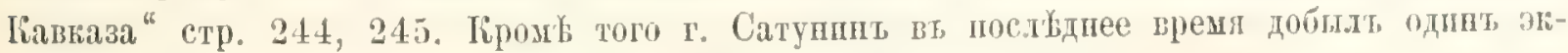

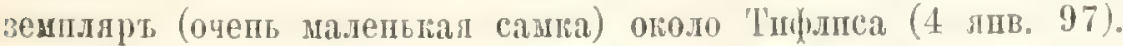

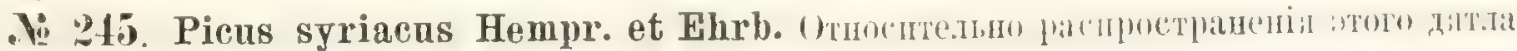

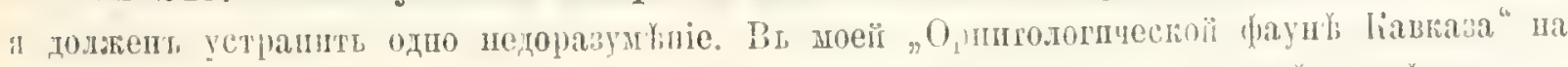

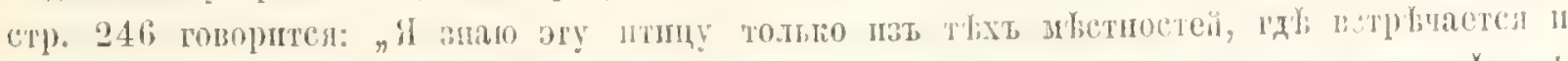

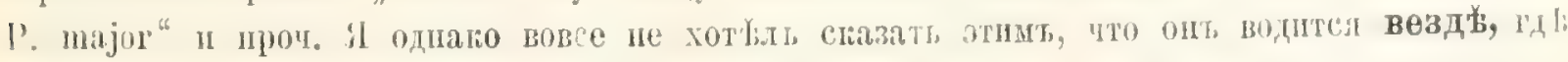

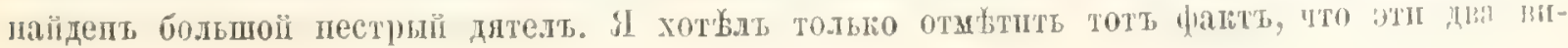




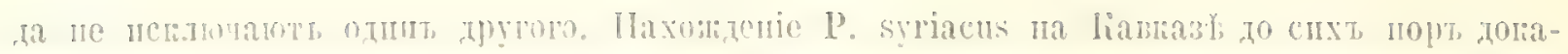

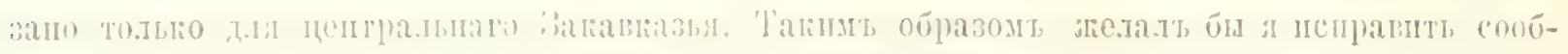

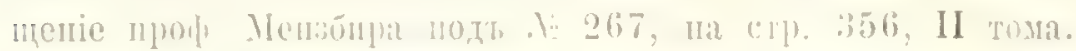

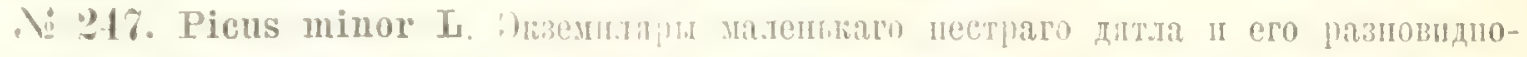

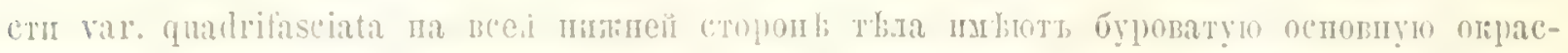

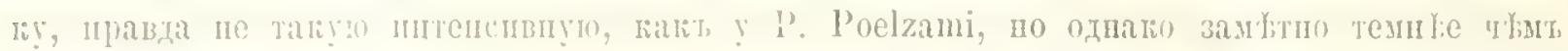

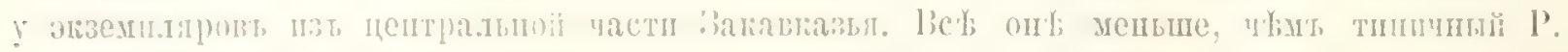

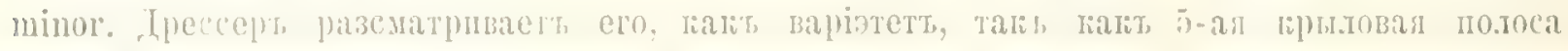

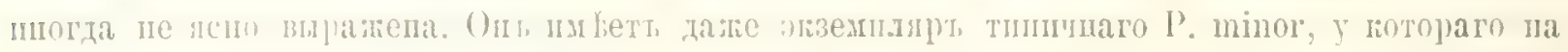

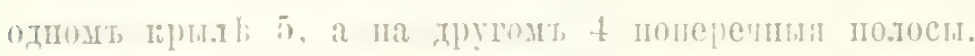

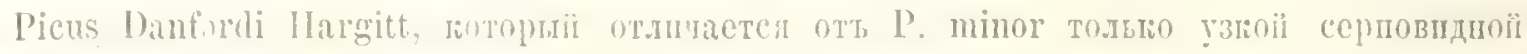

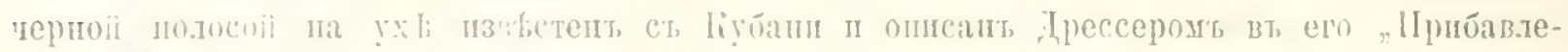

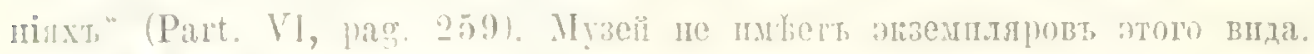

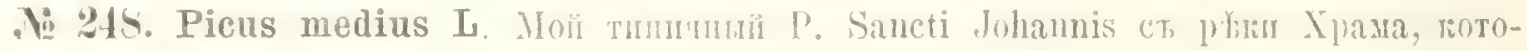

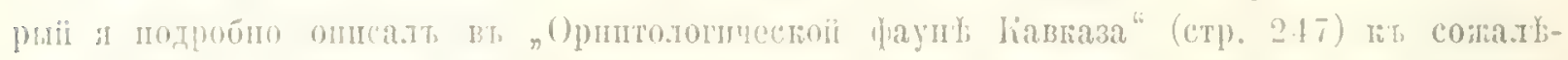

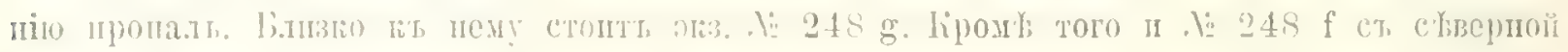

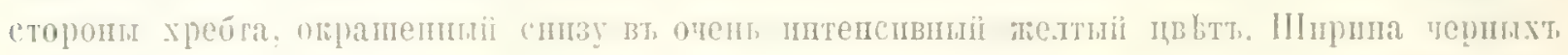

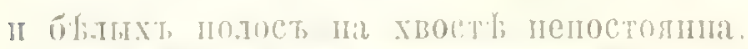

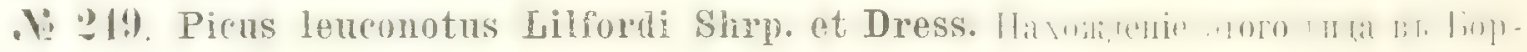

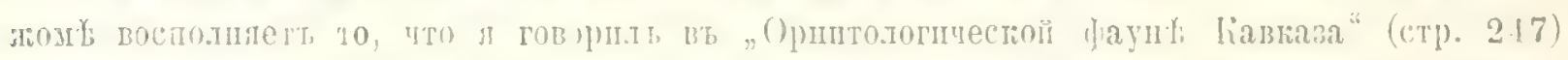

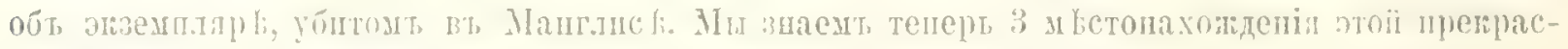

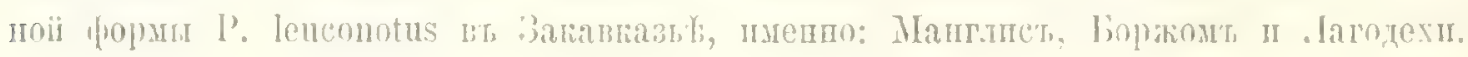

\section{COC C Y G E S}

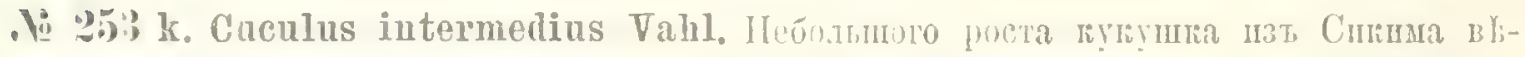

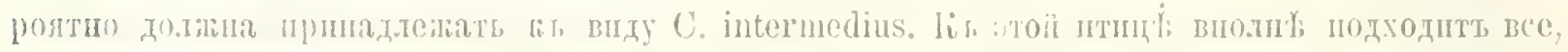

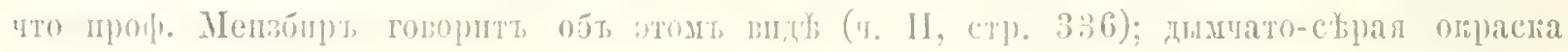

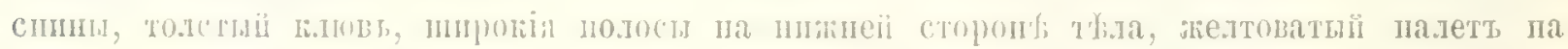

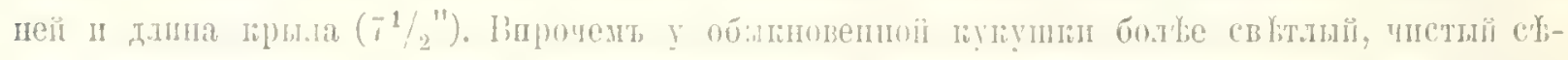

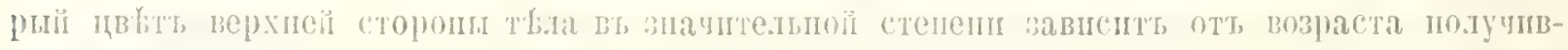

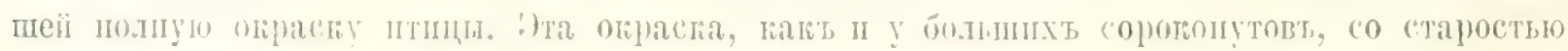

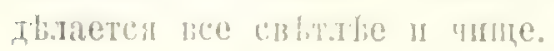

\section{MACROCHIRES}

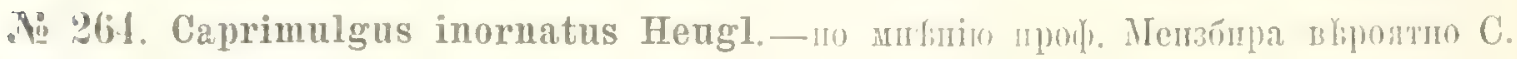
mubicus Licht. (crp). 4(09).

\section{A C C I P I T R E S.}

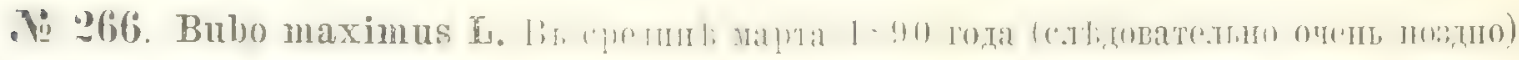

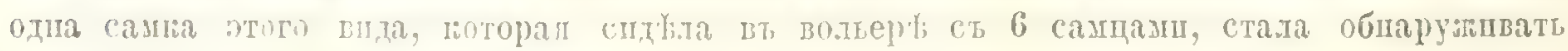

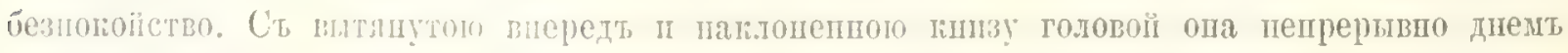

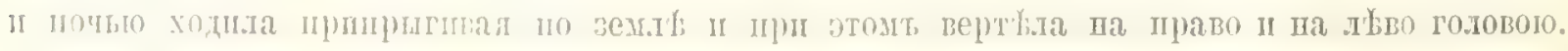

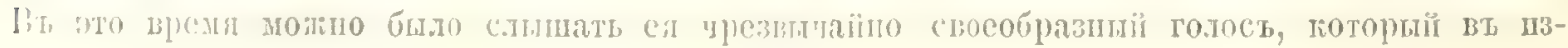




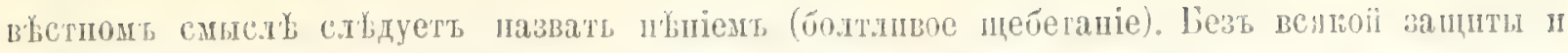

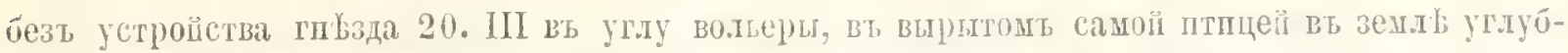

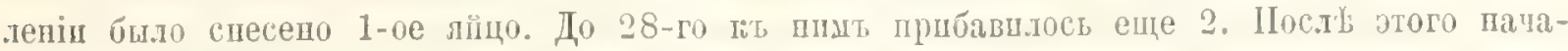

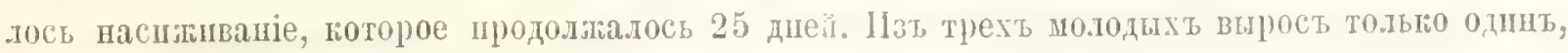

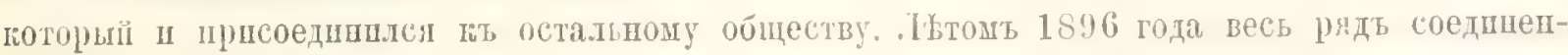

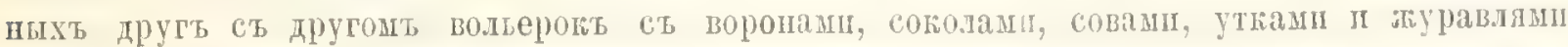

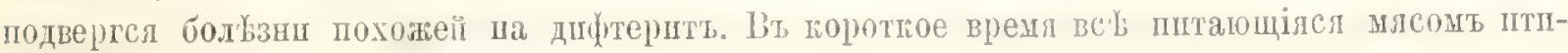

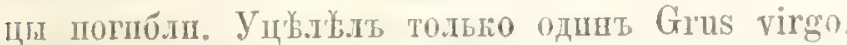

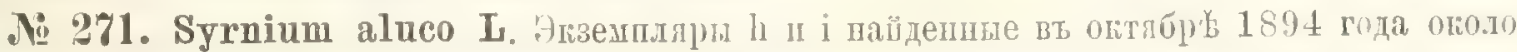

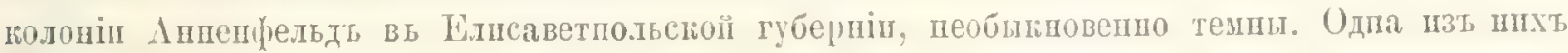

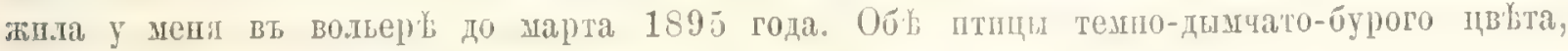

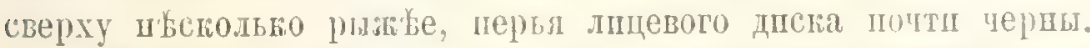

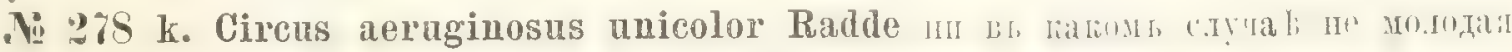

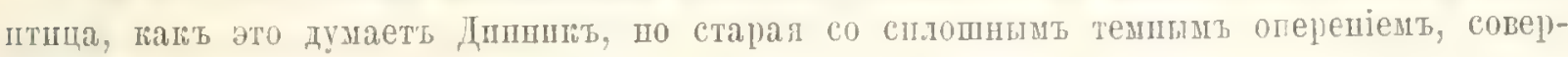

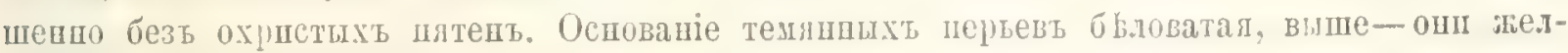

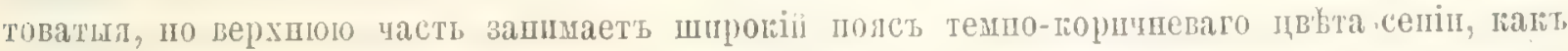

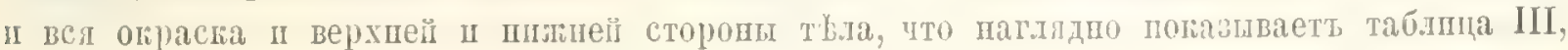

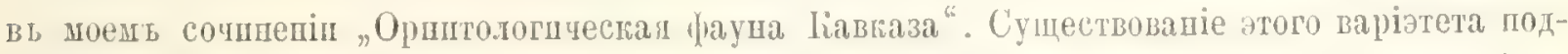

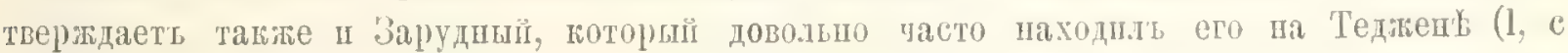
стр. 385$)$.

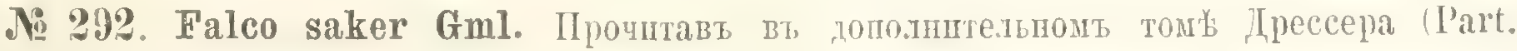

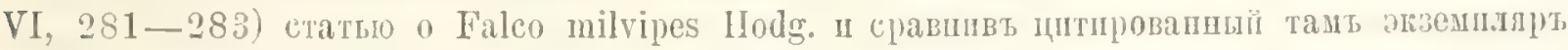

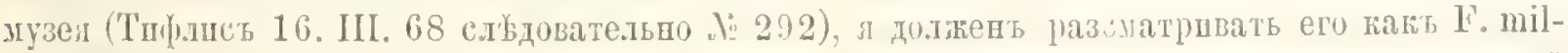

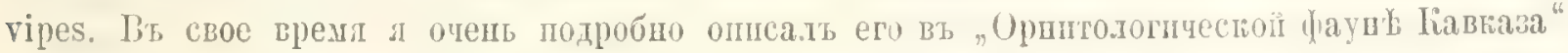

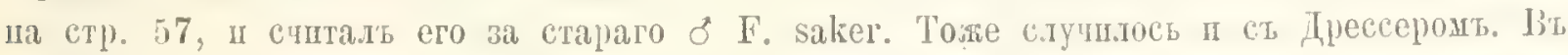

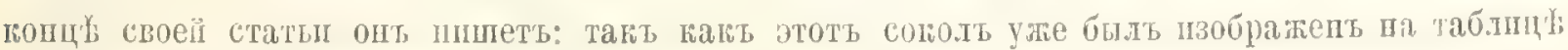

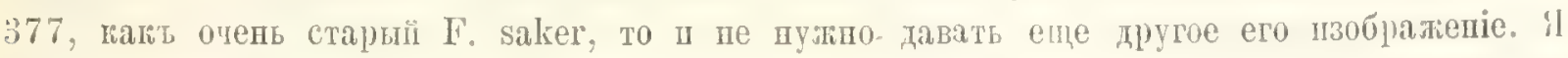

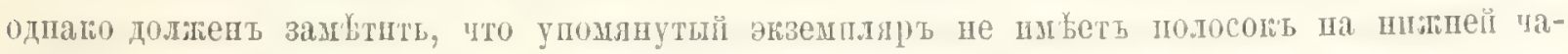

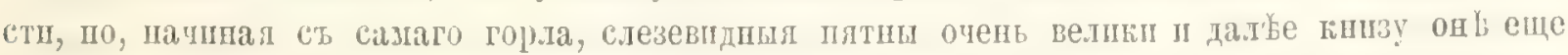

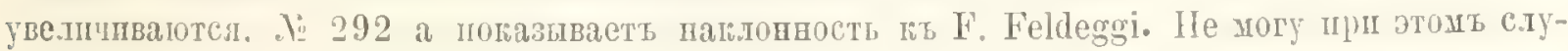

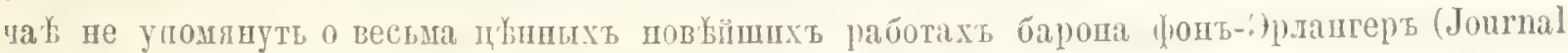
für Ornithologie T. XLVI, вып. III 1898 г.). Сочпеніл liлейшидта о сойахт, радно папьь вышеупоминуше труды о Gypaëtos barbatus, Milvus niger in Falco Feldeggi, образцови ғагт

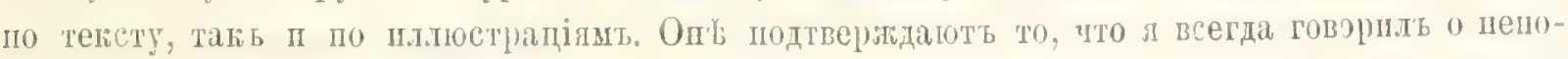

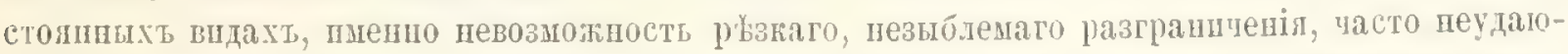

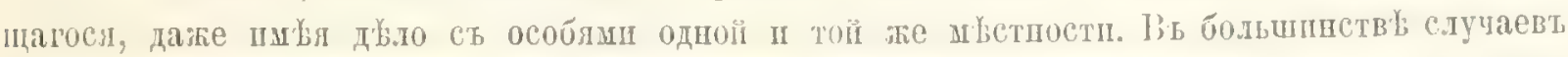

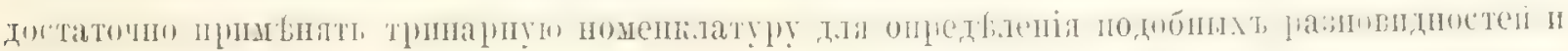

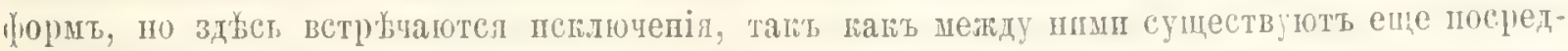

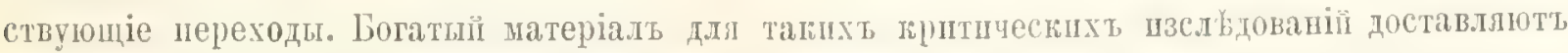
впды Motacilla и Budytes, далье состояміе вь родетве съ Buteo vulgaris, Picus major in me-

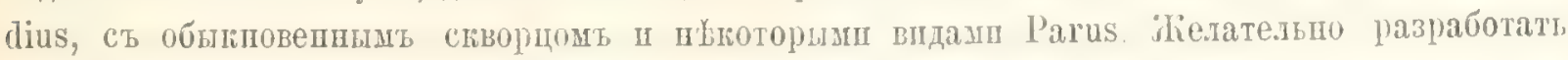

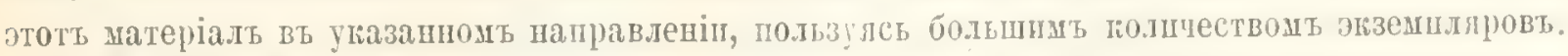

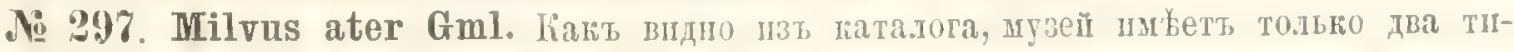

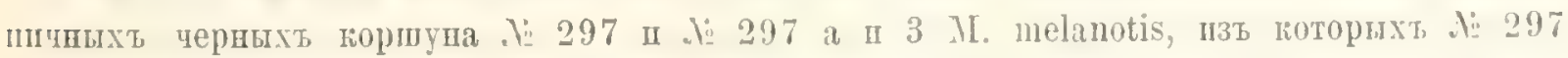

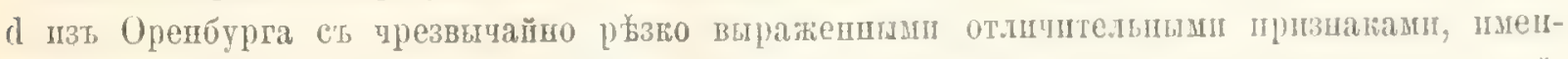

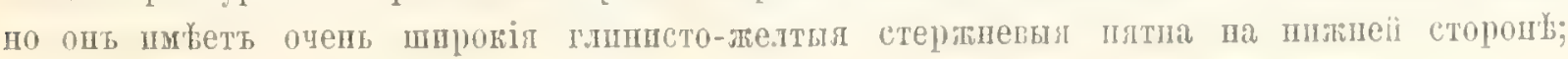




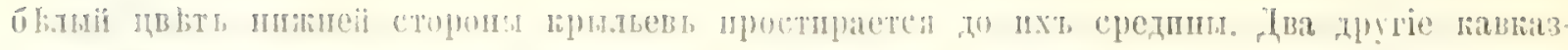

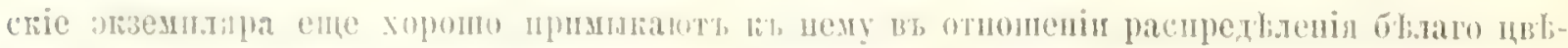

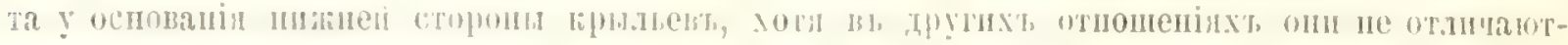

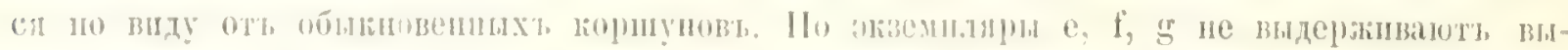

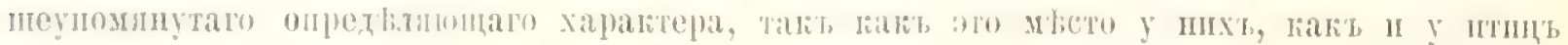

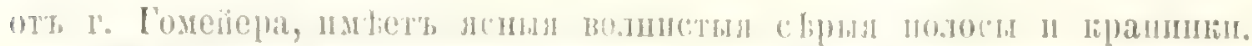

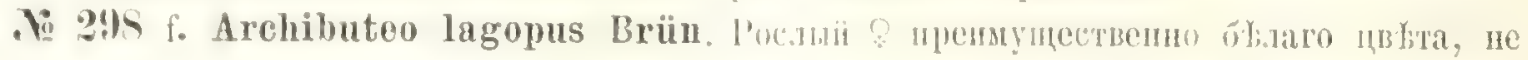

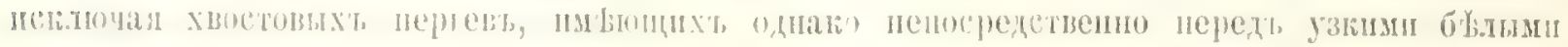

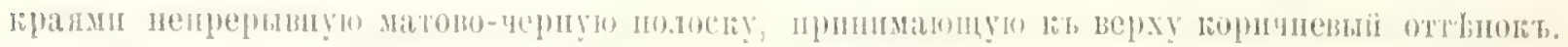

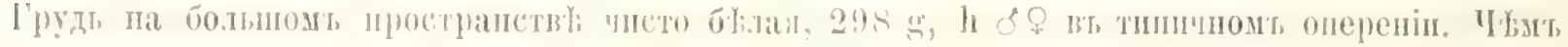

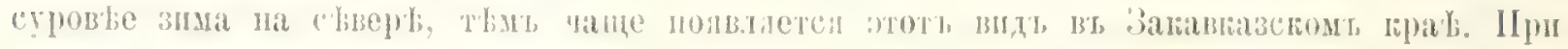

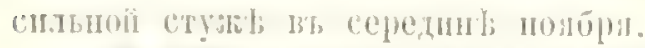

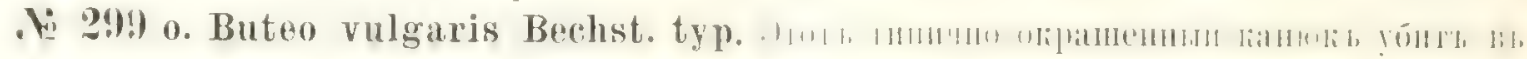

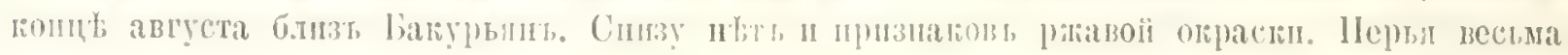

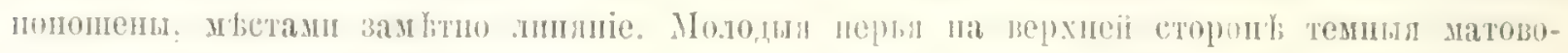

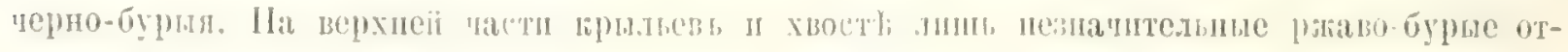
Thintris.

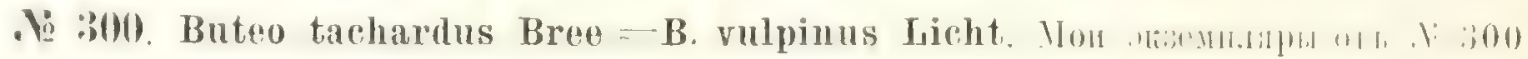

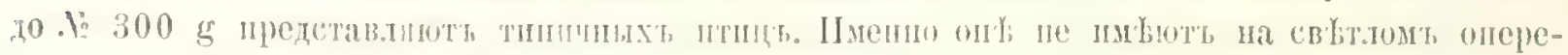

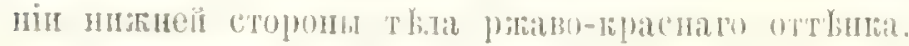

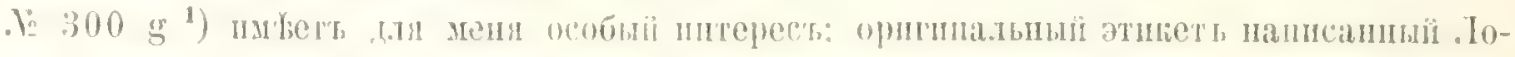

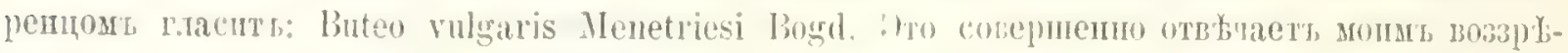

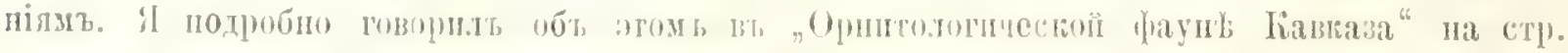

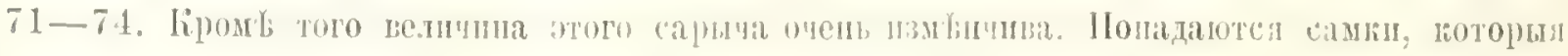

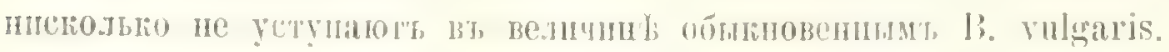

. $300 \mathrm{~h}$ нiе спльно рьавчато-гінасное.

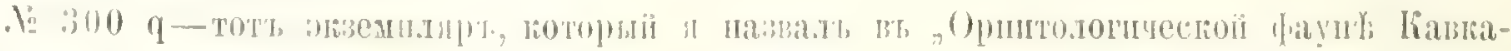

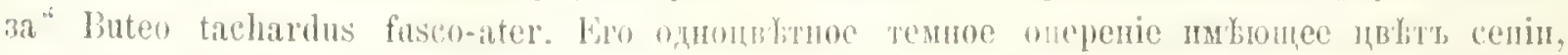

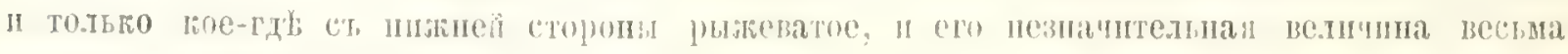

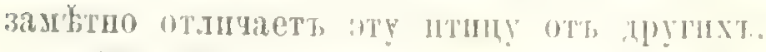

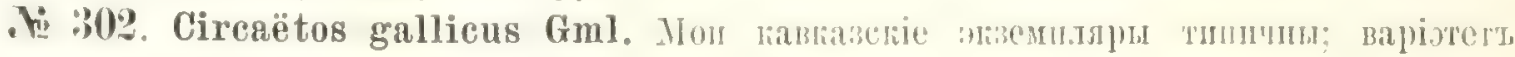

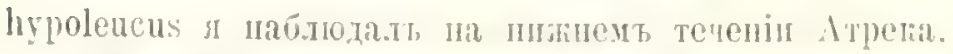

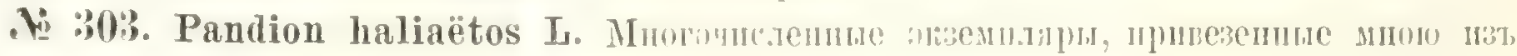

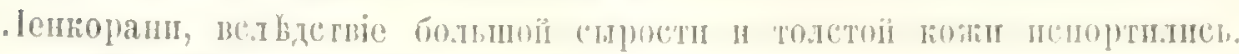

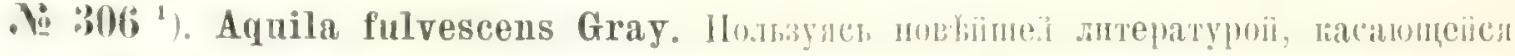

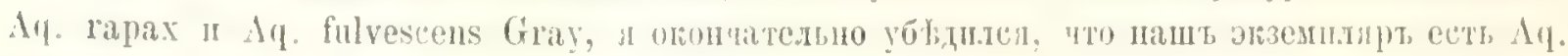

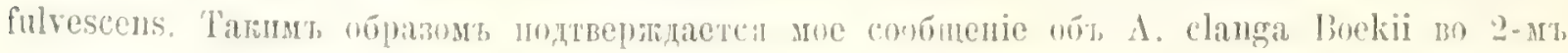

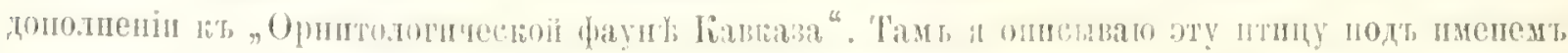

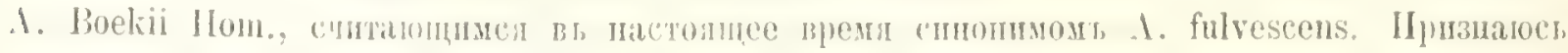

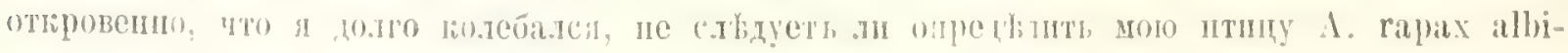

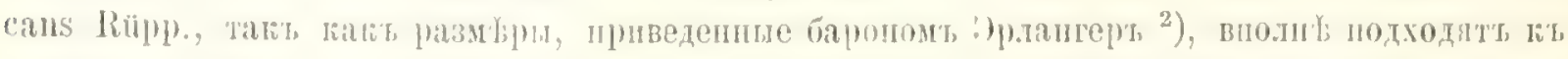

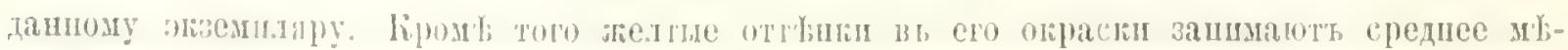

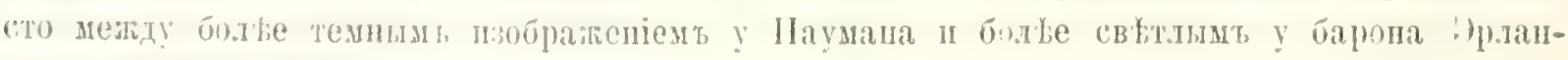

2) Vaumann Naturgeschichte der Yogrel Vittel-Europas pag. 236-237. Taf. 47.

$\left.{ }^{3}\right)$ Journal für Ornitlologie XI, VI IIett III 1998 pag. $418-432$. 


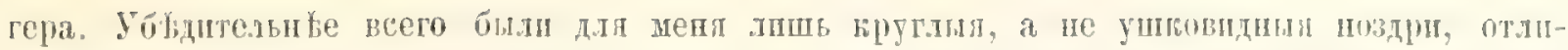

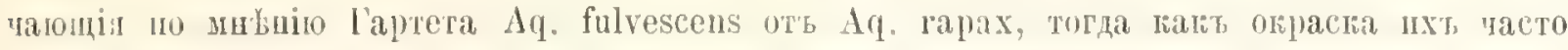

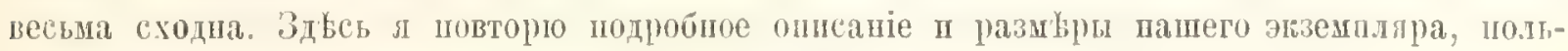

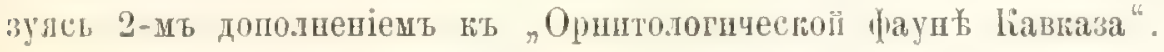

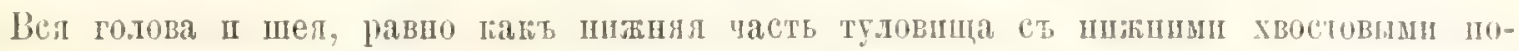

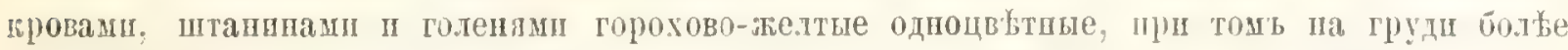

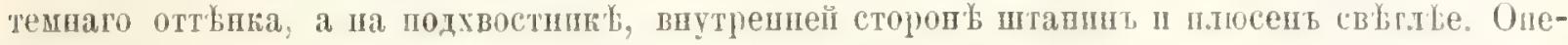

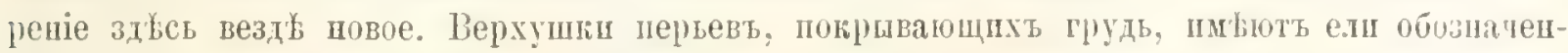

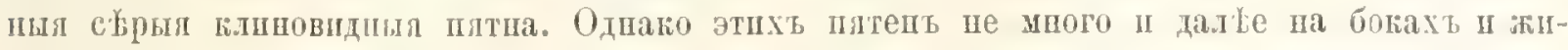

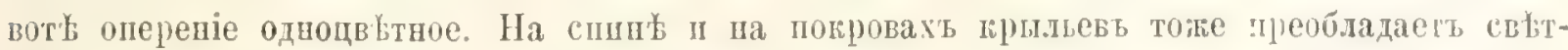

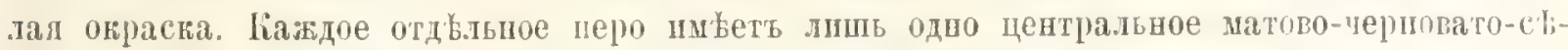

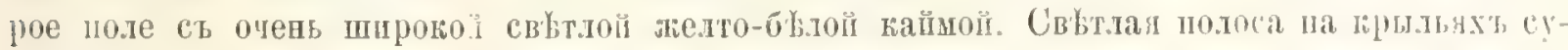

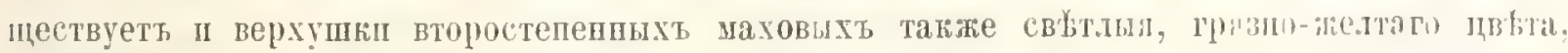

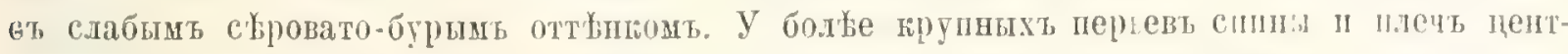

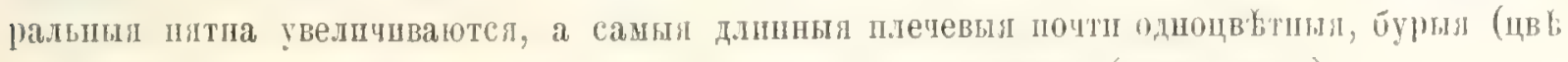

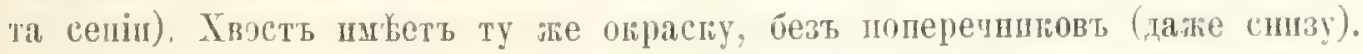

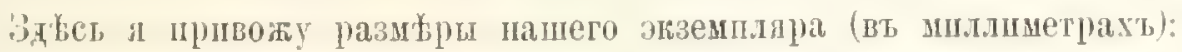

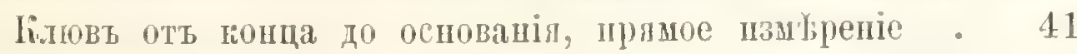

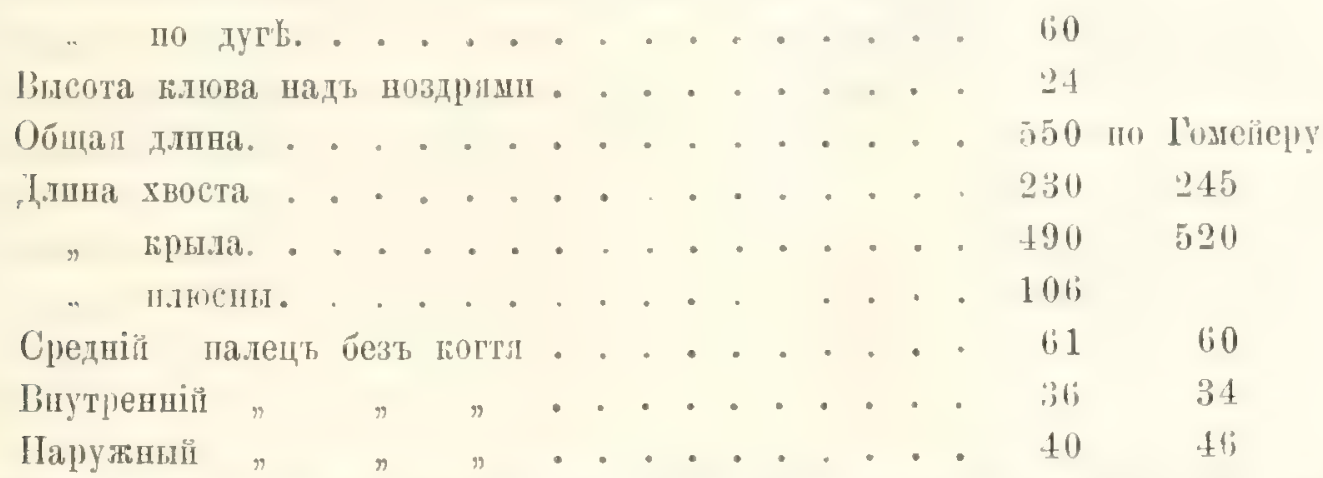

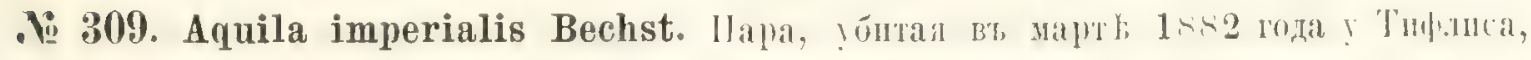

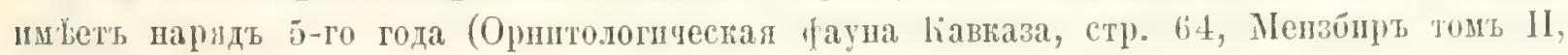

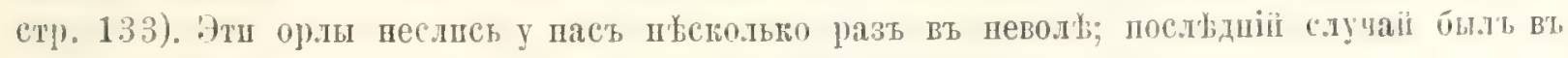
этомт (1898) году; съ 24 марта по 16 апруля они снесли три лйца

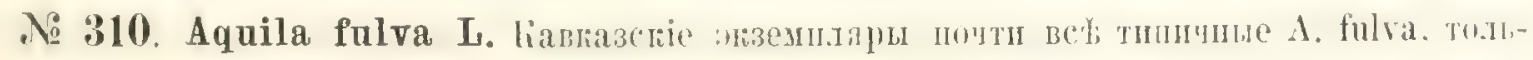

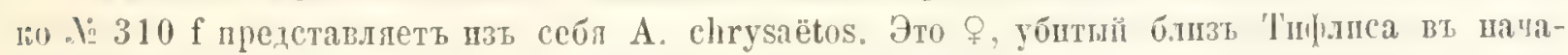

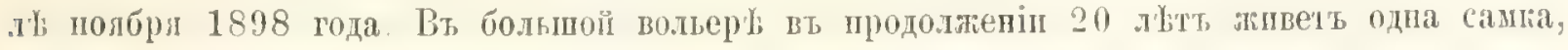

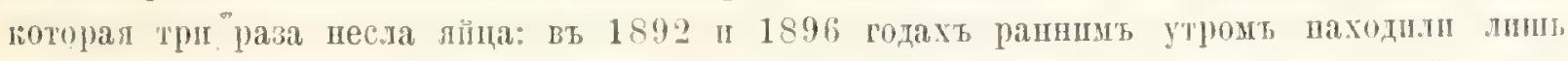

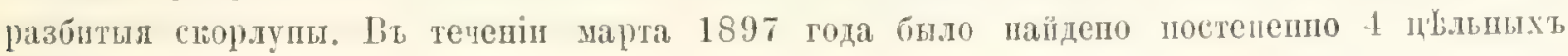
หlĭца . 310 e.

№ 315. Gyps fulvus Briss. 24. IT. 96 спесла вт певолt одшо лицю.

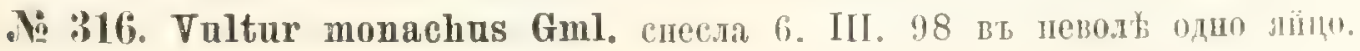

\section{STEGANOPODES.}

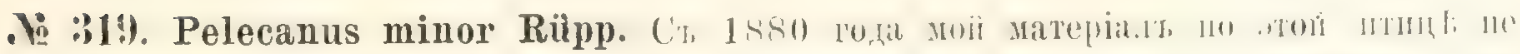

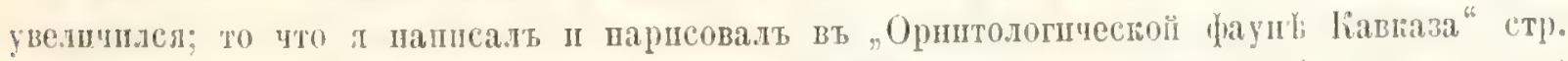

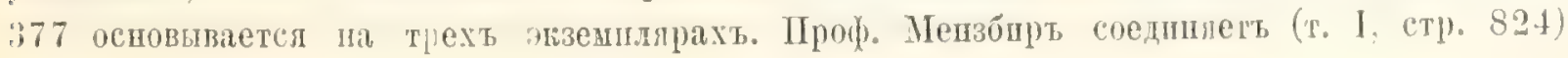




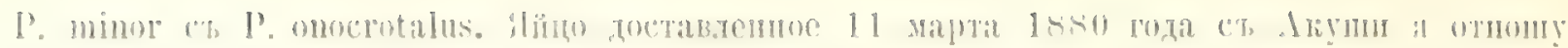

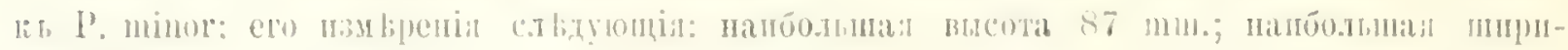
Itil is mm.

\section{A N SERES.}

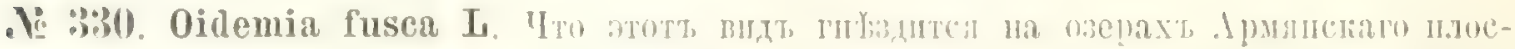

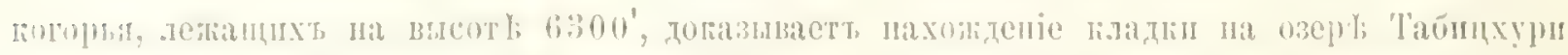

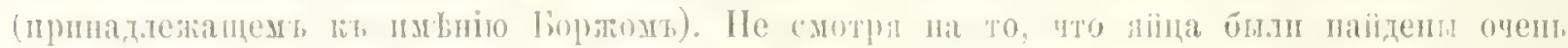

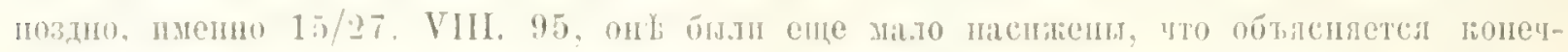

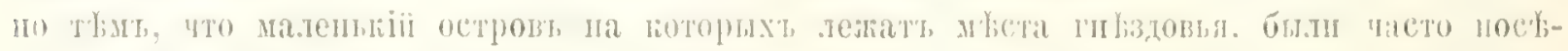

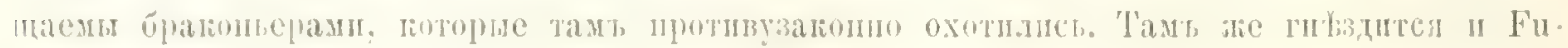
lica cristatio.

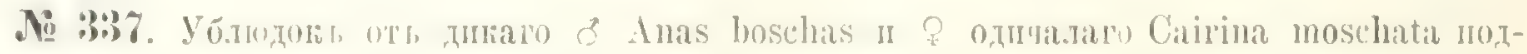

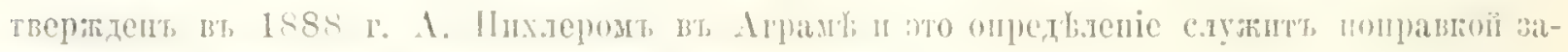

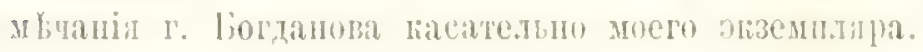

\section{IIER() DII}

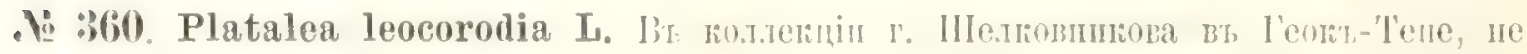

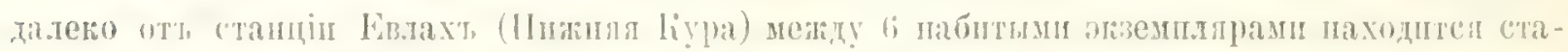

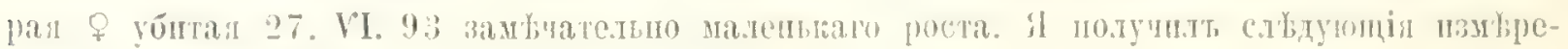
nim storo onesusina.

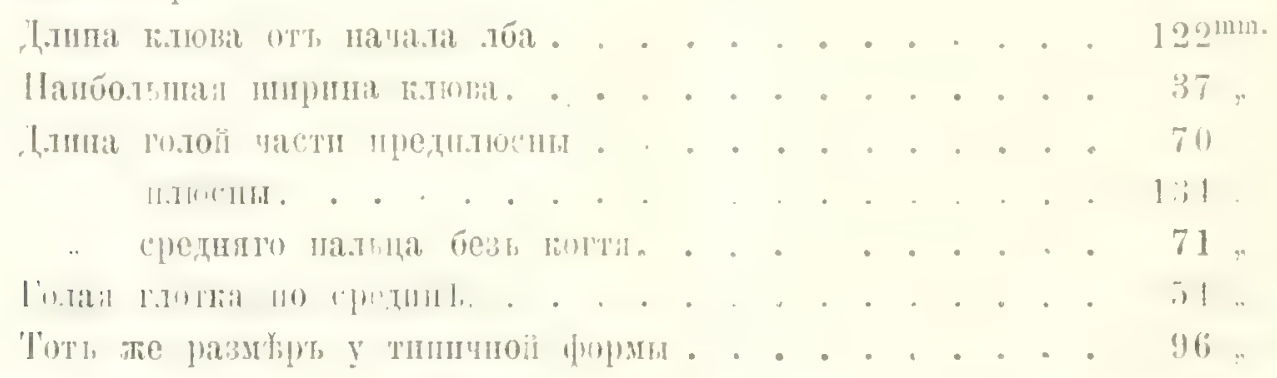

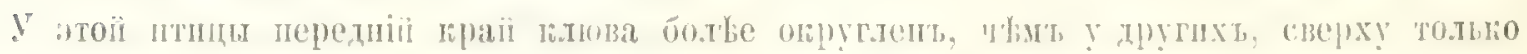

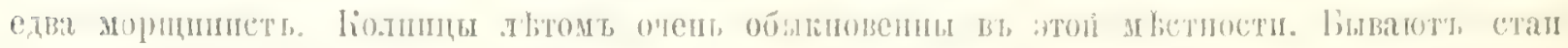

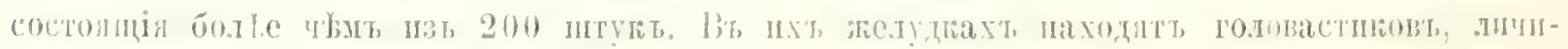

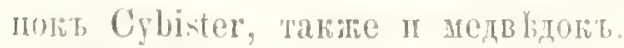

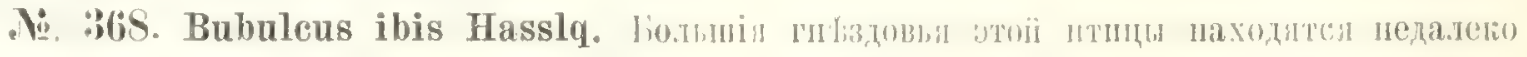

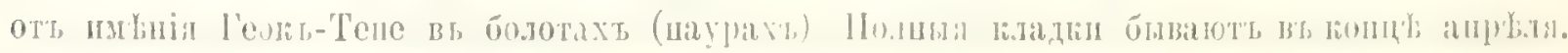

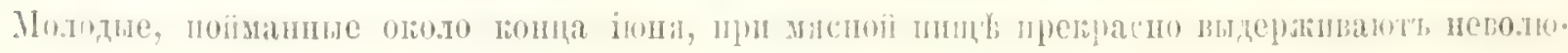

\section{COLUMBAE.}

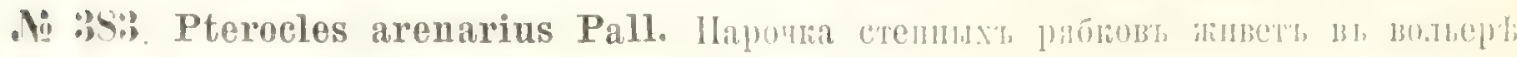

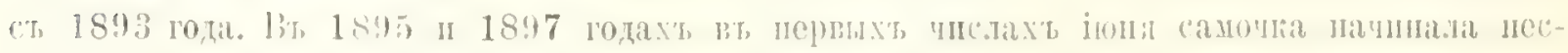

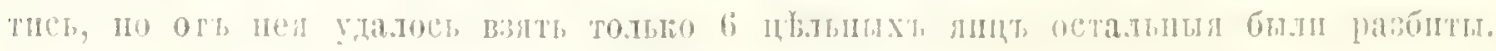

\section{GA L L I N E}

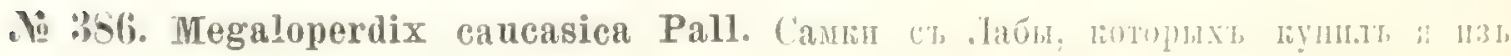




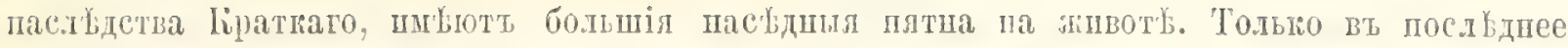
время удалось доказать пахопденіе әтого впда, хотл ғапь рыдиость, па аджаро-имеретин-

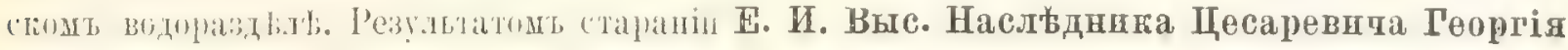

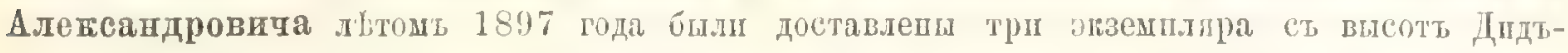

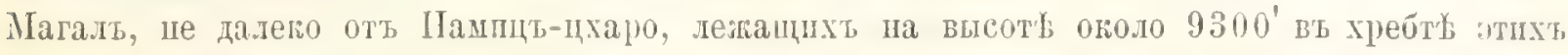

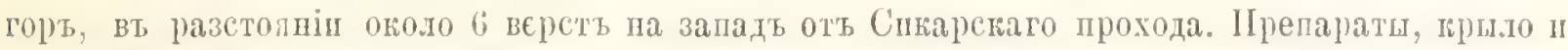

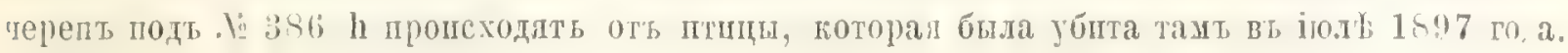

\section{GRALLAE EP LIMICOLAE}

Jo 411. Grus virgo L. Старая самка о которой я нодробно говорнлт вт „Оринто-

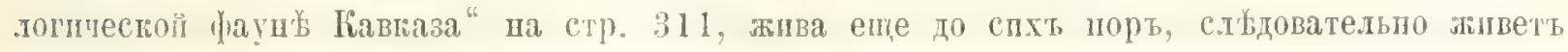

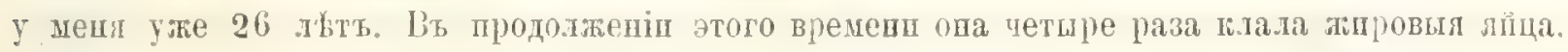
Сиерва 2 лйца сь 30. IV по 4. V. 79 года. Оба нйца снесеныя вь мағ 1883 года бы-

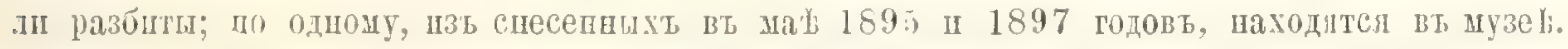

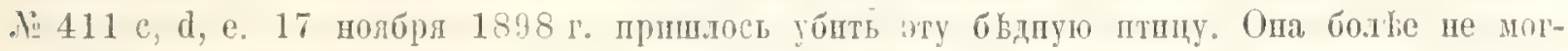
ла столть ша ногахь п не была в'ь состолніи феть безъ посторонней помоци.

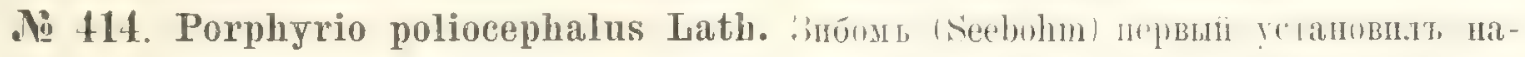

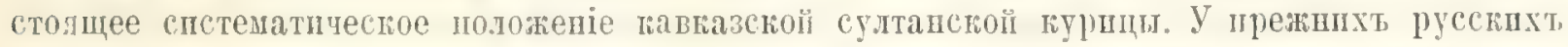

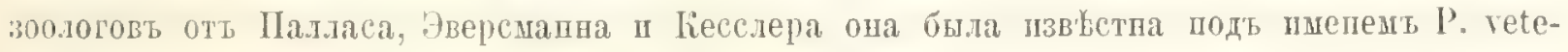
rum Gml. и P. hyacinthinus Temm. Богданов'ь привель ее подъ пмепен Porph. veterum,

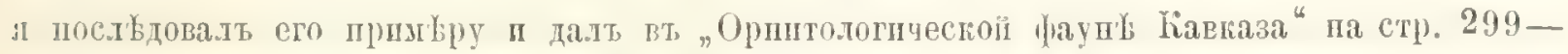
302 подробное описаніе әтой птиц, а ша таблицахъ XXI и XXIV-пзобраленіе ел пा ел

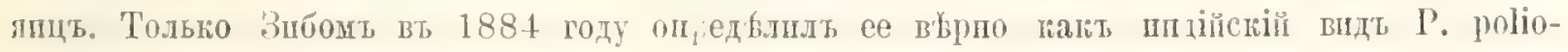
cephalus Lath.

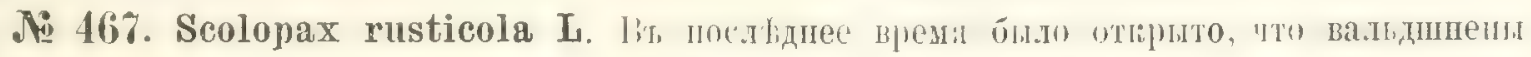

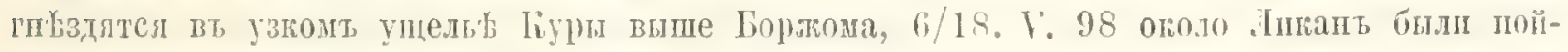

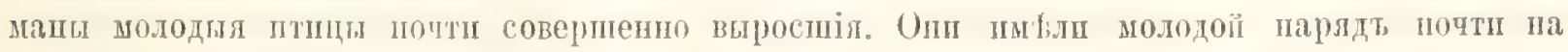

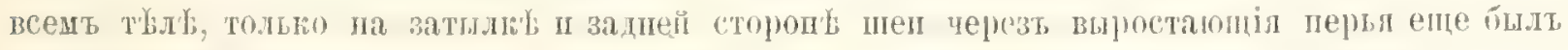

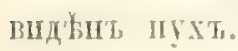

\section{G A V I A E.}

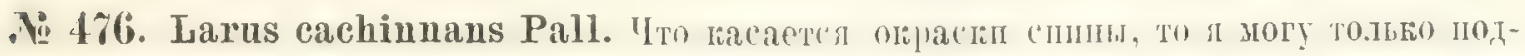

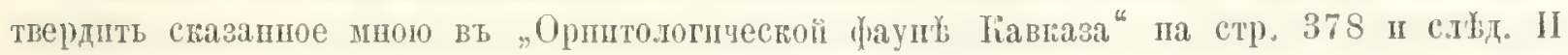

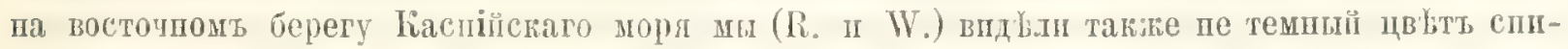

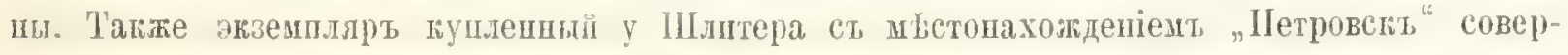

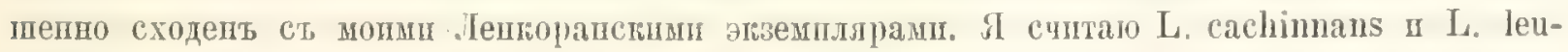
cophaeus за одно и толг. 


\title{
KURZE BEMERKUNGEN ÜBER DIE AUFGEFÜHRTEN VÖGEL.
}

\author{
P A S S E R E S.
}

Die Drosseln geben mir nur zu folgender liemerkung Veranlassung:

Ni S. Turdus merula L. l' im Februar bei Aschabad erlegt, hat die Maasse $255^{\text {mm. }}$

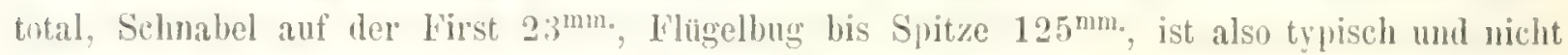
maxima, welche letztere ich nur als Grössen Varictiat betrachte.

. Ii Iturdus torquatus alpestris C. L, Brehm. i-m ham ich artlich von 'T'. torfuatus nicht trennen und erkene ihr mit 'Ischusi, Seebohm und Prazils mu' die trinäre lienennung zn.

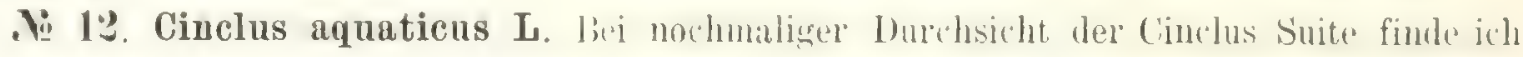
das bestätigt, was ich in der Ornis cauc, pag. 273 sagte. In der Vertheilung der braunen lirustfürbung und in der Intensität dieses Colorites sind bei meinen kauk. Lxpl. lieine feste Grenzen zu ziehen. Bald schliesst sich an die weisse Zone, deren Breite ebenfalls nicht constant ist, das matte Schwarz von C. melangaster, bald die bleiche bräunliche farbe von C. "aschmirimsis. Die Shlnabellingen schwanken ebenfalls. In der Gesammtgrosse stehen meine C. melanogaster den schwedischen Vögreln nahe. Bei l: 12 d-i stimmt die Grösse zu C. ('anchmiriensis, die Irustfirlunm zu C. melanogaster, wem das Letztere nicht der Fall wäre, so könnte ich diese Expl. alle zu C. caschmiriensis zählen. Das neuerdings von Sarudny erhaltene persische $\delta, 12$ n repräsentirt die typische form von C. caschmiriensis.

Ich betrachte diese Cinclus Arten nur als Formen von C. aquaticus, der freilich ganz typisch im Kauk. mur selten vorkommt. Dresser (Supl. ['art. 1 Jan. 95) trennt die Kaukasirr artlich als C. Canchmiriensis Gould. sagt aher, dass el sie nur fur eine Localform von C. melanogaster halte. Blanford behandelt die Perser nur als C. aqt. vart. caschmiriensis.

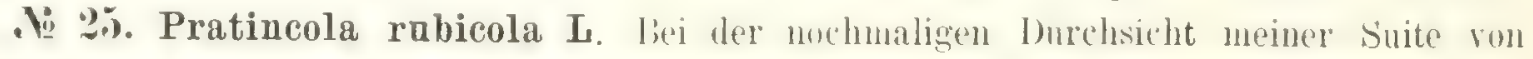
Pratincola rubicola habe ich mich wiederum davon ubberzeugt, dass es Uebergänge rom westlich lehenden typischen Vogel zur Fornu I'. Hemprichi srieht. Die lireite der weissen s'chwanzzone ist nicht bei allen Vögeln gleich, auch dass Weiss der Bürzelfedern ist bisweilen nur minimal und getribt wrhanden. Nach den Griginal signaturen, welche sich an Exemplaren Satunins hetinden, die l'rof. Mensbier bestimmte, erkennt derselbe solche Uebergänge an, da er sie als P'. Hemprichi intermedia bezeichnete. Sulche Vögel haben nur eine Spur von Weiss an der schwanzwrzel, dagesen die Bürzelferlern klar weiss und die unteren Decken an der Flügellenge schwar. Meine typischen Vügel ron l'. rubicula stammen unzweifellaft aus der Zaugzeit. An den mir vorliegenden Jugendkleidern aus Transkispien $125 \mathrm{k}, 1, \mathrm{~m}$ ) und dem älteren $f \mathrm{n}$ haben die Schwanzfedern keine Spur von Weiss an der Basis. Die typische Form muss demnach wohl ausnahmsweise in jenen Gegenden brüten.

Den grössten 'Theil meiner sonstigen kauk. P'ratincola Expl. musste ich, wenn wir die schwarze Farbung der unteren fiedern tes IIandgelenkes gelten lassen wollen zu P. maura 
l’all. zäblen, aber alle stimmen sonst in Folge der Vertheilung von Weiss und Schrarz auf den Schwanzfedern zu I'. Iemprichi, denen ich sie nach dem Vergleiche mit revidirten Lxempl. zuzählen will. Nur ein Expl. von Kumbaschins (25 q) entspricht vollkommen P. Hemprichi. Das Verzeichniss giebt dusliunft uber die rermittelnden Forme.1 mit einfarbigem Schwanze, "der doch nur einer Spur von Weiss an der Basis (25 r bis bb) wobei zu bemerken, dass die Expl. Satunins von Prof. Mensbier revidirt und signirt wurden. Die Suite 2 i ce. bis ss gehört nach der Schwanzzeichumng 211 P. Hemprichi, doch ist bei allen Expl. die untere seite der Handwurzel einfarbig schwarz.

Ni 99. Ruticilla ochrura Gm1. Unter den Rothschwänzen ist das Expl. 5!) § von husonderem Interesse. lis ist Ii. ochrma deren seitliche Bauchfedern heine Spur von liostfarbe hesitzen, sondern das Grau von R. tithys, der mattschwarze Ruckenmantel ist aber vorhanden. H. Lorenz, von welchem ich das Stitck erhielt, signirte es als R. ochrura, es stammt von der Nordseite des Gr. Kankasus.

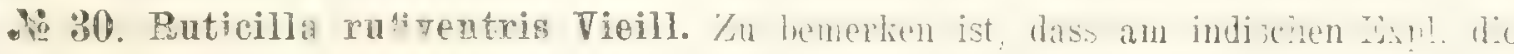
gesammte Rückenzone tief schwarz ist, bei 30 a (Sard.) ist die ganze obere Seite gran bränlich, bei 30 b (R. W.) dunkel aschgrau. Die intensive Rostfarbe der unteren Seite ist tei allen Exemplaren gleich stark und ebenso ihre Zonenbreite.

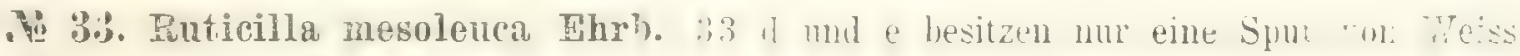
am Grunde auf den oberen Flügeldecken. In Jugendkleide ist es nicht immer angedentet. In Borshom bruten beide Formen, typische $R$. yhoenicura und $R$. mesoleuca uner einem Dache.

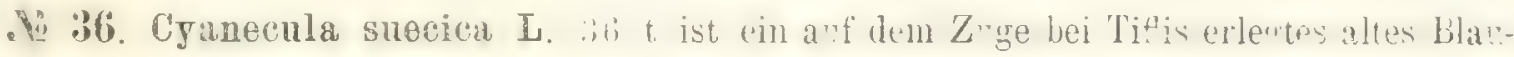
liehlchen, welches nur eine ganz geringe Spur von Iraun auf dem blausn Kehifelde hat und viel näher der C. suec. Woltii, als der C. suec. coerulecula steht.

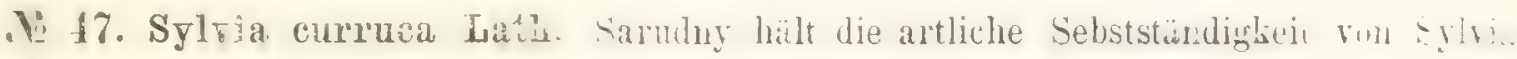
nimuscula IIume (pag. 90) und S. althea Hume aufrecht, sagt aber selbst, dass es Uebe:gangsformen zu S. c. affinis (pag. 95) giebt, welche er als Hybride zwischen beiden betrachtet. Ebenso spricht der Autor (pag. 9.9) ron Hybriden zwischen S. althea und S. c. affinis. Die Längenverhältnisse der Schwungfedern eriter Ordnung schwanken bei beiden Formen. Prof. Mensbier spricht (pag. 960) bei Gelegenheit seines Artikels uber S. curuca ron 4 nahen Formen. Zwei davon kommen dem europäischen Russland zu (S. currara um? $\therefore$ c. affinis) die beiden anderen gehören dem Aralo- Easpischen Gebiete und Turkestan an S. minuscula und S. althea). Ich schliesse mich der Ansicht des Professors an.

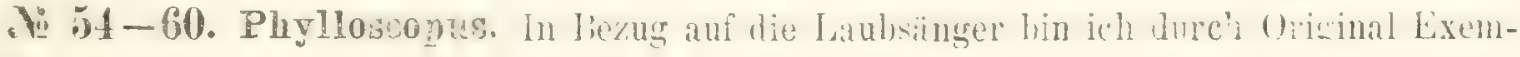
plare yon Herrn Sarudny in Stande gewesen meine Transkaspier nochmals zu verificiren. Anderseits erhielt ich durch Herrn Satumin kankasische Exemplare, welche Prof. Mensbier bostimmt hatte. Auch ron der Sammlnng des Herm Lorenz lagen deterninirte Exemplare ron der Nordseite des Gebirges ans den Ungegenden von Pjatigorsk vor. Bis auf zwe? kleinwhehsige Phylloscopus Individuen komte ich alles unterbringen. Schwingen 2:-8, oben beice mer grün als braun, das eine mit Gelb auf del Brust, das andere mit licht Graubraun. IBi a we Weiteres lege ich diese beilen Expl. zur. Seite ohre sie in den Katalog aufzenehmen.

Der in der Ornis canc. pag. 235 sub. i $13 \pm$ als Phylloscopus plumbeitarsts Swinh. angeführte Vogel (E. T. Homeyers Bestimmung) ist Ph. nitidus Blyth und jul Katalog . $5 \mathrm{~S}$ c als solcher jetzt placirt.

Was die durchweg dunkle Varictit von Phylloseopus rufus obscurus anbelangt, .l: 54 on, we?che ich sub 131 pag. 233 der Ornis caucasica erörtete, so kann ich diesen Voerel nicl:t 
anders placiren, aber das Kolorit auf 'Tafel XII ist zu wrtinlich auscrefallen. Untenher ist das Exemplar itberall recht intensiv rauchgran, oben mehr briunlich als grinlich.

Auch bei meinen diesmaligen Untersuchungen der Schwingenverhälnisse habe ich mich davon uberzeugt, dass die Schwankungen bei den verschiedenen Irten recht bedeutend sind und ron der Xorm in vielen Fällen mchr oder weniger abweicheu, sie allein künen bei dem bestimmen nicht massgebend sein.

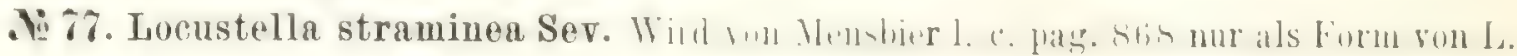
locustella behamlelt, während Dresser sie noch als selbstständige Species trennt (Supl. I'art II).

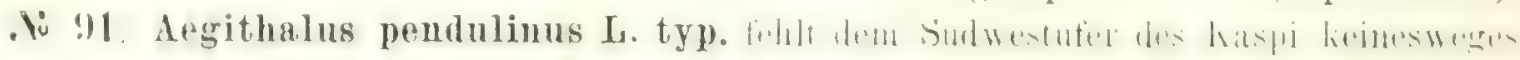

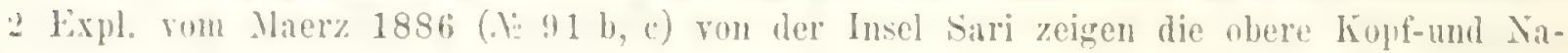
chenfarbe durchaus typisch, nimlich rein weiss, bu .91 d zieht der Ton in's Ischrane.

Die richtige Aeg. castaneus Severz. besitze ich nur aus 'Transkaspien.

. !6. Acredula irbyi caucasica Lor. Ich habe mir, wie man ans dem bertedinisse ersieht, eine grosse Suite ron der kaukasischen Schwanzmeise verschafft. Ich kann nach den Expl. $96 \mathrm{c}$ und d den directen Anschluss an typische Ac. irbyi nachweisen. Ich fuge auch das von II. Dresser erhaltene Lxemplar von Acredula rosea ohne Bedenken zu A. irbyi,

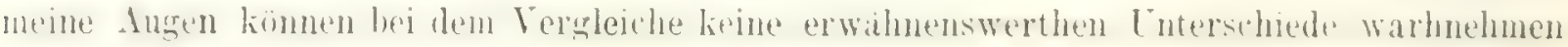
und der Vogel schliesst sich besser an $A$. irbyi als an A. caudata typ. Es scheint, dass in dem Alburs System die kauk. Schwanzmeise nur selten vorkommt. Fast Alles von dort Erhaltene ist die lileinere, starkschnäblige Ac. tephronota.

. 9\%. Cyanistes coerulous L. Ije kixemplare bun linshom sind alle grosswithig. Die von der unteren Kura, Kumbaschinsk und Lenkoran kleiner und ein wenig heller.

Vi 101. Paras major I. Die Exemplare von Borshm sind wahre Riesen, ich messt:

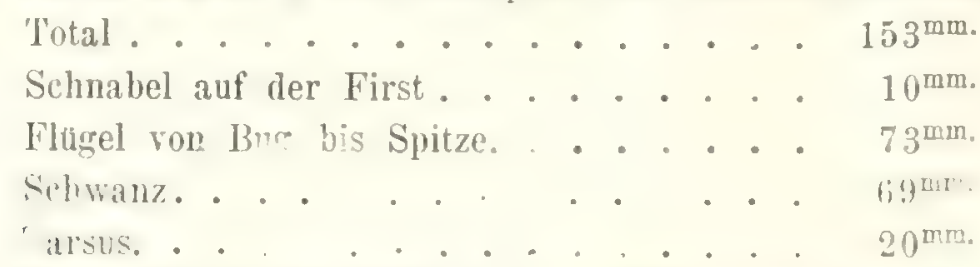

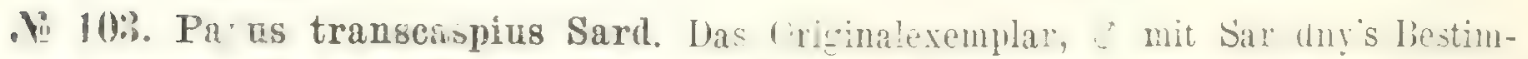

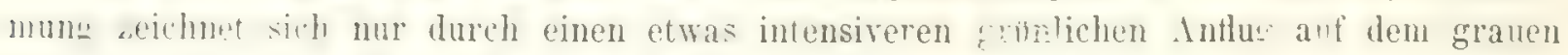
Mantel und an den Brustseicen aus. Auch in das Schwara der Kehle und untezen IIalsseit. nicht so stark entwickelt wie ar meinen Expl. ron P. cinercus Tieill.

" 10,5. Pa ns phaeorotof Blax?. Iie Expl. von Talyse sind kileiner als die centralkankasischen, hei 105 I ist das Weiss im Nacken fast ganz erschwunden auch fe'len diesem

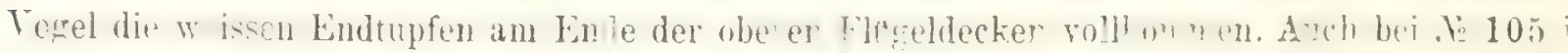
findet dasselbe statt. Auch Dresser rereinist, wie ich, im Supp! Part. III. P. Micialorshii Rogd. mit P. phaeonotus, wie ich das schon $188 \pm$ in der Otn's cauc, pas. 1.09 gethan habe.

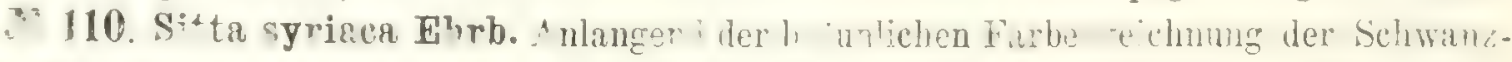

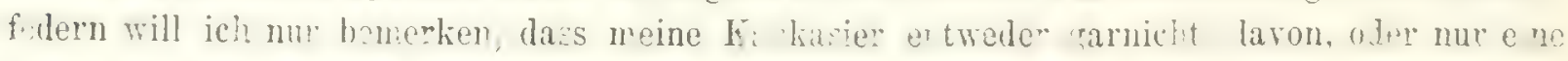

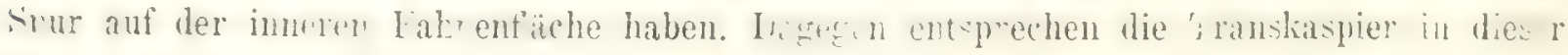
Hinsicht vollhommen der S. Neumayeri, sind auch auf dar Rïickenseite im Grau um einen con heller und stälier im Nuchse.

7: 111. Budytes a. a L. In der Suir ier hei nochmaliger Durchscht licine scharfen Grenzon wiscien E. farus, cinereocapillus, bo-

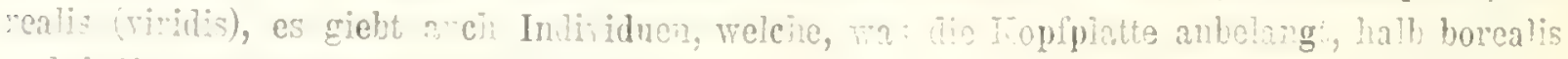
apd hab relarocepln?us sind (1120!。 
Ni 112. Budytes melanocephalus Licht. Int, xinthophrys Sharpe, welche nach ? Expl. von Batum beschrieben wurde, ist zwar von Dresser (Supl. Part. IV.) wieder art-

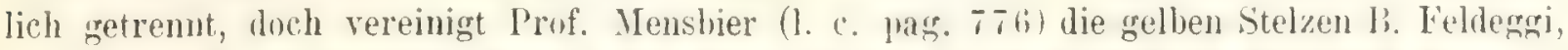
paradoxa und xanthophrys alle, da die Interschiede gering und nicht hestiondig sind und sie sich auch geographisch nicht ausschlie-sen.

. No. 1. 14-115. Budytes citreolus Pall. und B. citreoloides Hodgs. Nach dem geringen mir vorliegenden IIaterial uber Budytes citrenlus Pall und IB. citreoloides und nach Sarudny's Notizen musi ich letztere artlich trennen. Ins von Herrn sarudny erhaltene Exemplar, ein altes Mämchen, hat den gesammten Räckenmantel tief schwarz, was den Vogel ron B. citreolus scharf scheidet.

.0 117. Motacilla alba J. Das mir vorliegende Naterial vom Mut. alba habe juh nach den vorhandenen ()riginalbestimmungen von den Herrn Mensbier, Sarudny und I, renz nochmals durchmustert und mich dahei davon wiederum uberzeugt, dass es weder fiur die Vertheilung des schwarzen Colorits am Kopf mul llals noch futr das mehr oder weniger entwickelte Weiss auf der oberen Flugelseite foste (rrenzen griebt. Ich kam daher dit unter . 117 aufgefuhrten und näher hezeichneten Exemplare nur als Formen ron M. alla betrachten, sowohl ron XI. haicalensis als auch ron M. dukhunensis griebt es vermittelnde Uebergänge zur typischen M. alba. $117 \mathrm{gg}$ und 117 hh bezeichne ich nach dem indischen Original Expl. als M. luzoniensis, beides sind Winterkleider und absolut in Colorit

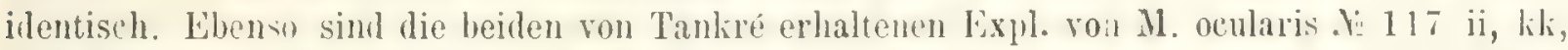
von denen des Herrn Lorenz sub M. dukhunensis o: 117 ee, ff, erhaltenen nicht zu unterscheiden. Prof. Mensbier hat ubrigens in seinem Irtikel uber Motacilla alba (T). II pas. 7st-788) M. dukhunensis nicht erwähnt, er spricht nur von M. batealensis, die sich whenfalls durch vieles Weiss auf der oberen Flugelseite auszeichnet.

1i 119. Motacilla personata Gould. Anch lnesser hat neuerdings (Supl. I'art. IV sich uber die vermittelnden Formen zwischen $\mathrm{H}$. persumata und alba anssespro hen, wel he M. personata persica 13lnf. repräsentiren, er hemerlit noch ausdrucklich: "the variations inter. se of this form are great".

№ 124. Anthus obscarus Lath. Bei nochmaliger Vergleichung von li: 124 d $f$ ad. mit dem schwedischen Vogel sub 124 b kann ich beide voneinader nicht unterscheiden. I) Anhaltspunkte welche Blar ford für das Vorkommen dieser Art bei schiras und Ispahan grieht, sprechen dafur, dass sie, die eigentlich der N. W. Kaste Europas und dem Norden angehört, vereinzelt sich auch ïstlich und gegen $\mathrm{S}$. findet. Wäre mein Vogrel jung, so kïmnte ich ihn wohl zu A. spinoletta jur. ziehen, aber er ist alt und unterscheidet sich gut rom Wasserpieper.

№ 1:6. Anthus Richardi Vioill. Unter den Piepern muss ich in Bezug auf Anthus Richardi Vicil. folgende Berichtigung fur den Artikel in der Ornis pag. '215 machen. Bei den Lixemplaren von Anthus campestris . 125 ee bis ii stimmt Alles gut zu A. Richardi. nämlich die verhältnissmässige Kurze der Hinterschwingen und die bedentende Iänge des spornes: aber die Ausmessung des Tarsus giebt doch nur 1 Zoll, an zweien Exemplaren mit einem kleinen Plus. Das Colorit der Brust ist nicht masssebend. I h habe daher dic betroffenden Expl. schliesslich doch nur als Anthus campestris signirt.

늘 137. Lanius phoendcurioldes Sevrz. i: $1: 37 \mathrm{a}-\mathrm{i}$. Ich halte die von manchen Ur nithologn artlich getrennten Wurger: Lan. Karelini logd., Romanovi lingd. und auch isabellina II. et Ehr. nur fur Formen der erst genamnten Art. Es handelt sich bei ihnen weder $u m$ constante Fürbung, noch um constante Spiegelgrösse. Die erstere geht auf Kopf und 


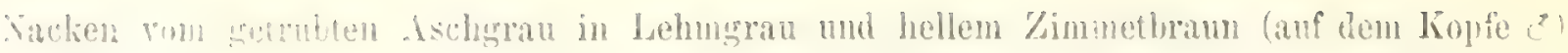
uber, bei I, isahellina sehe ich nur ein etwas helleres (iesammtcolorit, so dass z. L. die forn L. isabellina und I. Karelini, wenirstens bei meinen Exemplaren, nicht zu unterscheiden sind.

.6. 135. Ianius Raddoi Dresser. In Supplement zu seiner "Histury of the birds of Eurogle" Hart. IV. A ugust 1895, pas. 171 und 172 setat Dresser die Grunde anseinander, weshalb er dhe a: tliche Selbstständigkeit dieses Wïrgers aufrecht crhält. Ihm stimmt I'. Schuschlin bei, ron anderen Autoritäten, wie I'leste, Bianchi, Schalow ist der Vogel zu L. Jogdanovi gezogen. Mein Original Exemplar ist in der Sammlung Dresscrs geblieben. Nach ihm sind die Abbidunten fur "die Vogel Transcaspiens von R. et W. "für den "Ibis 1889". und fur den suphlementband des Dresser'schen Werkes gemacht worden.

. III mm 14. Laniu. Arimmi Eogd. mu I. assimilis L. et A. Erohm. Wenn ich nach Sarudn is Beispiel diese beiden gresondert aufulhe, so mus: ich doch offen gestehen, lass mach meinem treilich nu geringen Material sie mir als fast identisch erscheinen. I)as on II. Sarudny erhaltene Expl. ron I. Grimmi weich sogar in der Grösse niclat ron L. similis ab.

1. 11. Lonins ropax Brohm. Mit dem Original Expl. von Lanius borealis europaeus $\log d_{0}=I_{2}$, rapax, welches ich von Herrn Sarndny erhicht, stimmen dic drei kauka-

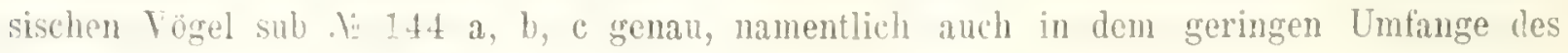
spiegets, üherein, weshalb ich sie danach signirte.

Auch bei dieser "Art" wird man bei grösserem Naterial mit der Bestimmung oft in Verlegenheit kommen. Prof. Mensbier schreibt Bd. II pag. 732: „Es kommen alle möglichen Leberginge von liesen Wurger zum gewöhmlichen grauen (L. excubitor) vor und in einigen Iällen wird man diese termittelnden Individuen als Kreuzungen der beiden nahen Formen erklïren künnen. Die Maasse stimmen zu denen des gewöhnlichen granen Würgers".

Ni 14. Mucicapa semitoruata F. V. Fom. L. V. Homeyer hat nach dem vin mir erhaltenen Lenkoran Material diesen Fliegenfünger als drt aufgestellt. Ich habe uber die mir damals rorliegenden Expl. pag. 286 meiner Ornis ausfuhrlich gesprocben und auf die Vittelstellung derselben zwischen M. atricapilla und M. collaris aufmerksam gemach. Hier alsn mur soviel, dass das einschneidende Weiss an den Halsseiten auch bei alten Männchen of sehr arering, ja fast Null, ist und dass die innere Fahne der äussersten Schwanfeder vor dem Ende gewöhnlich einen grösseren oder kleineren matt grauchwarzen Flecken bei stets weisscm Schafte zeigt. Dass der Vogel am S. Ufer des Kaspi aberwintere, wie Prof. Mensbier pag. 700 angiebt, ist mir nicht bekannt geworden. Alle meine Exemplare von dort wurlen vo 1 Mitte Maerz bis Mitte April auf dem Zuge beschafft. Bis auf . $149 \mathrm{~g}$ stammen auch die im Kaialog aufgefthrten Exempl. vom Zugr. Dass die Art im Kaukasus brütet habe ick schon in der Ornis gesagt. Die hïufigste Inliegenfänger Sp., auch als Brutrogel, ist Frythrosterna parva, Buchenwälder bis zu $4000^{\prime}$ Höhe berorzugt sie im Sommer.

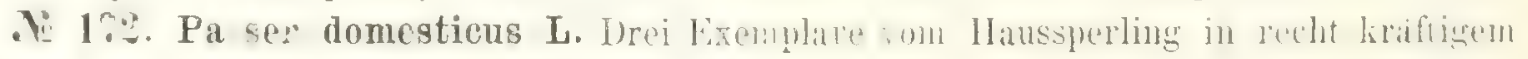
Wuchse .l: 172 bl, ce und dd brachte II. Flöricke von Kumbaschinsk, 20 Kl. nördlich von Lenkoran mit, bh weist am ganzen Körler ausgebildeten Melanismus auf, die ganze untere Seite ist tief schwarz, Wangen und Halsseiten dunkel schiefergrau. Die beiden anderen Exemplare sind wenigr helle..

178. Pyzrhala rubicilla Pall. Dic Suite meiner Dompfaffen to 178 zerfüllt in 2 Formen. Die erste ron ihnen enthält die Exemplare von 178 bis $178 \mathrm{r}$ incl. Alle diese sind starkwächsig und haben die schwarze Kopfplatte bis tief in den Nacken. 178 s und sind typische P. vulgaris Temm, bei ihnen endet das Schwarz der Kopfplatte auf dem IInter- 
haupt, bei $u$ und $v$ gent es schon etwas tiefer, bei $x$ ist es normal bei $y, z$ von der $N$. Seite, die ich von I. Lorenz als P. vulgaris erhielt, geht es etwas über das Ifinterhaupt hinas. I as Roth der letzteren beiden ist von dem der grosswithsigen P. coccinea nicht zu unterscheiden. Eine Suite von 10 Expl. beider Geschlechter, welche mir nenerdings von Herrn Sarudny gese.det wurde und welche von Orenburg und Pskow stammt, repräsentirt Pyrrh. coccinea. Die Vögel sind vollkommen identisch mit len sub .t. 178 a bis m aufgefuhrten, welche bei Tiflis und Borshom gesammelt wurden. Anch in Bezug auf das leuchtende Roth der Unterseite giebt es lieinen Unterschied. Ein wenig matter nur ist diese Färbung bei einem of $\left(178 \mathrm{~m}^{1)}\right)$, welches neuerdings bei Burslom erlent rirrle und welches genau zu cinem schwedischen Voggel stimut.

Ich mache darauf aufmerksam, dass alle meine kauk. Expl. von I. rub. major Wintervögel sind. Als Brutvögel dagegen P. vulgaris nur . $178 \mathrm{x}$ und zwar ron der Baumgrenze in Talissch erwähnt werden konnte.

Gerne gebe ich zu, dass ich, wie Prof. Mensbier mehrfach gelegentlich in seinem Werke "dic Vogel Russlands" und auch anderweitig mittheilt, die Fïhiglieit artlich so zu unterscheiden, wie es heute zu Tage viele Zoologen thun, nicht besitze. Obgleich ich im Verlaufe eines halben Jahrìnderts meine Augen nicht allein an Vogelbilgen im Stulirzimmer, sondern auch in der Natur an allen mögrlichen Objecten übte, so bin ich doch nicht z. B. dazu gekommen die Wüger aus der Gruppe des L. excubitor, und auch nicht die Dompfaffen gleich manwhen anderen Vogelspecies artlick scharf zu trennen. Nan mögre mir diesen Mangel ar. Erkenntniss grossmuthig verzeihen.

Ni 211. alerita cristata aronicola Tristr. . 211 n von lunis unterscheidet sicl: nur in Colorit der nberen hörperseite, wehthes rostiger ersheint als b i dem typischen Voce und kaum von dem bei G. magna und macrorhyncha ublichen abweiht. Mein Lxpl. von Gialerita nac"orhyncha (Tunis) stimmt in jeder Ilinsieht, in Schmabelstärke und Farbung znr magna von Aschabad :․ 212. Ich fuge es deshalb in die Suite dieser Species ein.

.1E 3. 0tocorys alpestris L. Die zahlreichen Oto orys Exemplare gruppiren sich je nach der Entwickelung des schwarzen Gefieders an den Kinf-und IIalsseiten und :.nt der Brust in vier Formen. Es liegt hier eine Parallelerscheinung vor, wie wir sie ähnlich bei der weissen Bachstelze benbchten. Wäre der $\Delta$ bshlusi des seitlichen Gesichtss ${ }^{+}{ }^{2}$ bei allen Exemplaren typisch, d. h. bei Otoc. alpestris und 0 . Brandti am IIalse scharf $\therefore$, schliessend und nicht bis zum schwarzen Felde der Brust reichend; dagragen bei Otce. penicillata, larvata und albigula damit ohne Unterbrechung verbunien, so musste man naiurlich trennen. Diese Schärfe der Ungrenzung findet aber nicht bei allen Exemplaren statt. 1:214, v, w, $z$ sind solche. Prof. Mensbier verificirte $z$, ein $q$, und signirte penicillata, an ihm ist das seitliche Schwarz mit dem der Brust nicht vereinint, die trennende gedhrrauc Zone ist zwar nur schmal, abel sie ist da. Auf das helle Schwefelgelb der Kehle lege ich liein Gewicht, Otoc. B'andti besitzi es entweder silnicht, wher im leisesten Influge. An miachtimsten kommt das Schwarz bei Otoc. albigula zul Entwickelung, wogegen der weisse KehlHeck auf ein Ninimum reduzirt erscheint do 214 tt repräsentirt solchen Vogel im ganz vertragenen Sommerklei : mis sehr breitem nechschwarzen Brustfelde, den der heiderseitige Halsstreif gerade noch erreicht. Betonen will ich, dass Otoc. penicillata aus dem liauk. Hochgebirge gewönlic.. starlswhehsig ist, doch gieht es auch Exemplare (21 $1 \mathrm{~mm})$. Welthe der

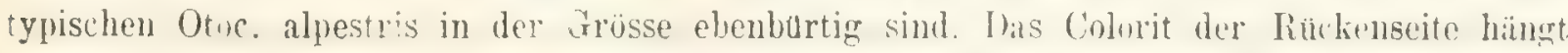
wesentlich vom Alter des Vogels ab. Die Exemplare der typischen Otoc. alpestris halte ich für Vögel welche im Winter aus dem Norden heranzogen, sie wurden alle von Decb. bis

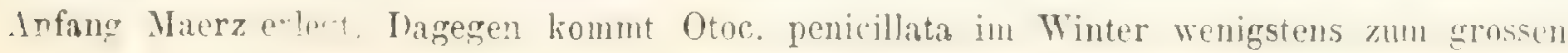




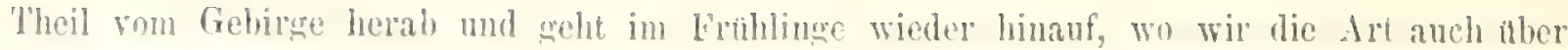
der schneelinie antreflen.

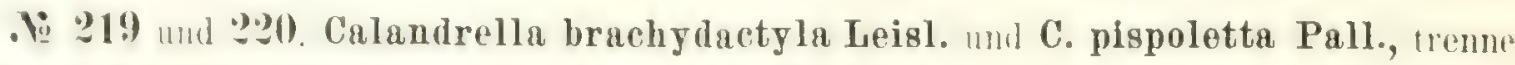
ich die beiden typischen formen, so muss ich futr 21! p. q, $r$, s die vermittelnde form mit normalem Schnabel von C. brachyl. und IIntershwingen von C. pispoletta, für 219 t mit normalen Schwingen ron C. brachydactyla und Schnabel von C. pispoletta notiren. Bei $220 \mathrm{~m}, \mathrm{n}$, o sind die Ilinterschwingen normal C. pispoletta, der Schnabel C. brachydactyla.

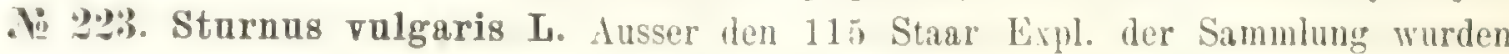
im Verlaufe del Jahre wohl ebensoviele präprart und ron mir rersendet und verschenkt. Alle diese kaknaschen Vögel lassen sich in 6 Hauptgruppen theilen, in denen man bei den alten Mïnnchen in Hochzeitskleide die Differenzen im glänzenden Colorit von Kopf,

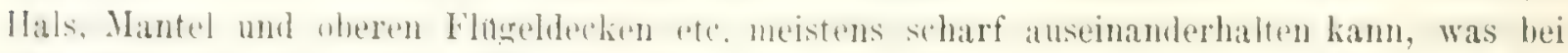

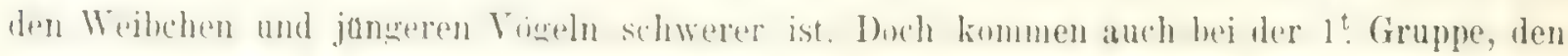
typischen Staaren, Exemplare mit Anklängen zu einer anderen Form vor. So besitzt .li 223 c als S. vulgaris typicus schon etwas von S. Poltorazkii, das ist auch hei di 223 e der Fall.

. $22: 3 \mathrm{a}^{1}, \mathrm{~b}^{1}, \mathrm{c}^{1}$ und $\mathrm{a}^{2}$ sind Original Exemplare, welche ich mit den Bestimmungen als S. Menzbieri und S. Sophiae von Herrn Saruduy erhielt und über die Beständigkeit. ihres Colorites nicht urtheilen kann.

. $223 \mathrm{a}^{y}, \mathrm{~b}^{3}$ repräsentiren den typischen S. purpurascens Gould; in der 8: Gruppe der Sammlung befinden sich von $\mathrm{g}^{8}$ bis $\mathrm{k}^{8}$ vier Vögel, welche zwischen cancasicus und murpurasiens stehen, es sind Weibchen im Herhstileide und nicht stark prononcirter Fürhung.

$.223 \mathrm{a}^{4}-\mathrm{n}^{6}$ bietet eine lange Suite von St. Pultorazkii Finsch, zum grössten Theile in deutlich ausgeprägtem Colorit.

I. $223 a^{7}-s^{7}$ enthält den typischen St. caucasicus Lor.; daran schliessen sich von t. $223 \mathrm{a}^{8}-\mathrm{p}^{8}$ Uebergangsformen von St. Polt. mit St. cauc. von St. cauc. mit St. purp. und endlich von $1^{8}$ bis $p^{8} 5$ Vögel, welche von Prof. Mensbier als nicht typische St. cauc. bezeichnet wurden, die wir aber $(\mathrm{R}$. K.) von den Exemplaren, die Lorenz von der Nordseite lieferte nicht zu unterscheiden vermögen.

Dresser kommt im Supplement Bande Part. V pag. 234 zu folgendem Schlussresultat seiner eingehenden Untersuchungen uber die verschiedenen Formen der Staare: Sturnus unicolor ist artlich zu trennen.

Die anderen Staare können in zwei Gruppen gebracht werden, in solche, welche die

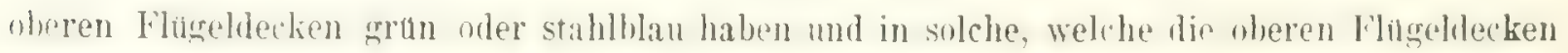
purperu haben.

Zur ersten Gruppe gehört: St. vulgaris und Menzbieri.

Kur zweiten Gruppe gehören: St. purpurascens, St. porphyronotus, St. Poltorazkii und St. cancasicus. Von diesen halte ich dafür (Dresser), dass man St, porphyronotus von St. purpurascens nicht trennen liann und dass St. Poltorazkii und St. cancasicus sehr nahe stehen zul St. purpurascens.

Der typische St. vulgaris ist in Transkaukasien ein seltener Vogel, wie es scheint lommt er our im Winter und anf dem Frühjahrsuge vor, denn .1 223 \&, ist ein junger Vogel, der zwar in Lenkoran ausgebrutet wurde, aber auch wie $22 ;$ e schon an S. Polt. erinnert. St. Poltorazkii beherrscht der Zahl nach von $0-3000^{\prime}$ 'Transkaukasien, zumal in seinem centralen 'Theile, er nimut gegen Osten merklich ab, wo dageren St. caucasicus vorwaltet. Dieser, so scheint es, präialirt auch an der Nordseite des Grossen Kaukasus, von woher ich kein Expl. yon St. Poltorazkii besitze. 


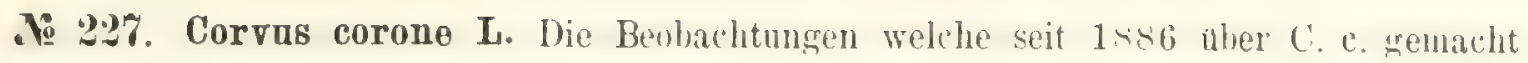
wurden, bestätigen das in der 3-t Fortsetzung zur Ornis caucasica („Ornis 1887. 4 Heft) (iesagte. Die Rabenkrihe ist ein seltener Tigel in den Tieflindern Transkaukasiens und zeigt sich nur jahrweise häufiger. Interessant ist der Bastard mit C. cornix von Petrowsk .li 226 e, also am W. Ufer des Kaspi und zugleich am Ende des Nordfusses der Hauptkette.

lì 236. Garralus glandarius I. und seine Furmen. In seiner Ibhandlung uber das Variiren von Garrulus grlandarius (Ornithologisches Jahrhuch. Jahre. IV. Heft. 5 pas. $167-$ 219) hat Ot(1) Kleinschmidt in er-chäpfender Weise die Verinderhichlieit der Häher auf deutschem Gebiete besprochen ${ }^{1}$ ). Fr erwähnt der Fälle, in denen der deutsche Häher sich dem japanischen nähert, spricht auch nach meinen Mittheilungen in der Ornis caucasica (pagr. 131 Hgd.) von solchen $G$. Krynickii und $G$. hyrcanus, welche sich zu G. glandarius himneigen. Seite 201 in der Ammerliung heisst es: „Ls ist übrigens die Mönlichkeit nicht ganz ausgeschlossen, dass wir es hier (bei (r. Krynickii und G. hyrcanus) mit wirklichen Ueberaingen zu thun haben und dass, wie Radde es will, die europäischen und ostasiatischen Häher zu einer Art gehüren". Die artliche Selbstständigkeit ron (iarrulus Brandti hält der Autor aber aufrecht und erwähnt pagr. 19,; des hesonders weichen Gefieders dieses sibirischen Hihhers. M[eine 3 Exyl. ostsibirischen Ursprunges besitzen nur im Nacken die Federn etwas feiner und weicher als an den sonstigen Körpertheilen und es ist nenerdings durch Menshier (I. c. p. II. pag. 495) nachrewiesen, dass im westlichen Theile des Permschen Gourernements aus er dem typischen G. Irandti auch die rermittelnde Ueheronangsorm zum G. slandarius leht. Diese Form (G. Severzowi) kommt auch in Kasanschen und Simbirskischen Gouvernement vor.

Als Endresultat seiner eingehenden L'ntersu'hungen vereinigt Kleins 'hnidt alle schwarzköpfigen Häher zu einer Art und benennt die Formen (subspecies) trinär als:

Garrulus melanocephalus hॅrcanus Blanf.

$\begin{array}{lll}n & n & \text { Krynickii Kalen } \\ n & n & \text { albifrons=atricapillus Geonir. } \\ n & \text { cerricalis Ripp. an. cacniura. }\end{array}$

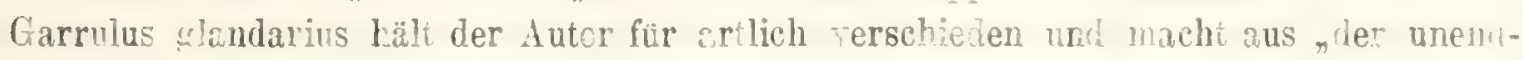

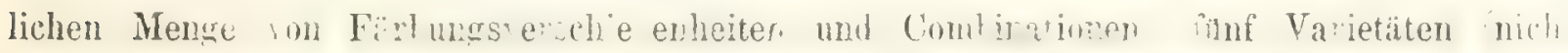
subspecies), råmlich

$\begin{aligned} \text { Garculus slandaries varietas } & \text { rufina, } \\ & \text { nigricans, } \\ & \text { albida, } \\ & \text { taeniura, } \\ & \text { ibcia a. }\end{aligned}$

Ich gehe lokannich noch einen Schrit, weter un! inton ich mich hei der Bezeichnum der dreinamigen Jiomenkla ur lie ene wird Jerormann aus dem Ka a ore ersenen, welche Form des Hähers ich meine. Dami ist der Fanptzweck in diesem und in allen anderor Fällen elfült. Was num die Häher Snito do: liauk. Museums anlolant, so habe ich nu: über die beiden Expl., welche Elöike 1896 dazu liefere ein Paar Worte zu sagen. Es sind das 236 s und 236 eg, heide. stammen von demselben Platze Krmbaschinsk, $20 \mathrm{klm}$. nördlich ron Lenkoran. Das ist eine Localität, die noch nichts mit den geschlossenen Laubwäl-

$\left.{ }^{3}\right)$ Diese Arboit hat in moincz Augen eicen hohen Wertk. "Der Autor hat sich hei allepeinlichster systeruatischer Urterscchung cinen freien. Blick fils allgemeine biologische Tragen erhaltes (p2.. 209 . ). Thm ist dis Natur kei-

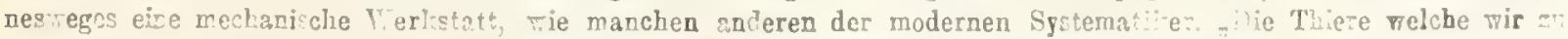

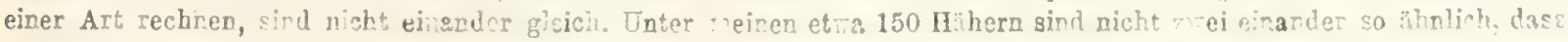

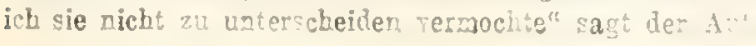


dern ron 'J'alysch zu thun lat, anch nichts nith hem Gebirge, sie liegt frei am Neere. Da leben num wie die Exemplare beweisen G. Krynickii und G. Iytanus unmittelbar bei und mit einander. $236 \mathrm{~s}$ reprisentirt den ersteren, 236 seg den letzteren. P'rof. Mensbier schliesst seinen Irtikel uber Garrulus shandarius 11. e. II, jag. 494) mit folgemden Worten: In Mittulrussland ist das Colorit der Iäher sehr verschiedenartig. Bei manchen herrscht ein rothbramer 'Ton vor, bei andern ein grau-weinbrauner. Aber ganz besonders wechselnd und verschichen ist das Colorit des Kopfes. Bei den cinen hat er mehr oder weniger entwickelte rothbräunliche firbung mit verschiedenen, of nur sehr wenigen schwarzen lilecken, was sie dem G. Brandti mahe stalt. Bei anderen sind solche schwarze liopftleclien sehr stark entwickelt, die Gruntarbe des Kopfes sehr viel mehr grau und schwarz; solehe bxemplaro

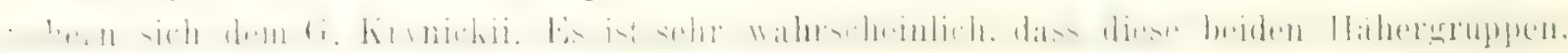
die sich durch das Cohrit unterscheiden im Verlaufe einer langen leihe von Xachkommensehaften aus der Krenzung von $G$. glandarius mit $G$. Brandti und $G$ Krynickii hervorgingen. wobei sich solche Hybriden wielerum in unbegrenzter Kombination auf's Neue kreuzten".

Hit diesem Ausspruche given Prof. Mensbier die vermittelnden Uebergangfo:men, welche weder das eine noch das andere sint, zwischen den beiden extremen gut zn unterscheidendon diten zu. Von manchen anderen Vogelarten darf mon ganz dasselbe behaupten.

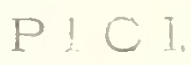

1i 214. Picas major I. f, g, h, i sind bei Tiflis gesammelte buntspechte mit getrübter unterer Körperfärbung, namentlich stehen f und i dem typischen P. l'oelami cčon recht nahe. Ébenso auch die beiden Buntspechte 2411 , mm welche im Septem er bei baknriani erlegt wurden. Nachdem ich dieses nachgewiesen kann ich den typischen Picus Poelz.mi Bogd. doch nur als eine scharf prononcirte form (subspecies) von P. major betrachten und fulge dem Beispiele des Prof. Mensbier, welcher ilm freilich noch unter getrennter fortlanfonler .l:aber als I'icus major Poelzami Bogd. aufruhrt. Alles Sonstige habe ich uber dicsen Specht in der Ornis cancasica pag. 310-311 gemeldet. Uebrigens hat Gatunin neuerdings ein Weibchen ron P. Poelzami (sehr klein) auch bei liflis (4. I. 97) erlegt.

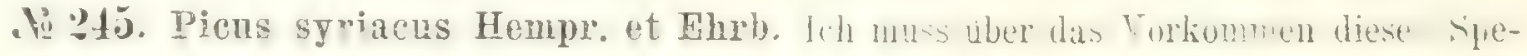
cics cin Missverständniss beseitigen. In meiner Ornis caucasica heisst es pag. 313: "Ich lienne den Yogel nur von den Localitäten, wo auch P. major typicus verlommt ete. Damit will ic? aber nicht gesagt laben, dass er überall vorhanden ist, wo der grosse Buntspecht angetroffen wird. Ich wollte damit nur das lactum erwähnen, dass sich beide nicht ausschliesEn. Bisjetzt ist fur den Kaukasus P. syriacus nur im Centraltheile T'anskaukasiens nachneviesen. In dieser Weise will ich die Mitheilung Prof. Menshiers sub 267 (pag. 356 Bd. II.) zurechtstellen.

.1․ 24\%. Picus minor Is. Die Exemplare vom kleinen Buntspecht in der vart. quadrifasciata besitzen auf der gesammten unteren Köryerscite eine bräunliche Grundfarbe, freilich nicht so gesättigt wic bei P'. major Poelzami, aber doch bedeutend dunkler als bei dem Exemplar aus dem centralen Theile 'Transkaukasiens. Alle sind kleiner als der typische P. minor. Dresser behandelt sie nur als Yarietät, da die b-t Binde auch bisweilen angedeutet ist. Er besitzt yom typ. P. minor sogar Expl., an denen die eine Flügulseite 5, die andere nux 4 Binden aufweist. L'icus Danfordi IIargitt, welcher sich von $P$. minor nur durch das schmale, sichelformige, schwarze Ohrenband auszeichnet, ist rom Kuban bekannt und ron Dresser int Supl. P'art. VI pag. 259 beschrieben worden. Das Museun besizt ein solches Exemplar nicht. 
Mi "24. Picus medius L. Mein typiseher L'. Sinneti-Juhanis ron chramtusse, den ich in der Ornis pag. 213 ausfuhrlicher besprach, ist leider eingegangen, nahe steht ihm $248 \mathrm{~g}$. Uebrigens ist auch $248 \mathrm{f}$ von der Nordseite des Gebirges untenher sehr intensiv gelb gefurbt. Die Irreite der Bänderung in Sihwarz und Weiss auf den Schwanzfedern ist nicht constant.

- 219. Picus lenconotus Lilfordi Shrp. et Dress. 219 a mit dem Fumbrte Borshom rerrollständigt das, was ich uber ein zerschossenes Exemplar von Manglis in der Ornis raucasica pag. 314 sagte. Wir kennen jetzt drei Fundorte dieser ausgezeichneten form vom P. leneonotus aus 'Transkankien, nimlich: Manglis, Borshom und Lagodechi.

\section{O C Y G E S.}

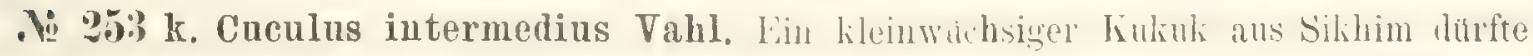
wohl C. intermedius Vahl sein. Es stimmt an diesem Vogel Alles mit dem, was Prof. Mensbier B. Il pag. :336 über diese Art sagt, das l'auchige Grau des Rüichengefieders, der liräftige Schubel, dic breite Bänderung der unteren Körperseite, der gelbliche Anflug derselben und die Flügellänge $\left(7^{1} / 2^{\prime \prime}\right)$.

Bei dem gewöhnlichen Kukuk hängt hbrigens das lichtere, reinere Gran der Oberseite sehr wesentlich vom Alter des ausgefübten Vogels ab. Ls wird, wie bei den grossen Würgern, mit zunehmendem Alter immer reiner, heller und klarer.

\section{MACROCHIRES.}

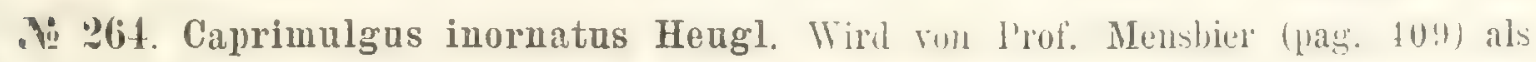
C. nụbicus Licht. gedentet.

\section{A C CIPITRES.}

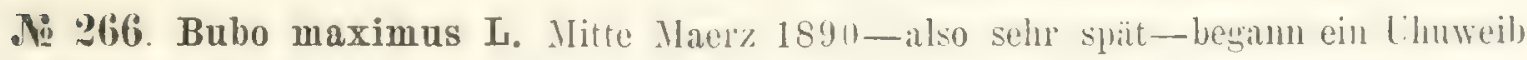
in der Voliere, welches dort mit sechs Uhus o zusammen lebte, am Loden unruhig zu werden. Nit y rogestrectitem und zum Boden geneigtem Kopfe trippelte es hestinding auch am Tage hin und her und wiegte dabei den Kopf links und rechts. Es liess sonderbare schwatzend zwitschernde Töne hören, ganz eigenartige, die nan gewissermaassen als Gesang benemnen durfte. Olne irgend einen Schutz und ohme Schonung war das erste Ei am $\frac{20 \text { III }}{1}$ in der Ecke

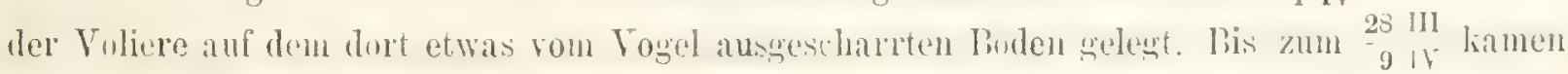
noch zwei dazu. Damn hegann das lirutgeschäft, welches 2; Tage danerte. Von den drei hungen erwuchs nur eines und schloss sich der Gesellschaft an. Im Sommer 1896 wurde die sanze Reille del zusanmenhïngumlen Vulieren mit den Krähen, Eulen, Falleen, Enten. Kuranichen von einer diphterieartigen Seuche befallen. In kurzer Zeit gingen alle Fleisclifresser ein.

ํo 271. Syrnium aluco L. Die Exemplare h und i sind auffallend dunkel, sie wurden bei der Kolonie Amnenfeld in Elisabethpolsehen Gour. im Octoh. 189t afunden. Das Weibchen lebte bei uns in der Voliere bis Maerz 1895. Heide Vuged sind runkel rauchbraun, obenher etwas brandiger, die Schleier fast schwarz.

. 279 k. Circus aeruginosus unicolor Radde ist leinesworges. wie Herr Dinnik meint, ein junger Vogel, sondern ein altes é mit durchweg dunliem Getieder, nirgend sicht man an ihm ochergelbe Flecken. Die Pasis der Schteitelfedern ist weisclich, damn höher gelblich. 
aber die breiten Limrindungen und Spitzen dunkel sepienbraun, wie die gesammte obere und untere Kürnerseite, wie las T'af. III meiner Ornis zur Anschaumer bringt. Anch Sarndny bestitigt diese Varietät, welche an T'edshen ron ihm ziemlich häutig angetrofien wurde (1. c. pag. 38i).

o. 2): Falco saker Gml. Nachden ich in Dresser's Supplement Band l'art VI. llag. 281 -28:3 den Artikel iber Falco milvipes Hodg. gelesen und das darin citirte Exemplar lles Museums (Tillis 16. III. 68 also .lo 292) rerglichen habe, muss ich es als fralco milvipes betrachten. Ich hahe das Exemplar seiner Zeit ganz ausfuhrlich in der Orn cauc. pag. 70 besprochen und es fur ein altes o von l'. salier gehalten. Lis ist ubrigens anch Dresser so ergugen, am linde seines Artikels schreibt er: „da dieser lialke auf 'l'afel 377 als cin recht alter $\mathrm{K}$. Salier bereits abgebildet wurde, so ist es nicht nöthig ihn nochmals zu geben". Lrwihnen muss ich aber doch, dass das in Rede stehende kxemplar auf der unteren beite nicht gebumert ist. Aber schon ron der Kehle an sind die Thränenflecken sehr gross und weiter alowalts noch mrösser.

Die IImeigung zum F. Feldeggi wird durch 292 a gegeben. Bei dieser (relegenheit liann ich nicht umhin der werthvilen neuesten Arbeiten des Barous von Lrrlanger (Journal für Ornithologic Bd. XIVI, Heft III 1898) zu erwähnen. Kleinschmidt's Arbeit über die Häher und die chenerwihnte aber Gypaëtos barbatus, Milvus niger und Falco Feldeggi sind in Wort und liild mustergültig. Sie bekräftigen das, was ich immer uber manche der "sihwankemlen Gestalten" behauntet habe, dass nämlich scharfe, feste Grenzen selbst bei den Individuen von cin und derselben Localitä in vielen Fiallen nicht zu ziehen sind. In den meisten solcher Falle wirl die triaare lenennung zur liezeichnung solcher Varianten und Formen ausreichen, aber nicht in allen. Es giebt auch zwischen ihen vermittelnde Übergänge. Die Intacilla und lindites Arten, die Verwandten von Buteo vulgaris, diejenigen von Picus majol und medius, die vom gewöhnlichen Staar und einigen Parus sp. liefern für solehe kritische Unter:u hungen cin reiches Material. Wünschenswerth ist es, dass dieses in der erwähnten Richtung nach grossen Suiten gesichtet wärle.

ํ. 997. Milvus ater Gml. Wie aus dem Kataloge zu ersehen, so besitzt das Museum nur zwei typische schwarze Milane to 297 und 297 a und drei M. melanotis, von denen 297 d aus Orenburg sehr stark in den Charakteren prononcirt ist, so auch namentlich sehr breite, lehmgelbe Schaftflecken untenher hat, das Weiss der unteren Flügelseite erstreckt sich bis auf die Mitte derselben. .lo 297 d typisch bezieht sich auf M. melanotis. Zwei andere Kaukasier schliessen sich an diesen Vogel in Bezug auf das Weiss der Basalfläche der unteren Fligelseite noch gut an, während sie sonst vou gewönlichen Milane

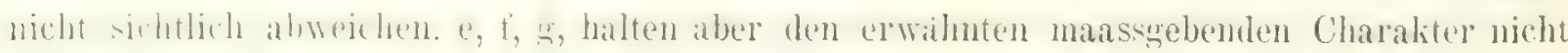
ein, die betreffende Zone ist bei ihnen, wie auch bei dem Vogel von Homeyer deutlich grau gewiassert und gesprenkelt.

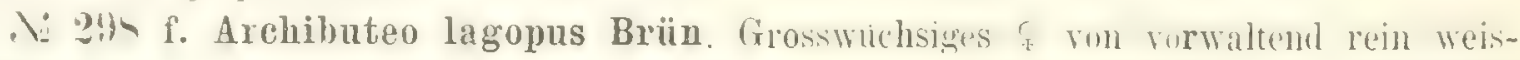
ser larbe, s, anch alle Schwanzfedern bis auf eine durchgehende matt schwarze, nach oben

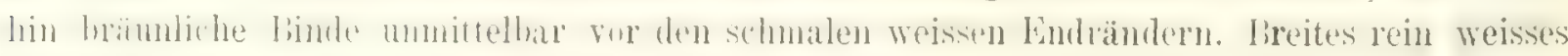
Brustfell, $298 \mathrm{~g}$, h of im typischen Kleide. Je nachdem der Wintel im Norden strenger

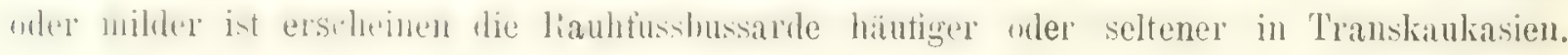
Mitte Novb. in strengen Wintern.

. 29: o. Buteo vulgaris Bechst. typ. Ende August wurle lieser typisch gefirbte

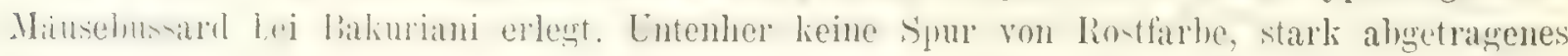
Kleid mit partieller Mauser. Die neuen Federn auf der oberen Seite dunliel matt schwar\%braun. Nur wenig Rostbraun auf den oberen Flügeldecken und den Schwanzfedern. 


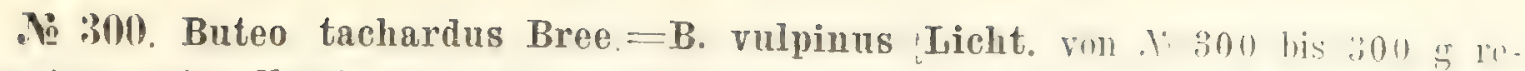
frasentiren meine Vögel den typischen Vogel, nämlich untenher, namentlich ron der lirust

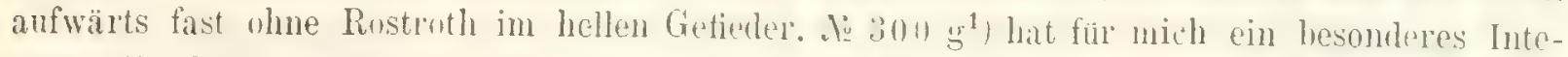
resse, die Originalsignatur, wn Lorenz geschriehen, lautete: Buteo vulgaris Menetriesi Bordanow. Das entspricht gan\% meinen Insthanunen. Ith habe daruher ja ansfühlich in der Ornis caucasica pag. 90 gesprochen. Uebrigens ist die Grösse dieser Bussarde doch recht s.hwankend. Es gieht Weibhen, wekhe denen des gewhonlichen I. vulgaris durhaus nicht nachstehen. o $300 \mathrm{~h}-\mathrm{n}$ repräsentiren den typischen B. vulpinus Licht. d. h. uberall im Gefieder stark rostroth. to 300 q ist der Vogel, den ich als B. tachardus fuseo-ater in der Ornis besprach. sein einfarlig dunkles, fast rein sepientraunes frefieder, wellhes nur hice und da auf der unteren Körperseite etwas fuchsig ist und sein geringer Wuchs zeichnen diesen Vogel sehr merklich von den übrigen aus.

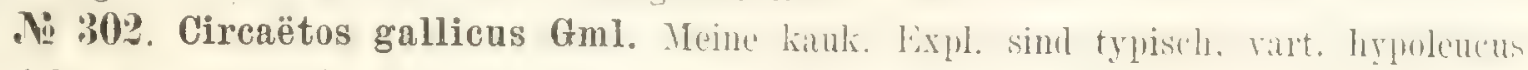
habe ich am unteren Atrek beobachtet

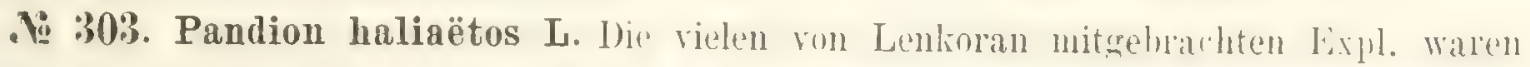
in Fulge der grossen Feuchtigheit und dicken llant verstockt und liessen sich nicht crhalten.

Vi: :06\%. Aquila fulvescens Gray. Mit Iülfe der neuesten I.iteritur üher Aq. rapas und Aq. fulvesceus Cray habe ich meinen Vogel endgiltig als Aq. fulvescens (iray ${ }^{1}$, bestimmt.

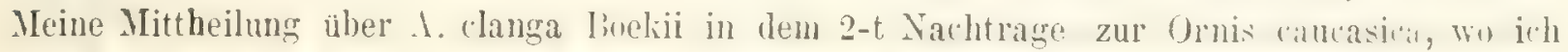
den Vugel als A. Iboekii Ifom. bespreche, findet also Bestätigung, da dioser jetzt als symunym rom A. fulvescens bctrachtet wird. Ich gestehe aufrichtig, dass ich lange zweifelte, ob mein Vogel nicht 1 . rapax albicans Rüpp. sei, da die Maasse, welche Baron [rlanger ${ }^{2}$ ) giebt genau zu meinen Vugel stimmen und sein Colorit im gelhen Farbenton zwi hon dem dunkleren

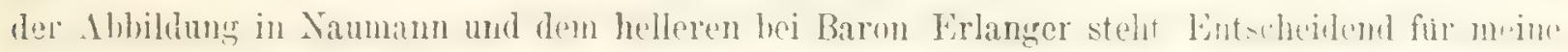
Teherzeuguner war nur das runde und nicht ohrformige Tasenloch, welches nach llartet, hei

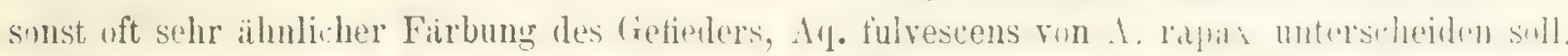

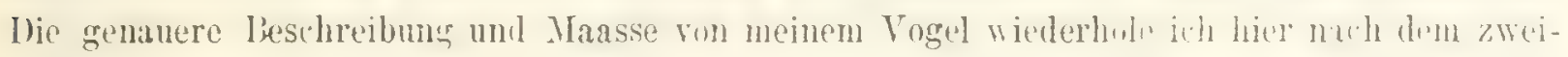
ten Nachtrage zu meiner Ornis caucasica. Der gesammte Kopf und Hals, sowie die ganze Unterseite des Körpers sammt den unt ren Schwanzdecken, den Hosen und Ständern simd einfarbig erbsengelb und zwar auf dem Irustfelde in etwas dunklerer Nuance, auf den Sub-

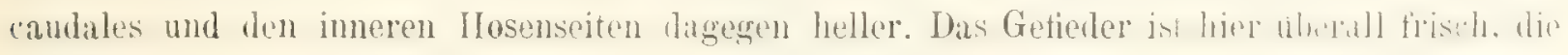
Spitzen der oberen Brustfedern sind in geringem Umfange mit kaum angedenteten kleinen, grauen Keilflecken versehen. Doch stehen solche nur in geringer Zahl da, tiefer am Leibe und auch auf den Flanken ist Alles einfarbig. Anf dem Mantel und auf den gesambnten oberen Flügeldecken dominirt ebenfalls die helle F'ärbung. Jede einzelne Feder besitzt nur ein mattgrauschwarzes Centralfeld, welches allseitlich von sehr breiter hell gelbweisslicher Einfassung umkantet ist. Die helle I3inde der grossen Fligeldecken ist vorhanden, und die Spitzen der Schwingen 느 Ordnung sind ebeifalls hell schmutzig gelblich, et was in graubrüu. lich ziehend. Bei den grösseren Ferlern des Mantels werden die dunklen Centralfelder mäch-

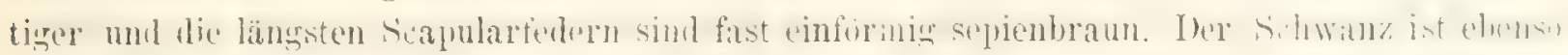
scfärbt, ohne Iäinderung (auch von imnen her). Ich nehme an diesem Vogel fulgende Maasse:

Schnabel von der Spitze bis zur Stirnbasis gerade gemessen. $\$ 1$ im liogen. 


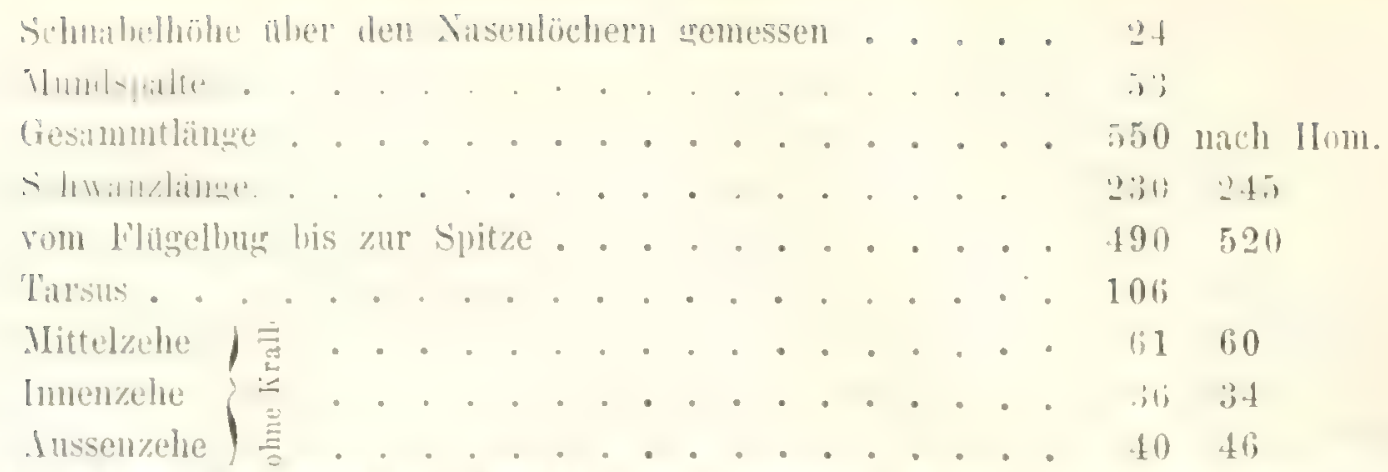

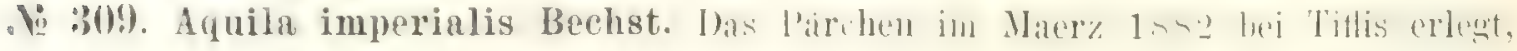
reprisentirt las Kleid der 5 t Mauser. (Ornis pag. 80-Nensbier Bd. II pag. 193) Melumals haben diese Liller in der Gefangenschaft gelegt, zuletzt brachte uns in diesen Jahre (98)

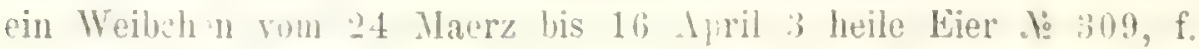

우 310. Aquila fulva L. Meine Kaukasier sind bis auf einen alle typische $\Lambda$. fulva. Das lixempl. $10 \mathrm{f}$ reprïsentirt A. chrysaëtus. Es ist ein $q$ und wurde bei Tiflis dnfangs Norbr. 18ys crlert. Im Verlaufe von 20) Jahren lebt in der grossen Voliere cin Weibchen welches ; mal lier legte, 1892 und 1s9t; fand man am frühen Morgen nur die zertrummerten Schalen. Im Verlaufe des Maerz Monats 1897 wurlen die Eier einzeln heil fortgenommen und zwar vier Stück eto 310 e.

. 10. Gyps fulvus Briss. legte am 24. II. 96. in der Gefangenschaft cin Ei.

- :ili. Vultur monachas Gml. leote am li. IH. 18 . in ler Gefangens halt (in bi.

\section{STEGANOPODES.}

- :319. Pelecanus minor Rüpp. Seit 1 s 80 hat sirh mein Material fiu liesen Vogel nicht vergrössert an den 3 Expl. bestätigt sich das, was ich in der Ornis sagte und zeichnete (pag. 473). Prof. Mensbier rereinigt (T. I pag. 824) P. minor mit P. onocrotalus. Das am 11 Maerz so. von del Akuschia gebrachte Ei rechne ich zu 1'. minor, seine Maasse sime: Grösste Höhe $87 \mathrm{~mm}$. Grösste Treite $58 \mathrm{~mm}$.

\section{A NSERES.}

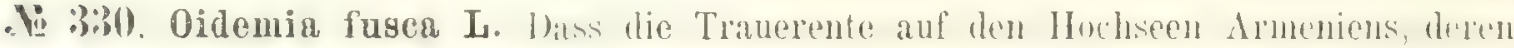
Spiegel circa 6300" uher dem Meere gelegen, brätet, wird durch den Fund eines Geleges vom Tabizchuri-See (zur Domäne Borshom gehörend) bestätigt. Trotz der späten Fundzeit 15/27. VIIL. 95 waren die Eier nur wenig bebrutet, was sich daraus wohl erliären lässt, dass die kleine Insel, auf welcher die Brutstellen liegen, in den letzten Jahren mehrfach ron Jägern besucht und widergesetzlich bejagt wurde. Auch Fuligula cristata britet dia.

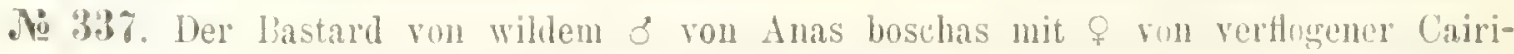
na moschata ist 1.585 durch A. I'ichler in Agram bestatigt worden, woklurch Bogdanows Bemerkung üher meinen Vogel zurechtgestellt wurde.

\section{H E R O D I I}

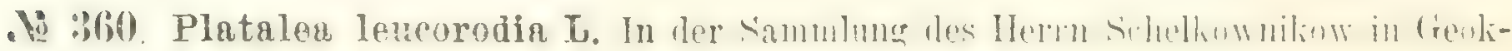


tepe, unweit von Jewlach, (Unt. Kura) befand sich unter 6 ausgestopften Lixmpl. cin auffal. lend likines altes o vom 27. VI. 93. Ich habe an diesem folgente Maasse genommen:

\begin{tabular}{|c|c|c|c|c|c|c|c|c|c|c|c|}
\hline bllänce yon & & & & & & & & & & & \\
\hline rösste Schmabelbreite. & 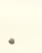 & . & . & . & & & & & & & \\
\hline Tackte Unterschenkellänge & & . & & & & & & & & & \\
\hline slänge & & & & & & & & & & & \\
\hline telzehe ohne Nagel. & & & & & & & & & & & \\
\hline Kelle gerade in de & & Mit & & & . & & & & & & \\
\hline istanz bel & & & & & & & & & & & \\
\hline
\end{tabular}

Bei diesem Vogel war der vordere Schnabelrand viel abgerundeter als bei den anderen, obenher nur wenig gerunze't. Der untele Umriss der kahlen Halshaut wal ebenfills gerundet, bei den typischen Exmpl. spitzer. Die Löffelreiher sind in jenel Gerend im Som. mer sehr häufig, es grielst Scharen von reichlich 200 Individuen Im Magen fank man Kaulquappen, die Larven von Cybister, auch eine Maulwurfsgrille.

No. :368. Bubulcus ibis Hasslq. Cirosse Brutiolonien betimlen sich unweit wil dem Gute Geok-tene in den Sümpfen (Naur). Ende April sind die Gelege vollzahlig. Die gergen knde Juni eingefangenen Jungen halten sich vortreftlich in der Ciufangenschaft bei Fleischnahrung:

\section{COLUMBAE.}

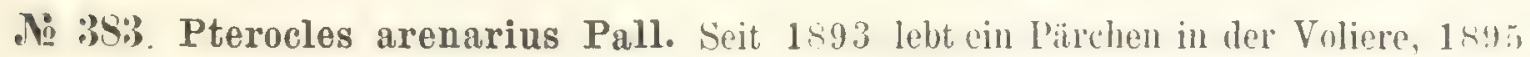
und 1897 begann dass ? in den ersten Tagen des Juni zu legen. Von den Eiern konnten nur 6 heil genommen werden, die anderen waren zerdrückt.

\section{GA L L I N E}

.12 :36. Megaloperdix caucasica Pall. Die Exemplare form der Laba, welcle ich ans dem Nachlasse Kratky's erstand, laben grosse Brutflocken auf der bauchtläche.

Erst in neuester Zeit ist es gelungen das Vorkom nen von dieser Art, wenn auch als Seltenheit, fur die Idsharo-imeretische Wassetscheide nawzuweisun. Hic lomulhungen Sr. Kaisl. Hoheit des Grossfürsten Thronfolgers George Alexandrowitsch fürderten in! Sommer 1897 drei Exemplare von den Höhen des Did-Magil unweit vom Nepis-tskaro, welche in annähernd 9300' Meereshöhe in der Kanmzone dieses Gebirges circa 6 Kilm. westlich vom Sikar Passe gelegen sind. Die Präparate, Flügel und Schädel sub. .li :386; h enstammen dem Vogel, der dort im Juli 1897 erlegt wurde.

\section{GRALLAE EI LIMICOLAE.}

№ 411. Grus virgo $\mathbf{L}$. Das alte Weibchen, von welchem ich in der Ornis pag. 39 ! ansführlich spreche, lebte immer noch, jetzt also bei mil schon 28 Jahre und hat im Verlaufe dieser Zeit viermal Eicr gelegt. Zuerst 2 rom 30 IV bis 4. V. 79. Die beiden Eicr rom Mai 1853 waren zerbrochen. Je eines vom Ende Mai 1895 und 1897 befinden sich

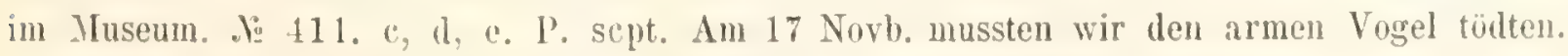
Lr konnte nicht mehr auf den Füssen stehen und musste gefuttert werden.

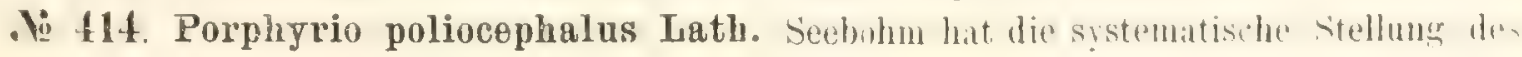




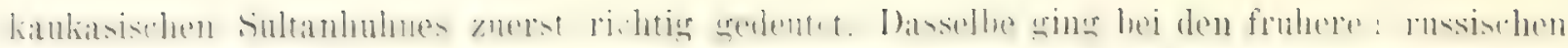

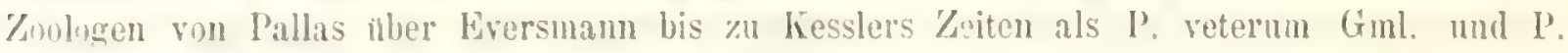
hyacinthinus Tem. Bogdanow fuhnte es als P. veterum auf, ich folgte ihm darin und gab in der Ornis pag. 380-38 ausführliche Beschreibung, anch auf 'laf. XXIV Abbildung des Vogels und Taf. XII der Lier. Krst Seebohm placirte es 1884 richtig unter dem Namen der indischen Art P. polioce, halus Lath.

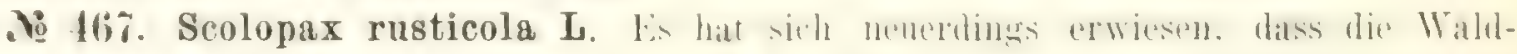
schnepfe sogar im Engthale der Kuri oberhall, von Borshom brütet. Am 6/18 V. 98 wurden

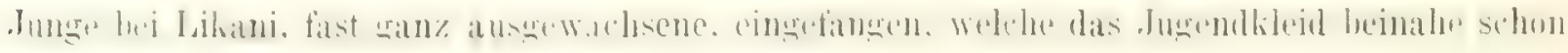
am ganzen Körper trugen, uu auf der hinteren Halsseite und im Nacken sah man Dunen zwischen den hervordrängenden Federn.

\section{G A V I A E}

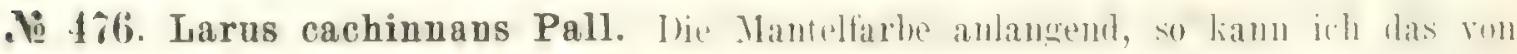
mir. Gesagrte (Ornis cauc. 1. $\$ 7 j$ flgd.) nur bestatigen. Was uns (mit Walter) an der Ost-

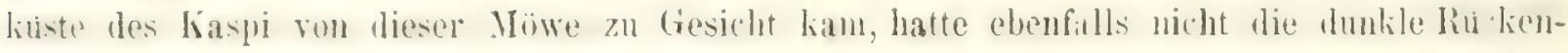
farbe. Auch das Exemplar, ron Schlüter gekauft, mit dem Fundorte "Petrowsk" signirt, ent-

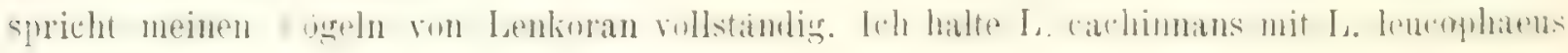
fir indentiseh. 


\title{
REPTILIA Eт BATRACHIA.
}

\author{
ПРЕСМЫКАЮЩІЯСЯ.
}

\section{REPTILIEN UND LURCHE.}

IIIкапъ -54.-Schrank. 



\section{Taf XIX.}

Salamandra

Pelodiftes cancasicus cancasica

Salamantra 14 caucasica. 
XIX थ

$\therefore+\cdots,+\div \quad 1+1$

$r+1, ; 1)+18 ;, i 1 \leq$

1) . . : : $: 1$ whitomaler

$\therefore, 2 \times 3,1$, 

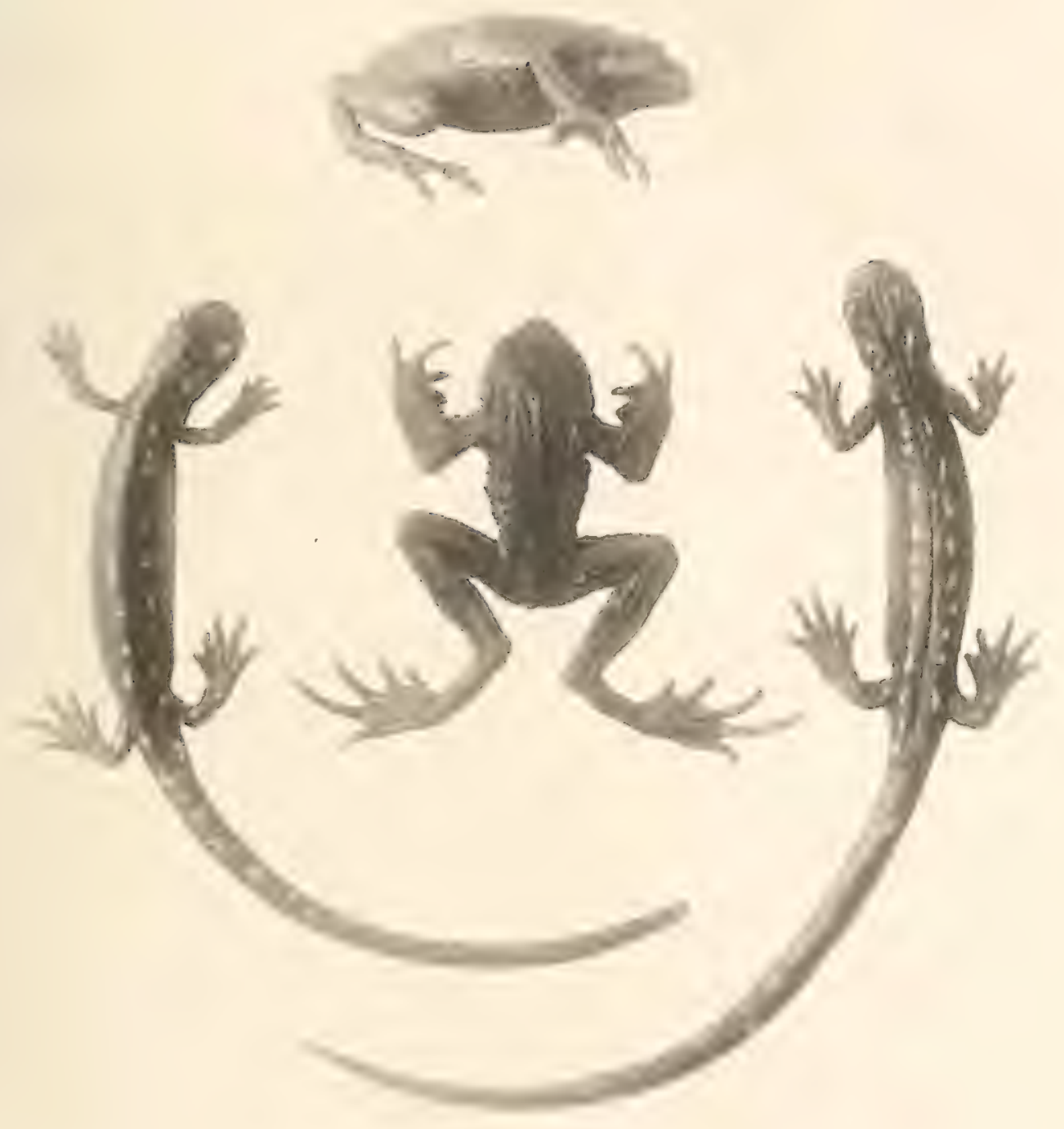



\section{REPTILIA Eт BATRACHIA. \\ COTРУДНИКИ-MITARBEITER.}

Prof. Dr. O. Boettger. Frankfurt a. MI.

G. A. Boulenger. London.

E. Koenig. 'Tiflis.

Dr. G. Radde. Tiflis.

Dr. A. Strauch. St.-Petersburg.

Dr. A. Walter. Titlis. Jena.

Составт колленціи пресингающиея до 1 января 1899.

(iesammtbestand der Sammlung von Reptilien uud Lurchen bis 1 Januar 1899.

Ord. Chelonia . . . . . 5 Arten 54 Expl.

"Lacertilia . . . . . 36 n 469 "

"Ophidia ....... 34 . 229 "

" Batrachia ecaudata. . . . 14 " 133 "

"Batrachia caudata.... 7 . 80 n

96 Arten 965 Expl. 


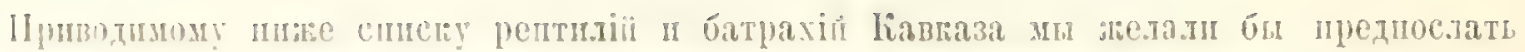

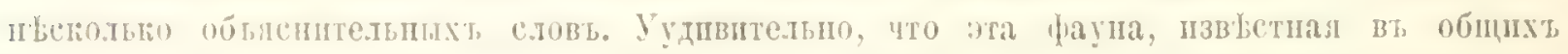

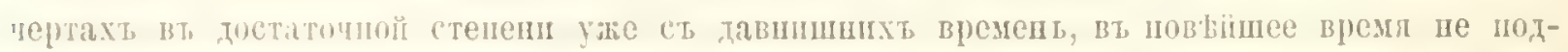

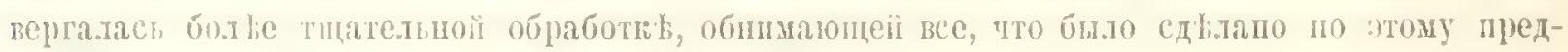

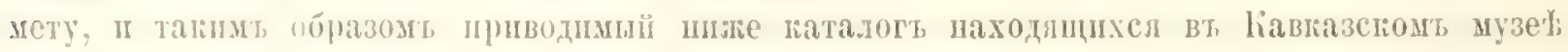

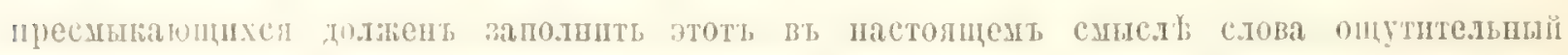

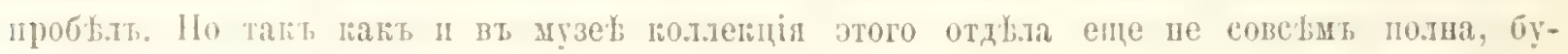

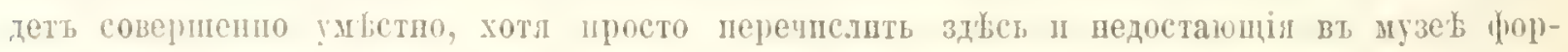

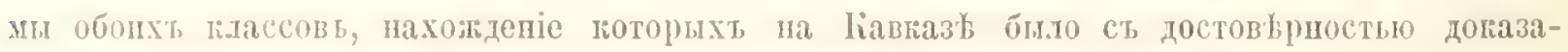

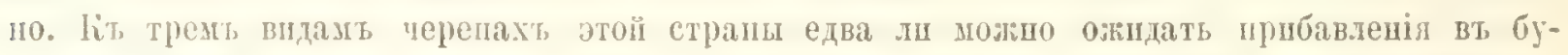

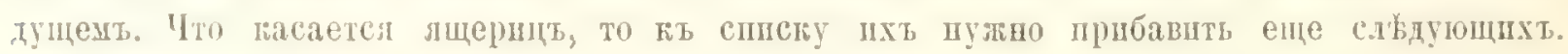
Шаъ I acertidae:

Lacerta Brandti de Fil. цзъ Разапо (Та.дыъ).

Taria ив. Scincidae:

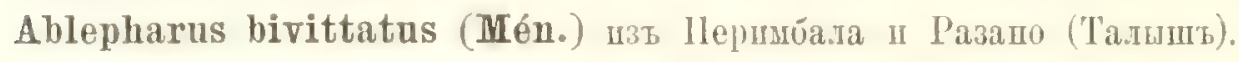

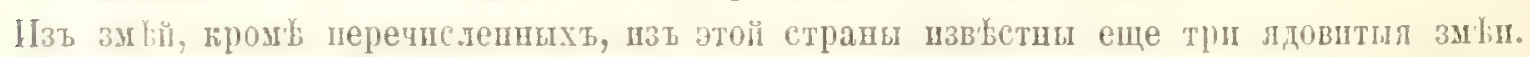

Naja tripadians Merr. var. caeca Gml. пз liaрабаха (Булеплерь).

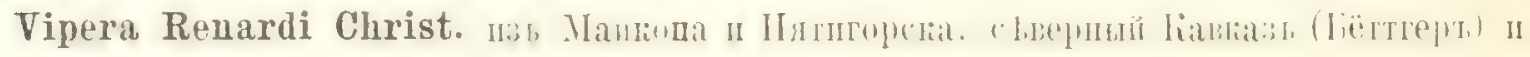
Ancistrodon halys (Pall.) пзь Талына (Бёттерь).

Џзъ батрахі і пукио упомпуть еще:

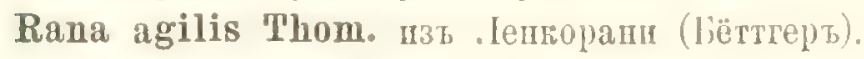

Pelobates fuscus (Laur.) (Беласуварт, .Іенгорань, Цапдеръ).

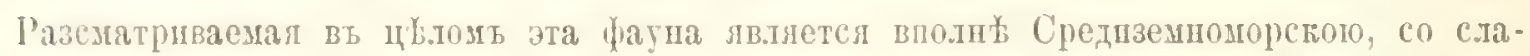
бою примьсьо тағнхь восточныхъ вшдовь, главнал область распространепіл юоторыхт па-

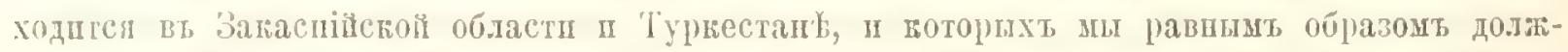

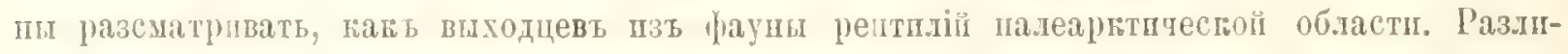
чіе между 中аупого Кавгаза и фаупоп напр. І'рецін не особепно велиғо и мало бросаетсл

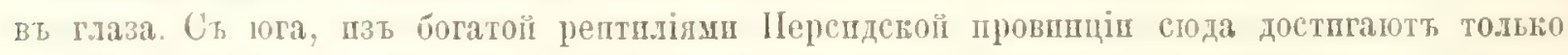

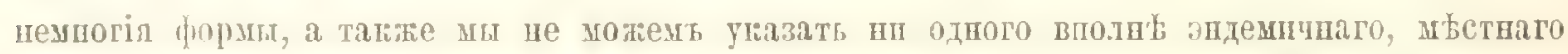

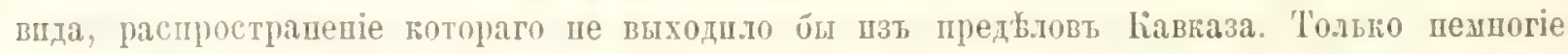

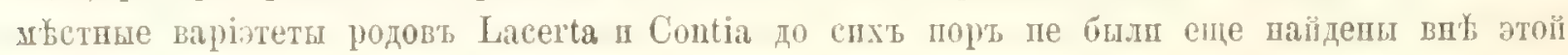
страны.

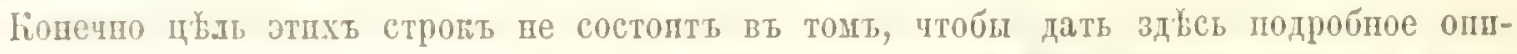

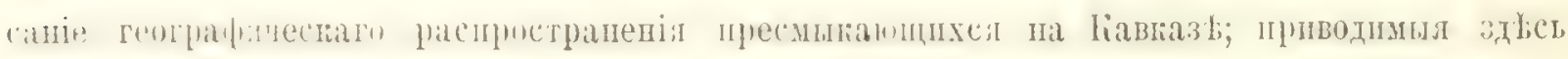

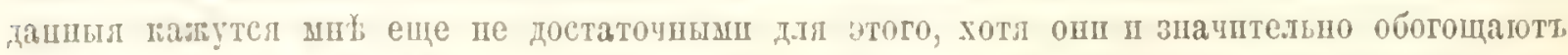

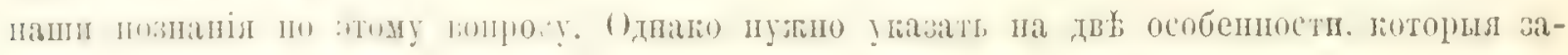

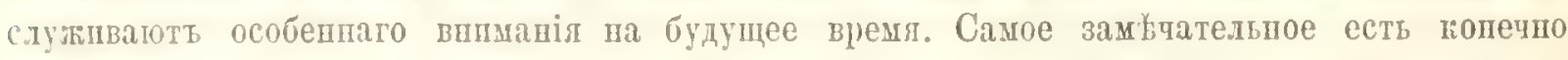

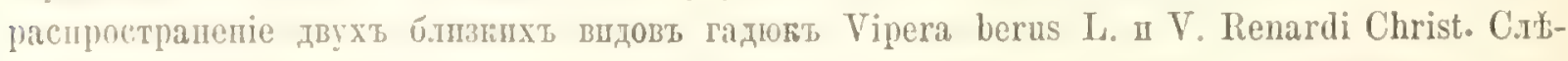

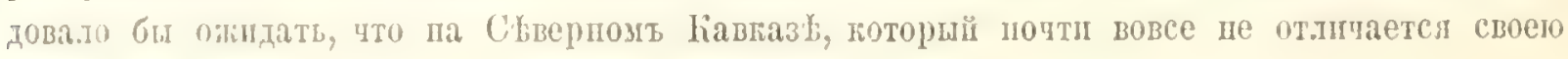




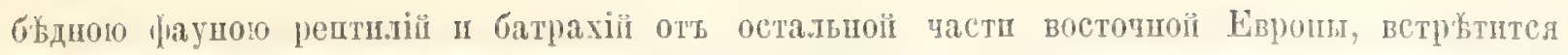

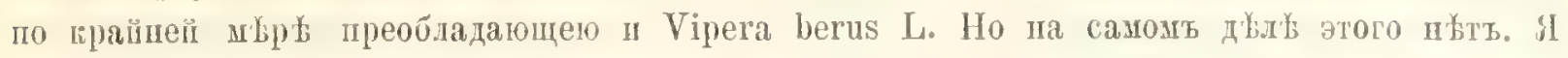

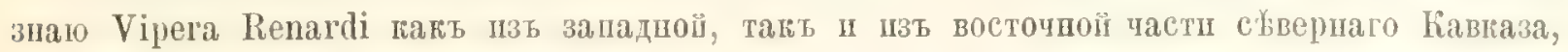

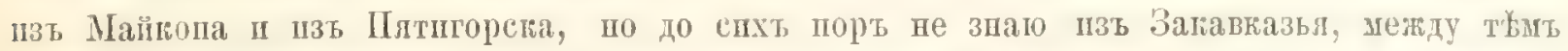

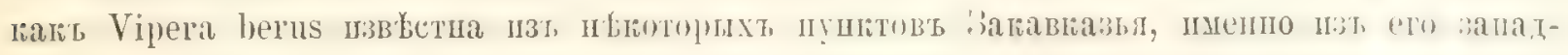

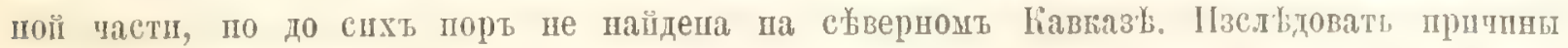

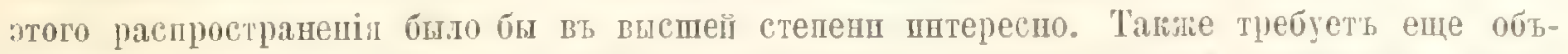

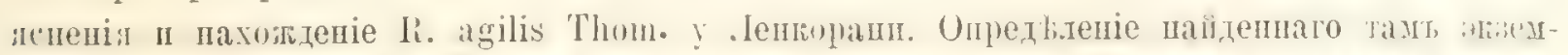

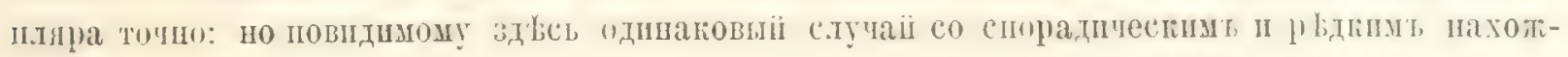

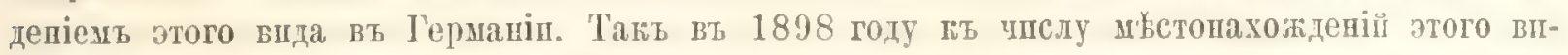

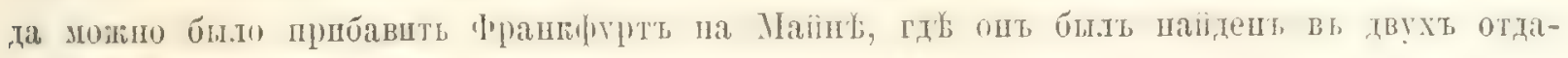

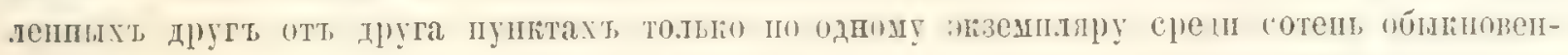

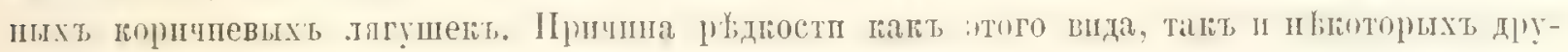
пихь вшдовь Lacerta п Rana молеть быть состопть въ трудности опредяленія этпхь вп-

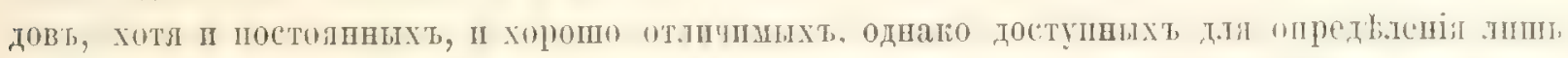

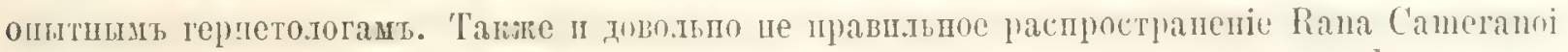
Blgr и R. macrocnemis Blgr. требуеть еще новыхъ наблюдені.

Профй Д-рь О. Бётmерй.

Der nachfolgenden Aufzählung der Reptilien und der Batrachier des liankasusgebietes möchten wir einige Worte zur Erklïrumg voransschicken. In ihren Grundzügen bereits seit längerer Zeit genügend bekannt, hat diese Fauna in neuerer Zeit doch anfiallender Weise keine eingehende, zusammenfassende liearbeitung mehr erfahren, und so dürfte die folgente Liste der im laukasischen Museum auferestellten Kriechthiere in wahren sinn des Wortes diese fühlbare Lücke ausfüllen. Da aber die Sammlung dieser 'Thiere anch in halukasischen Museum noch lieine vollständige ist, so dürte es am I'latz sein, die ührizen Furmen ans den genannten beiden Thierklassen, die bereits mit Nicherheit in den Kankasuslindern nachgewiesen worden sind, hier ebenfalls, wenigstens dem Namen nach, zu verzeichnen.

Zn den drei Schildkröten des Gebietes dürfte kaum ein Zuwachs in Aussicht stehen. Was die Eidechsen anlangt, so simd der Aufzählung hinzuzufugen ron Laccitilen:

Lacerta Brandti de Fil. von Rasano (Talysch), sowie von Scinciden:

Ablepharus bivittattus (Mén.) von Perimbal und Rasano (Talysch).

Von Schlangen sind ausserdem noch aus dem Gebiete dic drei Giftschlangen bekinnt:

Naja tripudians Merr. var. caeca Gml. aus Karabagh (Boulenger).

Vipera Renardi Christ. von Maikop und Pjatigorsk, Ciskaukasien (linettere) und Ancistrodon halys (Pall.) aus Talysch (Boettger).

Von Batrachiern sind weiter zu verzeichnen:

Rana agilis Thom. von Lenkoran (Boettger) und

Pelobates fuscas (Laur.) (Lenkoran, Belasuwar, Zander).

Im grossen Ganzen kam die Fanna aufgefasst werlen als eine eminent mediterane mit einer

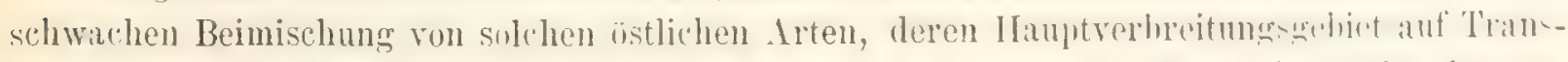
kaspien und Turkestan fällt, und die wir eleichfalls durchaus noch als dusliufer der pa- 


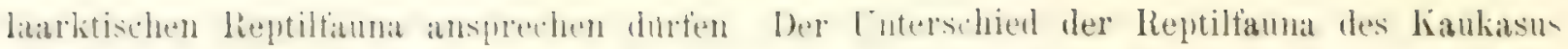

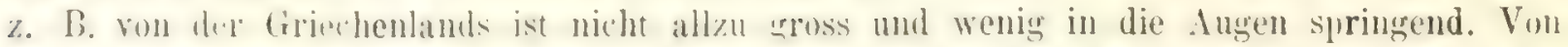

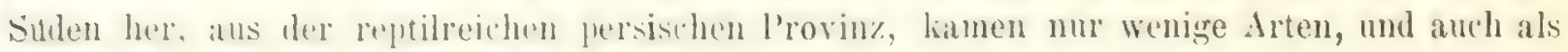

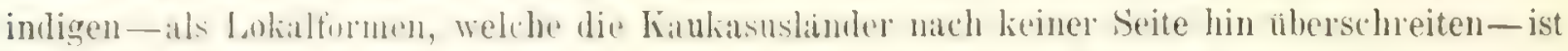

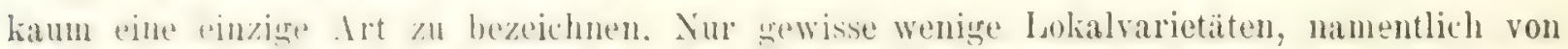
Latcerta und c'ontia haben lis jetat ausierhalb des diebietes noch nicht nathgewiesen werden können.

Es ist naturlich nitht der Zweck dieser Keilen, hier eine eingehende Darstellung der gengraphischen Verbreitung de' liriechthiere in den liaulasuslindern zu geben: dazu scheinen mir die vorliermden Inten, trotzdem, dass die gegebenen Fundorte eine recht ansehnli he liereicherung unstrer henntnisse bringen, noch nicht auszureichen. Iber anf ein Par Eigenthumlichkeiten, die fur künftighin der besonderen beachtung werth sind, durfte doch hinzuweisen sein.

Das Iuftallendste ist wohl die Verbreitung der beiden verwandten Viperiden. Vipera berus L. und V. Remardi Christ. Man sollte do h erwarten, in Ciskaukasien, das sich in seiner armlichen Reptil-u d liatrachierfatua von dem ubrigen istlichen Europa so gut wic nicht unterscheidet. Vipera berus mindestens vorwiegend anzutreffen. Aber das ist nicht der Fall. l'h kenne V. Renardi sowohl aus dem westlichen, wie aus dem üstlichen Theile Ciskaukasiens-von Maikou und ron Pjatigorsk, - aber lis jetzt nicht aus Transkaukasien, während mir $\mathrm{V}$. herus von einzelnen Fundpunkten Transkaukasiens-namentlich ans den Westen-, aber bis jetzt nilht aus Ciskitukasien bekamut geworden ist. Den Gründen dieser Verbreitung nachzugehen, wäre vom höchsten Interesse.

Auch dass Vorkommen von Rana agilis Thom. bei Lenkoran bedarf noch der Aufklarung. l)ie Bestimmungr des dort gefundenen Stülies ist sicher; aber es scheint hier ein ähnlicher lall rorzuliegen, wie hei den sporadichen und individuenarmen Iuftreton der nimlichen Art in Deutschland. So konute im Jahre 1898 den deutschen Fundorten anch Frankfurt a. M. zugefugt werlen, wo die Art an zwei weit von einander entfernten Punkten unter hunderten ron gesammelten braunen Fröschen je eimmal erkannt wurde. Der Grund der Seltenheit bei dieser wie bei mancher andern Irt von Rana und Lacerta liegt ubrigens vielleicht auch an der Schwierigkeit der Bestimmung dieser zwar recht kenntlichen und konstanten, aber nur fur den geubten Herpetologen fassbaren Art.

Auch die ziemlich regellose Verbreitung von Rana Cameranoi Blgr. und R. macrocnemis Blgr. fordert noch zu erneuter Beobachtung auf.

Prof. Dr. O. Boettger. 


\section{H E L O N I A.}

\section{FAM. TESTUDINIDAE.}

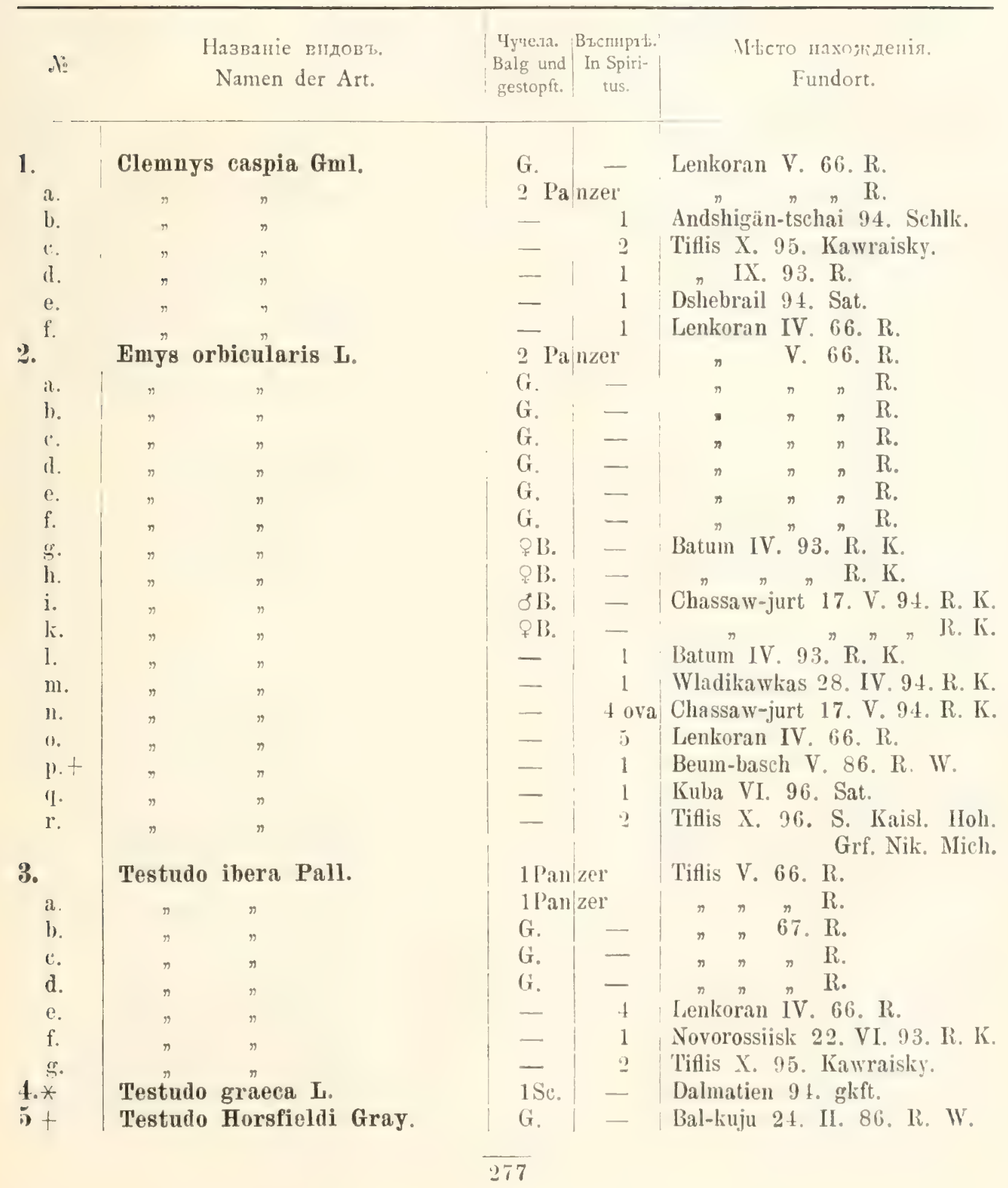


Hазваніс мидот\%

Namen der Art. \begin{tabular}{l|l} 
Iyncex. & 13 ncmupt. \\
Balg und & In Spin-
\end{tabular}

gestoptt. tus.

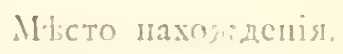

Fundort.

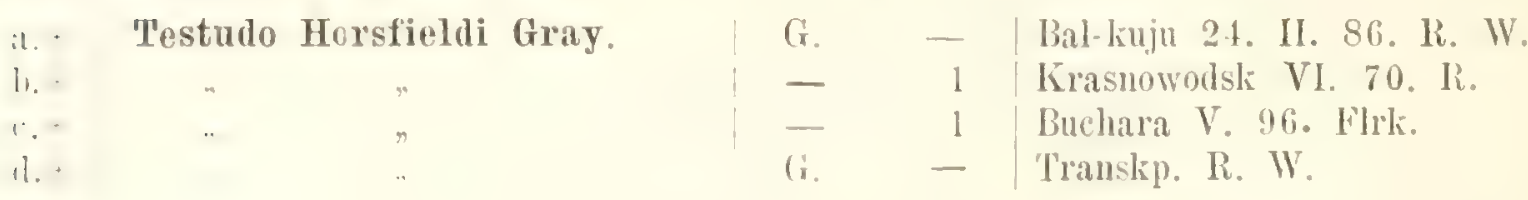

\section{LACERTILIA.}

FAM. GECKONIDAE.

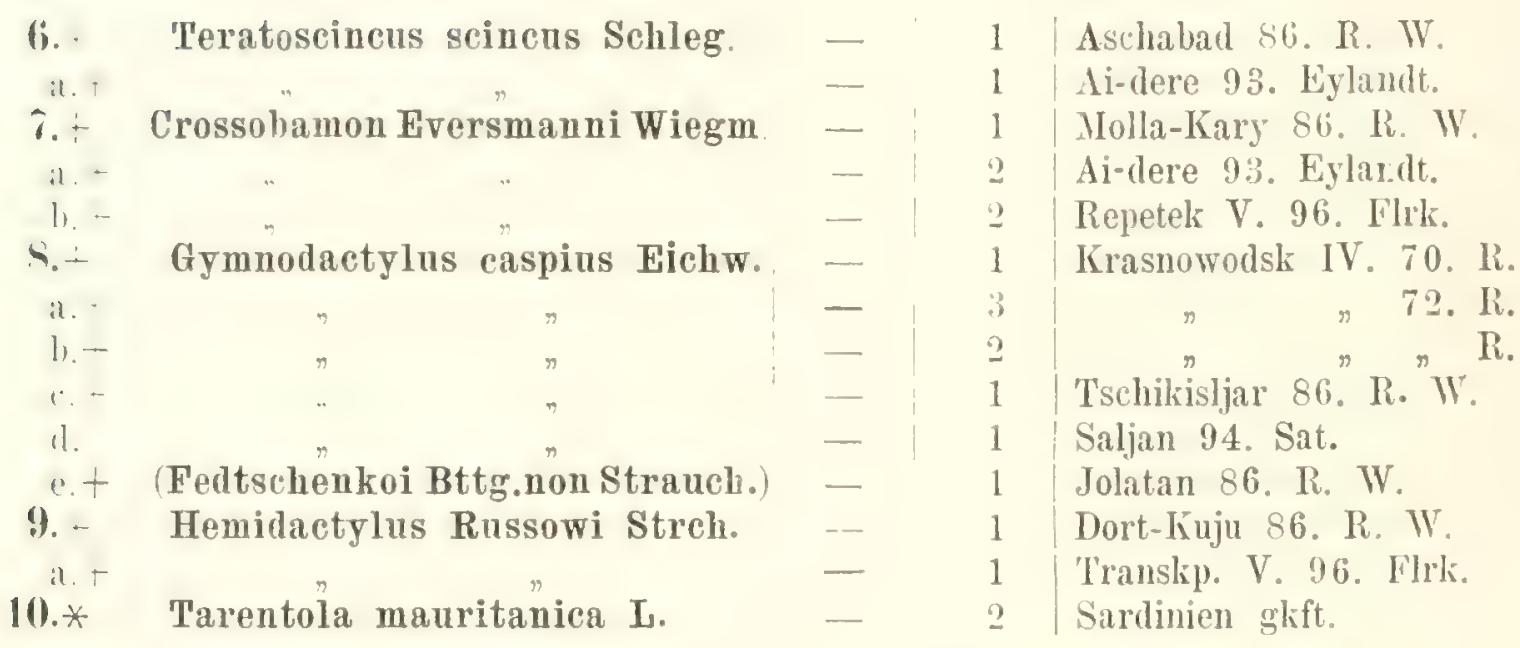

\section{FAM. A G A M D A E.}

11. - Agama sanguinolenta Pall.

12. Agama ruderata 0liv.

1:. Agama caucasica Eichw.

i.
b.
11.
i.
in.
b.

i.

\begin{tabular}{|c|c|c|}
\hline- & 3 & Balkuju-Kaaka 86. R. W. \\
\hline- & 7 & Krasnowodsk VI. 70. R. \\
\hline & G & VII. $70 . \mathrm{R}$. \\
\hline & 2 & Ost-Kaspi Ufer Akad. \\
\hline & 1 & 'Transkp. V. 96. Flik. \\
\hline & 2 & Araxes Dshebrail 94. Sat. \\
\hline C. & -- & Tiflis 3. VI. 85. R. \\
\hline & - & $\Rightarrow \quad n \quad \pi R$. \\
\hline & 3 & Araxes, istasur 94. Sat. \\
\hline & 7 & Tiflis III. 66. R. \\
\hline & 2 jur. & Borshom VII. 88. R. \\
\hline & 5 & Ai-dere 93. Eylandt. \\
\hline & 3 & Suant. VI. 70. R. \\
\hline & $\because ;$ & 'Titlis, Lisja gora 93. K. \\
\hline & 2 & $\begin{array}{l}\text { Geoli-tepe-Germab, Keltetschi- } \\
\text { nar 86. R. W. }\end{array}$ \\
\hline & 1 .juy & Borshom 75 . Sievers. \\
\hline
\end{tabular}




\begin{tabular}{|c|c|c|c|c|c|}
\hline is & & $\begin{array}{l}\text { Назвапіе вндовт. } \\
\text { Namen der Art. }\end{array}$ & $\begin{array}{l}\text { Yyпела. } \\
\text { Balg und } \\
\text { gestopft. }\end{array}$ & $\left|\begin{array}{c}\text { Bzcnuptt. } \\
\text { In Spiri- } \\
\text { tus. }\end{array}\right|$ & $\begin{array}{c}\text { Mьсто нахожденія. } \\
\text { Fundort. }\end{array}$ \\
\hline$k$. & Agama & caucasica Eichw. & - & 2 juv. & Tiflis $78 . R$. \\
\hline 1. & " & 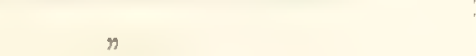 & - & 4 juv. & Marienfeld 9.). R. \\
\hline m. & n & $n$ & - & 'juv. & Girüsi-Djg. 94. Sat. \\
\hline 11. & $n$ & $"$ & - & 1 juv. & Awtschaly 19. X. 86. W. \\
\hline 0. & $n$ & 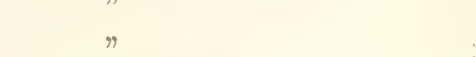 & - & 1 & Barsawu 97. Sat. \\
\hline 1.t & $"$ & $n$ & G. & - & Germab R. W. \\
\hline q. & $n$ & & - & $1 \mathrm{juv}$. & Borshom 1. V. 98. R K. \\
\hline 14. & Phrynoce & cephalus helioscopusPa1l & - & + & Sardarabad VI. 75. R. \\
\hline a. & & " & $--\cdot$ & $\ddot{-1}$ & Titlis IX. 86. R. \\
\hline b. & & " & - & 1 & Nachitschewan 93. Sat. \\
\hline c. $t$ & & " & - & 2 & Durun 86. R. W. \\
\hline d. + & & $n$ & - & 5 & Transkp. 83. Petruschewsky. \\
\hline e.t & & " & - & 5 & Krasnowodsk VI. 70. R. \\
\hline f. & & $n$ & - & 7 & ? ? \\
\hline g.t & & $"$ & - & 3 & Transkp. V. 96. Flrk. \\
\hline h. + & & $"$ & - & 1 & $\begin{array}{r}\text { 97. Kalischewsky und } \\
\text { Birschert. }\end{array}$ \\
\hline i. & & & - & 1 & Kjalwjas X. 98. Sat. \\
\hline 15. + & Phrynor & ceplualus Raddei Bttg. & - & 2 & ['erewalnaja $\$ 6 . \mathrm{R} . \mathrm{W}$. \\
\hline 16. & Phryno & cephalus caudivolvus & - & 2 & Transkp. V. 96. Flrk. \\
\hline & & Pall. & - & 7 & $\begin{array}{r}25 \text { Werst S. von Atschikulak } \\
\text { 8. V. 94. R. K. }\end{array}$ \\
\hline 17.t & Phrynoc & $\begin{array}{c}\text { cephalus interscapularis } \\
\text { Licht. }\end{array}$ & - & 4 & Molla-Kary 86. R. W. \\
\hline a.t & & $n$ & - & 1 & Transkp. 83. Petruschewsky. \\
\hline b.t & & $" 1, \quad n$ & - & 4 & V. 96. Flrk. \\
\hline 1S. + & Phrynoc & cephalus mystaceus Pall. & - & $\because ;$ & $\begin{array}{r}\text { Michailowskaja - Molla - Lar! } \\
\text { 86. R. W. }\end{array}$ \\
\hline a.t & & $n$ & - & 1 & Tscheleken Akad. \\
\hline b. + & & $"$ & - & 2 & Krasnowodsk $70 . \mathrm{R}$. \\
\hline c.t & & $n$ & - & 1 & Ost-Kaspi Ufer Akad. \\
\hline d.t & & $n$ & G. & - & Tschikisljar 86. R. W. \\
\hline
\end{tabular}

\section{F A $M . A N G U I D A E$}
19.
Ophisaurus apus Pall.
a.
b. *
c.
d.
2 Lenkoran IV. 66. R.
Geogr. Ges. 65.
'Tauria Akad.
Geok-tepe X. 92. Schlk.
" " "Germab 86. R. W.
Deutschland XII. 69. glift.
Geogr. Ges, 'Iift.
Batum IV. 93. R. K.
Schara-Argunj 27. VII. 94.R.K.
Bum Schlucht VI. 92. Schlk. 


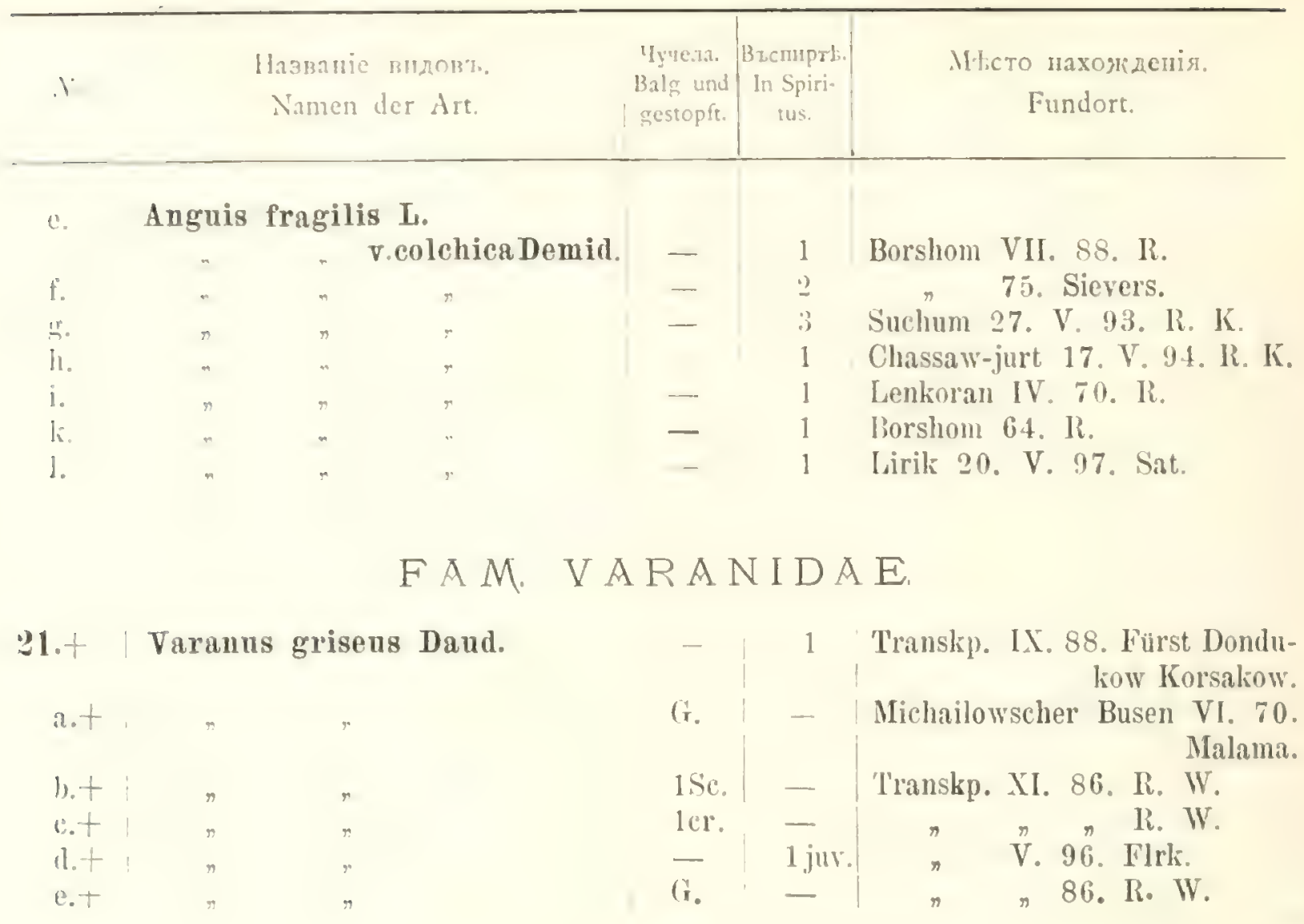

\section{FAM. AMPHISBAENIDAE}

Blanus Strauchii Bedr.

1 Asia minor gkft.

\section{FAM LACERTIDAE.}

23.* Tacerta viridis Laur.

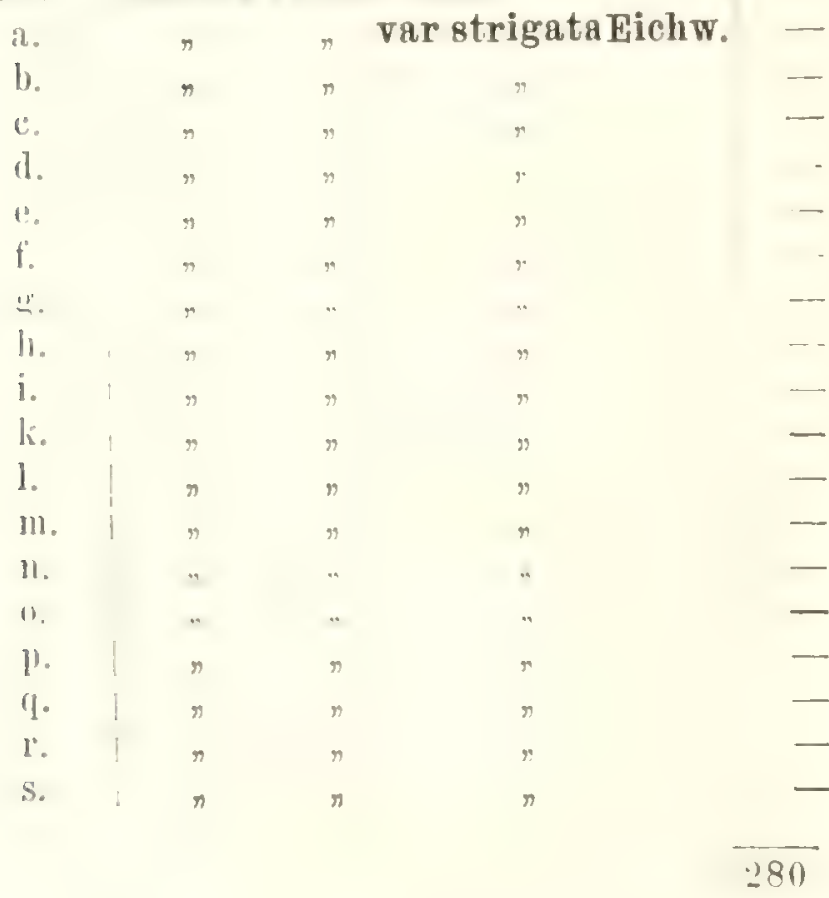

Tauria Akad.

Wladikawkas 27. IV. 94. R. K. Migri 94. Sat. Begmanly (Kr. Dshebrail)94. Sat. Stat. Kaspi IV. 90. P. L. Müller. Bum VI. 92. Schlk.

Atschikulak 7. V. 94. R. K.

Lenkoran IV. 66. R.

Chassaw-jurt 17, V. 94. K. K.

$n \pi \pi$ n $\pi$. K. Karabagh Steppe 9.4. Sat.

Saljan 94. Sat.

Geogr. Ges. 66 .

Tiflis R.

n 94. Sat.

Muschtaid IV. 94. Sat.

Ewdokimowsk 13. VII. 9 t. R. K.

'Iiflis 93. Sat.

Kr. Elisabethpol 94. Sat. 


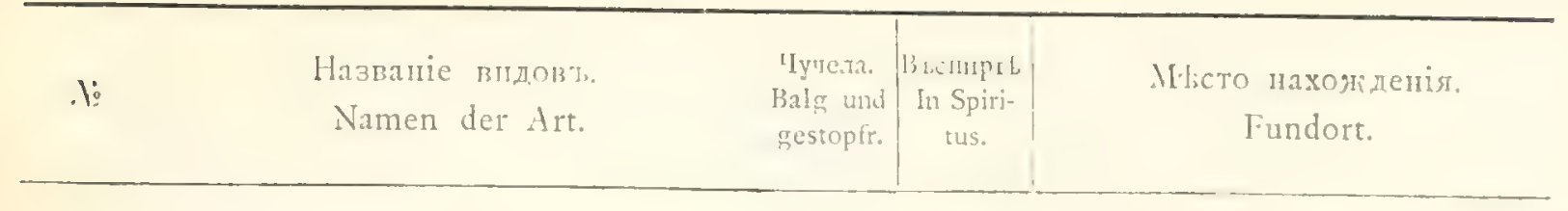

t Lacerta viridis Lanr.

\begin{tabular}{|c|c|c|c|c|c|}
\hline & $n$ & „Var strigataEichw. & - & $\vdots$ & Lorshom 96. R. \\
\hline $\mathrm{ul}$. & " & $"$ & -- & $\overline{1}$ & Kasikoporan 7. VII. 96. K. \\
\hline v. & $"$ & $"$ & - & $\rightarrow$ & Borshom 97. R. \\
\hline w. & 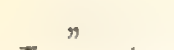 & $n$ & $\ldots$ & 2 & Lenkoran V. 97. Sat \\
\hline $24 . *$ & Lacerta & agilis $\mathrm{I}$. & $1 \dot{r i c}$. & - & Deutschland 69. glift. \\
\hline a. & $"$ & "var.exigua Eichw. & - - & 1 & Tiflis $R$. \\
\hline b. & $n$ & $"$ & - & 1 & "65. Geogr. Ges. \\
\hline c. & , & $\%$ & - & 2 & "II. 86. R. \\
\hline d. & , & ." & - & 2 & Tovotscherkask 93. Sat. \\
\hline e. & , & ? & - & 2 & Nororossiisk VII. 93. R. K. \\
\hline f. & $"$ & . & - & 1 & Poti IV. 93. R. K. \\
\hline g. & , & $"$ & & 1 & Batum IV. 93. R. K. \\
\hline h. & $n$ & & - & 1 & Elisabethpulskaja VII. 93. R. K. \\
\hline 25. * & Lacerta & vivipara Jacq. & -- & 1 & Mk. Brandenburg glift. \\
\hline a. $*$ & r & & - & 6 & St.-Petersburg 92. K. \\
\hline $\left.25^{1}\right)$ & Lacerta & praticola Ev. & - & 1 & Swanetien VII. 88. R. \\
\hline a. & $n$ & $\eta$ & -- & 2 & Muri-Lentechi-Pari VII. 64. R. \\
\hline b. & T $"$ & $n$ & - & (i & Bakuriani VII. 98. R. \\
\hline $96 . *$ & Lacerta & muralis Laur. & - & 2 & Sardinien glift. \\
\hline a. $*$ & $"$ & " & - & 1 & Tirol gkft. \\
\hline b. & $"$ & $\Rightarrow$ & - & $t$ & Tana Thal VII. 95. K. \\
\hline c. & $n$ & " & & 3 & Muschtail IV. 94. Sat. \\
\hline d. & $"$ & $"$ & -- & 1 & Kjalwjas X. 98. Sat. \\
\hline e. & , & 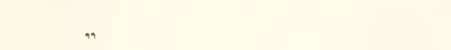 & - & 2 & Jewdokimowsk 11. VII.94.R. K. \\
\hline f. & $n$ & $"$ & - & 1 & Schatojewsk 10 . VII. 4 . R. K. \\
\hline g. & $\eta$ & " & - & 1 & Schara-Argunj 21. VII.94.R.K. \\
\hline l.. & $n$ & $"$ & & 2 & Lawas lit 11. VI. 94. R K. \\
\hline i. & $"$ & $"$ & - & + & Titlis X. y2. R. \\
\hline k. & 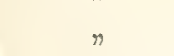 & $"$ & - & 1 & Muri-Lentechi-l'ari VII. 64. R. \\
\hline 1. & $"$ & $"$ & - & 2 & Lars 29. IV. 9.. R. K. \\
\hline$m$. & $"$ & " & - & 2 & Lomis-Mta $7000^{\prime}$ VII. 95. K. \\
\hline 11. & $"$ & $"$ & - & 11 & Daghestan VII. 85. R. \\
\hline 11. & $"$ & $"$ & - & 3 & Schachhans VI. 94. Sat. \\
\hline l. &. & . & - & 1 & Tiflis 1. IV. 96. K. \\
\hline 1. * & $"$ & $n$ & & 1 & Nkial. \\
\hline 1. & . & $"$ & - & 2 & 'Titlis Iisja-gora 93. K. \\
\hline$s$ & $n$ & .. & - & 1 & Suchum 27. V. 93. R. K. \\
\hline t. &. & .. & $\ldots$ & 1 & Pseaschcha $7000^{\prime}$ VI. 93. R. K. \\
\hline 11. & , & .. & $\ldots$ & 1 & Artwin V. 9:. R. K. \\
\hline v. & $n$ & . & - & 1 & Lirik V. 97. Sat. \\
\hline w & $"$ & , & & 5 ova & Borshom 97. Jithner. \\
\hline$x$. & $"$ & var. depressa Camor. & -. & 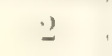 & Baku IV. 70. R. \\
\hline y. & $"$ & . & & 1 & Nakalakewi V. 93. R. K. \\
\hline$\%$ & $"$ & $"$ & & $\ddot{\prime}$ & Schachhaus 7500' 94. Sat. \\
\hline ila. & $"$ & . & & i & Migri (ierisi IX. 93. Sat. \\
\hline bh. & $"$ & . & & 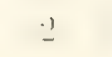 & (rengl. Ges. 'liflis 65. \\
\hline$\because *$ & 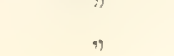 & " & & 1 & IImi-l,entechi-Pari VII. 6 t. R. \\
\hline
\end{tabular}




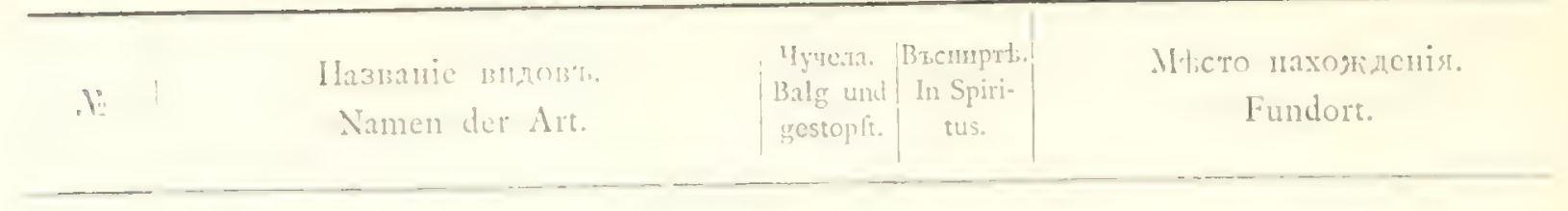

al. Lacerta muralis var. depres-

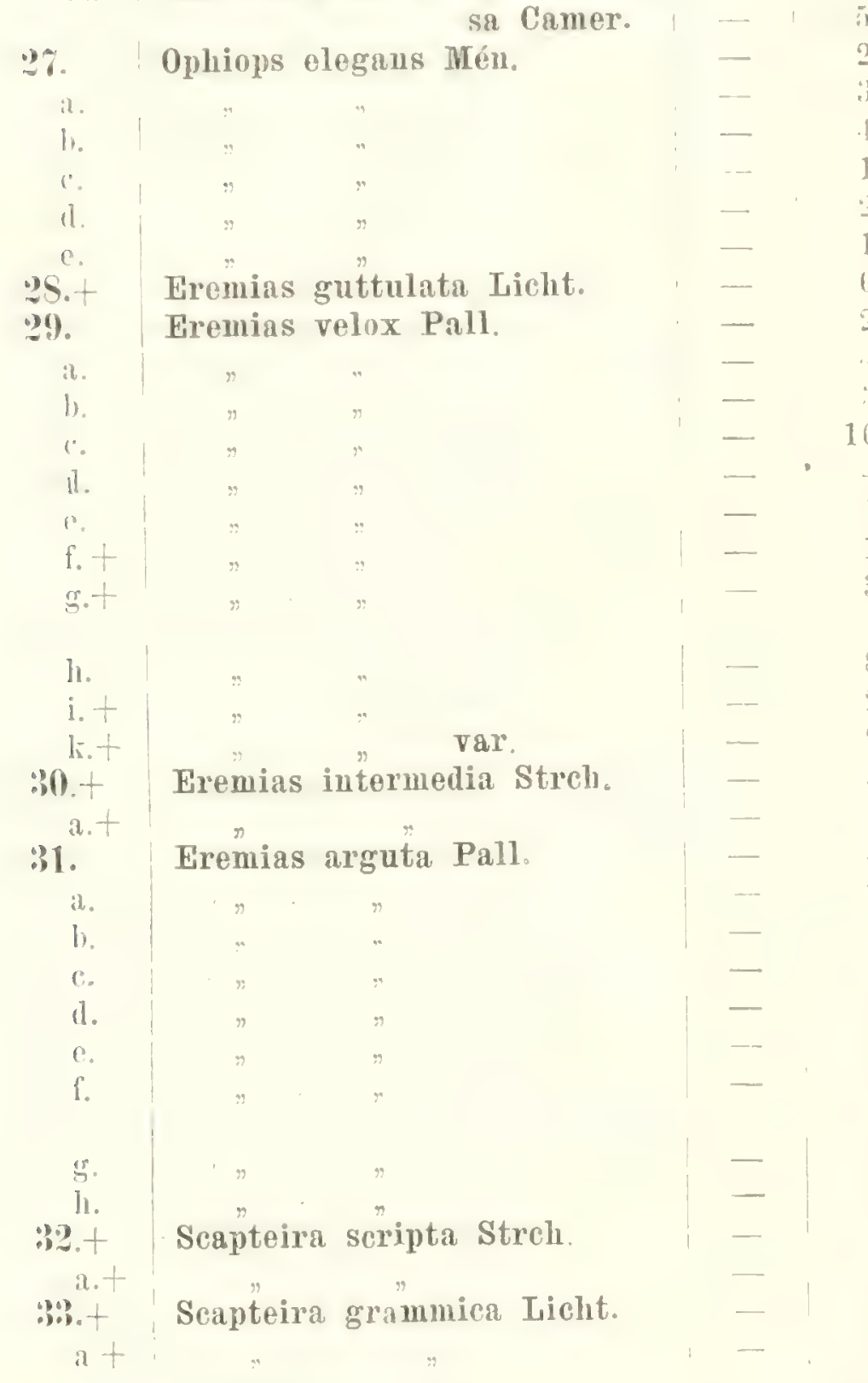

'I'schoroch IV. 9:. R. K.

Ijaku IV. T0. R.

'Tiflis li.

Araxesthal 9.1. Sat.

Baku Akad.

Kulp 3. VII. 96. K.

Genk-tepe IV. 97. K.

'Iranskp. 72. Sievers.

Bakill IV. 66. R.

Astasur 93. Sat.

Tithis IX. 86. R.

Baku IV. 70. R.

? Tillis.

Bos-dag Kr. Aresch 30.III.94.K.

Ai dere 'T'ranslip. 93. Eylant.

Durun, Aschabad, 'I'schikisljar'

86. R. W.

Kulp 3. VII. 96. K.

Transkp. V. 96. Flrk.

, $\Rightarrow$ Flrk.

Bal-kuju 86. K. W.

'Iranskin.72. Sievel's.

Baku IV. 70. R.

Temirgoje 5. VI. 94. I. K.

Saljan $9+$ Sat.

Baku, Akad.

Lawaschi 11. VI. 94. R. K. Atschikulak 7. V. 91. R. K.

Sand 25 Werst sül. v. Atschikulak 8, V. 94. R. K.

Kreis Aresch 94. Schll.

Kjalwjas X.98. Sat.

Bal-kuju 86. R. W.

Transkj, V. 96. Flrk.

Molla-kary-Jichailowa86.R, W.

Repetek V. 96. Flrk.

\section{FAM. SCINCIDAE}

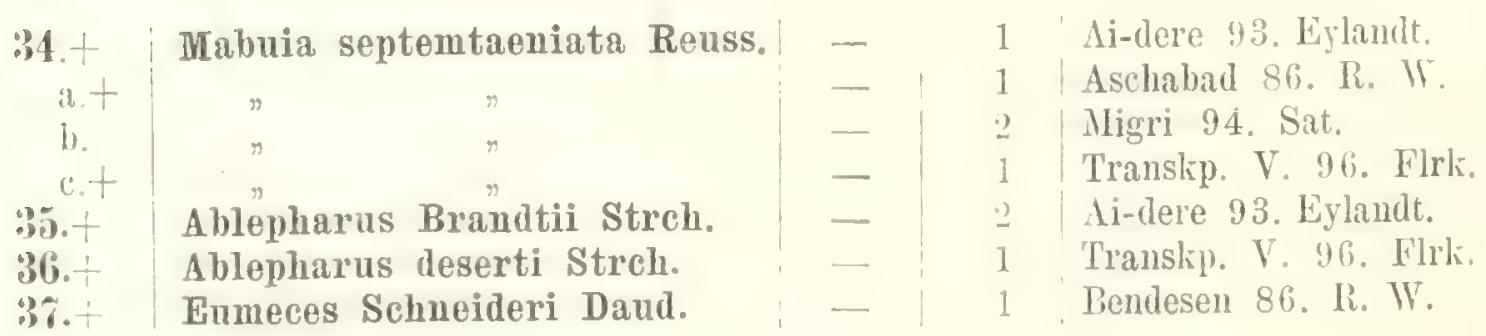




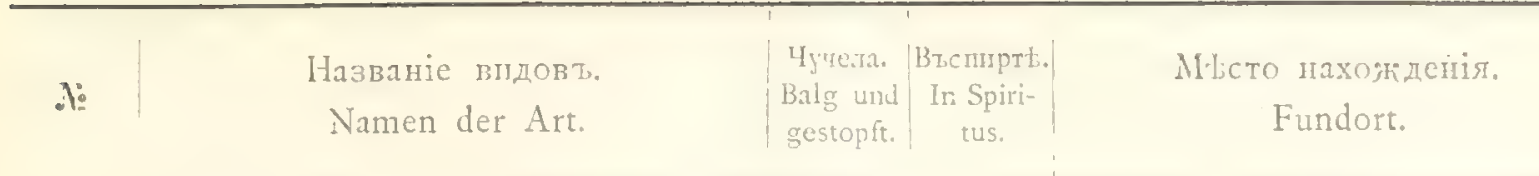

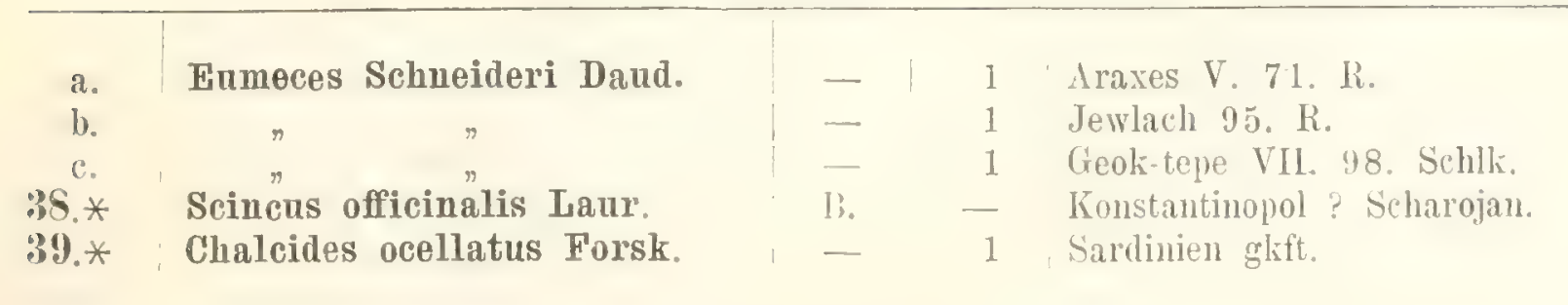

\section{FAM. CHAMAELEONIDAE.}

39. $\left.{ }^{1}\right) *$ Chamaeleon valgaris Gray. $\quad-\quad 1$ | Algier 97. Sievers.

\section{O P H I I A.}

\section{FAM. TYPHLOPIDAE.}

\begin{tabular}{|c|c|c|c|c|c|}
\hline 40. & Typhlops & vermicularis Merr. & - & 2 & Geogl. Ges. \\
\hline a. & $"$ & $n$ & - & 1 & Geok-tepe X. 92. Schllk. \\
\hline b.t & " & " & - & 1 & $\operatorname{lagyr} 86$. R. W. \\
\hline c.t & " & $"$ & - & 1 & Ai-dere 93. Eylandt. \\
\hline d. & " & $"$ & - & 1 & Lriwan 93. Sat. \\
\hline e. & $n$ & $n$ & - & & Geok-tepe 30. III. 94. K. \\
\hline f. & $"$ & $"$ & - & 2 & Tiflis, Lisja-gora 93. li. \\
\hline ↔. & $n$ & $\pi$ & - & 1 & Geoli-tepe 1. IV, 96. K. \\
\hline
\end{tabular}

\section{F A M. BOIDAE}

\begin{tabular}{|c|c|c|c|c|c|}
\hline 41. & Eryx jaculus & L. & - & 1 & Geok-tepe X. 92. Schlli \\
\hline a. & $"$ & & $\cdots$ & 1 & Kr. Dshebrail 94. Sat. \\
\hline b. & " & & - & 1 & Kaukas. Akad. \\
\hline c. $t$ & " & var. miliaris Pall. & & 1 & Molla-kary 86. R. W. \\
\hline d. + & " & $n$ & - & 2 & Transkip. Petruschewsky. \\
\hline e.* & " & $"$ & - & 1 & Persien, Akad. \\
\hline f.t & " & " & & & Transkp. V. 96. Filrk. \\
\hline 2.t & Eryx elegans & Gray. & - & & Ai-dere 93. Eylandt. \\
\hline
\end{tabular}

\section{FAM. COLUBRIDAE}

43. Tropidonotus natrix $\mathrm{I}$.

a.
b.
c.
Merro
A $M . B$
ris Pall.
M. COL
2 Geogr. Ges. 'Tiflis 65.

Borshom R.

Suchum 27. Y. 93. R. K.

Tschoroch IV, 93. R. K.

Dshewat 9\%. Sat. 


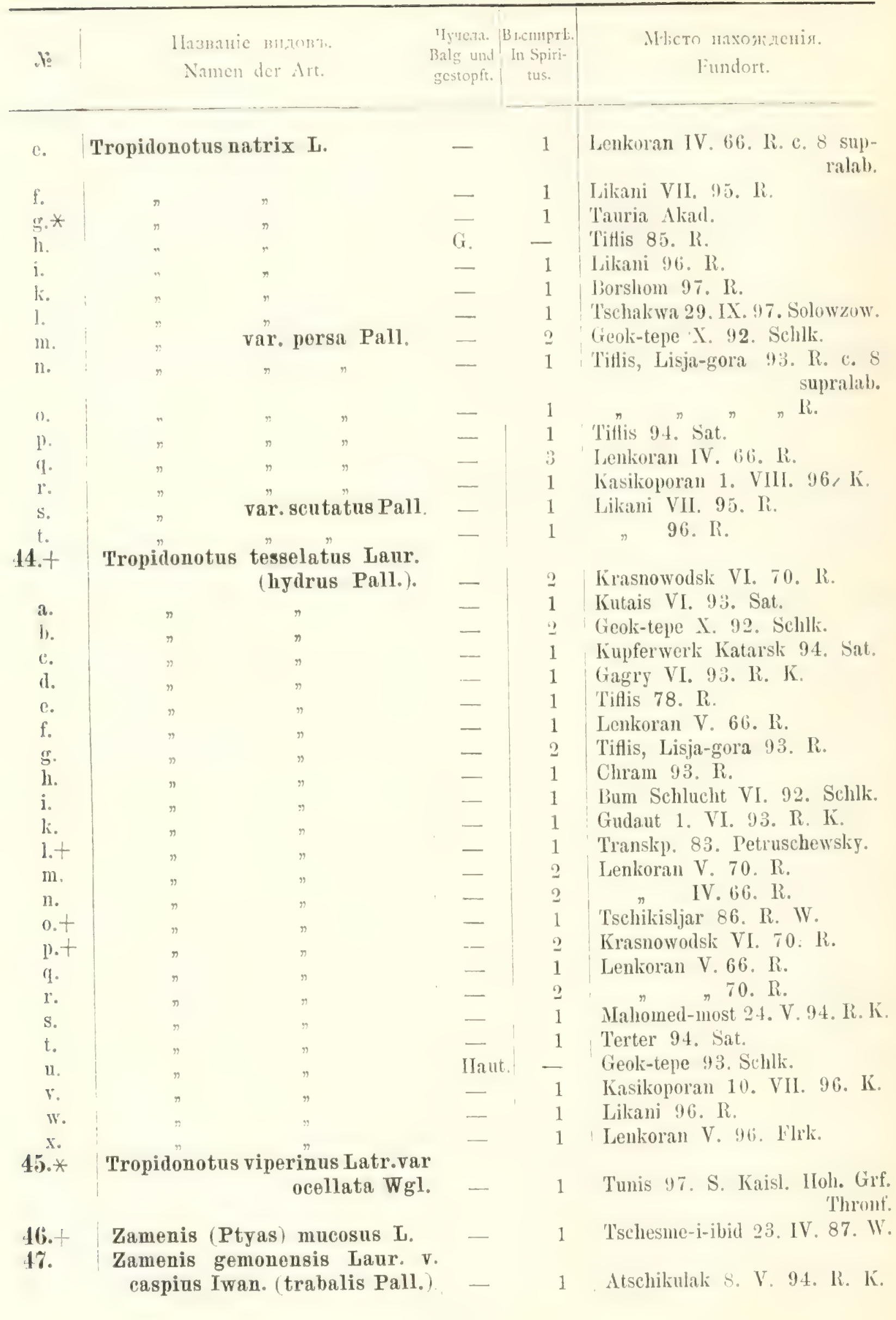




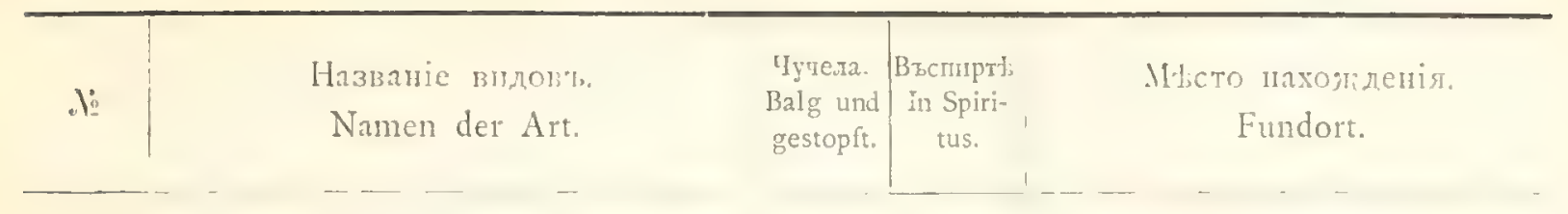

a. Zamenis gemonensis Laur. $v$. caspius lwan. (trabalis Pall.).

b.

c.

48. Zamenis Dahli Fitz.

a.

b.

c.

d.

e.

f. +

a.t
b.t
c. +

50.

a.

b.

c.

d.

e.

f. +

g.t

51. +

Zamenis Ravergieri Mén.

a.t
b.t
$c+$
$52 .+$
53.

Zamenis diadema Schleg. var. Schirazana Jan.

Lytorhynchus Ridgewayi Blgr. Coluber Hohenackeri Strch.

a.

b.

54. Coluber (Elaphis) Dione Pall.

\begin{tabular}{r|ccc} 
a. & $\#$ & $n$ & $"$ \\
b. & $n$ & $n$ & $n$ \\
\%5 & Coluber quatuorlineatus Lac.
\end{tabular} (Elaphis sauromates Pall).

56. Coluber Iongissimus Laur. (Aesculapi Lac.).
Geok-tepe XII. 92. Schll. $n \Rightarrow$ X. 92. Sclill.

Geogr. Ges. 65.

Borshom "X. 95 . R.

Karajas 85. R.

Abastuman VII. 65. li.

Achty Daghestan VI. 85. R.

Olty 95 . Sat.

Borshom 96. R.

Ai-dere 93. Eylandt.

Krasnowodsk VI. 70, R.

Transkp. 86. R. W.

, 86. R. W.

Petruschewsky.

Tiflis V. 82. R.

Gunib VII. 85. R.

| Tiflis IV.94. v.S. K. H.Grf.N. M.

Olty 95. Sat.

Kulp 6. VIII. 96. Lakatosch.

Gouv, Eriwan von N. N.

Chodsha-kala 86. R. W.

Ai-dere 93. Eylandt.

Krasnowodsk 86. R. W.

Transkp. 83. Petruschewsky. 86. R. W.

V. 96. Eylandt.

Durun 86. R. W.

Likani VII. 95. R. 96. $\mathrm{R}$.

Kasikoporan 12. VII. 96.K. 8. VII. 96. K.

Lenkoran IV. 66. R.

Kr. Aresch 94. Schllk.

Katschalajewka 24. V.94.R. K.

Lenkoran V. 96. Flik.

Mugan V. 70. R.

Elisabethpol Aliad.

"ova Geok-tepe 18. VII. 93. Schlli

7 uva Kupferwerk Katarsk 91. Sat.

1 \% $\%$ Sat.

Kasikoporan 12. VII. 96. K.

Suchum V. 93. R. K.

Batum VI. 93. R. K. 


\begin{tabular}{|c|c|c|c|c|}
\hline .1 & $\begin{array}{l}\text { Llazmanic втдпв\%. } \\
\text { Namen der Art. }\end{array}$ & $\mid \begin{array}{c}\text { Tryerta. } \\
\text { B.ilg und } \\
\text { gestopft. }\end{array}$ & $\left|\begin{array}{c}\text { Br.couspr 1.. } \\
\text { In Spiri- } \\
\text { tus. }\end{array}\right|$ & $\begin{array}{l}\text { Meto maxomacuist. } \\
\text { Fundort. }\end{array}$ \\
\hline 1. & $\begin{array}{r}\text { Colaber longissimus Laur. (Aes- } \\
\text { culapi Lac.). }\end{array}$ & - & 1 & Batum VI. 93. R. K. \\
\hline$\therefore$ & $n$ & 一 & 1 & I Lenkoran V. 70. R. \\
\hline$\therefore$. & Corouella austriaca Laur. & - & 3 & 'Likani VII. 95. R. \\
\hline i. & & - & $\because$ & Lenkoran IV. 66. R. \\
\hline i. & . & - & 1 & Batum V. 93. R. K. \\
\hline$\therefore$ &. & - & 1 & Suania $3000^{\prime}$ VII $66 . \mathrm{R}$. \\
\hline 11. &. & - & 1 & Bum Schlucht VI. 92. Schlk. \\
\hline$\because$ &. & - & 1 & Suchum V. 98. R. K. \\
\hline$i$ &. & - & 1 & Schara Argunj 21. VII 94. R.K. \\
\hline in. & $"$ & - & 1 & Borshom 93. R. \\
\hline lı. &. & - & 1 & Atene Thal VII. 95. K. \\
\hline i. & $\because$ & - & 1 & Pizunda 3. VI. 93. R. K. \\
\hline$k \div$ & $\eta$ & $1 \mathrm{Sc}$. & 一 & Deutschland XII. 69. glift. \\
\hline it. & Contia (Ablabos) collaris Mén. & - & 6 & Geok-tepe XI. 95. Schlk. \\
\hline$\because$ & & - & 1 & $" \quad " \quad 1 . \mathrm{IV} .96 . \mathrm{K}$ \\
\hline 1). & $"$ & - & 1 & ? Gouv. Eriwan 97, Y. N. N. \\
\hline 59 & Contia modesta Mart. & - & 1 & Tiflis VIII 95. K. \\
\hline ¿. & $"$ & - & 1 & Geogr. Ges. \\
\hline 1. & $n$ & - & 1 & Tiflis 93. K. \\
\hline$\therefore$ & $"$ & - & 2 & Gunib VII. 85. Ii. \\
\hline (ii). $t$ & Contia (Cyclophis) fasciata Jan. & 一 & 1 & Kaaka 86. R. W. \\
\hline $611^{i 1 .}$ & Contia (Pseudocyclophis) Wal- & - & 1 & Translip. V. 96. Flrk. \\
\hline (i). & $\begin{array}{l}\text { teri Bttg. } \\
\text { 'l'arbophis iberus Eichw. (vi- }\end{array}$ & - & 1 & Neu Serachs 87. R. W. \\
\hline & vax part.). & - & 1 & Akad. \\
\hline$a$ & $"$ & - & 1 & Kr. Aresch 94. Schlli. \\
\hline h. & 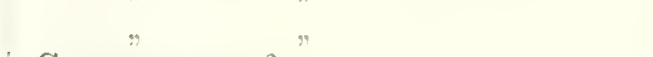 & - & 1 & Karajas $8 \check{0}$. R. \\
\hline $6: \%$ & Genus? spec? & - & 1 & Transkp. V. 96. Flrk. \\
\hline & $\begin{array}{l}\text { Coelopeltis monspessulana Helm. } \\
\text { (lacertina Wgl.). }\end{array}$ & - & 1 & Kupferwerk Katarsk 94. Sat. \\
\hline il. & $"$ & - & 1 & Kreis Aresch 94. Schllk. \\
\hline b. & " & - & 1 & Kr. Elisabethpol Sat. \\
\hline (c.) & $n \quad n$ & - & 1 & Geoli-tepe 1. V. 96. K. \\
\hline (i.). - & TaplirometoponlineolatumBrndt. & - & 1 & Krasnowodsk VI. 70. R. \\
\hline a. $!$ & $\eta$ & - & 1 & Murgab 87. W. \\
\hline (iti. & Naja tripudians Merr. var. cae. & - & $\because$ & Transkp. Petruschewsky. \\
\hline & ca Gml. (oxiana Eichw.). & - & 1 & Tschat 86. R. W. \\
\hline $\begin{array}{l}\text { it. } \\
\text { l. }\end{array}$ & $"$ : Steine 1 Gift»ahn. & - & 1 juv. & $\begin{array}{l}\text { Transkp. V. 96. Flrk. } \\
\text { Colombo R. }\end{array}$ \\
\hline
\end{tabular}

\section{FAM. VIPERIDAE}

(i). Vipera berus $\mathrm{I}$.

$3 \quad$ Suania $8000^{\circ}$ VII. 64. R. 


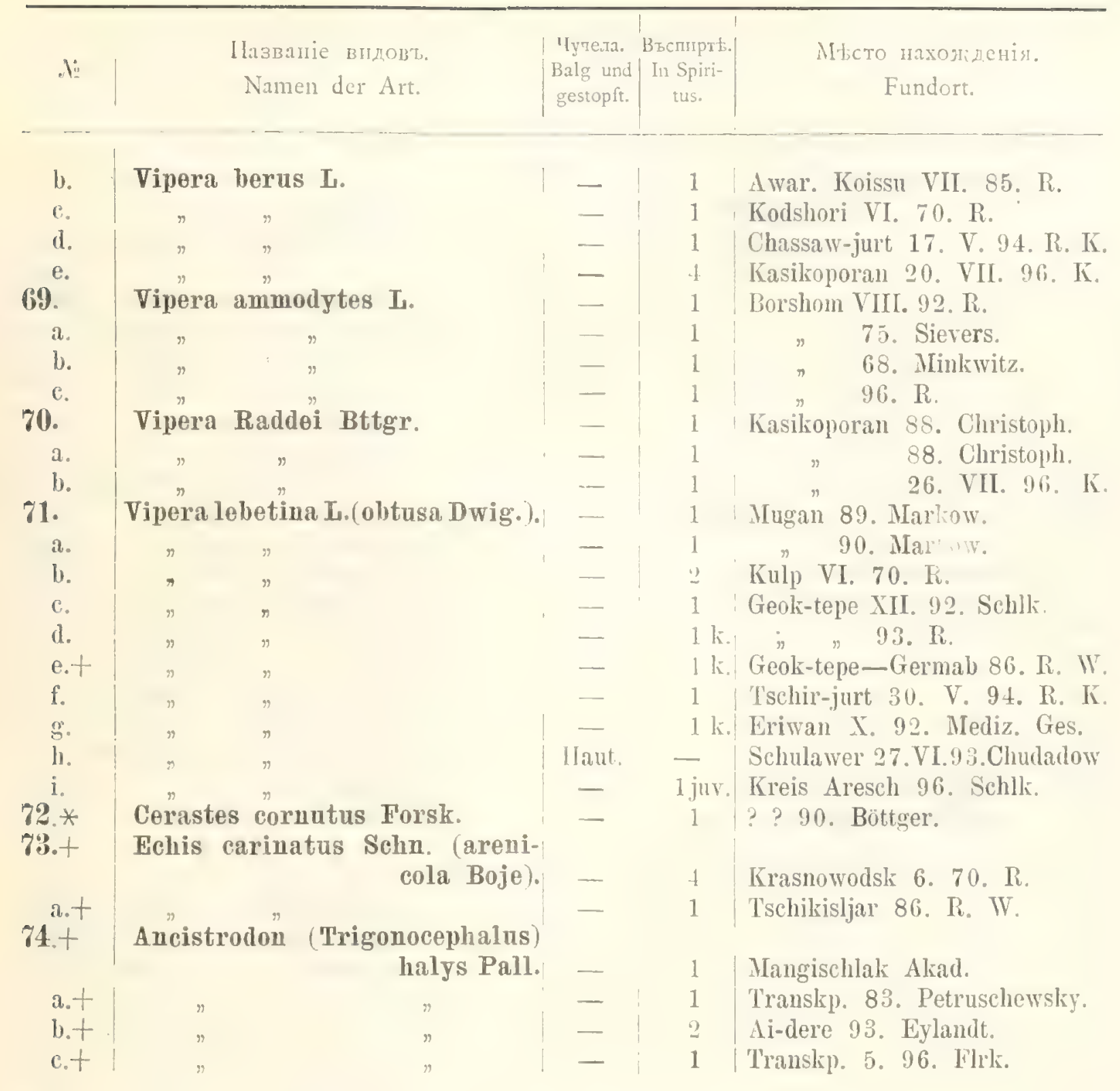

\section{BATRACHIA ECAUDATA.}

FAM. RANIDAE.

\begin{tabular}{|c|c|c|c|c|c|c|}
\hline ). $*$ & Rana & esculen & nta I. & - & 1 & Mik. Brandenburg 94. glsft. \\
\hline a. $*$ & $n$ & $"$ & & I Sc. & - & Gelmania 69. gkft. \\
\hline b. $*$ & $n$ & , & & - & 1 & Mk. Brandenburg 94. glift. \\
\hline c.t & $n$ & $n \mathrm{v}$ & var. ridibuuda Pall. & - & (i) & Aschabad, Beumbasch 86. R. IV. \\
\hline d. & $"$ & $"$ & $"$ & - & $2 c^{7}+9$ & Lenkoran 4. 66. IR. \\
\hline e. & $"$ & $"$ & " & - & 2 & Poti 4. 93. R. K. \\
\hline f. & " & $"$ & $n$ & - & 3 & Batum 4.93. R. K. \\
\hline g. & $r$ & $"$ & $"$ & 一 & 2 & 1)sliebrail 94. Sat. \\
\hline h. & $n$ & $n$ & $n$ & -. & 1 & |Vladikawkas 27. IV. 94. R. K. \\
\hline
\end{tabular}




\begin{tabular}{|c|c|c|c|c|c|}
\hline $.1:$ & & $\begin{array}{l}\text { Mазваніс видов'\%. } \\
\text { Nimen der Art. }\end{array}$ & $\begin{array}{l}\text { 'Iy"eisa. } \\
\text { Balg und } \\
\text { restopft. }\end{array}$ & $\left|\begin{array}{c}\text { Bucruppiti. } \\
\text { In Spiri- } \\
\text { tus. }\end{array}\right|$ & $\begin{array}{l}\text {.Hсто нахояденія. } \\
\text { Fundort. }\end{array}$ \\
\hline i. & Rana & $\begin{array}{l}\text { esculeuta L. } \\
\text { var. ridibunda Pall. }\end{array}$ & - & 4 & Batum 2. IX. 88. R. \\
\hline k. & $\leadsto$ & $"$ & - & 1 & $\begin{array}{r}\text { Pertschewan, Kr. Sangesur } 93 . \\
\text { Sat. }\end{array}$ \\
\hline 1. & $"$ & " & $\ldots$ & 2 & Georgiewsk 2. V.94. R. K. \\
\hline m. & " & " & - & 1 & Gouv. Kutais VI. 93. Sat. \\
\hline n. & " & n & - & 2 & Kr. Aresch 9 \&. Schlk. \\
\hline 0. & " & " & - & 2 larva| & Batum IV. 93. R. K. \\
\hline p. & $"$ & $n$ & - & 1 & Kr. Kuba 96. Sat. \\
\hline 4. & $"$ & $n$ & - & 1 & 'Tiflis 12. VII. 97. K. \\
\hline $86 . *$ & Raua & temporaria $L$. & - & 1 & Mlk. Brandenburg 94. gkft. \\
\hline a.* & $"$ & (fusca Rös). & - & 1 & Ungar'l 94. gkft. \\
\hline b.* & $p^{n}$ & $"$ & - & 1 & Moskau 94. Sat. \\
\hline $77 . *$ & Rana & arvalis Nills. & - & 1 & Ungarn 94. gkft. \\
\hline 78. & Rana & Cameranoi Blgr. & - & 2 & Kurusch VI. 85. R. \\
\hline a. & $n$ & $"$ & - & 1 & Tabiszchuri VI. 88. R. \\
\hline b. & $"$ & • & - & 1 & $" \quad$ VII. 95. K. \\
\hline 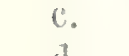 & $r$ & $"$ & - & 1 & Bach Kznia VII. 95. K. \\
\hline d. & $\rightarrow$ & 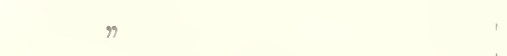 & - & 2 & Schach-dagh VI. 96. Sat. \\
\hline e. & $n$ & ... & - & 9 & Kasikoporan VI. VII. 96. K. \\
\hline $79 . *$ & Raua & agilis Thom. & 一 & 1 & Ungarn 94. \\
\hline 80. & Rana & macrocnemis Blgr. & 一 & 1 & Tillis 65 . Geogr. Ges. \\
\hline a. & $n$ & $n$ & - & 2 & Prijut VI. 79. R. \\
\hline b. & $\pi$ & $"$ & - & 1 & Gagry VI. 93 R. IK. \\
\hline c. & $"$ & $"$ & 一 & 1 & Georgiewsk 2. V. 94. R. K. \\
\hline $\begin{array}{l}\text { d. } \\
\text { e. }\end{array}$ & $n$ & $"$ & - & 1 & Schatojewsk 10. VII. 94. R. K. \\
\hline f. & $"$ & $"$ & 一 & 1 & Lawaschi 11. VII. 94. R. K. \\
\hline s. & $n$ & $"$ & - & $\begin{array}{l}1 \\
4\end{array}$ & $\begin{array}{c}\text { Lomis-Alta } \\
\pi \geqslant \text { VIII. 95. } 97 . \text { К. }\end{array}$ \\
\hline
\end{tabular}

\section{FAM. BUFONIDAE.}

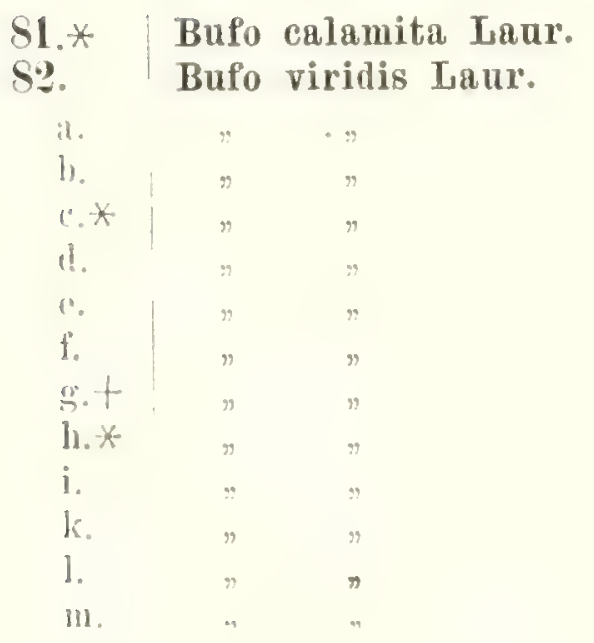

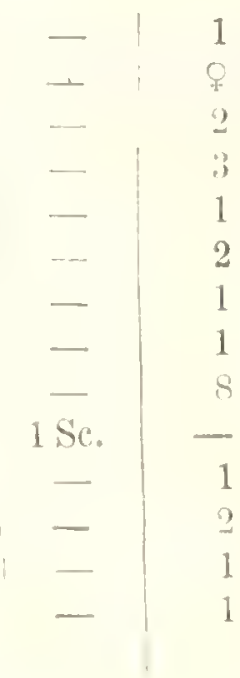

Mk. Brandenburg 94. gkft. Pjatigorsk 86. R. Kurusch VI. 85. R. Novolossiisk 23. VI. 93. R. K. ML. Brandenburg 94. gkift. Geok-tepe 30. III. 94. R. K. Kupferwerk Katarsk 94. Sat. Muschtaid 94. Sat. Aschabad 3. 86. W. Deutschland 69. glift. Nachitschewan 93. Sat. Tiflis 95. Sat. Kasikoporan VII. 96. K. Bos-Dagh Kr. Elisabethpol XI 96. Sat. 


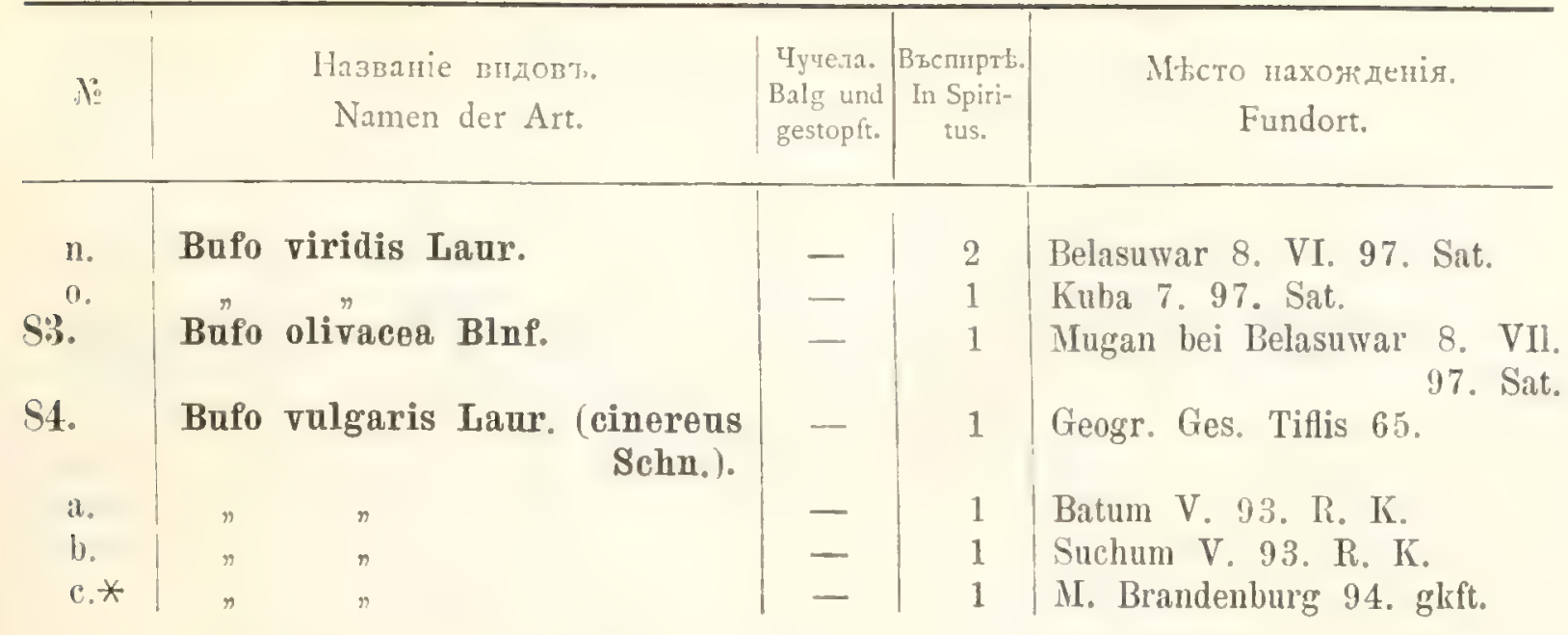

\section{FAM HYLIDAE}

\section{Hyla arborea I.}

\begin{tabular}{l|ll} 
a. & $n$ & $n$ \\
b. & $n$ & $n$ \\
c. & $n$ & $n$ \\
d. & $n$ & $n$ \\
e. & $n$ & $n$ \\
f. & $n$ & $n$ \\
g. & $n$ & $n$ \\
h. & $n$ & $n$ \\
i. & $n$ & $n$ \\
li. & $n$ & $n$ \\
l. & $n$ & $n$ \\
m. & $n$ & $n$
\end{tabular}

\begin{tabular}{c|c}
- & 1 \\
- & 1 \\
- & 3 \\
- & 2 \\
- & 1 \\
- & 2 \\
- & 1 \\
- & 2 \\
- & 1 \\
- & 1 \\
- & 2 \\
- & $5 j u v$ \\
- & 1
\end{tabular}

Batum VI. 93. R. K.

Chassaw-jurt VII. VI. 94. R. K.

Gagry VI. 93. R. K.

Lenkoran IV. 66. R.

Tiflis Sievers.

Poti 4. 93. R. K.

Sugdidi V. 93. R. K.

Mosdok IX, V. 94, R, K.

Gouv. Kutais 95. Sat.

Geogr. Ges. Tiflis 65.

Sardinien gkft.

var.

Aler VI. 93 R. K

Borshom 2. V. 98. R. K.

\section{FAM PELOBATIDAE}

S6.* Pelobates fuscus Laur.

57. Pelodytes caucasicus Blgr. $\quad-\quad 18$ Lomis-MIta 7000' 96. K. a.

FAM. DISCOGLOSSIDAE.

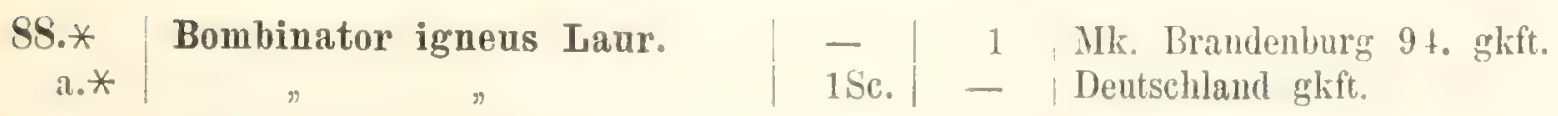

\section{BATRACHIA CAUDATA.}

FAM. SALAMANDRIDAE.

89.* Salamandra maculosa Laur. | - $\mid$ i | Mk. lirandenburg 94. glif 


\begin{tabular}{|c|c|c|c|c|c|}
\hline$\therefore$ & & $\begin{array}{l}\text { Ihazbamic momotr. } \\
\text { Namen der Art. }\end{array}$ & $\begin{array}{l}\text { 'Iучетit. } \\
\text { Balg und } \\
\text { l gestopfe. }\end{array}$ & $\begin{array}{l}\text { Buciupri. } \\
\text { In Spiri- } \\
\text { ius. }\end{array}$ & $\begin{array}{c}\text { Mticто пахожденія. } \\
\text { Fundort. }\end{array}$ \\
\hline 111 . & Salama & udra caucasica Waga. & - & 7 & Lomis-IIta VIII. 92. $8000^{\prime} \mathrm{K}$. \\
\hline : & & .. & & 6 & Borshom 93. R. \\
\hline h. & " & $"$ & - & 1 & n VIII. 93. R. \\
\hline$\because$ & & & - & 4 & Isomis-MIta 7000' VIII. 97. K. \\
\hline 11. & .. & & - & $t$ & $n \quad n 96 . \mathrm{k}$ \\
\hline 11. & 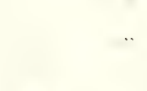 & .. & - & 1 & $\begin{array}{l}\text { Mbastmuan VII. 98. S. Kaisl. } \\
\text { Hoh. Grf. 'Thronf }\end{array}$ \\
\hline !1. $\therefore$ & Molge & ('I'xiton) cristata Gaur. & - & $8 \%$ & Mk. IBrandenburg 94. gkft. \\
\hline al. & $\because$ & "var. Karelini Strch. & - & 2 & Anitino 6. 70. R. \\
\hline b. & .. & $"$ & - & 5 & l'sebai VII. 9:3. R. K. \\
\hline 1. & & .. & 一 & 10 jux. & $n \quad n \quad n$ R. K. \\
\hline 11. & & n & - & 3 & $\begin{array}{r}\text { Bani-chewi bei) Borshom } 6500^{\prime} \\
\text { VIII. 92. li. }\end{array}$ \\
\hline$\because$. &. & $n$ & - & 3 & Bethanien 92. Kaukewitsch. \\
\hline$i$ & & $n$ & - & 2 & Bani-chewi $6500^{\circ} 93 . \mathrm{R}$. \\
\hline$! 12$. & Molge & alpestris Lanr. & - & 1 & Elsass gkft. \\
\hline $9: 3$. & Molge & vittata Gray. & - & $582 \%$ & Borshom 93. R. \\
\hline a. & .. & & - & 23 & Batum 93. Hiller. \\
\hline h. & .. & 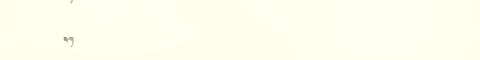 & - & 202 웅 & Bani-chewi $6500^{\prime} \mathrm{IX} .91 . \mathrm{R}$. \\
\hline$\because$. & .. & & - & 2 우 & Bethanien Kaukewitsch. \\
\hline 1 1. & . & ". & - & t larv. & Gagry 6. VI. 93. R. К. \\
\hline$\therefore$ &. & . & - & 1 & Lomis-Nita $7000^{\prime}$ VII. 95. K. \\
\hline f. & & & - & 1 & Borshom VII. 95. K. \\
\hline !). 1. & Míolge & vulgaris $\mathrm{L}$, (taeniatus). & 1sice. & - & Deutschland $69 . \mathrm{gkft}$. \\
\hline a. $*$ & . & , . . & 一 & of & Mk. Brandenburg 94. gkft. \\
\hline \%) & Moïge & $\begin{array}{l}\text { var. meridionalis Blgr. } \\
\text { spec.? }\end{array}$ & - & $\begin{array}{l}2 \% \\
1 \text { jur. }\end{array}$ & $\begin{array}{l}\text { Batum 4.93. R. K. } \\
\text { P'izmnda 3. VI. 93. R. K. }\end{array}$ \\
\hline
\end{tabular}




\title{
КРАТКІЯ ЗАМВТКИ ОТНОСИТЕЛЬНО НАЗВАННЫХ'В ПРЕСМЫКАЮОИХСЯ.
}

\author{
LACERTILIA.
}

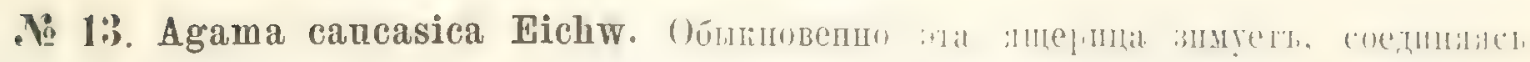

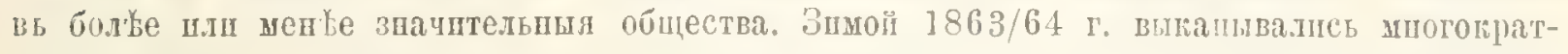

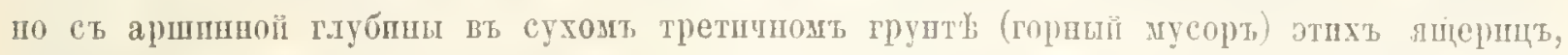

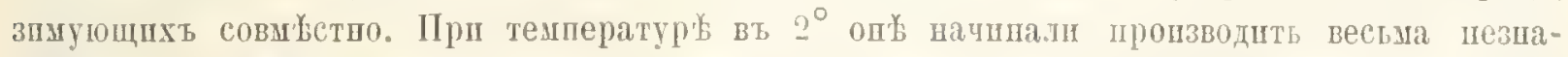

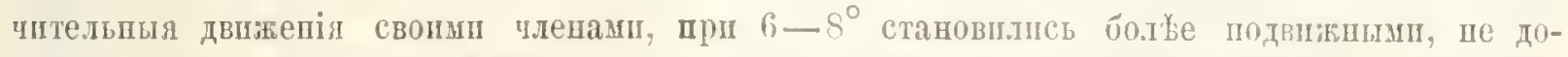

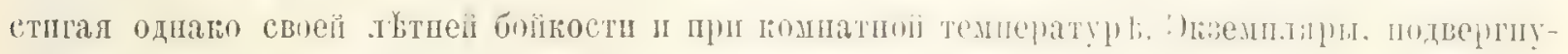
тыя нұскольюо разъ вліянію ходода, болшею частью погйлп.

P.

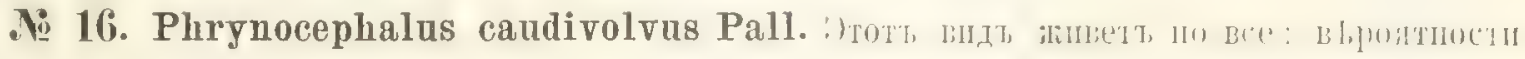

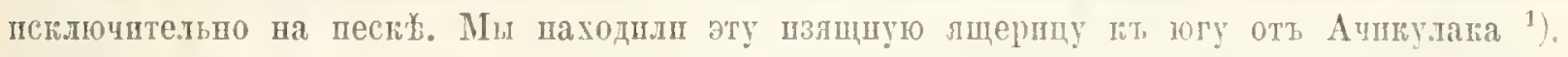

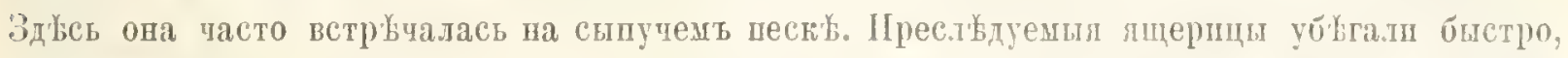
подымая хвость высоко кверху, при чемь он'ь ржшительно отказывалпсь ваходить в'ь растительный повровт степи. Дойдл до предыла песговт, эти звьри всегда поворачивали ша-

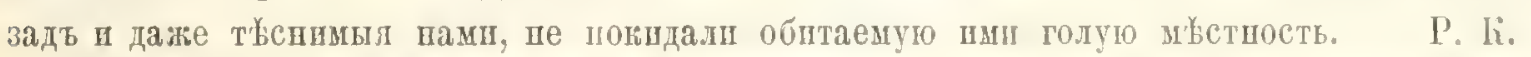

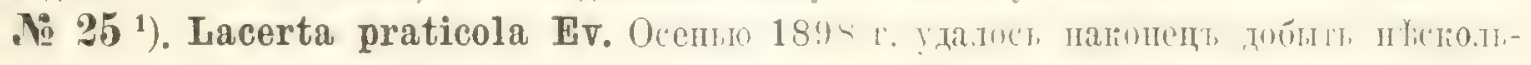

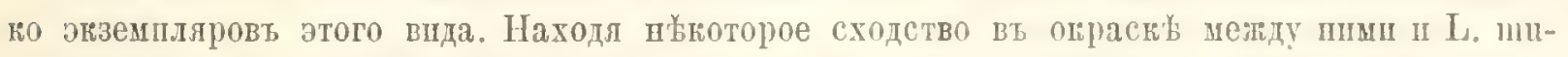

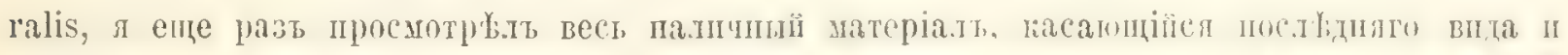

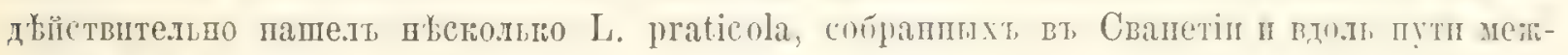
ду Мури пі Парн.

li.

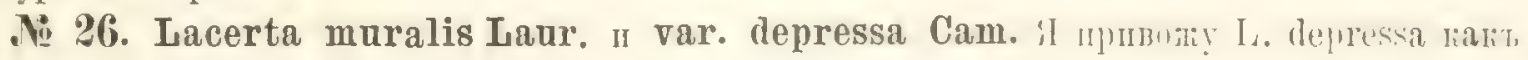
разновшдость L. muralis. Мщв не удалось строго разграшичть әти два вида. ІІродессорь O. Бёттгер ${ }^{2}$ ) счптаеть L. depressa тоже лшп варіэтетомъ L. muralis.

li.

\section{OPHIDIA.}

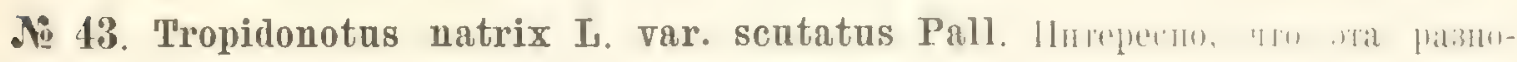

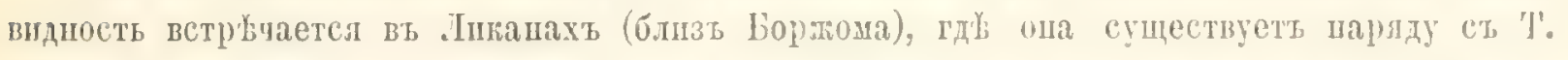
natrix L. typ.

i. 58. Contia (Ablabes) collaris Mén. u . 59. C. modesta Mart. livializi curдивлеть эти два вида вь "Cat. of the snakes in the British Mus. Vol. II, pag. 260".

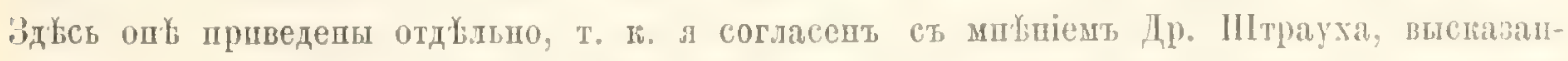

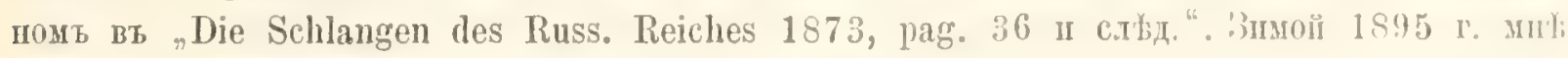

1) Cي. такље: Ëgänzh. Peterm, Mitth. No 117, 1895 pag. 16.

अ) Berichte Senck. Nat. Ges. 1832, pag. 140. 


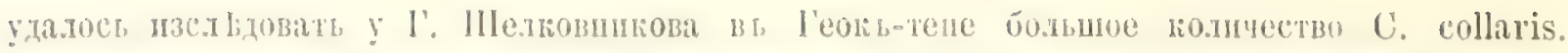

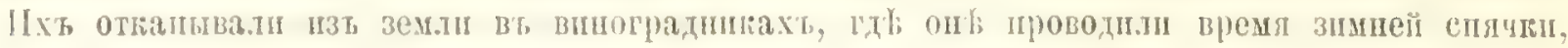

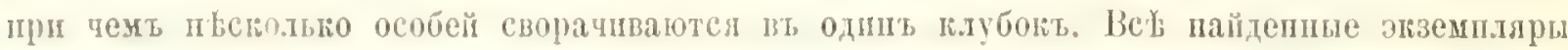

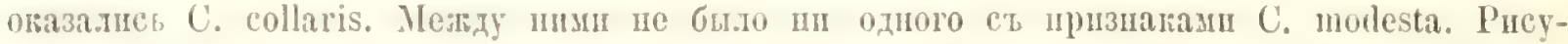

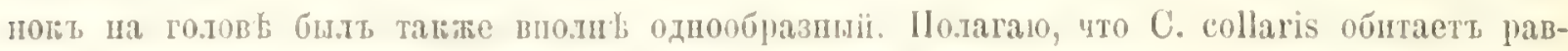

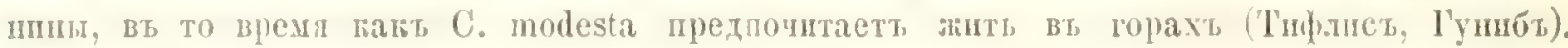

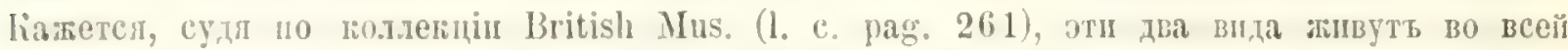

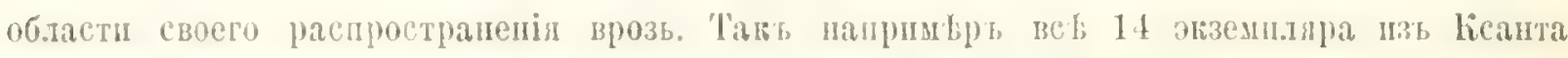
(Xanthus) павють по 17 рлдовь чешуш。

\section{BATRACHIA ECAUDATA.}

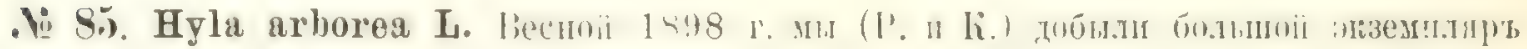

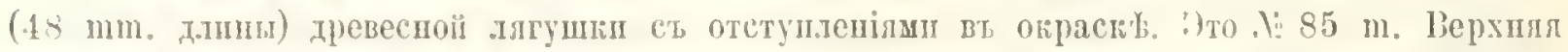

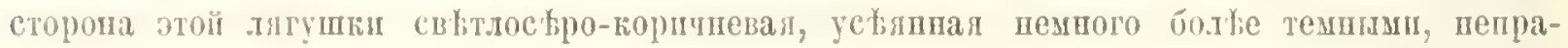
вн.льным пятная. Нижнял сторопа жестоватая. Вдоль боговт, шачниал съ поздрей, тя-

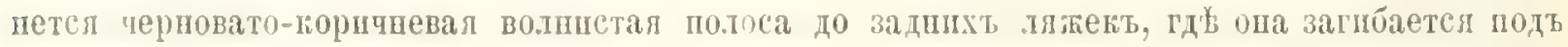

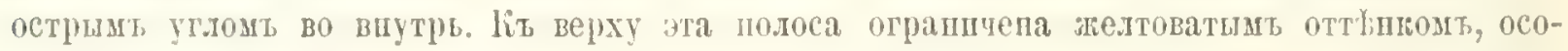

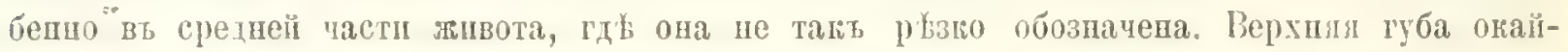

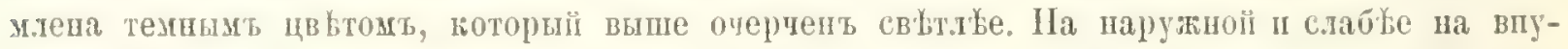

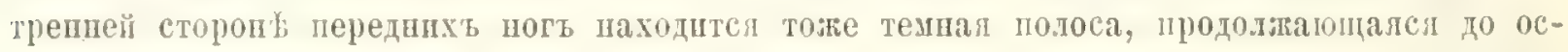

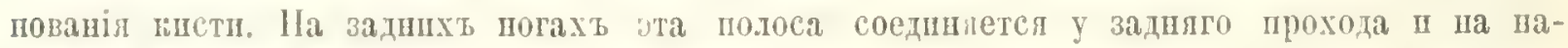

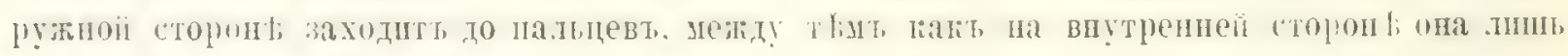
мұстам е.и-елп обозначена.

li. 


\section{KURZE BEMERKUNGEN ÜBER DIE AUFGEFÜHRTEN REP- TILIEN UND LURCHE.}

\section{LACERTILIA}

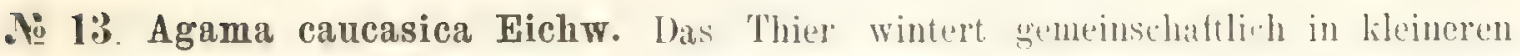
oder grösseren Gesellschaften. Im Winter 1s6:3-64 wurden boi Tiflis zu wiederhulten MaIen förmliche Yester gesellschaftlich überwinteruder Igamen auf 1 . Irschin Bodentiefe aus dem trockenen Tertiärterrain (Schuttand) entnommen. Die Thiere hegannon bei einer 'T'mperatur von $2^{\circ}$ sehr wenig die Gliedmassen zu regen, wurden bei $6-8^{\circ}$ lebhafter, nahmen aber auch in Stubentemperatur nicht ihre sonmerliche Frische an und kamen, wiederholt in die Kälte zurück gebracht, zum grossen Theile un.

$\mathrm{R}$.

. 16. Phrynocephalus caudivolvus Pall. Diese Art siheint ansschliesslich den Sand zu bewohnen. Wir beobachteten diese zierliche Eidechs südlich vun Atschilinlak ${ }^{1}$ ) wo sie auf dem Flugsande nicht selten war. Bei ihrer Verfolgung liefen die Thirre rasch, den Sihwanz hoch nach oben haltend, vermieden es aber auf das Entschiedenste in die Vegetatim der Steppe zu kommen, so wie sie an den Rand des Sandes kamen kehrten sie stets un und waren selbst wemn lurch uns bedrïngt, nicht zu zwingen ihr kahles Gebiet zu rerlassen.

R. K.

№ 25 1\%. Lacerta praticola Ev. Im Herbst 1s!n wurden chllich einige Exemplare dieser Art beschafft. Da sie in der Färbung etwas an L. muralis errimert, so sah ich das ganze Material von letzterer Art durch und es fanden sich anch in ihm einige Exemplare von L. praticola aus Swanetien und von der Strecke Muri-Pari.

K.

Mi 26. Lacerta muralis Laur. u'd var. depressa Cam. I h habe I. depressid als Varietät vom muralis aufgeführt. Ls wollte mir nicht grelingen beide Formen scharf anseinander zu laalten. Prof. O. Boettger ${ }^{2}$ ) hält ebenfalls L. de rressa nur für eine Varietüt der L. muralis.

K.

\section{O P H I D I A.}

. 10 43. Tropidonotus natrix L. var. scutatus Pall. Interessint ist das Vorkmmmen dieser Varietät in Likini (bei Borshom) wo sie mit T. natrix L. typ. zusammen lebt.

K.

№ jS. Contia (Ablabes) collaris Mén. und Nị9 C. modesta Mart. lionlenger in "Cat. of the snakes in the British Mus. Vol. II, pag. $260^{\circ}$ vereinigt beide Arten. Hier sind sie getrennt aufgeführt, da ich mich den Ansichten von Dr. Strauch in "Die Schlangen des Russ. Reiches $187^{\prime}$, 1)ag. 36 und ffgd." anschliesse. Im Winter 1895 konnte ich

") Sicle auch: Erginzh. Peterm. Mitth. K 117, 1895, pag. 16.

$\left.{ }^{2}\right)$ Berichte Senck. Nat. Ges. 1892, pag. 140. 


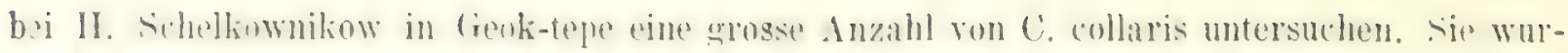

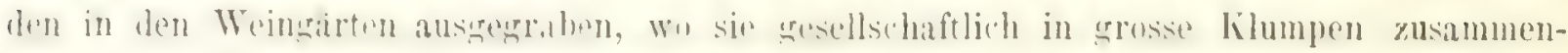
gerollt den Winterschlaf hielten. Alle erwiesen sich als C. collaris, es war kein Stück darunter, welches man auf C. modesta beziehen könnte. Auch die Zeichnung auf dem Kopfe war ausserst constant. Wie es mir scheint, so bewohnt C. collaris die tlachen Ebenen, während C. modesta die Gebirge bevor\%ugt (litlis, Gunib). Dass dies Arten an anderen Orten

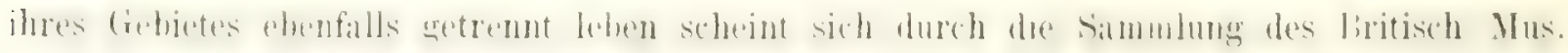
(1. c. pag. 261) zu bestitigen, nach ilmen besitzen \%. 1. 1.t lisemplare aus Janthus alle 17 Sehuppenreihen.

K.

\section{BATRACHIA ECAUDATA.}

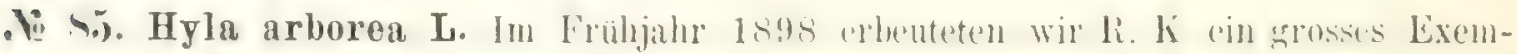
plar (von $48 \mathrm{~mm}$. Körperlänge) des Laubfrosches von abweichender Fürbung. lis ist das . 85 . m. Die Oberseite desselben ist hell graubraun mit etwas dunkleren, zerstrenten, unregelmässigen Flecken, die Unterseite gelblich. An den Seiten des Kürpers, von den Nasenlochern anfangend, zieht sich ein shwarzbrauner geweller streifen bis ror die Hinterschenkel, wo er in spitzem Winkel nach innen gerichtet ist. Nach oben ist er gelblich abgegrenzt, besonders an den Seiten des Bauches, wo der dunkle Streifen nicht so stark markirt ist. Die Oberliphe int dunkel geranlet und nath ohen heller eingefasst. Auf der Anssen-eite

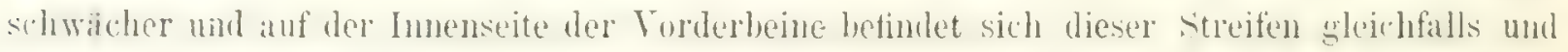
zieht sich verlängert bis auf das Handgelenk. Auf den Hinterbeinen geht er über den After, auf der Aussenseite der Tibien und Tarsen bis zu den Zehen, während er auf der Imnenseite nur stellenweise angedentet ist.

K. 


\title{
P I S C E S.
}

\author{
Р Ы Б.
}

F IS C HE.

IIкапь-51, 52.-Schrank. 



\title{
ЕГО ИМПЕРАТОРСКОМУ ВЫСОЧЕСТВУ
}

\author{
HАСЛЬДHИKY ЦЕСАРЕВИЧY

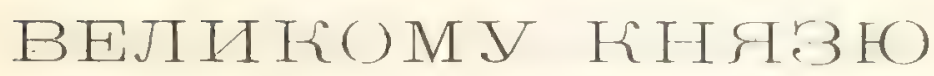 \\ ГЕОРГІЮ АЛЕКСАНДРОВИЧУ
}

ВСЕПРЕДАНН БЙШЕ

Посвљщаеть

Авторъ. 


\section{ВАШЕ ИМПЕРАТОРСКОЕ ВЫСОЧЕСТВО!}

Шодводи пастоицимь издапіемт, появлепіс котораго обязано милостиво-

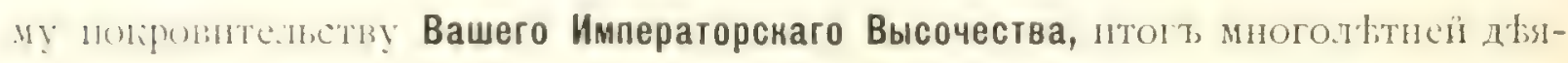

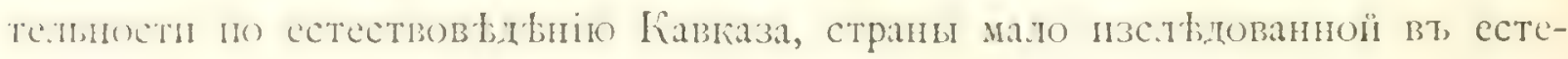

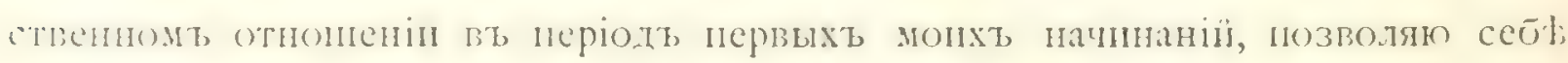

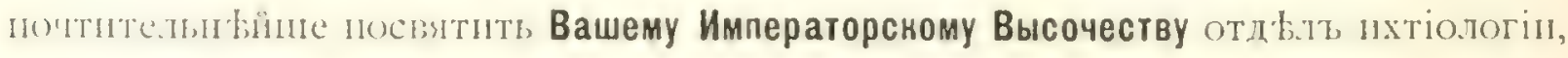
вт, знакь глуо̆окої благодарности за высокую и щедрую помоць, давшую возможность издать отдыльное сочниеніе о рыбахъ Кавказа.

\section{Вашего Императорснаго Высочества}

всепредани Бйніи слуга

Дрг I. II. Радәе. 


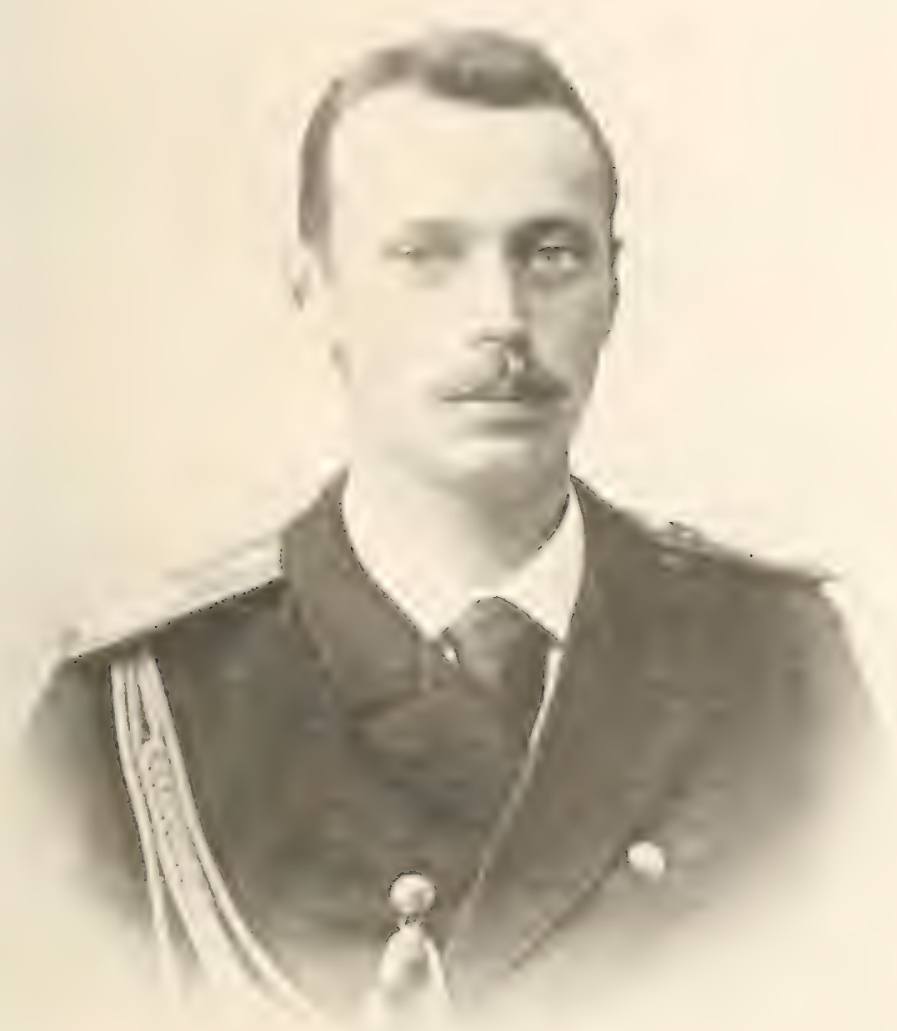

Teoprian 



\title{
SEINER KAISERLICHEN HOHEIT
}

\author{
D E M \\ grossfürsten thronfolger und Gasarewitsch \\ GEORG ALEXANDROWITSCH
}

EHREURCHTSVOLI

gewidmet

vom Autor. 


\section{EURE KAISERLICHE HOHEIT!}

Indem ich bei der Herausgabe dieses Werkes, dessen Erscheinen nur Dank Eurer

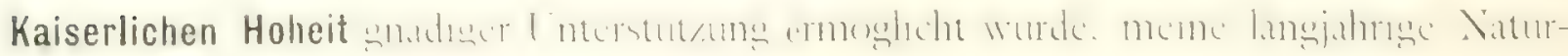
forscher Arbeit im Kaukasus überblicke-cinem Gebiete, welches bei Beginn meiner Thätigkeit in naturwissenschaftlicher Hinsicht nur wenig erforscht war-erlaube ich mir

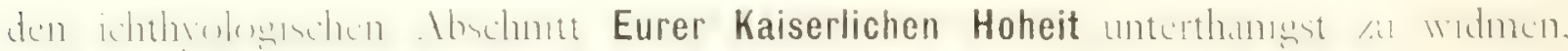

aus Dankbarkeit für die grosse und freigiebige Hülfe, welche die Publication eines Specialwerkes über die Fische der Kaukasuslïnder ermöglichte.

Eurer Kaiserlichen Hoheit

unterthänigster Diener

Di. G. Redele.

Tiflis, im Macrz I899 


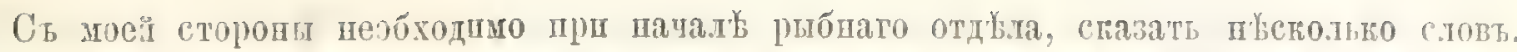

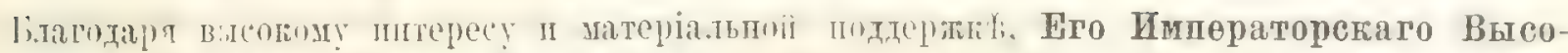

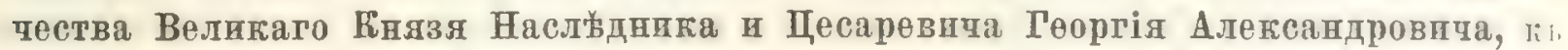

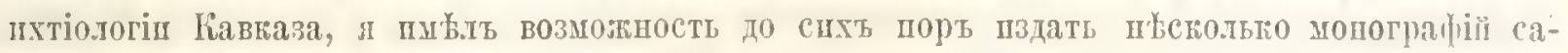
мыхъ пнтересныхъ семействъ.

Съ 1896 года понвилес въ двухъ выпускахъ Јососевыя, и до конца пыншияго го-

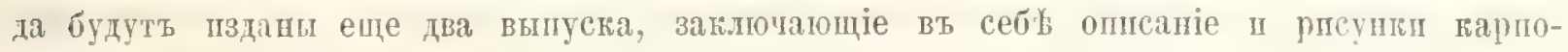
BI, '

Весьма жъелателын было бы, такимь же образомь, пзучить осетровыя породы (крас-

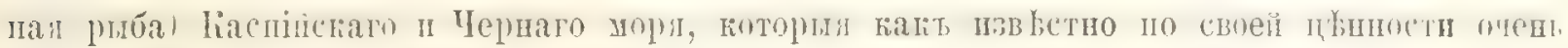

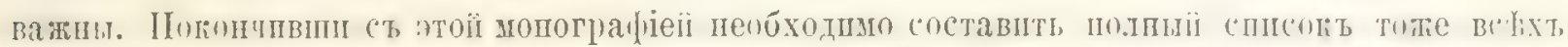

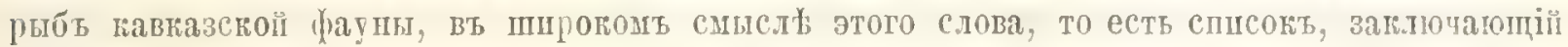

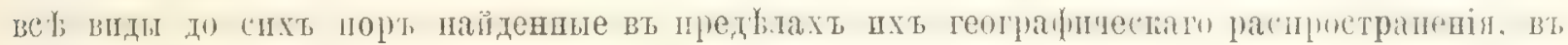
низовьяхт Волги, вт Азовскомь, Черномь п Каспійскомь моряхь.

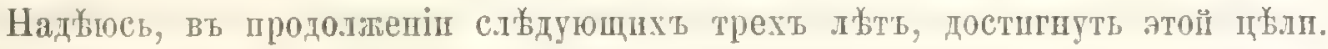

Такт какь шзь работт, по шзсльдованіо лососей, $\theta$. $\theta$. Каврайскаго оказываегея, что

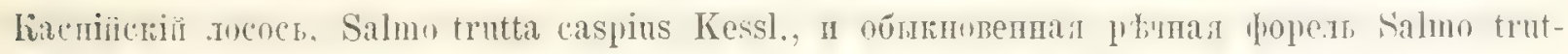

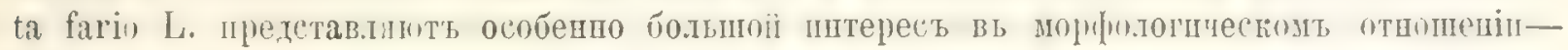

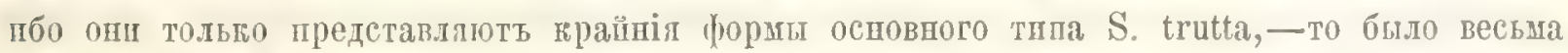

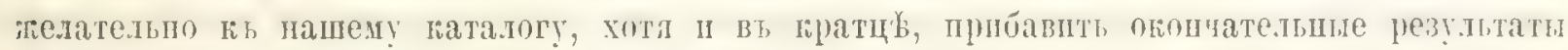

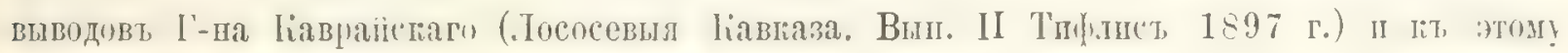
прнолоть обьяспительние рисуни.

Шодробныя цзсльдованія по әтому предмету уже били разосланы встит главныщъ пх-

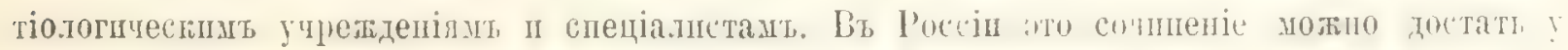
Н. Коммеля вт Риге, а заграницею у Фридлендера въ Берлинъ.

Дрэ I. Padde.

Тифдисъ, Марть 1899. 
Dem Abschnitte aber die lische wird es nothig sein meinerseits cinige Worte vorauszuschicken. Durch das hohe Interesse und die materielle lichülfe, welche Sr. Kaisl. Hoheit der Grossfiust Phronfolger und Caesarewitseh Georg Alexandrowitsch dem ¡chthyologischen Studium in den Kaukasusländerin gुewährt, war es bisjetzt möglich einzelne, besonders interessante Fimilien monographisch zu bearbeiten. Seit 1896 erschienen in zwei Lieferungen die Salmoniden und werden zwei weitere Lieferungen bis zum Schlusse dieses Jahres vollendet sein. Sehr wänschenswerth wäre es, eine eingehende und ebenfalls illustrinte Specialarheit über die wichtigen mol werthvollen Störarten (Acipenseres) des Kaspischenund Schwarzen Meeres zu geben und dann ein vollständiges Verzeichniss aller bisjetzt renittelten Fischarten aus dem kaukisischen faunen Gebiete im weiteren sime des Wortos, d. h. mit Einschluss der unteren Wolga, des Asow'schen, Shwarzen und Kaspischen Meeres al: Sehluss Lieferung folgen zu lassen.

Ich hoffe deses hiel im Verlaufe der niblisten dhei Jahre zu erreichen.

I) nun aber von dem bisjetzt beabeiteten Material aus der Lamilie der Salmoniden der kaspische Latehs, Salmo trutta caspins Kessl. und die gewöhnliche Bachforelle, Salmo trutta fario L. von besonderem morphologischen Interesse sind, weil sie sich nur als extreme Formen des Grundtyus ron s. trutta erweisen, so war es wünschenswerth diesem Verzeichnisse die darauf bezüglichen Untersuchungen des Lerrn Kawrasky (die Lachse der Kankasusländer, Lief. II, Tiflis 1897) wenigstens in ihren lindresultate wiederzugeben und auch die Abbildungen hinzuzufügen. Die ausführlichen Untersuchungen wurten bereits an alle mamhafte ichthyolugische Institute und Specialisten gesendet und sind fir liussland bei $\mathrm{N}$. Kymmel in Riga, fur das Ausland bei Friedlinder in Berlin noch einige Lsemplare im Vertriebe.

Dr. G. Rudde.

Titlis, Macrz 1899. 


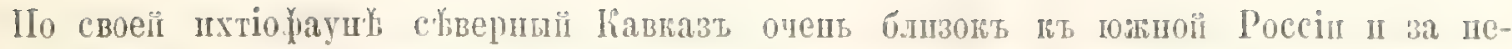

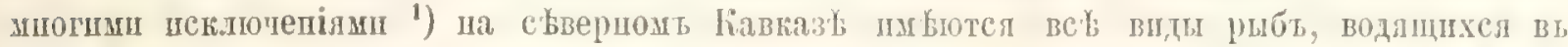

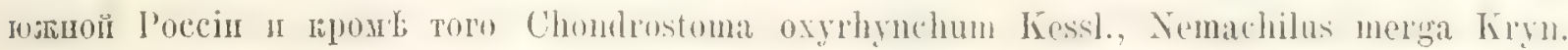

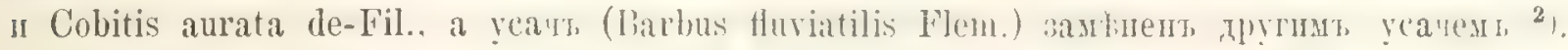

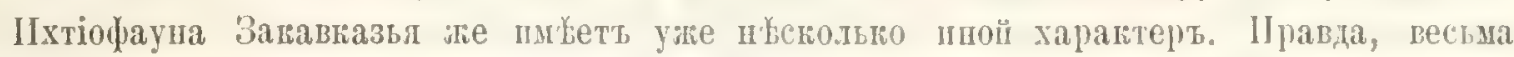

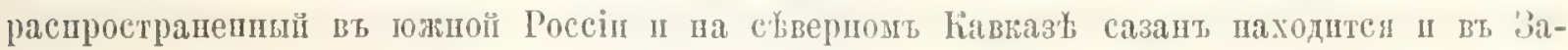

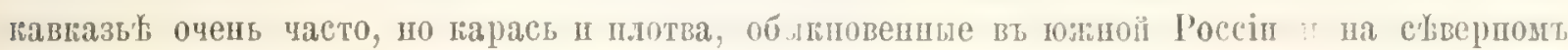

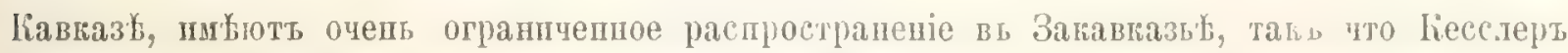

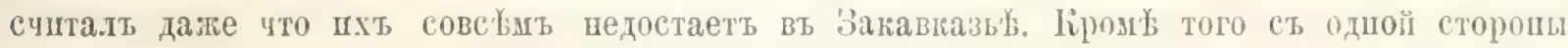

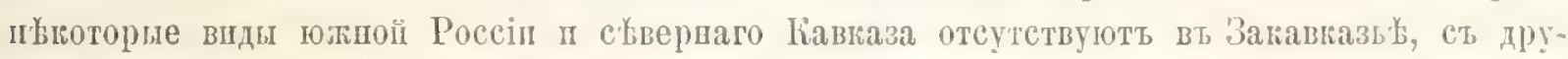

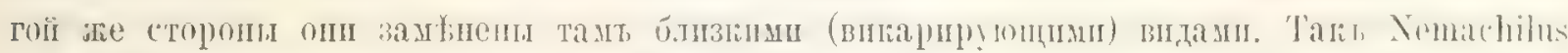

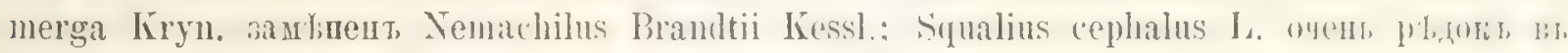
Закавказь' и вамынень тащт, Sq. turcicus de-Fil., Barbus tauricus Kessl. особенша: 1)азность этого вида ИІ т. ІІ.

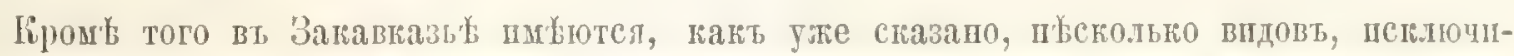

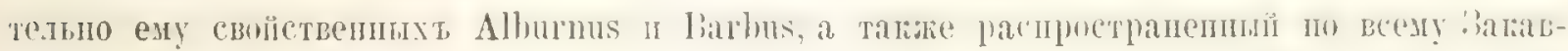

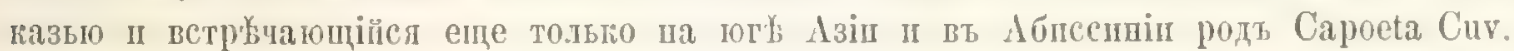

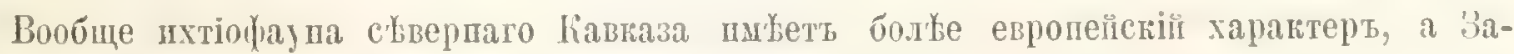
гавтазия лвствеппо переходинй пт средпеазіатскому.

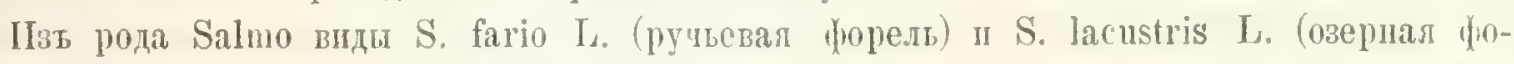
рель) по Каврайскому, pаспростапены по всему Закавтазьо, а S. ischchan Kessl. псклю-

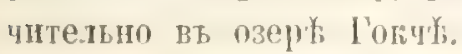

\section{(\%. lanенстій.}

$\left.{ }^{1}\right)$ Gobio fluviatilis Rond, Squalius leusicus Ileck, Squalius Danilewskii Kessl. In Nemachilus barbatulus I.

2) Barbus ciscaucasicus Kessl. 
In seiner lischfama schliesst sich der nördliche Kaukasus (Ciskankasien intim an diejenige Sudrusslands. Fast alle Arten, welche sich in dem letzteren Gebiete finden, leben auch in den Gewissern des nödlichen Kaukasus. Ausgeschlossen sind: Gobio fluviatilis Rond., Śqualius leuciscus Heck., Squalius Danilewshii Kéessl., Nemachilus barbatulus L. Auch Barbus fluviatilis Flem. ist, so viel bisjetzt bekan!t wurde, durch Barbus ciscaucasicus Kessl.

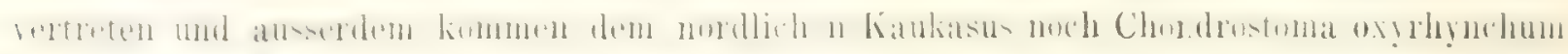
Kiessl., Cobitis aurata de-Fil. und Nemachilus merga Kryn.zu, welche in Südrussland fehlen.

Die Fischfauna Transkaukasiens unterscheidet sich schon merklich von der vorher erwïhnten. Zwar ist der weitverbreitete, auch an der Nordseite des Kaukasus vorliommende Karpfen anch in Transkaukasien sehr häufig, aber die Karasse und Plotwa (L. rutilus L.), welche gemein in Südrussland und im nördlichen liaukasus (liettand) sind, haben in 'Transkankasien eine so geringe Verbreitung, dass Kessler sie sogar daselbst als fehlend betrachtete. Ueberdies werden einige Arten der nördichen Gebiete, welche in Transkaukasien fehlen, durch nahe stehende, vicariende ersetat. So wird z. B. Nemachilus merga Kryn. durch X. Brandtii Kiessl. ersetzt. Squalius ceplalus. L. der nur sehr selten in 'Iranskaukasien ist, wird durch Squalins turcicus de-Fil. ersetzt und von Barbus tauricus Kessl. finden wir eine

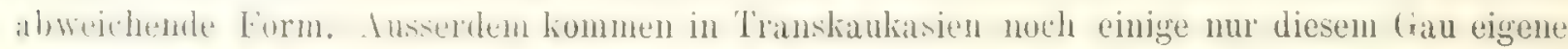
Arten aus dene diechlechtern Alburnus und Barbus vor und das südasiatische und Abissinische Genus Capoeta findet sich im gesammten 'Transkaukasien.

In allgemeinen hat die Fischfauna des nördlichen Kaukasus einen mehr eurnäischen ('larakter, diejenige von 'Transkiuliasien vermittelt den Jebergang zum entralasiatischen.

Von den Salmoniden sind S. fario L, und S. lacustris L uber ganz 'Transkaukasien rerbreitet, wïhrend $S$. ischehan Kessl. nur dem alpinen Goktschai-See zukommt.

S. Kamensky. 
E-

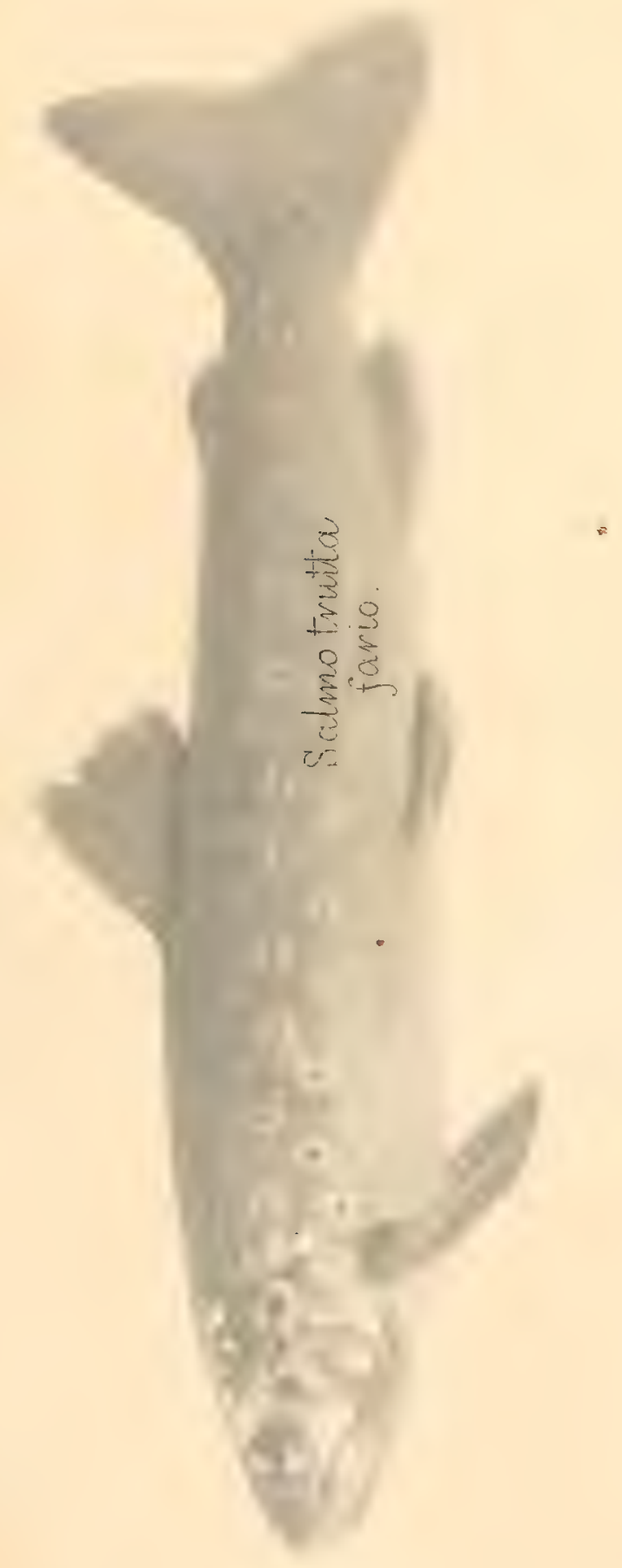




$$
\text { . }
$$

$$
-
$$

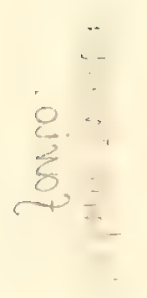



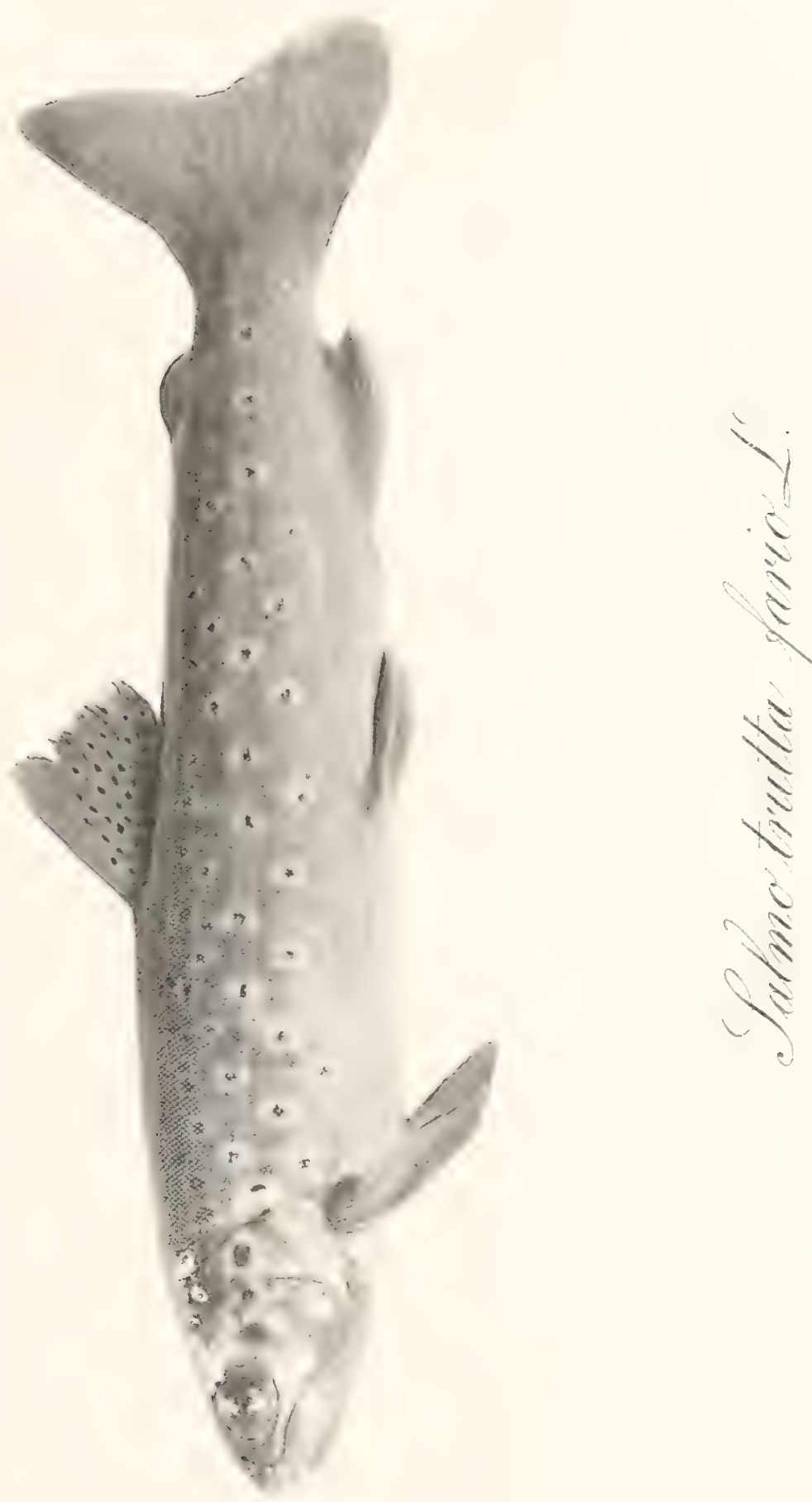



\section{P I S C E S.}

\section{СOTРУДНИКИ-MITARBEITER.}

Prof. A. Brandt. St.-Petersburg.

S. N. Kamensky. Charkow.

F. F. Kawraisky.

Prof. A. Ostroumow. Kasan.

Dr. G. Radde. Tiflis.

Составъ коллецціи рыбъ до 1 лпваяя 1899

Gesammtbestand der Sammlung von Fisshen bis 1 Januar 1899.

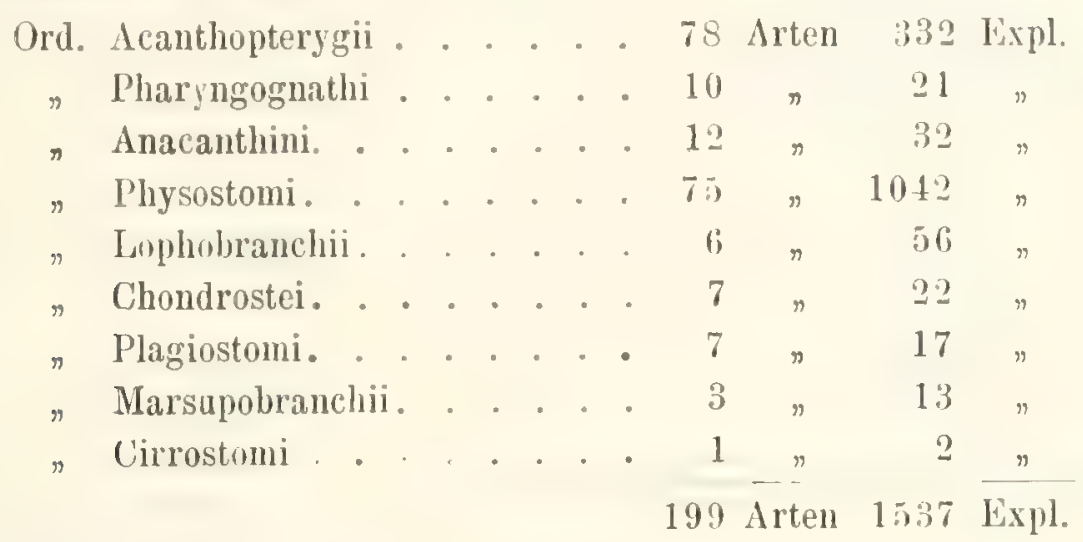




\section{ACANTHOPTERYGII.}

\section{FAM.GASTEROSTEIDAE.}

\begin{tabular}{|c|c|c|c|c|}
\hline 1 & 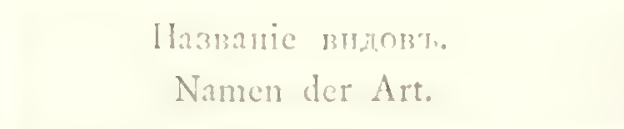 & $\begin{array}{l}\text { 'Iyqers. } \\
\text { Balg und } \\
\text { gcstopft. }\end{array}$ & $\mid \begin{array}{c}\text { Bъстиртt:. } \\
\text { In Spiri- } \\
\text { tus. }\end{array}$ & $\begin{array}{c}\text { Mleto naxomдеmis. } \\
\text { Fundort. }\end{array}$ \\
\hline $\begin{array}{l}\text { 1. } \\
\text { il. } \\
\text { b. } \\
\text { a. } \\
\therefore \text { a. } \\
\text { a. } k\end{array}$ & $\begin{array}{cc}\text { Gasterosteus aculeatus L. } \\
", \\
" \\
\text { Gasterosteus pungitius I. } \\
\text { Gastorosteus platygaster Kssl. } \\
\text { " }\end{array}$ & $\begin{array}{l}- \\
- \\
-- \\
- \\
- \\
-\end{array}$ & $\begin{array}{l}1 \\
1 \\
2 \\
2 \\
2 \\
2 \\
2 \\
4\end{array}$ & $\begin{array}{l}\text { Sewastopol 93. Ostroumow. } \\
\text { 'Theodosia 93. Retowsky. } \\
\text { Deutschland ghte. } \\
\text { Rostow a. D. 94. Kawraisky. } \\
\text { St.-Petersburg. Akad. } \\
\text { Iemirgoje 5. VI. 94. R. K. } \\
\text { Ural 98. Kawr. }\end{array}$ \\
\hline
\end{tabular}

\section{FAM. PERCIDAE.}

1. Perca fluviatilis $\mathrm{L}$.

il

1. .

i.

11. $\%$

(l.

¡. Acerina cernua I.

(i.

i)

b.

\%.

il.

l.

(". Asperina improvisa Ostr.

). Serranus scriba L.

i.

10.* Serranus hepatus Risso.

11. $\therefore$ Anthias sacer Bl.
Wladimirowka 5. V. 94. R. K. ['alaeostom V. 93. R. K.

Newa 68. 1. Brandt.

Lenkoran IV. 80. R.

Mk. Brandenburg 94. glift.

Boshy-Promysl. 97. Kawr.

Don. Akat.

Rostow "a. D. Kawr.

Nowotscherkask. Kawr.

Lenkoran 66. R.

\begin{tabular}{l|cccc} 
i. & - & IV. $80 . \mathrm{R}$. \\
li. & - & $n$ & n
\end{tabular}

boshy-Promysl. 94. gesch.

Asow'sches Meer. Kawr.

Nare nigr. 60. R.

" $\rightarrow$ 68. A. Brandt.

Theodosia 93. Retowsky.

Nare medt. 68. 1 . Branlt. Giglioli.

\section{FAM PRISTIPOMATIDAE。}

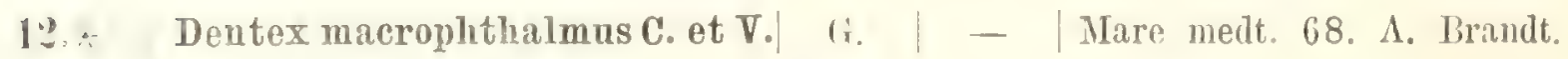




\begin{tabular}{|c|c|c|c|c|}
\hline Io & $\begin{array}{c}\text { Ilaзваніе впдовт. } \\
\text { Namen der Art. }\end{array}$ & $\begin{array}{l}\text { Чудела. } \\
\text { Balg und } \\
\text { gestopft. }\end{array}$ & $\begin{array}{l}\text { Bъcmuptb. } \\
\text { In Spiri- } \\
\text { tus. }\end{array}$ & $\begin{array}{c}\text { Maст пахожденія. } \\
\text { Fundort. }\end{array}$ \\
\hline $\begin{array}{l}13 . * \\
14 . * \\
\text { a. } \\
\text { b. } \\
\text { c. }\end{array}$ & 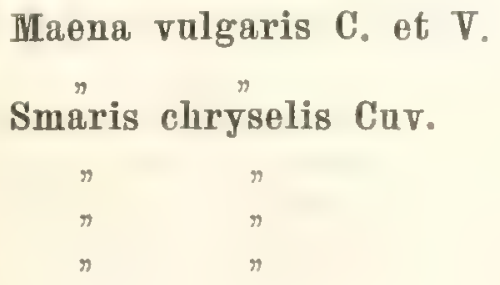 & $\begin{array}{l}- \\
- \\
- \\
-\end{array}$ & $\begin{array}{l}1 \\
1 \\
2 \\
2 \\
1 \\
2\end{array}$ & $\begin{array}{l}\text { Mare medt. 86. A. Brandt. } \\
\text { Algier. Gigl. } \\
\text { Mare nigr. } 60 \text {. R. } \\
\text { Theodosia IV. 93. Retowsky. } \\
\text { Sewastopol 94. Ustroumow. } \\
\text { Batum IV. 93. I. K. }\end{array}$ \\
\hline
\end{tabular}

\section{FAM. MULLIDAE.}

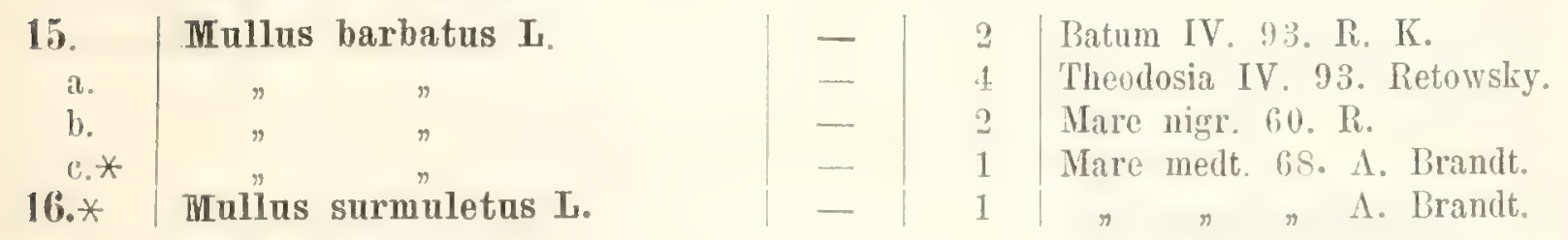

\section{$F \wedge M . S P \wedge R I D \wedge E$.}

\begin{tabular}{|c|c|c|c|c|}
\hline 17. * & Box vulgaris C. et $V$. & 一 & 1 & Mare medt. Gigl. \\
\hline 1S. $*$ & Oblata melanura $\mathrm{L}$. & - & 1 & Mare medt. 68. 1. Brandt. \\
\hline 19 . & Sargus annularis $\mathbf{L}$. & - & 2 & Mare nigr. $60 . \mathrm{R}$. \\
\hline a. & $\pi$ & - & 5 & Batum IV. 93. R. K. \\
\hline b. & $"$ & - & 5 & Theodosia 94. Retowsliy. \\
\hline c. & $"$ & - & 1 & Mare nigr. 94. Ostroumow. \\
\hline d. $*$ & $n$ & - & 1 & Mare medt. 68.4 . Brandt. \\
\hline o. * & Charax puntazzo L. & - & 1 & A. Brandt. \\
\hline * & Pagrus valgaris C. et V. & - & 1 & $n$ A. Brandt. \\
\hline * & Chrysophrys aurata I. & G. & 一 & A. Brandt. \\
\hline
\end{tabular}

\section{FAM. TRIGLIDAE.}

2:** * Scorpaena scrofa L.

$24 *$

25.

a.

b.

c.

l. *

$26 . *$

$2 \% *$

a

b.

c.

d.

98 .

$2 ! * *$
Scorpaena ustulata Isowl.

Scorpaena porcus $L$.

Cottus gobio L.

Trigla hirundo Bl.

Trigla lineata L.

Peristedion cataphractum I.
G. - Mare medt. 68. 1. Brandt. Algier Gigl.

Sewastopol 94. Ostroumow.

Mare nigr. 60. $R$.

Theodosia 93. Retowsky.

Batum IV. 93. R. K.

Mare medt. 68, A. Brandt.

Deutschland 96. grkft.

Mare medt. 68. A. Brandt.

Theodosia 93. Retorsky.

Bosporus 9.. Ostroumow.

Batum 17. II. 95. Burkhardt.

Anapa 30. IV. 97. Dulin.

Mare medt. (;8. 4. Brandt.

Algier Gigl. 


\begin{tabular}{|c|c|c|c|c|}
\hline $1:$ & $\begin{array}{l}\text { Названіс пндов". } \\
\text { Namen der Art. }\end{array}$ & $\begin{array}{l}\text { Ty"te.ta. } \\
\text { Balg und } \\
\text { gestopft. }\end{array}$ & \begin{tabular}{|c|} 
Bucruspth. \\
In Spiri- \\
tus.
\end{tabular} & $\begin{array}{c}\text { Mticто нахожденія. } \\
\text { Fundort. }\end{array}$ \\
\hline $\begin{array}{l}30 . \\
\text { a. } \\
\text { b. } \\
\text { c. } \\
\text { d.* } \\
31 . * \\
32 . \\
\text { at. } \\
\text { b.* }\end{array}$ & $\begin{array}{cc}\text { Uranoscopus scaber } \mathrm{I}_{3} \text {. } \\
n " \\
" & " \\
\text { Trachinus radiatus } \mathrm{C} \text { et } \mathrm{V} \text {. } \\
\text { Trachimus draco } \mathrm{L} \text {. } \\
" & n \\
& n\end{array}$ & $\begin{array}{l}- \\
- \\
- \\
- \\
\text { G. } \\
- \\
-\end{array}$ & $\begin{array}{l}1 \\
2 \\
1 \\
1 \\
1 \\
-1 \\
1 \\
1 \\
1\end{array}$ & $\begin{array}{l}\text { Sewastopol 94. Ostroumow. } \\
\text { Batum IV. 93. R. K. } \\
\text { Theodosia 93. Retowsliy. } \\
\text { Mare nigr. 60. R. } \\
\text { Mare medt. 68. A. Brandt. } \\
\text { Mare nigr. 60. R. } \\
\text { Sewastopol 94. Ostroumow. } \\
\text { Mare medt. 68. A. Brandt. }\end{array}$ \\
\hline
\end{tabular}

FAM. SCIAENIDAE.

\begin{tabular}{|c|c|c|c|}
\hline $\begin{array}{l}\text { a. } \\
\text { b. } \\
\text { c. } *\end{array}$ & $\begin{array}{cc}\text { Corvina nigra } & \mathrm{Bl} . \\
\eta & n \\
\eta & n \\
n & n\end{array}$ & - & $\begin{array}{l}\text { Mare nigr. 60. R. } \\
\text { Batum IV. 93. R. K. } \\
\text { Theodosia 93. Retowsky. } \\
\text { IIare medt. 68. A. Branc }\end{array}$ \\
\hline
\end{tabular}

\section{FAM. SPHYRAENIDAE.}

34.* | Sphyraena vulgaris C. et V. $|-| 1 \mid$ Algier.95. R.

\section{FAM. SCOMBRIDAE.}

35. * Scomber colias L.

36. Scomber scomber $\mathrm{L}$.

$37^{2} *$ Naucrates ductor $\mathrm{L}$

35. E Echeneis remora $L$.

39.* Zeus pungio C. et V.

\begin{tabular}{l|r} 
G. & $\overline{1}$ \\
\hline- & 1 \\
\hline $\bar{G}$. & $\overline{1}$ \\
\hline $\bar{G}$ & -
\end{tabular}

Mare medt. 68. 4. Brandt. Sewastopol 9:?. Ostroumow. Mare nigr. 60. $\mathrm{R}$. Mare medt. 68. A. Brandt. Mare atlantic. Gigl.

Mare medt. 68. A Brandt.

\section{FAM. CARANGIDAE.}

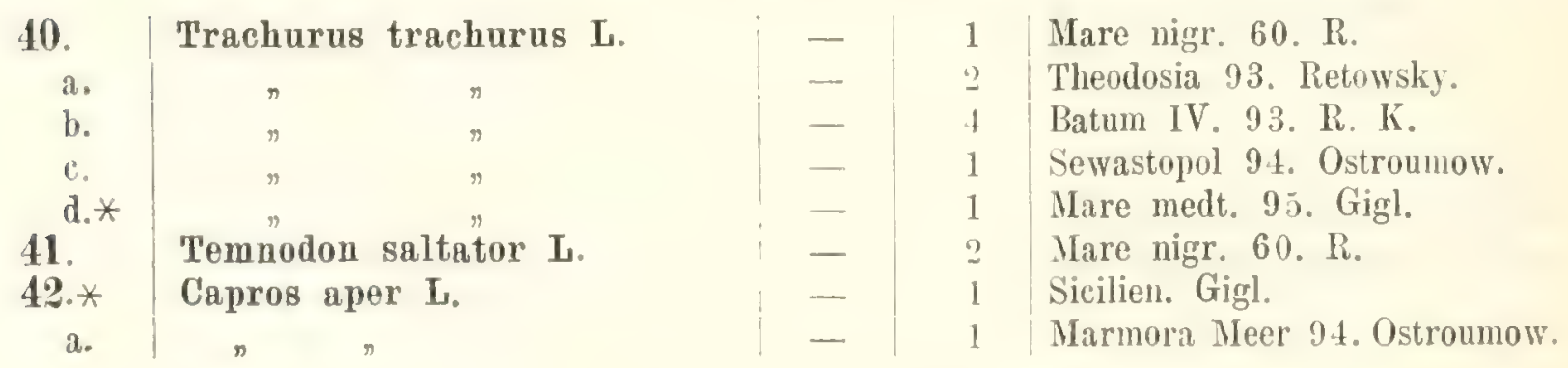




\begin{tabular}{|c|c|c|c|c|}
\hline Ii & $\begin{array}{l}\text { Названіе впдовъ. } \\
\text { Namen der Art. }\end{array}$ & $\begin{array}{l}\text { पyqe.тa. } \\
\text { Balg und } \\
\text { gestopft. }\end{array}$ & $\begin{array}{c}\text { Bъспирть. } \\
\text { Ir. Spiri- } \\
\text { tus. }\end{array}$ & $\begin{array}{c}\text { MАсто нахожденія. } \\
\text { Fundort. }\end{array}$ \\
\hline a. & Gobius marmoratus Pall. & - & 2 & Batum IV. 93. R. K. \\
\hline b. & $n \quad$ = $\quad$ var. ? & - & 2 & $\eta \quad, \quad \mathrm{R} . \mathrm{K}$. \\
\hline 14. & Gobius jozo I. & - & 1 & Sewastopol 94. Ostroumow. \\
\hline a. & $\pi \quad \pi$ & - & 4 & Batum IV. 93. R. K. \\
\hline b. $*$ & $n$ & - & 1 & Nare medt. 68. A. Brandt. \\
\hline c. $*$ & a & - & 1 & Algier. Gigl. \\
\hline 45. & Gobius ophiocephalus Pall. & - & 2 & Odessa 94. Kawr. \\
\hline 46. & Gobius capito $\mathrm{Cuv}$ & - & 1 & Batum IV. 93. R. K. \\
\hline$a^{a}$ & $" n$ & - & q & Sewastopol 93. Ostroumow. \\
\hline 47. & Gobius melanostomus Pall. & - & 2 & Batum IV. y 3. R. K. \\
\hline a. & $n$ & - & 1 & Sewastopol 93. Ostroumow. \\
\hline b. & $\pi$ & - & 1 & Poti V. 93. R. K. \\
\hline c. & $n$ & - & 1 & Mare nigr. $60 . \mathrm{R}$. \\
\hline d. & » & - & 5 & Petrowsk 1. VI. 94. R. K. \\
\hline e. & $"$ & 一 & 8 & $\Rightarrow \quad n \quad n \quad$ R. K. \\
\hline f. & $n$ & -- & 2 & Batum IV. 93. R. K. \\
\hline $\mathbf{s i}^{\mathrm{g} \cdot}$ & Gohius casnine" Ficluw & - & 2 & Petrowsk. Kawr. \\
\hline & Gobius caspius Eichw. & 一 & 6 & 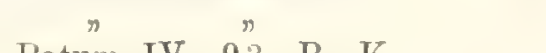 \\
\hline 49. & Gobius fluviatilis Pall. & - & 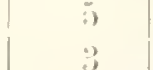 & $\begin{array}{l}\text { Batum IV. 93. R. K. } \\
\text { Poti IV. 93. R. K. }\end{array}$ \\
\hline b. & $n$ & - & 1 & Kertsch 94. Kawr. \\
\hline c. & $n$ & - & 6 & Petrowsk 1. VI. 94. R. K. \\
\hline d. $t$ & $"$ & - & 3 & Usun-ada V. 96. Flrk. \\
\hline e. & & - & 1 & Kaspi 98. Kawr. \\
\hline 50. & Gobius cephalargus Pall. & - & 1 & Mare nigr. 60. $\mathrm{R}$. \\
\hline it. & $"=$ & - & 1 & Odessa 94. Kawr. \\
\hline 51. & Gobius platyrostris Pall. & - & 2 & Noworossiisk 23. VI. 93. R. K. \\
\hline a. & " $\quad$ var. cyrius Kssl. & - & 10 & $n \quad n n$ \\
\hline b. & $"$ & - & 5 & Borshom 96. R. \\
\hline c. & $\pi$ & - & 2 & Tiflis VIII. 98 K. \\
\hline d. & $n$ & - & 3 & Osurgeti Kawr. \\
\hline e. & typ. & - & 1 & Borshom Kawr. \\
\hline f. & $n=" \quad n$ & - & 2 & Bachwi-tskali Kawr. \\
\hline 52. & Gobius Kessleri Günth. & - & + & Petrowsk 1. VI. 94. R. K. \\
\hline $53^{a}$. & Gobius syrman Nordm. & 一 & $\begin{array}{l}4 \\
2\end{array}$ & Berdjansk. "Kawr. ${ }^{\#}$ R. K. \\
\hline 54. & Gobius batrachocephalus Pall. & - & 1 & Odessa 94. Kawr. \\
\hline a. & $"$ & - & 1 & Berdjansk. Asow Meer 97.Kawr. \\
\hline $55^{b .}$ & Gohing cancasicns Kawr & 一 & 3 & Batun 0 " KV "Kawr. \\
\hline a. & Goorus caticasteus nawr. & - & 16 & Temirgoje 3. VI. 94. К. K. \\
\hline $56 . *$ & Gobius fluviatilis Cetti nec.Pall. & - & 3 & Messina gkft. \\
\hline $57 . *$ & Gobius niger L. & 一 & 1 & Madeira Gigl. \\
\hline 58. & Gobius spec.? & - & 1 & Petrowsk 1. VI. 94. R. K. \\
\hline a. & $" \quad$ " & 一 & 1 & Baku 67. R. \\
\hline $5 ! !$ & Gobius Steveni Nordm. var. & - & 4 & Palaeostom. Kawr. \\
\hline 60. & Bentophilus macrocephalus Pall. & - & 1 & Lenkoran IV. 66. R. \\
\hline 61. & Callionymns festivus Pall. & 一 & 1 & Bosporus 94. Ostroumow. \\
\hline
\end{tabular}




\section{FAM. PEDICULATI.}

6\%. Lophius piscatorius Is

G. - | Mare medt. 68. 4. Brandt.

\section{FAM. BLENNIIDAE}

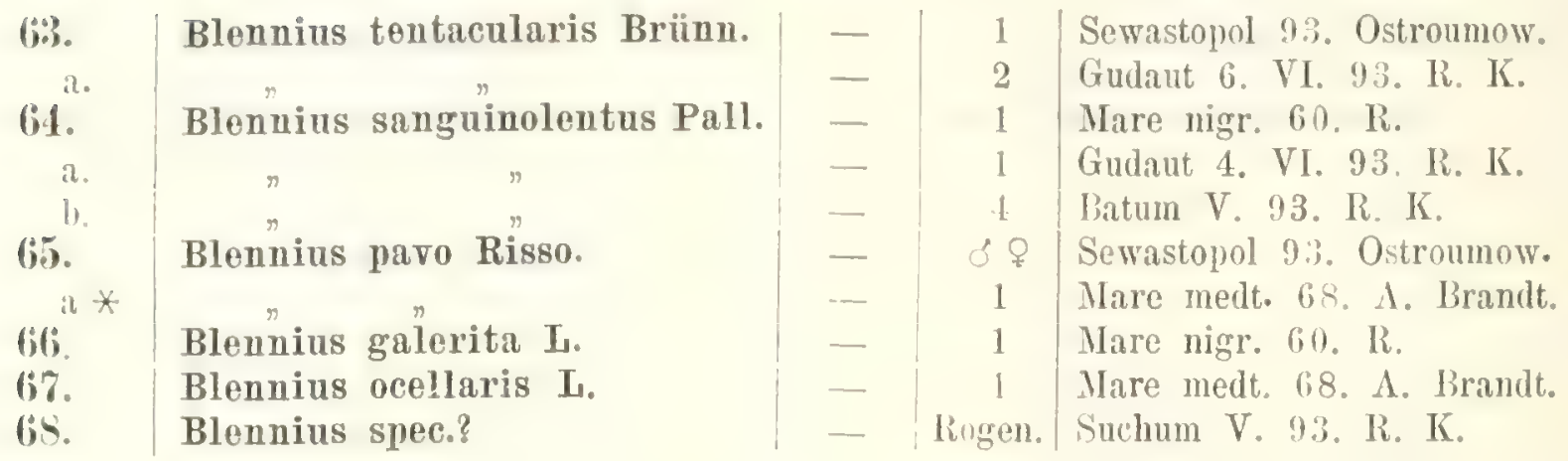

\section{FAM. ATHERINIDAE,}

\begin{tabular}{|c|c|c|c|c|}
\hline 69 & Atherina pontica Eichw. & 一 & 7 & Batum IV. 93. R. K. \\
\hline a & & - & 19 & Petrowsk 1. VI, 94. R, K. \\
\hline 70. & Atherina hepsetus $\mathbf{L}$. & - & $\because$ & $\begin{array}{l}\text { Theodosia 93. Retowsky. } \\
\text { Mare nigr. 94. Ostroumow. }\end{array}$ \\
\hline $1 . *$ & Atherins sarda" C. et V.? & & 3 & Cagliari Gigl. \\
\hline $2 *$ & Atherina Boyeri Risso.? & & 1 & Mare medt. Gigl. \\
\hline
\end{tabular}

\section{FAM, MUGILIDAE.}

\begin{tabular}{|c|c|c|c|c|}
\hline 73. & Magil cephalus Cuv. & - & 1 & Mare nigr. 94. Ostroumow \\
\hline & Mugil auratus Risso. & - & 1 & $" \quad$ Ostroumow \\
\hline & & & 1 & 68. Gigl. \\
\hline & Mugil saliens Risso. & & 3 & $\begin{array}{l}n \\
\text { Theodosia 93. Retowsky. }\end{array}$ \\
\hline b* $*$ & $" n$ & & 1 & Mare medt. 68. A. Brandt \\
\hline * & & & & \\
\hline
\end{tabular}

\section{FAM. CEPOLIDAE.}

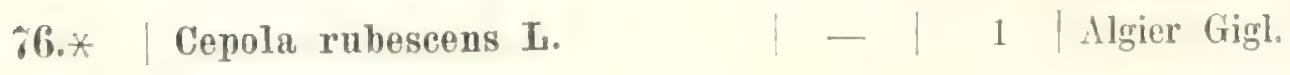

\section{FAM. GOBIESOCIDAE.}

7\%. Lepadogaster Decandolii Risso. - $\quad 1$ | Sewastopol 93. Ostrommow. 


\begin{tabular}{|c|c|c|c|c|}
\hline No & $\begin{array}{c}\text { Названіе вілдовт. } \\
\text { Namen der Art. }\end{array}$ & \begin{tabular}{|} 
Чyчe-ia. \\
Balg und \\
gestopft.
\end{tabular} & $\begin{array}{c}\text { Bzenuprt. } \\
\text { In Spiri- } \\
\text { tus. }\end{array}$ & $\begin{array}{c}\text { Mtсто naхонденіл. } \\
\text { Fundort. }\end{array}$ \\
\hline
\end{tabular}

78. Lopadogaster bimaculatus Penn.

1 Sewastounl 93. Ostroumow.

\section{PHARYNGOGNATHI.}

\section{FAM. POMACENTRIDAE}

\begin{tabular}{l|l|l|l|l} 
7.9. & Heliastes chromis Cav. & - & 1 & Sewastopol 94. Ostroumow. \\
S0. & Umbrina cirrlosa L. & - & $: 3$ & Iiatum IV. 93. R. K.
\end{tabular}

\section{FAM, L XBRIDAE.}

\begin{tabular}{|c|c|c|c|c|}
\hline 81. & Crenilabrus pavo Brïnn. & - & 201 웅 & Theodosia 93. Retowsky. \\
\hline a. & $n$ & - & 1 & Mare nigr. $60 . \mathrm{R}$. \\
\hline b. & & & 2 & R. \\
\hline 2. & Crenilabrus griseus L. & - & 1 & Batum IV. 93. R. K. \\
\hline $3^{a}$. & Creniläbrus quinquemaculatus & & 2 & 93. Retowsky. \\
\hline & BI & 一 & 1 & Batum IV. 93. R. K. \\
\hline & Crenilabrus ocellatus Forsk. & - & 2 & Mare nigr $60 . \mathrm{R}$. \\
\hline & abrus rostratus $\mathrm{Bl}$. & - & 1 & Sewastopol 93. Ostroumow. \\
\hline * & Crenilabrus melops Risso. & - & 1 & Mare medt. 68. A. Brandt. \\
\hline * & Crenilabrus mediterrane & 一 & 1 & $" \quad$ n 68. A. Brandt. \\
\hline * & Coris julis $\mathbf{L}$. & 一 & 1 & $n$ \\
\hline l. $*$ & $n$ & - & 1 & 刃 \\
\hline
\end{tabular}

\section{ANACANTHINI.}

FAM. GADIDAE.

89. Gadus enxinus Norim.

90 * Gadus minutus L."

91. Merlangus pontasson Risso.

92. Lota vulgaris Cuv.

93.

a.

b.*

c.
Motella tricirrata BI.

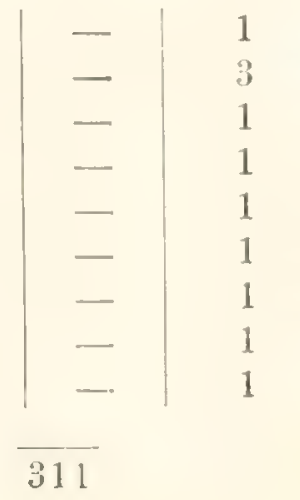

Nare nigr. 94. Ostroumow. Batum IV. 93. R. K.

Mare medt. 88, 4 . brandt. Mare medt. Gigl.

Moskau 94. Kawr.

Theodosia 93. Retowsliy.

Nare nigr. 60. $\mathrm{R}$.

Nare medt. 68. A. Brandt.

Sewastopol 93. Ostroumow. 
IItсто пахождепія. Fundort.

\section{FAM OPHIDIIDAE}

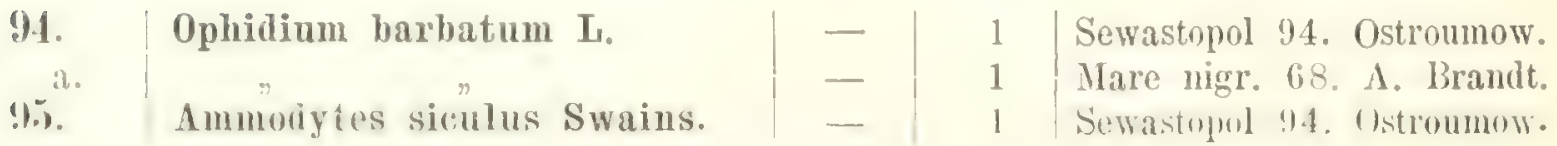

\section{FAM. PLEURONECTIDAE}

\begin{tabular}{|c|c|c|c|c|}
\hline 96 & Rhombus maeoticus Pall. & G. $P$ & - & Poti IV. 88. Consul Baer. \\
\hline a. & $n$ & G. & - & Poti I. 93. R. \\
\hline b. & $r$ & G. & 一 & liatum IV. 93. R. K. \\
\hline c. & $n$ & - & 1 & $\pi \quad \pi \mathrm{R} . \mathrm{K}$. \\
\hline d. & " & 一 & Kiemen. & $\pi \mathrm{R} . \mathrm{K}$. \\
\hline e. & \% & - & 1 & Theodosia 93. Retowsky. \\
\hline f. & & - & 1 & Mare nigr. $\mathrm{R}$. \\
\hline $17 . *$ & Rhombus laevis Rond. & G. & - & Mare medt. 68. A. Brandt. \\
\hline 15 & Plouronectes flesus $\mathrm{L}$. & - & 1 & Mare nigr. 94. Ostroumow. \\
\hline $\begin{array}{l}a . \\
b\end{array}$ & $\pi$ & - & $\begin{array}{l}1 \\
2\end{array}$ & 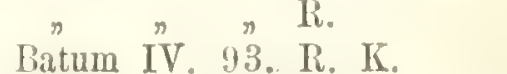 \\
\hline c. & 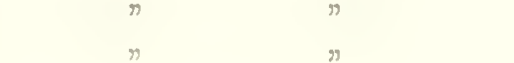 & - & 1 & Theodosia 93. Retowsky. \\
\hline$d . *$ & $n$ & - & 2 & Mare medt. 68. A. Brandt. \\
\hline (1). & Solea nasuta Pall. & - & 1 & Theodosia 93. Retowsky. \\
\hline $100 * *$ & Solea vulgaris Quensl.? & $\overline{G_{i}}$ & 1 & $\begin{array}{l}\text { Mare nigr. } 60 . \text { А. Brandt. } \\
\text { Mare medt. } 68 . \text { A. Brandt. }\end{array}$ \\
\hline
\end{tabular}

\section{PHYSOSTOMI.}

F A M STLURIDAE.

\begin{tabular}{r|c|c|c|c|c|} 
101. & Silurns glanis L. & (i.r & - & Tiflis I.93. R. \\
i. & $n$ & $n$ & - & 1 & $n$ XI. 88. R. \\
b. & $n$ & $n$ & - & 1 & Kisljar Terek 23. V. 94. R. K. \\
c. & $n$ & $n$ & - & 1 & Kars-tschai 27. X. 95. Kawr.
\end{tabular}

\section{FAM SALMONIDAE.}

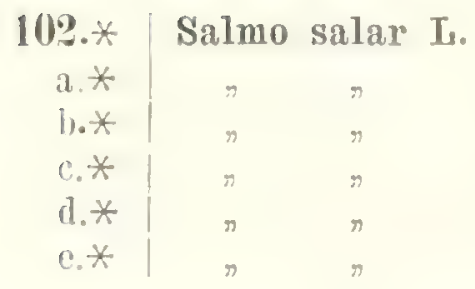

$$
\begin{array}{c|c|cc}
\text { G. } & - & \text { Nordsee gkft. } \\
- & \text { juv. } & \text { Ostsee } & \text { glft. } \\
- & " & n & n \\
- & \eta & n & n \\
- & n & n & n \\
- & \text { monstr. } & " & n
\end{array}
$$




\begin{tabular}{|c|c|c|c|c|c|}
\hline : & & $\begin{array}{l}\text { Названіе видовт. } \\
\text { Namen der Art. }\end{array}$ & $\begin{array}{c}\text { 'учела. } \\
\text { Balg und } \\
\text { gestopft. }\end{array}$ & $\begin{array}{c}\text { Bzспиртt. } \\
\text { In Spiri- } \\
\text { tus. }\end{array}$ & $\begin{array}{c}\text { Мьсто нахояденіл. } \\
\text { Fundort. }\end{array}$ \\
\hline $103 . *$ & Salmo & trutta $\mathbf{I}$ & - & 1 & Nordsee gkft. \\
\hline 104. & Salmo & lacustris L. & - & 2 & Tschaldyr-göll 21.X.95. Kawr. \\
\hline & $\eta$ & $n$ & - & 2 & " \\
\hline b. * & r & var. Romanowi Kawr. & $\bar{C}$ & 1 & Züricher-See 83. gkft. \\
\hline c. & $"$ & $\begin{array}{l}\text { var. Romanowi Kawr. } \\
\eta\end{array}$ & $\begin{array}{l}\text { G. } \\
G .\end{array}$ & - & Tabiszchuri-See 68. R. \\
\hline e. & $n$ & $n$ & G. & - & 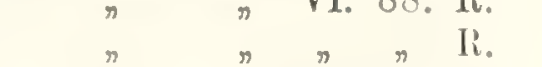 \\
\hline f. & $n$ & $n$ & - & 1 & $n \quad n \quad \mathrm{XI} .87 . \mathrm{R}$. \\
\hline$g$. & $n$ & $"$ & - & 1 & $n \quad n \quad n \quad \mathrm{R}$. \\
\hline h. & $"$ & $n$ & 一 & 2 & $\quad$ $\quad$ III. 95. R. \\
\hline i. & $n$ & $"$ & - & 2 & $" \quad n \quad 96$. Kawr. \\
\hline k. & 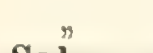 & typ. & - & $1 \mathrm{~K}$. & Tschaldyr 95. Kawr. \\
\hline 105. & Salmo & caspius Kssl. & G. & - & Achty VII. 85. R. \\
\hline a. & 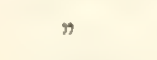 & $n$ & G. & - & Saljan $70 . \mathrm{R}$. \\
\hline b. & \% & $n$ & G. & - & $n$ \\
\hline c. & $n$ & $n$ & - & 1 & Samur 95. R. \\
\hline d. & $n$ & $n$ & G. & 一 & Kura 70. R. \\
\hline $\begin{array}{l}\mathrm{e} . \\
\mathrm{f}\end{array}$ & $"$ & n & 一 & ovarium & Saljan 21. XI. 96. Kawr. \\
\hline 106. & Salmo & ischchan Kssl. & $\bar{G}$. & Zame. & Goktschai 69. R." Kawr. \\
\hline a. & $"$ & " & G. & 一 & $n \quad n \quad \mathrm{R}$ \\
\hline b. & 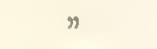 & $"$ & - & $\delta$ & $n \quad 94$. Medw. \\
\hline c. & $\pi$ & $"$ & - & 8 & $n \quad n \quad n$ \\
\hline d. & $"$ & $"$ & 一 & \& & $n \quad n$ \\
\hline e. & $"$ & $"$ & 一 & 1 & $n \quad n$ \\
\hline f. & 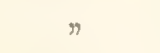 & $"$ & - & 4 & $n \quad n$ \\
\hline g. & $"$ & $n$ & - & 4 & $\eta \quad "$ \\
\hline lı. & $"$ & $"$ & 一 & 6 & $\pi \quad \pi$ \\
\hline i. & $"$ & $"$ & - & (3) & $m$ \\
\hline k. & $"$ & $n$ & 一 & juv. & 95. \\
\hline 1. & $"$ & $n$ & - & ova. & 20. VII, 93. \\
\hline III. & $n$ & $"$ & 一 & ova. & 20. VI. 94. \\
\hline 11. & $n$ & $"$ & 一 & ova. & $n n$ \\
\hline 0. & $"$ & $n$ & 一 & ova. & 12. VII. 94. \\
\hline $1 \%$ & $"$ & $"$ & - & ova. & 14. VIII.94. \\
\hline !. & $"$ & $"$ & - & ova. & $" n \quad " \quad "$ \\
\hline r. & $\pi$ & " & 一 & ova. & 6. X. 94 \\
\hline S. & $"$ & $"$ & - & ova. & $n n n$ \\
\hline t. & " & $\eta$ & 一 & ova. & 20. X. 94. \\
\hline 11. & $n$ & $\pi$ & 一 & ova. & 4. XI.94. \\
\hline v. & $n$ & var. gegarkuui Kssl. & - & 5 & 94. \\
\hline w. & $"$ & n & - & 4 & $n$ \\
\hline$x$ & $\pi$ & $r$ & - & ova. & 1. XII. 94. \\
\hline $\mathrm{y}$. & $"$ & 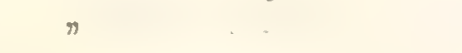 & - & ova. & " $\quad 95$. \\
\hline$\%$ & $n$ & $n$ & 一 & 10 & Käwor-tschai 7. XII. 94. \\
\hline an. & $n$ & $n$ & - & 5 & " $\quad 20 . \mathrm{XI} .94$. \\
\hline lop. & $"$ & ischehan Kssl. & - & $\begin{array}{l}4 \\
1\end{array}$ & Mexandrowka $" 4$. VIII. 95. \\
\hline
\end{tabular}




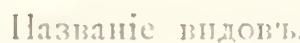

Namen der Art.

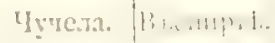

l3alg und In Spirigestopt. tus.
Мюто пахояденія.

Fundort.

10\%. Saino fario I.

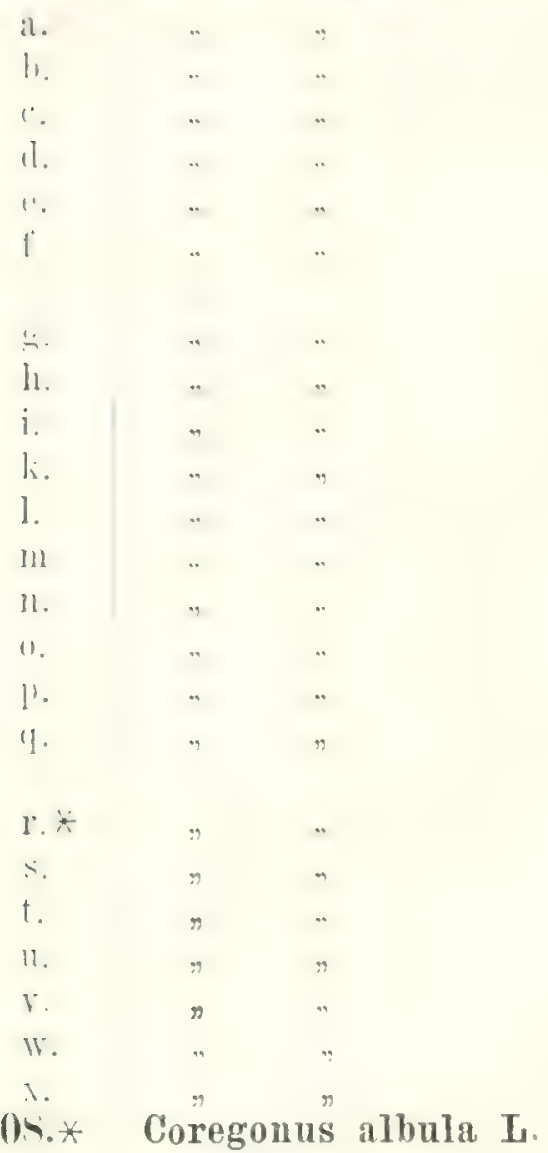

Bach Kznia VI. 88.6000' R. Psebai VII. 93. R. K.

Jewdokimowsk 13.VII.9t. R.K. Ichrek R.

Likani 97. R.

Bakuriani VIII. 95. R.

Bach I'sze (Abchasien) ¿. VI.

$$
\text { 93. R. K. }
$$

Bach Kznia VI. 88. R.

Laba V. 95. R.

$n \pi n$.

Tana V. 95. K.

'l'andurek-tschai 9. VII. 96. K.

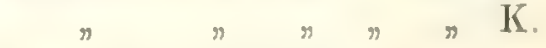

Batum V. 93. R. K.

Forellensee VII. 94. R. K.

Likani VIII. 95. R.

Sanga oberhalb Rendamak 9. VIII. 96. K.

Böhmerwald 8. V. 95. gkft.

Murow-dagh 97. Kawr.

Lenkoran 97. Kawr.

Kambilejewka 11. V. 94. R. K.

Sursuna Kawr.

See Babuscher Kawr.

Kuban Kawr.

See Perejaslaw Kawr.

FAM. SCOPELIDAE.

10!). Scopelus spec.?

- 1 | Mare medt. Gigl.

\section{FAM. ESOCIDAE,}

110. Esox lucius L。

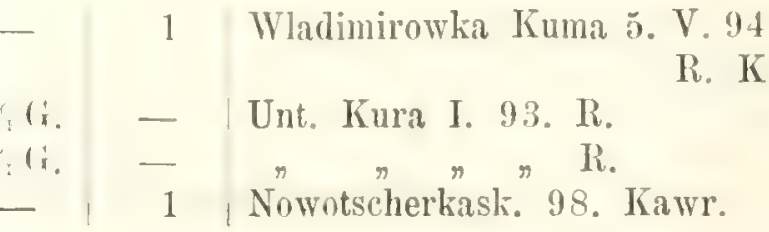

FAM SCOMBEROSOCIDAE.

111. Belone acus Cuv.

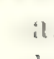

Nare nigr. 60. $\mathrm{R}$.

$\rightarrow$ 94. Ostroumow.

Batum IV. 93. R. K. 


\begin{tabular}{|c|c|c|c|c|}
\hline He & $\begin{array}{l}\text { Названіе вндов"э. } \\
\text { Namen der Art. }\end{array}$ & $\begin{array}{l}\text { Чучела. } \\
\text { Вalg und } \\
\text { gestopft. }\end{array}$ & $\begin{array}{c}\text { Bвспиртt, } \\
\text { in Spiri- } \\
\text { tus. }\end{array}$ & $\begin{array}{c}\text { Mьсто иахожденія. } \\
\text { Fundort. }\end{array}$ \\
\hline 112. * & Belone vulgaris C. et V.? & 一 & 1 & Mare medt, 68. $\Lambda$. Brandt. \\
\hline
\end{tabular}

\section{FAM. CYPRINODONTIDAE.}

113.* | Cyprinodon calaritanus Cav. | - | 5 | Cagliari Gigl.

\section{FAM. CYPRINIDAE.}

\section{Cyprinus carpio L.}

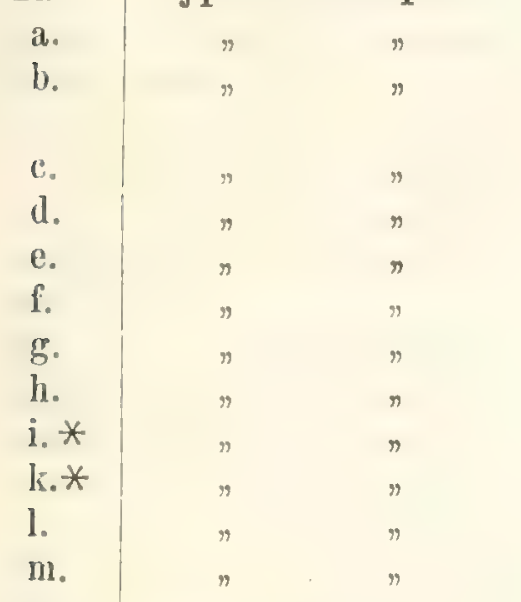

114. ${ }^{1}$ Cyprinus carpio L。 hybrid?

115.

$116^{\mathrm{a}}$

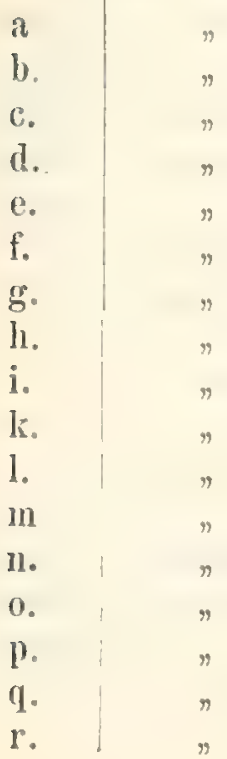

\section{Carassius vulgaris Nilss.}

Capoeta fundulus Pall.

\begin{tabular}{l|r}
- & 1 \\
\hline- & 3 \\
\hline & 1 \\
G. & - \\
G. & - \\
G. & - \\
G. & - \\
\hline- & 1 \\
\hline G. & 1 \\
\hline ISc. & - \\
\hline- & 1 \\
\hline- & 1 \\
- & 1 \\
- & 6 \\
- & 6 \\
- & 4 \\
- & 3 \\
- & 1 \\
& \\
- & 2 \\
- & 2 \\
\hline- & 3 \\
- & 2 \\
\hline- & 2 \\
- & 6 \\
- & 4 \\
- & 1 \\
- & 2 \\
- & 2 \\
- & 4 \\
- & 1 \\
- & 15 \\
- & 5 \\
- & 2 \\
- & 1 \\
- & 2
\end{tabular}

Kuban Kawr.

Kisljar 23. V. 94。 R. K

Andshigäntschai 18. VIII. 94. Schllk.

Tiflis 5. V. 92. R.

$$
\begin{aligned}
& \text { " }, \quad \mathrm{R} \text {. } \\
& \text { ఐ } \gg n \text {. } \\
& \text { " } 69 . \mathrm{R} \text {. }
\end{aligned}
$$

Tschaldyr 95. Kawr.

Chram 93. R.

Sachsen 69. gkft.

Deutschland gkft.

Jewlach-See 95. R.

Toporowan 95. Kawr.

"Kawr.

Batum-See IV. 93. R. K.

Wladimirowka 5. V.94. R. K. R. K.

Kisljar 23. V. 94. R, K.

Andshigäntschai 30 . III. 94.

Tiflis X. 88. R.

Schlk.

Borshom VII. 88, R.

Tiflis IV. 96. K.

Kars-tschai 9.. Kawr.

Tskenis-tskali Kawr.

Kura Kawr.

Kura Tiflis Kawr.

Agdam Kawr.

Tschaldyr Kawr.

Arpa-göll Kawr.

Kars-tschai Kawr.

Kura Korechi Kawr.

Borshom Kawr.

Titlis VIII. 98, R. K.

$n \pi$ R. K.

n n $n$ R. K.

Goktschai 94. Kawr. 


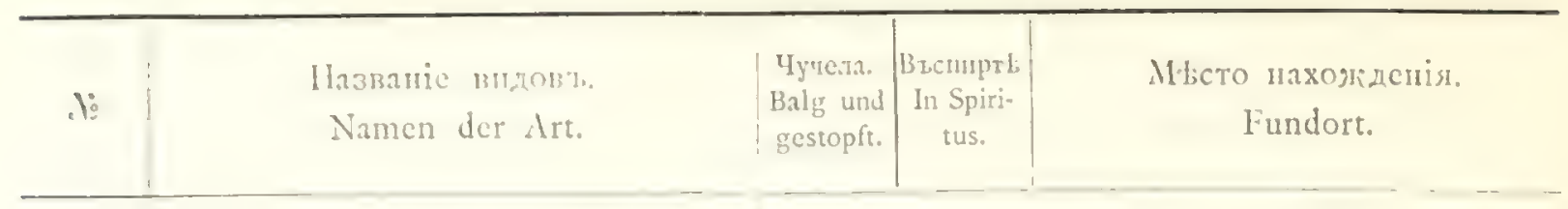

\begin{tabular}{c|c|} 
s. & Capoeta var. Sevangi de-Fil. \\
t. & $n$ \\
u. & $"$ " \\
$116 .{ }^{1)}$ & Capoeta fundulus Pall. Barbus \\
& \multicolumn{2}{|c|}{ tauricus Kssl.? }
\end{tabular}

117.* Barbus vulgaris Flem.

11S. Barbas tauricus Kssl.

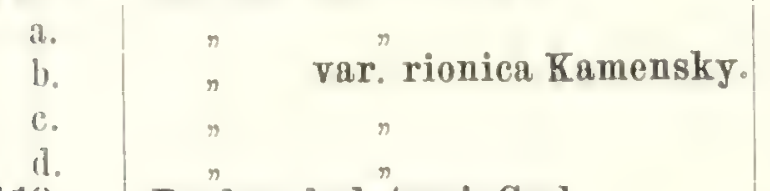

11!. Barbus bulatmai Gml.

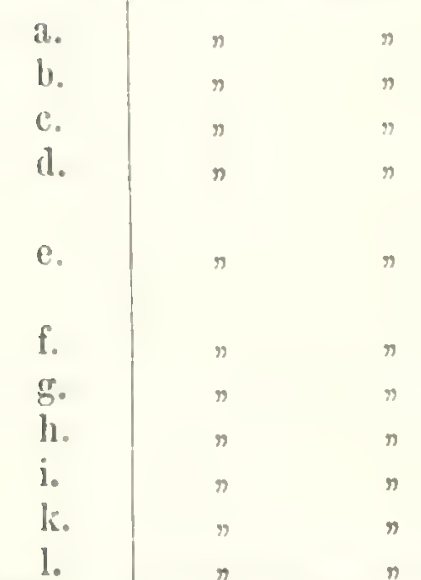

120. Barbus ciscaucasicus Kssl.

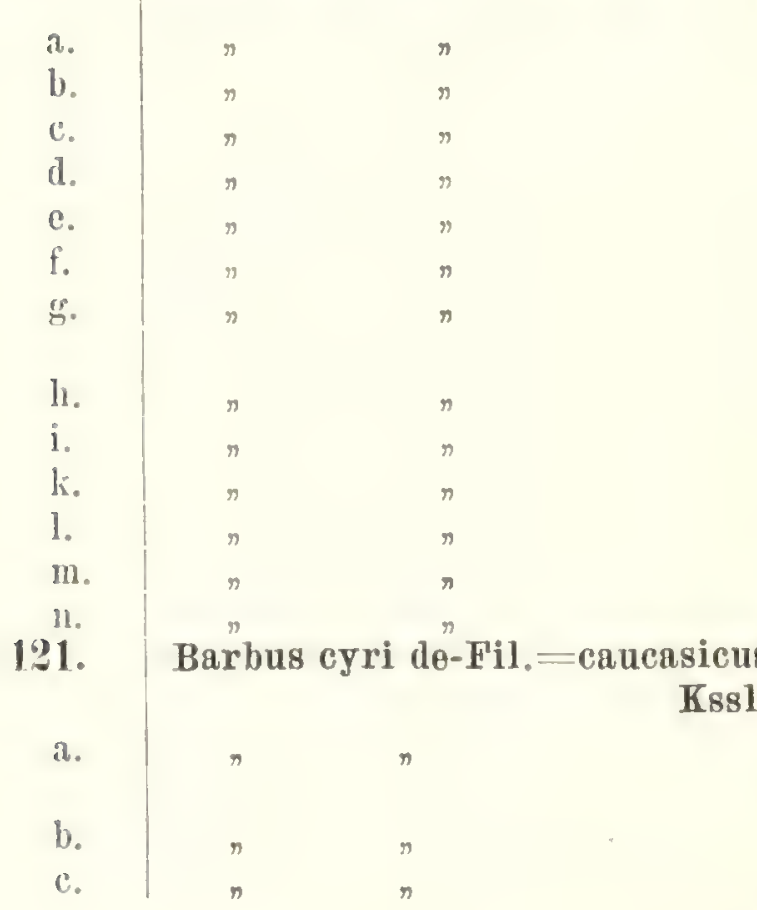

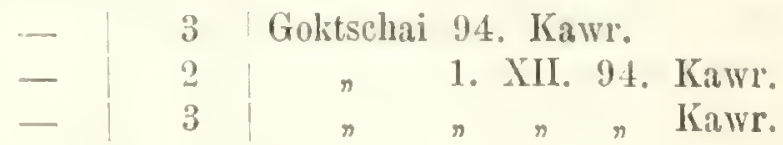
Sachsen gkft.

Salgir R.

Kuban Kawr.

Tskenis-tskali Kawr.

Kutais Kawr.

? Rion Kawr.

Borshom X. 76. v. S. K. II. Gr. M. N.

Tiflis IV. 92. R.

Petrowsk 1. VI. 9.1. R.K.

Lenkoran 66. R.

Andshigäntschai 30 . III. 94 . Schlk.

Kara-su bei Nucha 18. VIII. 94. Schlk.

Kars-tschai 27. X. 95. Kawr.

Titlis X. 88. R.

Borshom Kawr.

Kura Kawr.

Tiflis X. 98. R.

n $\gg \mathrm{R}$.

Sulak bei 'T'schirjurt 30. V. 9t. R. K.

Schatojewsk 10. VII. 94. R. K. Jaryk-su 16. V. 94. R. K.

Akdasch-su 18. V. 94. R. K. Georgiewsk 2. V. 94. R. K. Jaman-su 17. V. 94. R. K. Kambilejewka 11. V.94. R. K. Temir-Chan-Schura 27. VI, 94. R. K.

Grosny 5. VII. 94. R. K. Kisljar 23, V. 94, R. K. Chaldan Kawr.

Kasum-kent Kawr.

Podkumok Kawr.

Grosny, Sunsha Kawr.

'Tiflis X. 88. R.

Karasu bei Nucha 18. VIII. 94. Schlk.

Tanabach VII. 95. K.

Tiflis I. 95 . K. 


\begin{tabular}{|c|c|c|c|c|}
\hline. & $\begin{array}{l}\text { Названіе видовь. } \\
\text { Namen der Art. }\end{array}$ & $\begin{array}{l}\text { Чугела. } \\
\text { Balg und } \\
\text { gestopft. }\end{array}$ & $\begin{array}{c}\text { Becnupt5. } \\
\text { In Spiri- } \\
\text { tus. }\end{array}$ & $\begin{array}{c}\text { Mtсто нахождснія. } \\
\text { Fundort. }\end{array}$ \\
\hline
\end{tabular}

d. Barbus cyri de-Fil. = caucasicus

Kssl

e.

f. $n$ n

. $\pi$ var. tiflissica Kam.

122. Barbus toporovanicus Kam.

123. Barbus bortschalinicus Kam.

124. Barbus goktschaicus Kssl.

125. Barbus armenicus Kssl.

126. Barbus sursunicus Kam.

12\%. Barbus mursa Güld.

\begin{tabular}{l|ll} 
a. & $n$ & $"$ \\
b. & $n$ & $n$ \\
c. & $n$ & $n$ \\
d. & $n$ & $n$ \\
e. & $n$ & $n$ \\
f. & $n$ & $n$
\end{tabular}

128. Gobio uranoscopus Agas.

a. $\rightarrow$

b. $"$,

19!). Gobio macropterus Kam.

\begin{tabular}{r|cc} 
a. & $"$ & $n$ \\
130. & Go bio lepidolemus Kssl.
\end{tabular}

$\begin{array}{lll}\text { a. } & n & n \\ \text { b. } & n & n \\ \text { c. } & n\end{array}$

1:31.* Gobio fluviatilis Rond.

$13 . *$

Lenciscus rutilus $\mathbf{L}$.

a.

$b_{8}$

c.

$1: 3: 3$.

a.

b.

c.

d.

e.

134.

a.

b.

Squalius cephalus L.

Leucisous Frisii Nordm. var.

c. kutum Kam. 
.1

Назаніс видовт.

Namen der Art.

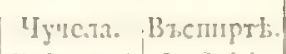

Balg und In Spiri-

gestopft. tus.
Mtсто нахояденія.

Fundort. d. Squalius cophalus $\mathbf{L}$.

$$
\text { e. }
$$

135.

136.

Squalius agdamicus Kam.

Squalius turcicus de-Fil.

it.

b.

c.

d.

e.

a.

b.

c.

d.

140. Tinca "vulgaris Cuv"

a.

b.

141.* Phoxinus laevis Agass

a.*

$14 \%$.

143.

Phoximus stagnalis Warp.

Chondrostoma oxyrhynchum

Kssl.

a.

b. , var. inversa Kam.

114. Chondrostoma abchasicum Kawr.

$145 . *$

a.

146. Chondrostoma cyri Kss1.

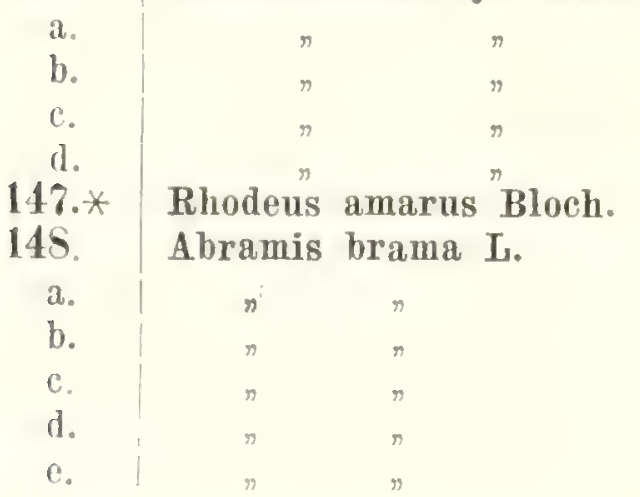

Chondrostoma nasus L.

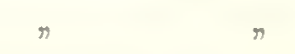

Idus melanotus Heck.

Scardinius erythrophthalmus L.

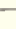

Jaman-su 17. V. 94. R. K. Wladimirowka 5. V. 94. R. K. Salgir $R$.

Agdam Kawr.

Kara-su bei Nucha 18. VIII. 94.

Schlk.

l'iflis IV. $96 . \mathrm{K}$.

94. Schlls.

Kars-tschai 26. X. 95. Kawr.

Tiflis Kawr.

Arpa-göll Kawr.

Toporowan-See Kawr.

omer.

3

Nowy- $\Delta$ fon Kawr.

Lenkoran IV. 66. R.

Petrowsk 1. VI. 94. R. K.

Kisljar 23. V. 94, R. K.

Mahomed-most 24. V. 94. R. K.

Batum-See IV. 93. R. K.

Poti, Palaeostom V. 93. R. K. n IV. 93. R. K.

Mahomed-most 24. V. 94. R. K.

Wladimirowka 23. V.94. R. K.

f. Swijaga Kawr.

Bachwi-tskali Kawr.

Kr. Zarewokoktschaisk Kawr.

Kuban Kawr.

Sulak bei Tschirjurt 30 . V. 9 .

Grosny 5. VII. 94. R. K.

IIokwa Aluchasien VI. 65. R.

Oka gkft.

Wolga bei Kasan 98. Kawr.

T'schoroch IV. 93. R. K.

Kutais Kawr.

Tschaldyr-göll Kawr.

Arpa-göll Kawr.

Tiflis Kawr.

Chaldan Kawr.

Naporiri Alasan Kawr.

\begin{tabular}{c|r}
- & 1 \\
G. & - \\
- & K. \\
\hline G. & - \\
G. & - \\
G. & - \\
G. & -
\end{tabular}

fl. Sura Kawr.

Boshy-Promysl I. 94.

$» \quad \leadsto 94$.

Lenkoran IV. 80. R.

$n$ n R.

Kura III. 71, R. 


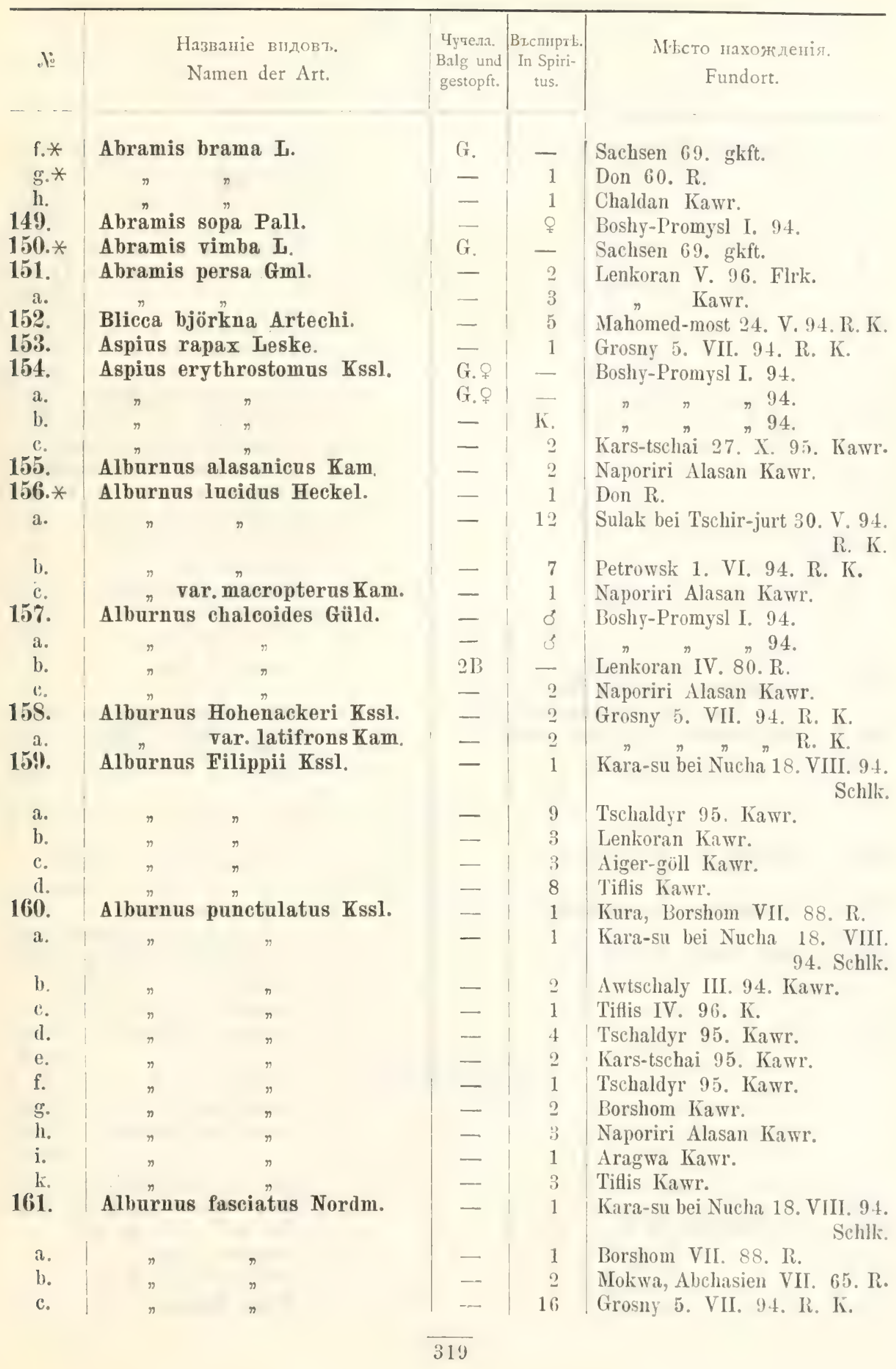




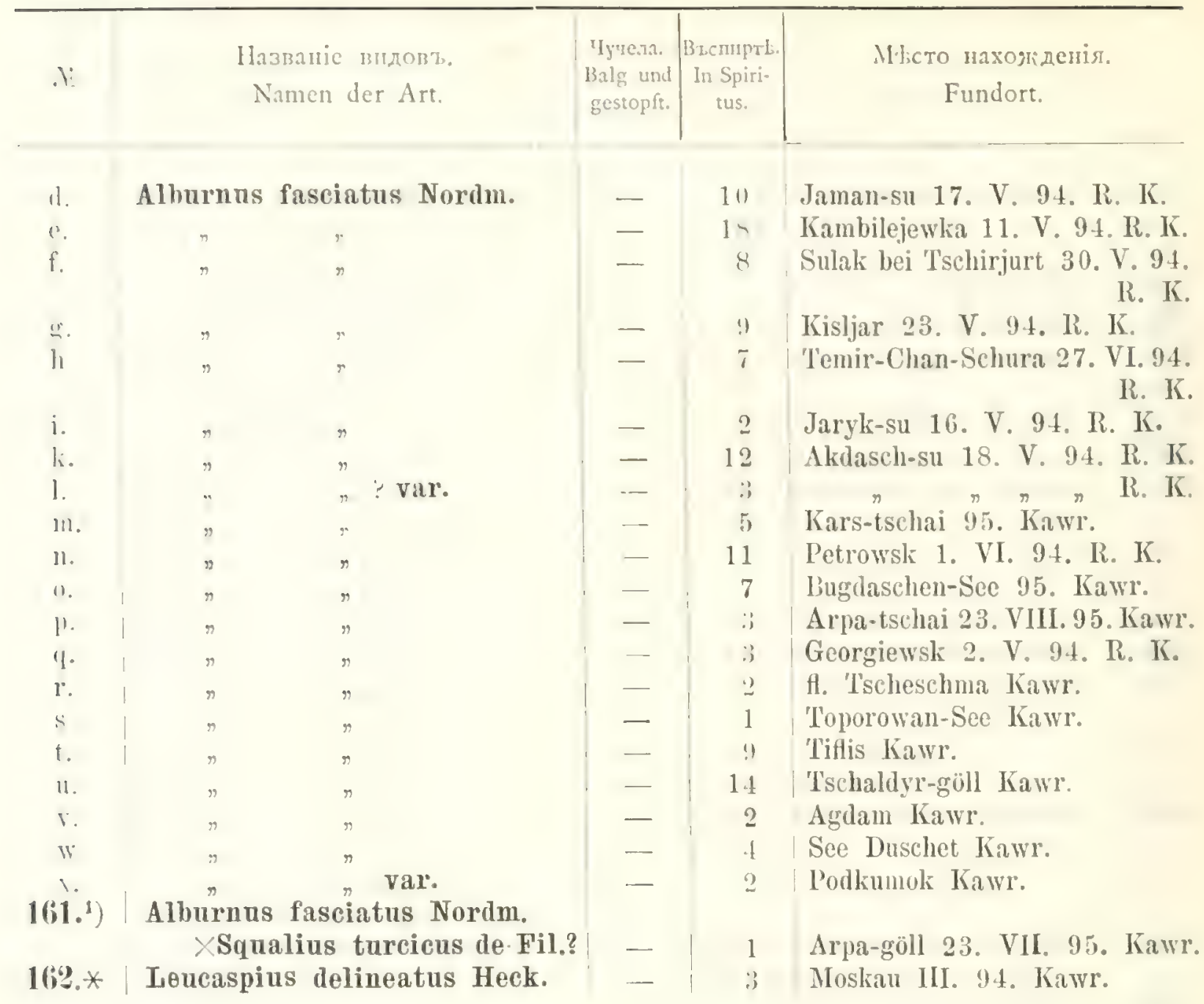

\section{FAM. COBITIDAE}

16::. Nemachilus Brandtii Kssl.

164. Nemachilus barbatulus L.

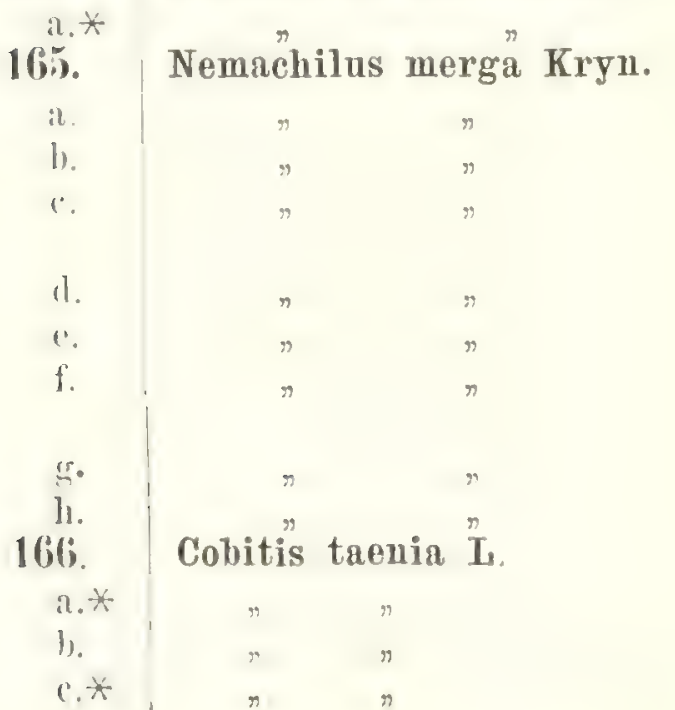

Tiflis Kura III. 94. Kawr.

" " " Kawr.

H. Kasanka Kawr.

fl. 'I'scheremschan Kawr.

Schatojewsk 10. VII. 94. R. K.

Balta 30. IV. 94. R. K.

Jaman-su 17. V. 94. R K.

Sulak bei Tschirjurt 29. V. 94 .

R. K.

Jaryk-su 16. V. 94. R. K.

Akdasch-su 18. V. 94. R. K.

Temir-Chan-Schura 27. VI. 94.

R. K.

Grosny VII. 94. R. K.

Kambilejewka 11. V. 94. R. K.

Poti 4. V.93. R. K.

Peipussee Akad.

Batum IV. 93. R. K.

Wolga Kawr. 


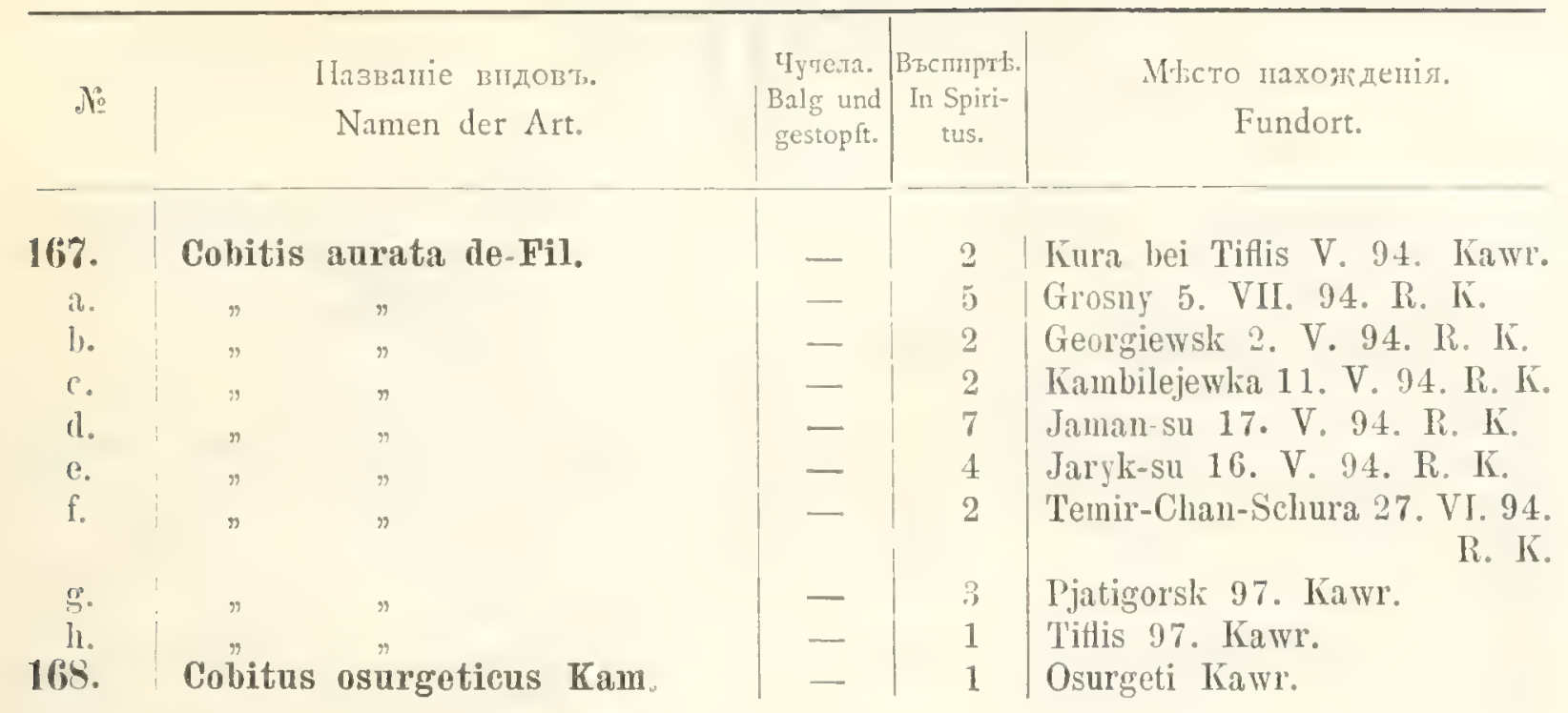

\section{FAM. CLUPEIDAE。}

\begin{tabular}{|c|c|c|c|c|}
\hline 169. & Engranlis encrasicholus $\mathrm{I}$. & - & 1 & Mare nigr. 94. Ostroumow. \\
\hline il. & & 一 & 2 & Theodosia I. 93. Retowsky. \\
\hline b. $*$ & & & 2 & Mare medt. 68. A. Brandt. \\
\hline 170. & Cluper pontica Eichw. & - & 2 & Noworossiisk I. 94. Ehrtmann. \\
\hline $\begin{array}{l}\text { a. } \\
\text { b. }\end{array}$ & $n$ & - & 1 & Mare nigr. 94 . Ostroumow. \\
\hline c. & $"$ & 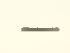 & 1 & Krim $60 . \mathrm{R}$. \\
\hline d. & $\pi \theta^{n}$ & - & 1 & Petrowsk 1. VI. 94. R. K. \\
\hline 171. * & Clupea sprattus I. & - & 1 & Mare german. gkft. \\
\hline 172. & Clupea caspia Eichw. & - & 2 & Batum IV. 93. R. K. \\
\hline $\begin{array}{l}173 . \\
174^{a} *\end{array}$ & $\begin{array}{l}\text { Clupea cultiventris Nordm. } \\
\text { Clüpea pilchardus Wall. }\end{array}$ & - & $\begin{array}{l}1 \\
2 \\
1\end{array}$ & $\begin{array}{l}\text { Don Mündung 94. Kawr. } \\
\text { Mare medt. R. " Kawl. } \\
\text { M" }\end{array}$ \\
\hline
\end{tabular}

\section{FAM. MURAENIDAE。}

175.* Conger valgaris Cav. $|-|-1$ | Mare medt. 68. A. Brandt.

\section{LOPHOBRANCHII.}

\section{FAM. SYNGNATHIDAE.}

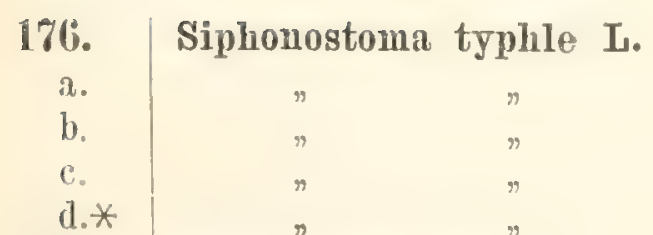

17\%. Syngnathus acus" L.

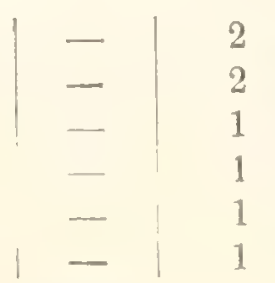

Batum IV. 93. R. K.

Mare nigr. 60. R.

Sewastopol 94. Ostroumow.

Theodosia I. 93. Retowsky.

Mare german. R.

Theodosia I. 93. Retowskt? 
Ilazmanic monerto.

Namen der Art.
'Jyersiz. |Bicussprti. 13alg und In Spirigestogrt. its.
Mr. To naxogrenis

Fundort. a. Syngnathus acus I

h.*

7. Syingathus bucculentus Rathe

$$
\text { i. }
$$

b.

10!. Syngmathus phlegon Risso.

iso. Nerophis ophidion Is.

a.
151.
i.
i.

\begin{tabular}{l|r}
- & 0 \\
- & 2 \\
- & 1 \\
- & 25 \\
- & 2 \\
- & 4 \\
- & 1 \\
- & 6 \\
- & 1 \\
- & 1 \\
- & 2 \\
- & 1 \\
- & 1 \\
- & 1 \\
- & 1
\end{tabular}

Sewastopol 94. Ostroumow.

Mare german. gght.

Sewastopol $60 \mathrm{k}$. L3altum 1V.93. R. K. Hare nigr. (i). R.

Petrowsk 1. VI. 94. K. K. Marmora Meer 94. Ostroumow. Sewastopol 94. Ostroumow. Mare nigr. 87. Ungern-Stemberg. liatum IV.93. R. K.

Theodosia I. 93. Retowsliy. Male nigr. 60. R.

Sewastopol 9. Ostrounow. Mare medt. 68. A. Brandt. Anapa 30. IV. 97. Dulin.

\section{CHONDROSTRI.}

\section{FAM. ACIPENSERIDAE}

18\%. I Acipenser rutheuts Is.

$\begin{array}{lll}\text { a. } & " & " \\ \text { b. } & " & " \\ \text { c. } & " & n\end{array}$

15\%. Acipenser sch"yna Lov.

154. Asipenser huso $I_{\text {s }}$

15\%. Acipenser stellatus Pall.

156. Acipenser Güldenstaedi Bondt.

a.

b.

18\%* Acipenser sturio "L。

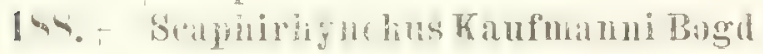

$$
\text { a.t }
$$

1.juv. I) III. 94. Kawr.

1 I I. 93. R.

liostow glift.

- 1 gesch.

¿juv. Don III. 94. Kaws.

Boshy-Promysl III. 9:. gesch.

$n$ Alichanow,

$»$ IV. 66. R.

Lenkolan IV. 66. R.

'liheodosia I. 93. Retowsliy.

Rion I. 9:). R.

Boshy-Promysl III. 93. gresch.

'liflis IV. 66. R.

Nordsee gkft.

Imu-Ibaja s:3. I'etrushowsliy.

Dshardshui-Amu-Darja 97. Licharew. 


\section{PLAGIOSTOMII.}

\section{FAM CARCHARIDAE.}

\begin{tabular}{|c|c|c|c|c|}
\hline$\therefore$ & $\begin{array}{l}\text { Haзванie вгдовт. } \\
\text { Namen der Art. }\end{array}$ & $\begin{array}{l}\text { Iyre.ta. } \\
\text { Balg und } \\
\text { gestopft. }\end{array}$ & $\left|\begin{array}{c}\text { Bronuptd. } \\
\text { In Spiri- } \\
\text { tus. }\end{array}\right|$ & $\begin{array}{c}\text { MH, to naxomzenis. } \\
\text { Fundort. }\end{array}$ \\
\hline
\end{tabular}

159.* $\mid$ Mnstelus vulgaris Mrüll. $\mid$ G. $\quad-$ Mare medt. 6. 4 . Brandt.

\section{FAM. SCYLLIDAE.}

190.* Scyllium canicula I. $\quad-\quad-\mid 1$ Mare medt. is. A. Brandt.

\section{FAM. SPINOCIDAE,}

191. | Acanthias vulgaris Risso. $|-| 1$ | Theodosia I. 93. Retowsky.

\section{FAM. RHINIDAE.}

19\%.* Squalina vulgaris Mül. $\mid$ C. $\mid$ - Mare medt. 68. A. Branlt.

$$
\text { FAM. RAJIDAE. }
$$

19): * | Raja miraletus L. $\mid$ G. $\mid-$ Mare merlt. 68. A. Brandt.

$$
\text { FAM. TRYGONIDAE }
$$

191. | Trygon pastinaca L. $\quad$ - $\mid 1$ | Batum IV.93. R. K.

$$
\text { FAM. TORPEIINIDAE. }
$$

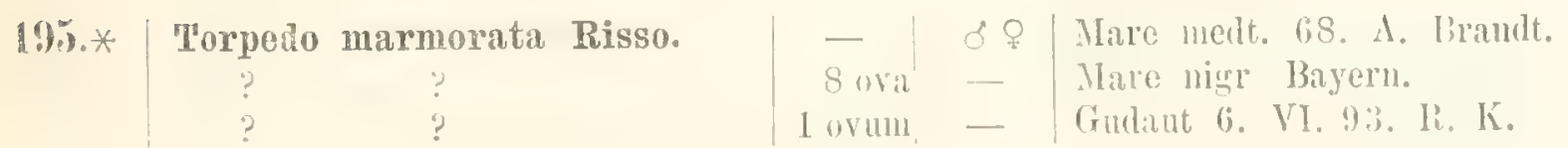




\section{MARSUPOBRANCHII.}

F A M. M Y X I N O I E I.

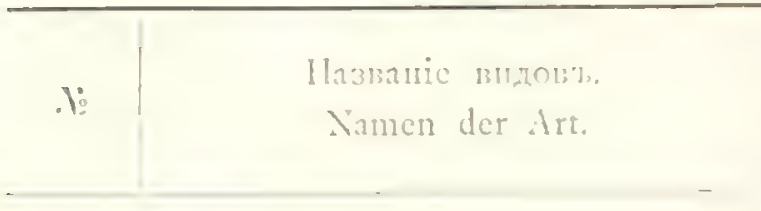

196.* / Myxine glutinosa L.

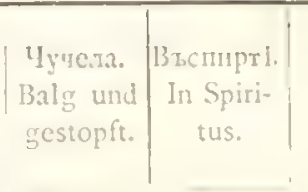

\begin{tabular}{c|c|} 
Myocia. & Bzominti. \\
Balg und & In Spiri- \\
gestopft. & tus.
\end{tabular}

- 1 | Mare german. glift.

\section{FAM PETROMYZONTIDAE}

\begin{tabular}{l|l|l|l|l|l|l|l} 
197. & Petromyzon Wagneri Kss1. & - & Lenkoran IV. 66. R,
\end{tabular}

\begin{tabular}{l|l|l|l|l} 
a. & $n$ & -1 & 'liflis II, 67. IR.
\end{tabular}

b. $n$

c. $n$

d. 1

e. $\rightarrow \quad r \quad-1$, Jewlach 96. Kawr.

195. $*$ Petromyzon fluviatilis L. $\quad-\quad$ | 1 Newa Mlad.

\section{CIRROSTOMI.}

\section{FAMA A M P TOXINI.}

19!. Branchiostoma lanceolatum Pall. $-\quad$ | Sewastugul !r. Ostrounow. 


\title{
Окончательный результатъ изсльдованій Salmo trutta caspius Kessl., S. trutta L. S. lacustris L. : S. trutta fario L.
}

\author{
Ө. КАВРАЙСКАГО.
}

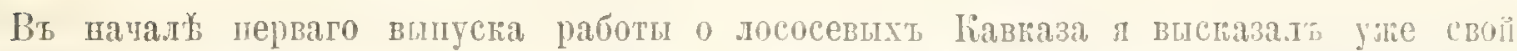

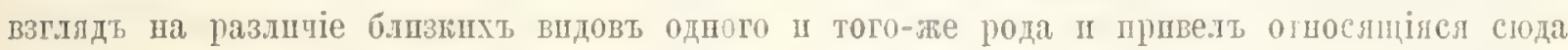

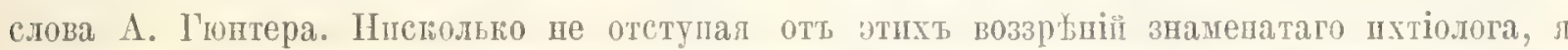

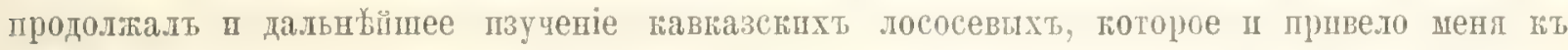

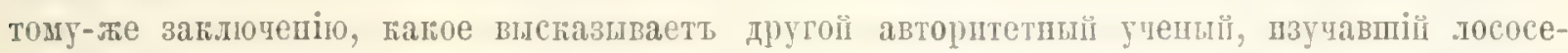

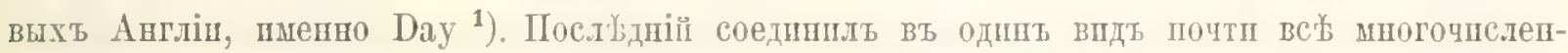

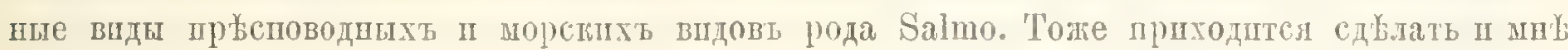

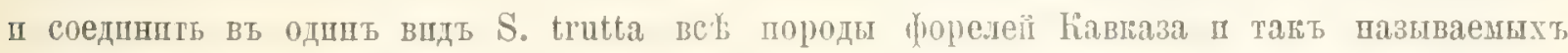
кавказскихь лососей. ІІравда, у меня не было хоропаго әкземпляра черноморстаго лососл, входящаго вт р’кп его восточнаго поберелья, но суди по одному эгземляру, полученно-

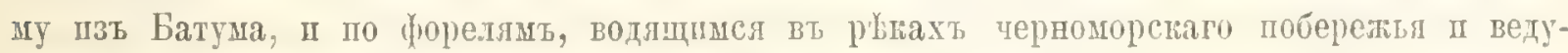

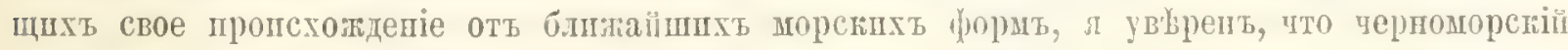
лосось, нослщії у прпбрежнихт жіптелеі пазваніе "ловрав" (Salmo labrax Pall.) отно-

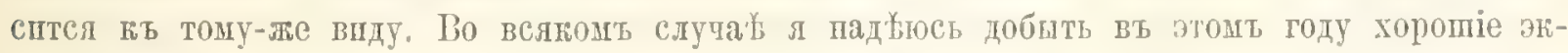

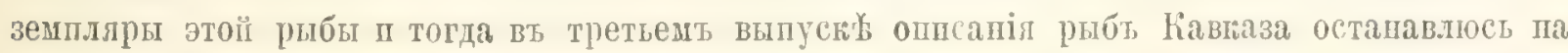

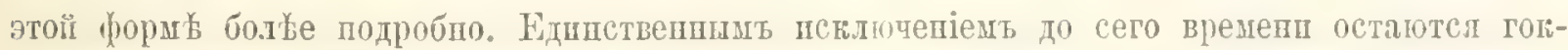

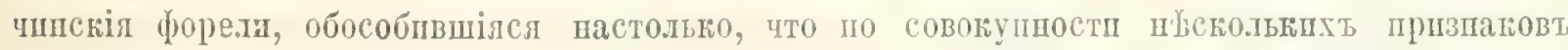

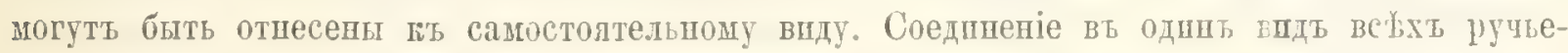

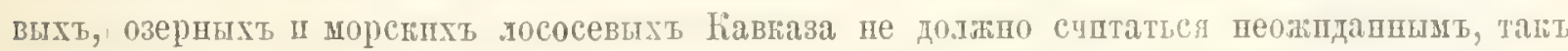

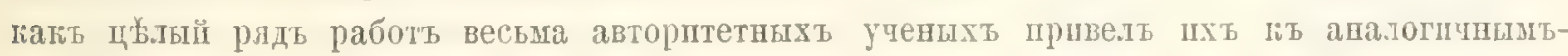

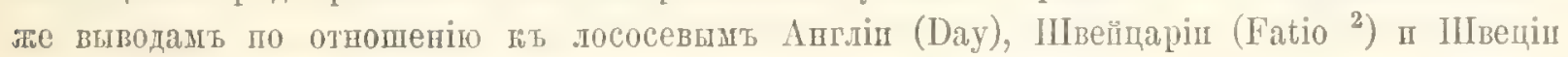
$\left(\right.$ Smitt $^{3}$ ). Поэтому подобный результать можно было предвндыть пи до огончанія работы,

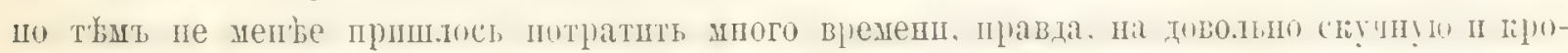

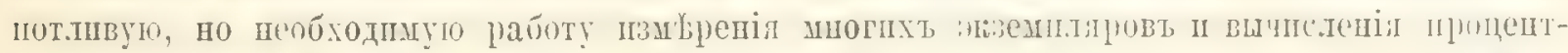

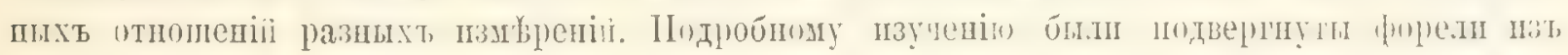

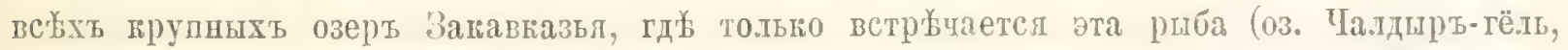

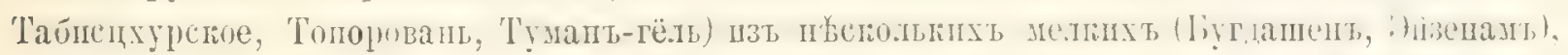

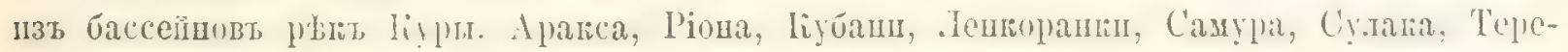

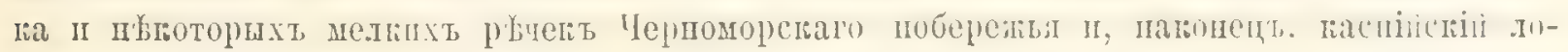

$\left.{ }^{1}\right)$ F. Day. British and Irish Salmonidae p. 145: If we examine the varions repudet species of British trout we find them divided into migratory anodromous forms and the nnn-migratnry tresh water races, but no one has been able to clearly define where ove ends and the other begins.

$\left.{ }^{2}\right)$ V. Fatio. La faune des vertébrés de la Suisse.

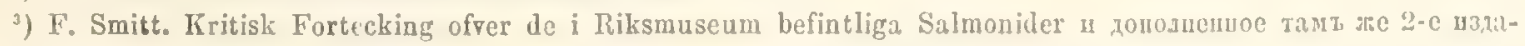
uie: A History of Scandinavian Fishes. 


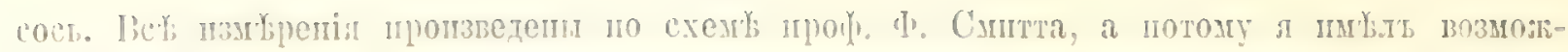

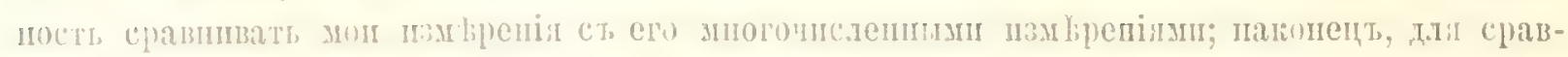

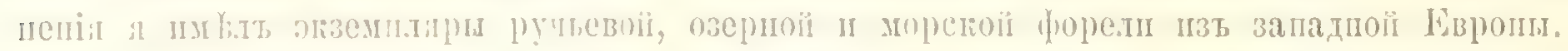

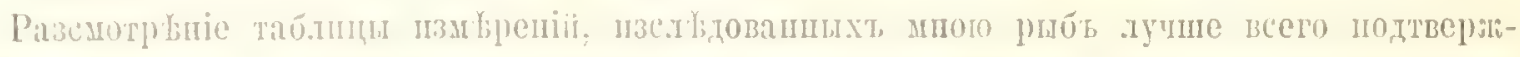

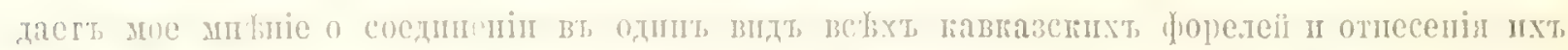

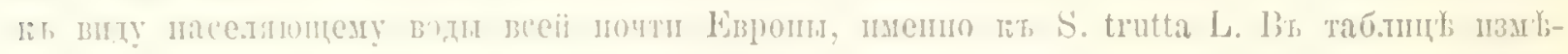

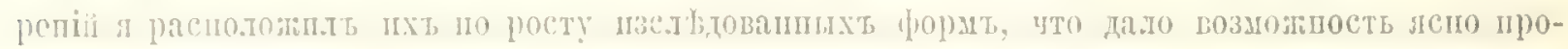

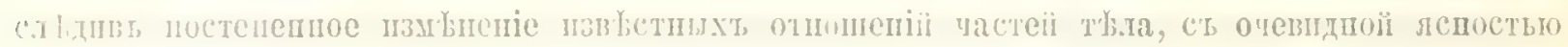

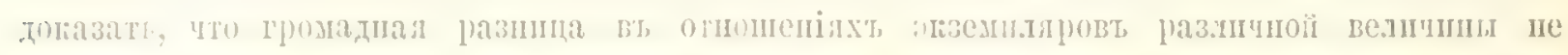

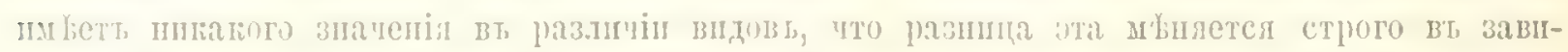

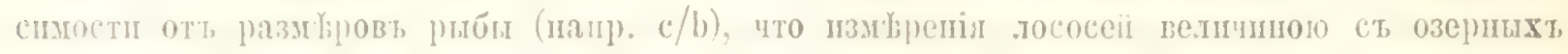

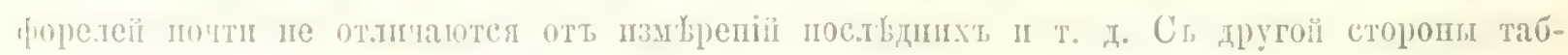

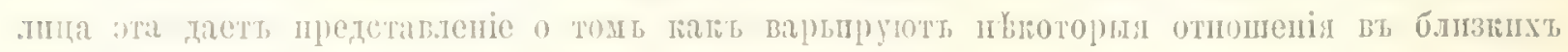

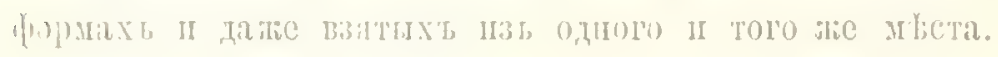




\title{
Schlussresultat iiber die Untersuchungen von Salmo trutta caspius Kessl. S. trutta L. S. lacustris und S. trutta fario L.
}

\author{
voll
}

\section{F. KA W RAIS KY.}

An Anfange der ersten Lieferung der Arbeit über die Lachse des Kaukasus hale idn sulon meine Ansicht über die Unterschiede nahe verwandter Arten in ein und demselben Genus ausgesprochen und führte die darauf bezüglichen Worte A. Günthers an. Nicht im Geringsten von diesen Anschauungen des beriahmten Ichthyolggen abweichend, setzte ich dic weiteren Untersuchungen der kaukasischen Lachse fort, welche mich zu denselben Suhlussen führten, die eine andere Autorität, welche dic Lachse Englands studirte, ermitteltc, nämlich der Gelehrte Day ${ }^{1}$ ). Letzterer vereinigte in eine Art fast sämmtliche zahlreiche Süsswasserund Neeres-Arten des Genus Salmo. Ich bin genüthigt das Gleiche zu thun und alle $\Delta$ rten der Forellen des Kaukasus und der sogenannten kaukasischen Lachse in eine Lrt: S. trutta zu vereinigen. Zwar habe ich kein gutes Exemplar des Lachses aus dem Schwarzen Meere vor mir gehabt, welcher in die Flüsse des Ostufers steigt. Jedoch nach einem aus Iatum erhaltenen Exemplare zu urtheilen und nach Forellen, welche in den Flüssen des Suhwarzen Meeres vorkommen und ihre Abstammung von den nächsten Meeresformen ableiten, bin ich überzeugt, dass der Schwarze Meer Lachs, welcher bei den Uferbewohnern den Namen „Lowraki" (Salmo labrax Pall.) führt, zu derselben Art gehört. Jedenfalls hoffe ich in diesem Jahre gute Exemplare von diesem Fische zu erhalten und werde mich dann in der

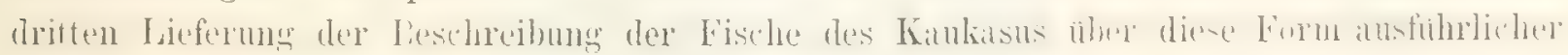
aussprechen, גIs einzige Ausnahme bleibt bis jetzt die Forelle aus dem Goktschai See, welche sich so weit ausgebildet hat, dass sie nach der Summe einiger Merlimale als selbstständige Art betrachtet werden kann.

Die Vereinigung sümmtlicher Fluss-See-und-Neeres-Lachse in cine Art kommt nicht unerwartet, da eine ganze Reihe Arbeiten sehr gelehrter Autorititen zu analogen Resulta-

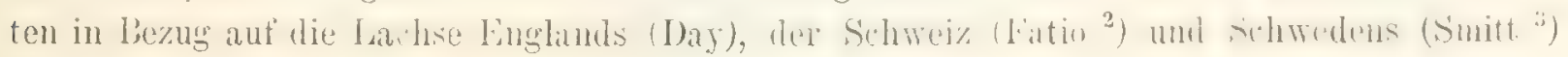
führte.

Daher war ein ähnliches Resultat vor Beendigung unserer Arbeit schon vorauszusehen, dessen ungeachtet wurde viel Zeit verwendet auf die zwar langwierige und mühsame, jedoch nothwendige Arbeit der Ansmessungen vieler Lemplare und atuf die Ansechumgen

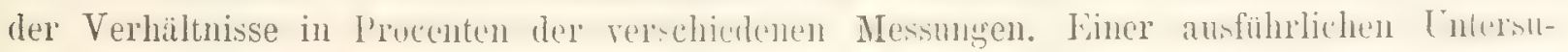

1) F. Day. British and Irish Salmonidae p. 143: "If we examine the various repulet species of British trout we find them divided into migratory anodromous forms and the non-migratory fresh water races, but no nne has been able to clearly define where one ends and the other begins.

$\left.{ }^{2}\right)$ V. Fatio. Faune des vertébrés de la Suisse.

${ }^{3}$ ) F. Smitt. Kritisk Fortecking ofver de i Riksmuseum befintliga Salmonider und die 2-te vom ihm vervollständigten Ausgabe von $\Lambda$ History of Scandinavian Fishes. 
chung wurden die forellen aus allen erossen Seen Transliaukasiens unterzogen, wo sie vorkommen, ('schaldyr-gül, 'T'ahiszchuri, 'Toporowan, Tuman-göll) aus einigen kleinen (Bugdaschen, Lisenam), ans den Gebieten der l'lïse lüura, Araxes, Rion, Kuban, Lenkoranka, S'amur, s'ulak, 'l'erek und einiger kleinen lilisschen des Schwarzen Meer Ufers und zum Schlusse: wurle der kaspische Lachs untedsucht. Alle Ansmessungen wurden nach dem Schema von I'rof. li. Smitt ausgefihht, daher war es mir möglich meine Messungen mit seinen zahlreichen zu rogleichen; endlich hatte ich Lixemplare der Fluss-See-und-Aceres-Forelle aus dem westlichen Luropa zum Verweich por mir.

Die Durchsicht der Messungstabellen der von mir untersuchten Fische bestätigt am besten meine Ansicht, dass alle kaukisischen forellen in cine Art z! vereinigen sind und zwar mit derjenigen Art, welche alle Gewässer ron fast ganz Europa bewohnt, nämlich mit S. trutta I. In den Messungstabellen habe ich sie nach der Grösse der untersuchten Formen wruppirt. Dieses gab die Möglichlieit deutlich die allmähliche Veränderung bestimmter Verhältnisse dir Kürpertheile zu verfolgen, und klar zu beweisen, dass die grosse Verschiedenheit der Verhältnisse an Exemplaren von verschiedener Grösse garkeine Bedeutung zum Untersheiden der diten hat, ferner, dass dieser Untersehied sich mit dem Wachsen der Fische rerindert (\%. Ib.c/b), endlich, dass die liessungen an den Lachsen, die von der Grösse der Seeforellen sind, ich fast garnieht ron den Messungen der letzteren unterscheilen $u$. s. w. 
e
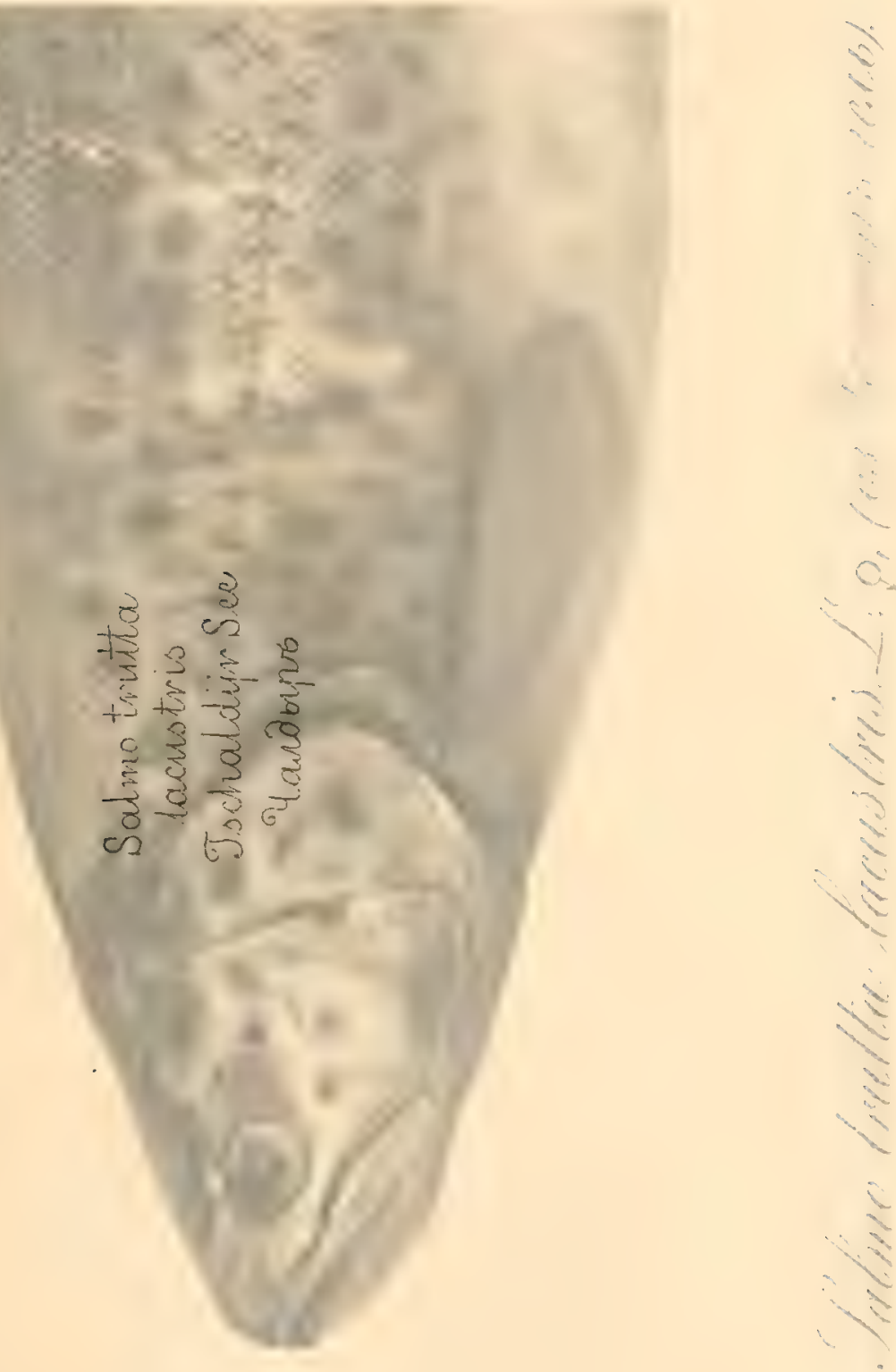


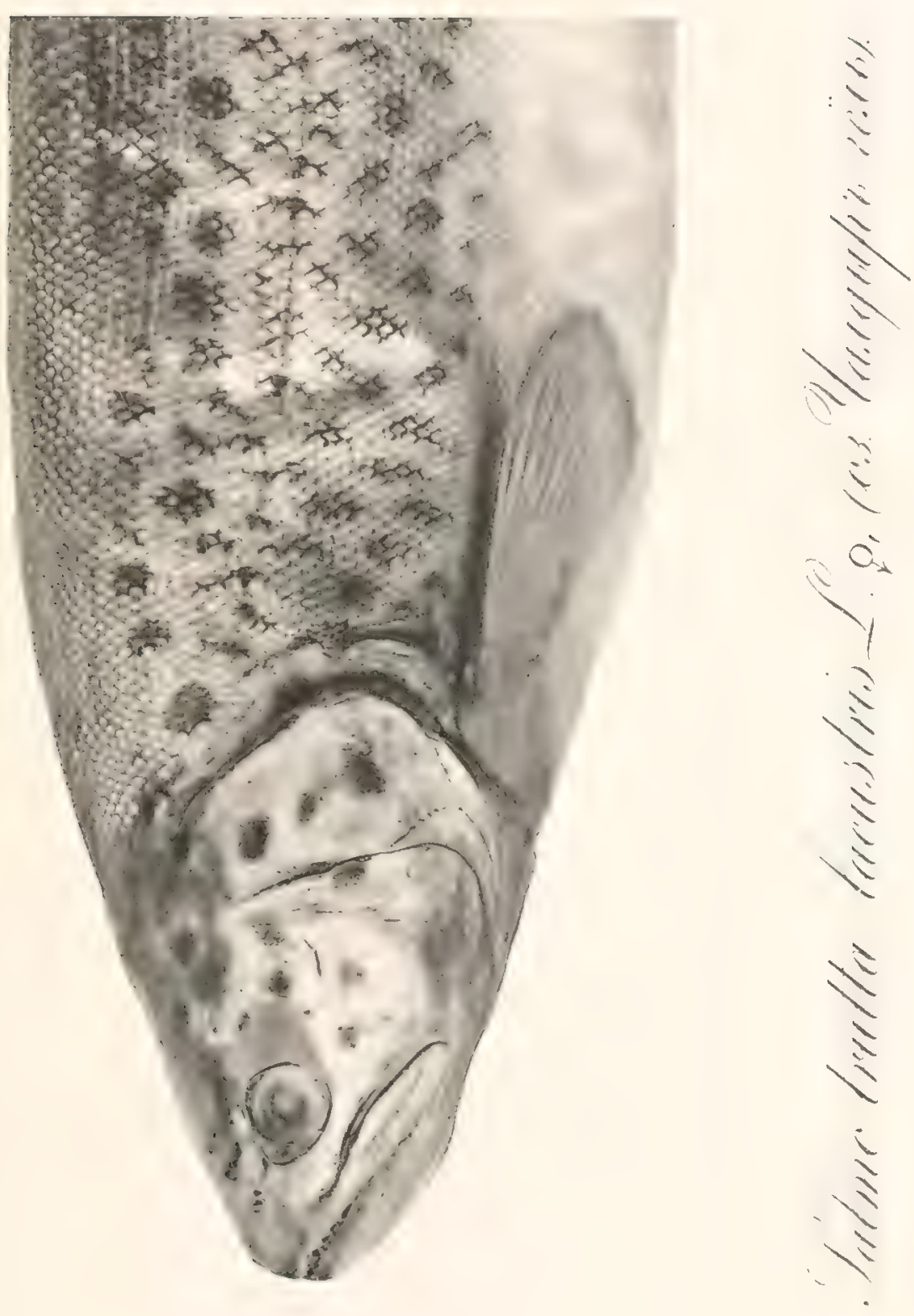


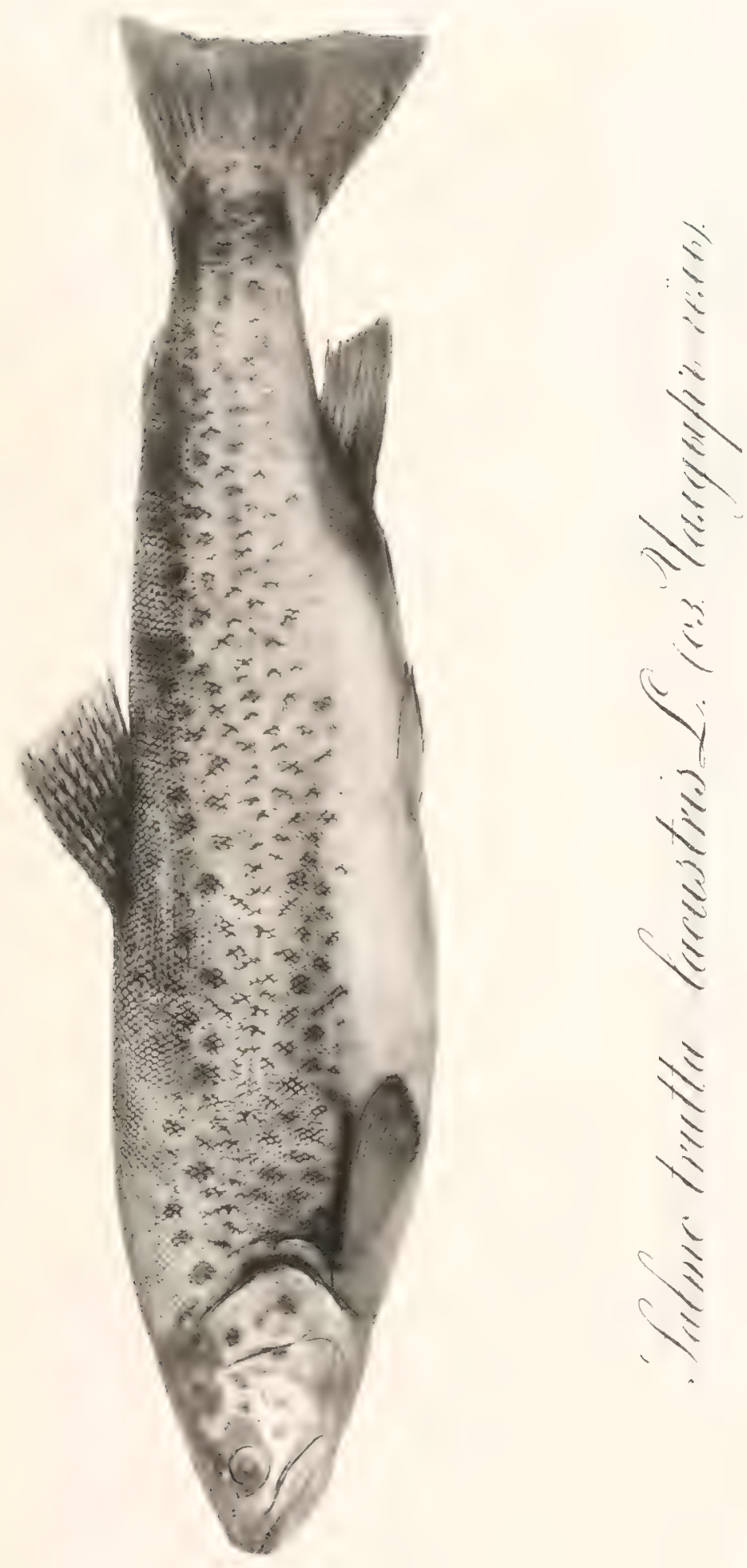



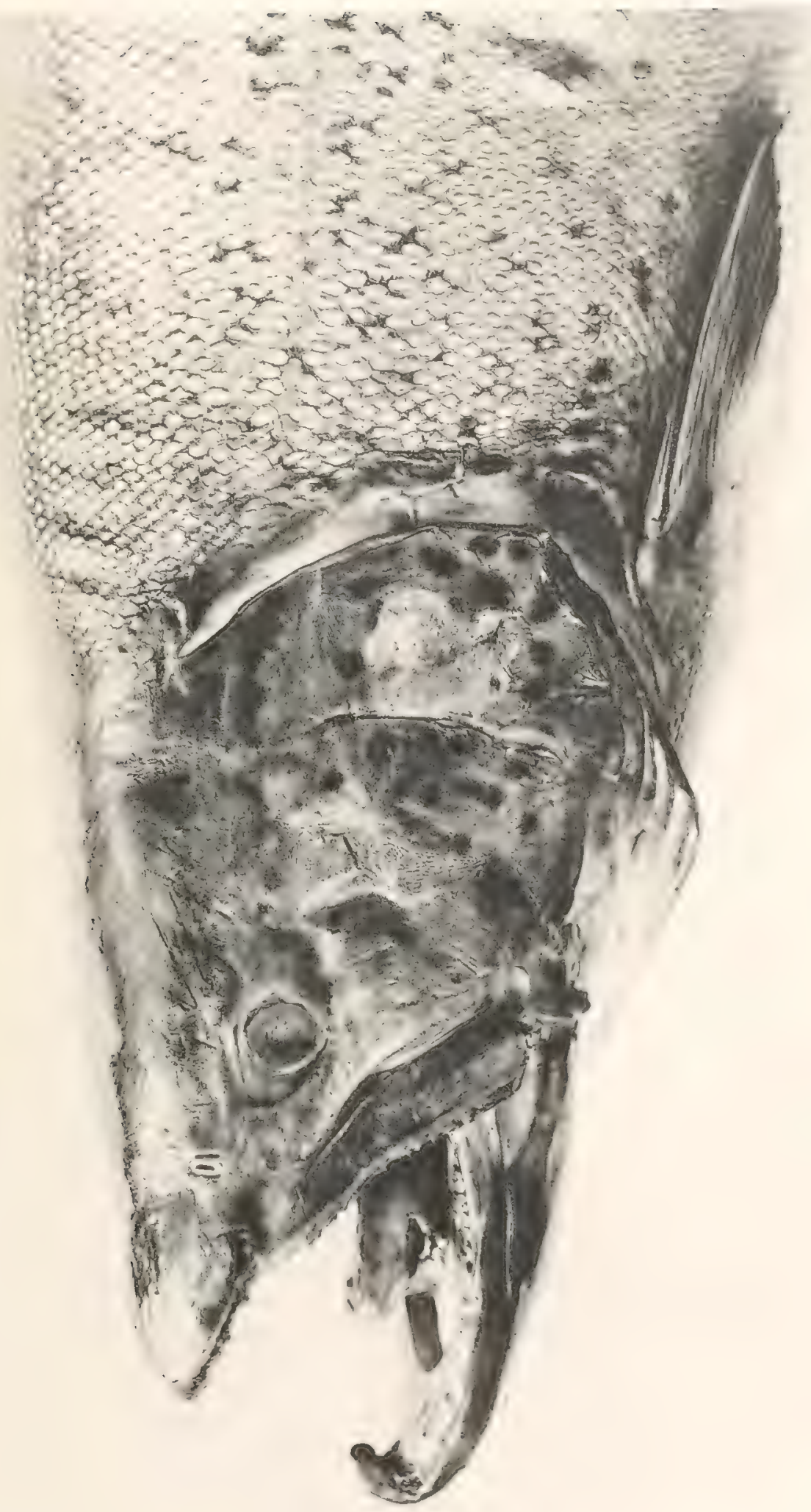




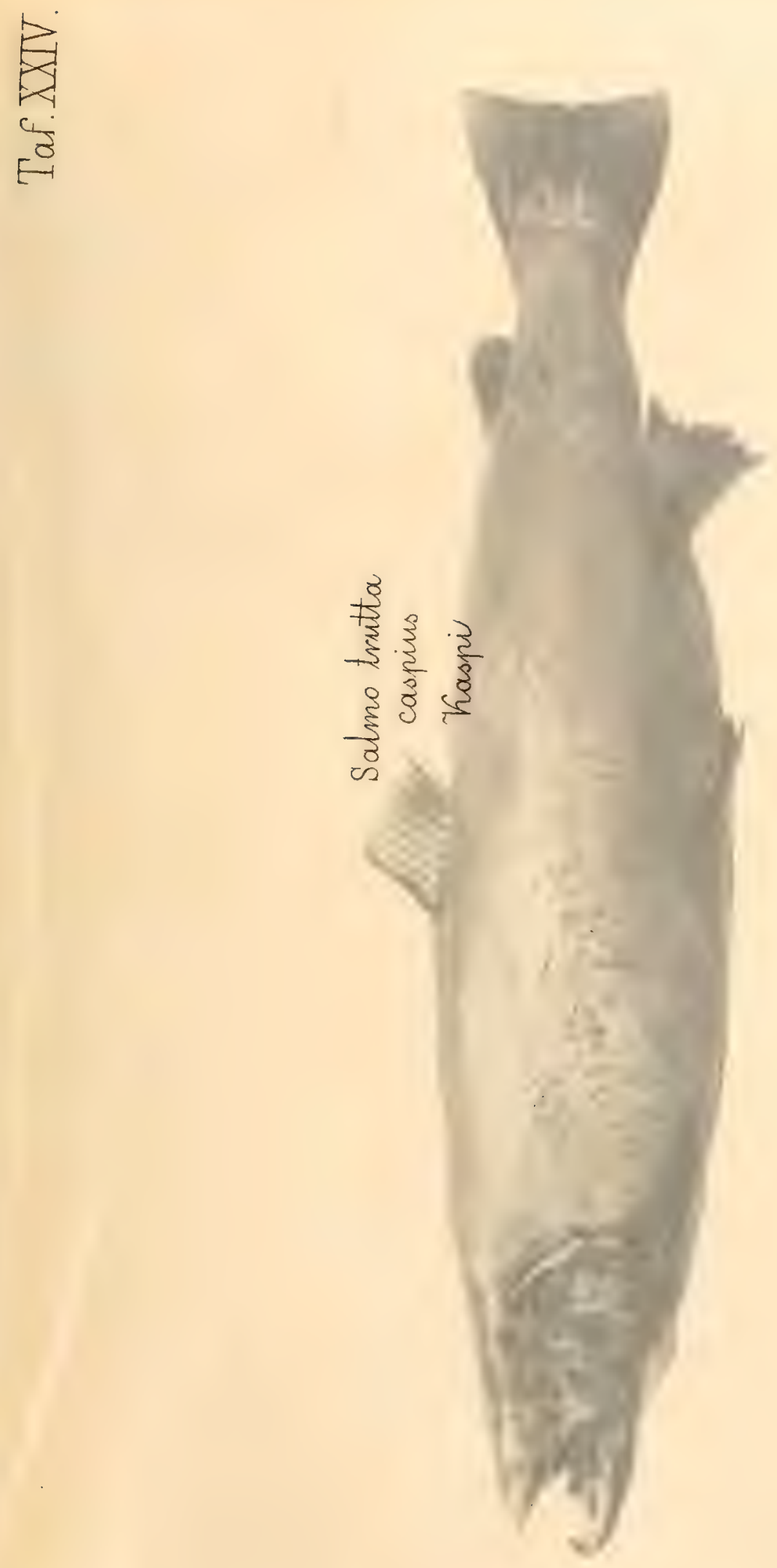



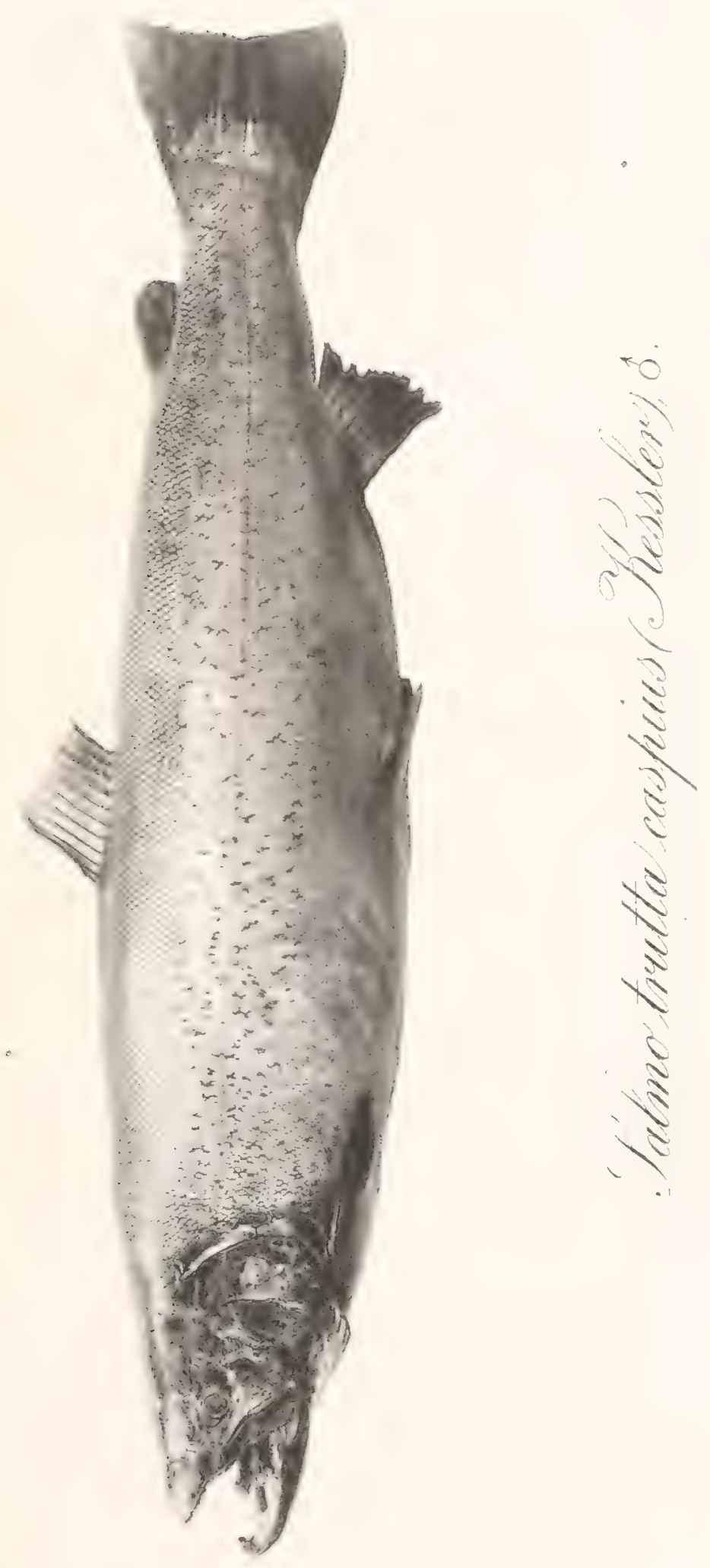



ARTHROZOA.

\title{
INSECTA.
}

\author{
H А С В К 0 M Ы Я.
}

\section{INSECTEN.}

Пккат_25, 29, 29 A, :30, 32.-Schrank 



\section{N S E C T A.}

\section{COTРУДНИКИ-MITARBEITER.}

\section{COLEOPTERA.}

E. Abeille de Ierrin. Marseille. Bupr. Malach.

E. Brenske. Potsdam. Melolonthidae.

J. Daniel. München. Leptura.

J. Desbrocher's des Loges. Tours. Curcul.

Dr. C. A. Dohm. Stettin 1863-1877.

Dr. E. Eppelsheim. Grünstadt. Stanlıyl,

Dr. K. Escherich. Karlsruhe. Meloidae.

J. F'aust. St.-Petersburg. Wiborg. Curcul.

L. Ganglbauer. Wien.

Dr. L. v. Heyden. Frankfurt a. M.

G. Jacobson. St.-Petersburg Chrysomel.

W. Jakowlew. Irkutsk. Sphenopt. Prionus.

II. v. Kiesenwetter. Dresden.

Th. Kirsch. Dresden. Cleonus.

L. Koenig. 'Tiflis.

Hans Leder. Paskan 1875-1898.

A. Morawitz. St.-Petersburg. Carabicidae.

Dr. G. Radde. Tiflis.

Dr. E. Reitter. Paskau. seit 1875.

J. Schilsky, Berlin. Dasytini, Byrrhidae, Mordellidae.

J. Schmilt. Garlitz. Histeridae

P'rof. O. Schneider. Dresden.

1. Schultze. Detmold. Ceutorrhynchidae.

O. Schwarz. Berlin. Elateridae.

Dr. G. Seidlitz. Königsberg, München. IIeteromera.

Dr. G. Sievers. Tiflis. Aufstellen der Sammlung.

S. M. Solsky. St.-Petersburg. Staphylinidae.

T. Tschitscherin. Olgino. Feronidae.

J, Weise. Berlin. Coccinellidae.

\section{LEPIDOPTERA.}

Seine Kaiserliche Hoheit Grossfürst Nikolai Michailowitsch.

S. Alpheraky. St.-Petersburg.

II. Christoph. Sarepta, St.-l'etersburg. 18711894.

Dr. G. Radde. Titlis.

Dr. G. Sievers, Tillis.

Dr. O. Staudinger. Blásewitz seit 1875.

\section{HYMENOPTERA.}

H Friese. Innsbruck. Apidae.

1. Handlirsch Wien.

F. Kohl. Wien.

F. Konow. p. Teschendorf. Tenthredinidae.

Dr. 1. Mocsary. Ludapest. Chrysididae.

Dr. F. Morawitz. St.-Petersburg. Aculeata, Alidae.

\section{DIPIIERA.}

B. Lichtwardt. Berlin.

\section{ORTHOPTERA.}

E. Koenig. Tiflis. Libellulidae.

J. Reltenbacher. Wien. Orthopt, transkip.

N. Subowsky. St-Petersburg, Orthopt, kauk.

H. Wasmann. Exaeten. T'ermiten.

\section{HEMIPIERA.}

E. Autran. Chambésy. Homoptera.

Dr. G. Horváth. Budapest.

W. Jakowlew. Irkutsk.

Dr. 1. Puton. Riemiremont. 


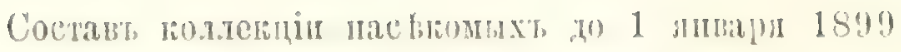
Gesammtbestand der Sammlung von Insecten bis 1 Januar 1899.

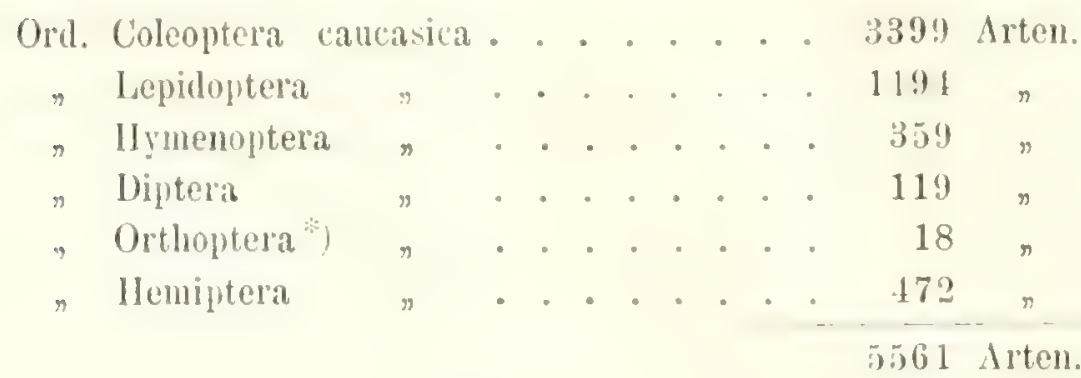

Ord. Coleoptera transcaspica. . . . . 874 Arten.

"Hymenoptera $n$...... 15j n

" Orthoptera ". . . . . . 58 r

, Hemipteria $n$...... 52 ,

639 Arten.

Ord. Coleoptera europaca. . . . . 2609 drten.

"Lepidoptera " . . . . . $1581 "$

, Ilymenoptera "....... 6.44 "

" Diptera $" . . . .0333$. . . 33

"Hemiptera $"$. . . . . 13\%"

5,300 Arten.

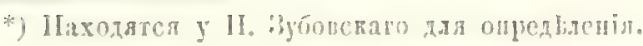

*) Befinden sich bei $\mathrm{X}$. Subuwsky zur Lestimmung. 


\section{СОКРАЩЕНІИ МБСТОНАХОНДЕНІИ.}

\section{ABKÜRZUNGEN DER FUNDORTE.}

A bago

Abastuman

Abchasien

Achalkalaki

Achalzich

Ach-bulach

Adsharia

Akstafa

Alagoes

Alburs

Alexanderhilf

Alexandropol

Alindshi-tschai

Anitino

A)scheron

Arabica Gebirge

Ararat

Araxes

Ardebil

Armenia

Artschewan

Aschisch-dade

Atschikulak

Awtschaly

lielasuwar

Betlınien

Bitschenag

Bjely-klutsch

Bogos-Jiäsan

IBonos-mta

Borshom

Burtunai

Chanakoi-tau

Chassaw-jurt

Chewsurien

Chosapinsk

Circassia

Dadiasch

Dagestan

Daratschinsk
Abg.

Abst.

Abch.

Achllk.

Achr.

Ach-bu.

Adsh.

Aksf.

Alag.

Albr.

Alexh.

Alexp.

Alind-tsch.

Anit.

Apsch.

Arab. G.

drat.

Arax.

Ardbl.

. $1 \mathrm{rm}$.

Irtschw.

Isch-da.

Itschkul.

Awtsch.

Belasw.

Bethn.

Btschng.

B-kitsch.

Bog-käs.

Bonos-m.

Borsh.

Burtn.

Chank-tau.

Chass-jrt.

Chews.

Chosp.

Circas.

Dadsch.

Dagt.

Dartschl.
Daratschitschag

Dawalu

Delishan

Derbend

Dshebrail

Elbrus

Elisabethpol

Elisabeththal

Eriwan

Erzerum

Erzerum-Bingöll

Etschmiadsin

Georgia

Georgiewsk

Golitschai

Gomereti

Grusien

Gudaur

Hamarat

Helenendorf

Helenowka

Hocharmenien.

Imeretien

Jewdokimowsk.

Jibiani

Kabarda

Kagisman

Kapudshich

Karabagh-jürdi

Kara-bulach

Kasbek

Kasikoporan

Kasum-kent

Katharinenfeld

Kraukasus

Kiptschag

Kislja!

Kislowodsk

Kodshory

Kor-ogly
Dartag.

Dawal.

Delsh.

Derb.

I)shelor.

Elbr.

Elsbp.

Elstuth.

Eriw.

Erzm.

Erz-Bgl.

Etschm.

Georg.

Georgk.

Golitsch.

Gomt.

Grus.

Gudr.

Hamrt.

Helnd.

Helnk.

Hoch- $\Lambda \mathrm{rm}$

Imrt.

Jewik.

Jib.

Kabrd.

Kagm.

Kapud.

Karb-jürd.

Kara-bu.

Kasb.

Kasikp.

Kas-knt.

Kathtld.

Kauk.

Kiptsch.

Kislj.

Kislw.

Kodsh.

K. ogrly 


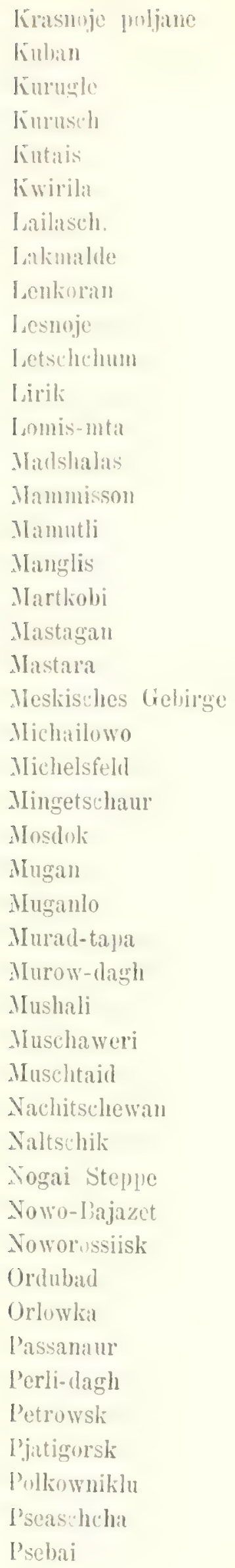

\begin{tabular}{|c|c|}
\hline Kirsn polj & Rasano \\
\hline Kíub. & Riatscha \\
\hline Kingl. & Sardarabad \\
\hline Kursch. & Sardarik \\
\hline línt & Sarijal \\
\hline Kwir. & Schach-agatsch \\
\hline I ailsch. & Schach-dagh \\
\hline I akimul. & Schambohell \\
\hline l.enk. & Shathl \\
\hline Lesuj. & Schatojewsli \\
\hline locteh. & Sohuwana \\
\hline lirk. & Sewanga \\
\hline l.om-mta & Signach \\
\hline Miarlsh. & Suchui fontan \\
\hline Mams. & Suclum \\
\hline Mamtl. & Suggdidi \\
\hline Mang. & Swanetien \\
\hline Martk. & 'Tabizchuri See \\
\hline Mastg. & 'lalysch \\
\hline Mastr. & Tana 'Thal \\
\hline Mesk. G. & T'ars-tschai \\
\hline Michlw. & 'Tbatani \\
\hline Micheld. & 'Tebulos-mta \\
\hline Mingtsch. & 'T'erek \\
\hline Mlosd. & 'T'emirgoje \\
\hline IIuge. & Temir-Chan-Schura \\
\hline Alugl. & 'Tiflis \\
\hline Murd-tp. & Toporowan \\
\hline MIur-dgh. & Tschatach \\
\hline Muschl. & 'T'schemachly \\
\hline Muschw. & 'Tschetschinu \\
\hline Muschel. & T'schibuchly \\
\hline Nachtw. & 'Tschir-jurt \\
\hline Naltk. & 'Tschitcharo \\
\hline Nosg. St. & 'T'schoroch \\
\hline N. Bajt. & 'T'skenis 'I'skali \\
\hline N. rossk. & Uruschten \\
\hline Ordb. & Utsch-dere \\
\hline Orlk. & Utseh-tapalar \\
\hline Passn. & Wladiliawlias \\
\hline ['er]i-d. & Zalka \\
\hline Petrwk. & Zchra-Zcharo \\
\hline r'jatgk. & Zebelda \\
\hline Polk. & Subalpin \\
\hline I'seasch. & Schneeschmelze \\
\hline
\end{tabular}

Rasn.

kittsel.

Sardal.

Sirrlls.

Saril.

Schlagtsch.

sich-d.

śchamb.

Schatl.

Schtjk.

Schuw.

Sewg.

Sign.

Such. lit.

such.

sugd.

Swnt.

Thiz. S.

Tial.

Tin.

l'ars-tsch.

'T'botn.

T'ebul-m.

Tris.

'lemrg.

'I in.-Ch.-Sch.

'Iff.

'Toporw.

Tscht.

'T'schml.

'T'schitl.

Tschibl.

'T'selir-j.

'Ischitch.

'I'schor.

T'sk. 'I'sk.

Uruseh.

U-der.

U-tpl.

Wldk.

Zlk.

Zch-Zch.

Zlbi.

$$
\text { * }
$$




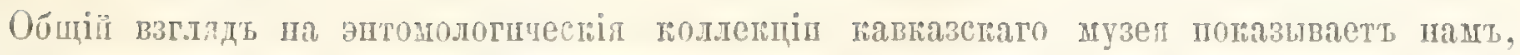

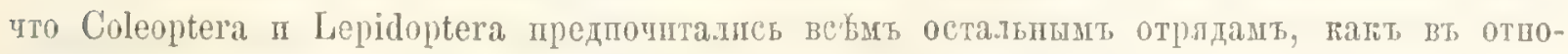

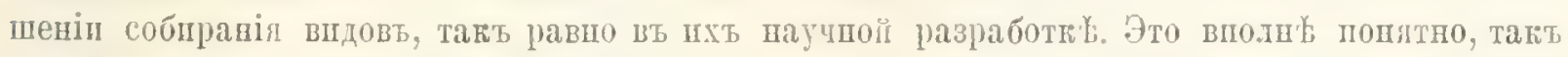

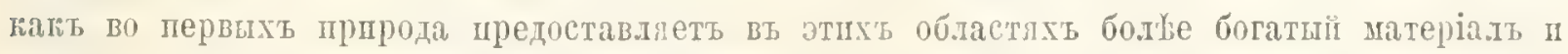

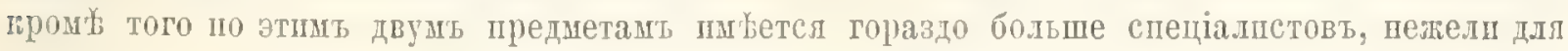

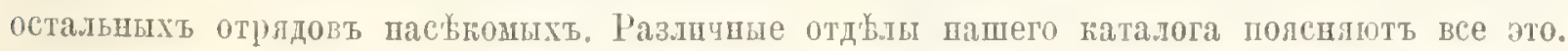

Iто паслется составленія поллещій, то тағовое началось сь перваго-же путешествія, предпрпнлтаго нною. Уже тогда, вь 1864 г. л привезь пзт сванетспит альп звачптель-

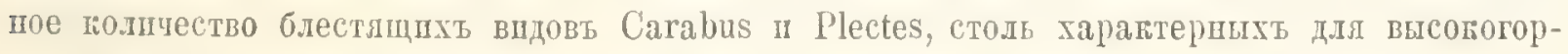
ныхь мвсть главнаго хребта, особенно въ его занддой пасти.

Благодарі участію д-ра Г. II. Сиверса ст 1870 г. вт мошхь путешествіяхь, рабочал спла значительн увелпнлась. Въ то время, юаєь мны прпходнлось въ пнтересахъ лу-

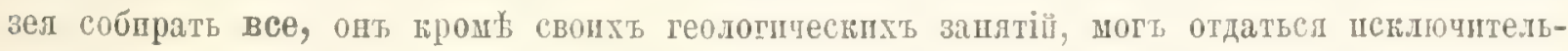

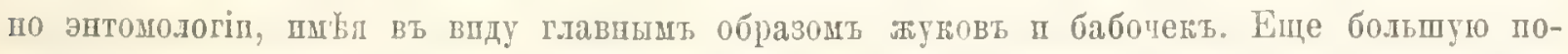

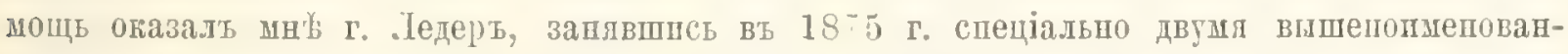
шымш отрядамп насъкомыхъ. Іосвятпвь себя до 1886 г. подобнымь работамь п этюдамь

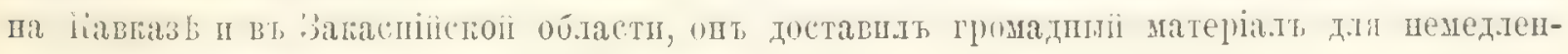
пой обработии иосыли д-ру Ә. Реитеру.

Въ установк ғоллецій участвовалп до 1892 г. въ значптельпой степени кромы мепл д-рь Спверсь и г. Ледер'ь. Но лишь съ поступеніемь вт мувей па должиость понсерватора г. Е. Кенига въ 1892 г. вся юоллегдія въ совогүности и особенпо представптели фауны жесткогрылыхь были хорошо обезпечепн. Какъ нзвьстно, г. Кенигъ пользуетсл

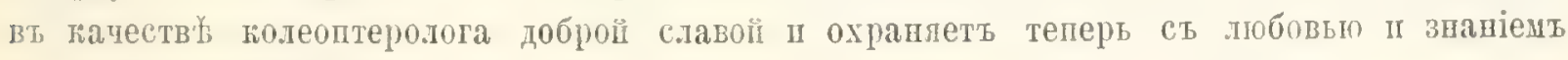
вст отдыл колдецтіп.

Еще я долженъ упомянуть, что мн

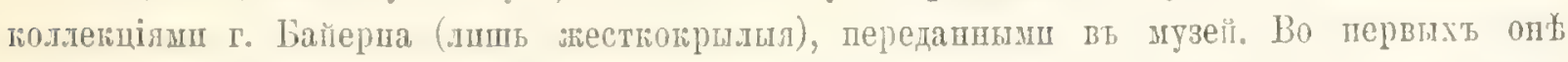

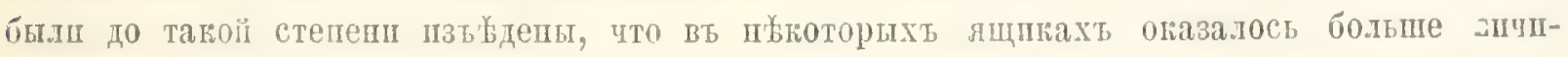

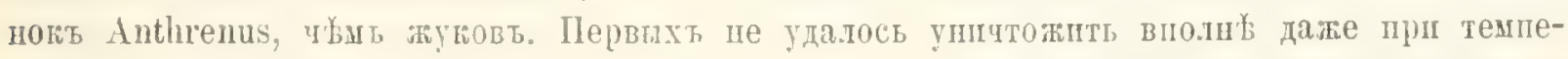
patyp

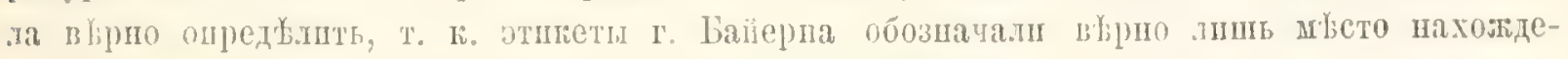
піи, все іке остальне было больше частьо неправилио.

Накопець я пу спо спать еще слидющее:

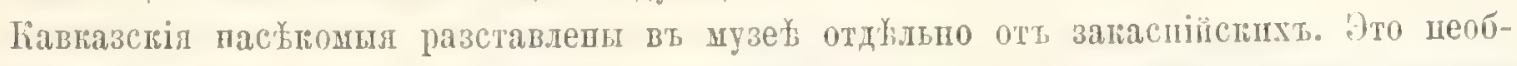

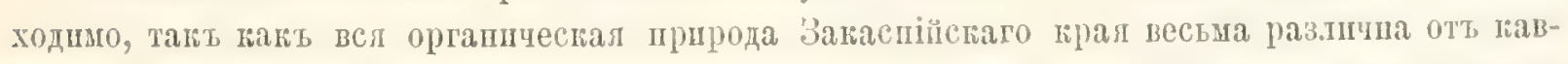

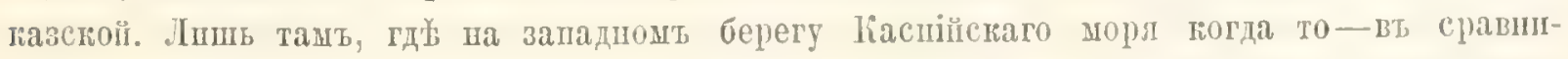

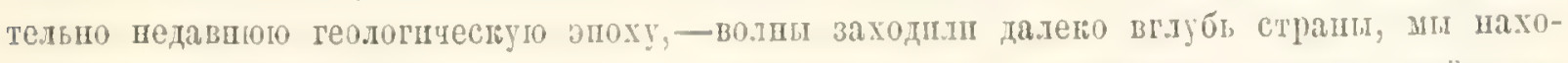

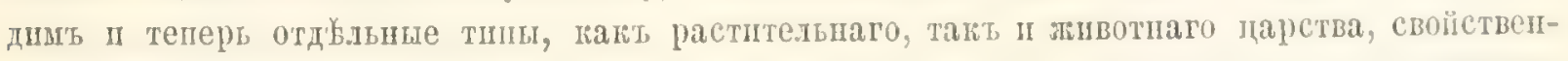

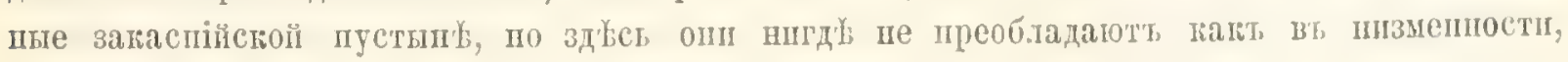
примканей непосредствено к'т востопу оть liacnis. 


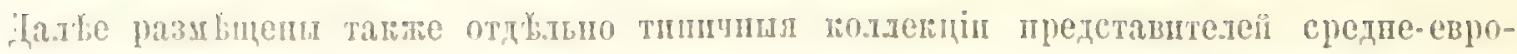

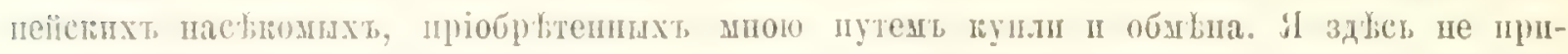

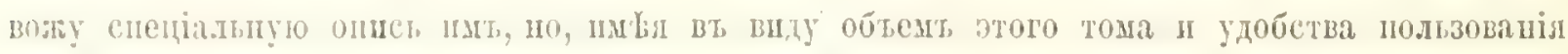

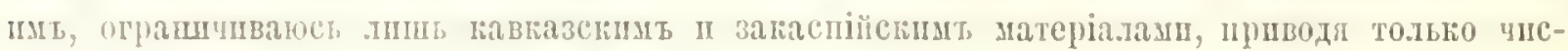

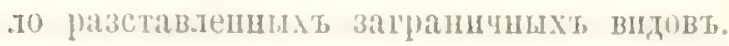

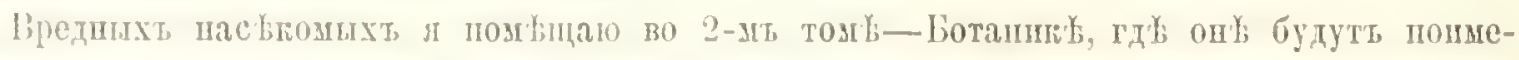

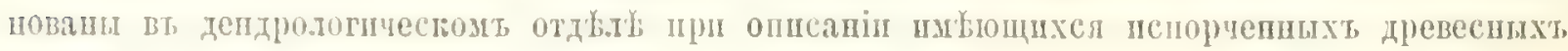

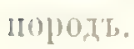

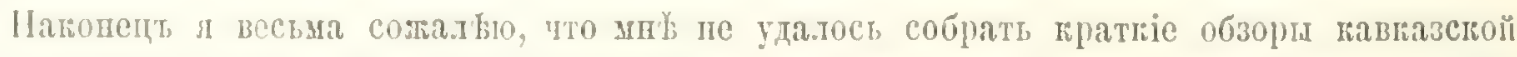

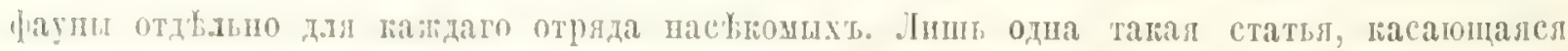

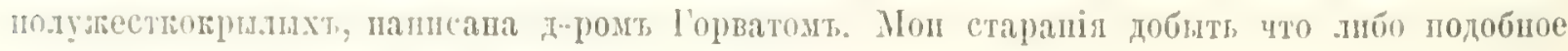

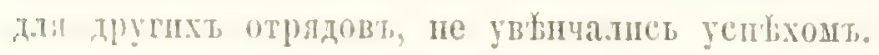

[- - I, I'. I'ldde.

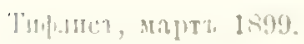


Fin allyemeiner Dick auf die entomologischen sammlungen des kaukasischen . Vuseums beleht uns darüber, dass die Colentera und Lepidoptera vor allen anderen (idnungen bevorzugt wurden, sowohl was das Einsammeln der Arten selbst, als auch ihre wissenschaftliche Bearbeitung anbelangt. Fs ist das sehr erliärlich, da einmal das von der Natur darwebotene Material reichhaltiger, als auch die Zahl der Specialisten auf diesen beiden Gebieten viel grösser, als für die anderen Insekten Ordnungen ist. Die verschiedenen $A b-$ s.hnitte unseres Kataloges geben darüber Ausknft. Was die Herstellung unserer sammlung anbelangt, so beginnt sie mit der ersten meiner Reisen. Schon damals, 1864, brachte ich aus den suanischen Hochalpen eine stattliche Inzahl jener brillanten Carabus und Plectes-Irten heim. die in so ausgezeichneter Weise die Hochgebirge namentlich des westlichen Theiles der Hauptkette charakterisiren.

Durch die Betheiligung an meinen Reisen von Dr. G. Sievers seit 1870 wurde die Irlxitskraft schr gestarkt. Wïhrend ich auf meinen Expeditionen im Interesse des Museums Alles sammeln musste, konnte er neben seinen genlogischen Situdien die Entomologrie ausschliesslich, namentlich Kïfer und Schmetterlinge, pflegen. Noch grvisser wurde die lieihulfe als 1875 Hans Leder sich ganz speriel den beiden erwähnten Insekten Ordnungenzuwendete. In Kaukasus und in Transkaspien blieb er diesen Irbeiten und Studien bis 1isti erhalten und lieferte das grösste Material für die sofortige Bearbeitung und den Vertrich) an Dr. E. Reitter.

Bei der Aufstellung der Sammlungen haben sich bis 1893 ausser mir, Dr. Sievers und IIans Leder wesentlich betheiligt. 1 ber erst mit dem Eintritte in den Dienst les Museums von IJerr Eugen Koenig (1:92), welcher die Stellung eines Konservaturs bekleidet, war die Entomologie in ihrer Gesammtheit und die Kiiferfauna ganz besonders auf das lieste besorgt. Ilerr E. Kuenig hat als Colenpternloge. wie bekannt, einen guten Namen und liflegt mit grosser Liebe und Sachlenntniss jetzt diese Sammlungen in allen Ordnungen.

Noch muss ich erwihnen, dass ich bei der Uebernahme der Sammlungen von Herrn Payern von seinen entomologischen Vorrïthen (nur Käfer' nicht profitiren konnte und zwar aus zwei Gründen. Erstens waren sie so zerfressen, dass in manchen Kästen mehl lebende Anthrenus Larven als todte Küfer sich vorfanden, welche ersteren selbst Temperaturen von $80^{\circ}$ R. nicht ganz beseitigten. Zwweitens aber hätte man den grössten Theil des etwat Geretteten erst richtig bestimmen müss'n, da die signaturen des Herm Fayern nur den Werth der Fundorte besassen, alles Andere aber in den meisten Fällen falsch war.

Schliesslich habe ich hier noch folgendes zu hemerken: Die kaukasischen Insekten sind im Museum getrennt von den transkaspischen aufgestellt. Es war das nüthig, weil Transkaspien in seiner gesammten organischen śchüpfung sehr verschieden von derjenigen des. Kaukasus ist. Nur da, wo an Westufer des Binnemmeeres einstens-und zwar in verhältnissmässig junger geolugischer Zeit-die kilspi Fluthen tief einschnitten, tinden wir auch jetzt noch einzelne Typen der transkaspischen Wisten. sowohl im l'flanzen-als auch im 'Thierroiche, aber nirgend so dominirend wie umnitedhar im ()sten des Kispi in den Tiefländern. Ferner wurden auch dic Typen Sammlungen der licprisentanten der centraleuropai- 
shen Insclitenfama, welche ich durch liauf und T'ausch erstand, sesondert anfgestellt. Von diesen gebe ich keine special Verzeichnisse, sondern beschränke mich in Hinsicht auf Zweckmissigkeit und Umfing dieses bandes, nur auf das Kaukasus-und Iranskaspi-Material, wogegen von den Ausländern nur die Zahl der aufgestellten Species erwähnt wird.

Den s:hädichen Insekten weise ich ihren Platz im 2t. Bande-Botanik-an, wo sie im dendrologischen Abschnitte bei Lrwähnung der vorhandenen Frasstucke genannt werden sollen.

Fndlich bedauere ich sehr nicht kurze Uebersichten ter kaukasischen Fauna fur alle Insekten Ordnungen geben zu kömen. Nur fur die Hemipteren hat Dr. Ilorvith einen solchen Artikel gestellt. Meine Remihungen auch für die anderen Ordnungen Aehnliches zu erhalten blicben ohne Lirfolg.

1). (i. Riulde.

Tiflis, im Marz 1599. 


\section{COLEOPTERA CAUCASICA.}

\section{FAM, CICINDELIDAE.}

\section{Tetracha Hope.}

euphratica Dej. var armeniaca Dokht. Saljan. Temrg.

\section{Cicindela $\mathbf{L}$.}

asiatica Brll. Arax.

campestris L. var pontica. Schaum. Lisbth., Borsh., Azkur, Alexp, Hesk. G.

desertorum Dej. Pari, Migri, Borsh., Kapud., Arax.

tallschensis Chd. Albr.

hybrida L. var riparia Latr. Borsh., Derb. Sturmi Mén. Lenk.

cau:asica Ad. Albr., Arax.

var. strigata Dej. Arax.

litterifera Chd. Kas-knt, Aresch.

sublacerata Solsky v. laevithoracica Horn.

Aresch, Arax., Tfl.

contorta Fisch. Lenk, Temrg., Petrwk.

chiloleuca F 'Temrg.

clegans Fisch. Aresch.

litturalis F. Lenk, Derb., Suant, Aresch, Petrwk.

lis heri Ad. Kauk.

var. alasanica Mot. Arax., Aresch, Borsh. germanica L. Suant, Btschng, Aresch, Temrg. "racilis Pall Kaschtan-tau 7000'.

melancholica F. Areseh.

orientalis Dej Lenk.

\section{FAM. CARABIDAE.}

\section{Calosoma Weber.}

inquisitor L. Kauk.

var. clathratum Kolen. Kauk.

sycophanta L. Borsh., Tan., Tal., Tfl.

denticolle Gebl. Petrwk. auropunctatum Hbst. v. funestum Géh. 'I'fi., Helnk.

substriatum Motsch. Tal., Lirk.

breviusculum Mnnh. Arm, Dartag.

orbiculatum Mot. Arm., Arax., Adsh.

Reichei Guèr. Arat.

Eversmanni Chd. Amasia.

\section{Cechenus Fisch.}

Boeberi Ad. Ossetia 7--1000 i'

Prichodkoi Sem. Circas. * euxinus Sem. Circas. *

Procerus Dej.

caucasicus Ad. Artwin, Borsh., Eriw, Dagt. var. colchicus Mot. Zbld.

Audouini Ad. Eriw., Erzm.

\section{Carabus L.}

impressus Klg. Kiasikp.

Chevrolati Cristof. Arm. türk.

clypeatus Ad. Kursch, Lom-mta 5-7000'. talyschensis Mén. Tal.

Stroganowi Zbk. Albr.

septemcarinatus Mot. Borsh., Chews., Dagt., Batum.

exaratus Quens. Chews, Kasb., Fischt., Kub. $0-7000^{\prime}$.

var. subexaratus Reitt. Laba.

violaceus L. var. Elbr., Kabrd. *

tenuitarsis Kr. Amasia.

Calleyi Fisch. Arax.

var, nigrinus Mot. Lenk.

var. Renardi Chaud. Saril, Suant, 'I'al.

prasinus Mén. Mlag., Mastr., Kurscle., Btschng, Kapud, Murd-tp, /Ch.-Zch. $5-7000^{\prime}$. 
Stjernwalli Mamuh. Adsh, Zch.Zl'h, Arm

$$
5-7000^{\prime} \text {. }
$$

var. Boschniaki Fald. Azkur.

var. Jartholomaci Mot. Arm.

var. Humbuldti Fald. Arm.

var. gordius Reitt. 'T'schor.

Bonplandi Mtén. Amasia.

mingens Quens. Kursch.

morio Mannh. v. Tamsi Mén. 'lal.

Biebersteini Mén. Elbr. $\$-7000^{\prime}$.

var. agnatus Ganglb. Kauk. occ

var. Kolenatii Chd. Imrt.

var. suramensis Kr. Suram, Mesk. G.

var. fossiger Chd. Kaschtantau, Imrt.

Kraatzi Cht. Kauk. 5000'.

Puschkini Ad. Kasb., Swnt., Dadsch., Lommta $3-8000^{\circ}$.

var. platessa Mot. Lom-mta.

circassicus Ganglb. Abg., Pseasch., Atschischelio, $6-7000^{\prime}$.

rar. Justinae Reitt. Circas, Mastg.

mingrelicus lieitt. Swnt.

osseticus Ad. Chews. 5-10000'。

nothus Ail. Chews, Tebul-m., lionos-m. $7-10100^{\prime}$.

Eormancki Reitt. Nucha *

Lederi Reitt. Swnt. 10000'.

Fausti Dohrn. Kurseh, 5-10000'.

ibericus Fisch. Borsh., Swnt., Mesk, G; 2 - i11100'.

var. Mellyi Chd. Sakao. Imrt.

Basilianus starck. Abch. Mastg., Laba.

oltusus Ganglb. Atschischho.

Prometheus Reitt. Circas.

var. Ganglbaueri Reitt. Circas, Obere Laba. imperator Starck. Dagomys.

Olgae Sem. Circas.

Stalcki Heyd. Pseasch., Atschischho 7000'* Filithae Reitt. Kub.

Kratkyi Reitt. Abch. Obere Laba.

Jiithneri Reitt. Laba.

Reitteri Retow.Pseasch.,Circas, Atschischho* dalensis Ro:t. Dal.

protensus Schaum. Zbld.

Komarowi Reitt. Swnt.

compressus Chd. Laschchrasch. kasakorum Sem. 'Trk.

punctiger Sem. Elbr. *

Steveni Mén. Elbr. *

Satanas Sem. Kaschtantau. *

Schamyli Hampe. 'I'rk.

Riedeli Mén. Circas. $0-7000^{\prime}$.

Bohemanni Mén. Hamrt.

Adansi Ad. var. Ilollbergi Mnnh. Kursch.

var, varians Fisch. Kodsh, Swut, Saril.

Helnd.

var. incatenatus Mnnh. Swnt, Mesk. G.

var. armeniacus MInnh. Borsh, Suram., Arm.

var. Adamsi Ad. Borsh.

var. alagoesus Reitt. Arm.

var. Eichwaldi Fisch. Borsh., Chews., 'I'biz-S. I'btn.

rar. porphyrobaphes Ganglb. Ossetia.

var. janthinus Ganglb. Atschischho., Krsnpolj.

Gilnickii Deyr. Erzm. Tschor.

stygins Ganglb. 'I'al.

granulatus L. Elbr. 7000'.

var. sculpturatus Mén. Lenkn., 'Tal., IIelnd. corticalis Mot. Kauk.

cumanus Fisch. Circas., Krsn-polj. $0-7000^{\prime}$.

(v.) submicans Reitt. Circas.

Karelini Fisch. Kub. 2000'.

campestris Fisch. Circas.

Wiedemanni Mén. var. Gotschii Chd. Kauk. Victor Fisch. Suram., Borsh.

cribratus Quens. Sch-agtsch., 'Tbiz-S., Chews., Tan., Dschaffar-aga, Zch.-Zch., Borsh., Kub., Ala-dagh, Lar's; Arm.

Roseri Fald. 'Tsehor., Sch-agtsch., Borsh., Arm.

swaneticus Reitt. 'I'schitch., Latpari, Swnt. imitator Reitt. Kauk.

Stählini Ad. Lachm., Bonos-m.g Chews., Kasb., Swnt, Kurselı., Laschehrasch, Dadsch.

Koenigi Ganglb. Circas, Nachar, Mastg. Atschischho.

bessarabicus Fisch. Kub. 2000'.

convexus F. Kasb.

falsarius Reitt. Arm.

biseriatus Chd. Borsh, Zlk. 
scabripennis Chd. Tan.

maurus $\Lambda$ d. Tfl. Kapud., Arax, Algetka.

var. discoideus Reitt. Toporw.

var. Hochhuthi Chd. Sch-agtsch.

pumilio Küst. Murd-tp.

\section{Cychrus Fb.}

aeneus Fisch. Borsh., Chews., Zlk., Lom-mta. Swnt.

Starcki Reitt. Cirkas., Pseaschha.

\section{Leistus Fröhl.}

fulvibarbis Dej. Kauk.

rufomarginatus Duft. Lirk.

fulvus Chd. U-der.

ferrugineus L. Kauk.

elegans Rost. Ossetia.

\section{Nebria Latr.}

picicornis $\mathrm{F}$. var. luteipes Chd. 'T'tl. nigerrima Chd. Dartlo, Chews. ** brevicollis F. Batum.

Faldermanni Mén. Suant.

alpicola Mot. Perli-d. **

Bonellii Ad. Lom-mta, Chews., Swnt, Dadsch,

$$
\text { Pari., Lakmd., Mamtl. * }
$$

var. cechenoides Reitt. Swnt.

viridipennis Reitt. Abg.

hyanthis Reitt. Tschor.

spec.? Tschor.

Schlegelmilchi Ad. Bloo., Kasb., Adsh.,

$$
\text { Zch-Zch. * }
$$

Fischeri Ad. Adsh.

elongata Fisch. Kasb., Chews.

patruelis Chd. Swut.

Lederi Reitt. Circas.

caucasica Mén. Swnt.

planulata Reitt. Circas.

var. tristicula Reitt. Circas. Fischt.

\section{Notiophilus Dum.}

aquaticus L. U-der.

rufipes Curt. Mang., IIclnd.

biguttatus F. Tan.

\section{Omophron Latr.}

limbatus F. Derb.

\section{Elaphrus F.}

riparius L. var. areolatus Reitt. Arax.

\section{Scarites Fb.}

eurytus Fisch. Baku, Aresch, Such.

salinus Dej. Aresch, Grosny.

arenarius Bon. Borsh., Such., 'Temrg.

planus Bon. Aresch, U-der.

\section{Dyschirius Bon.}

thoracicus Rossi. Suram, Goktsh.

Lafertei Putz. Borsh.

globosus Hbst. var. ruficollis Kol. Lenk.

Lederi Reitt. Swnt.

\section{Clivina Latr.}

fossor L. Lenk. Elsbp.

ypsilon Dej. Derb.

laevifrons Chd. Alag., Alexp., Tars-tsch.

\section{Siagona Iratr.}

europaea Dej. Aresch.

\section{Apotomus Ill.}

testaceus Dej. Derb. Aresch.

\section{Broscus $\mathbf{P z}$.}

cephalotes L. var. semistriatus Fisch. Samur, Baku, Sardk., Kars, Petrwk., Kulp, Aresch, 'Temrg., 'Tschr-j.

\section{Tachypus Lap.}

caraboides Schrk. Borsh., Chews.

flavipes $\mathrm{L}$. Borsh.

\section{Bembidion Latr.}

laticolle Duft. Swnt.

inserticeps Chd. Mugs.

lampros IIbst. Wldk., Kasb., Zlk., Lenk.

bipunctatum L Alag., Sch-agtsch.

var. rugiceps Chd. Kasb.

dentellum Thnbg. Derb.

fasciolatum Duft. Suram.

tibiale Duft. Lenk.

fulvipes Strm. 'Tschtg.

ripicola Duft. var. oblongum Dej. Kauk. 
Andracale F'. Til, Borsh.

var. anglicanmm Sharp. Arax.

ustulatum L. Suram, Mamtl, Chews.

rupestre I. Suram, Kasb.

Promethens Reitt. Aresch.

bisignatum Jin. Chews.

sieulum Dej. Swnt.

nitidulum Mrsh. Ijirk.

brunnicorne 1)ej. Chews.

cribrum Dur. Kank.

ruficorne Strm. Suram.

"Jongatum Dej var. Nordmanni Chd. Lailsch., Helnd.

minimum l', 'I'sk-'Tsk., Artschw.

val. maeoticum Kol. Arax.

quadriguttatum li. Isenk

tetrasemum Chd. Isenk.

quadripustulatum serv. Lenk.

quadrimaculatum Is. Lenk.

tenellum Lir. Borsh. Arax.

octomaculatum Goez. Isenk

obtusum Strm. Lenk., Mesk. G.

Jamerheini Sahlb. Kauk.

bigutatum F. Lenk., Swnt.

\section{Tachys Stph.}

Globosus liaudi. Kauk.

haemorrhoidalis Dej. Lenk.

"luadrisignatus Duft. Lailseh.

parvulus Dej. var. diabrachys Kol. Lenk.

histriatus Dft. Lailsch, Lenk.

var. gregarius Chd. Lailsuh, Lenk.

scutellaris Stph. Lenk.

brevicornis Chd. Lailsch, Lenk.

angustulus Reitt. Isenk

\section{Tachyta Kirby.}

nana Gyll. Lenk.

\section{Perileptus Schaum.}

arenlatus Crent\%. I senk.

\section{Trechus Clairv.}

quadristriatus Schrk. Weri, Lirk.

obtusus Lir. Lenk.

infuscatus Chd. Kasb.

liopleurus Chd. Lenk. wravidus Putz. Swnt.

mingrelicus Reitt. Circas.

nivicola Chd. Kasb, Kobi.

maculicornis Chd. Suram, Tbtn. Toporw.

tischtensis Reitt. Circas.

alpigradus Reitt. Circas

Lederi Putz. Suram.

Angelicae Reitt. Arm. G.

(Anophthalmus Schmidt).

Intoniae Reitt. Arax.

Pogonus Dej.

punctulatus Dej. Kank.

\section{Deltomerus Mot.}

elegans Chd. Blo., Chews. ** tibialis Reitt. Swnt. **

clongatus Dej. Blo., Chews. ** pseudoplatynus Reitt. Cireas.

Starcki Reitt. Kank.

(ircassicus Reitt. Circas.

\section{Platynus Bol.}

ubscurus Hbst. Elsbp.

assimilis Payk. Alag., Delsh., Kathfld.

sexpunctatus [. Derb.

viridicupreus Goeze. Kasikp.

var. chrssopraseus Mén. Kauk.

marginatus L. Swnt.

Mülleri Hbst. Tbtn., Swnt.

chalconntus Mén. Kauk.

lugreus Dit. Olty.

versutus Strm. Kauk.

viduus Pr. Swnt., Sch-agtsch.

var. moestus Dft. Sch-agtsch.

itratus Dft. Mamtl.

'I'horeyi Dej. var. pmellus Dej. 'Toporw.

dorsalis Pontopp. Kursch., 'Tfl, Kars, T'schbl, Kasikp., Mastr.

\section{Olisthopus Dej.}

Sturmi Duft. Kauk.

rotundatus Payk. Swnt.

\section{Pristodactyla Chd.}

cancasica Chd. Murd-tp., I'schitch., Borsh, Swnt 
var. femoralis Reitt. Abch.

Horsti Reitt. Circas.

praestans Heyd, Circas.

\section{Thermoscelis Putz.}

insignis Cht. Atschischho. * var. Kamberskyi Reitt. Atschischho.

Dobretsbergeri Reitt. Lom-mta. *

\section{Dolichus Bon.}

halensis Schall. Tsk-Tsk.

\section{Calathus Bon.}

alternans Fald. Kauk.

fuscipes Goeze. Borsh., Derb.

var. distinguendus Chd. Kauk.

var. punctipennis Germ. Sch-agtsch, Madsh. erratus Sahlb. Wldk., U-tpl. var. Inarginicollis Chd. Kauk. fuscus F. Baku, Borsh., Sch-agtsch. melanocephalus L. Kurseh, Kasb., Golitscha, Chews.

mollis Marsh. Derb., Lirk.

\section{Laemosthenus Bon.}

caspius Fald. Derb., Hamrt tauricus Dej. Derb., Saril. var. cyanipennis Dej. Ach-bu. sericeus Fisch. Kank.

Mannerheimi Kol. Toporw. gratus Fald. Lenk.

pretiosus Fald. 'Tbiz-S.

hepaticus Fald. Kursch., Chews. Koenigi Reitt. Pseaschha, Sotscha. bicolor Reitt. Kasikp.

\section{Sphodrus Clairr.}

leucophthalnus Is. Kiauk.

gigas Fisch. Krasnogorsk. 2000 '.

cellarum Ad. 'l'fl., Baliu, Swnt.

\section{Platyderus Steph.}

umbratus Mén. Kauk.

\section{Lagarus Chd.}

vernalis Panz. Kasb., Saril.

var. cursor Dej. Aresch.

\section{Poecilus Bon.}

anodon Chd. Atschkul.

marginalis Duft. Lawaschi.

lepidus Leske. Borsh.

gressorius Dej. var. stenoderus Chd. Kash., Chews, Swnt.

cupreus L. Kauk.

var. erythropus Fald. Gagry, Zlk., Saril.

var. armeniacus Reitt. Erzm.

coerulescens L. Kank.

subcoeruleus Quens. Kauk.

micans Chd. Kauk.

\section{Pterostichus Bon.}

inquinatus Strm. Erzm.

lyroderus Chd. Zlk.

advena Quens. Kauk.

macer Marsh. Kas-knt.

elongratus Duft. Lirk.

oblongopunctatus F. Helnd.

niger Schall. Goktsch., Borsh., Muschl., Elbr. var. subcordatus Chd.Kursch, Goktsch, Borsh., 'T'tl., Saril

brevicornis Gaut. Arm. nigrita F. 'Tal. Masto. confusus Chd. Lenk, Mamtl, Suram, Delsh. crassipes Mén. Krauk anthracinus Ill. Lenk., Kub. strenuus Pz. I,om-mta. var. difficilis Chd. Suram, Alexil. var. lectulus Reitt. Circas.

diligens Strm. Gudr. pseudopedius Reitt. Circas. percontator Reitt. Atschischho. quildraticollis Chd. Tbtn, Lom-mta. lagaroides Reitt, Atschischho. iripennis Chd. Lom-mta. pulchellus Fld. Chews., Swnt, Kasb., Mushl., $\mathrm{I}, \mathrm{m}-\mathrm{m}$ ta

tantillus Reitt. Atschischho.

rufipalpis Chd. Suram.

chefsuricus Putz. Chews.

platyderus Chol. Swnt.

validiceps Reitt. Arab. G.

daghestanicus Rost. Nucha.

caspius Mén. 'l'al., Hamrt. 
melas Creutz. Kurseh., Kasb., Lars, Chews. cucujinus leitt. Arax.

obscurus Dej. Kasb, Bonos-m., Chews. * var. ordinatus Fisch. Kasb. Swnt. * swancticns Reitt. Swnt. * obtusangulus Reitt. Swnt. * variabilis Mén. Lilbr. * nivicola Men. Kursch. lacunosus Chd. 'I'an., 'I'btu, Chews, Schuw, Adsh., Abg.

Schönherri Fald. Adsh., Dadsch. I,om-mta. Starcki Heyd. Atschischho.

'lamsi Dej. Kasb., Lom-mta. cancasicus Mén. Kasb., Circas.

chydaeus 'Tschit. Hilbr. Kasb.

var. goriensis 'Tschit. Zch-Zch., 'I'an. armenus Fald. Kch-Zch, Lom-mta, Swnt.

\section{Aphaonus Reitt.}

Starckianus Reitt. Atschischho.

cylindriformis Reitt. I'seasch.

pseudopercus Reitt. Gagry.

compressus Rost. Circas.

\section{Stomis Clairv.}

pumicatus Pnz. Borsh., Mesk, G. var. ovipennis Chd. Lirk.

\section{Amara Bon.}

rufipes Dej. Kauk. similata Gyll. Tan. ovata l'. var. adamantina Kóol. 'Tan. communis Pnz. Kauk. lunicollis Schdte. Elsbp. aenea Deg. Borsh., Suant, Tfl, Tan., Temrg. spreta Zimm. Kauk. famelica Limm. Kauk. eurynota Pnz. Zch-Zch. familarius Duft. Borsh. lucida Duft. Batum, Sch-agtsch. equestris Duft. Borsh. municipalis Duft. Anit. viridescens Reitt. Swnt. Schneideri Putz. Isenk. testicola Zimm. Chews. bifrons Gyll. Saril, Zch-Zch, Tan, Kasilpy. practermissa Salılb. Zch-Zch.

cordicollis Mén. Kasb., Elbr.

subdepressa Putz. Bonos-m., Tebul-m. * apricaria Payk. Kub, Kiptsch., Borsh., Zlk, Chows., Kch.-Zch.

consularis Duft. Kub.

abdominalis Mot. Kauk.

parvicollis Gebl. Kauk.

aulica Pz. Swnt, Kasikp., Kub., Zch-Zch. var. cancasica Mot, Arm.

var. circassica Reitt. Circas.

\section{Harpalodema Reitt.}

punctipennis Reitt. Arax.

\section{Zabrus Clairv.}

chalceus Falil. Adsh.

heros Fald. 'Tbiz-S.

aurichalceus Ad. Swnt, Alag., Adsh.

var. moestus Kuist. Arm.

var. punctipennis Chd. Alag.

aciculatus Schaum. Swnt., Murd-tp., Alag.

spectabilis Hampe. Erzm.

Trinii Fisch. Such. Ft., Sardab., Murd-tן., Zlk., Helnk., Rasn.

Araxidis Reitt. Arax.

gibbosus Zimm. Baku.

tenebrioides Goeze var. elongatus Mén. Derb. blapoides Creutz. var. rugosus Mén. 'Tal., kub.

\section{Acinopus Latr.}

ammophilus Dej. Derb., Kasikp., Temrg. picipes OI. 'Ifl., Baku, Mang.,Sardab., Petrwk laevigatus Mén. Tal.

megracephalus Rossi. Lirk

\section{Aristus Latr.}

obscurus Dej. Derb.

\section{Ditomns Bon.}

cordatus Dej. Such-I'.

calydonius Rossi. Elsbp.

rufipes Chd. Kauk.

angustus Mén. Derb. 


\section{Ophonus Stph.}

sabulicola Pz. Jewdk., Tan., Kas-knt., Dartag., Chews., Gagry.

var. columbinus Dej. Weri., Baku.

obscurus F. Kursch., Helnk.

punctatulus Duft. Kasikp.

rufibarbis F. Borsh., Dagt.

puncticollis Pk. Kauk.

azureus F. Swnt., Elsbp., Aresch., Jewilk.,

Lawaschi., U-der., Dagt.

convexicollis Mén. Azkur.

meridionalis Dej. Baku, Alexp.

pleuralis Rttr. Arax.

maculicornis Dft. Kauk.

planicollis Dej. Kodi.

var. suturalis Chd. Kauk.

pubescens Müll. Kut., Lenk., Kasilip., Kasb.,

Derb., Tf., Borsh., Mang., Suant.

griseus Pz. Asch-da., Sugd., Achzu., Tan.,

Muschl., Kursch., Tsk-Tsk., Nachtw.

hospes Strm. Alexp.

calceatus Duft. Kursch.

\section{Harpalus Latr.}

dispar Dej. Kauk.

circumpunctatus Chd. Kauk.

aeneus L. Zch-Zch., Tan., Lom-mta, Sirnt., Lars.,Jewdk., Kub., Batum., Weri., Alag., T'fl, Sch-agtsch.

var. confusus Dej. Kursch.

aeneipennis Fald. Kauk.

psittaceus Fourcr. Derb., Tfl., Sugd., Batum.,

Mastr.

quadratus Chd. Arax.

smaragdinus Duft. Derb., Mastr., Jewlli, Tan, Isars.

rubripes Duft. Tarnplut., Borsh., Latu:n. Zch-Zch., Kub.

latus L. Chews., Alexp., Lom-mta., Kch-Z゙h. quadripunctatus Dej. Iionos-1n., 'Tebul m., Zch-Zch.

Retowskianus Reitt. Abg.

clirysopus Reitt. Kauk.

abasinus Rost. Circas.

rufitarsis Duft. Arm. honestus Duft. Lawaschi., Lom-mta., Aish., Tet., Zch-Zch., Lars, Artwin., Tan.

zabroides Iej. Alexp., Rasn.

dimidiatus Rossi. Gagry., Lirk.

autumnalis Duft. Borsh.

reflexus Putz, Alexp.

fuscipalpis Strm, Nog-St.

serripes Quens, Mastr., Rasn., Atschk., Tf.

tardus Panz. Alexp.

flavicornis Dej. Kauk.

anxius Duft. Weri., Lawaschi., Elb., Alexp.

servus Duft. Alexp., Sardab.

picipennis Duft. Nog-St.

\section{Pangus Lec.}

scaritides Strm. Borsh.

brachypus Stev. Arax., Sardab.

\section{Anisodactylus Dej.}

binotatus F. Alag., Lirk.

var. spurcaticornis Dej. Kub., Lirk.

nemorivagus Duft. Sch-agtsch.

signatus Panz. Kub., Kas-knt.

pseudoaeneus Dej. Aresch.

\section{Gynandromorphus Dej.}

etruscus Quens. Kauk.

\section{Diachromus Er.}

germanus L. Lenk.

\section{Dichirotrichus Dav.}

obsoletus Dej. Lenk.

pubescens Payk. Kauk.

discicollis Dej. Lenk., Aresch, 'Tff.

\section{Tachycellus Seidl.}

placidus Gyllh. Mug., Swnt.

\section{Bradycellus Er.}

collaris Pk. Kauk.

val. caucasicus Chd. Mamtl.

\section{Stenolophus Latr.}

teutonus Schrk. Lenk.

var. aldominalis Fisch. I tenk.

Aisuophorus Fisch, Borsh.

morio Mén. Lenk, Anit. 
mixtus Ilbst. Anit, MIng., Lirk., Swnt. proximus Dej. Lenk., Anit.

marginatus Dej. Lirk.

\section{Acupalpas Latr.}

elegans Dej. Anit.

dorsalis F. Anit.

exiguus Dej. Lenk

\section{Amblystomus Er.}

metallescens Dej. Lenk.

\section{Badister Clrv.}

bipustulatus F. IIelnd., Mamtl, Lirk, sodalis Duft. Lirk.

peltatus Pz. Lirk.

\section{Derostichus Mot.}

caucasicus MIot. Imrt.

\section{Licinus Latr.}

aequatus Dej. Arm.

cassidens F. Borsh., Kursch., Aresch.

\section{Oodes Bon.}

gracilis Villa. Lenk.

var. parallelus Not. Aresch.

\section{Chlaenius Bon.}

aeneocephalus Dej. Kasikp., Lirk., Dartag. azureus Duft. Suram.

cruralis Fisch. Erzm.

coeruleus Stev. Tan., Schatl., Mang., Borsh., Kursch., Tfl.

tristis Schall. Sawalan.

chrysothorax Kryn. Derb.

vestitus Pk. Lenk., Mang., 'Ttl.

festivus F. Lenk., Btschng.

velutinus Duft. Kank.

circumscriptus Duft. Anit.

\section{Chlaenites Mot.}

spoliatus Rossi. Lenk.

\section{Callistus Bon.}

lunatus F. var. gratiosus Chd. Isenk.

\section{Panagaeus Latr.}

crux major L. Lenk.

\section{Hypercosmeton Reitt.}

callistoides Reitt. Arax.

\section{Lobia Latr.}

cyanocephala L. I'tl., Saril.

crux minor L. Btschng.

trimaculata Vill. Mamtl.

seapularis Fource. Derb., Mingtsch.

Metabletus Schm. Göb.

exclamationis Mén. Arax.

obscuroguttatus Duft. Lenk.

paracenthesis Mot. Lenk., Mamtl.

pallipes Dej. Lenk, Kathfld.

truncatellus L. Mamtl.

foveatus Fourcr. Alag., Kapud.

\section{Blechrns Mot.}

maurus Strm. Hamrt.

\section{Dromius Bon.}

linearis OI. Mamtl.

semiplagiatus Reitt. Circas.

nigriventris Thms. Nichlw.

\section{Demetrias Bon.}

monostigma Sam. Lenk.

\section{Cymindis Latr.}

axillaris F. Kursch, Alexp. var. palliata Fisch. Alexp. var. dorsalis Fisch. Alexp. Andraeae Mén. Bakin. discoidea Dej. Arax. picta Pall. Alexp. accentifera Zoubk. Mlag. scapularis Schaum. Chosp. Kursch., Baku., Erz-IBgl.

lateralis Fisch. Perli-d.

variolosa $\mathrm{F}$. 'Tars tsch., Alexp.

\section{Polystichus Bon.}

connexus Fourcr. Kauk.

fasciolatus Rossi. Derb.

\section{Zuphium Latr.}

olens F. Derb.

Chevrolati Cast. Tfl., Aresch. 
Drypta Latr.

dentata Rossi. Lenk.

\section{Odacantha Payk.}

melanura L. Lenk.

\section{Mastax Fisch.}

thermarum Stev. Derb., Sch-agtsch.

Brachinus Weber.

bipustulatus Quens. Derb., Anit.

cruciatus Quens. Kauk.

immaculicornis Dej. Derb., Lirk, Chosp.

crepitans L.Borsh., Kursch.,Isti-su, 'Tars-tsch., Dartag.

psophia Dej. Kauk.

var. plagiatus Reiche. Kauk.

explodens Duft. Lenk, Borsh., Kursch.

var. obscuricornis Mén. Derb.

\section{FAM. DYTISCIDAE}

\section{Haliplas Latr.}

fulvicollis Er. Kauk.

\section{Cnemidotas Ill.}

caesus Dft. Lenk.

\section{Coelambus Thms.}

impressopunctatus Schall., Kauk. caspius Whnke. Kauk.

\section{Bidessus Sharp.}

geminus F. Lenk., Arax., Zlk.

\section{Deronectes Sharp.}

variegatus Aubé. Arax.

assimilis $\mathrm{Pk}$. Kauk.

\section{Hydroporus Clairv.}

erythrocephalus L. Kauk.

angustatus Strm. Kauk.

palustris L. Kauk.

tesselatus Drap. Lenk.

memnonius Nicol. Lenk.
Laccophilus Leach.

obscurus Pz. Etschm.

Agabus Jueach.

guttatus Pl. B.-Kltsch.

bipustulatus L. Lenk., Suram.

Solieri Aubé. Lenk.

affinis Plr. Chws.

\section{Rantus Lac.}

notatus F. Lenk.

\section{Graphoderes Esch.}

zollatus Hoppe, Zlk.

\section{Dytiscus I.}

marginalis I. Suram., Tbiz. S.

\section{Cybister Cart.}

laterimarginalis Deg. Lenk., Kislj., Nog. St. tripunctatus 01. var. Gotschi Hochlh. Aresch.

\section{FAM. GYRINIDAE.} Aulonogyrus Regim.

concinnus Klug. Lenk. capensis Thnbg. Baku.

Gyrinus Geoffr.

bicolor Payk. Kauk. caspius Mén. Lenk. distinctus Aub. Arax. mergus Ahr. Kauk. Dejeani Brll. Kauk.

\section{FAM. HYDROPHILIDAE.} Hydrous Leach.

piceus L。 Gagry.

\section{Hydrophilus Geoffr.}

caraboides L. Suram.

\section{Hydrobius Leach.}

fuscipes L. Zlk., Tbiz. S.

\section{Heloohares Mls.}

lividus Forst. Lenk.

erythrocephalus F'. 'Llk. 


\section{Philfdrus Sol.}

frontalis Er. Lenk.

melanocephalus 01. Kauk.

nigricans 'Lett. Achllk.

\section{Cymbiodyta Bedel.}

marginella F. Lenk., Zlk.

\section{Anacaena Thus.}

bipustulata Marsh. Kauk.

limbata F. Isetch.

globulus I'k. Lenk.

\section{Laccobins Er.}

gracilis Mot, Lenk.

nigriceps 'Thms. Lenk.

alutacens 'Thms. Lenk., Till, litschm.

bipunctatus F. Kauk.

\section{Chaetarthrin Steph.}

seminulum Pk. Suram.

\section{Acanthoberosus Kuw.}

spinosus Ster. Balu.

\section{Berosus Leach.}

luridus L. Kauk.

signaticollis Charp. 'T'll.

\section{Cercyon Leacl.}

ustulatus Preyssl. Kúb.

obsoletus Gyll. Arab.

haemorrhoidalis F. Chlews.

flavipes F. Azkur., Iirk.

melanocephalus L. Suram.

terminatus Marsh. Lenk.

lyggmaeus Ill. Mamtl.

analis Ph. U-der.

granarius Er. Suram., dzkur.

lugubris $\mathrm{P} k$. Lenk.

\section{Megasternum Muls.}

caucasicum Kuw, Lenk, Chews.

\section{Cryptopleurum Muls.}

crenatum Janz. Kank.

atomarium Ol. Borsh.
Sphaeridium F.

bi unstulatum I'. Borsh.

var. marginatum F. Kauk.

scarabaeoides Id, Borsh., Kasb., Chews.

var. pictum lald. Pari.

\section{Coelostoma Brll.}

lispanicum Küst. Lenk., 'l'tl. orbiculare F. 'Tff.

\section{Helophorus F.}

rugosus Ol. Tars-tsch.

mubilus li. Kank.

var. costatus Göze. Circas.

micans Fald, var. subcostatus Kol, I

guttulus Mot. T'btı., Tbiz. S.

griecus Ilbst. Lenk.

var. brevi alpis bed. Lenk., Tbiz. S.

var. creticus Kiesw. Kauk.

aquaticus Is. Elsbth., Achllk., Lirk.

dorsalis Marsh. Suram.

granularis L. Borsh., 'Tfl., 'T'biz. S., Zlk. obscurus Mlls. Swnt.

\section{Hydrochus Leach.}

elongatus Schall. Kauk.

flavipennis Küst. Lenk.

angustatus Germ. Lenk.

Ochthebius Leach.

exsculptus Germ. Borsh.

juberulus Reitt. Tfl.

foveolatus Grin. Arax.

limbicollis Reitt. Lenk.

impressicollis Lap. Lenk.

margipallens Latr. Lenk.

marimus Pk. T'f., Borsh., 'J'biz, s

Crimeae Kuw. Lenk.

\section{Hydraena Irugel.}

riparia Kug. Lenk., Tbiz. S.

\section{FAM GEORYSSIDAE}

Georyssus Latr.

crenulatus Rossi. Lenk., Borsh. 
laesicollis Germ. Lenk.

costatus Lap. Lenk.

\section{FAM. PARNIDAE.}

\section{Elmis Latr.}

Germari Er. Borsh.

\section{Esolus Muls.}

angustatus Müll. Borsh.

\section{Riolus Muls.}

subviolaceus Müll. IBorsh.

\section{Potamophilus Germ.}

acuminatus F. Aresch.

\section{Dryops 01.}

longus Solsky. Tft. angulicollis Reitt. Tft.

\section{Parnus F。}

lutulentus Er. var. caspius Mén. Arax, Trt. striatellus Frm. Migri.

luridus Er. Kank.

caspicus Fald. var, caucasicus Kuw. 'Tft pilosellus Er. Lenk.

\section{FAM. HETEROCERIDAE.}

\section{Heterocerus F.}

sericans Ksw. Kauk.

multimaculatus Mot. Arax.

laevigatus Panz. var. corsicus Kúw. Leul. minutus Ksw. Arax.

vitticolis Reitt. L,enk.

obliteratus Ksw. Arax.

\section{FAM. STAPHYLINIDAE.}

\section{Ocalea Er.}

puncticollis Rey. $\Lambda$ ch-bu., Lirk.

dubia Mot. Helnd.

picata Stph Helnd., Zlli.

\section{Chilopora Kr.}

antemnata Epp. Ara:
Calodera Mannh.

rubens Er. Lenk.

Phloeopora Er.

reptans Grav. Abst.

latens Er. Lenk.

\section{Ischnoglossa Kr.}

corticina Er. Hamrt., Link.

Oxypoda Mannh.

lividipennis Steph. Mesk. G., Lirk.

opaca Grav. Gomt.

humidula Kr. Mantl.

umbrata Gyll. Kara-bu, Lirk.

t.gata Er. Kauk.

fusina Rey. Lenk., Lirk.

praccox Er. Saril.

formosa Kr. Lirk.

Microglossa $\mathrm{Kr}$.

suturalis Sahlb. Mamtl.

\section{Aleochara Grav.}

lucidula Hochh. Hamrt.

fuscipes F, U-der.

diversicornis Epp. Lenk.

crassicornis Lac. Mamtl.

bipunctata $\mathrm{Ol}$. $\Lambda \mathrm{rm}$.

Milleri Kr. Arm.

tristis Grav. Borsh., Hisbth.

lanuginosa Grav. Martk.

nitida Grav. Lenk., Kathfld.

\section{Homoeusa Kr.}

acuminala Märk. I lirk.

\section{Oxysoma Kr.}

Reitteri Faur. Arax.

Dinarda Mannh.

dentata Grav. Kauk.

\section{Lomechnsa Grav.}

strumosa $F^{\prime}$. var. cancasica Wasm. Lom-mta. 


\section{Zyras Steph.}

Haworthi Steph, Lirk.

collaris Pk. Letch., Mesk. G.

\section{Myrmedonia Er.}

laeviceps Epp. Abst.

\section{Drusilla Leach.}

canaliculata F. Lenk, Mamtl. gracilis Hochh. Lenk.

\section{Alenonota Thms.}

macella Er. Tienk.

\section{Colpodota Rey.}

melanaria Mannh. Mamtl.

pygmaea Grav. Lirk., Ilamrt.

parva Sahlb. Mamtl., Elsbth.

muscorum liris. Tal.

nigerrima Aubé. Elsbth.

fungi Grav. Martk., Lenk., I)umanis.

var. clientula Er. Lenk, Letch.

orphana Er. Mamtl.

laticollis Steph. Mamtl.

\section{Amischa Thms.}

analis Grav. Mamtl.

soror Kr. Lenk., Hamrt.

exilis Er. Arax.

\section{Geostiba Thms.}

formiceticola Epp. Zlk.

\section{Taxicera Rey.}

deplanata Grav. Helnd.

\section{Dinaraea Thms.}

angustula Gyll. Dumanis.

\section{Liogluta Thms.}

aquatilis Thms. Saril.

vicina Stph. Gont, Lirk.

sexnotata Thms. Circas.

georgiana Mot. Mesk. G.

\section{Atheta Thms.}

armaniaca Epp. Arax. castanoptera Mannh. Letch.

crassicornis F. Kauk.

liturata Steph. Gandsha, Lirk.

nigritula Grav. Mesk. G.

basicornis Rey. Lenk.

tibialis Heer. Kasb.

elongatula Grav. Kathfld.

picipennis Nannh. Arax.

longicomis Grav. Mamtl.

sordidula Er. Mamtl.

celata Er. Mesk. G.

\section{Alconota Thms}

languida Lir. Lenk. insecta Thms, Lenk. sulcifrons Steph. Lenk.

(ambrica Woll. Isenk.

\section{Gnypeta Thms.}

carbonaria Mamul. Algeth.

\section{Falagria Steph}

sulcata Pk. Kodsh.

thoracica Curt. Kank.

sulcatula Grav. Mamtl.

nigra Grav. Letch.

obscura Grav. Tfl., Mamtl., Lenk., Elsbtl.

\section{Autalia Steph.}

impressa 0l. Lirk.

rivularis Grav. Borsh.

\section{Bolitochara Mannh.}

lucida Gray. Lenk., Hamrt. obliqua Err. Ach-bu, Lirk.

\section{Silusa Er.}

areolata Reitt. Circas.

\section{Leptusa Kr.}

angusta Aubé. Martk., Tbtn., Elsbp.

venusta Hochh. Swnt., Dagt.

rufescens Epp. Lirk.

fuliginosa Aubé. Mesk. G.

Lederi Epp. Kauk.

microphthalma Reitt. Circas. 
caucasica Epp. Mesk. G. bituberculata Epp. Kauk. carinicollis Epp. Mamtl. cingulata Epp. Mamtl.

\section{Placusa Er.}

pumilio Grav. Dumanis.

\section{Gyrophaena Mannh.}

affinis Sahlb. Abst. gentilis Er. Abst., Helnd.

fasciata Mrsh. Saril.

bihamata Thms. Lenk., Mamtl. lucidula Er. Lenk. manca Er. Lenk. polita Grav. var. strictula Er. Saril

\section{Pronomaea Er.}

rostrata Er. Letch. araxicola Reitt. Arax.

\section{Myllaena Er.}

graeca Kr. Lenk. caucasica Epp. Mesk, G. infuscata Kr. Kauk.

\section{Oligota Mannh.}

pusillima Grav. Lenk., Such. pumilio Ksw. Kauk. atomaria Er. Elsbth. inflata Mannh. Mamtl.

\section{Trichophya Mannh.}

pilicornis Gyll. Mesk. G.

\section{Habrocerus Er.}

capillaricornis Grav. Dumanis, Lenk.

\section{Coproporus Kr.}

colchicus $\mathrm{Kr}$, Tenk.

\section{Tachinus Grav.}

proximus $\mathrm{Kr}$. Arab. G. marginatus Gyll. Kauk. rufipes Deg. Kauk. collaris Gray. 'Tbtn. subterraneus I. Arab. G.

\section{Tachyporus Grav.}

formosus Matth. Letch.

solutus Er. Namtl.

var. caucasicus Kolen. Kauk.

chrysomelinus L. Arm., Mamtl.

hypnorum F. Lenk, Lirk.

var. armeniacus Kol. Tal.

macropterus Steph. Mamtl.

nitidulus F. Kauk.

pusillus Grav. Kauk.

\section{Conurus Steph.}

pubesceus Pk. Lenk., Hamrt., Helnd. immaculatus Steph. Lirk.

dimidiatus Hochh. Hamrt.

pedicularius Grav. Hamrt, Mamtl.

\section{Bolitobius Steph.}

rostratus Mot. Swnt.

trinotatus Er. Lenk., Dumanis., Abst.

pygmaeus F. Lenk.

\section{Bryocharis Mannh.}

cingulata Mannh. Lenk.

\section{Mycotoporus Mannh.}

splendidus Grav. var. longicornis Mäkl. Kauk.

spelaeus Seriba. Circas.

myops Epp. Helnd.

tenuis Er. Gomt.

splendens Marsh. Mesk. G., Lenk., Mamtl.

\section{Quedius Leach.}

transcaucasicus Fald. Swnt.

var. suramensis Epp. Circas.

cruentus Ol. Mesk. G.

cinctus Pk. Rasn.

tristis Grav. Rasn.

fuliginosus Grav. Goktseh.

ochropterus Er. Martk.

umbrinus Er. Mamtl.

humeralis Steph. Kauk.

coxalis Kr. Kauk.

limbatus Heer. Swnt.

gemellus Epp. Circas.

obliteratus Er. Arax. 
pararlisianus Ileer. Hamrt. I illk.

attenuatus Grll. Kauk.

boops Gras. Tar. brevipennis Frm. Kank.

\section{Emas Curt.}

hirtus Is. Dilgt, Isom-mita.

\section{Creophilus Mannh.}

maxillosus I. Kink.

\section{Leistotrophus Perty}

murinus I. liorsh., Gomt.

\section{Staphylinas $\mathbf{L}$.}

lutarius Grav. Borsh.

chalcocephalus I: Jesk. G.

erythropterus I. Kasb.

caesareus C'ederh. IBorsh., (romt.

\section{0cypus Kirby.}

olens Mull. Borsh., IBaku.

alpestris kir. Swnt.

var. gracilicornis Unchh. Kauk.

ophthamicus Scop. Gomt.

nitens Schrk. Swnt.

picipennis F. Kasb., Gomt, Rasn.

fulvipennis Er. Mamt?.

denressus Hochh. Kauk.

\section{Physetops Mannh.}

tataricus Pall. Aresih.

\section{Actobius Faur.}

cinerascens Grav. Tenk.

\section{Philonthus Curt.}

intermerlius Lac. Kash.

chalceus Steph. Kauk.

politus It. Saril.

atratus Grav. Borsh.

debilis Grit. Isenk., Elsbth., IIamnt.

ebeninus Grav. Kank.

conciunus Grav. Arm.

frigidus Kisw. Kauk.

sanguinolentus Grav. Kauk.

quisquiliarius Gyll. Arm. var. rubidus Er. Tenk.

fimetarius Grav. Kasb. Jirk.

dimidiatipennis Lr. Arax.

astutus Fr. Arm.

nigritulus Grav. Lenk.

femoralis Itochh. Kank.

vernalis Grav. Isenk., IIelnd., IIamrt.

varius Gyll Kauk.

val. bimaculatus Grav. Kauk.

bipustulatus Woll. Borsh., Alexp.

varians P'k. Kauk.

albijes Grav. Kauk.

fumarius Grav. I.cnk.

micans Grav. Isenk.

salinus Ksw. Lenk.

fulvipes l'. Martk, Saril.

tenuis F. Lenk.

\section{Platyprosopus Mannh.}

elongatus Mannh. Dagt.

\section{0thius Steph.}

fulvipennis F. Kauk.

grandis Hochh. Saril

stenocephalus Epp. Circas.

myrmecophilus Ksw. Tbtn.

lapidicola Ksw. Kauk.

pallidus lirancs. Mesk. G., Swnt.

\section{Baptoliuns Kr.}

affinis l'k, Jbst.

\section{Leptacinus Er.}

batychrus Grll. Mamtl.

\section{Metoponcus $\mathrm{Kr}$.}

basalis Aube. Isenk., Swu.t.

Nudobius Thms.

umbratus Mot. Saril.

\section{Xantholinns Serv.}

punctulatus I'k. Kouk. fortepunctatus Mot. Kauk. crassicornis Hochh. Abst. variabilis Iochh. Hamrt. 
linearis 01. Lenk., Dumanis.

graecus $\mathrm{Kr}$. Kauk.

\section{Cryptobium Mannh.}

fracticorne Pk. Lenk., Gomt. var. egregium Reitt. Kauk.

\section{Dolicaon Iap.}

sparsus Reitt. Circas.

biguttulus Lac. Mangl.

\section{Lathrobium Grav.}

Eppelshoimi Czwal. Circas. castaneipenne Kol. Saril. fulvipenne Grav. Mesk. G longulum Grav. Lenk. quadratum Pk. Lenk. terminatum Grav. Tal. Lederi Epp. Hamrt. picipes Er. Lenk.

\section{Medou Steph.}

Araxidis Reitt. Arax. ripicola $\mathrm{Kr}$. Elsbth. apicalis $\mathrm{Kr}$. Lenk. bicolor OI. Lenk. melanocephalus F. Gandsha. obsoletus Nordm. Lenk.

\section{Scopaeus Er.}

pusillus Hochl. Lenk. laevigatus Gyll. Lenk. cognatus Rey. Martk. sulcicollis Steph. Arax.

\section{Stilicus Latr.}

angustatus Fourer. Lenk., Alexd., Saril. orbiculatus Pk. Mamtl. rufipes Er. Lenk., Lirk. Erichsoni Fauv. Lenk.

\section{Sunius Steph.}

filiformis Isatr. Kank. nigromaculatus Mot. Kauk. bimaculatus Er. Lenk., Martk. angustatus Pk. Lenk. neglectus Miärk. Lenk. thoracicus Baudi. Kauk. immaculatus Steph. Hampt, Letch.

\section{Nazeris Fauv.}

pallidipes Reitt. Kauk.

\section{Paederus Grav.}

littoralis Grav. Mamtl.

riparius L. Lenk.

fuscipes Curt. Artschw., Anit., Hamrt., Borsh., Lenk.

ruficollis F. 'TH., Borsh. sanguinicollis Steph. Helnd.

\section{Stenus Latr.}

bipunctatus Er. Borsh. nanus Steph. Lenk., Lirk. circularis Grav. Letch. humilis Er. Mamtl. ignotus Epp. Lenk. confrater Epp. Kauk. clavicornis Scop. Mamtl. providus Er. Lenk. ater Mannh. Mamtl. incrassatus Er. Tal. morio Grav. Lenk. buphthalmus Grav. Mamtl. piscator Saulcy. Elsbth. formicetorum Mannh. Arm. latifrons Er. Lenk. similis Hbst. Mamtl. fornicatus $\mathrm{Er}$. Lenk. pallitarsis Steph. Lenk, Mamtl. flavipes Steph. Borsh. cordatus Grav. Saril. elegans Rosh. Dagt. geniculitus Grar. Mamtl. flavipalpis Thoms. Mesk. G. coarcticollis Epp. Kauk. suramensis Epp. MIesk. G., Lenk. Erichsoni Rye. Kauk. lineola Epp. Circas. micropterus Epl. Mesk. G. grosscpunctatus Reitt. Circas. montivagus Ireer. Abst., Mamtl. 
clarmlus Hochln. Borsh., Ach-bu.

\section{Euaesthetus Grav.}

fulvis Mot. Kank,

\section{Oxypor'us F。}

rufus 1. Pseasch. 'l'an.

Plathysthetus Manmh.

cormutus (urar. Arm.

nitens salıll, Eilshth.

arenarins fourer. Fisbth.

lneris lisw. lenk.

\section{0xytelus Grav.}

rugosus I'. I a enk

picens L. Borsh., Lenk, Belasw.

hybridus Epp. Suram., Circas.

sculpturatus Grav. Isirk.

nitidulus Grav. Lenk., Mamtl.

gibbulus Lpp. Kauk.

pumilus Elr. 'T'fl

speculifrons Err. Lirk.

clypeonitens Pand. Lilsbtlı, Martk.

tetracarinatus Block. Borsh., Gont.

hamatus Fairm. Lenk

\section{Bledius ITannh.}

spectabilis Irr. Anit. tricornis Hbst. Anit. opacus Block. Lenk. atricapillus Germ. Kauk.

tibialis Heer. Isenk

fossor Heer. Mrax.

\section{Trogophloeus Maunh.}

Nannerheimi Kol, Lenk.

arcuatus Steph. Lenk., 'l'tl.

bilineatus Lir. Lenk.

memnonius Er. Isenk.

politus Ksw. Lenk.

corticinus Grav. Isenk, Dumanis.

pusillns Grav. Alget.

gracilis Mannh. Arax., Elsbth.

despectus Baudi, Arm.

exiguus Lir. Arax., Lenk.

\section{Thinobius Kiesw.}

longipennis IIcer. I,enk.

\section{Ochthephilus Rey.}

omalinus Wr. Juenk.

emarginatus lauv. IIelnd.

\section{Coprophilus Latr:}

pennifer Hot. Arix.

\section{Anthopliagus Grav.}

vracustus Mïll. Abst.

rotundicollis Heer. Kara-bu.

\section{Geodromicus Rath.}

globulicollis Zett. var, bruvicollis lauv. Arm.

\section{Lesteva Latr.}

longelytrata Goeze. Lirk.

\section{Olophrnm Er.}

fuscum Grav. Kasb., Kobi.

cancasicum Fauy. Tsenk.

\section{Lathrimaeum Er.}

atrocephalum Gyll. Mesk. G. melanoceplualum Ill. Mesk. G.

Arpedium Er.

fratellum Iitthg. Arax.

\section{Xylodromus Heer.}

concimus Marsh. Kara-bu.

testaceus lir. Kauk.

\section{Omalium Grav.}

pusillum Grav. Nuschw.

caesum Grav. Mesk. G., Muschw., Lirk.

florale Pk. var. nigrum Grav. Arm.

striatum Grav, Kank.

\section{Anthobium Steph.}

rufotestaceum Mot. Gambor.

Protinus Latr.

brachypterus F. Lenk, Abst. 
Psendopsis Nowm.

sulcata Newm. Kub.

\section{Trigonurus Muls.}

asiaticus Reiche. Kauk.

\section{FAM. MICROPEPLIDAE}

\section{Micropeplus Latr。}

caelatus Er. Lenk.

caspius Reitt. Tal.

fulvus Lr. Circas., Lirk.

longipennis $\mathrm{Kr}$. Lenk, Lirk.

\section{FAM. PSELAPHIDAE. Panaphantus Kiesw.}

atomus Kiesw. Lenk.

\section{'Irimiam Aubé.}

caucasicun Kol. Kurgl.

Koenigi Reitt. U-der.

\section{Euplectus Leach.}

nubigena Reitt. U-der.

Duponti Aubé. U-der

nanus Reichb. Lenk.

occipitalis Reitt. Lenk.

sanguineus Denny var.georgicus Saulcy. Elsbtlı. signatus Reichb. Lisbth.

Karsteni Reichb. Gudr.

minutissimus Aubé. Tuenk.

\section{Bibloporus 'I'hms.}

bicolor Denny. Lenk. variicolor Reitt. Lenk.

\section{Trichouyx Chd.}

lalyschensis Reitt. Lenk.

\section{Bergrothia Reitt.}

Saulcyi Reitt. Mesk. G.

Lederi Saulcy. Arm.

\section{Batrisus Iıap.}

liuprediti kol. I.enk.

rireassicus Reitt. Kauk.
Bryaxis Leach.

brumiventris Mot. Arax.

fossulata Reichb. U-der.

Ilelferi Schmidt. Lenk.

Araxilis Reitt. Arax.

nodosa Mot. Kauk.

melinz Solsliy. Arax., Tal.

iranica Sanley, 'I'al., Lenk.

montana Saulcy. Kauk.

impressa P'z, Lenk.

spinipes lieitt. 'T'al.

antennata Aubé. Kank.

\section{Rybaxis Saulcy.}

sanguinea I. Lenk, Leteh.

var. uigropygialis frm. Kauk.

gigas Baudi. Lenk.

\section{Bythinus Leach.}

caviceps Reitt. Lenk.

gracilis Mot. Lenk.

corpulentus Mot. Suram., Muschw.

giraffa Reitt Kauk.

Nakeralae Reitt. U-der.

elephas Reitt. Mesk. G.

clavipes Mnt. Dagt.

dimorphus Reitt. Dagt.

tscherkessicus Reitt. Circas.

argiolus Reitt. Kub.

Lerleri Reitt. Kub.

rostratus Mot. Letch.

bulbifer Reichb. Mamtl.

Tychus Leach.

niger Pk. Kiauk.

ral. dichrous Sehmidt. Kank.

colchicus Saulcy. Kauk.

angulifer Reitt. Isenk.

armeniacus Saulcy. Kauk

brumneus MIot. Lenk.

\section{Pselaphoptrus Reitt.}

Kubischtecki Reitt. Kinuk.

Psulaphus Hbst.

Heisci Hhet. liank. 
caspicus Reitt. Lenk.

acuminatus Mot. Assuret.

pentagonus Sauley Suram, Lenk,

\section{Ctenistes Reichb.}

palpalis Reichb. Lenk., Istch.

Enoptostomus Schaum.

globulicornis Mot. Lenk.

\section{FAM. CLAVIGERIDAE Claviger Preyssl.}

colchicus Mot. Weri., Mamtl.

\section{FAM. PAUSSIDAE.}

Panssus $\mathrm{L}$.

turcicus Friv. Suant, Rasn.

\section{FAM. SCYDMAENIDAE}

\section{Cephennium Müll.}

perispinctum Kolen. Mesk. $G$.

thoracicum Müll. Suram., Iseteh.

caucasicum Saulcy. Kank.

Nanophthalmus Mot.

armeniacus Reitt. Circas.

megaloderuides MIot. Mesk. G.

\section{Neuraphes Thms.}

balaena Saulcy. Mamtl.

regalis Reitt. Kub.

occipitalis Saulcy Mesli G.

\section{Cyrtoscydmus Mot.}

scutellaris Müll. Elsbtlı.

IIelferi Schaum. Kank.

collaris Müll. Mamtl.

var. subseriatus Reitt. Dagt.

pusillus Müll. Letch

Kamberskyi Reitt, Arax.

\section{Euconnus Thms.}

cornutus Saulcy. Lenk.

denticornis Müll. Mamtl, גch-bu. var. suramensis Reitt. Mesk. G., Melnd. robustus lieitt. Mesk. G.

Schlosseri Reitt. Mesk. G.

hirticollis 111. var. Sanguiniyemis lieitt. Lenk.

confusus liris. Isenk.

Wetterhali Gyll. Lenk., Nantl.

manus Schanm. Lenk.

Reitteri Saulcy. Suram.

Kraussi Reitt. Martk. Swnt.

Scydmaenus Latr.

I'nfus Müll. Lenk.

cormutus Mot. Kauk

Leptomastax Piraz.

caucasicns Reitt. Abch.

\section{FAM. SILPHIDAE.}

\section{Bathyscia Schioedte.}

persica $\Lambda$ b. Mesk. G.

pusilla IInt. Martk.

\section{Nargus Thms.}

conjungens Saulcy. Arax.

ovatus Reitt. Swnt.

Catopomorplius Aubé.

arenarius Hampe. Assuret

\section{Attumbra Gozis.}

fermoralis Reitt. Arax.

Sciodrepa Thms.

Watsoni Spence. Kathfll.

\section{Catops Payk.}

grusinus Reitt. Cireas. marginicollis Luc. Lenk.

fuscus $\mathrm{Pz}$. 'Tfl.

hybridus Reitt. Arax.

nitidicollis $\mathrm{Kr}$. Mantl.

dichrous Reitt. Swnt.

Nemadus 'Thms.

suturalis Murr. ArRx. 


\section{Ptomaphagus Hellw.}

circassicus Reitt. Circas.

Colon Hbst.

myous Czwal. Circas., Swnt

\section{Neccophorus F.}

liumator Goeze. Derb., Borsh.

interruptus Stph. Swnt., Tan.

funeror Reitt. Swnt.

vespillo L. Chram., Tan.

nigricornis Fald. Murd-tp., Swnt., Btscling.

\section{Pseudopelta Voet.}

simuata F. Lenk.

rugosa L. Tfl., Mzhet., Elsbth, Petrwk.

thoracica L. Derb., Suram.

\section{Aclypea Reitt.}

undała Müll Kapud., Tbiz. S., Kasb, Suram., Pari, Migri-tschai.

var. verrucosa Mén. Chews., Tan.

\section{Xylodrepa Thms.}

4-punctata Sclreb. Kauk.

\section{Silpha Is.}

lunata F. var. atropurpurea Küst. Borsh. Zlk., Circas.

obscura L. var. striola Mén. Adsh., Borsh., Kasb., Muschl., Lenk., Kasikp., Suram., Tan., Swnt., Helnd.

granulata 'Thnb. Kauk.

var. costata Mén. Lenk.

\section{Peltis Geoffr.}

atrata I var. nitida Fald. Suram., Kasb., Tan.

\section{Ablattaria Reitt.}

laevigata F. N. Rossk.

cribrata Mén. Borsh., Aresch.

\section{FAM. ANISOTOMIDAE.}

\section{Anisotoma Ill.}

orbicularis IIlost, Lenk., Mesk. (*., Lom-mta.

\section{Amphicyllis تr.}

Globus F. Saril.

var. ferrnginea Sturm. Circas.

\section{Agathidium III.}

nigripenne Kug. Kauk.

atrum Plk. Namtl.

cancasicum Reitt.' Isom-mta

seminulum $L$ Abst.

suturale Reitt. Kauk.

caspicum Reitt. Hamrt.

laevigatum Er. Alesd.

circassicum Reitt. Circas.

var. laeticolor Reitt Kank.

filicorne Reitt. Cireas., Swnt.

Lederi Reitt. Circas.

badium Fr. Lenk.

marginatum Sturm. Lenk.

piceum Er. Btschng.

rotundatum Gyll. Mesk. G.

rotundulum Reitt. Lom-mta.

plagiatum Gyll. Lenk, Lom-mta.

Ansibaris Reitt.

alexiiformis Reitt. Circas.

FAM. EUCINETIDAE.

Encinetus Germ.

haemorrhoidalis Germ. Mamtl.

\section{FAM. CLAMBIDAE,}

\section{Calyptomerus Rdtb.}

caucasicus Reitt. Mesk. G., Muschw.

Clambus Fisch.

minutus Strm. Lenk., Mesk. G., Elsbth. punctulum Beck. Mesk. G.

\section{Loricaster Mnls.}

testacens Muls. Isenk.

\section{FAM. CORYLOPHIDAE Parmulus Gundl.}

pusillus Gyll. Kauk.

latus Reitt. Mesk. G., Lirk. 


\section{Arthrolips Woll.}

piceus Com. Kaluk.

ferrugatus leitt. Kíuk.

\section{Sericoderus Stepl.}

lateralis Gyll. Isenk.

\section{Corylophus Stoph.}

('assidoides Mrsh. Lenk., Mamt\}.

\section{Orthoperus Steph.}

Kluki Wauk. Kauk.

\section{FAM. TRICHOPTER YGIDAF}

Nossidium Er.

pilosellum Marsh. Isenk, Mamtl.

\section{Ptenidium Er.}

myrmecophilum Mlot. Borsh.

pusillum Gyll. Arax., Bursh., log-kits., Elsbth var. corpulentum Luc, Arax.

var, orientale Flach. Lenk.

Reitteri Flach. Arax.

\section{Ptiliolum Flach.}

Oedipus rlach. Swnt.

\section{Neuglenes 'Thms.}

ipterus Ginér. Lenk.

\section{Trichopteryx Kirby.}

grandicollis Märk. Arm

Alontandoni Allis. Eisbsth.

rufilabris Flach. Lirk.

Flachi lieitt. Arm., Swnt.

soror Flach. Swnt.

sericans Heer. Arax.

\section{FAM SCAPHIDIIDAE}

\section{Scaphium Kirby.}

rulipes licitt. batum.

Scaphosoma doach.

atsiricimum 1s. benk lacviusenlum Reitt. I denk.

dilutum Reitt. Isenk.

boleti P'z. Isenk.

\section{Baeocera Er.}

Schinmeri Reitt. Isenk.

\section{FAM PHALACRIDAE.}

\section{Phalacrus Pk.}

frater lilach. Arax.

fimetarius F. Kiptsch., Borsh., Martk, 'l'fl. var. Ilumberti lye. Kauk.

\section{Olibrus Er.}

aeneus I:. Martk

Koltzei Flach. Kauk.

millefolii Pk. Borsh., Ilelnk

bicolor $\mathrm{F}$. Karasu., Etschm.

bisignatus Mén. Kauk

liquillus Er. Mamtl.

pygmaeus Strm. Martk., Muschel.

Havicornis Strm. Kank.

\section{Stilbus Seidl.}

testacens $\mathrm{P} \%$. Lenk.

oblongus lir. Lenk.

\section{FAM. EROTYLIDAE}

\section{Engis Pk.}

pontica Bedel. Isenk., Batum, U-der. semirufula Reitt. Lenk., N.-liossk., Helnd. rufifions $\mathrm{F}$. Isetch.

bipustulata T'hnb. Batum.

\section{Loborogosmus Reitt.}

fasciatus Kolen. Kank.

\section{Triplax Pk.}

Minsenli bied. Kauk.

acnea Schall., Suram., I,om-mita.

lepida Fald. U-der.

rufiues F'. U-der., 'T'an.

collaris Sihalk. bonk. lam-mta.

var, sulphuricollis Rejtt. Lenk, Hannt. 
Cyrtotriplax Crotch.

octonotata Pedel. Sugd., U-der.

valida Reitt. 'Tan.

bipustulata F. Batum., Krsu. ['olj., Mamtl

$$
\text { FAM, ENDOMYCHIDAE. }
$$

\section{Hylaia Rdtb.}

pordagrica Guèr. Batum.

\section{Lycoperdina Latr.}

succincta $\mathrm{I}_{\iota}$, Iom-mita.

\section{Mycetina Mls}

apicalis Not. Suram., Batum., Borsh., Tan.

Endomychus Pz.

armeniacus Mot. T'sk-T'sk., I,om-mta., I etch., Borsh.

\section{MIyrmecoxenus Chvr.}

picinus Aubé. Kauk.

\section{Lithophilus Fröhl.}

connatus Pz. Dartag. major Crotch. Kasikp. araxis Reitt. Arax.

\section{Leiestes Rdtb.}

seminigra Gyll. Kauk.

\section{Symbiotes Redtb.}

gibberosus Luc. Saril.

\section{Mycetaea Steph.}

hirta Marsh. Kauk.

\section{Agaricophilns Mot.}

reflexus Mot. Circas.

var. subaeneus Reitt. Suram., Batum., Lommta., Abst.

\section{Alexia Steph.}

circassica Reitt. Circas, Krasn. Polj. alutacea Reitt. Circas. pilifera Müll. Suram.

pilosella Reitt. Suram., Lirk., I,etch.

\section{FAM. CRYPTOPHAGIDAE Diphyllus Stph.}

frater Aubé. Lenk., U-der.

\section{Diplocoelus Guèr.}

fagi Chorl. Ienk, Hamrt., I,om-mta., Mesk.G. humerosus Reitt. U-der.

\section{Cryptophilus Reitt.}

integer Heer. Kauk.

\section{Telmatophilus Heer.}

sparganii Ahr. Lenk.

caricis Ol. Lenk.

brevicollis Aubé. Isenk.

var. I'ufus Reitt. Lenk.

\section{Tomarus Iec.}

pilifer Reitt. Kauk.

\section{Leucohimatium Ros.}

elongatum Er. Arax.

\section{Antherophagus Ltr.}

caucasicus Reitt. Abst.

\section{Haplophus Friv.}

robustus Moraw. Arm.

\section{Paramecosoma Cert}

melanocephalum Hbst. Kauk.

mivestre Reitt. Kank.

\section{Cryptophagus Host.}

araxicola leitt. Arax.

baldensis Er. Kauk.

pilosus Gyll. Kauk.

lapidicola Reitt. Mesk. G.

Skalitzkyi Reitt. Arax.

Schmidti Strm. Kauk.

Milleri Reitt. Mamtl.

cellaris Scop. Kauk. 
acutangulus Gyll. Mesk. G.

distinguendus Strm. Liauk.

quadrimaculatus Reitt. Iirk, IIchn.

lirucki Reitt. Mamtl., IIamrt.

scutellatus Newm. Kauk.

dentatus Ilbst. Lenk, Lirk.

dilatipennis Reitt. Kauk.

'Thomsoni Reitt. Hamrt., Lirk.

scanicus I. Lirk.

var. hirtulus Kr. Helnd.

nigricollis Reitt. Kauk.

villosus Heer. Borsh., Lenk.

\section{Mniomidius Reitt.}

sorricollis Reitt. Mesk. G.

\section{Caenoscelis Thms.}

ferruginea Sahlb. Kauk.

\section{Atomaria Steph.}

umbrina Gyll. Totn.

nigriventris Stph.var.puncticollis Thms. Kauk.

linearis Stph. Lilsbth.

pumila Reitt. Kauk.

diluta Hr. Kauk.

Uhagoni Reitt. Lenk.

alpina Heer. Lirk.

gracilicornis Reitt. Mesk. G.

prolixa Er. rar. pulchra Er. Kauk.

fuscicollis Hannh. Krasb., Lenk.

impressa Er. Kauk.

munda Fr. Arax.

unifasciata Er. Mamtl.

castanoptera Reitt. Lenk., Lirk.

fuscata Schh. Lenk.

atricapilla Stph. Lenk.

peltata Kr. Kauk.

fuscipes Gyll. Kauk.

pusilla Schh. Lenk.

nigripennis Payk. Kauk.

Attila Reitt. Swnt.

apicalis Er. Bogr-kïis., Mamtl.

ruficornis Mrsh. Borsh., Lenk., Lirk.

testacea Stph. Iirk.

var. viennensis Reitt. Kauk.

rubricollis Bris. Hamrt., Mamtl. thorictoides Reitt. Suram.

cephennioides lieitt. Mesk. G.

var. circassica Reitt. Circas.

\section{Sternodea Reitt.}

Isederi lieitt. Circas.

Raddei Reitt. Suram, I

Miki Reitt. Swnt.

\section{Ephistemus Steph.}

globulus 1 k. Isenk.

exiguus Lir. Lenk., Elsbp.

dilutus Reitt. Kauk.

\section{FAM. LATHRIDIDAE.}

Coluocera Mot.

formicaria Mot. Derb., Rasu, Lirk.

var. major Reitt. Lenk., Rasn.

\section{Merophysia Luc.}

formicaria Luc. Arax.

\section{Holoparamecus Curt.}

singularis Beck. var. Lederi Reitt. Arax.

\section{Dasyceras Brongn.}

crenatus Mot. Mesk. G., Mantl.

\section{Lathridius Hbst.}

angusticollis Gyll. Lenk., Lirk., Namtl. sinuatocollis Fald. Suram., Mesk. G., Lenk.

\section{Enicmus Thms.}

minutus L. Lenk., Elsbth. consimilis Mannl. Kauk.

Mannerheimi Kolen. Circas, Mesk. G. rugosus Ilbst. Lenk., Hamrt.

dubius Mannh. Kank.

transversus 0l. Lenk., Mesk. G., Lirk.

brevicornis Mnnh. U-der.

\section{Cartodere Thms.}

aequalis Reitt. Suram.

anatolica Mannl. Lenk. 
ruficollis Mannh. Zlk.

filiformis Gyll. Lirk.

Schüppeli Reitt. U-der.

\section{Metophthalmus Woll.}

humeridens Reitt. U-der.

\section{Corticaria Mrsh.}

pubescens Gyll. Kauk.

illaesa Mannh. Lenk., Rasn.

var. quadrimaculata Mamnh. Martk.

fulva Com. Kauk.

longicornis Hbst. Kauk.

longicollis Zett. Kauk.

serrati Pk. Lirk., Hamrt.

obscura Bris. Kauk.

elongata Gyll. Rasn.

Beloni Reitt. Ai'ax.

ferruginea Gyll. Lenk., Suram., Lirk.

\section{Melanophthalma Mot.}

transversalis Gyll. Lenk., Mamtl.

var. crocata Mannh. Kauk.

var. curticollis Mannh. Mamtl.

var. pallens Mannh. Lenk.

var. albipilis Reitt. Tschtg.

distinguenda Com. Lenk., Muschd.

var. parvicollis Mannh. Mamtl.

fuscipennis Mannh. Kauk.

gibbosa Hbst. Suchum., Lenk.

similata Gyll. Leenk., Lirk.

fuscula Humm, Suram.

\section{Migneauxia Dav.}

crassiuscula Aubé. Kodi., Lenk.

\section{FAM. TRITOMIDAE}

Triphyllina Reitt.

Lederi Reitt. Suram.

\section{Pseadotriphyllus Reitt.}

colchicus Reitt. Saril., Lom-mta.

\section{Triphyllia Reitt.}

Koenigi Reitt. Lom-mta.
Litargus Er.

comnexus Fourcr. Kauk.

\section{Tritoma Geoffr.}

quadripustulata L. Lenk., Helnd., Krsn. Polj., Lom-mta.

ancora Reitt. Lenk. Lirk.

picea F. Kauk.

ciscaucasica Sem. Arm.

atomaria $\mathrm{F}$. Suram.

quadriguttata MIüll. U-der.

infulata Reitt. Lenk., Hamrt., Lirk.

multipunctata Hellw. Mesk. G.

fulvicollis F. 'T'schtg.

\section{Atritomus Reitt.}

univestris Reitt. Lenk.

\section{Typhaea Curt.}

fumata L. Baku., Delsh.

\section{Berginus Er.}

tamarisci Woll. Mesk. G., Lenk., Saril.

\section{FAM NITIDULIDAE}

Amartus Lec.

aurosericeus Reitt. Kauk.

\section{Brachypterus Kug.}

gravidus Ill. Kauk.

quadratus Sturm. Atschk.

urticae F. Kiptsch., Lirk., Abst.

Carpophilus Leach.

bipustulatus Heer. Sugd., U-der.

sexpustulatus F. Kauk.

\section{Omosiphora Reitt.}

georgica Reitt. Mamtl.

\section{Epuraea Er.}

decemguttata $F$. U-der.

aestiva L. Suram.

melina Èr. Isetch.

fagi Bris. Kauk. 
variegratiz Illot. Iirk.

whsuleta li. Teenk. Saril.

longular bis. Kank

Marsenli lieitt. Tank

Horea lis surnm., limsh.

\section{Micrurnla Roitt.}

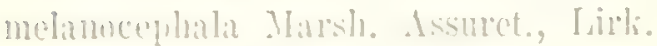

\section{Mitidula F。}

Haromaculatia Lossi. Th. Myhet.

rutipes I. Orlk.

caruaria Sidhall. Kank.

\section{Stelidota kl.}

sexenttata Sallib. Ihatum.

\section{Omosita Fr.}

culon Is. Mlost.

discoilea F'. Lenk, 'l'an.

\section{Soronia Er.}

grisea I. U-der.

\section{Amphotis $\mathrm{Cr}^{\circ}$}

maroinata l'. Tan.

\section{Pria Stopl.}

dulcamarae sicop. I.enk., Juetch.

Meligethes Steph.

heles Rr. Kauk.

rutipes (iyll. Dartag.

lumbaris Sturm. Achlk.

rubripes Nuls. I jirk.

pumilus Lr. Kauk.

var. decoloratus lörst. Lank.

coracinus Sturm, Azk, Kasb, I Iamrt.

subaeneus Sturm. Mamt].

anthracinus liris. Ach\%.

brassicae Scop. Link.

viridescens I: Kauk.

symphyti Heer. Kauk.

subrugosus Gyll. Iborsh., Zlk.

nanus Er. Achz.

obscurus Lir. L-der.
IIofmami lieitt. Kink. parallelus Reitt. Kituk.

bidens liris. liorsh.

umbrosus Sturm. Kiptsch.

maurus Sturm. Alget., 'lfl.

incanus Sturm. Borsh., Mamtl.

oratus Sturm. Suram., Mamtl., Alexp.

opracus Liosh. Kiauk.

brachialis Fir. Wamtl.

picipes Sturm. Kauk.

moestus lleer. Kauk.

flavipes Sturm. Jugr, Saril.

brumnicornis Sturm. Mamtl.

floribundus Reits. '/lk.

haemorrobidalis liörst. Kinn.

atramentarius liörst Kinuk.

clifficilis Mecr. Azkur.

morosus Eir. Suram.

viduatus Sturm. Kank.

pedicularius (tyll. Mamt].

assimilis sturm. Mug., Sch agtsch.

lepidii Mill. Kank.

discoideus lir. Tht.

maculatus Schilsky. Arm.

lugubris Sturm. Kank.

egenus lir. Kauk.

erythropus Gyll. Kauk.

\section{Thalyera Frs.}

fervidar Ol. Borsh.

\section{Pocadius Er.}

ferrugineus F. Kauk.

\section{Cychramus Kag.}

luteus $F$. var. funcricola IIccl. Surnm.

Cyllodes Er.

ater Ilbst. U-der., Batum.,Krasn.Polj., Mesk.G.

\section{Cryptarcha Shuk.}

strigata E. rar, circassica Reitt. U-der. imperialis F. Lenk.

Ips. $\mathrm{F}$.

latefasciatus Reitt, Abch., U-der. 
quadripunctatus Ol. Kauk.

quadripustulatus L. Azkur., Suram.

Pityophagus Shuck.

ferrugineus L. Tan.

\section{Rhizophagus Hbst.}

depressus F. Mesk. G.

perforatus Er. Hamrt.

similaris Reitt. Lenk.

dispar Pk. Kauk.

var. caucasicns Reitt. Swnt.

bipustulatus F. Kauk.

\section{FAM TROGOSITIDAE.}

\section{Nomosoma Latr.}

elongatum L. Kauk.

cornutum Sturm. Derb., U-der.

\section{Tenebrioides Pill.}

mauritanicus L. Sugd., N. Rossk., Helnd, Lirk., Lenk., Baku.

\section{Ostoma Laich.}

grossum L. Kutais., Tan. ferrugineum L. Borsh., T'an. pubescens Lr. U-der., Batum.

\section{Thymalus Latr.}

limbatus F. var. subtilis Reitt. Lom-mta, Urusch., Letch., Borsh., T'sk.-Tsk. var. Aubei Lếv. Batum.

\section{FAM. COLYDIIDAE.}

\section{Corticus Latr.}

tauricus Germ. Mesk. G. celtis Germ. Mesk. G., Lenk. brevipemis Reitt. Circas., Lenk., Swnt.

\section{Dechomus Dnv.}

sulcicollis Germ. Sugd., Batum., Lenk., Krsm. Polj., Lom-mta.

\section{Pycnomerus Er.}

terebrans Ol. Juenk.
Agelandia Reitt.

grandis Reitt. Lenk.

Synchita Hellw.

juglandis F. Kauk.

mediolanensis Villa. Hamrt.

Endophloeas Er.

cxsculptus Germ. Borsh., Batum, Krasn. Polj., Lom-mta.

\section{Niphopelta Reitt.}

imperialis Reitt. Hamrt.

Lastrema Reitt.

verrucicollis Reitt. Lenk.

Ditoma Hbst.

crenata F'. Lenk., Anit.

\section{Colydium F.}

elongatum F. Kauk.

filiforme F. Lenk., Arts:hw., Ilamrt.

\section{Auloninm Er.}

ruficorne O1. Kauk.

\section{Aglenus Er.}

brunneus Gyll. Kauk.

\section{Cerylon Iatr.}

grandicolle Reitt. Circas.

conicicolle Reitt. Isenk.

caucasicum Reitt. Lenk., Arm.

histeroides F. Kauk.

ferrugineum Steph. Lenk, Suram.

\section{FAM RHYSODIDAE}

\section{Rhysodes Dalm.}

exaratus Serv. Derb, I Iatum., Lenk. sulcatus F. Batum, U-der.

\section{Clinidium Kirby.}

canaliculatum Costa. Ifamrt.

marginicolle Reitt. 'Tal. 


\section{FAM CUCUJIDAE.}

\section{Cucujus E.}

hacmatodes Fr. var. cancasicus Mot. Kauk.

\section{Pediacns Shuk.}

depressus Hbst. Lenk., IIamrt.

dermestoides r. Krsn. Polj.

\section{Laemophloeus Steph.}

monilis F. Kauk.

nigricollis Luc. Kauk.

testaceus I'. Isenk.

ferrugineus Steph. B. Kltsch,, Lirk.

ater Ol. Lenk.

fractipennis Mot. Lenk.

\section{Lathropus Er.}

sepicola Mü̈ll. Lenk.

\section{Hyliota Latr.}

planatus L. Borsh., Lenk., Sugd., Hamrt

\section{Psammoecus Latr.}

bipunctatus F. var. Boudieri Lue. Lenk.

\section{Silvanus Isatr.}

surinamensis L. Tfl.

unidentatus Ol. Lenk.

similis Er. Kauk.

\section{Monotoma Hbst.}

spinicollis Aubé. Mamtl.

quadriforeolata Aubé. Mamtl.

quadriimpressa Mot. Lenk.

quadricollis Aubé. Lenk.

brevicollis Aubé. Mamtl.

conicithorax Reitt. Arax.

picipes Ubst. Kauk.

longicollis Gyll. MIamtl.

\section{FAM. TRIXAGIDAE Trixagus Kug.}

fumatus $\mathrm{F}$. Suram.

\section{FAM, DERMESTIDAE}

\section{Dermestes I.}

vulpinus $\mathrm{F}$. Lirk.

Irischi Kug. Lenk.

dimidiatus Stev. Derb.

murinus I. Mamtl.

mustelinus Fr. 'T'an.

undulatus Brahm. Borsh., 'Tan.

atomarius Fr. Lenk.

tesselatus I'. Kauk.

lardarius I. Borsh., Chass.-jurt, Lirk. ater 01. Dartag.

\section{Attagenus Latr.}

piceus Ol. Etschm., 'Tan.

var. sordidus Heer. Kauk.

var. brunneus Fald. Kank.

marginicollis Küst. Tfl.

pellio L. Kauk.

vigintiguttatus $\mathrm{F}$. Lirk.

tigrinus F. var. pulcher Fald. Arax., Artwin., Aresch.

orientalis Reitt. Baku., Arax.

lynx Muls. Kauk.

\section{Megatoma Sam.}

pubescens Zett. Tft., 'Tan.

\section{Globicornis Latr.}

marginata $\mathrm{Pk}$. Alexd.

Antoniae Reitt. Lirk.

nigripes F. Borsh., Abst.

breviclaris Reitt. Kauk.

quadriguttata Reitt. Tfl.

\section{Trogoderma Latr.}

variabilis Ball. Arax.

glabrum Hbst. Lirk.

\section{Anthrenus Geoffr.}

pimpinellae $\mathrm{F}$. Helnd.

rotundulus Reitt. Arax.

scrophulariae L. Lirk., Tan.

var. Proteus $\mathrm{Kr}$. 'T'fl.

var. albidus Brll. 'I'fl. 
verbasci $\mathrm{I}$. Helnd.

var. nebulosus Reitt. Tfl.

var. confusus Reitt. Tfl.

museorum L. Lenk.

caucasicus Reitt. Arax., Tfl.

fuscus Latr. Lirk.

minutus Er. Lenk., Anit.

\section{Trinodes Latr.}

hirtus F. Tan.

\section{Orphilus Er.}

niger Rossi. Borsh., Tan.

\section{FAM. CISTELIDAE.}

\section{Syncalypta Steph.}

spinosa Rossi. Lenk.

\section{Seminolus Mals.}

pilula L. Derb., Swnt.

fasciatus F. Kauk.

\section{Pelochares Mals.}

versicolor Waltl. Lenk.

\section{Limnichus Latr.}

aurosericeus Duv. Lenk.

pygmaeus Sturm. var. auricomus Reitt. Lenk.,

B. KItsch.

incanus Ksw. Borsh., Suram.

Lederi Weise. Kauk.

subchalybaeus Reitt. Lenk.

\section{FAM.THORICTIDAE}

\section{Thorictus Germ.}

Lederi Reitt. Arax.

laticollis Mot. Arax.

loricatus Peyr. Derb.

\section{FAM. HISTERIDAE.}

\section{Hololepta Pk.}

plana Fussly. Derb.

\section{Platysoma Leach.}

frontale Pk. Batum., Sugd., Chass.-jrt. compressum Hbst.Lenk., Krsn.Polj., Artschw., Tsk-T'sk., Sugd.

oblongum F. Abst., Tan.

\section{Hister I.}

inaequalis 01. Muschl.

quadrimaculatus L. Sardab., Dartag., Tf., Artschw.

cadaverinus Hoffm. Tfl., Helnk.

terricola Germ. Kauk.

stercorarius Hoffm. Lawaschi.

fimetarius Hbst. Kauk.

purpurascens Hbst. Tan.

neglectus Germ. Kauk.

carbonarius Ill, Kauk.

stigmosus Mrs. Kauk.

quadrinotatus Scriba. Baku., Belasw.

uncinatus Ill. Lenk., Borsh., Tfl, Alexp., Suant.

funestus Er. Hamrt.

duodecimstriatus Schrk. N. Rossk.

var. quatuordecimstriatus Gyll. Kauk.

bimaculatus L. Kub., Tf.

corvinus Germ. Kauk.

planulus Mrs. Tschr-j.

\section{Epieras Er.}

italicus Payk. Batum.

comptus Ill. Sugd.

var. russicus Mrs. Lenk., Borsh., Batum., Hamrt.

\section{Paromalus Er.}

complanatus $\mathrm{Pz}$. Kauk.

parallelopipedus Hbst. Tan.

flavicornis Hbst. Lenk., Lirk., Hamrt.

\section{Hetaerius Er.}

ferrugineus 01. Kauk.

\section{Saprinus Er.}

maculatus Rossi. Derb.

externus Fisch. Borsh., Achz.

semipunctatus $\mathrm{F}$. Lenk. 
chalcites 111. Morsh.

niger Mot. Arax.

nitidulus Pk. 'I'tl., Aresch., Chews, T'an.

acneus F. Kank.

amoenus bir: liorsh.

spretulus Er. Th.

foreisternus Schmidt. Nog. St.

rubripes Er. Alexp.

conjungens I'k. Borsh., Nog. St., Alexp.

yuadristriatus Hoflm. liorsh.

\section{Gnathoneus Duv.}

rotunclatus Kug. Achlk., Kathfld.

\section{Teretrins Er.}

picipes F. Borsh.

\section{Plegaderns Er.}

caesus 1ll. 'T'schtg., Hamrt.

\section{Onthophilus Leach.}

globulosus OI. Kauk.

striatus Forst. Borshl., Hamrt., Saril., Lirk

\section{Epiechinus MIars.}

Koenigi Schmidt. I’atum.

\section{Abraeomorphus Reitt.}

minutissimus Reitt. Lenk, Lirk.

\section{Abraeodes Roitt.}

Raddei Reitt. Elsbth.

\section{Abraeus Leach.}

globulus Crtz. Tm.-Ch.-Sch.

areolatus Reitt. Hamrt.

globosus Hoft'm. Kauk.

\section{Acritus Lec.}

minutus llbst. Sugd.

tataricus Reitt. Lirk.

rhenanus F'uss. Isenk. Ilamrt.

nigricornis IIoftm. Eilsbth.

\section{FAM. LUCANIDAE}

\section{Lncanus I.}

cervus Is, N. Rossk. ibericus Mot. Lenk, Lriw, Migri-tschai.,

MLang., lBorsh., Schara-Argunj, Tfl.

\section{Dorcus IM. I.}

parallelepipedus L. Batum., Lenk., Anit., Kut., Lriw., Suram.

\section{Systenocerus Weiso.}

caraboides It. Suram., Lirk.

var. rufipes Herbst. Borsh.

cancasicus Parry. Suram., Borsh.

\section{Aesalns F.}

Ulanowskii Ganglb. Borsh., Jirk.

\section{Sinodendron Hellw.}

cylindricum L. Lirk., Borsh., 'Tsk-'T'sk., l.om-mta.

\section{FAM. SCARABAEIDAE.}

\section{Scarabaus I.}

sacer Is. Lenk., Belasw., N. Rossli, Eriw., Gagry.

pius Ill. N. Rossk. Temrg.

puncticollis Latr. Sardab., Derb., Kasikp., Azkur., 'Tfl.

\section{Sisyphus Iatr.}

Schäfferi T. Borsh., Surnm., Kathfld.

boschnali Fisch. Kasikp., Aresch., Dartag., I.enk., Artsehw., Kathfld., N. Rossk.

\section{Gymnoplearus IIl.}

pilularius $I_{\text {, }}$ 'lff., Borsh., Azliur., lielasw. cantharus Es'. I'jatgk.

Alagellatus 1. Azkur, Dartag., . lexp., Achty., 'Iff., Borsh.

var, asperatu; Stev, Baku., Jirk.

\section{Copris Geoffr.}

hispanus I. Baku., lielasw., Lenk., 'lemrg. lunaris I.. Batum., Kasikp., Lirk., Elshtlı., Alexp., liorsh., 'Ifl., Eriw. 


\section{Onitis F.}

Damoetas Stev. Achty., Tfl.

liumerosus Pall. Belasw., Aresch., Derb., Kasikp.

\section{Chironitis Lansb.}

pamphylius Mén. Aresch., Elsbp., Kagm., Kasikp., Derb.

Haroldi Ball. Kasikp.

\section{Onthophagus Latr.}

Amyntas 0l. Mug., Alexp., 'Tfl., Dartag.

I'elschei Reitt. Aresch.

Ganglbaueri Reitt. Elbr., Kasikp.

taurus Schreb. Pari., Lenk., Tfl., Borsh.

verticicornis Laich. Helnk.

austriacus P\%. Baku., Alexp., Borsh.,Zeh-Zeh., Kasikp.

vacea L. Baku., I'schtgु.

coenobita Hbst. Pari.

fracticornis Preyssi. Chews.

nuchicornis L. Tfl, Alexp.

lemur F. Kank.

suturellus Brll. Kasilkp.

fissicornis Kryn. Aresch.

marginalis Gebl. Arax.

marmoratus Mén. Lirk.

truchmenus Kolen. Arax., Kasikp., Lirk.

var. araxicola Reitt. Kasikp.

viridis Mén. 'Tal.

Formaneki Reitt. Arax.

furcatus F. Tfl., Swnt., Achz, Mamtl.

ovatus L. Achz., Borsh., Elsbth., Lenk.

lucidus III. Derb., Belasw.

\section{Caccobius Thms.}

Schreberi L. Letch., Swnt,,Borsh,,Sch-agtsch. histeroides Mén. Nog. St.

mundus Mén. Arm.

\section{Oniticellus Serv.}

festivus Stev. Kasikp., Kagm.

fulvus Goeze. Swnt., Gomt., Alexp., Lenk., Borsh.

pallipes F. Tfl., Lenk., Mingtsch.

\section{Aphodias IIl.}

erraticus L. Borsh., Chews., Alexp., Achz, Pari., Kasb.

scrutator Hbst. Borsh., Arm.

subterraneus L. Arm.

fossor L. Lom-mta. *

haemorrhoidalis L. Borsh., Lom-mta., Lirk., Lenk., Abst., Alexp., Tbtn.

conjugatus Pnz. Borsh., Derb.

foetens F. Lirk.

fimetarius L. Kub., Tfl., Baku, Migri., Lirk., Kathfld., Belasw.

suarius Fald. Baku.

granarius L. Anit, Borsh.

var. suturalis Fald. Derb.

var. falsarius Reitt. Arax.

ater Deg. Kank.

rufus Moll. Lom-mta., Kapud., Chews., Alag.,

Baku.

lugrens Crtz. Tfl., Borsh., Dawal., Alexp.

punctipennis Er. Temrg.

niticlulus F. Dawal., Borsh., Asch-da., Schagtsch.

immundus Creutz. Borsh., Mesk. G., Weri. merdarius F. Elsbth.

melanostictus Schmidt. Tfl, Azkur., Temrog. sticticus Pz. Mesk. G.

Lederi Har. Kauk.

funcbris Reitt. Arm.

flammulatus Har. Lenk.

podromus Brahm. Lenk., Tfl., Kasb.

tabidus Er. Lenk.

obliteratus Panz. Baku.

obscurus K'. Suant., Kasb., Zch-Zch., Elbr., Lom-mta. *

var. dichrous Reitt. Arm., Zch-Zch.,Lom-mta. cribarius Brll.Etschm., Alag., Tbis.S.,Btschng. scrofa F. Kauk.

pusillus Hbst. Kauk.

quadriguttatus Hbst. Batum., Elsbth.

quadrimaculatus L. Mug.

biguttatus Germ. var. sanguinolentus $\mathrm{Pz}$. $\mathrm{Mug}$.

lividus 01. Kauk.

varians Duft. Baku., Temrg.

var. ambiguus Muls. T'emrg. 
Kraatzi Hlar. Suram.

Sturmi Har. N. Rossk.

abchasicus lieitt. Kauk.

alpinus Scop. Kauk. *

var. asphhaltinus Kó. Lilbr., Lom-mta. *

montanus Er. Kiauk.

satellitius IIbst. Mugr, Atschk.

planicollis Reitt. Kasb., Adsh., Borsh., Swnt.,

Dadsch. 'I'an.

rufipes I. Arab. G. *

depressus Kug, var. atramentarius Lir. Kasb.

luridus I:. Baku, Kathfld.

brevis lir. Kauk.

rhododactylus Irsh. Kauk.

\section{Heptaulacus Muls.}

sus Ilbst. Arat., Temrg.

alpinus Drap. Iom-mta., Chews.

\section{Oxyomas Lap.}

sylvestris Scop. Borsh., Swnt.

\section{Pleurophorus Muls.}

caesus Pz. Tars-tsch., Lenk., Suram. variolosus Kolen. Lenk.

\section{Rhyssemus Mals.}

germanus L. Suram., Lenk.

geminatus Reitt. Kauk.

parallelus Reitt. Arm.

\section{Psammodes Lap.}

sulcicollis Ill. Lenk.

\section{Ochodaeus Serv.}

chrysomeloides Schrk. Tan.

\section{Hybosoras M. L.}

Illigeri Reiche. Baku., Derb., Lenk.

\section{Trox. Fb.}

hispidus Pont. Tan.

scaber Is. Tfl.

\section{Goetrupes Latr.}

stercorarius I. Suram., Kasb., Borsh.,Dadsch., Elsbth. spiniger Mrsh. Lenk.

mutator Irsh. Baku., Tan.

molestus Fald. Arm.

caucasicus Weise. Muschl., Pari., Swnt, Lom-mta., 'Tschor.

inermis Mén. Muschl. 6000', Pseaschha., Arab. G. *

Fausti Reitt. 'I'al.

\section{Pentodon Hoppe.}

subdilatatus Mot. Dagt.

bidens Pall. Arax, Baku., Borsh., Tfl.

anthracinus Reiche. Tft.

\section{Phyllognathus Eschh.}

Silenus I'. Dagt.

\section{Oryctes III}

nasicornis L. Borsh., N. Rossk, Lenk., Anit, Mang.

grypus Ill. Bors., Lenk.

\section{Pachydema Lap.}

persica Mén. Borsh., Tfl., Aresch.

\section{Rhizotrogus Latr.}

pulvereus Knoch. Derb.

vulpinus Gyll. Kauk.

tauricus Blanch. N. Rossk.

Brenskei Reitt. U-der.

arcilabris Mars. Swnt.

aestivus 0l. Kauk.

solstitialis L. var. ochraceus Knoch. Tfl., Borsh., Sewg.

var. subsulcatus Fald. Swnt.

volgensis Fisch. Circas.

rudis Reitt. Arax.

caucasicus Gyll. Arax.

fuscus Scop. Kursch.

altaicus Mannh. Dagt.

fallax Mars. Borsh.

Ernesti Reitt. Arax.

\section{Asceptonychus Brsk.}

Erichsoni Brsk. Dagt. 


\section{Lasiopsis Er.}

Bergrothi Reitt. Kabrd.

\section{Cyphonotus Fisch.}

pauper IIampe. Arat.

\section{Anoxia Lap.}

pilosa E. Baku., Artschw., Tan.

\section{Polyphylla Harris.}

Joryi Brll, Anapa., Tan., Kathfld, Dshebr., Kasikp., Kut, TH., Lenk.

alloa Pall. Ordb.

adspersa Mot. Arax., Aresch., Tfl.

\section{Melolontha F.}

vulgaris F, var. extorris Ex. N. Rossk, Georgk.

var. soror Mars. Borsh.

pectoralis Germ. Arax.

permira Reitt. Adler., U-der.

aceris Fald. Tfl.

\section{Serica M. I.}

brunnea L. Apsch.

punctatissima Fald. Derb., Aresch.

\section{Homaloplia Steph.}

marginata F'üssl. Madsh.

alternata Kuist. Dagt.

spiraeae Pall, var. limbata Kryn. Arax., Borsh., Tfl.

\section{Triodonta Muls.}

flavimana Burm. Borslı, Tan.

\section{Adoretus Lap.}

nigrifrons Stev, Temrg.

discolor Fald. Derb., Bakin., TH.

\section{Anomala Sam.}

praticola F. Derb., Temr'g.

splendida Mén. Kauk.

var. luculenta Fr. Lenk.

aenea Deg. Chass-jrt.

oblonga Lì? Kauk.

\section{Phyllopertha Kirby.}

arenicola MIuls. Gagry., U-der. var. pilosella Reitt. Gagry., U-der.

lineata F. Migri-tschai., Dartag., Elsbth., Rasn., Borsh., Chram., Suant.

\section{Anisoplia Serv.}

leucaspis Lap. Such. Ft., Suant.,Eiljar.,Borsh., Dartag.

segetum Hbst. Petrwk., Chass-jrt., 'I'schr-j. scytha Mot. Arax.

campicola Mén. Kasikp.

signata Fald. Tan., Btschng., Derzeli., Migri., Achty., Azkur., Borsh.

Faldermanni Reitt. Erzm.

Koenigi Reitt. Eiljar.

agnati Reitt. Arax, Arm., Eiljar.

austriaca Hbst. Eiljar., Tars-tseh., Tschr-j., Lawaschi.

var. major Reitt. Baku.

farraria Er. Borsh.

var. Antoniae Reitt. Aresch.

crathigera Scop. Baku., Borsh., Derb, 'Tschr-j.

Zwicki Fisch. Tschr-j., 'T'emrg.

deserticola Fisch. Temrg.

\section{Hoplia Ill.}

corallipes Reitt. Lenk.

parvula Kryn. Kauk

caucasica Kol. Borsh., Kolchis., Derzeli., Swnt.

floralis O1. Tan.

pollinosa Kryn. U-der.

\section{Epicometis Burm.}

hirta Poda. Lars., Tfl., Filsbth., Lirk., Lenk.g Inorsh.

\section{Lencocelis Burm.}

funesta Poda. Derb., Mosd.

albopicta Mot. 'T'an.

cinctella Schanm. Lenk., Elsbp., IBorsh., Kasikp., Anit。

\section{Stalagmosoma Burm.}

allella I'all. Ar'm. 
Cetonia I.

aurati I. Azkur. Chosp., '1 an., I ink., Borsh., 'l'il, Kut.

var. pallida I) 1 . Chass-jnt.

ral, aeratula lieitt. Anit.

\section{Potosia MInls.}

speciosa dd. liriw, Tan.

funebris Gory. Kasikp.

funesta Mén. Hizm.

aftinis And. Migri., Chass-jrt. Kwril.

Horicola Ilbst. Bursh. Nachtw.

rar. hieroglyphica Mén. Anit., Borsl., Kut., Lenk., 'Tan, Chass-jrt, N. Rossk., Lirk. rar. splendidula Fald. Kasikp. Erzm.

rar. persplendens Reitt. Kasikp., Nachtw., Btschung., liorsh.

sibirica Gebl. var Godeti Gory. Isti-su, Such. Ft., Kasikp.

hungarica IIbst. Chass-jrt., N. Iiossk., Achlk., Azkur., Borsh., Chosp.

var. armeniaca Mén. Iirk., N. Iajł., Achz, litschng., (hosp)., Azkur., Such. Ft, Eiljar, Kasilip.

afflicta Gory. Erzm.

vidua Gory. Arax.

\section{Aethiessa Burm.}

rugipennis liurm. Nug., Nachtw.

\section{Valgus Scriba.}

hemipterus It. T'an., Aresch., Elsbth., Sch-ngtsch., Mosd., Anit., liorsh, Lenk., 'Jfil, Artwin.

\section{Gnorimus Serv.}

Bartelsi Fald. Borsh.

subcostatus Mén. Anit.

\section{IIrichins $\mathrm{L}$.}

fasciatus I. Bursh., Derzeli., Dartag. abdominalis Mén. Lirk., 'l'al., Anit., Lenk., Mirrri.

\section{Glaphyrus Latr.}

cancasicus Krr. Arax. micans Fald. Georen.

varians Mén. litschm.

festivus Mén. Kank.

\section{Amplicoma Latr.}

vulpes $\mathrm{F}$. Derb.

virr. vulpecula 'Truq. Atschk.

var. hirsuta Brll. Borsh., Ach-bu., Rasn.

var. distincta Fald. Such. Ft.

var. purpuricollis Waltl. 'Tfl., Kathfld., Iorsh., Ach-bur.

lineata F'ald. Arax.

bombyliformis l'all. Derb.

arctos Pall. Azkur.

val. chrysopyga Fald. 'T'l., Borsh., Migritschai, Suant., Nzhet., Lirk.

var. armeniaca lieitt. Mrax.

\section{FAM. BUPRESTIDAE}

\section{Julodis Eschh.}

Faldermanni Mannh. Ishulfi, Arax. variolaris l'all. Petrwk.

lineigera Mars. Mrax., 'I'fl., Dartag. Andrei Ol. Dshuifi, Arax., Kasikp.

globithorax Stev. Ordb.

\section{Chalcophora Sol.}

mariana Istp. liorsh., 'Ian.

\section{Aurigena Lap.}

lugubris F. Alget, Derb., Aresch. capnodiformis lieitt. Arm.

\section{Capnodis Eschh.}

cariosa Pall. Hriw.

miliaris Klug. Liriw., 'Tt., dresch., Nachtw. 'T'an.

carbonaria Klug. Ordb.

excisa Mén. Aralych.

tenebrionis I. Litschm., 'l'fl., Kúlp., Aresch., Ordb., N. Rossk., Chass-jit.

tencbricosa llbst. Itenk.

\section{Cyphosoma Manuh.}

sibiricum F. Areseh. 


\section{Dicerca Eschh.}

alni Fisch. Borsh.

chlorostigma Mannh Batum.

\section{Poecilonota Eschh.}

rutilans F. Borsh.

gloriosa Mars. Kasikp.

\section{Buprestis I.}

rustica It. Borsh.

haemorrhoidalis Hbst. Borsh.

araratica Nars. Tan.

novemmaculata L. Borsh., 'Tan., 'Tsk-'T'sk.

Salamoni 'Thoms. Arax.

octoguttata L. Borsh.

\section{Eurythyrea Sol.}

austriaca L. Borsh.

scutellaris Oliv. var, oblita Fald. Derb.

\section{Melanophila Eschh.}

decostigma F. Nachtw., Derb., Etschm., Aresch.

var. picta Pall. Migri., Etschm.

acuminata Deg. Borsh.

\section{Phaenops Lac.}

cyanea F. Borsh., Tschtl.

\section{Anthaxia Eschh.}

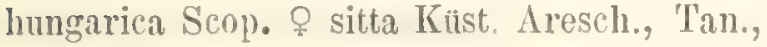
Borsh., Anit., Tars-tsch.

Sieversi Reitt. Aresch.

richorii Ol. Arax., N. Rossk

millefolii F. N. Rossk.

versicolar Ab. Kasikp.

aurulenta F. Anit.

manca I. Madsh.

Edithae Reitt. Aresch.

Passerinii Pech. Artwin., Aresch.

salicis F. Borsh.

bicolor Fald. Alget., Tfl., Lirk.

fulgurans Schrk. U-der., N. Rossk.

grammica Lap. Lenk.

nitidula L. var. signaticollis Kryn. Borsh., Aresch.

hyrcana Mars. Tal.

ferulae Gené. Etschm. discicollis Lap. Aresch.

funerula Ill. Borsh.

plicata Ksw. Sotscha.

sepulchralis H', Borsh., 'Tan.

canifions $\mathrm{Ab}$. Aresch.

quadripunctata L. Borsh.

spec.? Borsh.

\section{Ptosima Sol.}

11 maculata IIbst. Borsh.

\section{Acmaeodera Fschl.}

degener Scop. Derb.

flavolineata Lap. Artwin.

Havofasciata Pill. Borsh., N. Rossk.

var. Mimonti Boield. Arax.

fulvinaeva lieitt. Arax.

lanuginosa Gyll. Derb.

culrifera Isap. Arm.

lugens Lap. Arax.

Boryi Brll. Araz.

subcyanea Reitt. Alax.

obscura Reitt. Kulp.

\section{Sphenoptera Sol.}

glabrata Mén. Arax., Kasikp., Lirk.

coracina Stev. Suant., Kapud., Ordb.

antiqua Ill. Azkur.

inaequalis Stev. Eiljar.

aerata Jak. Arax.

excavata Fald. Derb.

mesopotamica Nars. Arax.

Scovitzi Fald. Etschm.

Beckeri Dohrn. Petrwk., Temrg., Aresch.

sancta Reitt. Arax.

Antoniae Reitt. Arax.

hispiidula Reitt. Arax.

molitor Reitt. Arax.

artemisiae Reitt. Arax.

Christophi Jak. Arax.

Sieversi Jak. Tfl.

anthaxoides Reitt. Arax.

Lugeniae Jak. Tfl.

\section{Chrysobothris Eschh.}

affinis $\mathrm{F}$. Lom-mta.

var. tetragramma Mén. Suram., Arax. 


\section{Coroebus Lap}

rubi L. Morsh., I)erb., liatsch.

clatus I'. Isawaschi., Jursh., 'Tsk-T'sk., Chass-jrt, 'l'an.

subulatus Hor. T'emror

acncicollis Vill, Aresch.

robustus Küust. Horsh., 'I’tl, Kasikp, kijljar.

amethystinus (Ol. Bursh., IBtschng

violacens Ksw. \rm.

Reitteri Sem. Arm.

\section{Agrilus Curt.}

viridis I. Suram., Borsh.

coerulcus Rossi. Borsh.

clongatus IIbst. Borsh.

angustulus Rossi. Chram, Bakll, Anit.

derasofasciatus Lac. I Ienk.

albogularis Gory. I)agt.

aurichalceus Ridtb. Bor'sh.

integerrimus Ratz. T'sk-T'sk.

Iyperici Crtz. Borsh.

roscidus Ksw. Helnd.

\section{Cyliudromorphus Ksw.}

subuliformis Mannh. Werb.

filum Gyll. N. Rossk.

Araxidis Reitt. Arax.

\section{Aphanisticus Latr.}

emarginatus F. Sch-agtsch.

\section{Trachys F.}

minuta L. Kauk.

Kocnigi Reitt. U-der.

troglodytes Gyll. Kauk.

pumila Ill. var. phlyctaenoides Kolen, Arax.

\section{FAM. EUCNEMIDAE.}

\section{Throscus Iatr.}

carinifrons lionv. liorsh.

asiaticus lonv. Ienk.

clateroides Heer. Kauk.

var. Bonvouloiri Deshr. Tal., I،enk.

Duvali Bouv. Mesk. G. orientalis Bonv. Mesk. G.

obtusus Curt. Lenk.

\section{Drapetes Redtb.}

biguttatus 1'ill. Tan., Seh-agtsch.

Tharops Lap.

melasoides Lap. Suant.

\section{Dromaeolus Ksw.}

barmabita Villa. Borsh.

maronita Bonv. Isesnj.

\section{Hylochares Latr.}

dubius 1'ill. Derb.

Nematodes Latr.

filum F'. N. Rossk.

\section{Xylobius Latr.}

alni IBonv. Hamrt.

\section{FAM. ELATERIDAE.}

\section{Adelocera Latr.}

punctata Hbst. Tan., Elsbth, Anit., Lenk,

Borsh., Batum.

lepidoptera Panz, Tan.

\section{Lacon F.}

crenicollis Mén. Schuw., Alexp, Gagry., Wldls.

\section{Alaus Eschh.}

Parreyssi Stev. Batum.

\section{Aeolus Eschll.}

crucifer Rossi. Ali-su.

Rossii Germ. Lenk.

atricapillus Germ. Derb.

grisescens Germ. Aresch.

\section{Drasterius Eschh.}

birnaculatus Rossi. Icenk., Ianilasch, Borsh. Far. quadrisignatus Küst. Lenk.

\section{Elater I.}

cimmabrinus Eschh, Batum., Muschw. 
var. satrapa Eschl. Lenk.

sanguineus L, Lirk.

praeustus F. Borsh.

pomonae Steph. 'Tan.

sanguinolentus Schrk. Lenk.

var. ephippium 01. Tan.

ferrugatus Lac. Lenk., Artschw., Dartag., Tan.

elongatulus F. Tan., Letch.

pulcher Reitt. var. Araxidis Reitt. T'al.

coenobita Costa Alget., Tan.

circassicus Reitt. Tan.

ochropterus Germ. Algeth., Borsh.

var. auranticulus Reitt, Tan.

elegantulus Schh. Lenk.

var. Lederi Reitt. Tal.

sinuatus Germ. Borsh., Lirk., Tan.

\section{Megapenthes Ksw.}

lugens Rdtb. Borsh.

rutilipennis Cand. Lenk., Lirk.

trans:ancasicus Strl. Tff.

\section{Batarmon Ksw.}

picipennis Bach. Borsh., Letch. var. adrastoides Reitt. Tan.

\section{Cryptohypnus Latr.}

riparius $F$. Kasb.

quadriguttatus Lap. Suram.

murinus Reitt. Lenk.

alysidotus Ksw. Lenk.

meridionalis Lap. Lenk.

minutissimus Germ. Lenk., Tan.; Leteh., Lirk.

\section{Cardiophorus Eschh.}

gramineus Scop. Borsh.

syriacus L. Aresch.

maculicollis Reiche. Arm.

nigropunctatus Mot. Arax.

rufipes Goeze. Lenk., 'T'an.

.permodicus Fald. Derb., Kathfld.

vestigialis Er. Borsh., Tan.

nigerrimus Er. Etschm., Heln, Nachtw.

melampus IIl. Borsh.

megathorax Fald. Arax.

ebeninus Germ. U-der. turgidus Er. U-der.

nigratissimus Buyss, Kulp., Eiljar.

concolor Desbr. Arm.

cinereus Hbst. Lirk., Tan.

decorus Fald. Kislw.

\section{Melanotus Eschh.}

tenebrosus Er. Suram.

brunnipes Germ. N. Rossk., Kislw., Chass-jrt. castanipes Pk. Borsh., Migri., Suant., Lirk., Saril.

rufipes Hbst. Borsh.

monticola Mén. Arax.

fusciceps Gyll. Bilet., Derb., 'T'A.

sobrinus Mén. Arax.

\section{Limonius Fschh.}

minutus L. Kauk.

\section{Athons Eschh.}

perniger Reitt. Arax.

Koenigi Schwarz, Kasikp.

Rosti Reitt. Lom-mta.

cavatus Cand.Abg.,U-der, ,N.Rossk, , Chass-jrt. utschderensis Reitt. Dychtau., Abg., Naltk., U-der.

mingrelicus Reitt. Isom-mta.

Schneideri Ksw. Schamb.

circassicus Reitt. Lom-mta.

Raddei Faust. Kauk.

subfuscus Müll. 'Tan., Abg.

astrabadensis Faust. Mug,

circumductus Mén. Kasb., Swnt, Lom-mta.

\section{Elathous Reitt.}

Buyssoni Reitt. Arax.

\section{Corymbites Iuatr.}

purpureus Poda. Borsh., Tan.

sulphuripennis Germ. Kauk.

tesselatus L. Lenk., Derb.

amplicollis Germ. 'Tan.

aeneus L. Kasb., Zlk.

var, caucasicus Mén. Derb.

latus F. Nog. St.

alpestris Mién. $\Lambda \mathrm{rm}$.

cinctus Pk. 'Tan. 
Agriotes Eschh.

meticulosus Cand. Borsh., Migri., Aresch. Starchi schwar\%. U-der.

turcicus Cand. Suram., Borsh., I dirk.

ustulatus Schall. 'Tbiz. S., Schtjk.

ral. sputator Rdtb. Schtik.

infuseatus lesbr. Martk., 'l'an.

lineatus L. IBog-kiis., Zlli, Suram., Lenk.

lapicida Fiald. Arm.

litigiosus liossi. Borsh.

molestus Kísw. Baliu.

subrimus Ksw: Mesk. G.

fatlicus Lac. Baku.

\section{Synaptus Eschh.}

hiliformis F. Poni., Elsbp.

var. erisanus Fald. L'an.

\section{Adrastus Eschh.}

namus IIbst. Suant.

\section{Denticollis Pill.}

mbens Pill. U-der.

parallelocollis Aubé. Batum.

\section{FAM. RHIPICERIDAE, Arrhaphipterus $\mathrm{Kr}$.}

Schelkownikowi Reitt. Aresch.

\section{FAM. DASCILLIDAE}

Dascillas Latr.

elongatus Fald. Pseasch., Dartag., Mamtl., Derb., Lenk., Mug., Adsh.

\section{Microcara Thms.}

testacea L. Lenk.

var. luteicornis Reitt. Circas.

\section{Cyphon Pk.}

variabilis Thnb. Borsh.

padi L. Suram., Mamtl.

coarctatus Pk. Kiptsch., Mamtl., Lirk.

var. palustris 'Thms. Mamtl.

pallidulus Boh. Lenk.

\section{Scirtes Ill.}

orbicularis $\mathrm{P} \%$. Derl.

\section{FAM. CANTHARIDAE.}

\section{Euanoma Reitt.}

Starcki Reitt. Circas.

\section{Platycis Ihms.}

Schneideri Ksw. 'I'al.

\section{Lygistopterus Mls.}

sanguineus L. Mang., Borsh., Urusch., I'an.

\section{Lampyris Geoffr.}

noctiluca I. Borsh., N. Rossk.

nrientalis Fald. Arax.

Zenkeri Germ. Tars-tsch., Migri-tsch.

\section{Lamprohiza Mot.}

splendidula L. Borsh.

\section{Luciola Lap.}

mingrelica Mén. Borsh., Such., Gagry., Inschl.

var. caucasica Mot. Swrut., Lom-mta.

\section{Nastonycha MIot.}

alagruesa Reitt. Arm.

\section{Cantlaris $\mathbf{L}$.}

caspica Reitt. Albr.

rufidens Mrs. Suram.

funesta Fald. Tff.

livida L. Muschw., Borsh., 'Tfl., Tan.

rufimana Mén. Zlk., 'Tan.

\section{Metacantharis Fanv.}

discoiden Ahr. Lenk.

araxicola Reitt. Arax.

\section{Rhagonycha Eschh.}

unicolor Fald. Imrt, Swnt.

nigritarsis Brll. Lenk., Lirk. 
fulva Scop. Lenk., Borsh., Anit., Baku. vitticollis Mén. Suram femoralis Brll. B. kltsch. nigricollis Mot. Arm. circassicola Reitt. Swan., Circas.

\section{Malchinus Ksw.}

circassicus Reitt. Abch.

\section{Malthinus Latr.}

punctatus Fourcr. Borsh.

\section{Malthodes Ksw.}

sulphuribasis Reitt. Arm.

pulicarius Ritb. Kauk.

ordubatensis Reitt. Arax.

\section{Drilus 01.}

concolor Ahr. Borsh., Tan., Aresch.

\section{Troglops Er.}

silo Er. Circas.

albicans L. Tan.

\section{Charopus Er.}

Philoctetes Ab. Tfl. docilis Ksw. Letch thoracicum Nor. Tan.

\section{Colotes Er.}

flavocinctus Mars, Arax.

\section{Ebaens Er.}

lepidus Abll. Tfl.

lnctuosus $A b$. Arax.

caspius Peyr. Kauk.

bulbifer" Kol. 'Tft.

\section{Axinotarsus Mot.}

pulicarius F. Anit.

marginalis Lap. Belasw., Borsh., T'sk-Tsk., Anit.

\section{Anthocomas Er.}

sellatus Abll. 'Tf., Tan. miniatus Kol. Kauk. equestris F. Lenk., MIugl., Hamrt., Anit.

fasciatus I. 'TH.

\section{Malachius F.}

rufus 01. Kauk.

versicolor Fald. Arax. Etschm.

Fausti Ab. Arax.

basalis Ab. Arax.

var. crucifer Reitt. Arax.

Faldermanni Fald. Tfl.

aeneus L. Tfl., Lirk., Borsh., Lenk., Sch-agtsch., Aresch.

var. medius Ab. Tfl.

var. aeneoides $\mathrm{Ab}$. Tft.

angustatus Mot. Tfl., Borsh.

marginellus Ol. Borsh.

bipustulatus L. Borsh., Mastr, , Azkur., Dartag. vittatus Mén. Aresch.

cavifrons Ksw. Borsh., Tan.

parilis Er. Kauk.

elegans Geoffr. 'Tan.

falcifer Al)。 'T'an.

geniculatus Germ. Lenk., Borsh., Anit, Martk., Baku.

var. armeniacus Fald. Lirk.

affinis Mén. Helnd.

viridis F. var, elegans $\mathrm{F} . \Lambda \mathrm{rm}$., Tff.

spinipennis Germ. Borsh., Migri., Dartag., Btschng.

debilis Ksw. Arm.

Koenigi Ab. Kasikp.

Anceyi Ab. Aresch.

armifrons $\mathrm{Kr}$. Aresch.

\section{Henicopus Steph.}

pilosus Scop. Dartag, Btschng., Chram., Kasikp., Eiljar., Aresch., Borsh., גdsh., Suant.

var. truncatus Frm. Kauk.

\section{Dasytes Pk.}

laeviusculus Schilsky. Artwin., Tan.

niger L. Borsh., Dartag., Lirk.

flavipes Mruls. Chass-jrt., Aresch.

plumbeus Müll. Lenk., Anit, I،etch., Lirk. aeneiventris Küst. Baliu. 
fusculus Ill. T'an.

subacneus Schh. Kasilip.

brevienllis Schilsky. Kasikp.

xanthocnemis Kolen. Kauk.

\section{Dolichosoma Steph.}

lineare linssi. Aresch.

simile Bril, Aresch., Iirk.

\section{Haplocnemus Steph.}

lateralis Schilsky. 'Tal.

caucasicus Schilsky. 'T'an

renustulus schilsky. Circas.

russieus Reitt. Arax.

serbicus Kisw. Borsh., I,etch.

'l'richooeble Thoms.

fulvopilis licitt. Arm.

memnonius l'. 'T'an.

\section{Dasytiseus Ksw.}

rufitarsis Iuc. Mrax, Eiljar., Th,

\section{Cerallus Duv.}

varians Mor. Kasilep.

pilosus Reitt. Arax.

Afavipemis Reitt. Arax.

\section{Danacaea Lap.}

pallipes Pz. Iuetch, Lirk.

nigritarsis Küst. Borsh.

angulata Kisst, Borsh.

flava Ksw. Arax, Borsh., Kasilip., Tan. micans Pruch. Kauk.

marginata Küst. Suram, lior.h., Batum. induta Proch. 'Tal.

aequilata l'joch. Mesk. G.

valida Heyd. Arm., T'an.

\section{Melyresthes Reitt.}

cardinalis Reitt. Kulp.

\section{FAM. CLERIDAE}

rillus 01.

clongatus I. Derzeli., Sugul, Krsn-polj. mifasciatus l'. Lenk., Mnit.

\section{Opilo Latr.}

mollis Is. 'lan.

domesticus Strm. Suram.

\section{Clerus Geoffr.}

mutillarius 1: N. Rossk.

mutillaroides Reitt. Arax.

formicarius L. Borsh, Tan., Lom-mta.

\section{'l'arsostenus Spin.}

univiltatus Rossi. Lesnj., U-der.

\section{Irichodes Hbst.}

alvearius l'. Kauk.

apiarius $\mathrm{L}$. Eilbr.

var, apiarioiles lieitt, Anit, Borsh., Baku., Mang., 'l'ars-tsch., 'I'an., Urusclı.

persicus Kr. 'Tal.

crabroniformis F. Kauk.

zebra Fald. Arax.

favarius Ill. Anit., Ardbl., Dartag.

var. axillaris Spin. Naclitw.

sipylus L. Derb., Migri.

armeniacus Baudi. Arax.

subfasciatus $\mathrm{Kr}$. Arax.

irkutensis Laxm. Kank.

\section{Corynetes Hbst.}

coeruleus Deg. Borsh., MIangl.

\section{Necrobia Latr.}

violacea I. Hamrt, Iirk, Elsbth.

\section{Opetiopalpus Spiu.}

Scutellaris I'z Arat., Georgk.

\section{Flateroides Sohiff.}

dermestrirles L, 'l'an.

\section{FAM. BRUCHIDAE,}

\section{Gibbium Scop.}

Boieldieni levrat. Arax.

\section{Mezium Curt.}

aftine Boield. Gambor., 'I'btn. 


\section{Niptus Boield.}

hololeucus Fald. Arax.

\section{Bruchus Geoffr.}

fur L. Derb., Anit.

latro F. Arax.

brunneus Duft. Suram., Ach-bu. pilosus Müll. Mesk. G., Lirk. subpilosus Sturm. Mantl. obesus Luc. Alexd. quadrisignatus Mén. Kauk. sexpunctatus $\mathrm{Pz}$. Anit. variegatus Rossi. 'TH., Suram.

\section{FAM. BYRRHIDAE.}

\section{Byrrhus Geoffr.}

pertinax L. Tan.

striatus 01. Lenk., Adler., Sotscha.

ruber Reitt. U-der., Tan.

nitidus Hbst. Lirk.

paniceus L. 'Temrg., Lirk., Chass-jrt., Ienk., Tfl., Wldk., Isars.

\section{Oligomerus Redtb.}

Reyi Bris. Lirk.

\section{Ernobius Thoms.}

abietinum Gyll. Tan.

Kiesenwetteri Schilsky. Tan.

nigrinus Sturm. Tan.

\section{Hedobia Sturm.}

pubescens F. Derb., Lirk.

Rosti Pic. Circas.

regalis Duft. Artwin.

angustata Bris. Letch.

circassica Reitt. Circas.

\section{Trypopitys Redtb.}

carpini Host. 'T'an., Nachtw., Borsh., Lenk. Tfl., Zch-Zch.

\section{Ptilinus Geoffr.}

aspericollis Mén. Suram., Martk., Lirk., Mdler., Sotscha., Lesnj.

\section{Plumaria Reitt.}

grandicollis Mén. Lenk., Sotscha., U-der.

Xyletinus Latr.

Alavipes Lap. var. fulvicollis Reitt. Arax.

\section{Iasioderma Steph.}

obscurum Solsky. Tfl., Nog. St.

Redtenbacheri Bach. Lenk.

\section{FAM SPHINDIDAE}

\section{Sphindus Chevrl.}

dubius Gyll. Lenk.

Aspidiphorus Isatr.

orbiculatus Gyll. Lenk., Hamrt., Mamtl.

\section{FAM. LYCTIDAE.}

\section{Lyctus F.}

unipunctatus Hbst. Michailw., Borsh. suturalis Fald. Borsh., 'Ifl., Lirk. pubescens Pz, var. caucasicus T'ourn. Arax. impressus Com. U-der., 'Tan.

\section{FAM. BOSTRYCHIDAE}

\section{Psoa Hbst.}

viennensis Hbst. Aresch.

\section{Sinoxylon Duft.}

bispinosum Ol. Azkur.

\section{Bostrychus Geoffr.}

capucinus L. Anit, T'ars-tsch., 'T'sk-'T'sk., Batum.

var. Inctuosus Ol. Derb., Poni., Kasb.

var. nigriventris Iuc. U-der.

\section{Xylopertha Guér.}

retusa 01. Ach-bu., Azkur., Alexd.

\section{Stephanopachys Wat.}

elongittus Payk. Borsh. 


\section{FAM, CIIDAE}

Xylographus Mell.

bostrychoides Dut. Isenk.

\section{Cis Latr.}

nitilus Hbst. Lenk.

lineatoeriblitus Mell. Jenk.

boleti li. liorslı. Liık.

caucasicus Mén. Borsh., Saril.

setiger Mlell. Mesk. G.

micans llbit. lirk.

comptus Gyll. Lenk., Lirk.

fissicollis Mell. Iaenk.

tomentosus Mell. Isenk. Suram., Eisbth.

setifer heitt. Isenk.

castaneus Mell. Kank.

vestitus Mell. Isenk.

bicornis Mell. Lenk., Hamrt.

\section{Rhopalodontus Mrell.}

Perrini Reitt. Isenk., Suram.

perforatus Gyll. Lenk.

fronticornis 1 '\%. lilk.

\section{Enuearthron Moll.}

affine Mell. Lilk, Letch.

cormutum Gyll. Lenk.

\section{Octotemnus Mell.}

mandibularis Gyll. Kiauk.

glabriculus Gyll. Derb., IIelnd.

\section{FAM TENEBRIONIDAE}

\section{Zophosis Latr.}

punctata lirll. Sardab.

rugosa lald. Arax.

\section{Arthrodeis Sol}

globosus Fald. Drtschk., Arax., Nachtw.

\section{Adesmia Fisch.}

L chmanni Mén. Arax. pulcherrima lisch. Arax.
Colposcelis Lac.

longicollis Zbk. Baku.

Capnisa Lac.

modesta Fald. Arax.

\section{Gnathosia Fisch.}

laticollis liess. Sardab., Nachtw., Alexp.

Carceli Sol. Sewg.

vicina Brll. Rasn.

variabilis Sol. Arax.

caraboides Fald. Kasikp.

\section{Anatolica Eschh.}

gibbosa Gebl. Dagt.

var. thoracica Bess. Derb.

\section{Calyptopsis Sol.}

caraboides Brll. Sardab.

convexicollis Desbr. Arax.

\section{Microdera Eschh.}

convexa T'ausch. Baku.

\section{Tentyria Latr.}

nomas Pall. Sardab., Nachtw., Kagm., Temrg.,

Nog. St., 'T'schrr-j.

tessulata 'I'ausch. Lenk, Baku., Mingtsch.,

Mlexp., Helud., Rasn.

scabripennis Sol. Dshuli.

\section{Platamodes Mén.}

dentipes Mén. Mrax.

\section{Stenosis Hbst.}

pilosa Mot. Arax.

turcestanica Reitt, drax.

\section{Oogaster Fald.}

piceus Mén. Sardab.

\section{Dichillus Dnv.}

Angelicae Reitt. Arax.

\section{Aspidocephalus Mot.}

desertus Mot. Derb. 


\section{Cyphogenia Sol.}

lucifuga Ad. Baku., Nachtw., Tfl. aurita Pall. Helnd., Tfl. gibba Fisch. Kauk.

\section{Prosodes Eschh.}

obtusus F. Nog. St.

\section{Blaps $F$.}

ominosa Mén. Baku.

gigas L. Sardab.

abbreviata Mén. Helnk.

luctuosa Mén. Arax.

Koenigi Seidl. Elbr.

mortisaga L. Alexp., Tf.

var. elongata Mén. Kathfld, Tfl.

montana Mot. Kursch.

graeca Sol. Kauk.

reflexicollis Fisch. Azkur., Borsh., Alexp., Sardab.

parvicollis Eschh. Kauk.

subalpina Mén. Baku., Clıews.

anthracina Fald. Anit.

pterotapla Mén. Kauk.

similis Latr. Alexp., Kathfld, Azkur.

subquadrata Brll. Erz-Bgl.

mucronata Latr. Kauk.

\section{Asida Latr.}

lutosa Sol. Derb.

Pimelia F.

tuberculata Mén. Rasn.

cephalotes Mén. Kiwrach., Sardab., Naclıtw., Helnk.

capito Kryn. Baku., Sardab., Temrg., Nachtw., Aksf., Rasn., Mingtsch.

ventricosa Fald. Arax.

subglobosa Pall. Baku.

\section{Podhomala Sol.}

Schönherri Fald. Arax.

\section{Pachyscelis Sol.}

clavaria Mén. Helnk., Sardab, Nachtw. metopotapha Mén. Suant.

musiva Fald. Arax.

\section{Ocnera Fisch.}

setosa Mén. Dshulfi, Baku, Sardal.

\section{Trigonoscelis Sol.}

muricata Pall. Ross. mer.

armeniaca Fald. Arax.

aftinis Mén. Arax.

\section{Crypticus Latr.}

quisquilius L. 'Tar's-tsch., .1 lag., Kasb., Borsh.. Btschng.

Platyscelis Latr.

Spinolae Sol. Lawaschi.

melas Fisch. Kub.

gages Fisch. Kasb., Kub., Lawaschi., Saril., N. Rossk.

\section{Heterophylus Muls.}

picipes Fald. Iamrt, Kathfld., Alag., Arax.

\section{Dendarus Latr.}

extensus Fald. Weri., Kura punctatus Serv. Borsh., Elsbth. foraminosus Küst. Sardab.

\section{Pedinas Latr.}

affinis Brll. Achlk., Azkur., Arax.

curvipes Muls. Achlk., Azkur., Sardab.

curtulus Muls. K-ogly.

aequalis Seidl. Mesk. G.

strabonis Seidl. Arax.

\section{Micrositus Muls.}

circassicus Reitt. Atschischho, Lom-mta.

\section{Opatrum F.}

sabulosum L. var. tricarinatum Mot. Suant, K-ogly., Lirk., Alexp., TH., Borsh., Azkur. geminatum Brll. Arm.

\section{Gonocephalum Muls.}

setulosum Fald. Arax., Arm

rusticum 01. Mang, Lirk.

pusillum $\mathrm{F}$. var: nigrum Kust. Lenk, dchalk., Elsbth., Nog. St. 
Scleropatrum Miedel.

breviusculum Reitt. Arix.

Penthicus Fald.

pinguis liald. Sartab.

molestus lialel. 'T'al.

penctulatus lirll. Kiwrach.

iners Mén. liasn.

\section{Lichonum Blanch.}

pulchellum Kitst. J,enk.

\section{Bolitophagus Ill.}

reticulatus Is. Isenk., Derb.

subintegrer Reitt. 'T'al.

inter'uptus IIl. Lenk.

\section{Diaperis Geoffr.}

fungi Mot. Borsh., Lenk., Anit., Zlk., 'Tsk-'Tsk.

Hoplocephala Lap.

hacmorrhoidalis F. Derb.

quadricornis Mot. Lenk.

\section{Scaphidema Rodtb.}

metalliea Mot. Borsh., Lenk.

\section{Amarantha Mot.}

viridis Mot. Tal.

azurea Waltl. Sugd, Batum.

\section{Platydema Lap.}

curopaca Lap. U-der.

violacea li. Derb., Lenk., Iilsbth., Batum. tristis Lapl. Batum., Tschteg., Lirk.

\section{Alphitophagus Steph.}

bilisciatus Say. Lenk., Sugd., Scll-argtseh.

\section{Pentaphyllus Latr.}

chrysomeloides Rossi. Lenk.

nitidulus Reitt. Lenk.

\section{Tribolium M. I.}

confusum I) uv. T'fl.

\section{Palorus Duv.}

Ratzeburoi Wissm. Lenk., 'T'fl.

\section{Corticens Pill.}

castaneus F. Kr'sn-polj., Lenk., Suant, Mnit., 'I'sk-'T'sk., Batum.

fraxini Kug. Abst.

bicolor OI. Jenk.

basalis Reitt. Lenk.

\section{Echocerus Horn.}

cormutus L'. U-der.

\section{Uloma Steph.}

culinaris I. Lenk, Sch-agtsch,

var. cucullata Mén. Lenk., Derb., Batum.

P'errondi Muls. U-der.

\section{Alphitobius Steph.}

chrysomclinus Ilbst. Sch-agtsch., Hamrt., Muschi., Lenk.

\section{Cossyphus 01 .}

tauricus Stev, Derb., Elsbtl.

\section{Anthracias Redtb.}

cornutus Fisch. Ifelnd,,U-der, ,Mang., 'T'sk-'Tsk.

\section{Monephilus Muls.}

cylindricus Hbst. Tan.

\section{Tenebrio Is.}

opacus Duft. Borsh., Helnd.

obscurus F'. Jib., Tan., Swnt. Rasu. Tsk-'Tsk. picipes Ibst. .Helnd., Tan.

\section{Boromorphus Woll.}

armeniacus Reitt. Arax.

\section{Centorns Muls.}

procerus IIuls. 'Tfl, Baku., Elsbth.

\section{Laona Latr.}

Leileri Weise. U-der. quadricollis Weise. Circas., Tan. Justinae Reitt. Mesk. G.

Starcki Reitt. Circas.

hirtipes Reitt. Lenk. 
Helops F.

coeruleus L. var. Steveni Kryn. Lenk., Batum. maurus Waltl. Assuret.

diteras Mars. Kasb., Zlk.

brevicollis Kryn. Lenk.

impressicollis Fald. Assuret.

Faldermanni Fald. Tfl., Tan.

gloriosus Fald. Mang., Borsh., Suram., Batum., Hamrt., Tan.

\section{Cylindronotus Fald.}

gibbicollis Fald. Arm.

funestus Fald. Elslop.

lugubris Fald. Zlk.

femoratus Fald. Arm.

\section{Hedyphanes Fisch.}

Menetriesi Fald, Arax., Aresch. laticollis Mén. Arax., Aresch.

Mannerheini Fald. Arax.

impressicollis Fald, Aresch.

tentyroides Mén. Derb.

\section{FAM. ALLECULIDAE.}

\section{Hymenalia Muls.}

basalis Faust. Aresch.

\section{Gonodera Muls.}

pulcherrima Fald. Suram., Mesk. G., Tam. macrophthalma Reitt. Abch.

antennata $\mathrm{Pz}$. Lenk. antennalis Reitt. Lirk. caucasica Reitt. Kauk. granifera Ksw. Tan.

murina L. Borsh., 'Tan.

\section{Mycetochara Berth.}

flavipes F. Lenk.

gracilis Fald. Lirk., 'T'schtl.

linearis Ill. Lenk.

\section{Mycetocharina Seidl.}

orientalis Faust. Arax., Derb.

\section{Podonta Muls.}

nigrita F. Derb., Kasilip., Azkur., Borsh., Alexp.

daghestanica Reitt. Dagt.

morio Ksw. Tfl., Mugl.

\section{Cteniopus Sol.}

flavus Scop. Nachtiv.

persimilis Reitt. Arax.

sulphuripes Germ. Derb.

\section{Omophlus Sol.}

ochraceipennis Fald. Helnk., Chews., Saril., Rasn., Tfi., Arax., Mang.

var. latitarsis Reitt. 'I'fl.

curtus Küst. Kank.

latipleuris Reitt. Kasikp.

quadricollis Brll. Lirk.

pilicollis Mén. Kauk.

tumidipes Kirsch. Bog. Käs.

dispar Costa. Rasn.

basicornis Reitt. Kank.

betulae Hbst. Tsk-Tsk., Lenk., Anit., Migri.

dilatatus Fald. Alexp., Lirk.

var. pallitarsis Reitt. Lirk., Rasn.

\section{FAM. LAGRIIDAE.}

\section{Lagria $\mathbf{F}$.}

atripes Muls. Tirk.

hirta L. Borsh., Lenk., Mang, Belasw.

pretiosa Reiche. Lom-mta.

\section{FAM MELANDRYIDAE Orchesia Latr.}

Kamberskyi Reitt. U-der.

Lederia Reitt.

suramensis Reitt. Mesk. G.

\section{Serropalpus Hellen.}

barbatus Schall. Borsh.

Neogonas Hampo.

Hampei Reitt. Arax. 
Molandrya $\mathbf{F}$.

caraboides I. Kauk.

var. luridipes Reitt. Kank.

Osphya IIl.

malensis Mot. Ijirk.

\section{FAM. MORDELLIDAE.}

\section{Mordella Is.}

bisignata Rdtb. Borsh., Derzeli.

fasciata F: Borsh.

var. basalis Costa. Flbr.

aculeata L. Borsh., Golitsch., Kub., Mang., Dartag.

var, velutina Em. Kasikp. U-der.

leucaspis Kilst. Kauk.

\section{Mordellistena Costa.}

abdominalis F. Lirk., 'an.

Neuwaldeggiana $\mathrm{P} z$. Kauk.

parvula Gyll. Tars-tsch.

episternalis Muls. Eiljar., Kasilip.

brevicanda Boh. Mugl., Nog. St., Tfl., Eiljar., Aresch.

micans Germ. Kasikp.

pumila Gyll. Borsh., Zch-Zch., Tfl., Eiljar.,

'I'an., Nog. St., Aresch.

stenidea Muls. Tars-tsch.

\section{Pentaria Muls.}

Reitteri Chobant, Arax.

\section{Anaspis Geoffr.}

frontalis L. Kauk.

var. verticalis Fald. Aresch.

thoracica L. Tan.

ruficollis H. Mosil.

nigripes Bris. Borsh.

subtestacea Steph. U-der.

Hava I, Tan.

var. basalis Lm. Lirk., 'Tan. curvicrus Schilsky. Dagt., 'Tan.

Schneideri Em. Borsh., Aresch., 'Ian.

Koenigri Schilsky. Tfl, Kasikp.

gracilis Schilsky. Kulp. varians Muls. Th., T'an.

orientalis Fald. Kauk.

\section{FAM RHIPIPHORIDAE.}

\section{Pelecotoma Fisch.}

fennica I'l. Schtjk., Lesnj.

\section{Evaniocera Guér.}

Dufouri Iatr. var. Boryi Luc. Dagt.

\section{Emenadia Lap.}

larvata Schrk. Derb, Lirk.

praeusta Gbl. Lenk., 'Temrg.

\section{FAM. MELOIDAE}

\section{Meloë I.}

proscarabaeus L. 'Ttt.

autummalis Ol. 'l'tl.

variegatus Don. 'Ifl.

tuccius Rossi. 'Tfl.

erythrocnemus Pall. TH.

rugosus Marsh. Lenk.

\section{Cerocoma Geoffr.}

festiva Fald. Arax.

Schreberi F. Eiljar.

Nithlfeldi Gyll. Arm.

var. gonocera Mot. Kauk.

var. gloriosa Muls. Arax.

Scovitzi Fald. Mug., Anit.

var. rufiventris Reitt. Arax.

var. obscuripes Reitt. Arax.

Dahli Kr. Arax.

\section{Rhampholyssa Kr.}

Steveni Fisch. Chass-jrt.

\section{Zonabris Har.}

cincta Ol. Derb., Mingtsch.

var. Matthesi Fald. Alind-tsch., 'Temrg.

Ledereri Mars. Aresch.

sexmaculata 01. Arax., Temrg., Petrwk. pusilla Ol, Dartag. 
variabilis Pall. Tars-tsch., Isti-su., Belasw., Migri.

var. quadrifaria. Lawaschi., Tschr-j.

unicolor Fald. Arax.

quadripunctata L. Borsh., Kasikp., N. Rossk., Azkur., Etschm., Tars-tsch.

var.quadripunctata Billb. Arm., 'Tfl, Nachtw., Tars-tsch., N. Rossk.

floralis Pall. Migri., Tars-tsch., Btschng.

steppensis Dokht. Kasikp.

6-notata Rdtb. Kasikp.

scabiosae 01. Bors., Kasikp., Helnd.

14-punctata Pall. 'Tschr-j.

alpina Mén. Derb., Kursch.

flexuosa Ol. Migri., Derzeli.

fusca O1. var. deleta Muls. Kasilip.

Dejeani Gyll. Kapud.

laevicollis Mars. Arm., Kasikp.

calida Pall. var. maculata 01. Arax.

alienigera Heyd. Arax.

impar Thnb. 'I'schibl., Kasikp., Erz-Bgl., Tan. excisofasciata Heyd., Chass-jrt., Temrg.

crocata Pall. Mingtsch., Migri., 'Tars-tsch., Aksf., Ordb.

decempunctata F. Borsh., Temrgo, 'Tschr-j., Petrwk., Kasikp.

sericea Pall. Derb., T'sehr-j.

\section{0enas Latr.}

crassicornis Ill. Liljar., Kulp.

\section{Lydus Latr.}

Halbhuberi Escher. Kasikp. var, unicolor Reitt. Erzm. trimaculatus F. Chass-jrt. var. 4-maculatus Tausch. Chass-jrt.

\section{Halosimus Muls.}

syriacus L. Nog. St.

armeniacus Reitt. Arax.

chalybaeus Tausch. Kauk.

gracilis $\Lambda \mathrm{b}$. Aresch.

araxis Reitt. Arax., Kasilkp.

collaris F. Dshulfi., Migri., Eriw., Lawaschi., Kasikp.
Lytta F.

optabilis Fald. Derb., Aresch.

vesicatoria $\mathrm{L}$. Tti., Mzhet.

var. dibapha Reitt. Martk.

Menetriesi Fald. Lenk.

\section{Epicauta Redtb.}

erythrocephala Pall. Arm., 'Temrg., Petrwk., Mingtsch., Madsh.

\section{Zonitis F.}

immaculata Ol. Borsh.

laticollis Escher. N. Rossk.

nigriventris Mot. Kasikp.

fenestrata Pall. Tan., Aresch., N. Rossk., Alag., Borsh., Lenk.

rubida Mén. Arm., Amasia.

bifasciata Swartz. Aresch.

\section{Stenodera Eschh.}

cancasica Pall. Tfl.

Sitaris Latr.

apicalis Latr. Nachtw.

\section{FAM, PYROCHROIDAE.}

\section{Dendroides Iatr.}

thoracicus Fisch. Lom-mta.

\section{Pedilus Fisch.}

errans Faust. Achty.

\section{FAM, ANTHICIDAE.}

\section{Euglenes Westw.}

pruinosus Ksw. Lenk., Mamtl.

atomus Costa. Arax.

populneus Pr. Muschd.

\section{Steropes Stev.}

caspius Stev. Derb.

\section{Notoxus Geoffr.}

brachycerus Fald. Borsh. 
monoceros Id. Borsh.

trifasciatus Rossi. 'Tll., Azlimer.

\section{Formicomus Laf.}

nobilis Fah. Elsbp., Helnk., Passn., Lenk, Dartag.

tinctus lieitt. Arax.

\section{Tomoderus Laf.}

compressicollis Mot. Lenk. scydmaenoides Reitt. Lenk.

\section{Anthicus Payk.}

Bremei Idaf. Kank.

Horalis $\mathrm{H}^{\mathrm{r}}$. Baku.

tenellus Isaf. Arax.

araxicola Reitt. Arax.

hispidus Rossi. Borsh., I Lenk.

antherinus $\mathrm{T}_{\text {s. Tsenk. }}$

paralleliceps leitt. Arax.

Reiteri Pic. Arax.

\section{Ochthonomus Schmidt.}

mifasciatus lon. Arax.

\section{FAM. OEDEMERIDAE}

\section{Xanthochroa Schmidt.}

gracilis Schmidt. Borsh.

\section{Nacerdes Schmidt.}

ruticollis F. Liriw., liorsh.

adusta Panz. Borsh., Eriw., Sch-agtsch.

\section{Asclera Sehmidt.}

sanguinicollis F. Borsh., Nachtw. coerulea L. Borsh., Migri., Letch.

\section{Dedemera 01.}

podagrariae I. Morsh., Migri.

similis Schmidt. Borsh, Eriw., Dartag.

flavescens Is。 Anit., I,enk.

subulata O1. Borsh.

rostralis Reitt. Martk, Dagt.

flavipes K. Migri-tsch.

virescens L. Borsh., Anit., Isenk., Sch-agtseh., Lurida Marsh. Borsh., Baku., Iirk.

\section{Chrysanthia Schmidt.}

viridissima I. Borsh.

planiceps Ksw. Borsh., Tan.

\section{Probosca Schmidt.}

Sieversi Ksw. Ltschm., Kulp. Ganglbaucri Reitt. Arax.

\section{FAM. PYTHIDAE.}

\section{Pytho F.}

depressus $I_{\text {s. }}$ rar. festivus $F$. Abago.

\section{Salpingus Gyll.}

Loderi Reitt. Circas.

\section{Rhinosimus Latr.}

planirostris I', U-der., Lom-mta.

\section{Mycterus 01.}

curculionoides F. Morsh., Derzeli., 'T'an. umbellatarum F. Tft., Belasw., Elsbtl. tibialis Küst. Arm., Aresch., Chass-jrt.

\section{FAM. CURCULIONIDAE. \\ 0tiorrhynchus Germ.}

pseudomias Hochh. Lirk.

granulatostriatus Strl. Kasb. 7000'。

crassicornis Strl.? Adsh.

Chandoini Hochh. Kasb., Lom-mta 7000'.

subcoriaceus Reitt. $\Delta$ bgg., Swnt.

cribripemis Iochh. Olty., Alag., Perli-d., $\Lambda$ seh-ila.

rotundatus Sieb. Goktsch.

Heinzeli Reitt. Circas.

aurosquamulatus Retow. Kauk.

'I'atarchani Reitt. I'seasch. Swnt. *

abchasicus Rost. Abch.

Koenigi Faust. Arab. G. $7000^{\prime}$.

Retowskyi Reitt. Hischt.

carbonarius Ilochh. Kasb., Chews., Elbr.* fischtensis Reitt. Fischt.

simulans Strl. Suram., Swnt.

ligustici I. Dartag., I 0 m-mta. 
subrotundatus Strl. Derb.

subconstrictus Reitt. Aresch.

abagoensis Reitt. Abg.

impressiceps Reitt. $\Lambda \mathrm{bg}$.

Eugeni Reitt. Tebul-m.*

punctirostris Strl. Arm.

eques Reitt. Arax.

cribrosicollis Boh. Arax.

foveicollis Hochh. Kaput., Muri-tp.

Fausti Strl. Derb, Perli-d. 10000'.

ratschensis Strl. Ratsch.

apschuanus Strl. Abch.

gracilicornis Strl. Circas.

Rosti Strl. Abch.

subparallelus Strl. Abch.

validiscapus Strl. Circas.

subbidentatus Strl, Abch.

pilifer Strl. Glus.

carcolliformis Strl. Abch.

caucasicus Strl. Helnd.

var.? Lom-inta.

cylindricus Strl. Suram.

Kirschi Strl. Mesk. G., Mamtl.

plebejus Strl. Aresch.

scopularis Hochh. Helnd.

Lederi Strl. Elsbp.

circassicus Reitt. Circas.

nasutus Strl. Kauk.

erinaceus Strl. Mesk. G., Mamtl.

bidentatus Strl. Abst.

Adelaidae Reitt. Fischt.

Raddei Strl. Kasb. 9000'.

hebes Reitt. Circas.

cinereus Strl. Kauk.

ptochoides Reitt. Arax.

decoratus Strl. Schuw.

brachialis Boh. Kauk.

var. dentitibia Reitt. Abg.

Starcki Retow. N. Rossk.

angustifrons Strl. Arm.

Reitteri Strl. Helnd.

Beckeri Strl. Kasb.

ovalipennis Boh. Gandsha.

transsylvanicus Strl.? Kasb.

globicollis Hochh. Kasb., Chews. 10000'.

Faldermanni Hochh. Toporw. pulvinatus Hochl. Karabul.

dispar Strl. Swnt.

swaneticus Reitt. Swnt.

Argus Reitt. Circas.

\section{Parameira Seidl.}

caucasica Strl. Kauk.

\section{Nastus Schh.}

Fausti Reitt. Atschischlo.

circassicus Reitt. Atschischho, P'seasch.

humatus Germ. Ratsch.

trapezicollis Faust. Arax., Tan.

\section{Aomus Schh.}

pubescens Boh. Arax.

\section{Mylacus Schh.}

verrucea Stev. Arm.

\section{Ptochus Schh.}

porcellus Stev. Achz. setosus Boh. Arax., Kulp., Temrg. lateralis Chevr. Lirk.

\section{Phyllobius Schh.}

urticae I)eg. Tan., Swnt.

circassicus Reitt. Kauk.

fulvago Stev, Kodsh.

piri L. Tft.

argentatus L. Borsh., Batum.

mediatus Reitt. Mesk. G., Arax.

pictus Stev. Aresch.

sulcirostris Ijoh. Derb.

var. cinereus Gyll. Alexp., Mamtl.

almeniacus Kirsch. Suram., Lailsch.

Reitteri Strl. Kaul.

sinuatus F. Borsh., Tfl., Batum.

\section{Polydrusus Germ.}

Reitteri Strl. Lenk., Swnt.

mollis Stroem. Borsh., Saril.

cocciferae Ksw. Suram.

inustus Germ. Tan., Lirk., Alexd., Aresch.,

Mamtl., Borsh.

spece? Batum.

pterygumaticus lioh. Mikwana. 
(ancasicus Destru. Circas. Tan. (o)ruscur (iorm. Arowed.

\section{Sciaphilus Steph.}

asperatus lionsel, Idenk, Adsh.

Edmundia Faust.

daviceps licitt. drax.

\section{Brachysomus Stepir.}

liubanensis leitt. Circas,

enciatus strl. Mesk. (i., Suram.

\section{Barypithes Duv.}

eques Chrrl. Lirk.

liosti Reitt. Abch.

\section{Omias Schh.}

Rosti lieitt. Abch.

strigifrons Gyll. Lenk., Mamtl. georgicus Reitt. Martk., Dasst. talyschensis Reitt. 'l'al. circassicus lieitt. Circass.

\section{Strophomorphas Seidl.}

porcellus Schh. Isenk., Lailsch., Inamtl.

\section{Ensomus Germ.}

Beckeri 'T'ou'n. Arax., Kasikp.

ovulum Germ. Iorsh., Rasu.

armeniacus Kirsch. Kasiky., I)artag.

pulcher Kirsch. Arax.

piliferus lioh. Arax.

\section{Epiphaneus Schl.}

jucundus Reitt. Arax.

Dohrui Faust, Arm., Kun!), Kasikp.

\section{Pholicodes Schh.}

inauratus Boh.? 'T'an.

plebejus lioh. Lom-muta.

trivialis Boh. Borsh., '/llk.

semicalvus Reitt. 'I'btn.

ellipticus Reitt. Arax.

\section{Brachyderes Schh.}

liosti Strl. Aloch.

\section{Sitona Germ.}

crinitus llbst. Borsh. seriesetosus Fahr. Kauk.

hispidulus Ii. Suant.

flavescens Mrsh. Ienk., Matum., Mugl.

catucasicus Strl. Arax.

humeralis Steph. Migri.

var. discoideus Gyll. 'I'fl.

lirucki dll. Kauk.

lineatus $I_{4}$. Polk.

sulcifions 'I'mbg. Namtl.

\section{Trachyphloeus Germ.}

laticollis lioh. Tuik.

altermans Boh. Mamtl.

aristatus Gyll. Mamtl.

\section{Psalidium IIl.}

maxillosum H'. Zlk , Alexp., Georerk, 1)agt., l'etrwk, Borsh., גchzu.

\section{Liophloens Germ.}

nubiculosus Schli. Dartas. tesselatus Mül. Goktsch, Kasb.

\section{Thelopius Desbr.}

Akinini Faust var. caspius lianst, Arax.

Thylacites Germ.

pilosus Ir. Alpsch.

\section{Xylinophorus Faust.}

seobinatus Kol. Alax.

\section{Phacophorus Schh.}

argerostomus Gyll. Awtsch.

\section{Chlorophanus Germ.}

kubanicus Reitt. Kauk.

graminicola Schh. Borsh.

vittatus Schl. Gandsha., Olty., Baku., Alexp., Awtsch., 'Tan.

caudatus Faln's. Derb. Tschr-j.

micans Stev. Alind-tsch., Tschir-j., Kub. G. voluptificus Gyll. Kislj., Kub., T'schroj. 


\section{Tanymecus Schl.}

argentatus Gryll. Arax.

dilaticollis Gyll. Arax., Aresch. urbanus Gyll. Arax., Derb.

Mniszechi Hochl. Arax.

\section{Chloëbins Schlı.}

immeritus Boh. Arax., Aresch.

\section{Brachycerus 01.}

cinereus 0l. var. lutosus Gyll. Derb., TH. junix Licht. Michlw.

var. sinuatus 01. Kasikp.

\section{Cleonus Schll.}

pulverulentus Zoubk. Sardab.

strabus Gyll. Nachtw.

anxius Gyll. Arax.

nigrosuturatus Goeze. Tfl., Borsh., B. kitsch. fasciatus Muill. Borsh.

candidatus Pall. Tfl.

clathratus 01. Derb., Dawal., Mingtsch.

marginicollis Fahrs. B. kitsch.

piger Scop. Eriw., Suram., Ilelnd.

cenchrus Pall. Arax.

tigrinus $\mathrm{Pz}$. Kauk.

achates Fahrs. Borsh.

mixtus H. Arax.

\section{Lixus F.}

iridis O1. Kasikp., Mosd

fascifarius Reitt. Arax.

furcatus 01. Arax., Such. Fit.

inops Schh. Dawal., Such. Ft.

hypocrita Chrr. Derb., Arax.

subulatus Faust. Arax.

subtilis Boh. Borsh.

Ascanii L. Borsh., Etschm.

myagri 01. Borsh.

cylindricus Hbst. Dartag.

circumcinctus Boh. Arax.

junci Boh. Kauk.

cardui OI. Gandsha., Tfl., Borsh., Tars-tsch., Artschw., Anit.

elongatus Goeze. Derb. tigrinus Reitt. Arax.

incanescens Boh. Alexd.

var. caucasicus Faust. Arax.

cribricollis Boh. Kauk.

\section{Tarinus Germ.}

onopordi F. Belasw.

inacqualicollis Cap. Kasikp.

maculatus Fald. Arax.

latus Hust. Borsh., Mug., Azkur., Eiljar., Kasikp., Such. Ft.

var. teretirostris Gyll. Kank.

ochroleueus Faust. Arax

flavescens Germ. liorsh.

syriacus Gyll. Borsh.

minutus Gyll. Chass-jit.

turbinatus Gyll. Clrews.

sturnus Schall. Kapud., Migri., Lenk., Borsh., Chews.

jacaeac F. Chews.

\section{Stolatus Muls.}

horridus Reitt, Arax.

\section{Bangasternus Gozis.}

orientalis Cap. Borsh.

Fausti Reitt. Arax.

\section{Rhinocylius Germ.}

Schönherri Cap. Chews.

conicus Fröhl. Migri, Borsh., Sch-agtsch, Anit., Artschw, Derzeli.

\section{Minyops Schh.}

Chatudoiri Hochh. Arax.

rhytirrhinoides Reitt. Arm.

\section{Rhytimhiuus Schh.}

giblus Kol. Mlexp., Sardab.

\section{Alopinus Schh.}

agrestis Boh. var. armeniacus IJochh, Arm. triguttatus F. Alag. Mamtl.

\section{Lepyrus Germ.}

palustris Scop. Helnd.

var. flavidulus Reitt. Kauk. 


\section{Hylohius Schh.}

abietis I. Borsh.

verrucipennis Boh. Lom-mta.

\section{Liparus 01.}

coromatus Goeze. Kauk.

\section{Plinthns Germ.}

Schneideri 'Tourn. Sucha.

irroratus Reitt. Kauk.

silphoides IIbst. Kasb., Chews., I dom-mta.

causticus Faust. Imrt.

vittatus Reitt. Grus.

Fausti Reitt. Atschischh\%. Pseasch., Alog.

dolosus Faust. Arax.

fallax Fald. Suram., Migri., Goktsch, T'sehibl.

squamosus Reitt. Circas.

Chandoiri Faust. Circas.

alternans Reitt. Cireas.

Starcki Faust. Atschischho, I'seasch., Abg.

\section{Liosoma Steph.}

Reitteri Bedel. Circas.

\section{Aparopion Hampe.}

costatum Fahrs. Suram., Mesk. G. aequale Reitt. Lenk.

\section{Adexins Schl.}

scrobipennis Gyll. Kank.

\section{Trachodes Germ.}

bŗstrix Gyll. Suram., Iamrt.

ovatus Weise. Circas.

oblongus Reitt. U-der.

elongatus Reitt. Lenk., Ilamrt.

hispidus L. Kauk.

\section{Anchonidium Bed,}

ulccrosum Aubé. Tlesk. G.

\section{Caulomorphns Faust.}

Lederi Chevrl. İenk.

\section{Cotaster Mot.}

uncipes Ioh. Suram., Mesk. G.

\section{Microcopes Faust.}

pilosus Mot. Mesk. G., Jirk.

\section{Hypera Germ.}

circassicola lieitt. Atschischho.

punctata F'. Kauk.

fasciculata Ilbst. Mug., Elsbp., 'I'schr-j.

anceps Boh. Kauk.

adspersa I'. Sch-agtsch.

rumicis I. Artschw.

meles H. Borsh.

variabilis IIbst. E'riw., Inamrt, 'T'an.

farinosa Boh. Erz-Bgl.

trilineata Mrsh. Sch-agtsch.

\section{Limobins Sehh.}

borealis Payk. 'Tfl.

\section{Coniatus Germ.}

splendidulus F'. 'l't.

splendidus. Derl., Tft.

\section{Acentrus Schh.}

histrio Hoh. 'Tfl.

\section{Pissodes Germ.}

piceae I11. Suram.

pini L. IBorsh.

\section{Arthrostenus Schl.}

ignoratus Faust. Arax.

Fausti Reitt. Lrax.

\section{Notaris Steph.}

limaculatus F. Mamtl.

atcrimus Hampe var. Lederi Faust. Circas.

\section{Dorytomus Steph.}

longimanus Forst. Namtl.

Schönherri Faust. Gagry.

Dejeani Faust. Mamtl.

taeniatus F. Derb., Dagt.

\section{Smicronyx Schh.}

scops 'Tourn. Mamtl. 
jungermanniae Reich. Lenk., Tff. basalis Schultze. Aresch.

\section{Anoplus Schh.}

plantaris Naezen. Batum. roboris Suffr. Letch.

\section{Tanysphyrus Germ.}

lemmae Pk. Lenk., Sch-agtsch.

\section{Bagous Schh.}

biimpressus Fahr. Kauk.

frit Hbst. Suram.

lutosus Gyll. Lenk.

glabrirostris Hbst. Lenk.

var. nigritarsis Thms. Borsh. argillaceus Gyll. Elsbth.

\section{Echinocnemus Schh.}

Sieversi Faust. Arax.

\section{Geranorrhinus Schh.}

Seidlitzi Kirsch. Arax., Aresch.

\section{Cossonus Clairv.}

linearis F. Borsh.

\section{Mesites Schil.}

pallidipennis Boh. U-der.

\section{Codiosoma Bedel.}

spadix Hbst. TH.

\section{Eremotes Woll.}

submuricatus Schh. Lonk.

\section{Rhyncolus Steph.}

truncorum Germ. Lenk. turbatus Schh. Arax.

\section{Acalles Sohh.}

denticollis Germ. Mesk. G.

camelus F. Mesk. G.

Aubei Boh. Mlesk. G.

Milleri lieitt. Circas., Lom-mta 7000'.

Chaudoiri Hochh. Kank. echinatus Germ. Circas.

ptinoides Marsh Suram., Mamtl.

hypocrita Boln. Circas.

caucasicus Reitt. Circas., Mesk. G., Mbst.

horridulus Reitt. Circas.

Reitteri Meyer. Mesk. G.

\section{Haptomerus Faust.}

Sehneideri Kirsch. Arax., Kiptsch., Such. Ft.

\section{Mononychus Germ.}

salviae Germ. Anit., Lenk., Sch-agtsch.

\section{Coeliodes Schh.}

dryados Gmel. Mesk. G., Martk.

nodirostris Schultze. 'Tan.

rubricrus Gyll. Kauk.

erythroleucus Gmel. Lailsch.

cardui Hbst. Martk, Mamtl.

fuliginosus Marsh. Kauk.

quadrimaculatus L. Lirk., Wldk., Tan., Polk., Borsh.

lamii F. Zlk.

affinis Pk. Borsh., Elsbth.

exiguus Ol. 'Tan.

asperatus Gyll. Borsh.

\section{Rhinoncus Steph.}

Castor F. Kauk.

bruchoides IIbst. Kauk.

pericarpius L. Lenk., Tan.

perpendicularis Reich. Suram.

var. rufofemoratus Schnltze. Kauk.

\section{Phytobius Șchl.}

Waltoni Boh. Lenk.

granatus Gyll. Borsl., Arax.

\section{Centorrhynchidius Duv.}

horridus Pz. Borsh, K-ogly.

troglodytes F. Kasilp., Klsbth., T'an.

terminatus IIbst. Elshpl.

quercicola Pl. Mamtl.

floralis Pk. Polk., Such !Et., Elsbth., Kiptsch.,

Suram., Kasikp., Lirk.

pyrrhorlynchus Narsh. T'th. 
pulyintus Gyll. 'T'scheml., 'lth, P'olk. mixtus Muls. l'olk.

\section{Centorrhyuchus Germ.}

tophiarius Germ. liorsh., Murl-t!).

abchasicus baust. Bursh.

pubicollis Gyll. Kank. oce.

yengrathicu Goeze. loorsh.

shlaucinus boh. 'I'an.

asperifoliarum GyH. Mamtlo, 'T'an.

urticae Boh. var. stachydis Jace. Mursh.

latidicus Gyll. 'Zlk., 'l'an.

"rucifer" ()1. Guberli.. Inush.

Auhei loh. biorsh.

'T'-album (ryll, Bursh., Elsuth.

Knenieri schultze. 'l'an.

trimaculatus l'. Azkur., 'l'il, IBorsh.

rufimamus Bris. Borsh.

macula-alba Ilbst. Kasilip.

Ilerhsti. Such. lit.

punctiger Gyll. Kathfld.

liagusae Bris. Kank.

Lethierryi Bris. Borsh, 'Tin.

denticulatus Schrk. Borsh.

verrucatus Gyll. Mamtl.

pollinarius Forst. Polk.

fireculentus Gyll. Kauk.

picitarsis Gyll. Tfl., Kasilkp., Zlk., IIelnd., Such. Ft., Mamtl.

pleurostigma Marsh. Kauk.

griseus liris. Lirk.

alliariae Bris. Kislj.

napi Gyll. Borsh.

sulcicollis L'k. Lirk., Elsbth., Polk., Borsh.

aeneicoilis Germ. K-ogly., Helnd.

erysimi li. Lirk., Borsh., Elsbp.

contractus Marsh. Borsh., Elsbpr, Lirk.

timidus Weise. Such. Ft.

cognatus Schultze, P'olls.

criwanus Schultze, Such. Ft.

aratur Gyll. drax.

miarioides Schnltze. Tan.

sinilis Pris, Kauk.

subpilosus Bris. 'lan.

nigritarsis Schultze. Kauk.

lilipntanus Schultze. Kauk. nanus Gyll, Elshth., T'il.

angustulus Gyll. 'Til.

\section{Baris Germ.}

desplicata laust. Mesk. G.

atricolor boh. Kasikp.

dalmatina Bris. Jetch.

timida Rossi. Hriw., lakk., Tschr-j., Mastr., Michlw., Arax., 'Tfl.

menmonia Boh. Derb.

angusta Jipll. Kauk.

lepidii Germ. Mesk. G.

janthina Boh. Iresch.

picicornis Marsl. Kauk.

coeruleseens Scop. Mang., Lenk.

picturata Mén. Derb.

\section{Limnobaris Bed.}

'l'allum Is var, crocopelma Gryll. Lenk.

\section{Lepidobaris Reitt.}

cruciata lieitt. Aresch.

\section{Calandra Clairv}

granaria I. Llsbth., I)artag., Artschw., Lenk. oryzile Is. Lenk.

\section{Balaninus Germ.}

venosus L. N. Rossk.

nueum Is. 'Tan.

turbatus (Gyll. Lirk., Borsh., Baku., Kathfld.

\section{Balanobins Jek.}

salicivorus Pk. Helnd.

pyrthoceras Marsh. Borsh.

\section{Anthonomus Germ.}

rubi llbst. Azliur., Mamtl.

cinctus Koll. Borsh.

pedicularius L. Lirk, Letch.

humeralis $\mathrm{Pz}$. Arax.

\section{Bradybates Germ.}

Kellneri liach. var. subfasciatus Gerst. Kathfld.

\section{Elleschus Steph.}

bipunctatus L. Namtl. 


\section{Lignyodes Sehl.}

enucleator Pz. Borsh.

\section{Tychius Germ.}

quinqquepunctatus L. Anit.

Morawitzi Beck. Etschm., Kara-st.

rufirostris Gyll. Arax.

Beckeri Tourn. Derb.

aureolus Ksw. var. medicaginis Bris, Circas.

flavus Beck. Borsh.

sulfureus Faust. Arax.

junceus Reich. Borsh., Etschn.

meliloti Steph. Martk., Elsbth.

picirostris F. Lenk., Borslı.

cuprifer $\mathrm{Pz}$. Baku., Lirk.

\section{Sibinia Germ.}

Tournieri Tourn. Kauk.

Zuberi Desbr. Kauk.

primita Hbst. Elsbth

var. phalerata Stev. Tf.

attalica Gyll. Borsh.

pellucens Scop. Tan.

viscariae L. Borsh., Such. Ft.

subirrorata Faust. Kauk.

\section{Orchestes IlI.}

quercus L, Kauk.

Quedenfeldti Gerh. C. Kauk.

fagi L. Suram.

testaceus Müll. Batum.

var. pubescens Stev. $\mathrm{Abg}$

avellanae Donov. Arm.

\section{Mecinus Germ.}

pyraster Ilbst. Kauk.

collaris Germ. Lenk.

\section{Gymnetron Schh.}

pascuorum Gyll. Tars-tsch., Elsbth.

var. bicolor Gyll. Kauk.

beccabungae L. Lenk., Mamtl., IIamrt.

jucundum Reitt. Kauk.

labile Illost. Tan.

asellus Grav. Suant., Borsh., Tfl., Tan.

thapsicola Germ. Mesk. G. netum Germ. Borsh.

fuliginosum Rosh. Kauk.

bipustulatum Rossi var. Germari Faust. TH.

spilotum Germ. Tfi., Borsh.

tetrum F. Tfl., Borsh., I'an.

var. plagiellum Gyll. Tfi., Tan.

var. haemorrhoum Desbr. Tfl.

noctis Hbst. 'Tan.

pilosum Gyll. Borsh.

\section{Miarus Stepl.}

longirostris Gyll. Borsh., 'Tan.

scutellaris Bris. Alexd.

graminis Gyll. Borsh., Alexd.

campanulae L. Borsh., Sugd., Kionthl., Alexd.

\section{Cionus Clairv.}

serophulariac L. Such. Ft.

Clairvillei Boh. Kislw.

thapsi F. Zlk., Borsh., Kasilip., Lom-mta.

hortulanus Fourer. Lom-mta., Sucl. Ft.

cancasicus Reitt. 'Tan.

goricus Schultze. Borsh.

olens F. Arax.

solani F. Such. Ft.

\section{Nanophyes Sohh.}

brevis Boh. Lenk.

Fausti Reitt. Arax.

marmoratus Goeze. Chews.

Komaroffi Faust. Derb.

quadrivirgatus Costa. Tfl, Mingtsch.

minutissimus Tourn. Arax.

\section{Magdalis Germ.}

rufa Germ. Borsh.

aterrima L. Anit.

asphaltina Boh. Kauk.

\section{Apion Host.}

Pomonac F. Kauk.

tamaricis Gyll. Arax.

onopordi Kirby.,Azkur.

holosericeum Gyll. Mamtl.

urticariun Hust. Borsh.

aeneum F'. Azkur., Derb., IIelnd.

validum Germ. Kauk. 
radiolus Marsh. Jlugh, IIelnd.

curvirostre (ayll. Lriw. Borsh., l'ioneti

seniculus Kirloy. Lorsh.

clongatum Germ. Mamtl.

fulvirostre Gyll. Eisbth.

rutirostre li. Kank.

longirostre Ol. 'Tt1., liriw., llelnd.

viciae Pk. Kauk.

Schönherri Boh. Kank.

apricans Hlbst. borsh.

trifolii I. Ilelnd. Fisbth.

var. ruticrus Germ. Mamtl.

nigritarse Kirby. Borsh., Hamtl.

tenue Kirby. Lenk., Mamt.

intermedium Lpp. Mamtl.

Gỵlenhali Kirby. Mamtl.

pisi $\mathrm{F}$. Lirk.

laevigatum Pk. Kank.

pavidum Germ. I3orsh.

Waltoni Steph. Elsbth.

miniatum Germ. Lenk., Sch-agtsch., 'Tfl., IIamtl.

malvae F. Tschml, Tft., Helnd.

cognatum Hochh. Helnd.

curtirostre Germ. Kank.

Anletes Schh.

Beckeri Desbr. Derb.

\section{Rhynchites Schneid.}

seminiger Reitt. Kauk.

pubescens F. Chram.

sericens Hbst. Borsh.

pauxillus Germ. Borsh, Isailsch.

purpureus L. var. semiruber Strl. Kathfld.,

Iirk., Aresch., Chass-jrt.

hungaricus Ilbst. Kasikp.

parellinus Gyll. Kauk.

coeruleus Deg. Lailsch., Lirk.

giganteus Kryn. Borsh, Gandsha, 'Tan., Bethn.

Jekeli Desbr. Kauk.

auratus Scop. Eriw.

Bacchus I. Chram., Tan., Polkl.

\section{Rhinomacer Geoffir.}

betulac L. Borsh., 'Tan.
Cyphus Thub.

nitens Scop. Migrri., Aresch., 'T'sk-T'sk.

$$
\text { FAM. NEMONYCHIDAE. }
$$

Nemonyx Redtb.

canescens Eirsch. Arax.

\section{FAM. ANTHRIBIDAE. Platyrrhiuus Clairv.}

resinosus Scop). Kauk.

\section{Tropideres Schh.}

albirostris Ilbst. Aresch.

marchicus Ifbst. Circas.

\section{Phaenotherion Friv.}

Pulskyi Friv. Circas.

\section{Platystomus Schneid.}

albinus Is Borsh., Lenk.

\section{Choragus Kirby.}

piceus Schaum. Lenk.

\section{Urodon Schh.}

suturalis Ir, Kauk.

pygmaeus Gyll. Nog. St., Tfl.

\section{FAM, MYLABRIDAE}

\section{Mylabris Geoffr.}

luteicornis IH. Sch-agtsch.

aftinis Fröhl. Eriw.

lufimana Boh. Borsh.

atomaria L. Kiptsil.

longicornis Germ. Nachtw.

quinqueguttata 01. Arm.

quinquepunctata Mot. Arax.

pusilla Germ. Borsh.

glycyrrhizae Falırs IIelnd.

cisti F. Borsh.

murina Boh. Borsh.

dispar Germ. var. braccata Gyll. Helnd.

tibialis Boh. Borsh., Anit.

sericata Germ. Elsbth. 
Spermophagus Stev.

cardui I3oh. Kriw., Kara-su., Tfl, Elsbth. variolosopunctatus Gyll. Borsh., Tfl, Tan.

\section{FAM. SCOLYTIDAE.}

Caxphoborus Eichl.

minimus F. Suram.

\section{Hylesiuus F。}

brevicollis Kolen. Isenk.

\section{Phloeotribus Latr.}

caucasicus Reitt. Arar.

\section{Scolytus Geoffr.}

scolytus fi. Anit.

intricatus Ratz. Alexd.

var. Fauveli Reitt. Arax.

rugulusus Ratz. Arax.

amygdali Guér. Arax.

\section{Crypturgus Er.}

pusillus Gyll. Abst.

cinereus Ilbst. Mbst.

\section{Ips Deg.}

sexdentatus Boern. Alst.

elosus Woll. Borsh.

laricis F. Abst.

\section{Taphrorychus Eichl.}

bicolor Hbst. Suant., Lenk., Borsh., Helnd. Lulmerinequi Kol. 'Iffl., Elsbth.

\section{Thamnurgus Eichh.}

Brylinskyi Reitt. Arax.

\section{Dryocoetus Eichh.}

coryli Perr. Kub., Swnt.

\section{Xyloborus Eichh.}

cryptographis Ratz. Tfl.

Saxeseni Ratz. Kauk.

monograplius F. Suram., Lenk.

dispar F. Ach-bu., Mamtl.

\section{Xyloterus Er.}

romesticus L. 'I'schtg.

signatus F. Helnd, Lirk.

\section{Platypus Hbst.}

cylindrus F. Lenk.

\section{FAM. CERAMBYCIDAE,}

\section{Parandra Latr.}

caspica Mén Lenk.

\section{Spondylis F.}

buprestoides L. Kutais, Borsh., Eriw., B. kitsch., 'Tan.

\section{Prionns Geoffr.}

coriarius L. Tan, Eriw,, Suram., Kut,, Achzu., Iorsh., Pseb.

asiaticus Fald. Aresch.

\section{Ergates F.}

faber L. Borsh., Mang., Swnt, 'Tan.

\section{Rhesus Mot.}

serricollis Mot. Lagodechi.

\section{Aegosoma Serv.}

scabricolne Scop. Eriw., Nachtw.

\section{Apatophysis Chevr.}

tomentosa Gebl. Derb., Areseh.

\section{Rhagiam F.}

sycophanta Schrk. ? Borsh., Adsh., Dartag. fasciculatum Fald. Schuw., Batum., Lom-mta. pygmaeum Gnglb. Lenk.

bifasciatum F. Schuw., T'an.

inquisitor $I_{\text {. }}$ Borsh., Kub.

\section{Enoploderes Fald.}

sanguineus Fald. Lom-mta., $0-7000^{\prime}$.

\section{Leptorrhabdium $\mathrm{Kr}$.}

cuteasicum kr. liorsh. 


\section{Oxymirus Mals.}

mirabilis Mot. Borsh., Suram.

\section{Toxotus Serv.}

insitivus Germ. 'T'an., 'I'sk-'l'sk, Chass-jrt. Borsh.o Isti-su.

persicus Fald. Arm., "l'al.

quercus Goeze. Azkur.

\section{Pachyta Steph.}

bifasciata OI. var. caucasica Rost. Kauk, occ.

\section{Brachyta Frm.}

variabilis Gebl. lilbr.

interrogationis L. Dagt.

\section{Acmreops Lec.}

pratensis Laich. Borsh., Lom-mta.

collaris I. Borsh., Suchum., Dartag., Zlk., Letch., Tan.

\section{Cortodera Muls.}

humeralis Schall. Adsh., Thiz. S.

var. suturalis F. Suram.

pumila Gnglb. Mesk. G., Tan.

holosericea F. Zlk.

Starcki Reitt. Abg.

umbripennis Reitt. Arn.

flavimana Waltl. Amasia

colchica Reitt. Arm.

confusa Reitt. Chank-tan.

alpina Mén. Kursch., Kasb, Chank-tau.

pseudomophlus Reitt. Arax.

\section{Pidonia Fald.}

elegans Fali. Suram., Borsh., Eiljar., Batum., Lirk., 'T'an.

\section{Leptura I.}

rufipes Schall. Suram., Derzeli., Borsh., Adsh., Sugd., N.Rossk., 'Tan., Aresch., T'sk-T'sk. var. Kruperi Gnglb. Atschischho., Sugd. unipunctata F'. Kasikp., Borsh., Kislw. rufa Brll. Arax.

bicolor Redtb. Balyk-göll. livida F. Borsh., Kislw., Alexd.

var. bicarinata Arnold. Jorsh., Alexd., 'I'schibl., 'I'schl-j.

circassica Dan. Sugd.

tonsa Dan. Tal., Aresch. B. kltsch., Mamtl., Helnd, Lirk., Borsh.

tesserula Charp. var. Dejeani Gnglb. Derzeli., Pseb., Borsh., N. Rossk., T'an., Urusch., Chews., Dartag., 'I'btn.

var. impunctata Heyd. Psebai., Borsh., N. Rossk., Lum-mta.

cordigera Fússl. Migri-tschai.

scutellata H. Borsh, Lirk.

dubia Scop. Borsh., 'I'sk-'T'sk., Migri.

var. melanota Fald. Borsh., Mastr., Urusch., Mastg., Lom-mta., Tan., Achzu., Borsh., Elbr.

erratica Dalm. Derzeli., Borsh., B. kltsch. var. erythrura Küst. Kauk.

quadrifasciata L. var. Lederi Gnglb. Urusch., Dartschk., Bonos-m., 'T'ebul-m., T'an., Chews., Achzu.

maculata Poda. Borsh., Achzu., Goktsch., Derzeli, Such., Swnt, 'Tan.

bifasciata Müll. Borsh., Btschng., Tan.

Jaegeri Humm. Derb., Sugd., N. Rossk., Tan., Chass-jrt., Lirk.

septempunctata F. Kauk.

nigra L. Borsh.

attenuata I. N. Rossk.

var. brunnescens Reitt. Kauk.

\section{Allosterna Muls.}

tabacicolor Deg. Borsh., 'Tsk-T'sk.

var. bivittis Mot. Mesk. G., Lom-mta., Tan. scapularis Heyd. var. talyschensis Reitt. 'I'al.

\section{Grammoptera Serv.}

ustulata Schall. Lenk.

ruficornis F. Tuenk.

variegata Germ. Borsh.

\section{Caenoptera Thms.}

minor L. Suram., Lenk.

umbellatarum Schreb. Aresch., Sch-agtsch., Borsh., Lenk., Anit. 


\section{Stenopterus Steph.}

rufus L. Kub., Urusch., Helnd., 'I'an., Migri., Anit.

\section{Callimoxys Kr.}

gracilis Brll. Muschw.

\section{Callimus Muls.}

angulatus Schrk. Lirk.

femoratus Germ. 'Tft., T'm.-Ch.-Sch., Elsbth.

\section{Cartallum Serv.}

ebulinum L. Aresch., Nog. St., Derb., Tfl., Alget., Mug.

\section{Obrium Curt.}

brunneum F. Borsh., Tan.

\section{Leptidea Muls.}

brevipennis Muls. Tf.

\section{Gracilia Serv.}

minuta F. Lenk., Adler., Lirk.

\section{Exilia Muls.}

timida Mén. Lenk., Bilet., Aksf., Helnd.

\section{Cerambyx L.}

carinatus Küst, Eriw., Tfl.

cerdo L. var. acuminatus Mot. Kut., N. Rossk., Eriw., Tan.

nodulosus Germ. Eriw., N. Rossk.

Scopolii Füssl. Suram., Batum., Borsh. multiplicatus Mot. Lenk., Derb., Lirk.

\section{Hesperophanus Muls.}

sericeus F. Derb.

griseus F. U-der., 'Tfl

\section{Stromatium Serv.}

fulvum Vill. Borsh., Eriw., Helnd.

\section{Drymochares Muls.}

Starcki Gnglb. U-der.

\section{Criocephalus Muls.}

rusticus L. Borsh.

ferus Kr. Borsh., Tan., Temrg.

\section{Asemum Eschh.}

striatum L. Elbr.

var, agreste F. Krsn-plj., Borsh.

\section{Phymatodes Muls.}

testaceus L. Sewg., Jewdk., N. Rossk., Helnd., Murd-tp., Delsh., Lawaschi., Migri., Goktsch.

var. variabilis I. Eiljar.

alni L. Zlk., Chews., Krsn-plj., Mesk. G.

\section{Pyrrhidium Frm.}

sanguineum L. Tfl., Borsh., B. kltsch., Elsbth.

\section{Semanotus Muls.}

russicus F. Aresch.

\section{Hylotrupes Serv.}

bajulus L. Mang., Tfl., Borsh., Eriw., 'lan.

\section{Rhopalopus Muls.}

Lederi Gnglb. Kislw. clavipes F, Borsh., Eriw.

macropus Germ. Borsh, Artwin., Mosd.

\section{Rosalia Serv}

alpina L. Kut., Eriw., Schtjk.

\section{Aromia Serv.}

moschata L. N. Rossk., Eriw.

var. ambrosiaca Stev. B. kiltsch., Mang., Schtjk.

var. thoracica Fisch. Lenk., Mang., Kut., Lirk., Helnd.

\section{Parpuricenas Fisch.}

Deyrollei Thms. var. talyschensis Reitt. Albr. budensis Goeze. Derb., Migri., Aresch., Kathfld., Chass-jrt.

Koehleri L Tan. ephippium Stev. 'T'schr-j. 


\section{Plagionotus Mruls.}

detritus L. Lriw,

arcuatus L. 'TH., Suram., Bor'sh., IIang., 'Tan. Bobelavei Brll. Derb.

floralis Pall. Alexp., Sardah, Achzt. var. armeniacus Reitt. Mlexp.

\section{Xylotrechus Chevrl.}

arvicola 01. Borsh, Tin.

\section{Clytus Laich.}

Schneideri Ksw. Borsh., I3. kiltsth.

arietis $I_{d}$. Borsh., Ilelnd.

lama Muls. Anit. Lirk.

rhamni Germ.Tars-tsch.,.tnit., Migri., Borsh., Tan.

\section{Clytanthus rhms.}

varius F. Elsbth., Tfl, Arax., Ilehd., N. Rossk, Tan., Eriw., Nachtw.

Faldermani Fali. l)erb.

nigripes [3rll. Borsh.

sartor F'. Tft, Borsh., Mirri.

figuratus Scop. Th., Martk., Sinril., deh-bu,

Dartag., N. Rossk.

speciosus Schneid. N. Rossk.

comptus Mannh. Lenk., Mdsh, b. kitsh.,

Eriw., Chass-jrt., Schtjk.

\section{Auaglyptus Muls.}

arabieus Küst. IBorsh., Gagry., 'Tan.

mysticus L. Borsh., Suram.

Raddei Guglb. 'T'al.

sexguttatus 1d. Suram.

Reitteri Gnglb. Lenk.

\section{Parmena Serv.}

balteus L. Isetch., Tan.

\section{Dorcalion Dalm.}

glyeyrrhizac Pall. Kauk. ?

carinatum Pall. Derl.

cylindraceum Reitt. Petrwk, Shass-jnt.Jewdk. Lawaschi.

Koenigi Jak. 'T'm.-Člı.-Sch.

Lederi Kr. Kank. niveisparsum T'hms, Azkitr.

pedestre L'oda. Lirt.

Beckeri Kr. 1)erb., l'etrwk.

sericatum Kryn. 'TH., Eisbth., H. kiltsch., N. Rossk.

sulcipenne Kïust, Tfl., Aresch.

striatum IJalm. Derb.

strilatum Kr. Arm., liorsh., Tan.

scabricolle Dalm. Lilsbp., B). liltsch., Lirk., Til.

rar. sevangense Reitt. Arm.

nobile IIampe. Erzm.

seminudum $\mathrm{Kr}$. 'lranskank.

dimidiatum Mot, Arm., Ilehd,

indutum Fald. Mur-dgh.

nigrosuturatum Reitt. Arm.

Reitteri Gnglb. Innt. 6000'。

talyschense Gnglb. Tal. 5000'.

nitidum Mot. Zch-Zch., 'Lbiz. S.

Wagneri Küst. Mrax. 7000$)^{\prime}$.

Mniszechi Kr: Eiljar., Mastr.

\section{Morimus Serv.}

funcrens Muls. Eriw.

asper Sulz, var. verecundus Fald. Borsh., Batum., Ienk., Scli-argtsch., Mastg., Kut, Anit., Suant.

\section{Lamia Fb.}

textor I. Artwin. 6000'.

\section{Monohammus Steph.}

galloprovincialis 01. var.tignator Kryu. Borsh. 13. kiltsch.

\section{Acanthocinus Stopl.}

aedilis I. Borsh.

reticulatus Razumow. borsh.

\section{Iiopus Serv.}

nebulosus L. Borsh.

caucasicus Gnglb. U-der.

femoratus Frm. Borsh., U-der.

Exocentrus Muls.

punctipemis Muls. N. Rossk. 
Pogonochaerus Gemm.

hispidus L. Kauk.

\section{Parmenopsis Gnglb.}

caucasica Led. U-der.

\section{Haplocuemia Steph.}

curculionoides L. T'an.

nebulosa F. Borsh., Tan.

caspica Dan. Tal.

\section{Anaesthetis Mnls}

testacea I, Derb.

\section{Agapanthia Serv.}

Kirbyi Gyll. Kislw.

asphodeli Latr. Borsh., Ėlsbth.

Dahli Richt. Aresch.

cynarae Germ. Lenk., Dartag., I3. Kltsch., Saril., Borsh., Zlk., Pari., Sch-agtsch villosoviridescens Deg. Tfl., Tsk-'Tsk., Derb., Belasw., Tan.

var. subchalybaea Reitt. Kauk.

violacea F'. Gagry., Aresch., Dartag., Wlsbth.,

Migri., Lenk.

var. intermedia Gnglb. Kauk.

chalybaca liald. Kauk.

leucaspuis Stev. N. Rossk.

\section{Saperda F.}

scalaris L. Borsh., Helnd.

perforata Pall. 'Pan.

octopunctata Scop. Kislw.

punctata L. Kislw.

\section{Tetrops Steph.}

pracusta L. Aresch.

gilvipes Fald. Lenk, Eisbth.

\section{Stenostoli Muls.}

niogripes $\mathrm{r}$. Borsli, 'Tan.

\section{Oxylia Muls.}

Duponcheli Brll. Imorsh., Eiljar., Kasikp.

\section{Mallosia Muls.}

Herminae Reitt. Arax.

Scovitzi Fald. Arax.

\section{Conizonia Frm.}

albolineata IIampe. var. fulvolineata Reitt. I3orsh.

compacta Fald. Arax.

\section{Pilemia Frm.}

hirsutula Fröhl. Arax., lan.

\section{Phytoecia lHuls.}

scutellata F'. T'H.

millefolii Ad. Arax.

practextata Stev. Arax.

armeniaca Friv. Arax.

Antoniae Reitt. Arax.

affinis Harr. var. nigropubeseens Reitt. Kauk.

var. Starcki Reitt, $\Lambda$ bs.

puncticallis Falel. Tfl, Derb., Suram.

var. persica Gnglb. Arax.

Astarte Gnglb. Arax.

Pici Reitt. Arax.

Boeberi Gnglb. Tan., Mams., Mamtl., Migri., Borsh.

volgensis $\mathrm{Kr}$. Kauk.

virgula Charp. Kauk.

pustulata Schrk. Borsh.. Belasw.

rulimana Schrk: Lenk, Bakn., Muschw. dresch.

croceipes Reiche. Derb.

cylindrica L. Borsh.

nigricornis F. N. Rossk.

coerulescens Scou. borsh., Etschm;, b. kitsch.

\section{Oberea Irinls.}

oculata L. Borsh., I'seaseh. erythrocephala Schrk. Morsh., Artwiı., Abst., IIclnd.

\section{FAM. CHRYSOMELIDAE. Orsodacne Iratr.}

cerasi L. Suram., Lirk. 
lineola 1'z. Lirk.

var. coerulescens Duft. Iirk.

\section{Donacia F.}

limbata P'z. var. meridionalis Jacobs. Michfld. bicolora Zschach. Gagry.

impressa Pk. Sch-agtsch., Lenk.

antiqua Kunze. Sch-agtsch.

simplex Ir. Artschw., Sch-agtsch.

\section{Plateumaris Thms.}

sericea L. Derb., Chass-jrt

var. micans $\mathrm{I}$ 'z. Mesk. G.

var. armata I'k. Mesk, G.

braceata Scop. Kauk.

\section{Zeugophora Kunze.}

Weisei Reitt. Arax.

\section{Lema Lac.}

Erichsoni Suffr. Derb.

Havipes Suffr. U-der.

melanopus L. Etschm., Borsh., Elsbth.

\section{Crioceris Geoffr.}

merdigera L. Borsh., TH., Muschl., Tsk-Tsk. Faldermanni Guér. Arm.

duodecimpunctata L. Lenk.

quatuordecimpunctata Scop. Derb., Baku.

bicruciata Sahlb. Derb., Borsh., Mamtl.

asparagi L. Anit, Lenk.

var. campestris L. Kauk.

\section{Labidostomis Lac.}

asiatica Fald. Borsh.

armeniaca Led. Arax.

propinqua Fald. Kut., Borsh., Btschng.,

Lirk., Chass-jrt., Tan., Dartag., Elsbth.

decipiens Fald. Mug, Arax.

lucida Germ. Kathfld.

longimana L. Borsh.

Reitteri Weise. Arax.

pallidipennis Gebl. Kauk.

cyanicornis Germ. Mug.

lepida Lef. Chass-jrt.
T'ituboea Lac.

macropus IIl. Derb.

\section{Clytra Laich.}

valerianae Mén. Borsh., Eiljar., Kasikp. Rasn., Dartag., Alexp., Mug., 'T'tl. novempunctata OI. Suant, Derb., Mugl., Delsh. laeviuscula Rtzb. N. Rossk., Btschng., Borsh., Suant., 'J'tl.

nigrocincta Lac. Frzm.

atraphaxidis Pall. Derb., Baku.

\section{Gynaudrophthalma Lac.}

limbata Stev. Polls., Aresch., Muschd., Elsbth., Derb., Lenk., Lirk. unipunctata Ol. Arax., Aresch. aurita L. Init., 'Tan.

\section{Chilotoma Lac.}

erythrostoma Fald. Borsh.

\section{Coptocephala Iac.}

apicalis Lac. Derb.

chalybaea Germ. Elsbth.

Gebleri Gebl. Kasikp., Migri.

unifaseiata Scop. Tfl, Borsh., Kulp., Kasilip.

\section{Cryptocephalus Geoffr.}

cribratus Suffr. Tan.

trapezensis Tapp. Borsh., Suram.

bipunctatus L. Belasw., Chass-jrt., Ischr-j.

flavicollis F. Kauk.

rubi Mén. Derb., Mingtsch.

astracanicus Suffr. Derb.

gamma II. S. Temrg.

flexuosus Kryn. Baku., Aresch.

apicalis Gbl. N. Rossk., 'T'an., Aresch.

Schäfferi Schrk. Suram.

villosulus Suffr. Derb.

sericeus L. Tsk-Tsk., Dartag., Dadsch., N. Rossk., Borsh., Azkur., Derzeli., Adsh. hypochoeridis L. Lom-mta., Swnt., Dadsch., Goktsch., Borsh., Tan.

concolor Suffr. Man., Suram., Borsh., Isti-su., Migri.,Kasikp.,'Ian., Murd-tp., 'Tebul-m., 
Dartag., Lirk,, Asch-da., Chass-jrt., Tschr-j., Burtn.

virens Suffr. Suant., Mug., Anit. parvulus Müll. Lenk., Anit.

flavipes F. Borsh., Suant. ocellatus Darp. Kislj. Tan.

labiatus L. Borsh.

Moraei L. Lawaschi., Lom-mta. sexpustulatus Ross. Baku. curda Jacobs. Kasikp. elegantulus Grav. Borsh. connexus Ol. Mug,, Kasikp.

\section{Pachybrachys Suffr.}

scriptidorsum Mars. Kauk.

albicans Ws. Kasikp.

var. lugubris Ws. Kasikp.

scripticollis Fald. Arax.

glycyrrhizae 0l. Karasu., Etschm.

haliciensis Mill. Tan.

fimbriolatus Suffr. Mug., Baku.

probus Ws. Arax., Temrg.

\section{Stylosomus Suffr.}

flavus Mars. Arax.

cylindricus Mor. Mingtsch.

\section{Pachnephorus Redtb.}

tesselatus Duft. var. sabulosus Gebl. Arax. villosus Duft. N. Rossk.

\section{Adoxus Kirby.}

obscurus L. Borsh., Tan.

\section{Chloropterus Mor.}

versicolor Mor. Derb.

\section{Bedelia Lef.}

angustata Lef. Kara-su.

\section{Chrysochares Mor.}

asiatica Pall. Dshulfi., Temrg.

Chrysochus Redtb.

pretiosus F. N. Rossk.

\section{Pseadocolaspis Lap.}

rubripes Schauf. var. diversicolor Schauf. Kasikp.

\section{Colaphus Redtb.}

IIöfti Mén. Belasw., Nog. St., Mug., Tff., Azkur.

\section{Pachnephoptrus Reitt.}

Weisei Reitt. Arax.

\section{Gastroidea Hope.}

viridula Deg. Kapud., Tan., Wldk., Migri. var. cyanescens Ws. Lom-mta.

polygoni I. Mang., Kachetien., Alexp., Mingtsch., Tan.

\section{Entomoscelis Chevrl.}

adonidis Pall. Arax., Nog. St.

sacra L. Tfl., Borsh., Derb., Baku., Elsbth.

\section{Timarcha Latr.}

tenebricosa F. var iberica Mot. N. Rossk., Chass-jrt., T'schr-j.

Hummeli Fald. Kut.,Goktsch.,Borsh.,Pseasch., Saril.

var. armeniaca Fald. Suram.

Chrysomela I.

abchasica Ws. Abch.

rufa Duft. Suram.

porphyrea Fald. Abg.

caspica Ws. Circas.

Rosti Ws. Abch.

fuscicornis Ws. Circas.

Sahlbergi Mén. Baku., Lenk., Borsh., Elsbth., Ratsch.

haemoptera L. Borsh.

diluta Germ. Chosp.

goettingensis L. Saril.

limbata F. Fischt., Jewdk.

discipennis Fald. Kursch., Alag., Chosp.

lurida L. Borsh., Baku., 'I'fl., Alexp.

Reitteri Ws. Kasikp.

staphylea L. Kasb.

var. Lederi Ws. Kauk. 
eypsophilae liüst. MIugr., lielasw.

val. Incidicollis Küust. Nogr. St.

saneruinolenta I. likbth.

turanica Reitt. Arax.

armeniaca labl.

hyreana IIs. Arm.

marginata $\mathrm{I}_{\text {. }}$ Chosp., Alexp., Idsh., 'Tft.,

Weri., Sardab., Rasn., Filsbth.

analis I, Borsh., Chosp), Chews., Swnt.

moxin Kryn. Jewdk.

chalcites Germ. 'Ith., I)artag.

geminata Pk. Borsh., 'l'an.

quatrigemina Suthr. Arax.

hyperici Forst. Jorsh., Gagry.

salviae Germ. Suant., 'Trl., Lorsh.

grata Fald. Kulp.

cerealis L. Isenk., Jiaku.

coerulans Scr. var. subfastunsa Mlot. Kasikp.

var. angelica liciche. Kasb.

fastuosa Scop. Mang., Thl., Chews.

maminis I. Kislj.

menthastri Suffi. var.resulendens Suffr. Iorsh.,

Rasn., Saril., Dartag., Eriw., Isti-su., Swant., Mignri.

polita I. Kasb., Isti-su., Lenk., 'l'an.

\section{Phytodecta Kirby.}

nivosa Sufir. 'l'sk-T'sk., Swut.

\section{Phyllodecta Kirby.}

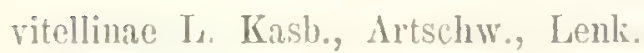

\section{Prasocuris Juatr.}

junci lirahm. Lenk., Lars, Helnd.

\section{Phaedon Latr.}

lacvigatus Duft. var. caurasicus IVs, Circas. errammicus Iuft. Kauk.

coshleariae F. I dailsch.

armoraciae $\mathrm{I}$. Eriw.

\section{Plagiodera Redtb.}

versicolora Laich. Lenk., Gagry., Kathfld.

Melasoma Steph.

vigintipunctata Scop. Borsh. populi L. Chass-jut., 'T'an., Nachtw., Kasikp., Tars-tsch., Eischm.

\section{Agelastica Redtb.}

alni L. I,enk., Sch-agtsch.

\section{Malacosoma Chevrl.}

collaris IIumm. Kasikp.

var. flaripes Heyd, $\Lambda \mathrm{rm}$.

\section{Phyllobrotica Redtb.}

clegans Kr. Ihatum., Borsh., I)artag., Tan.

\section{Luperus Geoffr.}

lividus Joann. Kasikp.

nigripes Ksw. Gudr.

orientalis l'ald. Kank.

amoenus Fali. Arax.

armeniacus. Ksw. Borsh., Elstoth., Alexp., Chass-jit,

kabardinus Ws. Kabre.

longicornis $F$. Mang., Borsh.

Koeniggi Jacobs. Kasikp.

cancasicus Ws. T'an., $\Lambda$ bst.

irritans Reitt. Arax.

\section{Lochmaea Woise.}

capreae I. var. pallidipennis Kust. Helnd., 'Tim.

crataegi Forst. Lirk.

\section{Gallerncella Crotch.}

viburni Pk. Eitschm.

lineola F. Borsh., Arax.

luteola Müll. Snmam, Balill., Aresch., l’olk.

ealmariensis Is. 'Itl., Anit.

pusilla Juft. Mesk. G.

\section{Dioxhabda Weise.}

elongata Brll. Martk.

var. sublincata Luc. Arax., Nachtw.

var. carinata Fald. Artwin.

persica Fald. Etschm., Arax.

\section{Galeruca Geoffr.}

tanaceti I. Borsh., Eisbth. 
armeniaca Ws. Jewdk.

circumdata Duft. Isti-su., Kasikp., Tschibl. var. jucunda Fald. Elsbth.

Pomonae Scop. Borsh.

orientalis Oscul. Borsh., Artschw., Kodsh., Erz-Bgl.

Rosti Ws. Circas.

\section{Sermyla Chap.}

halensis L. Kasikp., Borsh.

\section{Euluperus Weise.}

xanthopus Duft. Borsh., Kasikp., Kathfld. var. fuscipes Ws. $\Lambda \mathrm{rm}$.

\section{Podagrica Foudr.}

malvae Ill. Borsh.

saracena Reiche. Tfl.

semirufa Küst. Dartag., Eriw.

Menetriesi Fald. Kislj.

\section{Derocrepis Weise.}

serbica Kutsch. Borsh.

pubipennis Reitt. Arax.

\section{Crepidodera Chevrl.}

transversa Marsh. Kauk.

impressa F. Derb., Borsh., Eriw.

ferruginea Scop. Derb., Borsh., 'T'an.

\section{Epitrix Foudr.}

pubescens Koch. Suchum., Tfi., Lenk. var. ferruginea Ws. Lenk.

\section{Chalcoides Fondr.}

helxines L. Borsh.

var picicornis Ws. Kauk.

aurata Marsh. Suram., Lirk.

var. nigricoxis All. Kasilkp., 'Tan.

\section{Orestia Germ.}

caucasica Reitt. Mesk. G.

\section{Chaetocnema Steph.}

tibialis 11I. Tft.

breviuscula Fald. Derb. conducta Mot. Artschw.

confusa Boh. Borsh.

hortensis Fourer. Azkur.

\section{Psylliodes Latr.}

valida Ws. Circas.

attenuata Koch. Chass-jrt.

cuprea Koch. Tfl.

hyoscyami L. Kathfld.

\section{Haltica Geoffr.}

quercetorum Foudr. Anit., Lenk.

ampelophaga Guér. Saril.

tamaricis Schrk. Pseb., Helnd., Krsn-plj.

debilis Ws. Dagt.

lenkorana Ws. Arax.

globicollis Ws. Arax.

viridula Ws. Kauk.

oleracea L. Lenk, Baku., Such.,Lirk.,Lailsch.

\section{Batophila Foudr.}

aerata Marsh. Lirk., Borsh., Circas, Kathfld. var. fallax Ws. Mesk. G.

\section{Phyllotreta Foudr.}

ochripes Curt. var. caucasica Har. Arm., Lirk.

vittula Redtb. Such.

atra F. Kiptsch.

cruciferae Goeze. Azkur., Chass-jrt.

procera Redtb. Tff.

nigripes $\mathrm{F}$. 'TH.

\section{Aphthona Chevrl.}

cyparissiae Koch. Alexp.

grandis Reitt. Arm., Arax.

nigriceps Redtb. Ttt.

picipes Ws. Kauk.

pygmaea Kutsch. 'TH.

coerulea Fourcr. Lenk.

euphorbiae Schrk. Azkur., 'Temrg.

testaceicornis Ws. Circas.

Reitteri All. Lom-mta.

gracilis Fald. Borsh., Lenk., Saril.

\section{Longitarsus Latr.}

Lederi Ws. Circas. 
brunneus Duft. Saril.

suturalis Marsh. 'lemrg.

lycopi Foudr. Tal.

ochroleucus Marsh.? Chass-jrt.

pellucidus F'oudr. EIsbth.

\section{Mniophila Steph.}

muscorum Koch. Borsh., Saril. var. Wroblewskii Wank. Kauk.

\section{Hispa L.}

atra L. Kasikp.

\section{Monochirus Chap.}

inermis Zble. Arax.

\section{Cassida L.}

riridis $I_{d}$, Artschw.

canaliculata Laich. var. graminis Suffr.Circas. bella Fald. Tan, N. Rossk, Borsh.

murraea $L$. var. maculata $\mathrm{L}_{\text {. Circas. }}$

undecimnotata Gebl. Arax.

rubiginosa Müll. Isti-su, Kislj.

vilex $L$. Borsh.

ferruginea Goeze. Lenk.

deflorata Sufir. Anit.

inquinata Brll. var. depressa Suffr. Lenk., Chosp.

sanguinolenta Müll. Tan.

seraphina Mén. var. hablitziae Mot. Schuw. Borsh., Tan.

nobilis L. Borsh., Polk.

margaritacea Schall. Borsh.

saucia Ws. Arax.

Jakowleffi Reitt. Arax.

\section{FAM. COCCINELLIDAE.}

\section{Epilachna Redtb.}

Argus Fourcr. Kauk.

\section{Subcoccinella Haber.}

24-punctata L. Kasb, Eiljar., Polk.

\section{Hippodamia Mals.}

tredecimpunctata L, N. Rossk.

var. signata Fald. Tfl., Aresch., Kulp.

\section{Adonia Mnls.}

variegata Groeze. Eiljar.,Kulp., Polk., Litschm., 'Tan.

\section{Somiadalia Crotch.}

11-notata Schneid. var. 9-punctata liourcr. Kauk.

apicalis Ws. Tan.

Schneideri Ws. Mastg.

\section{Adalia Mnls.}

obliterata $I_{4}$. Tan.

bipunctata I. Lenk., Tan., Chass jirt., Polk.

\section{Coccinella L.}

septempunctata L. Mug., Lenk., Mamtl.

quinquepunctata L. Ldsh.

undecimpunctata L. Mug., Anit., Migri., Sch-agtsch.

distincta Fald. Tan.

hieroglyphica L. Urusch.

decempunctata L. 'T'an.

var. 10-pustulata L. Tan.

conglobata L. Tan.

var. impustulata L. Borsh, Ala-dagh.

14-pustulata L. Lirk., Helnk., Baku., Borsh., Tan.

sinuatomarginata Fald. Eiljar.

\section{Balaea Muls.}

Lichatschovi Humm. Tschr-j., Mingtsch., Sch-agtsch., Aresch., Elsbth., Nog. St., Kara-su., Lenk., Kulp., Mug., Artschw. var. coronata Weise. Arax.

\section{Halyzia Muls.}

sndecimguttata L. Tan.

12-guttata Poda. Tan.

14 -guttata L. Tan.

vigintiduopunctata L. Borsh., Tschtl., Mamtl.,

Eriw.

quatuordecimpunctata L. Eriw., Eiljar., Tan.,

N. Rossk., Artschw., Borsh., Lenk.

var. conglomerata F. Tan.

\section{Chilocorns Leach.}

renipustulatus Scriba. Archangelsk. 
bipustulatus L. Etschm., Borsh., Batum., 'Ian., Aresch.

\section{Exochomus Redtb.}

flavipes Thnb. Temrg., Mingtsch., Mug., Eriw., Kara-su., Etschm.

var. nigripennis Er. Arax.

pubescens Küst. Arax.

\section{Bramns Muls.}

octosignatus Gebl. Arax, Kulp.

\section{Platynaspis Redtb.}

luteorubra Goeze. Borsh.

\section{Hyperaspis Redtb.}

reppensis Hbst. var. femorata Mot. Arax.

\section{Coccidula Kug.}

scutellata Ilbst. Artschw. rufa IIbst. Mamtl.

\section{Scymnas Kug.}

haemorrhoidalis Hbst. Mamtl. subvillosus Goeze. Kara-su., Lirk. testaceus Mot. Kauk. punctillum Ws. Borsh., Lenk. rubromaculatus Goeze. Kara-su., Etschm. frontalis F. Borsh.

A petzi Muls. Saril., Eriw., Mug., Borsh., Sch-agtsch., Lenk. interruptus Goeze. Tfl.

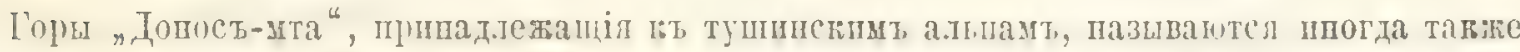

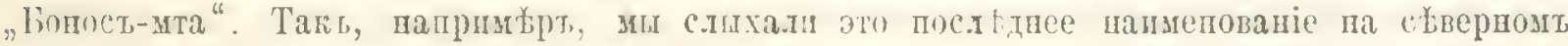
склонь, въ области пстоковъ ІШаро-Аргун.

P. K.

Das Gebirge "Donos-mta" in den Hehalpen der Tuschen wirl bisweilen auch „Bonos-mta gennant. So hörten wir den letzteren Namen an der Nordseite im Quellgebirge des Seharo- Irgunj.

IR. $K$.

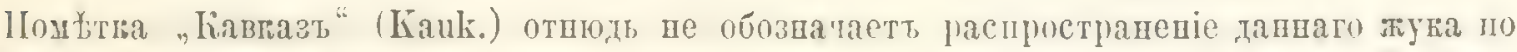

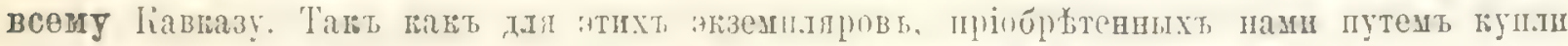

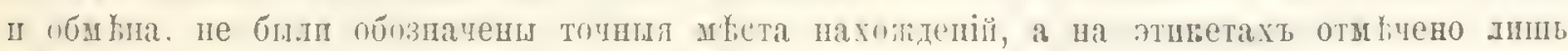
„Кавказъ“, то намъ пршшось удовлетворптьсл әтнъ общим обозначеніемъ.

P. K.

Die liezeichnung "Kaulasus" (Kauk.) soll licinesweges anzeigen, dass der betreffende Käfer überall im Kaukasus vorkommt. Da aber hei solchen Exemplaren, die wir im Tiausch mler durch Kauf erstanden kein specieller Fundort genannt war, sondern nur „Kaukasus" etiquettirt wurde, so mussten wir diese Allgemein Bezeichnung beibehalten.

R. $K$. 


\section{COLEOPTERA TRANSCASPICA.}

\section{FAM CICINDELIDAE}

'I'etracha Hope.

cuphratica Dej. var. armeniaca I)oliht. If. ghanengrenze.

Cicindela L.

decempustulata Mén. var. octusis Dohrn. Aschabad.

lischeri $\mathrm{Ad}$. var alasanica Mot. Pul-i-chatum obliquefasciata Ad. Aschabid. dignoscenda Chd. Kary-bend.

\section{FAM. CARABIDAE Calosoma Web.}

caspium Fiseh. Bagyr.

\section{Omophron Latr.}

limbatum $\mathrm{F}$. Afghanengrenze.

\section{Scarites F.}

curytus Fisch. 'Transkly. arenarius Bon. Aschabad.

bucida Pall. Aschabad.

planus Bon. Aschabad.

\section{Clivina Latr.}

ypsilon Dej. Aschabad., AIt-Nerw.

Siagona Latr.

europaea Dej. Ifghanengrenze.

\section{Anthia Chi.}

Mannerheimi Chd. Aschabad.

\section{Bembidion Latr.}

1-pustulatum Serv. Aschabar. octomaculatum Groeze. Neu-Merw.

\section{Tachys Steph.}

tetraspila Solsky. Aschabad.

fulvicollis Dej. var. caspica Kol. Aschabad.

\section{Calathus Bon.}

crratus Sahlb. 'l'ranskp.

\section{Poecilus Bon.}

liosomus Chd. Aschabad. subcocruleus Quens. Aschabad.

\section{Pterostichus Bon.}

politus Mot. Aschabad.

\section{Amara Bon.}

aenea Deg. Aschabad.

fusea Deg. Kuschk.

Schneideri P'utz. Kuschk.

abdominalis Mtot. Perewalnaja.

\section{Zabrus Clairv.}

gibbosus Mén. var. vicinus Chd. 'I'schat.

\section{Daptus Fisch.}

vittatus Fisch. Kuschk.

\section{Acinopus Latr.}

striulatus Zbk. Aschabad.

\section{Dioctes Mén.}

Lehmanni Nén. Akrobat.

concimus Dohrn. Artschman.

\section{Ophonus Steph.}

punctulatus Dej. Karybent. tataricus Mén. Afghanengrenze. var. interstitialis Reitt. Kuschk.

\section{Harpalus Latr.}

psittacus Fourer. Aschabad. tardus Pk. Perewalnaja.

\section{Stenolophus Latr.}

discophorus Fisch. Kary-bend. morio Mén. Afghanengrenze. mixtus Ilbst. Tedshen. marginatus Dej. Aschabad, Pul-i-chatum.

\section{Acupalpus Latr.}

dorsalis $\mathrm{F}$. Aschabad., Afghanengrenze. 
Chlaenius Bon.

festivus F. Aschabad.

var. vexator Reitt. Afghanengrenze.

circumscriptus Duft. Kary-bend.

\section{Lebia Latr.}

violacea Ball. Transkp.

humeralis Dej. var. lepida Brll. Hassan-kuli.

\section{Metabletus Steph.}

exclamationis Mén. Aschabad.

\section{Blechrus Mot.}

plagiatus Duft. Artschman.

\section{Glycia Chd.}

cingulata Gbl. Aschabad.

Cymindis Latr.

discoidea Dej. Perewalnaja. decora Fisch. Artschman. picta Pall. Nuchur.

\section{Brachynas Weber.}

quadripustulatus Dej. Beum-basch. cruciatus Quens. Nuchur., Tedshen.

\section{FAM. DYTISCIDAE Hygrotus Steph.}

musicus Kl. Tscherwach.

\section{Coelambus Thms.}

parallelogrammus Ahr. Neu-Merw.

\section{Bidessu8 Sharp.}

thermalis Aubé. Aschabad.

\section{Laccophilus Leach.}

interruptus $\mathrm{Pz}$. Neu-Merw.

\section{Agabus Leach.}

nebulosus Forst. Chodsha-kala., Neu-Merw.

\section{Rantus Lac.}

punctatus Foucr. Neu-Merw.
Cymatopterus Lac.

fuscus L. Neu-Merw.

\section{Cybister Curt.}

laterimarginalis Deg. Duschak., Talchatanbaba.

tripunctatus Ol. var. Gotschii Hochh. Duschak.

\section{FAM.GYRINIDAE \\ Aulonogyrus Regimb.}

concinmus Kl. Chodsha-kala.

Gyrinus Geoffr.

distinctus Aubé. Neu-Merw.

\section{FAM. HYDROPHILIDAE}

\section{Hydrous Leach.}

piceus L. var, ruticornis Deg. Neu-Merw.

\section{Hydrophilas Geoffr.}

caraboides L. 'T'edshen.

subreneus Mot. Tedshen.

\section{Phylidrus Sol.}

testaceus F. Beum-basch.

spec.? Kungruili.

\section{Laccobins Er.}

bipunctatus 'Thms. Aschabad.

\section{Acanthoberosus Kuw.}

spinosus Stev. Aschabad.

\section{Berosus Leach.}

asiaticus Kuw. Neu-Merw.

geminus Reiche. Tachta-basar.

aericeps Curt. Chodsha-kala.

\section{Sphaeridium F.}

bipustulatum F. Neu-Merw.

\section{Helophorus F.}

micans Fald. Nen-Nerw.

Erichsoni Bach. Kungruili.

granularis L. Tscherwach. 
FAM. PARNIDAE.

Dryops 01.

longus Solsky. Kary-bend.

\section{FAM. HETEROCERIDAE.}

Heterocerus F.

Ilavescens Schf. Amu-darja.

\section{FAM. STAPHYLINIDAE}

Myrmecopora Saulcy.

turanica Epp. 'Transkp.

\section{Conuras Steph.}

pubescens Pk. Molla-kary.

\section{Creophilus Mannh.}

maxillosus L. Tschikisljar.

Physetops Mannl.

tataricus Pall. Afghanengrenze.

\section{Philonthus Curt.}

punctatus Grv. Alt-Merw.

discoideus Grv. Aschabad.

dimidiatus Sahlb. Alt-Merw.

quisquiliarius Gyll. Aschabad.

var. rubidus Er. Asehabad.

salinus Ksw. Ak-dagh.

\section{Platyprosopas Mannh.}

elongatus Mannh. Aschabad.

\section{Achenium Curt.}

ustulatum Sahll. Aschabad.

\section{Prederus Grv.}

fuscipes Curt. Utsch-adshi.

\section{Blodias Mannh.}

atricapillus Germ. Aschabad., Utsch-adshi. tricornis Hbst. Adam-ilen., Amu-darja.

\section{Oxytelus Grv.}

piceus L. Aschabad.

\section{I'rogophloeus Mannh.}

politus Ksw. Aschabad.

nitidus I3audi. 'I'ranslip.

\section{FAM. PSELAPHIDAE. Pselaphoptrus Reitt.}

Kubischtecki Reitt. 'Transkp.

\section{FAM SILPHIDAE}

Necrophorus F.

humator Goeze. Aschabad.

morio Gebl. Aschahad.

antematus Reitt. Aschabad.

Psoudopelta Voot.

terminata Humm. Aschahad.

sinuata F. Aschabad.

rugiosa L. Jagly-olum.

\section{Silpha I.}

obscura I. Baggr.

FAM. SCAPHIDIIDAE

Scaphosoma Leach.

turcomanorum Reitt. Chodsha-kala.

\section{FAM. CRYPTOPHAGIDAE}

Cryptophagus Hbst.

acutangulus Gyll. Tachta basar.

\section{FAM. TRITOMIDAE. Typhaea Curt.}

fumata L. Bagyr., Aschabad.

\section{FAM. TROGOSITIDAE.} Tenebrioides Pill.

mauritanicus L. Jagly-olum.

\section{FAM: DERMESTIDAE.} Dermesteg $\mathbf{I}$.

sibiricus lir. Aschabad. 
Frischii Kug. Aschabad.

coronatus Stev. Aschabad.

cadaverinus F. Aschabad.

\section{Attagenus Latr.}

tigrinus F. var. pulcher Fald. Nurgab.

Iynx Muls. Aschabad.

Trogoderma Latr.

versicolor Crtz.? Aschabad.

nobile Reitt. Aschabad.

\section{Anthrenus Geoffr.}

pimpinellae F. Chodsha-kala.

caucasicus Reitt. Aschabad.

\section{FAM. HISTERIDAE.}

Hister $\mathbf{I}$.

gratiosus Mannh. Alt-Merw.

sinuatus Ill. Aschabad.

quadrinotatus Scrib. Aschabad.

\section{Saprinus Fr.}

semipunctatus F. Jagly-olum.

niger Mot. Beum-basch.

nitidulus Pk. Nuchur.

foveisternus Schmidt, Jagly-oIum.

\section{FAM. SCARABAEIDAE}

\section{Scarabaeus I.}

pius Ill. Aschabarl.

Typhon Fisch. Aschabad.

\section{Sisyphus Latr.}

Boschnaki Fisch. Bagyr.

\section{Gymnopleurus Ill.}

pilularius Geofir. Agamed.

cantharus Er. var. cyanescens Mot, Aschabad. flagellatus F. var. serratus Fisch. Agamed.

\section{Homalocopris Solsky.}

Tmolus Fisch. Aschabad.

\section{Copris Geoffr.}

hispanus L. Aschabad.

\section{Onitis E.}

humerosus Pall. Bagyr.

sterculus Ball. Kary-bend.

\section{Onthophagus Latr.}

Amyntas 01. Bagyr.

lineatus Reitt. Aschabad.

speculifer Solsky. Kopet dagh.

fissicornis Kryn. Bagyr.

marmoratus Mén. Bagyr.

lencomelas Solsky. Tedshen.

IIaroldi Ball. Bagyr.

\section{Caccobius Thms.}

Schreberi L. Bagyr.

\section{Oniticellus Serv.}

pallipes F. Aschabad.

\section{Aphodius Ill.}

subterraneus L. Tscherwach.

granarius L. Tscherwach., Bagyr.

brunneus Kl. Perewalnaja., Tedshen

bispinifrons Reitt. Aschabad.

punctipennis Er. Aschabad.

Kisilkumi Solsky. Alt-Merw.

albidipennis S. G. Bagyr.

melanostictus Schmidt. Alt-Merw., $\Lambda$ schabad.

tabidus Er. Aschabad.

lividus 01. Aschabad.

satellitius Hbst. Aschabad.

lividus $\mathrm{Pk}$. Aschabad.

\section{Pleurophorus Mals.}

caesus Pz. Pul-i-chatum.

variolosus Kol. Pul-i-chatum.

\section{Rhyssemus Muls.}

germanus L. Aschabad.

geminatus Reitt. Transkp.

\section{Hybosorus Muls.}

Illigeri Reiche. Aschabad.

\section{Lethras Scop.}

substriatus $\mathrm{Kr}$. Bagyr.

sulcatus Kr. Bagyr. 
Pentodon Hoppe.

bidens l'all. Chodsha-kala.

Phyllognathus Eschh.

silenus I'. Bagyr.

\section{Oryctes Ill.}

nasicornis I. Chodsha-kala.

\section{Pachydema Lap.}

tekkensis Reitt. Germab.

Walteri Reitt. Aschabad.

\section{Rhizotrogus Latr.}

spec.? Perewalnaja.

spec.? Aschabad.

\section{Polyphylla Han.}

arlspersa Mot. Aschabad.

\section{Serica M. L.}

euphorbiae Brm. 'I'schikisljar., Aschabad.

\section{Adoretus Lap.}

discolor liald. Chodsha-kala.

comptus Mén. Chodsha-kala., Tschikisljar.

validus Sem. Aschabad.

\section{Phyllopertha Kirby.}

massageta Kirsch. Aschabad.

lineolata Fisch. Beum-basch.

\section{Anisoplia Serv.}

Kocnigi Reitt. Kopet-dagh.

\section{Epicometis Brm.}

turanica Reitt. Utsch-adschi.

\section{Lencocelis Brm.}

cinctella Schaum. Chodsha-kala., 'I'schat., Aschabad.

Potosia Muls.

funebris Mén. 'T'schuli.

hungarica Ilbst. var. cirsii Mot. Chodshakala.

floricola I', var. depressiuscula Reitt. 'I'schuli.

\section{Aothiessa Brm.}

inhumata Gory. I'schikisljar.

\section{Glaphyrus Latr.}

oxypterus Pall. Aschabad.

\section{Amphicoma Latr.}

hombyliformis Pall. Chodsha-kala. vulpes I., var. Chodsha-kala., Bagyr.

\section{FAM. BUPRESTIDAE. Julodis Eschh.}

variolaris Pall. 'I'schat.

var. undulata Heyd. Aschabad. euphratica Lap. Aschabad.

\section{Psiloptera Sol.}

argentata Mannh. Chodsha-kaia.

\section{Capnodis Eschh.}

miliaris Klug. 'I'schuli.

tenebricosa Hbst. Aschabad., Tachta-basar.

\section{Cyphosoma Mannh.}

fulvovittis Reitt. Aschabad.

\section{Anthaxia Eschh.}

bicolor Fald. Transkp.

Acmaeodera Eschh.

caspica Gnglb. Murgab., Akrobat.

\section{FAM. ELATERIDAE}

\section{Aeolus Eschh.}

crucifer Rossi. Kuschk.

Ballioni Heyd. Kuschk.

sericeus Reitt, Asshabad.

\section{Drasterius Eschh.}

bimaculatus Rossi. Aschabad.

\section{Cardiophorus Eschh.}

decorus Fald. 'I'scherwach. 
Melanotus Eschh.

sobrinus Mén. Chaus-i-chan.

Trichophorus MIsls.

turanicus Reitt. Aschabad.

\section{Agriotes Eschh.}

caspicus Heyd. Aschabad.

\section{FAM. CANTHARIDAE.}

Lampyris Geoffr.

excisa Ol. Aschabad.

\section{Cantharis I.}

assimilis Pk. Chodsha-kala.

Rhagonycha Eschh.

nigritarsis Brll. Chodsha-kala.

Ebaeus Er.

tricolor Ball. Tscherwach.

\section{Anthocomus Er.}

miniatus Kolen. Chodsha-kala.

\section{Malachius F.}

aeneus I. Transkp.

turanicus Reitt. Tscherwach.

rubromarginatus Reitt. Tachta-basar.

Apalochrus Er.

flavicollis Schf. Aschabad.

\section{Dasytiscus Ksw.}

longipilis Reitt. Tscherwach, Jelotan.

\section{Microjulistus Reitt.}

fulvus Reitt. Tachta-basar.

\section{FAM. CLERIDAE.}

\section{Trichoiles Hbst.}

favarius Ill. Sumbar.

turcestanicus Kr. Beusch-berma.

\section{Necrobia Latr.}

ruffipes Deg. Aschabad.
FAM. BYRRHIDAE.

Sitodrepa Thms.

paniceum L. Tschikisljar.

\section{FAM, BOSTRYCHIDAE,}

Bostrychus Geoffr.

capucinus L. Murgab.

\section{FAM.TENEBRIONIDAE.}

\section{Zophosis Latr.}

nitida Gebl. Tscherwach.

rugosa Mén. 'Tachta-basar.

spec.? Chodsha-kala.

\section{Adesmia Fisch.}

Panderi Fisch. Geok-tepe, Chodsha-kala.

Colposcelis Lac.

longicollis Zbk. Hassan-kuli.

\section{Capnisa Lac.}

Karelini Fald. Aschabad.

Gnathosia Fisch.

nasuta Mén. Tachta-basar.

Microdera Eschh.

globulicollis Mén. 'T'schikisljar. transversicollis Reitt. Aschabad.

Tentyria Latr.

gigas Fald. Perewalnaja.

\section{Alcinoë Mén.}

helopioides Mén. Perewalnaja.

Psammocryptus Kr.

minutus Tausch. Tschikisljar.

\section{Himatismus Er。}

brevicollis Solsky. Aschabad.

\section{Oogaster Fald.}

Lehmamni Mén. Sary-jasy. 


\section{Dichillus Dnv.}

cordicollis Reitt. Geol-tepe. pusillus Mén. Perewalnaja.

\section{Cyphogenia Sol.}

aurita Mén. Kaaka., Aschabad. gibba Fisch. 'Translip.

Prosodes Eschh.

Solskyi Faust. Aschabad.

\section{Blaps F.}

'litanus Mot. Aschabad.

seriatus Fišll. Aschabad.

\section{Pimelia F.}

gigantea Fisch. Aschabad. cephalotes P'all. Aschabad.

Pachyscelis Sol. metapntapha Mén. Dusu-olum. nitidula Kr. Geok-tepe.

\section{Ocnera Fisch.}

pilicollis Fald. Durun.

Radlei Reitt. Durun.

Menetriesi Kr. Chodsha-kala.

triangularis Faust. l'erewalnaja.

\section{Sternodes Fisch.}

caspius Pall. Perewalnaja.

\section{Platyope Fisch.}

collaris Fisch. Sary-jasy.

\section{Diesia Fisch.}

sexdentata Fisch. Perewalnaja.

Lasiostola Sol.

minuta Kr. Geok-tepe., Aschabad.

Trigonoscelis Sol.

grandis Gebl. Aschabad.

pygmaea Mén. Aschabad.

Heterophylus Mals.

picipes Fald. Tschikisljar.
Gonocephalum Mals.

rusticum 01. Beum-basch. nigrum Kust. Atrek Mündung.

setulosum Fald. Aschabad.

\section{Scleropatrum Miedel.}

hirtulum Baudi. 'Tschikisljar.

\section{Ponthicus Fald.}

iner's Mén. Uassan-liuli.

punctulatus Brll. 'Tschikisljar.

\section{Anemia Lap.}

granulata Lap. Aschabad.

Fausti Ersch. Sary-jasy., Aschabad.

\section{Centorns Muls.}

procerus Muls. Adam-ilen.

filiformis Mot. Aschabad.

Hedyphanes Fisch.

Menetriesi Fald. Alt-Merw. coerulescens Fisch. Imam-baba. laticollis Mén. Aschabar.

\section{FAM. ALLECULIDAE.}

\section{Hymenalia Muls.}

basalis Faust. Aschabad.

\section{Omophlas Sol.}

hirtellus Kirsch. Chodsha-kala. plcuralis Reitt. Beum-basch. dilatatus Fald. Beum-basch.

\section{FAM. MORDELLIDAE Mordellistena Costa.}

micans Germ. Murgab.

\section{Anaspis Geoffr.}

spec.? Tachta-basar:

tenuicornis Schilky. Transkp.

\section{FAM, MELOIDAE}

\section{Cerocoma Geoffr.}

Mühlfeldi Gyll. Chodsha-kala. 


\section{Zonabris Har.}

elegantissima Zbk. Aschabad. excisofasciata Heyd. Sary-jasy. tekkensis Heyd. Aschabad. armeniaca Fald. Beum-basch. Javeti Mars, Aschabad. variabilis Pall. Aschabad. quadripunctata Billb. Beum-basch., Chodshakala.

maculata O1. Chodsha-kala.

undecimpunctata Fisch. Beum-basch.

flexuosa 01. Chodsha-kala.

Margarithae Reitt. Chodsha-kala.

cya!leovaria Reitt. Aschabad.

\section{0enas Latr.}

coccinea Mén. Tachta-basar.

\section{FAM, ANTHICIDAE. Euglenes Wstw.}

boleti Mrsh. Aschabad.

\section{Formicomus Laf.}

nobilis Fald. Sary-jasy.

\section{Anthicus Pk.}

tenellus Laf. Aschabad.

tristis Schmidt. Aschabad.

quisquilius Thms. Aschabad.

hispidus Rossi. Aschabad.

semiopacus Reitt. Aschabad.

turanus Reitt. Aschabad.

\section{Ochthenomus Schmidt.}

unifasciatus Bon. Aschabad.

\section{FAM. CURCULIONIDAE}

\section{Corigetus Desbr.}

Weisci Faust. Beum-basch.

\section{Eusomus Germ.}

piliferus Boh. Ach-dagh.

\section{Sitona Germ.}

cylindricollis Fahr. Jelotan.

\section{Tanymecus Schb.}

urbanus Gyll. Geok-tepe.

nebulosus Fahr.? Amu-darja.

cylindricollis Reitt. Kary-bend.

\section{Cleonus Schh.}

imperialis Zbk. Aschabad.

hololeucus Pall. Murgab.

strabus Gyll. Aschabad.

Faldermanni Schh. Beum-basch.

Fischeri F. Perewalnaja.

melancholicus Mén. var. subfuscus Faust. Perewalnaja.

var. innocuus Faust. Aschabad.

carinifer Schll. Geok-tepe,

punctiventris Germ var. halophilus Schh.

Aschabad.

anxius Gyll. Hassan-kuli.

confluens Fisch. Bagyr.

sulcirostris L. Aschabad.

astrabadensis Faust. Aschabad.

nomas Pall. Aschabad.

\section{Lixus F.}

circumcinctus Boh. Aschabad.

cardui 0l. Germab.

\section{Larinus Germ.}

vitellinus Gyll. Germab.

lanuginosus Faust. Transkp.

\section{Coniatus Germ.}

splendidulus F. Sary-jasy.

\section{Coeliodes Schh.}

cardui Hbst. Chodsha-kala.

\section{Baris Germ.}

sulcata Boh. Chodsha-kala.

loricata Boh. Artschman.

\section{Nanophyes Schl.}

minutissimus Tourn. 'Tscherwach.

\section{Urodon Schl.}

canus Kust. Transkp. 


\section{FAM MYLABRIDAE.}

Mylabris Geoffr.

mivacen (Ferm. 'Tachta-basar.

Spermophagus Stev.

cardui Boh. 'Tscherwach.

\section{FAM. SCOLYTIDAE Crypturgus Er.}

filum Reitt. Utsch-adshi.

\section{FAM. CERAMBYCIDAE. Polyarthron Serv.}

Komarowi Dohrn. Transkp. P'ustschewskyi Jakowl. Transkp.

\section{Plocederes Fisch.}

scapularis Fisch. Islim-tschesme.

Clythantus Thms.

Faldermani Fald. Aschabad.

\section{Agapanthia Serv.}

Dahli Richt. 'T'sechuli.

Angelicae Reitt. 'Transkp.

\section{FAM. CHRYSOMELIDAE.}

\section{Lema Lac.}

melanopa L. Aschabad.

\section{Labidostomis Jac.}

asiatica Fald. Chodsha-kala.

lucida Germ. Agamed.

\section{Tituboea Lac.}

macropus Ill Aschabad.

Clytra Laich.

maculifrons Zbk. Aschabad.

Cryptocephalus Geoffr.

rubi Mén. Chodsla-kala.

Pachnephorus Redtb.

canus Weise, Nen-Nerw.
Anidania Roitt.

rubripes Reitt. Aschabad.

Chrysochares Mor.

aenea 13all. Germab.

Colaphus Redtb.

Höfti Nén. Chodsha-kala.

\section{Entomoscelis Chevrl.}

adonidis Pall. Bagyr., Aschabad.

Chrysomela L.

cireumducta Mén. Chodsha-kala.

lurida L. Chodsha-kala.

hyreana Weise. Aschabad.

caerulans Sc. var. daghestanica Reitt. Aschabad.

menthastri Suffr. Artschman.

\section{Plagiodera Redtb.}

versicolora Laich. Transkp.

\section{Melasoma Steph.}

populi L. Aschabad.

\section{Luperus Geoffr.}

amoenus Fald. Chodsha-kala.

\section{Lochmaea Weise.}

cratacgi Forst. Chodsha-kala.

\section{Diorhabda Weise.}

persica Fald. Chodsha-kala.

Epitrix Foudr.

intermedia Foudr. Chodsha-kala.

\section{Chaetocnema Steph.}

conducta Mot. 'T'scherwach.

\section{Psylliodes Latr.}

cyanoptera Ill. Chodsha-kala.

cupreala Duft. Chodsha-kala.

\section{Haltica Geoffr.}

spec.? Chodsha-kala. 
Phyllotreta Foudr.

cruciferae Goeze. Aschabad.

\section{Longitarsus Latr.}

melanocephalus Deg. Aschabad.

\section{Cassida L.}

undecimnotata Gebl. Bagyr.

\section{FAM. COCCINELLIDAE} Anisosticta Dup.

19-punctata L. var. egena Weise.Tscherwach.
Coccinella I.

septempunctata L. Aschabad. undecimpunctata Is, Perewalnaja.

\section{Bulaea Muls.}

Lichatschovi Humm. Aschabad.

Exochomus Redtb.

pubescens Küst. Tscherwach

Brumus Muls.

octosignatus Gebl. Transkp.

Scymnus Kug.

minimus Rossi. Tscherwach. 



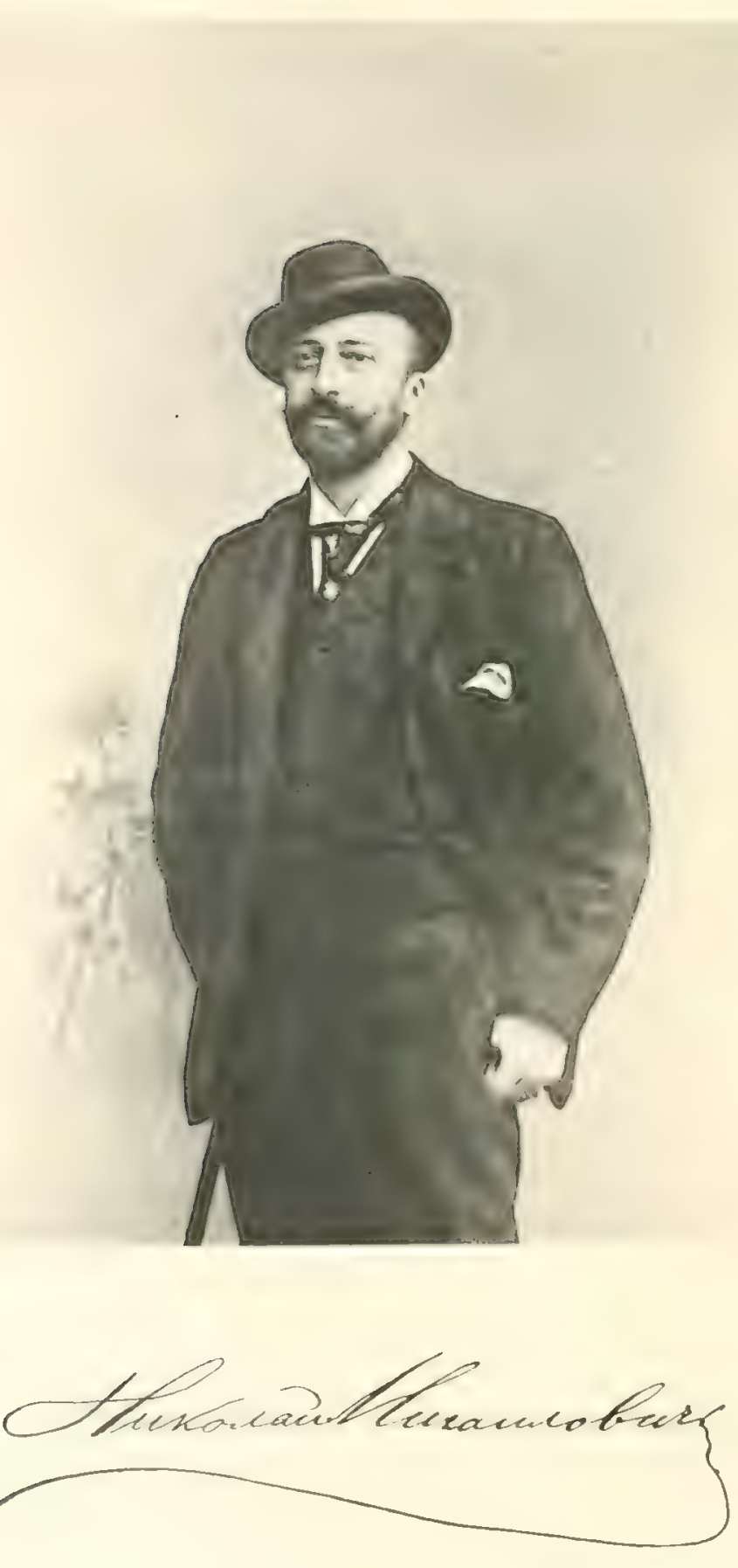




\title{
ЕГО ИМПЕРАТОРСКОМУ ВЫСОЧЕСТВУ
}

\author{
ВЕЛИІКОМУ ГНЯЗН \\ НИКОЛАЮ МИХАИЛОВИЧУ
}

IIOCBFITIAETE

вт знак' благодарности и преданності

Авторъ. 


\section{ВАШЕ ИМПЕРАТОРСКОЕ ВЫСОЧЕСТВО!}

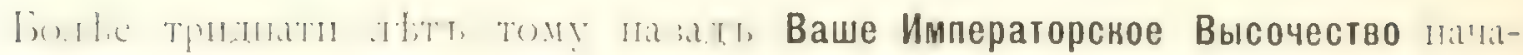

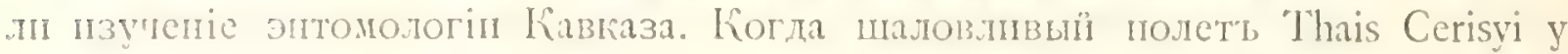
крал льспой тукайл, покрытой вессннсо зеленью, впсрвые приводиль Васъ въ радосное настроеніс, тогда же наслалденіе красотами ирироды нашло ола-

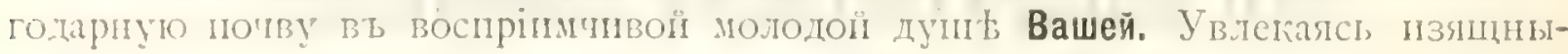
й формами пи великольпными красками бабочекь, Вы предавались серьезно-

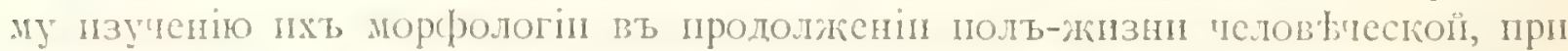
томъ жизни, не особенно благопріятствующей подоб̈нй накионости. Коллекція Ваша приндлежить кь одной пзъ самыхъ полныхт па земномт пп-

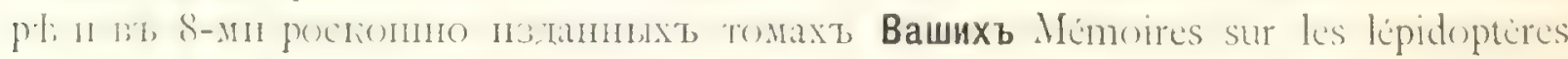

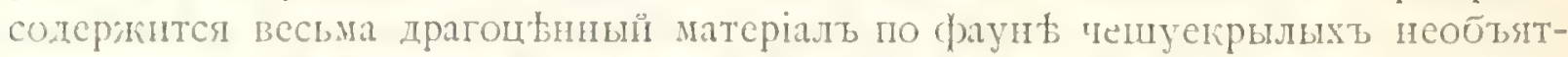
ной Россіиской Џмеріи.

Эти строги напомнять Вамь о Вашей дєятельности въ об̆асти энтомологпеской нуки въ волшео̆ныхъ Јиканахъ, когда въ лушные часы вечернихъ сумерект, многонисленные сфинксы прилеталп гъ цв бтоннымъ клумбамь, и Deilephila suellus порхаль надъ пышными цвьтами вербесни, пли когда рђдчаишій пзъ ночныхъ бражниковь, Deilephila Komarowi, становился добытею Вашей опытнои руки. Н Вы вспомните при этомъ ть темныя ночи, когда сь фонарент вь сосновомъ льсу Вы прослькивали жизнь рыдкихъ гусениць, скрыватцихся отъ дневного свђта, чтобы принести пхъ затьиъ для развода

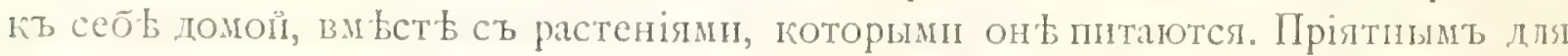
Васъ воспоминанісмъ будуть также солнечныс дни, когда на просторной пристрой

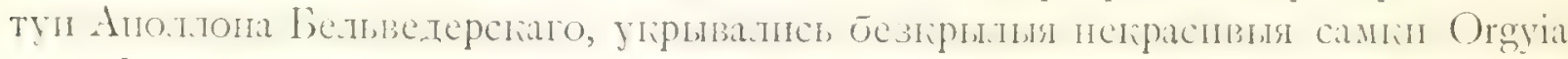
i затьмъ, гоннмыя пнстинтомь люӧви, прилетали сотнямп самцы, готорыс дьлались Вашей добычей.

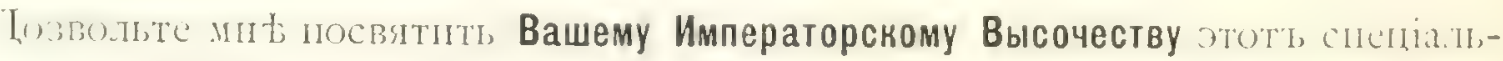

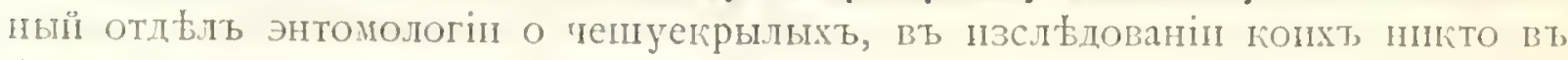
Россін ие пньеть равныхъ ст Вами заслугь.

Jучшіе Ваши сотрудники въ этой области, Сіверсъ и Христофь, поколтсл въ сырой земль у уле далеки оть всьхь житейскихъ волненій. Память о нихъ и непсчислиыя воспомннанія изъ міра легкокрылыхъ бабочекъ, среди восхитительныхь огруяающихъ видовъ Кавказской природы, павсегда оста-

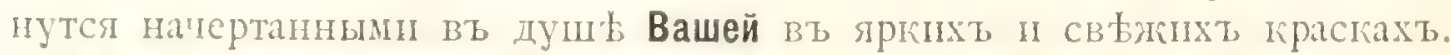

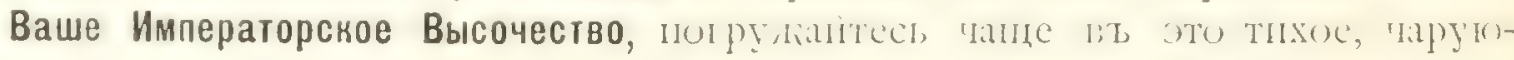
пес море, посль тялелой утомпельной работы па пользу Вашего отечества. Этого желаст, Вамь

пскренно преданый

Дрэ Г. Н. Рпәәе. 


\title{
SEINER KAISERLICHEN HOHEIT
}

\author{
D E M \\ GROSSFÜRSTEN \\ NIKOLAI MICHAILOWITSCH
}

in Dankbarkeit und Treue

der Autor. 


\section{EURE KAISERLICHE HOHEIT!}

Reichlich dreissig Jahre zurück licgt die Zeit, in welcher Sie das Studium der Entomologie im Kaukasus zu pflegen begannen. Damals, als der tändelnde Flug von Thais Cerisyi an Rande der Waldwiese im allerersten Frühlingsgrün Sie entzückte, fand die Freude an der Schönheit der Natur in Ihrer jungen Secle eine empfängliche Stitte, Sic ist darin geblieben und wurde im. Verlaufe. eines halben Menschenlebens von Ihnen sorglich gepflegt-eines Lebens, welches in seiner ausseren Gestaltung gewönhlich solcher Neigung nicht günstig ist. Aber auf ihrem speciellen Arbeitsfelde gesellte sich zu dem Genusse an den eleganten Formen und prachtvollen Farben der Schmetterlinge auch das ernste Studium ihrer Morphologie. Ihre Sammlung ist cine der Ersten auf der Frde und die acht Prachtbände der Mémoires sur les lépidoptères schliessen das kostbarste Material in Schrift und Bild über die Schmetterlingsfauna des unermesslichen Russischen Reiches in sich ein.

Mögen Sie sich in späterer Zeit bei dem Anblicke dieser Zeilen Ihrer entomologischen Thätigkeit in dem feenhaften Likani erinnern, wenn in schwüler Dämmerungsstunde dic zahlreichen Sphingiden zu den Blumen Rabatten kamen; wenn Deilephila suellus über die strotzende Blüttenfülle der Verbenen schwärmte, oder die sultenste aller Sphm. Arten Deilephila Komarowi Ihrer geschickten Itand zur Beute wurde. Auch der dunkeln Nächte gedenken Sie dann wohl, wenn mit der Laterne im Kiefernwalde den Leben seltener Raupen, die das Tageslicht scheuen, nachgespürt wurde, um sic sammt ihren Futterpflanzen für die Zucht heimzutragen. Auch der sonnigen Tage gedenken Sie dann wohl, wenn oben auf dem geräumigen Vorbau Ihres Schlösschens, nicht weit von der herrlichen Marmorstatue des belvederischen Apolloversteckt und zugedeckt das flügellose, hässliche Weibchen von Orgyia bewahrt wurde und num, - $O$ Wunder des unbegreiflichen Instinktes!-die Männchen, sonst so schwer zu funden, von allen Sciten heranflogen und die Stätte ihrer Liebe, ohne etwas zu schen, umgaukelten.

Gestutten Eure Kaiserliche Hoheit mir diesen entomologischen Abschnitt, specicl den über die Lepidoptera, Ihnen zu widmen. Niemand hat um die Erforschung dieser Branche im Russischen Reiche auch nur annähernd gleiche Verdienste, wic Sie.

Die Besten, welche Ihnen halfen, sind nicht mehr. Sievers und Christoph ruhen aus. Das Andenken an beide und unzählige Erinnerungen aus den Gebieten der leichtbeschwingten Falter in Mitten reizender Landschaften bleiben der Secle frisch und farbenreich erhalten.

Tauchen Sie oft, edler Grossfürst, in dieses ruhige, liebliche Meer, wenn die zwingende Tagesarbeit des Dienstes für Ihr Vaterland Sie ermüdet hat.-Das wünscht.

lhr getreuer

Tiflis, im Oktb. I 898.

Dr. G. Radule. 


\section{LEPIDOPTERA CAUCASICA.}

\section{FAM. PAPILIONIDAE.}

\section{Papilio L.}

podalirius L. Borsh.

machaon L. Borsh.

Thais F.

Cerisyi B. var. cancasica Ld. Lagodechi.

\section{Parnassius Latr.}

Apollo L. var. Iesebolus Nordm. Dartag., Kasikp., Latpari.

Nordmanni Nordm. Chimrik.

var. minimus Chr. Kursch.

Mnemosyne L. Dartag., Borsh.

var. nubilosus Clir, Kauk.

\section{FAM PIERIDAE}

\section{Aporia Hb.}

crataegi I. Suant. Borsh.

\section{Pieris Schrk.}

brassicae I. Tfl., Lenk.

rapae $\mathrm{L}$. Ordb.

napi L. Borsh.

ab. bryoniae O. Kauk.

callidice Esp. var. chrysidice H. S. Chodshadagh.

daplidice L. Borsh., Kasilip.

var. bellidice 0 . Ordb.

chloridice Hb. Borsh., Churjuk.

\section{Anthocharis B.}

Belia Cr. Kasikp.

var. Ausonia Hb. Ordb.

cardamines L. Borsh., Ordb.

ab. Turritis 0. Aresch.

Gruneri H. S. var. armeniaca Chr. Ordb.

Damone lieisth. Kasikp.

\section{Zegris Rbr.}

Ciupheme Esp. var. Menestho Mén. Ordb.

\section{Lencophasia Steph.}

sinapis L. Kauk. var, lathyri Hb. Kauk.

var. diniensis B: Kauk.

Colias F.

IIyale L. Borsh., Ordb. ab. sareptensis Stgr. Kauk.

Erate Esp. Borsh.

ab. pallida Stgre. Borsh.

Thisoa Mén. Kursch.

Olga Rom. Borsh.

Edusa F. Lenk., Tfl., Borsh.

ab. Helice Hb. Kauk.

Aurorina U. S. Kasilip.

chlorocoma Chr. Kasikp.

Rhodocera B.

rhamni L. Borsh.

\section{FAM. LYCAENIDAE.}

Thecla F.

spini Schiff. var. Melantho Klug. Borsh.

W. album Knoch. Borsh.

ilicis Esp. Ordb.

acaciae F. Borsh., Eriw.

Ledereri B. Tfl., Ordb.

quercus L. Kauk.

rubi L. Borsh., Mangl.

Thestor Hbst.

Romanovi Chr. Ordb.

Callimachus Ev. Ordb.

\section{Polyommatus Latr.}

virgaureae L. Kasikp.

Thetis Klug. Kasikp.

Ochimus H. S. Eriw.

Thersamon Esp. Ordb., Isti-su.

Asabinus H. S. var. Satraps Stgr. Ordb. dispar Hw. var. rutilus Wernb. Kauk.

Hippothoë L. var. Candens H. S. Dartag. Goktsch.

Alciphron Rott. var. Melibaeus Stgr. Ordb., Isti-su. 
Dorilis IIufn. Iorsh, Ondb.

Phlacas Is. Ordh.

var. liteus li. Ordb, liorsh.

\section{Lycaena $\mathbf{F}$.}

buetica L. ()rdb.

balkanica Frl. Nugl.

Argiades l'all. var. Polysperchon lierg. Borsh. truchilus lirr. Orilb.

Aegon Schn. Dartag.

Argus L. Arat.

Lnewii Z. Kasikp.

Zephyrus Friv. Orab

Eurypylus Frr. Ordb.

Baton Berg. Orilb.

Panamaea H. S. Ordb.

Orbitulus Prun. var. Mardanus. Frr. Kursuh.

Astrarche Bgstr. Borsh., 'Til.

var. aestiva Stgr. 'T'fl.

ab. Lllous Hb. Tschibl.

Anteros Frr. I'assu., Borsh.

liros O. Kursch.

Icarus Rott. Alag., Borsh., Eriw.

ab. Icarinus Scriba. Kauk.

liumedon Esp. Borsh.

Amanda Schn. Borsh.

lellargus Rott. Borsh.

Corydon Poda var. cancasica Ld. Borsh, Kasikp

Neleager Esp. var. Steveni Tr. Borsh, Kasikp.

ddmetus Esp. var. Ripartii Frr. Kauk.

I) amon Schiff. Elbr.

Damone Ev. Kauk.

Kindermanni Led. Kasikp.

var. Iphigenia II. S. Kasikp.

detis H. S. Kasikp.

Argiolus L. Borsh.

Sebrus 13. Kasikp.

minima Füssl. Elbr.

semiargus Rott. Kauk.

coelestina Ev. var. alticula Chr. Unmus.

Cyllarus Rott. Kasikp.

Alcon F. Isti-dara.

Euphemus Hb. Isti-su.

Arion L. Kasikp. val. cyanecula Liv. Kauk.

Areas liott. Kasikp.

\section{FAM. LIBYTHEIDAE.} Libythea $\mathbf{F}$.

Celtis Lsp. Borsh., Migri.

\section{FAM APATURIDAE} Apatur $\mathbf{F}$.

Ilia Schiff. var. Clytie Schiff, Borsh.

\section{FAM. NYMPHALIDAE.}

\section{Limenitis F.}

Camilla Schiff. Borsh.

Sibyllir L. IBorsh.

\section{Neptis F.}

Lucilla F. Kank.

var. Ludmilla II. S. Borsh., Dartag.

\section{Vanessa F.}

Ievana I. Kauk.

var. Prorsa L. Kauk.

Eigea Cr. Borsh.

C. album L. Aim., Borsh., 'Tan.

Polychloros L. Borsh.

Xanthomelas Esp. Borsh.

L. album Lsp. Borsh.

urticae I. Borsh.

var. turcica Stgr. Kauk.

Jo L. Lenk, Tan.

Antiopa L. Borsh.

Atalanta L. Borsh.

cardui L. Borsh., Lenk.

\section{Melitaea F}

Cinxia L. Borsh., Suant, Dartag.

Phoebe Knoch. 'Tan.

Aurinia Rott. Wardanlı., Lom-mta.

trivia Selitft. Ordb., Borsh.

didyma O. Dartaro, Borsh., Chews., Arm., Ordb.

var. caucasica Stgr. Eriw.

var. alpina Stgr. Borsh. 
dalmatina Stgre. var. Persea Koll. Dartag, Ordb.

Dictymua Esp. Borsh.

Athalia Rott. Dartag.

\section{Argynnis F.}

Euphrosyne L. Borsh., Lom-ıuta.

Pales Schiff. var. caucasica Stgr. Bakuriani, Gösäl-dara.

Dia L. Borsh.

Daphne Schiff. Borsh.

Ino Esp. Kauk.

IIecate Esp. Dartag.

Lathonia I, Tschibl., Borsh., Suant.

Alexandria Mén. Lenk.

dglaja L. Borsh., Isti-su., Churjuk., Asch-dad.

Niobe L. var. Eris Meig. Iorsh.

Idippe L. Boish.

ab. Cleodoxa O. Borsh.

Laodice Pall. Kauk.

Paphia L. Borsh., Lenk.

Pandora Schiff. Ordb.

\section{FAM. SATYRIDAE.}

\section{Melanargia Meig.}

Galathea L. Dartag., Borsh.

ab. leucomelas Esp. N. Rossk.

var. procida Hbst. 'Tan., Mang.

Larissa II. S. var. Astanda Nordm. Kasilip.

Iylata Mén. Kasikp.

Japygia Cyr. var. caucasica Nordm. Kasikp., Dartag.

\section{Erebia B.}

Medusa F. Schambobell., Isti su,, Bursh, Artwin.

var. Psodea Hb. Bursh.

Melas Hbst. var. Hewitsonii Ld. Lorsh., Artwin.

'Iyndarus Esp. var. Drgmus H. S. Elbr.

Goante Esp. Kauk.

aethiops Esp. Lom-mta., Tars-tsch., IBorsh., Golitsch.

var. Melusina H. S. Orrlb.

\section{Satyrus F.}

IIermione L. Borsh., Lom-mta.
Ciree I'. Borsh.

Briseis L. 'T'akjaltu.

ab. O Pirata Esp. Euphrat.

var. meridionalis. Stgr. TakjaItu., Kasilkp.g Bin-göll

Anthe O. Alag.

var. Hanifa Nordm. Kasikp.

Semele L. Borsh., Azkur.

Bischoffii II. S. Kasikp, 'Takjaltu.

T'elephassa IIb. Ordb., Pirogan.

Pelopea Klug. var. schahrudensis Stgr. Kauk.

var. caucasica Ld. Morsh.

var. persica Stgr. Ordb.

alpina Stgr. Kursch.

Mamurra II. S. Kasikp.

Beroë Frr. Kasikp.

Geyeri II. S. Kasikp.

Arethusa Esp. Kasikp.

Statilimus Hufn. Kasile p, Borsls, Arat.

Parisatis Koll. Migri.

Dryas Scop. Borsh.

Actaea Esp. var. amasina Stgr. Kasikp.

\section{Paragra Hb.}

Clymene Esp. Kasikp.

Maera L. var. Adrasta Dup. Borsh., Tan. var. Adrastoides Bien. Suant.

Menavi Moore. Ordb.

Megaera Is Ordb., Borsh.

Egeria L. var. Egerides Stgr. Borsh.

\section{Epinephele $\mathrm{Hb}$.}

Davendra Noore var. Comara Ld. Kauk.

Lycaon Rott. Dartag.

var. lupinus Costa. Pirogan.

Janira L. var. Hispulla Hb. 'Tan., Mug., Lenk, Suant., Borsh., 'Tit.

Hyperantlius L. Irkat.

\section{Coenopympha Hb.}

Leaniler Esp. Kasikp.

Iphis Schiff. Kasikp., Gösöl-dara.

Arcania L. Borsh.

Saadi Koll. Ordb., Dartag.

Pamphilus L. Borsh., Isti-su.

var. Lyllus Esp. Mugl. 
Iripliysa Z.

Phryne Pall. Kank.

\section{FAM. HESPERIDAE Spilothyrus Dup.}

alcene Lisp. Borsh., Lenk. var. australis Z. Dartag. althene IIb. Liriw., Ordb. var. baeticus Rbr. Kasikp. Lavaterae Esp. Borsh., Dartag.

\section{Syrichtus B.}

tessellum IIb. Ordb., Mug. cynarae Rbr. Isti-su.

Sidae Esp. I3orsh. carthami Ilb. Kauk. Aveus Hb Kasikp. serratulae Rbr. Kauk. malvae L. Borsh. phlomidis H. S. Kasikp., Isti-su. orbifer Hb. Borsh.

\section{Nisoniades Hb.}

tages L. Borsh.

Marloyi B. Ordb, Kasikp.

\section{Hesperia B.}

Thaumas Hfn. Kank. lineola O. Borsh., Isti-su. sylvanus Esp. Borsh. comma L. Borsh.

\section{Carterocephalus Ld.}

Palaemon Pall. Borsh.

\section{FAM SPHINGIDAE}

\section{Acherontia 0.}

Atropos L. TH., Borsh.

\section{Sphinx 0.}

convolvuli L. Borsh.

ligustri I. Borsh.

pinastri L. Borsh.

\section{Deilephila 0.}

vespertilio Esp. Kauk. zygophylli 0 . 'I'tl, Derb.

galii Rott. Kauk.

euphorbiae L. 'Tfl., Borsh.

ab. Paralias Nick. Kauk.

Livornica Lsp. Borsh.

Celerio I. Kauk.

Alecto Is. Helnd.

Elpenor L. Borsh.

porcellus L. Suram, Borsh., Kub.

var. suellus Stgr. Isti-su., Borsh., Artwin. nerii L. Batum.

\section{Smerinthus 0.}

tiliae L. Lagodechi.

quer us Schiff. Kauk.

Kindermanni Ld. Helnd.

ocellata L. Helnd. Borsh.

populi L. Suram, Helnd.

\section{Pterogon B.}

Proserpina Pall. Borsh. Gorgoniades Hb. Kauk.

\section{Macroglossa 0 .}

stellatarum L. Anit, 'TH. croatica Esp. TH. bombyliformis O. Borsh., Bakuriani. fuciformis L. Kauk.

\section{FAM. SESIIDAE, Trochilinm Sc.}

apiforme Cl. Kauk.

\section{Sciapteron Stgr.}

tabaniforme Rott. Kauk.

\section{Sesia F.}

conopiformis Esp. Borsh. myopaeformis Blh. Kauk. stomoxyformis Hb. Kauk. formicaeformis Esp. Kauk.

Masariformis O. var. Loewii minor Stgr. Kasilip., Isti-su.

annellata Z, var, oxybeliformis H. S. Ordb. empiformis Esp. var. schizoceriformis Kol. Borsh. 
astatiformis H. S. Kauk.

triannuliformis Frr. Kauk.

bibioniformis Esp. Ordb.

muscaeformis View. Kauk.

affinis Stgr. Kauk.

elampiformis H. S. Ordb.

\section{Paranthrene $\mathrm{Hb}$.}

tineiformis Esp, var. brosiformis $11 \mathrm{~b}$. Dartag.

\section{FAM. THYRIDIDAE}

Thyris Ill.

fenestrella Scop. Borsh., Mzhet.

\section{FAM. ZYGAENIDAE.}

Ino Leach.

ampelophaga Bayle. Derb.

pruni Schiff, Kauk.

chloros Hb. Mug.

var. sepium B. Derb.

tenuicornis Z. Kauk.

globulariae Hb. Azkur.

budensis Spr. var. volgensis Müschl. Azliur., Helnd.

statices L. Var. Mannii Ld. Borsh., Dartag. var. Heydenreichii Led. Drich.

\section{Zygaena F'.}

pilosellae Esp. Borsh., Chews.

ab. polygalae Esp. Kasikp.

lrizae Esp. Drich.

Erebus Stgr. Borsh., Lom-mta.

scabiosae Scheven. Dartag., Kursch.

Cambysea Ld. var. rosacea Rom. Kasikp.

armena Ev. Borsh., Dartag., Lom-mta.

achilleae Esp. Borsh.

ab. viciae Hb. Chews.

meliloti Esp. Kauk.

var. Stenzii Frr. Lischk., Kasikp.

trifolii Esp. Kauk.

lonicerae Esp. Dartag., Borsh.

Alpherakii Chr. Kursch.

stocchadis Blih. Borsh.

filipendulae L. Kauk. ab. cytisi Hb. Chews.

doryenii O. Borsh., Kasikp.

Cuvieri B. Kasikp.

fraxini Mén. Ochtshabert.

ab. Scovitzii Mén. Kauk.

Manlia Ld. Kauk.

Olivieri B. Kasikp., Bitschng.

carniolica Sc. Borsh.

occitania Vill. Kasilip.

spec.? Martk.

\section{FAM. SYNTOMIDAE.}

\section{Syntomis IIl.}

Phegea I. Kasikp., Mug, Lagodechi., Chews. caspica Stgr. Lenk., Derb.

\section{Naclia B.}

punctata F. Anit.

var. hyalina Frr. Derb.

\section{FM. NICTEOLIDAE. \\ Sarrothripa Gn.}

undulana Hb. ab. dilutana Hb. Lagodechi., Arm.

Earias Hb.

chlorana L. Kauk.

\section{Hylophila Hb.}

prasinana L. Kauk.

bicolorana Füssl. Kauk.

\section{FAM. LITHOSIDAE}

\section{Nola Leach.}

cucullatella I. Kauk.

centonalis Hb. Arm.

\section{Setina Schrk.}

irorella Cl. Kasikp., Chews.

var flavicans B. Borsh.

roscida Esp. Kauk.

Kuhlweini IIb, var, alpestris Z. Kauk.

mesomella L. Kauk. 


\section{Lithosia F.}

deplana Esp. Borsh.

lurideola Zinck. Kauk.

complana I. Borsh., Kodsh.

lutarella I. Bakuriani.

sororcula IIufn. Borsh., Anit.

\section{Gnophria Steph.}

quadra L. Lagodechi., Borsh.

rubricollis I. Borsh.

\section{FAM. ARCTIIDAE.}

Emydia B.

striata I. Kank

\section{Deiopeia Steph.}

pulchella I. HIelnd, Ani.

\section{Enchelia B.}

jacobaeae L. Gori., Isti-su., U-rler.

\section{Nemeophila Steph.}

russula L. Lagodechi., U-der.

plantaginis I. var. cancasica Mén. Schambobell.

\section{Callimorpha Latr.}

dominula L. var, rossica Kol. Borsh., Dartag. hera I. Borsh.

\section{Axiopoena Mén.}

Maura Eichw. Kauk.

\section{Arctia Schrk.}

caja L. Borsh.

villica $L_{\text {. }}$ Helnd., Aresch.

var. confluens Rom. Drich.

purpurata L. Tfl.

Hebe L. Lagodechi., Tff.

maculosa Gern. var. Mannerhcimi Ev. Kank.

\section{Euprepia H. S.}

livularis Menn. HeInd.

\section{Spilosoma Steph.}

fuliginosa $I_{d}$ snit. var. fervida Stgr. Helnd., Borsh.

luctifera lisp. Kank.

mendica $\mathrm{Cl}$. var, rustica Ilb. IIelnd. menthastri Esp. Borsh.

urticae Esp. Kauk.

\section{FAM. HEPIALIDAE.}

\section{Hepialus F.}

humuli L. Kauk.

sylvinus L. Kauk.

laetus Stgr. Mang.

Schamyli Chr. Lom-mta.

\section{FAM. COSSIDAE.}

\section{Cossus F.}

Cossus I. Helnd.

\section{Zeazera Latr.}

aesculi L. Lagodechi.

Phragmatoecia Newm.

castanea Hb. Helnd.

\section{Hypopta $\mathrm{Hb}$.}

Thrips. Hb. Derb.

caestrum Hb. Helnd.

Endagria B.

ulula likh. Porsh.

salicicola Fr. Helnd., Goktsch.

\section{FAM COCHLIOPODAE}

\section{Heterogenea Knoch.}

limacodes Ifn. Kauk.

asella Schiff. Lagodechi.

\section{FAM, PSYCHIDAE}

\section{Psyche Schrk.}

unicolor IIufn. Borsh.

vilosella 0 . Krauk.

lutea Stgr. var. armena Ileyl, Derb. quadrangularis Chr. Arax. plumifera O. Helnd., I'fl. 
Frnmea $\mathbf{H b}$.

pectinella F. Kauk.

\section{FAM. LIPARIDAE.}

\section{Pentophora Steph.}

morio L. var. caucasica IIeyl. Kursch.

\section{Orgyia 0.}

antiqua L. Kauk.

Christophi Alph. Borsh.

ericae Germ. Kauk.

\section{Dasychira Steph.}

fas clina T. Eibr.

\section{Lencoma Steph.}

salicis L. Erzm.

\section{Porthesia Stepl.}

chrysorrhoea I. Erzm., Alag. similis Fuessl. Borsh, Tfl.

\section{Psilura Steph.}

monacha I. Borsh.

Ocneria H. S.

dispar L. Borsh., Arm., Aresch.

\section{FAM BOMBYCIDAE.}

\section{Bombyx B.}

crataegi L. Lagodechi.

franconica Esp. Dartag., Kasikp.

castrensis L. HeInd., Tf.

var. kirghisica Stgr". Kauk.

neustria L. Helnd., Borsh.

neogena F. d. W. Kauk.

Eversmanni Ev. Helnd.

trifolii Esp. Helnd.

quereus L. Kauk.

\section{Crateronyx Dup.}

balcanica H. S. Borsh.

\section{Lasiocampa Latr.}

quercifolia L. Helnd., Aresch. tremulifolia IIb. Kauk. pini L. Kauk.

Otus Drury. Lagodechi.

\section{FAM. SATURNIDAE.}

\section{Saturnia Schrk.}

pyri Schiff. 'Tfl, Borsh. cephalariae Chr. Kasikp. pavonia L. Borsh., Azkur. caecigena Kupido. Borsh.

FAM. DREPANULIDAE. Cilix Ieach.

glaucata Sc. Borsh., Helnd.

\section{FAM. NOTODONTIDAE}

\section{Harpyia 0.}

furcula L. Lagodechi.

bifida IIb. Helnd.

interrupta Chr. Anit.

vinula $I_{\text {. }}$ Kasikp., Lagodechi.

\section{Stauropus Germ.}

fagi L. Lagodechi.

Uropus B.

ulmi Schiff. Anit., Mzhet.

\section{Notodonta 0.}

ziczac L. Kauk.

tritophus F. Kauk.

dromedarius L. Kauk.

chania Hb. Lenk.

trimacula Fsp. ab. dodonaea Hb. Lagodechi.

\section{Lophopteryx Steph.}

camelina L. Kauk.

\section{Pterostoma Germ.}

palpina L. Helnd.

\section{Drynobia Dap.}

velitaris Rott. Lagodechi.

Phalera Hb.

bucepuliala I. Borsh., N. Rossk. 
Pygaera 0.

enctula I. liorsh.

jigra IIfn. Hehd.

\section{FAM CYMATOPHORIDAE.}

\section{Gouophora Bril.}

derasa L. Lagodechi.

\section{Thyatira 0.}

batis L. Borsh.

IIedemanni Chr. Lagodechi.

Cymatophora Tr.

octogesima IHb. Ilelnd., Ordb.

or F. Lagodechi,, Borsh.

\section{FAM. NOCTUIDAE. Diloba Stepl.}

cacruleocephala L. Kauk.

\section{Simyra 0.}

dentinosa Frr. Tfl.

\section{Demas Steph.}

coryli L. Kiauk.

\section{Acroujeta 0 .}

leporina L. Kauk.

megacephala L. Kauk.

pontica Stgrr. Kauk.

psi L. Borsh.

cuspis Hb. Anit.

auricoma F. Etschm., Arm.

euphorbiae F. Lischk.

rumicis I. Borsh.

ligustri F. Lagodechi.

\section{Bryophila 'Tr.}

petricolor Ld. Helnd.

raptricula IIb. Kauk.

strigula Bkh. Kauk.

algae F. ab. calligrapha Ijkh. IBorsh.

muralis Eorst. Helnd, Areseh.

perla F. Borsh.

maeonis Ld. Jiljar.

\section{Agrotis 0.}

janthina lsp. Kauk.

linogrisea Schitr. Kauk.

timbria L. Helnd.

obscura Brahm. Pjatigorsk.

pronuba L. Kauk.

ab. inmuba Tr. Arm.

orbona llfn. Kank.

comes IIb. ab. prosequa 'l'r. Arm., Mug. baja F. Borsh.

candelarum Stgr. Kasikp.

C. nigrum L. Anit.

depuncta L. Kauk.

multangula Hb. Kauk.

rectangula $F$. var. Andereggii 15. Kauk.

luperinoides Gn. Kauk.

anachoreta II. S. Güsöl-dara.

alpestris B. Alag.

plecta L. Suant.

musiva Hb. Kauk.

flammatra F. Mug.

simulans IIfn. Kauk.

helvetina B. Kauk.

putris L. 'Ifl.

signifera F. Tfl.

improcera Ersch. Dartag.

forcipula Hb. Borsh.

squalorum Ev. Kauk.

IIahni Chr. Kank.

Raddei Chr. Ordb.

renigera $\mathrm{Hb}$. Ordb.

caucasica Stgr. Kauk.

marens Chr. Kasilip.

Kor:akowi Chr. Kauk.

exclamationis L. Borsh., Anit., Arm.

lutescens Ev. var. Romanowi Chr. Ordb.

nigricans L. Kauk.

adumbrata Ev. Kauk.

tritici I. Kauk.

var. aquilina Hb. Arat.

hilaris Frr. Kauk.

vitta Hb. Helnd.

conifera Chr. Kauk.

obelisca IIb. Helnd.

hastifera Donz. Kauk.

conspicua IIb. Borsh., Tfl. 
var. lycarum Ev. Ordb.

saucia IIb. Kauk.

ypsilon Rott. Borsh., Lenk.,

segretum Schiff. Borsh., Tfl.

corticea Hb. Dartag.

crassa Hb. Borsh.

obesa B. var. scytha Alph. Helnd.

faticida Hb. Kauk.

praecox L. Kauk.

prasina F. Kauk.

\section{Charaeas Steph.}

graminis L. var. megala Alph. Churjuck.

\section{Nenronia $\mathrm{Hb}$.}

popularis F. Kauk.

\section{Mamestra Tr.}

bombycina Ev. Ielnd.

serratilinea Tr. Balyk-gö̈ll, Golitsch, Lirzm. advena F. Kauk.

nebulosa Hufn. Borsh.

contigua Vill. Kauk.

thalassina Rott. Helnd.

brassicae L. Anit, Borsh.

persicariae L. Lagodechi.

albicolon Hb. Kauk.

oleracea L. Tfl., Anit., Borsh.

genistae Bkh. Anit.

dentina Esp. Kauk.

albipicta Chr. Eldar.

peregrina Tr. Kauk.

dianthi Tausch. Eldar., Abas-bek.

praedita Hb. Helnd., TH.

trifolii Rott. Tfl.

accurata Chr. Eiljar., Ogry-göll., Derb., Eldar.

reticulata Vill. Kauk.

chrysozona Bkh. Borsh., Tfl.

serena F. Kank.

var. leuconota Ev. Lagodechi.

cappa Hb. Kauk.

\section{Dianthoecia B.}

luteago Hb. Kauk.

var. argillacea IIb. Zarskije Kolodzy., Helnd. proxima Hb. Kauk.

caesia Bkh. Kauk.

filigrama Esp. var. xanthocyanea IHb. Kauk.

var. tephroleuca B. Helnd.

magnolii B. Borsh.

nana Rott. Kauk.

capsincola Hb. Borsh.

cucubali Fuessl. Lagodechi.

carpophaga Bkh. Irelnd.

silenes $\mathrm{Hb}$. Kauk.

irregularis Hfn. Kauk.

\section{Oncocnemis Ld.}

confusa Frr. Kauk.

\section{Episema 0.}

glaucina Esp. ab. dentimacula Ilb. Helnd., Helnk.

Lederi Chr. Helnd.

\section{Ulochlaena Ld.}

lirta IIb. Borsh.

Polia Tr.

rufocincta H. G. Kauk.

chi L. Borsh.

\section{Miselia Steph.}

oxyacanthae L. Lagodechi.

\section{Luperina B.}

matura Hfn. Kauk.

virens $L$. var. immaculata Stgr. Kasikp.

ferrago Ev. Kauk.

\section{Hadena Tr.}

zeta Tr. var, pernix H. G. Kauk.

furva Hb. Balyk-göll.

ahjecta Hb. Kauk.

lateritia Hfn. Kauk.

monoglypha Hufn. Borsh.

lithoxylea F. Borsh.

sordida Bkh. Kauk.

rurea F. Borsh.

ab. alopecurus Esp. Borsh.

didyma Esp. ab. nictitans Lsp. Kauk.

ab. leucostigma Lisp. Kauk.

strigilis Cl. Dartag., Borsh. 
Dypterygia Stepl.

scabriuscula L. Borstr.

Rhizogramma Id.

detersa Esp. Borsh.

Chloantha B.

polyodon CI. Gori.

\section{Polyphaonis B.}

sericata Esp. Borsh.

\section{Trachea Hb.}

atriplicis Is, Anit.

\section{Enplexia Steph.}

lucipara L. Kauk.

\section{Habryntis Ld.}

scita Hb. Isti-su.

\section{Brotolomia Id.}

meticulosa L. Borsh.

Mania Tr.

maura L. Borsh.

\section{Naenia Stepl.}

typica L. Kauk.

Hydroecia Gn.

nietitans Blh. Kauk.

Gortyna 0.

ochracea IIb. Kauk.

\section{Mycteroplus H. S.}

puniceago B. Kala-rlara.

\section{Tapinostola Ld.}

musculosa Hb. Kauk.

\section{Argyrospila H. S.}

succinea lisp. Kauk.

\section{Leucania 0.}

impudens IIb. Lagodechi.

pallens L. Anit.

conigera F. Borsh., Dartag.

vitellina Hb. Anit; Mug., Borsh.

L. album L. Mug.

albipuncta $\mathrm{F}$. Helnd. lithargyria lisp. Jorsh.

turea I. Kauk.

\section{Mithymna Gn.}

imbecilla F'. Dartag.

Caradrina 0.

exigua Hb. Anit., Arm.

morpheus Ilufn. Borsh.

quadripunctata F. Suant., Mug., Tfl., T'ïlgerut.

Káadenii Irrr, 'Til., Helnd

aspersa Rbr. Borsh.

superstes 'Tl. Borsh.

ambigua F. Anit.

taraxali IIb. Kank.

lenta 'Tr. Lagodechi., IIelnd.

glutcosa 'l'r. Kauk.

palustris IIb. Helnd.

Rusina B.

tenebrosa IIb. Kauk.

\section{Amphipyra 0.}

tragopoginis L。'I'fl.

tetra F. Kauk.

livida F'. Ilelnd.

pyramidea L. Borsh.

\section{Taeniocampa Gn.}

pulverulenta Esp. Kauk.

gracilis F. Kauk.

incerta Hufn. Kauk.

\section{Mesogona B.}

acetosellae F. Kauk.

\section{Hiptelia Gn.}

ochreago Hb. Kauk.

\section{Dicycla Gn.}

Oo L. ab, renago Hw. Kauk.

\section{Calymnia $\mathrm{Hb}$.}

affinis $\mathrm{I}_{\text {. }}$ Tffl.

trapezina L. Guris. 
Dyschorista Id.

fissipuncta View. Helnd.

\section{Plastensis B.}

subtusa F. Borsh.

\section{Cleoceris B.}

viminalis F. Kauk.

\section{Orthosia 0.}

circellaris Hfn. Kauk.

helvola L. Kauk.

Xanthia Tr.

flavago F. Kauk.

fulvago L. Kauk.

gilvago Esp. Borsh.

Hoporina B.

croceago F. Kauk.

\section{Orrhodia Hb.}

vaccinii L. Lagodechi.

ab. mixta Stgr. Kauk.

ligula Esp. ab. subspadicea Stgr. Kauk.

\section{Scopelosoma Curt.}

satellitia L. Kauk.

\section{Scoliopteryx Germ.}

libatrix L. Kauk.

\section{Calocampa Steph.}

exoleta L. Kasikp.

\section{Xylomiges Gn.}

conspicillaris L. Borsh.

\section{Asteroscopus B.}

sphinx Hufn. Kauk.

\section{Calophasia Steph.}

casta Bkh. Kauk.

platyptera Esp. Dartag.

Freyeri Friv. IJelnd.

lunula Hufn. Kauk.

\section{Cleophana B.}

antirrhinii $\mathrm{Hb}$. Kauk.

opposita Ld. Helnd.

\section{Cucullia Schrk.}

verbasci L. Kauk.

scrophulariae Cap. Helnd.

thapsiphaga Tr. Kauk.

umbratica L. Kauk.

lactucae Esp. Kauk.

improba Chr. Ordb.

santonici Hb. Ilelnd.

scopariae Dorfm. Kauk.

\section{Eurhipia B.}

adulatrix IIb. Borsh.

\section{Calpe B.}

capucina Esp. Kauk.

\section{Plusia 0.}

C. aureum Knoch. Kauk.

cheiranthi Tausch. Kauk.

co'sona F. Kauk.

modesta Hb. Kauk.

chrysitis L. Borsh., Pirogan.

cliryson Esp. Kauk.

bractea F. Kauk.

festucae L. Kauk.

gutta Gn. Kauk.

jota L. ab. percontationis Tr. Borsh.

gamma L. Borsh, Tfl.

circumflexa L. Kauk.

ni Hb. Isenk.

Hochenwarthi Hochenw. Kauk

Anophia Gu.

lencomelas L. Kauk.

\section{Aedia Hb.}

funesta Esp. Helnd.

\section{Heliothis 'Tr.}

ononis F. Isti-dara.

dispaceus L Arm.

scutosus Schiff. Mug.

peltiger Schiff. Borsh.

nubiger II. S. Kauk.

armiger Hb. IJelnd, Borsh.

incarnatus Frr. Kauk. 


\section{Chariclea Steph.}

delphinii L. Kauk.

tar. Darollesi Obth. Kank.

\section{Euterpia Gn.}

landeti Is. Ilelnd.

\section{Acontia 0.}

urania Friv. Kauk.

lucida IIfn. Anit.

ab. albienllis $\mathrm{F}$. Uelnd.

luctuosa kisp. Borsh.

\section{Thalpochares Id.}

areuimma Hb, var. blandula Rbr. Kauk.

Dardouini B, Kauk.

lacernaria Hb. Kank.

hansa II. S. Kauk.

respersa Hb. Kauk.

jocularis Chr. Kauk

chlorotica Ld. Kauk.

polygramma Dup. Helnd.

communimacula Hb. Kauk.

pamonica Frr. var, lenis Ev. Kauk.

purpurina Hb. Ilelnd.

ostrina Hb. var. porphyrina Fr't. Kauk.

debilis Chr. Kauk.

parva Hb. Kauk.

Wagneri II. S. Kasilip.

paula Hbst. Ordb.

griseola Ersch. Kasiki.

\section{Erastria 0.}

argentula Hbst. Anit.

obliterata Rbr. Init.

fasciana Is. Isenk.

diaphana Stgr. Ordb.

delicatula Chr. Ordb. Helnd.

\section{Photedes Iu.}

captiuncula Tr. Kauk.

\section{Prothymia $\mathrm{Hb}$.}

viridaria $\mathrm{Cl}$. Kank.

conicephala Stgr. Ordb.

Agrophila B.

trabealis Sc. Tfl, Lagodechi.
Metoponia Dup.

Koelieritziana IIb. Mug.

\section{Euclidia 0.}

glyphica L. Lenk.

munita IIb. Jeschak-tskali., Lldar.

Pericyma H. S.

albidentaria Frr. TH., Eldar.

Zethes Rbr.

insularis Rbr. Beibulag.

Acantholipes Id.

regularis IIb. Eldar., Helnd.

\section{Leucanitis Gn.}

rada B. Kank.

sesquistria Ev. Eldar., Kulp.

caucasica Kol. Helnd.

'ailino Lef. Kauk.

picta Chr. Lildar.

flexuosa Mén. Kauk.

saissani Stgr. Guris.

stolida F. T'fl.

Palpangula Stgr.

dentistrigata Stgr. Kauk.

\section{Grammodes Gn.}

bifasciata Petag. Wardanlu., Lagodechi.

algira L. Tfl., Lagodechi.

mirabilis Rom., Derb.

\section{Psendophia Gn.}

lumaris Schiff. Kauk.

\section{Catephia 0.}

alchymista Schiff. Helnd.

\section{Catocala Sohrk.}

fraxini I. Kauk.

elocata lisp. Kauk.

dilecta Ib. Kauk.

promissa Lisp. Kauk.

Iujina H. S. Helnd.

electa Bkh. Kauk. 
puerpera Giorna. Igdyr. neonympha Esp. Tơ., Aresch.

hymenaca Schiff. Guris.

conversa Esp. var. agamos IIb. Ilelnd.

nymphagoga Esp. Kauk.

\section{Spintherops B.}

spectrum Esp. TH., Mug.

var. phantasma Ev. Ordb., Nachtw.

cataphanes Hb. var. ligaminosa Fv. Nachtw.

dilucida Hb. Kauk.

\section{Exophila Gn.}

restangularis $H . G$. Kauk.

Toxocampa Gn.

craccae F. Lagodechi.

Aventia Dup.

Hexula Schiff. Anit.

\section{Boletobia B.}

fuliginaria I. Lagodechi., Borsh.

\section{Zanclognatha Id.}

tarsiplumalis Hb. Kauk.

tarsi jennalis Tr. Lenk.

tarsicrinalis Knoch. Lagodechi.

emortualis Schiff. Lagodechi.

\section{Madopa Steph.}

salicalis Schiff. Anit.

platyzona Ld. Helnd.

Herminia Latr.

tentacularia L. Kauk.

derivalis $\mathrm{Hb}$. Borsh.

Bomolocha $\mathrm{Hb}$.

opulenta Chr. Lagodechi.

\section{Hypena Tr.}

antiqualis Hb. Lagodechi.

lavalis H. S. Kauk.

ravulalis Stgr. Alasan.

revolutalis Z. Kauk.

rostrilis I. Kauk. proboscidalis L. Lenk., Kasikp., Isti-su.

munitalis Mn. Azkur.

palpalis Hb. Kauk.

obesalis Tr. Kauk.

caucasica Stgr. Kauk.

\section{Hyponodes Gn.}

costaestrigalis Steph. Arm.

Rivula Gn.

sericealis Gn. Helnd.

\section{FAM. BREPHIDAE. \\ Brephos 0.}

nothum $\mathrm{Hb}$. Lagodechi.

\section{FAM. GEOMETRID XE \\ Pseudoterpna H. S.}

pruinata Hufn. Borsh., Arm.

Geometra B.

papilionaria L. Kauk.

vernaria $\mathrm{Hb}$. Kauk.

\section{Phorodesma B.}

pustulata Hfn. Anit.

smaragdaria F. Dartag., Erzm.

var. prasinaria Ev. Kauk.

Eacrostis Hb.

herbaria Hb. Anit.

var, advolata Ev. Derb.

\section{Nemoria Hb.}

viridata L. Anit.

porrinata Z. Borsh.

pulmentaria Gn. Helnd.

strigata Muell. Borsh.

\section{Thalera Hb.}

fimbrialis Sc. Kank.

\section{Jodis $\mathrm{Hb}$.}

putata L. Anit.

lactearia L. Kauk. 
Acidalia Tr.

filacearia II. S. Mang.

trilineata Sc. Kauk.

flaveolaria IIb. Güsöl-dara.

perochraria F. Dartag.

nchrata Sc. Borsh.

rufaria IIb. Isti-su., Borsh., Etschm.

ossiculata Ld Bitschng.

sericeata Hb. Borsh.

moniliata Fi. Anit.

dimidiata IIufn. Dartag.

camparia H. S. T'tl., Ielnd.

sodaliaria II. S. Kank.

textaria Isd. Kauk.

straminata 'Tr. Lenk., Anit.

pallidata Bkh. Borsh.

subsericeata Hw. Lenk., Anit.

obsoletaria Rbr. Kauk.

bisetata IJufn. I)

trigeminata IIw. Helnd, I a godechi.

roseofasciata Chr. Kauk.

politata Hb. Iorsh.

rusticata F. Borsh.

humiliata IIufn. Isti-su.

dilutaria Hb. Anit.

holosericata Duj, Kauk.

Erschoffi Chr. Tfl.

degeneraria Hb. Lenk., Suant., Borsh.

inornata Hw. Borsh.

var. deversaria H. S. Kauk.

aversata L. Borsh., Arm.

var. spoliata Stgr. Borsh., Dartag.

immorata L. Kauk.

rubiginata Hufı. Kauk.

turbidaria II. S. Helnel.

immistaria H. S. Borsh.

Beckeraria Ld. Orilb.

marginepunctata Göze. Ordb.

luridata Z, var. romanaria Mill. Kank.

submutata Tr. Ordb.

incanata L. Kasikp.

immutata L. Kauk.

strigilaria Ub. Borsh.

flaccidaria Z. Suant.

ornata Sc. Dartag.

decorata Iskh. IJelud.

\section{Zonosoma Isd.}

porata l. Dartag., Arm.

Timandra Dup.

amata $I_{\text {do }}$ litschm., Anit.

Ochodontia Iud.

adustaria I.d. W. Tfl., Helnd.

\section{Pellonia Dup.}

vibicaria Cl. Kank.

var. strigata Stgr. Kauk.

calabraria Z/. Borsh.

auctata Stgr. Kasikp.

Sieversi Chr. Ordb.

Abraxes Leach.

pantaria L. Arm.

grossulariata L. Dartag.

sylvata Sc. Kauk.

adustata Schiff. Borsh., Dartag.

marginata L. Borsh.

\section{Orthostixis $\mathrm{Hb}$.}

cribraria Hb. Borsh.

Bapta Steph.

temerata Hb. Kauk.

\section{Stegania Dup.}

dalmataria Gn. Helnd.

Cabera Tr.

pusaria I. Isti-su., Borsh.

Ellopia Tr.

prosapiaria L. Kank.

\section{Eagonia Hb.}

quercinaria Ilufn. Bursh.

Seleuia Hb.

bilunaria Esp. var. juliaria IIw. Lagodechi. lumaria Schiff. Borsh.

var. delunaria IIb. Lagodechi.

Pericallia Steph.

syringaria L. Lagodechi. 


\section{Himera Dup.}

pennaria L. Lagodechi.

Crocallis Tr.

elinguaria L. Kauk.

\section{Eurymene Dup.}

dolabraria L Kauk.

\section{Angerona Dup.}

prunaria L. Borsh.

Urapteryx Ieach.

samlucaria L. var. persica Mén. Kauk.

\section{Rumia Dup.}

luteolata L. Kauk.

\section{Heterolocha Id.}

laminaria II. S. Dartag.

\section{Epione Dup.}

apiciaria Schift. Kauk.

paralellaria Schiff. Kauk.

\section{Canstoloma Ld.}

flavicaria IHb. Borsh.

\section{Venilia Dup.}

macularia I. Borsh.

\section{Eilicrinia $\mathrm{Hb}$.}

cordiaria Hb. Helnd.

trinotata Metzner. Kauk.

\section{Macaria Cart.}

notata L. Kank.

aestimaria $\mathrm{Hb}$. Kauk.

liturata Cl. Kauk.

Hybernia Latr.

aurantiaria Esp. Lagodechi.

marginaria Bkh. Kauk.

defoliaria Cl. Lagodechi.

\section{Anisopteryx Steph.}

aceraria Schiff. Mang. aescularia Schiff. Kauk.

\section{Biston Leach.}

zonarius Sehiff. Kauk.

stratarius Ilufn. U-der.

\section{Amphidasis Tr.}

betularius L. Helnd.

\section{Syuopsia Hb.}

sociaria Hb. Anit.

ab. unitaria Stgr. Erzm.

var. propinquaria Gn. Lagodechi.

serrularia Lv. Helnd.

var. phaeoleucaria Id. Kank.

Boarmia Tr.

gemmaria Brahm. Borsh., Anit.

umbraria $\mathrm{Hb}$. Ai-dara.

repandata L. Borsh., Goktsch., Mrm.

roboraria Schiff. Borsh.

selenaria IIb. Suant.

crepuscularia $\mathrm{Hb}$. Kank.

\section{Tephronia Hb.}

oppositaria Mn. Lenk.

sepiaria Hufn. Lagodechi.

\section{Gnophos Tr.}

Stevenaria B. Jeschak-tskali.

sartata Tr. Helnd.

obscuraria Hb. Borsh.

ab. argillacearia Stgr. Kauk.

onustaria H. S. Borsh., Isti-su.

var. serraria Gn. Lagodechi.

glaucinaria Hb. Borsh.

variegata Dup. Kauk.

Fidonia Tr.

fasciolaria Rott. var. tessularia Metzn. Kasikp.

Ematurga Ld.

atomaria L. Borsh.

var. orientaria Stgr. Borsh., Tars-tsch.

\section{Bupalus Leach.}

piniarius L. Kauk.

Selidosema Hb.

ericetaria Vill. Borsh. 


\section{Halia Dup.}

waunria I. Kauk.

\section{Diastictis $\mathbf{H b}$.}

artesiaria li. Helnd.

Phasiane Dup.

petraria llb. Artschw.

glarearia Jírahm. Lischm.

Eubolia B.

arenacearia IIb. Anit.

var. flavidaria Lw. Igdyr.

murinaria $\mathrm{F}$. Helnd.

Hopfferaria, Kauk.

\section{Scodiona B.}

belgaria Hb. Eiljar.

conspersaria I'. Karajas., llelnd.

\section{Scoria Steph.}

lineata Sc. Dartas.

Aspilates Tr.

mundataria Cr. Kauk.

acuminaria Kursch.

gilvaria $k$, Arm.

strigillaria Hb. Torsh.

\section{Eusarca H. S.}

badiaria Frr. Kursch.

cuprinaria Chr. Kauk.

\section{Gypsochroa Hb.}

renitidata Hb. Kank.

\section{Sterrha Hb.}

anthophilaria Hb. Kauk. ab. Subrosearia Stgrr. Derb.

\section{Lythria $\mathrm{Hb}$.}

purpuraria L. Eriw., Pirogan.

\section{Ortholitha $\mathrm{Hb}$.}

plumbaria F. Borsh., Arm.

Isangi Chr. Kauk.

cervinata Schiff. IIelnd.

limitata Sc. Borsh. moeniata Se. Kauk.

Alpherakii Chr. Kursch.

pimnaria Chr. Kursch.

bipunctaria Schift. Borsh.

ab. gachtaria Frr. Mang.

Mesotype Hb.

virgata Rott. Kauk.

\section{Minon B.}

murinata Se. Borsh.

var. monochraria H. S. Arm.

Stamuodes Gn.

depeculata Iol. Kodsh.

\section{Polythrena An.}

Haberhaneri Ld. Borsh.

Odezia B.

atrata L. Azkur, Dartag.

Siona Dup.

nubilaria Hb. Kank.

\section{Lithostege Hb.}

flavicornata $Z_{s}$. Helnd. griseata Schiff. Kauk. var. infuscata Ev. Kauk. duplicata Hb. Kauk. farinata IIufn. Kauk. bosporaria H. S. Tfl.

\section{Anaitis Dup.}

lithoxylata Hb. Kasikp. columbata Netzner. Asch-dad. Boisduvaliata Dup. Dartag. praeformata Ilb. 'I'tl., Lischk. plagiata L. 'Tfl., Suant, Isti-su. numidaria H. S. Kasikp. fraternata H. S. Kasikp.

\section{Cheimatobia Steph.}

brumata L. Kank.

\section{Triphosa Steph.}

taochata Ld. Azkur.

dubitata L. Borsh. 


\section{Eucosmia Steph.}

montivagata Dup. var. Iyreana Stgr. Kauk. undulata L. Kauk.

\section{Scotosia Stepl.}

vetulata Schiff. Kauk.

rhamnata Schiff. Borsh., Arm.

\section{Lygris Hb.}

prunata L. Borsh.

\section{Cidaria Tr.}

dotata L. Kauk.

fulvata Forst. Dartag.

ocellata L. Lagodechi.

variata Schiff. Borsh.

siterata Hufn. Kauk.

miata L. Arat.

truncata Hufn. Bakuriani.

olivata Bkh. Kauk.

viridaria F. Kauk.

rectifasciaria Ld. Kauk.

fluctuata I. var. acutangulata Rom. IIelnd. montanata Bkh. Dartag.

ferrugata Cl. Lagodechi.

pomoeraria Ev. Borsh.

fluviata IIb. Lenk.

dilutata Blih. Kauk.

caesiata Lang. Kauk.

verberata Scoul. Goktsch.

senectaria H. S. Kauk.

frustata Tr. Kauk.

riguata IIb. Helnd.

putridaria H. S. Helnd., Azkur.

picata Hb. Borsh.

corollaria H. S. var. unicata Gu. Helnd.

permixtaria H. S. Ordb.

cucullata Hufn. Kauk.

galiata Hb. Lenk.

rivata IIb. Borsh.

sociata Bkh. Kauk.

procellata F. Borsh.

lugubrata Hb. Kauk.

hastata L. Kauk.

tristata L. Kauk.

molluginata Hb. Kauk.

alchemillata L. Borsh. candidata Schiff. Borsh.

luteata Schiff. Kauk.

obliterata Iufn. Kauk.

bilineata L. Borsh., Anit., Mug.

sordidata F. Kauk.

silaceata Hb. var. deflavata Stgr. Kauk.

berberata Schiff. Kauk.

nigrofasciaria Goeze. Kauk.

rubidata F. Helnd.

polygrammata Bkh. Anit.

corticata Tr. Tars-tscli.

\section{Eupithecia Curt.}

oblongata Thub. Anit.

breviculata Donz. Anit.

glaucomictata Mn. Helnd.

venosata F. Kauk.

subnotata Hb. Kauk.

pusillata F. Kauk.

coronata Hb. Kauk.

rectangulata L. Kauk.

scabiosata Bkh. Kauk.

denticulata Tr. Kauk.

succenturiata L. Kauk.

subfulvata Hw. ab. oxydata Tr. Kasikp.

variostrigata Alph. Helnd.

innotata Hufn. Helnd.

fraxinata Crewe. Helnd.

graphata Tr. Lischk., Lagodechi.

scriptaria H. S. Kauk.

multilineata Mn. Helnd.

ultimaria B. Ordb., Eldar.

isogrammaria II. S. Kauk.

tenuiata Hb. Kauk.

plumbeolata Hw. Kauk.

castigata $\mathrm{Hb}$. Arat.

albipunctata Hw. Kauk.

assimilata Gn. Kauk.

lariciata Frr. Kauk.

oxycedrata Rbr. var, adscriptaria Ld. Arat.

pumilata Hb. Arat.

\section{FAM PYRALIDIDAE. \\ Cledeobia Dup.}

moldavica Esp. Tfl.

bombycalis Schiff. 'Tf. 
rar. provincialis J)up. 'Tars-tsch. consecratalis Lde. Kauk.

armenialis Iıl. Kauk.

comectalis IIb. Isti-su., Borsh.

brumealis 'I'r. Lagodechi.

infumatalis Ersch. Kank.

Stemmatophora GH.

obsoletalis Mn. Orill.

\section{Hypotia Z.}

massilialis I)ur. Ifelnd.

colchicalis 11. S. Anit.

proximalis Chr. Ilelnd.

\section{Aglossa Latr.}

pinguinalis L. Helnd., 'T't.

cuprealis 11b. Ordb.

\section{Asopia 'l'x.}

rubidalis Schift. Borsh.

glancinalis L. Isenk, $\mathrm{Arm}$.

costalis H. Lenk, Suant, Gösöl-dara.

farinalis L. Ordb., Lenk.

perversalis H. S. Kauk.

\section{Endotricha Z.}

flammealis Schiff. Kasikp.

\section{Talis Gn.}

quereella Schiff. Derb.

\section{Scoparia Hw.}

centuriella Schiff. Kauk.

absconditalis Chr. Kauk.

incertalis Dup. Ordb., Borsh.

ambigualis 'Tr. Kauk.

ingratella Z. Kauk.

dubitalis IIb. Kank.

Standingeralis Mab. Ordb.

sudetica Z. Kauk.

murana Curt. Borsh.

truncicolella Stt. Kauk.

crataegella IIb. Horsh.

\section{Aporodes Gn.}

floralis HIb. Igdyr.

rar. stygialis 'l'r. Arm.

\section{Heliothela Gn.}

atralis Hlb. lorsh.

\section{Noctuomorpha Gin.}

nolmalis IHB. Kauk.

renustalis Ld. Borsh.

\section{Thronodes Gn.}

pollinalis Schift, Kauk. cacuminalis Liv. Kank.

\section{Hercyna 'I'r.}

sericatalis II. S. Kauk.

Schrankiana Hochenw. Kank.

phrygrialis IIb. Kauk.

\section{Noctuelia Gn.}

superba Frr. Ordb, Lischk.

plebejalis Chr. Lischk.

vespertalis H. S. Kank.

\section{Ephelis Id.}

cruentalis HIb. 'I'atif.'

\section{Phlyctaenodes Gn.}

pustulalis IIb. IJelnd.

\section{Odontia Dup.}

dentalis Schiff. Borsh., IIelnd.

\section{Emprepes Ld.}

pentodontalis Ersch. Kank.

\section{Anthophilodes Gn.}

lepidalis H. S. Ordb.

Ioeschleri Chr. Igdir.

baphialis Ld. Eldar.

concinnalis Chr. Ordb.

Tegostoma Z.

comparalis Hb. Ordb.

Aeschremon Lid.

disparalis H. S. Ordb.

\section{Snellenia Stgr.}

monialis Erseh. Orib. 


\section{Eurrliypara Hb.}

urticata I. Mang.

\section{Botys Tr.}

octomaculata F. Kank.

cingulata L. Helnd.

aurata Sc. Mang., Borsh., Helnd.

purpuralis L. Mang., Ordb., Helnd.

var. chermesinalis Gn. Kauk.

var. ostrinalis Hb. Kank.

sanguinalis L. Helnd., Eldar.

var. auroralis Z. Kank.

castalis Tr. Ordb.

dulcinalis Tr. Helnd.

cespitalis Schiff. Borsh.

limbopunctalis H, S. var. frustalis II. S. Borsh. acrealis $\mathrm{Hb}$. var. ablutalis Ev. Isti-su, Dartag.

var. opacalis IIb. Kursch.

austriacalis II. S. Gösöl-dara.

polygonalis Hb. var. meridionalis Stgr. Ordb., Tff.

trinalis Schiff. Tars-tsch.

amasialis Stgr. Ordb.

fluvalis Schiff. Borsh., Helnd.

var. lutealis Dup. Ordb.

hyalinalis Hb. Mang.

cultralis Stgr. Kasikp,, Lagodechi.

repandalis Schiff. Ordb.

subsequalis II. S. Kasikp.

nubilalis Hb. IIelnd., Lagodechi.

praepetalis Ld. Kasikp.

rupicapralis Ld. var. daghestanica Chr. Derb.

fuscalis Schiff. Kauk.

terrealis Tr. Ifelnd.

diffusalis Gn. Ordib.

sambucalis Schiff. Kauk.

verbascalis Schiff. Helnt.

rubiginalis Hb. Borsh.

languidalis Ev. Kauk.

perochrealis Chr. Kasikp.

prunalis Schiff. Kauk.

olivalis Schiff. Bakuriani.

ochrofascialis Chr. Ordb.

ustrinalis Chr. Schirnki., Eldar., Kars.

confinalis Ld. var. graecalis Stgr. Kasilip. ruralis Si. Lenk.

\section{Eurycreon Ld.}

nudalis Hb. Iffl., IIelnd.

sticticalis L. Tfl., Poti.

mucosalis II. S. Eldar.

clathralis Hb. Kauk.

sulphuralis Hb. Eldar.

palealis Schiff. Kauk.

verticalis L. Borsh.

\section{Nomophila Hb.}

noctuella IIb. Borsh., Helnd., Dartag., Anit.

\section{Psamotis $\mathrm{Hb}$.}

pulveralis Hb. var. grisealis Stgr. Kauk.

\section{Pionea Gn.}

forficalis L. Tfl, Lagodechi.

\section{Orobena Gn.}

aenealis Schiff. Kauk.

subfuscalis Stgr. Ordb.

nomadalis Ld. Karabagh.

extimalis Sc. Lagodechi.

limbata L. Kauk.

politalis F. Ḱauk.

sophialis F. Kauk.

helenalis Stgr. Kauk.

frumentalis I. Helnd.

umbrosalis F. R. Kursch.

desertalis Hb. Ordb., Helnd.

manglisalis Ersch. Kauk.

Calamochrous Id.

acutellus Ev. Kauk.

\section{Perinephele Hb.}

lancealis Schiff. Kauk.

\section{Cybalomia Ld.}

pentadalis Ld. Ordb.

\section{Metasia Gu.}

suppandalis Hb. Znori.

\section{Stenia Gn.}

Iruguieralis Dup. Ordb.

intervacatalis Chr. Ordb., Lagodechi.

punctalis Schiff. Derb., EIdar., IJelnd. 
Amaurophanos Li.

stigmosalis II. S. Kauk.

Enclasta Ld.

splendidalis IT. S. Jeschak-tskali.

Agrotera Schrk.

nemoralis Sc. Lagodechi.

Hydrocampa Gn.

nymphaeata L. Anit.

Parapoynx Hb.

stratiotata Is. Kauk.

Cataclysta $\mathrm{Hb}$.

lemmata L. Lirk, Suant.

\section{FAM. CHILONIDAE}

\section{Scirpophaga Tr.}

praclata Sc. Anit.

\section{Schoonobius Dup.}

gigantellus Schiff. Anit.

Alpherakii Stgr. Jeschak-tskali.

\section{Chilo Zk.}

phragmitellus IIb. Lenk.

concolorellus Chr. Lagodechi.

\section{FAM CRAMBIDAE.}

\section{Calamotropha Z}

paludella IIb. Kauk.

\section{Ancylolomia $\mathrm{Hb}$.}

palpella Sehiff. Tft.

\section{Crambus F.}

carectellus $Z$. Eldar.

cerusellus Schiff. Arm.

pascuellus L. Lagodechi., Isti-su.

pritellus L. Kauk.

hortuellus IIb. Kasikp.

craterellus Sc. Suant.

var. cassentiniellus $Z$. Borsh., IIelnd.

chrysonuchellus Sc. Ordb., Borsh., Karskijekolodsy. fitsellus Schift. Kauk.

incertellus II. S. Lagolechi., Borsh.

pinellus L. Mang, Horsh.

colchicellus Ld. Borsh.

jucundellus II. S. Eiljar., Rubas.

profluxellus Chr. Kauk.

culmellus L. Kasikp.

saxonellus 'Zk. Kauk.

inquinatellus Schiff. Kiauk.

contaminellus IIb. Lenk.

deliellus IIb. Kasikp.

tristellus E. Borsh., Bakuriani.

luteellus Schiff. Borsh,, Dartag., Kasikp.

lithargyrellus Hb. Kauk.

laevigatellus Ld. Kasikp.

perlellus Se. Kasikp., Goktsch.

var. Warringtonellus Stt. Gösül-dara.

languidellus Z. Kauk.

\section{Eromene Hb.}

bella IIb. 'Tff.

Ramburiella Dup. Kauk.

var. Jaxartella Eirsch. Kauk.

superbella Z. Kasikp., Ordb., Lagodechi. ocellea Iw. Eldar., Helnd., Dartag.

\section{FAM PHYCIDEAE}

\section{Nephopteryx Z.}

I)ahliella Z. Isti-su.

janthinella IIb. Kasikp., Arat.

\section{Pempelia $\mathrm{Hb}$.}

semirubella Sc. Anit, Asch-lad., Lenk. formosa Ilw. Anit.

allornatella Tr. Borsh.

\section{Eucarphia Hb.}

antiquella H. S. Bitschng.

Catastia $\mathbf{H b}$.

marginea Schiff. Asch-dad.

\section{Myelois Schiff.}

cribrum Schiff. Lenk., Anit. flaviciliella II. S. Dartag. crudella Z. Azkur. 
xylinella Stgr. Kauk.

rosella Sc. Kauk.

\section{Ancylosis Z.}

morbosella Stgrr. Arm.

\section{Nyctegretis Z.}

achatinella II. S. Mug., Tfl., Borsh.

\section{Zophodia $\mathbf{H b}$.}

neglectella Hein. Igdyr.

\section{Homoeosoma Curt.}

nebulea Hb. Borsh., Tschibl.

Anerastia Hb.

lotella Hb. Kasikp.

Ephestia Gn.

elutella IIb. Kauk.

guidiella Mill. Kauk.

\section{FAM. GALLERIAE. Galleria F.}

melonella L. U-der.

\section{Aphomia Hb.}

sociella L. Kauk.

\section{Melissoblaptes Z.}

bipunctanus Curt. Mug., Lenk. anellus Schiff. Borsh., Suant.

\section{FAM. TORTRICIDAE.}

\section{Teras Tr.}

variegana Schiff. Lenk.

aspersana Hb. Kasikp.

\section{Tortrix L.}

rosana L. Kauk.

chondrillana H. S. Igdyr.

musculana Hb. Borsh.

dumetana Tr. Lenk.

diversana Hb. Kauk.

viburniana F. Kauk.

Steinerniana Hb. Borsh.

viridana I. Kauk.

Grotiana F. Borsh.

\section{Sciaphila Tr.}

Wahlbomiana I. Kauk.

Cochylis Tr.

hamana I. Borsh.

zoegana L. Kasikp.

margaritana $\mathrm{Hb}$. Isti-su.

zephyrana Tr. Kauk.

\section{Penthina Tr.}

variegana Hb. Kauk.

ochrolencana Hb. Borsh.

pruniana Hb. Anit.

arcuella Cl. Kauk.

deletana Stgr. Dartag.

urticana IIb. Kauk.

lacunana Dup. Kauk.

achatana F. Kauk.

\section{Aphelia Steph.}

lanceolana IIb. Asch-dad.

lamana Z. Kasikp.

Grapholitha Tr.

cynosbana F. Isti-su.

citrana Hb. Isti-su., Mug.

solandrana L. Anit.

modicana Z. Kasikp.

coagulana Z. 'Tschibl.

expallidana Hw. Kasikp.

conterminana H. S. Kauk.

tenebrosana Dup. Kauk.

Carpocapsa Tr.

pomonella L. Arm.

grossana Hw. Borsh.

Phthoroblastis Ld.

spiniana Dup. Kauk.

Dichrorampha Gu.

ligulana H. S. Isti-su.

\section{FAM CHOREUTIDAE Chorentis Hb.}

Bjerkandrella Thnb. var. pretiosana Dup. Kasilip.

Myllerana F. Arm. 
Simaethis Leach.

pariana Cl. Golitsch.

\section{FAM. TINEIDAE. Hapsifera Z.}

luridella \%. Mug.

\section{Enplocamus Latr.}

anthracinalis Sc. Borsh.

\section{Scardia Tr.}

boleti I. Arm.

\section{Tinea Z.}

fascipunctella Hw. T'schibl.

tapetzella L. Kank.

granella L. var. Kauk.

Myrmecocela Z.

danubiella Mn. Kank.

Inenrvaria $\mathrm{Hw}$.

muscalella F. Kank.

\section{FAM. ADELIDAE.}

\section{Adela Latr.}

Degeerella L. Dartag.

cuprella 'Thmb.? Kauk.

\section{Nemotois $\mathrm{Hb}$.}

metallicus Poda. Dartag.

Pfeifferellus Hb. Isti-su., Tars-tsch.

violellus L. Kank.

\section{FAM. HYPONOMEUTIDĀE.}

\section{Hyponomenta $\mathrm{L}$.}

cvonsmellus I. Arm.

padellus L. Etschim.

Argyresthja Hb.

mendica Hw. Kauk.

\section{FAM, PLUTELIIDAE,}

\section{Plutella Schrk.}

xylostella Is. Isenk.
Cerostoma Latr.

radiatella Don. Mang.

\section{FAM GEIECHIDAE}

Psocadia Hb.

pusiella lioem. Arm.

bipunctella F. Isti-su.

\section{Depressaria Hw.}

pallorella Z. Nug.

costosa IIw. Kauk.

arenella Schiff. Mang.

applana F. var.? Mang.

\section{Gelechia Z.}

cytisella 'I'r. Kauk.

Teleia Hein.

humeralis 7. Kauk.

\section{Parasia Dup.}

lappella L. Kauk.

neuroptella Z. Kauk.

\section{Brachycrossata Hein.}

cinerella $\mathrm{Cl}$. Kauk.

\section{Enteles Hein.}

Kollarella Costa. Kauk.

Ypsolophus F.

fasciellus Hb. Borsh.

Plenrota $\mathrm{Hb}$.

aristella L. Kasikp.

metricella \%. Kauk.

\section{0ecophora Z.}

Heringi Ld. Lenk.

Pokornyi Nick. Borsh.

\section{0egoconia Latr.}

quadripuncta Hw. Erzm.

FAM. COLEOPHORIDAE.

Coleophora Z.

lixella Z. Dartag. 
palliatella Zk. Kauk.

vibiciella $\mathrm{Hb}$. Gori.

\section{Laverna Curt.}

subbistrigella $\mathrm{Hw}$.

\section{FAM ELACHISTIDAE.}

Butalis Tr.

seliniella Z.? Dartag.

\section{Endrosis Kb.}

lacteella Schiff. Mang.

\section{Heliodines Latr.}

roesella L. Borsh.

Elachista St.

festucicolella Z. Kank.

\section{Micropteryx $\mathbf{B b}$.}

Paykullella F. Borsh.
FAM. PTEROPHORINA.

Platyptilia $\mathrm{Hb}$.

Metzneri Z. Kank.

\section{Oxyptilus Z.}

pilosellae Z. Kasikp.

\section{Mimaeseoptilus Wallgr.}

pterodactylus L. Anit, Asch-da.

Leioptilus Wallgx.

tephrodactylus $\mathrm{Hb}$. Kauk.

\section{Pterophorus Wallgr.}

monodactylus L. Borsh.

Aciptilia $\mathrm{Hb}$.

pentadactylus L. Lenk.

\section{Alucita Z.}

Huibneri Wallgr. Mang.

\section{HYMENOPTERA CAUCASICA.}

FAM, TENTHREDINIDAE. Pamphilius Knw.

Lethierryi Knw. Tan.

\section{Megalodontus Latr.}

flavicornis Klg. Derb.

laticeps Knw. Gunib.

\section{Cephas Latr.}

Parreyssi Spin. Derb., Tf.

pygmaeus L. Tf.

\section{Xiphydria Latr.}

picta linw. U-der.

\section{Sirex I.}

spectrum Is T'Tan.

juveneus L, N. Rossk. carinthiacus Knw. 'Iffl

gigas L. T'an.

\section{Oryssas F.}

abietinus Scop. Mang.

\section{Arge Schrank.}

coeruleipennis Retz. 'Tfl.

berberilis Schrk. 'Tan., Kub.

enodis L. 'I'an.

thoracica Spin. Tft.

ustulata L. Tan.

ustipennis Knw, Tan.

segmentaria Pz. Pseb.

melanochroa Gmel. Dagt.

cyanocrocea Först. Kas-knt, Lom-mta.

var. syriaca Mocs. Derb., Borsh., I

simulatrix Kuw. Liljar.

rosae Deg. Tfl, Kasikp., kilb., Derb., Kúb. 


\section{Cyphona DhIb.}

furcata Vill. 'T'an.

\section{Cladius Ill.}

pectinicornis Fourer. Kasikp.

Iygaeonematus Knw.

spec. ? Kasikp.

\section{Hoplocampa Htg.}

crataegi Klg. Mang.

\section{Tomostethus $\mathrm{KnW}$.}

ephippium $\mathrm{Pz}$. var, nigrans Knw. Polk., Borsh.

\section{Monophadnus Htg.}

ruficruris Isrll. var. l'olk.

\section{Athalia Leach.}

glabricollis Thms. Derb., Mang., 'T'tl.

rufoscutellata Mocs. TH.

var. obscurata Knw. 'Iti.

var. nigroscutellata Knw. Borsh.

spinarum $\mathrm{F}$. Derb, N. Rossk.

rosae L. var. cordata Lep. Polk., Nang., Tfl., Borsh.

var. liberta Klg. Kasikp.

annulata F'. Polk., 'Tfl.

\section{Selandria Klg.}

coronata KK. Tg. Tan.

\section{Poecilosoma Thms.}

luteola Klg. T't., N. Rossk.

\section{Dolerus Jur.}

pratensis Fall. Artwin., Aresch.

gonager F. Mang., Derb., l'olk., 'I'fl.

ciliatus Knw. Mang., Mksf.

\section{Rhogogastera Knw.}

picta Klg. Tan.

viridis L. Tan.

\section{Tenthredopsis Costa.}

'l'homsoni Knw. 'T'an.

var, nigripes $\mathrm{Knw}$. 'Tan.

Raddatri Knw. 'T'an. var. inornata Knw. 'Tan, Lom-mta.

sentellaris Pz. 'T'an.

\section{Pachyprotasis Htg.}

rapae L. 'T'an.

\section{Macropliya Dhlbm.}

rustica Is. Tan.

erythropus Bril. 'Tan., Azkur., Kasikp.

rubripes André. 'I'an., Such.-Ft.

quadrimaculata F. 'Tan.

var. tarsata Pz. 'I'an.

abicincta Schrk. Derb.

var. decipiens Knw. 'T'an.

12-punctata L. Borsh.

blanda F. Tan.j Aresch.

\section{Allantus Jur.}

annulatus Klg. Tan., Azkur.

vestitus André. 'Tan., Derb., Mang., Lom-mta.

temulus Scop. Tan.

luteipennis Ev. 'Tan., Lom-mta.

caucasicus Ev. Pari., Lom-mta.

violascens Knw. Suant., 'l'an.

costatus Klg. Azkur., Derb., Tan.

viduus Rossi. Derb.

vespa Retz, Kauk.

distinguendus St. Borsh.

fasciatus Scop. Mang., 'Tan.

Koehleri K.lg. Kub.

Lederi Knw. Lom-mta.

brevicornis Knw. Lom-mta.

arcuatus Forst. Lom-mta., Kasikp.

var. nitidior Knw. Lom-mta.

nigritarsis Knw. Derb.

parviceps Knw. Lom-mta.

lituratus Mocs. Tan., Lom-mta.

\section{Tenthredo $T_{\text {J }}$}

Koenigi Knw. Tan.

caligator Ev. Tan., Mang., Lom-mta.

discophora Knw. Zch-zch.

var. pullata Knw. Lom-mita.

FAM. BRACONIDAE. Earinus Wesm.

nitidulus Nees. Mang. 


\section{FAM. CHALCIDIDAE}

\section{Perilampus Latr.}

splendidus Dalm. Tfl.

\section{Eucharis Latr.}

adscendens Latr. Kasikp.

\section{Stilbala Spin.}

cynipiformis Latr. Derb.

\section{Leucospis $\mathbf{F}$.}

intermedia Ill. Kasikp.

spec.? Elbr.

\section{FAM. CHRYSIDIDAE}

\section{Ellampus Spin.}

auratus L. Derb., TH.

var. virescens Mocs. 'I'fl.

Bogdanovii Rad. Tft.

spina Lep. Derb.

\section{Holopyga Dahlb.}

amoenula Dahlb. U-der.

gloriosa F. Kasikp.

rosea Rossi. Kasikp.

\section{Hedychrum Latr.}

nobile Scop. Kub., N. Rossk., Kasikp.

\section{Stilbum Spin.}

cyanurum Forst. var, nobile Sulz. Ilelnk.

\section{Chrysis L.}

Chevrieri Mocs. Kauk.

var. orientalis Mocs. Kauk.

cuprea Rossi. Derb.

dichroa Dahlb, var. minor Mocs. Derb., 'Tfl. ignita L. U-der., Kub., Pseb., Borsh., Kasikp. indigotea Duf. U-der.

purpurata F.? Derb.

pustulosa Ab. Tht.

pyrocoelia Mocs. Lom-mta.

sexdentata Christ. Derb.

viridula L. var. cingulicornis Först. Derb., Eiljar.
Parnopes Latr.

grandior Pall. var. caspicus Mocs. Derb.

FAM. MUTILLIDAE,

Apterogyna Latr.

spec.? Kulp.

spes.? Kulp.

\section{Mutilla I.}

brutia Pet. Kulp., Kasikp.

ceplatica Rad. Kub.

continua F. Eiljar.

cormuta 01. N. Rossk

europaea L. Artwin.

littoralis Pet. Artwin., Kasikp.

maura L. N. Rossk., Kasikp

montana Pz. Kub.

tumensis F. Aresch.

spec.? Kasikp.

viduata Pall. Aresch.

\section{FAM. SCOLIIDAE,}

\section{Myzine Latr.}

spec. ? Kulp., Kasikp.

spec.? Kulp.

\section{Scolia F.}

hirta Schrk. Kasikp., Borsh., Kub. quadripunctata F. Kub.

\section{FAM. SAPYGIDAE.}

Sapyga Latr.

spec.? Kasikp.

\section{FAM. POMPILIDAE}

\section{Salius F.}

discolor F. Kasikp.

vulneratus Costa. Borsh.

\section{Pompilus F.}

dispar Dahlb. Kasikp.

fumipennis 'Lett. Kasikp.

samariensis Pall. Kasikp.

sanguinolentus F. Kub. 
Ceropales Inatr.

maculatus $\mathrm{k}$. Kulu.

\section{FAM.CRABRONIDAE}

\section{Diodontus Curt.}

minutus Ir. Kub.

\section{Sceliphron Klug.}

destillatorius 111. Kub.

\section{Ammophila KIrby.}

aftinis Kiby. Kub.

campestris Latr. Kub.

sabulosa I. Kub.

\section{Sphex I.}

maxillosus Fb. Küb.

Inesaryi Kohl. var. nudatus Kohl. Kasikp, subfuscatus Dhlb. Kasikp., N. Rossli.

\section{Cerceris Latr.}

quinquefasciata Rossi. Kasilip., Kub. Rybiensis L. U-der.

\section{Bembex $F$.}

bicolor Rad. Kasikp.

bidentata Lind. Kasikp.

pallida Rad. Kasikp.

rostrita L. Kub.

\section{Crabro F.}

alatus P'z. Kub.

quadricinctus F. Borsh.

vagus L. U-der.

\section{0xybelas Latr.}

miglunis L. Kub.

\section{FAM VESPIDAE}

\section{Ceramius Latr.}

Fonscolombei Latr. Kasikp.

Celonites Latr.

abbreviatus Vill. Kash.

\section{Eumenes Latr.}

coarcetata Id, Kub.

unguiculata Vill. Borsh.
Odynerus Latr.

Dantici lossi. Kasilip. melanocephalus Gmel. Kub. parietum L. U-der.

\section{Polistes Latr.}

bighunis $I_{\text {A. }} \mathrm{U}$-der.

gallica L. Kub., Borsh.

Vespa L.

silvestris Scop. Kasilip. vulgaris L. Kub.

\section{FAM. APIDAE. \\ Sphecodes Latr.}

ephippius It. Murut.

fuseipennis Germ. Borsh

giblons L. Helnd., Derb., Kub.

reticulatus 'T'hms. Derb.

\section{Prosopis F}

bipunctata F. Borsh.

communis Nyl. Helnd.

confusi Schenk. Kub.

dilatata IIl. Kasikp.

variegata $\mathrm{F}$. Helnd, Kasilip.

\section{Colletes Latr.}

cunicularis L. Helnd.

Daviesanus Smith. Kub., U-der.

floralis Ev. Helnd.

\section{Halictus Latr.}

albipes F. Karb-jürd.

calceatus Scop. Kub., Derb., Lirk., U-der. cariniventris Mor. Helnd., Eiljar.

caspicus Mor. Derb.

cephalicus Mor. Derb.

fulvipes Klug. Derb., Helnd.

leucopus Kby. Kub.

leucozonius Schrk. Isenk.

levis Kby. Kub.

maculatus Smith. Lenk., Kusari.

major Nyl. Kub.

meridionalis Mor. Kub. 
mucoreus Smith.? Kasikp.

pulvereus Mor. Sardab.

quadricinctus F. Murut., N. Rossk., Kub., Derb., Tfl., Eriw., Kasilip.

riparius Mol. Lirk.

sexcinetus F. Murut., TA., Kub.

Smeathmanellus Kby. Murut, Eiljar.,Kasikp.

tetrazonius Klg. Murut, U-der.

tumulorum L. Kub., Kasikp.

virescens Lep. Kasikp.

vulpinus Nyl. Kub.

xanthopus Kby. Lirk., Helnd, Helnk.

zonulus Smith. Kub.

\section{Anthrena F.}

aeneiventris Mor. Derb.

albicans Miull. Helnd.

albicrus Kby. Lirk.

albopunctata Rossi. Derb., Helnd.

bicolor F. Karb-jürd.

carbonaria L. Helnd., Derb.

chrysoscelis Kby. Kasikp.

cineraria L. Kasikp.

cingulata F. Kusari.

colletiformis Mor. Helnd.

convexiuscula Ill. Kasikp.

curiosa Mor. Derb.

curvungula Thms, Borsh.

elegans Gir. Eiljar.

ephippium Spin. Helnd, Kasikp.

fimbriata Brll. Kulp., Kasikp.

flavipes Pz. Helnd., Borsh., Lirk., Tbiz-S., Kasikp., 'Tfl.

Hattorfiana F. Kub.

humilis Imh. Derb., Helnd., Karb-jurd., Kusari., Murut, Lirk.

hypopolia Schm. Kulp.

hystrix Schm. Eiljar.

labiata Schenk. Kusari.

morio Brullé. Kub., liriw., Derb., T'fl., Alexp., Kasilip.

nana Kby. Kasikp.

nigroaenea Kby. Kusari., Lirk.

niveata lriese. Kasikp.

oraniensis Lep. Kasikp.

ovina Klg. Hehnd, Mang. parvula Kby. Kub, Derb., Lenk., Lirk.,

Kasikp.

polita Smith. Borsh.

propinqua Schenk. Helnd.

pyrrhopygia Kriechb. Derb.

scita Ev. Helnd. Etschm., Kasikp.

Shawella Kby. Kursch.

simillima Smith. Kasikp.

taraxaci Gir. Lirk., Derb.

thoracica F. Helnd., Karb-jüd., Lriw., Kasikp.

tibialis Kby. Derb., Helnd., Karb-jurd.

transitoria Mor. Helnd.

Trimmerana Kby. Helnd.

truncatilabris Mor. Derb.

varians Kby, var. helvola L. Helnd.

\section{Nomia Latr.}

diversipes Latr. Karb-jürd.

\section{Panurginus Nyl.}

lactipennis Friese. Nog. St.

variegatus Mor. Kasikp.

\section{Rhophites Spin.}

quinquespinosus Spin. Kursch., Kasikp.

Halictoides Nyl.

inermis Nyl. Kasilip.

\section{Camptopoeum Spin.}

frontale F. Kasikp.

\section{Panurgus $\mathrm{Pz}$.}

Banksianus Kby. Gudr.

calcaratus Scop. Kub., Kasikp.

\section{Dasypoda Latr.}

argentata Pz. Kub., Abst., Kasilip.

plumipes Pz. Helnd., Derb.

var. minor Mor. Kulp.

\section{Melitta Schenk.}

dimidiata Mor. Kasikp.

leporina P's. Alexp. 
Systropha I11.

planidens Gir. Kub, IIelnk, Lriw, Kasikp.

\section{Ceratina Latr.}

acuta. Kasikp.

callosa I. Borsh., Kasikp.

cyanca Kby. Borsh.

\section{Xylocopa Latr.}

Olivieri Lep. Eiljar.

valga Gerst. Eiljar., Kasilip.

violacer $\mathrm{L}$. Tff.

\section{Encera Scop.}

alternans Brullé. Kasikp., Liljar. cincrea Lep. Helnd., Lirk., Lriw.

clypeata Er. Derb.

Dufourii Per. Kasikp.

graja Ev. Eriw.

hispana Lep. var. nigripes Klg. Kasikp. interrupta Bär. Kusari.

longicornis L. Isenk., IIelnd., Lirk, Derb. malvae Rossi. Helnd., Kub.

nigrifacies Lep. Lirk.

nigrilabris Lep. Derb.

ruficollis Brullé. Derb.

ruficornis F. Kasilip.

similis Lep. Lirk.

tricincta Er. Derb.

velutina MIor. Derb.

\section{Meliturga Latr.}

clavicornis Latr. Kasikp.

\section{Podalirius Latr.}

acervorum Latr. Derb., Lenk., Helnd., N.Rossk. albigenus Lep. Tft., Etschm.

Dufourii Lep. Azkur.

Lrschowi Fedsch. Karb-jürd.

furcatus Pz. Kusari.

garrulus Liossi. Murut, U-der.

gracilipes Mor. Etschm.

modernus Mor. Karb-jürd.

orientalis Mor. Sch-d.

parietinus F. Borsh., Azkur.

quadrifasciatus Vill. Helnd.

rełusus L. var. aestivalis P'z. Baku., Azkur., Sech-d. robustus Klg. Azkur., Kasikp.

senescens Lep. Sch-d., I)erb., Karb-jitrd. vulpinus P’z. Kub., Azkur., Sardab.

\section{Melecta Latr.}

armata P'z. Helnd.

luctuosa Scop. Ilelnd., Isenk., Karb-jurd.

\section{Crocisa Jur.}

scutellaris 1:. Derh.

\section{Nomada Sc.}

fucata P'o. Murut., Ilelnd. furva Pz. Lirk., IIelnd.

Lathburiana Kby. Helnd.

sexfasciata $\mathrm{P} z$, Lirk.

succincta Pz. Lenk., Lirk.

\section{Eriades Spin.}

campanularum Kby. Borsh.

clavicornis Mor. Eriw.

foveolatus Mor. Kasikp.

nigricornis Nyl. Kub., Borsh.

truncorum L. Kub.

\section{Osmia $\mathrm{Pz}$.}

aurulenta Pz. Borsh.

caerulescens L. Helnd., Lirk., Derb., Lenk., Pseb.

claviventris Tlıms. Kub.

crenulata Mor. Eriw.

cmarginata Lep. Eiljar.

fulviventris $\mathrm{P} z$. Derb.

Panzeri Mor. Helnd., Derb.

papaveris Latr. Kasikp.

rufa L. IJelnd., Lirk., Lenk., 'T'tl.

rufohirta Latr. Derb.

signata Er. Helnd, Derl.

Solskyi Mor. Borsh., Melnd.

\section{Lithurgas Latr.}

chrysurus Fonse. Kulp.

cornutus F. Helnd.

\section{Megachile Latr.}

argentata F. Kub., Ielnd.

centuncularis L. Kusari.

derasa Gerst. Etschm. 
diabolica Friese. Kasikp.

lagopoda L. Murut., U-der.

melanopyga Costa. Helnd.

muraria Retz. Borsh., Karb-jürd.

octosignata Nyl. Murut.

pyrenaica Lep. Sch-d.

rotundata F. TH.

\section{Anthidium F.}

cingulatum Latr. Kasikp., Helnd.

florentinum F. Karb-jürd.

var. caucasicum Rad. Tfl., Ilelnd.

manicatum L. Murut., Kub., Helnd.

oblongatum Latr. Borsh., Kasikp.

pubescens Mor. Kasikp.

punctatum Latr. Kasikp.

strigatum $\mathrm{Pz}$. Helnd.

\section{Stelis $\mathbf{P z}$.}

aterrima $\mathrm{P} z$. Kub.

phaeoptera Kby, Kub., Murut.

\section{Coelioxys D. T.}

afra Lep. Helnd.

conoidea Ill. Murut.

mandibularis $\mathrm{Nyl}$. Kub.

rufescens Lep. Kub.

\section{Biastes Pz.}

brevicornis $\mathrm{Pz}$. Kasikp.

\section{Bombus Latr.}

agrorum F. Tars-tsch., N. Rossk., U-der., Arab. G., Murut,, Lirk., Kusari.

var. nigriventris Mor. Lirk.

argillaceus Scop. Murut, . Itelnd.

cancasicus Rad. Kasb., Murut, Borsh.
Derhamellus Kby. Sch-d.

eriophorus Klg. Kub., Pjatgk.

fragrans Pall. Helkn.

haematurus Kriechb. Batum., N. Rossk., Murut., Lirk., Lenk., Kursch., Helnd.

hortorum L. U-der., Lirk.

laesus Mor. Murut., Sign., Kasikp.

lapidarius L. var. incertus Mor. Helnk.

var. Sichelii Rad. Kub.

melanurus Lep. Kasikp.

mendax Gerst. Sch-d.

Mlokosiewitzii Radocz. Murut., Gudr., Sch-d. montanus Lep. Kursch.

pomorum $\mathrm{Pz}$. var, armeniacus Rad: Kub.

var. rufescens Ev. Sch-d.

pratorum L. var. perplexus Rad. Murut., Lirk. silvarum L, var, daghestanicus Rad. Murut., Kusari.

soroeensis F. Murut, Sch-d., Arab

subterraneus L. Murut,. Sch-d., Helnk.

var. collinus Smith. Murut.

terrester L. Kusari, Kasikp., Helnd., Karbjürd., N. Rossk., Murut.

var. lucorum L. Murut.

variabilis Schmkn. Lirk., Kub., Sch-d., Helnd.

vorticosus Gerst. var. niveatus Kriechb. Kasikp.

zonatus Smith. var. apicalis Mor. Eriw., Helnd.

var. calidus Ev. Kub, Kasikp., Helnk.

\section{Psithyrus Lep.}

barbutellus Kby. Kusari.

vestalis Foucr. Lirk.

\section{Apis $\mathrm{L}$.}

mellifera L. Derb., Sch-d., Kusari., Helnd.

\section{HYMENOPTERA TRANSCASPICA.}

\section{FAM, APIDAE}

Anthophora Latr.

quadrifasciatus Vill. Aschabad. agama Rad. Keltetschinar.

atricilla kr. Keltetschinar.

liturata Lep. Keltetschinar. 


\section{Saropoda Latr.}

bimaculata Istr. Nerw.

\section{Eucern Scop.}

clypeata Lr. 'I'achita-basar.

\section{Tetralonia Spin.}

metallescens Mor. 'Ischerwach. Radoszkowskyi Mor. Aschabad. albo-rufa Rad. Keschowrud. spectabilis Mor. 'Tscherwach.

\section{Xylocopa Latr.}

valga Gerst. Tschuli. hellenica Spin. Aschabad.

\section{Ceratinia Latr.}

egregia Gerst. Transkp.

\section{Andrena F.}

funebris Panz. 'T'schuli.

thoracica F. 'T'schuli.

Lepeletieri Luc. Chodsha-kala.

pilipes F. 'T'scherwach.

parvula Kirby. 'lachta-basar.

aulica Mor. Tschuli.

virescens Mor. Geok-tepe.

extricata Smith. 'Ischuli.

fulvicrus Kirby. Keltetschinar.

aeneiventris Mor. Keltetschimar.

\section{Halictus Latr.}

quadricinctus F. 'Tschuli. fulvipes Germ. 'Tschuli. minor Mor. Aschabad. scutellaris Mor. Tachta-basar. albitarsis Mor. Geok-tepe. pauxillus Schm. Tachta-basar. nasica Mor. Aschabad. rhynchites Mor. Adam-elan. croceipes Mor. Geok-tepe. sogdianus Mor. Akrabat-Kungiruili. aprilinus Mor. 'I'seherwach. desertorum Mor. 'Tachta-basar. fuscicollis Mor. T'scherwach. mucopeus Er. 'Transkp. pulvereus Mor. Transkp. major Nyl. Transkp.

\section{Nomia Latr.}

diverifues Latr. Aschabad. femoralis Pall. Keschowrud.

\section{Nomioides Schenk.}

variegata 0l. Geok-tepe. pulverosa IIandl. Afghanengrenze.

\section{Megachile Latr.}

sericans Fonsk. T'schuli. derasa Gerst. Merw. grisescens Mor. Merw. argentata lib. Aschabad. lagopoda L. 'Transkp. picicornis Mor. Transkip.

\section{Osmia Latr.}

Fedtschenkoi Mor. Aschabad. melanogaster Spin. T'schuli.

\section{Anthidinm F.}

florentinum Latr. 'Tschuli. Fedtschenkoi Mor. Kopet-dagh. oblongatum Latr. 'Tachta-basar. diadema Latr. 'T'schuli.

\section{Sphecodes Latr.}

fuscipennis Germ. Transkp. nigripennis Mor. Pul-i-chatum. pectoralis Mor. Tachta-basar.

\section{Prosopis F.}

flavipes Mor. Aschabad.

\section{Melecta Latr.}

Juctuosa Scop. Ruchora-bad. Baeri Rad. Aschabad.

\section{Nomada F.}

fucata $\mathrm{Pz}$. Tachta-basar. mutabilis Mor. Tscherwach. discicollis Mor. Tachta-basar.

\section{Coelioxys Latr.}

pulchella Mor. Asshabad. transeaspica Rad. Merw. 


\section{FAM. SPHEGIDAE.}

\section{Sphex Latr.}

regalis Smith. Kary-bend. puncticollis Kohl. Krasnowodsk. strigulosus Costa Tschuli. subfuscatus Dahlb. Tschuli. songaricus Eversm. Duschak. viduatus Christ. Keschowrud. albisectus Lep. Tschuli. lividocinctus Costa. Keschowrud. niveatus Duf. Kary-bend.

flavipennis F. Keltetschinar., Duschak., Krasnowodsk.

plumipes Rad. Tschuli.

maxillosus F. Aschabad.

\section{Ammophila F.}

ebenina Spin. Tscherwach.

hirsuta Scop. var. mervensis Rad. Pul-ichatum.

Tydei Guill. Pul-i-chatum.

lutea Taschb. Aschabad.

Heydenii Dahlb. Tachta-basar.

campestris Jur. Tachta-basar.

\section{Pelopoeus Latr.}

Walteri Kohl. Tschuli. pensilis III. Transkp.

\section{Larra Iatr.}

anathena Rossi. Transkp.

\section{Palarus Latr.}

gracilis Kohl. Pul-i-chatum.

\section{Tachysphex Kohl.}

Moczaryi Kohl. 'T'schuli.

dignus Kohl. Nuchur.

pygidialis Kohl. Pul-i-chatum.

nitidus Spin. Tachta-basar.

\section{Notogonia Costa.}

pompiliformis $\mathrm{Pz}$. Tachta-basar.

Cerceris Latr.

emarginata $\mathrm{Pz}$. Tachta-basar.

conigera Dahlb. $\Lambda$ schabad. tuberculata Rossi. Krasnowndsk.

ribyensis F. Transkp.

Astatus Latr.

minor Kohl. Chodsha-kala.

\section{Gorytes Lep.}

Walteri Handl. Sary-jasy. punctulatus v.d. L. Tschuli.

\section{Sphecins Dahlb.}

antennatus Klg Tschuli.

Uljanini Rad. Tschuli.

percussor Handl. Tschuli.

\section{Stizus Latr.}

dispar Mor. Kary-bend, Dschurtschuli.

Raddei Handl. Tschuli.

Koenigii Mor. Keltetschinar.

ruficornis F. Keltetschinar.

histrio Mor. Tschuli.

tridentatus F. T'schuli.

crassicornis F. Keschfrud.

Bembex Latr.

bicolor Rad. Nuchur.

\section{Crabro F.}

Walteri Kohl. Aschabad.

\section{FAM. POMPILIDAE.}

\section{Salius Iatr.}

errans Smith. Krasnowodsk. discolor F. Turcmen-Steppe. sarafschanicus Rad. Chodsha-kala.

\section{Pompilus Schdt.}

rufipes $\mathrm{L}$. Tschuli albonotatus v. d. L. Kary-bend. viaticus L. Neu-Merw., Aschabad. Kisilkumii Rad. Tschuli. nomada Kohl. Tachta-basar.

\section{FAM. SCOLIADAE. Scolia F.}

haemorrhoidalis F. Tschuli. quadripunctata F. Aschabad. erythrocephala F. Aschabad. 
Elis $\mathrm{F}$.

angulata Mor. Aschabad.

sexmaculata F. Transkp.

\section{Tiphia F.}

arenicola Kohl. Sary-jasy.

\section{Moria Ill.}

tartara Sauss. Merw.

nocturna Mor. Aschabad.

Timurella Sauss. T'ranskp.

tripunctata Rossi. 'Transkp.

\section{FAM, MUTILLIDAE}

\section{Mutilla Latr.}

Komarowii Rad. Nurgab.

continua F. Merw.

Fedtschenkoi Rad. Tachta-basar.

ornata Klg. Aschabad.

interrupta KIg. Tachta-basar.

pedunculata Klg. Artsclıman.

\section{FAM. FORMICIDAE.}

\section{Camponotus Mayr.}

sylvaticus Ol. var. turcestanus Andr. Beum. basch.

compressus F. Perewalnaja.

\section{Tetramoxiam Mayr.}

caespitum L. Aschabad.

\section{Pheidole.}

pallidula Nyl. Murgab.

Aphaenogaster.

barbara I. Murgab.

\section{Myrmecocystus.}

viaticus $\mathrm{F}$. Krasnowodsk.

altisquamis André. Transkp.
FAM VESPIDAE.

\section{Vespa L.}

crabro I. var. orientalis L. Aschabad. germanica L. Aschabad.

\section{Polistes Latr.}

gallica L. 'T'schuli.

Eumones Latr.

dimidiatipennis Sauss. 'Tschuli.

Baeri Rad. Aschabad.

tripunctatus Christ. Aschabad.

mediterranea Krchb. Aschabad.

pomiformis Rossi. Transkp.

coaretatus L. 'Transkp.

Leionotus Sauss.

tegularis Mor. Keschowrud.

\section{FAM. CHR YSIDIDAE}

\section{Stilbum Spin.}

nobile Sulz. Murgab.

\section{Chrysis L.}

viridula L. Chodsha-kala.

\section{Holopyga Dahlb.}

punctatissima Dahlb. Mor-kala.

FAM. EVANIIDAE

Evania Latr.

dimidiata F. Aschabad.

FAM. TENTHREDINIDAE. Sirex I.

Sah Mocs. T'ranskp. 


\section{DIPTERA CAUCASICA.}

\section{FAM. BIBIONIDAE}

\section{Bibio Geoffr.}

pomonae F. Tan.

marci L. Mang.

hortulanus L. Baku.

\section{FAM. PSYCHODIDAE}

Psychoda Latr.

albipennis Ztt. Tfl.

\section{FAM. STRATIOMYDAE.}

\section{Nemotelus Geoffr.}

argentifera Lw. Kas-knt.

\section{Lasiopa Brullé.}

villosa F. Achty.

\section{Clitellaria Mg.}

Dahlii Mg. Kasikp.

\section{Oxycera Mg.}

amoena Lw. Mang., Kasikp.

\section{Stratiomys Geoffr.}

chamaeleon L. Kasikp.

concinna Mg. Tan.

erythrocera Egg. Kasikp.

pyrrhocera Lw. Kasikp.

\section{Actina $\mathbf{M g}$.}

nitens Latr. Tan.

\section{FAM. TABANIDAE}

\section{Tabanus $\mathbf{L}$.}

tricolor Zllr. Mang., Eiljar., Kasikp.

paradoxus Lw. Kasikp.

quadrinotatus Mg. Tan.

bifarius Lw. Kasikp.

fulvus Mg. Kasikp.

graecus F. Zch-Zch. unifasciatus Lw. Tan.

autumnalis L. Derb.

decorus Lw. Kasikp.

apricus Mg. Zch-Zch., Lom-mta.

FAM. NEMESTRINIDAE.

Chrysops Mg.

caecutiens L. Derb.

\section{Fallenia Mg.}

fasciata F. Nog. St.

\section{FAM. BOMBYLIDAEE. \\ Authrax Scop.}

Paniscus Rossi. Mang.

flava Mg. N. Rossk., U-der.

melanurus Lw. Kasikp.

morio L. Mang., Tan.

velutina Mg. I'an.

\section{Argsromooba Schin.}

sinuata Fll. Mang., Borsh.

\section{Mulio Latr.}

obscurus F. Kasikp.

melaleucus Lw. Kasikp., Such.-Ft.

\section{Lomatia Mg.}

lateralis Mg. I'an.

\section{Bombylius L.}

ater Sc. Mang., Borsh., 'Tan.

pictus $\mathrm{Pz}$. Mang.

medius L. Mang.

fimbriatus Mg. Kasikp.

torquatus Lw. Anit.

undatus Mik. Mang.

fugax W. Tan.

pumilus Mg. Tan.

minor L. Tan.

Ploas Latr.

decipiens Lw. Mang. 


\section{FAM. THEREVIDAE}

Thereva Latr.

lugens Lw. Tan.

marginula Mgg. Kursch., 'l'an.

\section{FAM. ASILIDAE.}

\section{Leptogaster Mg.}

cylindricus Deg. I'an.

\section{Dioctria $\mathrm{Mg}$.}

atricapilla $\mathrm{Mg}$. Tan.

\section{Stenopogon Lw.}

sabaudus F. Kasikp., Kas-knt. elongatus Mg. Kub., Derb.

\section{Andrenosoma Rond.}

atra L. Mang., Tan., Lom-mta.

\section{Asilus I.}

forcipula Zllr. Tan.

rusticus $\mathrm{Mg}$. Lom-mta.

crabroniformis L. Mang.

\section{FAM. LEPTIDAE}

\section{Leptis F.}

tringaria $\mathrm{L}$. Tan.

\section{Chrysopila Meq.}

aurea Mg. Tan.

chlorophthalma Lw. Tan.

erythrophthalma Lw. Tan.

\section{FAM. DOLICHOPIDAE.}

\section{Gymnopterus Lw.}

regalis MIg. Tan.

\section{Medeterns Fisch.}

obesus Kaw. Tan.

\section{FAM. MUSCIDAE \\ Scatophaga Mg.}

stercoraria L. Mang.

\section{Limnia R.-Desv.}

cincta l', l'an.

\section{Trypeta Mg.}

spec.? Mang.

\section{Urophora R.-Desv.}

spec.? Kauk.

Myodina R.-Desv.

vibrans L. Tan.

\section{Platystoma Mg.}

umbrarum E, Derb, U-der. suavis Lw. Derb.

\section{Dorycera Mg.}

clavipennis Röd. T'an.

Anthomyia Mg.

pluvialis L. 'Tan.

\section{Hylemyia R.-Desv.}

spec.? Tan.

criniventris Ztt. Kasikp.

\section{Spilogaster Mcq.}

spec. ? Kasikp.

\section{Aricia R.-Desv.}

variabilis Fll. Zch-Zch.

signata Mg. Kasikp.

erratica Fll. Kasikp., Tan.

basalis Ztt. Zch-Zch., Lom-mta.

pallida F. Tan.

spec.? Tan.

Lacilia R.-Desv.

cornicina Fall. Kasikp., Lom-mta.

\section{Masca L.}

domestica L. Kasikp.

Pollenia R.-Desv.

vespillo $\mathrm{Mg}$. Tan.

Calliphora R.-Desv.

vomitoria $L$, Zch-Lch., Arab. G., Tan. 
erythrocephala Mg. Arab. G., Tan., Lom-mta., Zch-Zch., Derb.

\section{Mesembrina Mg.}

meridiana L. Zch-Zch., Perli-d., Derb.

mystacea L. Borsh., Lom-mta.

\section{Sarcophaga Mg.}

carnaria L. 'Tan.

haemorrhoidalis Mg. Tan.

spec.? Tan.

\section{Systomocera Schin.}

cristata Rd. Zch-Zch.

\section{Dexia Mg.}

pellucens Egg. N. Rossk.

\section{Tachina Meig.}

larvarum L. Derb.

spectabilis Mg. 'Tan.

Exorista $\mathrm{Mg}$.

cheloniae Rond. Tan.

Nemoraea R.-Desv.

spec.? Tan.

\section{Zophomyia Mcq.}

temula Sc. Tan.

\section{Echinomyia Dumér.}

ferox Mg. Arab. G., Zch Zch., Tan.

tesselata F. Kasikp.

grossa L. Tan.

magnicornis Ztt. Kasikp., Lom-mta., Zch-Zch. spec.? Tan.

Phasia Latr.

crassipennis F. U-der.
FAM SYRPHIDAE.

\section{Syrphus F.}

pyraster L. Arab. G.

ribesii L. Arab. G.

\section{Melanostoma Schin.}

mellina L. T'an.

\section{Cheilosia Mg.}

oestracea L. Zch-Zch., Kursch.

mutabilis Fll. Tan.

canicularis L. Lom-mta.

\section{Volucella Geoffr.}

bombylans L. var. plumata Deg. 'T'an., Urusch. var. caucasica Portsch.

zonaria Poda. Derb., N. Rossk.

\section{Eristalis Latr.}

tenax. L. 'l'an.

arbustorum L. Kursch., Tan.

\section{Helophilus Mg.}

floreus L. 'Tan.

nigrotarsatus Schin. Tan.

trivittatus F. Arab. G.

\section{Merodon Mg.}

aberrans Egg. Lom-mta.

aeneus Mg. Dagt.

\section{FAM CONOPIDAE}

Myopa $\mathbf{F}$.

ursula Lw. ? Derb.

\section{Sicus Scop.}

ferrugineus L. Tan.

\section{Conops L.}

vesicularis L. 'Tan. 


\section{ORTHOPTERA CAUCASICA.}

\section{FAM. ODONATA}

Libellala L.

depressa L. Borsh., Dshelal-ogly.

brunnea Fonsc. Kasikp.

erythraea Brulle. Aresch., Lom-mta.

pedemontana Allio. Kas-knt.

meridionalis Sélys. 'Tfl, Aresch.

striolata Charp. Lenk.

vulgata L. Kasikp.

Gomphus Leach.

forcipatus L. Aresch., Tf.

\section{Anax Leach.}

parthenope sélys. Dshewanschir.

\section{Aeschna F.}

mixta Latr. 'l'fl, Borsh., Dshewanschir. grandis L. Lenk.

\section{Calopteryx Leach.}

virgo L. Aresch.

syriaca. Lenk.

\section{Lestes Leach.}

sponsa Hansem. Kauk.

fusca Linden. Aresch.

\section{Platycnemis Charp.}

pennipes Pall. Lenk

\section{Agrion F.}

pumilio Charp. Lenk.

cyathigerum Charp.Aresch.,Borsh., Lom-mta.

\section{ORTHOPTERA TRANSCASPICA.}

\section{FORFICULODEA.}

\section{Labidura Leach.}

riparia Pall. Aschabad, Krasnowodsk. var. segmento anali integro. Aschabad.

Anechura Scadd.

bipunctata F. var. bignttata Kitt. Turem.Steppe, Keleta.

\section{BL A TTODEA. \\ Periplaneta Burm.}

tartara Sauss. Aschabad.

\section{Ischnoptera.}

spec.? Aschabad.

\section{Heterogamia Burm.}

pellucida Rdtb. Aschabad.

\section{MANTODEA. \\ Iris Saus8.}

polystictica If.d. W. Aschabal.
Fischeria Sauss.

caucasica Sauss. Aschabad.

Bolivaria Stål.

brachyptera Pall. Aschabad.

Oxythespis.

'Turcomaniae Sauss. Murgab., Beum-basch.

Empusa Ill.

pennicornis Pall. Krasnowodsk.

Ameles Burm.

decolor Charp. Kungruily.

Hierodala Burm.

tenuidentata Sauss. Aschabad.

Mantis I.

religiosa L. Aschabad.

\section{PHASMODEA.}

\section{Gratidia.}

bituberculata Rdtls. Aschabad. 


\section{ACRIDIODEA.}

\section{Tryxalis Fab.}

nasuta L. Aschabad. unguiculata Ramb. Aschabad.

\section{Ochrilidia Stål.}

tibialis Fieb. Aschabad.

\section{Duronia.}

fracta Fieb. Merw., Sary-jasy., Aschabad.

Stenobothrus Fisch.

bicolor Charp. Tschuli.

simplex Er. Pul-i-chatum.

\section{Stauronotus Fisch.}

tartarus Sauss. Buschwermak., Aschabal.

Epacromia Fisch.

thalassina F. Aschabad.

Pyrgodera F. d. W.

cristata F. d. W. Aschabad., Murgab.

\section{Pachytylus Eieb.}

migratorius L. Aschabad.

\section{Oedaleus.}

Mlokosiewicii Bol. Aschabad.

\section{Scintharista.}

Wagneri Er. Duschak., Aschabad.

\section{Oedipoda Latr.}

gratiosa Serv. Buschwermak., Aschabad.

\section{Acrotylus Fieb.}

insubricus Scop. Aschabad., Merw.

\section{Sphingonotus Fieb.}

callosus Fieb. Asehabad.

Satrapes Sauss. Adam-ilen., Kary-bend.

Savignyi Sauss. Karybend.

coerulans L. Aschabad.

\section{Trinchas.}

Schrenkii F, d. W. var. minor. Karybend.
Eremobia Serv.

fuscipennis Rdtb; Transkp.

\section{Pyrgomorpha Serv.}

grylloides Latr. Aschabad., Kary-bend., Kungruily., Murgab., Tachta-basar., Dusuolum.

Tettix Charp.

serripes Rdtb. Transkp.

Acridium Geoffr.

aegyptium L.Murgab.,Tachta-basar, Duschak.

Derocorystes.

curvipes Rdtb. Aschabad., Krasnowodsk.

roseipennis Rdtb. Karybend., Krasnowodsk.

\section{Caloptenus Burm.}

italicus L. Duschak., Aschabad.

\section{Euprepocnemis Fieb.}

plorans Charp. Aschabad. litoralis Ramb. Aschabad. pterosticha F. d. W. Aschabad. adspersa Rdtb. Aschabad.

\section{Tropidanchen.}

cultricolle Sauss. Ak-dagh 8000', Chodshakala.

Opomala Serv.

cylindrica Marsh. Tedshen.

\section{LOCUSTODE $\AA$.}

Platycleis Fieb.

affinis Fieb. Aschabad.

intermedia Serv. Aschabad., T'schuli.

\section{Decticus Serv.}

albifrons F. Aschabad.

\section{Glyphonotus Rdtb.}

thoracicus Fisch. Transkp.

\section{Locusta Deg.}

caudata Charp. Buschwermak, Aschabad. 
GRYLLODEA.

\section{Liogrillus.}

capensis F. Aschabad.

\section{Gryllus L.}

desertus Pall. Aschabad., Merw., Dusu-olum. domesticus L. Aschabad.

burdigalensis Latr. Aschabad., Murgab., Adam-ilen.

\section{Nemobins Serv.}

tartarus Sauss? Aschabad., Karybend.

\section{Gryllodes Sanss.}

spec.? Dusu-olum.

\section{Gryllotalpa Latr.}

unispinosa Sauss. Amu-darja.

\section{CORRODENTIA.}

\section{Holotermes Hag.}

spec.? Trinskp.

\section{HEMIPTERA CAUCASICA.}

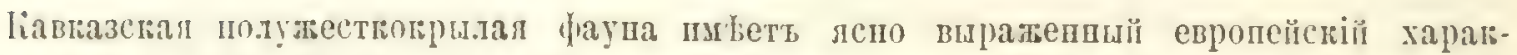

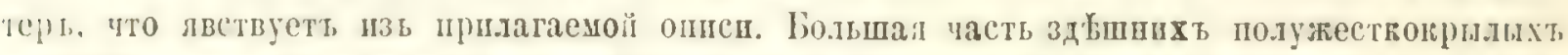

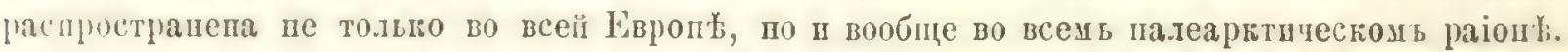

Но вь этим ойщераспрострапенния видамт присоединиотя еще элезент, прпдающе полужествоврылой фаун Кавказа особепшый интерест.

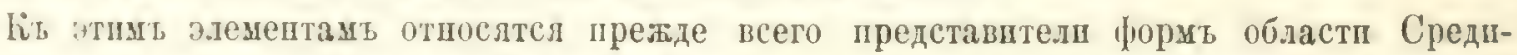

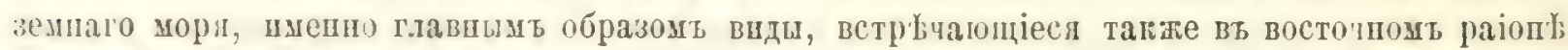

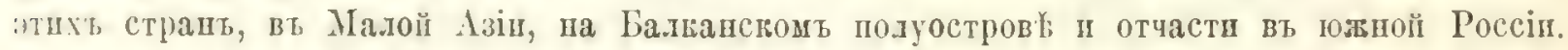
: ти види сльдуюціе: Eurygaster integriceps Put., Tarisa subspinosa Germ., Mustha spinosula Laf., Apodiphus Amygdali Germ., Lygaeus Tristrami D. S., Artheneis alutacea Fieb., Cymophyes ochroleuca Fieb., Peritrechus ambiguus Horv., Galeatus Komaroffii Jak., Pasira basiptera Stål, Reduvius testaceus II. Sch., Ilarpactor Kolenatii Reut., Nagusta Goedelii Konl, Plagiognathus pictus Fieb., Auchenocrepis Reuteri Jak., Corixa Rogenhoferi Fieb., Ci(aditra querula Pall. In hyalina Fabr., Tettigometra hispidula Fieb ${ }^{1}$ ). Относительно ра-

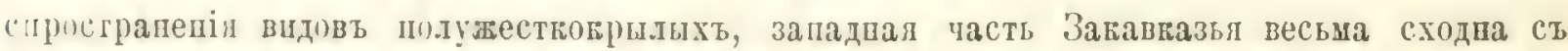

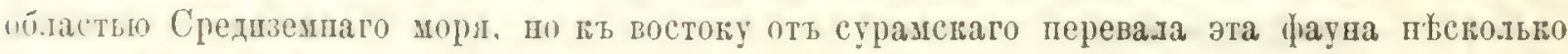

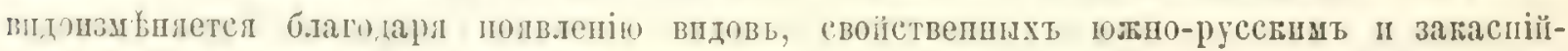

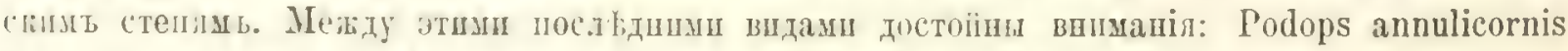
Jak., Cydnus ovatulus Jak., Aelia melanota Fieb., Aphanus Beckeri Frey, Scolopostethus I. thierryi Jak., Moninthia pilosa Iumm., Centroscelincoris desertus Beck. (ветрғчаетел тагmi вт L(nanir), Oncocephalus plumicornis Germ. u brachymerus Reut., Piezostethus ciliatus Jak., Anthucoris pilosus Jak., Maurodactylus nigricornis Reut., Cixius desertorum Beck., Acocephalus elongatus I،eth., Chlorita bipunctata Osch. Ir Psylla Glycyrrhizae Beck.

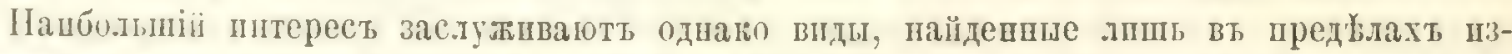

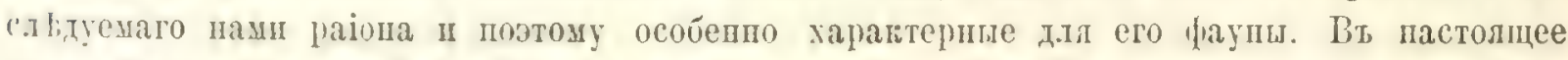

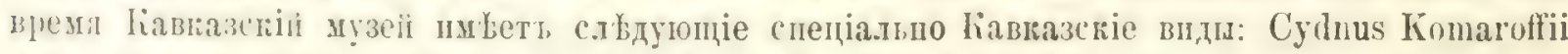
Jak., Sehirus robustus IIorv., Igatharchus Herrichii Kol., Artheneis hircanica Kol., Aco-

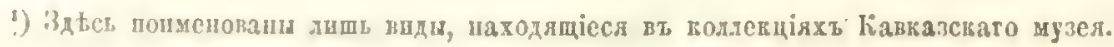


lypta uniseriata Put., Furycera brevicornis Jak., Nonanthia rotundicollis Jak. In dilatata Jak., Aradus diversicornis Horv. II caucasicus Kol., Harpactor rubrogularis Horv., calocoris Costae Reut., Brachycoleus lineellus Jak., Rhopalotomus cinctus Kol. In Issus ovifrons Put.

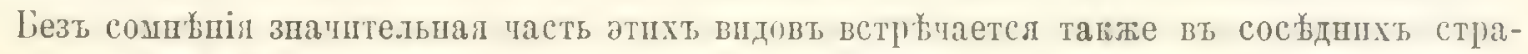

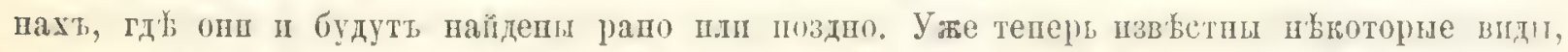

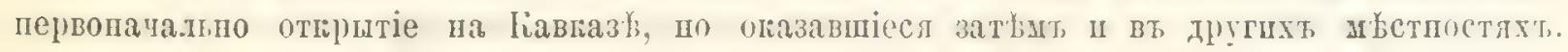
Haпрuм

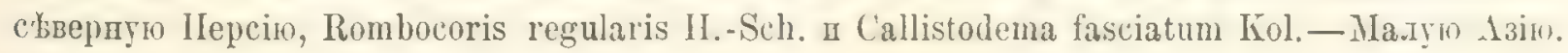
Rhyparochromus colon Put.-Грецію.

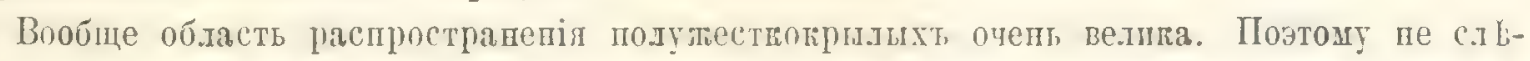

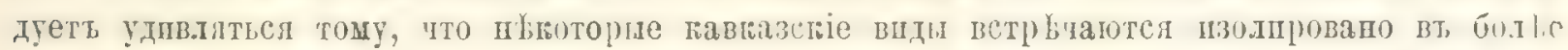

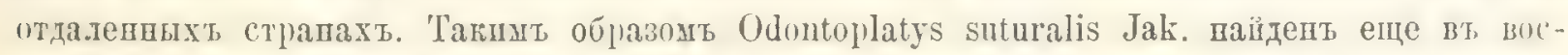
точшої Cпо̆щп, Trochiscocoris rotundatus Horv, Monanthia ciliaris I'ut. II Hebrus montanus Kol.—въ Ренгріи, Sehirus congener Jak.—вь гжпой गpanцін, Tibicen quadrisigna-

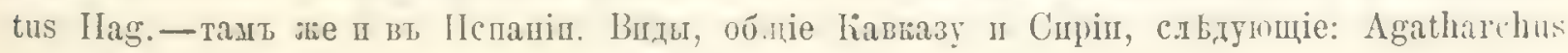
linea Klug, Holotrichius apterus Jak. In Cicadatra lineola Fieb.

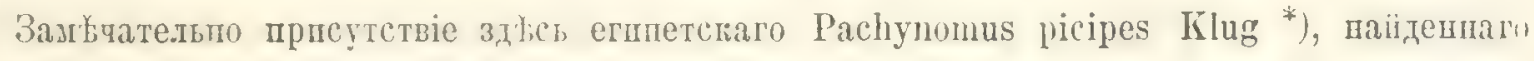

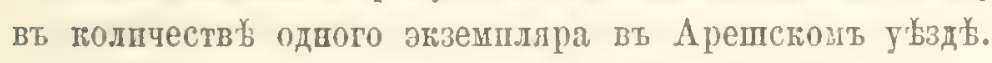

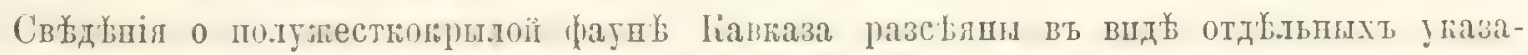

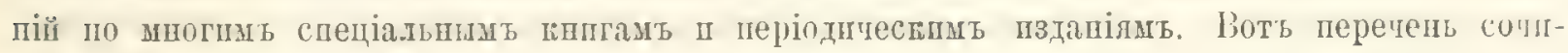
пеній, въ попхъ пзсльдуетсл пенио фауна этой областш:

Kolenati, Friedrich A., Meletemata Entomologica. II, IV, VI, VII 1845-57.

Flor, Gust., Rhynchoten aus dem Caucasus und von der Grenze Persiens (Bulletin de la Société Imp. des Naturalistes de Moscou. 1861. I. p. 619-623).

Horváth, G., Beitrag zur Ilemijteren-Fauna Transkaukasiens. (Dr. O. Schneider, Naturwissenschaftliche Beitrïge zur Kenntniss der Kaukasusländer. Dresden. 1878. p. 72_- (i).

Horváth, G., Hemipterologisches aus Transkaukasien. (Sitzungsberichte der Naturwissenschaftlichen Gesellschaft Isis zu Dresden 1879).

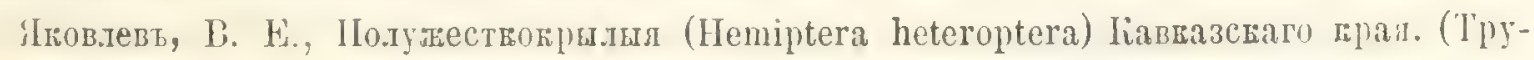
ды Русск. Энтоцолог. Общества. XII. 1880, p. 3-176 и XIII. 1882. p. 82-140).

Horvath, G., Die Hemijteren des Talysch-Gebietes (Dr. G. Radde, Die Fauna und Flora des sudwestlichen Caspi-Gebietes. Leipzig. 1886. p. 246-254).

Horváth, G., Hémiptères recueillis dans l'Arménie russe avec la description d'espièes et variétés nouvelles. (Revue d'Entomologie: X. 1891. p. 68-81).

Horváth, G., Hémiptères recueillis dans la Russie méridionale et en Transcaueasie (Revue d'Entomologie. XIII. 1894. p. 169-189).

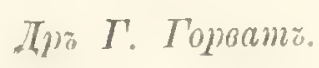

*) un apreancraro Pirates quadrimaculatus Serv. 
Die Ilemipterenfaun der Kaukasusländer hat, wie es auch aus dem nachfolgenden Verzeichniss ersichtlich ist, cinen entschieden europaischen Charakter. Die Ilauptmasse der hi sigen Heminteren ist nicht nur über linropa, sondern uber die ginze paläarktische Region verbreitet.

Zu diesen allgemein verbreiteten Arten gesellen sich aber noch andere Elemente, welche der katuasisehen Hemipterenfauma ein besonderes Interesse verleihen.

Solche Elemente sind in erster Reihe die Reprisentaten der Mittelmeerfauna und zwar besmlers solche Arten, welche auch im östlichen Mittelmeergebiet, in Kleinasien und auf der Balkan-Halbinsel cinheimisch sind und zum grossen 'I'heil auch in SuddRussland vorkommen. Solche Arten sind: Hurgaster integriceps Put., 'Tarisa subspinosa Germ., Mustha

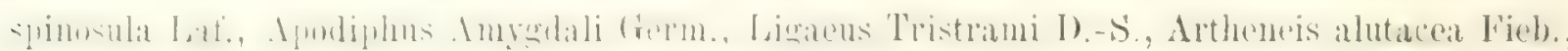
Cymophyes ochroleuca I'ieb., I'eritrechus ambiguus Horv., Galeatus Komaroffii Jak., Pasira

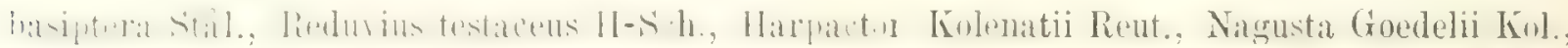

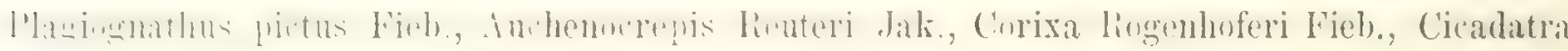
querula Pall. und hyalina Fabr., Tettigometra hispidula Fieb. ${ }^{1}$ ).

Der westliche 'Theil 'Transkaukasiens hat in hemipterologischer Beziehung ein fast aus-

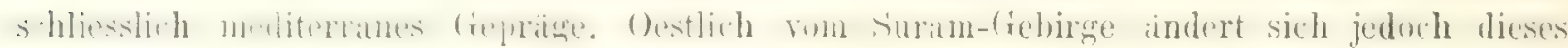
fanuistiscle libld und wird durch das Auftreten von solchen Arten, welche den sudrussischen

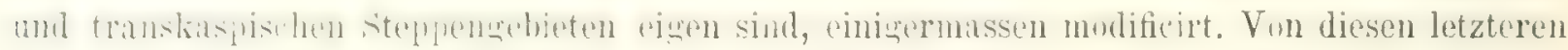
Arten sind erwähnenswerth: Podops annulicornis Jak., Cydnus ovatulus Jak., Aelia melanota Fieb., Aphanus Beckeri Frey, Scolopostethus Lethierryi Jak., IIonanthia pilosa Humm., Centrosceliocoris desertus Beck. (auch i: Spanien), Oncocephalus plumicornis Germ. und

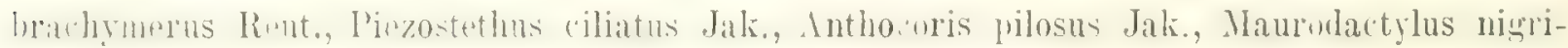
cornis Reut, Cixius desertorum Beck., Acocephalus elongatus Leth., Chlorita bipunctata Osch. und Psylla Glyçrrhizae Beck.

Das grösste Interesse bieten jedoch unzweifelhaft jene Arten, welche ausserhalb unseres Gebietes noch nirgend gefunden wurden und daher für lie hiesige Fauna besonders charakteristisch sind. Von diesen exclusiv kaukasischen Spezialitäten besitzt das Tifliser

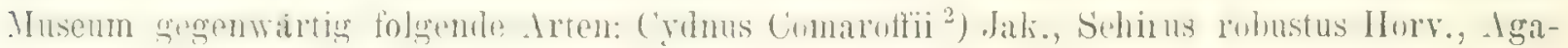
tharchus Herrichii Kol., Artheneis hircanica Kol., Acalypta uniseriata Put., Eurycera brevicornis Jak., Monanthia rotundicollis Jak. und dilatata Jak. Aradus diversicornis Horv. und cancasicus Kol, IIarpactor rubrogularis Horv., Calocoris Costae Reut., Brachycoleus lineellus Jak, Rhopalotomus cinctus Kol. und Issus ovifrons Put.

Es unterliegt wohl keinem Zweifel, dass ein grosser 'Theil dieser Arten auch in den Aachhariandern cinheinisch ist und dort froher oder spater ebenfalls aufgefunden werden wird. Fs sim ja sthon ohnehin mehere drten bekant. Welhe uripringlich aus dem Kauliasus beschrieben, später aber auch anderwärts entdeclit wurden. So leben z. B. Cnephosa

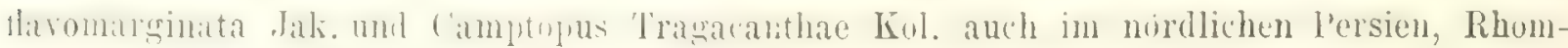

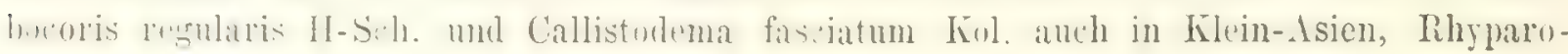
chromus colon Put. in Griechenland.

Die Hemipteren haben uberhaupt sehr grosse Verbreitungsbezirke. Es ist daher nicht zu verwundern, dass manche kaukasische Arten ganz isolirt auch in entfernteren Lündern vorkommen. So wurden Odontoplatys suturalis Jak. ausserdem in Ost-Sibirien,-Trochiscocoris rotundatus Horv., Monanthia ciliaris Put. und Hebrus montanus Kol. in Ungarn,--

") Ls sied hier und weiter unten bloss die im kiakliasischen Museum vorhandenen Arten angeführt.

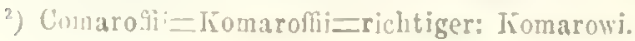


Sehirus congener Jak. in Sud-Frankreich, - Tibiecen quahrisignatus Hag. in Sul-Frankreich und Spanien gefunden. Mit Syrien gemeinsam sind: Igatharchus linea Klug., Holutrichins apterus Jak. und Cicadatra lineola Iíeb.

Bemerkenswerth ist das hierortige Vorkommen des ägyptischen Pachynomus picipes Klug. 1), von dem ein Stuck im Kreise Aresch erbentet wurde.

Ueber die Ilemipterenfauna der Kaukasusländer findet man in vielen Spezialwerken und Fachzeitschriften einzelne zerstrente Angaben. Speziell nit der lauma dieses Gebietes befassen sich folgende Arbeiten:

Kolenati, Friedrich $\Lambda$. ., Meletemata Entomologica. II, IV, VI, VII. $1845-57$.

Flor, Gust., Rhynchoten aus dem Caucasus und von der Grenze Persiens. (Bulletin de la Société Imp. des Naturalistes de Moscou. 1861. I. pag. 619-623).

Horváth, G., Beitrag zur Hemipteren-Fauna Transkaukasiens. (Dr. O. Schneider, Na-

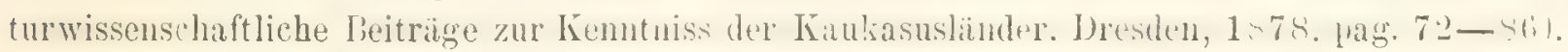

Horváth, G., Hemipterologisches aus Transkaukasien. (Sitzungsberichte der Naturwissenschaftlichen Gesellschaft Isis zu Dresden. 1879).

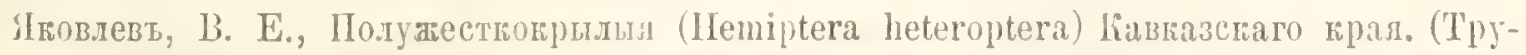
ды Pусск. Энтозолог. Общества. XIL. 1880, pag. 3-176. und XII. 1882. pag. 85-140).

Horváth, G., Die Hemipteren des Talysch-Gebietes. (Dr. G. Radde, Die Fauna und Flora des südwestlichen Caspi-Gebietes. Leipzig, 1886. parg. 216-254).

Horváth, G., Hemiptères recueillis dans l'Armenie russe avec la description d'espèces et variétés nouvelles (Revue d'Entomologie. X. 1891. jag. 68-81).

Horváth, G., Hémiptères recueillis daus la Russie méridionale et en Transcaucasic (Revue d'Entomologie. XIII. 1894. pag. 169-189).

Dr. Gr. Horváth.

\section{FAM PENTATOMIDAE.} Coptosoma Lap.

globus Ii. Derb., Gagry., N. Rossk.

Arctocoris H. S.

lanatus Pall. Derb.

\section{Odontoscelis Lap.}

fuliginosa L. Derb., Kasikp., U-der. dorsalis F. Derb.

\section{Odontotarsus Iap.}

grammicus L. Derb., Kasikp., N. Rossk.

\section{Psacasta Germ.}

conspersa Fieb. Derb.

\section{Eurygaster Lap.}

maura L. Kub., 'I'an., Michfld, Derb., Kasilkp.

integriceps Put. Aresch.

dilaticollis Dohrn. Derb.

\section{Tarisa Am.}

virescens H. S. Derb.

subspinosa Germ. Derb., Kulp., Mresch.

\section{Trigonosoma Lap.}

rusticum F. N. Rossk.

Ancyrosoma Am.

albolinentum F. Lenk., Anit., Derb., Arescli.

\section{Tholagmas Stil.}

flavolineatus $\mathrm{F}$. Derb.

1) Ind des afrikanischen Pirates quadrintaculatus Sirv. 
Graphosoma Iap.

semipunctatum F. Derb., Eiljar., Aresch. lincatum L. 'J'an,, T'm.-Ch.-Sch., U-der. Derb., Anit., Mang.

Podops Lap.

annulicornis Jak. Derb.

\section{Cyduas F.}

(rmatulus Jak. Derb.

Comaroftii Jak. I)erb.

nigrita F. Mlesk. G., Georgk.

\section{Macroscytus Fieb.}

brumens F. Aresch.

\section{Geotomus Muls.}

punctulatus Costa. Derb.

elongatus II. S. Derb.

Brachypelta Am.

aterrima Fuerst. Derb., Sardab,

\section{Sehirus Am.}

rolustus Horv. Eiljar.

morio L. TAf.

ovatus II. S. Derb.

luctuosus Nuls. Derb., Tan.

sesmaculatus Rbr. Derb., Mang.

bicolor L. Mang., Polk., Kub., Tan.

dubius Scop. Derb.

var, melanopterus H. S. Kasikp., Polk., Erz.Bgl.

congener Jak. Derb.

Gnathoconus Fjeb.

allomarginatus Goez. Káali.

Ochetostethns Fieb.

manus II. S. Derb., Kasilin., Iffl, גresch.

\section{Sciocoris Fall.}

macrocephalus rieb. Kasilip., Derb.

mirophthalmus Flor. Kauk.

sulcatus lieb. Derb.

terreus Suhrk. Derb.

\section{Dyroderes Spin.}

marimatus E: Derl,
Mustha Am.

simulosa Lef. Derb.

\section{Apodiphus Spin.}

anygdali Germ. Nachtw.

Aelia $F$.

acuminata L. Derb., Kasikp., Aresch.

var. Lummeisteri Kist. Kauk.

melanota Fieb. Aresch.

rostrata Boh. Alist.

\section{Neottiglossa Curt.}

intlexa Wolft var. lineolata M. R. Mang. leporina II. S. Kasikp., Tan.

\section{Stagonomus Gorsk.}

bipunctatus I:. Derb., N. Rossk., 'T'an.

\section{Ensarcoris Hahn.}

inconspicuus II. S. Derb., Ersi., Aresch.

\section{Staria Dohrn.}

lumata Hahn. Derb., N. Rossk.

\section{Cnophosa Jak.}

fluvomarginata Jak. Kasikp.

\section{Peribalus Muls.}

verualis Wolfi. Derb., Kasikp., Tan.

\section{Carpocoris Kol.}

fuscispinus Boh. Kasikp., Derb., Aresch. nigricomis $\mathrm{H}$. Anit, dzkur., Artwin., N. Rossk. lynx F. Derb., Kulp., Kasikp.

varius F. var. lunula F. Derb., Achty., N. Rossk.

Dolycoris M. R.

baccarum L. Derb., Kasikp., 'T'an.

\section{Agatharchus Sti̊l.}

linea Klug. Kasikn.

Herrichii Kol. 'Tfl.

\section{Rhombocoris Mayr.}

regularis II. S. Achty., Kasikp. 
Palomena M. B.

viridissima Pod. U-der., Elbr., Derb., Lenk., Mang.

prasina L. Lenk., Tan.

\section{Pentatoma 01.}

pinicola M. B. Mang.

\section{Brachynema Muls.}

virens $\mathrm{K}$ l. Derb.

\section{Nezara Am.}

viridula $\mathrm{L}$. U-der.

\section{Piezodorus Fieb.}

incarnatus Germ. Derb.

\section{Rhaphigaster Lap.}

grisea F. Derb., Mang.

\section{Tropicoris Hahn.}

rufipes L. Zch-Zch.

\section{Eurydema Lap.}

ornatum L. Tfl.

var. pectorale Fieb. Kauk.

var. dissimile Fieb. Kauk.

festivum L.

var, pictum H. S. Derb., Mang, 'Tbtn.

var. chloroticum Horv. Kasikp.

var. maracandicum Osch. Kauk.

decoratum H. S. Anit., Mang., Mug., Polk.,

Tfl., U-der.

dominulus Scop. Derb.

oleraceum L. Derb., Mang., Kul. var. annulatum Fall. Kasilip., Dagt.

\section{Trochiscocoris Horv.}

rotundatus Horv. Tan.

\section{Arma Hahn.}

custos F. Derb.

Podisus H. S.

luridus F. Tan.

\section{Zicrona Am.}

coerulea L. Derb., Ellor.

\section{Acanthosoma Cart.}

haemorrhoidale L. Derb., Mang., Tan.

Elasmostethus Fieb.

interstinctus L. Tan.

\section{FAM. COREIDAE.}

\section{Phyllomorpha Lap.}

laciniata Vill. Tfl.

\section{Centrocoris Kol.}

spiniger F. Derb., T'fl., Anit, U-der., Aresch.

Enoplops Am.

scapha F. Derb. Mang., Tan.

Syromastes Latr.

marginatus L. Elbr., Tan., Derb., Mang., Kasikp.

var. fundator H. S. Anit.

Verlusia Spin.

rhombea L. Kas-knt., Derb., Mang., Tan.

Gonocerus Latr.

juniperi H. S. Ausch.

venator $\mathrm{F}$. Derb., Aresch.

\section{Pseudophloeus Brm.}

Waltlii H. S. Kauk.

\section{Bathysolen Fieb.}

nubilus Fall. Kauk.

\section{Ceraleptus Costa.}

squalidus Costa. Derb

gracilicornis H. S. Derb.

\section{Coreus F.}

hirticornis F. Derb., Mang., Aresch., 'Tan.

Camptopus A. S.

lateralis Ger. Polk., Artwin., Aresch., Abst, Derb., Mang., Kub.

tragacanthae Kol. Tfl. 
Stenocephalus Latr.

agilis Scop. Derb, Kasilip., Aresch.

neglectus H. S. Abst.

'Iherapha Am.

hyoscyami I. Borsh., Kulp., Aresch., 'Tan., Derb., Martk.

\section{Corizus Fall.}

crassicornis L. Such., Derb., $\Lambda$ bst. var. abutilon Rossi. Anit., Polk., Th., Areseh. maculatus Fieb. I)erb.

capitatus Fab. Nbst., 'Tan. parumpunctatus Schill. Abst.

tigrinus Schill. Kasikp., Tft, Abst.

\section{Maccevethus Dall.}

errans F. Derb., Polk., Tf.

\section{Agraphopus Stůl.}

Lethierryi Stål. Madsh.

\section{Chorosoma Curt.}

Schillingi Schml. Derb.

\section{FAM, BERYTIDAE.}

\section{Neïdes Latr.}

tipularius L. Kauk.

\section{FAM. LYGAEIDAE.}

\section{Lygaeus F.}

leusopterus Goeze. Derb.

equestris L. Kasikp., Polk., Derb., Lenk.,

Anit,, Kub., Tan., Aresch., Lom-mta. saxatilis Scop. Derb., Eiljar., Kasikp., N.

Rossk., U-der.

apuans Rossi. Derb., Kasikp., Polk.

Tristrami Dgl. Derb.

punctatoguttatus F. Derb., Mug.

\section{Lygaeosoma Spin.}

reticulatum H. S. Derb.

\section{Arocatus Spin.}

melanocephalus F. Derb.

Roeselii Schum. Jerb.
Nysius Dall.

graminicola Kol. Derb.

senecionis Schill. Mesk. G., Derb.

punctipennis II. S. Derb.

\section{Cymus Hahn.}

melanocephalus Fieb. Derb.

claviculus Fall. I)erb.

\section{Ischnorhynchus Fiob.}

resedae P'z. 'T'an.

Ischnodema Fieb.

sabuleti Fall. Derb.

\section{Henestaris Spin.}

laticeps (urt. I)erb.

Geocoris Fall.

ergthrocephalus Lap. Derb., 'Tft., Polk , Aresch.

siculus Fieb. var, arenarius Jak. Kas-knt. albipennis $\mathrm{F}$. Derb.

lineola Ramb. Kulp.

\section{Artheneis Spin.}

hircanica Kol. Derb.

alutacea Fieb. Derb.

\section{Holcocranum Fieb.}

saturejae Kol. Derb.

\section{Chilacis Fieb.}

typlae Perr. Derb.

\section{Heterogaster Schill.}

rufescens H. S. Mang.

affinis II. S. $\Lambda$ bst.

var. rubricata Put. Tan., Aresch.

urticae F. Abst.

\section{Cymophyes Fieb.}

ochroleuca Fieb. Derb.

\section{Microplax Fieb.}

interrupta Fieb. Derb., 'Tfl.

\section{Brachyplax Fieb.}

palliata Costa. Derb. 
Metopoplax Fieb.

ditomoïdes Costa. Kauk.

origani Kol. Derb., 'I'fl., A resch.

\section{Oxycarenus Fieb.}

collaris M. R. Derb., Tffl.

\section{Macroplax Fieb.}

fasciata H. S. Derb.

\section{Rhyparochromus Curs.}

hirsutus Fieb. Kauk.

colon Put. Derb.

praetextatus H. S. Mesk. G.

dilatatus II. S. Tan.

chiragra F. Martk., Derb

var. sabulicola Thms. Kank.

Tropisthetus Fieb.

holosericeus Schultz. Derb.

Pterotmetus Am.

staphylinoides Bur. Derb.

Ischnocoris Fieb.

punctulatus Fieb. Tfl.

Lamprodema Fieb.

maurum Fieb. Derb.

Plinthisus Fieb.

lungaricus Horv. Derb.

Lasiosomus Fieb.

enervis H. S. Martk.

\section{Acompus Fieb.}

rufipes Wolff. Derb.

\section{Stygnocoris D. S.}

pedestris Fall. Kauk.

arenarius Hahn. Kank.

Peritrechus Fiob.

angusticollis Salılb. Derb.

geniculatus Hahn. Kauk.

gracilicornis Put. Mesk. G., Derb.
Microtoma Lap.

atrata Goeze. Derb.

Trapezonotus Fieb.

agrestis liall. Kauk.

dispar Stål. Mesk. G.

Calyptonotus Dgl.

Rolandri L. Derb., Nang.

\section{Aphanus Lap.}

consors Horv. Borsh.

lynceus F. Derb.

Beckeri Frey. Derb.

quadratus F. Kasikp., Derb.

pineti II. S. Mang.

pedestris $\mathrm{Pz}$. Derb., Nang.

vulgaris Schill. Derb., Mang.

pini L. Kauk.

phoeniceus Rossi. Derb., Mang.

Beosus Am.

erythropterus Brul. Derb.

var. ibericus Kol. A resch.

lascus F. Tfl., Tan.

\section{Nenrocladus Fieb.}

brachiidens Duf. Aresch., Tfl.

\section{Emblethis Fieb.}

verbasci F. Derb., Mesk. G., Mang.

griseus Wolff. 'Tff.

var. bullatus Fieb. Kauk.

denticollis Horv.'Derb.

ciliatus IIorv. Derb.

\section{Eremocoris Fieb.}

plebejus Fall. Mesk. G. podagricus $\mathrm{F}$. Kauk.

\section{Drymus Fieb.}

pilicornis Muls. Kauk.

sylvaticus F. Derb., Abst.

brunneus Sahlb. Mesk. G.

\section{Scolopostethus Fieb.}

pictus Schill. Mesk. G. 
affinis Schill. Derb., 'Tfl.

aljunctus Dgl. Derb., Ttr.

pilosus Reut. Kíauk.

Lethierryi Jak. Kauk.

\section{Notochilns Fieb.}

contractus H. S. Kauk.

marginicollis Isuc. Tft.

\section{Pyrrhocoris Fall.}

aegrptius L. Derb., Aresch.

apterus L. Derb., Mang.

marginatus Kol. Kauk.

\section{FAM. TINGIDIDAE.}

\section{Piesma Lep.}

Kolenatii Fieb. Derb.

maculata Lap. Derb.

\section{Cantacader Am.}

quadricornis Lep. Kauk.

\section{Serenthia Spin.}

atricapilla Spin. Derb.

laeta Fall. Derb.

\section{Acalypta Westw.}

uniceriata Put. Mesk. G.

\section{Dictyonota Curt.}

crassicornis Fall. Derb., 'Tfl.

\section{Galeatus Curt.}

Komaroftii Jak. Derb.

Tingis F.

pyri F. Derb.

\section{Enrycera Lap.}

clavicornis Fourc. Derb.

brevicornis Jak. Derb.

\section{Monanthia Lep.}

cardui L. Martk.

auriculata Costa. Derb., Poll.

rotundicollis Jak. I)erb. ciliaris P'ut. Derb.

ragusana Fieb. Derb.

grisea Germ. Kauk.

capucina Germ. Derb.

var. gracilis H. S. Derb.

geniculata Fieb. Derb., 'Tfl.

angusticollis H. S. var. reducta Horv. 'Tft.

pilosa Humm. Derb.

dilatata Jak. Derb.

cryngii Latr. Derb.

melanocephala $\mathrm{P} z$. Derb., Kasikp.

dumetorum H. S. Mang.

platyoma Fieb. Derb., Eiljar.

Wolffii Fieb. Derb., Tfl., Abst., 'I'an.

vesiculifera Fieb. Derb., Tan.

\section{Monosteira Costa.}

unicostata M. R. Kauk.

\section{FAM.ARADIDAE}

\section{Aradus F.}

versicolor $H$. S. Kauk.

diversicornis Horv. Lenk.

depressus F. Mesk. G.

dilatatus Duf. Derb.

lugubris Fall. Kauk.

caucasicus Kol. Derb., Tan.

betulae L. Derb., U-der., Lom-mta.

\section{Brachyrhynchus Lap.}

tremulae Bttn. Derb.

\section{Aneurus Curt.}

laevis F. Mesk. G., U-der.

\section{FAM. HEBRIDAE}

\section{Hebrus Cart.}

montanus Kol. Kauk.

FAM, HYDROMETRIDAE

\section{Hydrometra Latr.}

stagnorum L. Derb

\section{Velia Latr.}

rivulorum I'. Derb. 


\section{Gerris F.}

paludum $\mathrm{F}$. Derb.

Costae H. S. Derb.

thoracica Schum. Derb.

lacustris L. Derb.

\section{FAM, REDUVIDAE.}

Pygolampis Germ.

bidentata Fourc. Derb.

\section{Centroscelicoris Put.}

spinosus Jak Derb.

desertus Beck. Derb.

\section{Oncocephalus Klug.}

brachymerus Reut. $\lambda$ resch.

squalidus Rossi. Derb.

notatus Kl. Derb., Anit., Gagry., Kulp.

Holotrichins Burm.

apterus Jak. Eiljar., Kulp., Aresch.

\section{Reduvias F.}

personatus L. Derb., Tfl, Borsh., Aresch. testaceus II. S. Derb., Eiljar., Aresch. ciliatus Jak. Aresch.

\section{Pirates Berv.}

quadrimaculatus Serv. Aresch. ululans Rossi. Derb., Aresch. hybridus Scop. Derb., Mang., Aresch.

\section{Harpactor Lap.}

Kolenatii Reut. Apsch,

rubrogularis Horv. Tan.

iracundus Poda N. Rossk., Dartag., Derb., Kub., Artwin

var. rubricus Germ. Kasikp.

erythropus L. Kauk.

monticola Osch. var. rubricoxa Brgr. Kasikp.

\section{Coranus Curt.}

aegyptius F. Derb.

\section{Nagusta Stål.}

Goedelii Kol. Aresch.

\section{Callistodema Rout.}

fasciatum Kol. Derb., Aresch.

\section{Pachynomns Klug.}

picipes Klug. Aresch.

\section{Prostemma Lap.}

aeneicolle Stein. Mang.

sanguineum Rossi. Derb., Mang.

\section{Nabis Latr.}

lativentris Boh. Kauk.

sareptanus Dhr. Derb.

ferus L. Tan., Mang., Polk., Kulp., Tf., Derb.

rugosus L. Tan.

viridulus Spin. Derb.

\section{FAM. SALDIDAE}

\section{Salda F.}

orthochila Fieb. Kauk.

saltatoria L. Kas-kut.

pallipes F. Derb.

lateralis Fall. Derb.

\section{FAM. CIMICIDAE}

\section{Cimex L.}

lectularius L. Tfl.

\section{Lyctocoris Hahn.}

campestris F. Derb.

\section{Piezostethus Fieb.}

galactinus Fieb. Tff.

obliquus Costa. Derb.

ciliatus Jak. Derb.

\section{Temnostethus Fieb.}

pusillus H. S. Kauk.

\section{Anthocoris Fall.}

confusus Reut. Derb. nemoralis F. Kauk. gallarum-ulmi Deg. Ersi.

pilosus Jak. Derb. sylvestris L. Lom-mta. caucasicus Kol. Derb. 
I'riphleps Fieb.

nimpra Wolli. 'Tht, Derb.

majusculit lit. I)erb.

minnta Is. Káali.

\section{FAM. CAPSIDAE}

Gryllocoris Baer.

antusticollis liaer. Kasikp., 'Tan

\section{Acetropis Fieb.}

(arinata II. S. Kasilep.

\section{Mixis F.}

calcaratus Fall. Thil, Werb., N. Lossk.

virens: $I_{d}$. I)erb.

laevigatus J. Derb., 'T'un.

holsatus r'. Abst.

Megaloceraea Fieb.

crratica Is. Kank

longricornis Fall. Tan,

ruficornis Fourc. Derb., 'l'fl

Leptopterna Fieb.

dolabrata Is Kasikp

Monalocoris Dahlb.

flicis I, Mesk. G.

\section{Lopus Hahn.}

gothicus L. Derb.

infuscatus lirulle. Aresch.

\section{Allaeonotus Fieb.}

distinguendus If. S. Kauk.

\section{Calocoris Fieb.}

striatellus F. Mang.

Schmiltii Fieb. L,erb. Anit.

chenopodii l'all. Kasikp., Ḱub.

Costae Reut. N. Rossk.

randalicns Rossi. I)erb.

seticornis F. Mang, Kub.

var. pallidipennis Reut. Kasikp.

angularis Fieb. Mang., Kasikp.

\section{Odontoplatys Fieb.}

suturalis Jak. Tan.
Brachycoleus Fieb.

scriptus F. I)rb., Kasikp.

linectlus Jak. Kisikp.

\section{Lygus Hahn.}

pratensis F. N. linssk, Aresch., Polk, Derb., Til.

var. campestris F. Kasilip.

luenrum Ner. Mang.

Kalmii L. Derb., Kasikp., U-der.

var. flasorarius F. Derb.

var. pauperata II. S. Derb.

\section{Cyphodema Fieb.}

rubicunda Fall. Derb.

Poeciloscytus Fieb.

Gyllenhali Fall. ['olk., 'TH., T'an

holosericeus Hahn. 'Tan

unifasciatus F. Kasikp.

brevicornis Rt. Derb.

cognatus Fieb. Derb., Tfl.

\section{Camptobrochis Fieb.}

punctulata Fall. Derb., Kulp., Eiljar.. Tff. lutesceus Schill. Derb

\section{Liocoris Fieb.}

tripustulatus F. Derb., Tan.

\section{Capsus F.}

rutilus H. S, var. bellicosus Ilorv, N, Rossk.

trifasciatus L, Martk., Tan.

scutellaris I. Kasilip.

var. morio Boh. Derb.

Rhopalotomus Fieb.

cinctus Kol. I)erb.

\section{Plagiorhamma Fieb.}

suturalis II. S. Tft.

\section{Halticns Buxm.}

apterus L. Kasikp.

\section{Strongylocoris Costa.}

lencocephalus I. Tan.

niger H. S. Kasikp. 


\section{Labops Burm.}

Saltator Hahn. Derb., Eiljar.

vittipemis II. S. Kasikp., Tan.

\section{Dicyphus Fieb.}

pallidus H. S. Kauk.

errans Wolff. Derb.

globulifer Fall. Derb.

Globiceps Iratr.

sphegiformis Rossi, Marg.

flavomaculatus F. Kasikp.

\section{Orthotylus Fieb.}

marginalis Reut. Kasikip.

Havosparsus Sahlb. Derb.

minutus Jak. 'Tfl.

Platytomatocoris Reut.

planicornis II. S. M[artk.

Heterocordylus Fieb.

tumidicornis II. S. Martk.

\section{Malthacosoma Rent.}

junctipenne Reut. Tfl.

\section{Macrocoleus Fieb.}

molliculus Fall. Eiljar.

ochroleucus Kb. Kasikp.

tibialis Jak. Kasilip.

\section{Byrsoptera Spin.}

rufifrons liall. Derb.

\section{Pliylus Hahn.}

melanocephalus L. 'Tan.

coryli L, 'T'an.

\section{Criocoris Fieb.}

sulcicornis Ḱb. Kasikp.

\section{Plagiognathus Fieb.}

pictus Fieb. Kasikp.

chrysanthemi Wolff. Derb., 'lft.

arbustorum F. var. brunnipennis Mey? Kasikp.

albipennis Kall. Kasikp., Derb. var. Ianuginosus Jak. Derb.

rufinervis Jak.? Derb.

\section{Atomoscelis Rent.}

onustus kieb. 'Tf.

\section{Chlamydatus Curt.}

pullus Reut. Ersi., Kasikp.

Aachenocrepis Fieb.

lieuteri Jak. Derb.

Maurodactylus Rent.

nigricornis Reut. var. conformis Iorv. Tfl.

$$
\text { I'uponia Reut. }
$$

tamaricis Perr. Derb.

var. elegans Jak. Derb.

\section{FAM PELOGONIDAE}

Pelogonus Latr.

marginatus Latr. Aresch.

\section{FAM. NAUCORIDAE.}

Naucoris Geoffr.

cimicoïdes L. Derb.

\section{FAM. NEPIDAE.}

\section{Nepa $\mathbf{L}$.}

cinerea L. I)rb.

\section{Ranatra F.}

linearis L. Derb., Chass-jrt.

\section{F入M. NOTONECTIDAE.} Notonecta I.

glauca L. Derb., Kasikp., Hoch. Arm.

\section{FAM. CORIXIDAE} Corixa Geoffr.

Geoffroyi Leach. Kauk.

atomaria 111. Derb.

hieroglyphica Duf. Derb., Kulp., Kasilkp. 
Sahlbergi Kieb. Kauk.

limitata Fieb. Tf.

parallela Fieb. Kulp.

striata L. Derb.

praeusta Fieb. Kasikp.

carinata Sahlb. Chosp.

Rogenhoferi Fieb. Kulp.

\section{FAM CICADIDAE.}

Tettigia Am.

orni L. Derb. Kwril.

\section{Cicada I.}

plebeja Scop. U-der.

\section{Tibicen Am.}

haematodes Scop. Derb., Borsh. var. viridinervis Fieb. Mrax. quadrisignata Hag. Kaul.

\section{Cicadatra Am.}

lineola Fieb. Borsh., Kasikp., Tan. querula Pall. Kauk.

var. paliuri Kol. Aresch., Mingtsch.

hyalina F. Derb., Chass-jrt., Kasikp.

\section{Cicadetta Am.}

musiva Germ. Derb., Aresch.

var. caspica Kol. Temrg., Aresch.

montana Scop. Tan., Mang., Derb., Borsh.,

Pseasch.

tibialis Pall. Borsh., Derb.

prasina Pall. Kasikp., Eiljar., Sardab.

\section{FAM. FULGORIDAE.}

\section{Meenoplus Fieb.}

albosignatus Fieb. Kulp.

\section{Cixius Fieb.}

desertorum Fieb. Derb., 'Tf.

Scotti Edw. TH.

stigmaticus Germ. 'Tan.

simplex H. S. Mang.

vitripennis Kb. Kauk.

\section{Oliarus Stủl.}

melanochaetus Fieb. 'Tff. major Kb. Derb.

var. roridus Fieb. Kasikp., Kulp.

pallens Germ. Derb.

Panzeri Loew. Tfl.

quinquecostatus Duf. Derb.

\section{Dictyoptera Germ.}

multoreticulata Muls. N. Rossk, 'Tan.

\section{Mycterodes Spin.}

intricatus Stål. N. Rossk.

\section{Issus F.}

Koenigi Horv. Kasikp.

frontalis Fieb. Mang., U-der., 'Tan.

ovifrons Put. Tfl., 'Tan.

\section{Hysteropterum Am.}

montanum Iieb. Derb., Kasikp.

pictifrons Horv. Kulp.

\section{Asiraca Latr.}

clavicornis 1 . Tfl., Polk.

\section{Araeopus Spin.}

crassicornis F. TH.

\section{Conomelus Fieb.}

lepidus Boh. 'TH.

\section{Delphax F.}

pellucida F. Tft.

albostriata Fieb. Polk.

propinqua Fieb. 'TH.

\section{Tettigometra Latr.}

longicornis Sig. Kauk.

Barani Sig. Derb.

sulphurea M. R. I)erb, Tfl.

hispidula Fieb. Derb.

obliqua Pz. 'TH, Derb.

costulata Fieb. Kulp.

\section{FAM. CERCOPIDAE Triecphora Am.}

sanguinolenta L. Derb., Mang., Polk., Tfll, 'Tan., Aresch. 
Lepyronia Am.

coleoptrata L. Such., Kasikp

\section{Aphrophora Germ.}

alni Fall. Borsh., Derb., Such.

\section{Ptyelns Lep.}

lineatus L. Kasikp.

spumarius L. Tfl., Kasikp., Tan.

var. lateralis L. 'Tff.

var. marginellus F. Tft.

var. fasciatus F. TA

var. lineatus $\mathrm{F}$. Tfl.

var, pallidus $\mathrm{F}$. Tfl.

var. populi L. Tfl.

\section{FAM. MEMBR ACIDAE.}

Centrotus $\mathrm{L}$.

cornutus Is. Borsh., Mang., Ersi., Tan.

Gargara Am.

genistae $\mathrm{F}$. Abst.

\section{FAM JASSIDAE}

\section{Ledra F.}

aurita L. Mzhet., Borsh., N. Rossk.

\section{Idiocerus Lew.}

scurra Germ. Aresch.

Ilerrichii Kb. Nlang.

affinis Fieb. Mang.

elegans Flor. Mang.

ustulatus M. R. Derb.

\section{Bythoscopas Germ.}

flavicollis L. Tan.

\section{Pediopsis Burm.}

dispar F. Derb.

nana II. S. Derb.

\section{Agallia Curt.}

sinuata M. R. T'f. reticulata H. S. Mang. venosa Fiall. Derb., TH.
Tettigonia 01.

viridis $L_{4}$. Anit., Tfl.

\section{Euacanthus Lep.}

interruptus L. Kasikp.

acuminatus F. Borsh.

\section{Eupelix Germ.}

producta Germ. Derb.

\section{Acocephalus Germ.}

striatus F. TAl, Derb., Kasikp., Borsh.

bifasciatus L. Tbtn., T'an.

tricinctus Curt. Kasilip.

elongatus Leth. Derb.

\section{Solenocephalus Germ.}

obsoletus Germ. Kasikp.

\section{Parabolocrutus Fieb.}

viridiı.ervis Horv. Tfl.

\section{Paramesus Fieb.}

nervosus Fall. TH.

\section{Gnathodus Fieb.}

punct:tus Thnb. Mang., Derb., Polk.

Cicadula Zett.

sexnotata Fall. Tfl., Kasilp.

erythrocephala Ferr. TH.

\section{Phlepsias Fieb.}

jintricatus II. S. Mang

binotatus Sign. Kulp.

\section{Thamnotettix Zett.}

fenestratus H. S. Tfl., N. Rossk.

var. guttulatus $\mathrm{Kb}$. 'Tfl.

prolixus Leth. Tft.

attenuatus Germ. Mang.

\section{Athysanus Burm.}

stactogala Am. Kauk.

striola Fall. 'Tt1.

obscurellus Kb. Tht, Polk.

distinguenlus Kb. Derb.

procerus II. S. 'Iffl. 
Goniagnathus Fieb.

brevis II. S. Mang., Derb.

\section{Jassus $F$.}

atomarins Germ. 'TH., Areseh.

Mayri Kb. Borsh.

\section{Platymetopius Burm.}

rostritus H. S. 'l'tl.

Deltocephalus Burm.

ocellaris Fall. Kauk.

striatus L. Nang., 'Til., Kasikp.

linnei l'ieb. Tft.

\section{Chlorita Fieb.}

Havescens di. Mang., TH,

bipunctata Osch. 'TH.

\section{Eupteryx Curt.}

carpini lourc. Thl.

Curtisii Flor. Tfl.

\section{Zygina Fieb.}

tiliae Geoffr. Mang.

$$
\begin{gathered}
\text { FAM. PSYLLIDAE. } \\
\text { Rhinocola Forst. }
\end{gathered}
$$

speciosa Fl. 'T'tl.

\section{Psylla Geoffr.}

glyeyrrhizae lieck. Derb.

mali Scholbg. Mang.

nigrita Zett. 'T'll.

\section{I'riozn Fist.}

viridula Kett. Mang.

\section{FAM. APHIDAE}

\section{Siphopophora Koch.}

rosae L. 'TH.

\section{Aphis L.}

hederae Kalt. Tf.

labuni Kalt.? Tfl.

\section{Pterochlorus.}

ammlipes Horv. Tfl.

Chermes I.

funitectus Dreyf. Borsh.

FAM. COCCIDAE.

Lecanium Ill.

coryli L. T'an.

\section{HEMIPTERA TRANSGSSPICA.}

FAM. PENTATOMIDAE.

0dontoscelis Lap.

fuligmosa I, var. dorsalis Ialn. Ifohanengrenze.

Eurygaster Lap.

integriceps I'ut. 'T'ekke.

\section{Amaurocoris Stal.}

camdidatus IIorr. Artsehman.

\section{Apodiphus Spin.}

amygidali Cierm. 'Transkip.

\section{Carpocoris Kolen.}

fus:ispinus Boh. Jelotan., Islim-tschesme, Aschabal.

\section{Dolycoris MuIs.}

baccarum L. Jelotan, Akrabad., Sary-jasy.

Chroantha Stål.

ormatula H.-Sch. Ach-1agh 9000'.

Brachynema Muls.

turanicum Ilorv. Achodagh 9000 '.

virens lilug. 'Transkp. 
Eurydema Lap.

ornatum I. Teklie.

festivum L. var. pictum II. S. Transkp var. decoratum $H$. S. Transkp.

Zicrona Am.

coerulea L. Jelotan., Beusch-berma.

\section{FAM, COREIDAE}

\section{Centrocoris Kol.}

Volxemi Put. Sary-jasy.

Ceraleptus Costa.

squalidus Costa. Tekle.

\section{Dasycoris Dall.}

denticulatus Seop. Jelotan.

Camptopus A. et S.

lateralis Germ. Transkp.

Chorosoma Curt.

Schillingi Suhum. Ach-dagh $9000^{\prime}$.

\section{FAM LYGAEIDAE.}

Geocoris Fall.

siculus Fieb, var. arenarius Jak. Neu-Merw.

Artheneis Spin.

alutacea Fieb. 'Tscherwach.

Oxycarenus Fieb.

collaris Muls. Jelotan.

Lamprodema Fieb.

raaurum F. Aitschman.

\section{Hyalocoris Jac.}

pilicornis Jak. Artschman.

longicollis Jak. Transkp.

\section{Calyptonotus $\mathrm{Dgl}$.}

Rolandri L. Alt-Merw., Jelotan.

\section{Beosus Am.}

maritimus Scop. Beusch-berma.
Emblethis Fieh.

verbasci $\mathbf{F}$. Afghanengrenze.

Camptocera Jak.

Horvathi Jak. Transkp.

Scanthius Stål.

aegyptius Is. Alt-Nerw.

FAM. HYTROMETRIDAE.

Gerris F.

thoracica Schum. Neu-Nerw., Amu-Darja. argentata Schum. Neu-Merw, Amu-Darja.

FAM. REDUVIIDAE.

\section{Oncocephalus Klug.}

plumicornis Germ. Tekke.

brachimerus Reut. Tekke.

Stirogaster Jak.

Fausti Jak. Transkp.

Reduvius $\mathbf{F}$.

tabidus Klg. Adam-ilen., Sary-jasy.

disciger Horv. Transkp.

var infuscatus Horv. Transkp.

Christophi Jak. Transkp.

\section{Ectomocoris MIayr.}

ululans Rossi. Sary-jasy.

\section{Harpactor Lap.}

Abramovii Osch. Akrabad.

\section{Nabis Latr.}

sareptanus Dohrn. Jelotan., T'kelke.

ferus L. Jelotan.

FAM. CAPSIDAE

\section{Lopus Hahn.}

infuscatus Brll. var. turcomanus IIorv. Beusch-berma.

\section{Calocoris Fieb.}

lineolatus Goeze. I'ul-i-chatum. 
I'uponia Rout.

tamaricis Perr var. clegans Jak. Sary-jasy.

\section{FAM. CORIXIDAE}

\section{Corixa Geoffr.}

Jakowlefti Horv. Neu-Merw.

hieroglyphica Duf. Neu-Merw.

atomaria Ill. 'Transkp.

striata L. 'Transkp.

\section{FAM. NOTONECTIDAE}

\section{Notonecta L.}

gnlatuca Is. Amu-darja., 'Tachtabasar.

\section{FAM. JASSIDAE.}

Phlepsius Fieb.

binotatus Sign. Pul-i-chatum.

\section{FAM, CERCOPIDAE.} Ptyolus Lop.

nebulosus Lath. Ach-dagh 9000'.

\section{FAM. FULGORIDAE.}

\section{0liarns Stål.}

pallens Germ. 'T'ekke.

cuspidatus lieb. Beusch-berma.

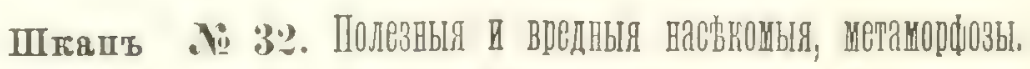

Schrank ํㅜ :32. Nützliche mil schädliche Insecten, Metamorphosell.

Nomenclature de la collection d'échantillons de soies, de déchets de soie de cocons; et de déchets de cocons pour le Gouvernement.

1) Sole Grêge de filature a vapeur provenant de cocons verts de race japonaise $9 / 11$ Deniers.

2) Soie Grêge de filature a vapeur provenant de cocons verts de race japonaise, 16/18 Deniers.

3) Soie Grêge de filature a vapeur provenant de cocons jaunes de race française.

4) Sole Grêge de filature a vapeur provenant de cocons blanes de race française.

5) Organsin tours comptés provenant de cocons verts de race japonaise, 28 deniers.

6) Orannin tours comptés provenant de comns verts de race japonaise, 2B/30 deniers.

7) Organsin tours comptés provenant de cocons verts de race japonaise, 42 deniers.

8) Trame tours comptés provenant de cocons verts de race japonaise, 60 deniers.

9) Trame tours comptés provenant de cocons verts de race japonaise, 34/36 deniers.

10) Soie Grêge irrégulière provenant de filature indigène et de cocons verts de race japonaise.

11) Soie Grége irregulière provenant de filature indigene et de cocons jaunes safranés race bâtarole.

12) Frisons de filature a vapeur.

13) Frisonnets de filature a vapeur et moligêne.

14) Bassinés.

15) Cocons cuits $=$ bouillis.

16) Cocons triés de race jaune française.

17) Cocons verts triés de race japonaise.

18) Cocons jaunes safranés de race japonaise abâtardie. 
19) Cocons doubles de race japonaise.

20) Cocons tachés, piqués et chiques.

21) Cocons de rase provenant de Perse ou du Talich.

22) Cocons de race Khorassan.

23) Cocons percés de graines de race française jaunes et blancs.

A. Lehericey.

4 образца пелга отъ К. А. Бабаева, Ордубадъ.

2 » $\quad$ Г. Герсп, Јенкорапь.

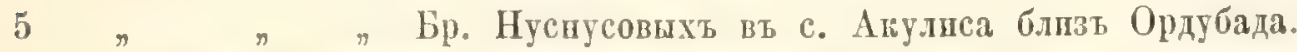

4 Seidenproben von K. A. Babajew, Ordubad.

$2 \pi$ ॠ. Gersi Lenkoran.

$5 \pi$ Gebr. Nusnusow in Akulissa bei Ordubad.

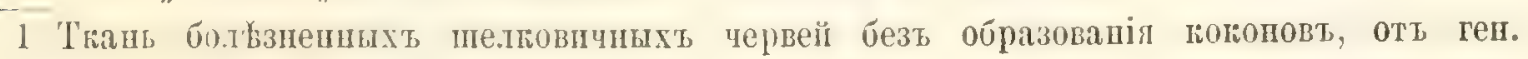
Агаларова.

1 Gewebe kranker Seidenraupen ohne Kokonbildung von Gen. Agalarow.

1 осце гпғздо, Абастуманъ Дрь Гаврилю.

1 Wespennest, Abastuman Dr. Gawrilko.

Cocon Psyche quadrangularis Christ. Aschabad, Krasnowodsk.

Phylloxera vastatrix Planch. 60. Praeparate.

\section{Въ спирть, in Spiritus.}

Eruca Bombyx mori L. ital. Lenkoran 71.

Развтіе шелвовпнихт червей въ 5 возрастахт.

Entwickelung ron Seidenraupen in 5 Stadien.

Metamorphose Cis boleti L. Sugd.

Melasoma populi L. Tan.

Larva Cerambyx cerdo L. var. acuminatus Mot. Sugd.

Eruca Acherontia atropos L. TH.

n Sphinx ligustri L. Aresch.

" Deilephila euphorbiae L. Tfl.

"Saturnia pyri L. N. Rossk.

" $\quad$ cephalariae Christ. Kasikp.

Chrysalis Scolia haemorrhoidalis F. Batum.

Gallae Chermes funitectus Dreyf. Borsh.

Метаморфозы въ стеклянныхъ ящинахъ отъ Бришке.

Metamorphosen in Glaskästen von Brischke.

Polyphylla fullo L.

Melolontha vulgaris $\mathrm{F}$.

Anobium pertinax $\mathrm{L}$.

Pissodes pini L.
Anthonomus pomorum L.

Orchestes quercus $\mathrm{L}$.

fagi $L_{\text {s. }}$

Rhinomacer betulae $\mathrm{L}$. 
Pityogenes bidentatus Ilbst. Ips sexdentatus Boern.

Hylotrupes bajulus L.

Aromia moschata L.

Acanthocinus aedilis L.

Saperda populnea $L_{s}$.

Phytodecta rufipes Deg.

Nelasoma aenea $L$. populi L.

Agelastica alni L.

Galerucella viburni $\mathrm{Pk}$.

Cassida nebulosa L.

Coccinella 7 -punctata L.

Aporia crataegi L.

Pieris brassicae L.

napi L.

Vanessa polychloros L.

Sphinx pinastri $\mathrm{I}$

Sesia spheciformis Gern.

Spilosoma lubricipeda Esp.

Dasychira pudibunda $\mathrm{I}$.

Leucoma salicis L.

Porthesia similis Fuessl.

Psilura monacha $I_{\text {d. }}$

Bombyx neustria L. mori L.

Lasiocampa pini L.

Phalera bucephala L.

Diloba caeruleocephala L.

Acronycta aceris $\mathrm{L}$.
Mamestra pisi L.

n brassicae L.

n persicariae I.

Panolis piniperda $\mathrm{Pz}$.

Hypena rostralis L.

Abraxes grossulariata L.

Hybernia defoliaria $\mathrm{Cl}$.

Amphidasis betularius $L$.

Acrobasis consociella Hb.

'Tortrix Pilleriana Schiff.

Retinia buoliana Schift.

resinella $\mathrm{L}$.

Grapholitha funebrana Tr.

Carpocapsa pomonella L.

Hyponomeuta evonymellus L.

Coleophora nigricella Stph.

Tischeria complanella Hb.

Lyda flaviventris Retz.

Cimbex femorata L.

Arge rosae Deg.

Pteronus pavidus Lep.

salicis $\mathrm{L}$

Croesus septentrionalis L.

Eriocampoides limacina Retz

Hoplocampa rutilicornis $\mathrm{K} \lg$.

Athalia spinarum $\mathrm{F}$.

Phylloxera vastatrix Planch.

Lecanium hesperidum $\mathrm{L}$.

Aspidiotus nerii Bouché. 


\section{ARACHNIDA.}

\section{II А У К 00 Б Р А 3 Н Ы Я.}

\section{SPINNENTHIERE.}

Шкапь_31._-Schrank. 


\section{A R A C H NID A.}

\section{COTРУ ДНИКИ-MIT ARBEITER,}
A. Birula. St.-Petersburg. Solpugidae.
E. Koenig. 'Tillis. Euscorpius.
E. Simon. Paris.
Dr. A. Walter. 'Tiflis. Jena. Solpugidae.

Состапь ґол.тегіи пауюобразныхь до 1 лнваря 1899.

Gesammtbestand der Sammlung von Spimnenthieren bis 1 Januar 1899.

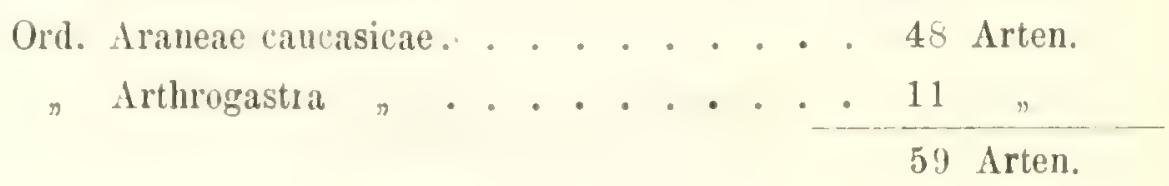

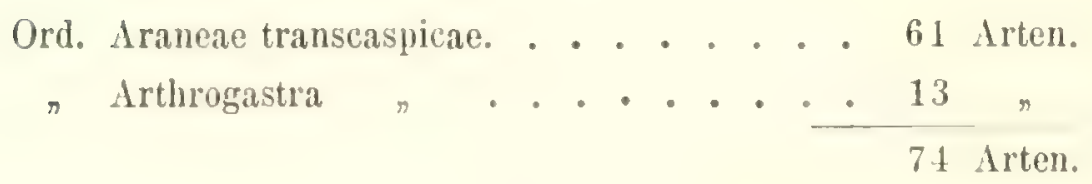

Ord. Araneae europaeae. . . . . . . 23 Arten.

"Arthrogastra $₫ . . . . . \cdot \frac{2}{25}$ Arten. 


\section{ARANEAE CAUCASICAE.}

\section{FAM. EPEIRIDAE}

Epeira Walck.

adiante Walck. N. Rossk.

angulatus $\mathrm{Cl}$. Wardane, Tfl.

inconspicuus E. S. Batum.

marmoreus Cl. Mastg.

Reedi Scop. Poti.

tatarica Cron. Mastg.

\section{FAM. THERIDIDAE.}

\section{Lithyphanthes Thor.}

Paykullianus Walck. Gagry.

FAM. DICTYNIDAE. Asagena Sund.

phalerata $\mathrm{Pz}$. Batum.

$$
\text { FAM. AGALENIDAE. }
$$

Tegenaria Latr.

longimana E. Sim. Batum.

Agalena Thor.

labyrinthica $\mathrm{Cl}$. Tff.

\section{FAM. ARGYRONETIDAE. Argyroneta Latr.}

aquatica Cl. Poti.

\section{FAM. DYSDERIDAE Dysdera Latr.}

punctata C. K. Batum. crocata C. K. Poti.

\section{Segestria Latr.}

florentina Rossi. Poti.

\section{FAM. DR ASSIDAE}

\section{Gnaphosa Latr.}

lugubris C. Ir. Gagry., Sugd., Tebul-m.

\section{Melanophora.}

caucasica L. K. Gagry.
Anyphaena Sund.

salina L. K. Batum.

Chiracanthium C. K.

punctorium Vill. Jewdk, Poti.

Clubiona Latr.

pallidula $\mathrm{Cl}$. Batum.

\section{Drassodes.}

lapidosus Walck. Batum, Temrg.

Micrommata C. K.

virescens $\mathrm{Cl}$. Zbld.

Thanatus C. K.

arenarius Thor. Tfl.

\section{Zora C. K.}

spinimana Sund. Batum.

Philodromus C. K.

dispar Walck. Batum.

lepidus Bl. N. Rossk.

FAM. THOMISIDAE.

Thomisus Walck.

albus Gml. Temrg.

Tibellus.

oblongus Walck. Sugd.

\section{Xysticus C. K.}

acerbus Thor. Zbld.

Kochi Thor. Tfl.

\section{Misumena Latr.}

tricuspidata F. Batum.

vatia Cl. N. Rossk.

\section{FAM SALTICIDAE}

Heliophanus C. K.

spee.? N. Rossk 
FAM. DENDRYPHANTIDAE

Marpessa C. K.

spec.? 'T'schor.

Philaens Thor.

phalangioides Fuess. Batum.

bicolor Walck. liatum.

\section{FAM. OXYOPOIDAE} 0xyopes Latr.

lineatus Latr. Zobld.

heterophithalmus Latr. 'Temrg.

Dolomedes Latr.

spec.? P'oti.

\section{FAM LYCOSIDAE Pisaura.}

mirabilis Cl. TH.

novicia C. K. Gagry., liatum., Sugd.
Lycosa Latr.

cinerea $\mathrm{H}$. Batum., l'emrg.

infernalis Mts. Chass-jrt.

ruricola Deg. 'Tt1., Batum., Zbld., Sugd. 'emrg.

singoriensis Luc. Tfl.

\section{Hyctia.}

Canertrinii Cron. Gagry.

\section{Heriaeus.}

hirsutus C. K. Temrg. N. Rossk.

\section{Synaema.}

slobosum F. 'Zbld.

Runcinia.

lateralis C. K. 'Temro.

\section{ARTHROGASTRA CAUCASICA.}

FAM. PHALANGIDAE. Phalangium $\mathrm{L}$.

spec.? N. Rossk.

\section{FAM. SOLPUGIDAE}

Galeodes 0liv.

araneoiles Pall. Aresch., Eiljar., Eriw., Kasilin, Dshebr., Kulp., Nachtw.

Rhax 0liv.

melanopyga Walt, Kulp.

Karschia Walt.

mastigofera liir. Kasikp.

FAM. PSEUDOSCORPIONIDAE Chelifer Leach.

spec.? Aresch., Batum.

\section{Obisium Leach.}

spec.? Gagry., Batum., Aresch., Lom-mta.

\section{FAM. SCORPIONIDAE.}

\section{Euscorpins Thor.}

awhasicus Nordm. Gagry.

mingrelicus Kessl. Batum., Gudaut, Sugd.

\section{Buthus Leach.}

cognatus Koch. Eriw. Arax, Nachtw., Jewdk., Saltinsk., Schtjk.

eupreus L. Koch. 'Tfl., Chram, Atene, Sardab., Lenk., Iiorsh., Dshebr. crassicauda Oliv. Ordb., Nachtw.

\section{ARANEAE TRANSCASPICAE.}

\section{FAM, ATTIDAE.}

Psendicins.

vittatus L. Sim. Sary-jasy.
Heliophanus C. K.

niveivestis $\mathrm{K}$. Sim. Mlt-Merw. melinus I. K. Ai-dere. 
Attulus E. Sim.

validus E. Sim.Alt-Merw.,Bergwäste Murgab.

\section{Aelarillus.}

ater Croneb. Aschabad.

\section{FAM OXYOPIDAE 0xyopes Latr.}

heterophthalmus Latr. Bagyr.

FAM. LYCOSIDAE.

\section{Pisaura.}

novicia Koch. Aschabad.

\section{Lycosa Latr.}

singoriensis Luc. Krasnowodsk.

ruricola Deg. Alt-Merw.

alticeps Cronb. Aschibbad.

Raddei E. Sim. Limu-darja.

soror E. Sim. Neu-Merw.

sp. juv.? Acrobat.

\section{Pardosa.}

orientalis Cronb. Neu-Merw., Ai-dere.

\section{Hippasa.}

deserticola E. Sim. Murgab.

\section{FAM. AGELENIDAE.}

\section{Cedicas.}

maerens E. Sim. Aschabad.

\section{FAM SPARASSIDAE}

\section{Sparassus Walck.}

oculatus Cronb. Artschman.

0lios.

sericeus Cronb. Aschabad.

\section{FAM.THOMISIDAE.}

\section{Thanathas C. K.}

imbecillus Koch. Artschman,; Ai-dere. spec.? Transcp.
Tibellus.

oblongus Walck. $\Lambda$ schabad oblongiusculus Luc. Bagyr., Ai-dere.

Philodromas C. K.

lepidus Blckw. Utsch-adshi. spec.? Ai-dere.

Monaeses Thor.

paradoxus Luc. Geok-tepe.

\section{Thomisus Walck.}

albus Gmel. Kungruili., $\Lambda$ i-dere.

Xyticas C. K.

Tristrami Cambr. Durun.

juv. ? Tekke.

acerbus Thor: Ai-dere.

Kochi Thor. Ai-lere.

\section{0xyptila.}

lugubris Cronb. Aschabad.

\section{FAM. EPEIRIDAE}

\section{Argiope Sav.}

lobata Pall. Aschabad, Krasnowodsk.

\section{Epeira Walck.}

adiante Walck. Ai-dere.

cornuta Clerck. Teklie

cerolegia Walck, var, victoria Thor, Durun. inconspicuus E. Sim. Ai-dere.

pubiventris E. Sim. Pul-i-chatum.

Redii Scop. $\Lambda$ i-dere.

\section{Zilla C. K.}

caspica. E. Sim. Imam-baba.

\section{Tetragnatha.}

extensa L. Tekke., Ai-dere.

\section{FAM THERIDIONIDAE.}

Lithyphantes Thor.

Paykullianus Walck. T'ekke.

\section{Linyphia Walck.}

pusilla Sund. Neu-Merw. 


\section{FAM. ZODARIIDAE.}

\section{Zodarium.}

Raddei E. Sim. Artschman.

\section{FAM. DRASSIDAE. Drassus Walck.}

fugax E. Sim. Krasnowodsk.

\section{Pythonissa.}

exornata Koch. Pul-i-chatum.

spec.? jur. 'lekke.

Chiracanthium C. K.

Siedlidzi Koch. Mor-kala.

erroneum Cron. Ai-dere.

Drassodes.

lapidosus Walck. Ai-dere

\section{FAM.DYSDERIDAE} Dysdera Isatr.

aculeata Cronb. 'Tekke., Ai-dere.

Micrommata Latr.

virescens $\mathrm{Cl}$. Ai-dere.

\section{FAM ERESIDAE.}

\section{Eresus.}

cinnabarinus Ol. var. rotundiceps E. Sim.

Chodsha-kala.

niger Petagn. Ai-dere.
FAM ULOBORIDAE

Uloborus.

Walckenaerius Isatr. Neu-Merw.

\section{FAM, DYCTINIDAE Dyctina Walck.}

Cronebergi L. Sim. Neu-Merw.

\section{FAM. AVICULARIDĀE Phyxioschema E. Sim.}

Raddei K. Sim. $\Lambda$ i-dere.

\section{Cyclosa.}

conica Pall. Ai-dere.

\section{Heriaens.}

hirsutus C. K. Ai-dere.

\section{Stegodyphus.}

lineatus Latr. Krasnowodsk.

\section{Synaema.}

plorator Cron. Ai-dere.

\section{Uroctea.}

limbata C. K. Ai-dere.

\section{ARTHROGASTRA CAUCASICA.}

FAM. PHALANGIDAE. Phalangium L.

spec.?'T'ekke., Ai-dere.

\section{FAM. SOLPUGIDAE.}

\section{Galeodes 01.}

caspius Bir. Aschabad.,Krasnowodsk., $\Lambda$ i-dere. araneoides Pall. Krasnowodsk., Ai-dere. fumigatus Walt. Aschabad.

\section{Rhax. 01.}

melanus Ol. Aschabal-Dort-kuju. plumbescens Walt. Aschabat.
Eylandti Walt. Dort-kuju. melanopyga Walt. Aschabad.

\section{Gluvia Koch.}

caucasica L. K. Ai-dere.

\section{FAM, SCORPIONIDAE: Buthus Leach.}

cognatus L. Koch. Krasnowodsk. eupaeus C. Koch. Ai-dere, Krasnowodsk.

Butheolus E. Sim.

Conchini E. Sim. IBely-bugor., Transkp.

Schneideri L. Koch. 'Transkp., Krasnowodsk. 


\title{
CRUSTACEA.
}

\author{
Р А К 0 О Б РА 3 Н Ы Я.
}

\section{KRUSTENTHIERE.}

ІІкапъ-31.-Schronk. 


\section{CRUS T A CEA.}

\section{COTPУ ДНИКИ-MITARBEITER.}

Akad. F. Brandt. St.-Petersburg.

E. Koenig. 'litilis.

Prof. Dr. 1. Ostroumow. Sewastopol. Kasan.

I). G. Radde. 'Tiflis.

Dr. A. Walter. 'Tiflis. Jena.

Составь голтеніи равообразних до 1 ливарл 1899.

Gesammtbestand der Sammlung von Krustenthieren bis 1 Januar 1899.

Crustacea caucasica et transcaspica. . . . . 108

exotica. . . . . . . $\frac{34}{142}$ 


\section{CRUST A CEA.}

\section{PANTOPODA.}

\section{Clotenia Dohrn.}

conirostris Dohrn. Bosporus.

\section{BRANCHIOPODA.}

\section{Branchiopus Dam.}

Raddeanus Wait. Ak-podlauk.

\section{Artemia.}

salina L. var. Molla-kary.

asiatica Walt. Salzquelle östl. Murgab.

\section{Estheria.}

dahalacensis Strn. Transkp.

\section{Evadne Lov.}

Nordmanni Lov. Mare nigr.

Podon Lillj.

Mecznikovi Czrn. Mare nigr.

\section{COPEPODA.}

Hersilia Phil.

apodiformis Phil. Nare nigr.

\section{Temora Baird.}

finmarchica Baird. Mare nigr.

Pontellina Cls.

mediterranea Cls. Mare nigr.

Nereicola Kfstn.

ovata Kfstn. Sewastopol.

Anchorella Cuv.

emarginata Kr. Sewastopol.
CIRRIPEDIA.

Balanus Aut.

ebernus Gould. Sewastopol.

improvisus Darw. Such., Sewastopol.

Amphitrite Darw. Mare nigr.

Chtamalus Ranz.

stellatus Ranz. Sewastopol.

\section{Verruea Schum.}

Spengleri Darw. Bosporus.

\section{ARTHROSTRACA.}

\section{Proto Leach.}

ventricosa Mein. Sewastopol.

\section{Caprella Lam.}

ancanthifera Leach. Sewastopol.

aequilibra Say. Sewastopol.

\section{Chelura Phil.}

pontica Czern. Sewastopol.

\section{Corophium Latr.}

longicorne Latr. Sewastopol.

Cerapes Say.

bidens Crs. Sewastopol.

Microdentopus Costa.

gryllotalpa Costa. Sewastopol.

Podocerus Leach.

falcatus Mont. Sewastopol.

Amphitoë Leach.

picta Rthke. Sewastopol. 
Orchestia Lesch.

littorea Iseach. Sewastopol.

Dexamine.

spinosa Leach. Sewastopol.

\section{Gammarus F.}

locusta F. Sewastopol.

macoticus Sow. Sewastopol.

Melita Leach.

palmata Leach. Sewastopol.

Tanais M. Edw.

vittatus Lillj. Sewastopol.

\section{Leptocheila Dana.}

Savignyi Sp. B. Sewastopol.

\section{Paratanais Dana.}

Savignyi Kr. Sewastopol.

\section{Apseades Ieach.}

coecus Ostr. Sewastopol.

Paranthura Sp. B.

penicillata Cls. Sewastopol.

\section{Anceus Risso.}

yorax Luc. Sewastopol.

\section{Aega Leach.}

Deshayesiana Hell. Marmora Meer.

\section{Sphaeroma Latr.}

granulatum M. Edw. Bosporus. serratum Leach. Sewastopol.

\section{Cymodocea Leach.}

pilosa M. Edw. Marmora Meer.

\section{Idotea $\mathrm{F}$.}

tricuspidata Desm. Sewastopol. acuminata White. Sewastopol. angustata Luc. Bosporus. algirica Luc. Sewastopol.

Limnoria Leach.

lignorum White. Sewastopol.

\section{Bopyrus Latr.}

squillarum Latr. Sewastopol.

\section{Ligia F.}

Brandtii lithke. Sewastopol.

\section{Hemilepistus.}

Klugii Brndt. Afghanengrenze. elegans Ulj. Keltetschinar., Artschman. elongatus B. L. I'schikisljar. nodosus 13. L. Imam-baba.

\section{Porcellio Latr.}

orientalis Ulj. 'Transkp., Amu-darja. var. rubricornis Walt. Amu-darja. spec.? Aschabad, Beum-basch., Krasnowodsk.

\section{THORACOSTRACA.}

\section{Pseadocuma G. 0. Sars.}

pectinata Sow. Sewastopol.

\section{Squilla F.}

mantis L. Mare medt. A. Brandt. 68.

\section{Mesomysis.}

Croyeri Czern. Sewastopol.

\section{Myвis Latr.}

cornuta Czern. Sewastopol.

\section{Euphausia Dana.}

Nülleri Cls. Marmora Neer.

\section{DECAPODA.}

\section{Penaens Latr.}

membranaceus Risso. Marmora Meer. caramote Desm. Tunis S. Kaisl. Hoh. Grfo 'Thronf.

\section{Palaemon F.}

serratus F. Marmora Meer.

squilla F. Sewastopol.

rectirostris Zadd. Nare nigr., Batum. 
Typton Costa.

spongicola Costa. Bosporus.

\section{Virbius Stmps.}

gracilis Hell. Sewastopol.

\section{Athanas Leach.}

nitescens Leach. Sewastopol.

\section{Alpheus F.}

dentipes Guèr. Marmora Meer.

\section{Crangon F.}

vulgaris $\mathrm{F}$. Bosporus.

maculosus. Sewastopol., N. Rossk.

\section{Astacus F.}

fluviatilis L. var. colchicus Kssl. Kolchis, Batum.

var. leptodactylus Esch. Rostow., Stawropol., Michelsfeld.

var. caspius Eichw.Lenk.,Baku.,Adshi-kabul., Akdasch., Mahomed-most., Jewlach., 'I'schr-jrt.

\section{Homarus M. Edw.}

vulgaris M. Edw. Mare medt., A. Brandt. 68.

\section{Arctus Dana.}

ursus Dana. Italia 70.

Palinurus F.

vulgaris Latr. Mare medt.

\section{Galathea Fb.}

strigosa F. Mare medt.

nexa Embl. Marmora Meer.

\section{Munida Loach.}

rugosa Leach. Bosporus.

\section{Gebia Leach.}

litoralis Desn. Sewastopol.

\section{Eupagurus Brdt.}

Lucasi Hell. Marmora Meer.

\section{Diogenes Dana.}

varians Hell. N. Rossk., Sewastopol.

\section{Paguristes Dana.}

maculatus Hell. Bosporus.

\section{Clibanarias Dana.}

misanthropus Hell. Sewastopol.

Porcellana Lam.

longicornis M. Edw. Such., Sewastopol,

\section{Dromia F.}

vulgaris M. Edw. Mare medt.

\section{Dorrippe $\mathbf{F}$.}

lanata Bosc. Mare medt.

\section{Ilia Leach.}

nucleus Leach. Nare medt. rugulosa Risso. Marmora Meer.

\section{Ebaliu Leach.}

Pennanti Leach. Marmora Meer.

\section{Stenorhynchus Lam.}

longirostris M. Edw. Sewastopol.

\section{Inachus $\mathrm{F}$.}

leptochirus Leach. Bosporus.

\section{Maja Lam.}

squinado Latr. Mare medt., A. Brandt 68., Bosporus.

Pisa Leach.

Gibbsii Leach. Marmora Meer. tetraodon Leach. Bosporus.

\section{Lissa Leach.}

chiragra Leach. Mare medt.

\section{Lambras Leach.}

angulifrons M. Edw. Bosporus.

\section{Xantho Leach.}

rivulosa Risso. Sewastopol.

Pilumnus Leach.

hirtellus Leach. Such., Gudaut., Sewastopol. 
Eriphia Latr.

spinifrons Sav. Mare medt., A. Brndt. 68., Sewastopol, N. Rossk.

\section{Portunus Fb.}

corrugatus Leach. Bosporus.

arcuatus Leach. Gudaut., Sewastopol.

Liocarcinus Stimps.

holsatus Stimps. Serastopol.

Carcinus Ieach.

maenas Leach. Sewastopol.

Pinnotheres Latr.

pisum Latr. Marmora Meer.
Gonoplax Leach.

angulata Leach. Mare medt.

\section{Brachynotus D. Haan.}

sexdentatus Hlgdf. Sewastopol.

\section{Geryon Kr.}

tridens Kr. Marmora Meer.

\section{Pachygrapsus Stimps.}

marmoratus Stimps. N. Rossk., Sewastopol.

Telphusa Latr.

fluviatilis L. Borsh., Batum., Germab., Aschabad., Tekke, Italia. 


\section{VERMES.}

प Е Р В Ы.

\section{WÜRMER.}

IIIкапъ_31._Schrank. 


\section{E R M E S. OOTРУДНИКИ-MITАRBEITER.}

Prof. R. Blanchard. Paris.

Prof. Dr. A. Ostroumow. Sewastopol. Kasan.

Составт коллекци червей до 1 январл 1899.

Gesammtbestand der Sammlung von Würmern bis 1 Januar 1899.

Vermes. . . . . . . 51 Arten 


\section{E R M E S.}

\section{PLATELMINTHES.}

\section{Tetrarhynchos Cuv.}

corollatus Miesch. Sewastopol.

\section{Leptoplana Ehbg.}

tremellaris Oerst. Sewastopol.

\section{Lineas Swby.}

gesserensis M'Int. Bosporus.

Cerebratulus Ren.

lacteus Hubr. Bosporus.

\section{NEMATELMINTHES.}

\section{Oncholaimus Duj.}

fusus Bst. Nare nigr.

\section{GEPHYREA.}

\section{Bonellia Rol.}

viridis Rol. Marmora Meer.

\section{Phoronis Wr.}

hippocrepia Wr. NIare nigr.

\section{Petalostoma.}

minutum Kef. Bosporus.

\section{DISCOPHOR A.}

\section{Hirudo L.}

medicinalis L. Sugd., Gagry., Archangelsk., Such.

\section{Haemopis Sav.}

sanguisuga L. Lenk., Goktsch., Tschaldyr., Schatj., T'biz. S., Burtn.

\section{Herpobdella.}

atomaria Car. Goktsch., Kars-tschai., Toporw. Burtn.,'Tuman-göll., Aiger-göll., T'schibl., Chosapin-güll., Parget-See.

\section{Glossosiphonia.}

stagnalis L. Goktsch., Dsheil., Aiger-göll., Kars-tschai. complanata L. Tschaldyr., Tuman-göll., Chosapin-göll., Tbiz.S., Aiger-göll., Tschibl., Kars-tschai. Goktsch.

\section{Dina.}

quadristriata Gr. Tbiz. S., Tschaldyr-göll., Toporw., Goktsch., Chantschali-göll.

\section{Placobdella.}

catenigera Nioq. Poti., Batum.

\section{Cystobranchus.}

respirans 'Tr. Garzis-chari., Kura.

\section{Hemiclepsis.}

marginata. Golitsch.

tesselata O. F. MI. Tschibl., Goktsch., 'Tschaldyr-göll., 'Tbiz. S.

\section{CHAETOPODES \\ Pachydrilus.}

gracilis Czrn. Mare nigr.

\section{Clitellio.}

arenarius Sow. Mare nigr.

\section{Saccocirrus Bobr.}

papillocercus Bobr. Sewastopol.

\section{Hermione Blv.}

hystrix Kbg. Bosporus.

\section{Polynoe Sav.}

reticulata Clpde. Sewastopol.

\section{Pholoe̊ Johnst.}

minuta Mgrn. Sewastopol.

\section{Chloeia Sav.}

venusta Qtrfirs. Marmora Neer.

Eunice Qtrfgs.

vittata DCh. Mare nigr.

\section{Iysidice Sav.}

ninetta Aud. Sewastopol. 
Staurocephalus Gr.

rubrovittatus Gr. Sewastopol.

Nereis Gr.

Costac Gr. Marmola Meer.

diversicolor Müll. Gudaut., Sewastopol.

\section{Nephthys Cuv.}

scolopendroines DCh. Sewastopol.

\section{Glycera Sav.}

convoluta Kf́stn. Sewastopol.

\section{Pnedophylax Clpde.}

clariger Clpde. Sewastopol.

\section{Carobia.}

maculata l'er. Mare nigr.

\section{Capitella Blnv.}

capitata V. Iien. Narmora Neer.

\section{Arenicola Iam.}

Grubii Clpote. Nare nigr.

\section{Chaetopterus Cuv.}

variopedatus Clpde. Marmora Meer.

\section{Sternaspis 0tto.}

scutata Mllmgr. Bosporus.

assimilis Mllmgr. Marmora Meer.

\section{Lagis Mlmgr.}

Koreni Jllmgr. Sewastopol.

\section{Amplitrite Mlmgr.}

gracilis Mrzll:. Sewastopol.

Terebellides Sars.

carnea Bobr. Sewastopol.

$$
\text { Melinna Mlmgr. }
$$

adriatica Mrzlly. Sewastopol.

\section{Serpnla Phil.}

Whilipuii Möreh. I3osunrus.

aspera Phil. liosporus.

\section{Ditrupa.}

sabulosa. Bosporus.

\section{Pomatocerus Phil.}

triquetroides Panc, Sewastopol, Bosporus.

\section{Spirorbis Imk.}

pusilla Rtke. Hosporus.

\section{Vermilia Phil.}

infundibuliformis Bosporus.

Myzostoma I.

glabrum Lckt. Marmora Meer.

\section{ENTEROPNEUSTA。}

Balanoglossus D. Ch.

chavigerus DCh. Marmora Meer. 


\title{
GASTEROZOA.
}

\section{MOLLUSCA.}

\author{
IV 0 ЛII $10 \mathrm{C}$ К И.
}

\section{MOLLUSCEN.}

IIranъ-31 A, :31 B, :31 C.-Schrank. 


\section{GASTER0Z0A.}

\section{COTPУДНИКИ-MITARBEITER.}

Prof. O. Boettger. lirankfurt a. MI.

prof. A. lirandt. Charkow.

S. Clessin. Ochsenfurt.

L. v. Martens, Merlin.

Prof. A. Ostroumow. Sewastopol.

O. Retowsky. 'Theodosia.

Dr. G. Sievers. 'Tiflis.

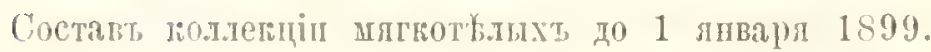

Gesammtbestand der Sammlung von Weichthieren bis 1 Januar 1899.

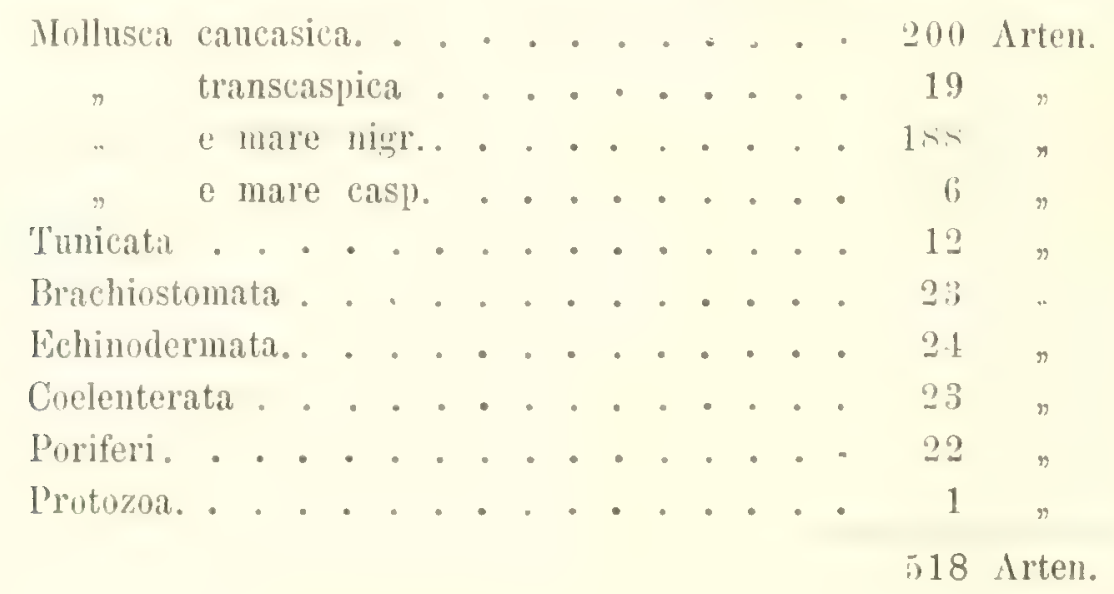

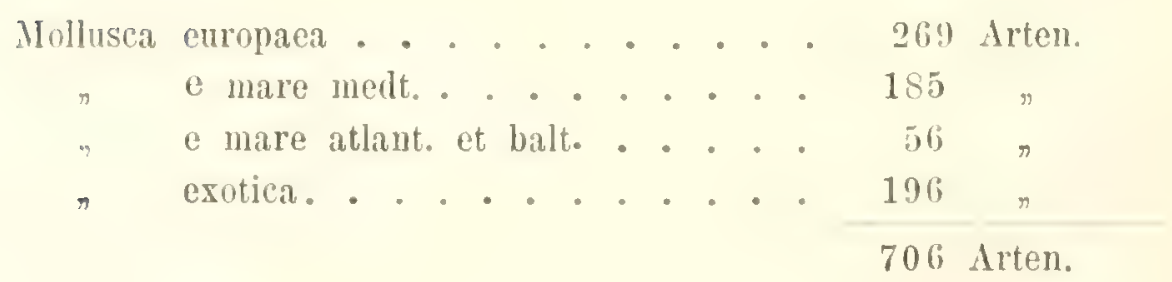

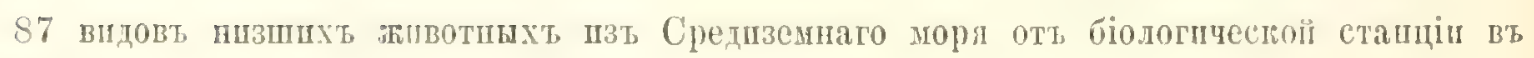
Ileamori.

87 Arten niederer 'Thiere aus dem Mittelmeer von der biologischen Station in Neapel. 


\section{MOLLUSCA CAUCASICA.}

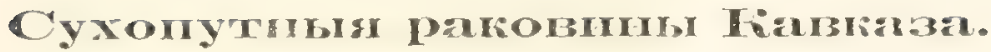

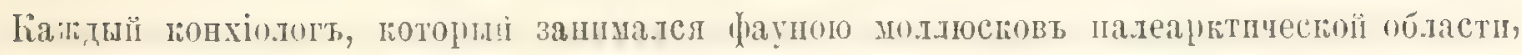

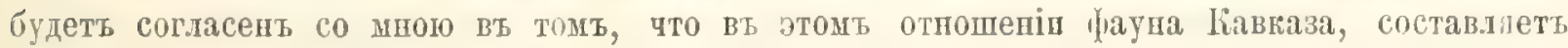
одну пзъ саныхь интересныхь частей ея. Больпое число особенпыхъ видовь, составляюпихь прнблизительпо пять шестыхь всеї богатоі фауны. какъ и грасота или исойениость

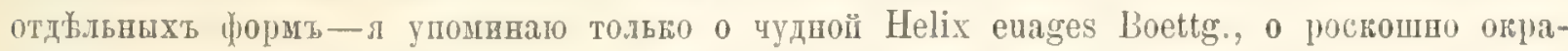

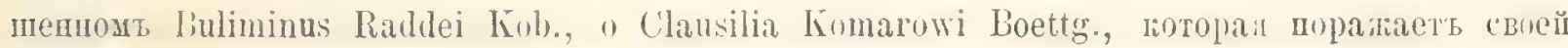

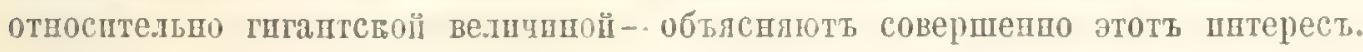

Несмотря на то, что обшнрныя пространства Кавказа еще пе излядованы конхіологамп и нав'ьрпо въ будушемъ отгроются пьюоторые до сихъ порь непзвстные виды,

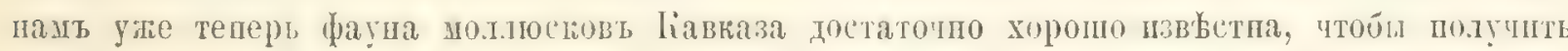
ясное представленіе о ея состояніи п дълать сравненія сь фаунами другихъ частей палеарктичеспой области. Нов'йшую опись, встручающпхся вь области Кавказа вшдовт мы

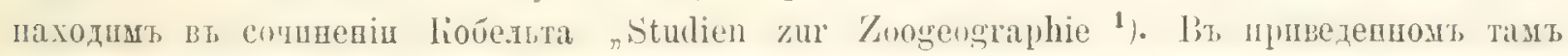

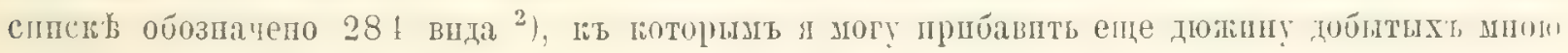

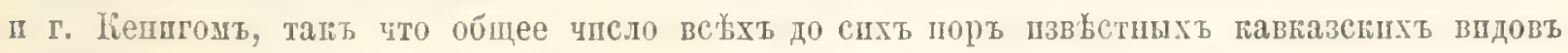
составляет 296. Если мы изъ этой обцей суммы исключит пресповодные виды, а тақже

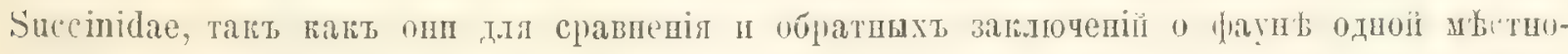
сти, мало, пли вовсе негодны, то нащъ остаетсл круглымт чпслощъ 250 сухопутныхъ раковпнь. ІІъ нихь 10 вддовь, сльдовательно мен Һе одной пестой части всей суммы, такіе,

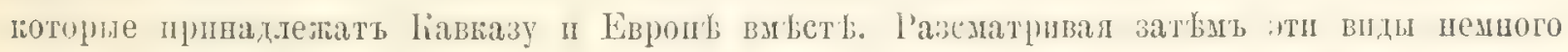

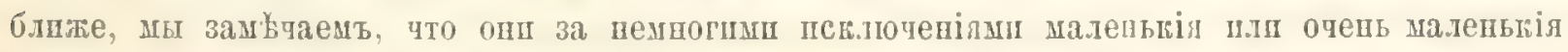
раковпны, қоторыя распространены болье или менъе во всей 亡вропь и частью за ея пре-

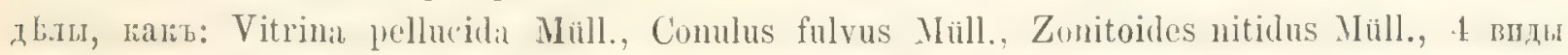
рода Iyalinia (H. pura Ald, H. hammonis Stroem, H. petronella Pfr. II H. cellaria Müll.), 2 Patula (P. ruderata Stud. II P. rupestris Drap.), oбł пзвъстицљI Vallonia (V. cristata Müll. Ir V. pulchella Müll.), Acanthinula aculeata Müll., Trichia hispida L. II Tr. sericea Drap., Chondrula tridens Müll., Cimella lubrica Müll, Caecilianella acicula Müll, Carychium mini-

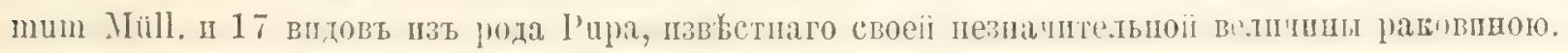

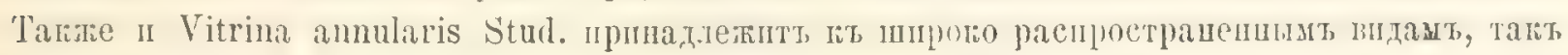

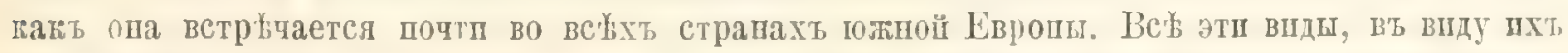

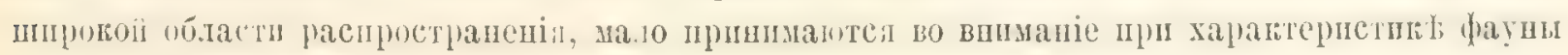

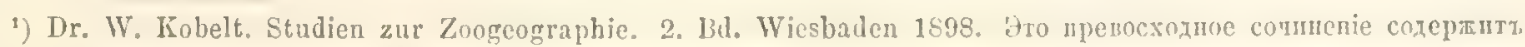

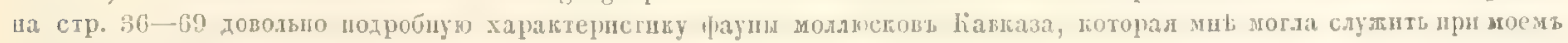

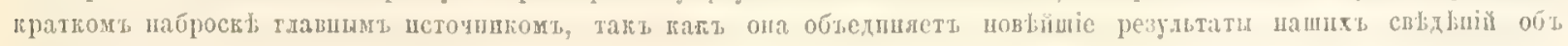
этой 中ауны.

2) Kobelt. I. c. pag. 57-60. 


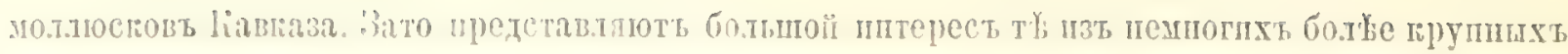

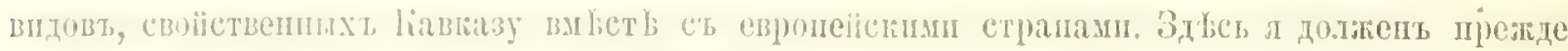

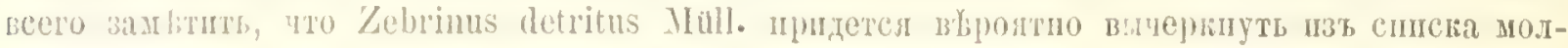
.

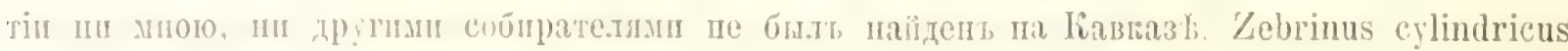

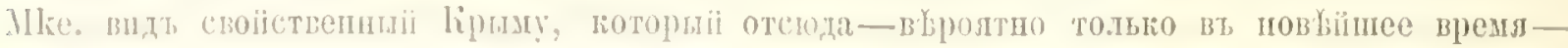

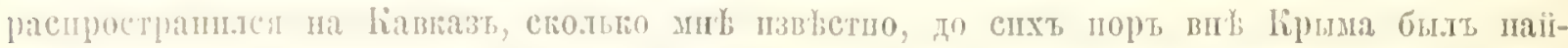

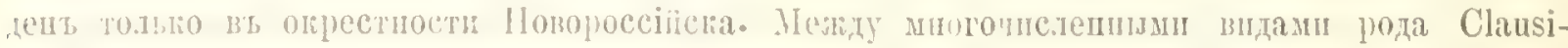

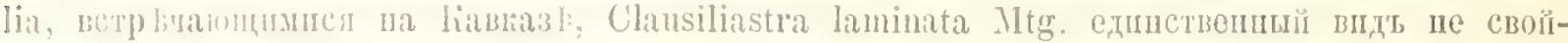

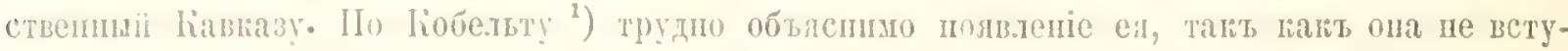

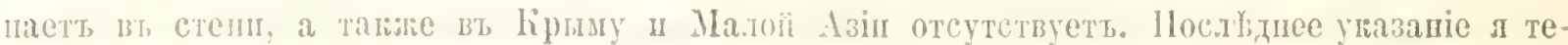

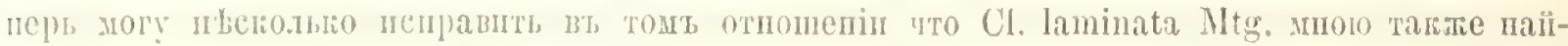

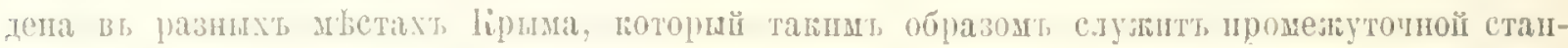

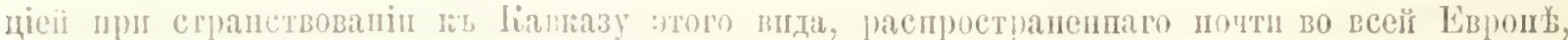

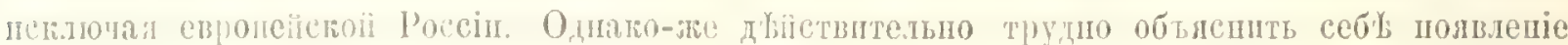

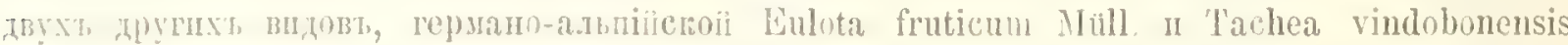

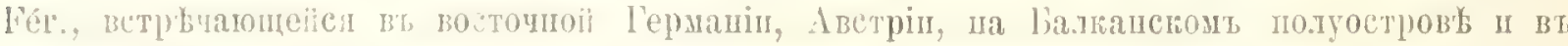

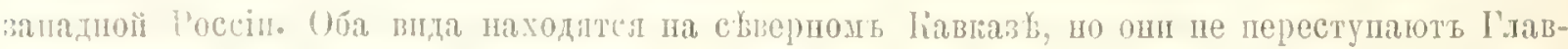

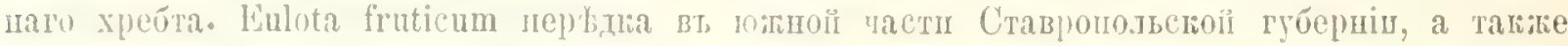

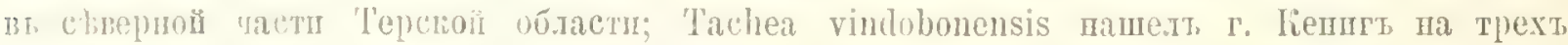

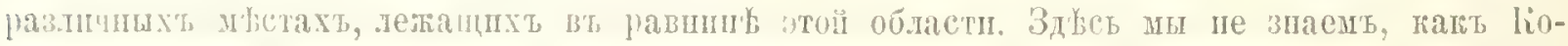

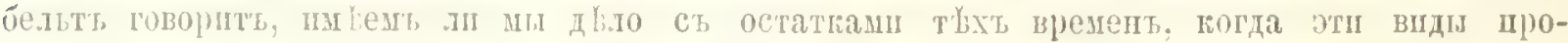

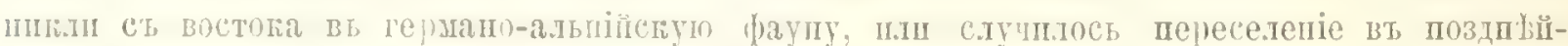

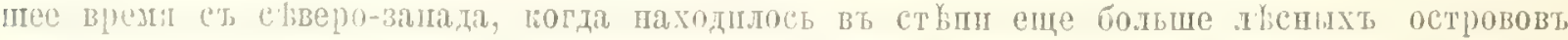

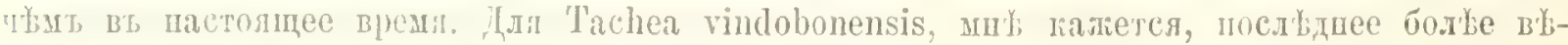

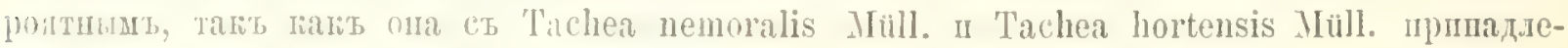

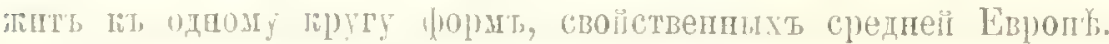

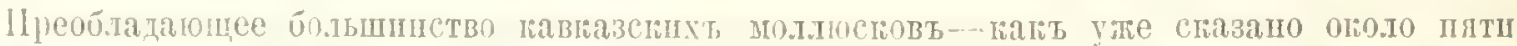

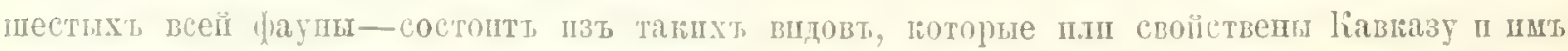

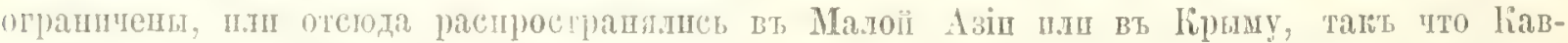

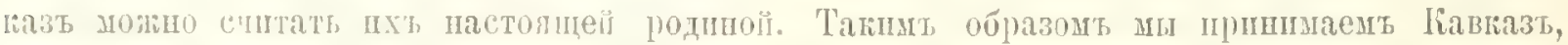

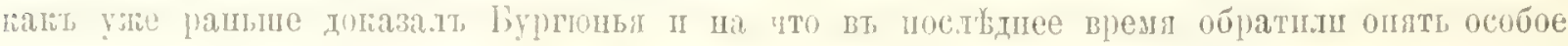

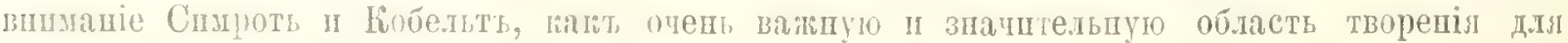

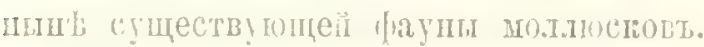

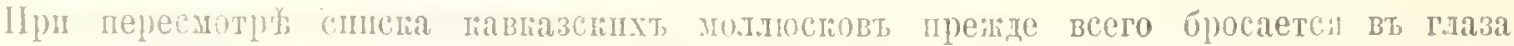

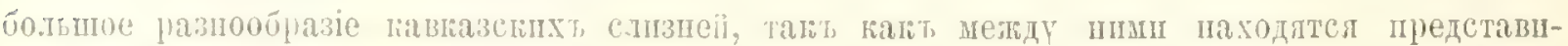

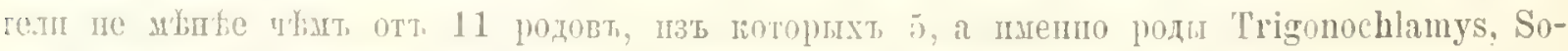

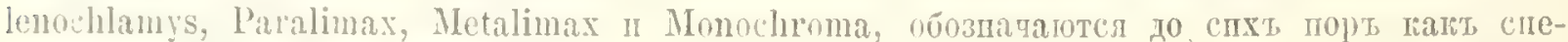

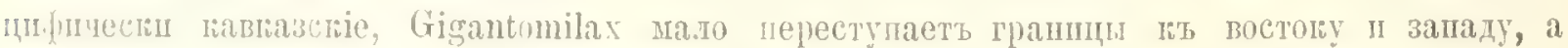

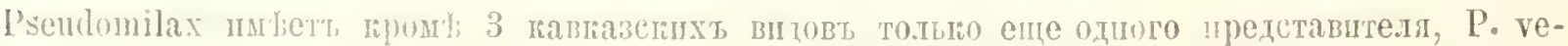

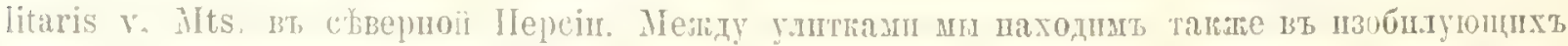

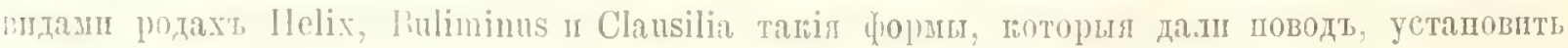

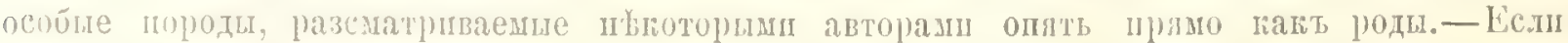

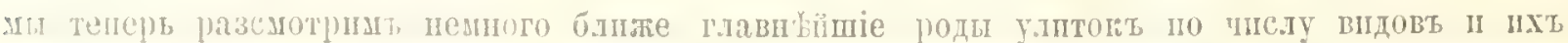

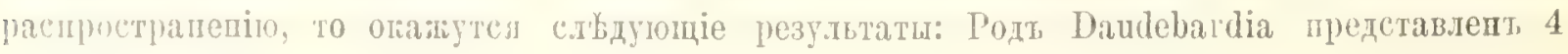
9) Kobelt. I. c. pag. 41 . 


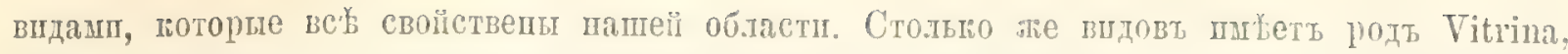

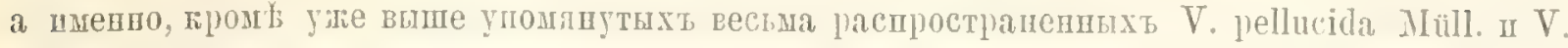

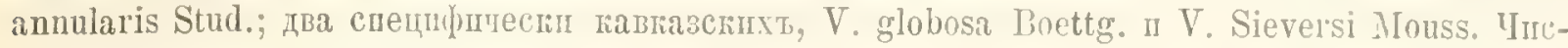

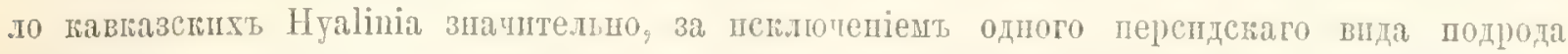

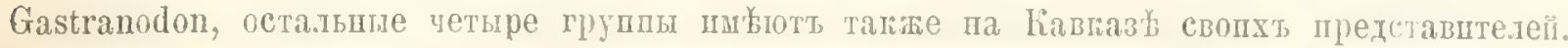

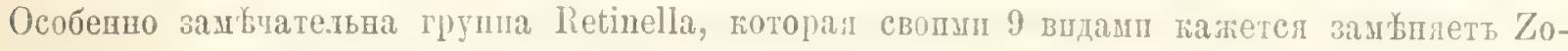

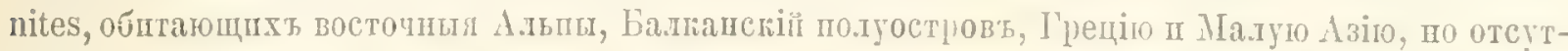

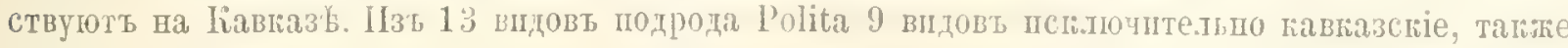

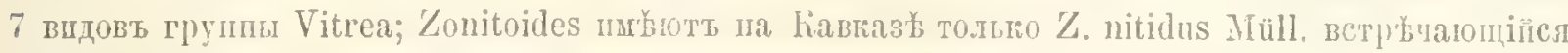
во всеї области. Въ родъ Helix подроды Punctum, Patula, Vallonia u Acanthinula представленш совокупно 7 вндамп, пзт готорыхъ тольто одна H. (Patula) goktschana Niss. пrсключптельно

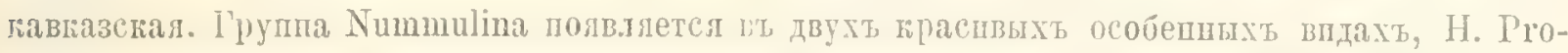
metheus Boettg. п H. Jasonis Mouss. Meжiдy Trichia находятея 2 шшипғо распространен-

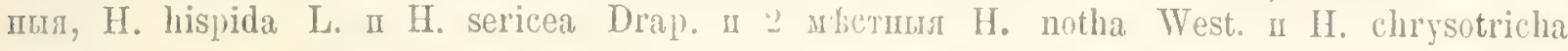

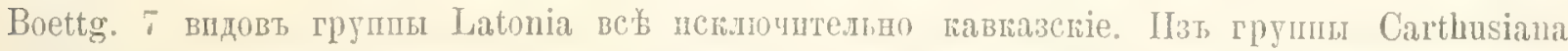

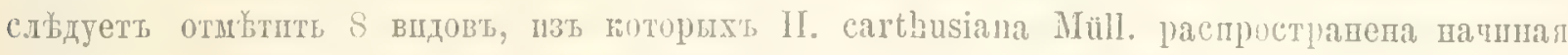
съ Кавказа къ запалу по всей средней Eвpon'b, а H. frequens MLuss. n H. carascaloides

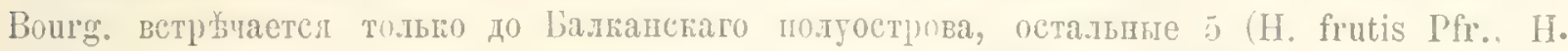
circassica Charp., II. Alaveola Kryn., H. pachnodes Boettg. II II. aristata Kryn.) пзвжетны тольго сь Кавказа. Между ними сльдуеть обратшть особепное вншапіе на II. circassica

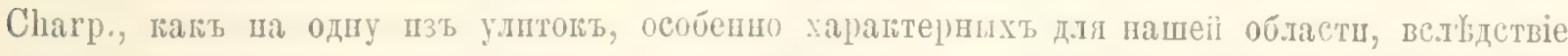

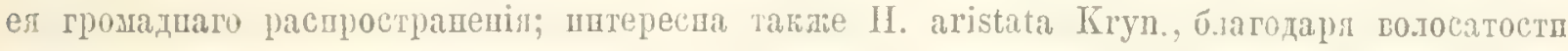

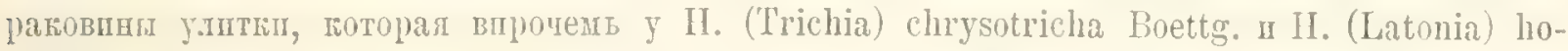

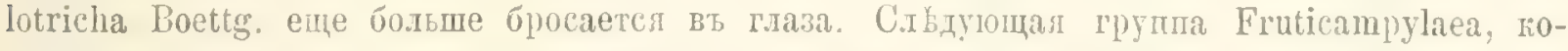

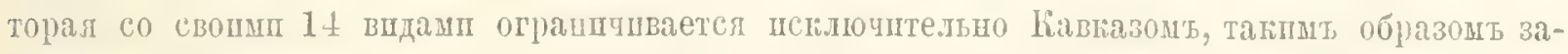

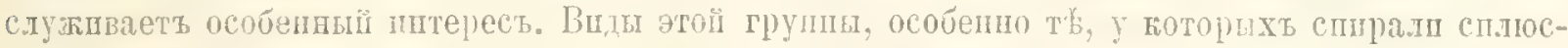

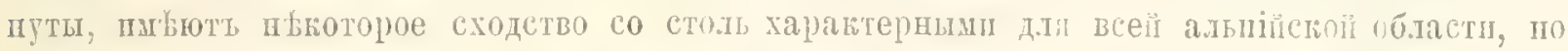

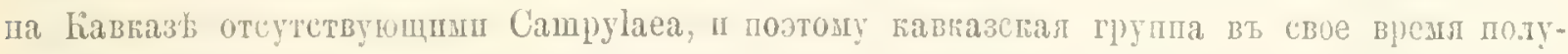

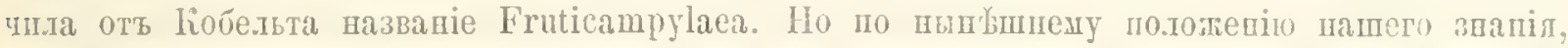

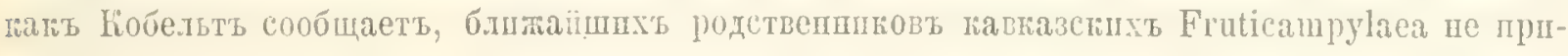

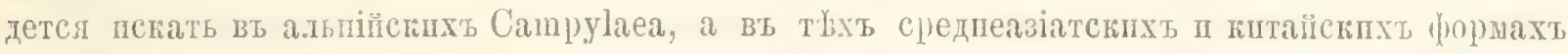

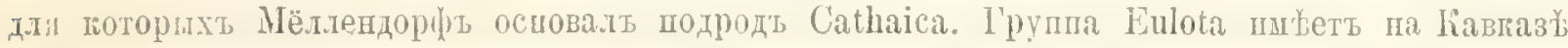

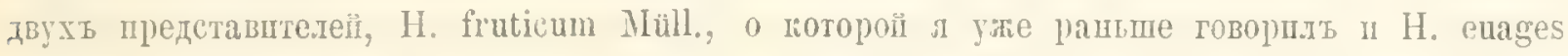

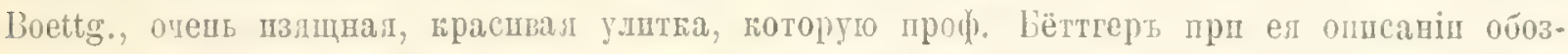

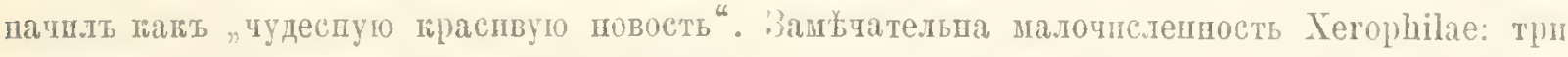
пзт нпхт II. derbentina Kryn, II. Krynickii Andrz. In II. crenimargo Kryn. пмұnтб боль-

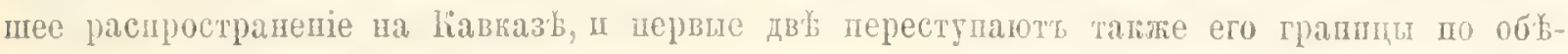

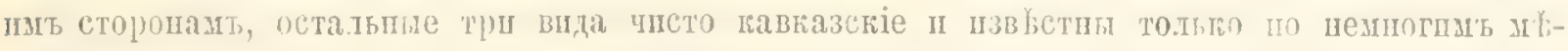

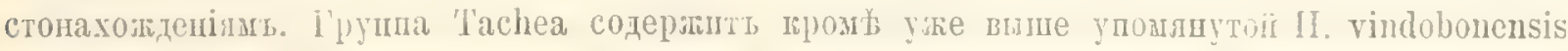

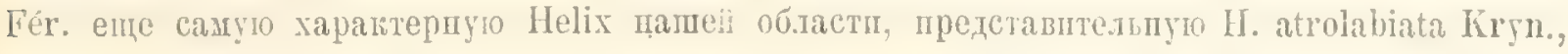

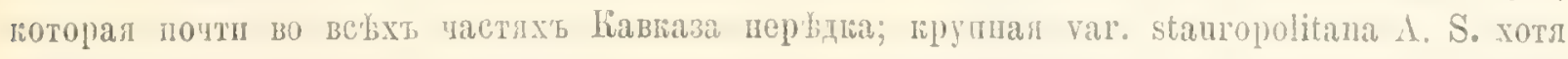

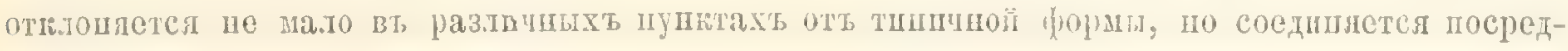

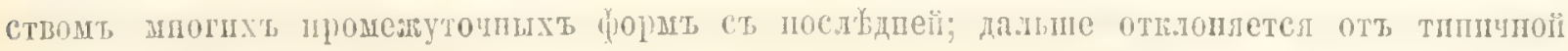

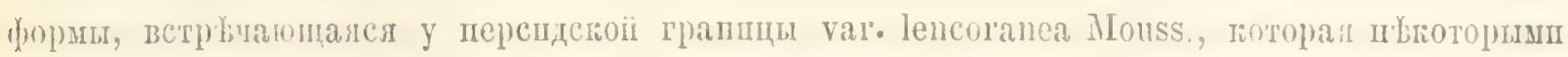

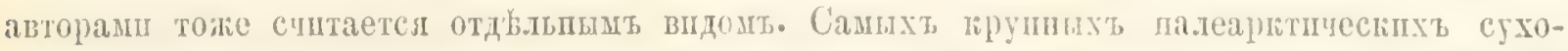

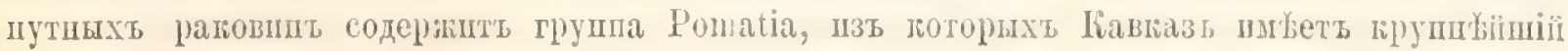




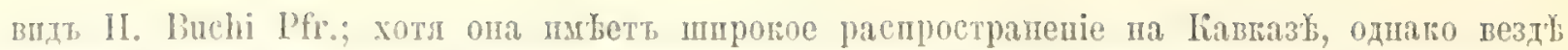

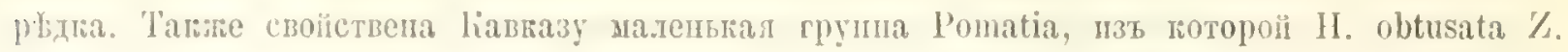

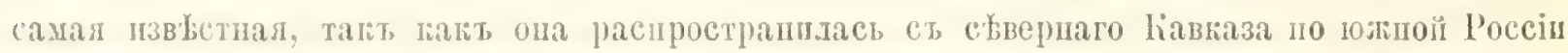

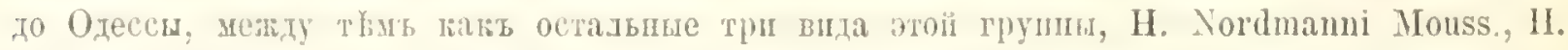
Christophi Boettg. II II. Raddei lBoettg. orpannumanotes Kaßiazom.. II. taurica Boettg. (non

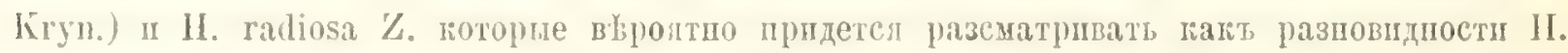

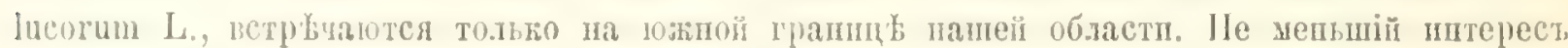

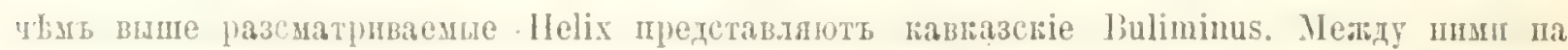

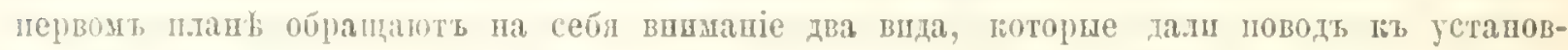

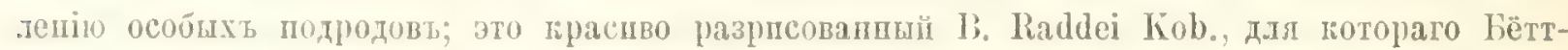

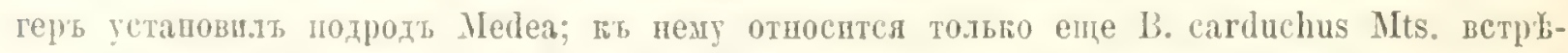

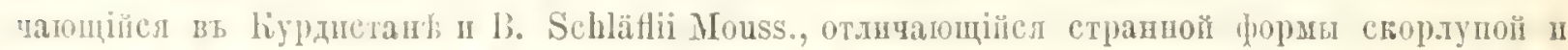

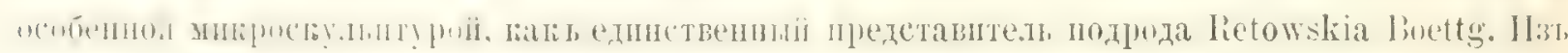

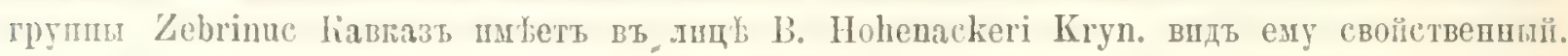

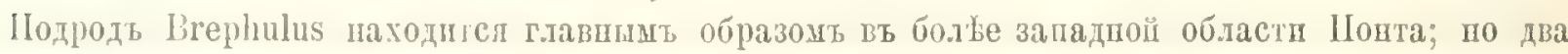

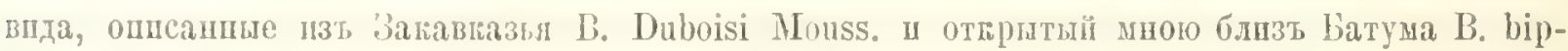

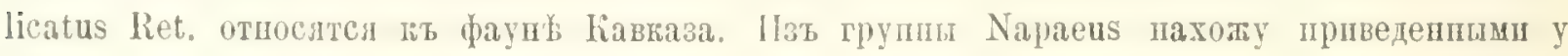
lióе.тьта 6 видовь, из' которыхъ трп (В. caucasicus Pfr. B. Boettgeri Cless. zi B. talyschanus

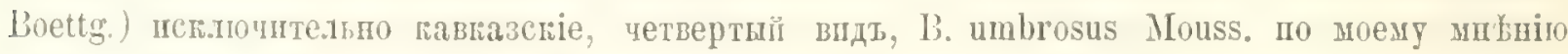

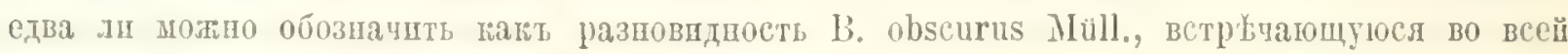

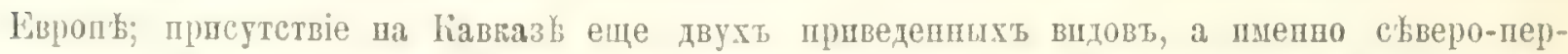

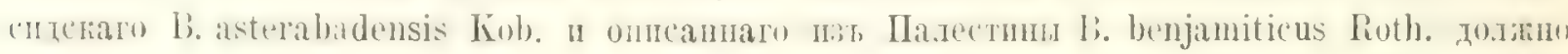

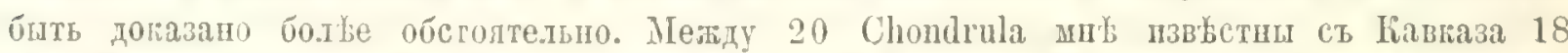

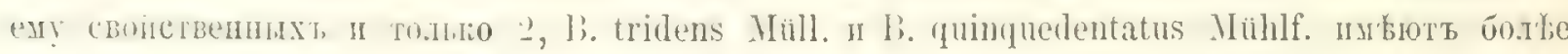

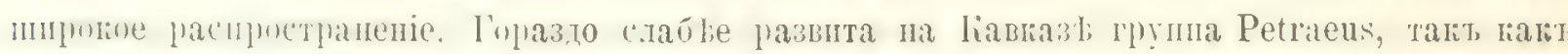
до сихь порь тольго трп пь пеї относящіяея фориы пайдепш, B. niveus Rssm., B. brevior Mouss. a 13. lycicus Pfr. var. borealis Mouss, ІІзъ 31 вшдовъ рода Рupa въ болье

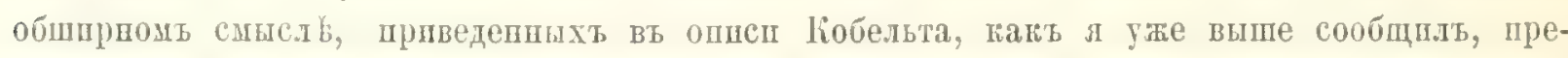

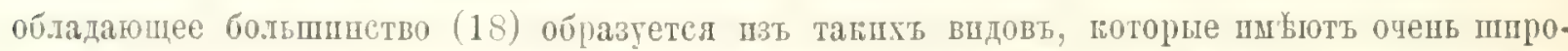

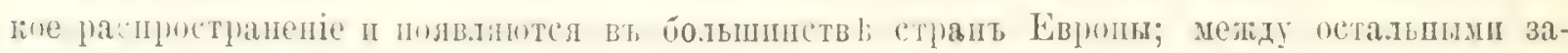

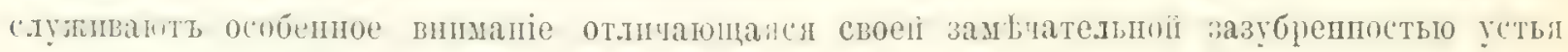
группа Lauria, P. pulchra Ret., P. superstructa Mouss. I P. zonata Boettg., a талте мa-

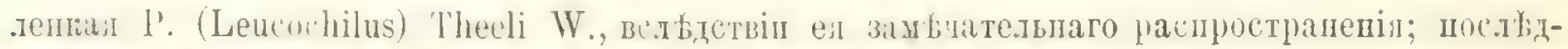

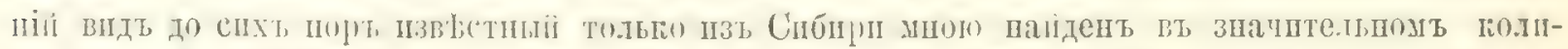

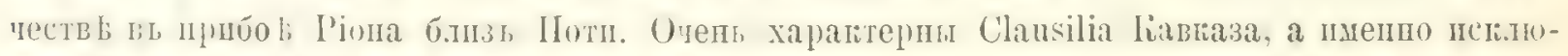

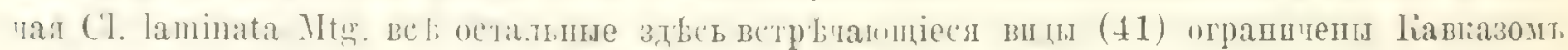

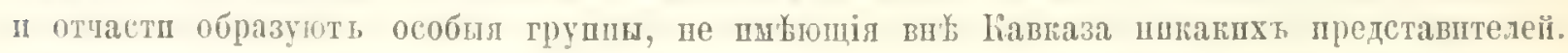

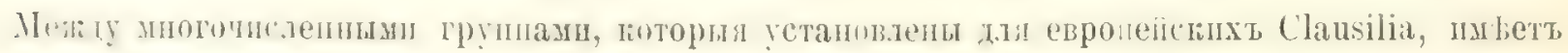

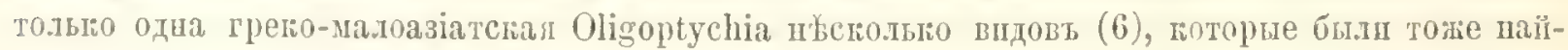

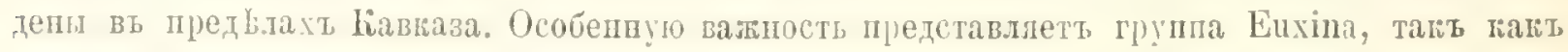

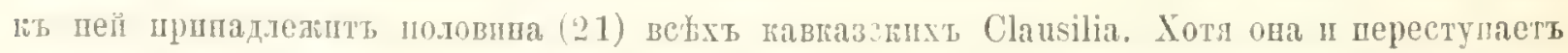

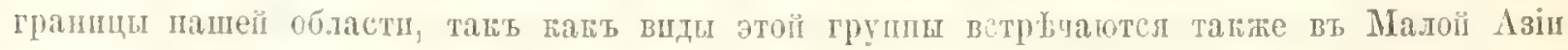

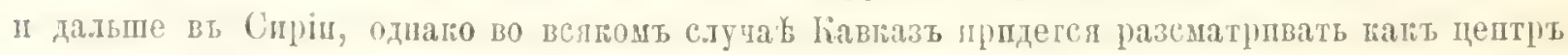

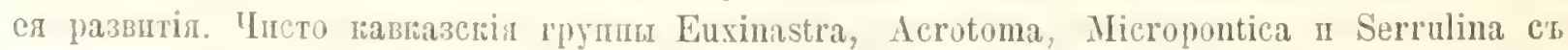

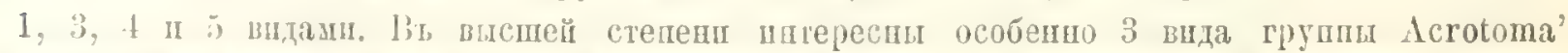

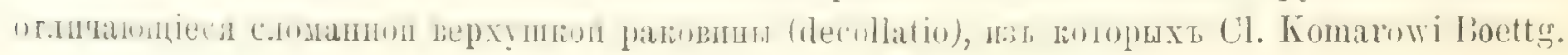




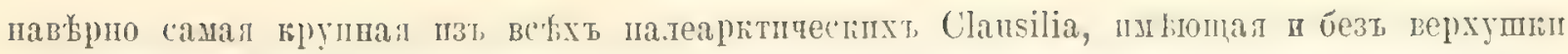
еще длин въ $37 \frac{1}{2} \mathrm{~mm}$. Одинъ видь раповппы безъ верхуши находшся также между виданг групы Serrulina, которая снльно отлпчаетсл вь разныхь пунятахь оть остальныхь

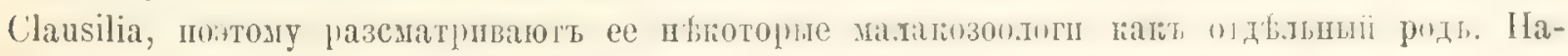

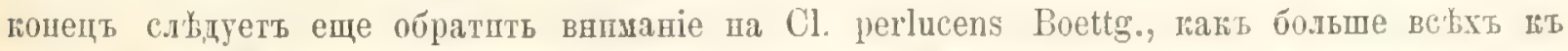

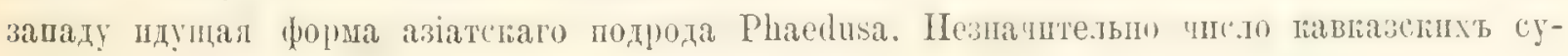

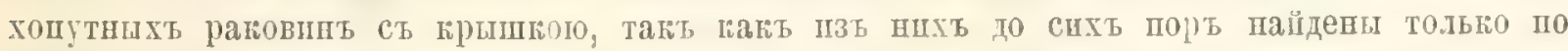
одному виду родовъ Acme и Pomatias, a таґже по два вида родовъ Cyclostoma п Cyclotus,

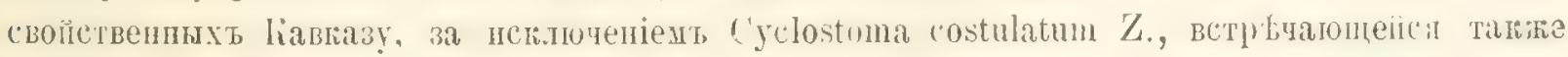
въ Крыму пг въ области Карпатовъ. Нахожденіе рода Cyclotus, вообще совершенио чуж-

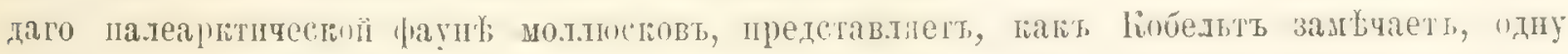
шзъ самыхь замұчательныхъ загадогт, которую памъ задаеть географическое распространепіе моллюсковъ въ палеаютической области, а пменно 2 (или 3) вида, встршчающеся

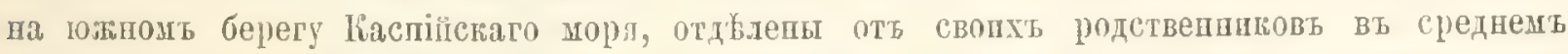

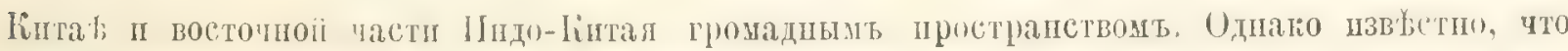

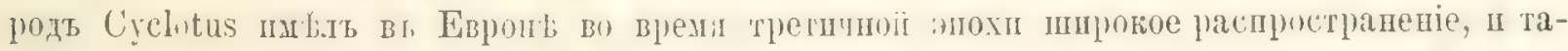

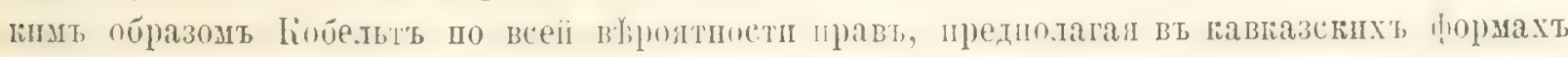
остаткі прежипхь времень, сохраншвпихея въ этой полутропческой стран悉 до нашего времени.

Нмег въ впду больпую велпчну области, ея разнообразіе въ орографпческощ отно-

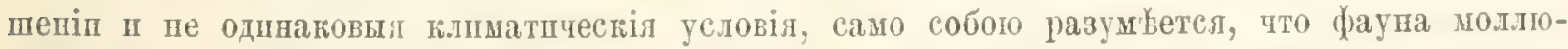

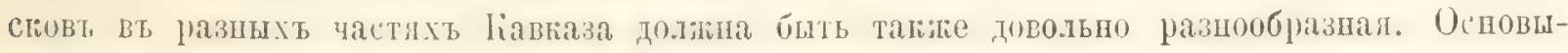

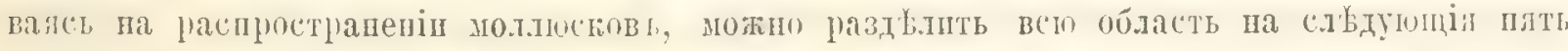

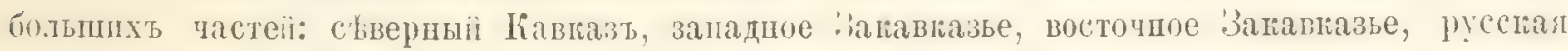

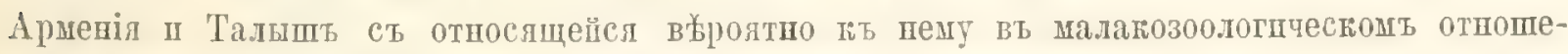

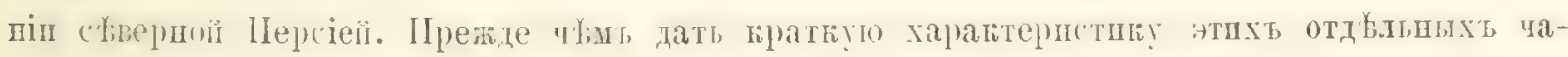

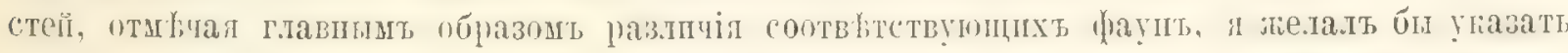
на ты черты, которшл доказывають однородность всей областп. Копечно здъсь могуть быть

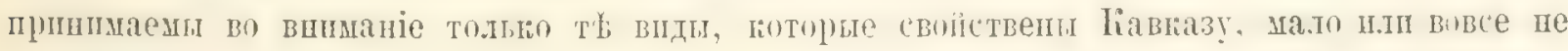
переступая за его предыл. Iрежле всего сльдуеть понстатпровать прпсутствіе Frutico-

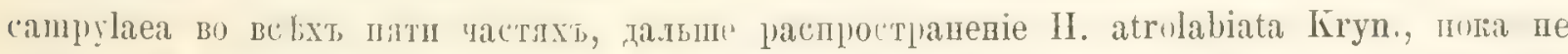

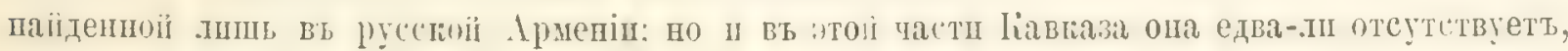
такь пакт вь Талышы встржчается также ел разновпдость var. lencoranea. 'T'ольо въ по-

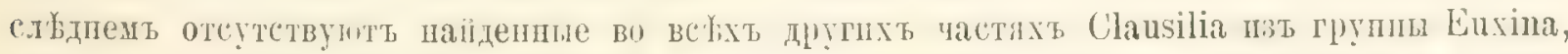

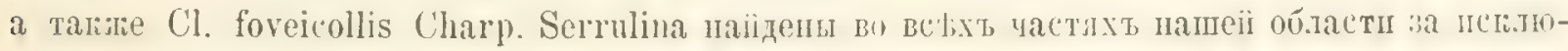

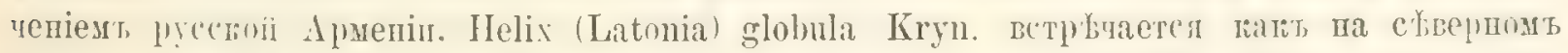

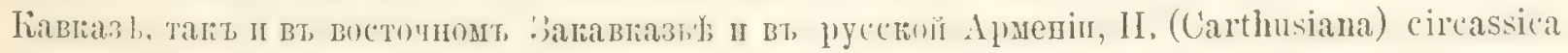

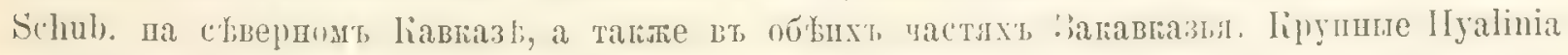

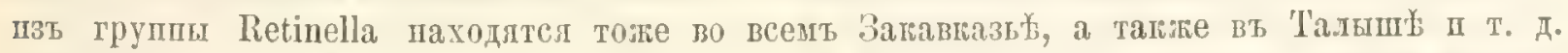

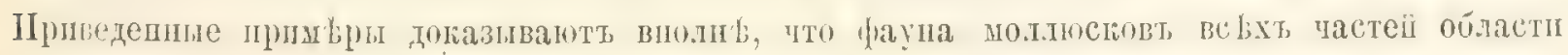
можесь называтьел вь совогуппости павғазскою. Несмотря па әто согласіе въ общемъ

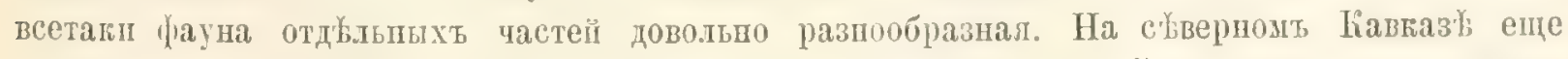

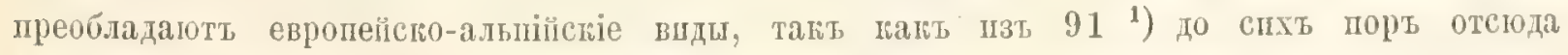

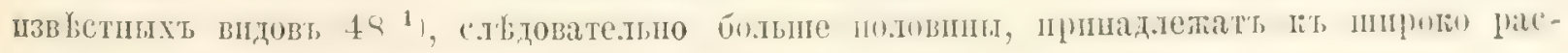

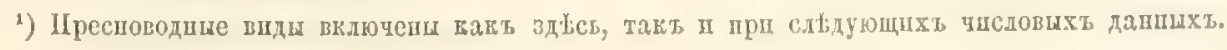




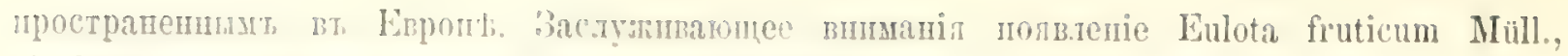

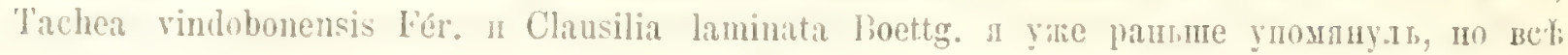

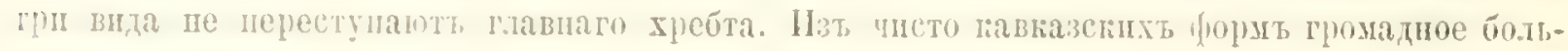

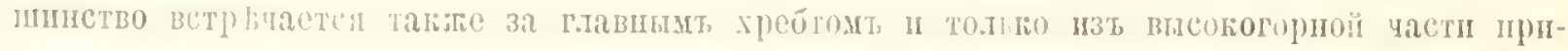

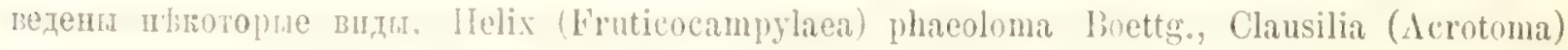

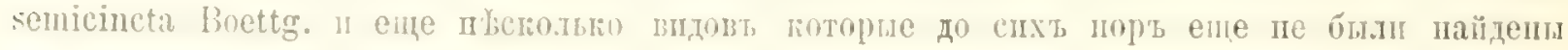

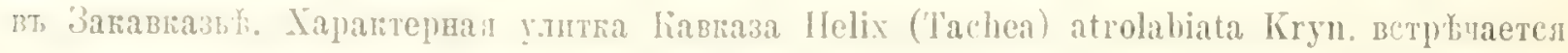

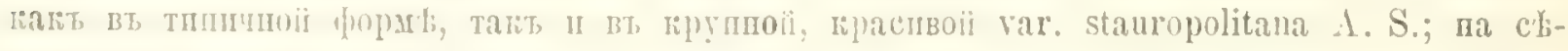

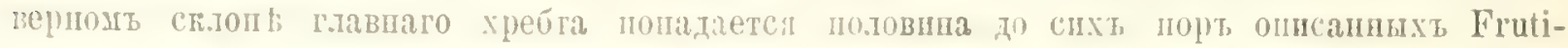

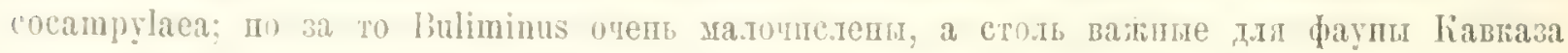

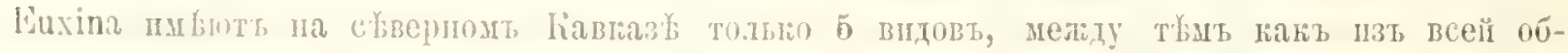

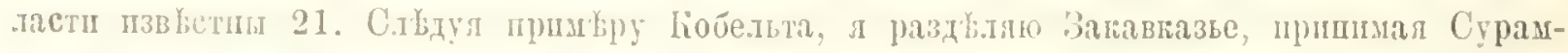

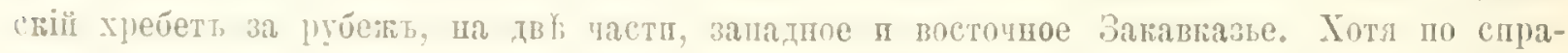

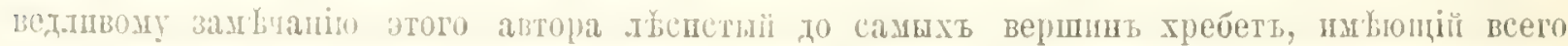

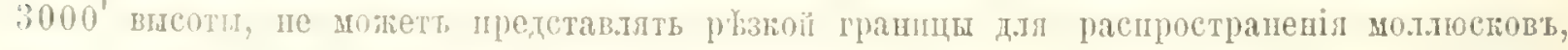

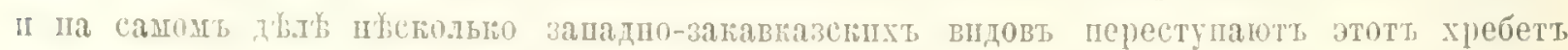

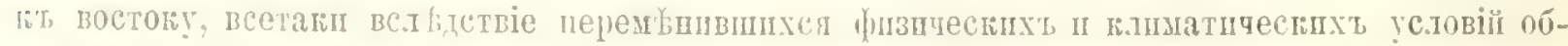

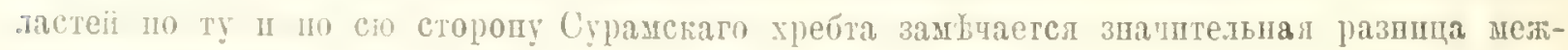

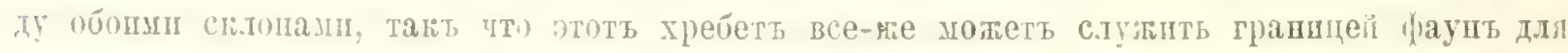

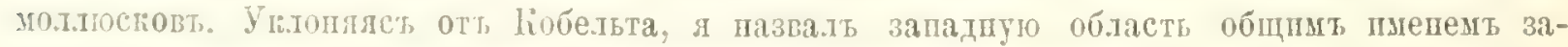

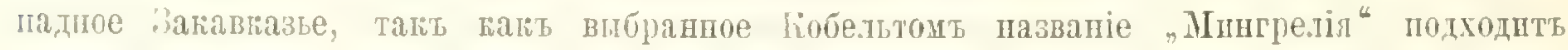

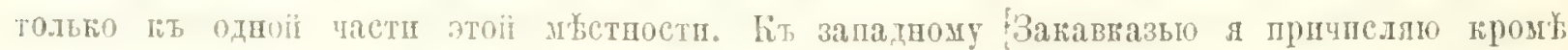

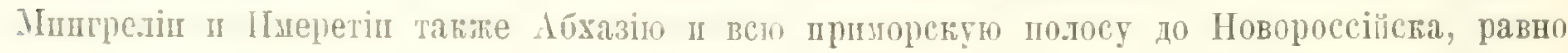

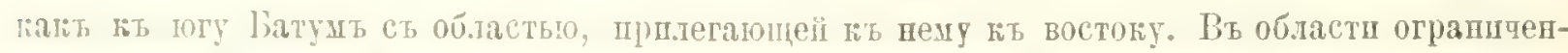

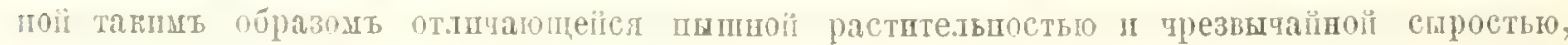

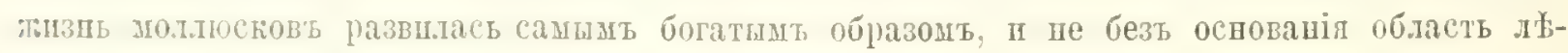

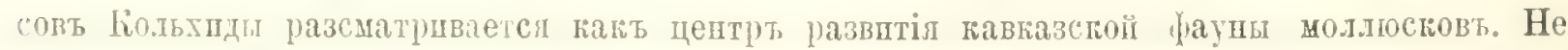
смотра на ти что и здьсь большія прострапста еце вовсе пе изслдованы, намь уже из-

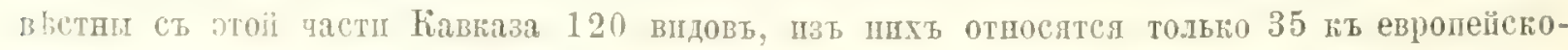

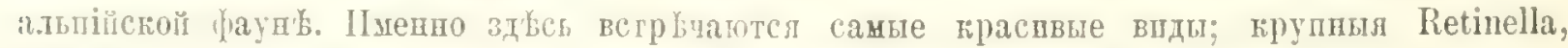

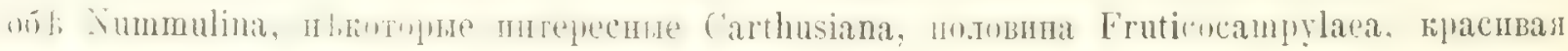
Eulota euages Boettg., об́ pocromнпе подроды Buliminus'a, Retowskia п Medea, большинство Euxinae и гиганская Clausilia, Acrotoma Komarowi Boettg. Сравнптепьо съ әтой

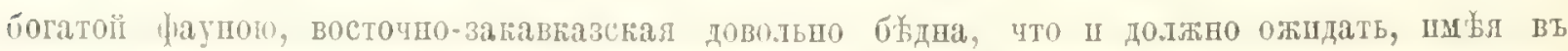
виду гораздо болте слабо развитуо растительность этой области. Особенно велика бвдность

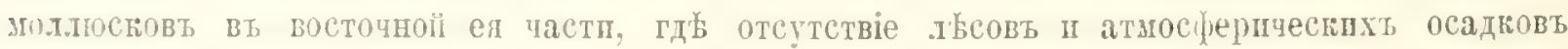

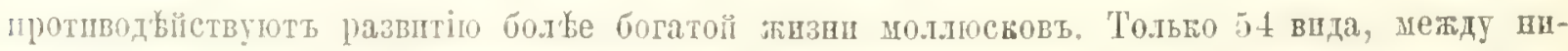
мп 22 западно-европеискихь, извостне до сихь порь сь восточнаго Закавгазья и между

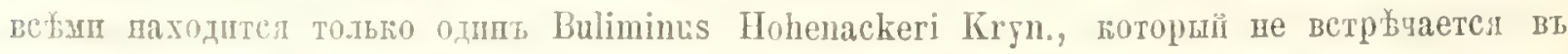

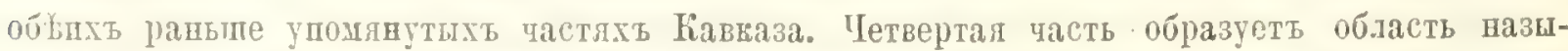

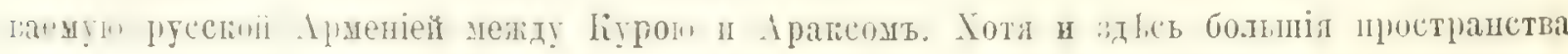

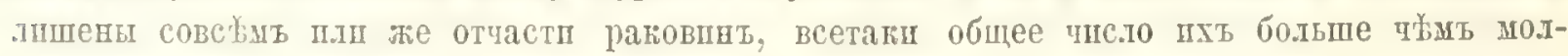

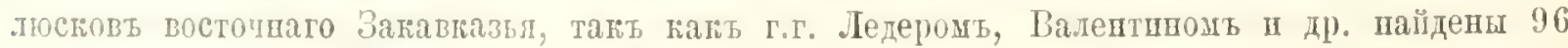

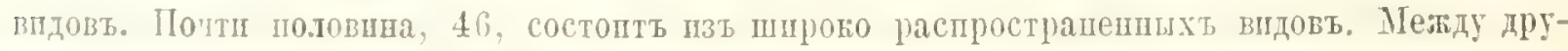

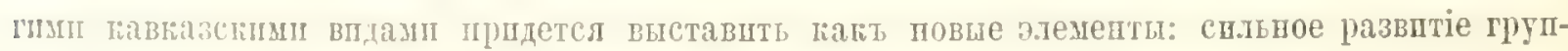

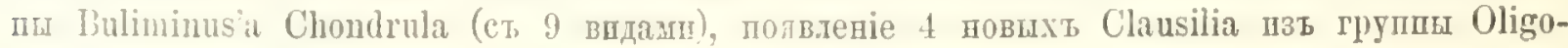




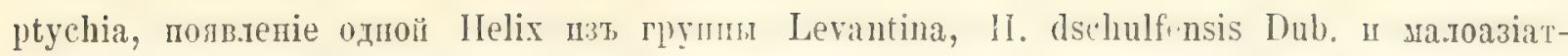
ской Helix (Pomatia) taurica Boettg. Фауна Талыша состопт ивт 72 видсв', цзъ қото-

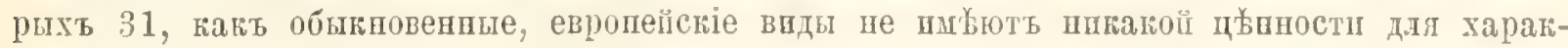
теристик фауны молюсковь этой областв; мељлу остальым 41 находятся тольъо 14 ,

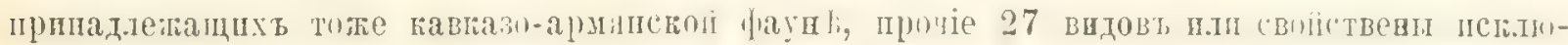

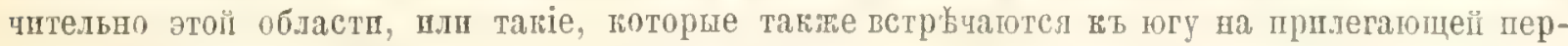
спдской горной возвыненностп. Хогл присутствіе 14 общихт видовт можетт служать до-

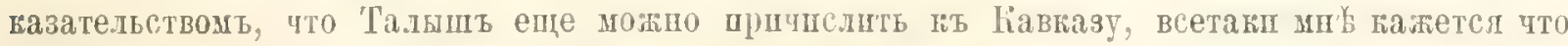

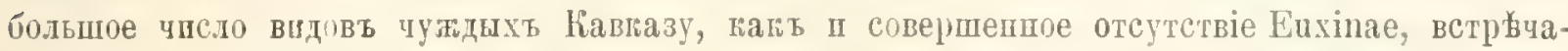

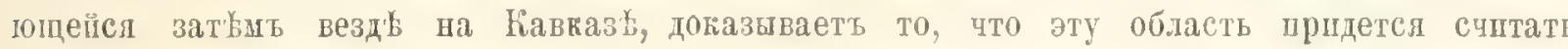
каћъ особый раіонь сравнительно съ другыи областям liaвгаза. Между ему свойствен-

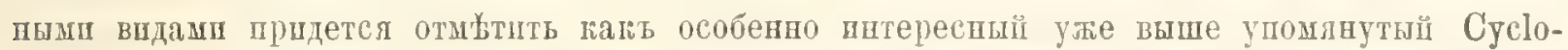

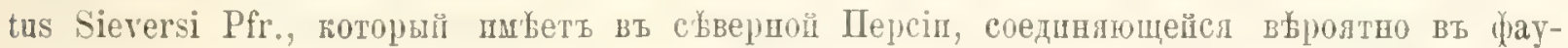

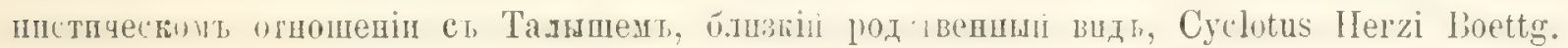

Вь заклоченіе мего праткаго обзора гавказскоі фауны уолгосковт я еще замту,

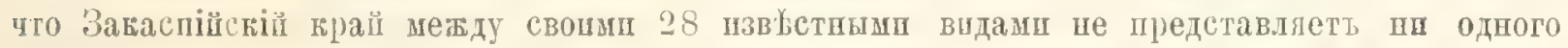

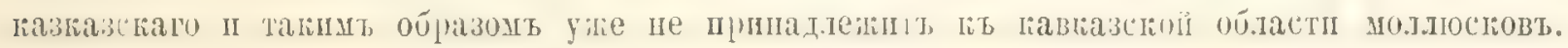

\section{O. Pemoвckiz.}

\section{Die I andconchylien des Kanliasus.}

Lin jeder Malakuzmloge, der sich mit der Molluskenfauna des paliarktischen Gebiets beschäftignt hat, wird mit mir dari IIinsicht einen der interessantesten Theile derselben bildet. Die gruse Zahl der eigenthümlichen Arten, die etwa fün Sechstel der gesammten reichen Fauna ausmachen, sowie die Shönheit nder Ibsunderlichkeit einzehner Frmen-ich arinnere nur an lie rrachtvolle Helix cuages lonettg., den farbenprächtigen buliminus Radhei Kob.. die durch ilhre verhältnissuäs-igr riesige Grösse aufallende Clausilia K'mulonwi Iuettg.--machen dieses Interesse vollkommen erklärlich.

Obgleich weite Strecken des Kaukasus noch von keinem Malakuzoolıgen betreten sind und die Zukunft sicher manche bisher noch unbekannte Form zur Kenntniss bringen wird, so kennen wir doch heute schon die Molluskenwelt des Kaukasus gut venug, um ein likares IBild von ihrer Beschaffenheit zu erhalten und Vergleithe mit den Faunen anderer Theile der paläarktischen Zone anstellen zu können. Die neneste Zusammenstellung der im Gebiete des Kaukasus vorlommenden Arten tinden wir in Kobelts Studien zur /ongeographie ${ }^{1}$ ). In der dort gegebenen Liste werden $2 \times 4$ Species ${ }^{2}$ ) aufrefuhrt, denen ich nach meinen eigenen Sammlungen und denen des Herm König noch ein Dutzend hinzufugen kann, so dass die Gesammtzahl der his jetzt bekannten kankasischen Species „29a hetrïgt. Scheiden wir von dieser Gesanmtzahl die Süswa-serarten sowie die Succincen au-, da dieselhen zur Instel-

1) Dr. W. Kobelt. Studien zur Zoogcographic. 2. Bl. Wiesbaden 1898.-Dieses ausgezeichneto Werk cnthält a uf site 36-69 eine ziemlich ausführliche Charakteristik der Molluskenfanna des Kaukasus, welche mir bei meiner kurzen Skizzirung als Iauptquelle dienen konnte, da sie die neuesten Resultate unserer Kenntnisse dieser Fauna zusammenfiast.

2) Kobclt. 1. c. p. 57-60. 


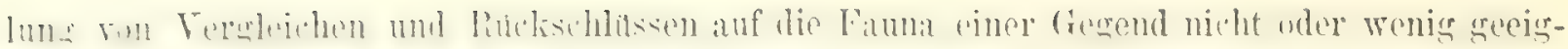
net sind, so bleiben in runder Zahl 250 Landconchylien. Von diesen sind 40 Arten, also noch kein Sechstel der Gesammtsumme solche, die dem Kaukasus und Luropa gemeinsam zukommen. Iictrachten wir zunächst diese Arten etwas näher, so bemerken wir, dass es mit wenimen Aumahmen kleine oder sehr kleine Schnecken sind, die mehr oder weniger durch ganz Luropa und theilweise noch driber hinaus rerbreitet sind, wie Vitrina pellucida IIüll., Connlus fulvus Mull., Zonitoides nitilus Mull., vier Species des Genus Hyalinia (II. pura Ald., H. hammonis Ström, II. petronella Pfr. und II. cellaria Müll.), zwei Patula (P. ruderata Stud. mul P. rupestris Drap.), die beiden bekannten Vallonia (V. cristata Müll. und r. pulchella Muh.), Acanthinula aculeata Mlüll., Trichia hispida L. und Tr. sericea Drap.,

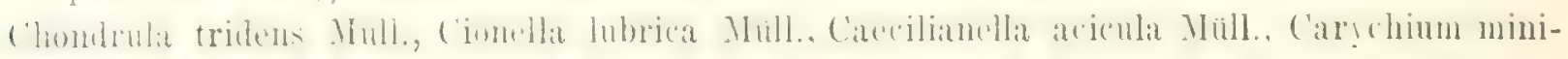

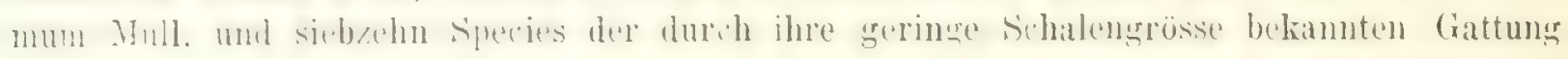
Pupa. Ferner gehört auch Vitrina anmularis Stud, zu den weitverbreiteten Arten, da sie sich in fast allen Gebirgsgegenden Südeuropas tindet. Alle diese Arten kommen in Folge ihres

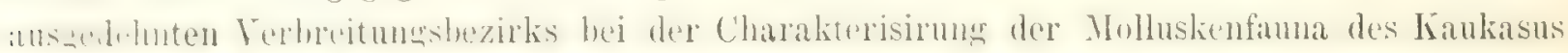

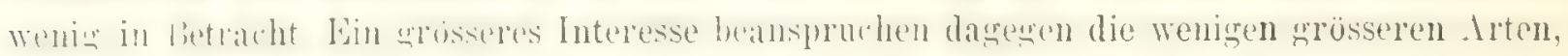
die der Kaukasus mit Lïndern des eigentlichen Europas gemeinsam hat. Hier muss ich zunächst bemerken, dass Zebrinus detritus MIül. wohl aus dem Verzeichnisse der Mollusken des Kinnkasus zu streichen ist, da diese Art wedel" von mir, noch, soweit mir bekannt ist, von eine $n$ andern Sammler der letzten Jahrzehnte im Gebiet des Kaukasus aufgefunden ist. Zebrinus cylindricus Mke, ist eine specifische Krimer Art, die von hier aus-wahrscheinlich erst in nenerer Zeit-nach dem Kaukasus vorgedrungen ist; meines Wissens ist sie bisher ansserhalb der Krim nur in der Umgebung von Novorossiisk gefunden worden. Unter den zahlreichen im Kaukasus vorkommenden Clausilien ist Clausiliastra laminata Mtg. die enzige Species, die dem Kaukasus nicht eigenthümlich ist. Nach Kobelt ${ }^{1}$ ) ist ihr Auftreten schwer zu erklären, da sie die Steppe nicht betritt und auch in der Krim und in Kleinasien fehlt. Diese Angabe kamn ich nun etwas berichtigen, insofern als Cl. laminata Itg. von mir auch an verschiedenen Orten der Krim aufgefunden ist, die somit eine Zwischenstation fur diese in fast ganz Europa mit Ausnahme des eigentlichen Russlands vorkommende Art bei

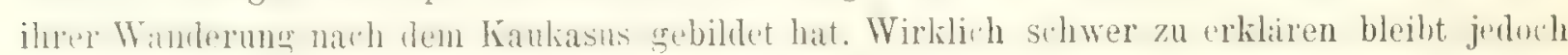
das Auftreten zweier anderer Arten, der germanisch-alpinen Eulota fruticum Müll. und der

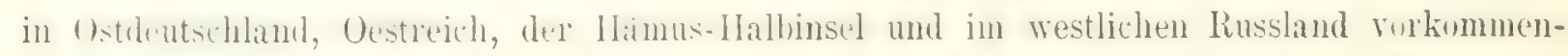
den Tachea vindobonensis Fér. Beide Arten kommen in Ciskaukasien vor, den Kamm des Gebirges iberschreiten sie jedoch nicht. Eulota fruticum ist im Süden des Gouv. Stawropol sowie im nördlichen Theile des Terek Gebietes nicht selten; Tachea vindobonensis wurde von II. Künig an drei verschiedenen, in der Ebene gelegenen Orten dieses Gebiets aufgefunden. Man weiss hier eben nicht, wie Kobelt sagt, ob man es mit Relikten aus einer Zeit, wo diese Arten von Osten her in die germanisch-alpine Fauna eindrangen, zu thun hat, oder ob die Einwanderung in späterer Zeit von Nordwesten her erfolgt ist, als sich in der Steppe noch meln' Waldinseln befanden als hente. Fur Tachea vindobonensis scheint mir das letatere wahrscheinlicher zu sein, da sie mit Tachea nemoralis Müll. und Tachea hortensis Müll. cinem Formenkreise angehört, der Mitteleuropa eigenthümlich ist.

Die überwiegende Mehrheit der kaukasischen Mollusken-wie bereits gesagt etwa fün Sechstel der ganzen Fauna-besteht aus solchen Arten, die entweder dem Kaukasus eigenthünlich und auf diesen beschränkt sind, oder von hier aus nach Kleinasien oder nach der

i) Iíobelt. 1, c. p. 41 . 
Krim vorgedrungen sind, so dass der Kaukasus als ihre eigentliche Heimat betrachtet werden muss. Wir haben somit, wie schon früher Bourguignat nachwies und neuerdings von Simroth und Kibelt wieder besonders hervorgehoben wird, den Kaukasus als ein selır wichtiges uni bedeutendes Scliöpfungsgebiet für die heute existirende Molluskenfauna anzusehen.

Bei einer Durchsicht der Liste der kaukasischen Mollusken fällt zunächst die starke Difłerenzirung der Nacktschnecken anf, da sich unter denselben liepräsentanten von nicht weniger als 11 Gattungen befinden, von denen 5, und zwar die Genera Trigonochlamys, Selenohlamys, Paralimas, Metalimax und IIomochroma, bis jetzt als specifisch kaukasische bezeichnet werden. Gigantonilas die Grenzen nach (Isten und Westen hin nur wenig überschreitet und Pseudomilax ausser den drei kaukasischen Species nur noch einen Vertreter, P. velitaris v. Mts. in Nordpersien hat. Auch unter den Gehäuseschnecken finden wir in den artenreichen Gattungen Helis, Puliminus und Clausilia solche Formen, die Veranlassuug gergeben haben, besundere Untergattungen aufzustellen, welche ja von manchen Autoren wiederum gradezu als Gattungen bezeichnet werden. Betrachtes wir nun die hauptsü̈hlichsten Gattungen der Gehäuseschnecken auf die Anzahl der Arten und deren Verbreitmug hin etwas nüher, su crgehen sich folgende Resultate: Die Gattuog Daudebardia ist im Kaukasus durch vier Arten vertreten, die sïmmtlich dem Gebiet eigenthümlich sind. EbenSoviel Species weist das Genus Vitrina auf, uud zwar ausser den bereits erwähnten weitresbrejteten V. pellucida Müll. und V. annularis Stud. zwei specifisch kaukasische, V. globusa linettg. und V. Sieversi Mouss. Bedeutend ist die Anzahl der kaukasis hen Hyalinien. Mit Ausnahme del fur eine persische Art aufgestellten Untergattung Gastranodon haben die anlern vier Grupen auch im Kaukasus ihne Vertreter. Besonders ist bemerkenswerth die Grupne der Retinellen, die mit ihren 9 Arten, welche in den Ost-Aljen, auf der. HämusIJalbinsel, in Griechenland und in Kleinasien auftretenten Zonites-letztere im Kaukasus ganz fuhlend,-zu crsetzen scheint. Von den 1 ; Species der Untergattung I'olita sind 9 ausschliesslich kankasisch, ebenso die 7 Arten der Vitrea-gruppe; Zonitoides besitzt im Kaukasus nur d’n im ganzen Gebiet vorkommenden Z. nitidus Müll In der Gattung Helix sind die lintergattungen Punctum, Patula, Vallonia und Acanthinula durch zusammen 7 Species vertreten. Von denten nur eine II. (Patula) goktschana Mss. ausschliesslich kaukasisch ist. Die Nummulina-gruppe tritt in zwei schënen, eigenthumlichen Arten auf, H. Prometheus Jioettg. und II. Jasonis Mouss. Unter den Trichien sind zwei weit verbreitete, H. hispida L. und H. sericea Drap. und zwei indigene, $H$. notha West. und II. chrysotricha Boettg Die $T$ Arten les Gruple Iatonia sind alle rein kaukasisch. Von Carthusianen sind is Species zu verzeichnen, von denen II. carthusiana Müll. sich vom Kaukasus an nach Westen durch ganz Mitteleuropa verbreitet, H. frequens Mouss. und H. carascaloides Bourg. aber nur bis zur IIämus-Halbinsel vorgedrungen sind, die übrigen 5 (H. frutis Pfr., H. circassica Charp., H. Haveola Kryn., H. pachnodes Boettg. und I1. aristata Kryn.) sind nur aus dem Kaukasus bekannt. Unter ihnen muss in Folge ihrer grossen Verbreitung H. circassica Charp. als cine der für das Gebiet besonders charakteristischen schnecken hervorgehoben werden: interessant ist auch $H$. aristata Kryn. durch die Behaarung der Schale, die übrigens bei II. (Trichial chrysotricha Boettg. und II. (Latonia) holotricha lioettg. nuch mehr hervortritt. Die nächste Gruppe ist die der Fruticocamplaeen, die mit ihren $1+$ Arten ganz anf den Kaukasus beschränkt ist und somit ein besonderes Interesse verdient. Die Arten dieser Gruppe, vornehmlich die mit gedrülitem Gewinde, haben eine gewisse Lehnlichkeit mit den fur das ganze. Alpengebeit su charakteristischen. jedoch im Kaukasus fehlenden Campylaeen, und wurde auch deshalb der kitukasischen Gruple seiner Zeit von liobelt der Na- 
me "Frutienamplatm" herigelegt. Xa"h dem heutigen Stande unseres Wissens sind aber,

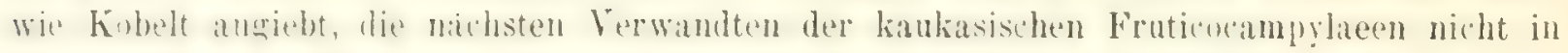
den alpinen Campylaeen, sondern in jenen centralasiatischen und chinesischen Formen zu

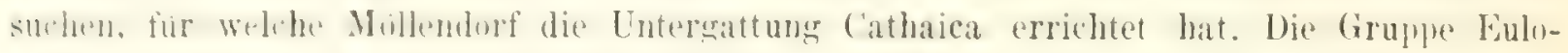
ta hat im Kaukasus zwei Vertreter. H. fruticum Mull, uber die ich bereits früher gesprochen habe und H. euages Boettg, eine sehr zierliche Schnecke, welche Prof. Boettger bei seiner Bes hreibung der Art als nwunderbar schöne Novität ${ }^{*}$ bezeichnete. Auffallend ist die geringe Zahl der Xeroluhlen: drei derselben H. derbentina Kunn, II. Krynickii Imlrz. und H. crenimaren Kryn. haben eine grossere Verbreitung im ciebiete des Kaukasus und die ersten beiden uberschreiten auch dessen Grenzen nach beiden Seiten hin; die andern drei Arten sind rein kaka-isch und nur von wenigen Fundorten bekannt. Die Gruple 'Tachea enthält ausser der bereits oben erwihnten $H$. vindobonensis Fér. noch die charakteristis. Isste Hedis a s ganzen Gebiets, die stattliche H. atrolabiata Kryn., die fast in allen Theilen des Kauka:us nicht selten ist; die grosse var. stauropolitana $A$. S. weicht zwar in

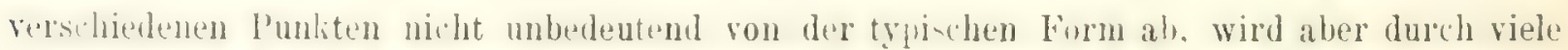
\%wischenformen mit derselhen verbunden; weiter entfernt sich vom 'Tyus die an der persischen Grenze vorkommende var. lencoranea Mouss, die auch von manchen Autoren als hesmblere Species butrachtet wird. Die rössten paliarktischen Landschnecken enthält die Cirupe P'omatia, aus welher der Kaukasus die allergrösste Species, H. Huchi Pfr. besitzt, die zwar eine ziemlich weite Verbreitung im Kaukasus hat, aber doch überall selten ist. Ehenfalls dem Kaukasus eigenthumlich ist eine kleine Grulye von l'omatien, aus der H. mbtusata $Z$. am bekanntesten ist, la sie sich von Ciskaukasien aus über den süden Russlands bis nach Odessa verbreitet hat, während die drei andern Arten dieses Kreises, II. Nordmanni Mouss. H. Christıphi Boettg und H. Raddei Buettg. auf den Kaukasus beschränkt sind. Die wohl als Varietäten von H. lucorum L. aufzufassenden H. taurica Boettg. (non Kryn.) und H. radiosa Z. kommen nur an der Südgrenze des Gebiets vor.-Von nicht geringerem Interesse als die burstehend besprochenen Helix sind die liankasischen liulminus. Unter ihnen sind in erster Linie zwei Arten hervorzuheben, die Veranlassung zur Aufstellung hesonderer Lintergattungen gegeben haben: es sind dies der schongezeichnete I;. Raddei liob. fur welchen ron linettger die Untergattung Iedea errichtet wurde, zu der ausserdem nur der in Kurdistan volkommende I. carduchus Mts gehört, und der namentlich durch die ahsonderliche Schalenfurm und die eigenthümhe Mikruskulptur ausgezei lnete B. Schliflii Ilouss, als einziger Vertreter des Subgenus Retowskia Boettg. Aus des Gruppe der Zebrinen besitzt der Kaukasus in B. INohenackeri Kryn. eine ihm eigenthümliche Art. Die Untersattung brephulus timlet sirh houptsächirl in dem meln westlich gelerenen Gebiet der Pontusländer; zwei Arten jedoch, der aus Transkaukasien beschriebene 13. Duboisi MIouss. und der von mir bei liatum entdeckte B. biplicatus Ret. gehören zur Fauna des Kaukasus. Aus der Gruppe Na aeus finde ich bei Kobelt 6 Species aufgeführt, von denen drei (B. caucasicus Pfr., B. Boettgeri Cless. und B. talyschanus Boettg.) ausschliesslich kaukasisch sind; die vierte Art, B. umbrosus Mouss. ist meiner Meinung nach eine kaum als Varietät zu bezeichnende Form des in ganz Europa vorkommenden B. obscurus Nüll.; ob die beiden noch aufgefühten Species, der uordpersische B. asterabadensis Kob. und der aus Palaestina beschriebene B. benjaniticus Roth wirklich im Kaukasusgebiet anftreten, bedarf wohl noch besserer Bestatigumg. Unter den 20 mir aus dem Kaukasus bekannten Chondrulen sind 10 demselben eigenthünlich und nur 2, B. tridens Mül. und B. quinquedentatus Mühl. haben cine weitere Verbreitung. Weit schwacher ist dir Gruple Ietraeus in Kaukasus ent- 
wickelt, da bis jetzt nur drei zu derselben gehörende Formen aufgefunden sind, 1: niveus Rssm., B. brevior Mouss. und B. lycicus Pfr. v. borealis Mouss. Von den 31 im Kobelt'schen Verzeichnisse aufgefuhrten Irten der Gattung Pupa im weitern Sinne wird, wie ich

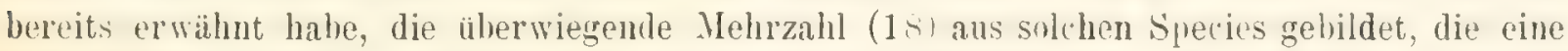
sehr gronse Verbreitung haben und in den meisten Lümlern Europas auftreten; unter den übrigen verdienen eine hesondere Beachtung die durch die merkwürdige Bezahnung der Iündung ausgezeichneten Arten des Lauria-gruple. P. pulchra Ret., P'. superstructa Mouss. und I'. zonata l'bettg., sowie die kleine I'. ILeucochilus' Theeli W. in Folge ihrer merkwürdigen Verbreitung: letztere, bisher nur aus Sibirien bekannte Art, wurde nämlich von mir in ziemlicher Anzahl im Auswurf des Rion bei Puti aufgefunden. Sehr charakteristisch sind die Clausilien des Kaukasusgebiets. Iusgenommen Cl. lamirata IItg. sind nämlich alle übrigen hier vorkommenden Species (41) auf den Kaukasns beschränkt und bilden zum Theile besundere Gruppen, die ausserhalb der Kankasuslinder lieine Vertreter haben. Unter den vielen (iruphen, die man für die europüischen Cilausilien errichtet hat, giebt es nur eine, die griechischkleinasiatische Oligntychia, aus welcher auch im Gebiet des Kaukasus einige Species (6) anfrgefunlen sind. Von besonderer Wichtigheit ist die Gruppe Euxina, da die Häfte aller kaukasischen Clausilien (21) derselben angehört. Sie überschreitet zwar die Grenzen des Gebiets, da sich Irten derselben auch in Kileinasien und weiterhin in Syrien finden, doch ist der Kaukasus jedenfalls als das Entwicklungscentrum dieser Gruppe zu hetrachten. Rein kaukasisch sind die Gruppen Euxinastra, Acrotoma, Micropontica und Serrulina mit 1 resp. $3, \frac{1}{4}$ und ¿ Irten. Hochinteressant sind namentlich die drei durch die Decollation der Jugendwindungen ausgezeichneten Arten der Gruppe Acrotoma, von denen Cl. Komarowi Boettg. wohl die grüsste aller paläarktichen Clausilien ist, da sie decollirt noch eine Länge von $371 / 2$ m!n. hat. Fine decollirte species findet ich auch unter den Arten der Serrulina-gruppe, die sich in verschiedenen Punkten stark von den übrigen Clausilien unterscheidet, sodass manwe Malikozonlogen sie als besondere ('rattung betrachten. Schliesslich verdient noch $\mathrm{Cl}$. perlucens linettg. als am weitesten nach Westen gehende Form der asiatischen Untergattung Phaedusa hervorgehoben zu werden. Gering ist die Anzahl der geophilen Deckelschnecken des Kaukasus, da von diesen bis jetzt nur je eine Art der Gattungen Acrue und Pomatias, sowie je zwei der Genera Cyclostoma und Cyclotus aufgefunden wurder, die mit Ausnahme der auch in der Krim und in Gebiet der Karpathen häufigen Cyclostoma costulatum Z. den Kauka-usländern eigenthümlich sind. Das Vorkommen der sonst der paliarktischen Molluskenfauni völlig fremden Gattung Cyclotus bildet, wie Kubelt bemerkt, eins der merkwürdigsten Ratsel, whlches uns die geographische Verbreitung der Mollusken im paläarktischen Gebiet aufgiebt, insofern als die 2 (oder :) am Südrande des Kaspischen Meeres vorkommenden Arten durch ungeheure Länderstrecken von ihren Verwandten im mittleren China und östli(hen Hinterindien getrenut sind. Bekanntlich hatte aber die Gattung Cyclotus wïhrend der Tertiärepuche in Luropa eine weite Verbreitung und somit dürfte Kobelt wohl Recht haben, wenn er in den kaukasischen Formen Relikten aus früher Zeit sieht, die sich in dem halbtropischen Gebiet bis auf unsere Zeit erhalten haben.

Bei der grossen Ausdehnung, der verschiedenen orographischen Beschaffenheit und den ungleichen klimatischen Verhältnissen des Gebiets ist es selbstverständlich, dass die Molluskenfauna in den verschiedenen Theilen des Kaukasus auch eine recht verschiedene sein muss. Die Verbreitung der Mollusken zu Grunde legend, liann man das ganze Gebiet in folgende fün grosse Theile zerlegen: Ciskaukasien, Westtranskakisien, Osttranskaukasien, RussischArmenien und das Talysch-Gebiet mit dem malakozoologisch wohl dazu gehörenden nördli- 
'he'n l'ersion. Ehe ich eine kurge ('haraliteristik dieser einzelnen Theile webe, in der ja be-

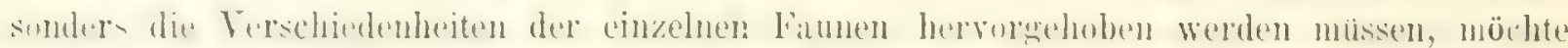
i,h anf di.jenigen Zuge hinweisen, welche die Kusammengehourigheit des ganzen Gebiets beweisen. Natürlich kömen hier nur die Arten in Betracht kommen, welche dem Kaukasus eigenthumlich sind und die Grenzen desselben nicht oder nur wenig überschreiten. Da ist zunäclist das Auftreten von lruticocampylacen in allen fün Abtheilungen zu constatiren, ferner die Verbreitung von II. atrolabiata Kryn., die nur aus Russisch-Armenien noch nicht bekannt ist, aber auch diesem 'l'heile des Kaukasus kaum fehlen dürfte, da sie in der var. lencoranea auch im l'alysch-Gebiet vorkommt. Nur dem letzteren fehlen die sonst überall aufgefundenen Clausilicn aus der Gruppe Euxina, sowie Cl. foveicollis Charp. Serrulinen sind mit Ausnahme fun Russisch-Armenien in allen theilen tes Gebiets gesammelt worden. Helix (Latunia) gluhula kryn kommt sowohl in ('iskaukasien wie in (Mottranskaukasien und Rusisch-Armenien ror, H. (('arthusiana) circassica Schub. in Ciskankasion und auch in beriden Thesilen Transkakasiens. Die grossen Ilyalinien aus der Gruple lietinella fimlen sieh "benfalls im ennzen Transkukasien, sowie auch im Talysch-Gebiet u. s.w. Die angeführten lieisplele zeigen zur (ienüge, dass man vollhommen berechtigt ist, die Molluskenfauma aller Theile des (iebiets mit dem Gesammtnamen einer kakasischen zu bezeichnen. Trotz dieser Lelereinstimmung im Grossen und Ganzen ist die Fauna des einzelnen Abtheilungen jednch eine recht verschiedene. In Ciskaukasion herschen noch die eurnäisch-alpinen Arten vor, da von den $91^{1}$ ) bis jetzt von hier bekannten Species $48^{1}$ ), also meln als die Hälfte, zu den weitverbreiteten curopaischen Arten gehören. Das eigenthümliche Iuftreten von Eulota fruticum Mül., Tachea vindobmensis Fér. und Clausilia laminata Buettg. labe ich bereits früher erwihnt, alle drei Arten übersthreiten jedoch den Kamm des Gebirges nicht. Ton den specifish katuksisthen Furmen sind weitaus die meisten solche, die anch jenseits der Hauptgebirgsititte gefunden worden und nur aus dem IIochgebirge selbst werden emige Splecies, Ilelix (Fruticocampylatal phaeoloma lioettg., Clausilia (Acrotoma) semicineta boettg. und now ein patar Irten aufgeführt, die in Transliaukacien bisher noch nicht aufgefunden sind. Die Charakterschnecke des Kankasus Helix ('Tachea) atrolabiata Kryn. findet sich suwohl in der typischen Eurm, als in der grossen, schönen $v$. stauropolitana 1 . S.; in den Nordabhängen des Gebirges lommt die Hialfte der bis jetzt beschriehenen Fruticocamplacen vor; dafü ist aber die 'Zahl der liuliminen eine sehr geringe, und von den für die Kaukasusfauna so wichtigen Euxinen besitzt Ciskaukasien nur 5, während aus dem ganzen Gebiet deren 21 bekannt sind. Dem lieispiele Krubelt's folgend, theile ich 'Transkaukisien, unter Annahme des suram Gebirges als Scheidegrenze, in zwei Theile. West-und Ost-Transkaukasien. Wie genannter Autor sehr richtigr bemerkt, kann zwar ein nur 3000' hoher, bis zum Gipfel hinauf bewaldeter Ilohenzug heine scharfe Grenze für die Verbreitung von Mollusken bilden und in der That aberschreitet auch manche westtransiaukasische Art diesen Bergzug nach Usten hin, doch ist in Folge der veranderten physikalischen und klimatischen Verhiltnisse der Lünder diesseits und jenseits des Suram (iebirges ein bedeutender Unterschied zwischen den beiderseitigen Faunen zu bemerken, :0 dass dieser Bergzug immerhin als Faunenscheide für die Nollusken dienen kann. Ich habe, abweichend ron Kobelt, das westliche Gebiet mit dem allgemeinen Namen Westtranskilukasien bezeiclnet, da die von Kobelt gewählte lezeichnung" Mingrelien" doch nur für cinen Theil passt. Zu Westranskaukasien rechne ich ausser Mimerelien und Imeretien auch Abchasien und den ganzen Küstenstrich bis nach Novorossiisk hinauf, sowie im Süden liafum mit dem dazu gehrigigen Ilinterlande. In diesem so begrenzten Gebiet, das sich durch

1) Die Süsswasserarten sind hier somohl, wie bei den folgenden Ziffern mitgezählt. 
üppigste Vegetation und abergrosse Feuchtigkeit auszeichnet, ist das IIolluskenlebeu am reichsten entfaltet und nicht mit Unrecht wird das knlchische Waldgehiet als das Entwicklungsrentrum der kaukasischen Molluskenfauna angesehen. Obschon auch hier weite Landstriche noch ganz unerforscht sind, so kennen wir aus diesem Theile des Kaukasus doch schon 120 Arten, von denen nur 35 zur europäisch-al!inen Fauna gehören. Hier finden sich grade die schönsten Formen; die grossen Retinellen, die leiden Nummulinen, mehrere interessante Carthusianen, die Hälfte der Fruticoampylaeen, die schüne Euluta enages Boetto., die beiden p̧rächtigen Untergattungen von liuliminus, Retıwskia und Medea, die meisten Euxinen und die Riesenclausilie, Acrotoma Komarowi Buetg. Im Vergleiche mit dieser reichen Fauna ist die Osttranskaukasiens eine recht arme, wie es ja bei der viel schwärhern Vegetation des durren Grusiens nicht anders zu erwarten ist. liesonders gross ist die Armuth an Mollusken im östlichen Theile des Gebiets, wo Mangel an Wald und atmosphärischen Niederschlägen der Lntwicklung eines reicheren Molluskenlebens hindernd entgegentreten. Nur 54 irten, darunter 22 westeurnuäische, sind his jetzt aus Osttranskaukasien beliamt geworden, und unter allen findet sich nur eine, Buliminus Hohenackeri Kryn., die in den beiden früher besprochenen Theilen des Kaukasus nicht vorkommt. - Die vierte Abtheitung bildet das als Russisch-Armenien bezeichnete Gebiet zwischen Kinra und Araxes. Zwar scheinen auch hier grosse Landstriche ganz nder doch fast ganz von Schnecken entblösst zu sein, doch ist die Gesammtzahl derselhen eine grössere als die der Mollusken Osttranskaukasiens, da durch Leder, Valentin und Andere (9) Arten aufgefunden sind. Fast die Hälfte derselben, 46, besteht aus weitverbreiteten europäischen Arten, unter den sonstigen, kaukasischen Species sind als neue Elemente hervorzuheben: die starke Entwicklung der Buliminengruppe Chondrula (mit 9 Arten), das Auftreten von vier neuen Clausilien aus der Gruppe Olignfitychia, das Erscheinen einer Helix aus der Gruple Levantina, II. dschulfensis Dub., und der kleinasiatischen Helix (Pumatia) taurica lBoettg. - Ilie Fauna des Talysch-Gebiets besteht aus 72 Arter, von denen:;1, als gewöhnliche, enropuische Splecies, für die Charakterisirung der Molluskenfauna des Gebiets keinen Werth haben; untel den ibrigen 11 sind nur 14, die gleichfalls der kaukasisch-armenis hen Fauni angehören, die übrigen 27 sind entweder dem Gebiet eigenthümliche Arten oder solche, die anch in dem südlicher gelegenen persischen Hochland vorkommen. Wenn num auch das Vorhandensein von 14 gemeinsamen Arten als Beweis dienen kann, dass das Talyschgebiet noch dem Kaukasus zuzurechnen ist, so scheinen mir doch die grosse Zahl dem eigentlichen Kaukasien fremder Arten, so»ie das vollständige Fehlen der sonst überall im Kaukasus vorkommenden Euxinen dafür zu sprechen, dass es als besondere Abtheilung den übrigen Ibtheilungen des Kaukasus gegenüber zu stellen ist. Unter den eigenthümlichen Species ist als besonders interessant der bereits oben erwähnte Cyclotus Sieversi Pfr. zu bezeichnen, der in Nordpersien, das in faunistischer Beziehung wohl mit dem Talyseh-Gebiet zu vereinigen ist, eine nahe verwandte Art, Cyclotus Herzi Boettg. besitzt.

Zum Schlusse meiner kurzen Uebersicht der kaukasischen MIolluskenfauna will ich noch bemerken, dass Transkaspien unter den 28 von dort bekannten Formen keine einzige kaukasische aufweist, und somit schon nicht mehr dem kaukasischen Molluskengebiet angehürt.

O. Retowski. 


\section{GASTROPODA.}

\section{Trigonochlamys Bttg.}

imitatrix Bttg. Batum.

\section{Selenochlamys Bttg.}

pallida Bttg. Gagri.

\section{Amalia Moq. Tand.}

Lederi Bttg. Lom-mita.

Kiollyi Ret. Batum.

\section{Lytopelte Bttg.}

Raddei Sinr. 'Tft.

\section{Limax List.}

carinatus. 'Tft.

melanocephalus Kal. Lom-mta.

varius. Nowy Afon.

intermittens Bttg. Nowy Afon.

\section{Daudebardia Hn.}

Heydeni Bttg. Kasb., Alst.

\section{Glandina Scham.}

algira Brug. var. mingrelica littg. Kut, Nowy Afon.

\section{Parmacella Cnv.}

Olivieri Cuv. Lenk., Aresch. var. ibera Eichw. Lenk

\section{Vitrina Drp.}

pellucida Müll. Pjatgk.

gilobosa Bttg. Tbtn.

annularis Stud. Wldk.

Lederi Bttg. Suram.

subcarinata Bttg. Lenk.

\section{Conulus Fitz.}

fulvus Drp. Wldk., Abst., Michlw.

Raddei Bttg. Such.

\section{Hyalinis Ag.}

angystropha Bttg. Suram., Poti.

contortula Kryn. Suram., Lenk., Abst.

subeffusa Bttg. Mzchet. sorella Mss. 'Transk.

nitida Mull. Lenk., Kussari.

pura Ald. Abst., Wldk.

petronella l'fr. Tbtn.

suturalis Bttg. Gagri.

cellaria Mull. var. Sieversi [Bttg. Georgk, Tbtn., Lenk., Wldk.

nitidula Drp. Kub.

caspia littg. Hamrt.

patulaeformis I3ttg. v. calculiformis Bttg. 'I'btn. Duboisi Ch. Kut., Lenk, Batum., Gagri. difficilis 13ttg. var. batumensis Ret. Batum. elegans Bttg. Lenk.

mingrelica Mss. Kut., Gudaut.

var. intermissa Kob. Gagri., Pizunda.

filicum Kryn. Lenk.

kutaisiana Mss. Kut., Mzchet., Borsh., Ratsch

\section{Helix I.}

Lederi Bttg. Lenk.

pygmaea Drp. Lenk., Abst., Borsh.

ruderata Stud. Kussari.

rupestris Drp. Kut., Now. Afon.

costata Mull. Mzchet., Hamrt., Pjatgk.

pulchella Mull. Lenk., Martk.; 'T'f.

aculeata Müll. Kussari.

Promotheus Bttg. Muri.

Jasonis Mss. Zlbd.

globula Kryn. Borsh., Kut, Kub., Abst., Helnd, , Imrt.

pisiformis Pfr. Sch.-d. 5-7000', Lenk. talyschana MIts. Lenk.

holotricha Bttg. Nowy Afon.

circassica Mss. Gordi., Gambor., Kut., Batum., Tioneti., Borsh., Tschetschna., Wladimirowka., Tbtn., Imrt., Dagt.

var. colchica Mss. Mzichet.

frequens Mss. Pjatgk,; Tfl., Tuapse., Kut. carascaloides Bttg. Nowy $\Lambda$ fon.

cantiana Mont. N. Rossk.

carthusiana Mull. N. Rossk., Pjatgk., Essentucki.

flaveola Kryn. Nowy Afon.

f. albina Bttg. Nowy Afon.

aristata Kryn. Kut., Kub., Grus., Pjatgk.

Appeliusi Mss. Suram., Thtn., N. Rossk. 
narzanensis Kryn. Wladimirowka,. Kasb., A waria., Sch.-d., Daralagoes., Asch.-d., -Koblian-tschai., Lars., Burtn., Lawaschi. var. unicingulata Bttg. Kasb. va:. subunicolor Bttg. Kasb. var. unicolor Bttg. Kasb.

f. rudis Ret. Kasikp., Batum.

f. subdepressa Ret. Schtjk.

pratensis Pfr. Borsh., Chews., Awaria., Nakarala., Imrt., Ossetien.

tschetschenica Ret. Bon-m. 8000'.

Joannis Mort. Novo-Senaki., Bortschcho. var. pellucidipunctata Ret. Bortschcho.

Ravergieri Bttg. Pjatgk., Imrt., Geok-tepe., Chass-jrt.

transcaucasica Mss. Tfl., Mosd., Geok-teje., Aresch., Ratsch., Helnd.

f. pygmaea Bttg. Gambor.

phaeolema Bttg. Sch-d. 5-7000'.

Eichwaldi Pfr. Kobi.

var. albocostata Ret. Dagt.

var. daghestanica Kob. Kasb. 9000'. Chews.

var. Koenigi Ret. Tebul-m. 8000'.

armeniaca Pfr. Sch-d. 5-7000'.

fruticum Müll. Imrt., Pjatgk, Georgk., Kub., Kut.

f. major. Mosd.

euages Bttg. Zbld., Wardane.

virgata DaC. var, variabilis Drp. N. Rossk. Krynickii Andrz. Anapa., Lenk.

vestalis Pfr. var. radiolata Mss. Lenk.

crenimargo Kryn Uelnd., Pjatgk., Mingtsch. derbentina Kryn. Tuapse., Gori., Kut., Jora., Abst., Karabagh., Scheschepi Mingr., Chass-jrt., Georgk., Marienfld. Dagt., Baku., Tfl, Chertwis., Geok-tapa., Anapa., Gengerep., Dargo., Achzu., Kistasur., Petrwk., Chews., Pjatgk., Helnd. ilschujfensis B. Ordb., Nigri.

atrolabiata Kryn. Kut, Batum., N. Senaki., T'uapse., N. Rossk., Achlz, Poti., Pizunda., Gudaut., Abst., Ana ıa., Such., Protschny-okop., Tfl., Bortschcho, Afips., Neberdsha., Martk., Ijatgk., Georgk. var. lenkoranea Mss. Enseli., Lenk. var. intercedens Ret. Nowy $\Lambda$ fon. vindobonensis Fér. Neberdsha., Chass-jrt., Kisl., Mosd., Pjatgk.

Christophi Bttg. N. Senaki., Artwin.

obtusata Z. Imrt., Delishan., Arm., Tuapse.,Kut.,Achtala,Somchet.,Atschkura., Kuban., Lars., Chass-jrt., Geok-tepe., N. Rossk. Achz.

Buchi Pfr. Koblian-tschai., Gurien., Choni., Kut., Marienfeld., Grus., Bjely-klutsch., Salalet., Suram., Nakalakewi., Mzhet., Tbtn.

lucorum L. var. euphratica Mits. Trapezund.

radiosa Z. (taurica Bttg.) Namet-tapa., Schemacha., Murud., Mur-dgh., Grus., Kopan-tacha., Achzu., Tatiew Kloster., Damardshuli., Gudaut.

\section{Buliminus Bk.}

IIohenackeri Kryn. Achz,, Artwin., Rasu., Wand (Karabagh), Bunukli., N. Senaki., Chertwis., Kut., Gori., Ratsch., Achlk., Abst., Ordb., Daralagoes., Rasn., Kasikp.

cylindricus Mke. Tfl., Ratsch., Imrt.

var. subacuminatus Ret. N. Rossk.

Raddei Kob. Gagry., Wardane.

Schläflii Mss. Poti.

Merduenianus Kryn. Kut., Imrt.

caucasicus Pfr. Nowy Afon.

Boettgeri Clss. Kut.

obscurus Mull. var, umbrosus Mss. Sch-d., Georgk.

brevior Mss. Tbiz S.

diffusus Mss. Sagmag.

tridens Mull. Kut, Gordi., Georgk.

var. atf. eximius Rssm. Georgk., Aresch., Michlw., Schtjk.

var. Bayerni Pfr. Dargo., Dagt, Pjatgk., Tti., Kub.

f. marcida Bttg. Lenk.

var. terkensis Ret. Georgk.

var. kubanensis Mss. Kut., Ossetien., Gori.,

Imrt., Protschny-okop.

quinquedentatus $\mathrm{Rm}$. Aksf.

tetrodon Mort. Davidsberg bei Tfl. 
lammeliferus Rm.var. phasianus Mss. Michlw., it wtsch.

angustior Ret. N. Rossk.

didymodus Bttg. Helnd., Rasn.

linenigi Ret. Bos-dagh dresch.

adjaricus Ret. Artwin.

tricollis Mss, var. minor Bttg. Kars.

var. excellens Ret. Batum.

\section{Pupa Drp.}

cylindracea DaC. Kussari., Mzchet, Lenk. Semproni Ch. Kut.

r. caspia Iffr. Lenk.

pulchra Ret. U-der.

superstructa IIss. Kut., Suram.

zonata Bttg. Oschten-Fischt.

doliolum ling. Kussari., Lenk., Abst.

var. batumensis Ret. Batum.

Baymondi Iittg. Kut., Suram.

bifilaris Mss. Now. Afon

pagodula Desm. var. Lederi Bttos. Lenk.

avenacea lirug. Kut.

granum Irp. Davidsberg bei Tfl., Helnd.

triplicata Stud. Sch.-d., Michlw., Mzchet,

var. luxurians Reinh. N. Rossk.

var. suboviformis Bettg. Pjatgk.

var. inops Reinh. Kasb.

interrupta Reinh. Helnd., Muscht.

Strobeli Gredl. Mang.

claustralis Gredl. var. clavella Reinh. Abst. costulata Nills. Mzhet, Martk., Mang.

minutissima IIn. Poti., Michlw.

'Theeli W. Poti.

pygmaea Drp. Kussari., Lenk., Michlw.

Sieversi Bttg. Kussari.

substriata Jeffr, var, mitis Bttg. Kasb.

antivergo Dr\%. Lenk.

pusilla Müll. Kussari., Mbst.

angustior Jeffr. Helnd.

\section{Clausilia Drp.}

laminata Mont. Georgk.

hamata Bttg. Batum.

Komarowi Bttg. Nowy Afon.

Releauxi littg. Batum.

filosa Mss. Batum.
Duboisi Ch. Abst., Gordi., Suram., Kut., Borsh., Kussari.

f. minor A. S. Batum.

pleuroptychia Bttg. Letch., Kut.

var. polygyra Bttg. Kut.

litotes 1. S. Ossetia., Tbtu., Suram., Ratsch., 'T'schetschna.

var. litoderma Bttg. Batum.

qnadriplicata A. S. Kussari., Tioneti., Ossetia., Ratsch., Martk.

dipolauchen Bttg. Gordi.

var. multistriata Ret. Nakalakewi.

pumiliformis Bttg. Nowy Afon.

Lederi Bttgr. Suram.

var. gradata Bttg. Kut.

aggesta Bttg. N. Rossk.

subaggesta Ret. Batum.

acuminata Mss. Tbiz. S.

Strauchi Bttg. Mzchet.

index Mss. Ossetia., Borsh., Elpi.

climax Bttg. Batum.

ossetica A. S. Ossetia., Abst., Kut., Adsh., Tschetschna., Borsh., Suram.

var. derasa Mss. Kut.

somchetica Pfr. Pjatgk., Pari., Abst., Kut., Kub., Kwischet., Ratsch., Sch.-d., Ossetia., Lars.

var. Raddei Siev. Tbiz. S.

transit. ad tschetschenica. Lars.

tschetschenica Pfr.Ossetia., Kasb., Forellnaja.

Kut., lagra., Dagt., Burtn., Schtjk.

perlucens Bttg. Kussari., Lenk.

Gustavi Bttg. Schindan-kala.

foveicollis Pfr. Suram., Kussari, Kut, Kub.,

Borsh., Abst., 'Zbld.

closta 13ttg. Gagry, Nowy Ifun.

Sieversi Pfr. Lenk.

serrulata Pfr. Suram., Kut., 'T'btn.

funiculum Mss. Batum.

semilamellata Mss. Suram., 'T'btn.

\section{Cionella Jeffr.}

Iubrica Mull. Abst., Lenk., Michlw.

var. exigua Mke. Michlw.

var. columna $\mathrm{Cl}$. Hamrt.

acicula Mull. var. abchasica Ret. Nowy Afon. 


\section{Saccinea Drp.}

putris L. Tff., Lenk.

elegans Risso. Pjatg.

Pfeifferi Rm. Lars, Batum., Gorätschewodsk. oblonga Drp. Shelesnowodsk.

\section{Carychinm Müll.}

minimum Müll. Kussari., Lenk., Suram.

Lederi Bttg. Lenk.

\section{Limnaea Rang.}

stagnalis L. Jekaterinodar.

auricularia L. Suram.

lagotis Schr. Polk., Pjatgk., Lissoi-osero., Kura.

var. batumensis Ret. Batum.

var. elegantula Ret. Forellensee.

ovata Drp. T'fl.

var. tenera Porr. Lissoi-osero., Lenkoranka. palustris Müll. Poti., Batum.

truncatula Müll. 'Tfl, Lenkoranka.

\section{Physa Drp.}

hypnorum L. Poti.

\section{Planorbis Guett.}

umbilicatus Müll. Forellnaja., Poti., Burtn., J.enk., Pjatgk., Tschetschna., Grus., Michlw, Kub.

var. subangularis Phil. Lissoi-0sero., Pjatgk., Georgk.

spirorbis L. Mingrelien.

glaber Jeffr. Lenkoranka.

\section{Ancylus Geoffr.}

fluviatilis Müll. Polk.

var. armenius Bttg. Balta.

lacustris L. Poti.

\section{Acme Hart.}

Moussoni Bttg. Sura!n.

\section{Cyclotus Guild.}

Sieversi Pfr. Lenk., Lirk.

\section{Cyclostoma Drp.}

costulatum Rm. 'Til., 'Tioneti., N. Rossk.,
Pjatgk., Chews., Kut., Martk., Balta., Georgk.

hyrcanum Mts. Lenk.

\section{Pomatias Stud.}

Lederi Bttg. Letch, Kut.

\section{Paladina Lam.}

contecta Mill. var. caucasica Cl. Batum., Poti.

vivipara L. Palaeostom., Poti., Redut-kale. spec.? Achtanisow Liman.

\section{Melanopsis Fér.}

buccinoidea Oliv. var. mingrelica Mss. Imrt., Redout-kale., Palaeostom., Wardane., Kut.

\section{Neritina Lam.}

fluviatilis L. var. thermalis Boub. Kut. var. subthermalis Bttg. Poti. var. Boettgeri W. Nowy Afon. liturata Eichw. Astara., Derb., Sewastopol., Petrwk

\section{PELECYPODA. \\ Corbicula Mhlf.}

fluminalis Müll. var. crassula Mss. Lenk. var. fluviatilis Müll. Lenk.

\section{Sphaerium Scop.}

corneum I. Poti.

spec.? Forellensee.

\section{Pisidium Pfr.}

fontinale Pfr, Lenk.

\section{Unio Rtz.}

Stevenianus Kryn. Arax.

mingrelicus Drt, Michlw., Ziva Mingrel.

Raddei Drt. Rion.

colchicus Drt. Ziva Mingrel., Afips.

tumidus Rtz. Kub.

rostratus Lam. Kub.

Sieversi Drt. Ziva Mingrel. 
Veseni H. Michlw.

araxenus I)rt. Arax.

spec? Palacostom., Achtanissow Liman.

\section{Anodonta Cur.}

Sieversi Drt. 'Ziva Mingrel., Rion. anatima A. var. Adshi-Kabul.

var. Raddei Ret. Achtanisow Liman.

cyrea I)rt. Lenk., Mahomed-most., Palaeostom. lenkoranensis Drt. Isenk.

complanata Rm. Afips.

\section{MOLLUSCA TRANSCASPICA.}

\section{GASTROPODA}

\section{Vitrina Drap.}

Raddei Bttg. 1k-dagh 10000 '.

Helix L.

adela West. vir. mionecton Bttg. Ak-dagh $100000^{\prime}$.

tra:scaspica littg. Kopet-dagh.

Krynickii Kryn. Germab., Gersch-chana.

\section{Buliminus Bk.}

cremita Rve. Keltetschinar, Gaudan-Schlucht. Walteri Bttg. Mk-dagh: 10000'. ghilanensis Iss. Kopet-dagh.

\section{Papa Drap.}

granum Drp. Gr. Balchan.

cupa Jan. var. turemenia littg. Ig-dagh. $10000^{\prime}$.

signata Mouss. Gr. Balchan.

\section{Succinea Drap.}

l'feifferi Rm. Germab fl. Kukulan.

\section{Limnaer Rang.}

impurus 'Trosch. var, oxiana Bttg. Amu-darja. lagotis Schrk. Derègess $6000^{\circ}$

var. attica Roth. Nerw. Oase.

var, tener K. Artschman., Germab., Aschabad. truncatulus Mull. Aschabad.

\section{Planorbis Gnett.}

umbilicatus Müll. var. subangulata Mull. Germab fl. Kukulau.

\section{Melanopsis Fér.}

praemorsa L var. sphaeroidea Bttg. Aschabad., Germab., Geok - tepe - Germab., Geok-tepe-Bagyr.

var. variabilis Phil. Keschefrud., Chorassan.

\section{Hydrobia Hartm.}

ventrosa MItg. var, pusilla Eichw. Molla-kary.

\section{Psoudamuicola Paul.}

Raddei Bttg. Chodsha-kala.

\section{PELECYPODA. \\ Corbicala Mühlf.}

fluminalis Müll. var. oxiana Mts. Aschabad.

\section{MOLLUSCA E MARE NIGRO.}

\section{SCAPHOPODA.}

Dentalium I.

novencostatum Lam. Bosporus.

vulgare IaC. Busporus.
Siphonentalis Sars.

quinquangularis Jeffr. Marmora Meer.

AMPHINEURA.

Chiton I.

olivaceus Spglr. Bosporus. 
marginatus Penn. Mare nigr.

Rissoi Payr. Bosporus.

\section{Acanthochiton Leach.}

discrepans Mont. Bosporus.

\section{GASTROPODA \\ Tornatina Ad.}

truncatula Fisch. Sewastopol.

umbilicata Car. Sewastopol.

Volvala Ads.

acuminata Sars. Bosporus.

\section{Cylichna Lov.}

cylindracea $\lambda$ d. Bosporus.

\section{Bulla I.}

utriculus Brocchi. Marmora Meer.

Haminea Leach.

hydatis Ad. Bosporus., Sewastopol.

\section{Ringicala Desh.}

buccinea Desh. Bosporus.

\section{Philine Asc.}

aperta Lam. Bosporus.

quadrata $F$. et H. Marmora Meer.

\section{Aplysia $\mathrm{L}$.}

depilans L. Marmora Meer.

\section{Tectura Aud.}

virginea Jeffr. Bosporus.

\section{Patella I.}

coerulea L. Mare. nigr., Sewastopol.

\section{Scissurella 0rb.}

costata d'Orb. Bosporus.

\section{Fissurella Brug.}

graeca Lam. Bosporus.

\section{Emarginula Lam.}

conica Schum. Bosphorus.
Phasianella Lam.

pullus Payr. N. Rossk., Sewastopol.

tenuis Mich. Mare nigr.

Clanculus Mgle.

corallinus Wkf. Bosporus.

Monodonta Lam.

turbinata Fisch. Bosporus.

\section{Gibbula Risso.}

adriatica Brus. Mare nigr., Sewastopol.

ardens Mits. Mare nigr.

albida MIrs. N. Ross., Bugas., Sewastopol.

divaricata Brus. Sewastopol.

fanulum Brus. Bosporus.

\section{Zizyphinus Gray.}

exiguus Kob. Bosporus.

Odostomia Mtrs.

conoidea Forb. Marmora Meer.

Parthenina Loc.

interstincta Kob. Mare nigr., Bosporus.

\section{Enlima Risso.}

intermedia Cantr. Sewastopol.

\section{Bcalaria Lam.}

tenuicostata Mich. Bosporus. commutata Mtrs. Bosporus.

\section{Natica Ad.}

intricata Phil. Bosporus.

Josephinia Risso. Marmora Meer.

\section{Lamellaria Mtg.}

perspicua L. Marmora Meer.

\section{Crepidula Lam.}

unguiformis Lam Bosporus.

\section{Calyptraea Lam.}

chinensis L. Mare nigr., N. Ross., Sowastopol.

\section{Truncatella Risso.}

truncatula Sow. Sewastopol. 


\section{Hydrobia Hrtm.}

pusilla Lichw. Sewastopol.

\section{Rissoa Frém.}

splendida kichw. Mare nigr., Sewastopol.

similis Schacchi. Bosporus.

monodonta Phil. Bosporus.

cimex $\mathrm{F}$. et H, Bosporus.

reticulata Jefir. lBosporus.

lactea Mich. Sewastopol.

sculpta Phil. Marmora Meer.

\section{Rissoina d'Orb.}

Bruguieri Horns. Bosporus.

\section{Homalogyra Jeffr.}

atomus Jeffr. Mare nigr.

\section{Solarium Lam.}

fallaciosum 'lib. Marmora Meer.

\section{Litorina Fér.}

neritoides Phil. Sewastopol.

\section{Caecum Flem.}

irachea F. et H. Sewastopol.

\section{Turitella Lam.}

communis Risso. Bosporus.

Vermetus Ad.

corneus Forb. Marmora Meer.

\section{Cerithium Ad.}

vulgatum Brug. Sewastopol., N. Rossk.

\section{Bittium Leach.}

reticulatum B. Sewastopol.

var. ferrugineuin Mdl. Mare nigr, N. Rossk. pusillum Loc. Sewastopol.

\section{Triforis Desh.}

perversa Chenu. Sewastopol.

\section{Cerithiopsis Forb.}

tubercularis F. et H. Bosporus.

\section{Chenopus Phil.}

pes-pelecani L. Marmora Meer.
Murex $\mathrm{I}$.

trunculus L. Marmora Meer.

cristatus Broce. Bosporus.

\section{Trophon Jeffr.}

breviatum Jeffr. Sewastupol.

Ocinebra Leach.

erinaceus L. Bosporus.

\section{Columbella Lam.}

scripta Sandri. Narmora Neer.

\section{Nassa Lam.}

reticulata Flem. Sewastopol., Mare nigr., Batum., N. Rossk., Gudaut. incrassata Flem. Bosporus.

\section{Cyclonassa Sws.}

neritea L. Sewastopol.

Kamiesch. Desh. Mare nigr.

\section{Mitra Lam.}

olivoidea Cantr. Marmora Meer.

\section{Crassopleura Mtrs.}

Maravignae Mtrs. Bosporus.

\section{Rhsphitoma Bell.}

costulatum Wkf. Bosporus.

attenuatum Wkf. Marmora Meer.

brachystoma Wkf. Bosporus.

\section{Clathurella Carp.}

purpurea B. Bosporus.

inflata Carus. Narmora Meer.

\section{Conus I.}

mediterraneus Brug. Marmora Meer.

\section{Pterotrachea Forsk.}

coronata Forsk. Marmora Meer.

\section{Alexia Leach.}

myosotis Mörch. Kuschiewsk., Sewastopol.

\section{PELECYPODA.}

\section{Ostrea I.}

lamellosa Brocchi. Batum., Sewastopol. 
adriatica Lam 'Tauria., Redout-kale., Odessa., Anapa.

edulis L. Poti.

cochlear Poli. Marmora Nleer.

\section{Anomia Is.}

ephippium L. IBosiorus.

patelliformis L. Marmora Meer.

\section{Lima Brug.}

hians Gm. hosporus.

\section{Pecten I.}

Jacoloens Lain. Marmora Meer.

varius Lam. Liosporus.

opercularis Lam. Bosporus

glaber Chemn. Sewastopol.

var. sulcatus Lam. Such., Anapa, 'Taman., Gulaut, Redout-kale.

flexuosus Lain. Marm ra Meer.

similis Lask. Marmora Meer.

pusio Lam. Marmola Meer.

\section{Mytilns Is.}

edulis I. Bugas, Domau-delta., Batum, N. Russk.

var. Havus Poli. N. Rossk.

var. galloprovincialis Lam. N. Rossk, liatum., Anapa., Bugas, Sakko., Gudaut

minimus l'oli. Sewastopol.

crispus Cantr. Such., Gudaut., Batum., Sewastopol.

latus Chemn. Gudaut., Sewastopol.

lineatus Gmel. N. Rossk.

\section{Modiola Lam.}

barbata Lam. Bosporus.

phascolina Phil. Sewastopol.

adriatica Lam. Sewastopol, Gudaut., N Rossk., Such., Cdessa.

\section{Lithodomus Cuv.}

lithophagus Payr. Odessa.

\section{Modiolaria Gray.}

marmorata Jeffr. Bosporus.
Arca I.

Noae L. Odessa.

tetragona Poli. Bosporus.

lactea L. Busporus.

barbata L. Odessa.

diluvii Lam. Marmora Neer.

pectunculoides Scacchi. Marmora Meer.

\section{Nneula Lam.}

sulcata Bronn. Marmora Mieer.

nucleus Lov. Bosporus.

\section{Leda Schum.}

commutata Phil. Bosporus.

tenuis Jeffr. Marmora Meer.

\section{Kellia Tint.}

suborbicularis 'Turt. Bosporus.

\section{Cardium I.}

chinatum L. Marmora Meer.

paucicostatum Sow. Odessa., Sewastopol.

tuberculatum $I_{d}$. Narmora Meer.

edule L. N. Rossk, Sewastopol., Anapa., Gudaut, Kertsch, Bugas., Achtanisow Liman.

esiguum Gm. N. Rossk., Sewastopol.

minimum Phil. Marmora Meer.

fasciatum Mtg. Servastopol.

oblongum Chmn. Bosporus.

coloratum Eichw. Tauria., Sewastopol.

\section{Chama I.}

gryphoides L. Marmora Meer.

\section{Cytherea Lam.}

rudis Req. N. Russk., Gudaut., Sewastopol.

\section{Circe scham.}

minima Forb. Sewastopol.

\section{Dosinia Gray.}

exoleta Röm. Bosporus.

\section{Venus Lam.}

verrucosa L. Bosporus.

fasciata Don. Bosporus. 
ovata l'enn. IBosporus.

gallina I. Latum., Such., liudaut., lingras., N. Lossk, Odessa., liedout-kale, Sewastopol.

\section{Tapes Mgle.}

decussatus Forb. Sulshuk-kale., Marmora Meer.

laetus Wlif. N. Rossk., Gudaut. nitens Wlif. Bosporus.

aureus Forb. Sewastopol.

\section{Venerupis Lam.}

irus Lam. Odessa, Sewastopol. decussata Puli. MIare nigr.

\section{Petricola Lam.}

lithophaga Phil. Odessa., Sewastmol.

\section{Aximus Sow.}

flexuosus Jeffr. Marmora Mleer.

\section{Diplodonta Bronn.}

rotundata Phil. Bosporus.

\section{Donax I.}

semistriatus Poli. Sewastopol.

renustus Poli. Redont-kale., liugas., Anapa., Odessa.

politus Seacchi. Losporus.

\section{Psammobia Lam.}

vespertina Lam. Bosporus.

\section{Caltellus Schum.}

pellucidus Penn. Marmora Neer.

\section{Solen I.}

vagina L. Marmora Meer., Odessa., Inapa . Krim.

ensis L. Anapa., Marmora Meer.

siliqua L. Tauria.

\section{iriesodesma Desh.}

corneum Petit. Odessa., 'Tauria., Sewastopol.

\section{Miactra I.}

stultorum L. Bosports. subtruncata Mltg. Sewastopol.

edulis L. Anapa.

\section{Rangia.}

trigona Puli, Suchum, Redout-kale, Krinn.

\section{Corbula Brug.}

gibba Jeffr. liosporus.

\section{Corbulomya Nyst.}

mediterranea Whif. Sewastopol.

\section{Saxicava Flr.}

arctica Desh. Bosporus.

\section{Gastrochaena Spglr.}

dubia Jesh. Sewastopol.

\section{Pholas L.}

dactylus L. Marmora Necr.

candida L. Hare nigr.

pontica Nordm. Odessa.

\section{Xylophaga 'Inrt.}

dorsalis Turt. Marmora Meer.

\section{İeredo L.}

mavalis I. Batum, Sewastopol.

\section{Lucina Brug.}

borealis $F$. Bosporus.

spinifera Mtg. Bosporus.

reticulata Wkf. bosyorus.

fragilis Phil. Bospor'us.

leucoma Turt. N. Rossk., Odessa., Sewastopol., Bugas.

divaricata 1:. et H. Sewastopol.

Tellina L.

donacina L. Odessa., Sewastopol.

exigua Poli. Sewastopol, Odessa.

do varietas. Tauria, Anapa.

balaustina L. Bosporus.

crassa Penn. Marmora Meer.

cumana Hanl. Narmora Meer.

\section{Capsa Brag.}

fragilis Mörch. Odessa., Bugas., Sewastopol., N. Rossk. 
Syndesmya Recl.

alba Recl. Sewistopol.

longicallis Arad. Marmora Meer.

nitida Lov. Mare nigr.

ovata Wkf. Odessa., N. Rossk., Sewastopol.

Neaera Gray.

abbreviata Forb. Marnora Meer. costellata Hinds. Marmora Neer.

cuspidata Hinds. Marmora Meer.

rustrata Lov. Marmora Meer.

Thracia Leach.

papyracea Wkf. Sewastopol.

\section{MOLLUSCA E MARE CASPICO.}

\section{PELECYPODA,}

\section{Dreissenia v. Ben.}

polymoruha L. MI casp., Baku., Petrowsk.

\section{Cardium I.}

edule L. II. casp.

var, rusticum Chmen. Michailow. Bucht.
Didacne Eichw.

trigonoides Pall. I. casp., Baku., Michailow. Bucht.

crassa Eichw, MI. casp.

Monodacne Fichष.

caspia Eichw. M. casp.

Aducne Eichw.

laeviuscula Eichw, M. cas', Baku.

\section{T UN I C A T A.}

Molgula Forb.

occulta Kupff. Bosporus.

\section{Microcosmus Hell.}

vulgaris IIell. Sewastopol.

Styela M. I.

canopoides Hell, Bosporus.

Ascidiella Roule.

scabra Roub. Bospor'us.

virginea Müll. Sewastopol., N. Rossk.
Ascidia Hanc.

depressa Ald. N. Rossk.

mentula Müll. Bos!orus.

fumigata Grube. Narmora Meer.

venosa Müll. Marmora Meer.

\section{Botryllus D. V.}

Schlosseri Sav, Such., N. Rossk.

Didemnum Giard.

Grubei v. Dr. Marmora Meer. niveum. Sewastopol.

\section{BRACHIOSTOMATA.}

BRYOZOA.

Aetea Lmx.

anguina Lmx. Bosporus.
Scrupocellaria Van. Ben.

scruposa V. Ben. Bosporus.

Bertholletii Aud. Sewaspotol. 
Caberea Imx.

lorvi linsk. Marmora Mcer.

Bugula 0ken.

phumosa linsk. Buspinius

Membrauipora Blv.

lostrata Ilell. Mammoral Mecr.

reticulum L. Sewastopol.

Salicornaria Cuv.

listulosa Carns. Mammora Meer.

Retepora Johnst.

cellulosa Juhnst. Marmora Meer.

Lopralia Hcks.

l'allasiana liusk. Such., Sewastojul.

vinlacea Johnst. Bosporus.

Porella Gray.

rervicornis Wat. Marmoral Meer.

Schizoporella Hcks.

unicornis Ilelis. Mosporus.

Crisia Busk.

cburnea Lmx. Bospurus.
Idmonea Imx.

fromlusa Menergh. Mamora Meer.

Hornera Lmx.

lichenoides smitt. Narmora Mreer.

Lichenopora Dfr.

raliata IIcks. Marmora Mcer.

Mimosella Hels.

gracilis Heks. Marmora Mecr.

Pelicellina Sars.

cernua Sinitt. Bosporus.

\section{Barentsia Hcks.}

gracilis Helss. Iosporus.

Loxosoma Kfst.

nor. spec. Marmora Meer.

\section{BRACHIOPODA.}

Megerlia King.

truncata King. Marmora Neer.

Cistella Gray.

Kowalewskii schulg. Marmora Meer.

\section{ICHINODIRMATA.}

\section{CRINOIDEA.}

Antedon Frem.

rosacea Norm. Mare medt, Buspurus

\section{ASTEROIDEA.}

Astorias Gray.

gracialis Mull. Josporus.

\section{Palmipes I.}

membranaceus $\mathrm{Ag}$. Bosprorus.
Astropecten Mirill. platyacanthus $\mathrm{M}$. et Tl'. Inosporus. pentacanthus M. et 'Tr. Bosporus.

\section{OPHIUROIDEA. Ophioglypha Lym.}

albida I yym. Bosprorus

\section{Amphiura Forb.}

squamata sines. Sewastopol.

Chiajii Forb. Sewastopol. 
Ophiopsila Forb.

aranea Forb. Bosporus.

Ophiothrix M. et Tr.

fragilis Düb. Bosporus.

alopecurus MI. et Tr. Busporus.

echinatus M. et Tr. Bosporus.

\section{ECHINOIDEA.}

\section{Arbacia Gray.}

pustulosa Gray. Bosporus.

Sphaerechinus Des.

granularis Ag. Bosporus.

Echinocyamus v. Phls.

pusillus Gray. Bosporus.

Echinocardium Gray.

cordatum Gray. Marmora Meer.
Brissopsis Ag.

Iyrifera Ag. Marmora Meer.

\section{HOLOTHURIOIDEA.} Holothuria I.

tubulosa Gm. Narmora Meer.

\section{Cucumaria Blainv.}

Planci v. Mrzlle. Nare nigr.

pentactes Forb. liosporus.

tergestina Sars. Bosporus.

\section{Ocnus Torb.}

orientalis Ostr. Sewastopol.

\section{Synapta Eschsch.}

digitata Müll. Mare merlt, Bosporus. hispida Hell. Sewastopol.

\section{COELENTERATA.}

HYDROMEDUSAE, Cordylophora.

lacustris Allm. Sewastopol.

Eudendrinm Allm.

ramosum L. Sewastopol.

Hydractinia V. Ben.

echinata Flem Mare nigr.

Campanularia Heks.

flexuosa Hicks. IIarmora Hecr.

Sertularella Gray.

jolyzonias Gray. Such., Serrastopol.

Aglaophenia Mic. Rady.

pluma Itmx. Sewastopol.

Nemertesia Lmx.

Janini Lmx. Marmora Meer.

Sarsia Forb.

tubulosa Fibs. Sewastojol.
Lncernaria Müll.

campanulata Lmx. Sewastopol.

Aurelia P. et. L.

aurita II. Edw. Mare nigr.

\section{CTENOPHORAE}

Pleurobrachia Flem.

rhododactyla $A \mathrm{~g}$. Nare nigr.

$$
\text { POLYPI. }
$$

Rhizoxenia Ehbg.

rosea Dana. Bosporus.

Sympodium Ehbg.

coralloides Pall. Bosporus.

\section{Alcyoniam L.}

falmatum L'all. Narmora Meer.

Muricea Lmx.

echinata v. Koch. Bosporus. 
Virgularia Lan.

spee? Sewastopol

Funicnlina I,am. quatrangularis Herkl. Marmora Meer.

Actinia MI. Edw.

equina Is. Sewastipol.

\section{Cylista Gosse.}

viduata Wright. Sewastopol.

\section{Auroliana Gosse.}

regalis Andr. Bosporus.

\section{Palithoa Lamx.}

axinellae O. Schm. Marmora Neer.

Caryophyllia H. Edw.

clavus Scacchi. Bosporus.

\section{Balanophyllia S. Wood.}

italica M. Ldw. Marm ra Neer.

\section{P O RIFERI.}

\section{Halisarca Duj.}

lobularis bit. Sewastopol

Chontrosia.

reniformis. Mare medt

Spongelia Nardo.

incrustans Sut. Sewastopol., N. Rossl. pallescens-elastica Sulltz. Marmora Meer.

\section{Aplysina.}

aérophoba Lsp. Marmora Meer.

\section{Enspongia.}

exigua Sch. Marmora Meor.

Hippospongia.

equina Sch. Marmiora Neer.

Cacospongia.

cavernisi Sdt, Marnora Meer.

Esperia Nardo.

foraminosa Sit. var. dura Czr. N. Rossli. var. pontica Czr. N. Rossk.

Reniera Sdt.

arqueductus Silt. S'ewastopol. ... IRossk.

informis Sit. X. Rossli
Suberites Nardo.

massa Sdt. Mire medt. Sewastopol.

domuncula Nardo N. Rossk, Marmora Mecr. apendiculatus Bals. Marmora Meer.

\section{Tethya.}

morum Sit. Marmora Neer.

\section{Axinella.}

damicolnis Esp. Jare medt, Marmoria Meer.

\section{Acanthella.}

obtusa Silt. Marmora Meer.

Geodia Lam.

conchilega Sdt. Marmora Mcer.

\section{Tisiphonia.}

agariciformis 'Thms. Narmora Meer.

\section{Sycou.}

setosum Sit. Sewastopol.

Ute.

glabra Sdt. Marmoria Neer.

\section{Sycandra.}

\section{PROTOZ0A.}

Noctiluca Lam.

miliaris I . Nare nigr. 


\section{Д О В А В Л E H I E.}

Во гремл петатавія паталога возеращены г. Вубовския опреднлепне им 52 вида Orthoptera cancasica, которше должн были бы быть помшены на стр. 454.

\section{N A C H T R A G.}

Widhend des Drukes kamen die 5:- Irten bestimnter Orthoptera caucasica von 11. Subowsky zurück, sie müssen auf pag. 154 eingeschaltet werden.

\section{FORFICULARIA.}

Labidara Leach.

riparia Pall. U-der.

Labia Leach.

minor L. 'T'fl.

Forficula í.

auricularia $L_{\text {. }}$. Zch-Zch.

smyrnensis Serv. U-der.

\section{BLATTODEA. \\ Aphlebia Br.}

polita Krauss. U-der.

\section{Phyllodromia Serv.}

germanica L, U-der.

\section{Periplaneta Burm.}

orientalis L。Tfl.

\section{Heterogamia Borm.}

aegyptiaca L. Tft.

\section{MANTODEA}

Hierodula Burm.

bioculata Burm. 'Tfl., N. Rossk.

\section{Mantis $\mathbf{L}$.}

religiosa L. Tfl., N. Rossk.

\section{Iris Sauss.}

oratoria L. 'Tfl, N. Rossk.

\section{Bolivaria Stål.}

brachyptera Pall. Tfl., Arax., Kasikp.
Empusa Ill.

pennicornis Pall. TH.

\section{ACRIDIODEA}

\section{Tryxalis F.}

nasuta L. N. Rossk., Dshebr.

\section{Stenobothrus Fisch.}

lineatus $\mathrm{Pz} . \mathrm{N}$. Rossk.

morio F. Lom-mta.

apricarius L. Lom-mta.

pulvinatus F. d. W. Kasikp.

dorsatus Zett. Kasikp., N. Rossk.

Stauronotus Fisch.

brevicollis Ev. Kasikp.

Stethophyma Fisch.

fuscum Pall. Kub.

\section{Sphingonotus Fieb.}

coerulans L. Kulp., Borsh.

Savignyi Sauss. Borsh.

Kittaryi Sauss. Borsh.

\section{Acrotylus Fieb.}

insubricus Scop. Borsh., Areseh, Arax.

\section{Oedipoda Latr.}

variabilis Pall. Borsh., Kasikp.

Schochi Br. W. Kasikp.

coerulescens L. N. Rossk, Kub., U-der.

Pachytylus Fieb.

nigrofasciatus Deg. TH., Borsh., Kasilip.

Pyrgodera F. d. W.

armata F. d. W. Kulp. 
Psoplus Fieb.

stridulus L. Kubli, I am-mita.

Acridium Geoflr.

aceprotium 1. 'lit.

Caloptenus Burm.

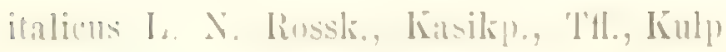

\section{Platyphyma Fisch.}

Gimme linsi. N. liussk.

\section{lettix Charp.}

ilepressus liris. 'Tth., Borsh., Aresch.

\section{LOCUSTODEA.}

\section{Phaneroptera Serv.}

fuatripunctata lir. N. Rossk.

'I'ylopsis Fieb.

liliifulia F'. N. Rossk.

\section{Xiphidium Serv.}

thoracicum l', d. W. 'TH.

\section{Locusta Deg.}

viridissima I, Kunh.

caudata Charpl. Kasikp.
Paradrymadusa Herm.

spec? Kasilip.

\section{Platycleis Fieb.}

aftinis Fieb, 'Tfl, N. Rossk.

\section{Decticus Serv.}

verpucivorus $\mathrm{I}$. Kub.

albifrons $\mathrm{H}$. 'TH., Aresch.

\section{Saga Charp.}

serrata F. Kasikp.

\section{GRYLLODEA. \\ 0ecanthus Serv.}

pellucens Scop. N. Rossk.

var. aqueus $\mathrm{F}$. 'l'fl.

\section{Gryllus I.}

campestris I. N. Rossk., Kub., 'Tan., Lenk. desertus Pall. U-der, Wiljar.

domesticus Id. U-der., Tfl., Libr.

burdigalensis Latr. Tfl., Belasuwar.

frontalis Fieb. IBorsh., Kasikp.

\section{Gryllotalpa Latr.}

vulgaris Iatr. 'T'tl., U-der. 


\section{OMEЧATHИ-DRUCKFEHLER.}

\begin{tabular}{|c|c|c|c|}
\hline $\begin{array}{l}\text { сгр. } \\
\text { Seite. }\end{array}$ & $\begin{array}{l}\text { стровп. } \\
\text { Zeile. }\end{array}$ & $\begin{array}{l}\text { шашечаташо: } \\
\text { gedruckt: }\end{array}$ & $\begin{array}{l}\text { पnтaî: } \\
\text { lies: }\end{array}$ \\
\hline 8 & $10 \mathrm{v} .11$ & gangen & ganzen \\
\hline 8 & 8 v. 11. & Ebenzo & Ebenso \\
\hline 10 & $16 \mathrm{v}, \mathrm{u}$ & wissenschaflich & wissenschaftlich \\
\hline 15 & $11 \mathrm{cB}$. & пвыта вь каталогы, & цвита. Вь ката.точ) \\
\hline 36 & $13 \mathrm{~V} . \mathrm{u}$. & phacus & phaeus \\
\hline 40 & 7 v. 11. & vagus $\mathrm{Bl}$. & vagus Pall. \\
\hline 50 & $20 \mathrm{cB}$ & borealus & borealis \\
\hline$\vdots \because$ & 9 сп. & слстена & спстемы \\
\hline 55 & $1 \mathrm{cB}$. & тигры & тirpa \\
\hline .76 & $10 \mathrm{cII}$ & ОТНОСШТОЛЬНО & отпосптельпо \\
\hline $6: ;$ & $4 \mathrm{cls}$ & врененек'ь & времени \\
\hline $6: 3$ & $1 y \mathrm{cB}$ & горнастал & Горностал \\
\hline 64 & $16 \mathrm{cB}$ & Ho & по \\
\hline 6.4 & 3 ен. & Аи́хидха & Айдпдља \\
\hline 71 & $4 \mathrm{cH}$. & ма.лениць & маленькихт \\
\hline 72 & $\begin{array}{l}23 \text { св. } \\
\text { Ве.Іичниа }\end{array}$ & $\begin{array}{l}\text { вавсто периыхт 4-хт словт } \\
\text { роговь косули па таб. XVI обоз }\end{array}$ & 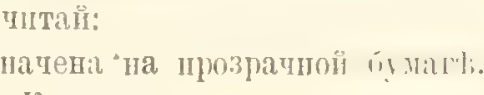 \\
\hline 76 & б crl. & Курумъ & Курушъ \\
\hline $8: 3$ & 1 cH. & йезуловно & безусловно \\
\hline 89 & (;) V. 0 & 60 & 10 \\
\hline 101 & 3 v. u. & viele & mehrere \\
\hline 245 & 16 сн. & части & часто \\
\hline 2.55 & $5 \mathrm{cB}$. & Намиць-цхаро & Непист-цгаро \\
\hline 2.55 & $6 \mathrm{cB}$. & Cukaperaro & Векарскаго \\
\hline$: 316$ & $10 \mathrm{v}, \mathrm{u}$. & 120 k. Chaldan. Kawr. & вычергнуть, zu streichell. \\
\hline$\because 2-i$ & 3 cri. & Әйзенамь & Эзенамъ \\
\hline 157 & $6 \mathrm{cB}$. & открітіе & отьрытые \\
\hline
\end{tabular}






